Historic, Archive Document

Do not assume content reflects current scientific knowledge, policies, or practices. 



\section{ENDANGERED AND THREATENED SPECIES}

OF THE SOUTHEASTERN UNITED STATES

INCLUDING PUERTO RICO AND THE VIRGIN ISLANDS

Compiled and Edited by

Andrew F. Robinson, Jr.*

Revised JuTy 1982

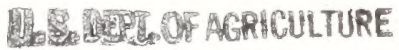

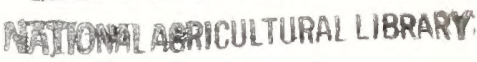

HoV $20,00 \%$

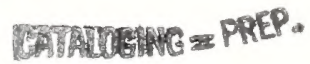

*At the time of the initial compilation, Dr. Robinson was an Endangered Species Specialist, Special Forestry Services Staff, Cooperative Forestry, Southeastern Area, State and Private Forestry, USDA Forest Service, Atlanta, GA. He is now with the Fish and Wildlife Service, 75 Spring Street, Atlanta, GA. 30303. Credits for contributions by Dr's. Kral and Robinson are noted on appropriate pages. 


\section{7}

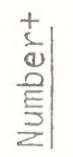

๑
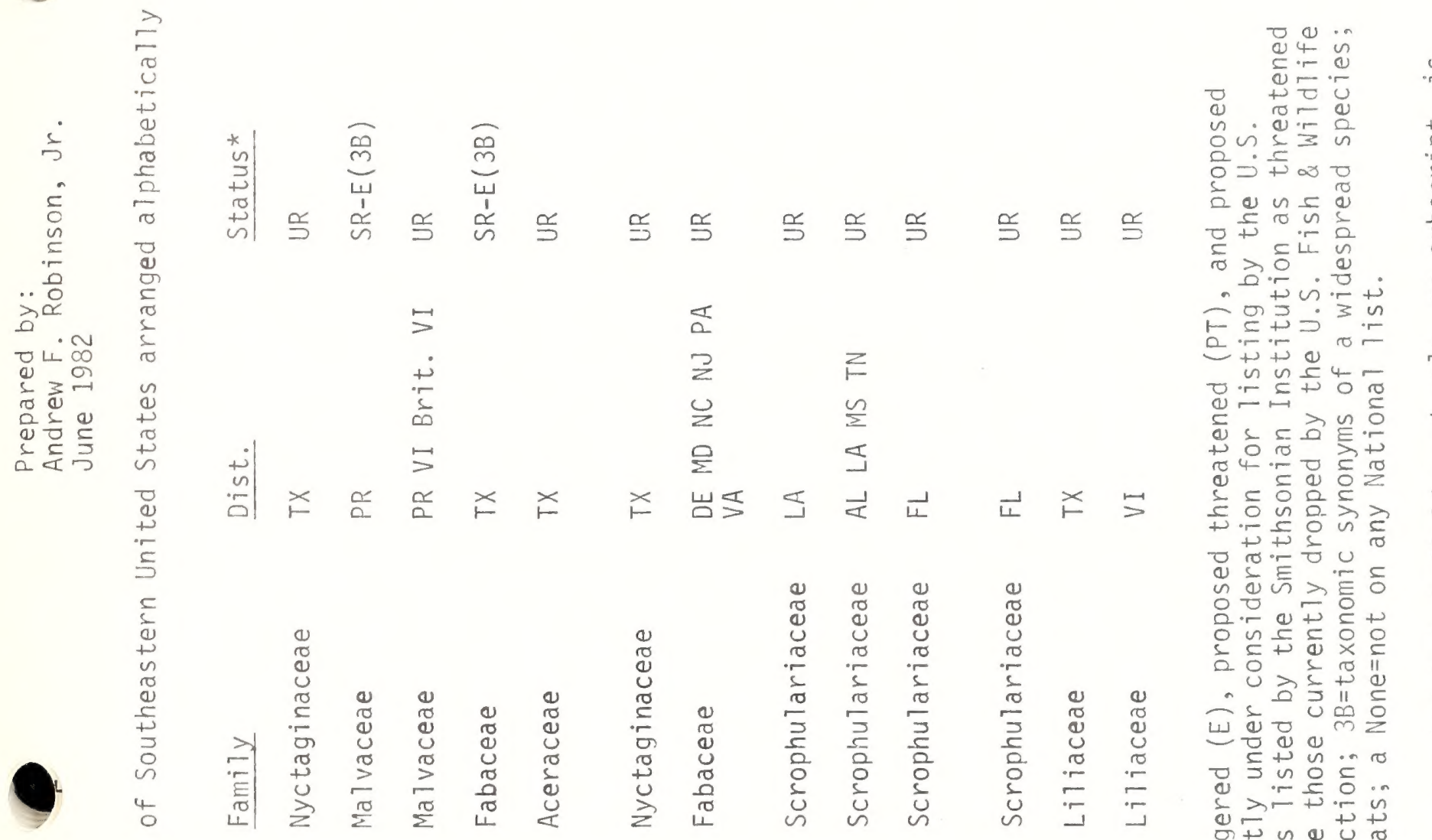

n

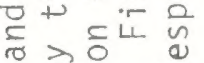

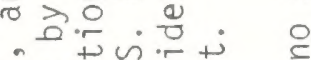

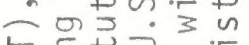

近足

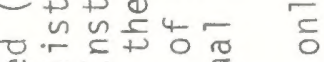

巳一ฑ

के

त्ष

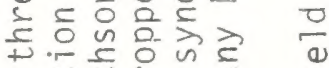

ช

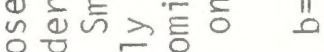

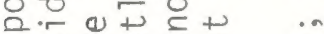

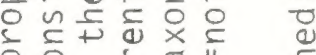

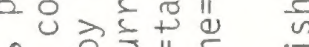

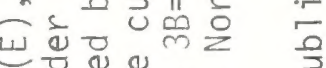

- E\& in

고의.

$\therefore>$ 드요 in

ये

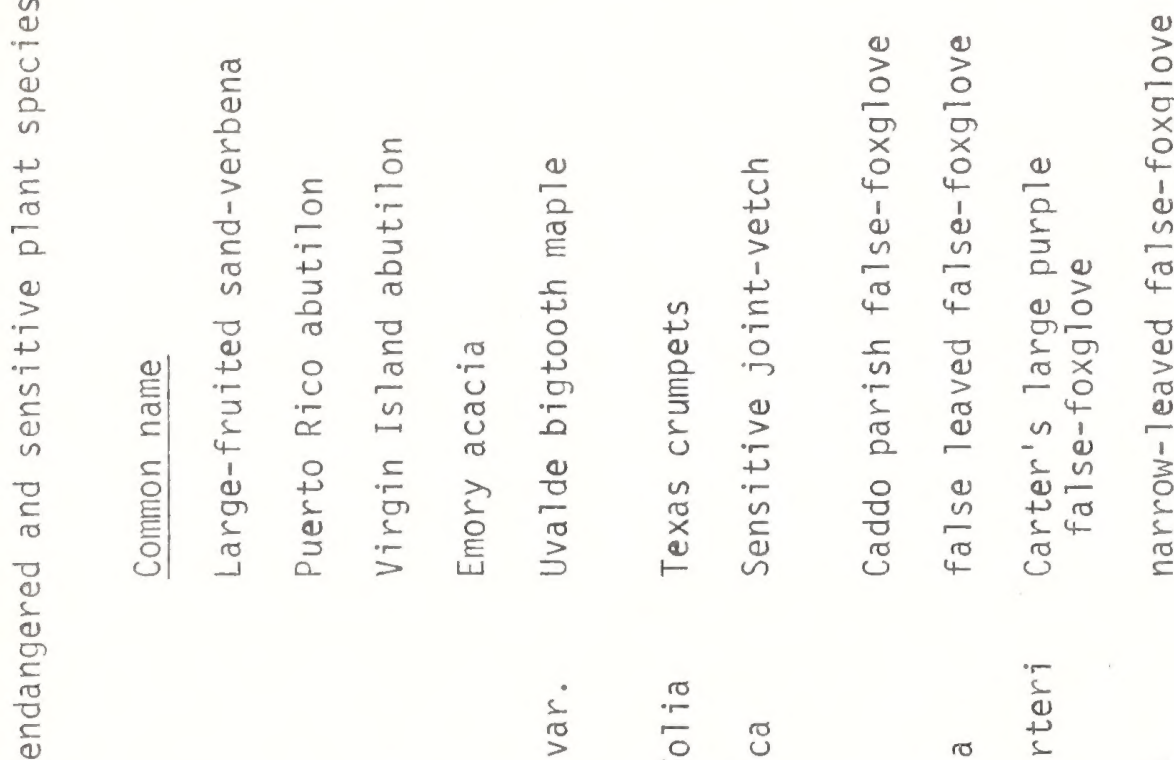

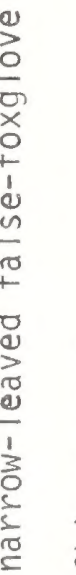

ᄃㄴ

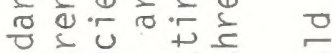

ฮิ

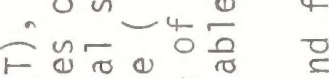

上.

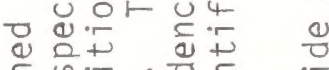

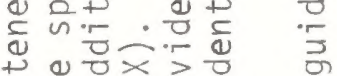

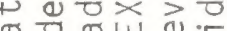

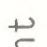

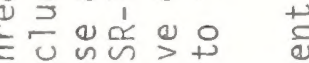

क.

곡 \&

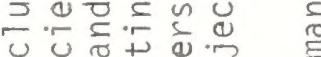

$\therefore$ 정

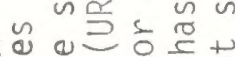

ᄃำ

$\frac{1}{0}$
$\frac{0}{0}$
$\frac{0}{2}$

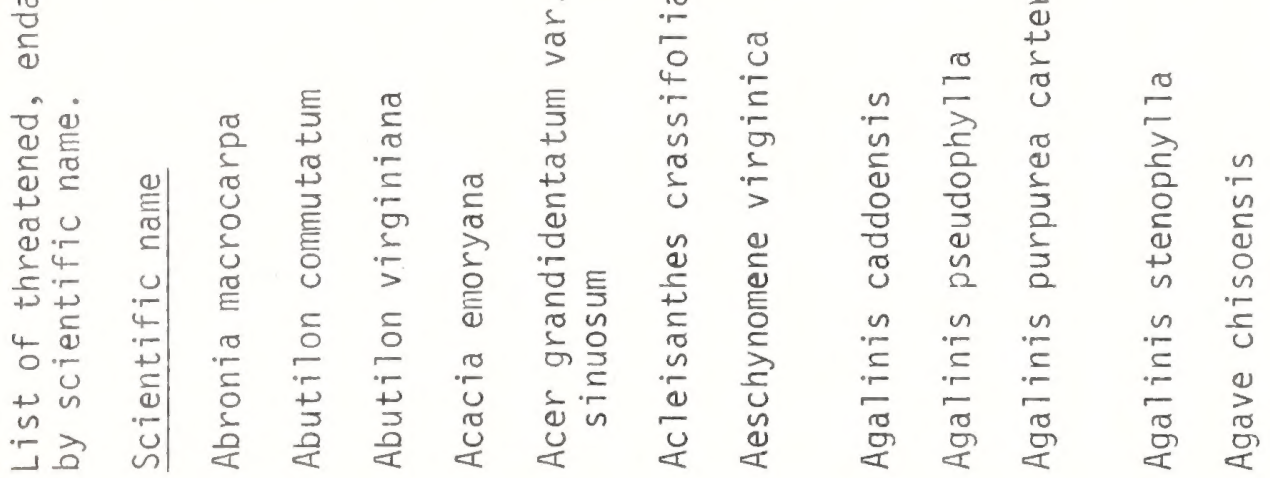

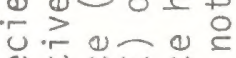
ब品山心 क n

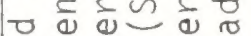

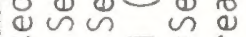

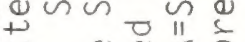
$\because$ \& \& $\frac{1}{2}$ $+$

. 


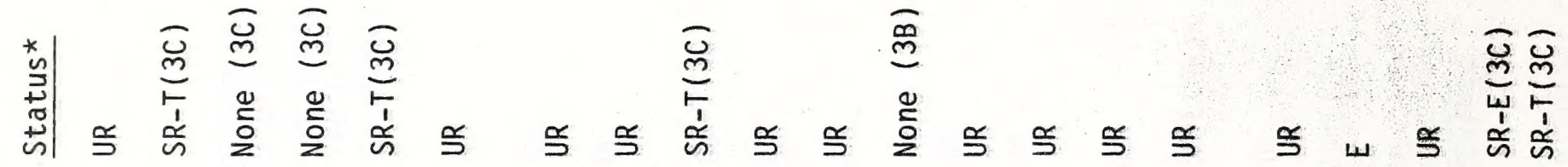

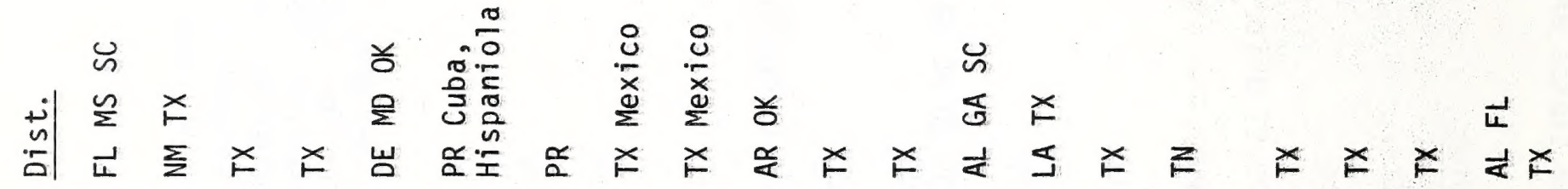

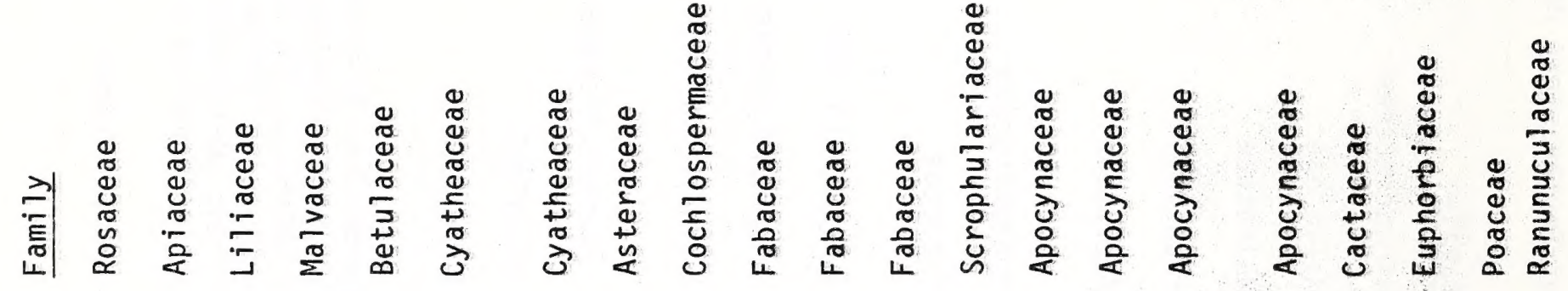

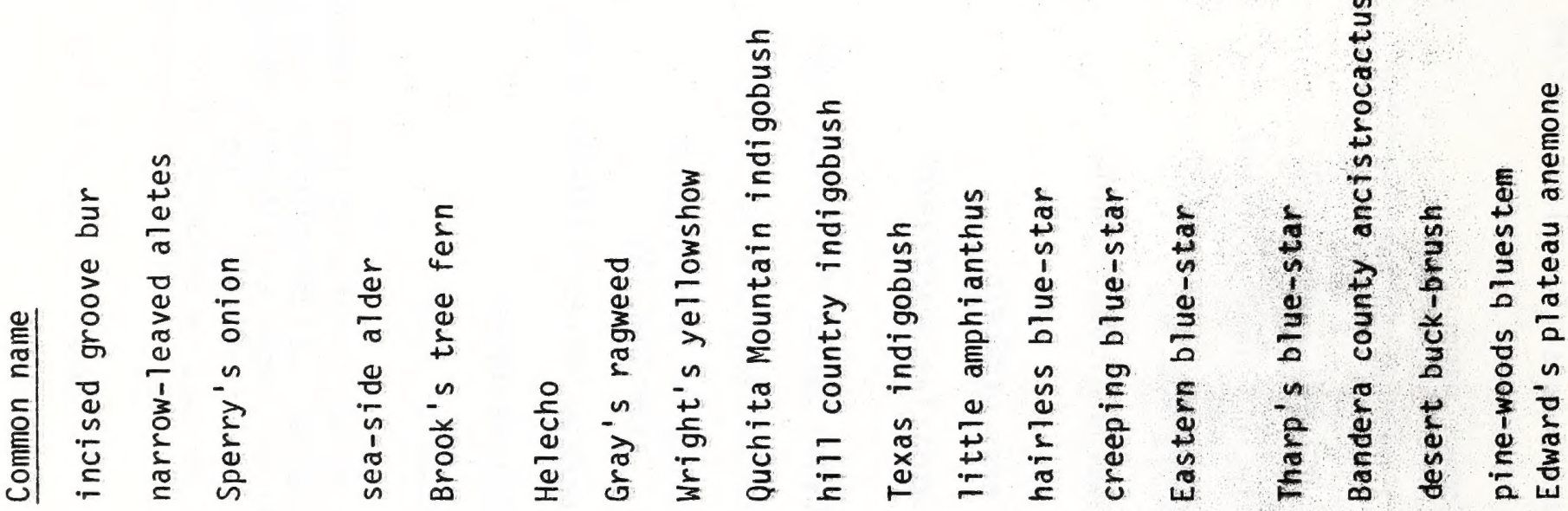

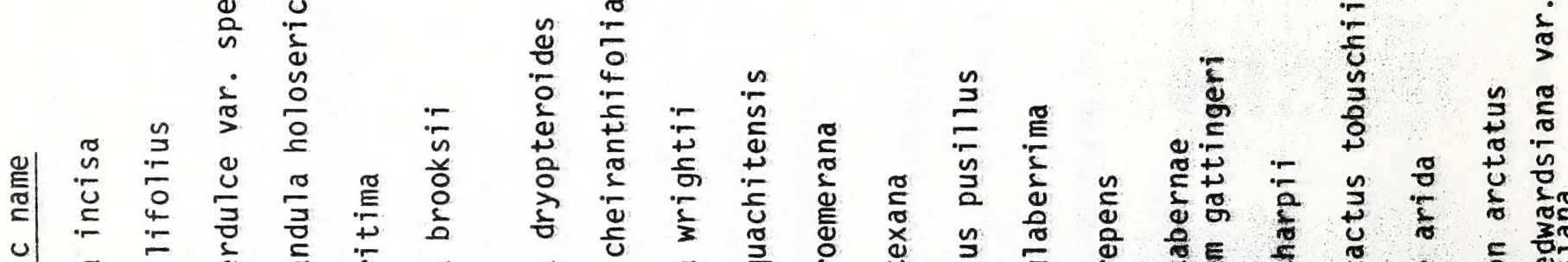

:

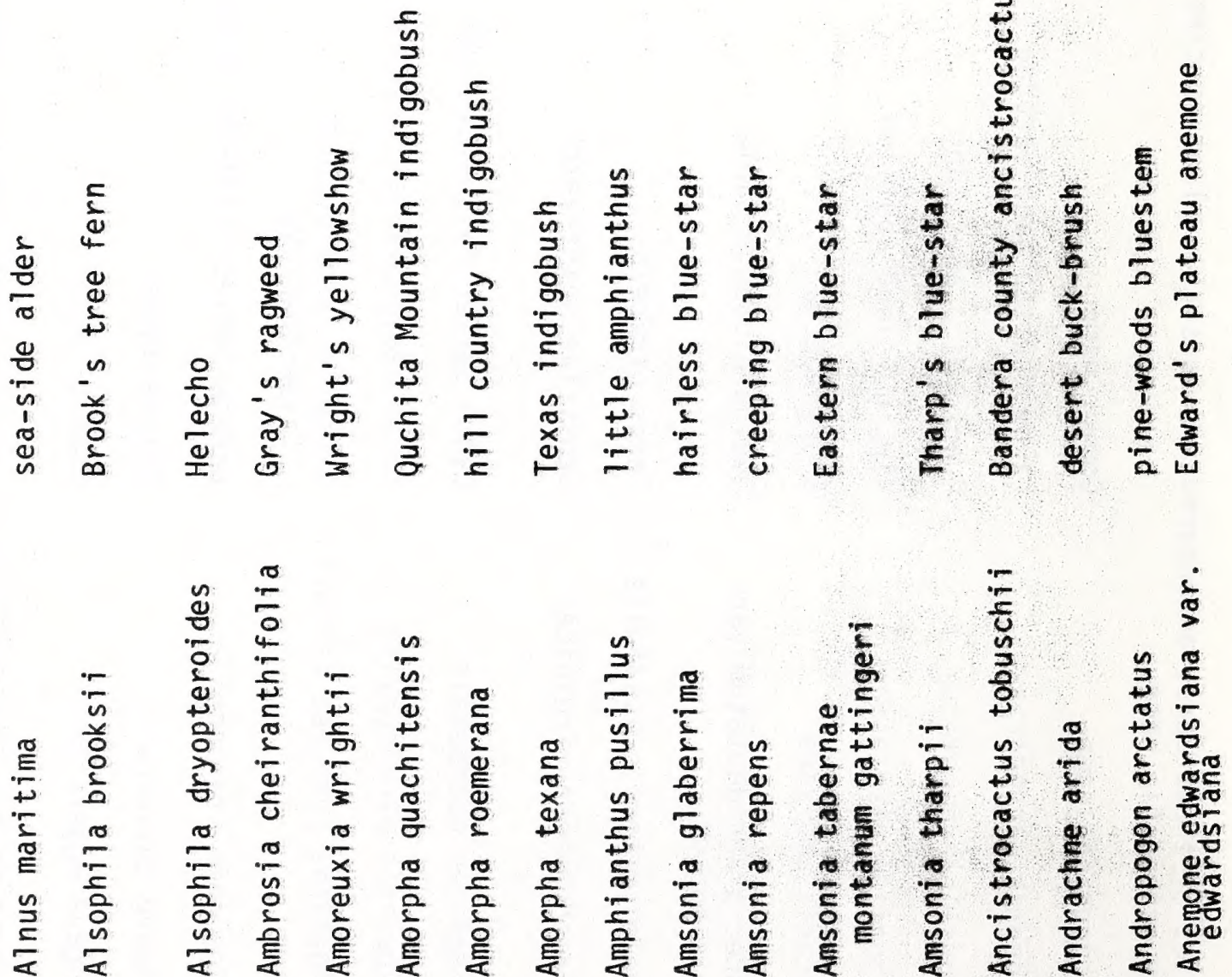




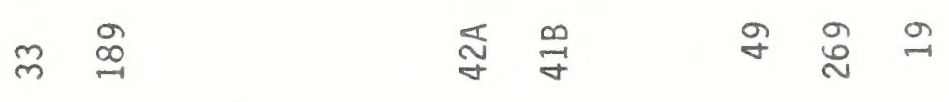

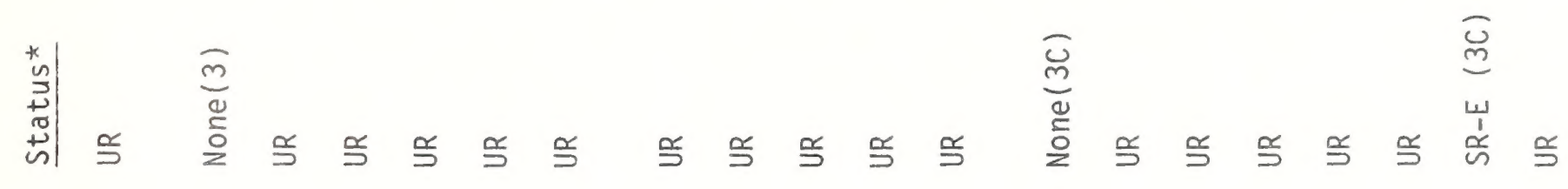

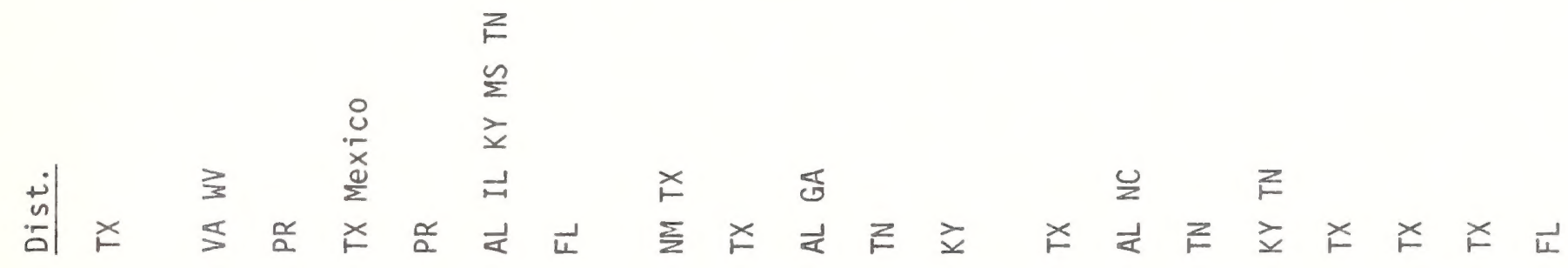

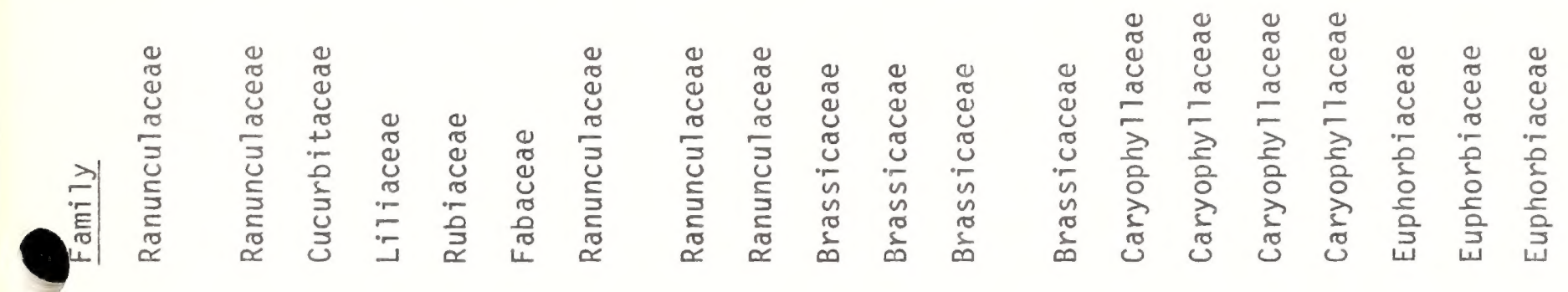

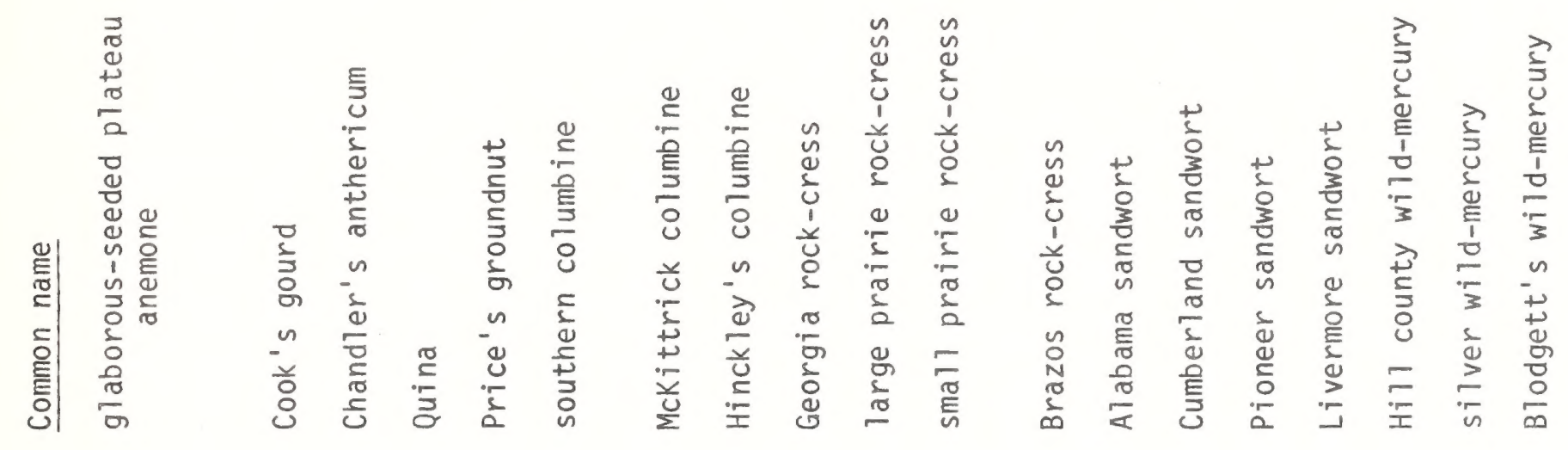

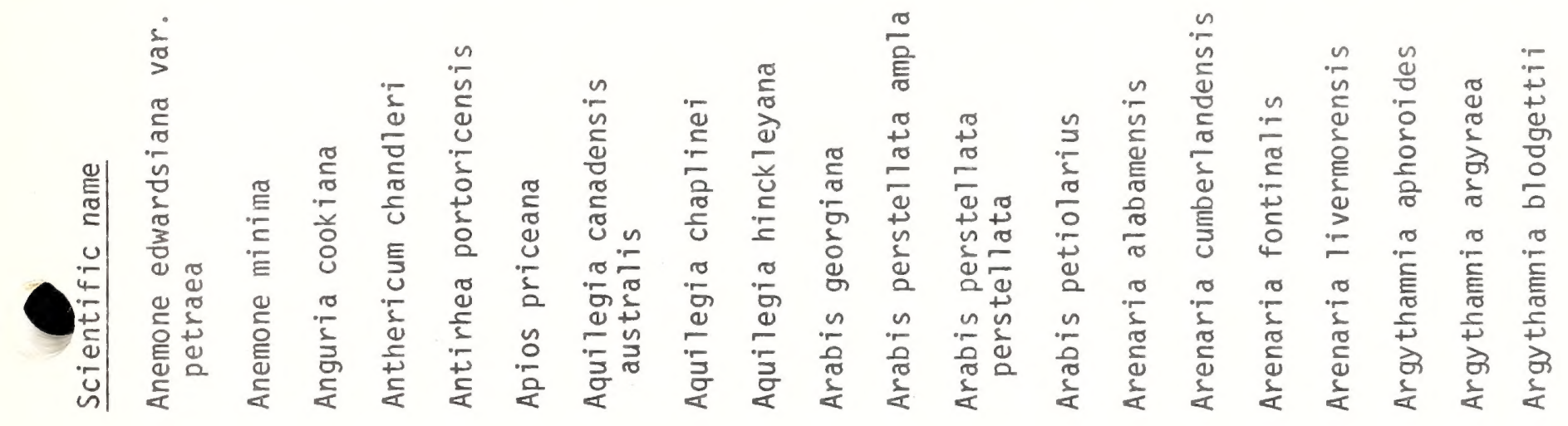




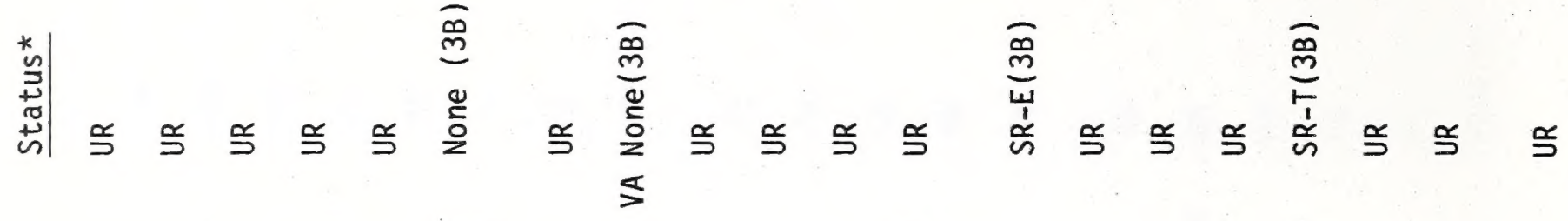

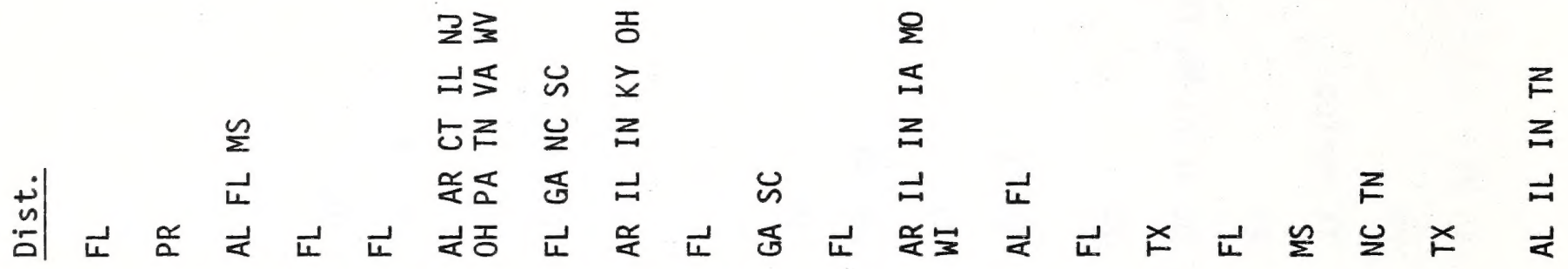

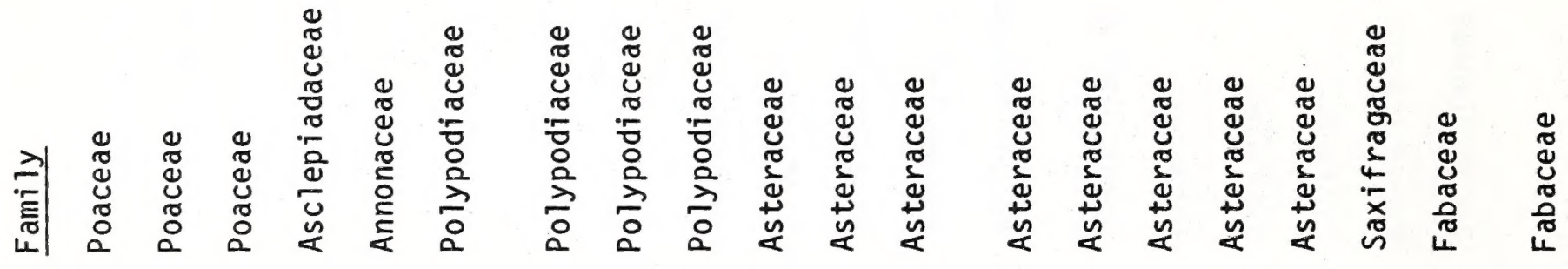

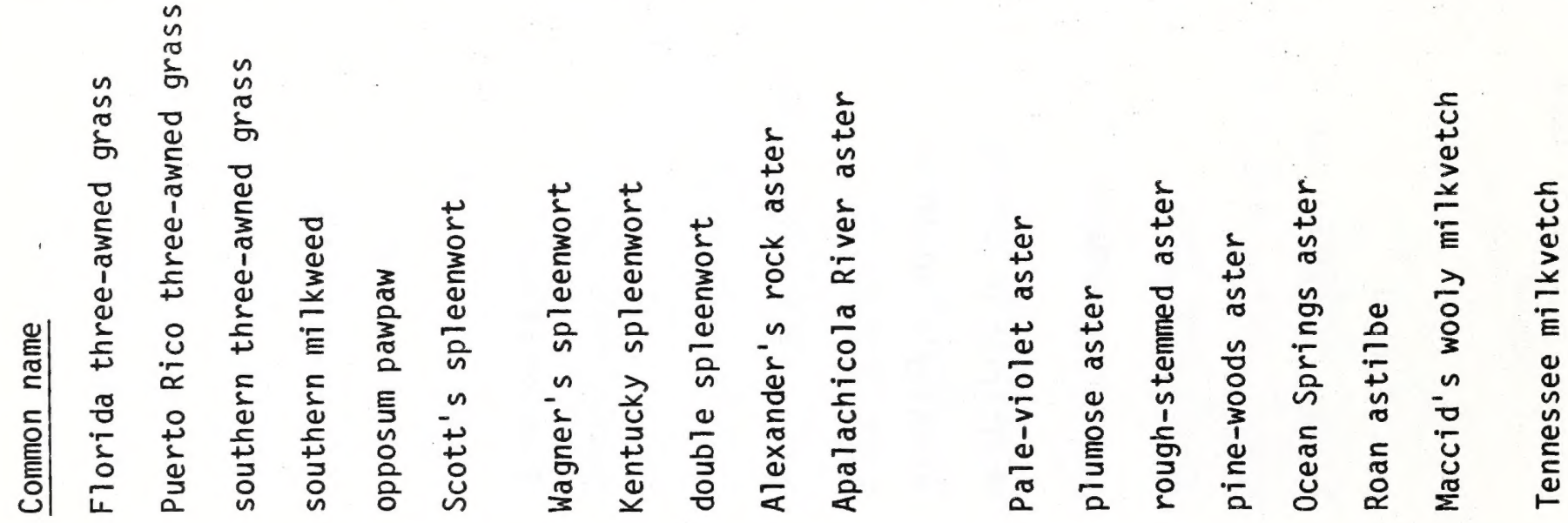

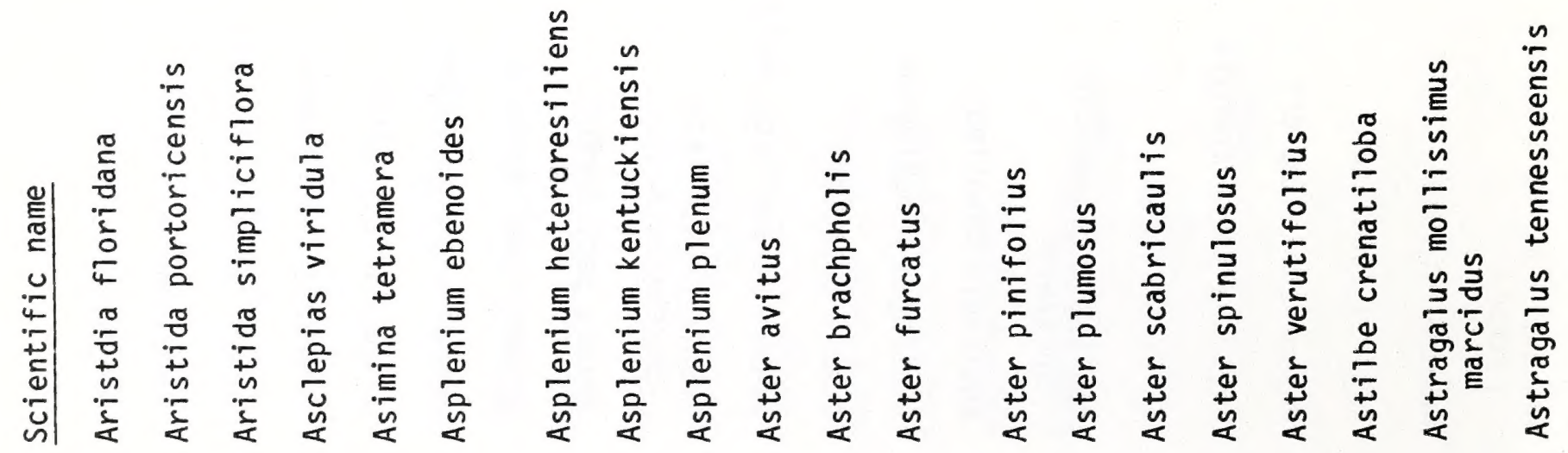


$\begin{array}{ll}\frac{1}{2} & \\ \text { है। } & \\ \text { है। } & \end{array}$

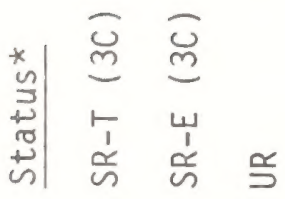

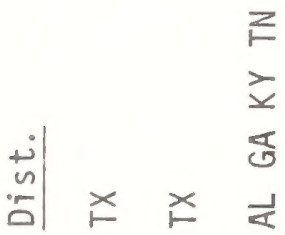

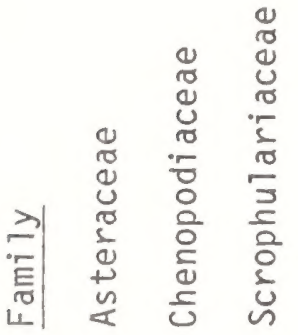

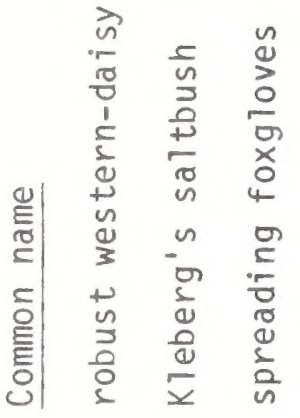

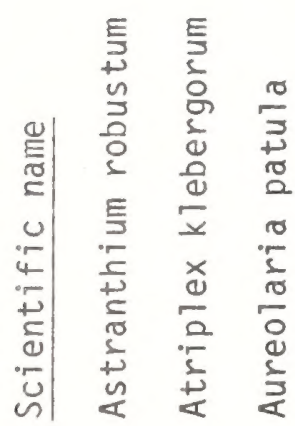




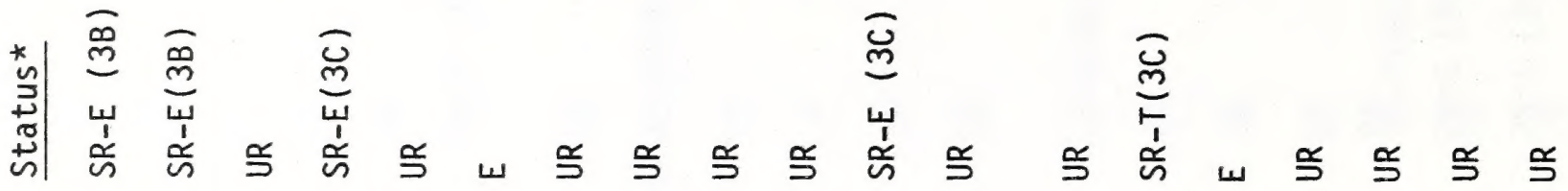

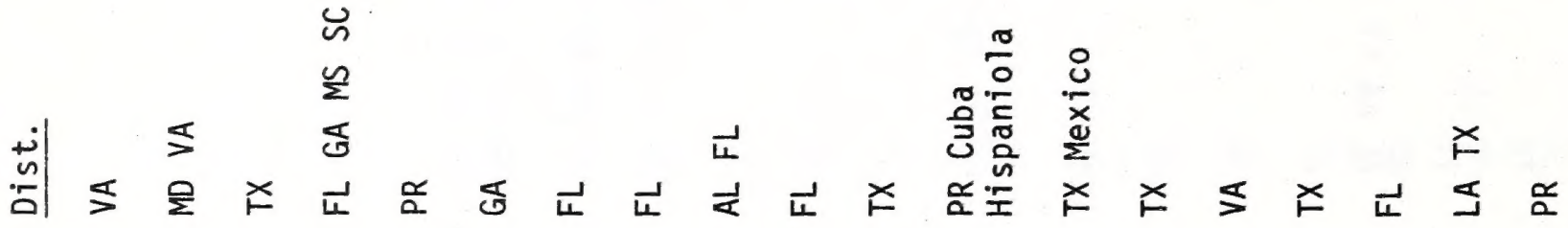

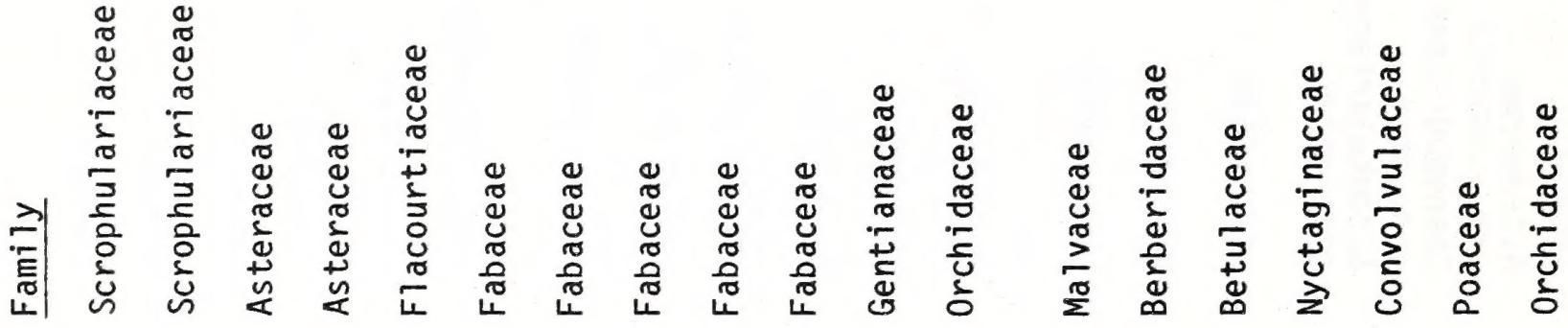

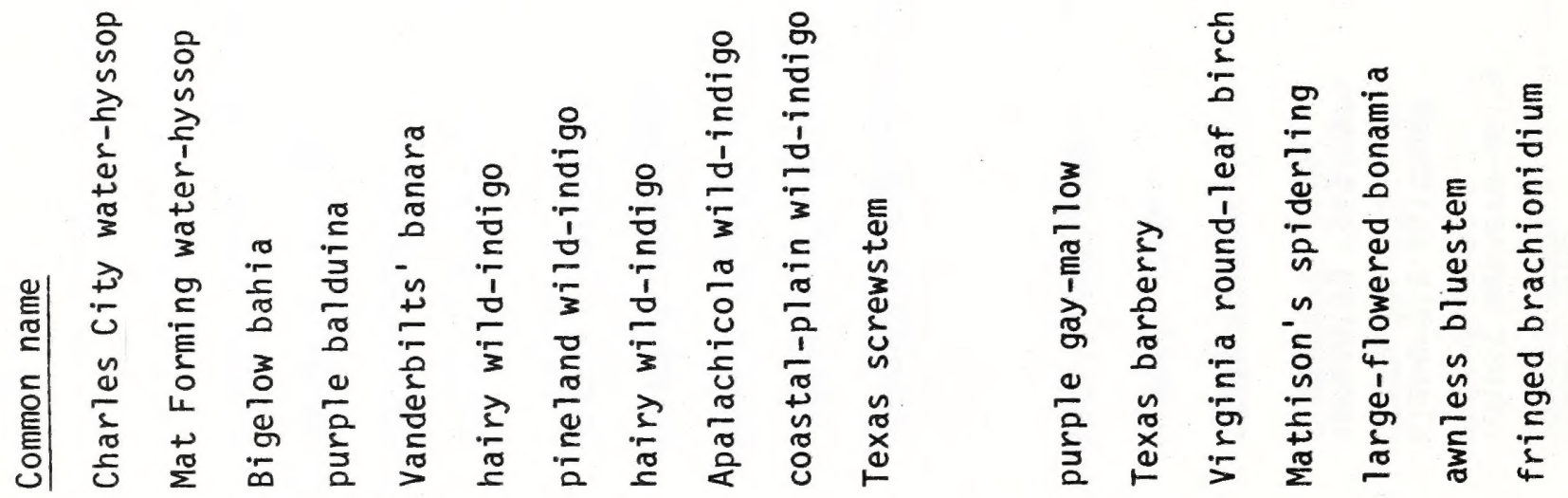

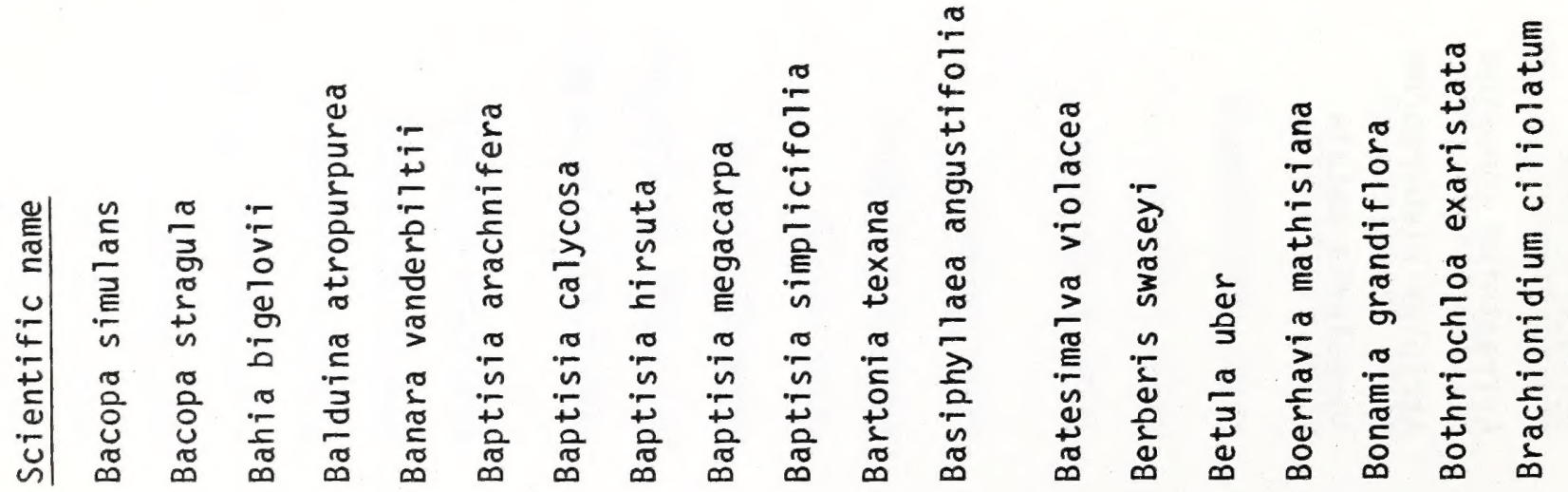




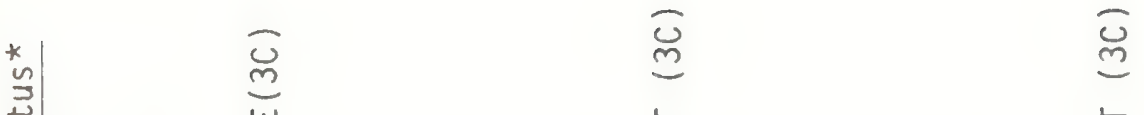

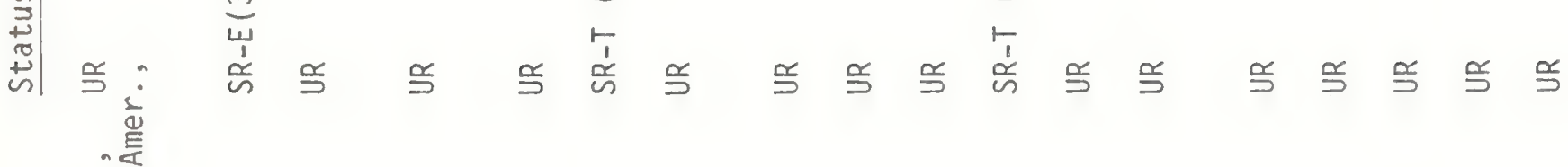

i)

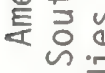

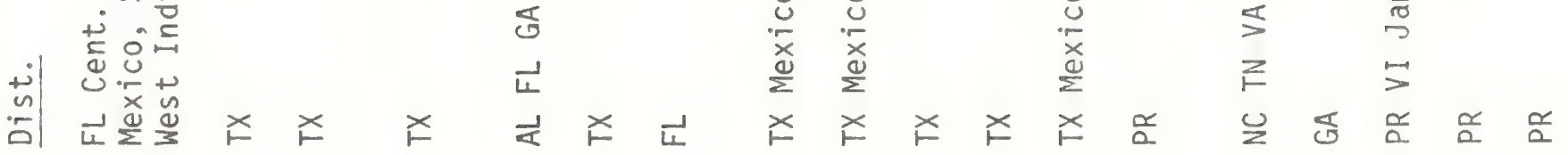

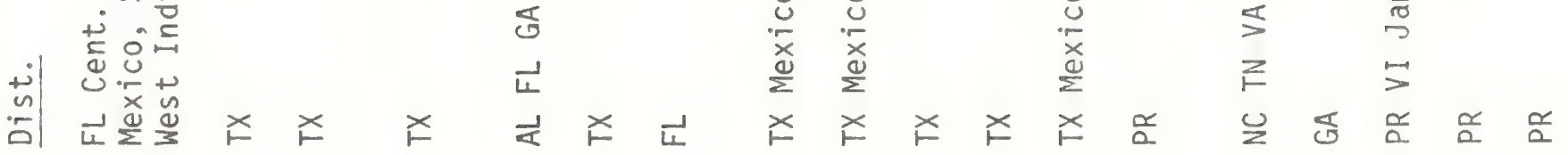

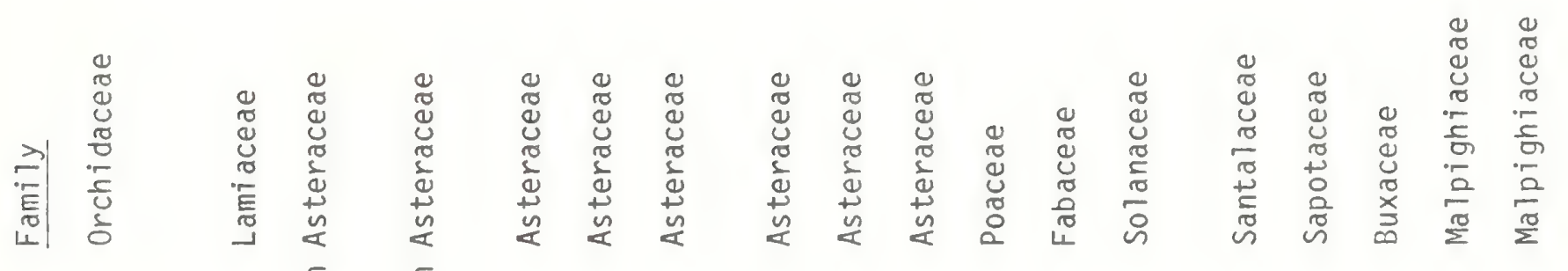

(2)

气 $\frac{5}{3}$

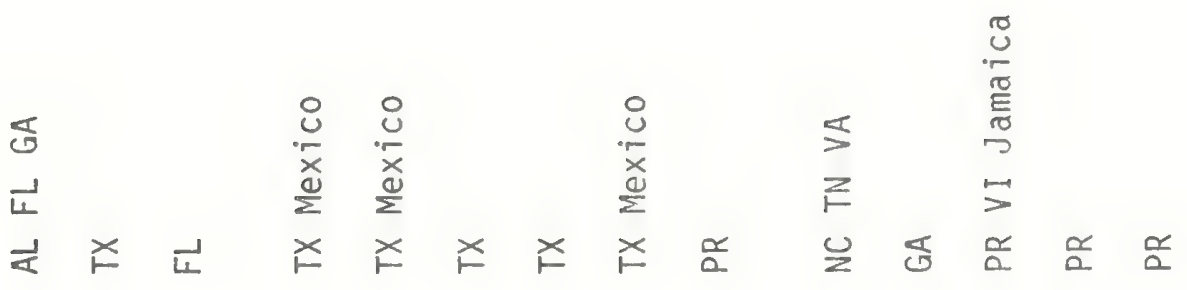

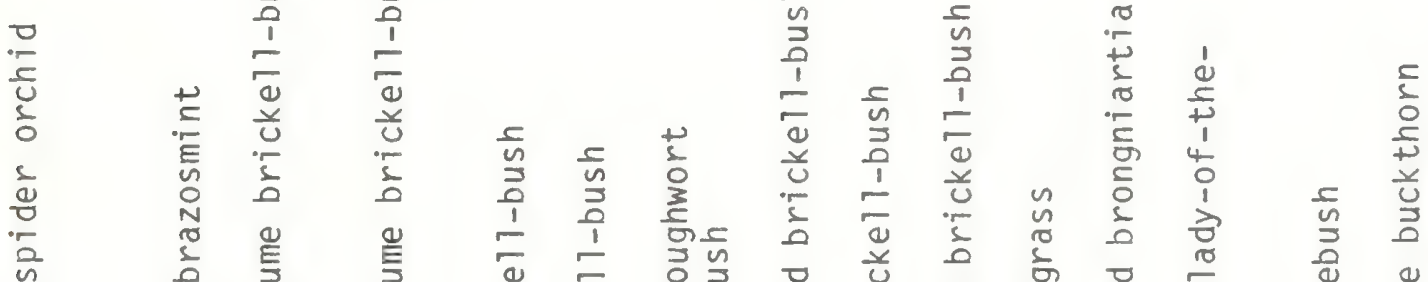

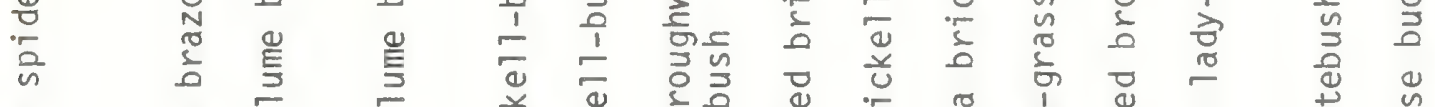

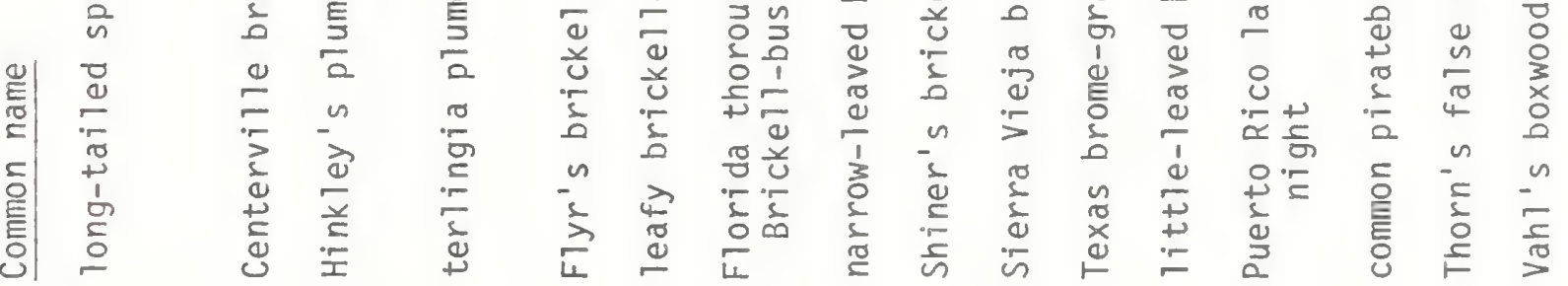

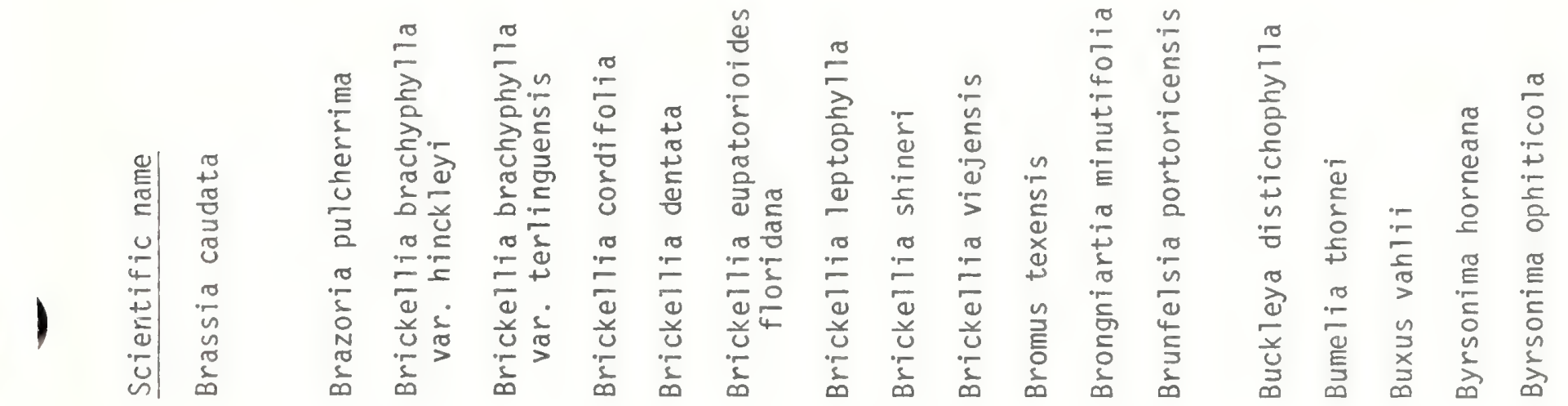




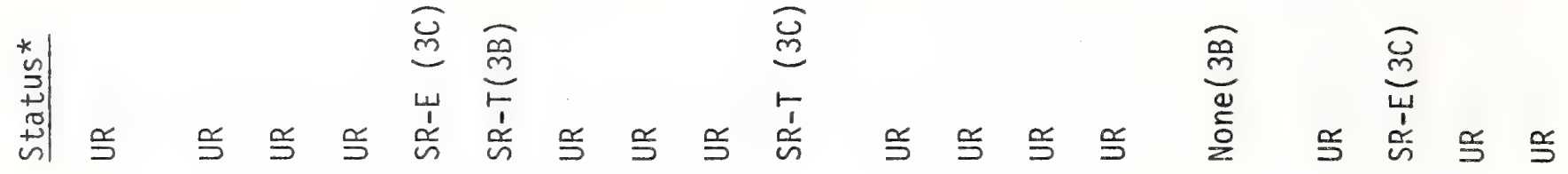

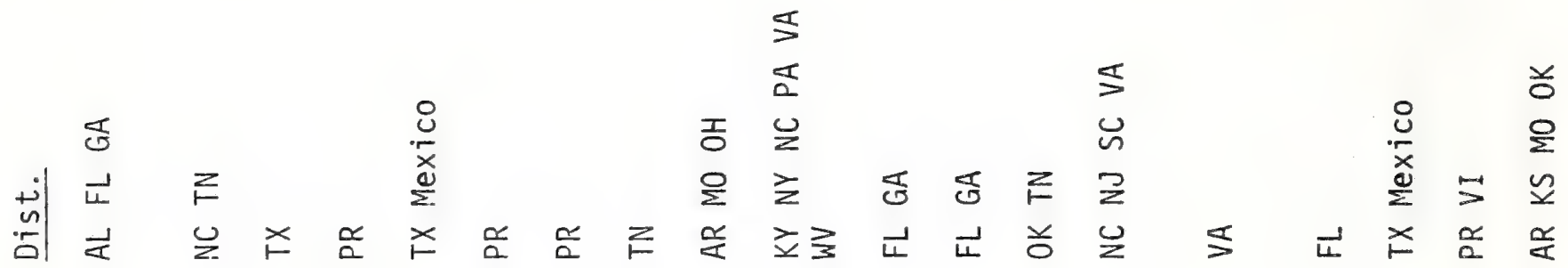

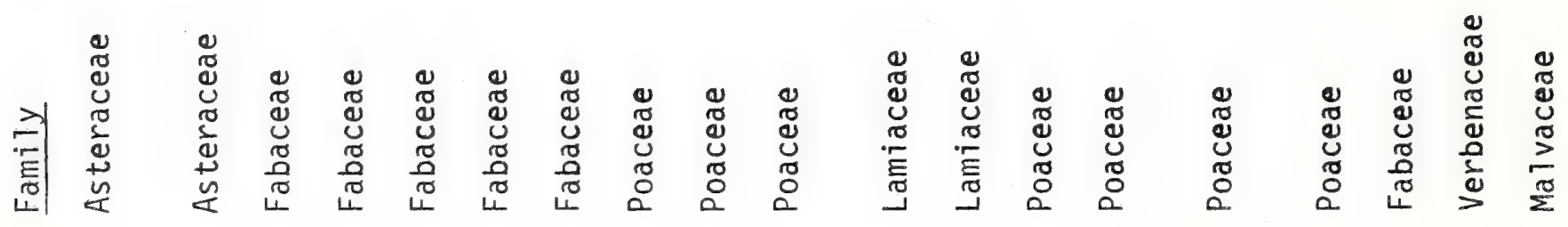

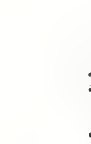

言

部

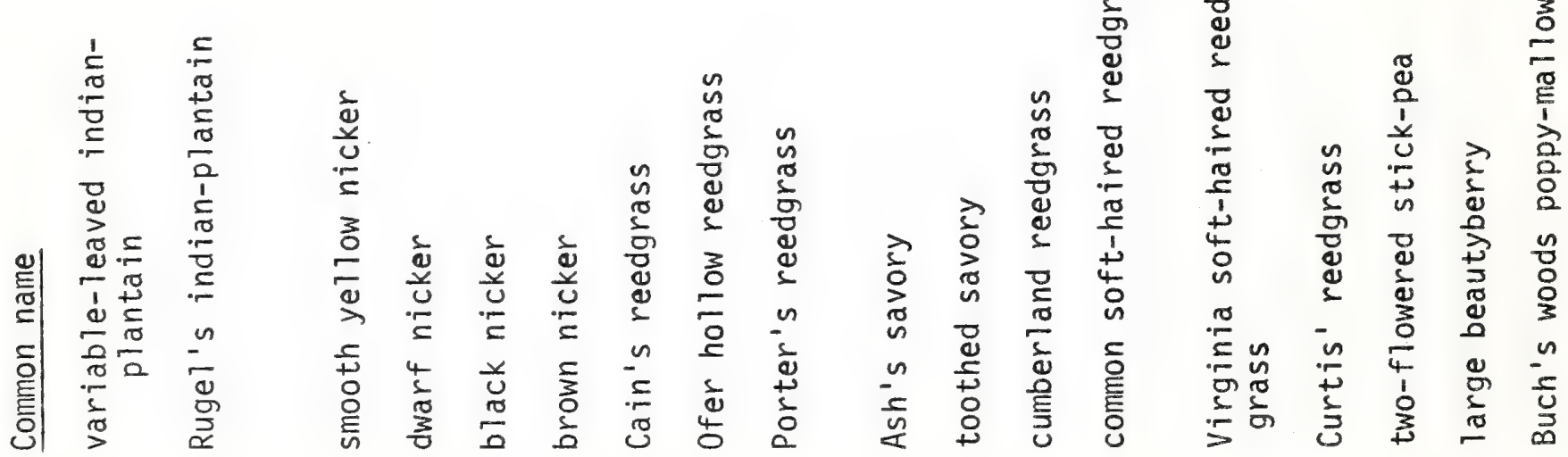

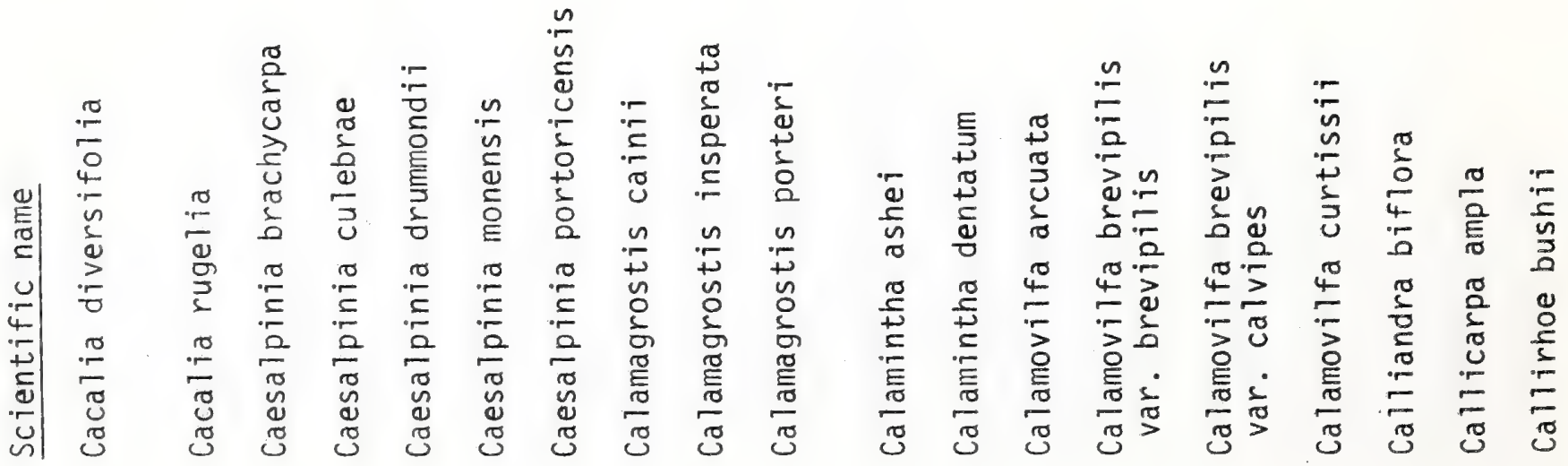




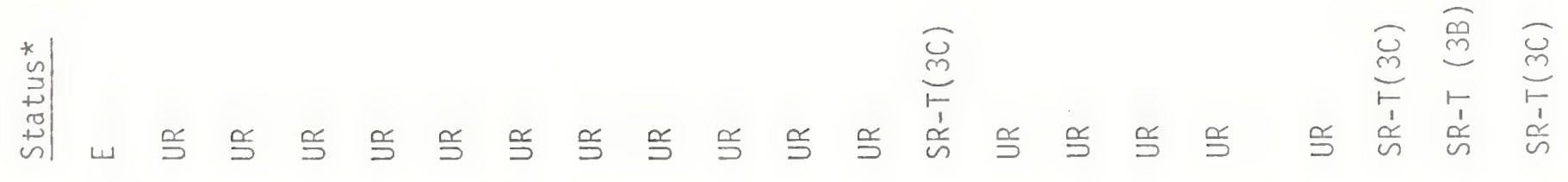

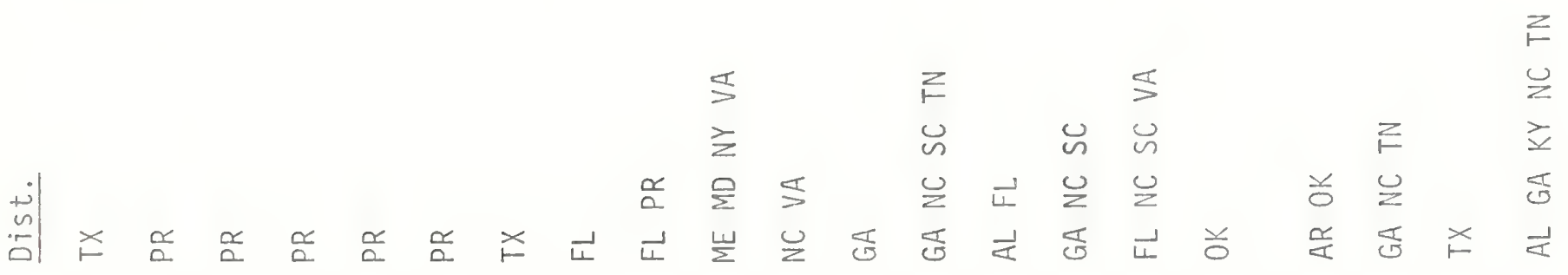

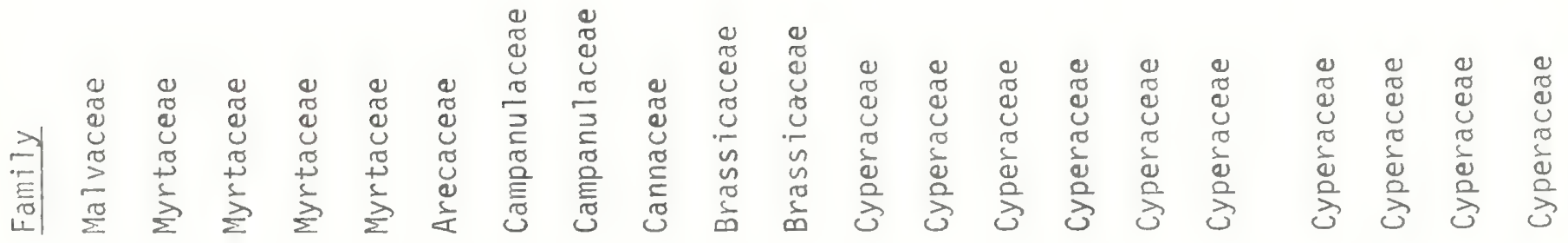

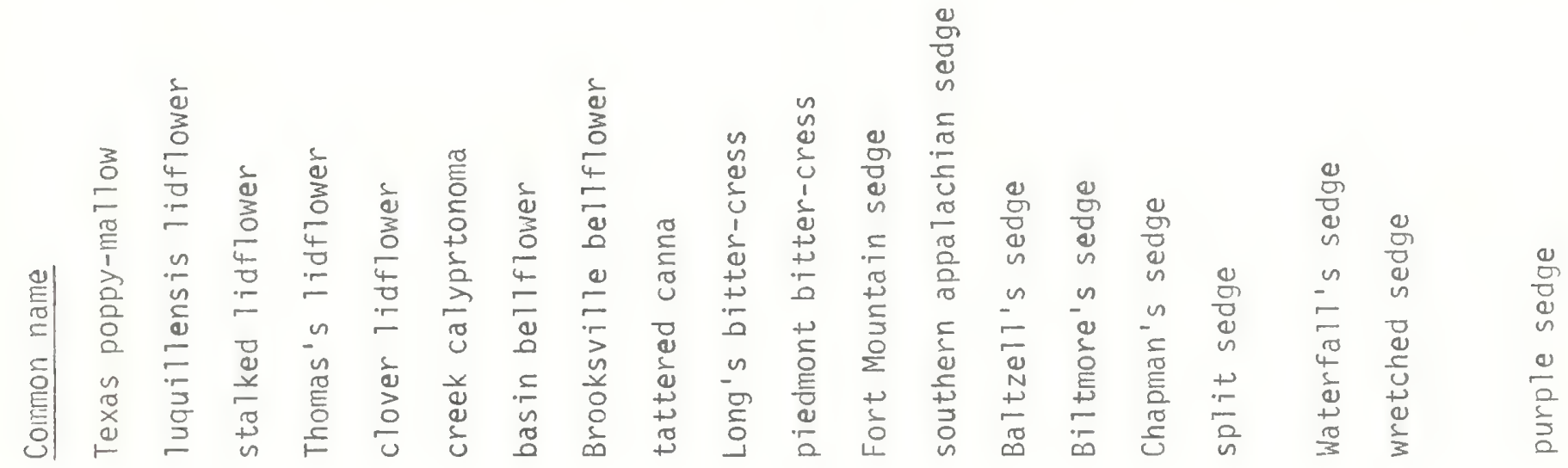

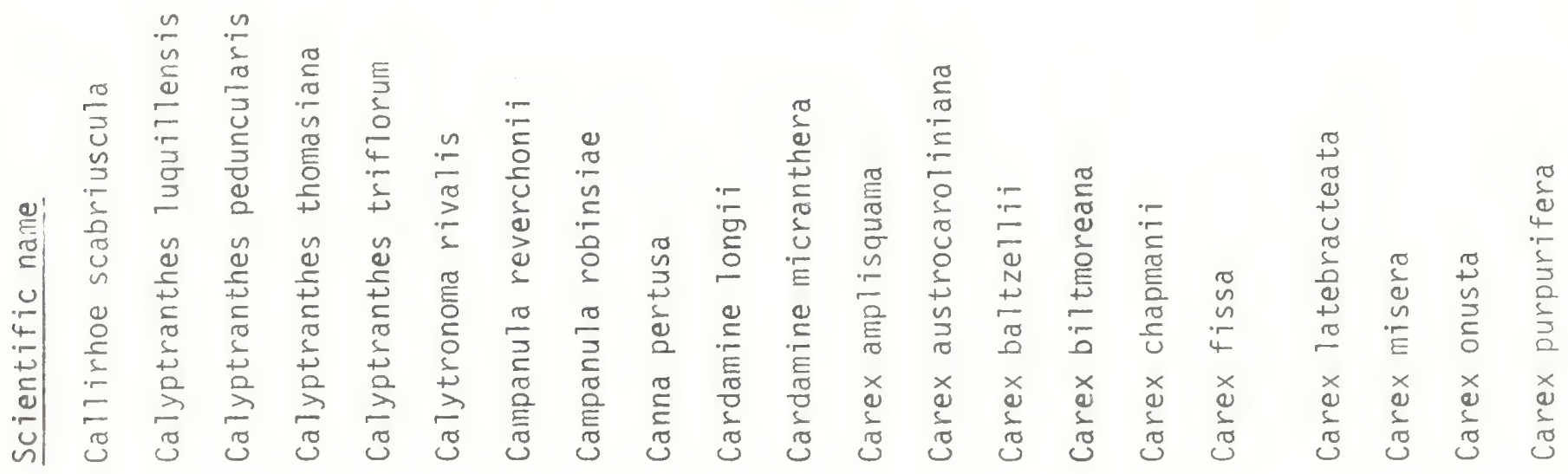




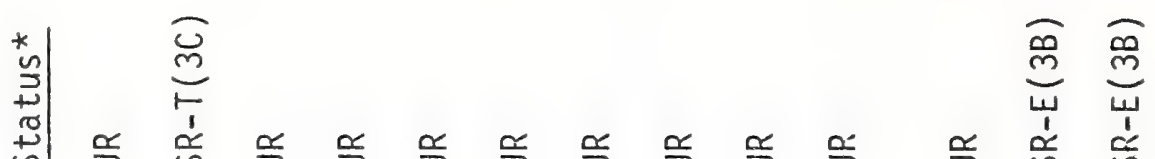

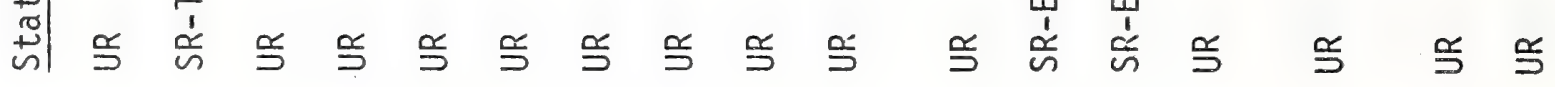

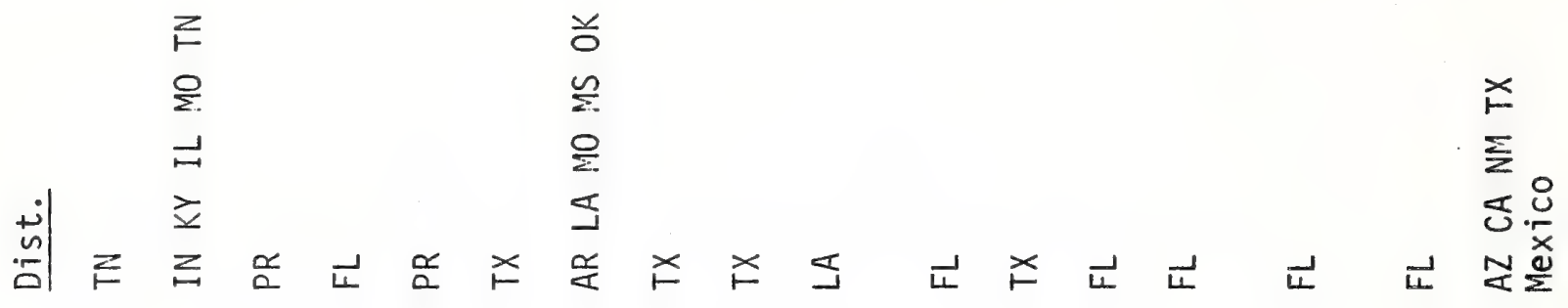

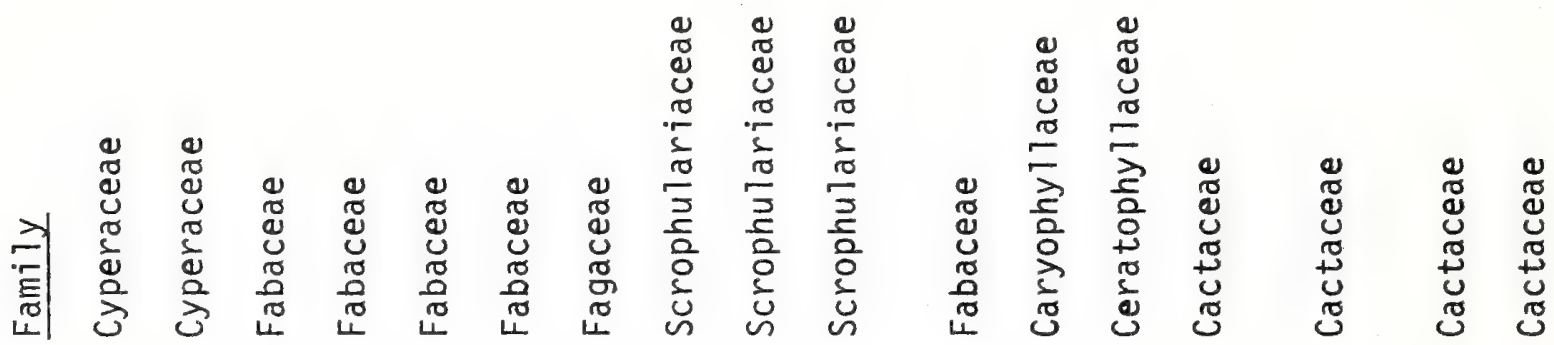

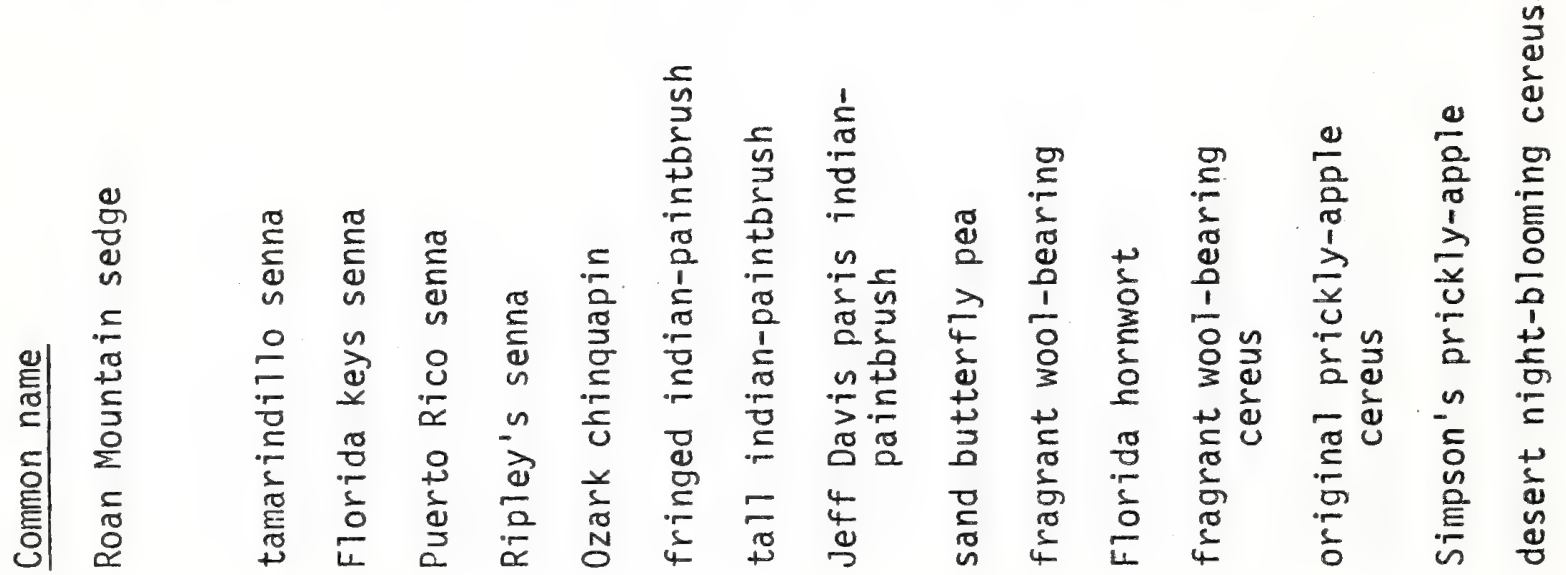

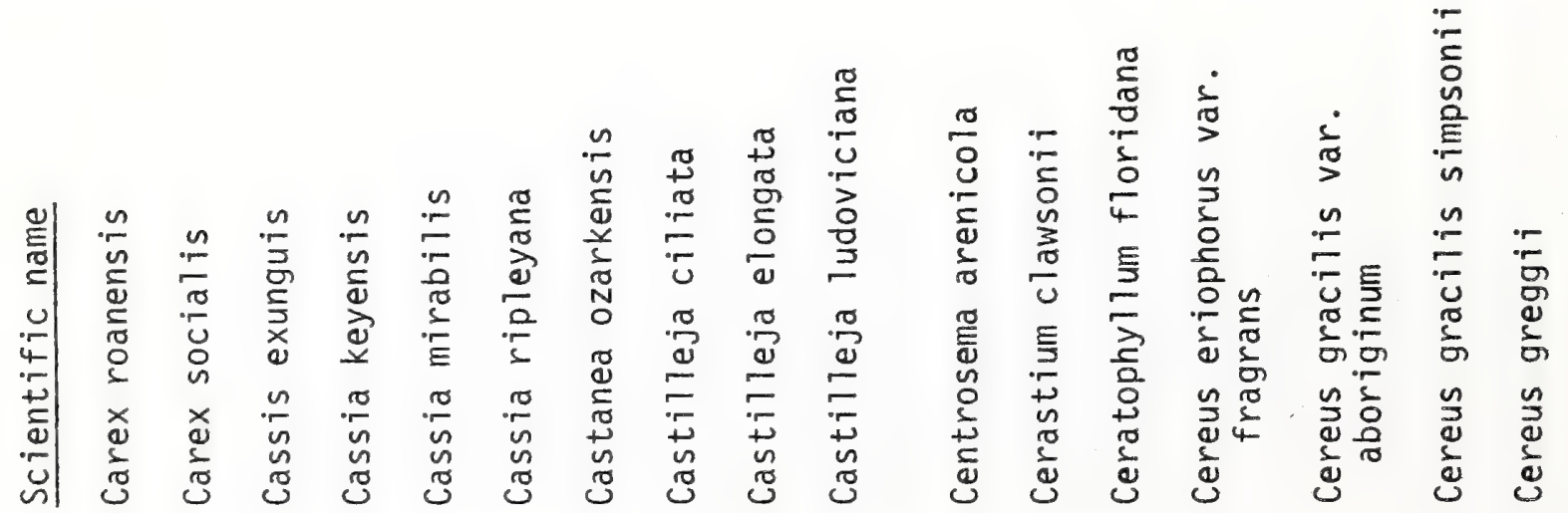


* क्ष<smiles>[CH]1CCC1</smiles>

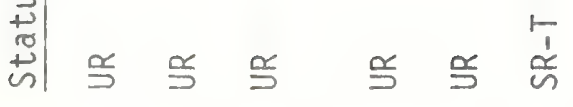

홍

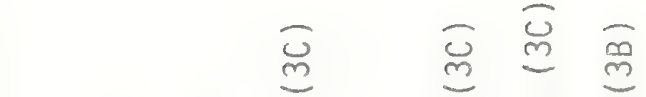

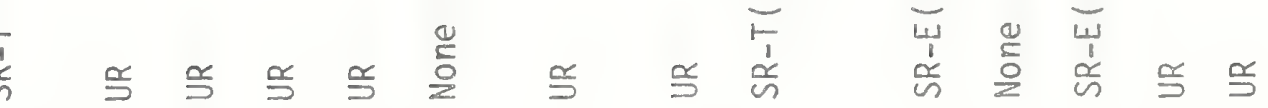

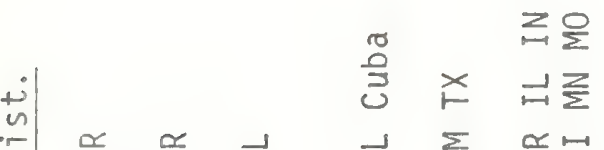

ע

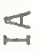

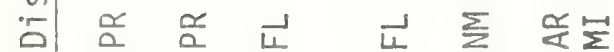

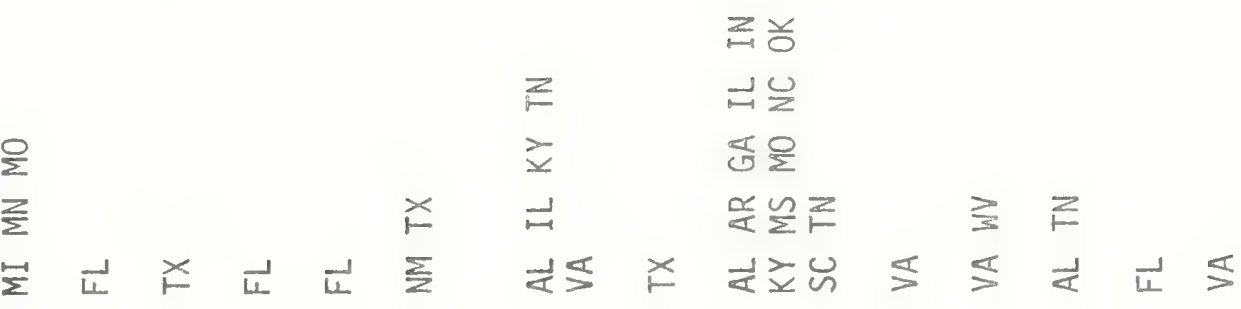

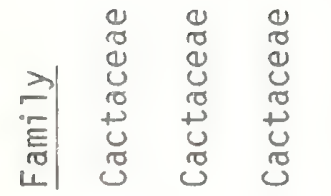

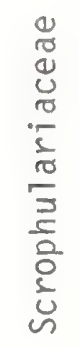

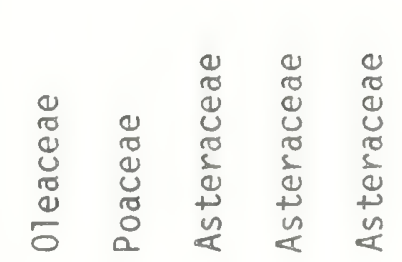<smiles>O=S(=O)=O</smiles>

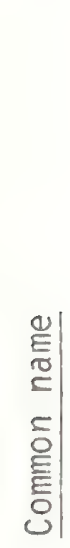

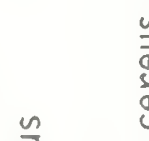

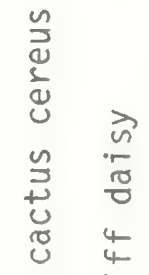

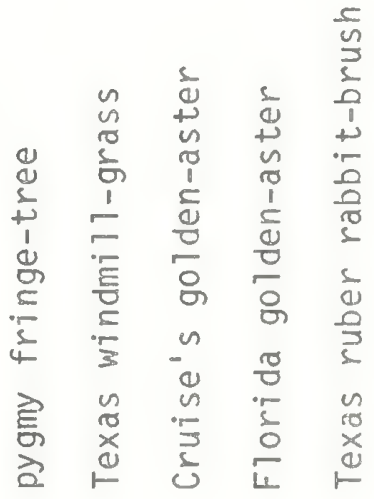

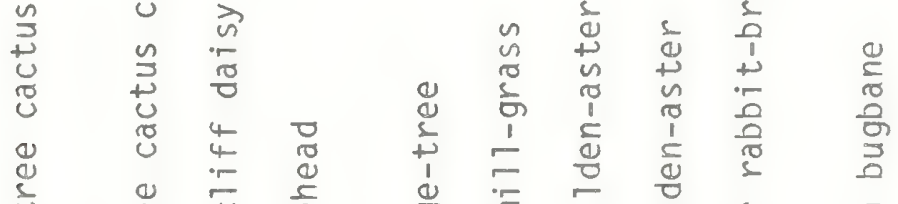

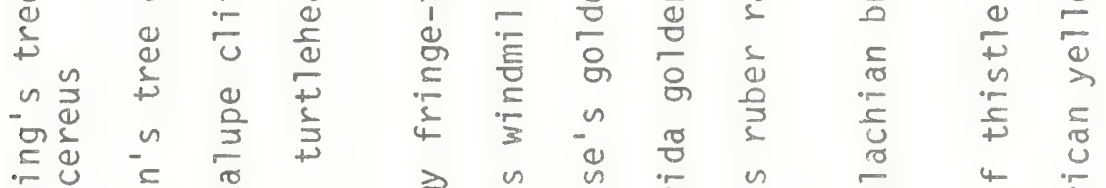

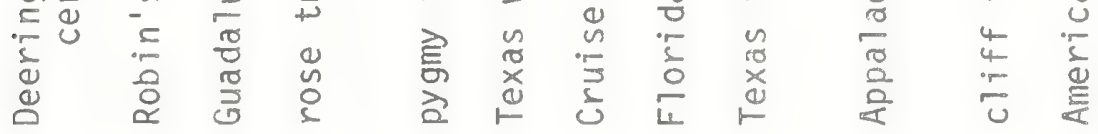

$$
\text { ○ }
$$

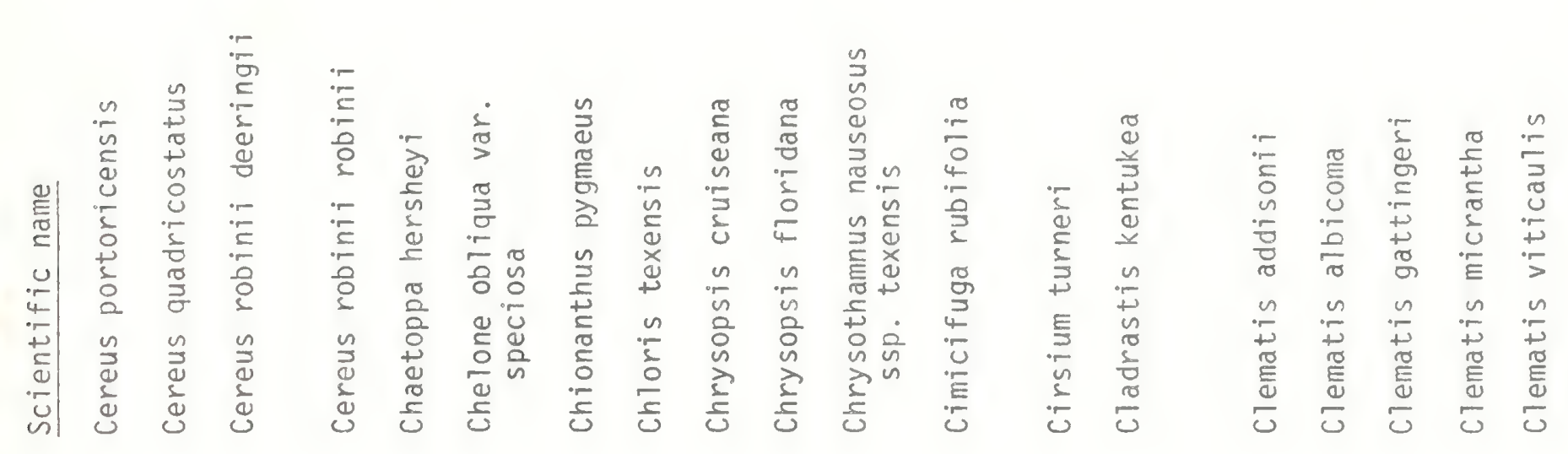

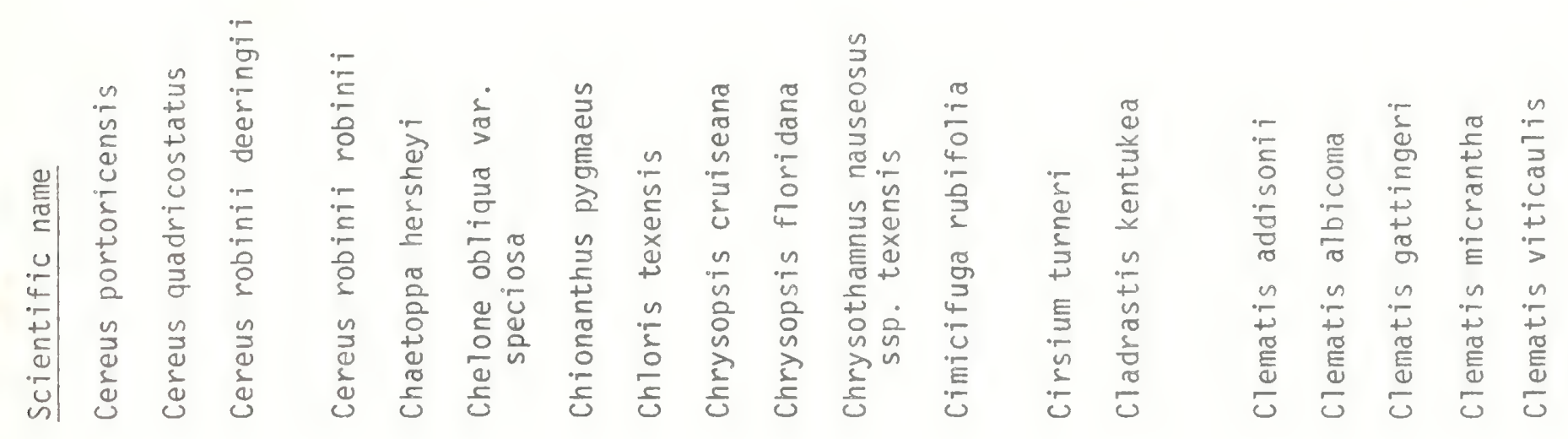




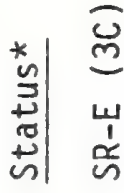

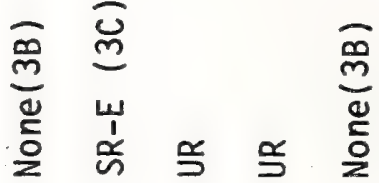

$\gtreqless$

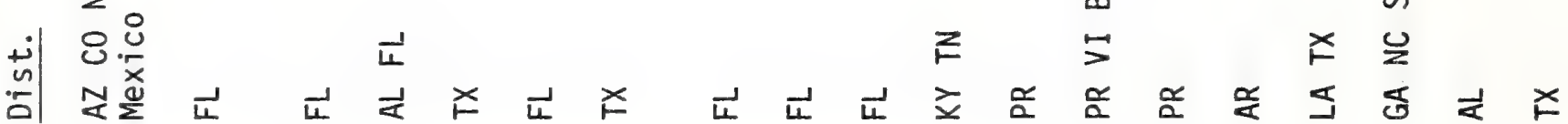

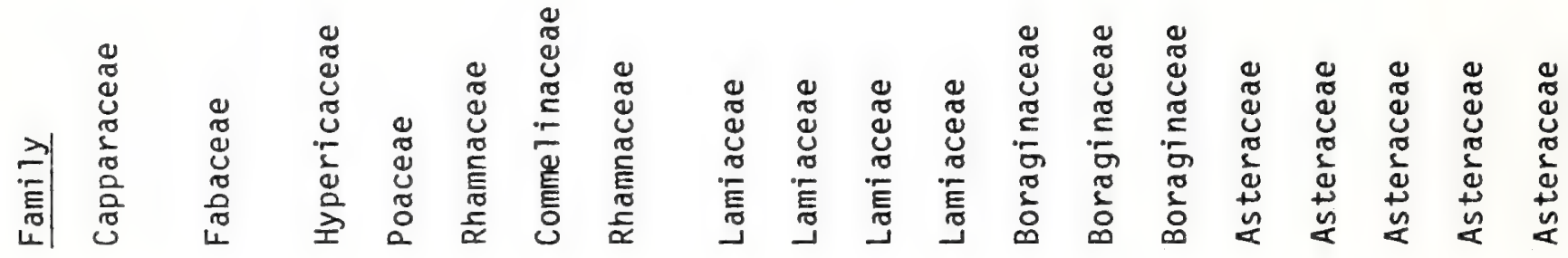

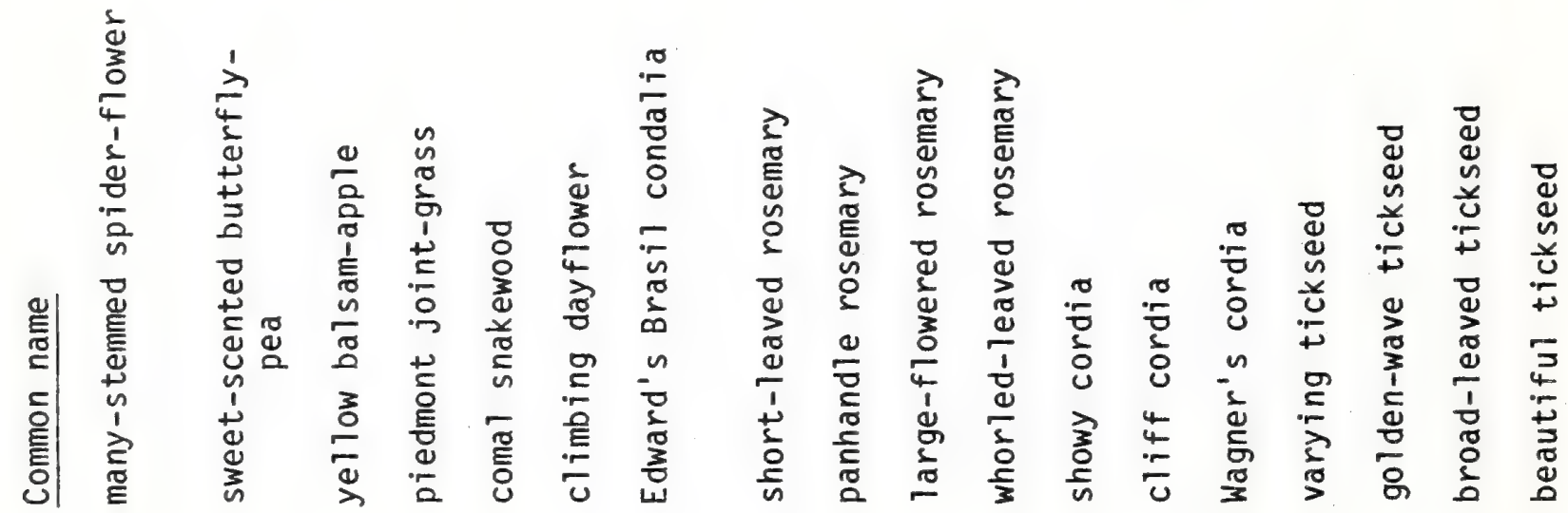

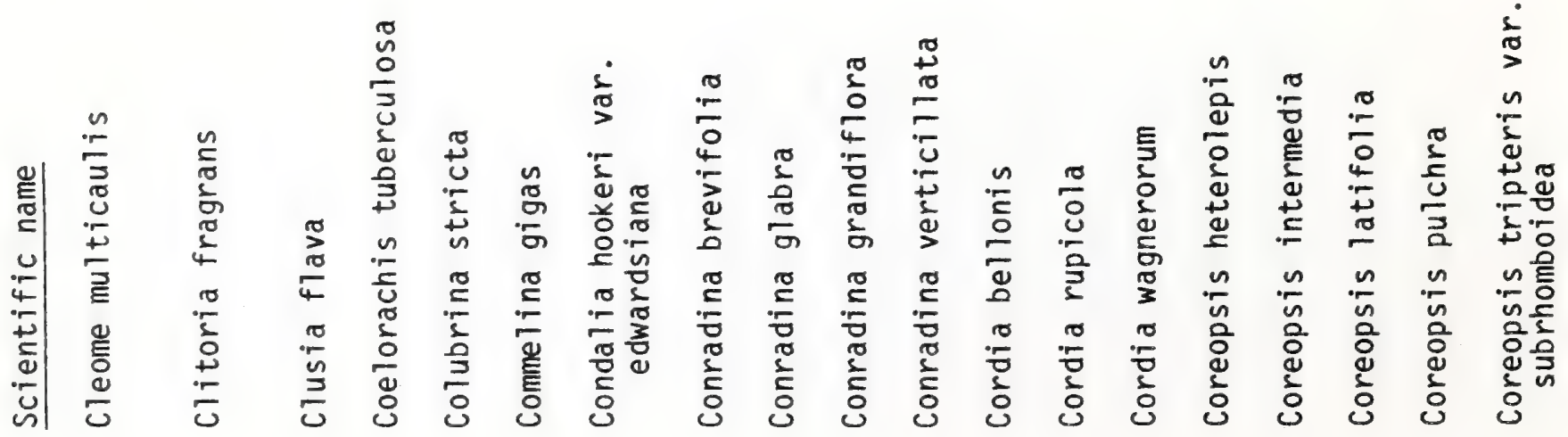


*

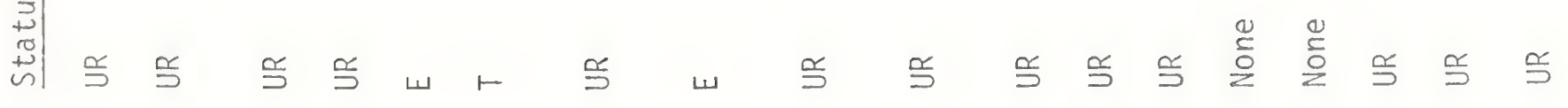

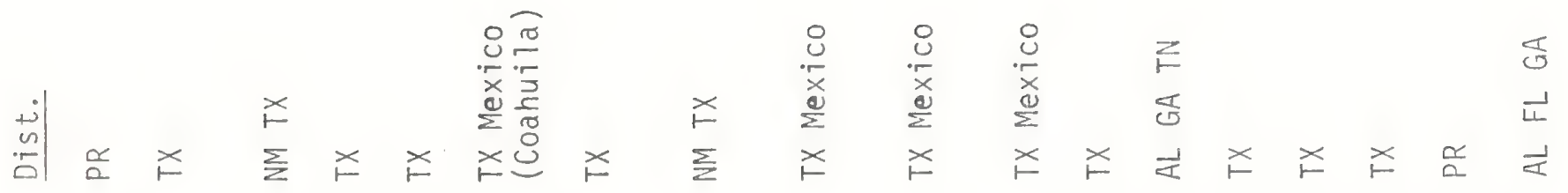

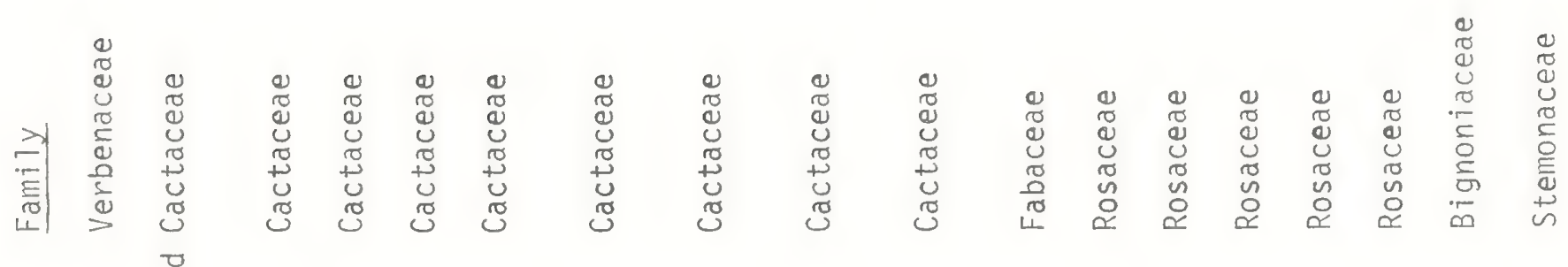

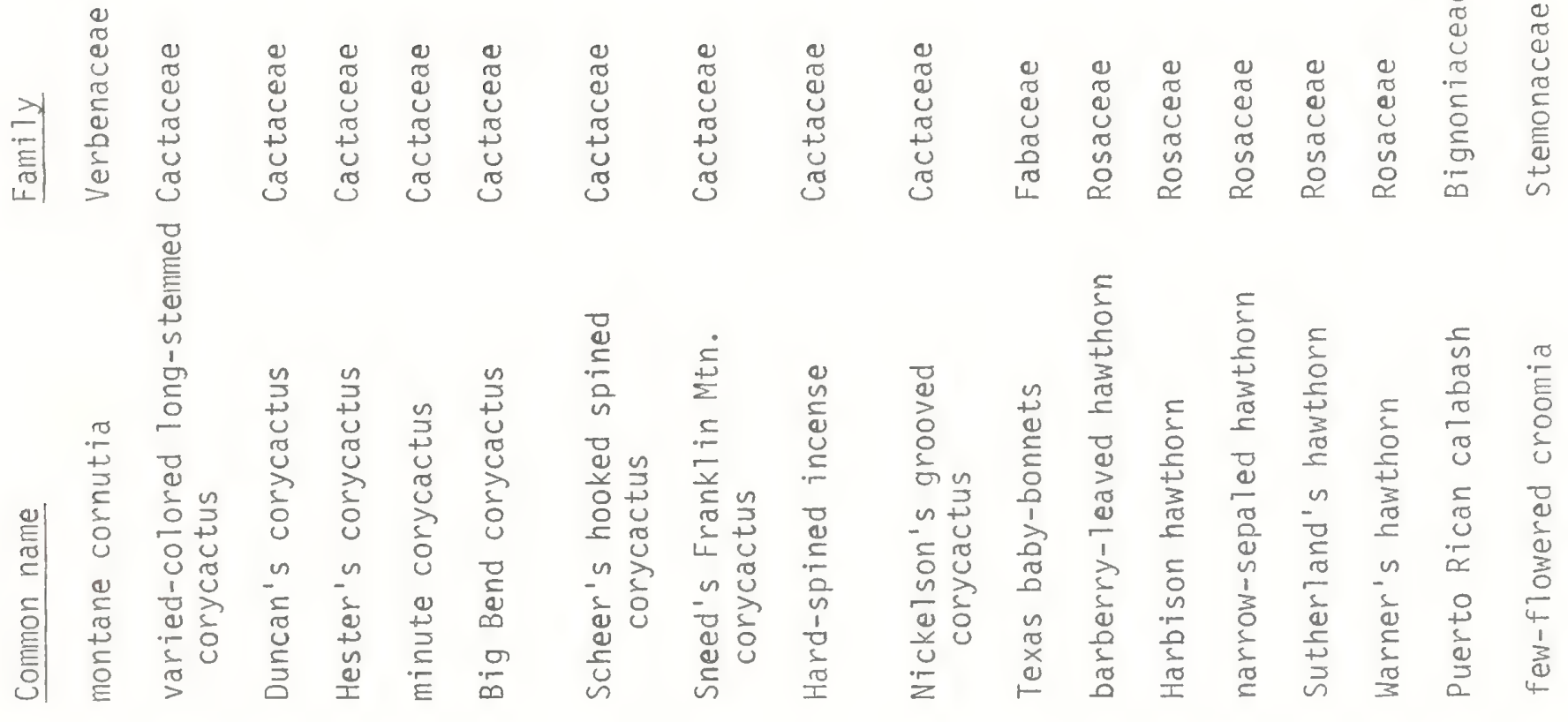

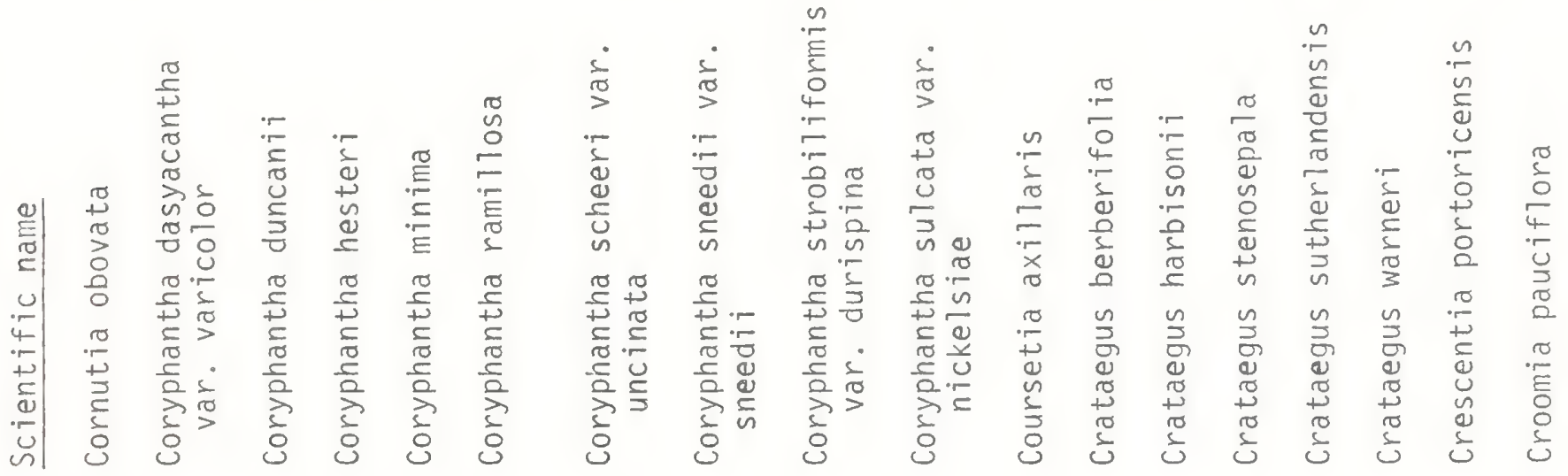




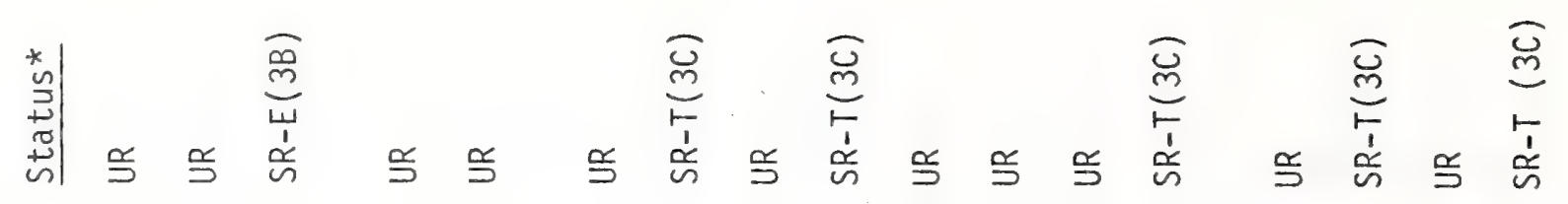

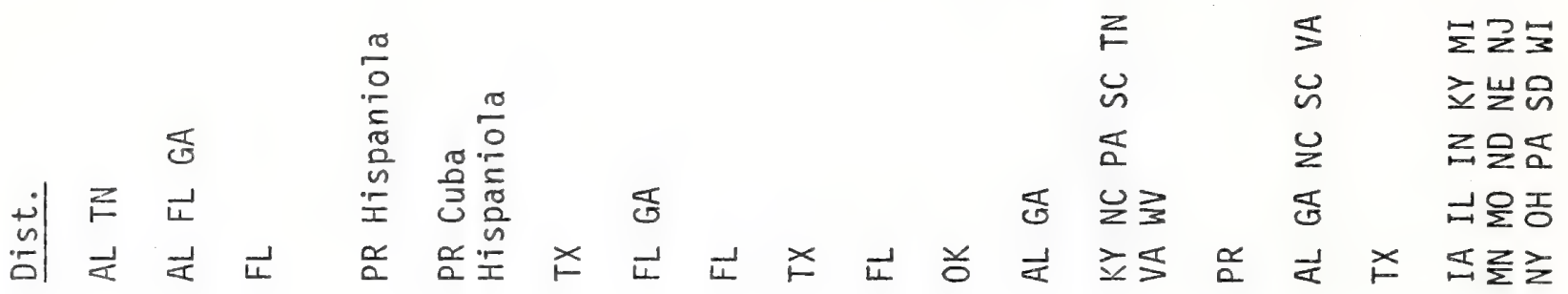

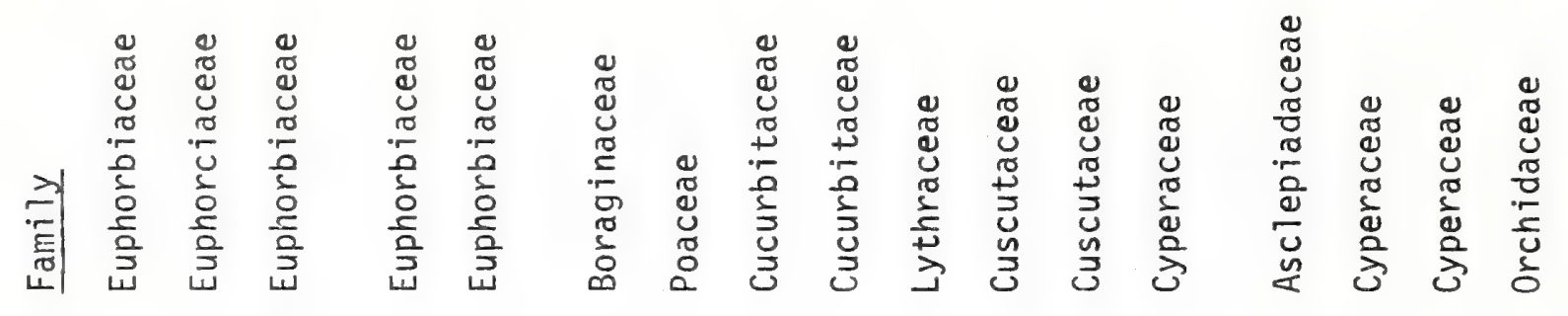

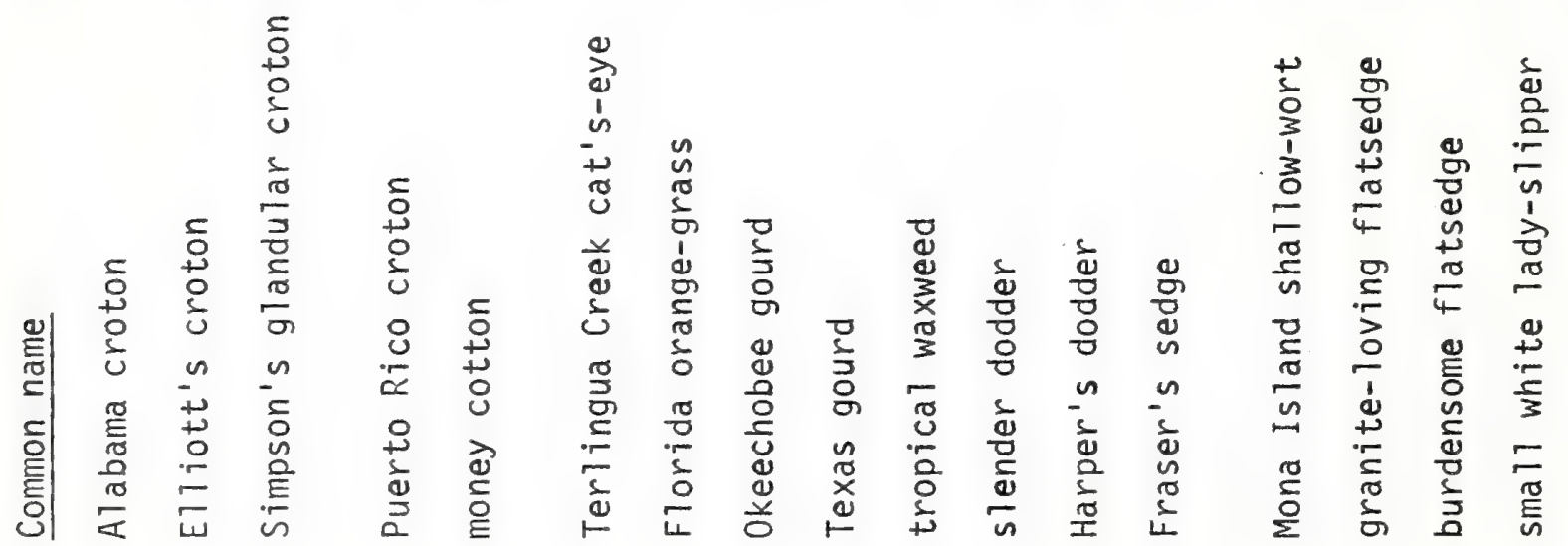

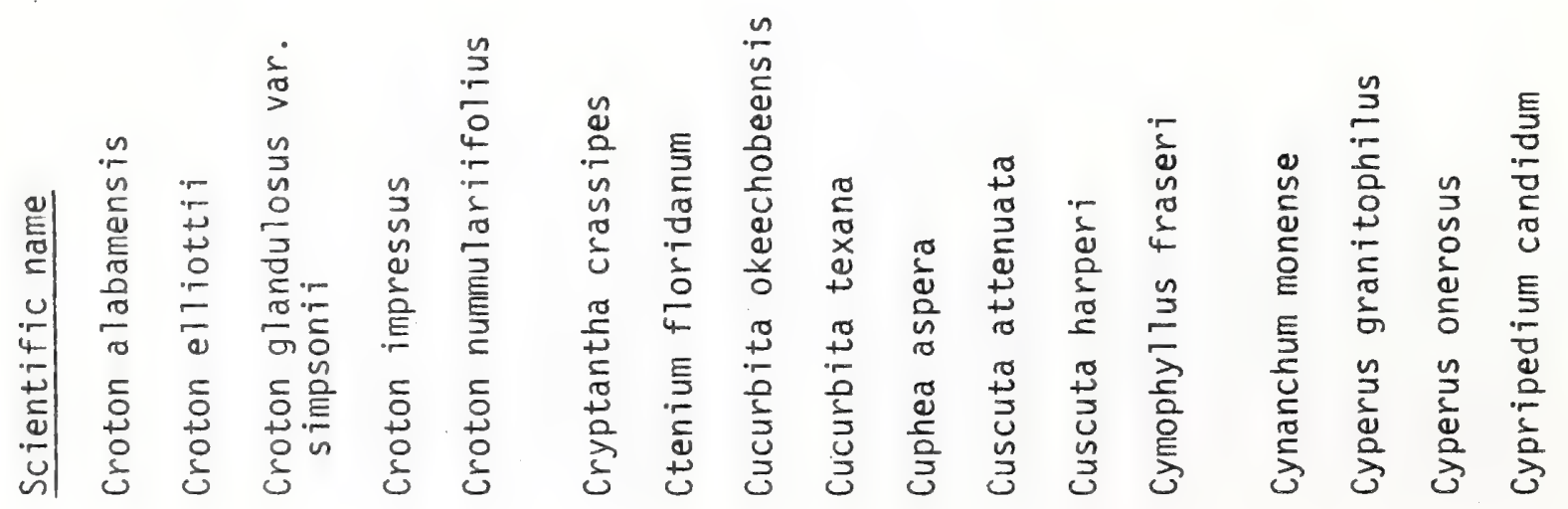




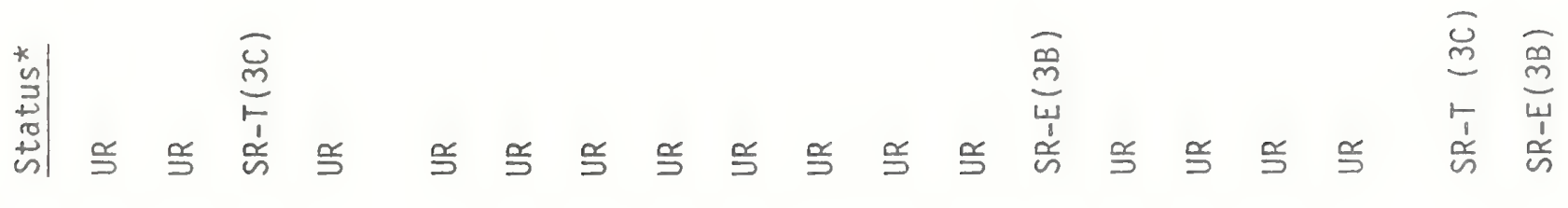

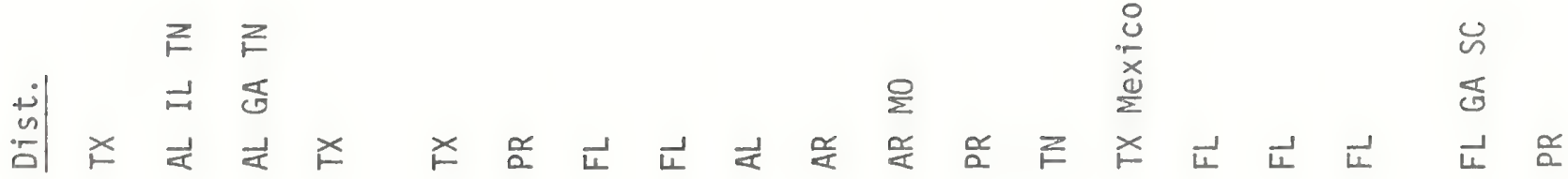

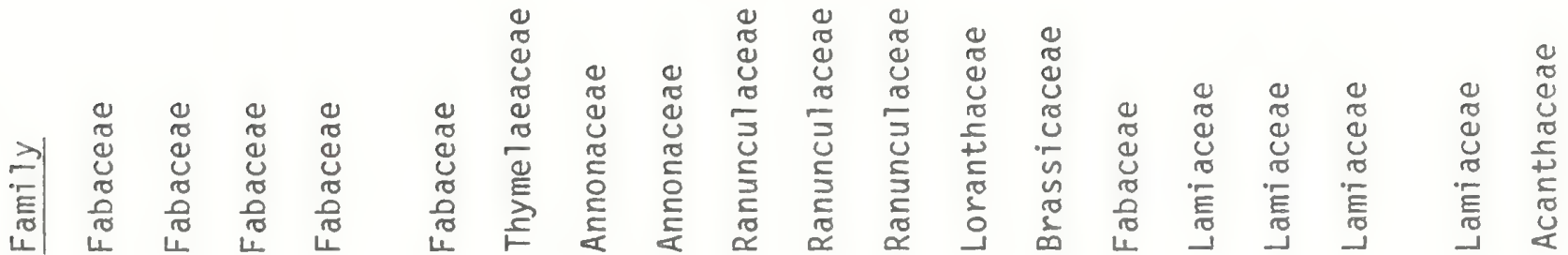

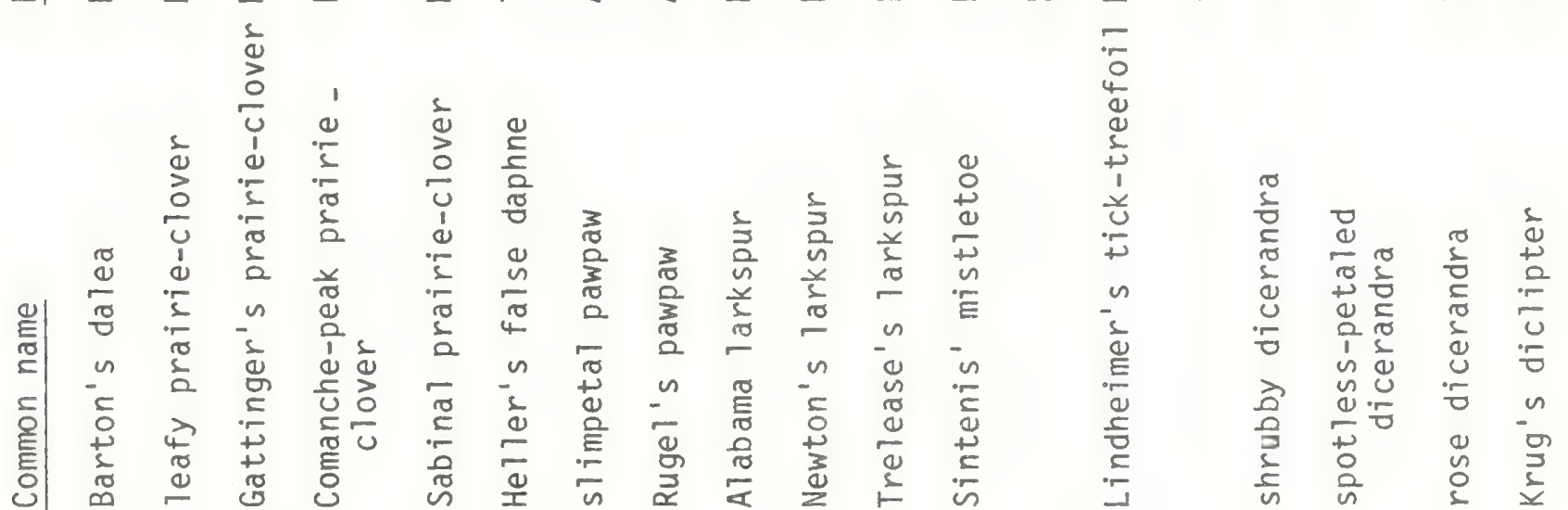

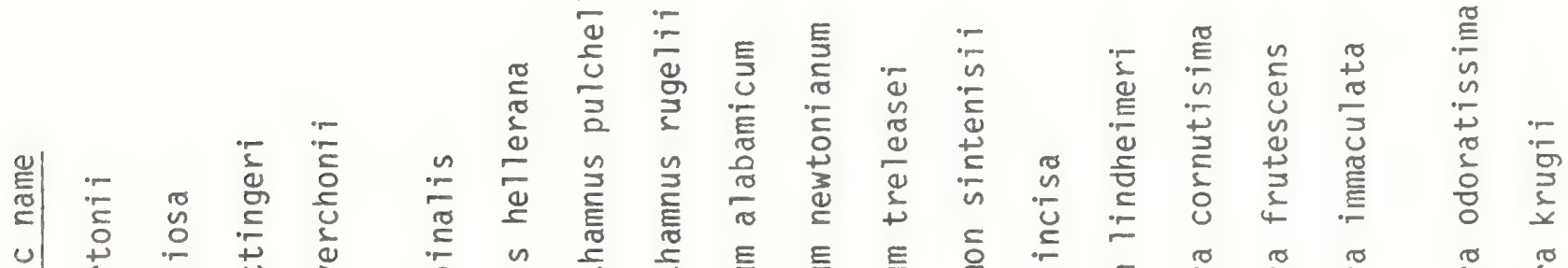

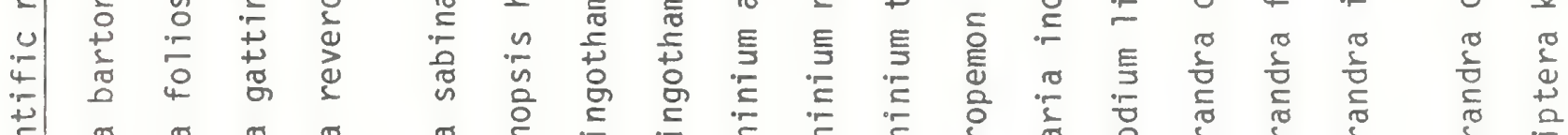

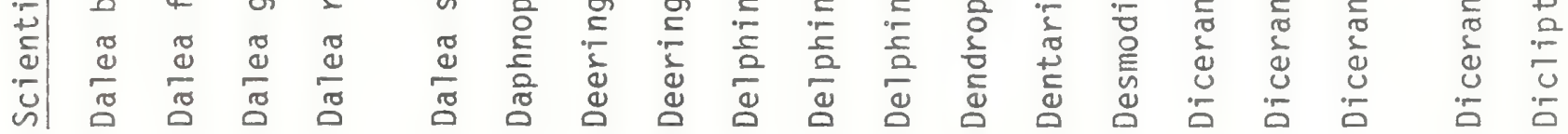


离|

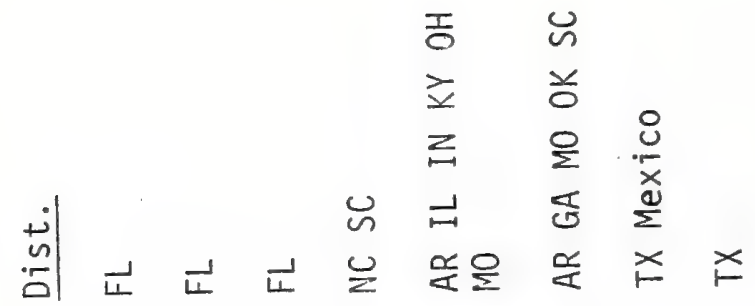

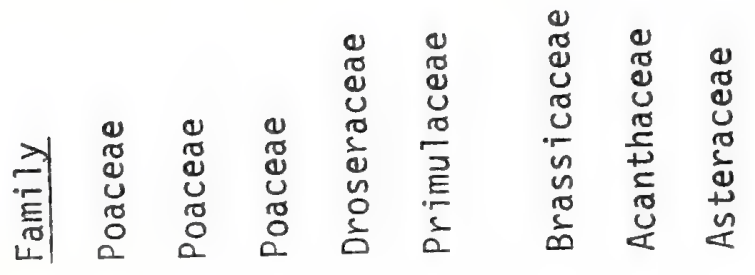

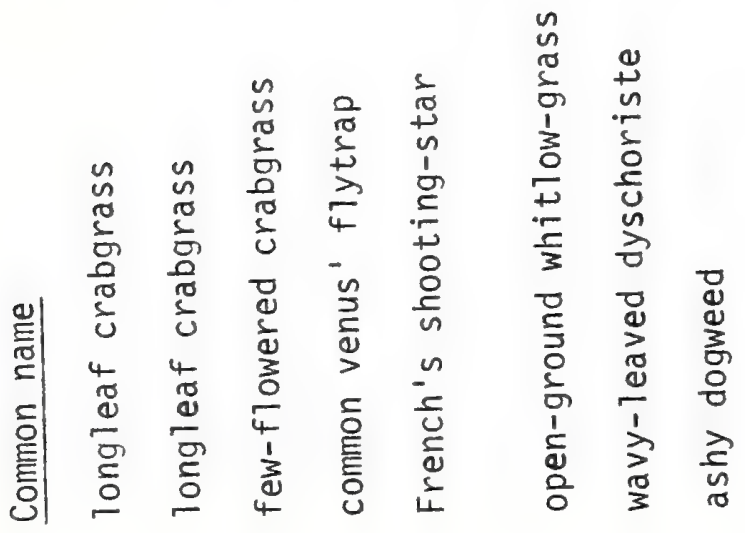

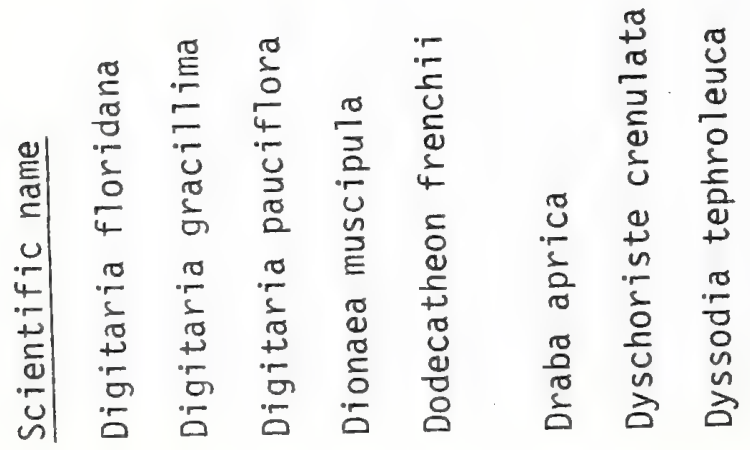


部。

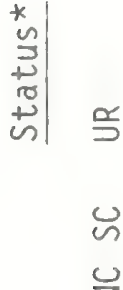

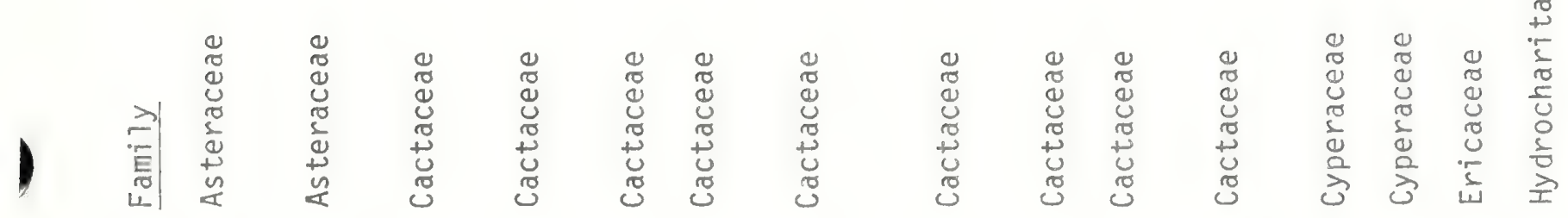

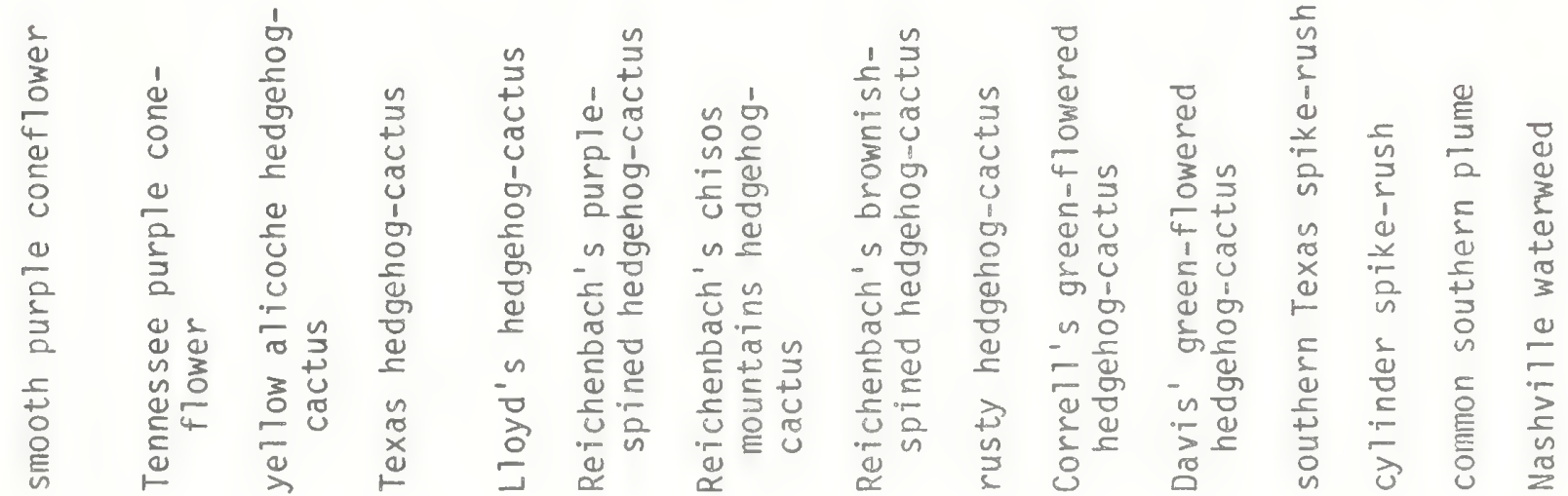

)

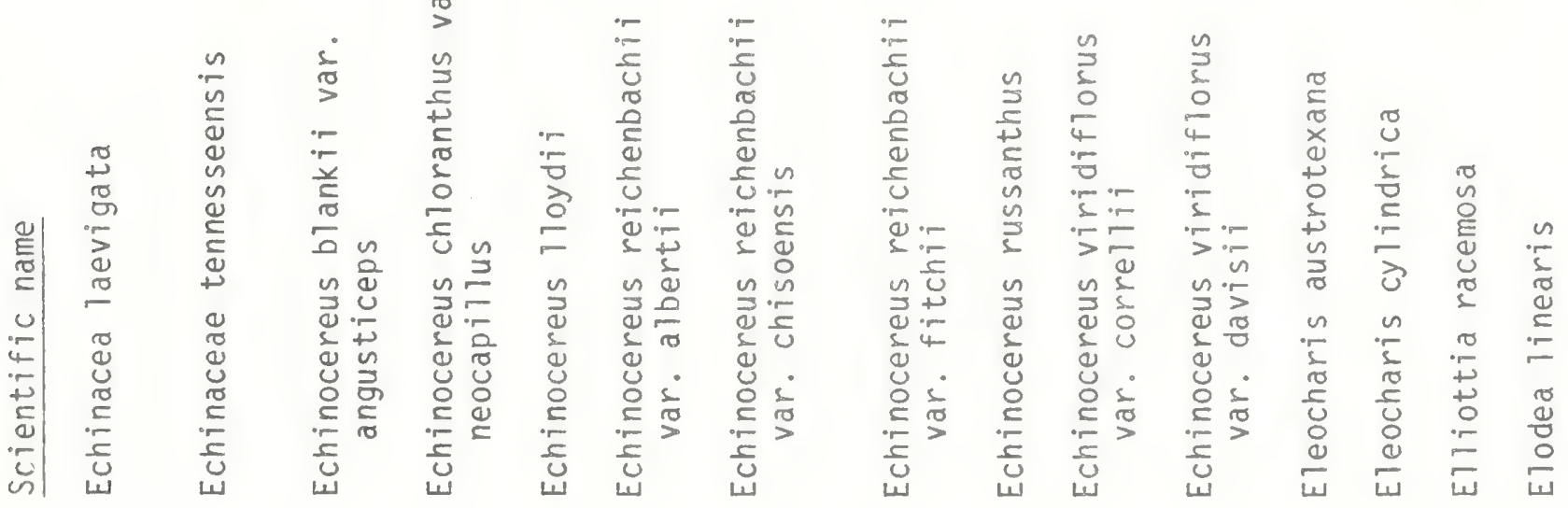




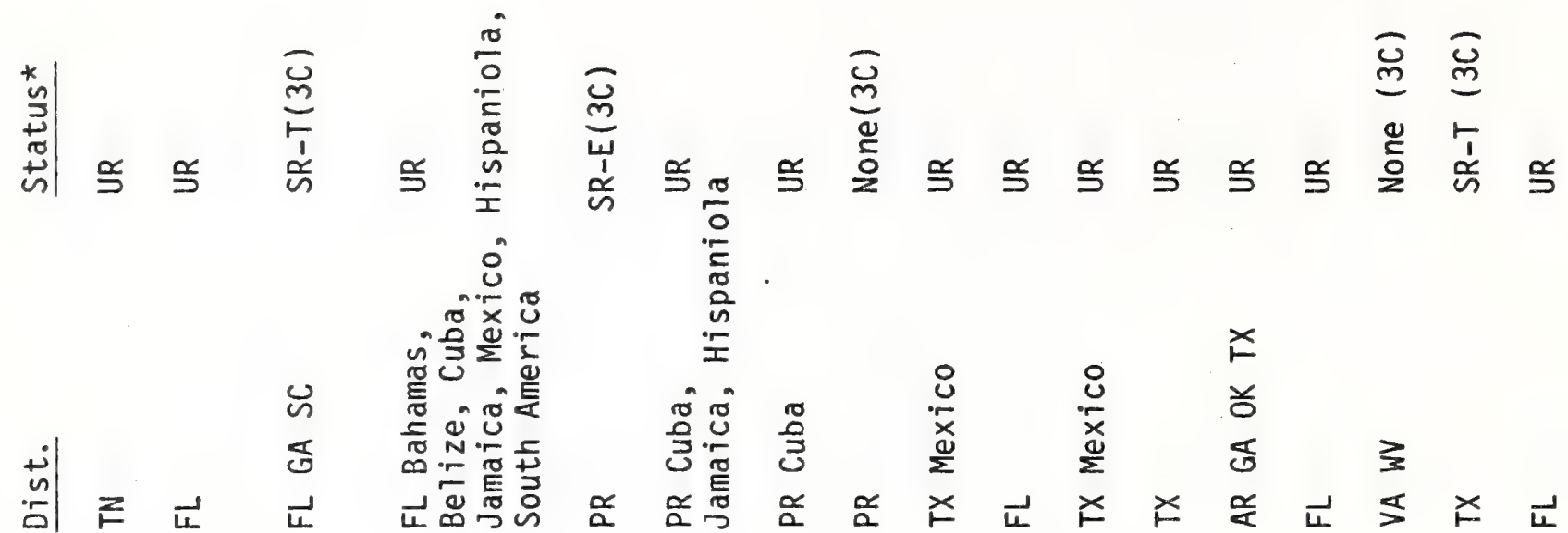

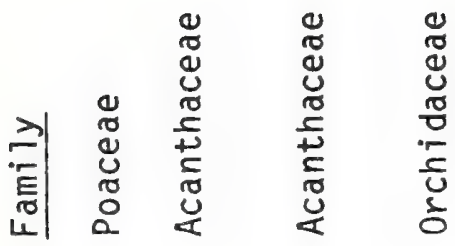

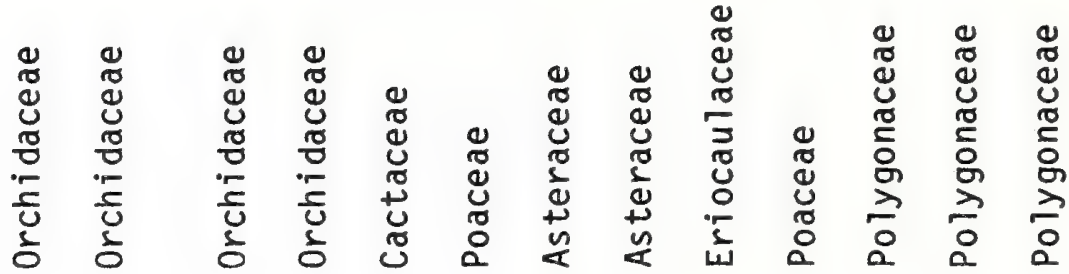

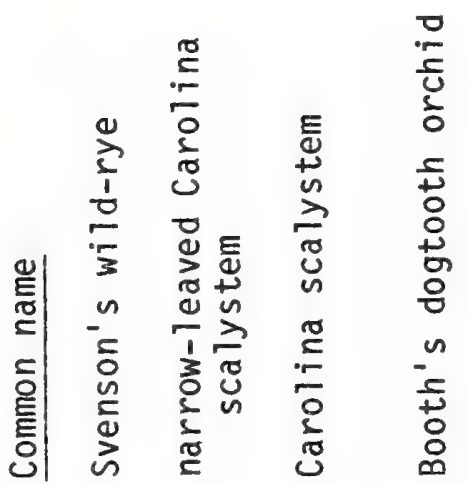

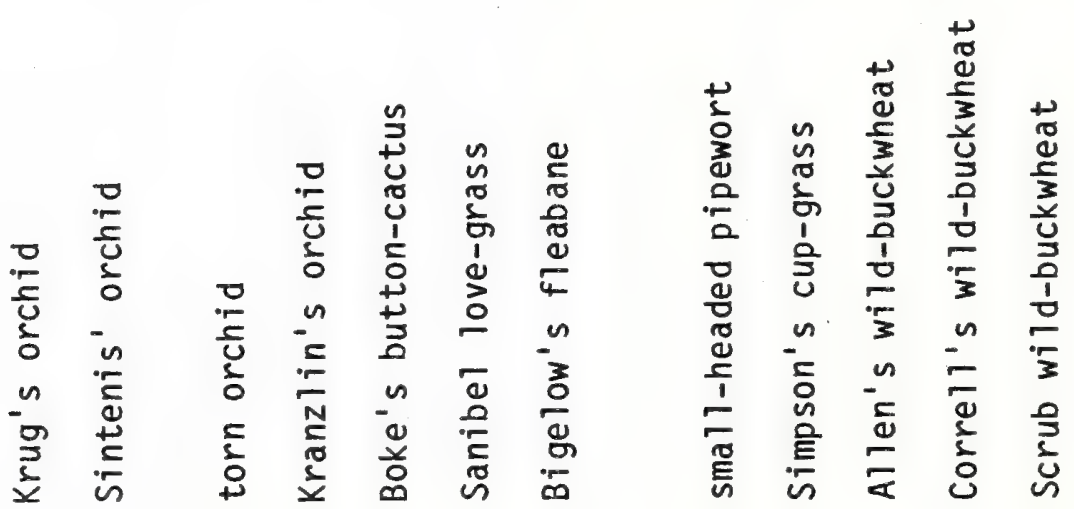

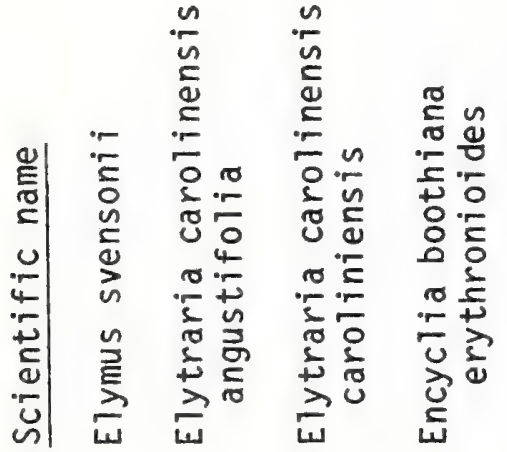

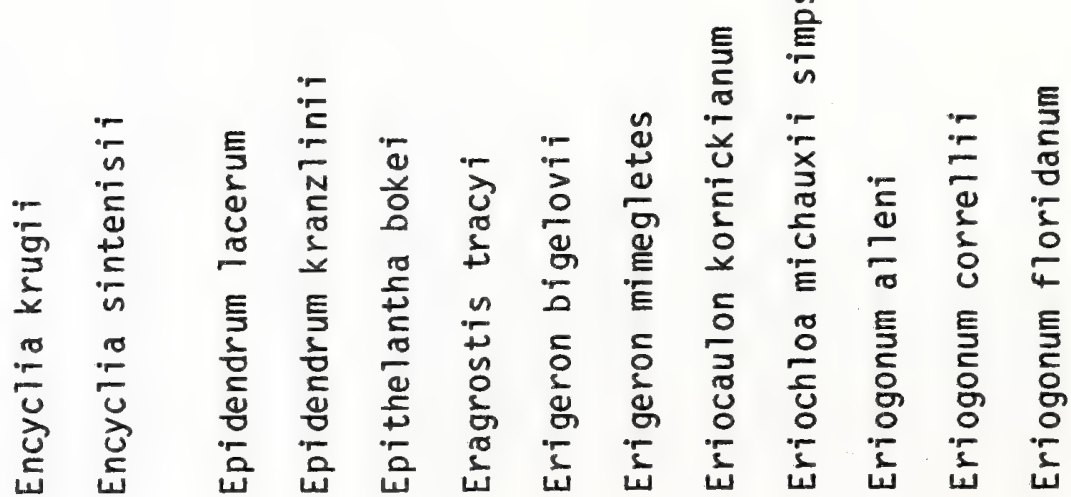




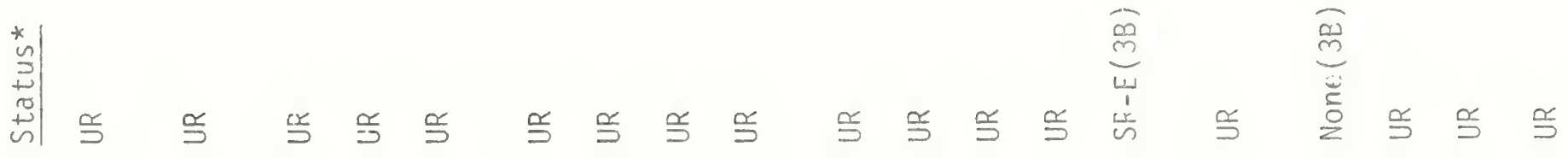
us 논

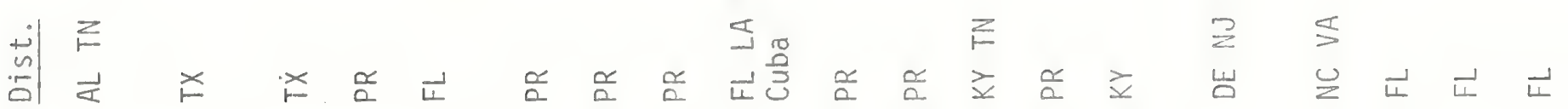
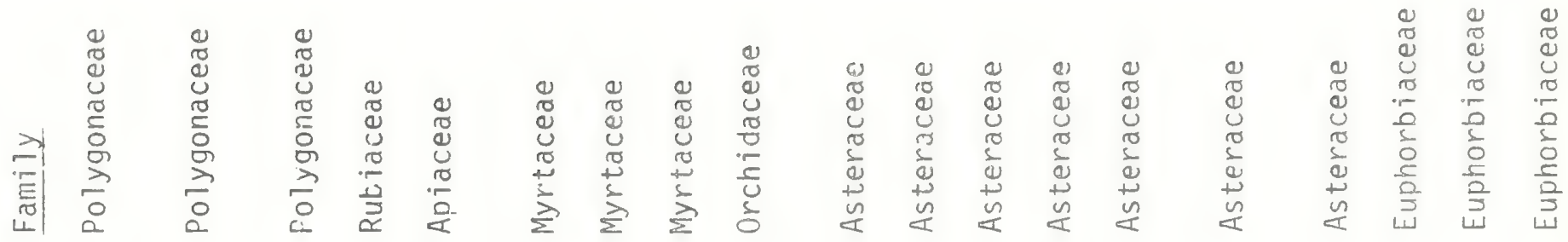

$\frac{1}{\frac{1}{3}}$

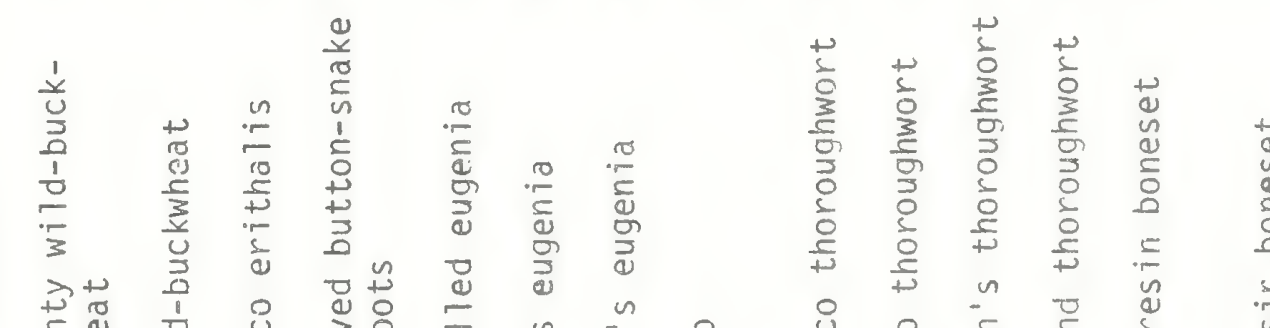

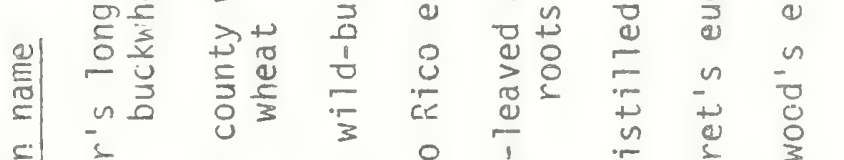

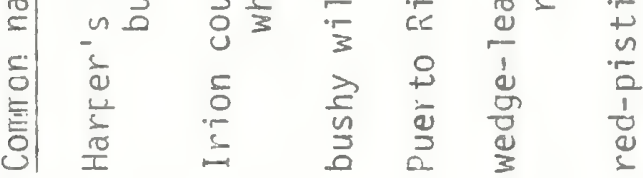

部咅

:

递

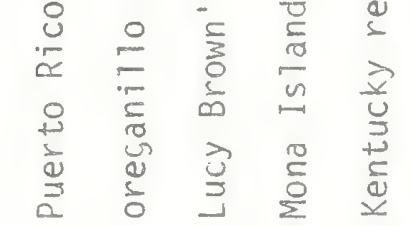

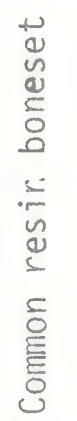

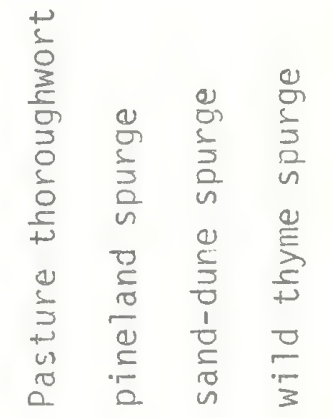

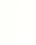

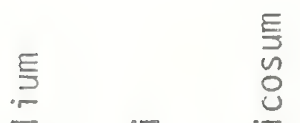
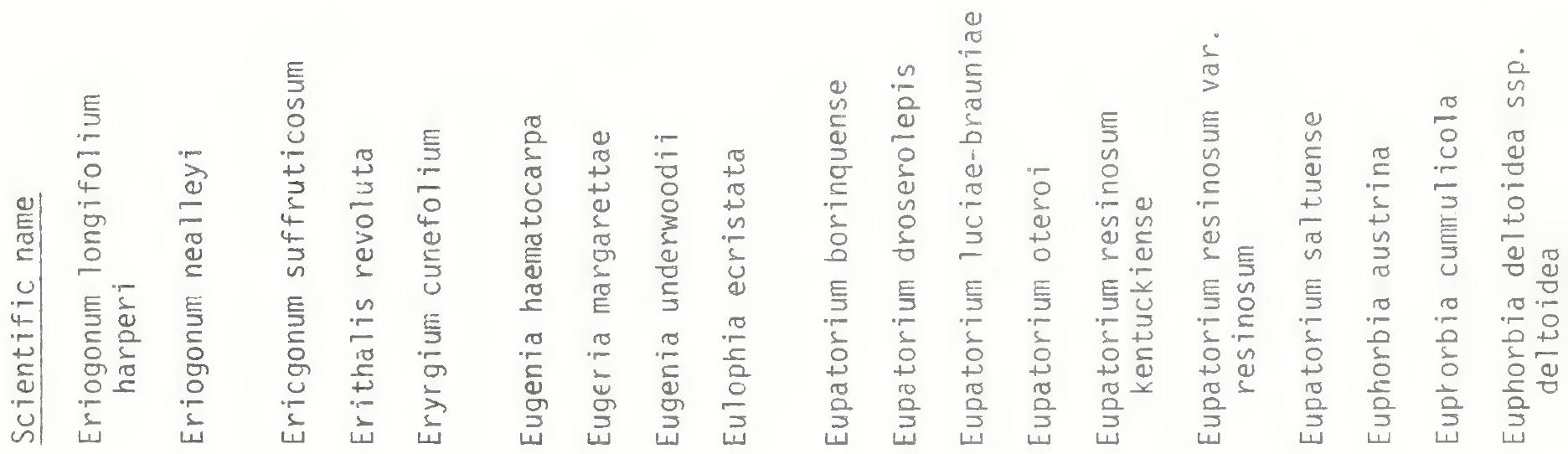


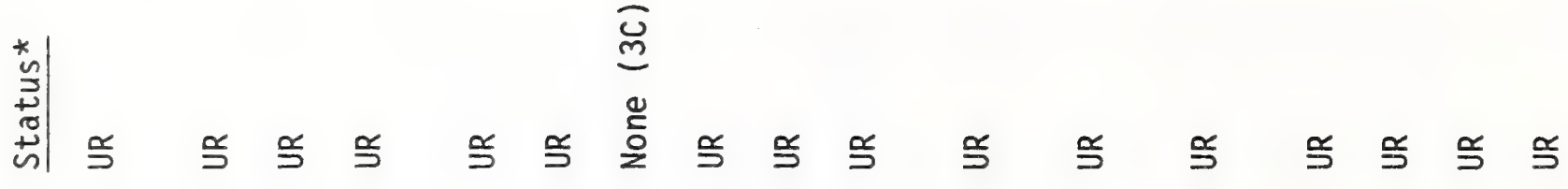

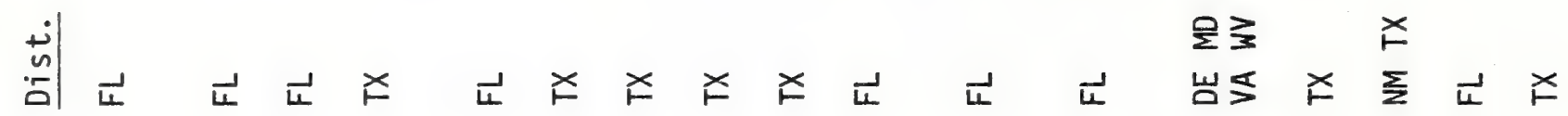

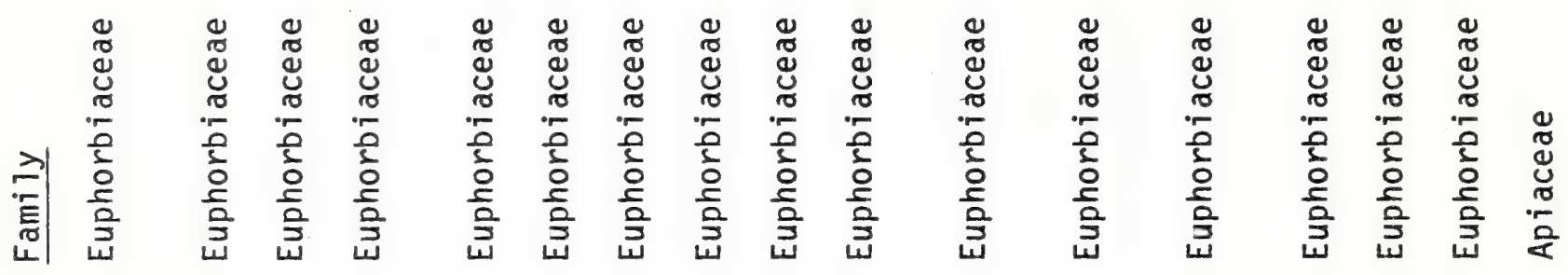

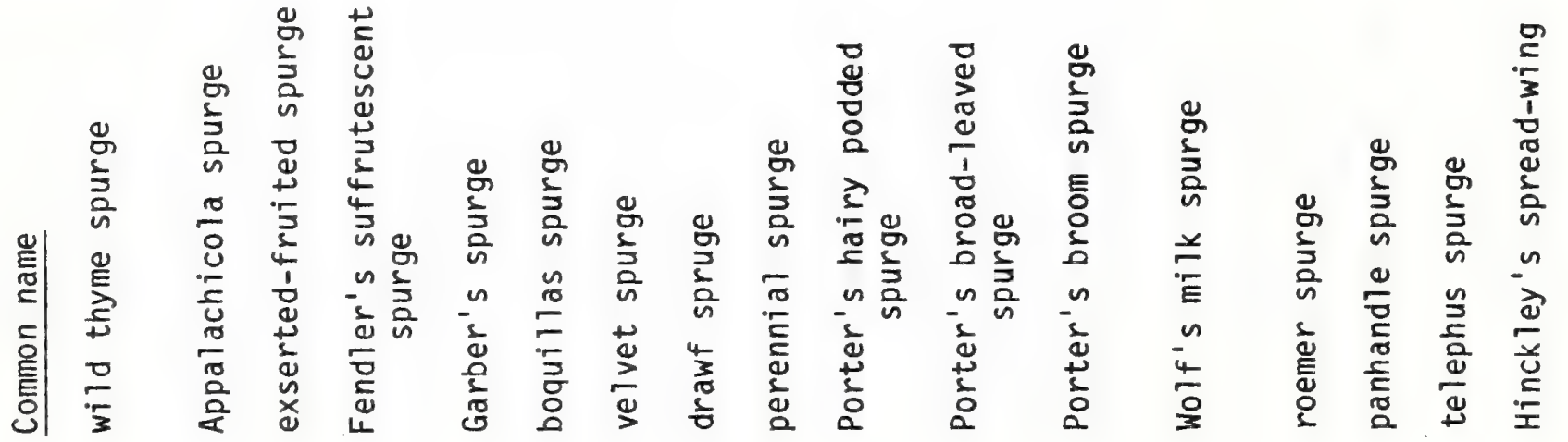

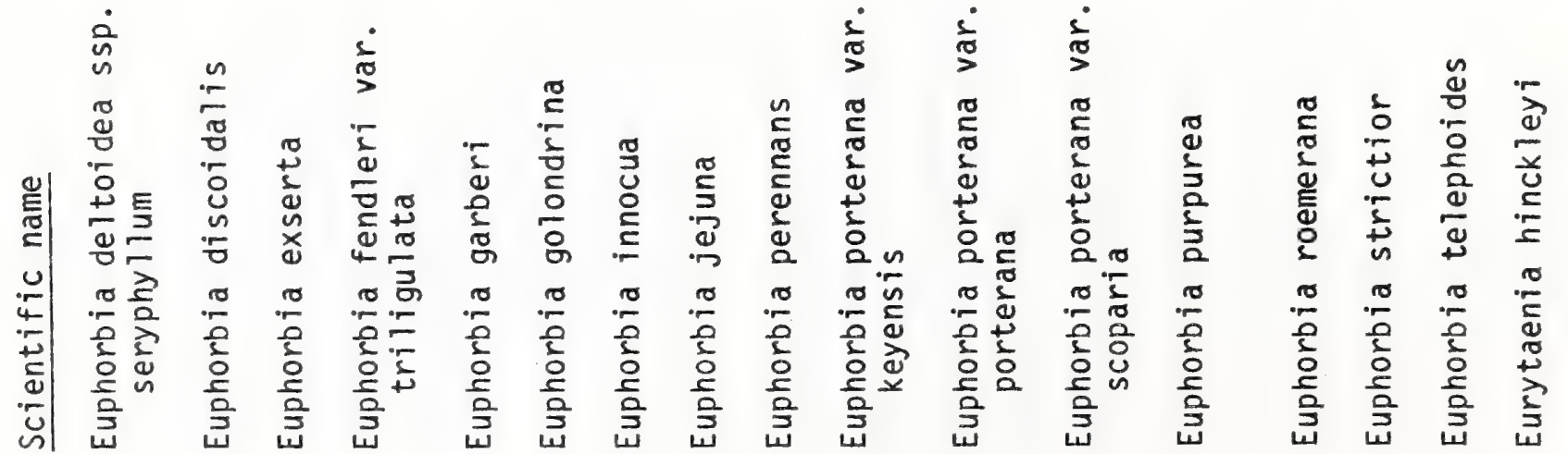


$\begin{array}{ccc}+ & \\ \frac{+}{2} & & \\ 0 & \infty & \infty\end{array}$

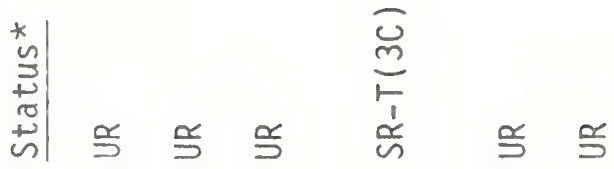

닌

$\sum$

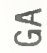

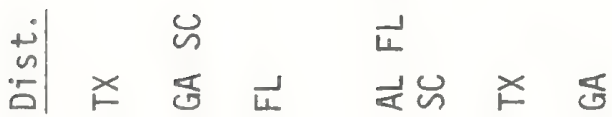

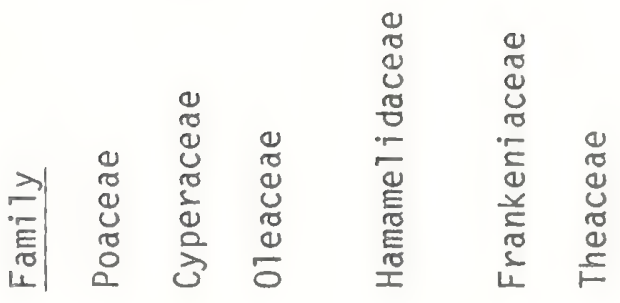

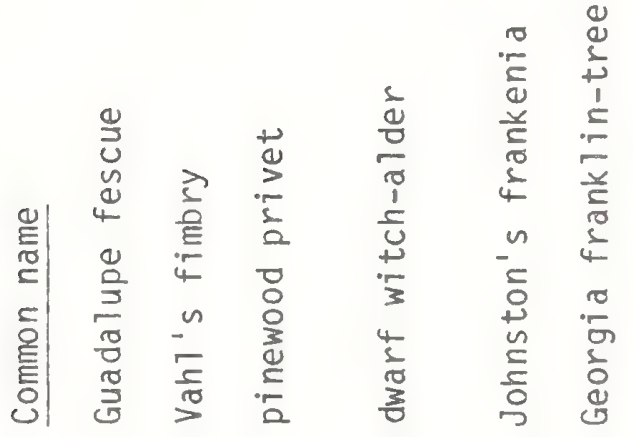

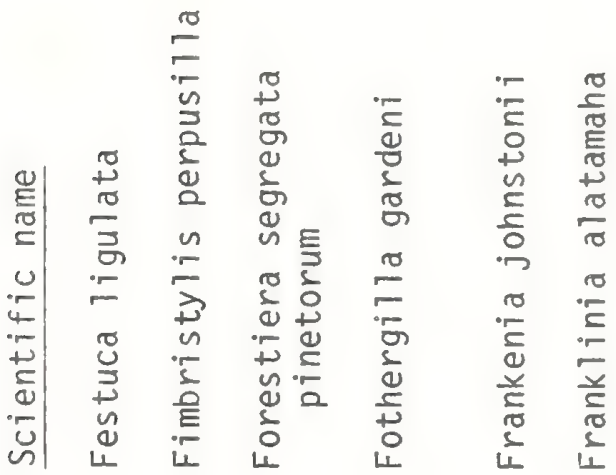




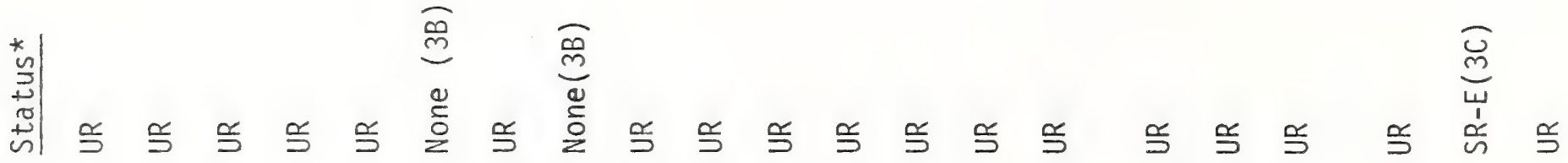

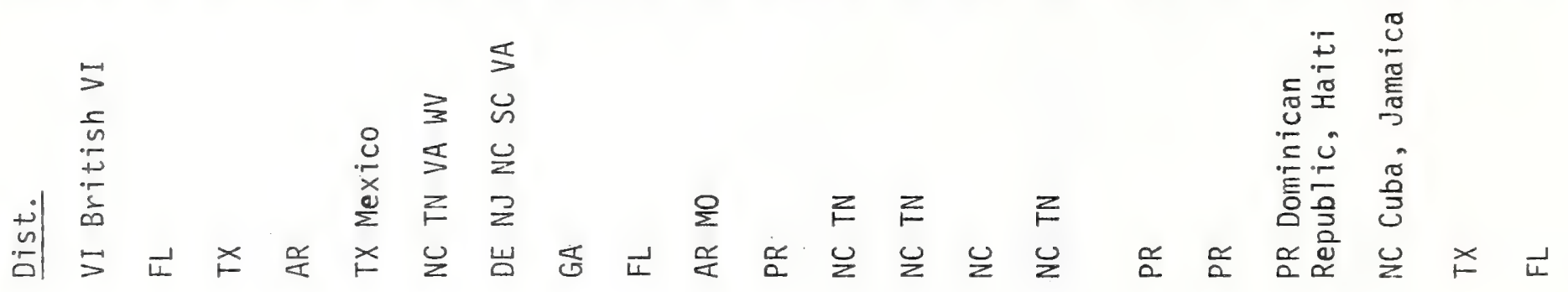

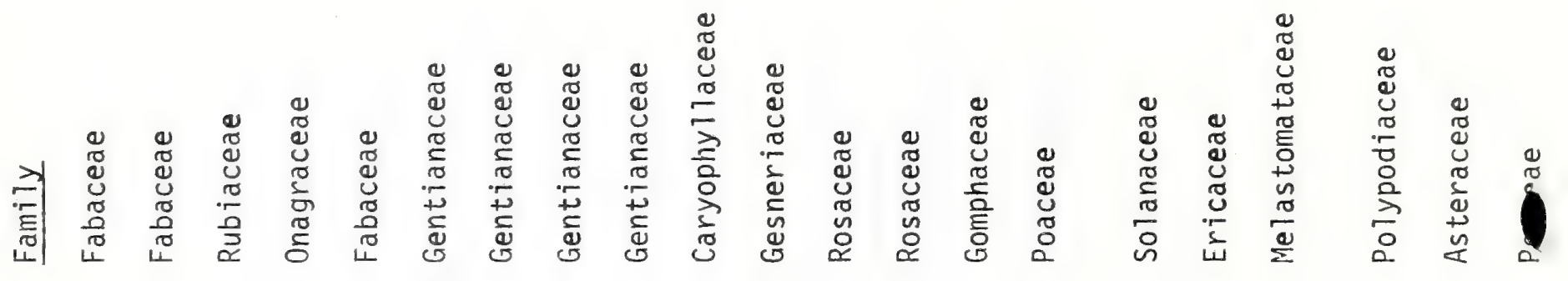

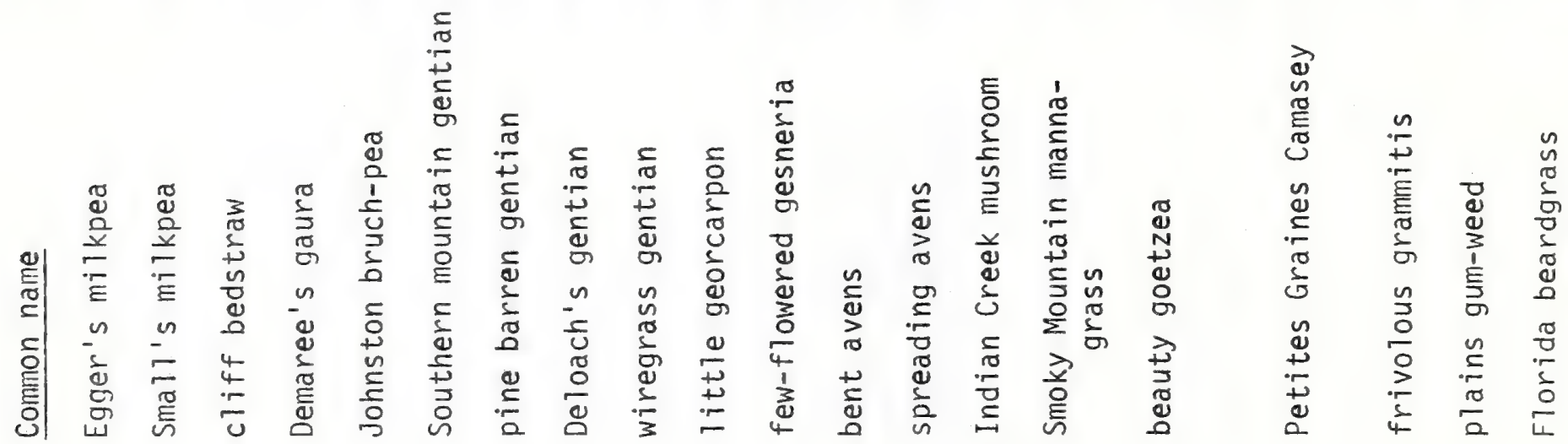

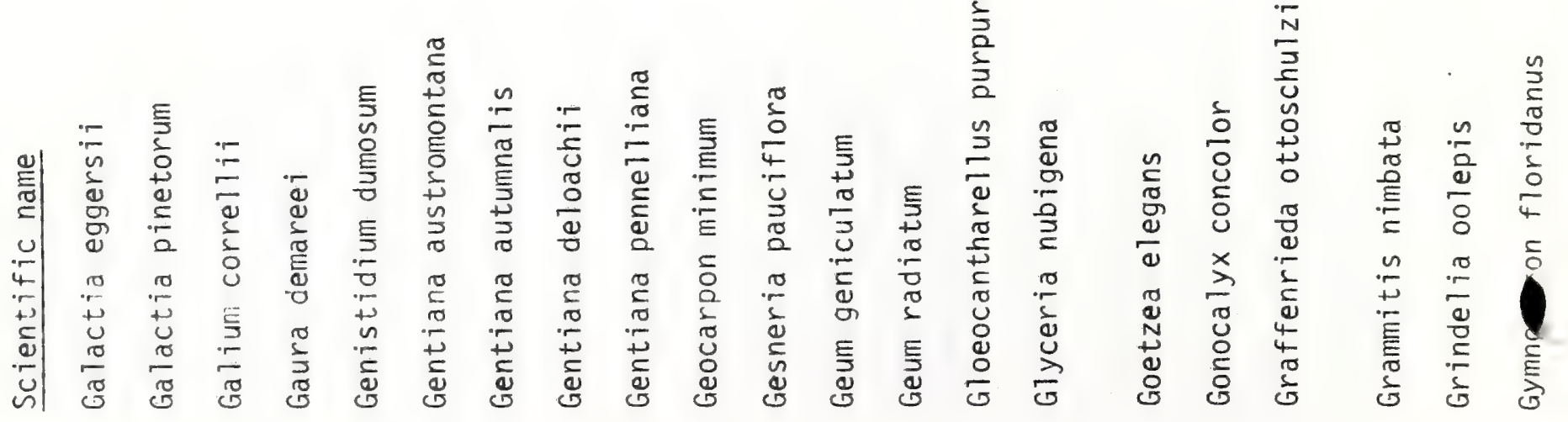




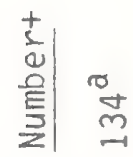

$\infty$

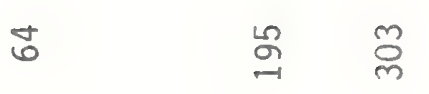

교 8 \&

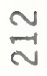

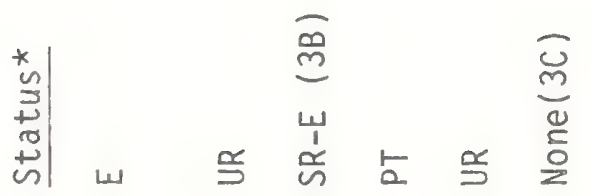

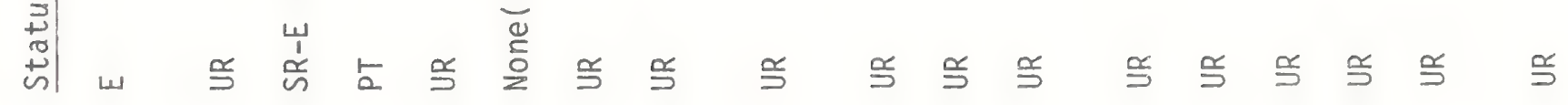

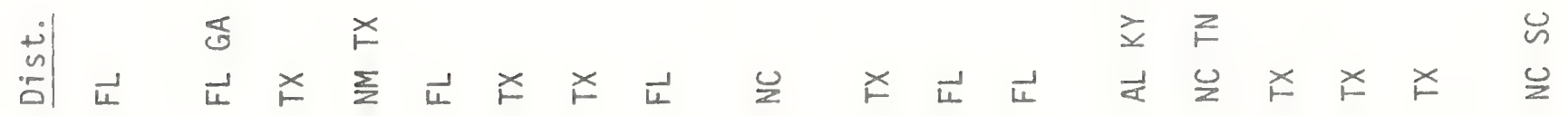

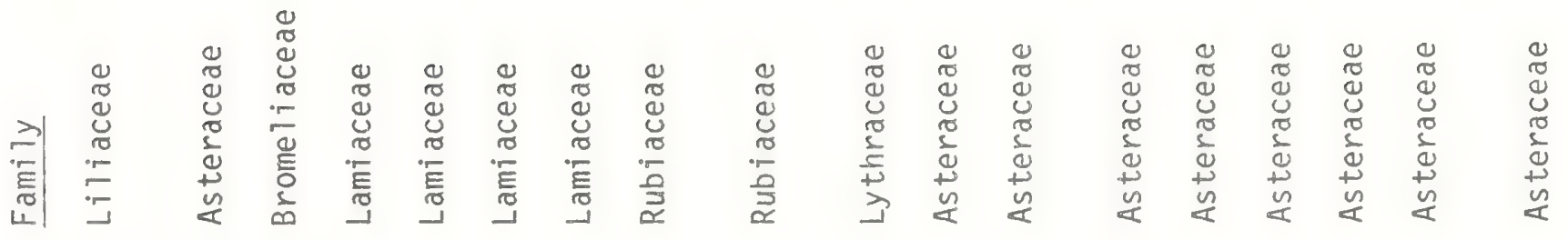

$\begin{array}{lll} & \\ 0\end{array}$

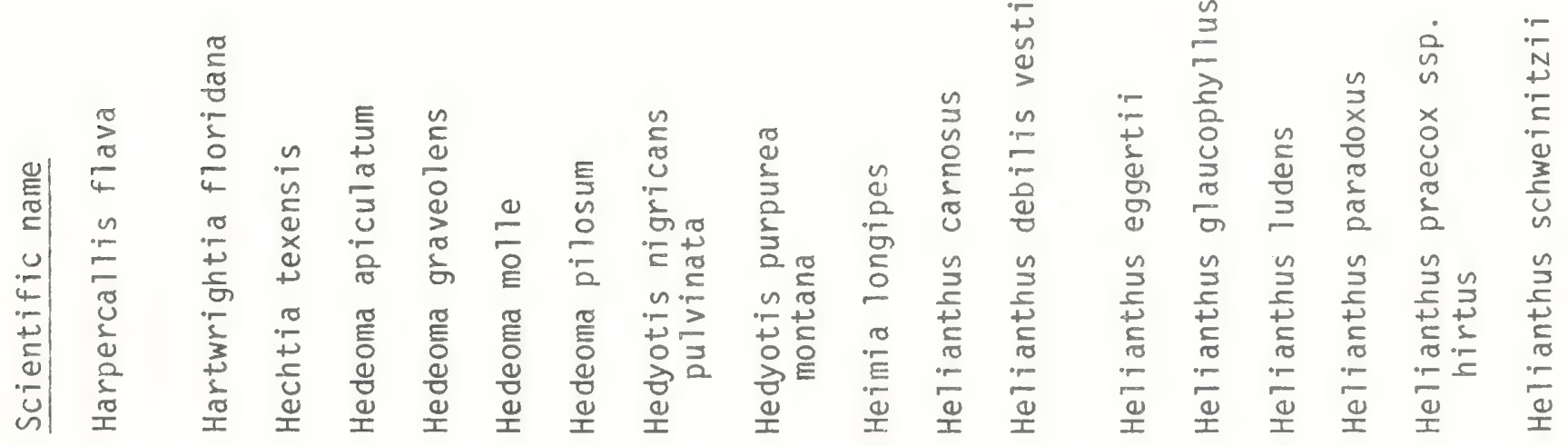




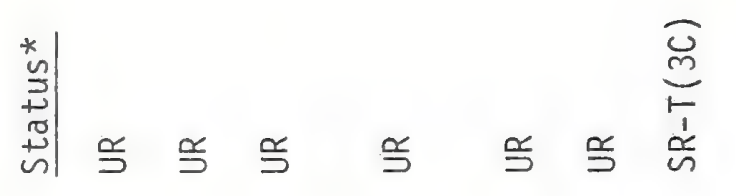

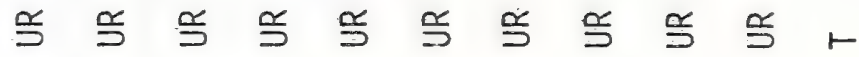

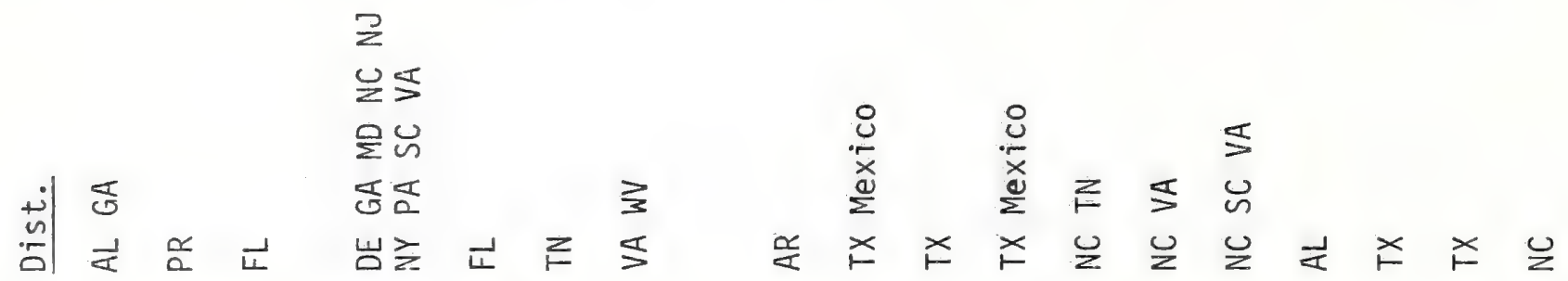

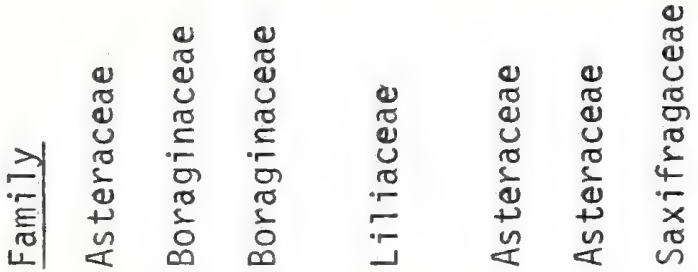

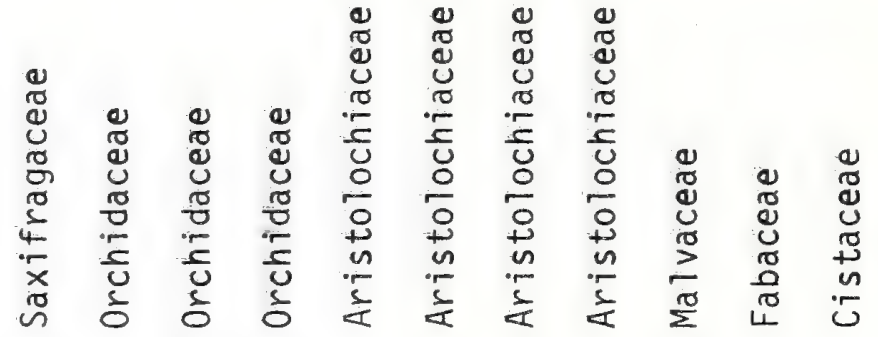

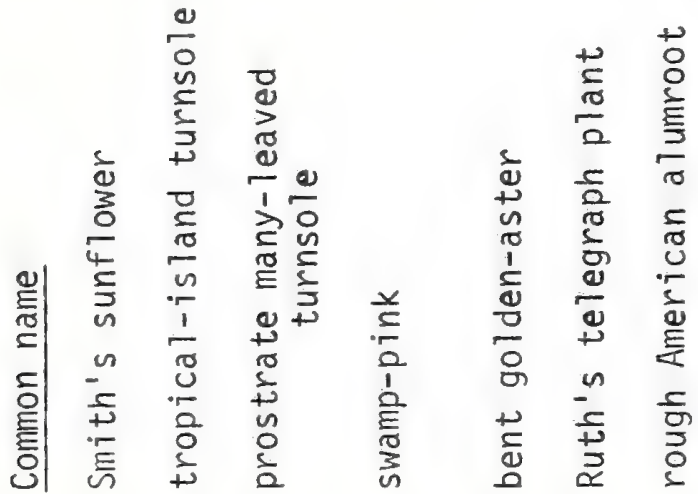

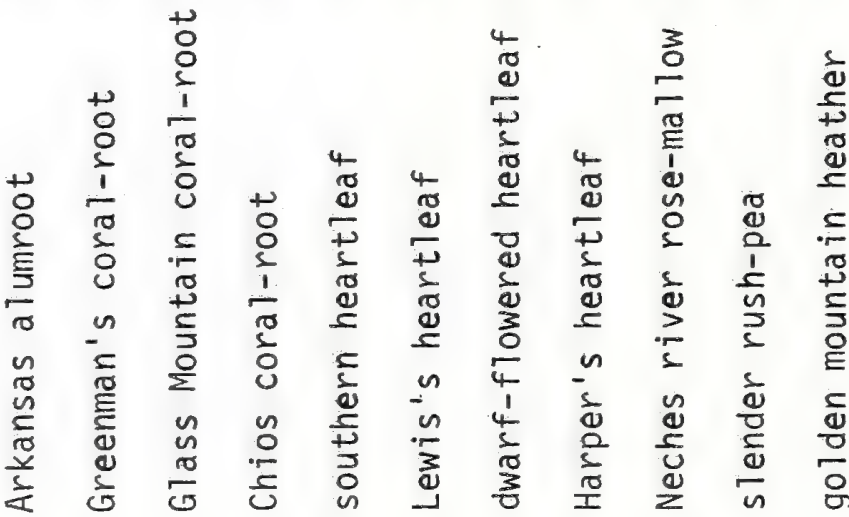

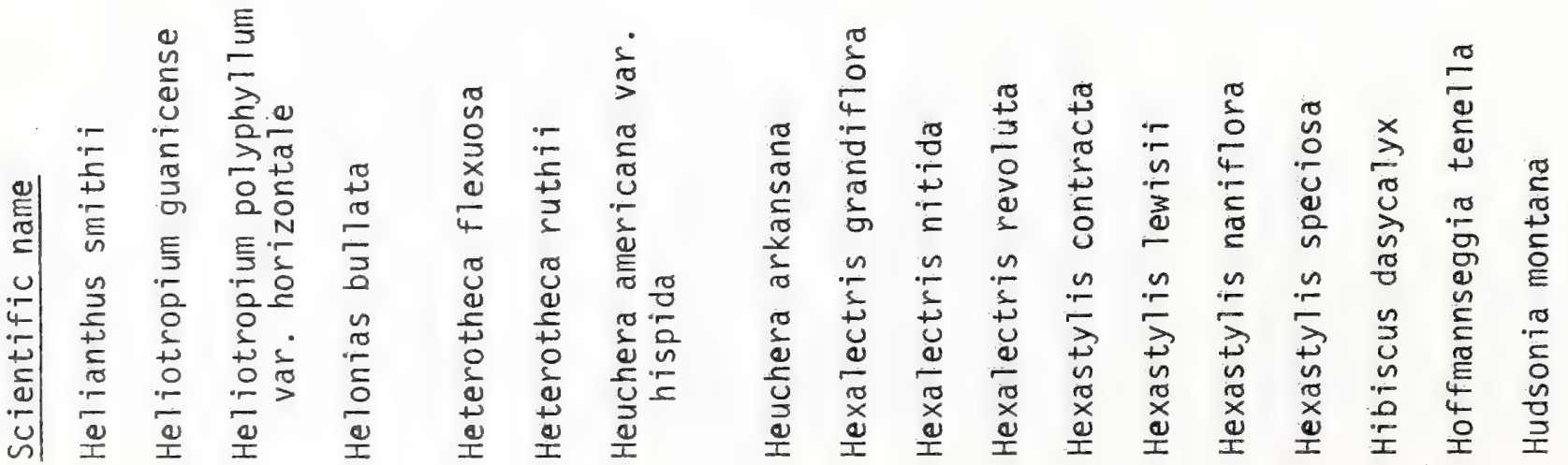


$\stackrel{m}{n}$

$\infty \quad \infty \quad \stackrel{\sim}{\infty}$

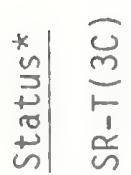

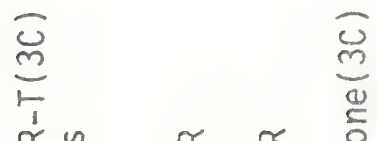

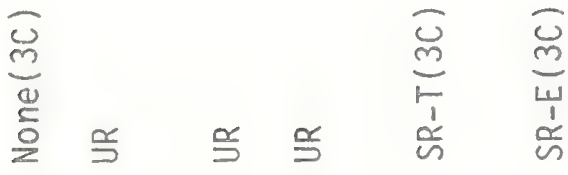

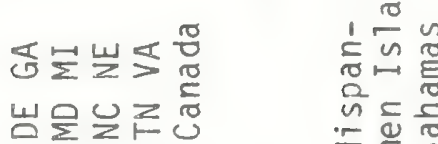

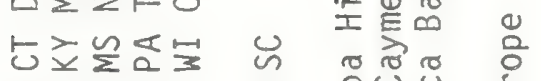

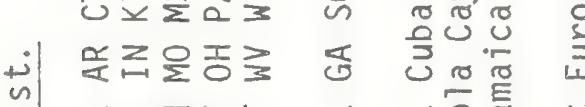

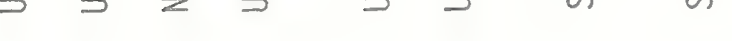

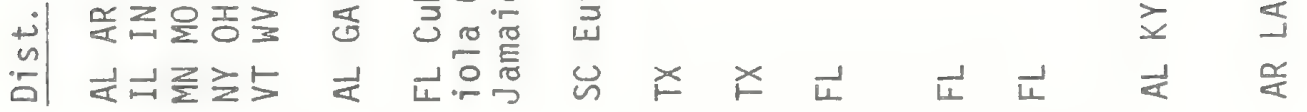
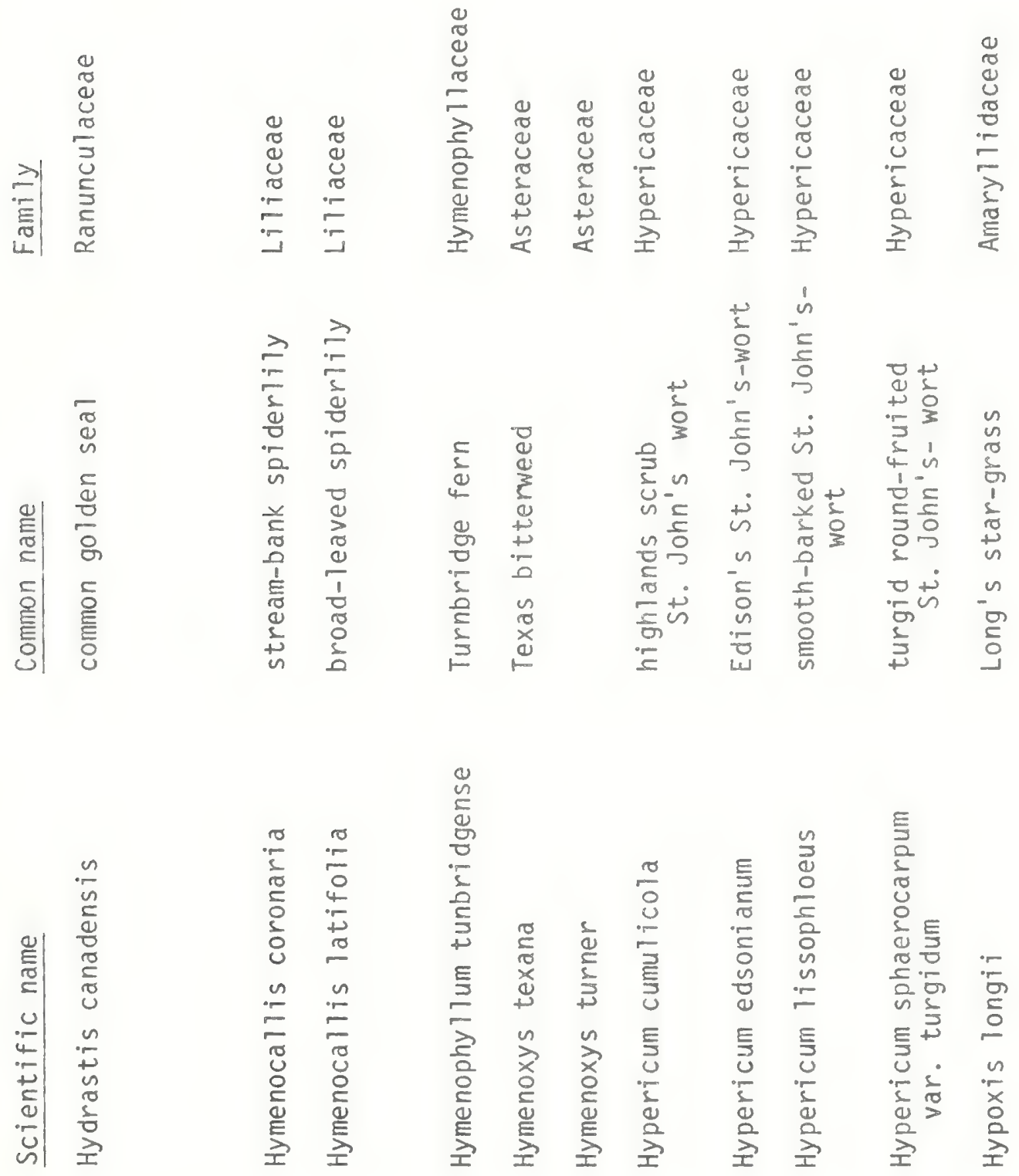


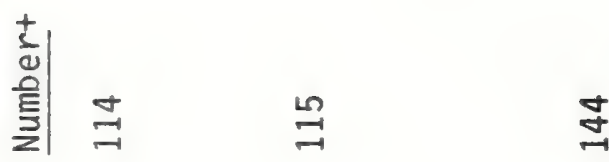

$\underset{1}{\mathbb{N}}$

$\stackrel{\text { in }}{m}$

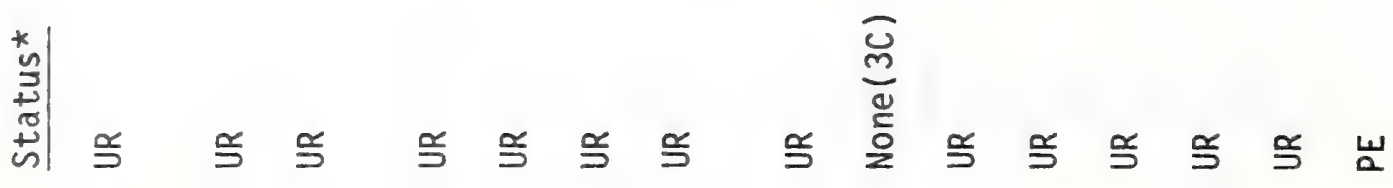

管是岂出

$\perp$

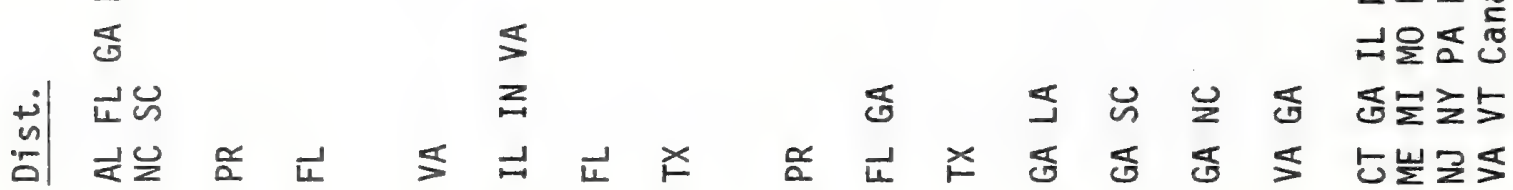

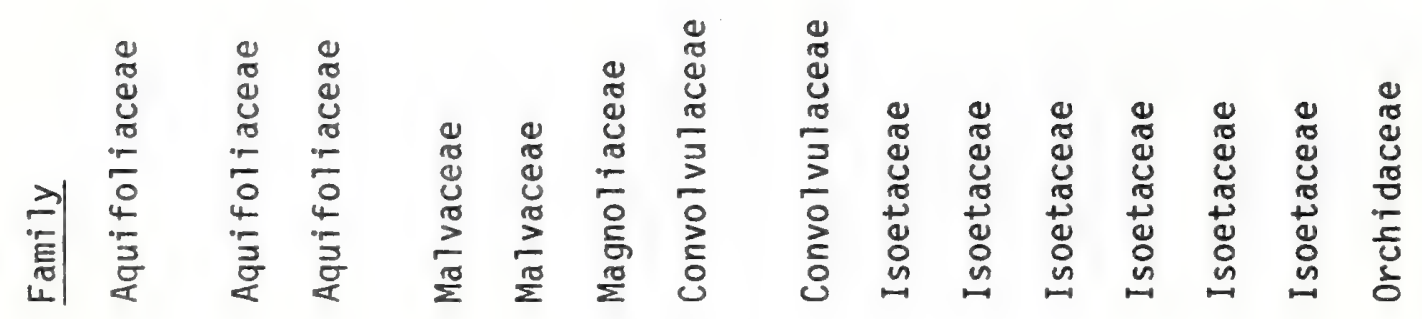

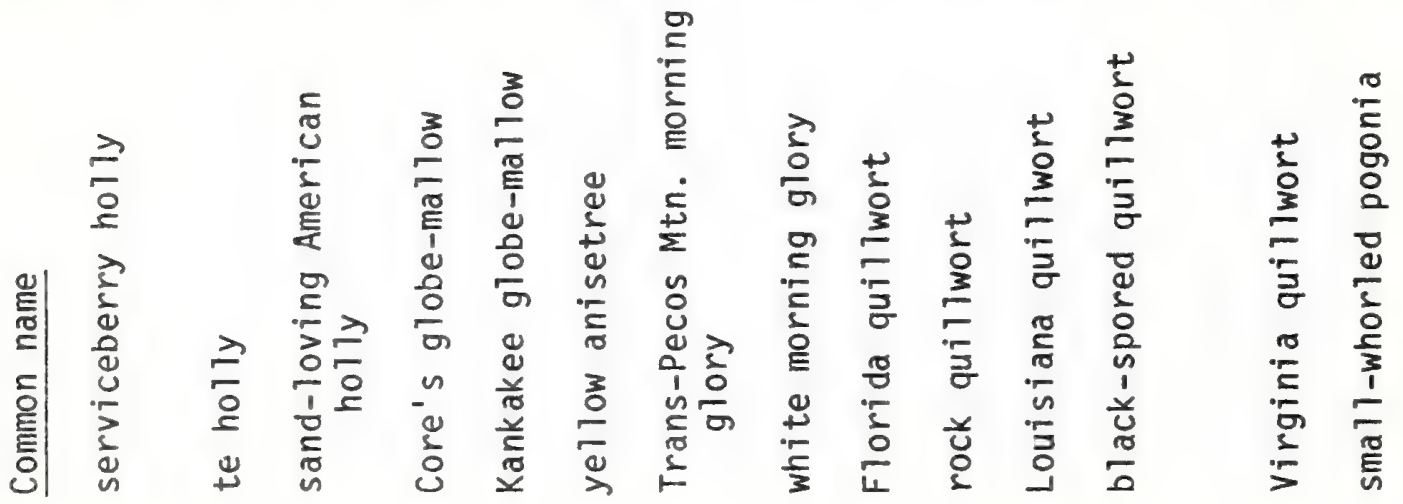

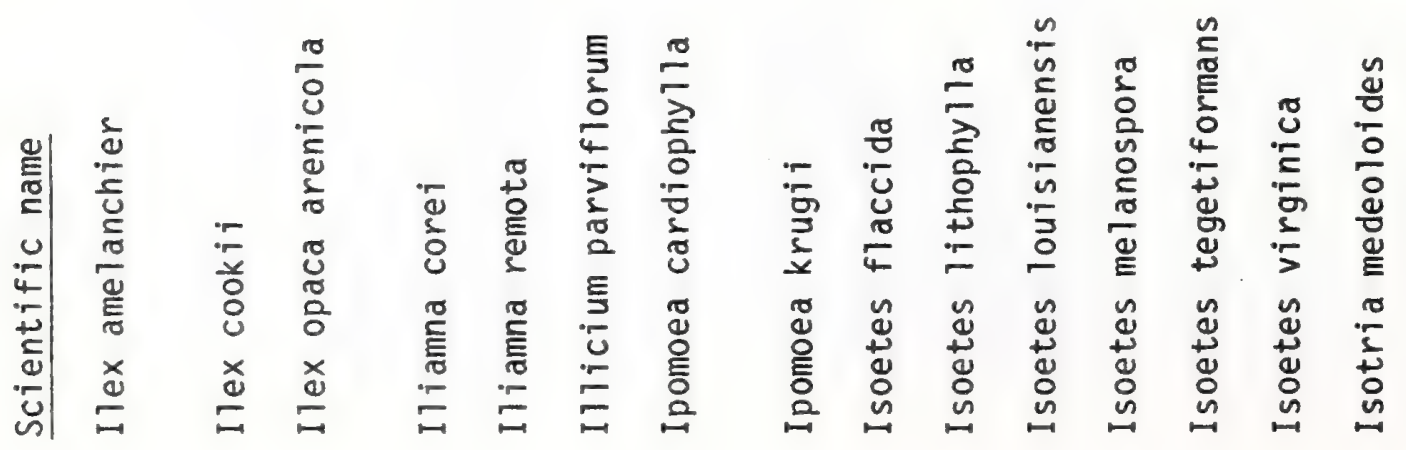


I

$\stackrel{\vec{\sim}}{\sim} \infty$

吕

$\stackrel{\circ}{\sim}$

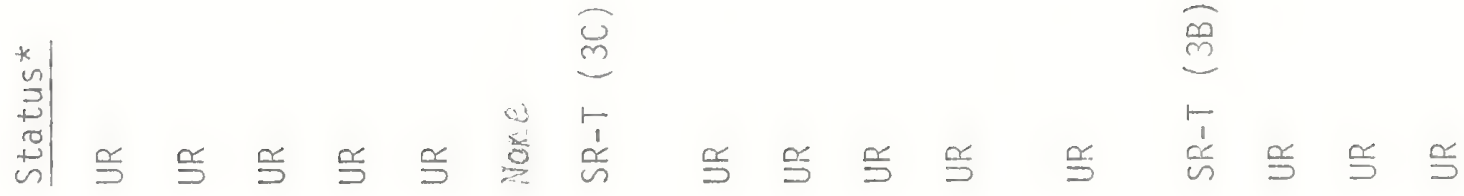

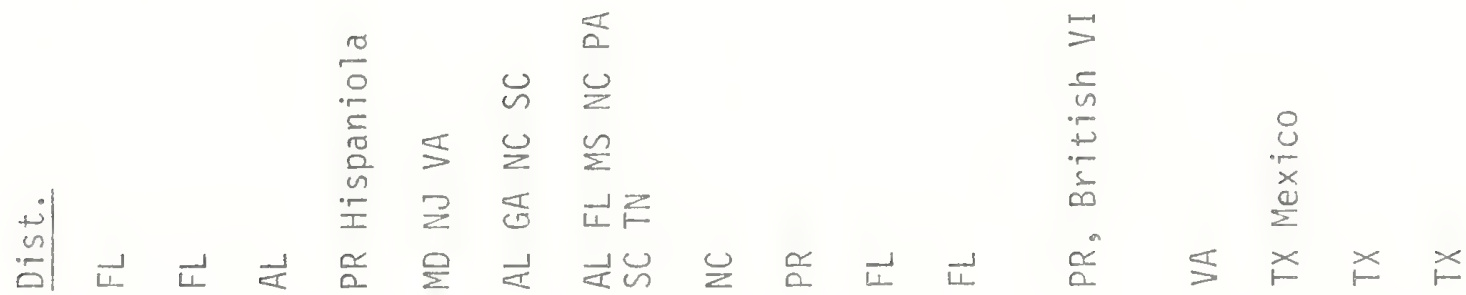

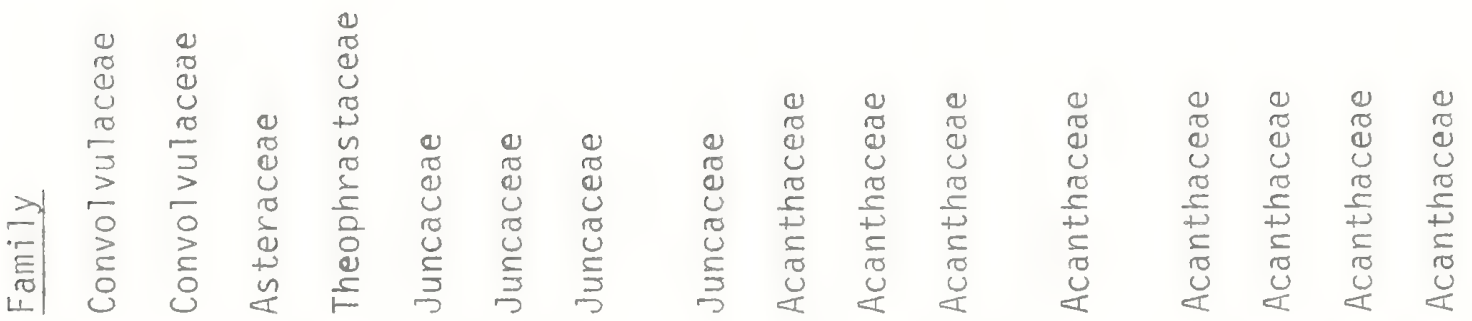

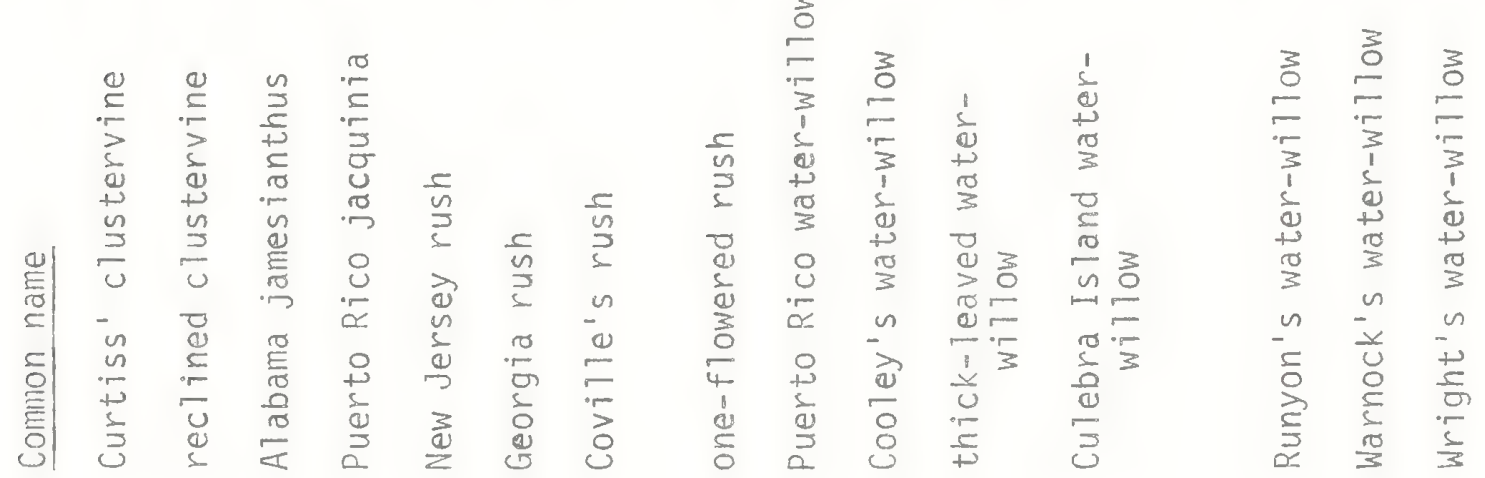

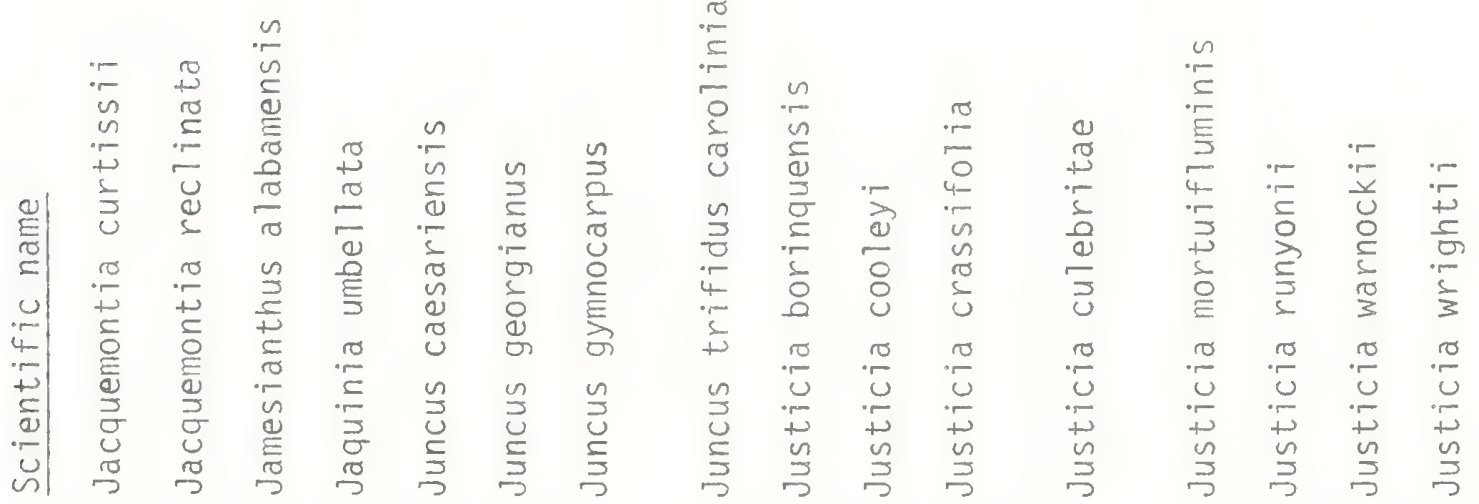


期

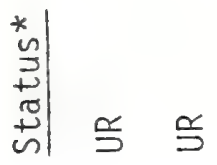

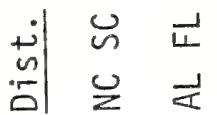

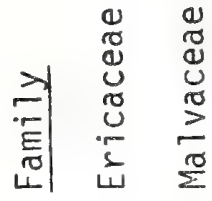

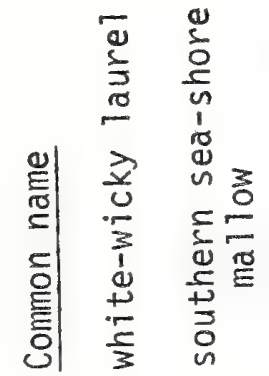

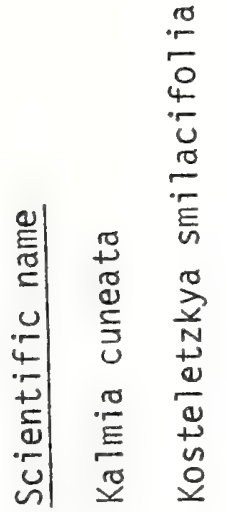




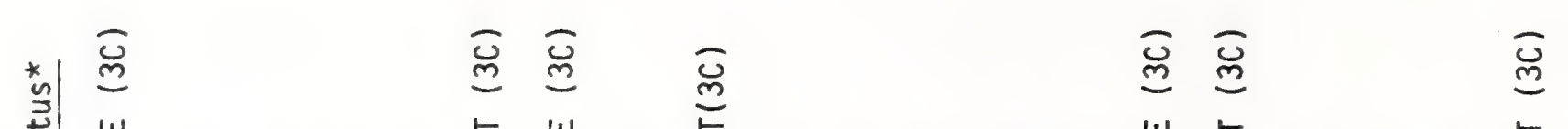

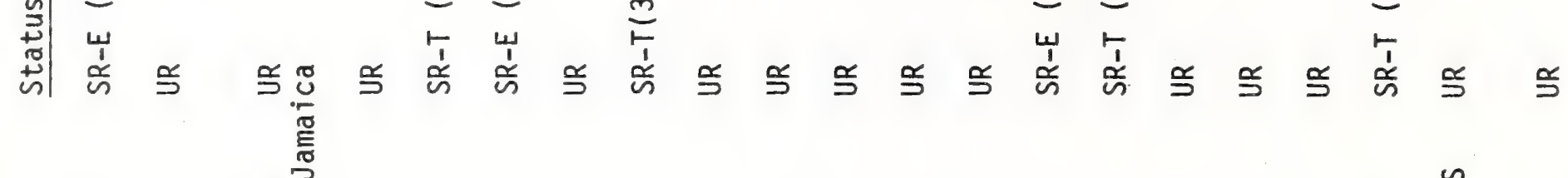

芒

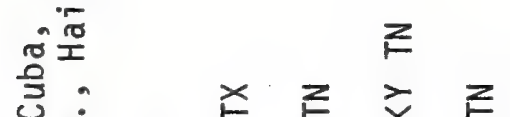

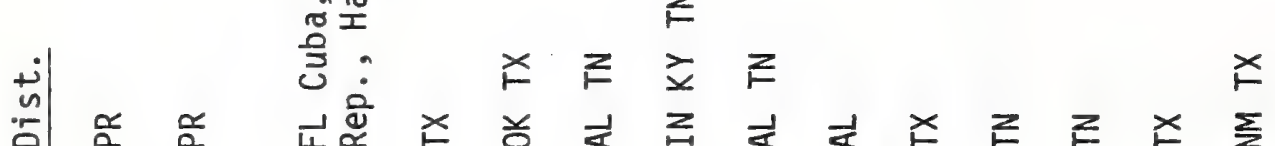

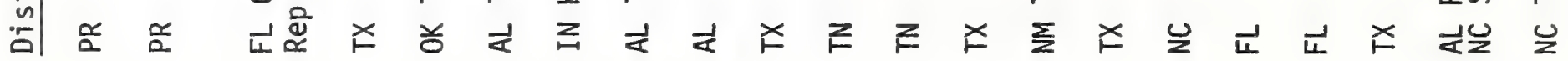

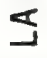

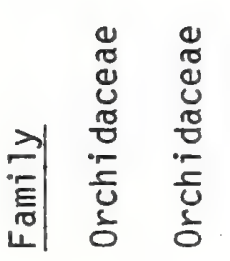
密

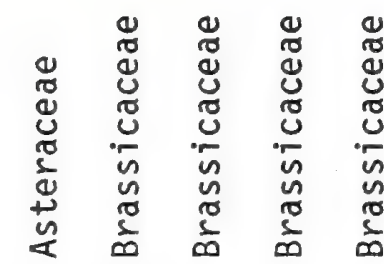

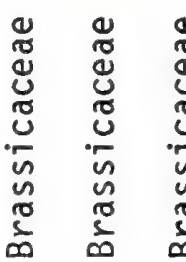

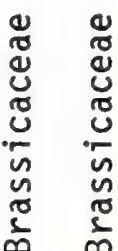

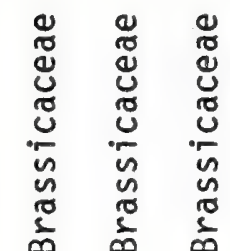

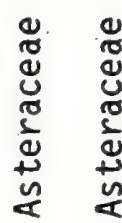

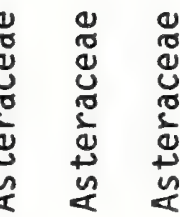

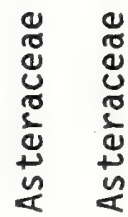
$\frac{7}{\frac{5}{0}}$

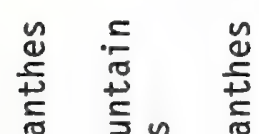

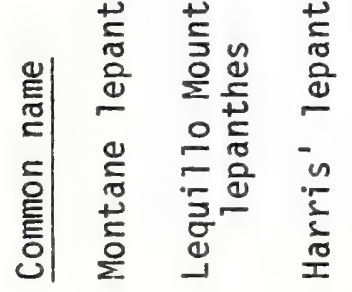

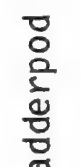

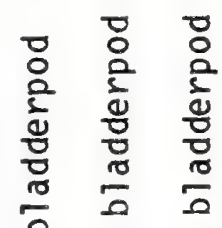

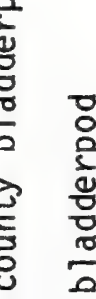

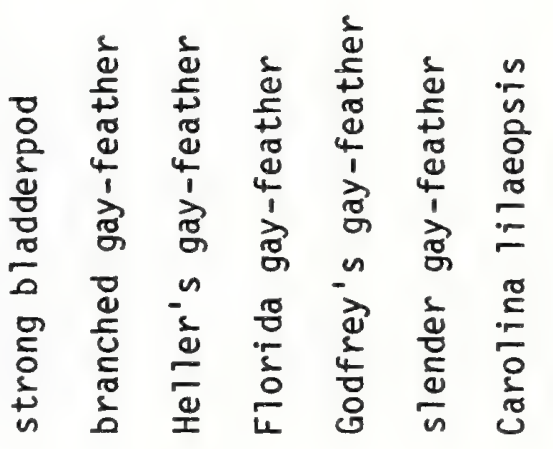
0
0
0
0
$:=$
$\div \square$

$$
\begin{aligned}
& \frac{\pi}{=} \\
& -2 \\
& \frac{1}{0}
\end{aligned}
$$

$\sum$
ธ외 虽 
${ }^{k}$ ले लु

ভ్

ल

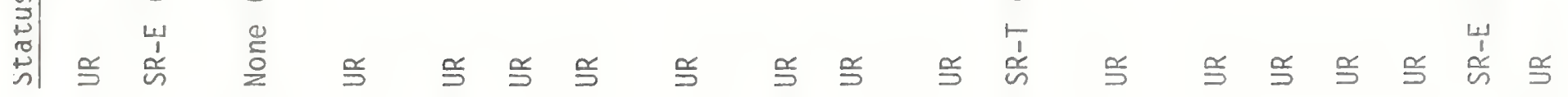

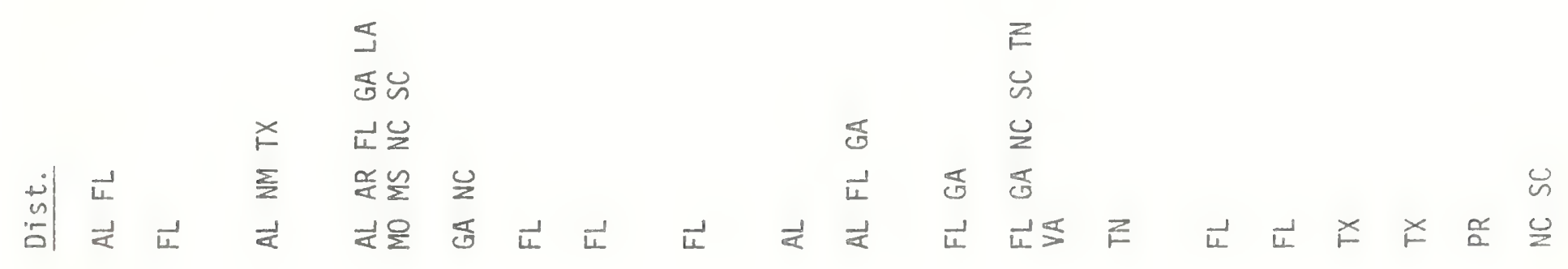

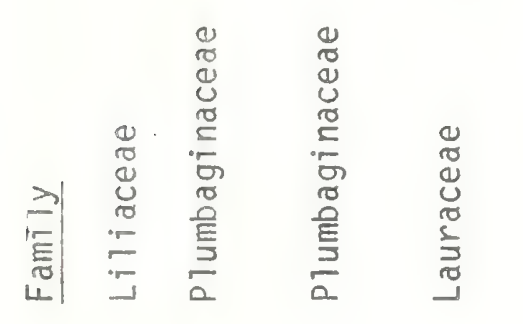

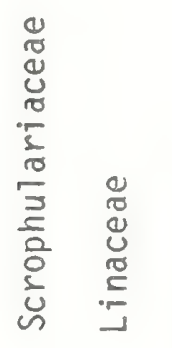

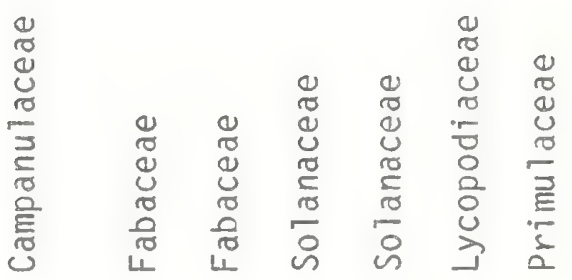

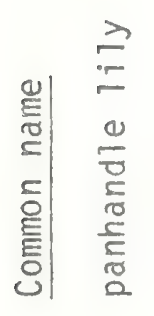

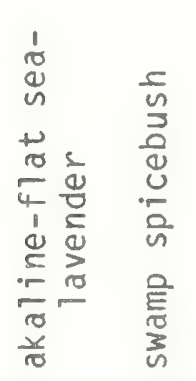

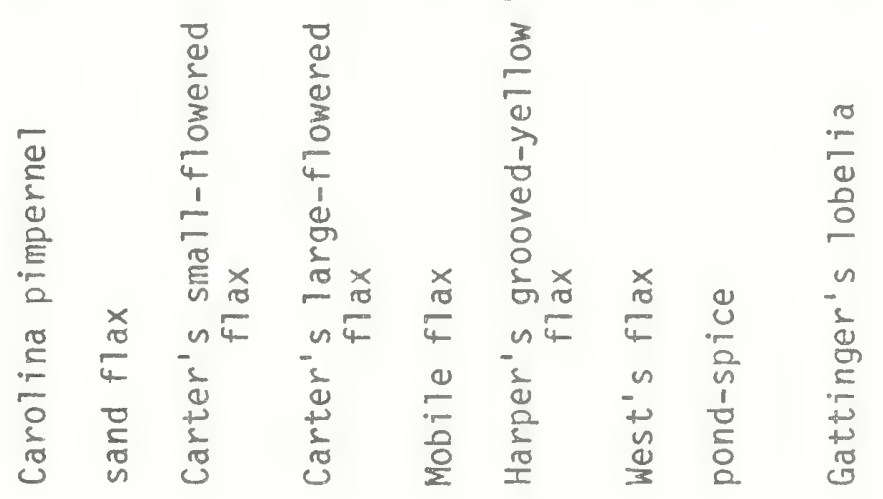

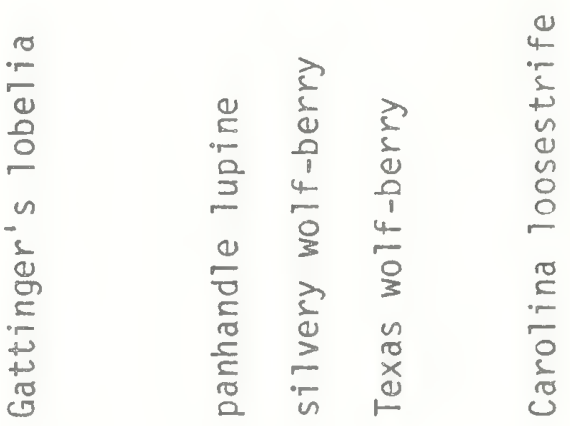

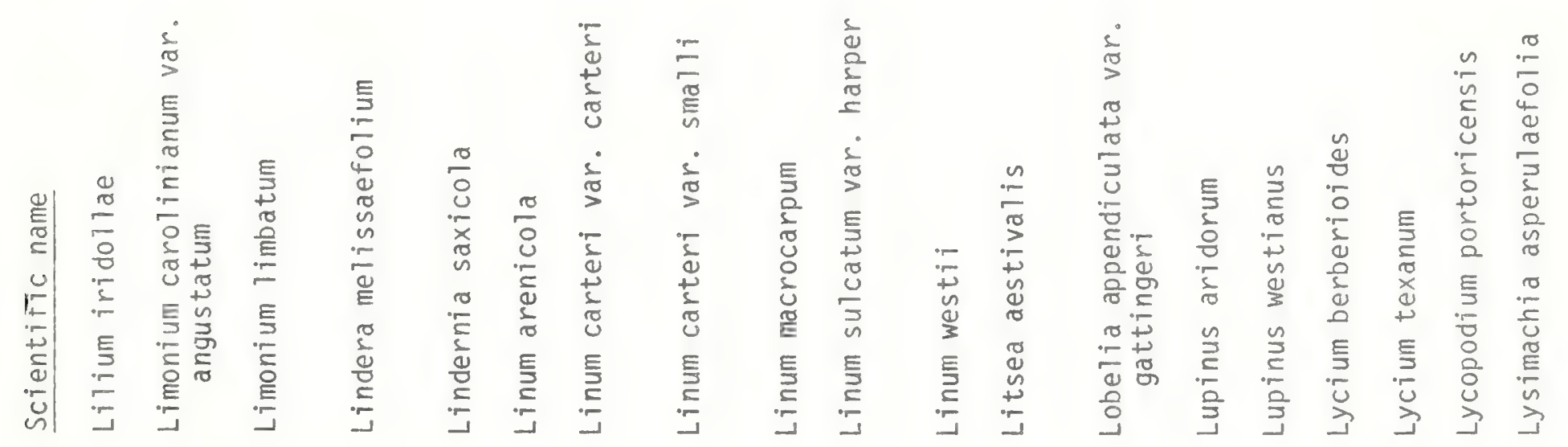


量手

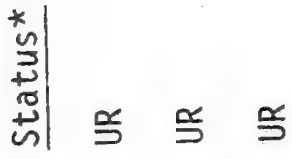

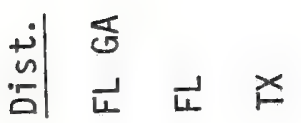

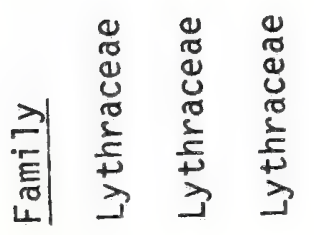

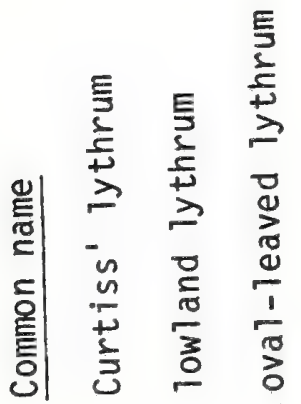

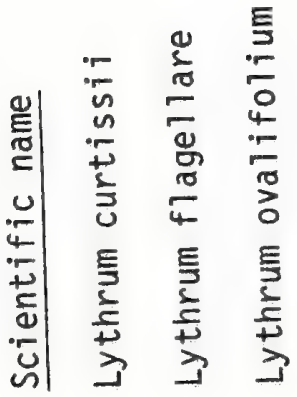


*.

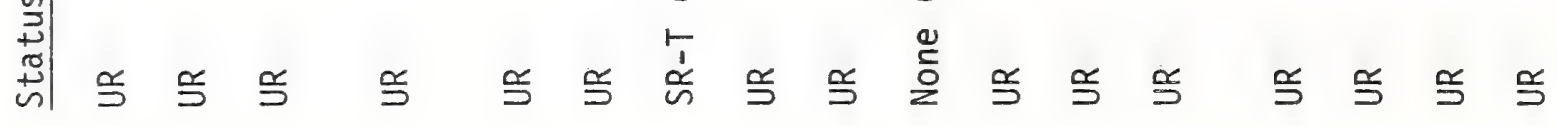
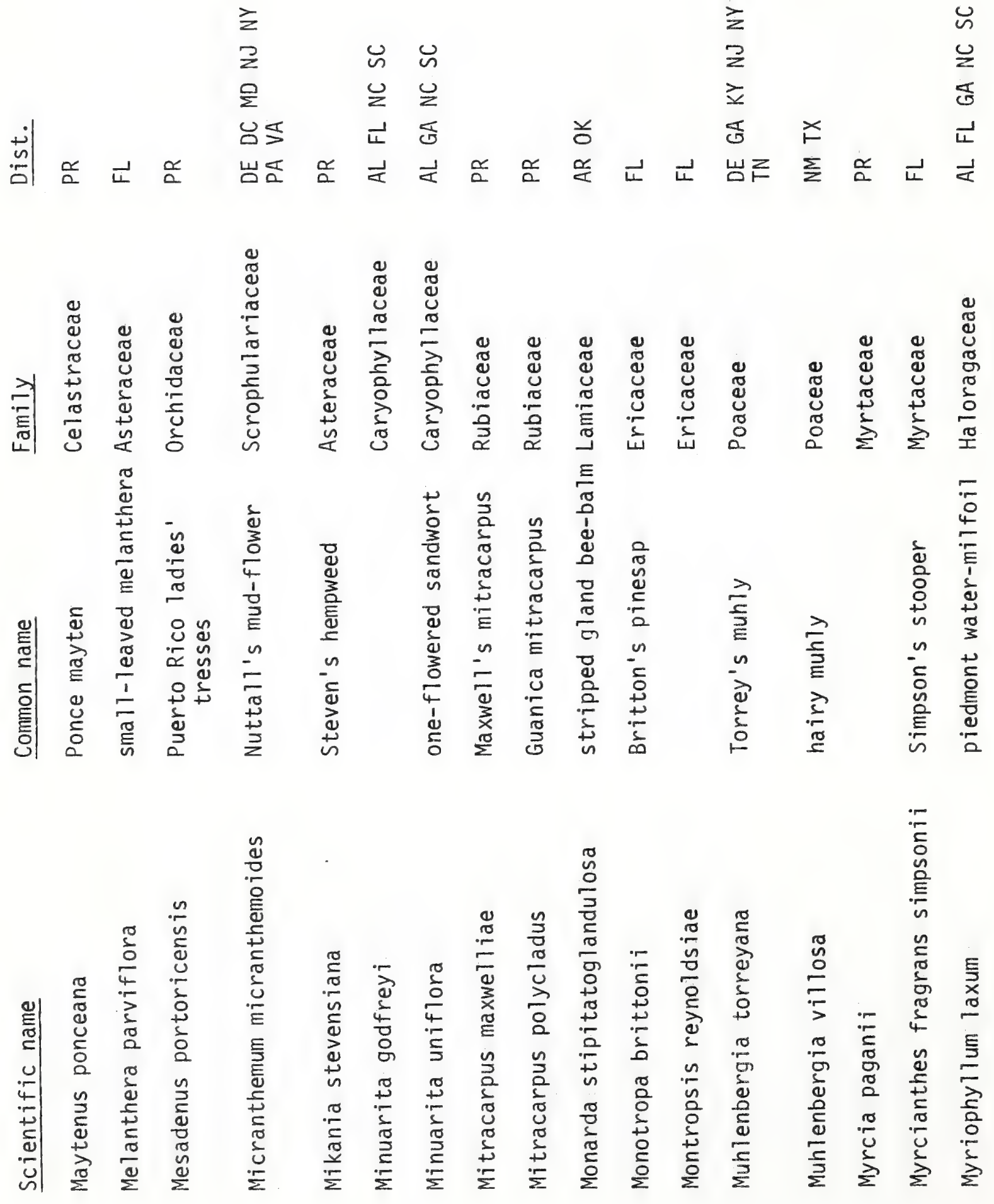


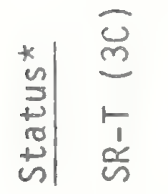

$\widetilde{\omega}$

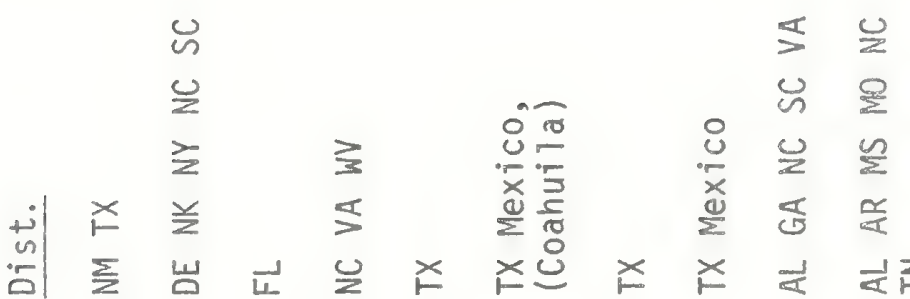

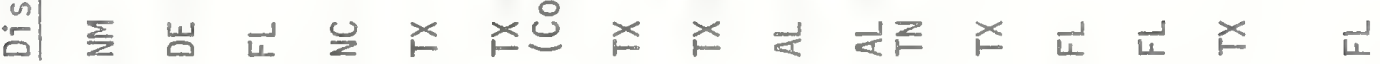

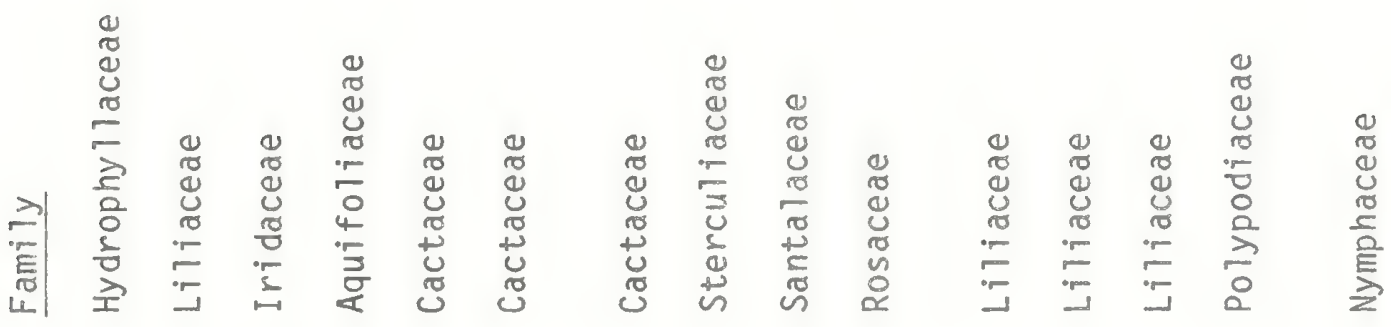
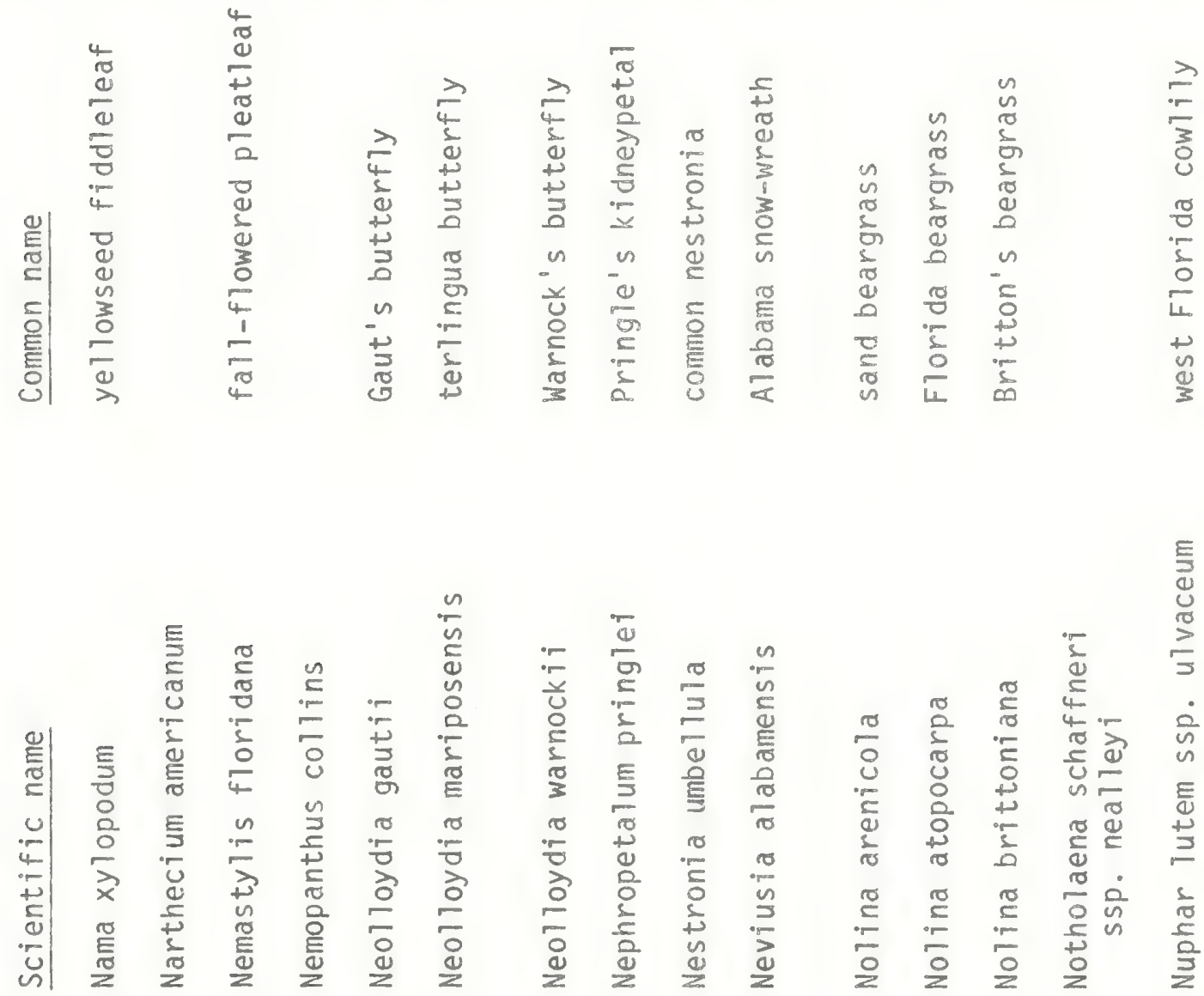


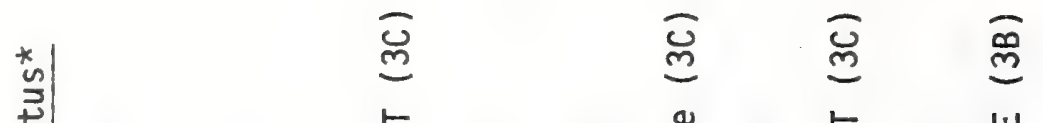

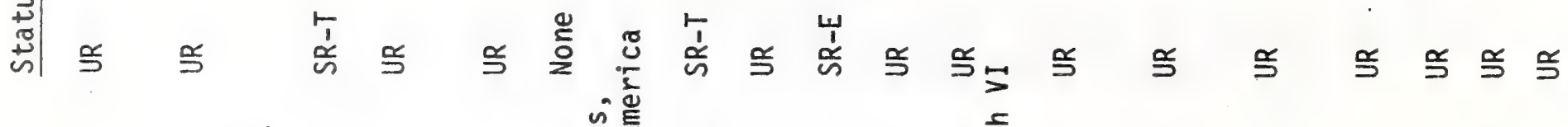

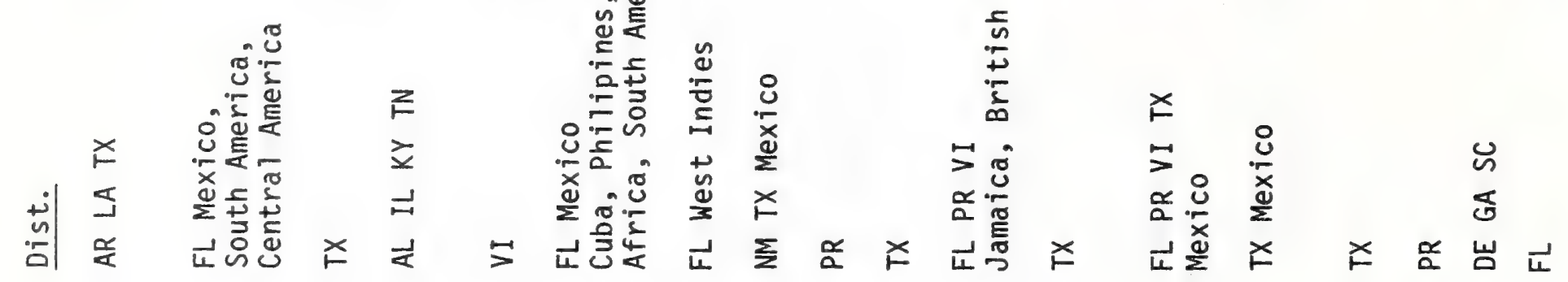

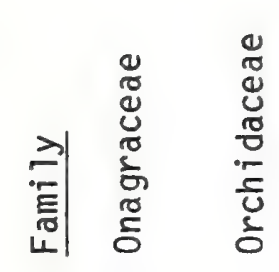
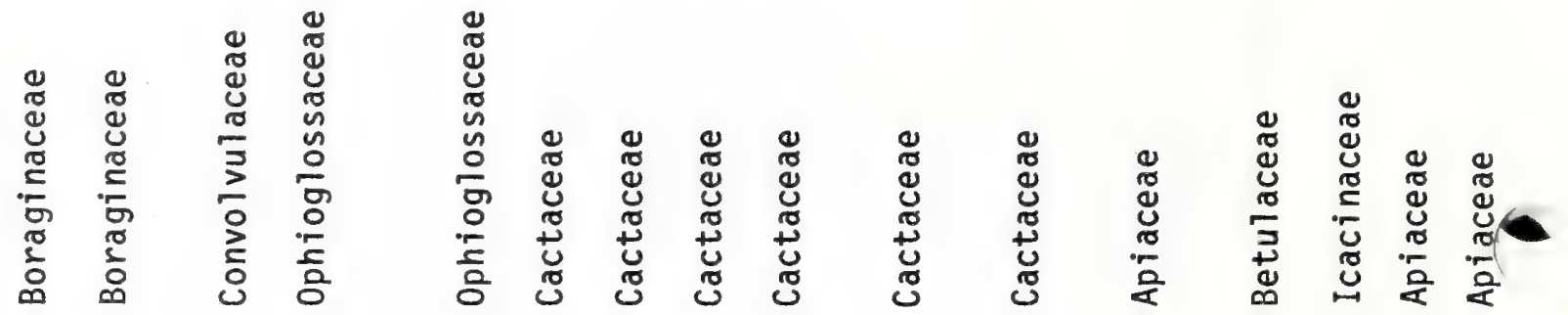

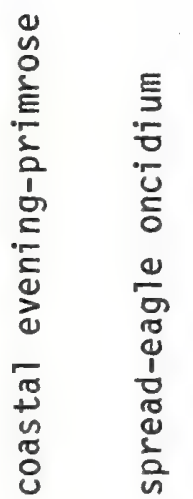
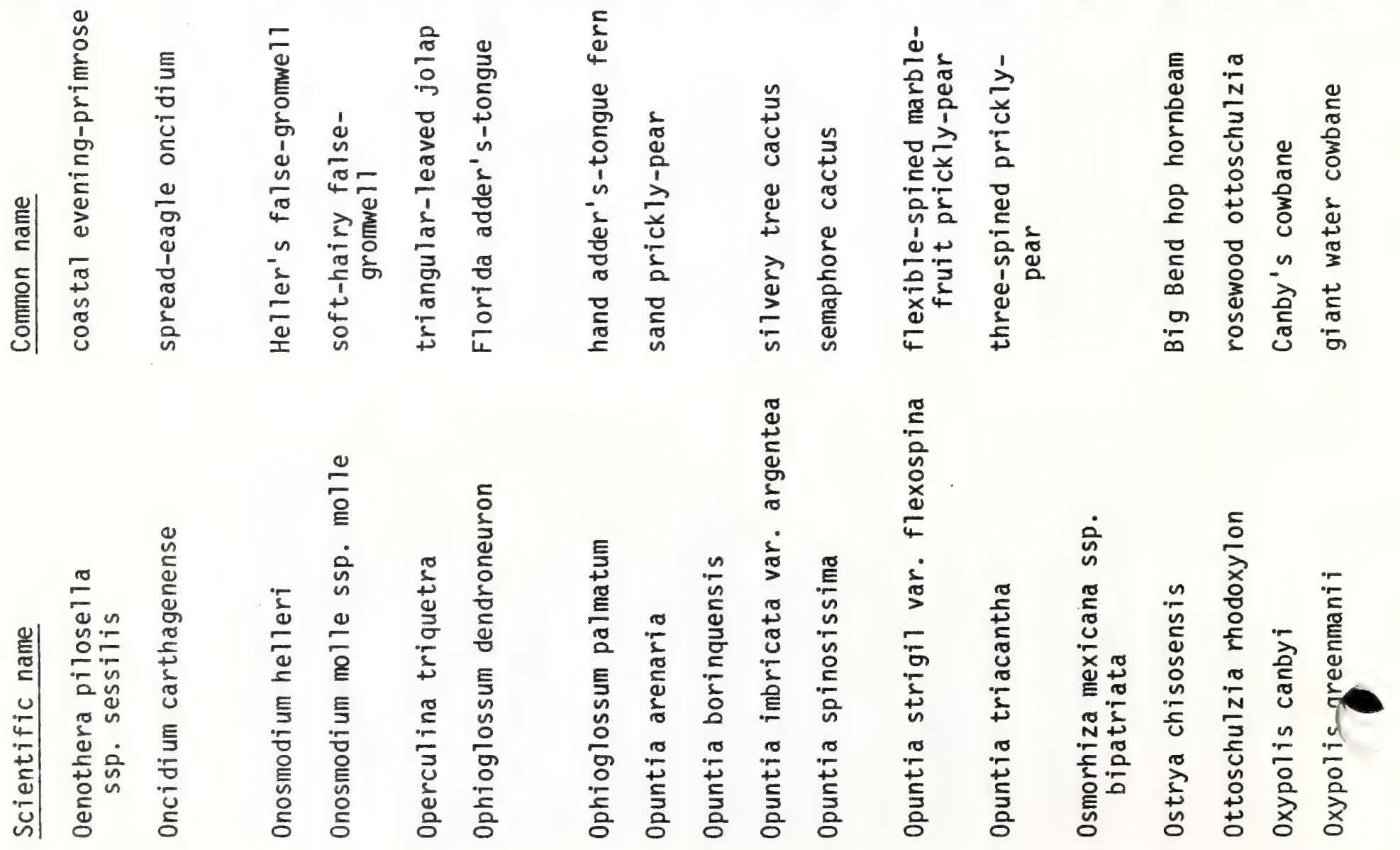


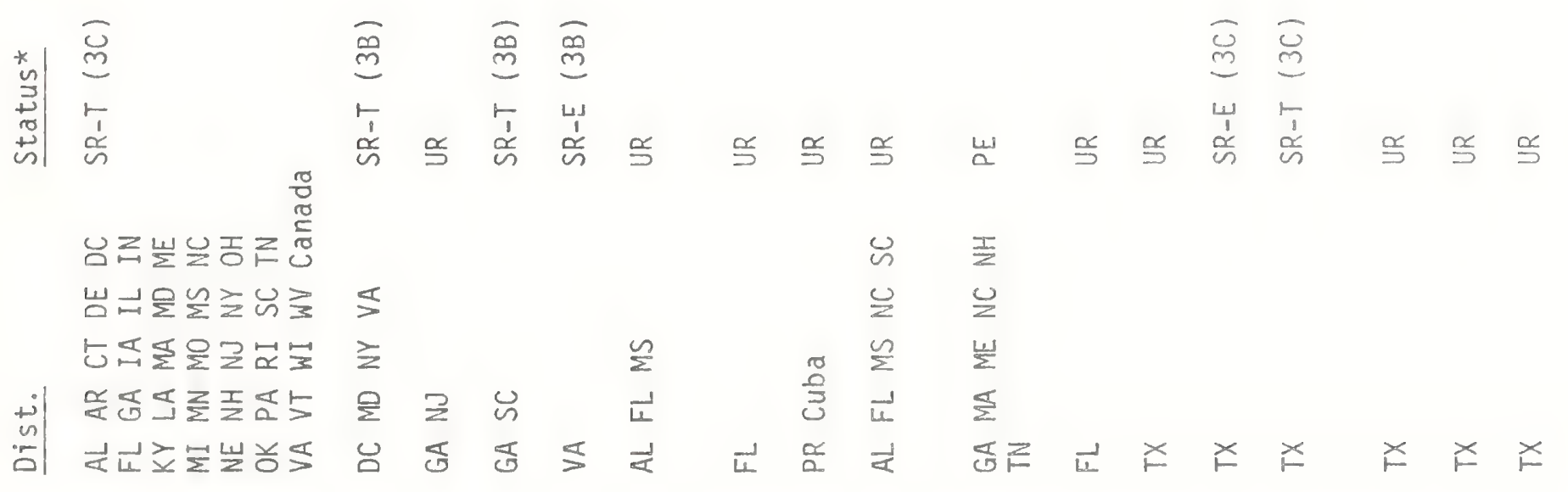

굴

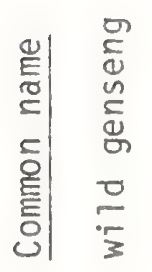

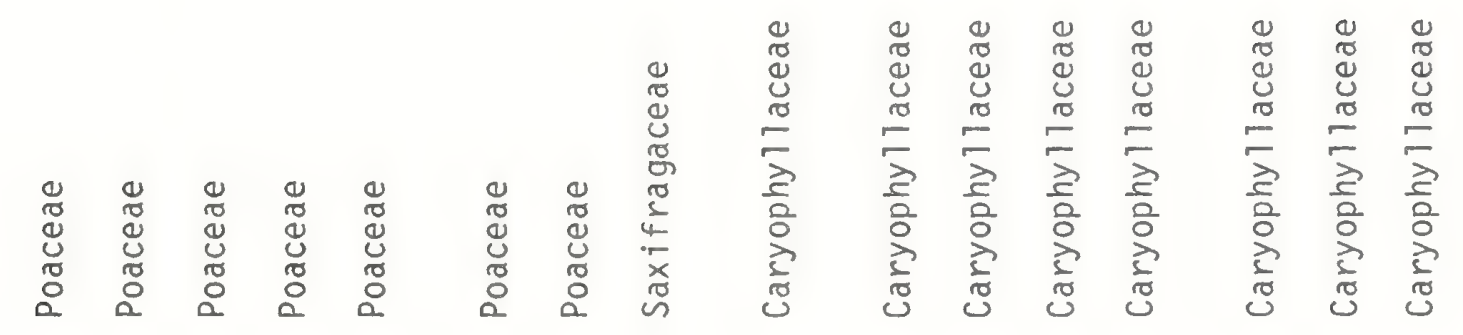

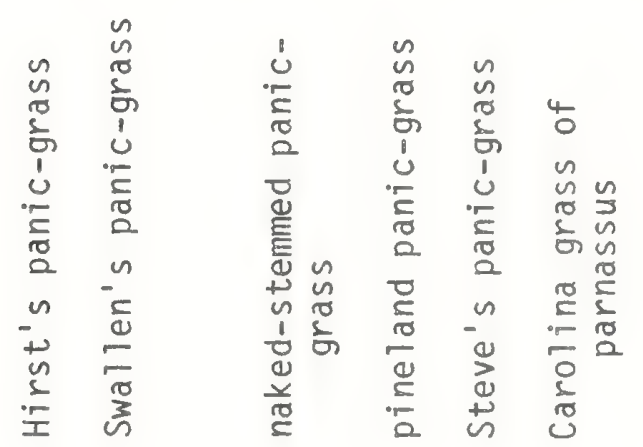

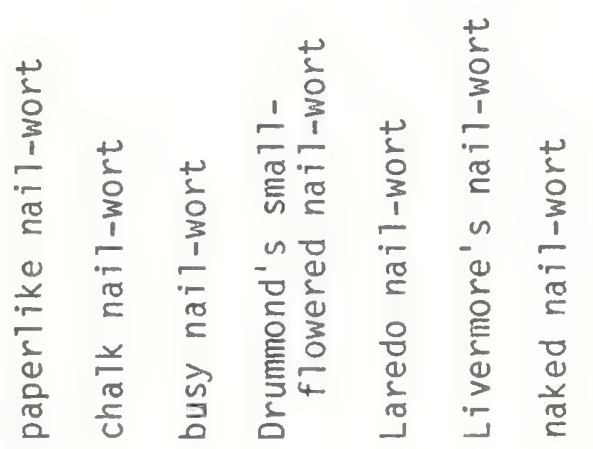

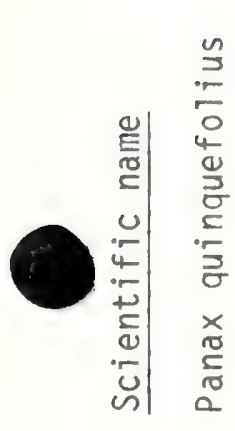

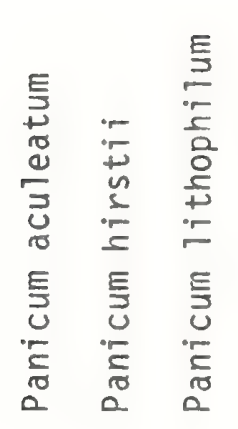

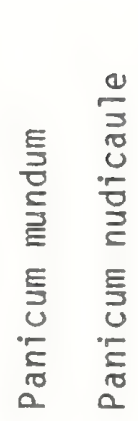

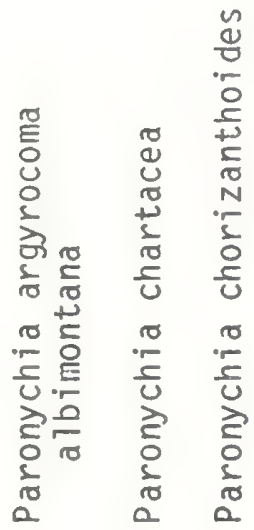




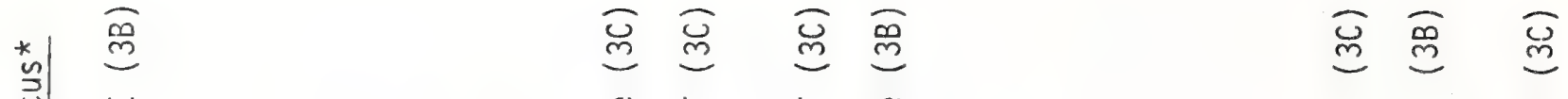

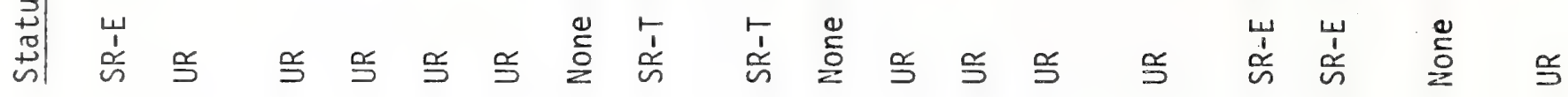

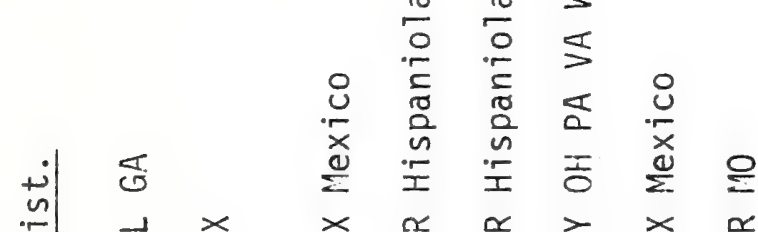

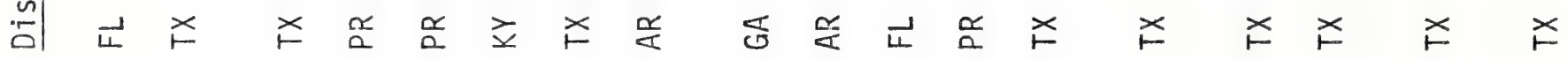

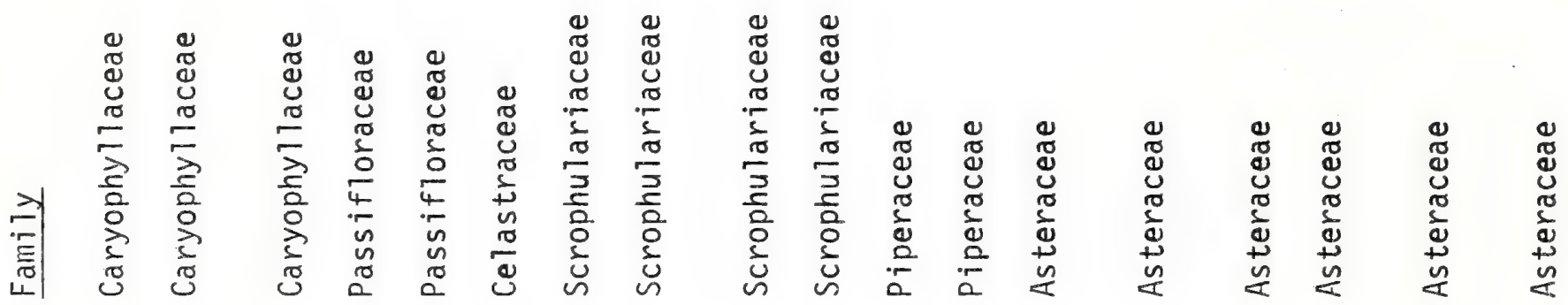

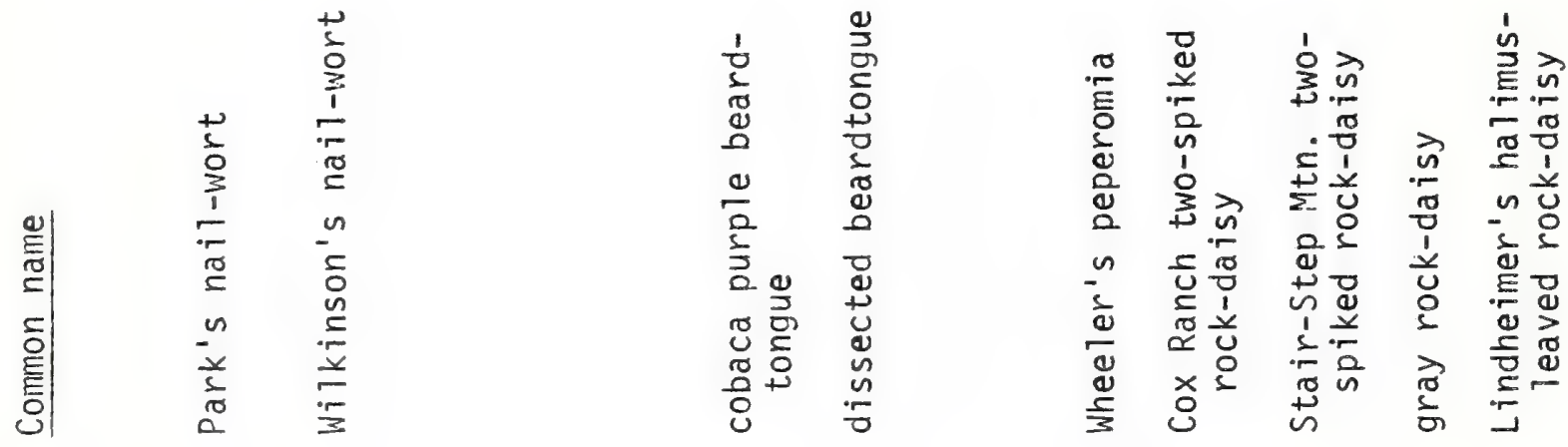

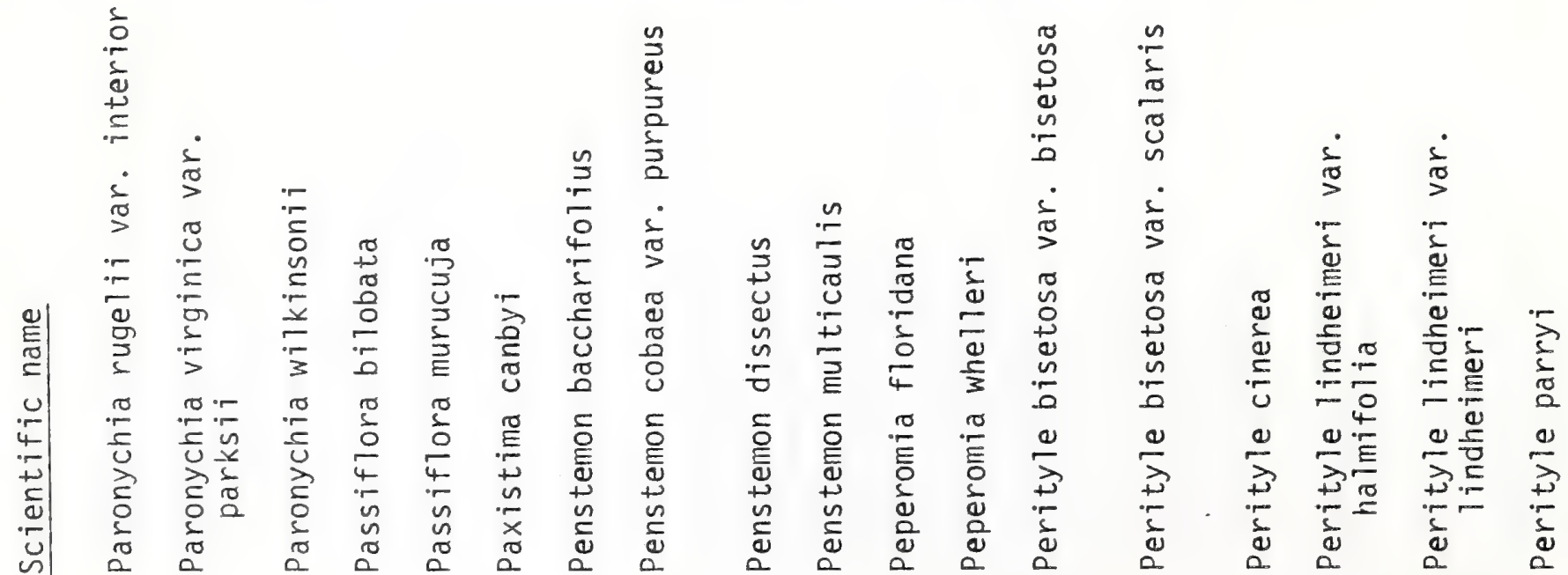




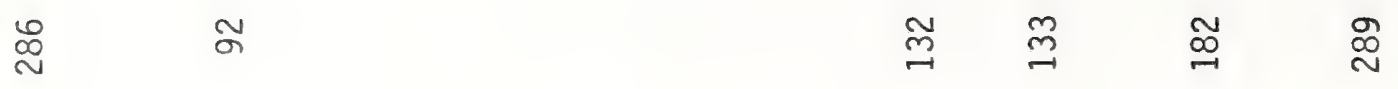

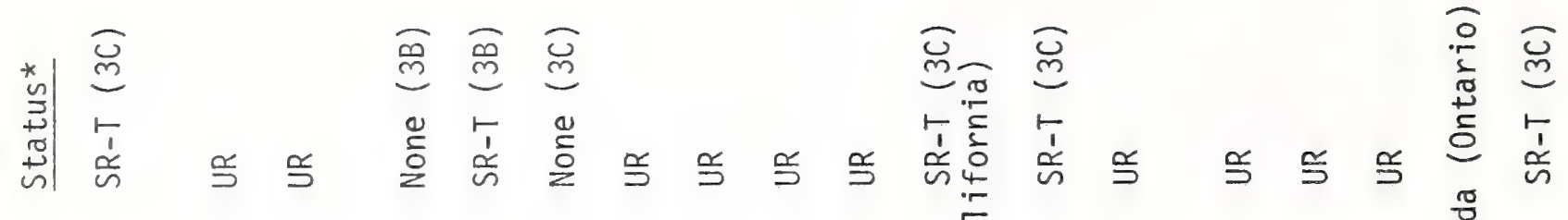

$>0$

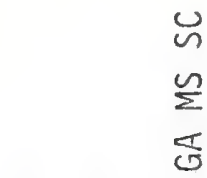

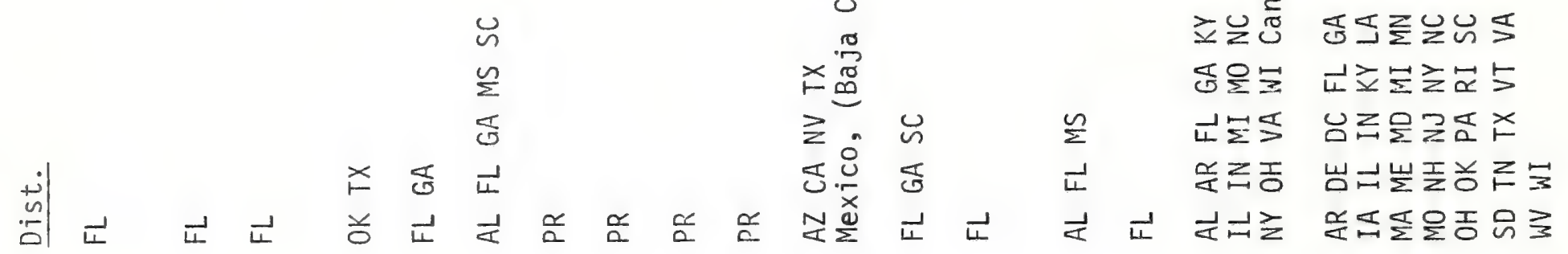

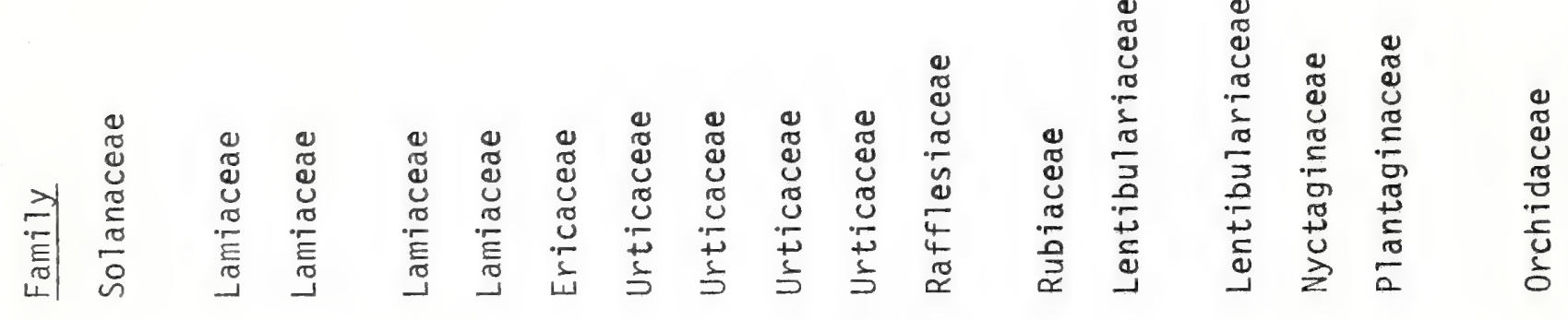

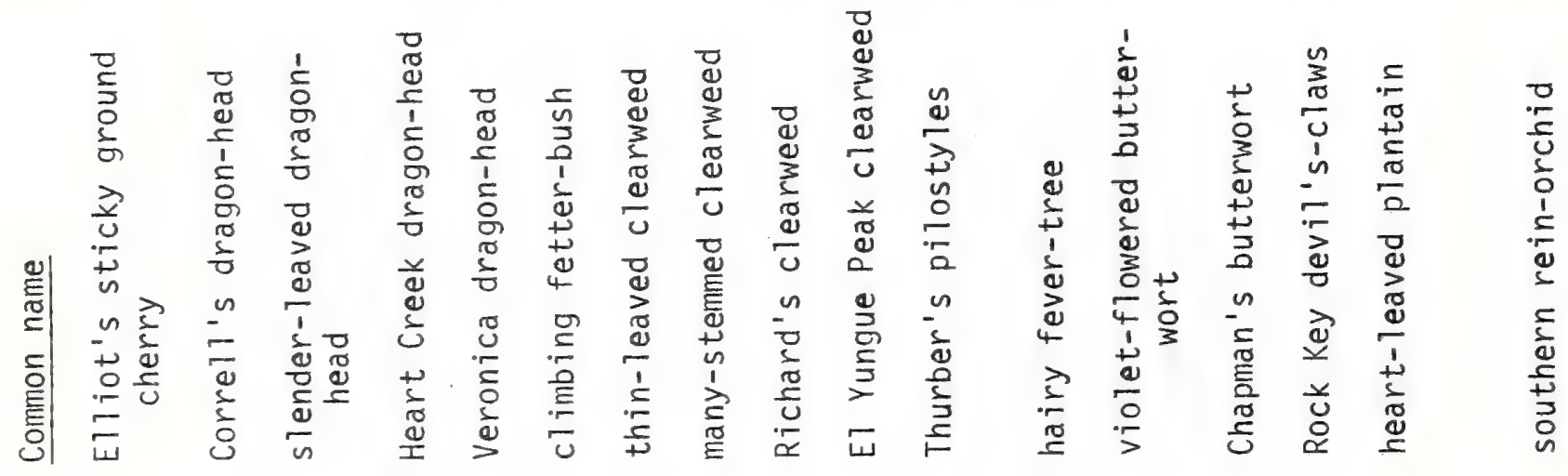

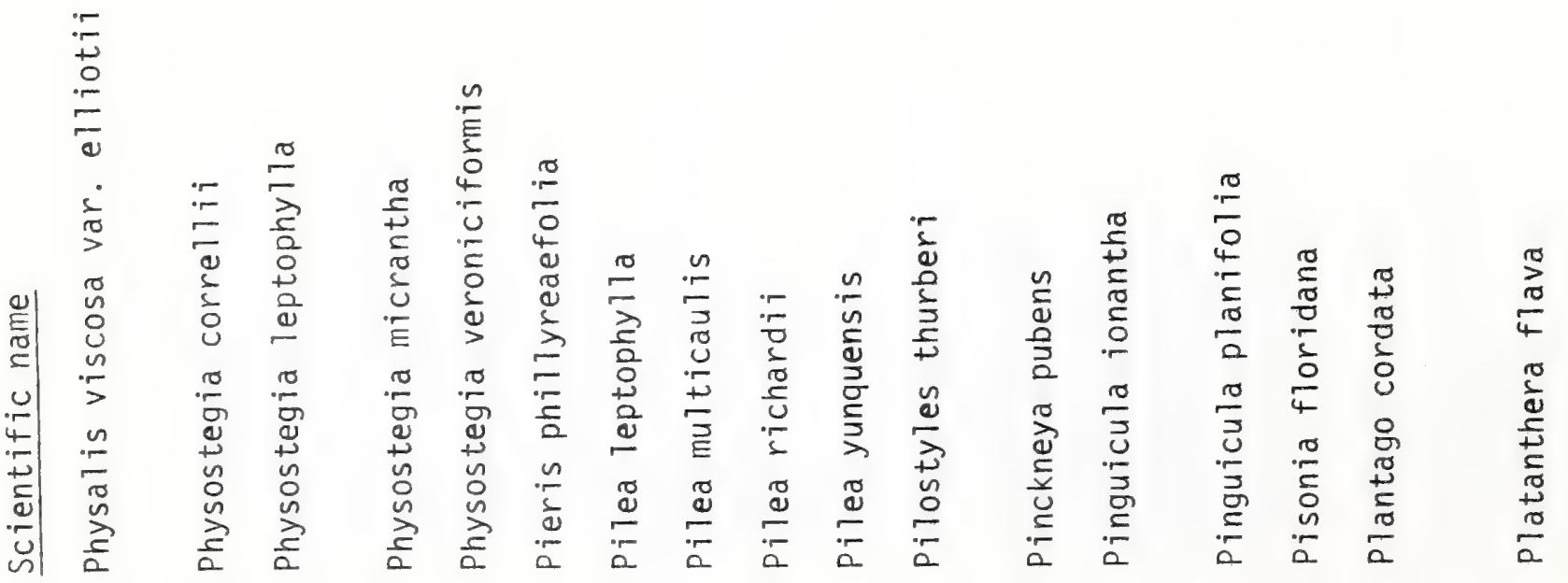




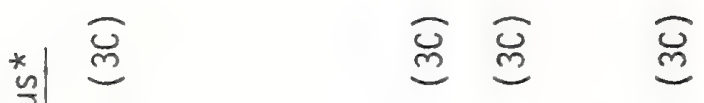

ত্ল $\quad \bar{j} \quad \bar{j}$

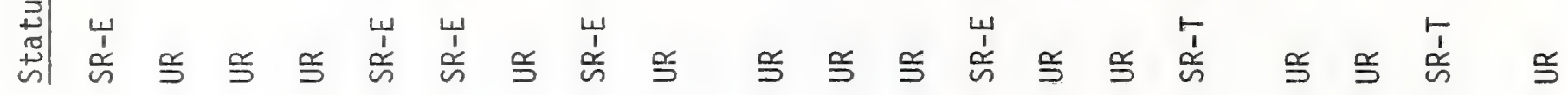

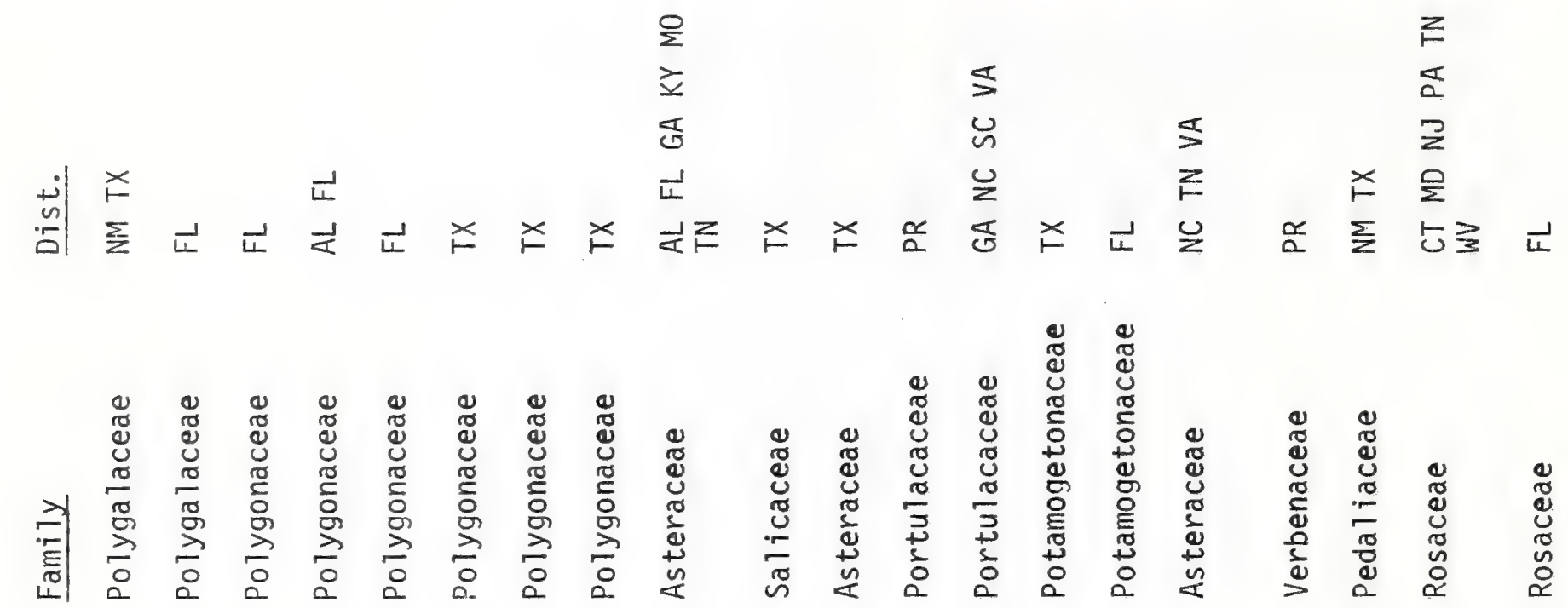

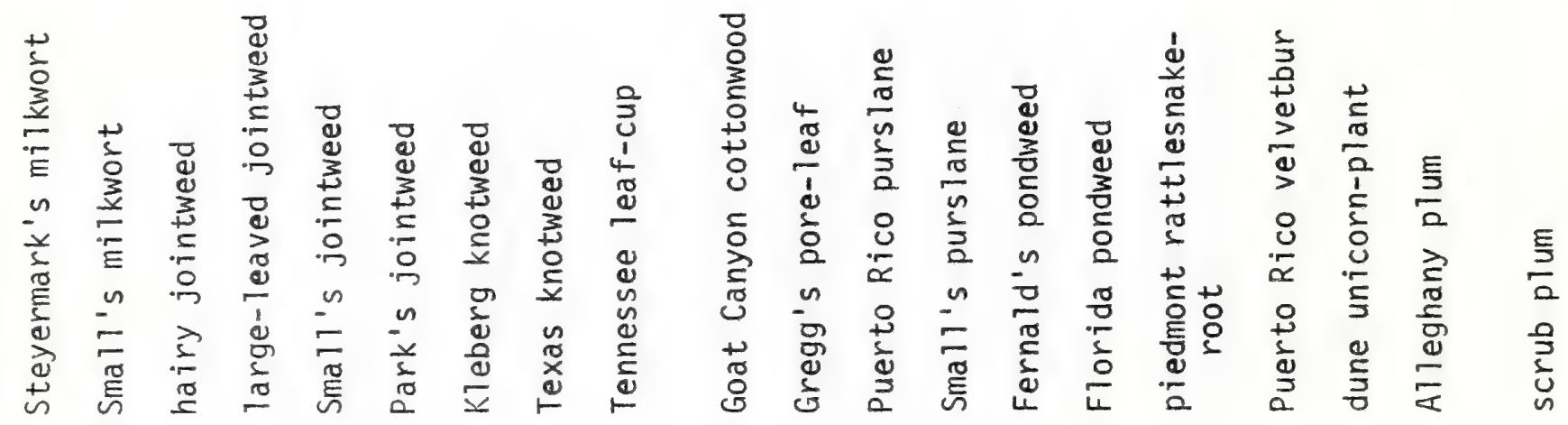

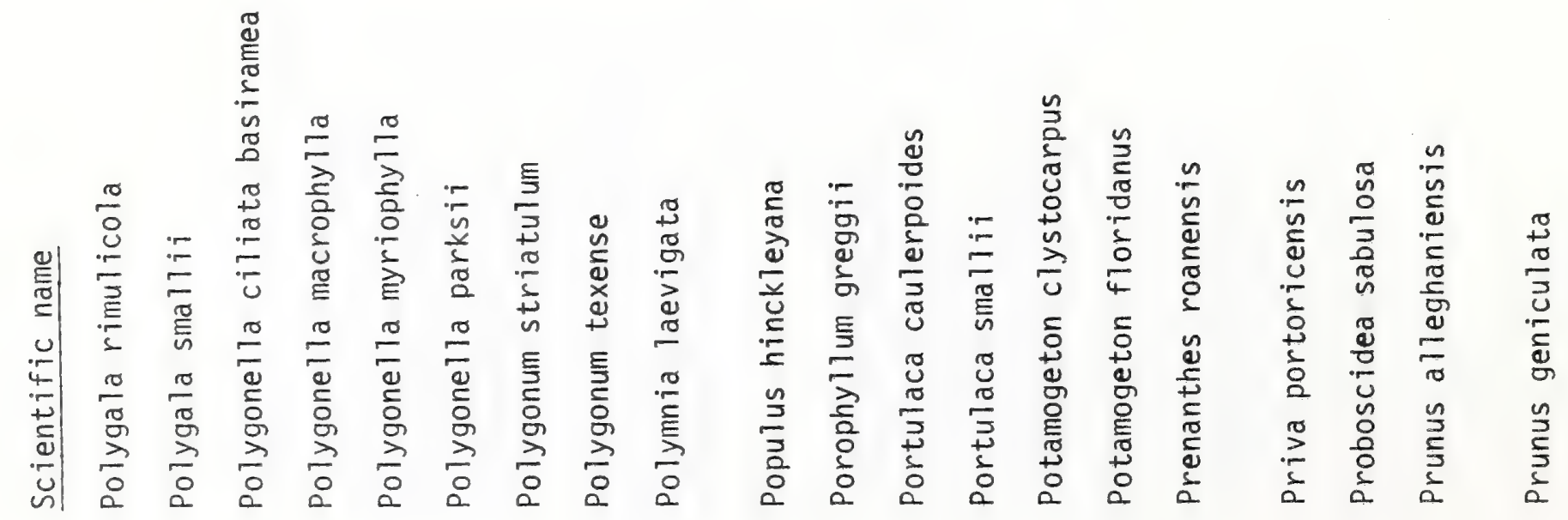




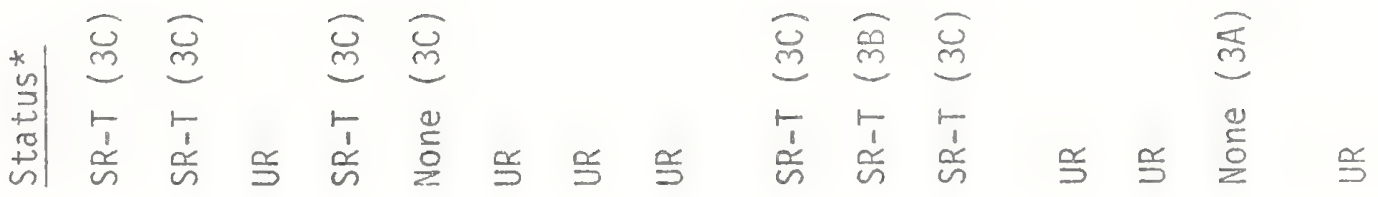

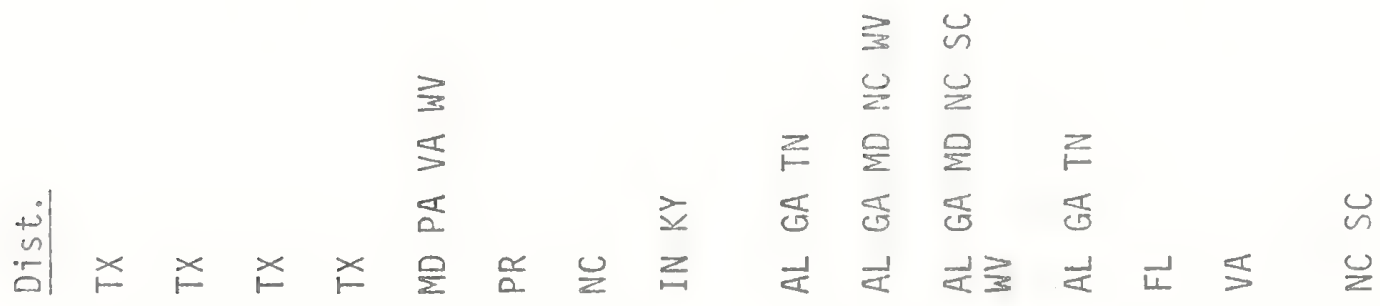

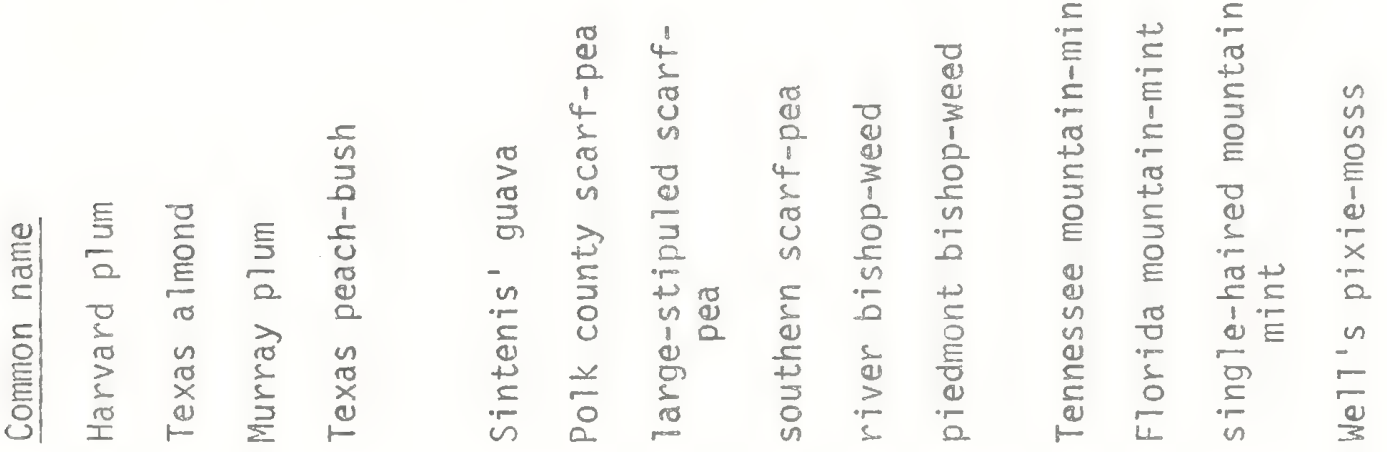

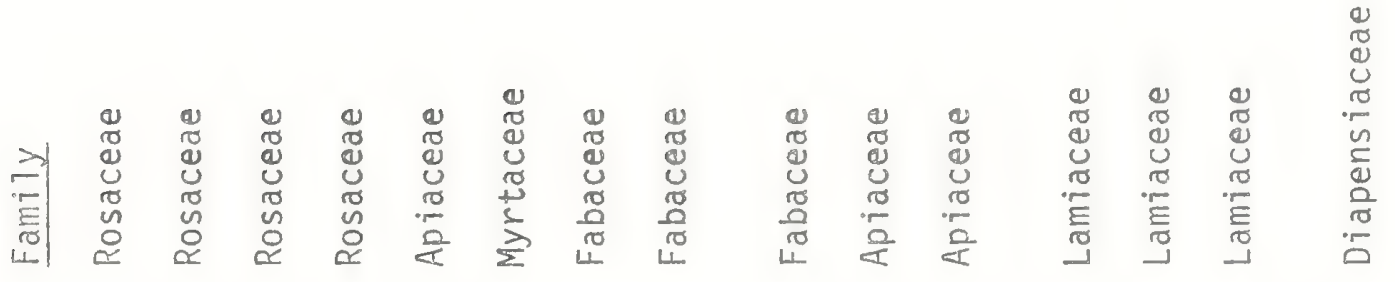

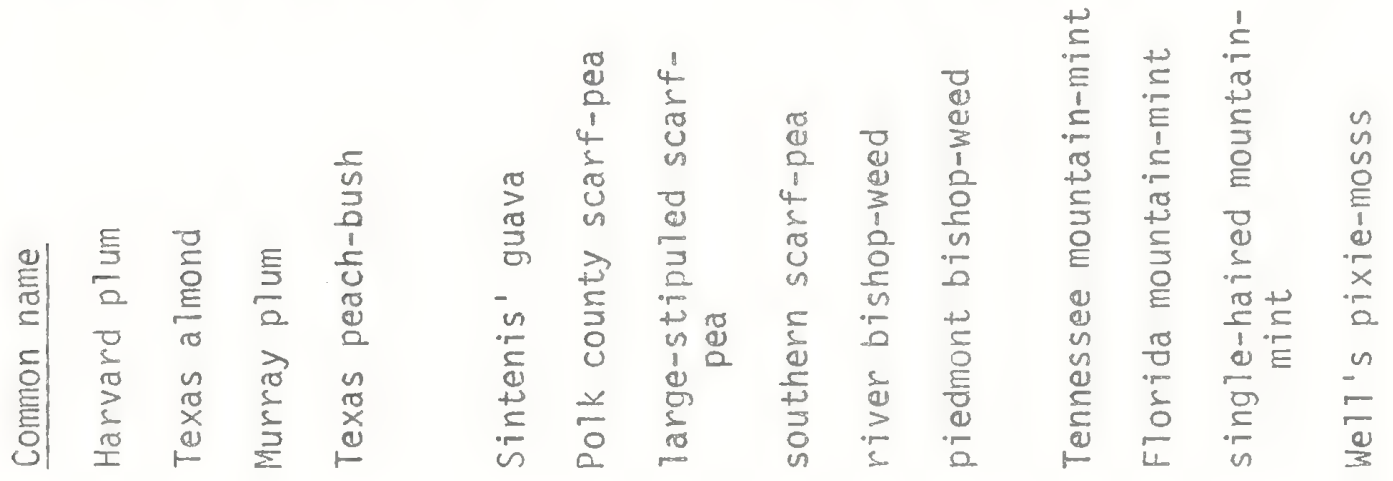

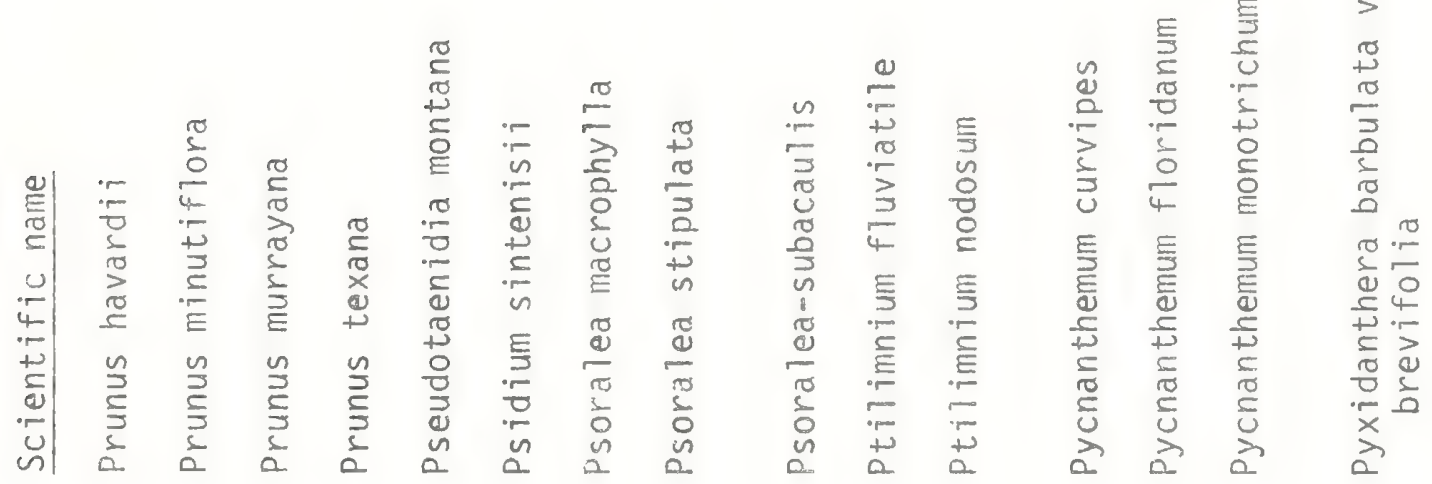




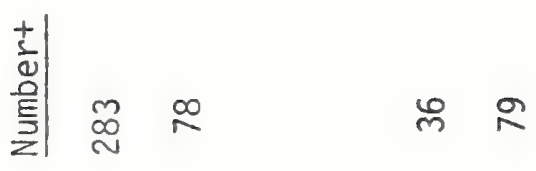

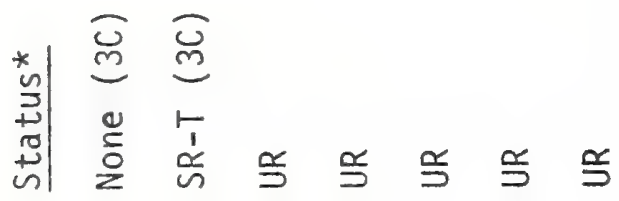

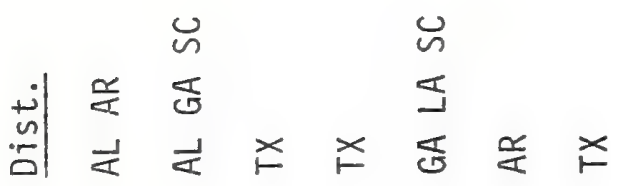

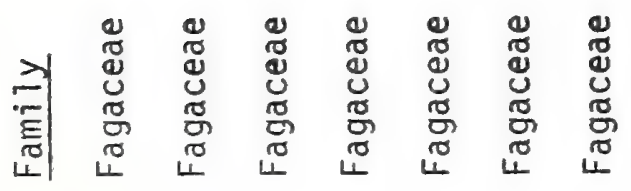

$\frac{1}{0}$

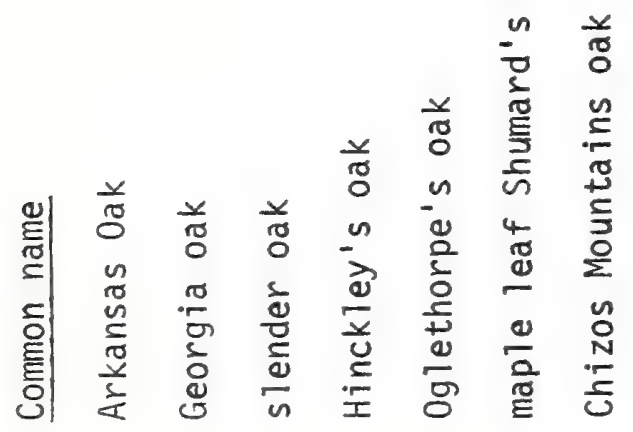

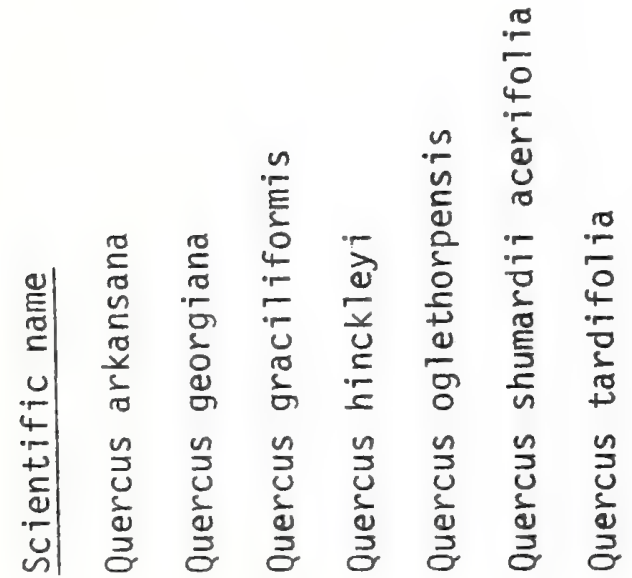


* 要

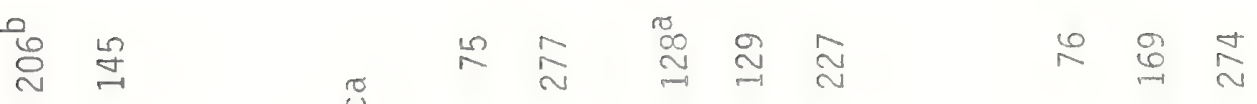

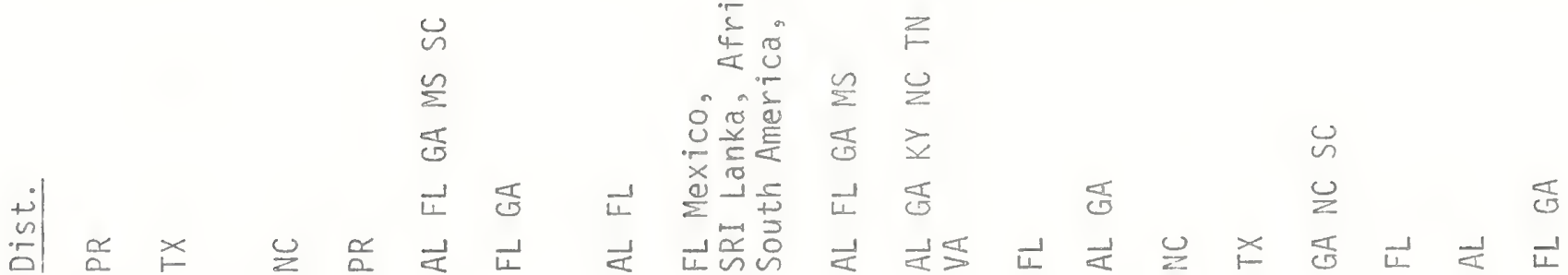

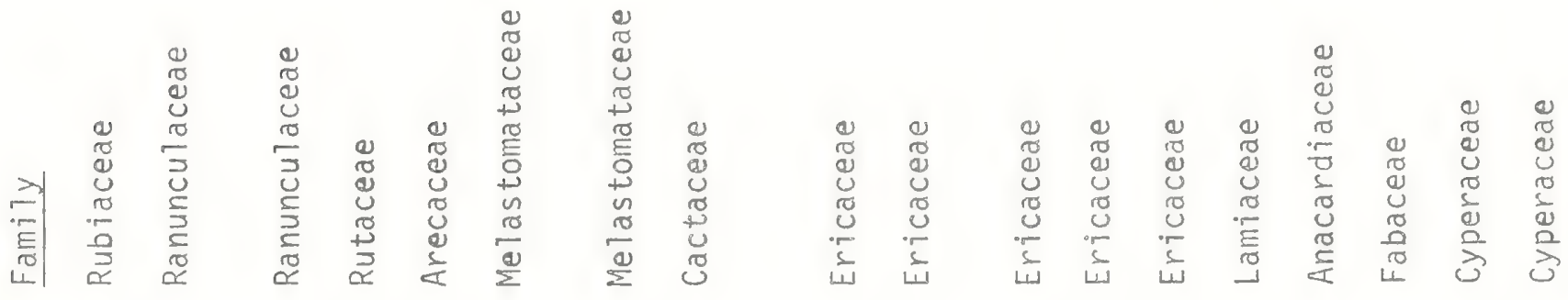

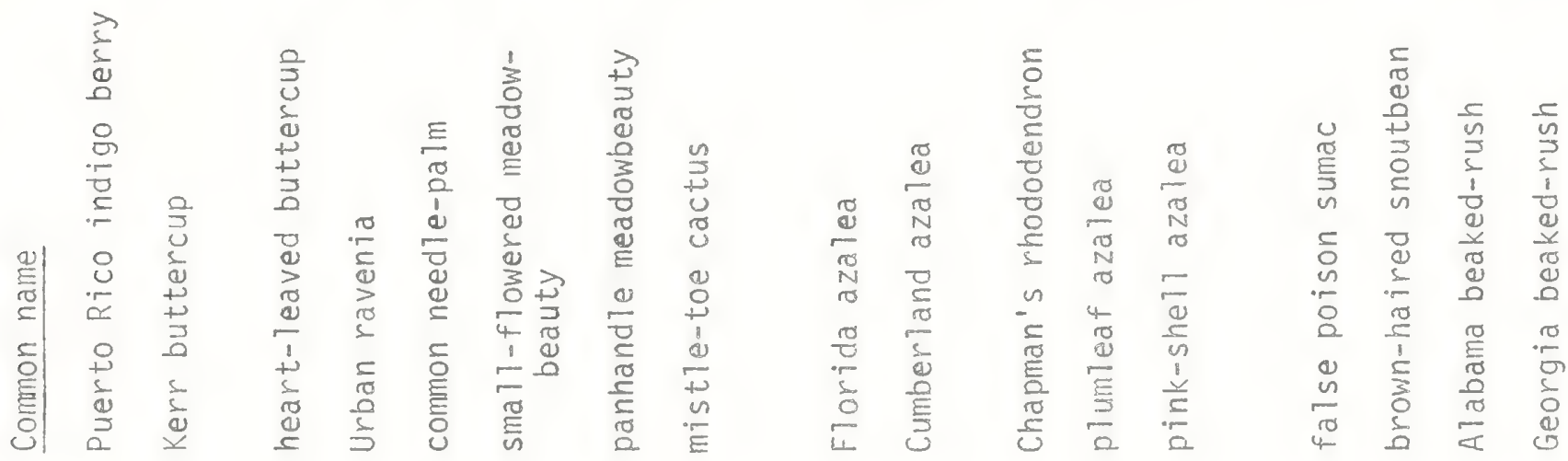

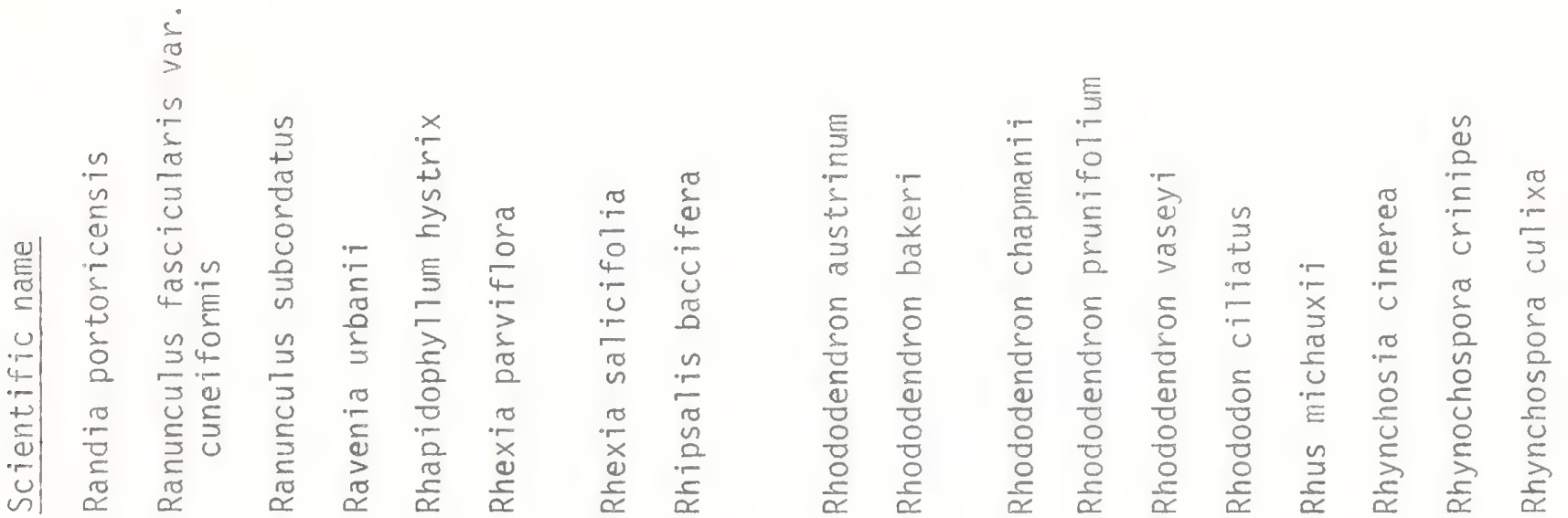




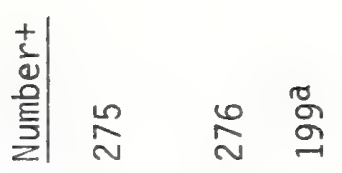

L $0 \quad \stackrel{\text { a }}{4}$

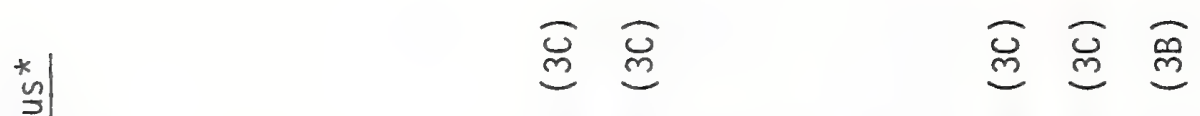

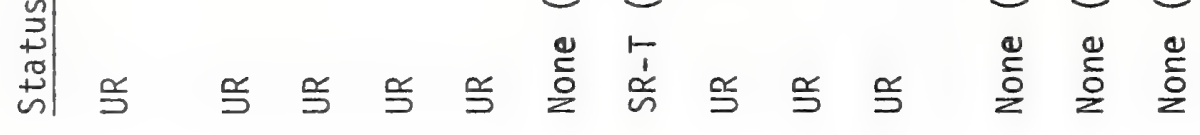

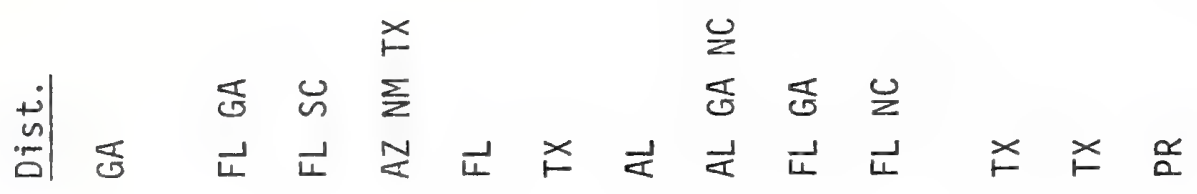

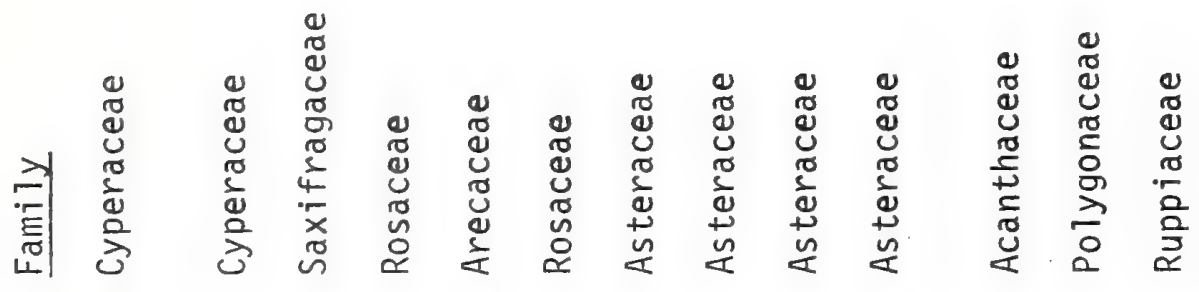

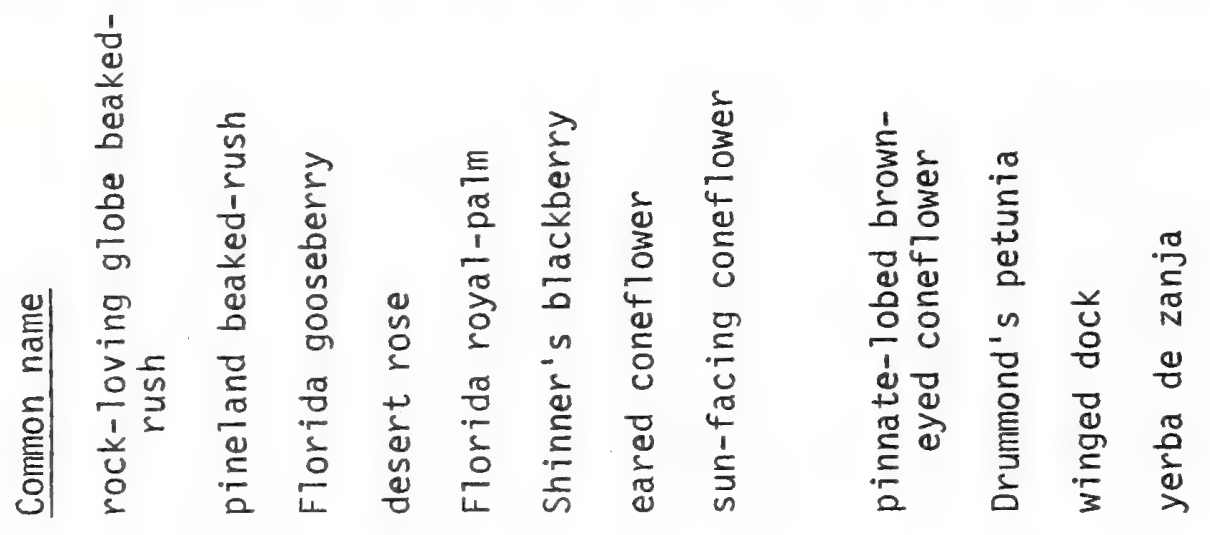

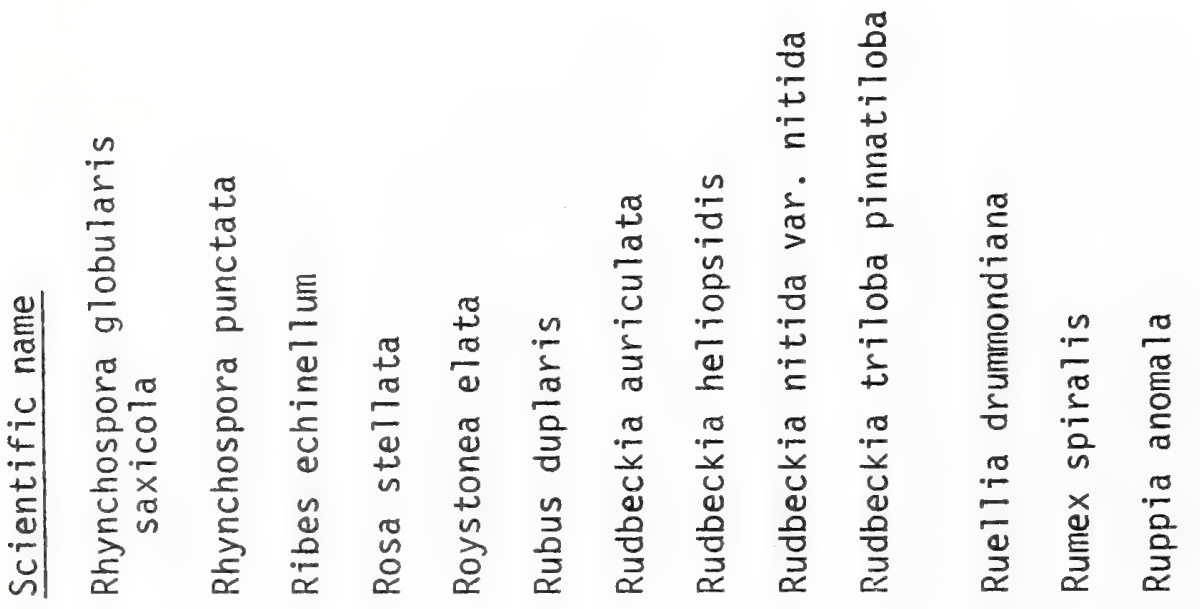




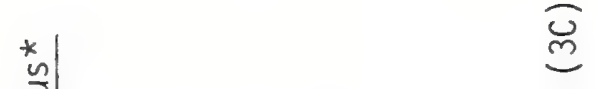
商 $\bar{g}$ 庐

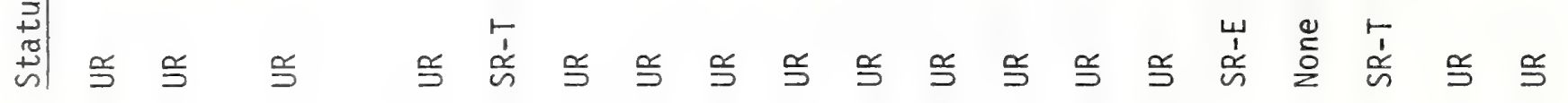

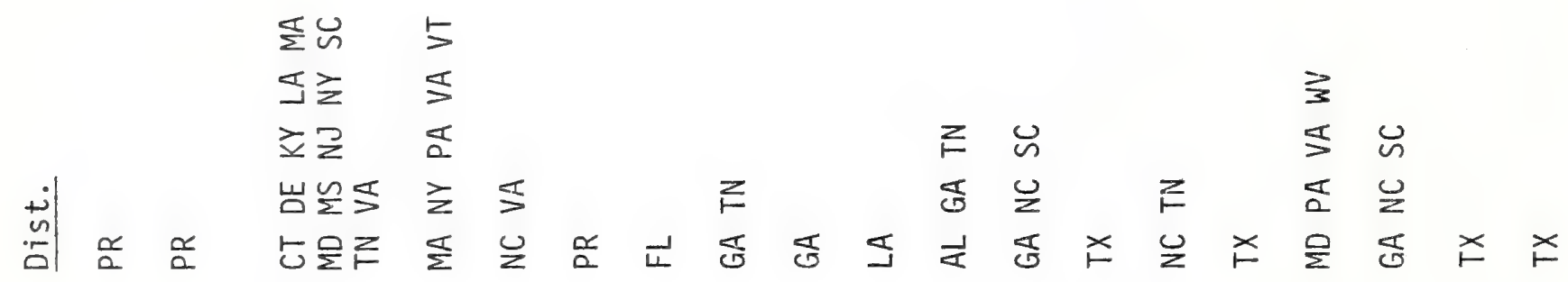

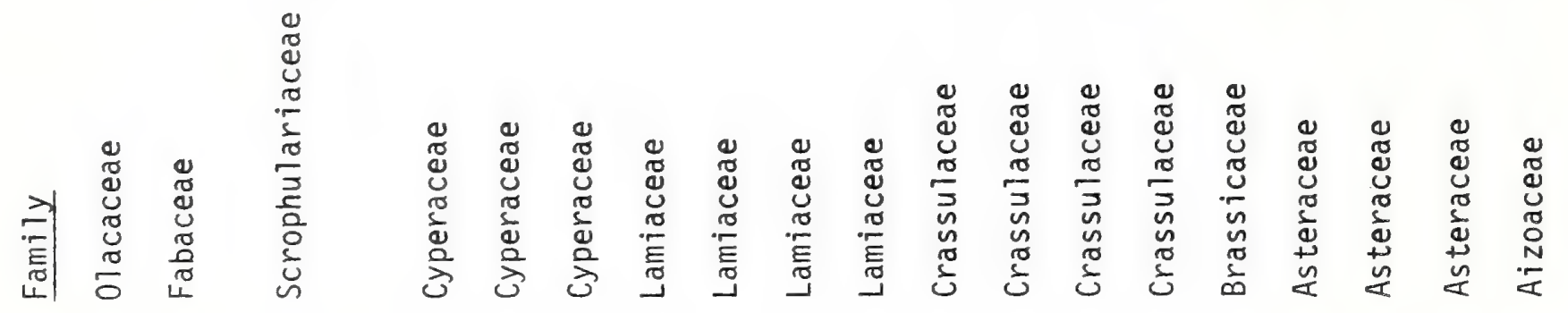

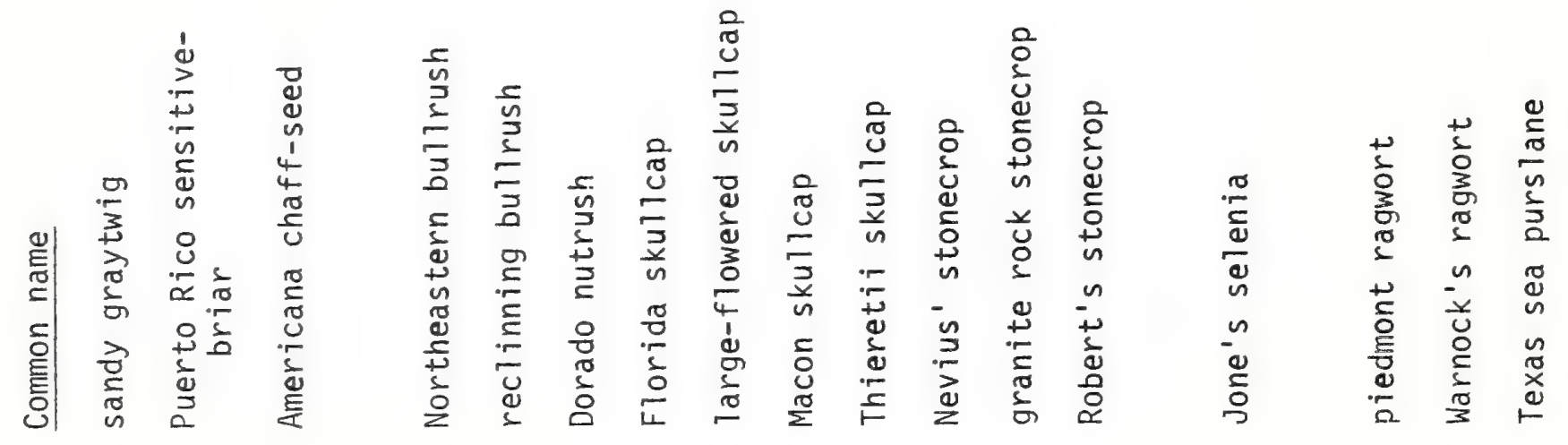

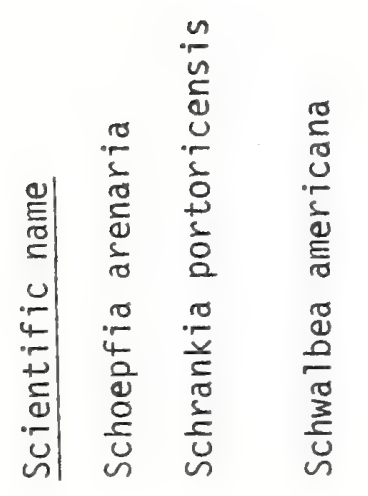

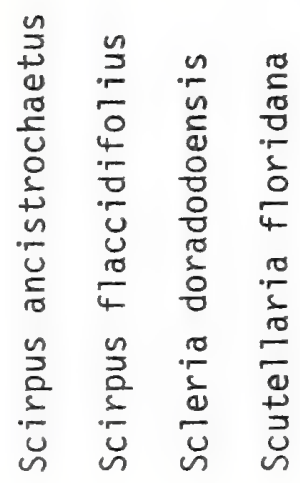

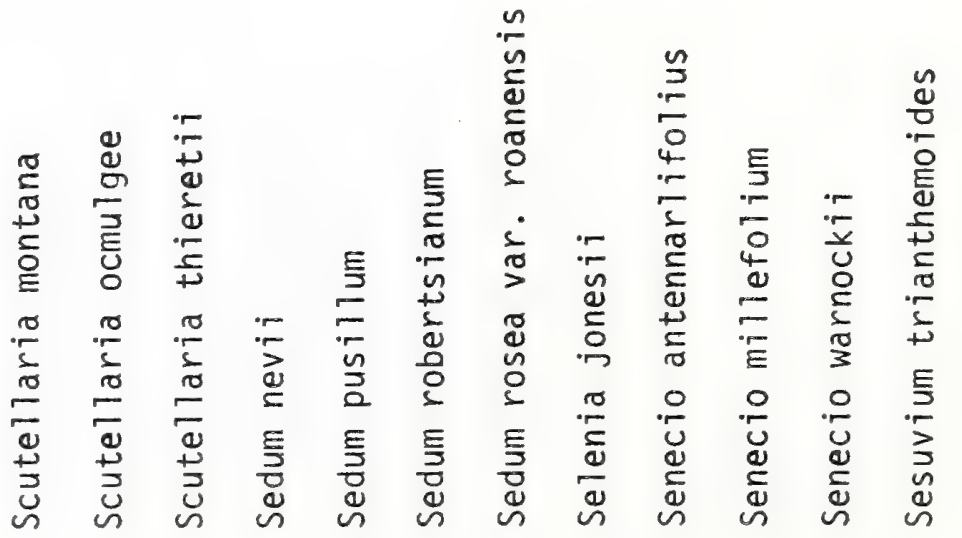




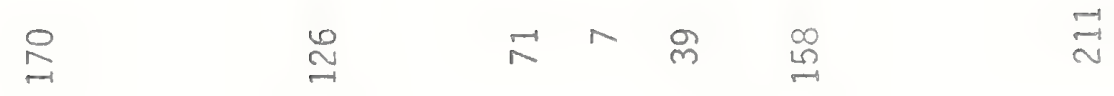

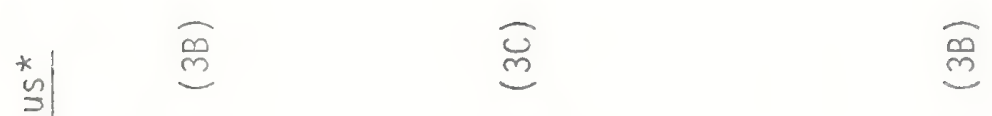

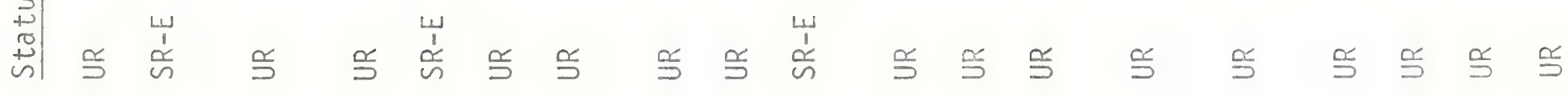

z

$\$$ 可并

出 虫 중종

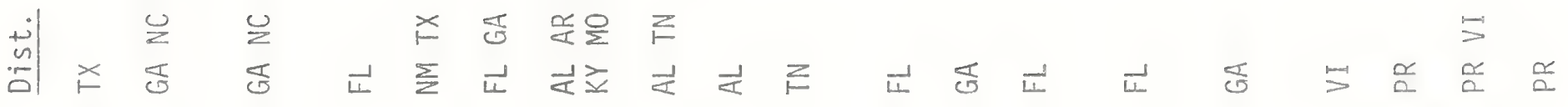

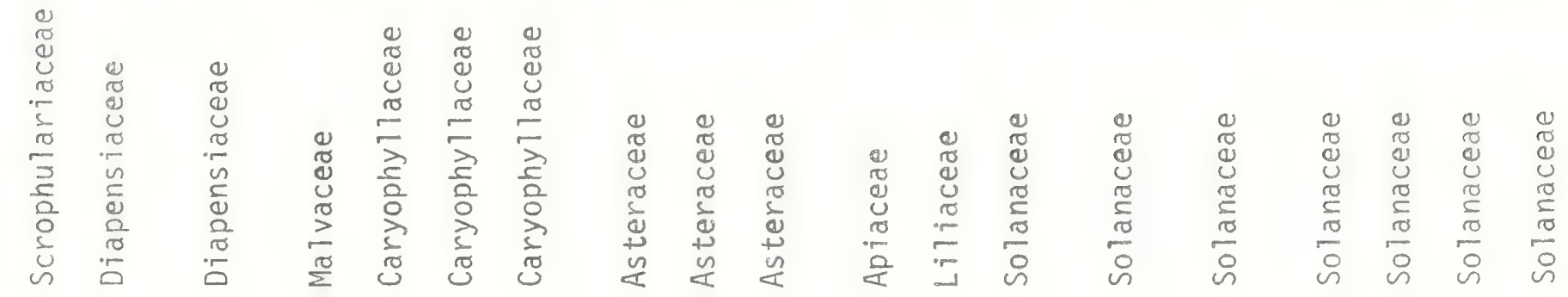

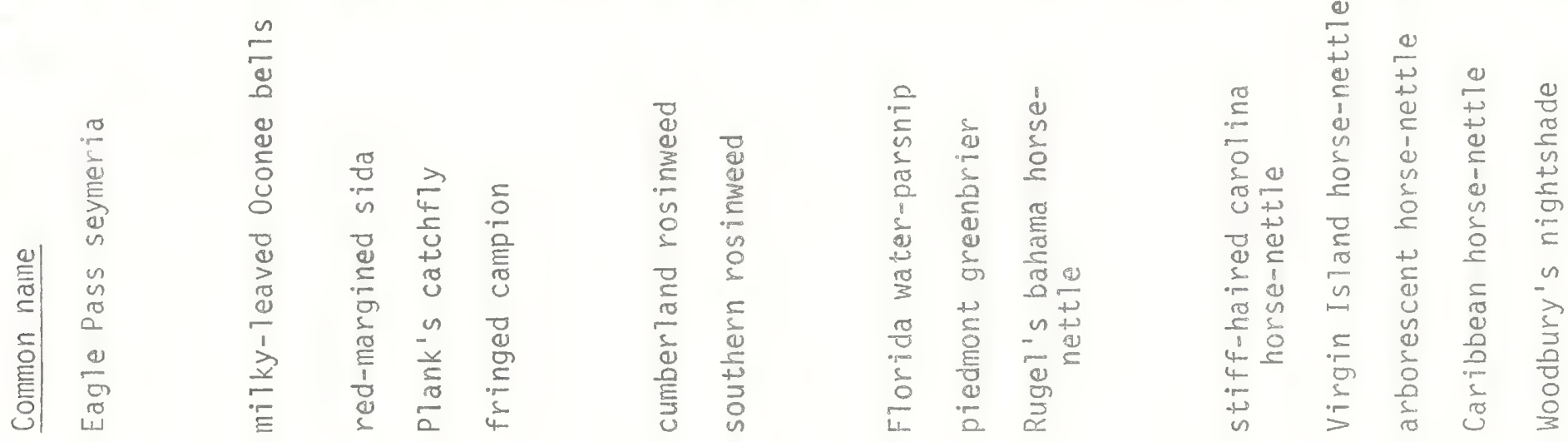




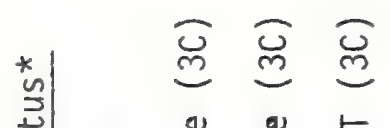

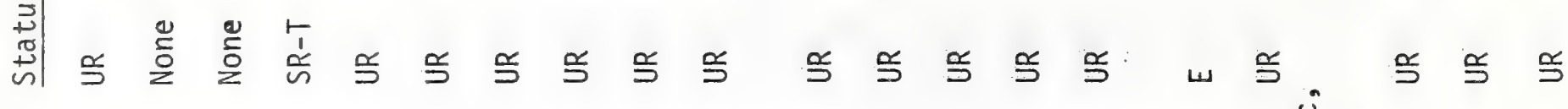
$\stackrel{0}{\because} \frac{0}{3}$

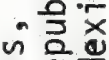

३)

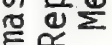

要

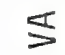

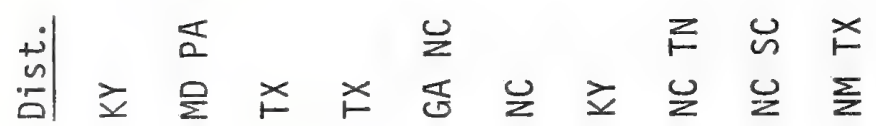

$\div \frac{\pi}{\pi}$

.

응.

$\underset{\frac{u}{0}}{\frac{0}{0}}$

言

"
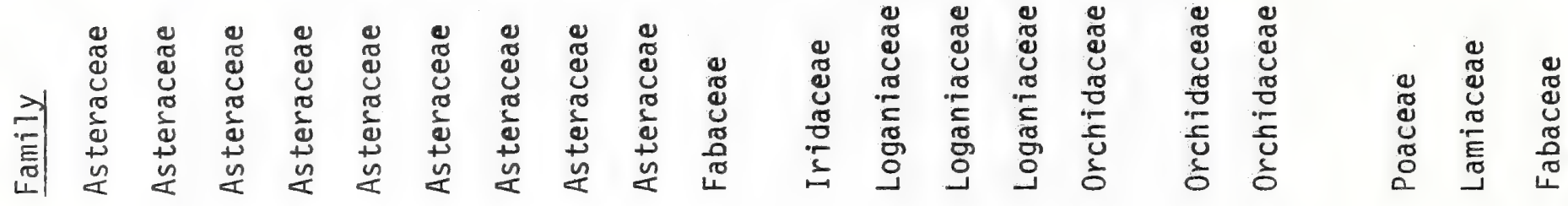

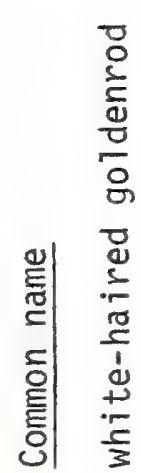

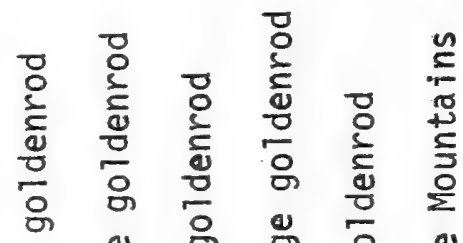

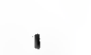

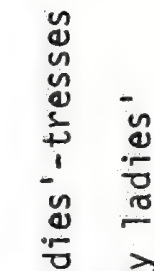

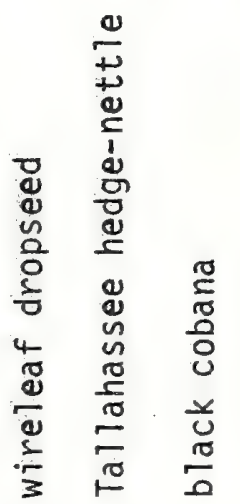

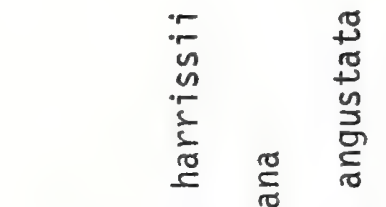

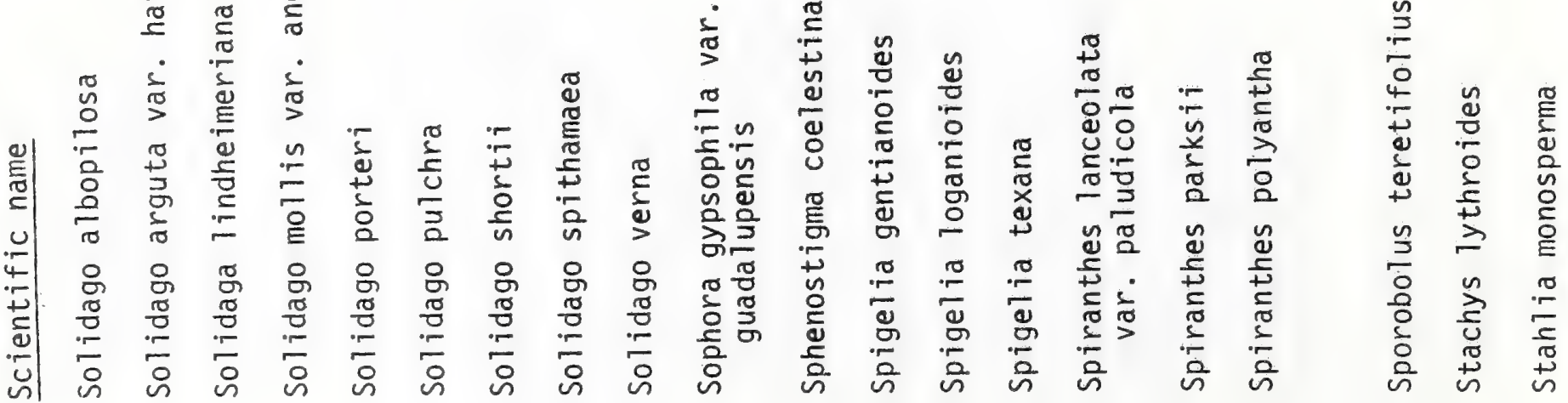

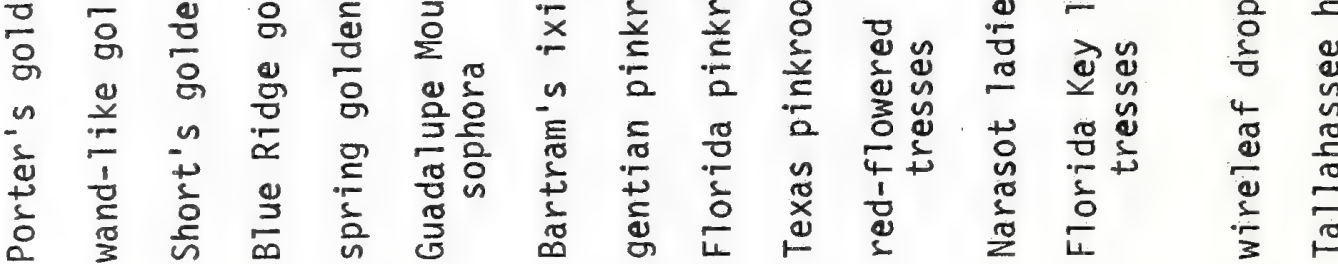




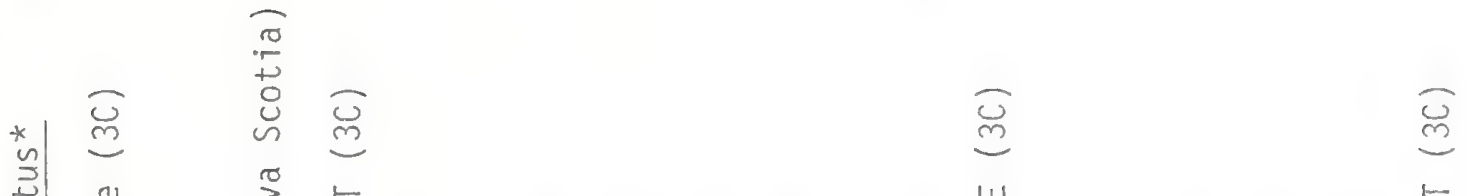

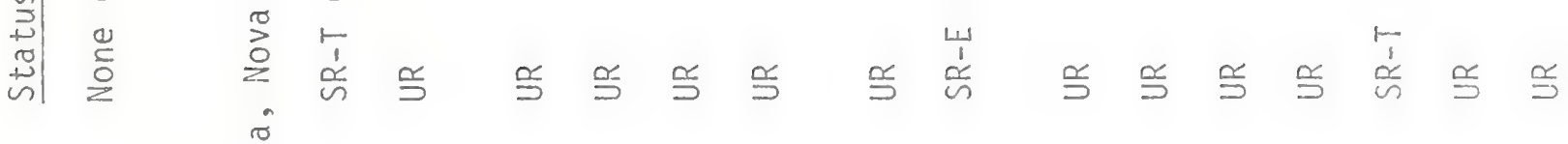

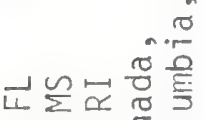
떤뜽힝ㅇㅇ U $0 \sum \sum \frac{1}{2} \frac{5}{n}$.

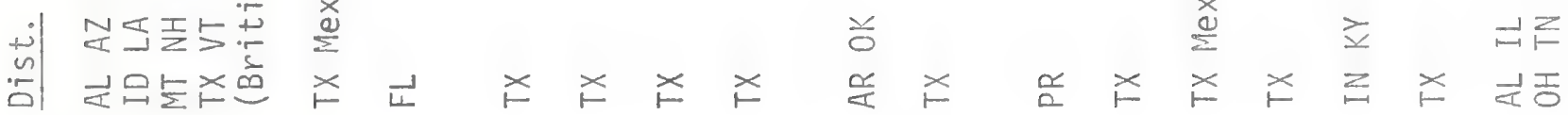

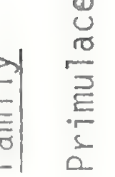
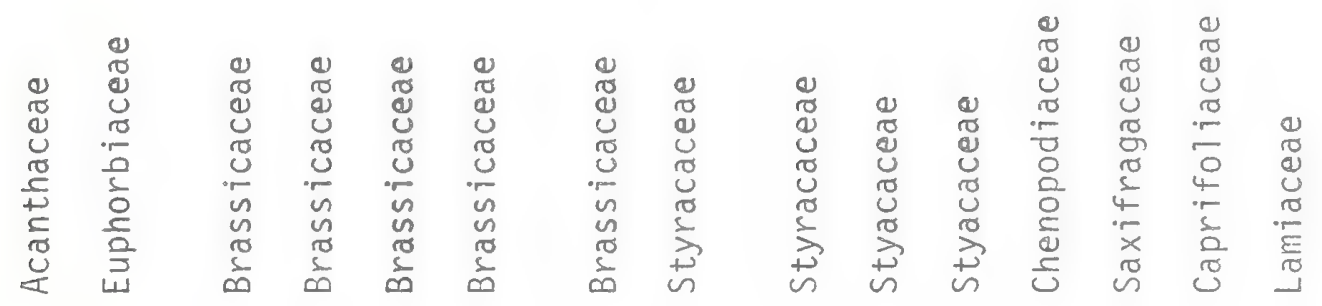

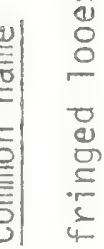

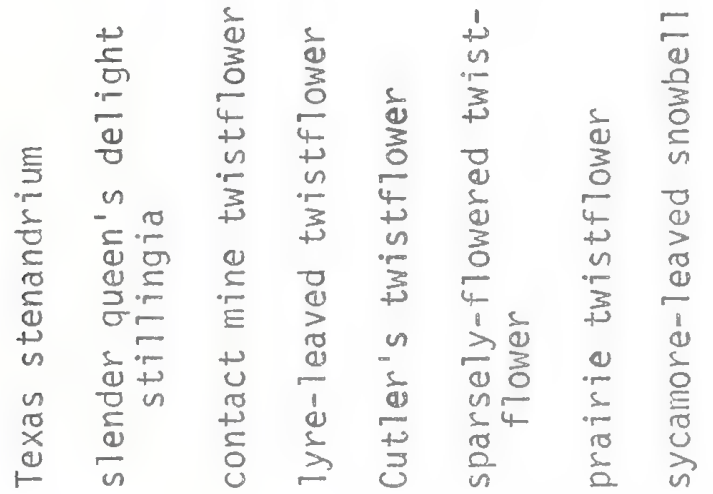

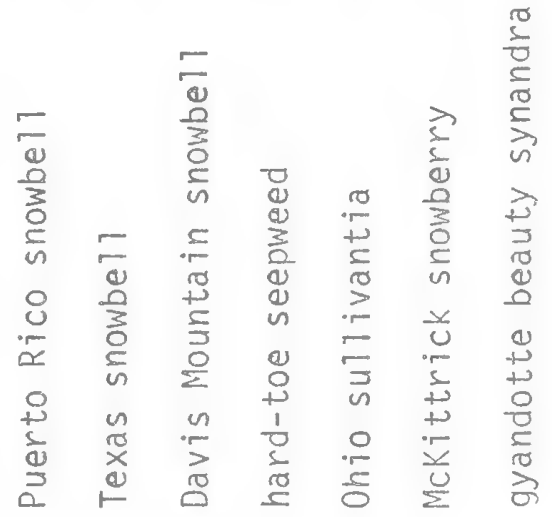

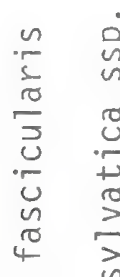

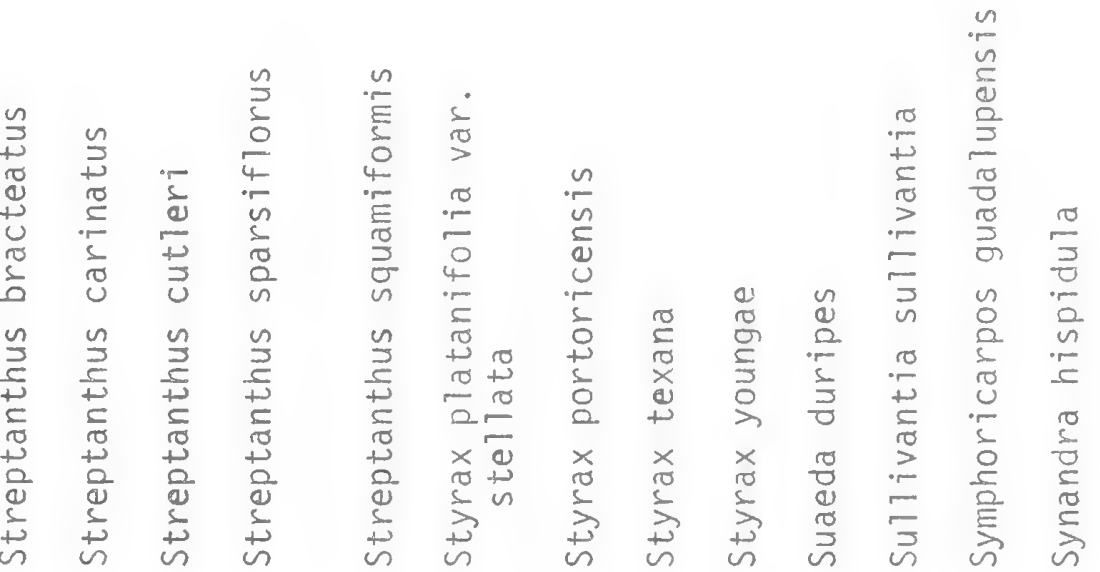


盇|

$\approx \quad \widetilde{\Omega}$

声

$\stackrel{0}{\sim}$

可 可 迎

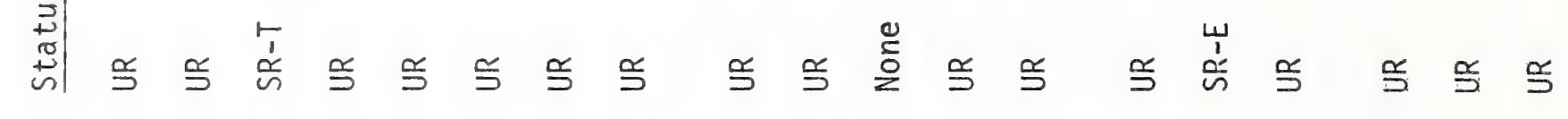

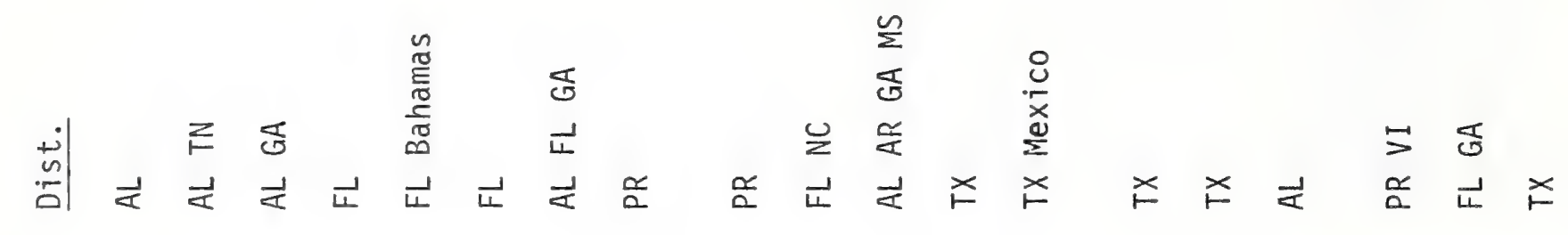

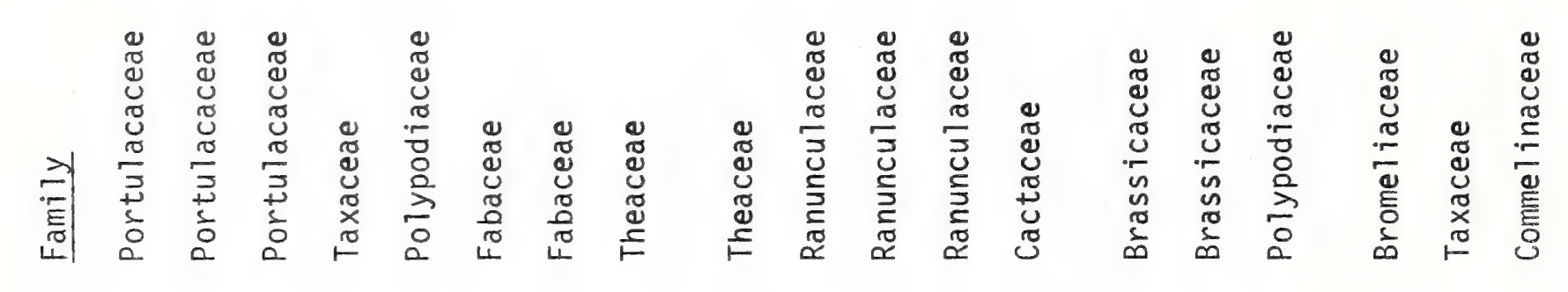

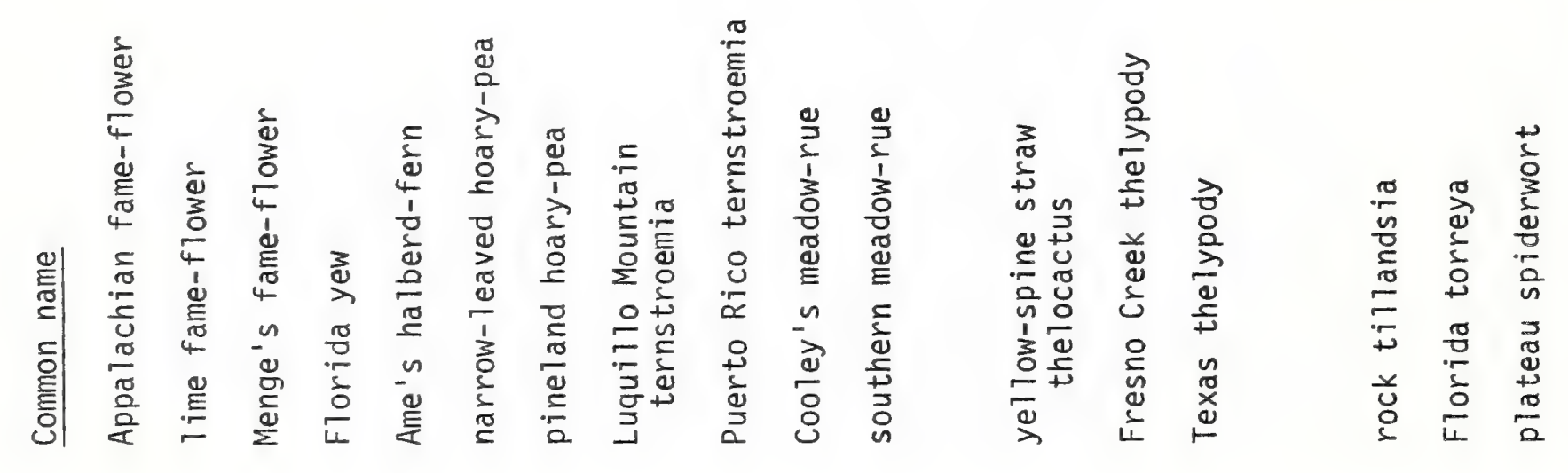

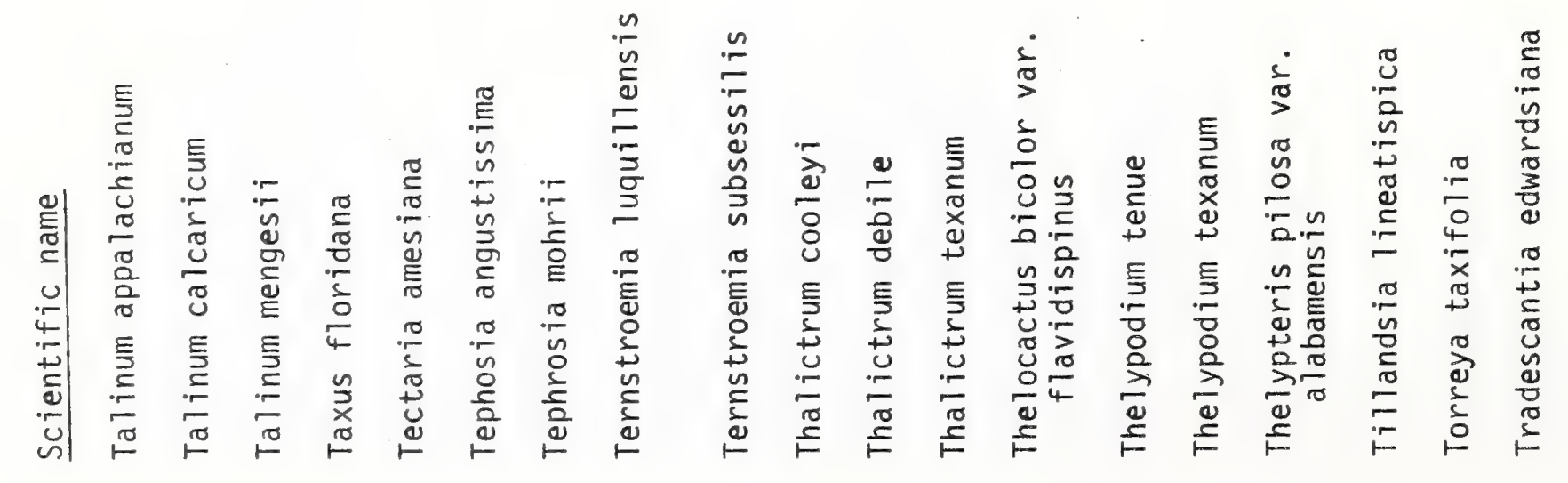




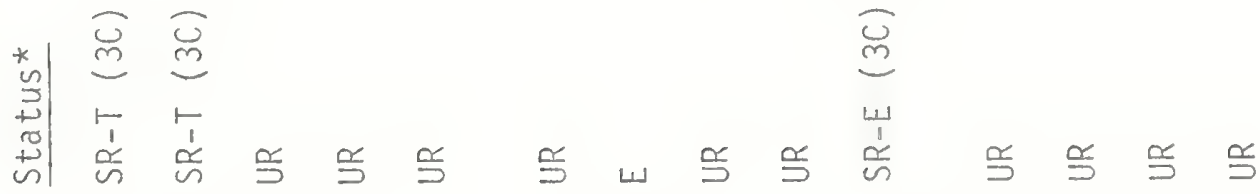

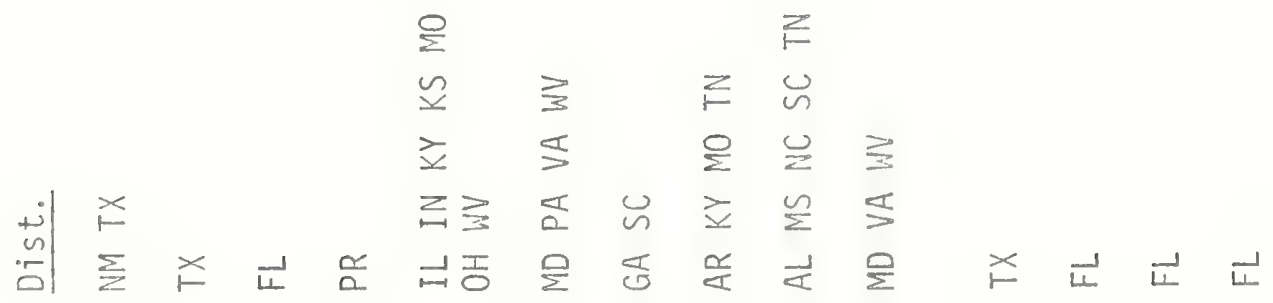

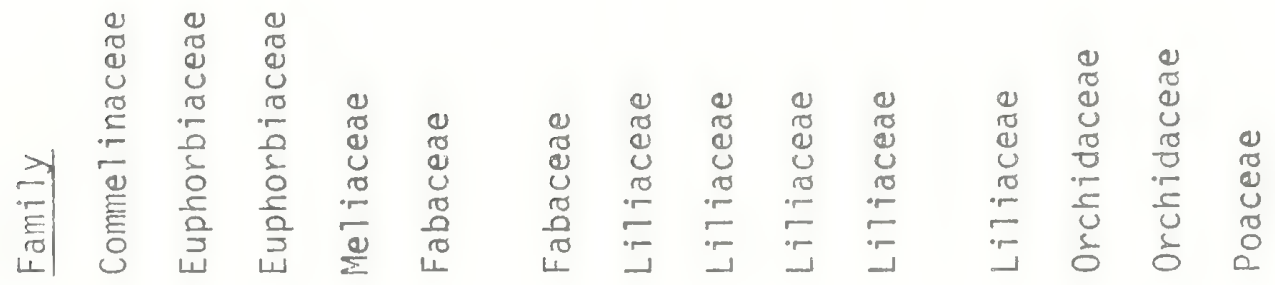

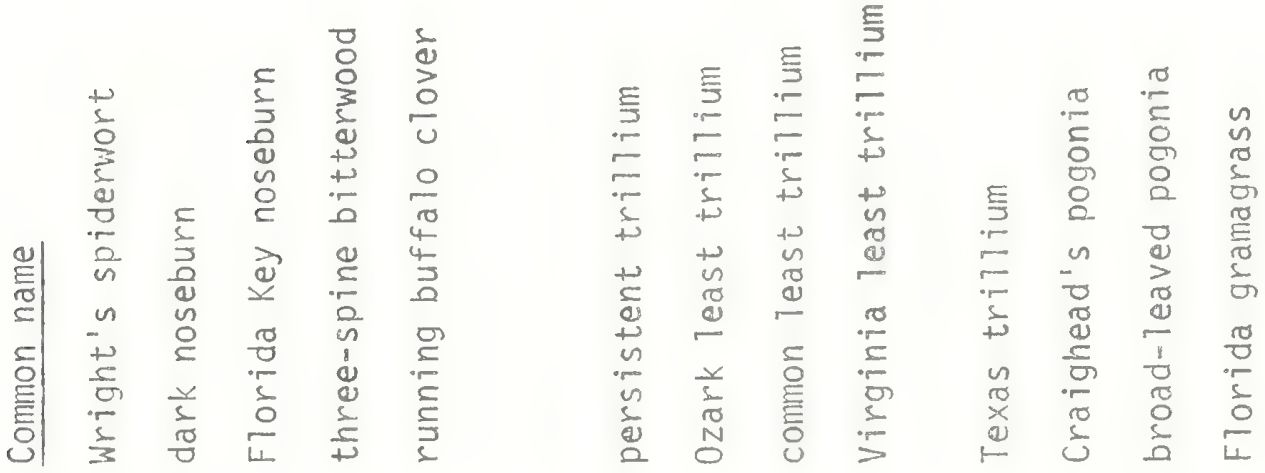

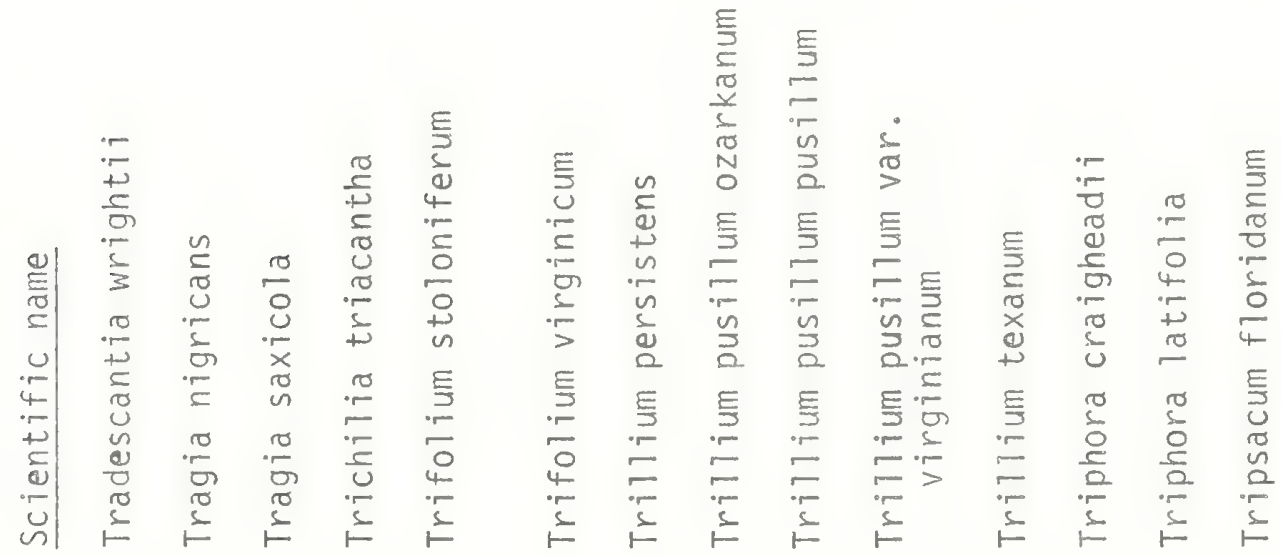


+1
ป
है
हो।

莎

站

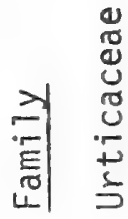

잃

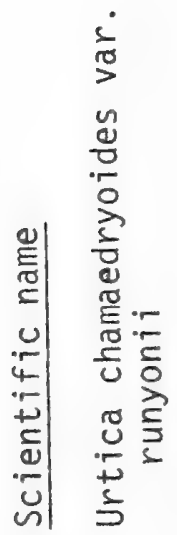


I

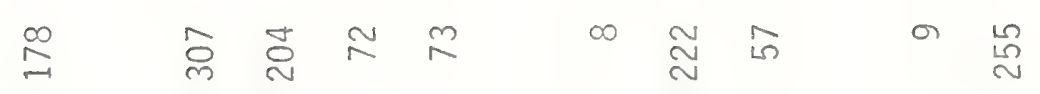

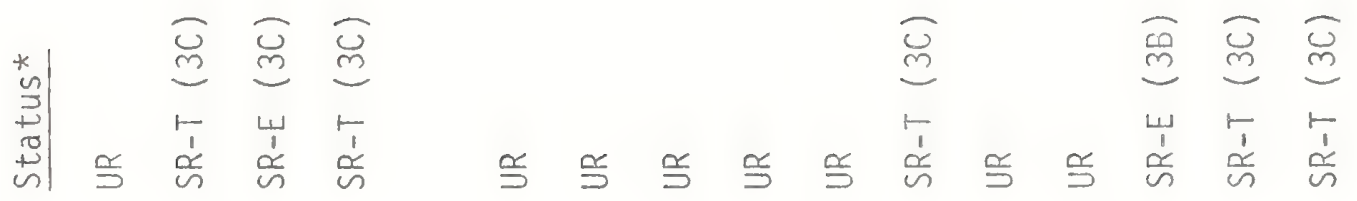

$\sum_{1}$

曰岂

而을

Z

文

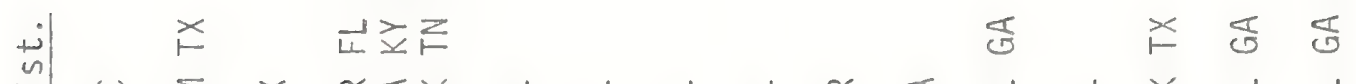

吕出 至

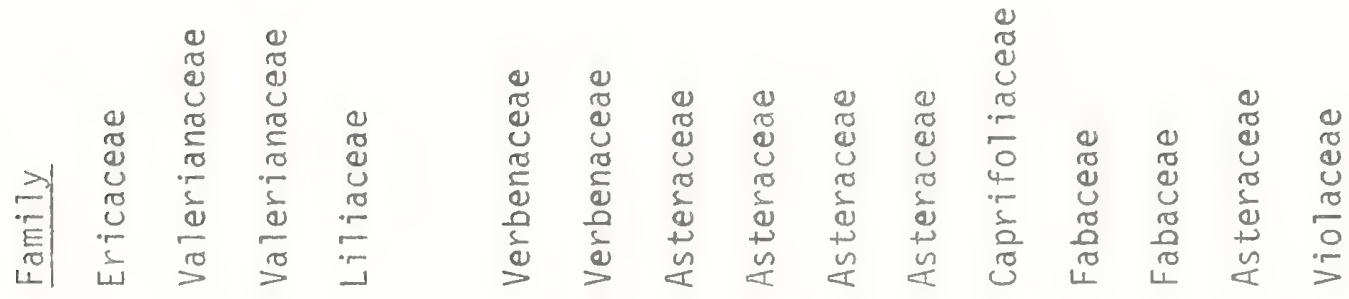

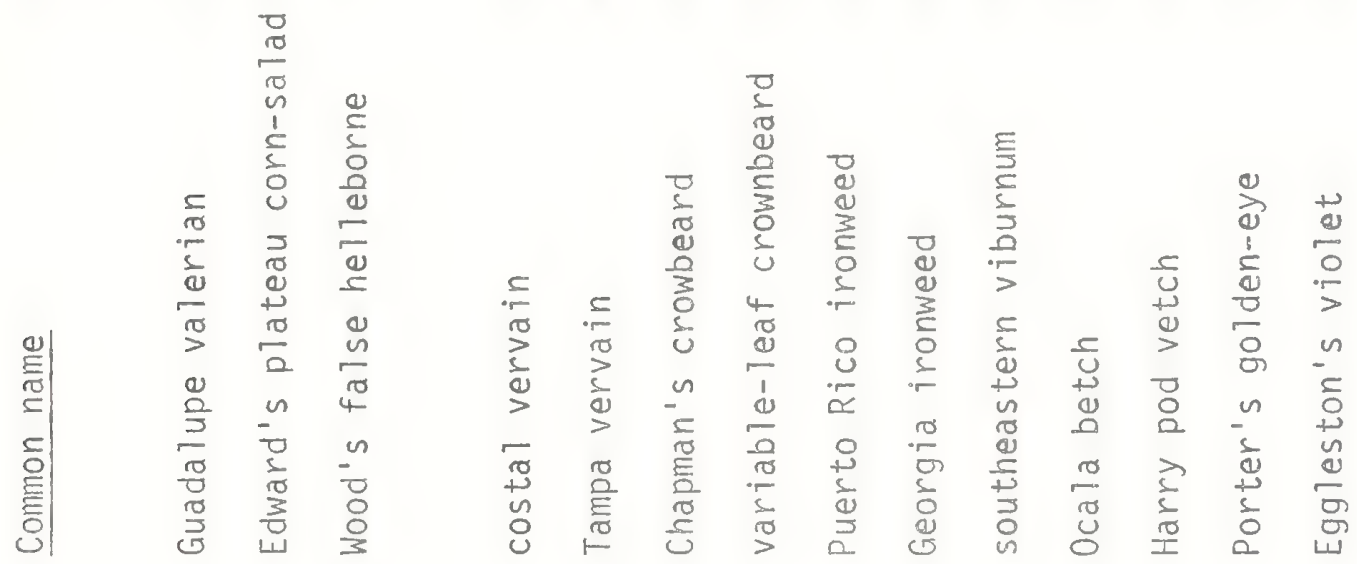

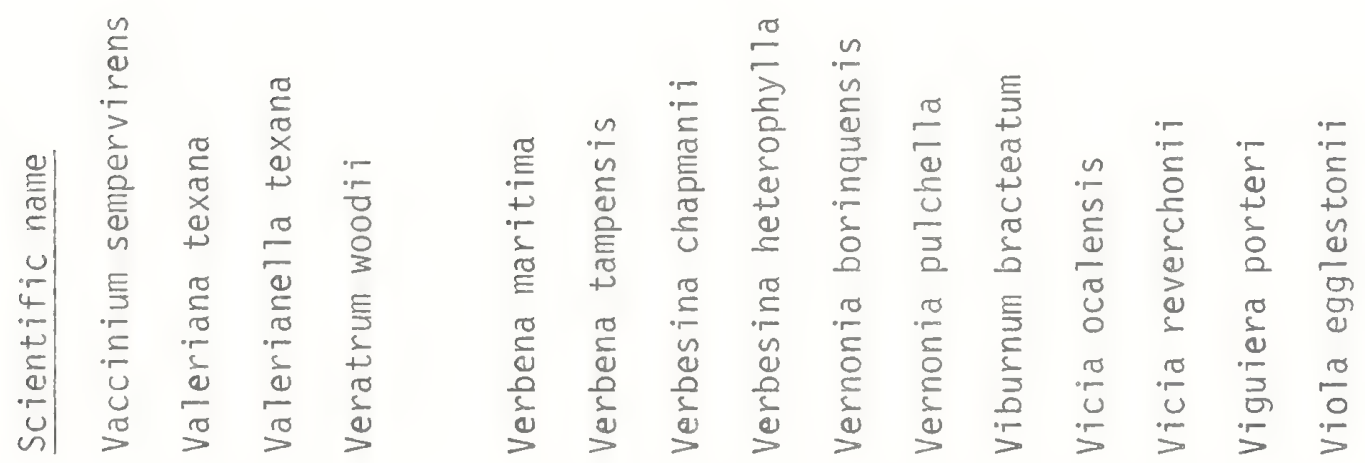




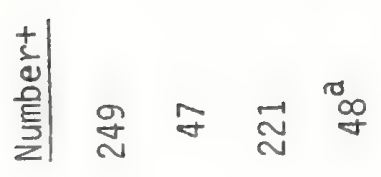

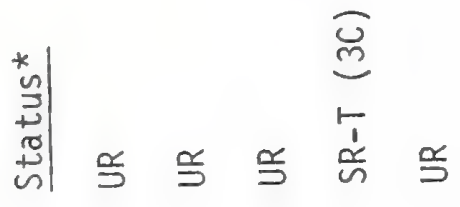

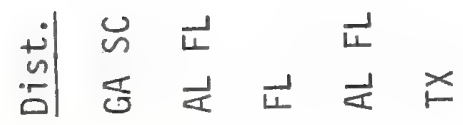

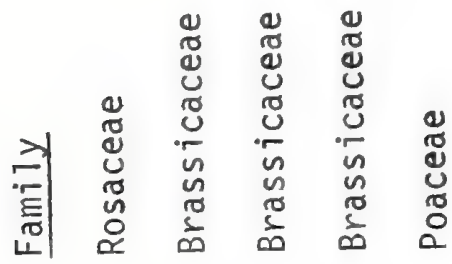

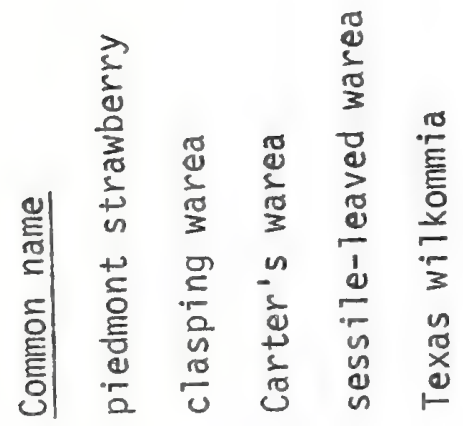

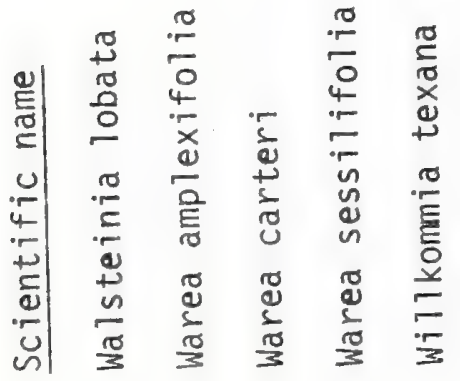




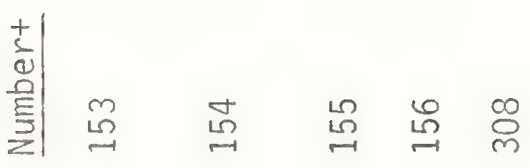

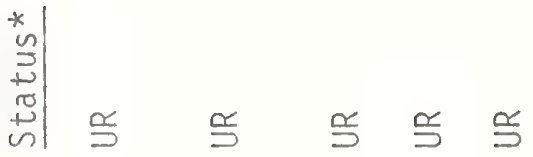

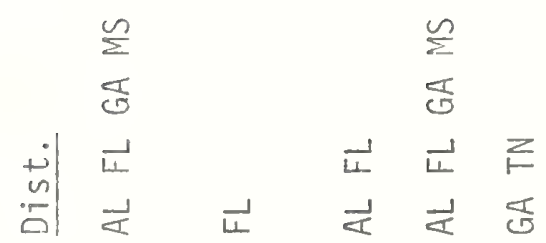

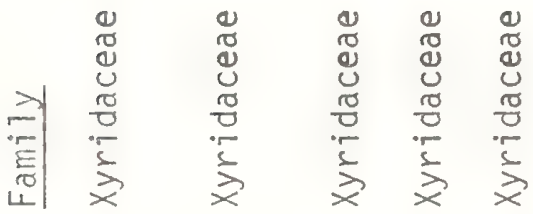

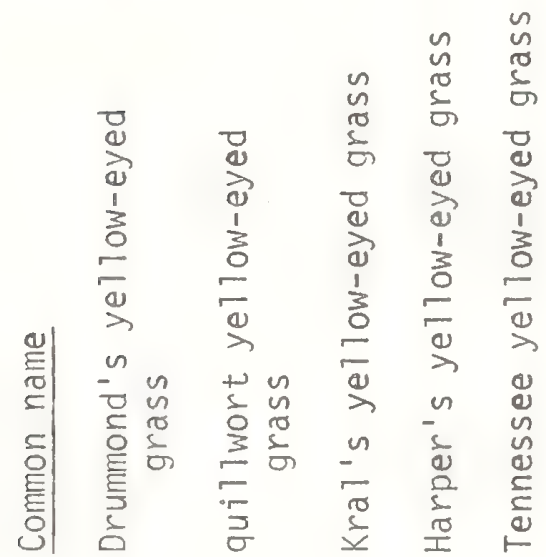

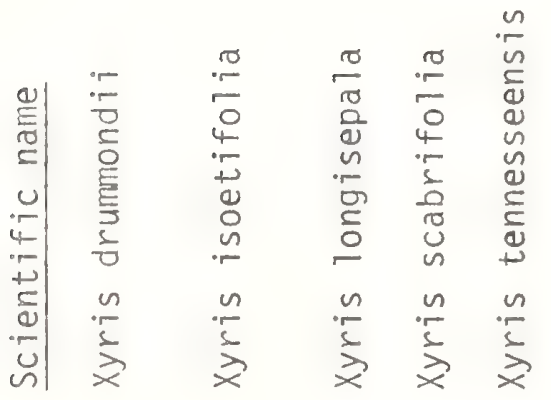




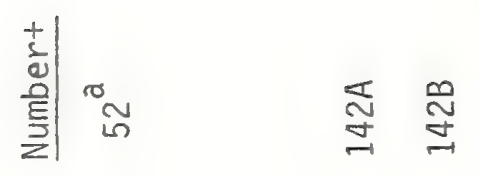

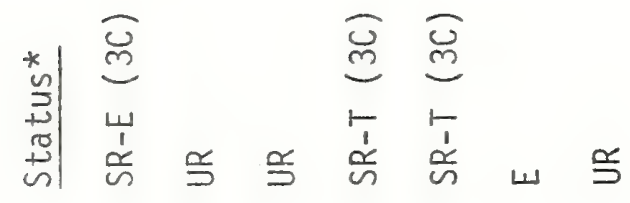

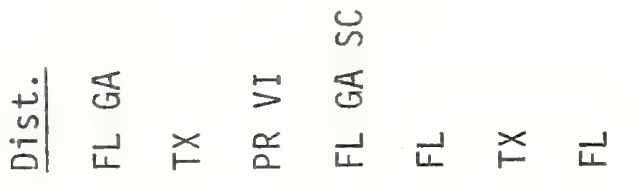

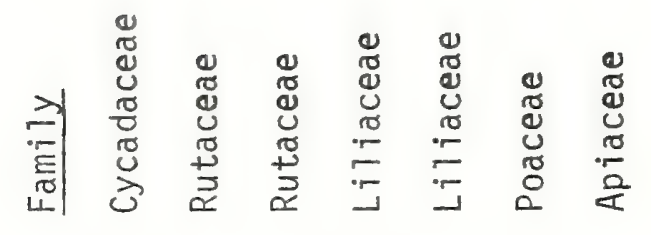

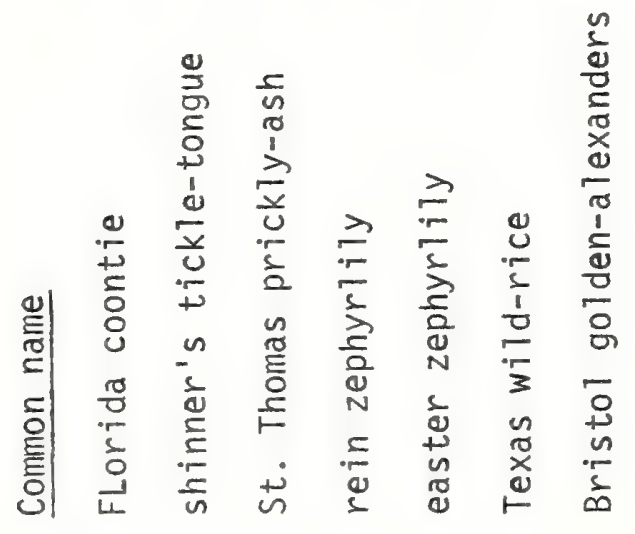

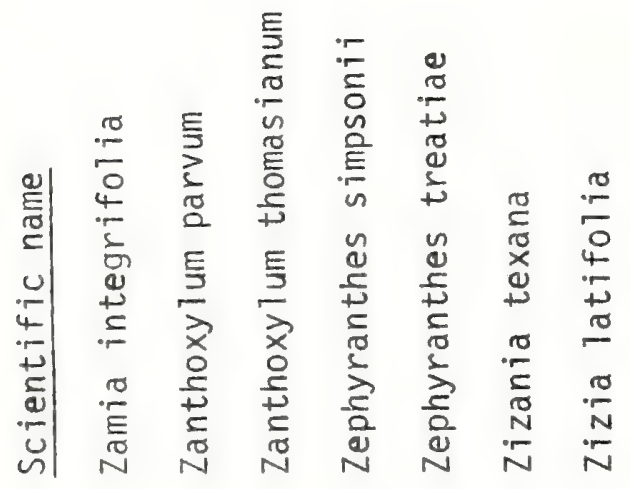




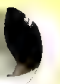


-

0 
\#1 Lesquerella densipila Rollins: Duck River bladderpod

\#2 Asclepias viridula Chapm. southern milkweed

\#3 Aster spinulosus Chapm; pine-woods aster

\#4 Prenanthes roanensis (Chick.) Chick.; piedmont rattlesnake-root

\#5 Rudbeckia auriculata (Perdue) Kral: eared coneflower

\#6 Rudbeckia heliopsidis $T$ \& \& G.: sun-facing coneflower

\#7 Silphium confertifolium Small: southern rosinweed

\#8 Vernonia pulchella Small; Georgia ironweed

\#9 Viguiera porteri (A. Gray) Blade; Porter's golden-eye

\#10 Leavenworthia alabamica Rollins var. alabamica; Alabama glade-cress

\#11 Leavenworthia alabamica Rollins var. brachystyla Rollins; short-styled glade-cress

\#12 Leavenworthia crassa Rollins var. crassa; fleshy-fruited glade-cress

\#13 Leavenworthia crassa Rollins var. elongata Rollins; Falkville glade-cress

\#14 Leavenworthia exigua Rollins var. exigua; Tennessee glade-cress

\#15

\#16

\#17

\#18

\#19 Leavenworthia exigua Rollins var. Iaciniata Rollins; Sheperdsville glade-cress Leavenworthia exigua Rollins var. Iutea Rollins; pasture glade-cress Leavenworthia stylosa Gray; limestone glade-cress Leavenworthia torulosa Gray; string-of-beads glade-cress

\section{Arenaria fontinalis (Short and Peters) Shinners; pioneer sandwort}

Iechea cernua Small; nodding pinweed

Lechea divaricata Shuttle: pine pinweed

Bonamia grandiflora (A. Gray) Heller; large-flowered bonamia

Carex amplisquama F. J. Hermann; Fort Mountain sedge

Carex baltzellii Chapm. ex Dewey; Baltzell's sedge

Carex chapmannil steud.; Chapman's sedge

Carex purpurifera Machenzie; purple sedge

Cymophylius fraseri (Andr.) Mackenzie; Fraser's sedge

Fimbristylis perpusilla Harper; Vahl's fimbry

Elliottia racemosa Ell.; comon southern plume

Iachnocaulon beyrichianum sporleder ex Korn.; southern bog buttons

Eriocaulon kornickianum Van Heurck \& Muell. - Arg.; small-headed pipewort

Euphorbia telephoides Chapm.; telephus spruge

Apios priceana B. L. Robins.: Price's groundnut

Astragalus tennesseensis A. Gray; Tennessee milkvetch

Petalostemum foliosum A. Gray; leafy prairie-clover

Quexcus oglethorpensis Duncan; Oglethorpe's oak

Schisandra glabra (Brickell) Rehder; smooth magnolia vine

Marshallia ramosa Beadie \& F. E. Boynt.; southern barbara's-buttons

Silphiuro integrifolium Mchx. var. gattingeri Perry; Gattinger's entire-leaved rosinweed

\#40 Solidago shortii T. \& G.; Short's goldenrod

\#41 Arabis perstellata (complex) Braun; prairie rock-cress

\#42 Iesquerella globosa (Desv。) Wats.: globose bladderpod

\#43 Iesquexella Iescurii (Gray) Wats.; Nashville bladderpod

\#44 Lesquerella lyrata Rollins; lyrate bladderpod

\#45 Lesquerella perforata Rollins; Spring Creek bladderpod

\#46 Lesquerella stonensis Rollins; Stone's River bladderpod

\#47 Warea amplexifolia (Nutt.) Nutt.; clasping warea 
Warea sessilifolia Nash: sessile-leaved warea Arenaria alabamensis (McCormick, Bozeman \& Spongberg) Wyatt; Alabama sandwort Sedum nevii A. Gray; Nevius' stonecrop Sedum pusilium Michx.; granite rock stonecrop Zamia integrifolia Ait.; Florida coontie Croton alabamensis E. A. Smith; Alabama croton Phyllanthus liebmannianus Muell. Arg. ssp. platylepis (Small) Webster;

Florida leaf flower

Baptisia arachnifera Duncan; hairy wild-indigo

Baptisia simplicifolia Croom; coastal-plain wild-indigo

Vicia ocalensis Godfrey \& Kral; Ocala vetch

Castanea ozarkensis W. W. Ashe; Ozark chinquapin

Gentiana pennelliana Fern.; wiregrass gentian

Conradina brevifolia Shinners; short-leaved rosemary

Conradira verticillata Jennison; whorled-leaved rosemary

Dicerandra frutescens Shinners; shrubby dicerandra

Dicerandra imnaculata Lakela; spotless-petaled dicerandra

Hedeoma graveolens Crapm.: mock pennyroyal

Macbridea alba Chapm.; white birds-in-a-nest

Linum westii C. M. Rogers: West's flax

Iliamna remota Greene; Kankakee globe-mallow

Hartwrightia floridana A. Gray ex S. Watson; Florida hartwrightia

Helianthus eggertii Small; Eggert's sunflower

Heterotheca flexuosa (Nash) Harms; bent golden-aster

Silphium brachiatum Gattinger; cumberland rosinweed

Verbesina chapmanii J. R. Coleman; Chapman's crownbeard

Verbesina heterophylla (Chapm.) A. Gray; variable-leaf crownbeard

Paronychia chartacea Fernald; paperlike nail-wort

Rhododendron austrinum (Small) Rehder; Florida azalea

Rhynchosia cinerea Nash; brown-haired snoutbean

Tephrosia mohrii (Rydb.) Godfrey; pineland hoary-pea

Quercus georgiana M. A. Curtis; Georgia oak

Quercus shumardii Buckley var. acerifolia Palmer; maple-leaf shumard's oak

Myriophyllum Iaxum Shuttlw. ex Chapm.; piedmont water-milfoil

Fothergilla gardeni Murr.; dwarf witch-alder

Phacelia dubia (L.) Trelease var. georgiana McVaugh; Georgia small-flowered phacelia

Hypericum cumulicola (Small) P. Adams; highlands scrub hypericum

Hypericum edisonianum (Small) Adams \& Robson; Edison's St. John's-wort

Nemastylis floridana small; fall-flowering peatleaf

Sphenostigma coelestina (Bartr. ex Willd.) R. C. Foster; Bartram's ixia

Juncus gymocarpus Coville; Coville's rush

Calamintha ashei (Weatherby) Shinners; Ash's savory

Calamintha dentata Chapm.; toothed savory

Conradina grandiflora Small; large-flowered rosemary

Dicerandra odoratissima Harper: rose dicerandra

Physostegia veroniciformis Small; Veronica dragon-head

Pycnanthemum floridanum Nash ex Grant \& Epling; Florida mountain-mint

Scutellaria floridana Chapm.; Florida skullcap

Scutellaria montana Chapm.; large-flowered skullcap

Scutellaria thieretii Shinners; Thieretii skullcap

Stachys lythroides Small; Tallahassee hedge-nettle 
\#98 Synandra hispidula (Michss.) Baill.: gyandotte beauty synandra

\#99 Lindera melissaefolirum (Walt.) Blume: swamp spicebush

\#100 Persea humilis Nash; dwarf redbay persea

\#101 Iitsea aestivalis (I.) Fern.: Pond spice, pond bush

\#102 Balduina atropurpurea Harper; purple balduina

\#103 Aster plumosus Sma11: plumose aster

\#104 Brickellia cordifolia Ell.; Flyr's brickell-bush

\#105 Cacalia diversifolia T. \& G.: variable-leaved indian-plantain

\#106 Justicia cooleyi Monachino and Leonard; Cooley's water-willow

\#107 Justicia Crassifolia (Chapman) Small; thick-leaved water-willow

\#108 Asimina tetramera Small; opposum pawpaw

\#109 Deeringothamnus pulchelius Small; slimpetal pawpaw

\#110 Deeringothamnus rugelii (Robins.) Small; Rugel's pawpaw

\#111 Eryngium cunefolium Small; wedge-leaved button-snake root

\#112 Oxypolis greennani Mathais \& Constance; giant water cowbane

\#113 Ptilimnium fluviatilis (Rose) Mathias; river bishop-weed

\#114 Ilex amelanchier M. A. Curtis; serviceberry holly

\#115 Ilex opaca I. var. arenicola (Ashe) Ashe; sand-loving American holly

\#116 Hexastylis speciosa Harper: Harper's heartleaf

\#117 Aster pinifolius E. J. Alexander; pale-violet aster

\#18 Echinacea laevigata (Boynt \& Beadle) Blake; smooth purple coneflower

\#19 Echinacea temnesseensis (Beadle) Small; Tennessee purple coneflower

\#120 Helianthus carnosus Smal1; lake-side sunflower

\#121 Jamesianthus alabamensis S.F. Blake \& E. E. Sherff; Alabama jamesianthus

\#122 Liatris ohlingerae (Blake) Robinson; Florida gay-feather

\#123 Liatris provincialis Godfrey: Godfrey's gay-feather

\#124 Marshalilia mohrii Beadle and Boynton; Mohr's barbara's-buttons

\#125 Solidago albopilosa E. L. Braun; white-haired goldenrod

\#126 Silene polypetala (Walt.) Fern. \& Schub.; fringed campion

\#127 Dionaea muscipula Ellis: common venus'-flytrap

\#128 Rhododendron chapmanii A. Gray: Chapman's rhododendron

花129 Rhododendron prunifolium (Small) Millais; plumleaf azalea

\#130 Baptisia calycosa Canby: pineland wild-indigo

\#131 Iupinus westianus SmaII; panhandle Iupine

\#132 Pinguicula ionantha Godfrey; violet-flowered butterwort

\#133 Pinguicula planifolia Chapm; Chapman's butterwort

\#134 Harperocaliis flava MCDaniel; yellow-petaled Harper's beauty

\#135 Hymenocallis coronaria (Ieconte) Kunth; stream-bank spiderlily

\#136 Lilium grayii S. Wats; Gray's lily

\#137 Lilium iridollae M. G. Henry; panhandle lily

\#138 Nolina atopocarpa Bartlett; Florida beargrass

\#139 Nolina brittoniana Nash: Britton's beargrass

\#140 Trillium pusillum Michx. (complex); Wake robin

\#141 Trillium tesanum Buckley; least trillium

\#142 Zephyranthes simpsorii Chapm.; rain zephyrlily

4143 Cuphea aspera Chapm; tropical waxweed

\#144 IIICium parviflorum Michx. ex Vent.; yellow anisetree

\#145 Rhexia parviflora Chapm.; small-flowered meadowbeauty

\#146 Calamovilfa arcuata K. E. Rogers; cumberland reedgrass

\#147 Phlox pulchra Wherry: Wherry's phlox

\#148 Polygonella ciliata Meisn. in DC. var. basiramea (Small) Horton; hairy jointweed 
\#149 Polygonella macrophylla Small; large-leaved jointweed

\#150 Polygonella myriophylla (Small) Horton; woody wireweed

\#151 Cimicifuga rubifolia Kearney; Appalachian bugbane

\#152 Croomia pauciflora (Nutt.) Torr.; few-flowered croomia

\#153 Xyris arumondii Malme; Drummon's yellow-eyed grass

\#154 xyris isoetifolia Kral; quillwort yellow-eyed grass

\#I55 Xyris longisepala Kral; Kral's yellow-eyed grass

\#156 Xyris scabrifolia Harper; Harper's yellow-eyed grass

\#157 Sagittaria fasciculata E. O. Beal; bunched arrowhead

\#158 Sium floridanum Small; Florida water-parsnip

\#159 Hexastylis naniflora Blomquist; dwarf-flowered heartleaf

\#160 Matelea alabamensis (Vail) Woodson; Alabama milkvine

\#161 Thelypteris pilosa (Mort \& Gal) Crawford var. alabamensis

Crawford; streak-sorus fern

\#162 Phyllitis scolopendrium (L.) Newm. var. americana Fern;

Arerican hart's-tongue fern

\#163 Coreopsis intermedia Sherff; golden-wave tickseed

\#164 Helianthus smithii Heiser; Smith's sunflower

\#165 Heterotheca ruthii (Small) Harms: Ruth's telegraph plant

\#166 Draba aprica Beadle; open-ground whitlow-grass

\#167 Hudsonia ericoides L. ssp. montana (Nutt.) Nickerson \& Skog;

golden mountain heather

\#168 Lechea maritima Legg. var virginica Hodgdon; virginian pinweed

\#169 Rhynchospora crinipes Gale; Alabama beaked-rush

\#170 Shortia galacifolia T. \& G.; Oconee bells

\#171 Kalmia cuneata Michx.; white-wicky laurel

\#172 Croton elliottii Chapm.; Elliott's croton

\#173 Hymenophyllum tunbridgense (L.) Smith; Tunbridge fern

\#174 Isoetes Iouisianensis Thieret; Louisiana quillwort

\#175 Pycnanthemum curvipes (Greene) Grant \& Epling; Tennessee mountain-mint

\#176 Schoenolirion wrightii Sherman; Texas sunnybell

\#177 Trillium persistens Duncan; persistent trillium

\#178 Veratrum woodii Robbins in Wood; Woods' false helleborne

\#179 Linum carteri Small var. smallii Rodgers; Carter's large-flowered flax

\#180 Spigelia gentianoides Chapm: gentian pinkroot

\#181 Spigelia loganioides (T. \& G. ex Engl.) A.D.C.; Florida pinkroot

\#182 Plantago cordata Iam.; heart-leaved plantain

\#183 Andropogon arctatus Chapm.; pine-woods bluestem

\#184 Calamovilfa curtissii (Vasey) Vasey; Curtis' reedgrass

\#185 GIyceria nubigena Anders.; Smoky Mountain manna-grass

\#186 Polygala lewtonii Small; Lewton's milkwort

\#187 Eriogonum harperi Goodman; Harper's long-leaved wild-buckwheat

\#188 Talinum appalachianum W. Wolf; Appalachian fame-flower

\#189 Aguilegia canadensis L. var. australis (Small) Munz; southern columbine

\#190 Clematis addisonii Britt.; Addison's leather-flower

\#191 Clematis viticaulis steele; grape leather-flower

\#192 Thalictrum cooleyi Ahles; Cooley's meadow-rue

\#193 Geum radiatum Michx.8 spreading avens

\#194 Prunus geniculata Harper; scrub plum

\#195 Hedyotis nigricans (Iam.) Fosb. var. pulvinata (Small) Fosb.; mat-forming narrow-leaved bluet 
Salix floridana Chapm: Florida willow Sarracenia alabamensis Case \& Case; Alabama cane-break pitcher-plant Sarracenia oreophila (Rearny) Wherry; green pitcher-plant Ribes echinellum (Coville) Rehder: Florida gooseberry Amphianthus pusillus Torrey: little amphianthus Solanum Carolinense I. var. Eloridanum Chapm.; Florida horse-nettle Taxus floridana Chapm.: Florida yew Torreya taxifolia Arn.; Florida torreya Verbena tampensis Nash; Tampa vervain Sarracenia psittacina michx.; parrot pitcher plant Rhapidophyllum hystrix (Pursh) H. Wendl \& Drude; common needle palm Ophioglossum palmatum L.; hands adder's-tongue fern Matelea floridana (Vail) Woodson; Florida milkvine Cacalia rugelia (Shuttlw. ex Chapm.) Barkley \& Crong.; Rugel's indian-plantain Coreopsis latifolia Michx.: broad-leaved tickseed Helianthus debilis Nutt. ssp. vestitus (Wats.) Heller; hairy cucumber-leaf sunflower Helianthus schweinitzii T. \& G.; Schweinitz's sunflower

Liatris helleri T.C. Porter: Heller's gay feather Rudbeckia triloba I. var. pinnatiloba T. \& G。; pinnatelobed brown-eyed coneflower Senecio millefolium T. \& G.; Piedmont ragwort Solidago spithamea Curtis; Blue Ridge golden rod Betula uber (Ashe) Fern.; Virginia round-leaf birch Onosmodium molle Michx; soft-hairy false-gromwell Leavenworthia aurea Torr.; golden glade-cress Streptanthus squamiformis Goodman; prairie twistflower Warea carteri Small; Carter"s warea Viburnum bracteatum Rehd.; southeastern viburnum Carex biltmoreana MacKenzie: Biltmore's sedge Carex latebracteata waterfald; Waterfall's sedge Carex misera Buckl. wretched sedge Pyxidanthera brevifolia Wells: Well's pixie-moss Rhododendron vaseyi Gray; shell-pink azalea Euphorbia discoidalis Chapman Baptisia megacarpa Chapm. ex Torr; streamside wild indigo Clitoria Fragrans Small: sweet-scented butterfly pea Juncus caesariensis Cor $;$ i New Jersey rush Juncus georgianus Coville: Georgia rush Conradina glabra Shinners; pan handle rosemary Lythrum curtissii Fermald; Curtiss ${ }^{*}$ lythrum Lythrum flagellarea Shuttlw.; lowland lythrum Magnolia ashei Weatherby: Ashe magnolia Callirhoe papaver (Cav.) Gray var. bushil (Fern.) waterf.: Bush's woods poppy-mallow Nuphar Iuteum (I.) sibth. \& Sm. ssp. Ulvaceum (Miller \& Standl.) Beal; Florida cowlily Chionanthus pygmaeus Small; pygmy fringe-tree Ctenium floxidanum (Hitchc.) Hitchc。; Florida orange-grass Panicum hirstii Swallen; Hirst's panic-grass Panicurn 1ithophilum Swallen; Swallen's panic-grass Portulacca smallil P. Wils.: Small's purslane clematis catesbyana Pursh; old man's beard virgin bower. Delphinium alabanicum Kral; Alabama larkspur Delphinium newtonianum D. M. Moore; Newton's larkspur Sageretia minutiflora (Michx.) Trel.; tiny-leaved buckhorn 
Geum geniculatum Michs.; bent avens Waldsteiria lobata (Baldw.) T. \& G.; Piedmont strawberry Nestronia umbellula Rat.; common nestronia Heuchera arkansana Rydb.: Arkansas alumroot Saxifraga careyana Gray: golden-eye saxifrage Saxifraga caroliniana Gray: Carolina saxifrage Penstemon dissectus EI1.: dissected beardtongue Viola egglestonii Brainerd; Eggleston's violet Justicia mortuifluminis Fernald; dead water water-willow Oxypolis canbyi (Coult. \& Rose) Fern.; Canby's cowbane Ptilimnium nodosum (Rose) Mathias; piedmont bishop-weed Hexastylis contracta Blomguist; Southern heartleaf Hexastylis lewisii (Fernald) Blomquist \& Oosting; Lewis's heartleaf Aster avitus Alexander: Alexander's rock aster Eupatorium Iuciae-brauniae Fernald; Braun throughtwort Eupatorium saltuense Fernald; pasture throughwort Helianthus glaucophyllus D. M. Smith; white-leaved sunflower Folymnia laevigata Beadle: Tennessee leafcup Solidago pulchra Small; wand-like goldenrod Solidago verna M. A. Curtis ext.T.\&G.; spring goldenrod Iobelia gattingeri A. Gray; Gattinger's lobelia Arenaria cumberlandensis Wofford \& Kral; Cumberland sandwort Geocarpon minimum K. K. Mackenzie; little geocarpon Paxistima Canbyi Gray; Canby's mountain-lover Cuscuta harperi Small; Harper's dodder Cyperus granitophilus McVaugh; granite-loving flatsedge Rhynchospora culixa Gale: Georgia beaked-Tush Rhynchospora globularis (Chapm.) Small;/ rock-loving glove beaked-rush Rhynchospora punctata Ell.; pineland beaked-rush Rhododendron bakeri (Iemmon \& MCKay) Hume; Cumberland azalea Euphorbia exserta (Small) Coker; exserted-fruited spurge Baptisia hirsuta (Small): hairy wild-indigo Petalostemongattingeri Heller; Gattinger's prairie-clover Psorlea subacaulis $T_{\text {. \& }} G_{\text {.; }}$ southern scarf-pea Coreopsis pulchra F. Boynton in Small; beautiful tickseed quercus arkansana Sargent; Arkansas oak

Hypericum Iissophloeus P. Adams; smooth-bark St. John's wort Monarda stipitoglandulosa Waterfall: striped-gland bee-balm Physostegia leptophylla Small; slender-leaved dragon-head Leitneria floridana Chapm.; Florida corkwood Oenothera pilosella Raf. ssp sessilis (Pennell) straley; coastal evening-primrose Plantanthera flava (I.) Lindl.; southern rein-orchid Plantanthera integra (Nutt.) Gray ex. Beck; yellow fringeless orchid Plantanthera integrilabia (Correli) Luer; white fringeless orchid Plantanthera peramoena (Gray) Gray; purple fringeless orchid Schizachyxium niveum (Swallen) Gould; riparium autumgrass Elymus svensonii Church; Svenson's wild-rye Manisuris tuberculosa Nash: piedmont joint-grass Panicum nudicaule vasey: Naked-stemmed panic grass Sporobolus teretifolius Harper; Wireleaf dropseed Phlox bifida Beck ssp. Stellaria (Gray) Wherry; Starwort cleft phlox Talinum calcaricum Ware; lime fame-flower 
\#300 Talinum mengesii W. Wolf: Menge's fame-flower

\#301 Lysimachia asperuliaefolia Poirett; Carolina loosestrife

\#302 Agrimonia incisa T. \& G.i incised groove bur

\#303 Houstonia montana (Chickering) Small; Mountain bluet

\#304 Agalinis pseudaphylla (Pennell) Pennell; False-leaved false-fox-glove

\#305 Aureolaria patula (Chapr.) Pennell; spreading foxgloves

\#306 Schwalbea americana L.; American chaff-seed

\#307 Verbena maritima Small; Coastal vervain

\#308 Xyris tennesseensis Kral; Tennessee yellow-eyed-grass

\#309 Calyptronoma rivalis (O.F. Cook) Bailey; Manac palm

\#310 Buxus vahlii (Baill.) Britt; Vahl's boxwood

\#311 Cereus eriophorus fragrans (Small) L. Benson; Fragrant Florida cereus

\#312 Cereus gracilis aboriginum (Small) L. Benson; Original prickly-apple cereus

\#313 Cereus robinii L. Benson; Tree cactus cereus

\#314 Cassia mirabilis (Pollard) Urban; Puerto Rico senna

\#315 Isotria medeoloides (Pursh) Raf.; Small-whorled pogonia

\#316 Sarracenia rubra jonesii (Wherry) Wherry; Jones' pitcher plant

\#317 Goetzea elegans Wydler; Malabuey

\#318 Arenaria godfreyi Shinners; Godfrey's sandwort 


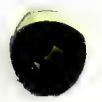

0 
()

○ 
6

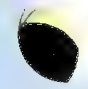

$\checkmark$ 
Paper 2

Text \& map by:

Robert kral

\section{ASCLEPIADACEAE}

Asclepias viridula Chapm.; southern milkweed, Milkweed

Technical Description

Perennial herb from a large, elongate-oblong, vertical rootstock. Stems.--Spreading or erect, I-several, slender and wand-like, 3-6 dm long, greenish or tinted with purple toward the base, terete, smooth other than for a vertical line of low, weak, whitish hairs between nodes.

Leaves.--opposite, Iinear, 5-10 cm long, mostly $2-3 \mathrm{~mm}$ broad, spreadingascending, broadening slightly toward the acute tips, smooth or with some roughening toward and along the margin above, I-nerved. Inflorescence.--Umbels from axils of all or most upper leaf pairs, on slender, sparsely puberulent peduncles between 1 and $2 \mathrm{~cm}$ long, with involucral bracts 2-3 mm long, narrowly triangular, scabrous margined, with rays numexous, between $I$ and $2 \mathrm{~cm}$ long, angulate, purplish on the backs, greenish and puberulent on a line within.

Flowers.--Symmetrical, smallish, the calyx lobes 5, narrowly ovate, reflexed, 2.5-5.0 mm long, glabrous, the upper (inner) surface pale green, the lower (outer) surface darker green tinted with maroon. A short (1 mm ) unit of column arises from the calyx and from it the 5 petals arise, the boat-shaped hoods pouched toward the base, narrowly ovate or slightly obovate, $3-4.5 \mathrm{~mm}$ long, the tips narrowly or broadly rounded, the margins with a txiangular auricle toward base, the backs yellowish or whitish green with a purplish mid-rib zone; from within the petal "pouch" arises a narrow, yellowish or greenish-white, incurved horn about as the hood. Anther head ca. $1 \mathrm{~mm}$ long, $1.5 \mathrm{~mm}$ broad. Fruit.--Follicles smooth, erect, narrowly fusiform, 8-10 cm long.

Distribution and Flowering season

Moist acidic pineland savanna, northeastern and northwestern Florida; flowering from April through July.

Special Identifying Features

Asclepias viridula is superficially much like A. longifolia Michx. in habit, leaf chaxactex and flower size; however that species has an anther head longer than the corolla, which itself is somewhat broader and lacks horns.

Habitats and Management Implication

This threatened species is usually found in large or small clearings dominated by grasses and sedges or in large, fire created savannas dotted with slash and longleaf pine with an understory of saw palmetto interspersed with gallberry and wax myrtle or, in wetter places with shrubby Hypericum or titi-black gum. Its substrate is typically a highly humified, thus blackish, fine sand which remains moist or wet for most of the year. Thus it is a plant of high hydroperiod soil which undergoes gleization. 
It, a cormophyte, together with other threatened or endangered species with which it frequently associates (such as Verbesina chapmanii, v. heterophylla, Justicia crassifolia, Euphorbia telephoides, Scutellaria floridana, Cuphaea viscosa, etc. has been maintained historically by naturally caused, periodic, and doubtlessly sometimes intense, fire. This burning reduces shrub competition, together with that of grasses and sedges, opens up the overstory of pine thus admitting the light this plant needs. Most of the collections of this plant show remnants of burned bases, and have been made from burned over savanna. Thus prescribed burning would benefit it, as would cutting or thinning an overstory. Tree planting, preceded by such as dozing, root raking, and chopping would have a negative effect. Bedding, in that it leaves a part of the substrate intact, would allow some plants to survive, but subsequent crown closure of planted pine would later shade it out.

This is a plant that never assumes aspect dominance even within the center of its small range, but which is always of scattered occurrence. Thus it easily qualifies as a "sensitive" species whose maintenance will be a challenge.

References

Small, J. K. 1933. Manual of the southeastern flora, p. 1071.

Woodson, R. E. 1954. The North American species of Asclepias L., Ann. Mo. Bot. Gard. XLI (1): 1-211. 
SPECIES: \#2 Asclepias viridula Chapm. Milkweed

\begin{tabular}{|c|c|c|c|c|c|c|c|c|}
\hline \multicolumn{9}{|c|}{ Management Practices } \\
\hline $\begin{array}{l}\text { Expected* } \\
\text { Effect on } \\
\text { the Species }\end{array}$ & $\begin{array}{c}\text { Prescribe } \\
\text { Burn }\end{array}$ & $\begin{array}{l}\text { Bulldoze } \\
\text { or } \\
\text { Root Rake }\end{array}$ & Bed & Chop & $\begin{array}{l}\text { Thin } \\
\text { over- } \\
\text { story }\end{array}$ & $\begin{array}{l}\text { Cut } \\
\text { Over- } \\
\text { story }\end{array}$ & $\begin{array}{l}\text { Establish } \\
\text { Plantation }\end{array}$ & Graze \\
\hline Destroy & & $\mathrm{X}$ & & $\mathrm{x}$ & & & $x$ & \\
\hline Damage & & & $\mathrm{X}$ & & & & & \\
\hline $\begin{array}{l}\text { No Lasting } \\
\text { Effect }\end{array}$ & & & & & & & & $x$ \\
\hline $\begin{array}{l}\text { Beneflclal } \\
\text { if Done } \\
\text { Properly }\end{array}$ & $\mathrm{X}$ & & & & $\mathrm{x}$ & $\mathrm{X}$ & & \\
\hline
\end{tabular}

\section{Other Comments:}

*Expected effect on the species is an estimate made by Dr. Robert Kral based on his knowledge of the habitat and on knowledge gained from personal field observations. Estimates are "rough" in many instances. Results of practices may be modified depending upon the degree of application, intensity of treatment, nearmess to plant communities, etc. A management practice for which no entry is made indicates a lack of sufficient information from which to predict expected results. As observations are made in the field by users of the data, the expected effect will be refined. 
Asclepias viridula Chapman

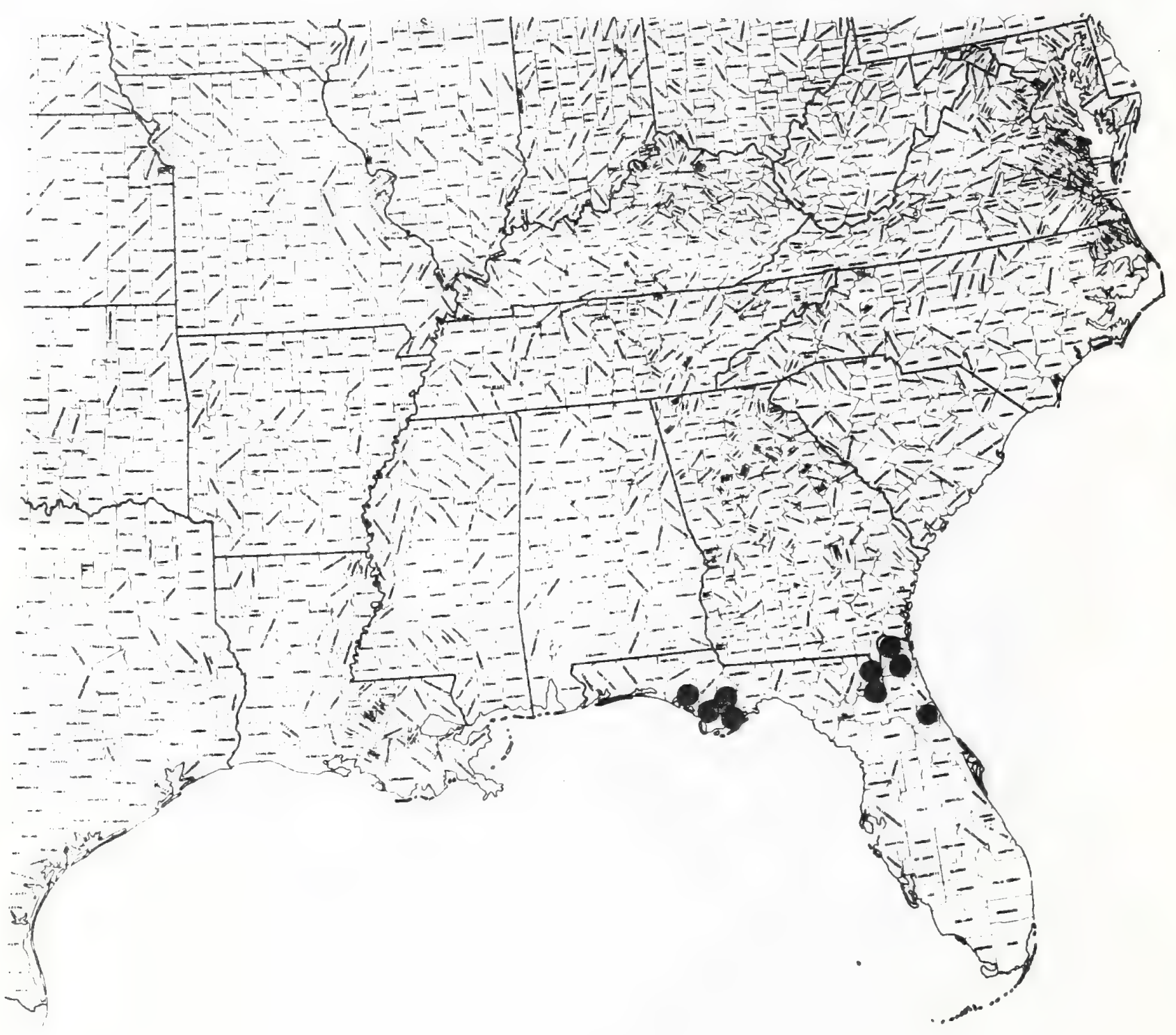


Paper 3

Text \& map by:

Robert Kral

ASTERACEAE

Aster spinulosus Chapm. pine-woods aster: Aster Heleastrum spinulosum Greene

Technical Description

Stiffish perennial herb, mostly $6-8 \mathrm{~cm}$ tall, from a short stout caudex cloaked in persistent chaffy-fibrous old leaf bases. Rhizomes, slender, pale, and scaly.

Stems.-Flowering stems 1-few, mostly erect, terete but also ribbed, toward the base greenish and pilose (spreading hairy), upwardly becoming reddishtinted and smooth.

Ieaves.--Linear, numerous and crowded toward the base, there Iongest, somewhat spreading, up to $2 \mathrm{dm}$ long, smooth save for distantly spinulose margins toward the base, toward the apex entire or somewhat scabrid; leaves gradually dimishing in size upward on the stem, becoming erect, lance-linear with short-spiny tips, and grading into progressively shorter bracts.

Inflorescence.--Heads numerous, arranged in spike-like racemes, each short peduncle subtended by a spreading, lance-linear stiff bract longer than the head. Peduncles rarely as long as $2 \mathrm{~mm}$, supporting 1-2 lance-linear spreading bracts, these grading into the phyllaries. Heads broadly campanulate, about I cm from base to pappus tips. Phyllaries (bracts) numerous in several loosely imbricated series, rigid, lanceolate or narrowly triangular, thickish, green with narrow, thinnish maroon, spinulose-serrate or erose borders, the tips narrowed to spiniform short prickles.

Flowers.--Ray florets numerous, the ligules linear-oblong, $\mathrm{ca} .1 \mathrm{~cm}$ long, nearly white to pale lilac or pale blue, the heads in full bloom about $2 \mathrm{~cm}$. across. Disc florets numerous, the corollas narrowly tubular, yellow, the 5 short-triangular lobes erect.

Fruit.--Akenes linear-columnar, about $2 \mathrm{~mm}$ long, pale gray-brown, hairy; pappus 6-7 mm long, of numerous, yellowish-white, rigid, upwardly barbellate, bristles.

Distribution and Flowering season

Savannas in pinelands, northwestern Florida, primarily in drainages from the Apalachicola River. Flowering from May into July.

Special Identifying Features

This species most closely resembles $A$. paludosus, a widespread aster of the southeast, but has smaller heads with paler flowers, longer and narrower basal leaves, all leaves sharper pointed and with margins more entire.

Habitats and Management Implications

This plant, said by small to be in wet pinelands, actually is in more moist than wet situations. Its substrates are acid sandy peats, and it is particularly abundant where fire maintains savanna conditions in what would ordinarily be be longleaf pine-gallberry type. Typically it is found associated with grasses 
such as Aristida, Andropogon, Ctenium, sedges such as Rhynchospora globulosus, R. grayii, Xyris caroliniana, Lachnocaulon, Rhexia alifanus, and a variety of other composites indicative of a constantly moist but definitely not wet substrate. It is a plant of full sun or very light shade, thus pines usually only dot its landscape. The shrub understory is usually Ilex glabra, Myrica, Gaylussacia, Lyonia.--Prescribed burning favors such a species by reducing woody competition, as would cutting the pine overstory and understory removal. Most methods of site preparation that involve exposure of the mineral earth through bulldozing, plowing, raking or plowing would eliminate this species, the least damaging method probably being bedding. A successful planting of pine would eliminate this Aster through ultimate crown closure of the young pines. Much of the former area of this species, which includes about four counties, has been lost either through pine plantations, improved pastures, or development of row crop agxiculture.

References

Small, J. K. 1933. Manual of the Southeastern Flora, p. 1392. 
SPECIES :

\#3 Aster spinulosus Chapm. Aster

\begin{tabular}{|c|c|c|c|c|c|c|c|c|}
\hline & \multicolumn{8}{|c|}{ Management Practices } \\
\hline $\begin{array}{l}\text { Expected* } \\
\text { Effect on } \\
\text { the Species }\end{array}$ & $\begin{array}{c}\text { Prescribe } \\
\text { Burn }\end{array}$ & $\begin{array}{l}\text { Bulldoze } \\
\text { or } \\
\text { Root Rake } \\
\end{array}$ & Bed & Chop & $\begin{array}{l}\text { Thin } \\
\text { over- } \\
\text { story }\end{array}$ & $\begin{array}{l}\text { Cut } \\
\text { Over- } \\
\text { story } \\
\end{array}$ & $\begin{array}{l}\text { Establish } \\
\text { Plantation }\end{array}$ & Graze \\
\hline Destroy & & $\mathrm{x}$ & & $\mathrm{x}$ & & & $\mathrm{X}$ & \\
\hline Damage & & & $\mathrm{X}$ & & & & & $\mathrm{X}$ \\
\hline $\begin{array}{l}\text { No Lasting } \\
\text { Effect }\end{array}$ & & & & & & & & \\
\hline $\begin{array}{l}\text { Beneficlal } \\
\text { If Done } \\
\text { Properly }\end{array}$ & $\mathrm{x}$ & & & & $X$ & $\mathrm{X}$ & & \\
\hline
\end{tabular}

\section{Other Comments:}

*Expected effect on the species is an estimate made by Dr. Robert Kral based on his knowledge of the habitat and on knowledge gained from personal field observations. Estimates are "rough" in many instances. Results of practices may be modifled depending upon the degree of application, intensity of treatment, nearness to plant communities, etc. A management practice for which no entry is made indicates a lack of sufficlent information from which to predict expected results. As observations are made in the field by users of the data, the expected effect will be refined. 


\section{Aster spinulosus Chapman}

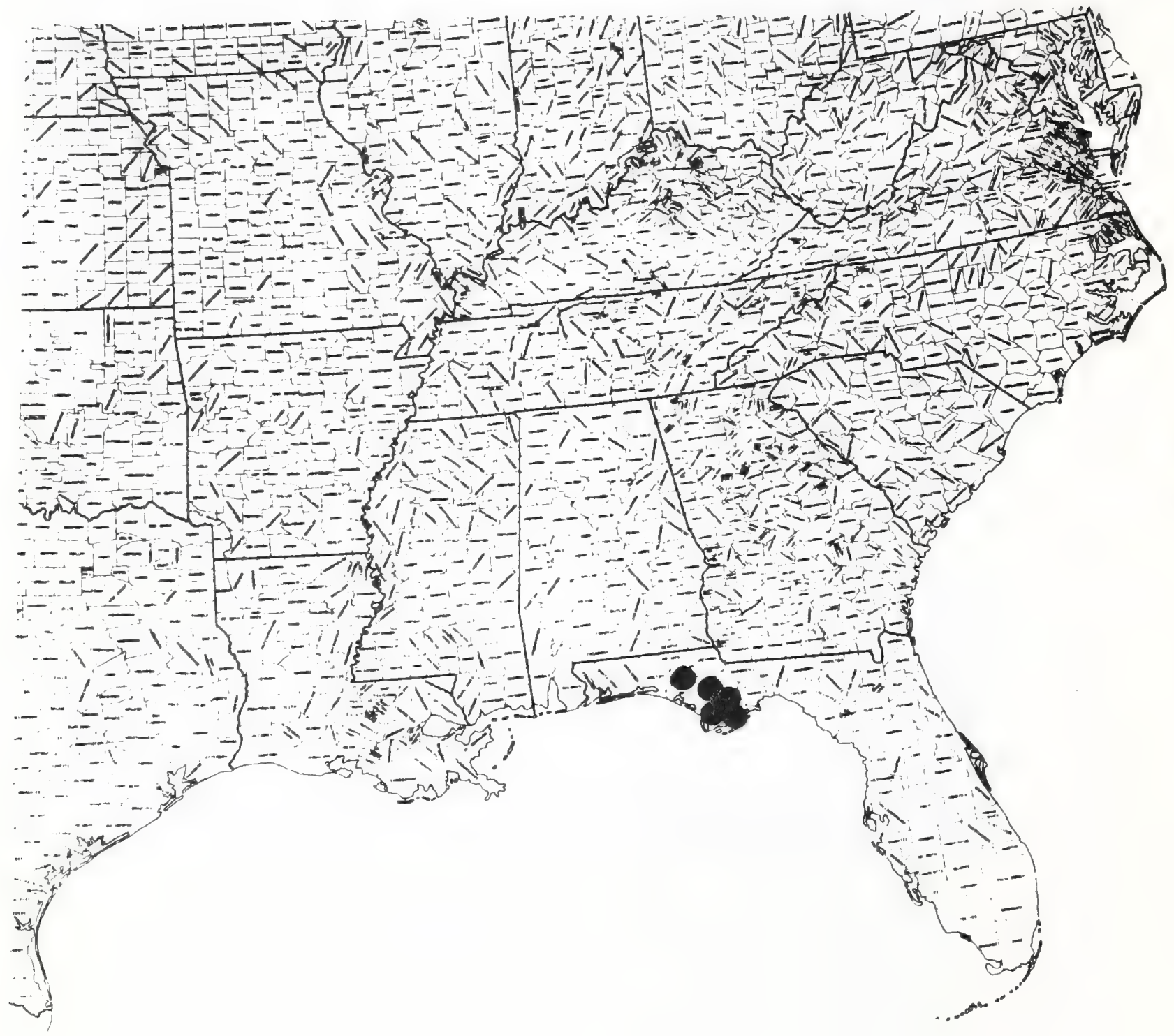




\section{ASTERACEAE}

Prenanthes roanensis (Chick.) Chick Pledmont rattlesnakeroot; Rattlesnake-Root Nabalus roanensis Chick.

Technical Description

Perennial herb from a thickened-tuberous, erect caudex (this and all other parts with milky juice), this in winter producing a rosette of long-petioled, triangularbladed leaves.

Stems.--Erect, to 1 meter all, basally terete, toward apex often fluted or angulate, greenish or maroon, smooth below, toward the apex often with short, crisped hairs. Leaves.--Rosette and lower leaves usually absent by flowering time, the lowest evident ones long petiolate, alternate, highly variable but blades usually of an ovate or triangular type, the margins irregularly or evenly dentate or denticulate, the apices acuminate, the bases hastate, truncate or broadly rounded, rather abruptly then attenuately narrowing to the petiole, the upper surface dark green, smooth save for short bristles along the midrib, the lower surface paler, shorthairy along the main veins: leaves becoming smaller, with shorter petioles or sessile toward the upper nodes, all the upper ones subtending inflorescence branches.

Inflorescence.--Mostly cylindrical, leafy, of several to many ascending short to somewhat elongate short-hairy branches, these terminating in dense, semicircular cymose clusters of nodding heads. Heads on short-recurved densely crisped-hairy, short-bracted peduncles, narrowly campanulate-cylindric, ca. $1.5 \mathrm{~cm}$ long; receptacle naked; phyllaries mostly in 2 series, the outer short, triangular, the inner linear, 5-9, about $1 \mathrm{~cm}$ long, blunt-tipped, entire, erect, thin, green sometimes with tints of maroon at tips, the margins thinner, broad, pale, entire, the backs with long, rather stiffish, sordid to nearly black hairs. Flowers.--All radiate, mostly 5-9/head, the corollas each with a narrow tube ca. 3 $\mathrm{mm}$ long and a short-linear, yellowish green blade (ligule) ca. 4-4.5 mm long, this slightly spreading away from the erect (downward-pointing) exserted anthers. Fruit.--Akenes subcylindric or somewhat angulate, sometimes broadening slightly toward apex, 4-5 mm long, pale brown, smooth. Pappus of numerous yellowishwhite, capillary, finely barbellate bristles, in fruit about 7-8 mm lorg.

Distribution and Flowering Season

Moderate to high elevations in the Blue Ridge and Valley and Ridge provinces of the Applachians from western Virginia southward through western North Carolina and eastern Tennessee. Kentucky? Flowering from August to frost.

Special Identifying Features.

This species, with its yellowish-green corollas and its hairy phyllary backs is closest to $\underline{P}$. aspera but this is a stockier, taller species of prairies to the west and has oblanceolate or spathulate, coarser leaves together with a racemose inflorescence and paler phyllary hairs. It for the same reasons is near $\mathrm{P}$. serpentaria, a plant of lower elevations in the southeast, but that species tends to have more lobate leaves, a broader inflorescence, and more phyllaries/head. 
Habitats and Management Implication

P. roanensis usually found on dark, well drained sandy loams either in clearings at or toward sumit elevations or in grassy balds. It is not a plant of heavy shade, so when found in forests, it is usually toward the edges. The forest types it is commonest in are fir, spruce-fir, spruce-hemlock-yellow birch, or hemlock-birch-maple. Where there has been fire it may be found around firecherry and aspen. There is therefore reason to suspect that fire may increase it by eliminating woody competition and/or shade. Clear cutting would favor its increase, but most known localities for Prenanthes roanensis are not at present being cut.

\section{References}

Milstead, W. I. 1964. A revision of the North American species of Prenanthes. pp. 1-223. Unpublished Ph.D. thesis.

Radford, A. E., Ahles, H. E. and C. R. Bell. 1968. Manual of the vascular flora of the Carolinas, P. 1020. Chapel Hill, N.C.

Small, J. K. 1933. Manual of the southeastern flora, Pp. 1490-1492. Chapel Hill, N.C. 
SPECIES: \#4 Prenanthes roanensis (Chick.) Chick.: Rattlesnake-Root

\begin{tabular}{|c|c|c|c|c|c|c|c|c|}
\hline & \multicolumn{8}{|c|}{ Management Practices } \\
\hline $\begin{array}{l}\text { Expected* } \\
\text { Effect on } \\
\text { the Species }\end{array}$ & $\begin{array}{c}\text { Prescribe } \\
\text { Burn }\end{array}$ & $\begin{array}{l}\text { Bulldoze } \\
\text { or } \\
\text { Root Rake } \\
\end{array}$ & Bed & Chop & $\begin{array}{l}\text { Thin } \\
\text { over- } \\
\text { story }\end{array}$ & $\begin{array}{l}\text { Cut } \\
\text { Over- } \\
\text { story }\end{array}$ & $\begin{array}{l}\text { Establish } \\
\text { Plantation }\end{array}$ & Graze \\
\hline Destroy & & $\mathrm{X}$ & $\mathrm{x}$ & $x$ & & & $\mathrm{x}$ & \\
\hline \multicolumn{9}{|l|}{ Damage } \\
\hline $\begin{array}{l}\text { No Lasting } \\
\text { Effect }\end{array}$ & $\mathrm{x}$ & & & & & & & \\
\hline $\begin{array}{l}\text { Beneficlal } \\
\text { if Done } \\
\text { Properly }\end{array}$ & & & & & X & $\mathrm{X}$ & & \\
\hline
\end{tabular}

\section{Other Comments:}

*Expected effect on the species is an estimate made by Dr. Robert Kral based on his knowledge of the habitat and on knowledge gained from personal field observations. Estimates are "rough" in many instances. Results of practices may be modifled depending upon the degree of application, intensity of treatment, nearmess to plant communities, etc. A management practice for which no entry is made indicates a lack of sufficient information from which to predict expected results. As observations are made in the field by users of the data, the expected effect will be refined. 
Prenanthes roanensis (Chick.) Chick.

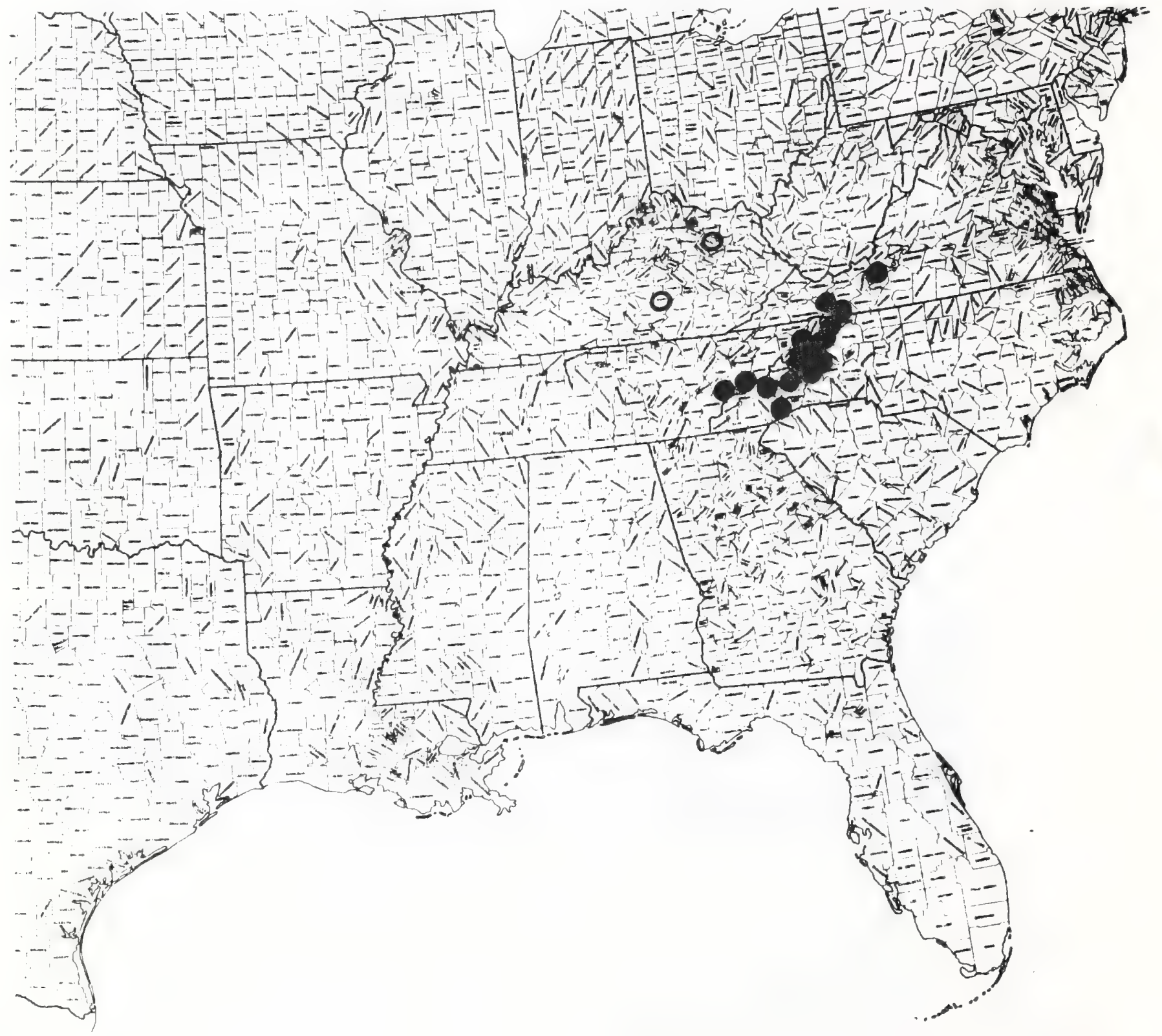


Paper 5

Text \& map by:

Robert Kral

\section{ASTERACEAE}

Rudbeckia auriculata (Perdue) Kral. Eared coneflower; cone Flower: blackeyed susan

R。 fulgida Ait. var. auriculata Perdue

Technical Description

A large smoothish perennial herb to 3 meters tall from stout rhizomes and increasing by slender rhizomatous offshoots.

Stems.--Arising from very leafy, overwintering rosettes, exect, stiffish, fully $1 \mathrm{~cm}$ thick below, terete but usually with many low ribs. Leaves.--Rosette and lower stem leaves to $6.5 \mathrm{dm}$ long, the blades oblong to oblanceolate or ovate-lanceolate, tips short acuminate to rounded or acute, entire to sinuate, crenate, dentate or coarsely toothed, on long petioles, the surfaces smooth to scabrous or strigose on the veins below and on the petiole. Middie and upper stem leaves sessile, progressively reduced up the stem, elliptic to ovate or fiddleshaped, the bases clasping, auriculate.

Inflorescence.--Heads many in an open broad, paniculate cyme on short to elongate, short-bracteate stalks. Involucre with greenish, stiffish bracts, these oblonglinear, spreading, shorter than the rays, smooth save for scabrous edges. Receptacle elevated, the chaff oblong-cuneate, about $6 \mathrm{~mm}$ long, acute, ciliate, the backs with small hairs, the tips deep reddish-brown.

Flowers.--Ray florets with ligules bright yellow, oblong-linear, ca. $2 \mathrm{~cm}$ long, spreading-ascending, the backs often short-hairy. Disc $1.0-1.7 \mathrm{~cm}$ broad, the corollas purple-brown, 3.0-3.5 $\mathrm{mm}$ long, the short tube expanding to a narrowly funnelform throat, the lobes short-triangular and erect.

Fruit.--Akenes oblong-curvate, 4.0-4.5 mm long, a rich, shining, reddish-brown, 4-ribbed, the pappus unevenly 4-6-toothed, the teeth pale tan, rigid, narrowly triangular, up to $2 \mathrm{~mm}$ long.

Distribution and Flowering season

Bogs, seeps, swamps, ditches and swales, in Alabama mostly Costal plain, rarely in contiguous areas of Appalachian Alabama. Flowering from August to early October.

Habitats and Management Implication

R. auriculata is a plant of highly organic, high hydroperiod substrate of varying reaction, ranging from nearly neutral to quite acid (on the basis of associated species). Usually it is in full sunlight, sometimes in the partial shade at edges of hardwood swamps. In bogs and seeps, it will appear in clearings amongst Alnus, Myrica, Cephalanthus, Cyrilla in association with various sedges (particularly Rhynchospora) and wetlands grasses, bog orchids and liliaceae. While its populations are quite scattered and local, such are usually made up of one or more very large clones which may dominate a small area. The plants are fully the height of robust $\mathrm{R}$. laciniata which at a distance they slightly resemble, but in character of head are much more like R. nitida and in total character are unlike any other species of Rudbeckia. A logging of the low hardwood stands it often grows around or in would probably increase its habitat providing this was not accompanied by drainage. The same could be said of 
the pine flatwoods areas it is in. Any site preparation involving drainage would eliminate the species. It would not survive under the closed canopy of pine plantatation or dense hardwood regeneration.

References

Kral, R. 1975. Rudbeckia auriculata (Perdue) Kral, a species distinct from R. fulgida Ait. Rhodora 77 (809): 44-52=

Perdue, R.W., Jr。 1957. Synopsis of Rudbeckia subgenus Rudbeckia. Rhodora 59: 293-299.

- 1961. A new variety of Rudbeckia fulgida. Rhodora 63:119-120. 
SPECIES: \#5 Rudbeckia auriculata (Perdue) Kral, Cone flower, Blackeyed susar

\begin{tabular}{|c|c|c|c|c|c|c|c|c|}
\hline & \multicolumn{8}{|c|}{ Management Practices } \\
\hline $\begin{array}{l}\text { Expected* } \\
\text { Effect on } \\
\text { the Species }\end{array}$ & $\begin{array}{c}\text { Prescribe } \\
\text { Burn }\end{array}$ & $\begin{array}{c}\text { Bulldoze } \\
\text { or } \\
\text { Root Rake }\end{array}$ & Bed & Chop & $\begin{array}{l}\text { Thin } \\
\text { over- } \\
\text { story }\end{array}$ & $\begin{array}{l}\text { Cut } \\
\text { Over- } \\
\text { story }\end{array}$ & $\begin{array}{l}\text { Establish } \\
\text { Plantation }\end{array}$ & Graze \\
\hline Destroy & & $\mathrm{X}$ & $x$ & $x$ & & & $\mathrm{X}$ & \\
\hline Damage & & & & & & & & $x$ \\
\hline $\begin{array}{l}\text { No Lasting } \\
\text { Effect }\end{array}$ & $\mathrm{NA}$ & & & & & & & \\
\hline $\begin{array}{l}\text { Beneficlal } \\
\text { if Done } \\
\text { Properly }\end{array}$ & & & & & $x$ & $\mathrm{X}$ & & \\
\hline
\end{tabular}

\section{Other Comments:}

*Expected effect on the species is an estimate made by Dr. Robett Kral based on his knowledge of the habitat and on knowledge gained from personal field observations. Estimates are "rough" in many instances. Results of practices may be modified depending upon the degree of application, intensity of treatment, nearness to plant communities, etc. A management practice for which no entry is made indicates a lack of sufficient information from which to predict expected results. As observations are made in the field by users of the data, the expected effect will be refined.

Drainage will also destroy 
Rudbeckia auriculata (Perdue) Kral

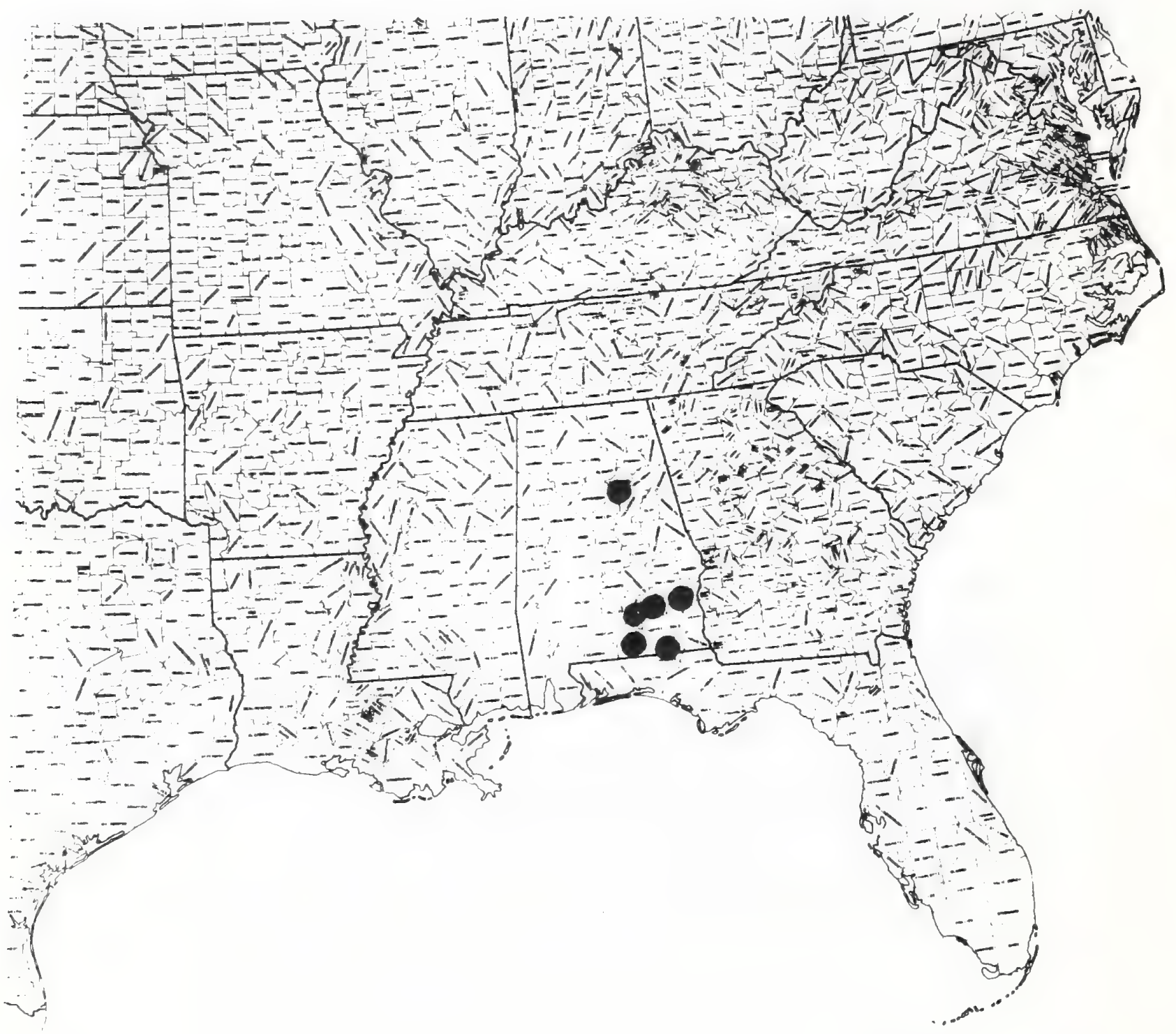


Paper 6

Text \& map by:

Robert Kral

\title{
ASTERACEAE
}

Rudbeckia heliopsidis To \& G. Sun-facing coneflower:

\author{
black-eyed Susan
}

Technical Description

Perennial herb forming large clones by means of spreading-branching systems of elongate, thickish rhizomes, the branches terminating in overwintering rosettes of strongly petiolate leaves.

Stems.--Arising usually singly from each rosette, mostly between 0.5 and 1 meter tall, erect or decumbent, slender but stiffish, at base perhaps $4 \mathrm{~mm}$ thick, terete and dull green, many ribbed and hirsute toward base, upwardly smoother or smooth, sometimes slightly angulate, often with some maroon tints, usually branching only in the inflorescence.

Leaves.--Rosette leaves the largest, from new rhizomal branches produced as the flowering shoots develop from the old, the blades mostly ovate or broadly lanceolate, 6-15 cm long, acute or short-acuminate, distantly or closely serrate, the bases abruptly attenuate, the upper surfaces dark green with a scattering of short appressed hairs (strigillose), the lower surfaces paler, sparsely hirsute along the veins; petioles elongate, slender, longer than or as long as the blades, villous hirsute or hirsute. Lower stem leaves similar to rosette leaves or slightly smaller, often absent by flowering time, scattered sparingly up the stem, becoming progressively shorter petioled, smaller, and more ovate, each from about mid-stem upward subtending an upwardly arching, stiffish inflorescence branch, the lower ones of these either simple or sparingly rebranched. Inflorescence.--Branches of inflorescence simple or with 1 or 2 stiffish branches, elongate, sparingly bracted with small ovate bracts, each terminating in a longpedunculate head. Head short-conic, 7-9 mm high, mostly around I0 mm. broad, the phyllaries green, lance-linear, 5-7 mm long, rather loosely imbricated, spreading or reflexed, slenderly acute, or acute, subentire, the outer surfaces tomentose with pale hairs. Receptacle of head conic, the chaff oblong, acute, or broady rounded, the outer surface of the tips with whitish hairs (some club-shaped) often admixed with sessile white glands, the upper margin ciliate or erose. Flowers.--Ray flowers sterile, 7-10, the ligules oblong, $1.5-2.0 \mathrm{~cm}$ long, spreading, 2-toothed at apex, a clear bright yellow. Disc florets very numerous, the corollas $3.0-3.5 \mathrm{~mm}$ long, with a short tube, a slightly expanded tubular throat, and short, triangular, spreading or reflexed lobes, reddish-brown. Fruit.--Pappus vestigial, the akene apex with very low bluntly triangular teeth at the angles and a rim of short-stalked glands: akene oblong, ca. $3 \mathrm{~mm}$ long, usually 4-angled dark brown or nearly black, the ribs and interfaces sometimes with a scattering of pale hairs.

Distribution and Flowering season

Small seeps, ditches, boggy places, usually over sand or siliceous rock or in wet to moist depressions in outcrops of siliceous rock, mostly Fiedmont and Appalachian Plateau of eastern Alabama and western Georgia with outliers in the inner Coastal Plain of Harnett Co. North Carolina and in the Blue Ridge of South Carolina

(Oconee County) Flowering from late July into late september. 
Sections in Rudbeckia are distinguished on the basis of fine characters involving chaff (pales) and character of stigma tips. This species has blunt, hairy chaff tips and stigma tips that are short and obtuse, which distinguish it from most of the common Rudbeckias. Its closest relatives have either larger heads or sessile lower stem leaves or both. The only species with which it would be associated in the wetlands it frequents is $\mathrm{R}$. fulgida, $\mathrm{a}$ highly variable but smoother species with more deeply yellow (orange yellow) rays and a totally different chaff and pappus character.

Habitats and Management Implication

The forest type in which $\underline{R}$. heliopsidis is found in is mostly either upland oakhickory or oak-pine-hickory or open pine-mixed hardwoods (as in the little River Canyon of northeastern Alabama). It is a plant of seeps, bogs, sandy wet clearings along rivers, always on wet sandy-organic substrates. Most of it is in outcrop areas or very bouldery situations, poorly suited to most agriculture. The seeps it frequents are usually quite acid, mostly populated by grasses, sedges and herbs of bogs (including the rare Sarracenia oreophila in northern Alabama). logging of the mostly low-quality forest around it, so long as drainage was not involved, would probably effect this species very little unless it would be to increase its area as it freely seeds into wet sandy places. Thus far, its main enemies appear to be drainage of some upland swales for farming or pasture, or simply grazing. It does not hold up well under grazing.

References

Radford, A. E., Ahles, H. E., and C. R. Bell. 1968. Manual of the vasular flora of the Carolinas, pp. 1108. Chapel Hill, N.C.

Small, J. K. 1933. Manual of the southeastern Flora, pp. 1422-1424. Chapel Hill, N.C. 
SPECIES: \#6 Rudbeckia heliopsidis T.\& G. Black-eyed susan

\begin{tabular}{|c|c|c|c|c|c|c|c|c|}
\hline & \multicolumn{8}{|c|}{ Management Practices } \\
\hline $\begin{array}{l}\text { Expected* } \\
\text { Effect on } \\
\text { the Species }\end{array}$ & $\begin{array}{c}\text { Prescribe } \\
\text { Burn }\end{array}$ & $\begin{array}{l}\text { Bulldoze } \\
\text { or } \\
\text { Root Rake }\end{array}$ & Bed & Chop & $\begin{array}{l}\text { Thin } \\
\text { over- } \\
\text { story }\end{array}$ & $\begin{array}{l}\text { Cut } \\
\text { Over- } \\
\text { story } \\
\end{array}$ & $\begin{array}{l}\text { Establish } \\
\text { Plantation }\end{array}$ & Graze \\
\hline Destroy & & $x$ & $x$ & $x$ & & & $\mathrm{x}$ & \\
\hline Damage & & & & & & & & $x$ \\
\hline $\begin{array}{l}\text { No Lasting } \\
\text { Effect }\end{array}$ & & & & & & & & \\
\hline $\begin{array}{l}\text { Beneficlal } \\
\text { if Done } \\
\text { Properly }\end{array}$ & ? & & & & $\mathrm{X}$ & $\mathrm{X}$ & & \\
\hline
\end{tabular}

\section{Other Comments:}

*Expected effect on the species is an estimate made by Dr. Robert Kral based on his knowledge of the habitat and on knowledge gained from personal field observations. Estimates are "rough" in many instances. Results of practices may be modified depending upon the degree of application, intensity of treatment, neamess to plant comunities, etc. A management practice for which no entry is made indicates a lack of sufficient information from which to predict expected results. As observations are made in the field by users of the data, the expected effect will be refined. 
Rudbeckia heliopsidis T.\& G.

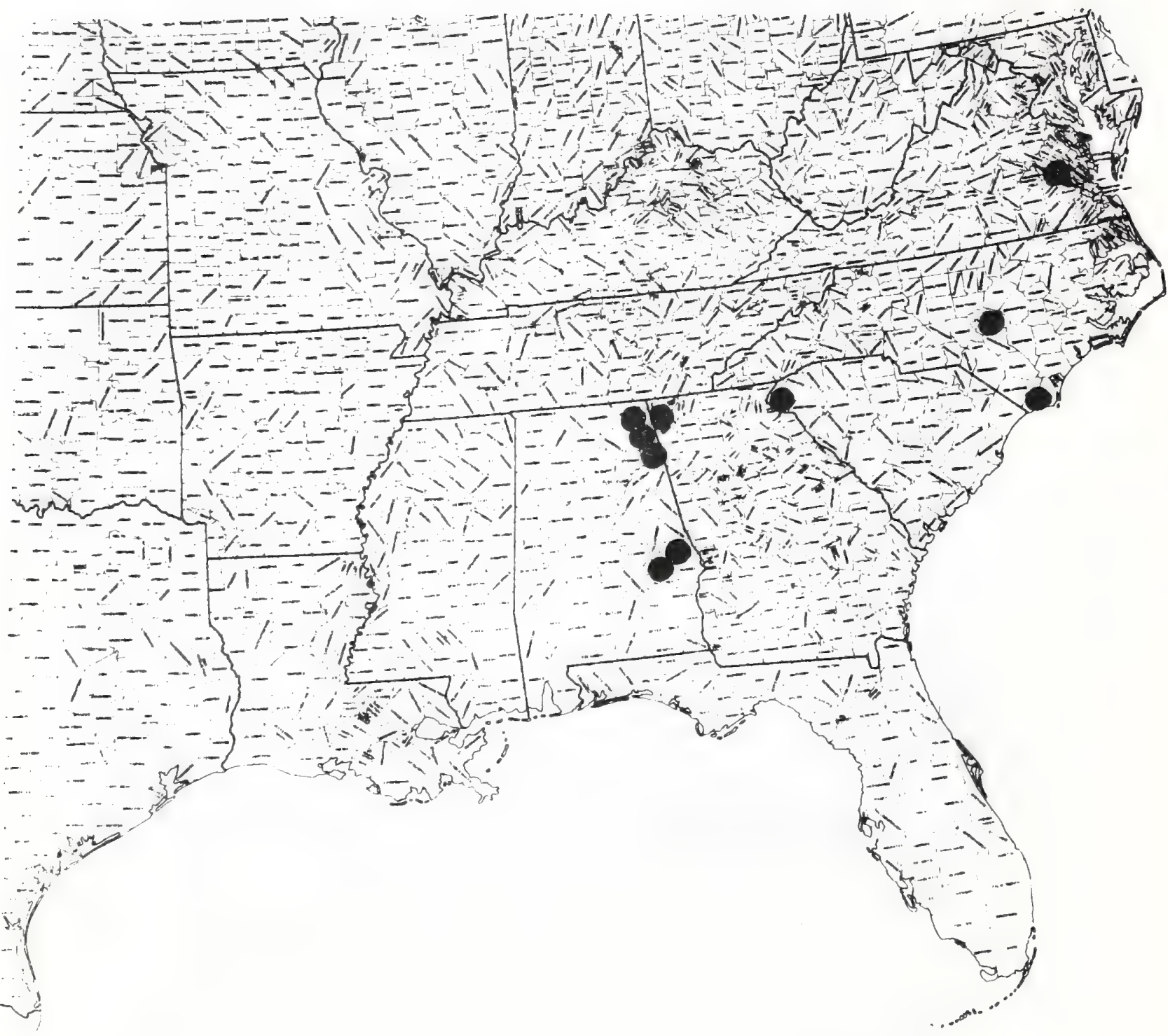


Paper 7

Text \& map by:

Robert Kral

\section{ASTERACEAE}

\section{Silphium confertifolium Small. Southern rosinweed; rosinweed}

\section{Technical Description}

Coarse smoothish perennial from a stout erect caudex or with knotty, ascending rhizome, the roots thick.

Stems.--Usually solitary from overwintering rosettes, to 7 dm tall, but usually lower, erect, unbranched save in inflorescence, terete but fluted, greenish with tints of red or maroon. Leaves.--stem leaves concentrated toward the base and there largest, blades broadly lanceolate or ovate, variable in length, from 7-20 cm long, acute, entire, ciliate-scabrid, the bases from broady rounded to broadly cuneate, thence abruptly attenuated down the petiole which is no more than 1/3 the blade length: upper leaf surface smooth or with distant short sharp hairs, dark green; lower surface paler, veiny, sometimes with a scattering of hairs along the prominent midrib; leaves above the stem base sharply reduced in size and on more elongate internodes, erect, opposite sessile or short-petiolate, more often elliptic or lanceolate, grading into distant pairs of small ovate bracts.

Inflorescence.- - Of few to many heads in a more or less open or congested cyme on peduncles much longer than themselves, the inflorescence branches stiffly ascending from the upper stem nodes. Heads broadly campanulate, across the bracts ca. $1 \mathrm{~cm}$ high and to $1.5 \mathrm{~cm}$ broad, the several finm bracts overlapping loosely spirally, mostly ovate, the greenish tips often spreading apically, acute to obtuse, the margins stiffly ciliate; involucral bracts grading gradually to narrower (mostly oblong) pales (chaff) whose tips are purplish, with a strigillose whitish pubescence.

Flowers.--Ray florets 8-10, fertile, the ligules spreading, oblong-1inear, ca. $1.5 \mathrm{~cm}$ long, lemon yellow; disc florets on a slightly elevated receptacle, mostly sterile, the corollas tubular with ascending, broadly triangular lobes, greenishyellow.

Fruit.--Akene broadly obovate, flattened, ca. 6-7 mo long laterally winged with wings $1 \mathrm{~mm}$. or less broad, these terminating in 2 low-triangular teeth at sides of akene summit; akene body appressed white-hairy on its inner concave face, otherwise smooth, gray-brown when ripe.

Distribution and Flowering Season

Prairies and glades over chalk, Black Belt Alabama; flowering July into early september.

\section{Special Identifying Features}

This species is closest taxonomically to extremes of silphium trifoliatum L. var. latifolium Gray, and both may occur in the same area, the latter distinguished by its lower habit, smaller leaves, and especially by its tendency to have the leaves more crowded toward the base with the mid and upper stem leaves abruptly reduced in size. It should probably be treated as an extreme or at best as a subspecies

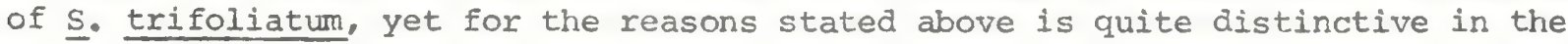


field. So far it has been found only in Choctaw, St. Clair, and sumpter counties in Alabama.

Habitats and Management Implication

S. confertifolium appears to be calciphilic, being thus far found only on the heavy black clay earths that weather from calcareous rock. These soils, with their very fine texture, tend to be very wet and sticky during the rainy periods, bake to bricklike character during dry periods. This silphium is usually in association with prairie plants including a large array of grasses, sedges, composites, umbellifers in areas that once were probably fire maintained and thus could be termed savannaprairie. Oak species such as 2 . shumardii, 2. phellos, Q. nigra, Q. durandi, . stellata, hickory such as Caxya ovata, C. carolinae-septentrionalis, C. myristicaeformis, elm, osage-orange, hercules club, green and white ash, and juniper typify the forest. The region this plant grows in is dotted with outcrops of limestone, particularly chalk, these unsuited for any row crops and $\underline{\mathbf{S}}$. confertifolium will grow in shallow soils that accumulate in and around such outcrops. It may have ranged into the deeper soils further from outcrops but such have largely been converted to row crops or to improved pasture grasses, these last tending to close out the original growth of forbs and grasses. $\underline{\text { s. }}$ confertifolium and other such plants thus are on the border of extinction. Outcrops where these may yet be found are mostly heavily grazed, and their poor quality pasture is mostly eaten to the ground by poor quality cattle or goats. In areas where both cattle and fire are excluded, trees are coming back in, particularly Juniper, and such forbs are being closed out.

References

Perry, Lily M. 1937. Notes on Silphium, Contribs Gray Herb. CXVII: pp. 281-296. Small, J. K. 1933. Manual of the southeastern Flora, pp. 1408-1415. Chapel Hill, N.C. 
SPECIES: \#7 Silphium confertifolium Small. Rosinweed

\begin{tabular}{|c|c|c|c|c|c|c|c|c|}
\hline \multicolumn{9}{|c|}{ Management Practices } \\
\hline $\begin{array}{l}\text { Expected* } \\
\text { Effect on } \\
\text { the Species }\end{array}$ & $\begin{array}{c}\text { Prescribe } \\
\text { Burn }\end{array}$ & $\begin{array}{l}\text { Bulldoze } \\
\text { or } \\
\text { Root Rake } \\
\end{array}$ & Bed & Chop & $\begin{array}{l}\text { Thin } \\
\text { over- } \\
\text { story }\end{array}$ & $\begin{array}{l}\text { Cut } \\
\text { Over- } \\
\text { story } \\
\end{array}$ & $\begin{array}{l}\text { Estab1ish } \\
\text { Plantation }\end{array}$ & Graze \\
\hline Destroy & & $\mathrm{x}$ & $\mathrm{x}$ & $Y$ & & & $x$ & \\
\hline Damage & & & & & & & & $\mathrm{X}$ \\
\hline $\begin{array}{l}\text { No Lasting } \\
\text { Effect }\end{array}$ & & & & & & & & \\
\hline $\begin{array}{l}\text { Beneflclal } \\
\text { If Done } \\
\text { Properly }\end{array}$ & but NA & & & & $x$ & iz & & \\
\hline
\end{tabular}

\section{Other Comments:}

*Expected effect on the species is an estlmate made by Dr. Robert Kral based on his knowledge of the habitat and on knowledge gained from personal field observations. Estimates are "rough" in many instances. Results of practices may be modified depending upon the degree of application, intensity of treatment, nearness to plant conmunities, etc. A management practice for which no entry is made indicates a lack of sufficient information from which to predict expected results. As observations are wade in the field by users of the data, the expected effect will be refined. 
Silphium confertifolium small

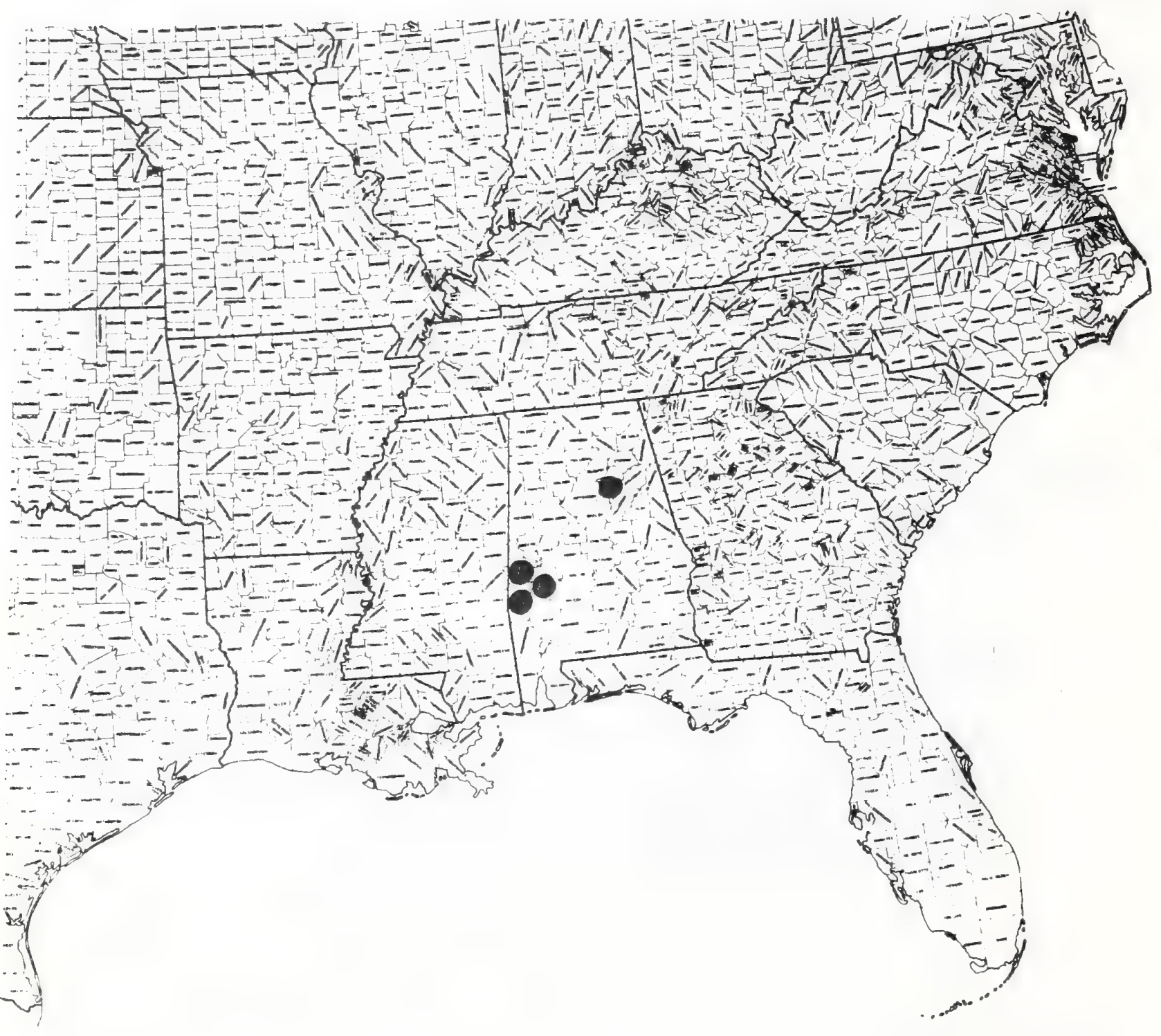


Paper 8

Text \& map by:

Robert Kral

\section{ASTERACEAE}

Vernonia pulchella Small; Georgia ironweed; ironweed

Technical Description

Perennial herb, rather coarse, but usually 1 meter tall or less. Stems.--One to several from a short, stout, thick-rooted caudex, slender but stiffish, not branching below the inflorescence, round in cross section, also fluted with several ribs, variable in pubescence from nearly smooth to villous, appressed-puberulent or scatteringly hirsute or with a mixture of these hairs, strongly maroon or purple-tinted.

Leaves.--Stiffly erect or spreading, numerous, alternate, lanceolate to oblong, elliptic or obovate, the lowest smallest and distant, the largest at or just below mid-stem, mostly $3-6 \mathrm{~cm}$ long, the tips acute or obtuse angled, the margins revolute, entire or coarsely serrate, the base sessile or on a short stout petiole, auriculate, the upper surface dark green, the lower paler, both surfaces scabrous. Inflorescence.--Several to numerous-headed, an open broad cyme of cymes, the main branches ascending from the axils of reduced stem leaves and stiffish, the peduncles erect or spreading, usually fine-hairy and longer than the heads or sessile. Heads campanulate, from base to tip of phyllaries $\mathrm{ca} .1 \mathrm{~cm}$ and nearly as broad, the phyllaries (bracts) numerous, imbricate in several spirals, narrowly triangular to narrowly ovate, the outer ones smallest, loosest, and narrowest, the longer ones ca. $7 \mathrm{~mm}$ long, the tips slender acuminate, recurved, giving a "bristly" look to the heads, the surfaces green with maroon or purple tints, cobwebby ciliate-hairy marginally and sometimes on the backs. Flowers.--All discoid, all fertile, 20-36 on an elevated, naked receptacle, the purple corollas projecting ca. $5 \mathrm{~mm}$ beyond the bracts, about $1 \mathrm{~cm}$ long with a long tube, narrowly funnelform throat and 5 narrowly triangular, spreading lobes. Fruit.--Ripe akenes about $3 \mathrm{~mm}$ long, oblong, strongly many-ribbed and bristly along the ribs, yellowish-green with flecks of purple, the pappus of many capillary stiff barbellate bristles ca. $8 \mathrm{~mm}$ long, these sordid or dull-brown.

Distributon and Flowering season

Pine-saw palmetto flatwoods, southeastern Georgia, late July to early September.

Habitat and Management Implication

This distinctive ironweed is not rare within its rather small range, though it is nowhere aspect dominant. Its soils range from rather dry to quite moist, but are usually those of low rises in flatwoods or of edges of seep areas in longleaf pine forested ridges. It is a plant either of full sun, or is found in savannas or in the intermittent shade of tall and scattered pines. It is best developed in areas that have been burned recently, where it may be locally abundant together with a myriad of other summer flowering composites, grasses and sedges, etc. It will 
appear in clearings amongst palmetto, gallberry, wax-myrtle, and various ericaceous shrubs particularly Lyonia, Vaccinium, Gaylussacia. As is true of cormophytes it holds up well even under hot fires, putting up new shoots rapidy and producing heavy crops of flowers and fruit in the burns. It will persist in drained areas but is shaded out in young plantations. It will occupy areas that have been subjected to nearly all methods of site preparation, so long as a contiguous seed source is available, but the shade of well stocked pine plantations eliminates it and most other savanna forbs. As is true of many ironweeds the species can survive moderate grazing activity.

References

Gleason, H. A. 1906. Vernonieae, North American Flora 33: 52-95.

Jones, S. B. 1964. Taxonomy of the narrow-leaved Vernonia of the Southeastern United States, Rhodora 66 (768): 382-401. 
SPECIES: \#8 Vernonia pulchella Small Ironweed

\begin{tabular}{|c|c|c|c|c|c|c|c|c|}
\hline & \multicolumn{8}{|c|}{ Management Practices } \\
\hline $\begin{array}{l}\text { Expected* } \\
\text { Effect on } \\
\text { the Species }\end{array}$ & $\begin{array}{c}\text { Prescribe } \\
\text { Burn }\end{array}$ & $\begin{array}{l}\text { Bulldoze } \\
\text { or } \\
\text { Root Rake } \\
\end{array}$ & Bed & Chop & $\begin{array}{l}\text { Thin } \\
\text { over- } \\
\text { story }\end{array}$ & $\begin{array}{l}\text { Cut } \\
\text { Over- } \\
\text { story }\end{array}$ & $\begin{array}{l}\text { Establish } \\
\text { Plantation } \\
\end{array}$ & Graze \\
\hline Destroy & & $\mathrm{x}$ & $\mathrm{X}$ & $\mathrm{x}$ & & & $\mathrm{X}$ & \\
\hline \multicolumn{9}{|l|}{ Damage } \\
\hline $\begin{array}{l}\text { No Lasting } \\
\text { Effect }\end{array}$ & & & & & & & & $\mathrm{X}$ \\
\hline $\begin{array}{l}\text { Beneficlal } \\
\text { if Done } \\
\text { Properly }\end{array}$ & $\mathrm{X}$ & & & & $x$ & $\mathrm{X}$ & & \\
\hline
\end{tabular}

\section{Other Comments:}

*Expected effect on the species is an estimate made by Dr. Robert Kral based on his knowledge of the habitat and on knowledge gained from personal field observations. Estimates are "rough" in many instances. Results of practices may be modifled depending upon the degree of application, intensity of treatment, nearness to plant communities, etc. A management practice for which no entry is made indicates a lack of sufficlent information from which to predict expected results. As observations are made in the fleld by users of the data, the expected effect will be refined. 


\section{Vernonia pulchella Small}

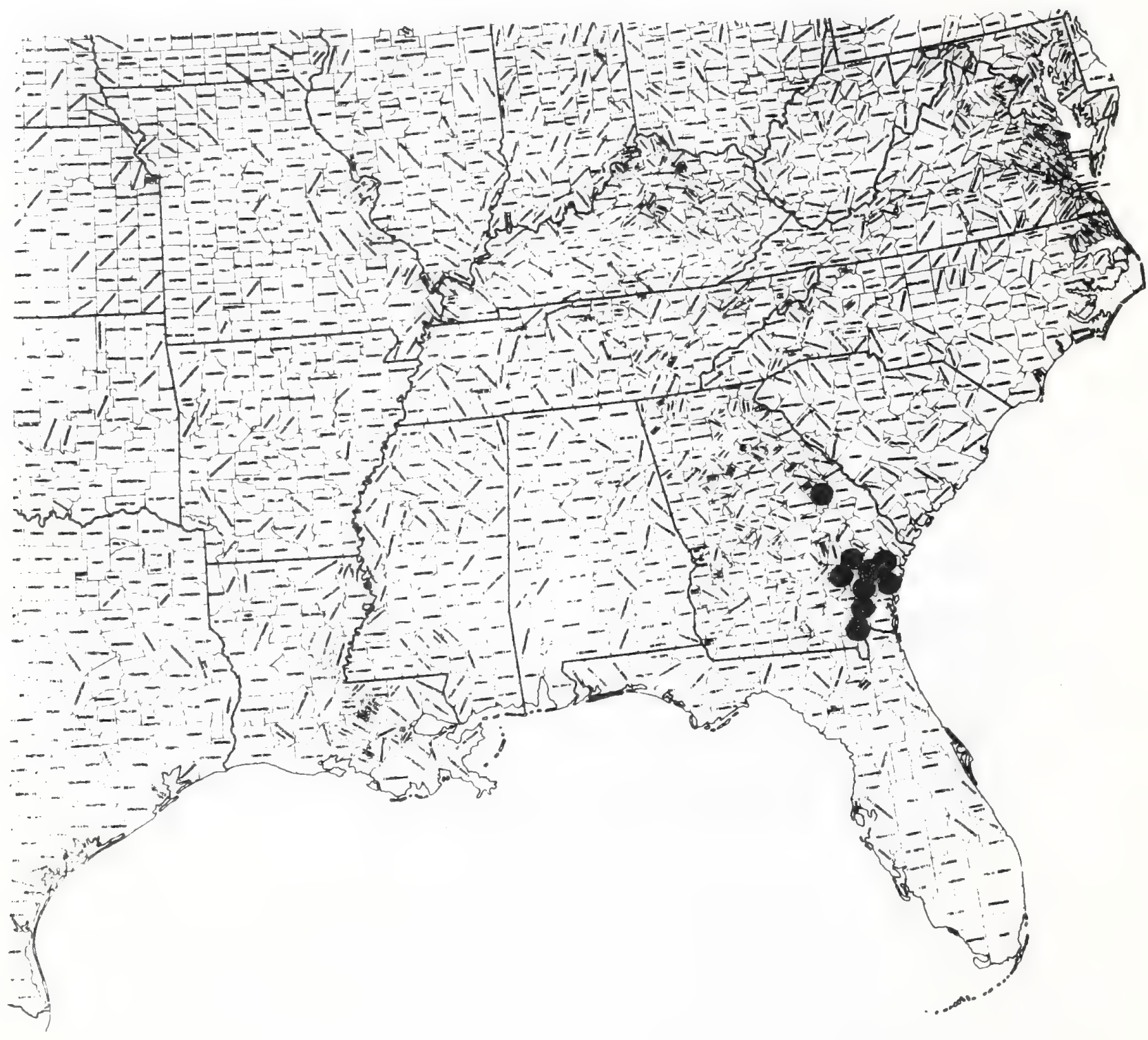


Paper 9

Text \& map by:

Robert Kral

\title{
ASTERA*EAE:
}

\author{
Viguiera porteri (A. Gray) Blake. Porter's golden-eye; \\ Confederate daisy \\ Gymnolomia porteri A. Gray
}

\section{Technical Description}

A taprooted annual.

Stems.--The main stem erect, to $8 \mathrm{dm}$ tall but usually lower, simple or many and oppositely branched from below the middle, thus bushy and spreading, the main shoot slender but stiffish and brittle, terete below, somewhat ribbed toward the tip, yellow-green or tan, or tinted with maroon, somewhat harsh. Ieaves.--Numerous, alternate, the lowest gone by flowering time, those of mid-stem or mid-branch longest, spreading-ascending linear, or lance-linear, mostly 3-4 (-6) cm long, acute, revolute, sessile or nearly so, I-veined, the upper surface harsh, dark green, the lower surface paler, harsh or even hirsute along the mid-rib: stem leaves grading gradually into narrower and shorter bracts of peduncles.

Inflorescence.--Peduncles slender, arching upward from upper bracteal leaves, themselves much longer than the heads and with few or no bracts. Heads ovoidconic, 1.0-1.4 cm, high, the involucres hemisphaeric, 4-5 mm high, 7-10 mm broad across phyllary tips. Involucral bracts with outer series narrowly triangular, spreading, green, smooth or with a scattering of pale hairs on backs and edges and with inner series fimer, yellowish-tan, strongly many nerved, ascending, lance-ovate, acuminate, grading on the conic receptacle to narrower, thinnish, narrowly acute-tipped chaff, this greenish-brown with paler nerves. Flcwers.--Ray florets mostly 8-10, sterile, the corollas $1.0-1.5 \mathrm{~cm}$ long, oblong or elliptic-oblong, bright yellow, spreading. Disc flowers numerous, fertile, the corolla ca. $2.5 \mathrm{~mm}$ long, yellow with a short narrow tube flaring into a campanulate throat, the narrowly triangular lobes recurved.

Fruit.--Akene slightly flattened, about $2.5 \mathrm{~mm}$ long, in outline oblong or obovate, the apex broadly rounded or truncated, without a pappus, the surface dark graybrown with darker blotches, toward the apex with several short, erect, pale hairs.

Distribution and Flowering season

On and around granite outcrops in the Piedmont from Alexander County, North Carolina southwestward to Randolph and Chambers Counties, Alabama in Saint Clair and Shelby counties of Appalachian Alabama.

\section{Special Identifying Features}

This species, called "Confederate Daisy" is a northeastern representative of a largish genus of the southwestern U.S.A., Mexico and southward, thus has no near taxonomic relatives in the southeast.

Habitats and Management Implication

It was first known from the large granite outcrops, particularly stone and Panola Mountains, of Georgia. In that the outcrops are local, so is the species, but 
where it does occur it is an aspect dominant in fall, turning acres of granite to yellow gold. In that some of the outcrops are being converted to parks and nature conservacies, and in that it is weedy in such places, its future is bright. A plant of full sunlight and shallow soils it is forest related in the sense only that pines and low quality hardwoods ultimately occupy outcrops. Cutting of contiguous pines and erosion would probably increase this species whose major man-caused threat is the quarrying away of its granitic substrate.

References

Blake, S. E. 1918. A revision of the genus Viguiera. Contribs. Gray Herb. Harvard 54: 1-205.

MCVaugh, R. 1943. Vegetation of the Granite Flatrocks of the Southeastern U. S. Ecol. Monograph 13: 120-166.

Small, J. K. 1933. Manual of the southeastern flora, pp. 1421-1422. Chapel Hill, N.C. 
SPECIES: \# \# \#iguiera porteri (A. Gray) Blake. Confederate daisy

\begin{tabular}{|c|c|c|c|c|c|c|c|c|}
\hline & \multicolumn{8}{|c|}{ Management Practices } \\
\hline $\begin{array}{l}\text { Expected* } \\
\text { Effect on } \\
\text { the Species }\end{array}$ & $\begin{array}{c}\text { Prescribe } \\
\text { Burn }\end{array}$ & $\begin{array}{l}\text { Bulldoze } \\
\text { or } \\
\text { Root Rake }\end{array}$ & Bed & Chop & $\begin{array}{l}\text { Thin } \\
\text { over- } \\
\text { story } \\
\end{array}$ & $\begin{array}{l}\text { Cut } \\
\text { Over- } \\
\text { story }\end{array}$ & $\begin{array}{l}\text { Establish } \\
\text { Plantation }\end{array}$ & Graze \\
\hline Destroy & & & & & & & $\mathrm{X}$ & \\
\hline Damage & & & & & & & & $\mathrm{x}$ \\
\hline $\begin{array}{l}\text { No Lasting } \\
\text { Effect }\end{array}$ & $N A$ & & & & & & & \\
\hline $\begin{array}{l}\text { Beneficlal } \\
\text { if Done } \\
\text { Properly }\end{array}$ & & & & & $x$ & $\therefore$ & & \\
\hline
\end{tabular}

\section{Other Comments:}

*Expected effect on the species is an estimate made by Dr. Robert Kral based on his knowledge of the habitat and on knowledge gained from personal field observations. Estimates are "rough" in many instances. Results of practices may be modified depending upon the degree of application, intensity of treatment, nearness to plant communities, etc. A management practice for which no entry is made indicates a lack of sufficlent information from which to predict expected results. As observations are made in the field by users of the data, the expected effect will be refined. 
Viquiera porteri (A. Gray) Blake

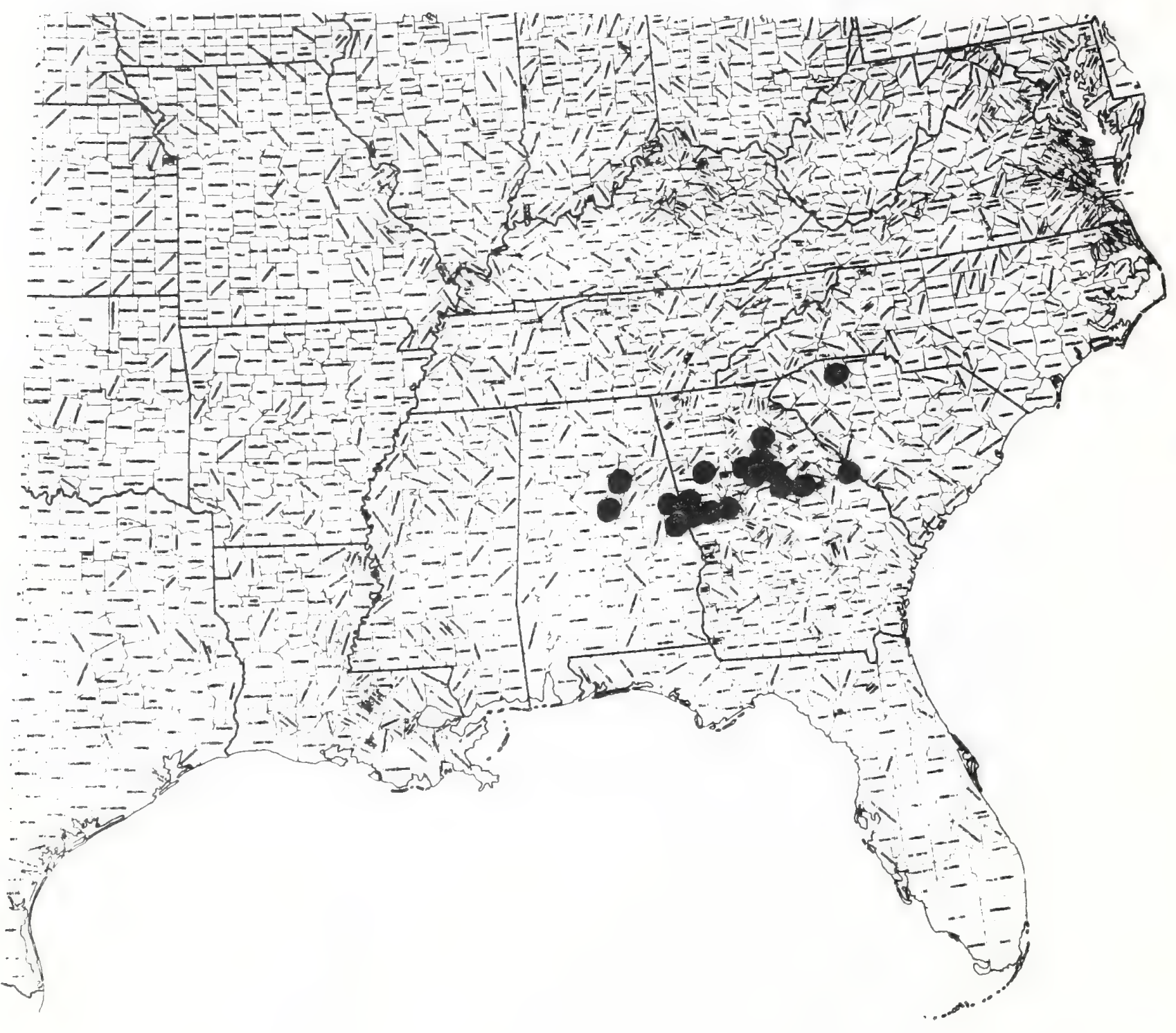


Leavenworthia alabamica Rollins var. alabamica; Glade cress

\section{Technical Description}

Leaves:--Larger rosette leaves rarely longer than $1 \mathrm{dm}$. 1ong, oblanceolate, the terminal segment sometimes round but more often reniform (broader than long), usually coarsely dentate or crenate; lateral segments usually several pairs, mostly asymmetrical, from broadly to narrowly triangular (often with til s pointing upward or downward) or obovate, entire or variously toothed or lobed, and with leaflet pairs progressively reduced in size and more distant on the rachis downward. Flowers.-- Sepals mostly oblong, 5-7 m. long, spreading at flowering time, pale green with tints of maroon. Petals obovate-bladed, $1.0-1.4 \mathrm{~cm}$. 1ong, spreading at anthesis, the blade white to pale lavender, deeply emarginate, the base (including the short claw) yellow or orange yellow. Fruit:--Silique narrowly oblong, not fleshy, acute above and below, strongly flattened, $1.5-2.5 \mathrm{~cm}$. long, 3.0-4.5 mm. wide; style 2.5-5.5 mm. long. Seeds dark brown, orbicular, winged, $3-4 \mathrm{~mm}$. in diameter.

Distribution and Flowering Season

Open limestone glades and heavy soils of open fields derived from limestone, northwestem Alabama from central Colbert and Franklin counties eastward to middle Lawrence county. Flowering from late February through April.

\section{Special Identifying Features}

In flower this species resembles L. torulosa, L. exigua or white or lavender flowered forms of L. stylosa. It differs from the first by not having a torulose ovary and fruit; it differs from the second by its longer (10-16 mm. versus 7-10 $\mathrm{mm}$.$) petals which are more deeply emarginate; it differs from the third in its$ shorter (6-12 mm. vs. 12-25 mm.) flatter, less fleshy siliques. This is perhaps the showiest and most abundant of the genus in Alabama. 
Leavenworthia alabamica Rollins

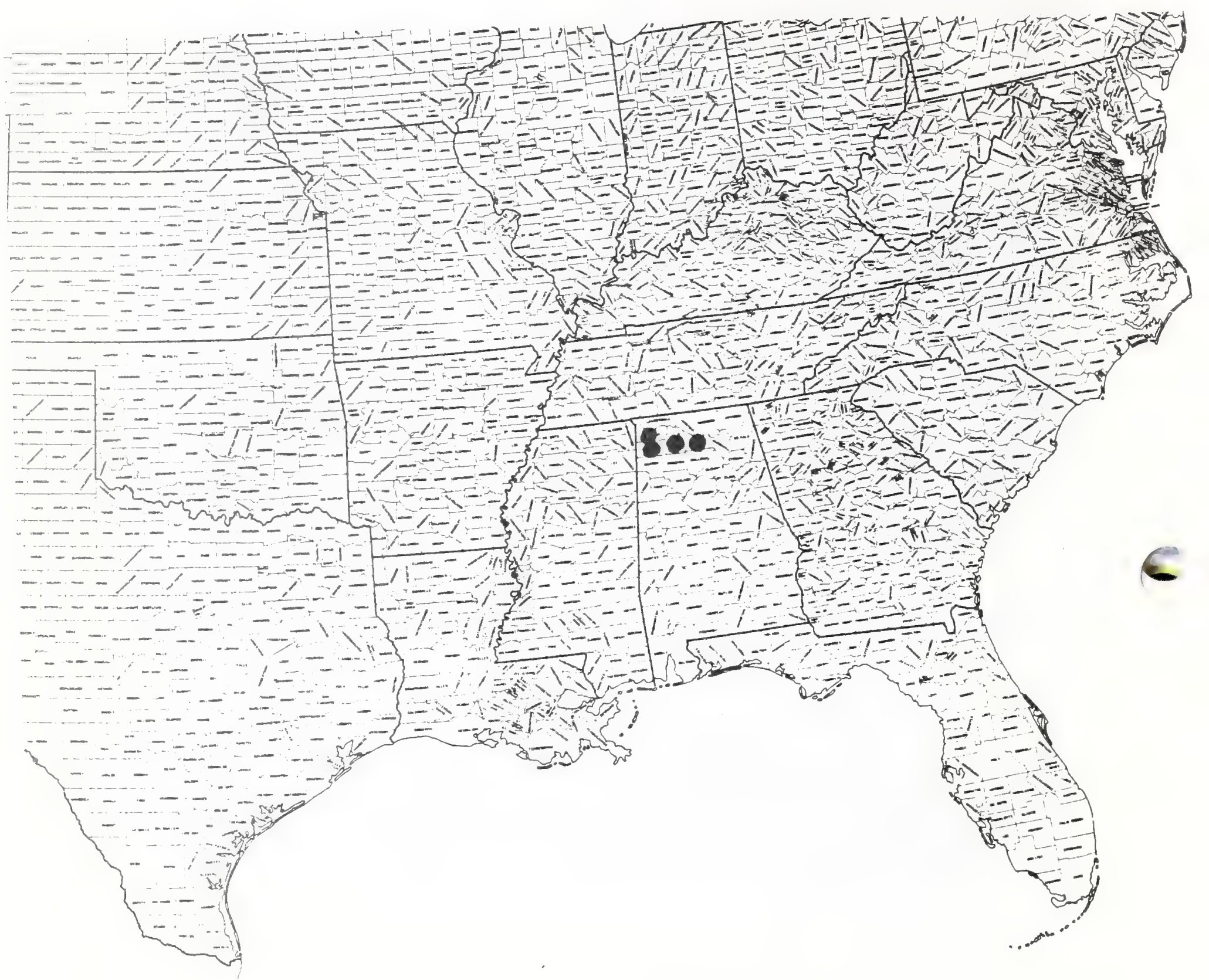


Paper 14

Text \& map by:

Robert Kral

Leavenworthia exigua Rollins var. exigua; Glade cress

Technical Description

Leaves:-Early leaves with a remote, shallowly toothed terminal lobe, fully developed leaves lyrate-pinnatifid (see genus description), $1.5-6 \mathrm{~cm}$. long, the lobes with varied margins.

Flowers:-Sepals 1inear-oblong, 3.5-5.5 mm. Iong, greenish or with lavender tints, erect or spreading in full flower. Petals spatulate to tongue-shaped, shallowly emarginate, 6-9 mm. long, 3.0-4.5 mm. wide, blade white to light lavender, the "eye" spot yellowish or petals yellow in the variety 1utea. Fruit:-Siliques very flattened, non-fleshy, oblong, $1-2 \mathrm{~cm}$. 1ong, $3.5-5.5 \mathrm{~mm}$. wide, obtuse above and below, the style 1-3 mm. long. Seeds 4-10/silique, winged, nearly flat, unevenly round, 3-4 mm. broad.

Distribution and Flowering Season

Local in limestone glades in the Central Basin of Tennessee and in northwest Georgia.

Special Identifying Features

This species differs from other emarginate-petalled Leavenworthia as follows:

1. Petal blades shallowly emarginate, petals 7-10 mm. long, styles 1-3 mm. long. This eliminates L. stylosa, L. crassa, L. alabamica which have longer and more deeply emarginate petals, longer styles.

2. Siliques thin, without margins. This eliminates the species $\underline{\text { L }}$ aurea which occurs only in Oklahoma and eastern Texas.

3. Fruit not torulose. This excludes $L_{\text {. }}$ torulosa, whose fruit is constricted between the roundish seeds. 
Leavenworthia exiqua Rollins

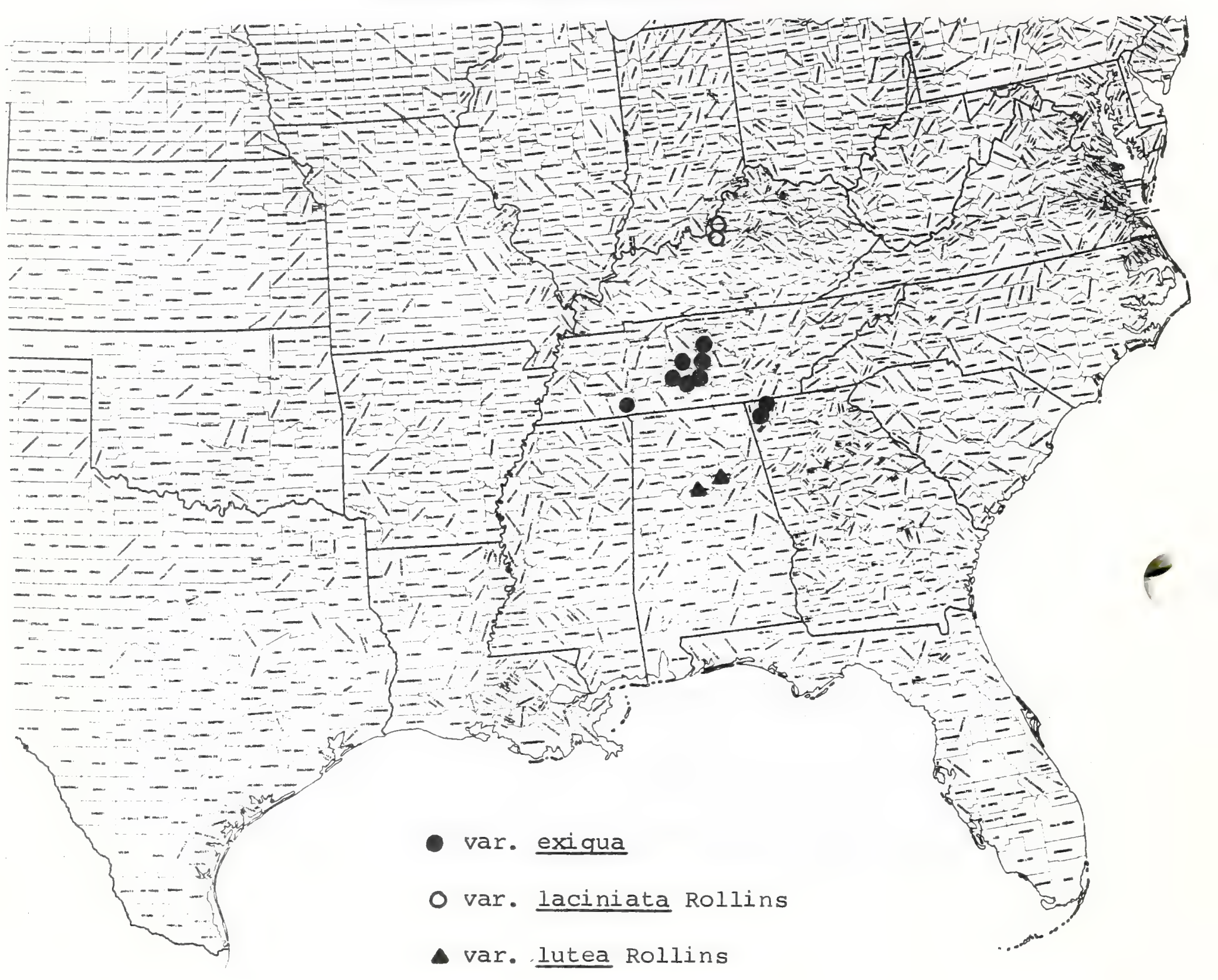


Paper 17

Text \& map by:

Robert Kral

Leavenworthia stylosa Gray; Glade Cress

Technical Description

Leaves:-Fully grown leaves lyrate pinnatifid, the terminal lobe largest, usually broader than long, the lateral lobes varied in number and margin.

Flowers:-Sepals linear-oblong, spreading at flowering time, 4-8 mm. long, greenish or with tints of maroon. Petals obovate to broadly spatulate, 9-15 mm. 1ong, deeply emarginate, the blades white, yellow (mostly) or lavender, the claws deep yellow or orange, the blades spreading broadly at full flower.

Fruit:-Siliques oblong to linear, 1-3 cm. long, 2.5-4.5 mm. broad, 2-4 mm. thick, the body obtuse above and below, fleshy, on an evident stalk (gynophore) to $1 \mathrm{~mm}$. long; style $3-8 \mathrm{~mm}$. long. Seeds dark brown, winged, broadly oblong to suborbicular, $3.0-4.5 \mathrm{~mm}$. 1ong.

Distribution and Flowering Season

Locally abundant in the Central Basin of Tennessee in limestone glades and calcareous fields. Commonest in Davidson, Rutherford and Wilson Counties, areas of Tennessee in which limestone glades are best developed.

Special Identifying Features

Distinguished by its large (comparatively) deeply emarginate mostly yellowish petals, by its comparatively elongate siliques which while somewhat compressed are also fleshy, and its elongate styles.

Habitats and Management Implication

In some glades an early spring aspect dominant, covering acres with a carpet of golden-yellow, very fragrant blooms. Some of the greatest concentrations of this species have been lost through the daming up of the Stones River, subsequent development of lakeshore estates, and through expansion of the cities of Nashville, Murphreesboro, and Smyrna. 
Leavenworthia stylosa Gray

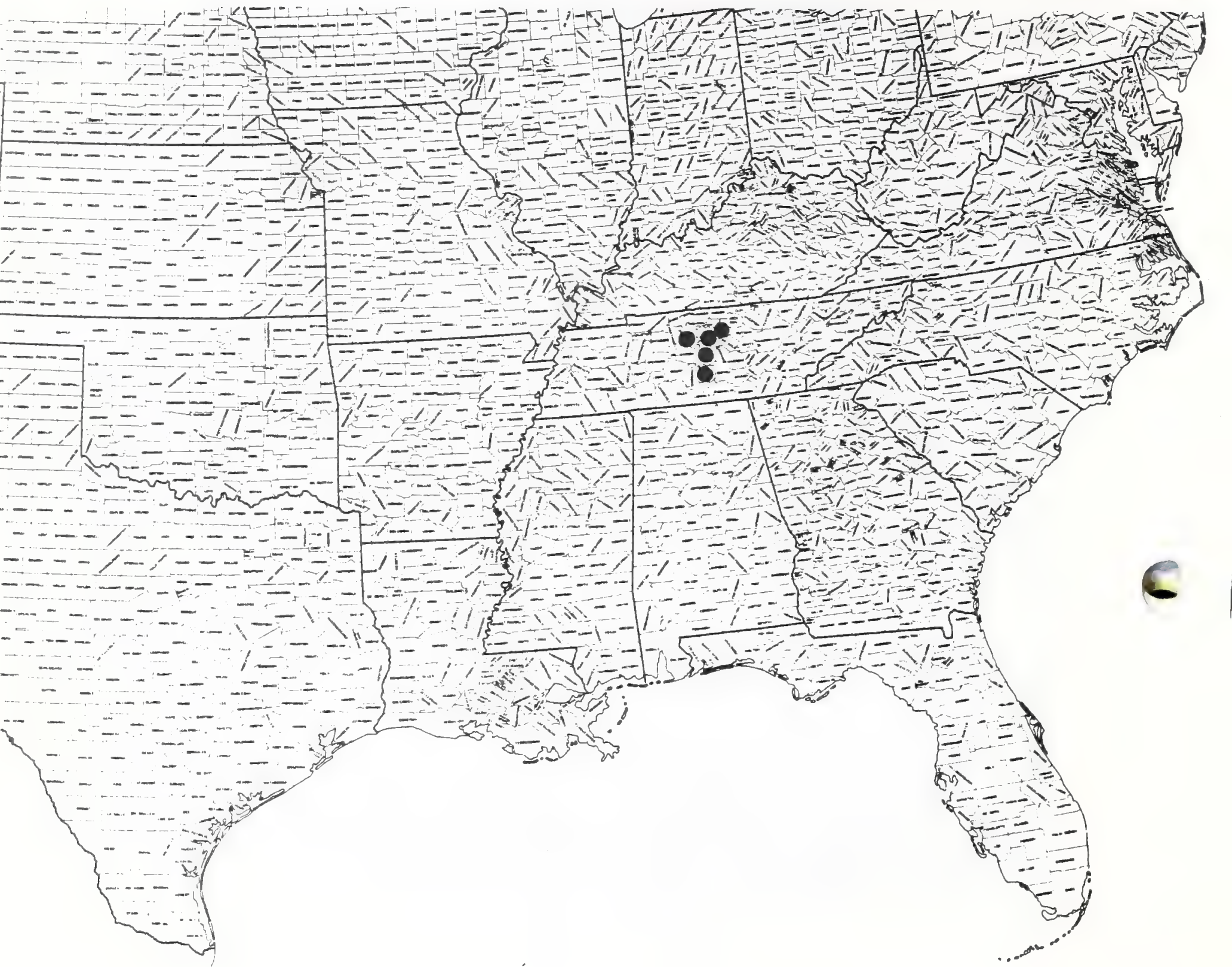




\section{Technical Description}

Leaves:-Early leaves with a long petiole and a broad, cordate blade; later fully grown leaves lyrate pinnatifid (as in the other species).

Flowers:-- Sepals narrowly oblong, 3.5-5.5 mm. long, greenish or with tints of lavender or maroon, spreading or erect at flowering time. Petals spatulate, 6-10 mm. long, emarginate, white or light lavender bladed usually, rarely yellow or deep lavender.

Fruit:- Siliques linear, torulose (constricted between seeds so as to resemble a string of beads), $1.5-3.0 \mathrm{~cm}$. 1ong, $2.5-4.0 \mathrm{~mm}$. wide, 2.0-3.5 mm. thick, styles 2.5-5.0 mm. long; gynophore (stalk below ovary and fruit) about $1 \mathrm{~mm}$. long. Seed nearly wingless, longer than broad.

Distribution and Flowering Season

Locally abundant in limestone glades and calcareous soil of low fields and ditches, southern Kentucky through middle Tennessee, with one outlier in Bradley county in Southeastern Tennessee.

\section{Special Identifying Features}

This species is distinguished from all others by its torulose ovary and fruit. It is found in but one locality in Kentucky, but is often the most abundant species in many of the glades of middle Tennessee. 
Leavenworthia turulosa Gray

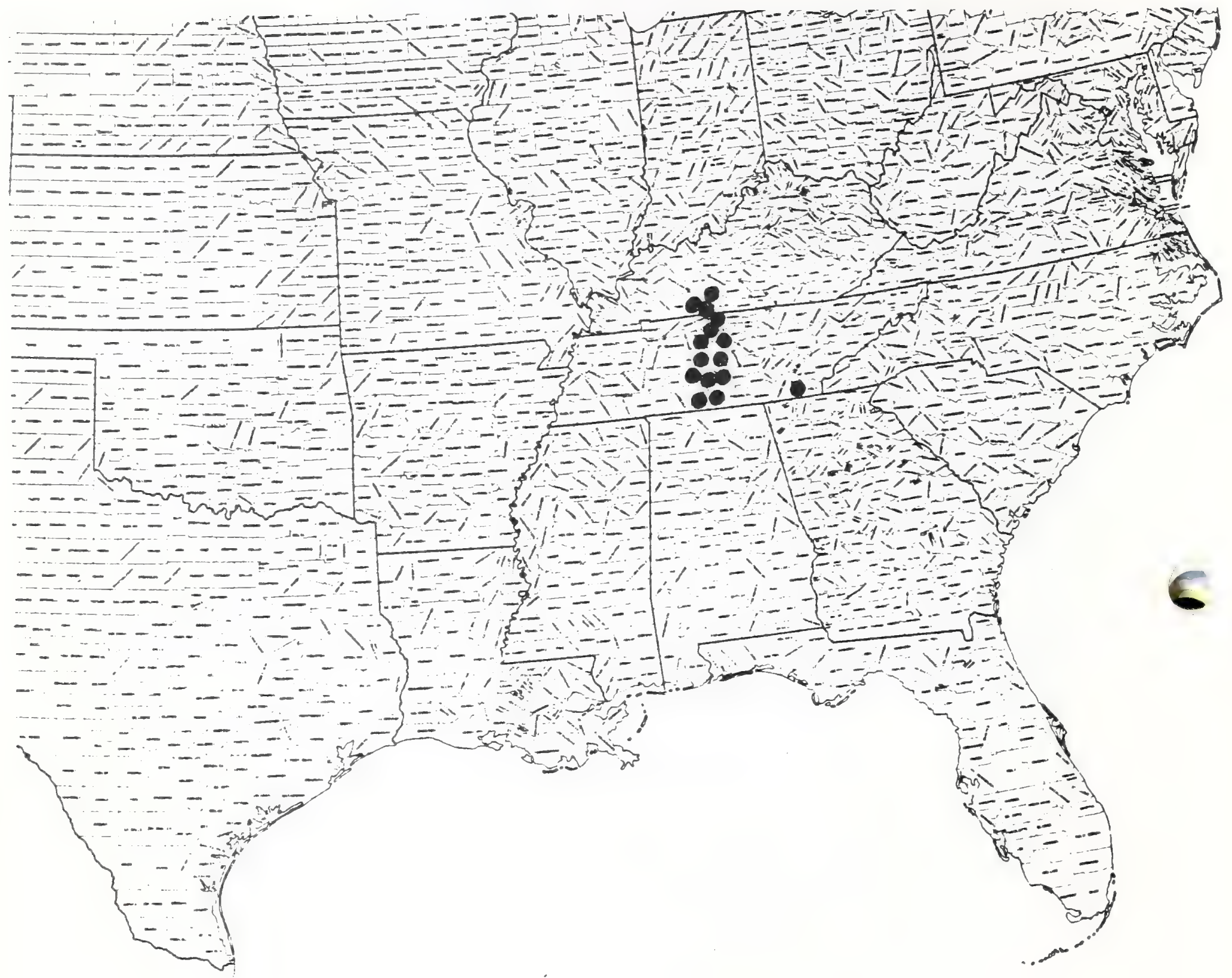


Paper 19

Text \& map by:

Robert Kral

\title{
CARYOPHYLIACEAE
}

\author{
Arenaria fontinalis (Short and Peters) Shinners: pioneer \\ sandwort: Sandwort \\ Sagina fontinalis short and Peter \\ Stellaria fontinalis (Short and Peter) B. I. Robins \\ Alsine fontinalis (Short and Peter) Britton
}

Technical Description

Slender but stiffish smooth annuals with shallow, diffuse flimsy roots. Stems.--Up to $1.5 \mathrm{dm}$ long, mostly much shorter, several erect or spreading from the base, terete or with narrow wings decurrent from leaf bases.

Leave -- Opposite from overwintering tufts, the cauline narrowiy oblanceolate or Iinear, spreading, mostly $1.0-1.5 \mathrm{~cm}$ long, acute, entire with thinnish margins, attenuate to slightly clasping bases, pale yellowish-green. Inflorescence.--Basically but asymetricaliy cymose, the stems branching from near the base, each branch bearing at its axil a long-stalked symetrical. flower. Flower stalks 5-10 mm long in flower, elongating to $2 \mathrm{~cm}$ or more in fruit, smooth, slender, somewhat ribbed or angulate. Flowers.--Sepals 4-5, erect in bloom, narrowly ovate-triangulax, thin, about $2.5 \mathrm{~mm}$ long, pale yellow-green with very broad thin entire margins, apically mucronate and acute, 3-nerved. Petals absent or vestigial. Stamens as many as 10 but usually around 4-5, shorter than the sepals. Ovary superior, the styles $3-4$ the placentation free-central with several oviles. Fruit.--Capsule 3.0-35 mm long ovoid, its tip projecting above the perianth, at maturity splitting into 3 valves. Seeds nearly round or round and unevenly compressed in places, nearly $1 \mathrm{~mm}$. broad, covered with tiny papillae, a dark lustrous redaish-brown.

Distribution and Flowering Season

Seeps over limestone or in calcareous soil, known only from the Interior Low Plateau near Lexington, Kentucky and middle Tennessee. Flowering in April and May.

Habitats and Management Implication

This rare species is known only fram permanently wet areas, usually seeps and seepage areas around limestone outcrops or bluffs. It is in clearings in or in light shade of calciphilic hardwood species such as Maclura pomifera, guercus muhlenbergii, g. shumaraii, ulmus serotina, U. rubra, Acer saccharum, Carya carolinae-septentrionalis, gymnosperms such as Juniperus virginiana. Comon shrubs of such areas are Rhus aromatica, Rhus glabra, Rhamnus caroliniana, Symphoriocarpos.

In the seeps this plant may dominate small wet areas with mats of growth, these mats interspersed with other herbs such as Cyperus, Eleocharis (particularly E. compressa, E. obtusa), Agrostis stolonifera, Gratiola neglecta. By late May the Arenaria begins to die back and by early June the plants are not in evidence. 
Best growth of the species is in full sun or light shade. Iogging of contiguous hardwoods where local seeps occur would probably favor increase; however, the topography is such and the site quality of such areas is such, that good merchantable species are few. The main enemy this plant has is drainage in that permanently wet substrates are required for its maintenance.

References

Gleason, H. A. 1958. Illustrated Flora, Vol. II, pp. 123-126.

Small, J. K. 1933. Manual of the southeastern flora, pp. 497-498.

Shinners, I. H. 1962. New names in Arenaria (Caryophylaceae). Sida I (1): 49-52. 
SPECIES: \#19 Arenaria fontinalis (Short and Peters) Shinners. Sandwort

\begin{tabular}{|c|c|c|c|c|c|c|c|c|}
\hline & \multicolumn{8}{|c|}{ Management Practices } \\
\hline $\begin{array}{l}\text { Expected* } \\
\text { Effect on } \\
\text { the Species }\end{array}$ & $\begin{array}{c}\text { Prescribe } \\
\text { Burn }\end{array}$ & $\begin{array}{c}\text { Bulldoze } \\
\text { or } \\
\text { Root Rake } \\
\end{array}$ & Bed & Chop & $\begin{array}{l}\text { Thin } \\
\text { over- } \\
\text { story }\end{array}$ & $\begin{array}{l}\text { Cut } \\
\text { Over- } \\
\text { story }\end{array}$ & $\begin{array}{l}\text { Establish } \\
\text { Plantation }\end{array}$ & Graze \\
\hline \multicolumn{9}{|l|}{ Destroy } \\
\hline Damage & & & & & & & $\mathrm{X}$ & $\mathrm{x}$ \\
\hline $\begin{array}{l}\text { No Lasting } \\
\text { Effect }\end{array}$ & $\mathrm{NA}$ & & & & & & & \\
\hline $\begin{array}{l}\text { Beneflclal } \\
\text { If Done } \\
\text { Properly }\end{array}$ & & & & & $\mathrm{X}$ & $x$ & & \\
\hline
\end{tabular}

\section{Other Comments:}

*Expected effect on the species is an estimate made by Dr. Robert Kral based on his knowledge of the habitat and on knowledge gained from personal field observations. Estimates are "rough" in many instances. Results of practices may be modified depending upon the degree of application, intensity of treatment, nearmess to plant communties, etc. A management practice for which no entry is made indicates a lack of sufficient information from which to predict expected results. As observations are made in the field by users of the data, the expected effect will be refined. 


\section{Arenaria fontinalis (Short \& Peter) Shinners}

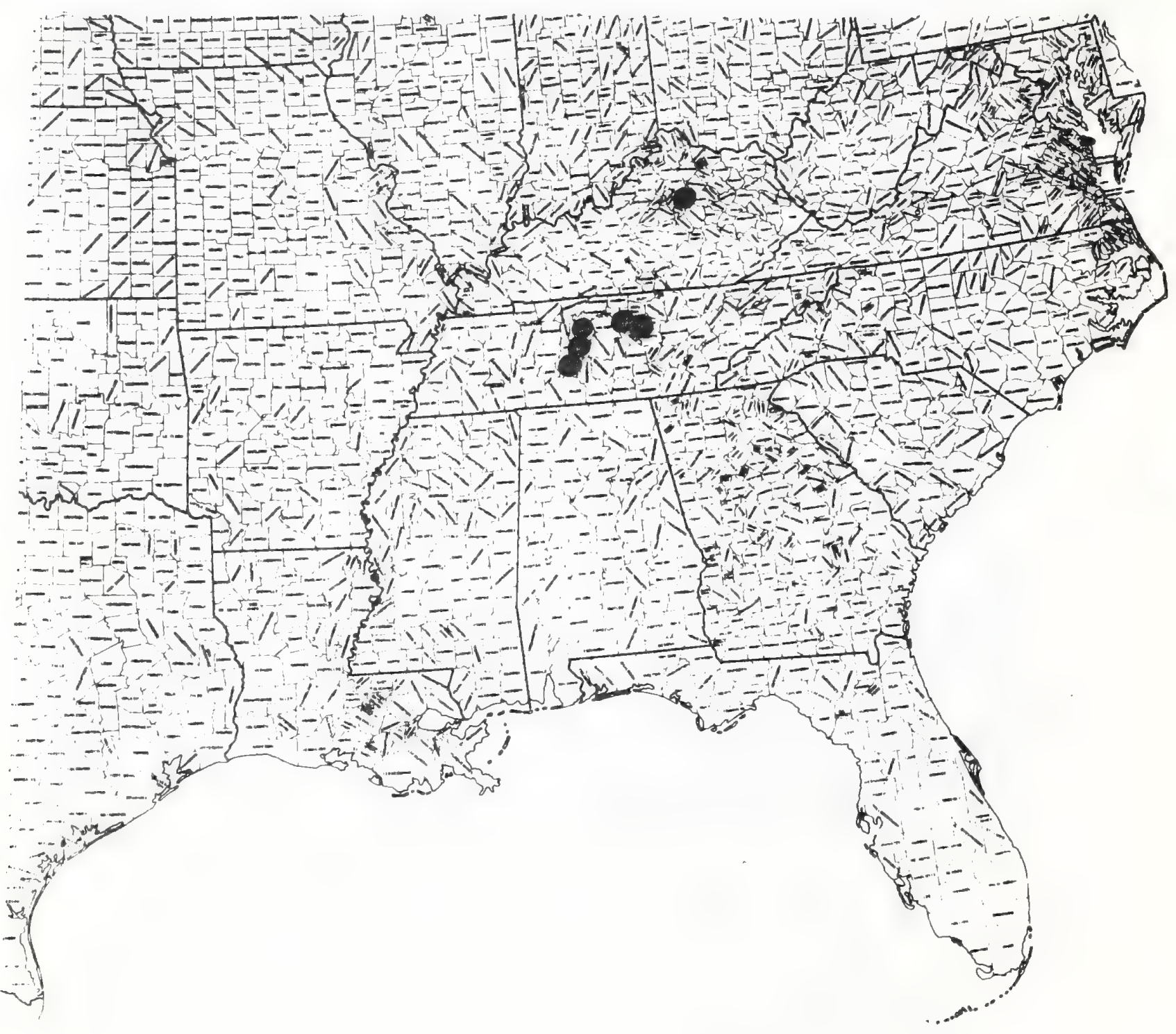


Paper $2 \theta$

Text \& map by:

Robert KraI

\section{CISTACEAE}

Lechea cernua Small. Nodding pinweed; pinweed

Technical Description

Shrublike perennial herb, usually from a deep taproot and with several spreading, ascending or erect shoots from a branching caudex.

Stems.--New shoot growth usually spreading, forming overwintering "rosettes", the shoot surfaces and the broad (around $0.5 \mathrm{~cm}$ long) ovate or elliptic new shoot leaves tomentose with white hairs. Flowering shoots up to $5 \mathrm{dm}$ tall, woody, much branched at least above the middle, the secondary branches again rebranching, the crown of a shoot therefore with a ovoid or pyramidal aspect, the shoot surfaces redilish, but cloaked with appressed grayish or whitish hairs. Leaves.--All but the uppermost shoot leaves of fertile shoots absent by flowering time (these thus usually confined to the numerous branchlets), narrowly ovate or elliptic, sessile or short stalked, $1 \mathrm{~cm}$ long or less, very firm, acute, sometimes mucronate or apiculate, entire, the bases cuneate, the surfaces slightly to copiously appressed hairy.

Inflorescence.--Flowers solitary or in small fascicles in the axils of upper leaves of branchlets, on appressed-hairy stalks $1.5-2.5 \mathrm{~mm}$ long.

Flowers.--Calyr ca. $2 \mathrm{~mm}$ long, sepals 5 fused to form a pyriform outline, the inner 3 lobes broadly obovate, the backs appressed-hairy, much longer than the short-linear outer 2. Petals short, reddish, lost just after anthesis. Stamens $5-15$.

Fruit.--Capsule ellipsoidal or ovoid, dull, about $2 \mathrm{~mm}$ long, slightly surpassed by or equalling the inner sepal tips, the valves blunt, firm. Seeds 1 or 2 , equilateral to irregular. slightly more than $1 \mathrm{~mm}$ long, dark brown, the dorsal surface convex.

Distribution and Flowering season

Sandy rises, sandhills and sandhills scrub, mostly in the sand-pine type, southern peninsular Florida. Flowering July, August.

Special Identifying Features

This species is part of the complex in which the outer sepals are shorter than the inner sepals, and in which the ripe capsule is exceeded by or slightly exceeds the calyx. Within that complex it is the only species in which both stem leaf surfaces are hairy and in which the basal leaves are very densely so on both surfaces.

Habitats and Management Implication

L. cernua is always found in deep sands, usualiy ancient dunes, on which the most conmon forest is a mixture of evergreen scrub oaks such as 2. maritima, 2. myrtifolia, 8. chapmanii, hickories such as Carya floridana, other scrub species such as Ceratiola, Osmanthus, Lyonia, palmetto. The dominant pine is $\underline{\mathrm{p}}$. clausa, 
with $P_{\text {. elliottii and }}$. palustris occasional. The lechea may be found under mature scattered pine or oak, but is more frequently in sandy openings along with species of Andropogon, Aristida, dryland species of Rhynchospora such as $\mathrm{R}_{0}$ megalocarpa, Cyperus. Fire has probably helped to maintain the clearings it naturally frequents. Drastic soil disturbance such as logging probably increases it. Site preparations involving exposures of the sandy substrate, so long as there are contiguous areas to provide a seed source, increase this species.

References

Hodgdon, A. R. 1938. A taxonomic study of Lechea. Contribs. Gray Hexb. CXXI: 29-131, plates $488-491$.

Small, J. K. 1933. Manual of the southeastern flora, pp. 881-884. Chapel Hill, N.C.

Wilbur, R. I, and H, S. Daoud. 1961. The genus Lechea (Cistaceae) in the southeastern United States. Rhodora 63 (748): 103-118. 
SPECIES: \#20 Iechea cermua Small, Pinweed

\begin{tabular}{|c|c|c|c|c|c|c|c|c|}
\hline & \multicolumn{8}{|c|}{ Management Practices } \\
\hline $\begin{array}{l}\text { Expected* } \\
\text { Effect on } \\
\text { the Species }\end{array}$ & $\begin{array}{c}\text { Prescribe } \\
\text { Burn }\end{array}$ & $\begin{array}{l}\text { Bulldoze } \\
\text { or } \\
\text { Root Rake } \\
\end{array}$ & Bed & Chop & $\begin{array}{l}\text { Thin } \\
\text { over- } \\
\text { story }\end{array}$ & $\begin{array}{l}\text { Cut } \\
\text { Over- } \\
\text { story } \\
\end{array}$ & $\begin{array}{l}\text { Establish } \\
\text { Plantation }\end{array}$ & Graze \\
\hline Destroy & & $x$ & & $\mathrm{X}$ & & & $\mathrm{X}$ & \\
\hline \multicolumn{9}{|l|}{ Damage } \\
\hline $\begin{array}{l}\text { No Lasting } \\
\text { Effect }\end{array}$ & NA & & NA & & & & & \\
\hline $\begin{array}{l}\text { Beneficlal } \\
\text { if Done } \\
\text { Properly }\end{array}$ & & & & & $x$ & $x$ & & \\
\hline
\end{tabular}

Other Comments:

*Expected effect on the species is an estimate made by Dr. Robert Kral based on his knowledge of the habitat and on knowledge gained from personal field observations. Estimates are "rough" in many instances. Results of practices may be modified depending upon the degree of application, intensity of treatment, nearness to plant communities, etc. A management practice for which no entry is made indicates a lack of sufficient information from which to predict expected results. As observations are made in the field by users of the data, the expected effect will be refined. 


\section{Lechea cernua small}

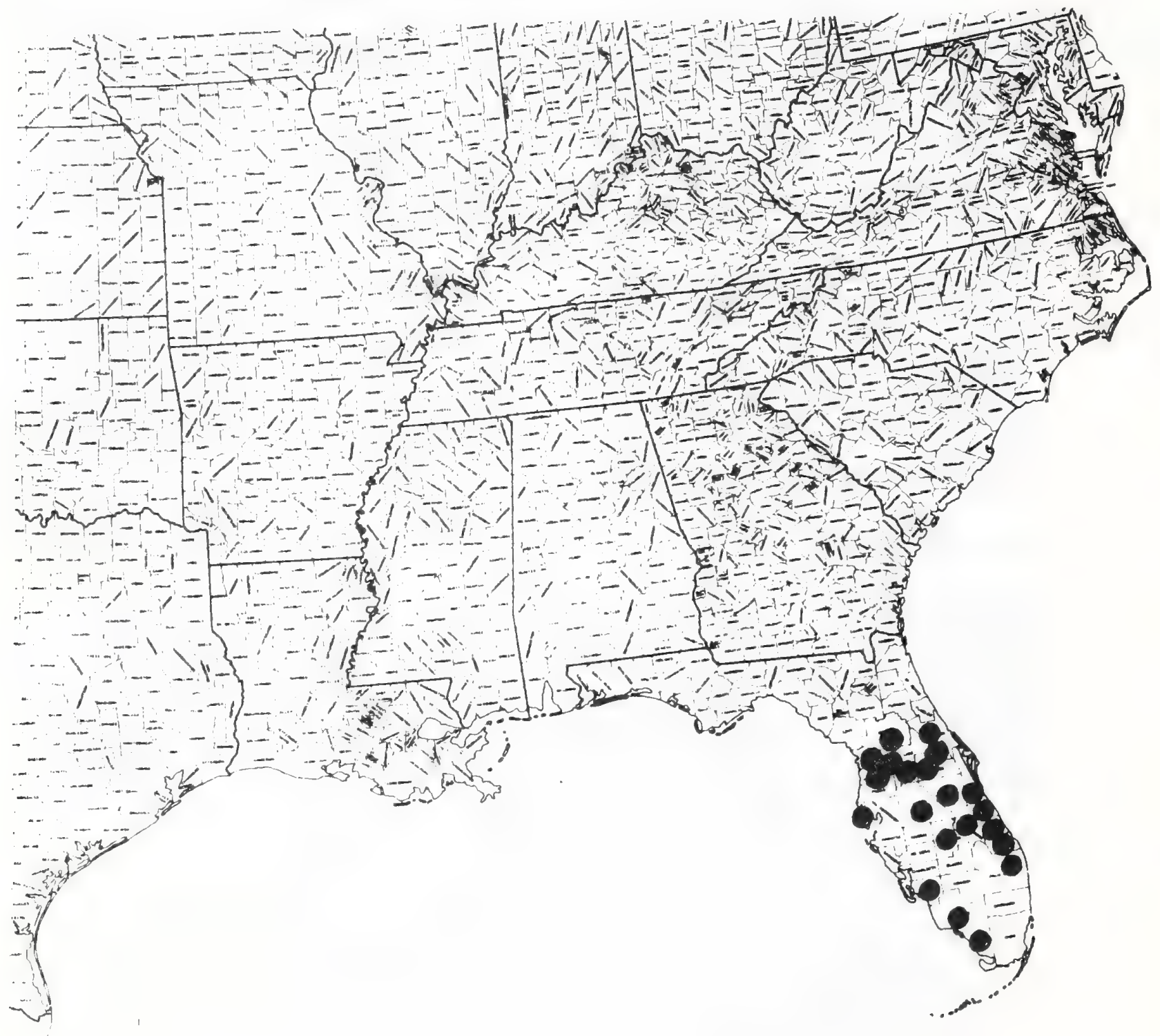


Paper 21

Text \& map by:

Robert Kral

\section{CISTACEAE}

Iechea divaricata shuttlw.Pine pinweed; pinweed

\section{Technical Description}

Somewhat shrubby perennial herb to $5 \mathrm{dm}$. Stems.--All shoots developing flowers (no resting shoots produced), with several spreading from a taproot with a branched lower stem, the young shoots numerous, very hairy at first, as they develop arching outward, then upward, or sprawling, branchlets numerous, spreading, all shoots and branches spreading-hairy. Leaves.--Spirally arranged, the basal ones scattered, the ones on the secondary shoots and branchlets rather close-set, spreading, lanceolate to elliptic or oblong, 3-8 mm long, sharply acute, entire, firm, nearly sessile, the lower surfaces pilose with long white hairs, the upper surface smooth. Inflorescence.--Flowers produced along all or most the length of the mostly short ultimate branches, rather numerous, the whole inflorescence of a branch rather naxrow, often cylindric, on the lower branches usually from axils of bract leaves, on the upper branches as bractless, compact racemes. Flower stalks 1.0-1.5 mm long, strongly appressed-hairy.

Flowers.--Calyx lobes 5, the calyx ca. $2 \mathrm{~mm}$ long, the fused portion campanulate, the lobes slightly spreading or erect, the inner three broadly ovate, rather cup-shaped, hairy-backed, the outer 2 much shorter, linear. Petals reduced, Stamens numerous, 15-25.

Fruit.--Capsule elliptic-ovoid, about $2 \mathrm{~mm}$ long, its tip projecting conspicuously beyond the sepal tips, lustrous. Seeds 1-4 but only 1 usually maturing, about $1 \mathrm{~mm}$ long asymetrically oblong, round angled and with large irregular concavities.

Distribution and Flowering Season

Mostly in sand pine sandscrub, central and southern peninsular Florida, Julyoctober.

\section{Special Identifying Features}

This species is like the widespread L. Villosa in the spreading hairs of its stems and lower parts of branches, but differs in its slender, more spreading, habit, in its more exserted capsule which does not split at maturity. Also its leaves are smaller, shorter.

It is one of 2 species whose exterior sepals are shorter than the interior ones, and whose capsules are much longer than the calyx. Here it differs from $\mathrm{L}$. deckertii in its spreading (versus more appressed) stem pubescence, its thicker walled capsules, its broader leaf outlines.

Habitat and Management Implication

The habitat of L. divaricata is similar to that of I. cernua and the management implications are the same. 
I. divaricata is always found in deep sands, usually ancient dunes or ecotonal to moister duneswales, on which the most common forest is a mixture of evergreen scrub oaks such as 2. maritima, 2. myrtifolia, 2. Chapmanii, hickories such as Carya floridana, other scrub species such as Ceratiola, Osmanthus, Lyonia, palmetto. The lechea may be found under mature scattered pine or oak, but is more frequently in sandy openings along with species of Andropogon, Aristida, dryland species of

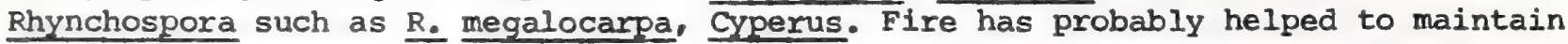
the clearings it naturally frequents. Drastic soil disturbance such as logging probably increases it. Site preparations involving exposures of the sandy substrate, so long as there are contiguous areas to provide a seed source, increase this species.

\section{References}

Hodgdion, A. R. 1938. A taxonomic study of Iechea. Contribs. Gray Herb. CXXI: 29-131, plates 488-491

Small, J. K. 1933. Manual of the southeastern flora, pp. 881-884, Chapel Hill, N.C.

Wilbur, R. I. and H.S. Daoud. 1961. The genus Lechea (Cistaceae) in the southeastern United States. Rhodora 63 (748): 1 103-118. 
SPECIES: \#21 Iechea divaricata Shuttiw. pinweed

\begin{tabular}{|c|c|c|c|c|c|c|c|c|}
\hline & \multicolumn{8}{|c|}{ Management Practices } \\
\hline $\begin{array}{l}\text { Expected* } \\
\text { Effect on } \\
\text { the Species }\end{array}$ & $\begin{array}{c}\text { Prescribe } \\
\text { Burn }\end{array}$ & $\begin{array}{l}\text { Bulldoze } \\
\text { or } \\
\text { Root Rake } \\
\end{array}$ & Bed & Chop & $\begin{array}{l}\text { Thin } \\
\text { over- } \\
\text { story }\end{array}$ & $\begin{array}{l}\text { Cut } \\
\text { Over- } \\
\text { story }\end{array}$ & $\begin{array}{l}\text { Establish } \\
\text { Plantation }\end{array}$ & Graze \\
\hline Destroy & & $\mathrm{x}$ & & $\mathrm{x}$ & & & $\mathrm{x}$ & \\
\hline \multicolumn{9}{|l|}{ Damage } \\
\hline $\begin{array}{l}\text { No Lasting } \\
\text { Effect }\end{array}$ & NA & & NA & & & & & \\
\hline $\begin{array}{l}\text { Beneficlal } \\
\text { if Done } \\
\text { Properly }\end{array}$ & & & & & $\mathrm{x}$ & $\mathrm{x}$ & & \\
\hline
\end{tabular}

\section{Other Comments:}

*Expected effect on the species is an estimate made by Dr. Robert Kral based on his knowledge of the habitat and on knowledge gained from personal field observations. Estimates are "rough" in many instances. Results of practices may be modified depending upon the degree of application, intensity of treatment, nearmess to plant comunities, etc. A management practice for which no entry is made indicates a lack of sufficient information from which t predict expected results. As observations are made in the field by user: of the data, the expected effect will be refined. 
Lechea divaricata Shuttlw.

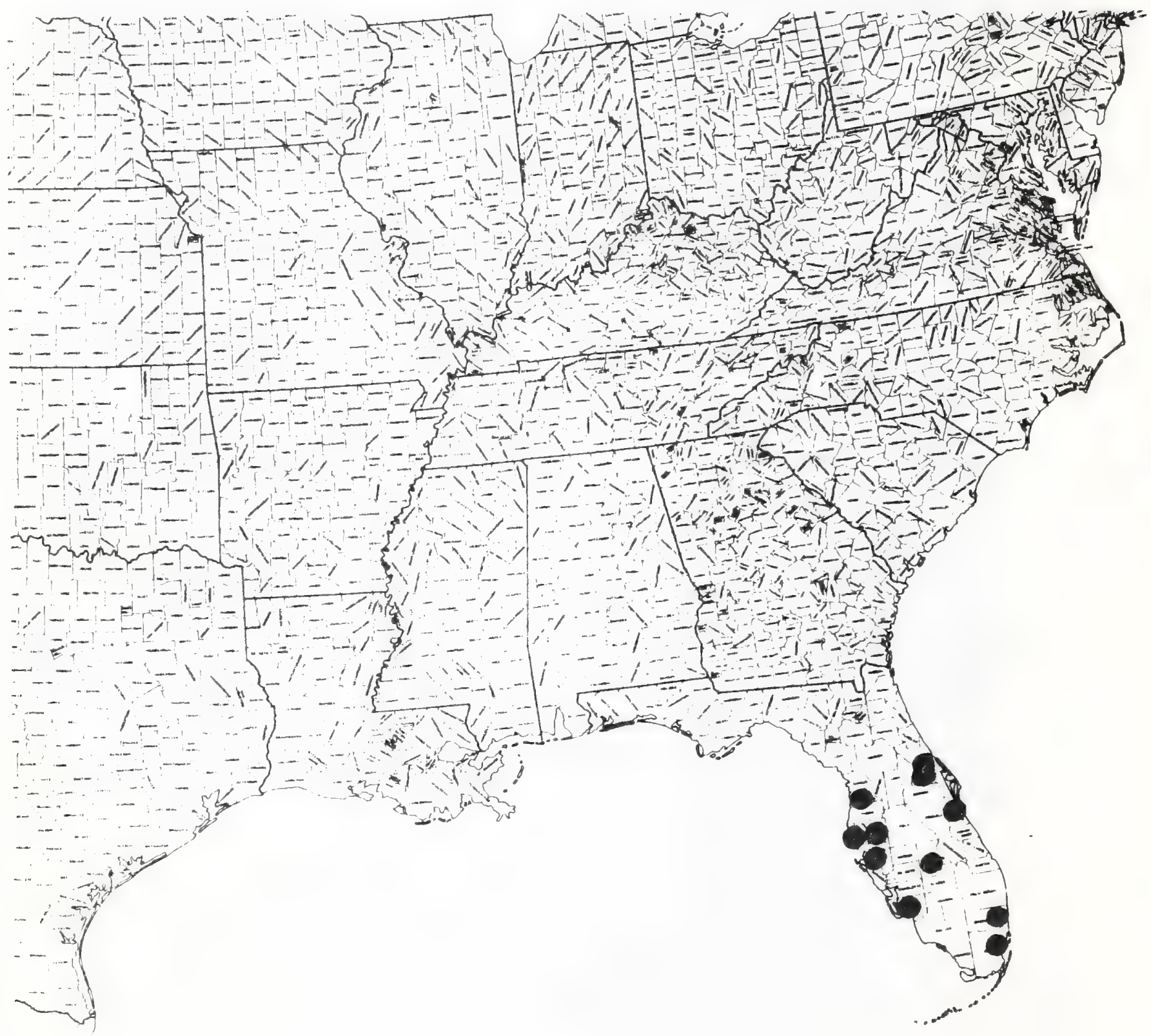


Paper 22

Text \& map by:

Robert Kral

\section{CONVOLVUTACEAE}

Bonamia grandiflora (A. Gray) Heller; large-flowered

bonamia; N.C.N.

Breweria grandiflora A. Gray

Technical Description

A sprawling perennial herb.

Stems.--Several weak stems to 3 meters long extending outward flat over the sand from a central semiwoody deep rootstock, round in cross-section, shcrt and appressed-hairy with fine, silky hairs.

Leaves.--Numerous, the blades erect or spreading firm, ovate, broadly oblong or obovate, the largest $4-5 \mathrm{~cm}$ long, rounded or emarginate, usually shortmucronate, the margins entire, the base usually broadly rounded or cordate, the surfaces appressed-silky-short-hairy, the petioles short, about $3 \mathrm{~mm}$ long, densely short-hairy. Smallest stem leaves toward stem base, the largest at about mid-stem, these grading gradually into bracteal leaves which are along the distal $1 / 2-1 / 3$ of the shoot.

Inflorescence.--Flowers solitary in the bract axils, erect on stiffish, appressed-hairy stalks mostly $1.0-2.5 \mathrm{~cm}$ long, these midway with a pair of erect, lanceolate, pukerulent bracts around $5 \mathrm{~mm}$ long. Flowers.--Sepals 5, unequal, in 2 series, oblong, narrowly ovate or lanceolate, stiffish, erect, the apex acuminate, the margins entire, the backs pale green and covered with appressed silky hairs, the whole calyx up to $2.0-2.5 \mathrm{~cm}$ long. Corolla opening in early morning, closing by early afternoon, funnelform, 7-10 cm long, fully $7-8 \mathrm{~cm}$ across the limb, a pale but vivid blue with a paler centre. stamens 5, alternating with petal midribs, up to $5 \mathrm{~cm}$ long, the slender filaments with bases glandular-hairy, the anthers narrowly oblong, yellowish, about $5 \mathrm{~mm}$ long. Ovary superior, the style about $4 \mathrm{~cm}$ long, branched into 2 slender branches about midway up, each branch terminating in a small, buttonlike stigma. Fruit.--Capsule broadly ovoid, $1.3-1.5 \mathrm{~cm}$ long, with 4 valves, the walls firm but thin. Seeds smoothish, pale brown or greenish brown, 5-8 ma long, oblong, the outer face convex, the inner 2 flat, forming an angle.

Distribution and Flowering season

Sandy clearings in sandscrub, peninsular Florida. Flowering May to August.

Special Identifying Features

This species is unlike any other southeastern convolvulaceous plant. A sprawler, not a vine, it has flowers fully as large and spectacular and with the same color as the Heavenly Blue Morningglory.

Habitats and Management Implications

B. grandiflora is strictly a sandhills plant, being locally abundant on deep white sands of ancient dunes and sandridges in clearings amongst scrub oaks 
(mainly Q. myrtifolia, Q. chapmanii, Q. maritima), Ceratiola, Lyonia, Ilex ambigua, Garberia, palmetto, etc. The overstory, when present, is usually sand Pine.

Because this a plant of full sun and of dry sandy sites its history is probably one of fire increasing its area through reducing woody competition. Clearcutting of the pine would increase its area, as would mechanical removal of areas of scrub. However, a complete overturning of the sandy substrate such as would be involved in most site preparation on such soils, would temporarily eliminate this species. These artificial clearings would ultimately be occupied by such species as this, providing there were contiguous seed sources but a dense plantation or a natural stand of pine would create too much shade for its maintenance.

Reference

Small, J. K. 1933. Manual of the southeastern flra, pp. 1080. 
SPECIES: \#22 Bonamia grandiflora (A. Gray) Heller. IJ.C.N.

\begin{tabular}{|c|c|c|c|c|c|c|c|c|}
\hline & \multicolumn{8}{|c|}{ Management Practices } \\
\hline $\begin{array}{l}\text { Expected* } \\
\text { Effect on } \\
\text { the Species }\end{array}$ & $\begin{array}{c}\text { Prescribe } \\
\text { Burn }\end{array}$ & $\begin{array}{l}\text { Bulldoze } \\
\text { or } \\
\text { Root Rake }\end{array}$ & Bed & Chop & $\begin{array}{l}\text { Thin } \\
\text { over- } \\
\text { story }\end{array}$ & $\begin{array}{l}\text { Cut } \\
\text { Over- } \\
\text { story }\end{array}$ & $\begin{array}{l}\text { Establish } \\
\text { Plantation }\end{array}$ & Graze \\
\hline Destroy & & $x$ & & $x$ & & & $\mathrm{X}$ & \\
\hline Damage & & & NA & & & & & \\
\hline $\begin{array}{l}\text { No Lasting } \\
\text { Effect }\end{array}$ & & & & & & & & \\
\hline $\begin{array}{l}\text { Beneficlal } \\
\text { if Done } \\
\text { Properly }\end{array}$ & $\mathrm{X}$ & & & & $\mathrm{X}$ & $\mathrm{X}$ & & \\
\hline
\end{tabular}

Other Comments:

*Expected effect on the species is an estimate made by Dr. Robert Kral based on his knowledge of the habitat and on knowledge gained from personal field observations. Estimates are "rough" in many instances. Results of practices may be modified depending upon the degree of application, intensity of treatment, nearmess to plant commuties, etc. A management practice for which no entry is made indicates a lack of sufficient information from which to predict expected results. As observations are made in the field by users of the data, the expected effect will be refined. 
Bonamia grandiflora (Gray) Heller

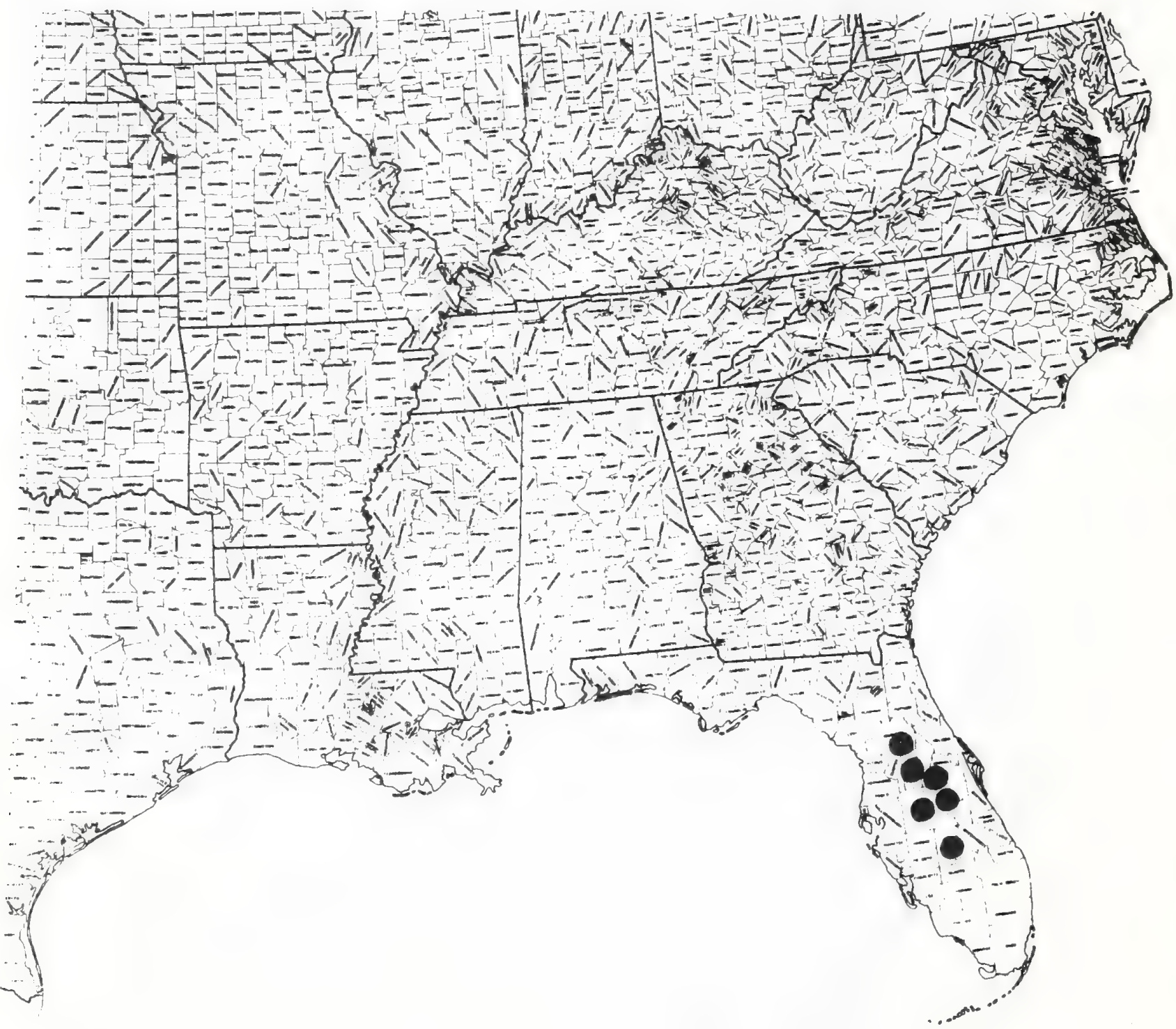


Paper 23

Text \& map by:

Robert kral.

\section{CYPERACEAE}

Carex amplisquama F. J. Hermann: Fort Mountain sedge: Sedge

Technical Description

The plants in small to large tufts, the bases leafy, covered by the fibrous remnants of old leaf bases, increasing by elongate slender stoloniferous rhizomes, these covered by shreddy-fibrous narrow, rhizome-scales.

Leaves.--Narrowly linear, 2-3 dm long, I-2 mm broad, pale yellow-green tapering-tipped, the margins scabrous; sheathes whitish, the apex thin but firm. Inflorescence.--Scapes slender, not much longer than the longer leaves, about 0.5 mm thick, longitudinally several-ridged, erect or arching outward. Lateral spikes strictly female, (1-) 2-3, ovoid, few-flowered, rather distant at the scape tips, the lowest with an essentially sheatheless, lance-linear, subulate bract up to $1.5 \mathrm{~cm}$ long, or this bract reduced, the uppermost with lowest bract shorter than the spike. Fertile female scales ovate, boat-shaped, hiding perigynes, about $3 \mathrm{~mm}$ long, smooth acute or retuse, the margins thin, pale or greenish, the backs with a broad maroon median zone and a greenish, raised midrib, this projecting as a mucro beyond the scale tip. Perigynes about $3 \mathrm{~mm}$ long, the body broady obovoid, short-stipitate, hairy, pale green, closely filled by the akene, abruptly narrowing to an oblique-tipped, mainly toothless, narrow beak about $1 \mathrm{~mm}$ long. Male spike short-stalked or nearly sessile, linear, $1.0-1.5 \mathrm{~cm}$ lorg, the scales narrowly ovate or oblong, acute, smooth, each with thin pale margins and a broad maroon median band, this with a whitish or pale tan raised midrib which may or may not project as a mucro.

Distribution and Flowering Season

Thus far known only from dryish sandy or rocky clearings toward or at summit of Fort Mountain, in Gilmer and Murray counties, Georgia. Flowering in late April and early May.

Special Identifying Features

This species is a part of the "Montanae" complex and is chiefly to be distinguished by its combination of a stoloniferous-rhizomatous habit with its broadish, greenish-midribbed female bracts. It is nearest $C$. pensylvanica in appearance and there is some question as to whether it is different from some other species in the complex.

Habitat and Management Implication

The summit of Fort Mountain occupied by this sedge has dryish, acidic sandy and rocky soil and is forested chiefly by mixed oak-pine (virginia pine, white pines with an a mixture of sweet birch, tulip poplax, red maple, hard maple. The shrub layer is mostly ericaceous, with several species of Rhododendron, Sourwood, Vaccinium, Gaylussacia. The Carex is found in the thin shade of open forest, in moist sandygravelly clearings therein, or on gravelly slopes beside the highway itself. Thus, within its small area, it is found either in shade or in full sunlight. Most 
robust growth appears where the overstory has been thinned by previous logging. One large part of what appears to have been former area for it has had all forest removed, has had some plowing, and has gone over largely to grass (Danthonia, Aristida, Andropogon, Panicum). It is not to be found in this large cleared place. The range of this species is so restricted and collections so few (outside the type and my own) that no substantial information on the species is as yet available. Reference

Hermann, F. J. 1955. Rhodora 57: 157. (This is a description of the type!) 
SPECIES: \#23 Carex ampliscuama F. J. Hermann Sedge

\begin{tabular}{|c|c|c|c|c|c|c|c|c|}
\hline \multicolumn{9}{|c|}{ Management Practices } \\
\hline $\begin{array}{l}\text { Expected* } \\
\text { Effect on } \\
\text { the Species }\end{array}$ & $\begin{array}{c}\text { Prescribe } \\
\text { Burn }\end{array}$ & $\begin{array}{l}\text { Bulldoze } \\
\text { or } \\
\text { Root Rake } \\
\end{array}$ & Bed & Chop & $\begin{array}{l}\text { Thin } \\
\text { over- } \\
\text { story }\end{array}$ & $\begin{array}{l}\text { Cut } \\
\text { Over- } \\
\text { story }\end{array}$ & $\begin{array}{l}\text { Establish } \\
\text { Plantation }\end{array}$ & Graze \\
\hline Destroy & & $\mathrm{x}$ & $\mathrm{X}$ & $x$ & & & $x$ & \\
\hline Damage & $\mathrm{X}$ & & & & & $\mathrm{x}$ & & $\mathrm{X}$ \\
\hline $\begin{array}{l}\text { No Lasting } \\
\text { Effect }\end{array}$ & & & & & & & & \\
\hline $\begin{array}{l}\text { Beneficial } \\
\text { if Done } \\
\text { Properly }\end{array}$ & & & & & $\because$ & & & \\
\hline
\end{tabular}

Other Comments:

*Expected effect on the species is an estimate made by Dr. Robert Kral based on his knowledge of the habitat and on knowledge gained from personal field observations. Estimates are "rough" in many instances. Results of practices may be modified depending upon the degree of application, intensity of treatment, nearness to plant communties, etc. A management practice for which no entry is made indicates a lack of sufficlent information from which to predict expected results. As observations are made in the field by users of the data, the expected effect will be refined. 
Carex amplisquama F. J. Hermann

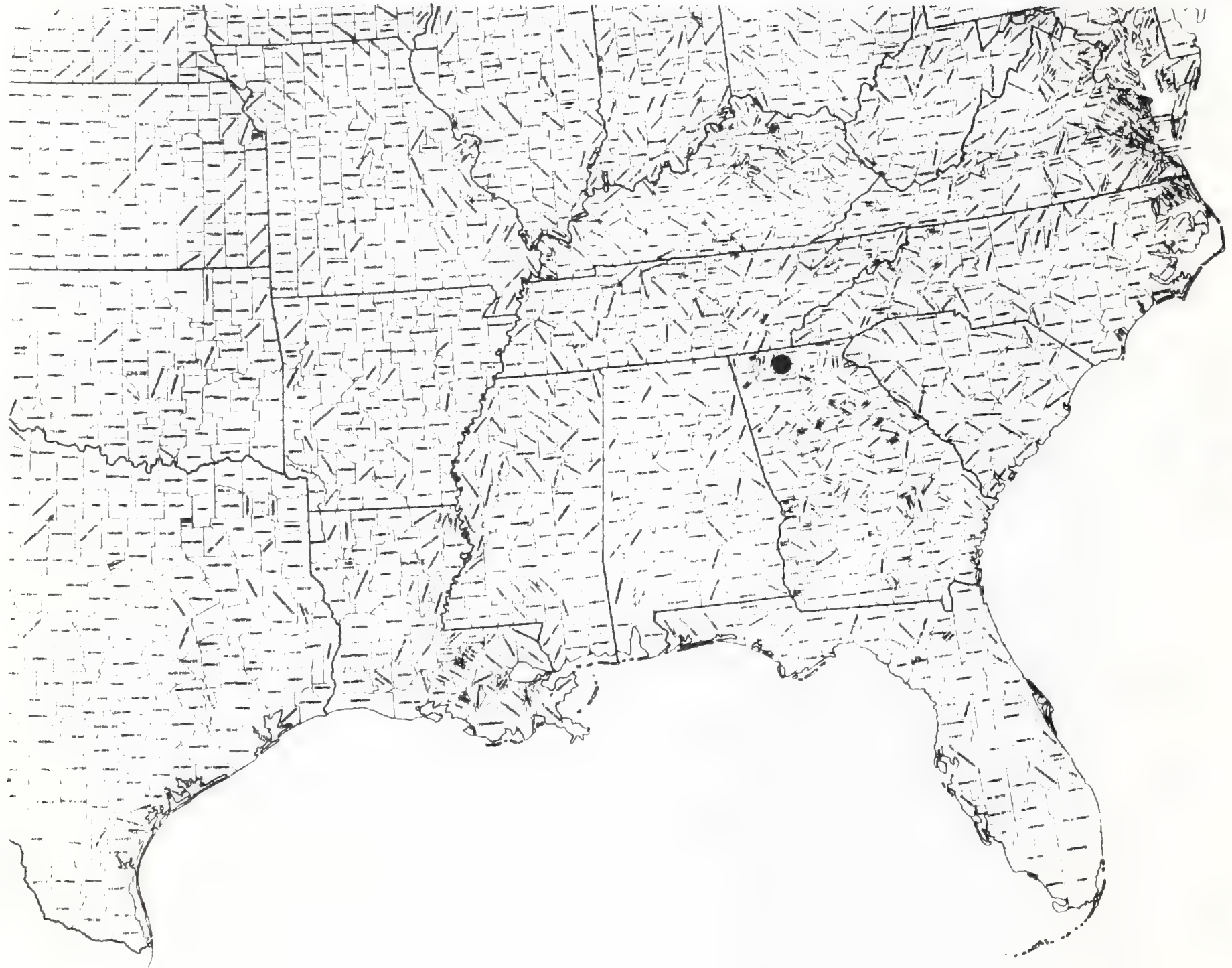


Paper 24

Text \& map by:

Robert Kral

\section{CYFERACEAE}

Carex baltzellii Chapm. ex Dewey: Baltzell's sedge: Sedge

\section{Technical Description}

Perennial, forming tufts from spreading-ascending, scaly, fibrous rhizomes. Leaves and Shoots.--Numerous per tuft, Iinear, the longest to $6 \mathrm{dm}$ long, 0.5-1.0 cm broad, pale green, somewhat spreading, scabrous along the raised veins, firm, spreading, and overwintering, gradually tapering at the apex, the bases pale or straw colored. Fertile shoots up to $30 \mathrm{~cm}$ tall, thus exceeded by foliage leaves and forming in late winter or early spring, shorter-leaved with the lower and outer-most scale-like and pale or pale brown. Inflorescence.--Spikes 3-5, on erect or ascending, long stalks, the lower ones often obscured in bracteal and foliage leaves, linear-cylincrical, 3-5 cm long, the terminal spike longestastalked and exclusively of male florets, the bracts of which closely overlap, are obovate, with broadly rounded or almost truncate apices and are a rich reddish brown save for a strong, pale midnerve, this prom jecting as a strong mucro. Lateral spikes entirely female or female below, male at the tips.

Flcrets.--The bracts of the female florets also strongly overlap' hide all but the tips of the florets, and have the same shape and color as the male. The fruiting female perigynia (covering of the fruit) narrowly obovoid, about $4 \mathrm{~mm}$ long, tight, narrowing gradually to the base, apically to an erect, oblique and toothless beak; the body is obscurely trigonous, finely hairy, with many fine but strongly raised ribs.

Fruit.--Ripe akene dark brown, trigonous, with a short stalk.

Distribution and Flowering Season

This rare species is found in mesic sandy loamy ravines in the lower coastal plain in northwestern Florida, scutheastern Alabama and southwestern ceorgia. It begins bloom in February, fruits in April.

Special Identifying F'eatures

Taronomically this is closest to a nore northerly sedge, $C$ - pedunculata, which has narrower but shorter leaves, shorter spikes with fewer florets, and rurplish or brownish culm bases. Superficlally, and in range it is closest to C. picta Steud. in general appearance of the plant, in leaf, and in shape and color of spikes. Hovever, this latter species is one of the few Carex which produces unisexual plants; its bases are usually reddish-tinted, its spike bracts, while strongly red-brown tinted lack the strong mucro produced by c. baltzellii.

Habilats and Management Implication

C. baltzellii is always found on moist, well-drained, humified fine sands in steep ravines whose slopes are forested with Magnolia grandiflora, Fagus, Acer sacchaxum (southern vars.), Nyssa sylvatica, Cornus florida, Liriodendron, 
together with occasional pinus glabra, P. taeda. The acid sands it favors are also populated with such spring flowering forbs as Hexastylis, various

Trillium species, Uvularia, Vicla etc., together with an abundance of other species of carex. It has not yet been found in areas where logging has removed the dense overstory or where heavy grazing has occurred, which would lead collectors to corclude that it responds negatively to heavy or clear-cutting and grazing. It is nowhere a common plant, being known for years only from its type locality in the Apalachicola bluff country of northwestern Florida.

Reference

Small, J. K. 1933. Manual of the Southeastern Flora. 213. 
SPECIES: \#24 Carex baltzellii Chapm. ex Dewer. Sedge

\begin{tabular}{|c|c|c|c|c|c|c|c|c|}
\hline \multicolumn{9}{|c|}{ Management Practices } \\
\hline $\begin{array}{l}\text { Expected* } \\
\text { Effect on } \\
\text { the Species }\end{array}$ & $\begin{array}{c}\text { Prescribe } \\
\text { Burn }\end{array}$ & $\begin{array}{c}\text { Bulldoze } \\
\text { or } \\
\text { Root Rake }\end{array}$ & Bed & Chop & $\begin{array}{l}\text { Thin } \\
\text { over- } \\
\text { story }\end{array}$ & $\begin{array}{l}\text { Cut } \\
\text { Over- } \\
\text { story } \\
\end{array}$ & $\begin{array}{l}\text { Establish } \\
\text { Plantation }\end{array}$ & Graze \\
\hline Destroy & $x$ & $x$ & $\mathrm{X}$ & $\mathrm{x}$ & & $\mathrm{X}$ & & \\
\hline Damage & & & & & & & $\mathrm{NA}$ & $x$ \\
\hline $\begin{array}{l}\text { No Lasting } \\
\text { Effect }\end{array}$ & NA & & & & $x$ & & & \\
\hline $\begin{array}{l}\text { Beneficial } \\
\text { if Done } \\
\text { Properly }\end{array}$ & & & & & & & & \\
\hline
\end{tabular}

\section{Other Comments:}

*Expected effect on the species is an estimate made by Dr. Robert Kral based on his knowledge of the habitat and on knowledge gained from personal field observations. Estimates are "rough" in many instances. Results of practices may be modified depending upon the degree of application, intensity of treat.ment, nearness to plant communities, etc. A management practice for which no entry is made indicates a lack of suffictent information from which to predict expected results. As observations are made in the field by users of the data, the expected effect will be refined. 
Carex baltzellii Chapm. ex Dew.
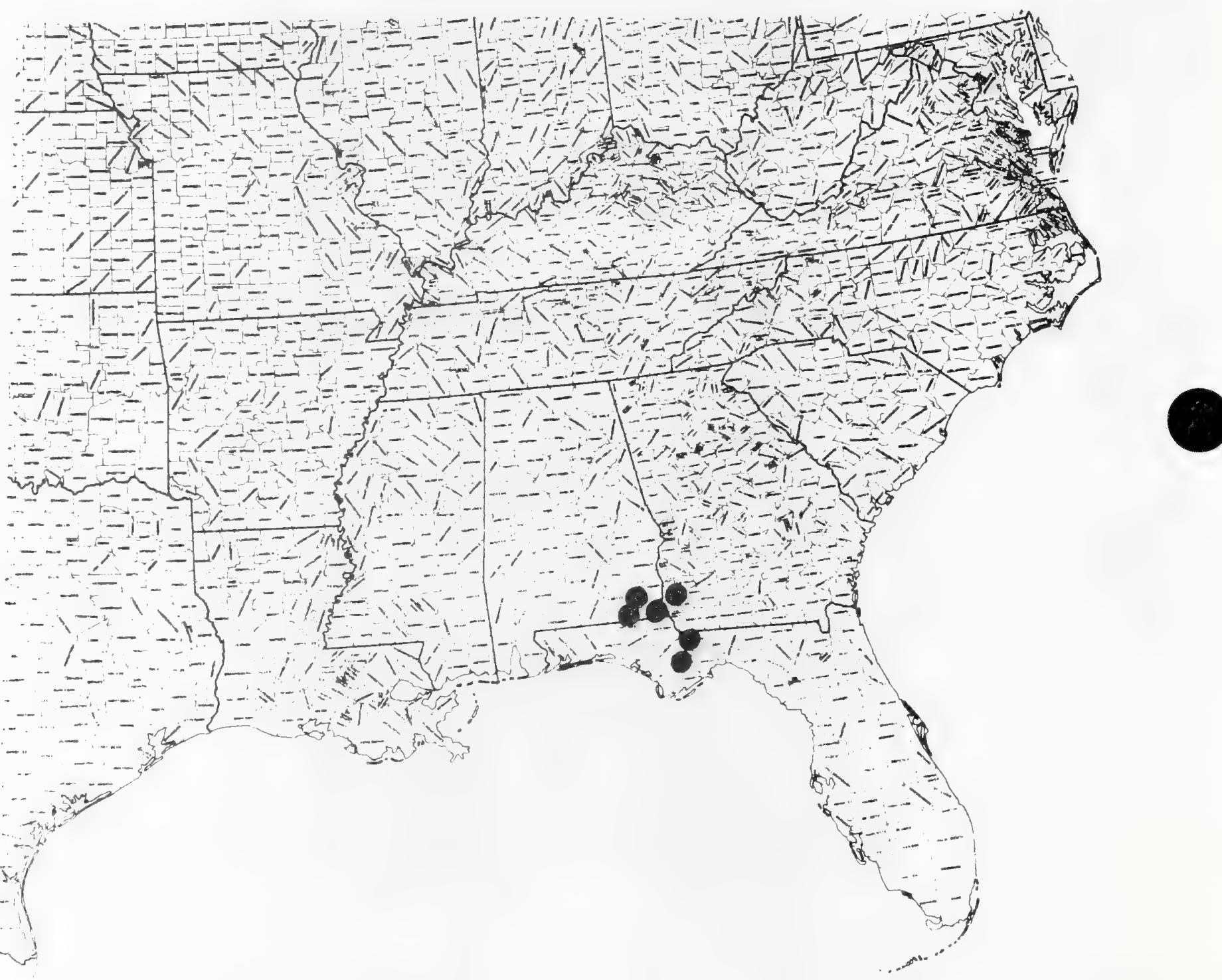
Paper 25

Text \& map by :

Robert kral

\section{CYPERACEAE}

Carex chapmanni Steud.; Chapman's sedge: Sedge

\section{Technical Description}

Perennial smooth sedge forming small to large tufts, these increasing by means of slender, spreading stolons.

culms.--Erect from spreading, upwardiy arching bases, the lower part leafy, slender, rather weak, outwardly arching, somewhat flattened and also strongly ribbed, long-sheathed, I rib scabrid, with most of the culm leaves subtenaing spikes. Leaves.--The lowest leaves scale-like, mostly sheath, pale to dark brown. Larger foliage leaves mostly $2-3 \mathrm{dm}$ long, the sheathes pale, very thin on the inner face, the outer face strongly ribbed, the blades dark green, thin, linear, tapering, lax, mostly 3-4 mm brcad, strongly nerved beneath, the margin downwardiy scabrid.

Inflorescence and Florets.--Lateral spikes exclusively female, the lowermost usually hidden in the clump leaves, all few-flowered, the florets either close together or with the lowermost well separate on the spike axis. Stalks of lowermost female spikes elongate, up to $8-10 \mathrm{~cm}$ long, very slender, weak; stalks of uppermost spikes much shorter, progressively reduced as are the subtending leafy bracts. Fertile female scales elliptic to broadly lanceolate with thin white sides and a broad, green mid-rib zone, this projecting beyond the bract tip as a flattish, green mucro. Perigyria 4-5 mm long, longer than the fertile bracts, fusiform (spindle shaped), the body with several raised nerves (2 strongly raised), yellow-green, smooth, gradually narrowing into a prominent, erect or outcurved, toothless beak. Male spikes $1.5-2.5 \mathrm{~cm}$ long, linear, the male bracts similar in outline and midrib to the female, short-stalked to nearly sessile, the uppermost female spike usually just beneath, its bract not overtopping.

\section{Distribution and Flowering Season}

Sandy hammocks, in the Coastal Plain, from eastern North Carolina southward and westward through northwestern Florida. Flowering in March and April fruiting through May.

Special Identifying Features

This species is in the section Paniceae, in the manuals difficult to distinguish from the closely related Laxiflorae. It is distinguished primarily for its elongate stoloniferous rhizomes projecting from the clum, its brownish culm bases, jts rather long perigrnes with their (usually) outcurved beaks.

Hatitats and Management Implication

It frequents well-drained hamock woodlands or cleared areas of these, and is always on sands or sandy loams. A typical situation wauld be beech-magnoliasouthern hard maple or red maple with some admixture of oak and pine. Usually it is in association with several other Carex, particularly C. laxiflora (vars.), C. dasycarpa, C. crebriflora, C. digitalis, etc. and grasses such as uniola 
and various panicums. Logging disturbance, unless accompanied by extremes of erosion or heavy grazing, usually does not affect abundance.

References

Radford, A. E. et al. 1968. Manual of the vascular flora of the carolina, pp. 234.

Small, J. K. 1933. Manual of the southeastern flora, pp. 214-215. 
SPECIES :

\#25 Carex chapmannii steud. Seckje

\begin{tabular}{|c|c|c|c|c|c|c|c|c|}
\hline & \multicolumn{8}{|c|}{ Management Practices } \\
\hline $\begin{array}{l}\text { Expected* } \\
\text { Effect on } \\
\text { the Species }\end{array}$ & $\begin{array}{c}\text { Prescribe } \\
\text { Burn }\end{array}$ & $\begin{array}{l}\text { Bulldoze } \\
\text { or } \\
\text { Root Rake } \\
\end{array}$ & Bed & Chop & $\begin{array}{l}\text { Thin } \\
\text { over- } \\
\text { story }\end{array}$ & $\begin{array}{l}\text { Cut } \\
\text { Over- } \\
\text { story }\end{array}$ & $\begin{array}{l}\text { Establish } \\
\text { Plantation }\end{array}$ & Graze \\
\hline Destroy & & $\mathrm{X}$ & & $x$ & & Z & & \\
\hline Damage & & & $x$ & & & & & $x$ \\
\hline $\begin{array}{l}\text { No Lasting } \\
\text { Effect }\end{array}$ & NNA & & & & & & & \\
\hline $\begin{array}{l}\text { Beneficial } \\
\text { if Done } \\
\text { Properly }\end{array}$ & & & & & $x$ & & & \\
\hline
\end{tabular}

\section{Other Comments:}

*Expected effect on the species is an estimate made by Dr. Robert Kral based on his knowledge of the habitat and on knowledge gained from personal field observations. Estimates are "rough" in many instances. Results of practices may be modified depending upon the degree of application, intensity of treatment, nearness to plant communities, etc. A management practice for which no entry is made indicates a lack of sufficient information from which to predict expected results. As observations are made in the field by users of the data, the expected effect will be refined. 
Carex chapmanii Steude1

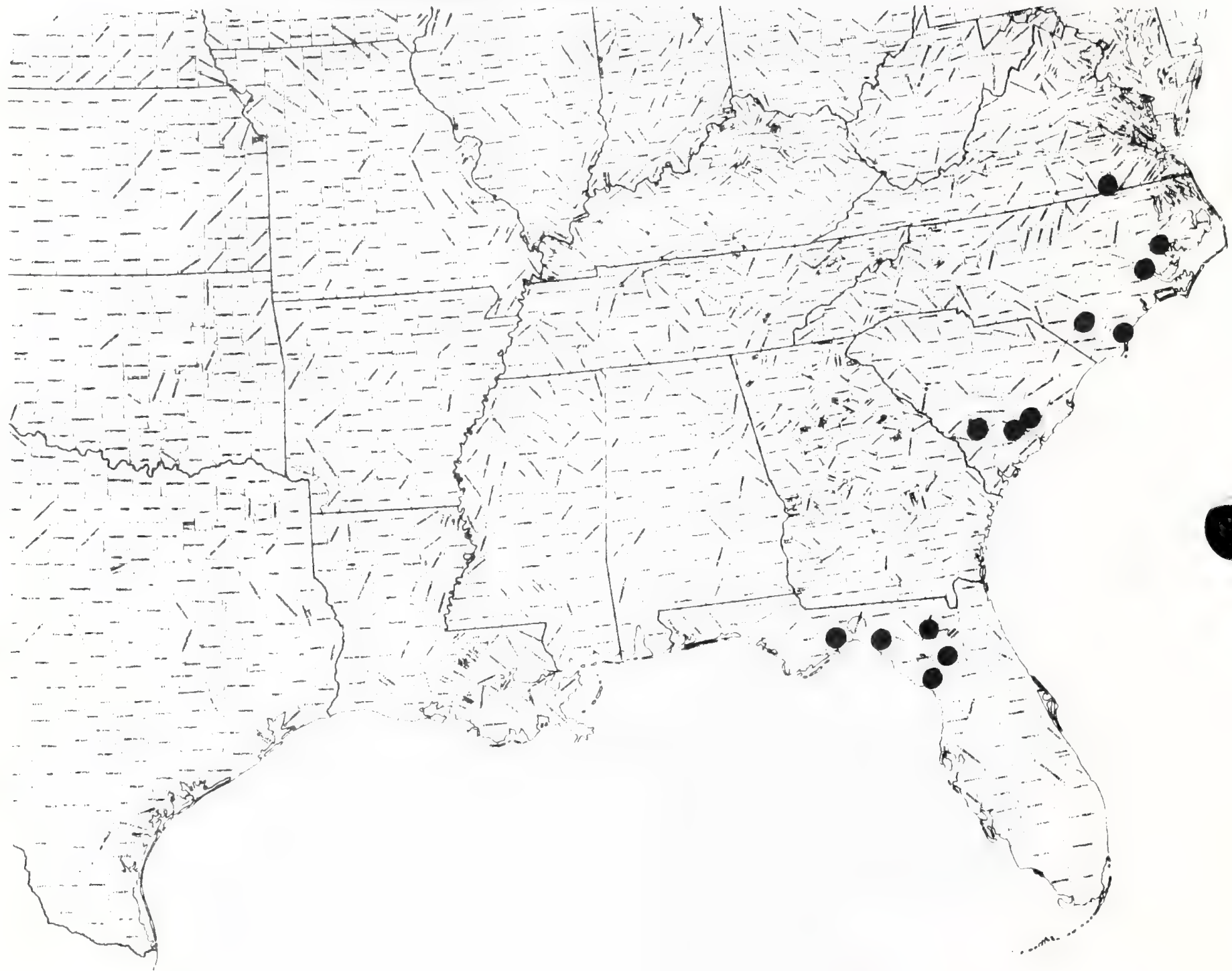


Paper 26

Text \& map by:

Robert Kral.

\section{CYPERACEAE}

Carex purpurifera Mackenzic; purple sedge; Sedge C. laxifora Lam. var. purpurifera (Mackenzie) Gleason

Techrical Description

Perennial, in small tufts, the stem and sheath bases a deep purplish brown. Culms and Leaves. - Two sorts of offshoots produced from a clump: one consists of leaves only, the lowest (outermost) mostly much shorter, mostly sheath, mostly purplish, the uppermost longest, mostly $30-50 \mathrm{~cm}$ long, to $1 \mathrm{~cm}$ brcad, linear, tapering slenderly toward the apex, bright green, smooth save for the finely scabrous margins, longitudinally with 304 prominent veins and several less distinct ones. These leafy shoots overwinter. Fertile shoots produced in early spring, elongating to produce slender erect to spreading culms to $7 \mathrm{~cm}$ tall, these with basal, purplish, sheathing lower leaves, the leaves up the culm while longer never reaching half the length of leaves of sterile shoots, their sheathing bases often with purplish tints. Inflorescence.--Mid to upper nodes of fertile shoots each producing a slenderstalked spike, the terminal one exclusively male-flowered, and densely cylindrical, 2.0-2.5 cm long, with the numerous, spirally imbricated (overlapping) scales ovate, acute to obtuse, strongly tinted with purplish brown with a paler midrib, smcoth, entire, the spike stalk (peduncle) projecting the male spike beyond the tip of the subtending bracteal leaf. Female spikes usually several, shorter or longer than their subtending stalks but usually exceeded in length by the subtending bracteal leaf, the spike outline linear-cylindric. Flcrets.-- The florets with some overlap or somewhat loosely arranged along the axis. Ripe florets (with mature fruit) $3.5-4.5 \mathrm{~mm}$ long, asymetrically broacly fusiform, the perigynial beak bowed outward, with 3 rounded angles and several low, raised longitudinal ribs, pale green, smooth. (The perigynium is the thin, usually greenish modified bract which covers all of the female flower except for the style tip which itself protrudes from a terminal hole in the perigynial beak or perigyne apex. Bracts of floret oval, slightly shorter or slightly longer than the florets, thin save for a thicker greenish midrib, the sides either pale or straw-colored or brownish-tinted, the apex acute, short-acuminate, or mucronate.

Distribution and Flowering season

Carex purpurifera is found in rocky woodlands in the appalachian provinces from Kentucky and western North Carolina southward into northern Alabama. It begins to flower in March and frujting material may be collected into early May.

Special Identifying Features

This species is a part of the sect. "Iaxiflorae", one of the most difficult complexes in a difficult genus. Most are woodland species, several rather broadleaved. Leaves of fertile shoots have both sheathes and leaf blades well developed, 
with the solitary terminal spike strictly staminate. The fruiting perigynia are mostly ellipsoidal or fusiform, the short beaks with low teeth or none, the surfaces with raised longitudinal nerves. Many, like this species, produce sterile leafy offshoots which frequently overwinter. Within the complex there are several that have purplish bases (C. plantaginea, C. careyana, C. gracilescens). Of these, C. gracilescens steud. (C. laxiflora Lam. var. gracillima (Boot.) Robins. \& Fern. Is nearest taxonomically differing only in its shorter perigynia, its more slender somewhat lower habit, its somewhat narrower leaves.

Habitats and Management Implication

C. purpurifera is usually found in the ecotone between rich mixed mesophytic cove woods and the largely oak - hickory of upper ravine slopes. It is often along the transition zone between calcareous underlying rock and argilliceous or sandy parent material. Very often it is amongst outcrops, in talus, or in very rocky soils in pockets of loam, always on well drained substrata and in open woods. It, together with other woodland sedges and forbs tends to be reduced or lost in clear-cut areas, probably because of a complex of factors involving too much light and heat, attendant soil exosion, and invasion of weedy forbs, vines, etc. with which it cannot compete. It is lost in grazed woodlots. Management involving the least impact on the soil and the light factor would favor it most, this management involving either selection or group selection.

References

K. K. Mackenzie, 1935. Carex in North American Flora 18 (5):241-312 (Continuation)

J. K. Small. 1933. Manual of the Southeastern Flora, Pp. 216-218. 
SPECIES: \#26 Carex purpurifera Mackenzie Sedoe

\begin{tabular}{|c|c|c|c|c|c|c|c|c|}
\hline & \multicolumn{8}{|c|}{ Management Practices } \\
\hline $\begin{array}{l}\text { Expected* } \\
\text { Effect on } \\
\text { the Species }\end{array}$ & $\begin{array}{c}\text { Prescribe } \\
\text { Burn }\end{array}$ & $\begin{array}{l}\text { Bulldoze } \\
\text { or } \\
\text { Root Rake } \\
\end{array}$ & Bed & Chop & $\begin{array}{l}\text { Thin } \\
\text { over- } \\
\text { story }\end{array}$ & $\begin{array}{l}\text { Cut } \\
\text { Over- } \\
\text { story }\end{array}$ & $\begin{array}{l}\text { Establish } \\
\text { Plantation }\end{array}$ & Graze \\
\hline Destroy & & & & & & $\mathrm{x}$ & & \\
\hline Damage & & & & & & & & $x$ \\
\hline $\begin{array}{l}\text { No Lasting } \\
\text { Effect }\end{array}$ & $N A$ & & & & & & & \\
\hline $\begin{array}{l}\text { Beneficlal } \\
\text { If Done } \\
\text { Properly }\end{array}$ & & & & & & & & \\
\hline
\end{tabular}

\section{Other Comments:}

*Expected effect on the species is an estimace made by Dr. Robert Kral based on his knowledge of the habltat and on knowledge gained from personal field observations. Estimates are "rough" in many instances. Results of practices may be modifled depending upon the degree of application, intensity of treatment, nearness to plant communties, etc. A management practice for which no entry is made indicates a lack of sufficient information from which to predict expected results. As observations are made in the field by users of the data, the expected effect will be refined. 
Carex purpurifera Mackenzie

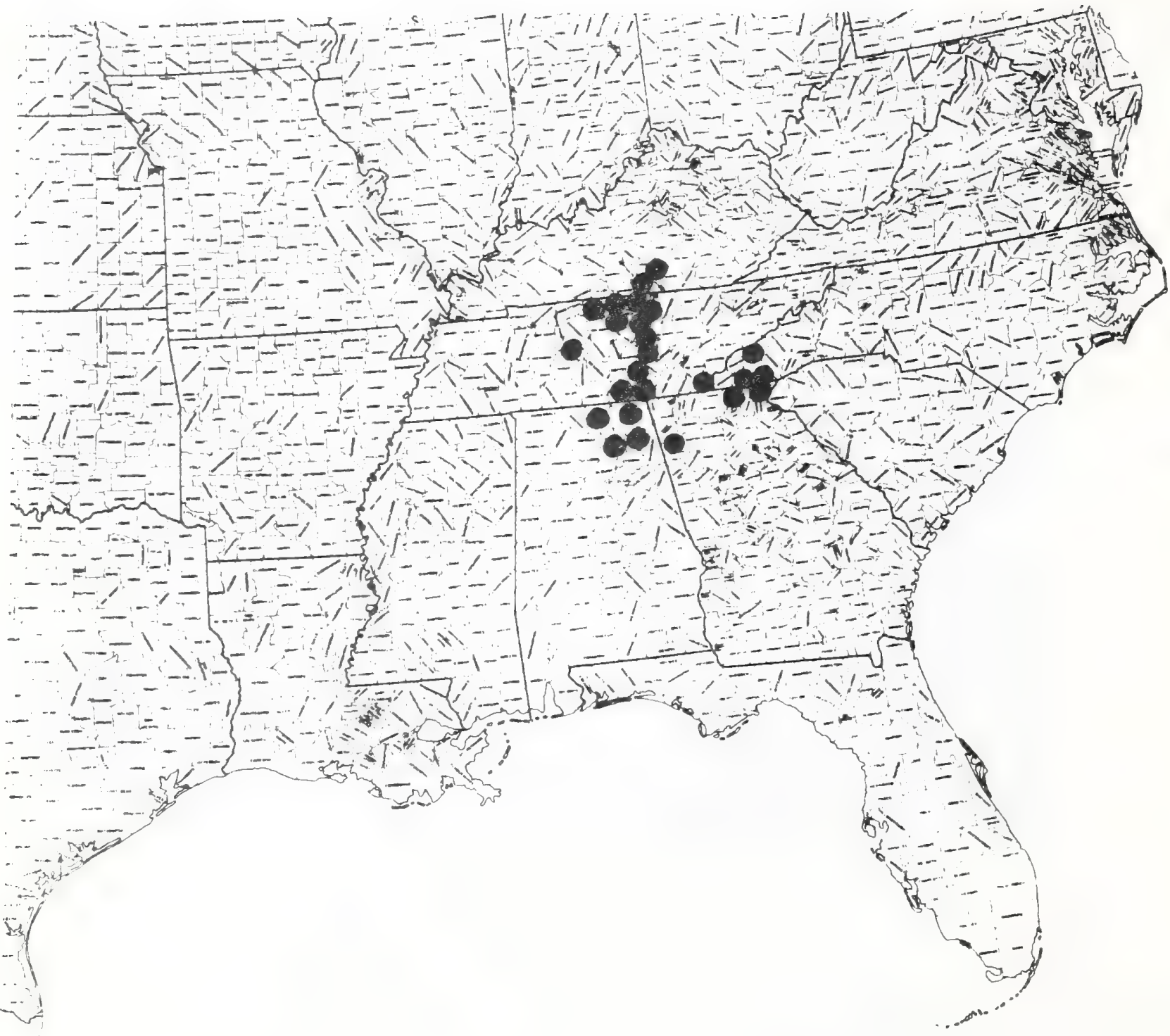




\title{
CYPERACEAE
}

\author{
Cymophyllus fraseri (Andr。) Mackenzie: Fraser's sedge: \\ sedge \\ Carex Exaseri Andr.
}

Technical Description

Perennial, usually in laxge tufts of several, close-set rhizomal offshoots. stems and Leaves.--Each offshoot with several leaves, the lowest pale, strawcolored or nearly white toward the base, loosely sheathing the flowering shoot, cylindrical but expanding above at the pale green oblique-bluntly triangularbladed orifice. Uppermost leaf by far the largest, its base pale, inroliedsheathing, dilating and spreading above to a broadIy linear green blade to 6 dm long and $2-5 \mathrm{~cm}$ broad; this blade has smooth, very finely ribbed surfaces, a thinnish, puckered margin and an acute or short-acuminate apex and persists over winter. The flowering shoot is stiffish but slender, pale green or near white, its base encased in leaf sheath, its total length less than or slightly longer than the subtending foliage leaf and at its tip bearing a single shortoblong, naked (bractless) spike about $2.0-2.5 \mathrm{~cm}$ long. Inflorescence and Florets.--The base of the spike produces several spreading, broadly fusiform, whitish perigynia (as in Carex) about 5 m long in fruit; the perigynium is thinnish, very faintly nerved. Above the middle of the spike all flowers are male, their thin oblong, acute bracts closely imbricated in several spirals, the filaments and anthers whitish and projecting beyond in flower. Female scales ovate, very thin, near-white, about as long as or distinctly shorter than the ripe perigynia.

Eruit.--Ripe akene trigonous, Iustrous brown, the sides concave.

Distribution and Flowering

Rich, usually rocky woods in full shade in the mountains from eastern Kentucky, southwestern Virginia and West Virginia southward to western North Carolina and eastern Tennessee. It blooms from May to July.

Special Identifying Features

This species has no near relatives and its phylogeny is argued. At a distance it is often confused with some liliaceous plants because of its tufts of broad, brightish green leaves and particularly because of its chalk-white flowering inflorescences. Some botanists place the species in carex, in that it does produce the perigynium.

Habitats and Management Implications

C. Eraseri appears to require a highly humified, moist (though well-drained), slightly aciaic substrate and a humid atmosphere. It is found in mixed-mesophytic forested or boreal-transitional forested areas that usually remain cool and humid even in summer. Generally it is at elevations of at least 2,000 ft. It is another species that responds negatively to clear-cutting, being a plant of at least semishade and evidently responding poorly to the admission of light and the 
sort of weedy herbaceous and woody species that invade after a clear cut. It disappears from grazed woodlands.

References

M. I. Fernald. 1950. Gray's Manual of Botany, ed. 8. 293.

J. K. Small. 1933. Manual of the Southeastern Flora, pp. 235-236. 
SPECIES: \#27 Cymoplizllus fraseri (Andr.) Mackenzie, Sedge

\begin{tabular}{|c|c|c|c|c|c|c|c|c|}
\hline & \multicolumn{8}{|c|}{ Management Practices } \\
\hline $\begin{array}{l}\text { Expected* } \\
\text { Effect on } \\
\text { the Species }\end{array}$ & $\begin{array}{c}\text { Prescribe } \\
\text { Burn }\end{array}$ & $\begin{array}{l}\text { Bulldoze } \\
\text { or } \\
\text { Root Rake }\end{array}$ & Bed & Chop & $\begin{array}{l}\text { Thin } \\
\text { over- } \\
\text { story }\end{array}$ & $\begin{array}{l}\text { Cut } \\
\text { Over- } \\
\text { story }\end{array}$ & $\begin{array}{l}\text { Establish } \\
\text { Plantation }\end{array}$ & Graze \\
\hline Destroy & & & & & $x$ & & & $\mathrm{X}$ Or \\
\hline Damage & & & & & & & & $x$ \\
\hline $\begin{array}{l}\text { No Lasting } \\
\text { Effect }\end{array}$ & $\mathrm{NA}$ & & & $x$ & & & & \\
\hline $\begin{array}{l}\text { Beneficial } \\
\text { if Done } \\
\text { Properly }\end{array}$ & & & & & & & & \\
\hline
\end{tabular}

\section{Other Comments:}

*Expected effect on the species is an estimate made by Dr. Robert Kral based on his knowledge of the habitat and on knowledge gained from personal field observations. Estimates are "rough" in many instances. Results of practices may be modified depending upon the degree of application, intensity of treatment, nearness to plant communities, etc. A management practice for which mo entry is made indicates a lack of sufficient information from wh ch to predict expected results. As observations are made in the field by users of the data, the expected effect will be refined. 
Cymophyllus fraseri (Andr.) Mack.

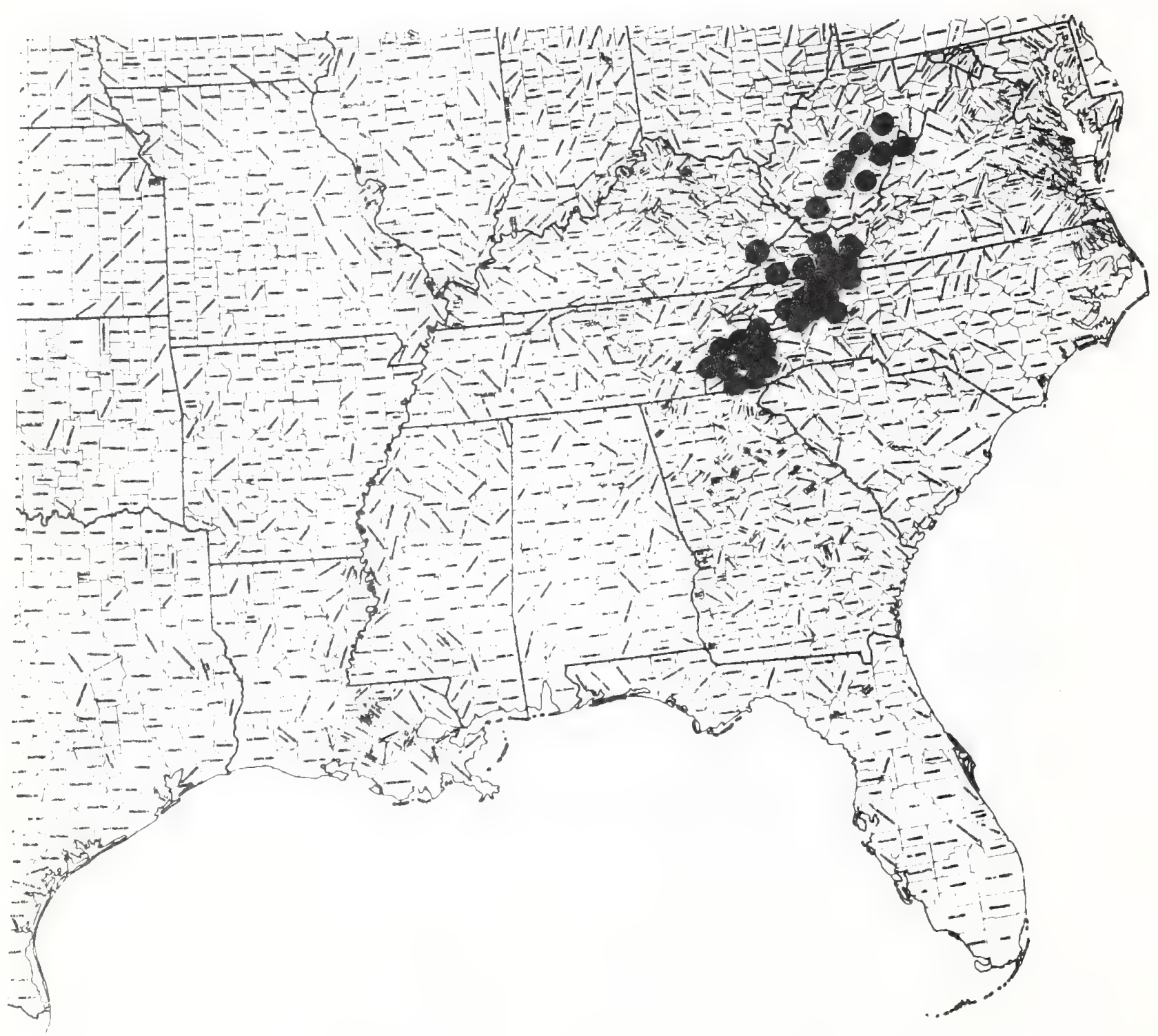


Paper 30

Text \& map by:

Robert Kral

\section{ERIOCAULACEAE}

Lachnocaulon beyrichianum Sporleder ex. Korn. southern bog buttons; hairy-Pipewort or bog-buttons

Technical Description

Perennial herb, forming large shallowly domeshaped clumps of rosettes which cover a multibranched system of chaffy short stems.

Leaves..-Narrowly li near-attenuate, to $4 \mathrm{~cm}$. 1ong, grayish green, hairy, with sheathing bases.

Inflorescence.--Scape sheathes slender but loose, about as long as leaf

blades, hairy with long crinkled hairs. Scapes $15-24 \mathrm{~cm}$. long, slender, twisted, obscurely ridged, hairy with long translucent hairs, thus appearing grayish. Mature heads globose or short-oblong, pale-gray, 3.5-5.0 mm. broad. Outer involucral bracts ovate, about $1 \mathrm{~mm}$. long, brownish, smooth or fringed with small clubshaped pale hairs on the backs and apically. Bracts of receptacle surface fiddleshaped, 1.5-2.0 $\mathrm{mm}$. long, obtuse, brownish, basally smooth, hairy on the backs towards the tips with short, whitened, clubshaped hairs.

Flowers.--Male flower wi th 3 linear-spatulate sepals $1.5-2.0 \mathrm{~mm}$. 1ong, obtuse, brownish, hairy with white clubshaped hairs on the backs towards and at tips; androphore (stalk supporting stamens) smooth, clubshaped, about as long as sepals; anthers yellowish, slightly exserted. Female flower: sepals linear or linear-spatulate, about as long as but broader than male sepals, obtuse, tan or pale brown, backs and margins pilose, hairs toward apex white and club shaped; gynophore (stalk supporting ovary) short, densely hairy at base; carpels 3. ovary 3-locular, 3-ovulate, styles 3, branched.

Fruit..--Seeds ellipsoidal, somewhat flattened, reddish-brown, about $\overline{0.5 \mathrm{~mm}}$. long, very lustrous.

Distribution and Flowering Season

Sands, sandy peats and peat of pine flatwoods, savannas, and rather dry oak-pine barrens, southeastern North Carolina southward into central Florida. Flowering from May to frost, given proper weather conditions.

Special Identifying Features

These and related genera are often called "bog batchelor-buttons" or "hatpins" because of the slender scapes arising from rosettes and terminating in button-like heads of chaffy bracts and florets. The Lachnocaulons differ from Ericaulons mainly in their more slender rootsystems of non-partitioned roots, their comparatively hairy foliage and scapes, their perianths which are usually 3-parted rather that 2-parted, and their tendency to be found often in drier sites than most Ericaulon, mainly have 2 carpels and a 2-branched style whilst Lachnocautons mainly have 3 carpels and 3 style branches. 
Lachnocaulon beyrichianum looks most like L. anceps, a wide ranging Coastal plain species wi th larger, paler heads, larger perianth parts, broader leaves, and less lustrous seed. The two are often found in the same area, but L. beyrichianum in these cases is on higher, drier sites. Typical habitat for it is in dryish acidic white sands or sandy peats of clearings in longleaf or slash pinelands. It may appear in mature open stands of pine, but is shaded out of heavily stocked younger stands. of the Eriocaulaceous plants it is least effected by drainage. Common associated herb and shrub genera are Andropogon. Aristida, Xyris (X. carolinensis), Polygala (those of drier sands), Rhexia, Heterotheca (mostly Graminifolia types), Panicum (Dichanthelium), Bulbostylis, Serenoa, Ilex (gallberry), Myrica, Lyonia. It probably maintains in nature through periodic burnings which would remove some grass-sedge competition and create forest openings. Site preparation methods, so long as they do not involve total drainage, probably favor this species so long as there are contiguous seed sources. However, it is shaded out later as the crowns of seeded or planted pines close.

\section{References}

Kral, R. 1966. Eriocaulaceae of continental North America north of Mexico. Sida $2(4):$ 285-332.

Moldenke, H.N. 1937. Eriocaulaceae in N. Amer. Fla. 19 (1).

Sma 11, J.K. 1933. Flora of the southeastern United States, pp. 255-256. Chapel Hill, N.C. 
SPECIES: \#30 Ixachnocaulon beyrichianun Sporlexler ex rom. Hairy-Pipewort

\begin{tabular}{|c|c|c|c|c|c|c|c|c|}
\hline & \multicolumn{8}{|c|}{ Management Practices } \\
\hline $\begin{array}{l}\text { Expected* } \\
\text { Effect on } \\
\text { the Species }\end{array}$ & $\begin{array}{c}\text { Prescribe } \\
\text { Burn }\end{array}$ & $\begin{array}{l}\text { Bulldoze } \\
\text { or } \\
\text { Root Rake } \\
\end{array}$ & Bed & Chop & $\begin{array}{l}\text { Thin } \\
\text { over- } \\
\text { story }\end{array}$ & $\begin{array}{l}\text { Cut } \\
\text { Over- } \\
\text { story }\end{array}$ & $\begin{array}{l}\text { Establish } \\
\text { Plantation }\end{array}$ & Graze \\
\hline Destroy & & $\mathrm{X}$ & & $x$ & & & $x$ & \\
\hline Damage & & & $x$ & & & & & $\because$ \\
\hline $\begin{array}{l}\text { No Lusting } \\
\text { Effect }\end{array}$ & & & & & & & & \\
\hline $\begin{array}{l}\text { Beneficlal } \\
\text { If Done } \\
\text { Properly }\end{array}$ & $\mathrm{X}$ & & & & $\because x$ & $\therefore$ & & \\
\hline
\end{tabular}

\section{Other Comments:}

*Expected effect on the species is an estimate made by Dr. Robert Kral based on his knowledge of the habitat and on knowledge gained from personal field observations. Estimates are "rough" in many instances. Results of practices may be modified depending upon the degree of application, intensity of treatment, nearmess to plant comunities, etc. A management practice for which no entry is made indicates a lack of sufficient information from which to predict expected results. As observations are made in the field by users of the data, the expected effect will be refined. 
Iachnocaulon beyrichianum Sporl. ex Korn.

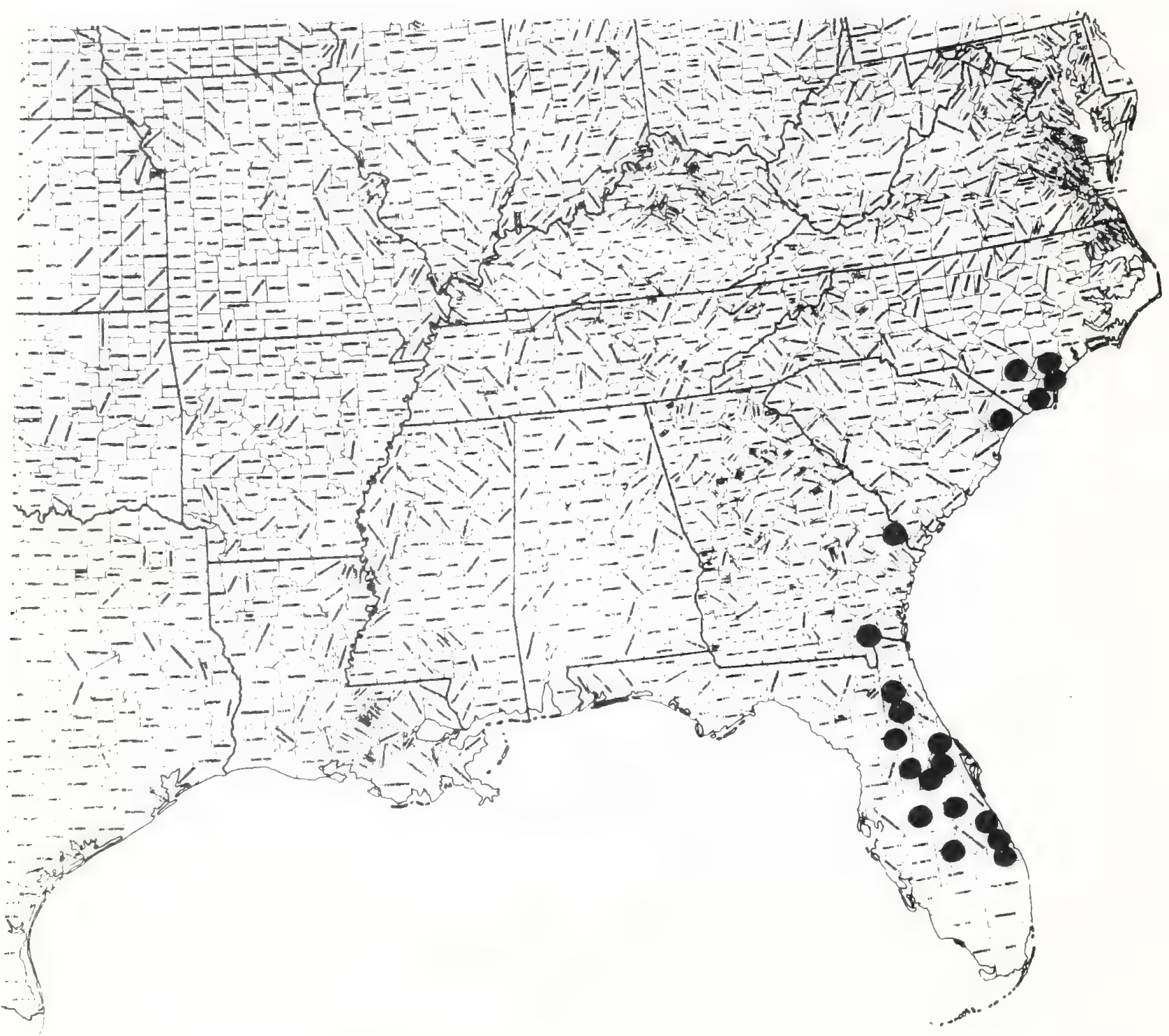




\section{EUPHORB IACEAE}

Euphorbia telephoides Chapm. Spurge Galarhoeus telephoides (Chapm.) Small

\section{Technical Description}

Perennial smooth, milky-juiced herb from a thickened, deep-set woody rootstock.

Stems.--Stems arising usualiy well below-ground, solitary or several, close-set toward apex of thickened crown, erect or ascending, at most to $3 \mathrm{dm}$ high, terete, sometimes branching at base, otherwise simple except in the inflorescence, the above ground parts of ten tinged with red, distally green, there with decurrent ribs from leaf midrib bases. Leaves.--Numerous, alternate-spiral, on main axis, opposite in inflorescence, the Tower ones triangular, scale-like, the largest at midstem or directly beneath inflorescence branches, broadly obovate to suborbicular, broadly spathulate, elliptic or oblanceolate, mostly 3-6 cm long, rounded to broadly acute or obtuse-angled,entire, the base cuneate or short-attenuate, sessile or nearly so, or in uppermost leaves and bracts clasping and with blades narrowly ovate or triangular; leaf surfaces deep to pale yellow-green or suffused with maroon, the midrib and margins usualiy maroon. Inflorescence.--Broader than Tong, a compound of leafy-bracted cymes of cyathia (the cyathium is a cup-shaped involucre bearing inside, usually, few to several male flowers comprised mainly of stamen and one stalked female flower which at maturity projects, and bearing around its margin appendaged or unappendaged, often petal-like, glands; in this complex of species the glands are unappendaged), these in bloom top-shaped, maroon, 2.5-3.0 mm 1ong, bearing on their rim 4, short-stalked, half-round, fleshy, greenish-maroon glands alternating with 4 erect, red, roundish to obtuseangled, scale-like ciliate-fimbriate appendages nearly as high as the glands, the whole cyatnium on a slender maroon stalk mostly 3-10 mm long and frequently concealed by the leafy subtending bracts.

Fruit.--Capsules in outline reniform, ca. $6-8 \mathrm{~mm}$ broad and $5 \mathrm{~mm}$ high, strongly 3-lobed, each lobe keeled, the keel edge maroon, the surfaces otherwise du7t green, minutely pebbled. Seeds $1 /$ locule, nearly round, ca. $3 \mathrm{~mm}$ across, gray or gray-brown, smooth to minutely pebbled.

Distribution and Flowering Season

Sandy longleaf pineland, low sandy ridges, mostly near the coast, northwestern Florida; flowering mostly from Aprit into July, but if disturbed blooming throughout the growing season.

\section{Special Identifying Features}

This species is nearest $E$. inundata Torr. a taller plant of moister habitats, usually moist to wet pine flatwoods savannas and hypericum pond borders from northwestern Florida to southern Alabama. E. inundata is normally bushier, with leaves ranging narrower; its inflorescence is more diffuse, the cyathia more numerous on longer stalks; the cyathial glands are fleshy and obliquely truncated, entire or nearly so as in E. telephoides, but the scale-like 
cyathial appendages tend to be lacerate-fimbriate and with mucronate apices.

Habitat and Management Implications

E. telephoides is mostly either in wire-grass dominated longleaf pine-slash

pine savanna or on the low sandy rises contiguous, these usually dominated

by turkey oak and other scrub oaks interspersed with pine. In either case the deep woody rootstock extends down into a dark moist sand. Serenoa is abundant throughout, as are Conradina, Hypericum, Yucca. Grasses in Panicum, Aristida, Sporobolus, Muhlenbergia, Anthenantia, Sorghastrum dominate, interspersed with Xyris caroliniana, many Polygala, Rhexia al ifanus, and an abundance of composites in genera Chrysopsis, Aster, Solidago, Liatris. Phoebanthus tenuifolius is an almost constant associate.

Natural woods fires probably maintained this species historically, in that burning reduces woody competition and increases the wire-grass area. Most herbarium specimens of $E$. telephoides show some evidence of fire disturbance. Many cormophytes such as this one respond vigorously after a burn; certainly controlled burning would tend to increase abundance. Neither are most mechanical site preparatory techniques fatal, in that a number of the deep rootstocks survive to produce vigorous shoots. However, the purpose of such preparation is to develop plantations of slash pine, and as soon as the crowns of the young pines close E. telephoides is shaded out.

Reference

Sma11, J. K. 1933. Manual of the southeastern flora, pp. 800-801. Chapel Hill, N. C. 
SPECIES Euphorbia telephoides Chapm. Spurge

\begin{tabular}{|c|c|c|c|c|c|c|c|c|}
\hline \multirow[b]{2}{*}{$\begin{array}{l}\text { Expected* } \\
\text { Effect on } \\
\text { the Species }\end{array}$} & \multicolumn{8}{|c|}{ Management Practices } \\
\hline & $\begin{array}{c}\text { Prescribe } \\
\text { Burn }\end{array}$ & $\begin{array}{l}\text { Bulldoze } \\
\text { or } \\
\text { Root Rake }\end{array}$ & Bed & Chop & $\begin{array}{l}\text { Thin } \\
\text { over- } \\
\text { story }\end{array}$ & $\begin{array}{l}\text { Cut } \\
\text { over- } \\
\text { story }\end{array}$ & $\begin{array}{l}\text { Establish } \\
\text { Plantation }\end{array}$ & Graze \\
\hline Destroy & & & & & & & $x$ & \\
\hline Damage & & $x$ & $x$ & $x$ & & & & $x$ \\
\hline $\begin{array}{l}\text { No Lasting } \\
\text { Effect }\end{array}$ & & & & & & & & \\
\hline $\begin{array}{l}\text { Beneficial } \\
\text { if Done } \\
\text { Pronerly }\end{array}$ & $x$ & & & & $x$ & $x$ & & \\
\hline
\end{tabular}

Other Comments:

*ixpected cffect on the species is an estimate made by Dr. Robert Kral based on his knowledge of the habitat and on knowledge gained from personal field observations. Estimates are "rough" in many instances. Results of practices may he modified depending upon the degree of application, intensity of treatment, nearness to plant communities, etc. A management practice for which no entry is made indicates a lack of sufficient information from which to predict expected results. As observations are made in the field by users of the data, the expected effect will be refined. 
Euphorbia telephoides Chapm.

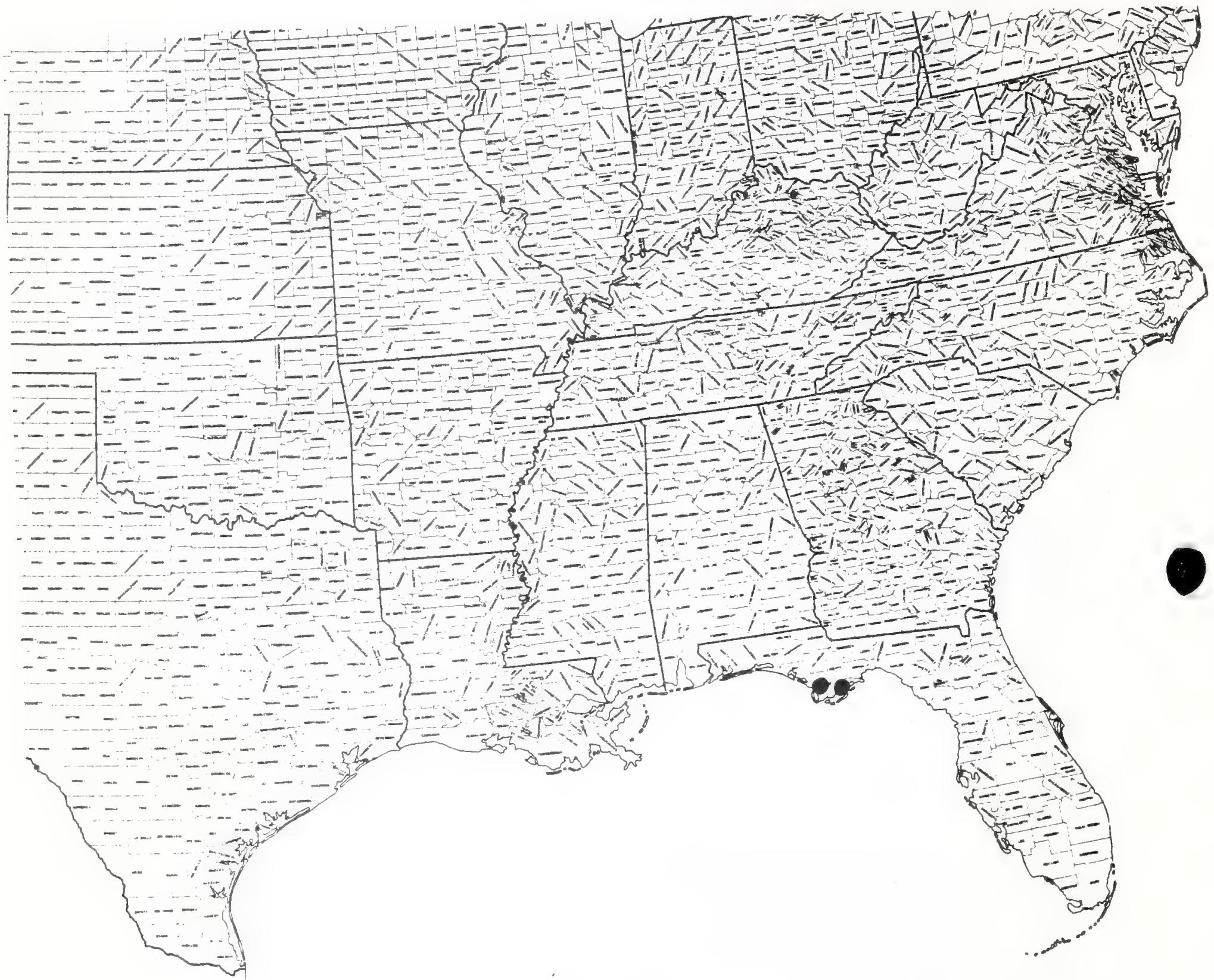


Paper 34

Text \& map by:

Robert Kral

\section{FABACEAE}

Astragalus tennesseensis A. Gray; Ternessee milkvetch; Milk vetch Geopmumin tensesseense (A. Gray) Rydb.

Technical Description

Perennial herbs from strong, stout taproots. Stems.--Usually several, arising from short, stoutish branches at sumit of taproots, usually spreading over the ground, arching upward toward the tips, mostly 2-7 dm long, pale green or straw colcred, simple or sparingly branched, with several close-set leafless nodes toward the base, thickening upward, there densely long-spreading-hairy with whitish hairs.

Ieaves.--Alternate, ever-pinnate with stipules pale green, thin, ovate, acuminate, ciliate, about 1-2 cm long, leaf rachis spreading, $5-15 \mathrm{~cm}$ long, longspreadinguhairy, less than $1 / 2$ petiole; leaflets between 10 and 20 pairs, spreading on short (ca. $1 \mathrm{~mm}$ )), hairy stalks, mostly elliptic or oblong, 5-15 mm long, the apices rounded or emarginate, often with a small mucro, the margins entire and long ciliate, the upper surfaces dark yellow green, smooth, the lower surfaces with long, appressed hairs.

Inflorescence.--Flowers in long-stalked compact racemes from the axils of midstem leaves upward, the stalks spreading-ascending, spreading-long-hairy, mostly 5-10 cm long, the racemes ovoid or cylindric, mostly 3-8 cm long, each flower with a pale green, thin, erect lanceolate or narrowly ovate, acuminate, long ciliate bract 5-10 mm long and on a short stalk $1.5-2.0 \mathrm{~mm}$ long. Flower.--Calyr narrowly campanulate, longmhairy, 5-lobed, the tube 8--10 nm long, yellow-green, the lobes unequal, narrowly triangular to nearly linear, green, to $3 \mathrm{~mm}$ long. Corolla pale yellow, pea-like but narrow, the standard longest, bent upward toward its tip, narrowly obovate, retuse, $1.5-2.0 \mathrm{~cm}$ long; wing petals long clawed, the blades oblong, rounded-tipped; keel petals shortest, sharply bent upward. Stamens 10 , hidden by the petals, 9 joined by their filaments most of the length, the loth distinct, all smooth. Ovary superior, hairy, narrow, the style bent upward at its tip. Fruit.--Narrowly ovoid-cylindric, $3.0-3.5 \mathrm{~cm}$ long, long beaked, vary thick-walled and fleshy, persistently long-hairy, becoming brownish and wrinkled when fully ripe. (Racemes of fruit are usually persistent long after the leaves have withered, lyjing flat on the ground with the browning remants of stems and leaves)。

Distribution and Flowering Season

Dry calcareous pxairies and barrens, northern and central Illinois; midale Tennessee; northern Alabama. Flowering April into May.

Habitat and Management Implication

This species, wiped out or nearly so in its Illinois range, is now most abundant (through local) in the cedar glades of middle Tennessee, less so in small or large clearings in limerock woods. It is a plant of full sun or very light shade, usually on very thin soils over limestone and associated with other calciphiles such as psoralea subacaulis. Delphinium virescens, 
Petalostemon, Onosmodium, Arenaria patula, Talinum, various carices and grasses. The woodlands associated with the clearings are marked by Juniperus virginiana, guercus shumardii, Q. muhlenbergii, Q. alba, Morus rubra, Ulmus

serotina U. rubra, U. Americana, Carya ovata, C. carolinae-

-septentrionalis, Rhamnus, Fraxinus, with Rhus aromatica and

symphoriocarpos common in the understory. The soils, while fertile, are thin and poorly drained, being sticky clay in winter and spring, drying to bricklike. consistency in summer and fall drought.

A. tennesseensis, a plant of open areas, may increase as clearings are produced through logging. Its decrease over the total range is probably due mainly to converstion of the lanc. to row crops or pasture on the one hand and the enrochment on its area by scrub forest on the other. Historically it may have been maintained through summer and autumn fire.

References

Quarterman, Elsie. 1950. Major Plant Communities of Tennessee Cedar glades. Ecology 31: 234-254.

Small, J. K. 1933. Manual of the southeastern flora, PP. 708-709. 
SPECIES: \#34 Astragalus tennesseensis A. Gray. 1iilk vetch

\begin{tabular}{|c|c|c|c|c|c|c|c|c|}
\hline \multicolumn{9}{|c|}{ Management Practices } \\
\hline $\begin{array}{l}\text { Expected } \\
\text { Effect on } \\
\text { the Specles }\end{array}$ & $\begin{array}{c}\text { Prescribe } \\
\text { Burn }\end{array}$ & $\begin{array}{l}\text { Bulldoze } \\
\text { or } \\
\text { Root Rake } \\
\end{array}$ & Bed & Chop & $\begin{array}{l}\text { Thin } \\
\text { over- } \\
\text { story }\end{array}$ & $\begin{array}{l}\text { Cut } \\
\text { Over- } \\
\text { story }\end{array}$ & $\begin{array}{l}\text { Establish } \\
\text { Plantation }\end{array}$ & Graze \\
\hline Destroy & & $N A$ & & & & & $x$ & \\
\hline \multicolumn{9}{|l|}{ Damage } \\
\hline $\begin{array}{l}\text { No Lasting } \\
\text { Effect }\end{array}$ & NA & & & & & & $P C$ & isoncus \\
\hline $\begin{array}{l}\text { Beneficial } \\
\text { if Done } \\
\text { Properly }\end{array}$ & & & & & $X$ & $y$ & & \\
\hline
\end{tabular}

\section{Other Comments:}

*Expected effect on the species is an estimate made by Dr. Rubert Kral based on his knowledge of the habitat and on knowledge gained from personal field observations. Estimates are "rough" in many instances. Results of practices may be modified depending upon the degree of application, intensity of treatment, nearness to plant communities, etc. A management practice for which no entry is made indicates a lack of sufficient information from which to predict expected results. As observations are made in the field by users of the data, the expected effect will be refined. 
Astragalus tennesseensis A. Gray

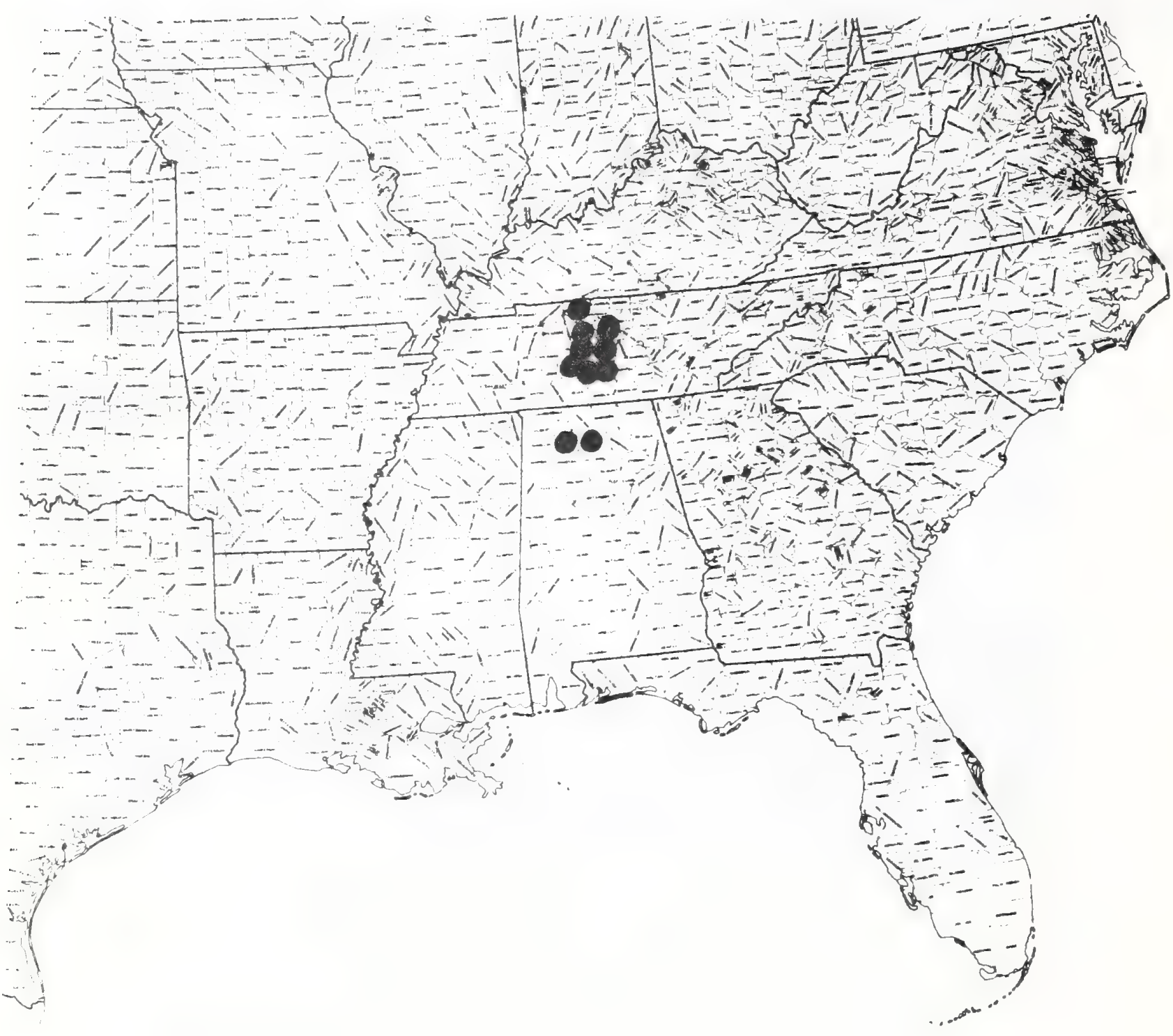


Paper 36

Text \& map by:

Robert Kral

FACACEAE

Quercus oglethorpensis Duncan。 Oglethorpe oak

Technical Description

A medium-sized to large tree (to 25 meters tall).

stems. - The bark on older trunks platey, gray (as in Durand Oak, White Oak, etc.) New shoots with scattering of stalked stellate hairs, later becoming smooth or nearly so, somewhat lustrous, reddish-brown. Winter buds with terminals about $3 \mathrm{~mm}$ long, ovcid, bluntish, dull reddish-brown, the inner scales conspicuously low-ciliate.

Leaves.--Spreading on smoothish, short petioles (3-8 mm long), deciduous, the blades from oblong to narrowly elliptic or oblanceolate, mostly $5-10 \mathrm{~cm}$ long, (similar to willow-leaved oaks), the tips prickle-less, rounded to obtuseangled, the margins entire or rarely with a few low, sinuate lobes, slightly emarginate, the bases acute or cuneate, the upper surface yellow-green, somewhat lustrous, the lower surface more yellowish, sparsely to densely covered with short-stalked, stellate and tan hairs.

Fruit.--Acorn about $1 \mathrm{~cm}$ long, nearly sessile, maturing in 1 year, the cup $1 / 2$ or less as long as the nut, thinnish, turbinate, about $1 \mathrm{~cm}$ broad, the numerous naxrow cup scales tightly appressed, dull reddish-brown, tomentose with short weak hairs toward their bases, thinner, paler and less hairy toward their narrow but blunt tips, those of the margin erect, the rim of the cup rot fxinged: nut round or ellipsoidal, dull brown or tan, with a scattering of appressed, weak hairs over the shell.

Distribution and Flowering Season

Poorly drained bottoms and adjacent slopes, in the piedmont from western south Carolina south into eastern Georiga.

Special Identifying Features

This oak is taxonomically closest to the Durand Oak, differing from it orily in slight ways, such as in the darker colored leaf hairs, the slightly smaller fruit, and perhaps sholid be considered a mere variant of that species, particularly if ones concept of Durand Oak includes 2 . austrina.

Habitats and Management Implication

It is found in poorly drained alluvial sites, mixed with other bottomiand species of oaks, particularly the willow oaks, and various species of ash, elm, hickory.

Management should be as for other bottomland oaks, but owing to the scarcity of the species, every effort should be made to preserve the specimens. No observations as to its silvicultural characteristics are available to this reporter. 


\section{References}

Duncan, W. H. 1940. A new species of oak from Georgia. Am. Midl. Nat. $24: 755-756$.

Radford, A. E。 et al. 1968. Manual of the vascular flora of the Carolinas, pF. 372-385. Chapel Hill, N.C. 
SPECIES:___ \#36 Quercus oglethorpensis Duncan. Oglethorve oak

\begin{tabular}{|c|c|c|c|c|c|c|c|c|}
\hline \multicolumn{9}{|c|}{ Management Practices } \\
\hline $\begin{array}{l}\text { Expected* } \\
\text { Effect on } \\
\text { the Species }\end{array}$ & $\begin{array}{c}\text { Prescribe } \\
\text { Burn }\end{array}$ & $\begin{array}{l}\text { Bulldoze } \\
\text { or } \\
\text { Root Rake }\end{array}$ & Bed & Chop & $\begin{array}{l}\text { Thin } \\
\text { over- } \\
\text { story }\end{array}$ & $\begin{array}{l}\text { Cut } \\
\text { Over- } \\
\text { story }\end{array}$ & $\begin{array}{l}\text { Establish } \\
\text { Plantation }\end{array}$ & Graze \\
\hline \multicolumn{9}{|l|}{ Destroy } \\
\hline \multicolumn{9}{|l|}{ Darnage } \\
\hline $\begin{array}{l}\text { No Lasting } \\
\text { Effect }\end{array}$ & & & & & & & & \\
\hline $\begin{array}{l}\text { Beneficial } \\
\text { if Done } \\
\text { Properly }\end{array}$ & & & & & & & & \\
\hline
\end{tabular}

\section{Other Comments:}

* Expected effect on the species is an estimate made by Dr. Robert Kral based on his knowledge of the habitat and on knowlelge gained from personal field observations. Estimates are "rough" in many instances. Results of practices may be modified depending upon the degree of application, intensity of treatment, nearness to plant communties, etc. A management practice for which no entry is made indicates a lack of suffictent information from which to predict expected results. As observations are made in the field by users of the data, the expected effect will be refined.

No doubt behaves as do others of the bottomland white oats and would be managed accordingly, but with particular attention to reproduction in that this tree appears to be quite scarce! Now reported from IA. 
Quercus ogelthorpensis Duncan

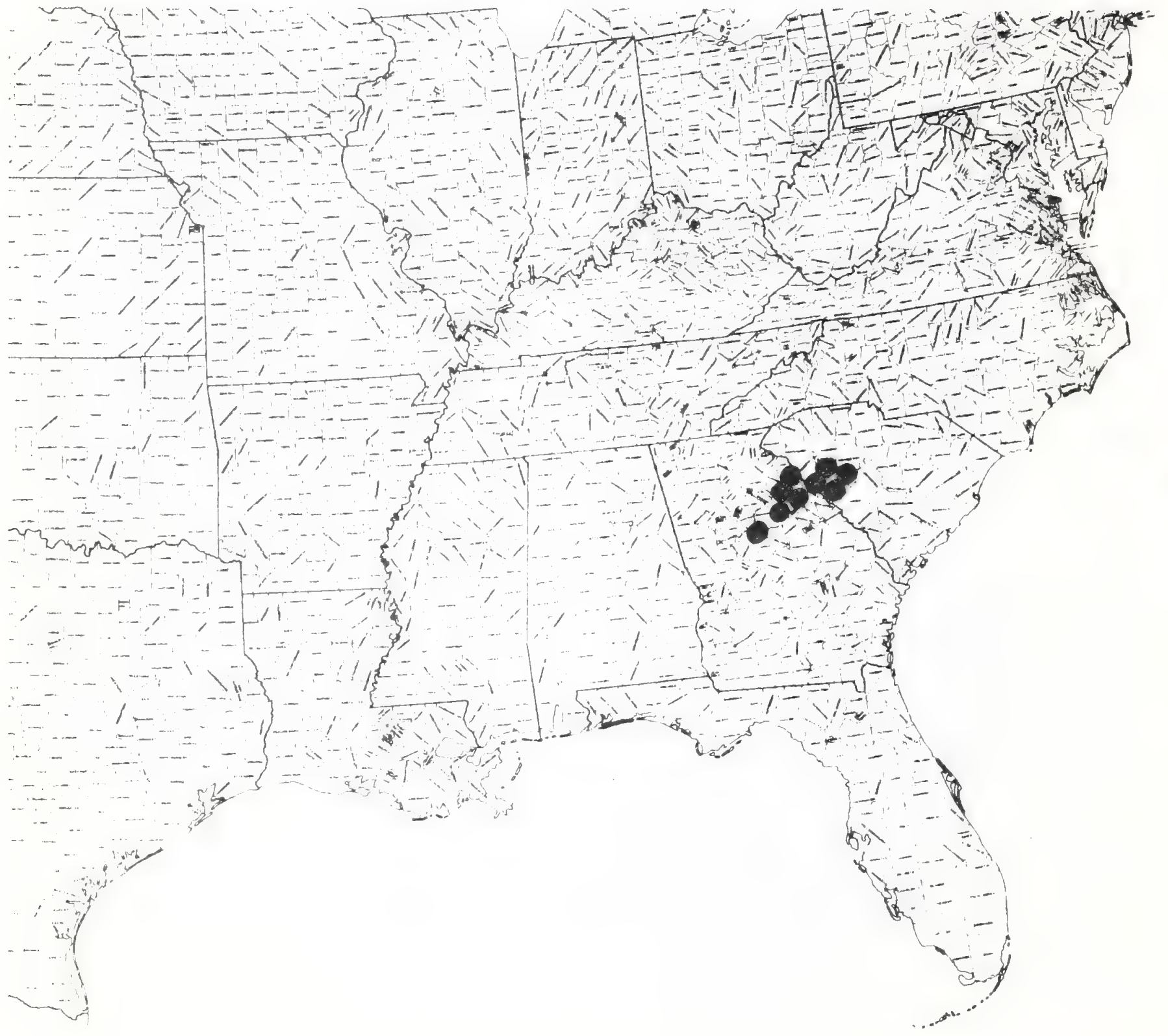


Paper 37

Text \& map by:

Robert Kral.

\section{MAGNOLIACEAF,}

Schizandra glabra (Brickeli) Rehder. Smooth magnolia vine; bay star-vine or Wild Sarsaparilla

(S. Coccinea Michx.)

Technical Description

A woody vine, both twining and clambering on both understory and overstory shrubs and trees.

Stems.--Bark pale graymbrown, smooth, interrupted by raised, largish, tan, Ienticels. Winter buds ca. $4 \mathrm{~mm}$ long, ovoid, sharp-tipped, reddish-brown, imbricate-scaled. Ieaf scars elevated, round, with 3 bundle traces toward the center; stipular scars lacking.

Leaves.--Produced alternately on shortish, stout knobby spur shoots or on long shoots, are smooth, deciduous, thin, mostly obovate or elliptic, to $10 \mathrm{~cm}$ long, acuminate, the edges above the mid-point low-toothed, the bases gradually or abruptly narrowed to slender stalks up to $4 \mathrm{~cm}$ long. Flowers.--The flowers, produced singly from leaf axils, are on spreading-drooping slender stalks up to $5 \mathrm{~cm}$. When fully open they are somewhat flattened as in strawberry bush, in outline round, about $1.5 \mathrm{~cm}$. wide, the sepals mostly shortoblong, round tipped, yellow-green, the petals broadly elliptical or short-oblong, a maroon color (much like those of Anise-tree). The flowers are unisexual, usually both developing on the same shoot with female usually opening first. The stamens are joined together into a flattened 4-6-notched disc with the anthers borne along the sides of the narrow notches. The ovaries are numerous (as in buttercup, blackberry), small, raised on the receptacle which elongates after fertilization。

Fruit. $\rightarrow$ The fruit is of berries, borne like narrow bunches of grapes along the fruiting axis. Each berry has two seeds, is roundish, yellow-green when ripe, and ca. $1 \mathrm{~cm}$ long. No parts of the plant are edible.

Distribution and Flowering Season

This vine occurs naturally only in the Atlantic and Gulf coastal plains from North Carolina south to northern Florida, west to Louisiana and up the Mississippi Embayment into western Tennessee and east Arkansas. In Alabama it is found inland to the southern tip of the Appalachians in Bibb county. It blooms from late June to August.

Habitat and Management Implication

S. glabra, or wild sarsparilla, is always in heavy woods, usually in the understory, usually in bottomlands or in the bluffs along creeks and rivers generally on rich sandy-silt-loams. The forests it frequents are almost always mixedmesophytic. Selective cutting of such axeas should not effect the vines, but clear-cutting would adversely effect this shade tolerant species, in that it 
is a plant usually of steepish terrain or in bottoms where heavy logging and subsequent erosion would have a negative effect.

Reference

SmaIl, J. K. 1933. Manual of the Southeastern Flora, P. 534. Chapel Hill, N.C. 
SPECIES: \#37 Schizandra glabra (Brickell) Rehder, Bay star-vine or vilor sars

\begin{tabular}{|c|c|c|c|c|c|c|c|c|}
\hline & \multicolumn{8}{|c|}{ Management Practices } \\
\hline $\begin{array}{l}\text { Expected* } \\
\text { Effect on } \\
\text { the Species }\end{array}$ & $\begin{array}{c}\text { Prescribe } \\
\text { Burm }\end{array}$ & $\begin{array}{c}\text { Bulldoze } \\
\text { or } \\
\text { Root Rake } \\
\end{array}$ & Bed & Chop & $\begin{array}{l}\text { Thin } \\
\text { over- } \\
\text { story }\end{array}$ & $\begin{array}{l}\text { Cut } \\
\text { Over- } \\
\text { story }\end{array}$ & $\begin{array}{l}\text { Establish } \\
\text { Plantation } \\
\end{array}$ & Graze \\
\hline Destroy & & & & & & & & \\
\hline Damage & & & & & & $x$ & & \\
\hline $\begin{array}{l}\text { No Lasting } \\
\text { Effect }\end{array}$ & $\mathrm{NA}-$ & & & $\longrightarrow$ & & & $N A$ & \\
\hline $\begin{array}{l}\text { Beneficlal } \\
\text { if Done } \\
\text { Properly }\end{array}$ & & & & & $x$ & & & \\
\hline
\end{tabular}

\section{Other Comments:}

*Expected effect on the species is an estimate made by Dr. Robert Kral based on his knowledge of the habitat and on knowledge gained from personal field observations. Estimates are "rough" in many instances. Results of practices may be modified depending upon the degree of application, intensity of treatment, nearness to plant communties, etc. A management ractice for which no entry is made indicates a lack of sufficient informat Lon from which to predict expected results. As observations are made in the lield by users of the data, the expected effect will be refined. 
Schizandra qlabra (Brickell) Rehder

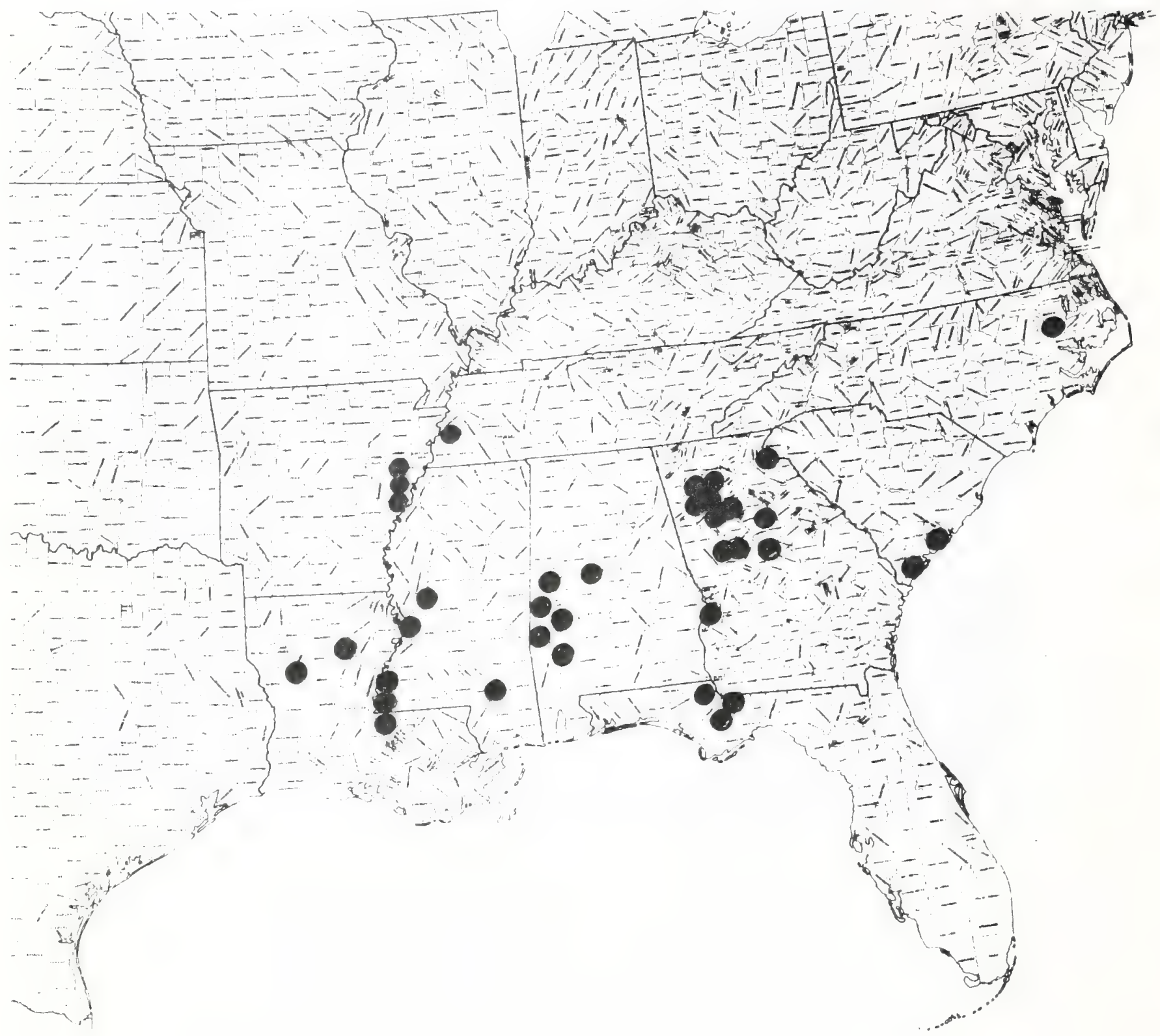


Paper 38

Text \& mas by:

Robert Kral

\section{AS TERACEAE}

Marshallia ramosa Beadle \& $F$. E. Roynt. Southern barbara'sbuttons: Barbara's buttons

Technical Description

Perennial from a short erect caudex, the roots thickish. Stems,--Erect, 3-7 dm long, slender but stiffish, angled or finely fluted, yellow-green with (often) tints of maroon below, the lower part smooth, the upper part smooth or with scattered short, crisped hairs.

Leaves.--Both in rosettes and on the stem, the lowest largest, with blades from elliptic to oblanceolate, linear or elliptic-linear, variable in length from 5-20 cm the apices rounded even if narrow, the margins entire, the surfaces yellwagreen, smooth, triplemerved, the bases attenuated to an ascending maroon petiole less than $1 / 2$ the blade in length. Inflorescence.-mranches (peduncles) arising from about mid-stem upward from the axils of much smaller upper stem leaves, slender, elongate, short-bracted, with a scattering of short, crisped hairs, upwardly arching candelabra-like to produce a more or less open, flatotopped cyme. Heads/inflorescence mostly 3-9, usually but one terminating a branch (rarely 2), mostly hemisphaeric, from base to bract-tip 5-7 mm high, 10-12 $\mathrm{mm}$ across, in flower from head base to corolla tips $10-15 \mathrm{~mm}$ and $15 \times 20 \mathrm{~mm}$ across. Bracts of head several, loosely imbricated in 2 weak series, elliptic linear to oblanceolate, 5-7 mm long, acute or mucronate or short-acuminate, greenish, entire with narrow pale margins.

Flowers, - All discoid, all fertile, the corollas 6-7 mm long, with a long, slender tube, a short, campanulate throat and 5 long, slender spreading lobes, pale lavender and covered externally with pale crisped hairs. Anther head projecting conspicuously above the spreading petal lobes, a deeper lavender. Fruits.-Akene broadly wedge-shaped, angled (prismatic), about $2 \mathrm{~mm}$ long, the angles ascending-bristly-hairy, the tip capped by a crown of narrowly triangular, actite to slender-tipped, thin scales, these often bronze with purplish tints.

Distribution and Flowering season

Dry to moistish sandy outcrops or sandy rises in longleaf wiregrass pinelands, scuth-central Georgia and northwestern Florida (Washington County): flowering from late May through June.

Speical Identifying Features

In appearance of leaves it is nearest $M_{0}$ graminifolia and $M_{0}$ tenuifolia, which do overlap its range, but these plants do not bloom until late summer and fall. In character of pappus (scales) it is nearest Mo caespitosa, but this complex species is always west of the Mississippi River.

Habitats and Mangement Implications

This species is thought to be confined to and around the Alatamaha Grit outcrops of south-central ceorgia and its one outcrop occurrence in north- 
west Florida (Rock Hill). This is a highly ferrugineous sandrock, and the plants are usually rooted in pockets thereon, or nearby. The same situations harbor the also rare (and threatened) Penstemon dissectus. M. ramosa, though considered rare, is locally abundant and forms small, but showy patches within its small range. It is usually in full sun, associated with wiregrass or with grass-sedge and other savanna formation plants where the overstory is mainly a scattering of longleaf pine, or it may actually be found on bog edges in more humified sands. Its being on and around outcrops protects it from most agricultural activity save for pasturing. Prescribed burning would probably favor the species, together with the other savanna formation forbs it associates with. Removal of the sparse pine overstory would probably increase its local area. Most methoas of site preparation would be inapplicable in its habitat, though plantings of slash pine have to some extent been intrusive. Where such plantations are developed, this species is eliminated through shade, at least until such time as planted stands "open up."

References

Channell, R. B. 1956. A revisional study of the genus Marshallia (Compositae), Contribs. Gray Herb., CLXXXI: 41-132.

Small, J. K. 1933. Manual of the southeastern flora, pp. 1455-1457. Chapel Hill, N.C. 
SPECIES: \#38 Marshallia ramosa Beadle \& F. E. Boynt. Barbara's buttons

\begin{tabular}{|c|c|c|c|c|c|c|c|c|}
\hline & \multicolumn{8}{|c|}{ Management Practices } \\
\hline $\begin{array}{l}\text { Expected* } \\
\text { Effect on } \\
\text { the Species }\end{array}$ & $\begin{array}{c}\text { Prescribe } \\
\text { Burn }\end{array}$ & $\begin{array}{l}\text { Bulldoze } \\
\text { or } \\
\text { Root Rake } \\
\end{array}$ & Bed & Chop & $\begin{array}{l}\text { Thin } \\
\text { over- } \\
\text { story }\end{array}$ & $\begin{array}{l}\text { Cut } \\
\text { Over- } \\
\text { story }\end{array}$ & $\begin{array}{l}\text { Establish } \\
\text { Plantation } \\
\end{array}$ & Graze \\
\hline Destroy & & & & $\mathrm{X}$ & & & $\mathrm{x}$ & \\
\hline Damage & & & & & & & & $x$ \\
\hline $\begin{array}{l}\text { No Lasting } \\
\text { Effect }\end{array}$ & & & $X$ & & & & & \\
\hline $\begin{array}{l}\text { Beneficial } \\
\text { if Done } \\
\text { Properly }\end{array}$ & $X$ & $x$ & & & $x$ & $\mathrm{X}$ & & \\
\hline
\end{tabular}

\section{Other Comments:}

* Expected effect on the species is an estimate made by Dr. Robert Kral based on his knowledge of the habitat and on knowledge gained from personal field observations. Estimates are "rough" in many instances. Results of practices may be modified depending upon the degree of application, intensity of treatment, neamess to plant comunities, etc. A management practice for which no entry is made indicates a lack of sufficient information from which to predict expected results. As observations are made in the field by users of the data, the expected effect will be refined. 
Marshallia ramosa Beadle \& Boynt.

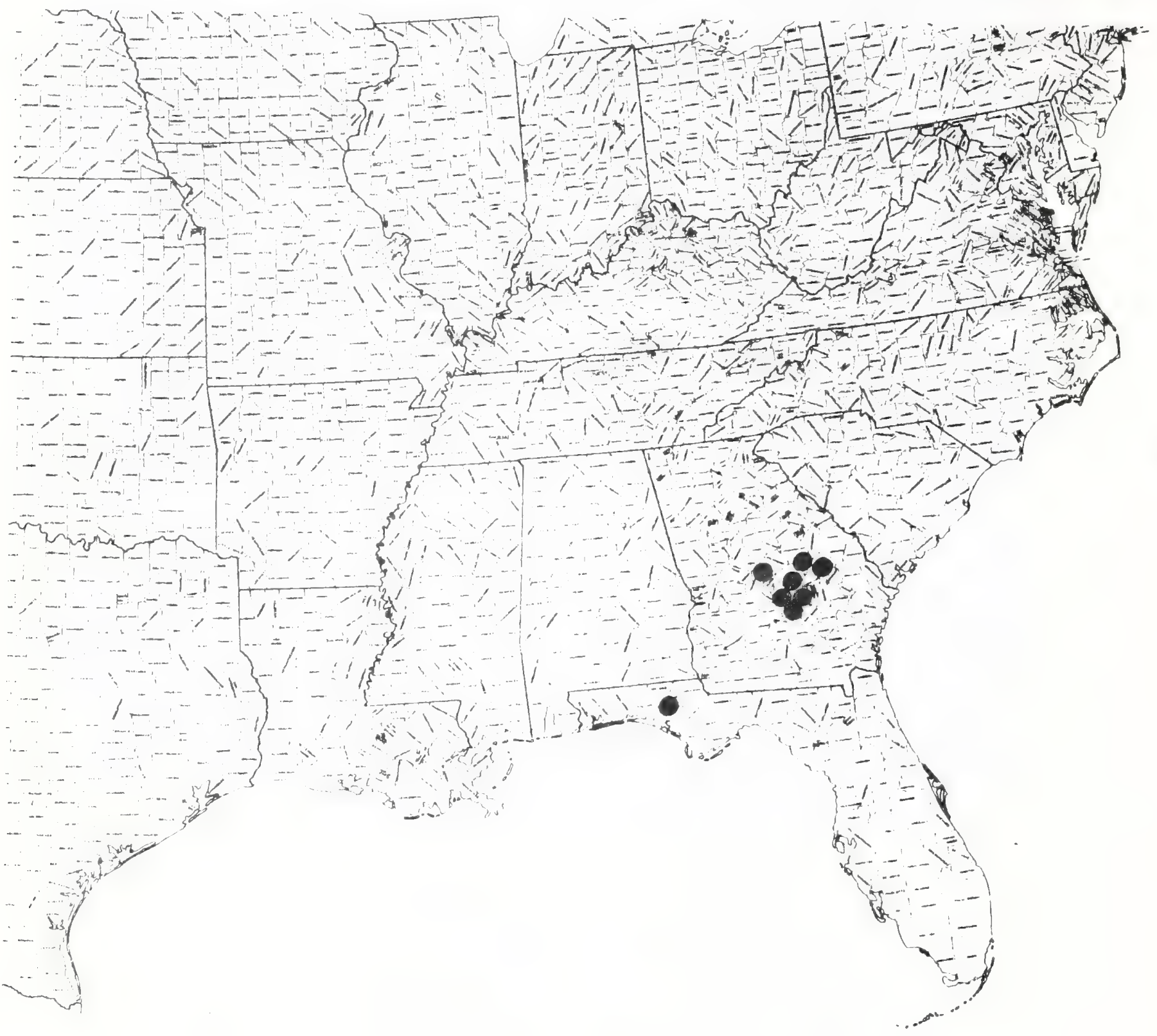




\title{
BRASS ICACEAE
}

\author{
Lesquerel la globosa (Desv.) Wats. Globose bladderpod; \\ bladder-pod
}

\section{Technical Description}

Perennial or annual herb from a very stout taproot or a woody caudex. Stems.--Usually numerous, giving plant a bushy appearance, arching shortly outward in all directions from the plant base, becoming erect, to $5 \mathrm{dm}$. Tong, terete, grayish because of a rather dense covering of simple and stellate hairs, the simple hairs attached at mid-point. Leaves.--Numerous, mostly crowded along the stem from base to inflorescence, the lowest sometimes withered by flowering time, these usually longest and long-petiolate, with oblong, oblanceolate or elliptic blades $3-4 \mathrm{~cm}$. long, the apices broadly acute or bluntish, the margins entire, undulate, distantly dentate, (rarely nearly pinnatifid) often emarginate, the bases cuneate or attenuate to petioles up to $\frac{1}{2}$ as long as the blade, the surfaces gray-green because of a liberal coating of appressed-stellate-hairs. Leaves becoming gradually narrower and more sessile, shorter up to the stem to the inflorescence.

Inflorescence.--Of severai to very many regular flowers on mostly spreading slender pedicels longer that themselves, forming a more or less elongate raceme.

Flowers.--Sepals 4, elliptic to obovate, $2.5-4.0 \mathrm{~mm}$. long, the laterals with sac-like bases, mostly nearly erect in flower, the backs finely stellate-hairy, pale yellow-green. Petals 4, obovate, 3.5-7.5 mm. long, spreading-bladed, margins sinuate, the surfaces a bright yellow. Anthers Tinear, erect on 6 filaments, 2 usually shorter, the filament bases flattened and dilated. Ovary globose or nearly so, its surface densely stellate-hairy, the style much longer, fully $2 \mathrm{~mm}$. Tong. Fruit.--Globose, about $2.0-2.5 \mathrm{~mm}$. Tong with a scattering of stellate hairs, the margins of the 2 valves somewhat raised along contact; partition of fruit thin but continuous; style persistent. Seeds $2 / 1$ ocule of fruit, dimorphic, from oblong to nearly round, 1 side or the other often more convex, wingless, 1.0-2.5 mm. 1 ong.

\section{Distribution and Flowering Season}

River bluffs, talus of lower bluff slopes or calcareous soils of clearings, middle Tennessee north through north central Kentucky into Posey County, Indiana. Flowering from March through May.

\section{Special Identifying Features}

This species is to be distinguished from other southeastern area Lesquerella by its often perennial habit, its greater stature, its small rounded siliques which have stellate hairs and its widely spreading flower and fruit stalks. 
Habitats and Management Implications

The habitats of the species are varied but it is most common either in full sun or in light shade on the limestone ledges along major streams such as the Cumberland. Here it may form locally heavy patches as well as the jumble of talus at bluff bases. It has also been found in pastures amongst scattered Juniperus. Wherever it is found in shade, some of the shade is contributed by juniper, along with such species as oaks (mainiy Q. shumardi i, Q. muhlenbergi i, Q. imbricaria, Q. a lba), hickories, and ash, particularly the Blue and White. It may be amongst a scattering of shrubs such as Rhus aromatica, Forestiera li oustrina, Rhamnus. Its soils are always over Timestone, are usualiy thin, heavy, often quite dry. In most cases the sites this plant frequents are steep, very poor for timber and, where desirable oak or juniper is present, would probably be cut selectively if at all. However, removal of the overstory to expose the limestone bluffs and outcrops would probably not promote increase of the species.

References

Rollins, R.C. 1955. The auriculate-leaved species of Lesquerella (Cruciferae). Rhodora 57:241-264.

and E.A. Shaw. 1973. The genus Lesquerella (Cruciferae) in North America. pp. 1-288. Cambridge, Mass.

Sma11, J.K. 1933. Manual of the southeastern flora, pp. 555-556. Chapel Hill, N.C. 
SPECIES: \#42 Iescuerella globosa (Desv.) Wats. I3Iadderpods

\begin{tabular}{|c|c|c|c|c|c|c|c|c|}
\hline & \multicolumn{8}{|c|}{ Management Practices } \\
\hline $\begin{array}{l}\text { Expected* } \\
\text { Effect on } \\
\text { the Species }\end{array}$ & $\begin{array}{c}\text { Prescribe } \\
\text { Burn }\end{array}$ & $\begin{array}{c}\text { Bulldoze } \\
\text { or } \\
\text { Root Rake }\end{array}$ & Bed & Chop & $\begin{array}{l}\text { Thin } \\
\text { over- } \\
\text { story }\end{array}$ & $\begin{array}{l}\text { Cut } \\
\text { Over- } \\
\text { story } \\
\end{array}$ & $\begin{array}{l}\text { Establish } \\
\text { Plantation }\end{array}$ & Graze \\
\hline Destroy & & & & & & $\mathrm{x}$ & & \\
\hline Damage & & & & & & & & $\mathrm{X}$ \\
\hline $\begin{array}{l}\text { No Lasting } \\
\text { Effect }\end{array}$ & INA & & & & & & $M$ & \\
\hline $\begin{array}{l}\text { Beneficial } \\
\text { If Done } \\
\text { Properly }\end{array}$ & & & & & 8 & & & \\
\hline
\end{tabular}

Other Comments:

*Expected effect on the species is an estinate made by Dr. Robert Kral based on his knowledge of the habitat and on knowledge gained from personal field observations. Estimates are "rough" in many instances. Results of practices may be modified depending upon the degree of application, intensity of treatment, nearness to plant commities, etc. A management practice for which no entry is made indicates a lack of sufficient information from which to predict expected results. As observations are made in the field by users of the data, the expected effect will be refined. 
Lesquerella qlobosa (Desv.) Wats.

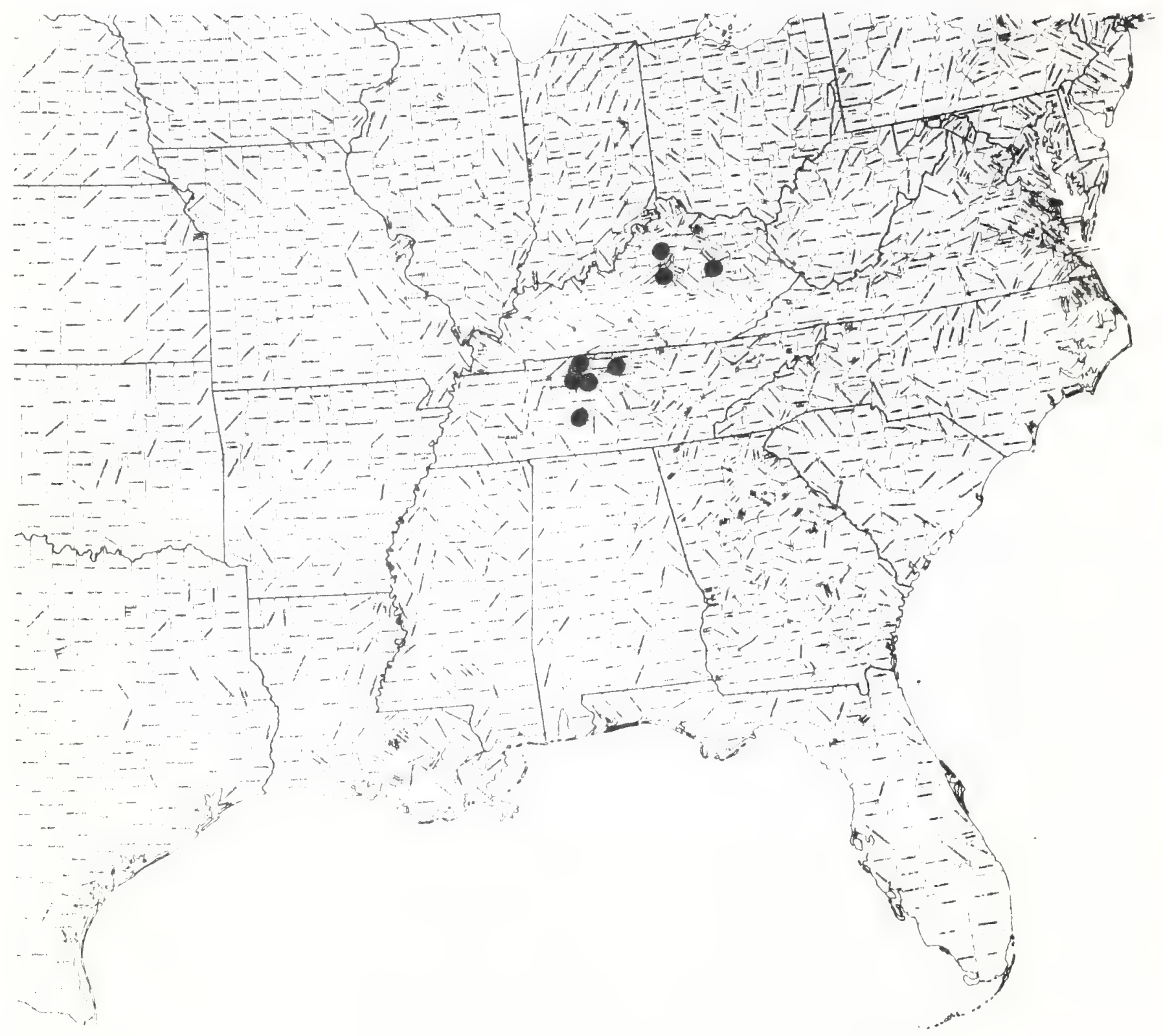


Paper 43

Text \& Map by;

Robert Kral

BRASSICACEAE

Lesquerella lescurii (Gray) Wats. Nashville bladderpod;

Alyssum lescurif (Gray) Gray

Technical Description

This herb is similar in most ways to L. densipila (which see) but mostly somewhat lower, rarely with stems longer that $2 \mathrm{dm}$., and stem leaves with margins more consistently low-toothed. Significantly differing in the fruit, which is orbicular or slightly elliptical, $4-7 \mathrm{~mm}$. 1ong, definitely compressed, the valve surfaces covered with a mixture of pustular-based long trichomes and shorter branched hairs; septum of fruit complete. Seeds 2-4/10cule, 2-3 mm. long, flattened and margined.

Distribution and Flowering Season

Open riverbottom fields and pastures, roadbanks, clearings and lots, in full sun and on alluvial clay, occasionally on thin soils over limestone outcrops, through most of middle Tennessee and particularly along the major drainages southward into northern Alabama (Limestone County). Flowering from March through April.

Habitat and Management Implication

This species is probably the most abundant in Davidson and Cheatham Counties of middle Tennessee where it is sometimes an aspect dominant in patchy lawns, in empty lots, or in riverbottom fields. It is definitely a lower successional level species, giving way to perennial forbs, ultimately to hardwood forest. It is known to hybrize both with L. densipila and the very local, white flowered L. stonensis. Much of the area in which it frequently abounded has gone over to housing, such developments being its major threat. It is maintained through that sort of natural or artificial disturbance that would keep an area of calcareous low soils open, relatively free of perennial forbs or forest.

References

Rollins, R.C. 1955. The auriculate-leaved species of Lesquerella (Cruciferae) Rhodora 57:241-264.

and A.E. Shaw. 1973. The genus Lesquerella (Crudiferae) in North America. pp. 1-288. Cambridge, Mass.

Sma 11, J.K. 1933. Manual of the southeastenn flora, pp. 555-556. Chapel Hill, N.C. 
SPECIES: \#43 Lesciuerella Iescurii (Gray) Wats. Bladdenools

\begin{tabular}{|c|c|c|c|c|c|c|c|c|}
\hline \multicolumn{9}{|c|}{ Management Practices } \\
\hline $\begin{array}{l}\text { Expected* } \\
\text { Effect on } \\
\text { the Species }\end{array}$ & $\begin{array}{c}\text { Prescribe } \\
\text { Burn }\end{array}$ & $\begin{array}{l}\text { Bulldoze } \\
\text { or } \\
\text { Root Rake }\end{array}$ & Bed & Chop & $\begin{array}{l}\text { Thin } \\
\text { over- } \\
\text { story }\end{array}$ & $\begin{array}{l}\text { Cut } \\
\text { Over- } \\
\text { story }\end{array}$ & $\begin{array}{l}\text { Establish } \\
\text { Plantation }\end{array}$ & Graze \\
\hline Destroy & & & & & & & $\mathrm{X}$ & \\
\hline Damage & & & & & & & & $\mathrm{X}$ \\
\hline $\begin{array}{l}\text { No Lasting } \\
\text { Effect }\end{array}$ & $N A$ & & & & & & & \\
\hline $\begin{array}{l}\text { Benefoldal } \\
\text { 1f Done } \\
\text { Properly }\end{array}$ & & & & & $x$ & $\mathrm{X}$ & & \\
\hline
\end{tabular}

\section{Other Comments:}

*Expected effect on the species is an estimate made by Dr. Robert Kral based on his knowledge of the habitat and on knowledge gained from personal field observations. Estimates are "rough" in many instances. Results of practices may be modified depending upon the degree of application, intensity of treatment, nearness to plant communities, etc. A management practice for which no entry is made indicates a lack of sufficient information from which to predict expected results. As observations are made in the field by users of the data, the expected effect will be refined. 
Lesquerella lescurii (Gray) Wats.

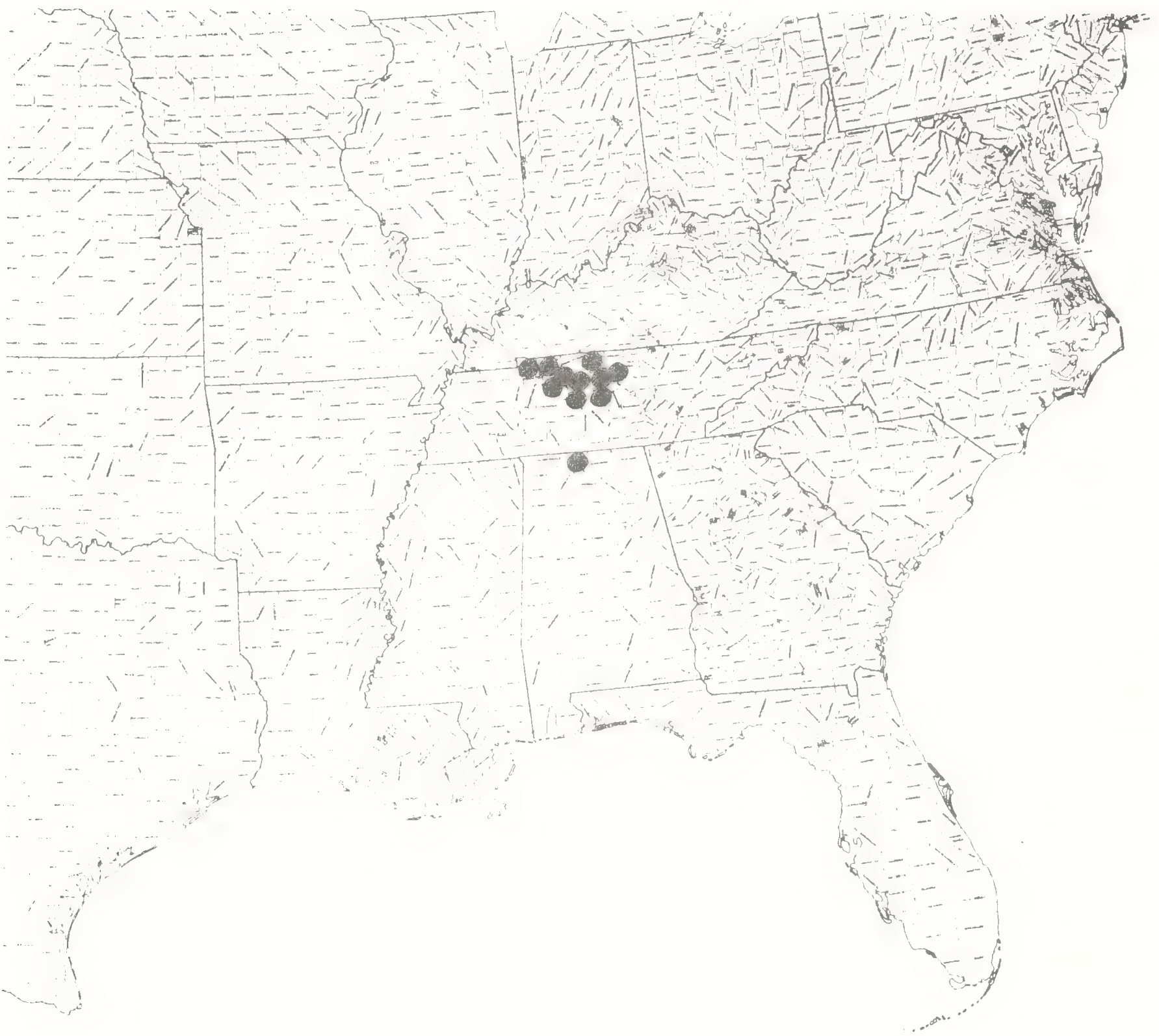


0

-

0 


\section{BRASSICACEAE}

Warea amplexifolia (Nutt.) Sma 11; clasping warea

W. auriculata Shinners

Technical Description

Smooth, taprooted annual.

Stems.--Most1y 3-10 dm. Tong, erect, terete, the lower part brownish with shallow cracks, upwardly becoming greenish, shallowly grooved, branching from the middle, the branches spreading, then arching upward, or unbranched. Leaves.--Alternate, the lowest absent by flowering time, the largest lowest, all rather closely spaced, ovate or elliptic, mostly 2-3 cm. long (progressively smaller and more distant upward on the stem and branches), acute, entire, the bases deeply auriculate-clasping.

Inflorescence.--Racemes rather short and broad, terminal to main stem and branches, the flowers symmetrical, close-set, spreading on slender stalks $1.0-1.5 \mathrm{~cm}$. long.

Flowers.--Sepals 4, linear-spatulate, 5-6 mm. long, erect in bud, later reflexed, greenish with lavender tints. Petals 4, 8-10 mm. long, spreadingascending, lavender-rose, the broadly obovate blades $3.0-3.5 \mathrm{~mm}$. long on slender claws with papillate bases. Stamens 6 , erect or ascending, the slender lavender filament projecting the linear, curved anthers well beyond the petals. Ovary erect, linear, on a stalk fully half as the filaments.

Fruit.--Linear, on spreading stalks, usually curved, $3-5 \mathrm{~cm}$, 1ong, laterally flattened.

Distribution and Flowering Season

Sand ridges, sandy open-pine scrub, central peninsular Florida; flowering from mid-summer through September.

Special Identifying Features

This species is nearest $W$. sessifolia Nash (which see), but the leaves are deeply auriculate-clasping (rather than just sessile) and the petal claws are not as roughened basally. The two do not overlap at all in range.

Habitats and Management Implication

This, like all warea, is a plant of nearly pure sands, is locally abundant in both turkey oak-Longleaf pine and sand pine-evergreen scrub oak types, particularly where growth is open, or where it has been disturbed in the creation of roads or fields. Fire has doubtless long been the most important factor in creating or maintaining the openings Warea amplexifolia occupies. Logging and brushing increases it, and it will move into lands cleared and prepared for pine, persisting there in abundance until the crowns close. 
References

Channel1, R.B. and C.W. James. 1964. Nomenclatural and taxonomic corrections in Warea (Cruciferae). Rhodora 46 (765):18-26.

Shinners, L.H. 1962. Warea auriculata instead of W. amplexifolia of Sma11 (Cruciferae). Sida 1:105-106.

Sma11, J.K. 1933. Manual of the southeastern f1ora, pp. 573-574. Chapel Hil1, N.C. 
SPECIES: \#47 Warea amplexifolia (Nutt.) Nutt.

\begin{tabular}{|c|c|c|c|c|c|c|c|c|}
\hline & \multicolumn{8}{|c|}{ Management Practices } \\
\hline $\begin{array}{l}\text { Expected* } \\
\text { Efiect on } \\
\text { the Species }\end{array}$ & $\begin{array}{c}\text { Prescribe } \\
\text { Burn }\end{array}$ & $\begin{array}{c}\text { Bulldoze } \\
\text { or } \\
\text { Root Rake }\end{array}$ & Bed & Chop & $\begin{array}{l}\text { Thin } \\
\text { over- } \\
\text { story }\end{array}$ & $\begin{array}{l}\text { Cut } \\
\text { Over- } \\
\text { story }\end{array}$ & $\begin{array}{l}\text { Establish } \\
\text { Plantation }\end{array}$ & Graze \\
\hline Destroy & & & & & & & $\mathrm{X}$ & \\
\hline Damage & & & & & & & & $?$ \\
\hline $\begin{array}{l}\text { No Lasting } \\
\text { Effegt }\end{array}$ & & ? & $\perp M A$ & & & & & \\
\hline $\begin{array}{l}\text { Beneficial } \\
\text { If Done } \\
\text { Properly }\end{array}$ & $x$ & & & & $\therefore$ & $\mathrm{X}$ & & \\
\hline
\end{tabular}

Other Comments:

*Expected effect on the species is an estimate made by Dr. Robert Kral based on his knowledge of the habitat and on knowledge gained frou personal field observations. Estimates are "rough" in many instances. Results of practices ray be modified depending upon the degree of application, intensity of treatrient, neamess to plant comunities, etc. A managenent practice for which no entry is made indicates a lack of suficient information from which to predict expected results. As observations are made in the field by users of the data, the expected effect will be refined. 
Warea amplexifolia (Nutt.) Nutt.

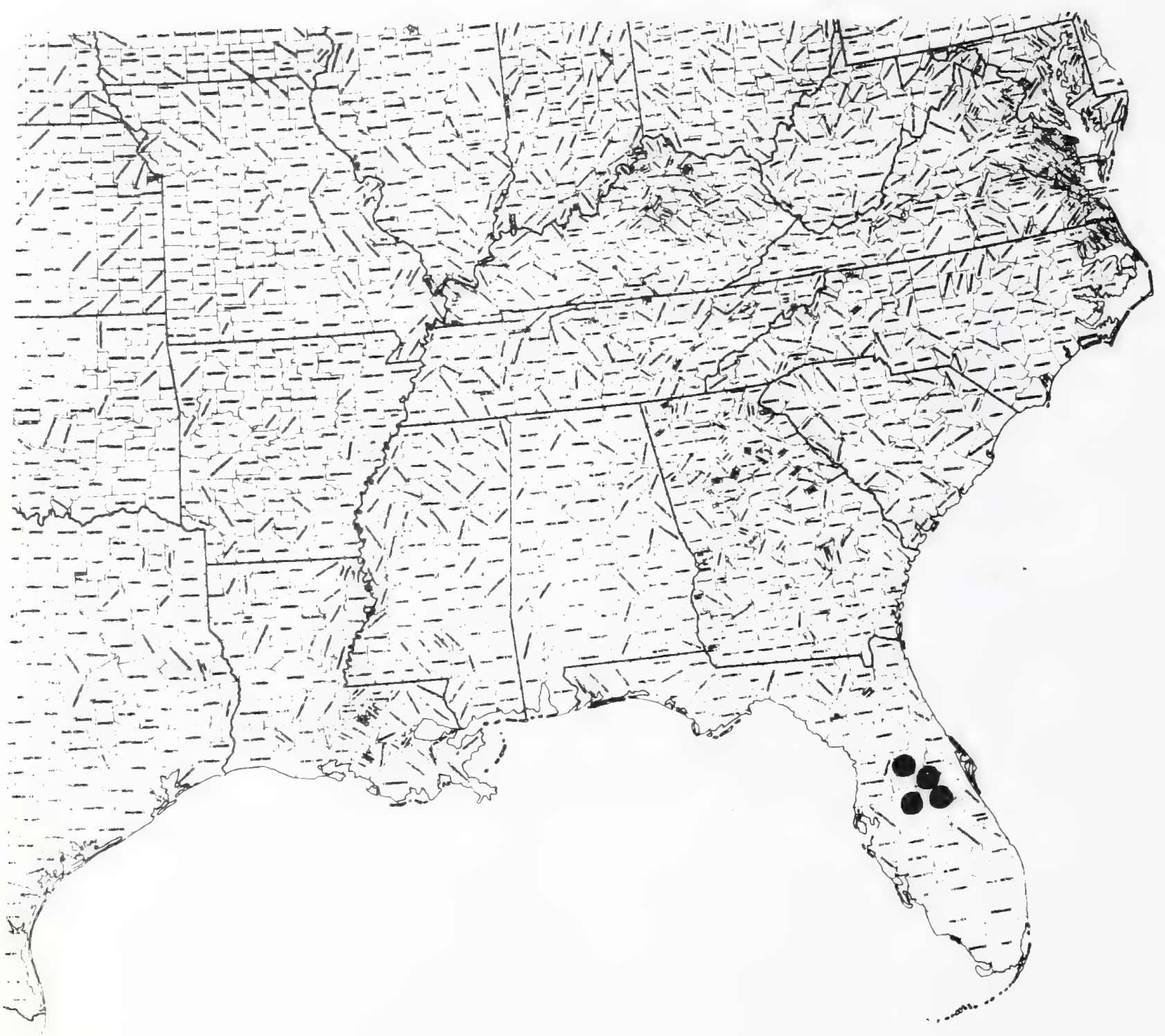




Paper 52

rezE \& nap by:

Robert Rra

\section{CRBSSUTACEZE}

$\frac{\text { Sedurn pusidum Michs. Granite rock stonecrop: }}{\text { Puck'smorpine }}$

rechnical Description

Annual smooth succulent heros Erom Eldmsy, shallow, difivse poots and winter rosertes.

Stems - Shoots solitary or tufted" nostip 8 chl long or less spreading or erect, round in cross section. pale green, simole save in the inflorescence or sometimes with short, densely leafy lateral brarchas below, or much branched with numerous. upsweeping lateral branches.

Leaves.-mumerous, spirally arzanged, the lowest gone by flowering time, al estipulare, al turgid (much thickened) 1 cm long, usually less, ellipic, spatulate, or obovate, greenish.

Elowers - Symetricals about 5 mw broad in a simple cyme or a compound of cymes on slender but fleshy stalks 5 m or less long. Sepals \& (-5) roming a cup with the receptacle, the lobes broadiy trianguar, thinnish, entire, greenish, about $1 \mathrm{~m}$ Iong. Petals 4 (-5). white with thin pumplish IInes or tints, oblong

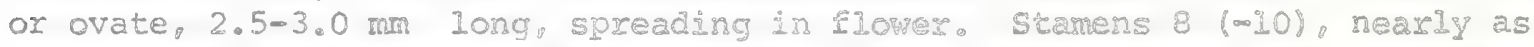
Iong as the petals, the anther very short, dark redashobrown, the filanents lavender-pink-tinted, broadening and flattening toward their bases. spreading. Ovary superior, the campels $4(-5)$, in Elower about 2 mm long. oblong narrowing abrupty to short, slender, beakdike styles, ersct dn bloor, separate to near their bases, growing into spreading foldicles up to fin long. Fruit, seds numerous, broady wedge-shaped, about 0.5 mon Iong, often greenish.

Distriontion and Flowering Season

Granite outcrops, Piedmont and Blue Ridge, North Caroline southward and westward into Georgia. Flowering from March into May.

Special Identifying peatures

Sedum pusillum is the smallest species of the genus in the southeast and differs From the others in its deltoid sepals. Superfieialiy it is much moxe like Diamorpha, amall (2 species), closely related genus of the same outcrop areas. but Diamorphe has its carpel bases Eused and its pinkish petals toward the apex tend to be somewhat pouched. The best way in the iseld to distinguish the two is by the color of foliage, that of Diamospha forming patches strongly tinted with red or maroon. looking like patches of ships rust on the granite, while leaves of the sedum are green.

Habitats and Managenent Implication

Mis small species is usuaIIy Found in full sun becoming very abundant on the granite outcrops whexever there are shallow depressions large enough for water to pool and some thin substrate to wash in and accurrulate. There it will be 
found with other outcrop plants such as Lindernia monticola, Amphianthus pusillus, Diamorpha, Talinum etc. The granite outcrops range from small relatively low patches to considerable domes of hundreds of acres, and all are in the oakhickory-yellow pine belt. The climax forest is mostly oak-hickory with pines occupying the thinnest mantles of soil first. As forest proceeds to occupy plants such as this one of the open granite are shaded out. Logging in such delicate systems as this is not recomended, nor is burning, but in either instance the result might well be to increase their area by reducing shade. The most significant threat to sedum pusillum is through quarrying away of the granite, a process which has already eradicated the species over a part of its range.

Referecnes

Small, J. K. 1933. Manual of the southeastern flora, pp. 585-587. Chapel Hill, N.C. 
SPECIES: \#5I Sedum pusilim Michw. Pucksompine

\begin{tabular}{|c|c|c|c|c|c|c|c|c|}
\hline & \multicolumn{8}{|c|}{ Maragement Practices } \\
\hline $\begin{array}{l}\text { Expected\% } \\
\text { Effect on } \\
\text { the Species }\end{array}$ & $\begin{array}{c}\text { Prescribe } \\
\text { Burz }\end{array}$ & $\begin{array}{l}\text { Bulldoze } \\
\text { or } \\
\text { Root Rake }\end{array}$ & Bed & Chop & $\begin{array}{l}\text { ThLn } \\
\text { over- } \\
\text { story }\end{array}$ & $\begin{array}{l}\text { Cut } \\
\text { Over- } \\
\text { story }\end{array}$ & $\begin{array}{l}\text { Establish } \\
\text { Plantation }\end{array}$ & Graze \\
\hline \multicolumn{9}{|l|}{ Destroy } \\
\hline Damage & & & & & & & & $\mathrm{X}$ \\
\hline $\begin{array}{l}\text { No Lasting } \\
\text { Effect }\end{array}$ & $\mathrm{NA}$ & & & & & & NA & \\
\hline $\begin{array}{l}\text { Beneficial } \\
\text { If Done } \\
\text { Propery }\end{array}$ & & & & & $\because 6$ & X & & \\
\hline
\end{tabular}

\section{Other Comernic:}

* Expected affect on the spectes is an estinate made by Dr. Robert Kral based on his knowledge of the habitat and on knowledge gained from persona field observarlons. Estimates are "rough" in many lnstances. Results of practices may be modified depending upon the degree of application, intensity of treatrent, rearmess to plant comunities, etc. A management practice for which no entry is made indicates a lack of sufficient infomation from which to predict expected results. As observations are made in the field by users of the data, the expected effect will be refined. 
Sedum pusilium Michx.

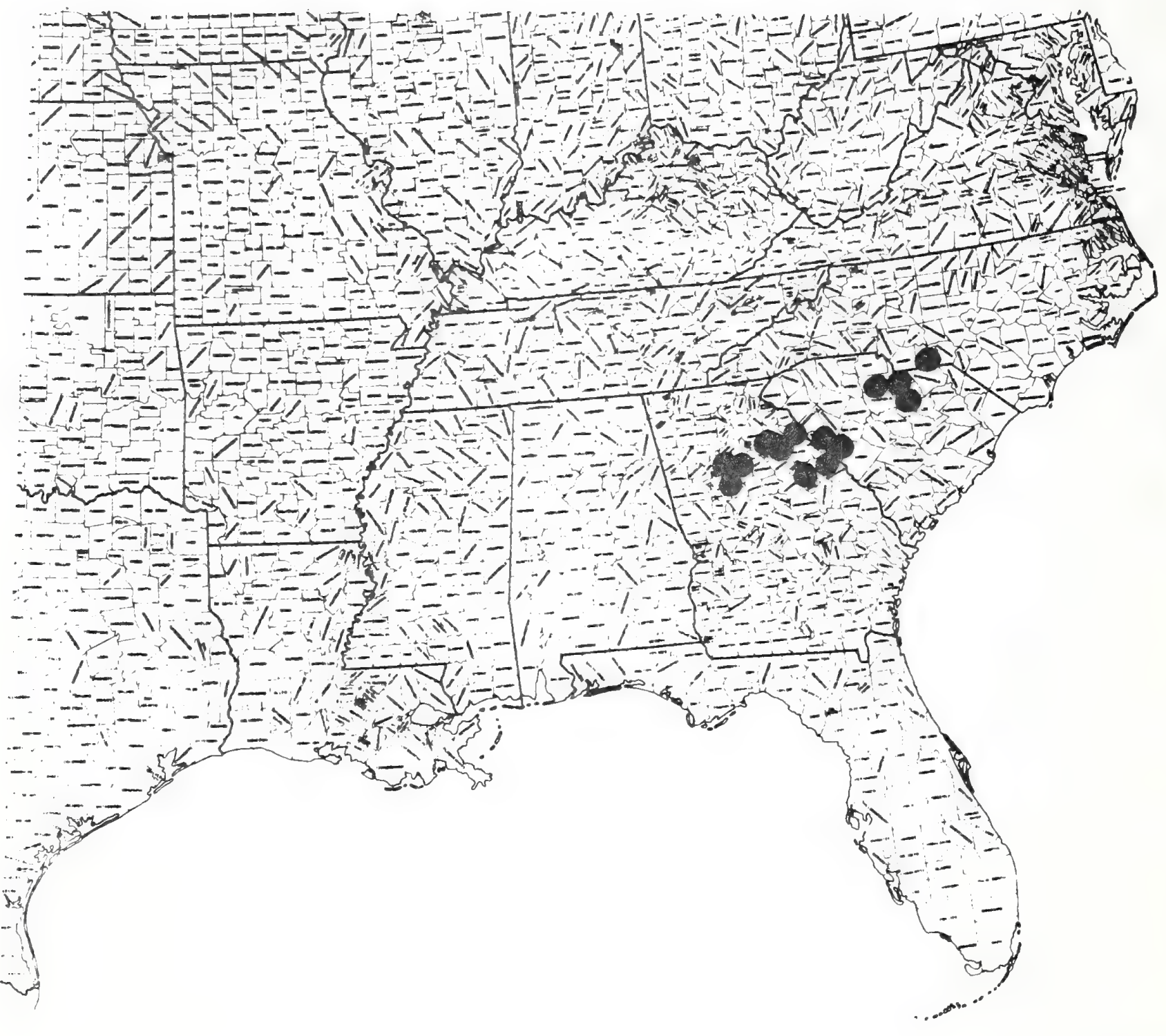




\section{EUPKORBIECER}

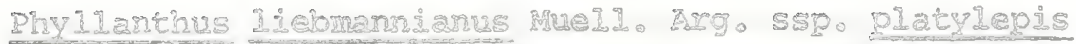

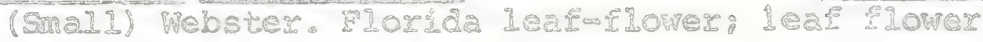
phyilanthus platylards Sneld

\section{Tachnical Description}

Glabrous perenrial herb, the rootstock blachish, slender, wooky, horizontal or with ascendirg or exect braxches irom which come ore or nore slender. erect leary shoots.

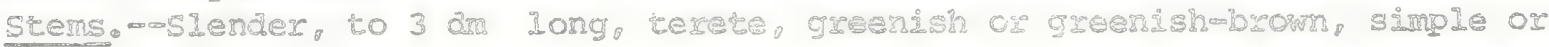
sparingly branched.

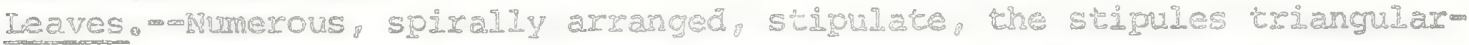
ovate, reddishwbrown, small: Iear blades narrowly obovate, obovate, or oblanceolate, $1-2 \mathrm{~cm}$ long, the apices rounced or obtuse, apiculate (with a small tooth or apiculus!, the margins entires, slightly revolute, the base cuneate, sessile or shostopetiolate, the upper surace daricer green, the lower surface faincly reticulate with a radsed midnerve.

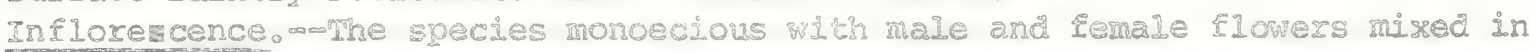
smalI umbel-1ike clusters at some upper nodes, simgle at others: riower stalks 2om 3 m. Iong in flower, slender, spreading, the Eenale one elongaring to 5 mm or more in Eruit.

Iowers, montaninate flowers with sepals b, distinct, obovate or spatulate,

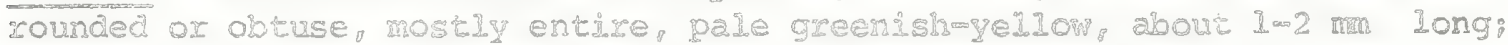
stamens 3 fillaments $0.6-1.0$ m long, joined lnto a colum by filaments at base: anthers about 0.4 mn long. Female Flowers mith calyg lobes 6 g suborbicular ox rhombic, acute, greenish, in imait up to $2.8 \mathrm{~m} 3.5$ rain long. Trưt.m-Capsules depressed-globose, about 4 stom broad. Seeds usually 3 , ovoid, dark brom. minutely and irregularis ridged fverscose'.

Distribution and Flowering Season

Fardwood-palm hammocks, Elacwoods, Gulf Hamock xegion on northwestern perinsular Forida. Flowering all year, but most heavily irs springtime.

special zontifying Features

This is the only species of ghyllantris irithe southeast that has a Female caly\% that becomes foliaceous in the lirute and which ever in bloom is larger

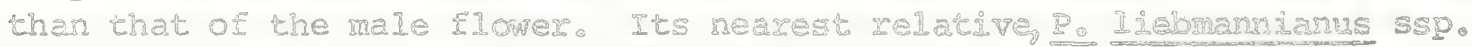
Iiebmannianus, Is across the Guj. of dexico in the Mesican Coastal PIain and in British Ponduras.

Habitats and Management Impizations

The species is one of high hydroperiod, Ene hestrued, highly drained. sometimes alluvial soils derived Erom massive Iimestones of rampa Fomation A typical haitat would be lon hamock, forested by a sajxture of tupelo, sweetrgun, popm ash, cabbage palm, palnetto, magnolia where lt forms clones of considerable 
size in moderate to dense shade. Such forests are still extensive in the Gulf Hammock region on northwestern peninsular Florida from southern Taylor County south into Levy county. P. liebmannianus is also found in forest which has an admixture of slash pine-galberry-saw palmetto. Plants will persist in hamocks which have undergone either heavy logging or grazing, and are sometimes found in full sunlight; however, it is not known how long they will remain in such sites. It has been observed in low Iimerocky pasture along the highway east of Cedar Key, but is more abundant in contiguous areas of unlogged, ungrazed woodland. Fire is a rare factor in these low hamock areas so that there is no information on the response of this species to fire. A McDaniel specimen (S. McDaniel 4778 ) collected from $3 \mathrm{~m}$. n.w. Steinhatchie in July 1964 is from a recently bulldozed area and from a good though local population, some evidence to the effect that the plants might seed into heavily mechanically disturbed sites. However, no specimens have ever been observed in contiguous drained areas.

\section{References}

Small, J. K. 1933. Manual of the southeastern flora, pp. 777-779. Chapel Hill, N.C.

Webster, G. L. 1970. A revision of Phyllanthus (Euphorbiaceae) in the continental United States. Brittonia 22: 44-76. 
SPECIES: \$\$54 Phyllanthus liebmannicanus Muell. Arg。 SSp。 platylepis (Smal1) Webster Ieaf plower

\begin{tabular}{|c|c|c|c|c|c|c|c|c|}
\hline & \multicolumn{8}{|c|}{ Management Practices } \\
\hline $\begin{array}{l}\text { Expected* } \\
\text { Effect on } \\
\text { che Spectes } \\
\end{array}$ & $\begin{array}{c}\text { Prescribe } \\
\text { Burm }\end{array}$ & $\begin{array}{c}\text { Bulldoze } \\
\text { or } \\
\text { Root Rake }\end{array}$ & $B a d$ & Chop & $\begin{array}{l}\text { Thin } \\
\text { over- } \\
\text { story }\end{array}$ & $\begin{array}{l}\text { Cuc } \\
\text { Over- } \\
\text { story }\end{array}$ & $\begin{array}{l}\text { Establish } \\
\text { Plantarion }\end{array}$ & Graze \\
\hline Destroy & & 5 & $y$ & 8 & & & & \\
\hline Damage & & & & & & $\mathrm{x}$ & & \\
\hline $\begin{array}{l}\text { No Lasting } \\
\text { Effect }\end{array}$ & $\mathrm{NA}$ & & & & & & & isonous \\
\hline $\begin{array}{l}\text { Beneilcial } \\
\text { \&E Done } \\
\text { Properly }\end{array}$ & & & & & $\mathrm{x}$ & & & \\
\hline
\end{tabular}

\section{Other Compents:}

*Expected effect on the species is an estimate made by Dr. Robert Kral based on his knowledge of the habitar and on knowledge gained from personal field observations. Estimates are "rough" in many Linstances. Results of practices ray be modified depending upon the degree of application, intensity of treatment, nearmess to plant comunities, ecc. A management practice for which no entry is made indicates a lack of sufficient infomation from which to predict expected results. As observations are made in the field by users of the data, the expected effect will be refined. 
Phyllanthus Iiebmannianus Muel1.-Arg. ssp. platylepis (Small) Webster

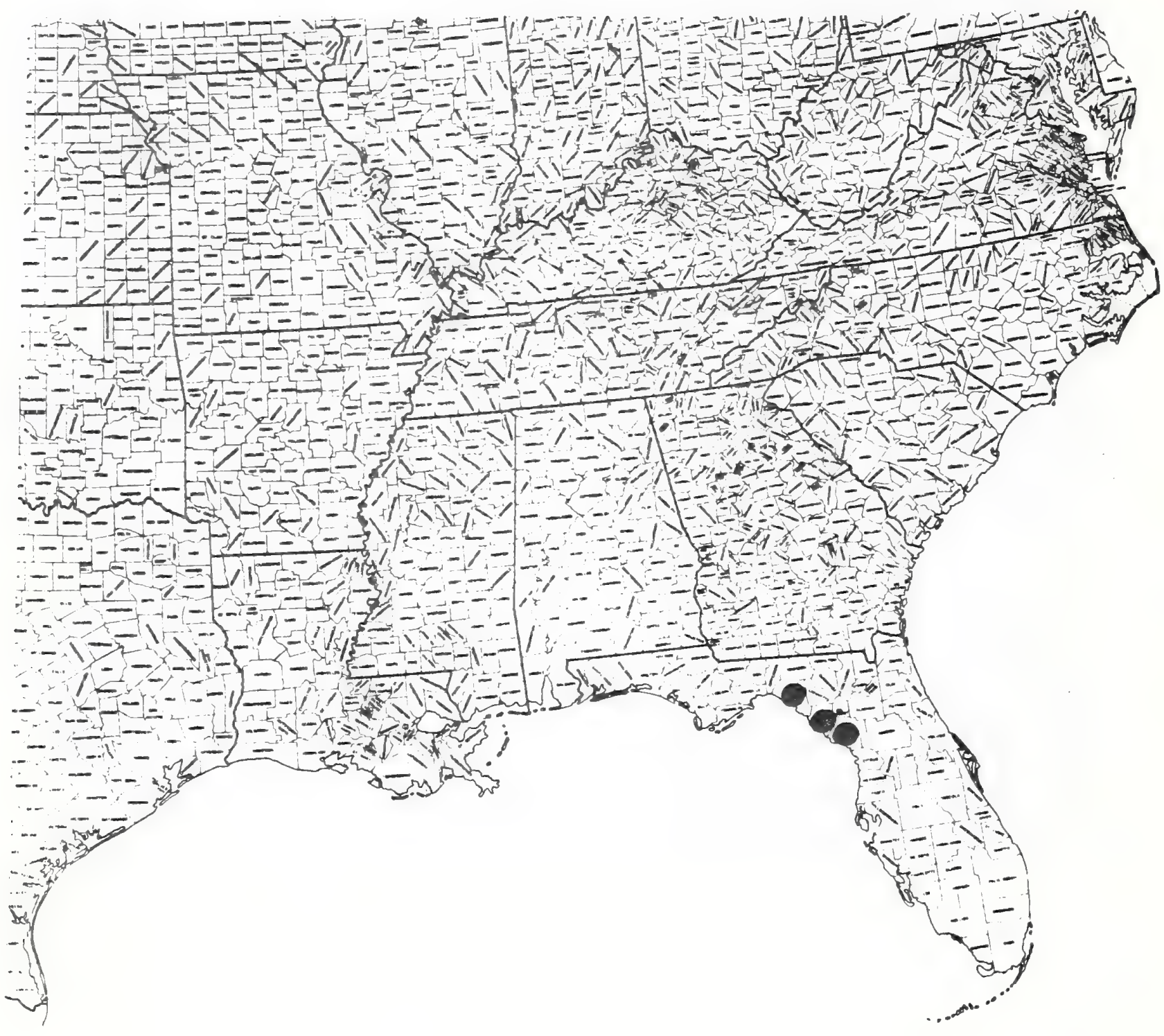


Paper 56

Teqre \& nisp by:

Robart Tral

\section{TABACEAE

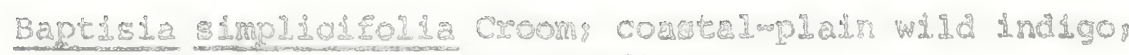

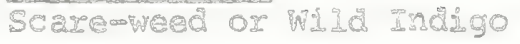

Technicad Description

Perennial legune Fror a knotty stout rootitock.

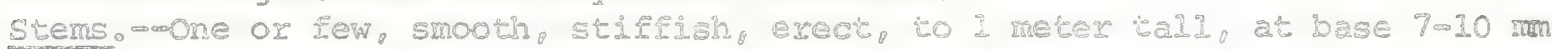

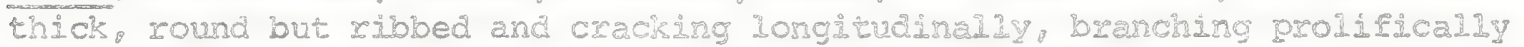
from neas the base to rom a bushy leafy broad crom . bhe branches somemat zig-zag, tan or with redaishabrom tints.

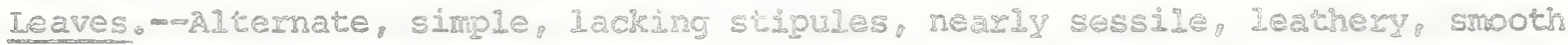
ovate, broady eliptic ox obovate, 5 mo cm Iong. obtuse but apiculate, entire and revolute, the bases broadjy acure or broadi cunste the upper surface dark green. Iustrous leaves dry black? the lowex suriece much palex and finely teticulate.

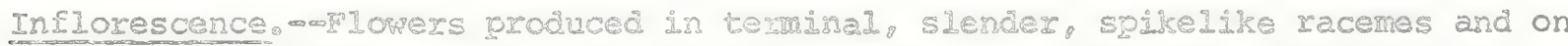

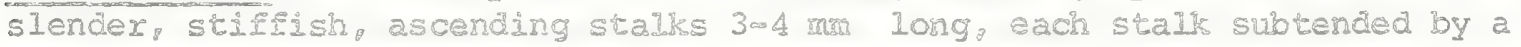
small. narrowly lanceolate bract.

Elowers wCalyr broady beld-shaped, smooth. about 5 m long, the 5 lobeslobes broadIy or narrowIy sxiangudar, about as long as the calys taib corolla clear gellow, 1.3-1.5 cr 1ong, the standard blade about as broad as lorg or broader. erect, somewhat shorter than the wing and kes petals whis project Eorward. the reel strongly curved upward. Stamens 10 , al separate smooth. Fruit when young with cobuebly white haixs beconing smooth and nearly black when ripeg on a stipe $45 \mathrm{~m}$ losg the narrowig ovoid body abovi $10 \mathrm{~mm}$ long, with a persiscent slender style beak Fuly as long or longer.

Distribution and Flohering season

Sandy pinelands, northwestern Lorida. Fowerang Iato JuIy. August. Special Identiping Featuxes

mis and two other species. B. perfolict and Be arachrifera are the only south eastem Hid Indigos which lack sijpules and at the same tine have simpie leaves. Bo arachnifera, siruiar in inflorascence has ovate foliage covered with cobwebby hairs: B. perioliata has a broaser perfoliate leaf and produces Its Elowers singly in leaf asils. NeIther of these overdag the range of B. S1molicifolia.

Habitars and Managenent Implicator

This species is always associated rith Iorgleaf pinewdeciduous scrub oak. It may be on sand ridges or in the driex ilats, sometimes interspexsed with saw palmetto, gallberry and a variety of heaths such as Vaccinium Gaylussacia. KaInja anc Iyonia. of the grasses, wiregrass is its comonest associate.

The plants are not infrequent in sapling or larger sized plantations seeming to seed in from adjacent ratural stands. site preparaton involving clearcutting or prescribed burning tends to increase it, togebher with ocher relatively shade 
intolerant forbs but as plantations form dense crowns closure this Baptisia is not found. Common mechanical methods of preparation involving discing, raking, chopping, etc. eliminate this plant. Optimal habitats are recently burned pineland savanna, where, in Leon, Liberty and Gadsden counties, the species is locally abundant.

References

Lairsey, Mary M. 1940. A monograph of the genus Baptisia. Ann. Mo. Bot. Gard. 27: 119-224.

Small, J. K. 1933. Manual of the southeastern flora, Pp. 674-678. 
SPECIES: $\quad$ H56 Baptisia Simplicifolia Cron! Scare-weed or Wild intigo

\begin{tabular}{|c|c|c|c|c|c|c|c|c|}
\hline \multicolumn{9}{|c|}{ Management Practices } \\
\hline $\begin{array}{l}\text { Expected* } \\
\text { Effect on } \\
\text { the Species }\end{array}$ & $\begin{array}{c}\text { Prescribe } \\
\text { Burs }\end{array}$ & $\begin{array}{l}\text { Bulladoze } \\
\text { or } \\
\text { Roor Rake } \\
\end{array}$ & Bed & Chop & $\begin{array}{l}\text { Thin } \\
\text { over- } \\
\text { story }\end{array}$ & $\begin{array}{l}\text { Cut } \\
\text { Over- } \\
\text { story }\end{array}$ & $\begin{array}{l}\text { Establish } \\
\text { Plantation }\end{array}$ & Graze \\
\hline Destruy & & $x$ & & $x$ & & & $\mathrm{X}$ & \\
\hline Damage & & & $x$ & & & & & \\
\hline $\begin{array}{l}\text { No Lasting } \\
\text { Effect }\end{array}$ & & & & & & & & \\
\hline $\begin{array}{l}\text { Beneficial } \\
\text { If Done } \\
\text { Properly }\end{array}$ & $\mathrm{X}$ & & & & $\mathrm{Y}$ & $x$ & & \\
\hline
\end{tabular}

\section{Other Comments:}

*Expected effect on the species is an estimate made by Dr. Robert Kral based on hia krowledge of the habitat and on knowledge gained from personal field observations. Estinates are "rough" in many instances. Results of practices may be modified depending upon the degree of application, intensity of treatnent, rearness to plant comuties, etc. A management practice for which To entry is wace indicates a lack of sufficienc information from which to predict expected results. As observations are made in the field by users of the data, the expected effect will be refired. 
Baptisia simplicifolia Croom

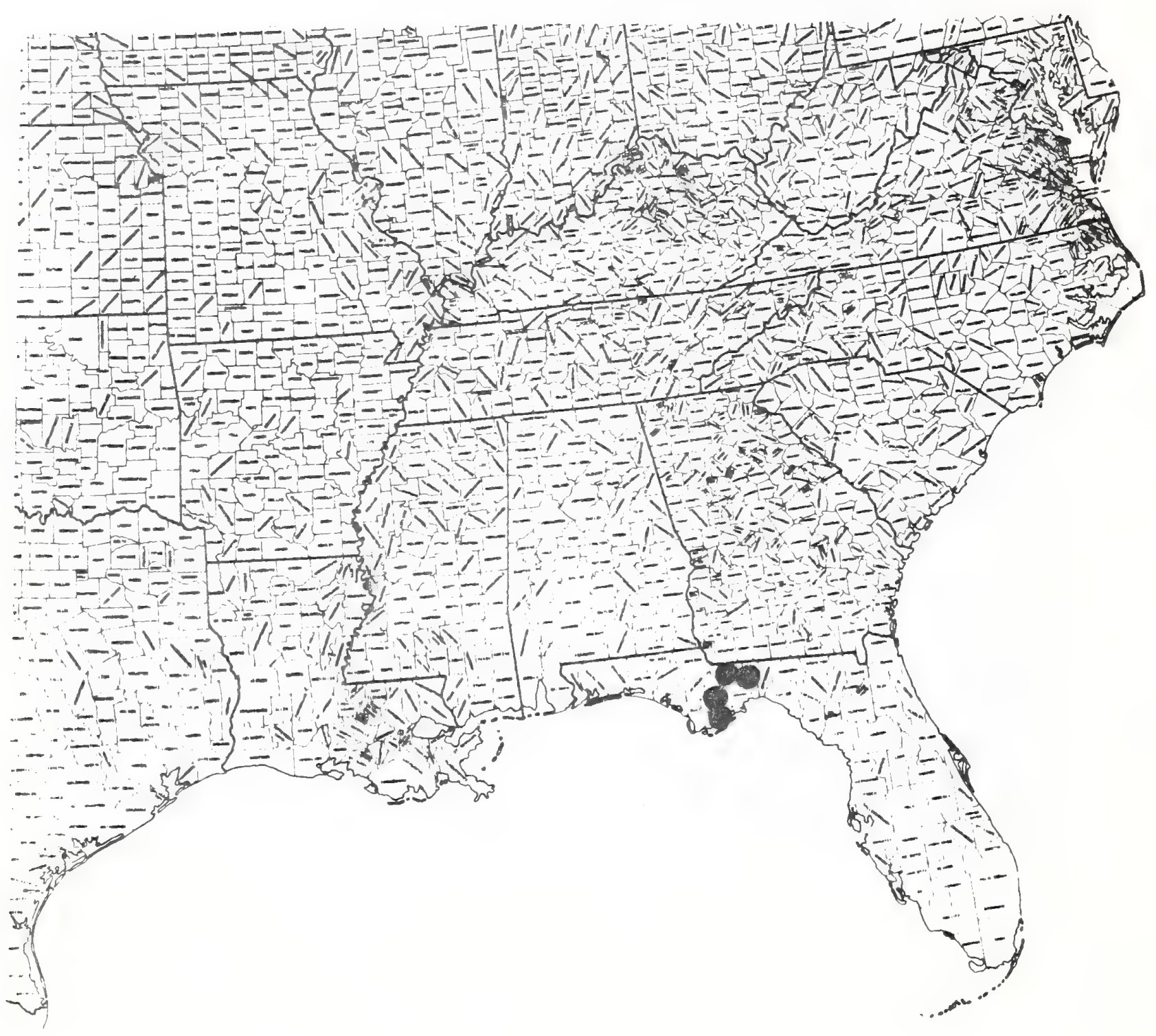




\author{
ASTERECEA

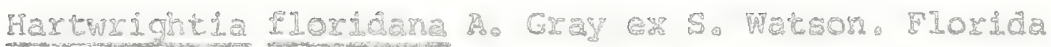 \\ hastwredghts
}

\title{
Technical Description
}

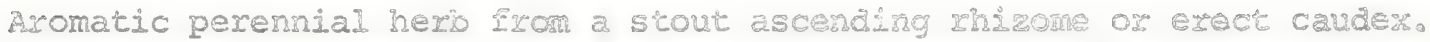

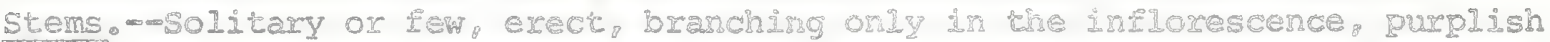
below, greenish toward midile and above, dotted with glistening small glands. Leaves. - moth in rosettes (Irom overwintering of the rosette and lower ones largest, the blacies oblong, Idrearmelidptic to elliptic or oblanceolate. $8 \times 25 \mathrm{~cm}$ long $1-5 \mathrm{~cm}$ broad on slender petioles from $1 / 3$ as long to nearly as $20 n g$, the apices nargowed bur roumed, the margins entire, the bases cuneate or attenuate, bot's suriaces dull greer, glabrous, glanadotted. Stem leaves gradually diminishing uporard, alternate, ascending, becoming sessile, linear, grading into scattereb inflorescence bracts. Inflorescence, - A compound, conves cyme of cymules, the branches arching upward candelabra like, shencer but stiff, elongate. Heads several to numerous per cymule, on glanduIar peduncies from lorger than to bout aE Iong as the heads. Flowering heads with involucres campanulete, abour ans am high or with flowers, $7-8 \mathrm{~mm}$ high and about $1 \mathrm{~cm}$ across. Recepsacle naked. Bracts of involucres in nearly 1 serdes, with a reu shorter ones outside, the longest oblong, blunt, entire, greenish, glandwotted, slightiy spreadirge.

Elowers, mil discold the corollas narrowly bell shaped from a short tubo, about 3 m. high, the slightly spreading lobes crianglar, the surface gland-cotted. pale lavencier to white or pink. Pappus a crom or short, naprow bristles or absent.

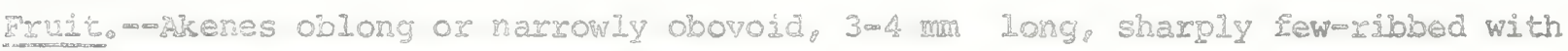
the intervals concave, gland-cotted.

Distribution and lowexing season

Sandy peat, geat or peat muck of low elearings in pine flatwoods, pineland swamps, or bogs, soucheastern Georgia southward to southern peninsular Florida. Flowering October through Noveraber.

Special Identifying Features

This species is monotypic, supericicialy resembing some Buparoriuns, but different in pappus and akere character, in aromatic character, as piell as ir leaf. As Swall (1933) commented, the toliage In genaral appearance most resembles that of the sea lavender Limondun.

fiabitats and Management Implication

This species is always on wet, peatwenciched, usually sphagnous substrates, mostiy in fuI sunlight or light shade. A typical habitat would be set in slash pine lor longleafy-saw palmetrongallberryotitl. Comon associated herbs would be those of bogs, thus mostly grassmsedge, with an admirture of eriocauls, xyrids, 
bog orchids, pitcher plants (particularly S. minor), various fall flowering composites. It will often be amongst shrubby competition made up of gallberry (both species), Myrica, Magnolia, Persea, Cyrilla and various shrubby heaths, particularly Vaccinium, Lyonia.

Its range is diminishing in that habitat is lost through systematic drainage and conversion to pine plantation or to improved pasture. I have seen none where cattle are admitted, though it may be abundant just on the other side of a pasture fence. Iogging of the overstory pine, including clearcutting, would favor the species. Of the various site preparations, dozing, root raking, chopping would eliminate it; bedding would have the least effect until such time as the pine crowns close. The species is probably maintained naturally through periodic fires which would remove competing shrub and grass.

References

Gray, A. 1898. Proceedings Amerc. Acad. Sci. 23 (Florula): 265.

Small, J. K. 1933. Manual of the southeastern flora,p.1318. Chapel Hill, N.C. 
SPECIES: H68 Hartwrightia floridana A. Gray ex S. Watson。N.C.N.

\begin{tabular}{|c|c|c|c|c|c|c|c|c|}
\hline & \multicolumn{8}{|c|}{ Managenenc Practices } \\
\hline $\begin{array}{l}\text { Expected* } \\
\text { Effect on } \\
\text { the Spec1es }\end{array}$ & $\begin{array}{c}\text { Prescrive } \\
\text { Bums }\end{array}$ & $\begin{array}{c}\text { Bulldoze } \\
\text { or } \\
\text { Roor Rake }\end{array}$ & $B \in d$ & Crop & $\begin{array}{l}\text { Thin } \\
\text { over- } \\
\text { story }\end{array}$ & $\begin{array}{l}\text { Cut } \\
\text { Over- } \\
\text { scory }\end{array}$ & $\begin{array}{l}\text { Establish } \\
\text { Plantarton }\end{array}$ & Graze \\
\hline Destroy & & $\mathrm{X}$ & $x$ & 8 & & & $\mathrm{X}$ & \\
\hline Damage & & & & & & & & $\mathrm{X}$ \\
\hline $\begin{array}{l}\text { No Lasting } \\
\text { Effect }\end{array}$ & & & & & & & & \\
\hline $\begin{array}{l}\text { Beneficlal } \\
\text { If Done } \\
\text { Properly }\end{array}$ & $\mathrm{X}$ & & & & $\mathrm{X}$ & $\mathrm{X}$ & & \\
\hline
\end{tabular}

\section{Other Comments:}

*Expected effect or the species is an estimate made by Dr. Robert Kral based on his knowledge of the habltat and on knowledge gained from personal field observacions. Estimates are "rough" in many instances. Results of practices may be modiried depending upon the degree of application, intensity of treatment, neamess to plant comunities, etc. A managenent practice for which $s 0$ entry is made indicates a lack of suffictent information from which to predict expected results. As observations are made in the fleld by users of the data, the expected effect will be refined. 


\section{a}

Hartwriqhtia floridana Gray ex Wats.

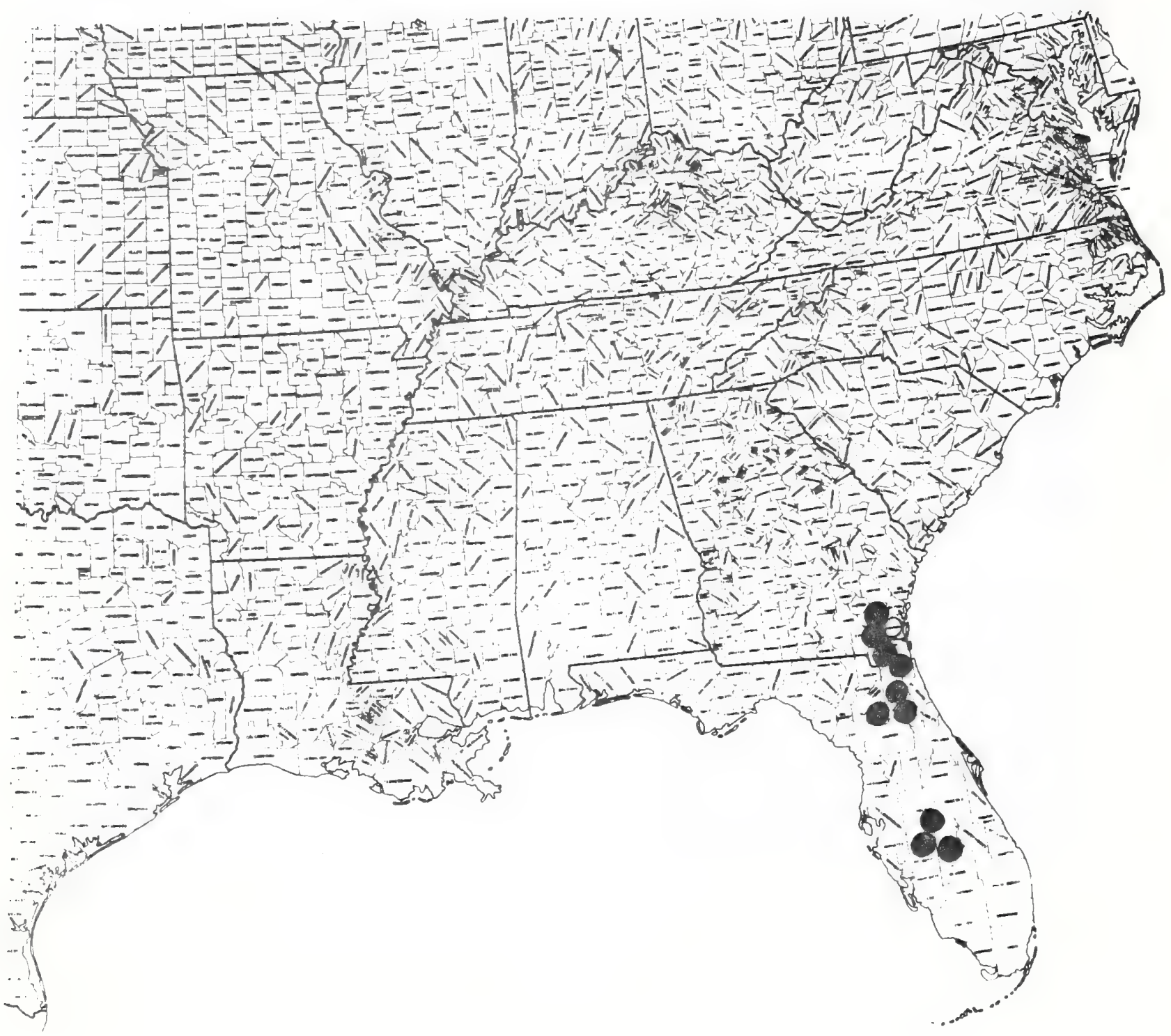




\section{ASTERACEAE}

Helianthus eggectij. Smal. Surniower

Technical Description

Tall (to 2.5 meters) perennal from a short, thicis cardes, perensting by shallow elongate, Fleshy rhizomes, the whole plant swoothish except for some slight roughening of the upper lear surfaces.

Stems,-Erect, terete, usually purplish or redisis at least a'sove the middle, stiffish but slender (at base hardly thicker than 1 cm . solitary or few. rarely branched save above the midde.

Leaves.mosty ovate to broady lanceolato, the 2axgest $10=20 \mathrm{~cm}$ long. alternate or opposite (above) the lowermost gone by fowexIng time, the longest at about mid-stem, the apices narrowly acute or acuminate, the nargins entire, undulate or distanty and coarsely lowmoothed, somewhat revolute, the bases from rounded to narrowly or broadly cuneste or acute, the petioles 5 min long or less, the upper surfaces smoothish or sparsely scabrid the lower surfaces glaucous. Stem leaves progressively reduced ir size above midale into the inflorescence.

Inflorescence-m-Corpound, of few to several elongate upwardly arching branches, these with a scattering of distant, opposite leaves and terminating in one to few heads. Heads with slightly elevated chaffy receptacles, mostly $2.0-2.5 \mathrm{~cm}$ across the involucre and $1.5 \mathrm{~cm}$ from base to apes of Involucre: phyllaries (bracts) marrowly lanceolate or lance linear, loosely spreading on spreading ascending in several sexies, the outermost shortest the mid and inner ones mostiy $1.0-1.5$ cm. long, narrowly acuminate, ciliate, greenisho Flowers.-Ray florets about 10, the biades sterile, oblong, about 3 cri Iong, a xidhyellow trhe whole head in bloon ca, 6-8 crn broads Dise florets slightly longer than the acute or shor acuainate, elilate charf, the corollas ca. $5 \mathrm{~mm}$ long, with a short narsow tube and a narrowly caripanulate throat producing 5 siightly spreadingwtriangular lobes. Pappus of $2-3$ lanceolate or subulate deciduous ciliate or fimoriate scales.

Fruit, - Aikene narrowly obovold, prismatic, 3a4mangled, ca, $4-5$ man Iong, smooth, deep brown.

Distribution and Flowering Season

Sands, sandy-clays, cherts, and gravels of open uplend woods, midale kentucky southward into northwestem Alabana. Elowering August through September.

Special Identifying Eeatures

This species has habit, stem and foliage much like Mo glaucophyllus, an Appalachian species from eastem Tennessee and western North Carolina but its heads are larger and its Foliage somewhat harsher. It resembles also $\mathbb{1 1}$. laeviogeus, but has thicker rhizomes and larger heads. There appear to be no close relatives to it within its somewhat narrow range. 
A typical habitat would be open oak-hickory upland woods, usually in small natural or artificial clearings or underneath open stands. It is always on well drained soils, these usually gravelly with a high silicon content from weathered chert, and usually rather low in moisture. Its late summer herbaceous associates are other sunflowers such as H. microcephalus, H. mollis, H. august-

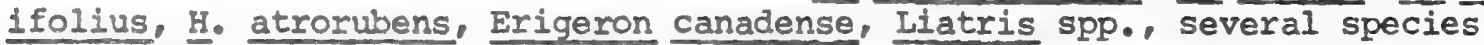
of goldenrod, aster, etc., Iechea, many Iespedeza and Desmodium. Understory woody plants consist of Smilax, Rubus, Vaccinium (both high and low bush). As mentioned above, the overstory when present is usually a mixture of several species of upland oak and hickory, with an admixture of Nyssa, Diospyros, Ulmus alata, Oxydendron, Cornus. The plants are most likely to be found in the western Highland Rim of middle Tennessee, an area which once was much given to cotton culture or to unfenced pasture in the past but much of which subsequently was allowed to go back to ungrazed forest of a low quality. Much fire used to occur in even the recent past, fire which maintained a savanna aspect in large areas. Subsequent protection from fire has doubtless reduced the area of this and several other species of herbs in that heavy resultant stands of oaks have sparse herbaceous cover beneath, or go over to much braken fern and vaccinium.

Thus prescribed burn would (if timed properly) increase this species. Most site preparation methods would not effect $\mathrm{H}_{\text {. }}$ eggertil adversely providing contiguous areas of seed source were left undisturbed. Cutting or thinning of overstory would increase this species by admitting light and reducing competition. A closed hardwood canopy would shade it out. Grazing eliminates the species.

\section{References}

Small, J. K. 1933. Manual of the southeastern Flora, p. 1437. Chapel Hill, N.C.

Heiser, C. B. 1969. The north American sunflowers (Helianthus), Mem. Torr. Bot. Club 22 (3): 1-218.

Beatley, J. C. 1963. The sunflowers (genus Helianthus) in Tennessee Jour. Tenn. Acad. Sci. 38: 135-154. 


\section{SPECIES: \#69 Helianthus egcjerti Small Sunflower}

\begin{tabular}{|c|c|c|c|c|c|c|c|c|}
\hline & \multicolumn{8}{|c|}{ Management Practices } \\
\hline $\begin{array}{l}\text { Expected* } \\
\text { Effect on } \\
\text { the Species } \\
\end{array}$ & $\begin{array}{c}\text { Prescribe } \\
\text { Burn }\end{array}$ & $\begin{array}{c}\text { Bullare } \\
\text { or } \\
\text { Root Rake }\end{array}$ & Bed & Chop & $\begin{array}{l}\text { Thin } \\
\text { over- } \\
\text { story }\end{array}$ & $\begin{array}{l}\text { Cusc } \\
\text { Over- } \\
\text { story }\end{array}$ & $\begin{array}{l}\text { Establish } \\
\text { Plantation }\end{array}$ & Graze \\
\hline Dostroy & & $\mathrm{x}$ & $\mathrm{x}$ & $\mathrm{x}$ & & & $x$ & \\
\hline Damage & & & & & & & & $x$ \\
\hline $\begin{array}{l}\text { No Lasting } \\
\text { Effect }\end{array}$ & $x$ & & & & & & & \\
\hline $\begin{array}{l}\text { Bersicial } \\
\text { 1E Done } \\
\text { Properly }\end{array}$ & & & & & $x$ & $X$ & & \\
\hline
\end{tabular}

\section{Other Coments:}

* Expected efrect on the epecies Is an escimate made by Dr. Robert Kral based on his knowledge of the habitat and on knowledge galned from personal field observations. Estimates are "rough" in many instances. Results of practices may be modifled depending upon the degree of application, intensity of treatment, neamess to plant comunties, etc. A management practice for which mo entry is made indicates a lack of suficient information from which to predict expected results. As observations are made in the fleld by users of the data, the expected effect will be refined. 
Helianthus eqgertii Small

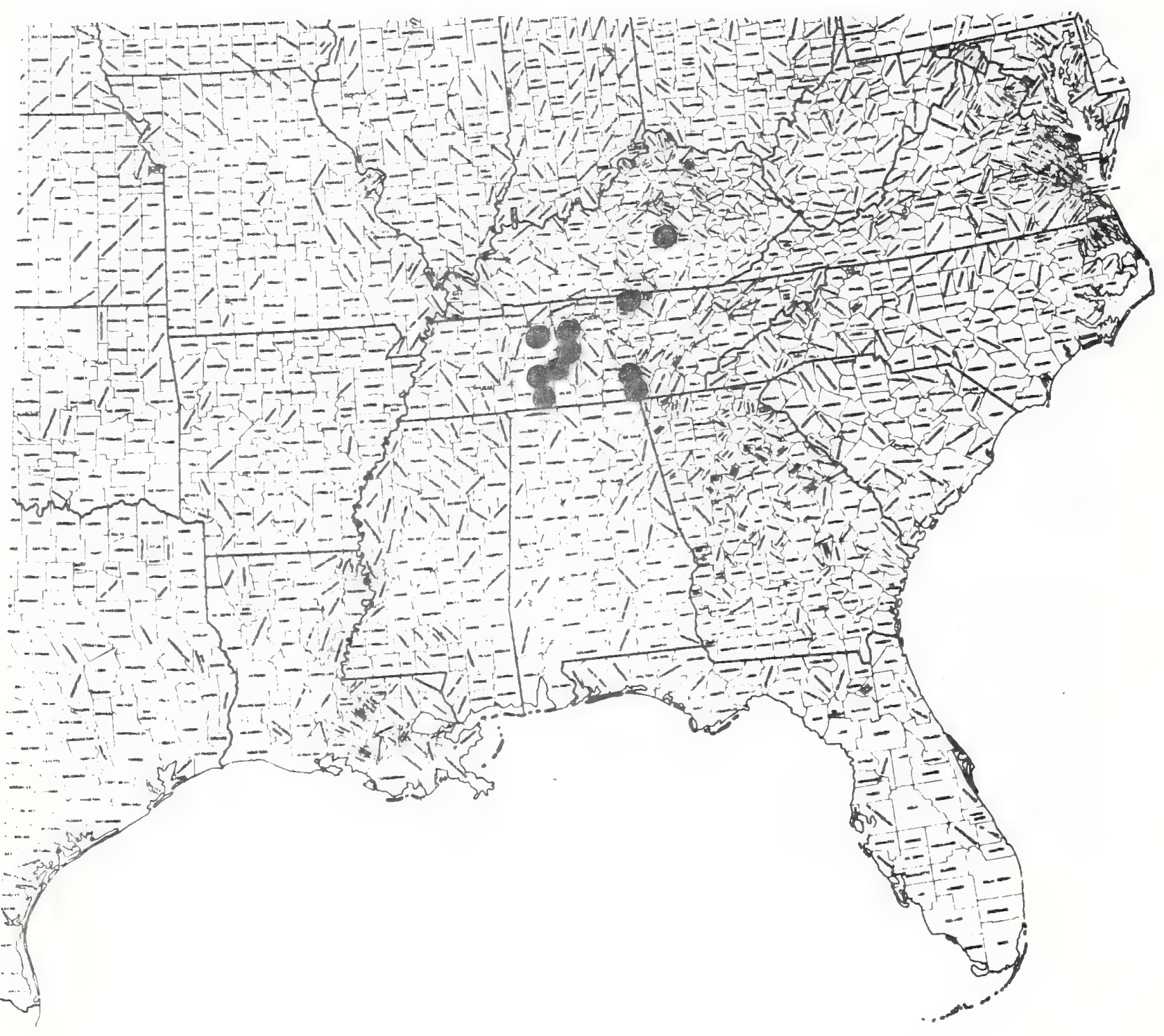


Paver 70

Tert a 2 ap by:

Robert $\mathbb{R r}^{2} \mathrm{I}$

\section{ASTERECEE}

Hecerotheca Elenuosa (Nash) Hams Brat goldenmaster: N.C.N. ChIYsopsis Elexuos a Wash

Technical Description

Perennial herb, several sloots 30 mo cm long axising Eron a turt of short-inear overwintering leaves, most of these primary shoots spreading outward briefly. then arching upward (decumbent).

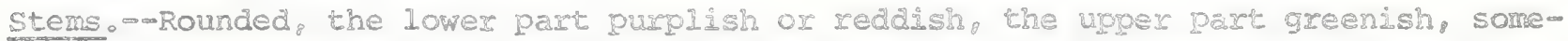
what zig-zag, siender but stifilsh, the surpees wostlg with appressed. long, weak, whitish hairs. Primary shoots ustaliy branched from ald or most of the upper and middle (sometimes even lower) nodes, these branches arching upward ahso. thus the entire plant often quite Euldo

Ieaves.-Alcernate, numerous, 1ineas, oblong ianceolate, or oblanceolace, the longest mostly $5-8 \mathrm{~cm}$ Long, mosty under 1 cro broad, spreading or ascending, the lowermost scalelike, the lower leaves ofter dried and gone by flowering time, the longest lowest, then progressively shorter lato the inilorescence, grading finally into the bracteal leaves of the long peduncles, these short linear and under $1 \mathrm{~cm}$. Iong.

Inflorescence meads several to numerous, each one erect on siender, elongate, cobwebby-hairy peduncle, involueres bbout $1 \mathrm{~cm}$ high and less than $1 \mathrm{~cm}$ broad, the phyllaries (bracts) nunerous, linear, in several loosely overlapping series, the outemost smaIIest, short with scarious margins, the apes sinderly acuminate the sureaces eglandular or with sparse, long, mostly appressed hadrs. Sugface op receptacle smooth. Flowers.--Ray flowers stevile, about 10, the ligules bright yeliow, spreading,

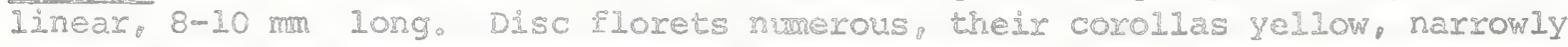
tubular with erect, short-uriangular lobes: papprs $5 \mathrm{~m} 7 \mathrm{~m}$ long of several capiliary antrorsely (upwardiy) barbedate bristles. Fruit.-Akene narrow Ly cylindrical, about 3 m long. appressedwhiry.

Distribution and Flowerirg season

Sandy clearings, mostiy in pinelands, northwest Florida flowering in september and october.

\section{Special Iảentifying Features}

This localized species is in the section Pitropsis of a genus whose 1 imits are still argued by taxonomists. Nost of the Pityopsis are species with Iinear. silvery or pale pubescent, monocotwike, leaves, Ir size character of the flowering head, this species is closest to I graminifoliag a comon species in pinelands through most of the southeast: however Ho Ilexuosa has shorter, sometimes Ealcate, rather than straight, leaves, a lower habit and zigmag stems. Indeed, it superficially is most like Heterotheca Ealcete (Pursin) 踏m, a plant of similar habitat in coastal situations From Mass. souti Into New Jersey differing from that species in minor (though consigtenc) characterg such as pubescence. head size, akene. 
Habitats and Management Implication

H. flexuosa 18 always found on deep sands near the pregent coast, usually in sandy clearings amongst sand pine, slash pine and/or longleaf pine, there sometimes in considerable abundance. It may often be associated with several other species of Heterotheca, and other herbs of such dry sandy sites such as Polygonella,

Ifatris Chapmanii L. provincialis, Petalostemon caroliniense, Bulbostylis, varlous Panicum (sect. Dichanthelium) and Andropogon. It is frequently amongst shrubs such as Conradina, Clinopodium, Myrica, and various shrub oaks, particularly 2. myxt1folla, \&. chapmanil, 2. minima.

This is a plant of full sunlight or at most, light shade. Removal of enroaching overstory will encourage its spread. It will seed into areas within its range where site preparation involving complete removal of all cover has taken place. Prescribed burning would have an effect difficult to measure here in that this is a species of open, sandy sites where such burning is not really applicable. Natural fires have doubtless in the past been beneficial to this species in removing some competing shrubby and overstory woody vegetation.

References

Bowers, Frank D. Unpublished Thesis on Heterotheca - Pityopsis sect. University Tennessee, Knoxville.

Dress, W. J. 1953. A revision of the genus Chrysopsis in eastern North America. (Unpublished Ph.D. thesis at Cornell)

- 1954. Two new Flortdean species of Chrysopsis Ell. (Compositae). Gentes Herbarium 8:404-409.

Harms, Vernon Io 1969. A preliminary conspectus of Heterotheca sect. Pityopsis (Compositae). Castanea 34: 402-409.

1974. A preliminary conspectus of Heterotheca sect. chrysopsis. Castanea 39: 155-165. 
SPECIES: \#70 Heterotheca flexuosa (INash) Hans. MJ.C.N.

\begin{tabular}{|c|c|c|c|c|c|c|c|c|}
\hline & \multicolumn{8}{|c|}{ Management Practices } \\
\hline $\begin{array}{l}\text { Expected* } \\
\text { Effect on } \\
\text { the Species }\end{array}$ & $\begin{array}{c}\text { Prescribe } \\
\text { Burs }\end{array}$ & $\begin{array}{l}\text { Bulldoze } \\
\text { or } \\
\text { Roor Rake }\end{array}$ & Bed & Chop & $\begin{array}{l}\text { Thin } \\
\text { over } \\
\text { story }\end{array}$ & $\begin{array}{l}\text { Cut } \\
\text { over- } \\
\text { story } \\
\end{array}$ & $\begin{array}{l}\text { Establish } \\
\text { Plantation }\end{array}$ & Graze \\
\hline Destroy & & & & $x$ & & & $x$ & \\
\hline Damage & & $\mathrm{x}$ & $\mathrm{X}$ & & & & & \\
\hline $\begin{array}{l}\text { No Lasting } \\
\text { Effect }\end{array}$ & & & & & & & & \\
\hline $\begin{array}{l}\text { Beneficlal } \\
\text { LE Done } \\
\text { Properly }\end{array}$ & $\mathrm{x}$ & & & & $y$ & $\mathrm{X}$ & & \\
\hline
\end{tabular}

\section{Other Conumenes:}

tExpected effect on the specieg Is an estinare made by Dr. Robert Kral based on hia knowledge of the habitat and on knowledge galned from personal field observations. Estirates are "rough" in many instances. Results of practices may be modified depending upon the degree of application, incensity of rreatment, nearmess to plant commuties, etc. A management practice for which no entry 13 wade indicates a lack of surficient information from which to predict expected results. As observatons are made in the fleld by users of the data, the expected eprect will be reflned. 
Heterotheca flexuosa (Nash) Harms

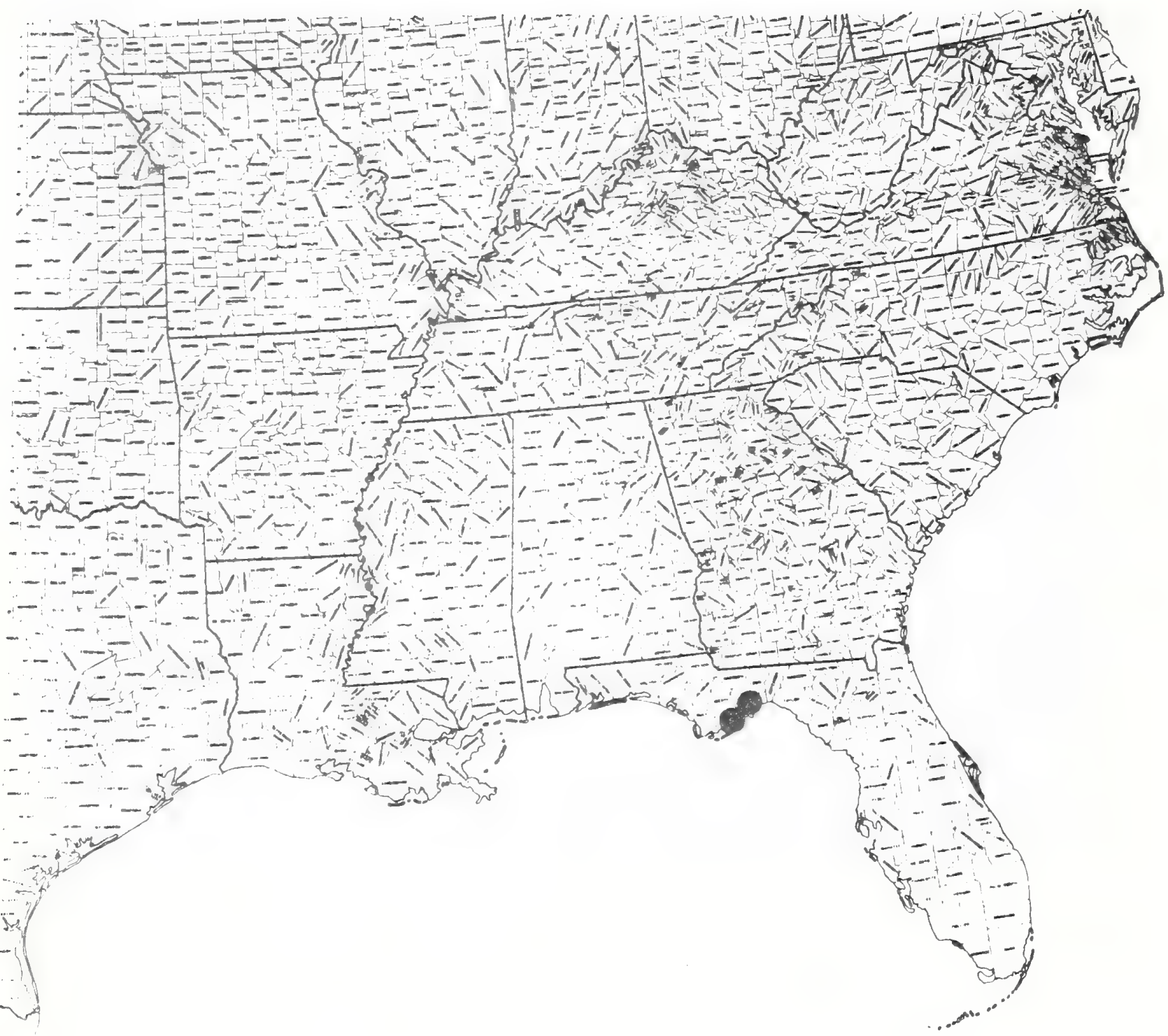


paper 72

Tert \& map iog:

Robert IR2A

\section{ASTERACEAT}

\section{Verbesine chapmanil J.R. Colamas Chapman' ${ }^{B}$ crowmbeard:} crownibeard

\section{Technical Description}

Robust, bushy perennial from a thich, knottr cauoes with Eleshy roots. Stems.--Usualiy numerous, stiff, erect or ascerding simple or sparingly branched. round but many-ribbed, minutely roughened. Leaves.--irect, opposite or mearly so, sessile or neariy so, Fim. Ianceolate to

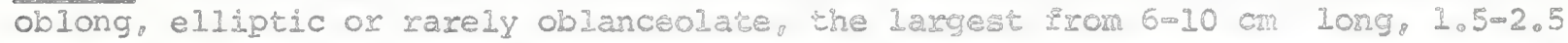

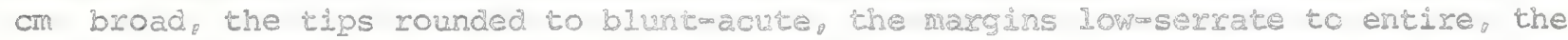
bases acute, cuneate or rounded, the suriaces scabrous. Iowest Leaves smallest, mostly oblanceolate or spatulate, the pairs meld separated. grading up the stem to the largest at midwstem, then smaller into the inflorescence.

Inflorescence.-Heads solitary at tips of long peduncles, or pew and stalised in a teminal cyme or, rarely, the plant also producing longastalked cymes from upper lear axils and the inflorescence fuldex. Heads shorc-conic. $1.5-2.0 \mathrm{~cm}$ broad across the base, the bracts numerous, imbricated in 2 w series, the largest about $7 \mathrm{~mm}$ long, oblong or naxrowly elliptic or oblarceolate. acute or shortacuminate, entire, the backs manyoribbec, scabrous, greenish or (more often) maroon-tinted. phyllaries grading into redish-brow chaff or about the same Iength but narrower tipped, each chafiscale entoracing a floret. Elowers.-All discoid, numerous, the coroldas abort 7 min Iong. Yellow with narrow tubular bases and narrowly campanulate limbs, the lobes triangular and erect, the surfaces scatteredopuberulent.

Eruit.-Akene sonewhat flattened so that one edge fits into the rold or subtending chafi, to 7 or $8 \mathrm{~mm}$ long, oblong or narrowly obovate, the greenish seod cavity with strong, broad lateral wings, the apex truscate and Iaciring pappus.

Distriburion and Flowering season

Moist pine Eatwoods savannas, northwest Loxida. Flowering in June, JuIy and intermittenty through sumer.

Habitats and Management Imp ldetcon

This species is confred to kigh hyaroperioa, black, sandyopaty, savanna solls, usually in open stands of siash or longleaf plne, grassusedge Pormations where wiregrass oiten dominates, and at the edges of boggier sites. It is most abundant where there have been recent fires surficient to remove competiojon from the whrub (particularly painetto anc galdbersy) understory and the more vigorous grasses (particularly Mristida). Areas within its former range that have been drained, row planted to slash pine, and protected Irom fire are without this species.

References

Chapman, A. W. 1860 Flora of the southern U.S. P. 255. Cambrage, Mass.

Coleman, James R.1972 Nomenclatural Ciatidcator of two species of Verbesina (Compositae) endenic to RLoria. Rhodora 74 (797):97-101.

Sma11. J. K. 1933. ManuaI of the southeastexn Flora.PI.1443-1444. Chapel HIII, N.C. 
SPECIES: \#72 Verbesina chapmanii J. R. Colernan, Crownbeard

\begin{tabular}{|c|c|c|c|c|c|c|c|c|}
\hline \multicolumn{9}{|c|}{ Management Practices } \\
\hline $\begin{array}{l}\text { Expected* } \\
\text { Effect on } \\
\text { the Species }\end{array}$ & $\begin{array}{c}\text { Prescribe } \\
\text { Burn }\end{array}$ & $\begin{array}{l}\text { Bulldoze } \\
\text { or } \\
\text { Root Rake }\end{array}$ & Bed & Chop & $\begin{array}{l}\text { Thin } \\
\text { over- } \\
\text { story }\end{array}$ & $\begin{array}{l}\text { Cut } \\
\text { Over- } \\
\text { story } \\
\end{array}$ & $\begin{array}{l}\text { Establish } \\
\text { Plantation }\end{array}$ & Graze \\
\hline Destroy & & $\mathrm{X}$ & & $\mathrm{x}$ & & & $\mathrm{X}$ & \\
\hline Damage & & & $\mathrm{x}$ & & & & & \\
\hline $\begin{array}{l}\text { No Lasting } \\
\text { Effect }\end{array}$ & & & & & & & & \\
\hline $\begin{array}{l}\text { Beneficial } \\
\text { If Done } \\
\text { Properly }\end{array}$ & $\mathrm{X}$ & & & & $\mathrm{x}$ & $\mathrm{x}$ & & \\
\hline
\end{tabular}

\section{Other Coments:}

*Expected effect on the species is an estimate made by Dr. Robert Kral based on his knowledge of the habitat and on knowledge gained from personal field observations. Estimates are "rough" in many instances. Results of practices may be modified depending upon the degree of application, intensity of treatment, nearmess to plant communities, etc. A management practice for which no entry is made indicates a lack of sufficient information from which to predict expected results. As observations are made in the field by users of the data, the expected effect will be refined. 
Verbesina chapmanii $J_{0} R_{0}$ Coleman

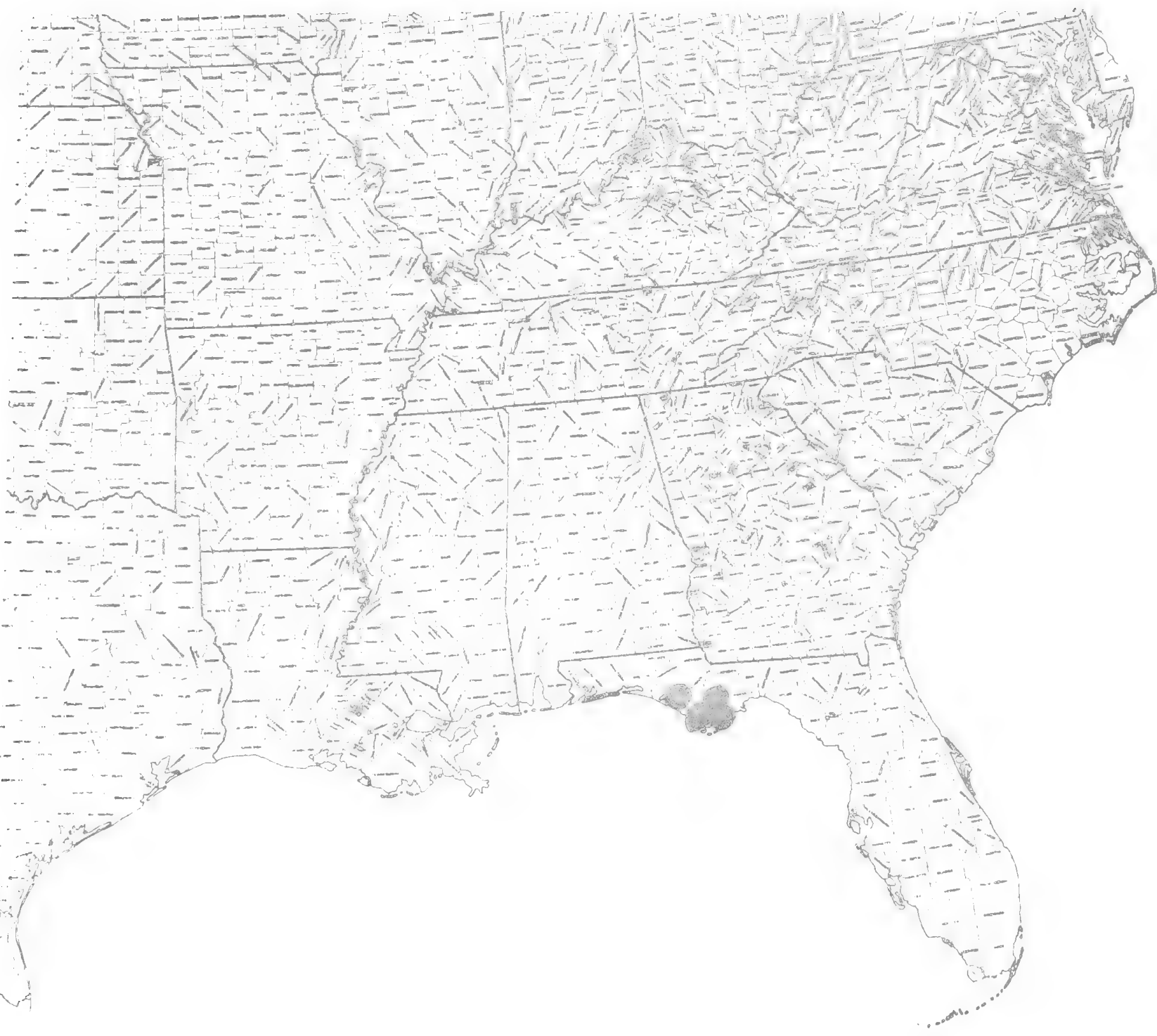




\section{ASTESRCRE}

Verbesina heterophy II lChapm. IA Gray. Variable-leave crownioard: crownoeard

Actinomeris heteronhylla Cham.

Verbesine weres a Gray

Distribution and Flowering Season

V. heterophylla is in similar habitats to $\mathrm{V}$. chapdand fwhich see! but is confined to the flatwoods of eastern peringnlas Florde and usually on somewhat drier sites. It aiso flowers mostiy in early sumex.

\section{Special Identifying Features}

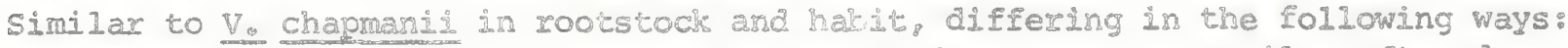
Siems more scabrous. strongly winged betweer nodes. Leaves sessile, often decurrent (biade margins merging with stexhings), mostly broady elliptic or obovate, the tips acute to rounded, the rargins coarsely serrate or dentate, the bases cuneate, the suriaces very harsh. Heads roore numerous, usually single on numerous, upwardly arching, elongate stiffish stalks, narrower, between 1 and 1.5 $\mathrm{cm}$ broad, the phyllaries (bracts) narrower tipped, acuminate. Ray florets present, spreading, yellowish. Akene shorter, ca. 5 min long, with a broader outline.

Mabitats and Management Implication

The plants are to be looked for on sandy peat in filre-maintained savannas or in open stands of slash plnemplnetto where wiregrass dominates. Problems in management would be essentilily the sane as those for V. Chapmandid, (whin soo).

References

Chapman, A. W. 1860. Flora of the Southern U. S. PP. 255.

Coleman, J. R. 1972. Nomenclatural clarification of two species or Verbesina (Compositae) endemic to Florida. Rhodora 74 1797):97 - 201.

Small, J. K. 1933. Manual of the southeastexn Elora, Pp.1443-1444. Chapel Hill, N.C. 
SPECIES: \#73 Verbesina heterophylla (Charm.) A. Gray. Crownbeard

\begin{tabular}{|c|c|c|c|c|c|c|c|c|}
\hline & \multicolumn{8}{|c|}{ Management Practices } \\
\hline $\begin{array}{l}\text { Expected* } \\
\text { Effect on } \\
\text { the Species }\end{array}$ & $\begin{array}{c}\text { Prescribe } \\
\text { Burn }\end{array}$ & $\begin{array}{l}\text { Bulldoze } \\
\text { or } \\
\text { Root Rake } \\
\end{array}$ & Bed & Chop & $\begin{array}{l}\text { Thin } \\
\text { over- } \\
\text { story }\end{array}$ & $\begin{array}{l}\text { Cut } \\
\text { Over- } \\
\text { story }\end{array}$ & $\begin{array}{l}\text { Establish } \\
\text { Plantation }\end{array}$ & Graze \\
\hline Destroy & & $\mathrm{x}$ & & $x$ & & & $\mathrm{X}$ & $x$ \\
\hline Damage & & & $\mathrm{X}$ & & & & & \\
\hline $\begin{array}{l}\text { No Lasting } \\
\text { Effect }\end{array}$ & & & & & & & & \\
\hline $\begin{array}{l}\text { Beneflclal } \\
\text { if Done } \\
\text { Properly }\end{array}$ & $\mathrm{X}$ & & & & $X$ & $x$ & & \\
\hline
\end{tabular}

\section{Other Comments:}

*Expected effect on the species is an estimate made by Dr. Robert Kral based on his knowledge of the habitat and on knowledge gained from personal field observations. Estimates are "rough" in many instances. Results of practices may be modifled depending upon the degree of application, intensity of treatment, nearness to plant comunities, etc. A management practice for which no entry is made indicates a lack of sufficient information from which to predict expected results. As observations are made in the field by users of the data, the expected effect will be refined. 
Verbesina heterophyl Ia Chapm。 ess Gray

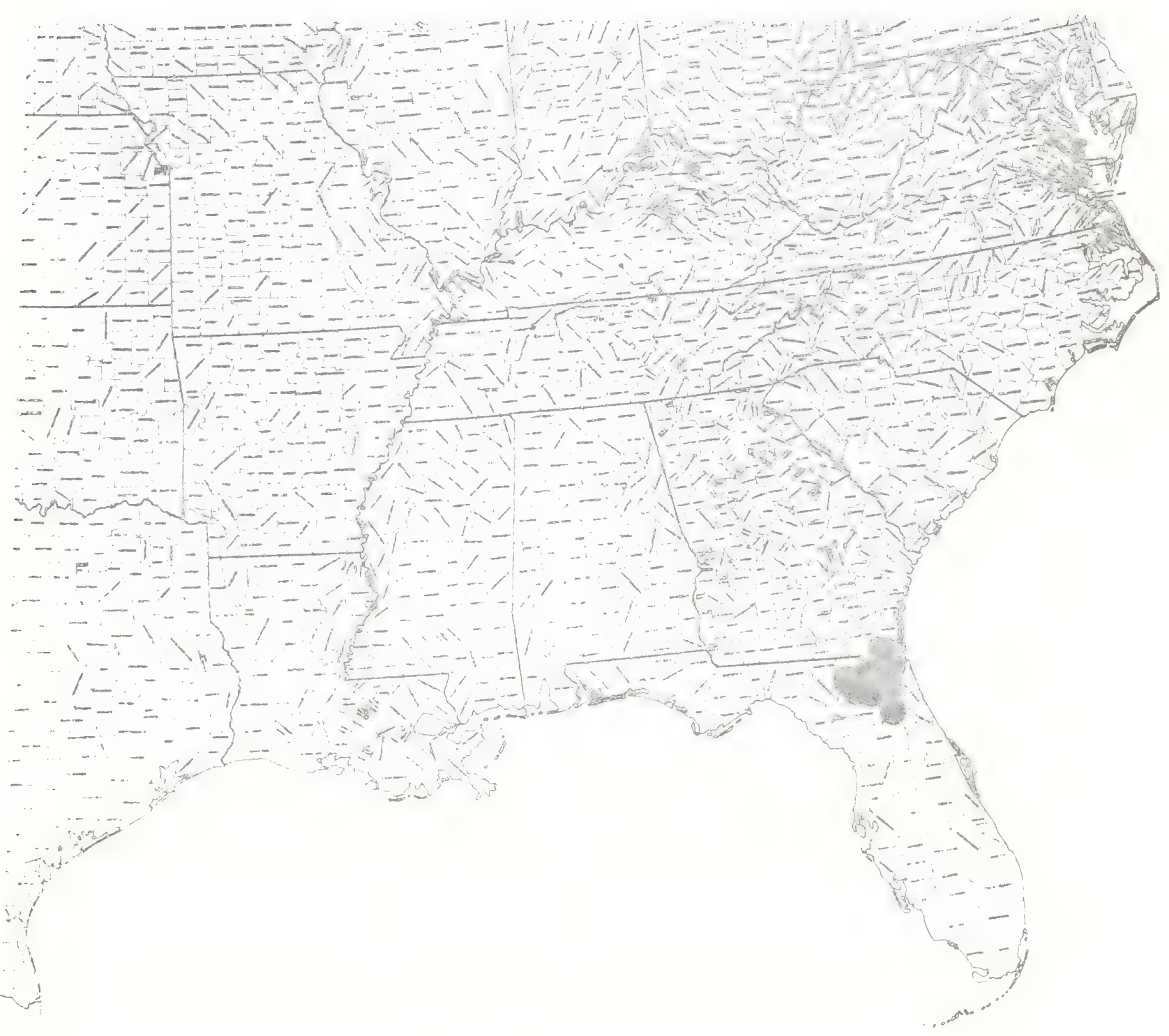


-

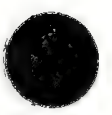

• 
Peregra 75

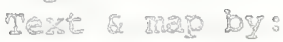

Robert iscad

\section{RRICECEE}

\section{Rhododendron austrinum (Small) Rehder. Florida awalea: Aralea} Azalea austrine \$midi

\section{Technical Description}

Deciduous shrub, mosty 2 m 3 meters tall. producing Imsoveral siender shoots from a shallow but strong root system.

Stens. - Bark of older stems grayinh, thin. loosening, that of new shoots redish brown, puberulent, beccuing smoothish. Primagy shoots rebranching just below the teminal bud. this rebranching appearing whorded so that oldest shoots develop several sets of "whorls" the appearance of the whole shirub being a broad spreading compound of bxanch crowns.

Leaves, - Alternate, rather closemst on the numerous new shoots, these unFolding mostly after fiowering time. Leaf blades spreading to ascending on short stalks, (these hairy with a mixture of short pale hairs and longer, gland-tipped hairs.l narrowly obovate to oblanceolate. elliptic or oblong, mostly 5-8 cm Iong, acute and with a short mucro, entire and ciliate, the bases attenvate or cuneate, the upper surface dark yellow grear, at first puberulent, later smoothish, the lower surface paler, persictently pilose, at least along the mid-nerve. Inflorescence.-Fiowers arising From ovoid, largish, irmbicate teminal buds FulIy $1 \mathrm{~cm}$ Iong, the scales of which are covered on the backs with white, appressed hairs. Inflorescence a short, compact raceme of spreading IIowars, the pedicels slender, puberulent and glandularchairs, up to $1 \mathrm{~cm}$ Iong. Flowers - corollas mostly salverform, between 3 and 4 cri long, the tube bearing a mixture of white, Eine but bristiy hairs mised with a few staike glandular hairs, the corolla lobes unequal, elliptic to broally or narrowly tzlargular, the whole corolia ranging in the species rrom yellow tricough add shades of red. very rarely roseate (then probably a hybrid with R. canegcens). Flowering calyx cup-shaped, with 5 glightiy spreading-triassgiar, white-hairy and glandular Lobes. Filaments elongate, projectirg Forvard then curving upwara well beyond the corolla tip. somevhat redaish. Ovary lance ovoli, ca, 4 gne long, densely whitemappressedhairy: style elongated byond the stamens, curved upward.

Fruit.- Capsules oblong, $1 \mathrm{~cm}$ long, or straight or somewhat curved, brownish, puberulent with a mixture of stalked glands.

Distribution and Flowering Season

Khododendron austrinum, which bloorn from Febsuary through April, is Found in ravines and bottoms from northwest Florida northward and westward into southwestern Georgia, southern Rabarna and southeastern Missisgippl.

Special Identifying Features

R. austrinum resembles the Dame azalea, R. Calendulaceur (Michs, Torr. the closest, but that species has leaves filling as the Flowers reach full bloom.

Habitats and Management Implication

This species is found In moist acidic sandy soilg, primarily in shadey ravines and bottoms, never where the shallow roots would be flooded over long periods. 
Thus in large bottoms it is generally either on rises of sandy alluvium or on the older terraces. Generally the overstory is of willowmoaks, southern sugar maples, beech, Magnolia grandiflora, M. virginiana, lowland hickory. Common associated understory woody plants are such as Rhododendron canescens (with which this hybridizes), Symplocos, Sebastiana, Ilicium, Vaccinium arborescens, other highbush Vaccinium, particularly $V_{0}$ elliottii. Fairly high intensity logging of the Lowlands $R_{0}$ austrinum frequents, so long as some overstory remains, does not seem to affect $1 t$ adversely. Clear-cutting of such stands is usually accompanied by, if forest is developed, planting of slash pine, to the detriment of this shrub. More often, this sort of bottom, if broad, is converted either to pasture, which reduces its numbers, or to some type of row crop culture, which eliminates it.

These plants are so showy that they are subjected to much cutting and uprooting of whole shrubs. Occasionally the species is seen in cultivation as a result usually of moving the shrubs; more often such transplants lead to failure.

Duncan, W. and Puller, T. K. 1962. Iepidote Rhododendron of the Southeastern U.S. Brittonia 14: 290-298.

Kral, R. 1973. Some notes on the flora of the southeast... Rhodora 75:366-410.

Small, J.K. 1933. Manual of the Southeastern Flora, p. 995. Chapel Hill, N.C. Wilson, E. H. and A. Rehder. 1921. A monograph of Azalea. P. 219. Univ. Press, Cambridge, Mass. 
SPECIES: \#75 Rhododendron austrinum (Smail) Relider. Azalea

\begin{tabular}{|c|c|c|c|c|c|c|c|c|}
\hline & \multicolumn{8}{|c|}{ Management Practices } \\
\hline $\begin{array}{l}\text { Expected* } \\
\text { Effect on } \\
\text { the Species }\end{array}$ & $\begin{array}{c}\text { Prescribe } \\
\text { Burn }\end{array}$ & $\begin{array}{l}\text { Bulldoze } \\
\text { or } \\
\text { Root Rake }\end{array}$ & Bed & Chop & $\begin{array}{l}\text { Thin } \\
\text { over- } \\
\text { story }\end{array}$ & $\begin{array}{l}\text { Cut } \\
\text { Over- } \\
\text { story }\end{array}$ & $\begin{array}{l}\text { Escablish } \\
\text { Plancation }\end{array}$ & Graze \\
\hline Destroy & & $x$ & & $x$ & & & $x$ & \\
\hline Damage & $\mathrm{X}$ & & $\mathrm{X}$ & & & $\mathrm{X}$ & & $\mathrm{X}$ \\
\hline $\begin{array}{l}\text { No Lasting } \\
\text { Erfect }\end{array}$ & & & & & & & & \\
\hline $\begin{array}{l}\text { Beneflcial } \\
\text { if Done } \\
\text { Properly }\end{array}$ & & & & & Y & & & \\
\hline
\end{tabular}

\section{Other Commenes:}

* Expected effect on the species is an estimate made by Dr. Robert Kral based on his knowledge of the habitat and on knowledge gained from personal field observations. Estimates are "rough" in many instances. Results of practices may be modifled depending upon the degree of application, intensity of treatment, nearness to plant comumities, etc. A management practice for which no entry is made indicates a lack of sufficient information from which to predict expected resules. As observations are made in the field by users of the data, the expected effect will be refined. 
Rhododendron austrinum (Small) Rehder

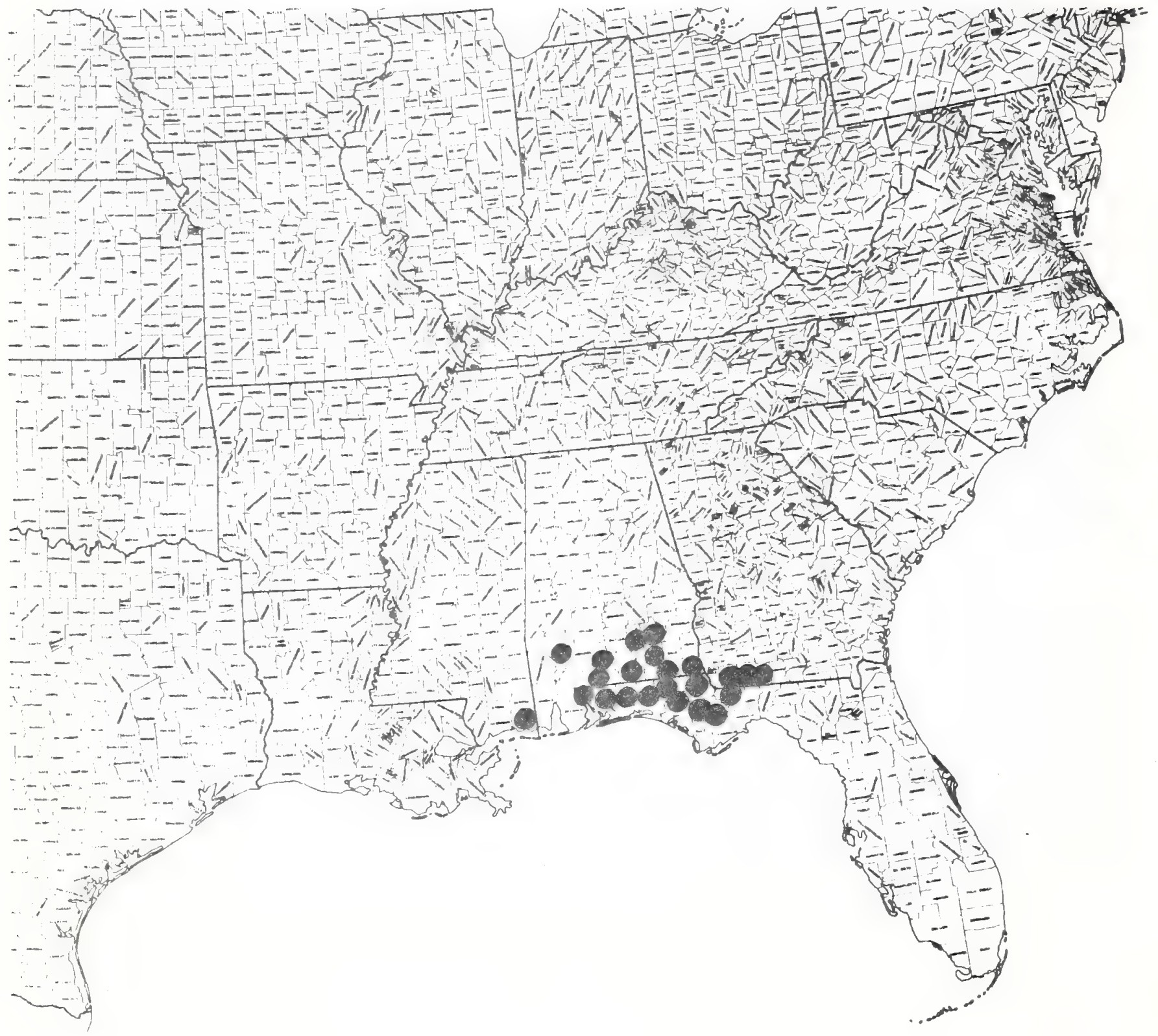




\section{FABACERE}

Rhynchosia clnerea Nash. Bromminalred snout bean: N.C.N.

\section{Technical Description}

Perennial prostrate (non-climbing vine.

Stems.--Several shoots forming from a woody taproot, Ehese rebranching to form sprawling slender viney shoots from 1 to several meters in length. Sterns slender, somewhat rib-angled, greenishwrown, puberulert with downardy directed whitish hairs particuiariy along the ribs frequenty branching toward the main stem base.

Leaves.-Alternate, fairly well separaced, spreading, stipulate with stipules exect, early deciduous, narrowly triangular, scaly, puberulent: petioles mostly 1.5-2.0 cm long, puberulent, spreadng (sometimes arising in pairs, and opposite, from a short stalk: leaflets mostiy 3 , ovate to round or broader than long. Im $3 \mathrm{~cm}$ long, fina, the teminal one largest, the apes obtuse, rounded, sometimes short-mucronate, the margins entire, somebhat revolute, the bases rounded or low-cordate, the surfaces dark yellowagreen, reticulate, the upper surface finely appressed-hairy, the lower surface short hairy nostly on the veins. Inflorescence.-Flowers $1-7$, usually in short racemes on slender, shortwhairy, ascending stalks to 10 morn long from axils of most median and upper leaves, and shorter than the subtending leaf. Flowers, - Calyx about I cm long. slightly longer than the corolla, the 5 Iineal, puberulent, ascending, tapering-tipped lobes unequal, much longer than the short. campanulate tube. Corolla yellow, the standard short-clawed, nearly round, rew tuse, slightiy arched upwaxd, but folded over the sightly shorter wings and the keel petals. ovary narrow densely shortwhairy, the style elongate, bent.

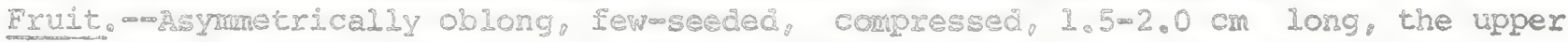
valve edge straight, the lower strongly eurved into the acuminate, slender tipped beak; seeds mearly round, Flattemed, about 3 mm broad, dark brown.

Distribution and Flowering Seasos

Sandy uplands and pinelands, peninsular Florida southward into the Florida Keys. riowering from June into autuma

Special Identirying Features

This plant, while a vine, never twines and thus ds not a elimber. It is distinguished from other species which are trifoliolate and prostrate-viney, by Its cinereous hairs, the more oblong Irut, and the more or less lateral position of the frult beak. Its nearest relative, Ro difforms, a climber, has larger learlets.

Habitats and Management Implication

Ro cinerea is found in a vaxlety of associations. It mas be on low sandy rlses in Elatwoods of slash or longlear plne with palmetto and gallberry, here on sandy clearings. It may be in sandy fields adjacent to high hamocks or true live oak, 
or in clearings in such hammocks. Or it may be in the longleaf pine-turkey oak sandhills, again in clearings. Finally it may be in clearings in sand pine-evergreen scrub on ancient dunes. In any event it is on dryish, at least well-drained sands, and is always either in full sun or light shade. As is true of other leguminous plants of such situations, It increases and maintains through periodic fire. Clearing of forest increases it through reducing shade or producing openings. It is threatened mostly through housing developments, development of orange groves or improved pastures over much of its former range.

\section{References}

Nash, G.V. 1895. Notes on some Florida plants. Bull. Torr. Bot. Club 22: 141-161.

Smal1, J. K. 1933. Manual of the southeastern flora, pp. 713-715. Chapel Hill, N.C.

Walraven, W. C. 1970. A statistical analysis of sixteen taxa of Rhynchosia (Ieguminosae) in the United States. Brittonia 22(10): 85-92.

Vail, Anna M. 1899. Notes on the genus Dollcholus (Rhynchosia) in the U.S. Bull. Torr. Bot. Club 26: 106-117. 
SPECIES: $\quad 476$ Rhymchosia cincrea Nasho N3.C.N.

\begin{tabular}{|c|c|c|c|c|c|c|c|c|}
\hline & \multicolumn{8}{|c|}{ Management Practices } \\
\hline $\begin{array}{l}\text { Expected* } \\
\text { Effect on } \\
\text { the Specles }\end{array}$ & $\begin{array}{c}\text { Prescribe } \\
\text { Bura }\end{array}$ & $\begin{array}{c}\text { Bulldoze } \\
\text { or } \\
\text { Roos Rake }\end{array}$ & Bed & Chop & $\begin{array}{l}\text { Thin } \\
\text { over- } \\
\text { stogy }\end{array}$ & $\begin{array}{l}\text { Cut } \\
\text { Over- } \\
\text { atory }\end{array}$ & $\begin{array}{l}\text { Establish } \\
\text { Plantation }\end{array}$ & Graze \\
\hline Destroy & & & & & & & $\mathrm{x}$ & \\
\hline Damage & & $\mathrm{x}$ & $\mathrm{X}$ & $\mathrm{X}$ & & & & $x$ \\
\hline $\begin{array}{l}\text { No Lasting } \\
\text { EfFect }\end{array}$ & & & & (NA) & & & & \\
\hline $\begin{array}{l}\text { Benefledai } \\
\text { Lf Done } \\
\text { Properiy }\end{array}$ & $X$ & & & & & & & \\
\hline
\end{tabular}

\section{Other Commers:}

*Epected effect on the species is an estrmate made by Dr. Robert Kral based on his knowledge of the habltat and on knowledge gained from personal field observations. Estimates are "rough" in many listances. Results of practices mey be modified depending upon the degree of application, intensity of treatment, neamess to plant comunities, etc. A management practice for which no entry 18 made indicates a lack of sufficlent information from which to predict expected results. As observations are ade in the field by users of the data, the expected efrect will be refined. 
Rhynchosia cinerea Nash

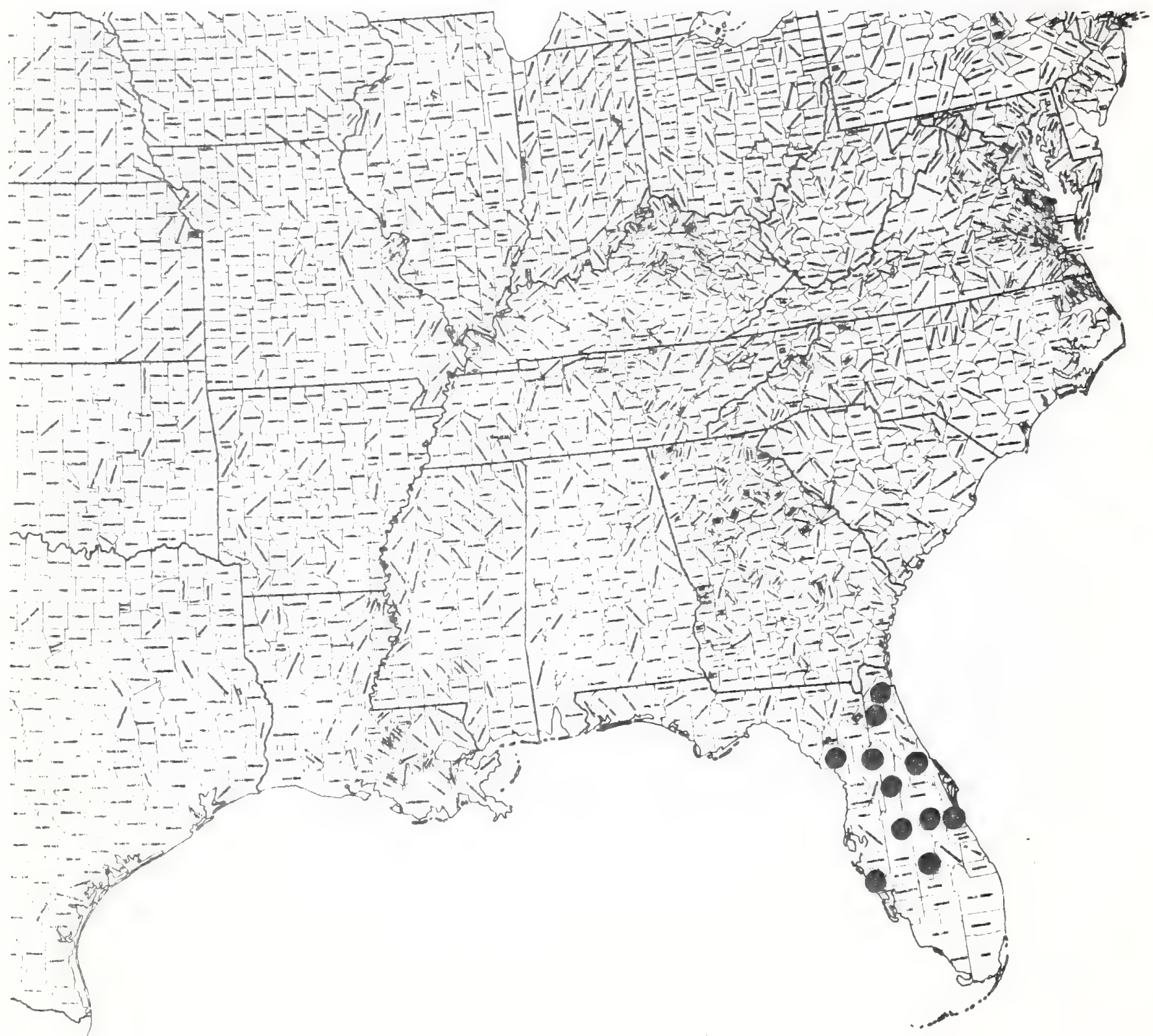


Papez 77

Tast gar my:

Robert Reas

\title{
TABACEAE
}

\author{
Tephrosia moinris (Fydio) Codirey. Pineland hoary-pea: \\ Moary peas \\ Cracca mohri I gydio.
}

Technical Description

Perennial herbs from deep branched taproot systems, these producing (usually) several spreading and branched undergrownd shoots from which arise a number of spreading to erect leafy flowering shoots.

Stems.-Flowering shoots slender but stiffish, simple or sparingly branched toward the base, ribbed, at most to 3 dm. mostly 2 dm or less long, greenish or redaish tinted, appressedwhiry with erect, pale shortish hairs.

Ieaves, - Altemate, l-pinnate, sprealing or ascending, the appressed hairy lanceIinear stipules 3 m 5 men long, early falling rachis slender, tan, appressed-hairy. the petiole shorter than the longer leaflets: leaflets mostly $25-20$ pairs or more, on short stalks (ca. 2 mm), elliptic or oblong, firm, mostly I-2 cm long, rounded, obtuse, acute or emargisate, uswally wits a short mucro, the margins ertire, the bases acute, the uppex surface dark yellow green and veiry , hairy with short, appressed, stiffish hairs, the lower surface paler. Inflorescence。mlowers $1-2$ axil in congested to somewhat loose, ovold or shortcylindrical racernes, these learyobracted at least toward the bases, exceeded by the leaves terminal but on slender, ascending appressodouberulent axes. Elowers, - Calyr 5-tooched, appressed pubescent, somewhat bilabiate, ca. 5 m long, the lobes broadiy triangularmbased, slenderly acuminate, longer than the tube. Corolla about $1-5-2.0 \mathrm{~cm}$ long, showy, the standard petal longest, short-clawed, its blace broadiy obovate to suborbiculat, somewhat emarginate, pale yellowishgreen or crean, the wings short-clawed, oblong, rourd-tipped, auricled on the upper side, Lavendermirose, the keel strongly bowed, yellowishmith with tints of Iavender rose. Stamens 20 in 2 lengths, the Filaments fused for more than I/2 the length, the anthers all alike, short. Eruit.- - Iinearmoblong, strongly slattened, mostly $4-5 \mathrm{~cm}$ long, with a narrow beak lateraliy at the tip and splitting along both edges, the surface appressedu hairy, the seeds numerous, round, somewhat flattened, dark brows.

Distribution and Flowexing season

Iongleaf pine-turicey oak sandridges, southern Geosgia westward into southern Alabama and southward through northwesters Florida. Flowering Erom April into early June.

Special Identifying Features

Godfrey (1958) differs considerably from the last revisor of North American Tephrosia, (Wood 1949), In thinking that this is a species distint from T. virginiana $\left(I_{0}\right)$ Pers. It does differ from most Io virginiana in being a shorter plant with shorter leaves, in its inforescence being exceeded by the bracteal leaves, in its smallex fowers. Whatever To mohxid really is, it is a rather uniform entity with a rairly coneinuous range. 
Habitats and Management Implication

T. mohrii is confined to the longleaf pine-turkey oak sandhills and flats, usually in some of the driest sites, and often locally abundant. Clear cutting has little effect upon it, unless it would be to increase abundance. It will as readily seed into areas where logging has been followed by bulldozing, raking, etc. as it does into disturbed highway shoulders and rights of way. In nature it probably maintained through being part of fire disclimax in the longleaf pine belt.

References

Godfrey, R. K, and R. Kral. 1958. Observations on the Florida flora. Brittonia $10: 166-177$.

Small, J. K. 1933. Manual of the southeastern flora, Pp. 704-708. Chapel Hill, N.C. Wood, C. E. 1949. The American barbistyled species of Tephrosia (Leguminosae). Rhodora $51(609,610,611,612$.$) .$ 
SPECIRS: \#77 Tephrosia mohrit (Rydb.) Godfrey. Iloary peas

\begin{tabular}{|c|c|c|c|c|c|c|c|c|}
\hline & \multicolumn{8}{|c|}{ Menagerent Practices } \\
\hline $\begin{array}{l}\text { Expected* } \\
\text { Effect on } \\
\text { the Species } \\
\end{array}$ & $\begin{array}{c}\text { Prescribe } \\
\text { Burn }\end{array}$ & $\begin{array}{l}\text { Bulldoze } \\
\text { or } \\
\text { Root Rake }\end{array}$ & Bed & Chon & $\begin{array}{l}\text { Thin } \\
\text { over- } \\
\text { story }\end{array}$ & $\begin{array}{l}\text { Cut } \\
\text { over- } \\
\text { story }\end{array}$ & $\begin{array}{l}\text { Establish } \\
\text { Plantation }\end{array}$ & Graze \\
\hline Destroy & & & & & & & $\begin{array}{l}\text { even thalk } \\
\text { serouthatis }\end{array}$ & \\
\hline Damage & & & & & & & & $\mathrm{X}$ \\
\hline $\begin{array}{l}\text { No Lasting } \\
\text { Effect }\end{array}$ & & $x$ & $x$ & $x$ & & & & \\
\hline $\begin{array}{l}\text { Beneficial } \\
\text { If Done } \\
\text { Proper } 1 \%\end{array}$ & $x$ & & & & $x$ & $\mathrm{X}$ & & \\
\hline
\end{tabular}

other Coments: If adjacent seed source

*Expected erfect on the species Is an estimate made by Dr. Robert Kral based on his knowledge of the habitat and on knowledge galned from personal field observations. Estimates are "rough" in rany instances. Results of practices may be modfied depending upon the degree of application, intensity of treatment, neamess to plant compunities, etc. A management practice for which 830 entry is made indicate a lack of surficlent information from which to predict expected results. Me observations are made in the field by users of the data, the expected ertect will be reflned. 
Tephrosia mohrii (Rydb.) Godfrey

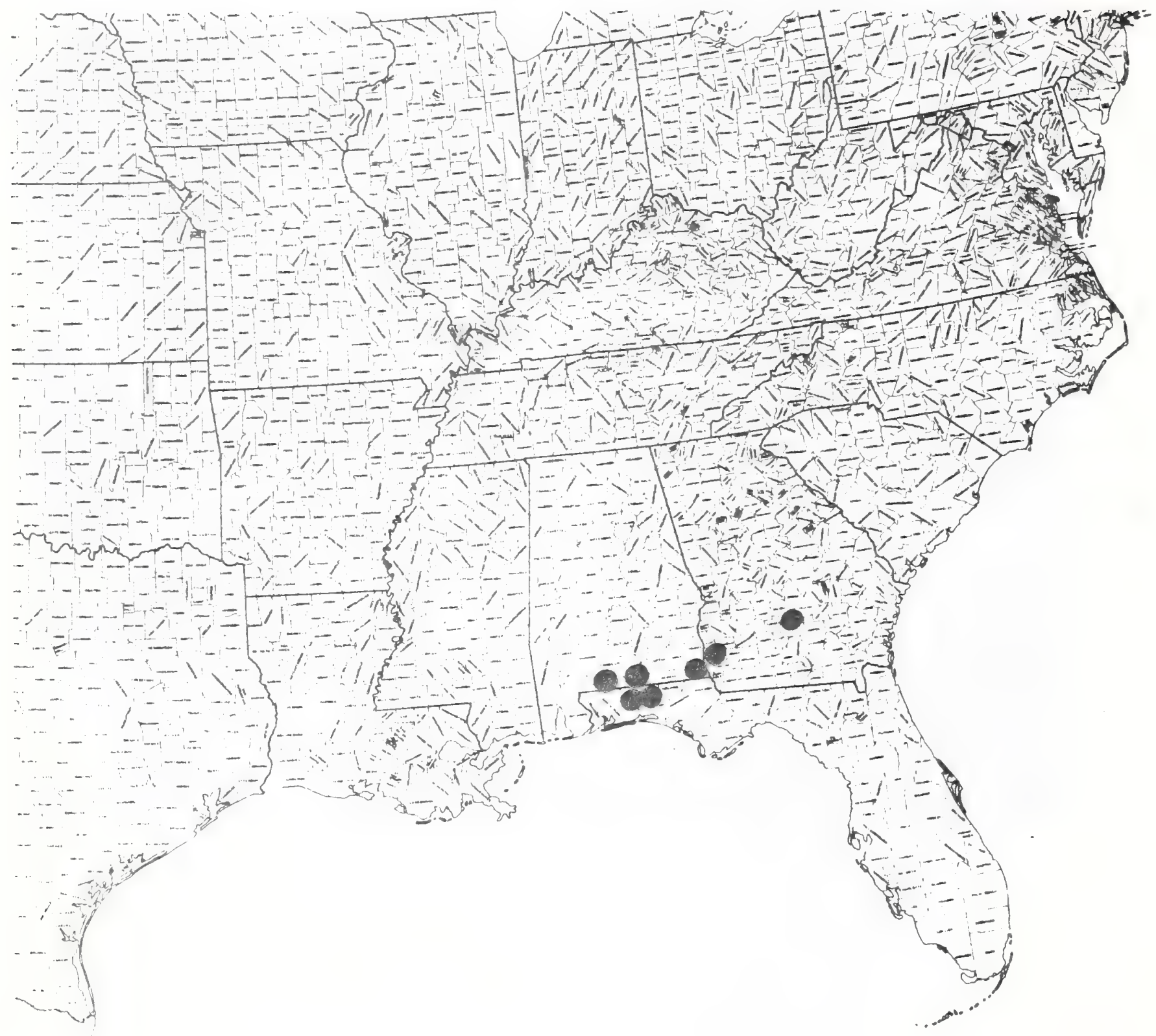


ouercus georgiasa Ho Curels. Cargla ak or store Mountain as

\section{Technical Description}

Tall shrub or small tres, rarely to 12 meters tall. Stems. -The trunks 1 or several, with dimeter rasely resching 20 cho the bark graywbrown, moothish, in age developing shallok lengitudinal cracks and cross broken into thin plates, the branches spreading, smoothishe twigs slender but stiffish, smooth, reddish-brown, the wirter buds, with larger teminals lanceovoid, ca. 4 min long, round in crossmsection, narrowly acute, the scales lustrous reddish-brown, smooth save for Lownditate margins. Leaves.--Obovate to oblanceolate or elliptie, the bladeg $5-10(-15)$ crn Iong

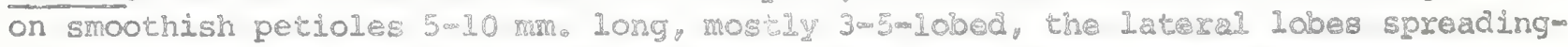
ascending, oblong ur triasular, prickle-tipped, and thenselves otharwise entire or with l-few low pricklewtipped teeth, the slnuses broal and rather shallow, the teminal lobe usually broadest and longest, simple or low toothed apically, the base cuneate, the upper surface dark yellowmgren, Iustrous, the lower surface paler, smooth save for tufts of dully yellow cottony hairs in the vein axils. Fruit,--Ripening in 2 years, sessile on short, stiffish spreading peduncles: acorn nearly $1 \mathrm{~cm}$ long, broadiy ovoid to round, dull brown and fantrly strlped: acorn cup shallowly turbinate, covering the nut about $1 / 2$ its length or less, $7-8$ m high, 12-13 m broad, 10-11 m across the apes, the scales smali, tightly appressed, narrow the pale redishobrom. sparsely shortwhiry and ciliate, the tips truncated, those of the rion with tips exact.

Distribution and Flowering Season

On and around granite outcrops, primarily in the piedmont, from South Carolina across Georgia into eastocentral Rabama.

Habitat and Management Implication

This rather rare tree is a prolific mast producer similar in that respect to 2. ilicirolia. In bark and twig, particulariy bud, it is like ge phellos or 2o palustris: in leak it is like shallow lobed extremes of g. palustris (which has broad, rather than cuneate leaf bases:y. It may be abundant locally within its rather small range. If not actualy Eound on granite outerops it will be on sandy soils close to then, usually in association with other oaks such as Q. margaretta (mostly the low, ruming variety) Q. Staliata. Q. velutina. O. marilandica, 2. falcata. 2. prinus, etc. upland hickories, sourwod, sassafrass, with an understory mostly of heaths such as Vaccirium, Ralmia. Rhododendron (primarily $R_{0}$ canescens or other deciduous rhododendrons). Pines may also be in the overstory or even doninating, these mainly B $_{0}$ echinata, P. palustris. P. taeda. 
The sites this oak occupies are usually of a poor quality. Cutting of suitable pine and hardwood would tend to increase this species. All oaks, including this one, sprout prolifically from the stump on cutting or burning. Thus it would increase as a result of clear-cutting, or fire. However, the rocky sites and thin soils occupied by this species are not favorable to such practice, nor are they favorable to most site preparation methods, including controlled burning.

References

Radford A. E. et al. 1968. Manual of the vascular flora of the Carolinas, pp. 372-385. Chapel Hill, N.C.

Sargent, C. S. 1949. Manual of the trees of North America, Vol. I, pp. 249-250. Dover Press. 


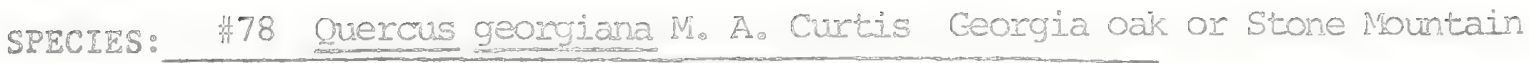

\begin{tabular}{|c|c|c|c|c|c|c|c|c|}
\hline & \multicolumn{8}{|c|}{ Maragement Practices } \\
\hline $\begin{array}{l}\text { Expected* } \\
\text { Effect on } \\
\text { the Specles }\end{array}$ & $\begin{array}{c}\text { Prescribe } \\
\text { Burer }\end{array}$ & $\begin{array}{l}\text { Bulldoze } \\
\text { or } \\
\text { Root Rake } \\
\end{array}$ & Bed & Chop & $\begin{array}{l}\text { Thin } \\
\text { over- } \\
\text { story } \\
\end{array}$ & $\begin{array}{l}\text { Cut } \\
\text { Over- } \\
\text { story }\end{array}$ & $\begin{array}{l}\text { Establish } \\
\text { Plantation }\end{array}$ & Graze \\
\hline \multicolumn{9}{|l|}{ Destroy } \\
\hline Danage & & & & & & & & $x$ \\
\hline $\begin{array}{l}\text { No Lasting } \\
\text { Effect }\end{array}$ & NA & & & & & & NA & \\
\hline $\begin{array}{l}\text { Benefichal } \\
\text { 1f Done } \\
\text { Properly }\end{array}$ & & & & & X & $x$ & & \\
\hline
\end{tabular}

\section{Other Commeres:}

*Expected effect on the species is an estrace made by Dr. Robert Krai based or hls krowledge of the habitat and on krowledge galned from personal fleld observations. Estinates are "rough" in nany instances. keeults of practices mey be modified depending upon the degree of application, Intensity of treatment, neamess 50 plant communies, etc. A management practice for which no entry is made indicares a lack of sufficlent lnfortatlon from which to predict expected results. As observations are made in the field by users of the data, the expected erfect will be refined. 
Quercus georgiana M.A. Curtis
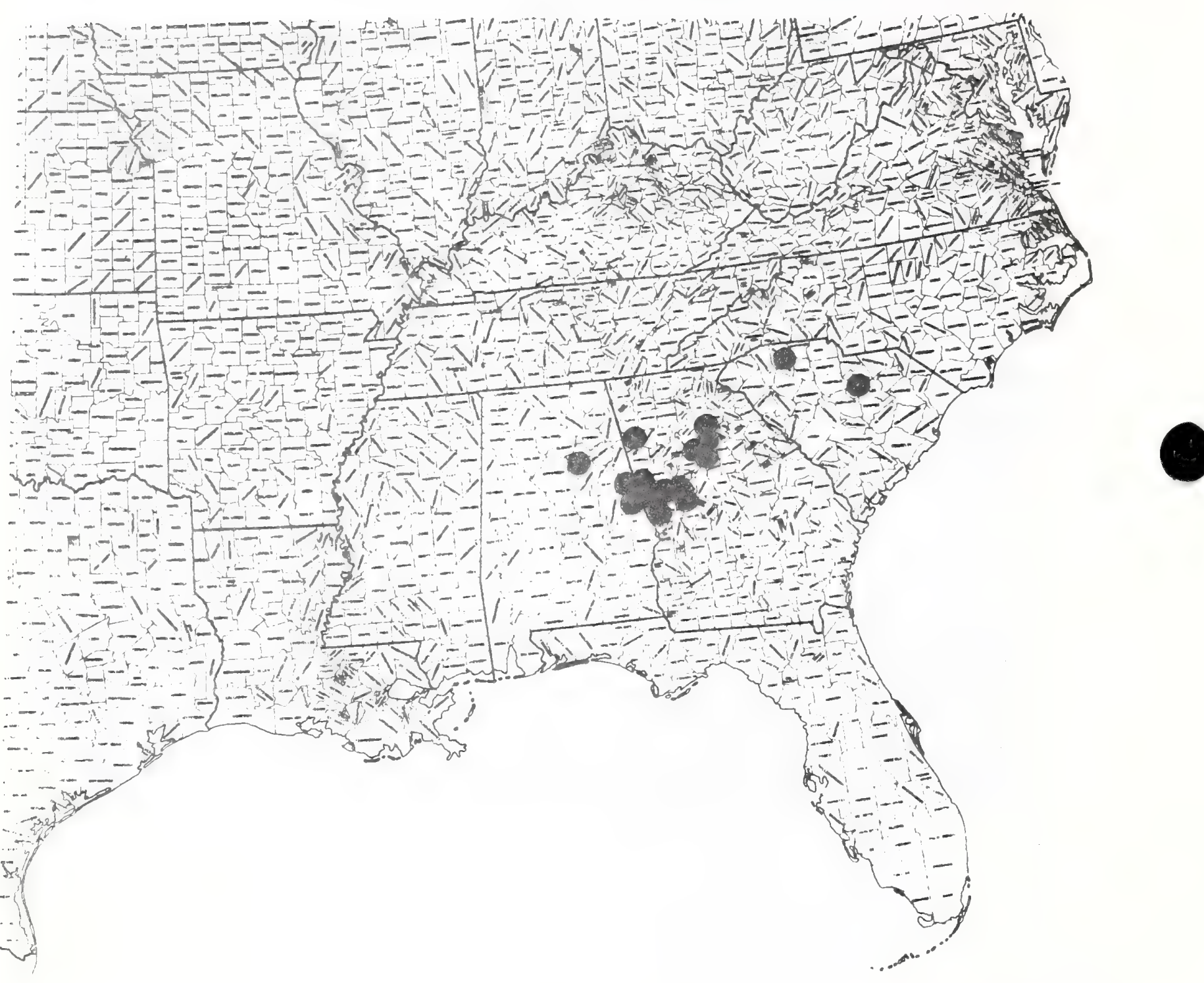
Papo: 79

Text \& map by:

Robert kral

\section{EAGACEAE}

Quercus shumardi Buckloy var. acrifolie taines oak: maplo lear Shumard 's oak

\section{Technical Description}

In bark and habit comparable to go shumasedis.

Stems. - Twigs slender but stiffish, grayisin-brown, smooti: winter buds narrowly ovoid, $4=5 \mathrm{~mm}$. Iong, acute, the scales dull graym redobrown, sreoth with very thin, broad margins.

Leaves,-mon slender, spreading, smooth petioles $3 \mathrm{co}$ cm long, the blades broadiy ovate to round or even reniform, in the certral form rainly with 5 principal lobes, these spreading palmately as in some hard maples, but the venation truly pinnate, the lobes mostly narrowly or broad'y cuneate or obovate, basally entire, toothed or shallowly triangularly lobed apically, all teeth ana lobes prickletipped, the sinuses between the main lobes deep, tending to be closed, the blade base obliquely truncate or cordate, the upper surface dark green, lustrous, the lower surface paler, with turts of pale cotcony hairs in the vein axils. Fruit as in \&. shumardii, nearly sessile, $2 \mathrm{~m} 3 \mathrm{~cm}$ long, the cup shallow, $1.5-2.0 \mathrm{~cm}$ across, covering less than $1 / 3$ of the nut, the numerous small ovare scales tightly appressed, round-tipped, the backs duIl graymbrown with a close covering of small, weak, flattish haiss, the margirs broad, thir, brown, smooth, ciliate. Fruit, - Acorn ovoid, ellipsoidal, or nearly round, pale grayworown with a dusting of Flat, pale, stellate or simple hairs.

Distribution and Flowering Season

This tree, thus rar, has beer found onIy on Magazine Mourstain. Logan County. Arkansas. This puts it in the Ouachita system. The specimens are medium sized, are toward the rocky rian, at elevations of about 2500 It. and are mixed with a variety of upland oaks and hickories. The only known locality is in the Ozark National Forest.

Special Identifying Features

While this is but a variety, and probably has silvical character comparable to that of the rest of the species, it is so unusual as to bear preservation and, hoperully, propagation as well. As the name and description inaicate, the leaves are suprisingly maple-like, in size and outline very comparable to Acer grandidentatum.

Roference

Palmer, E. J. 1927. Journ. Arnold Arb. 8:54. 
SPECIES: \#79 Quercus shumardii Buckley var. acrifolia Palmer; oak

\begin{tabular}{|c|c|c|c|c|c|c|c|c|}
\hline \multicolumn{9}{|c|}{ Management Practices } \\
\hline $\begin{array}{l}\text { Expected* } \\
\text { Effect on } \\
\text { the Species }\end{array}$ & $\begin{array}{c}\text { Prescribe } \\
\text { Burn }\end{array}$ & $\begin{array}{c}\text { Bulldoze } \\
\text { or } \\
\text { Root Rake }\end{array}$ & Bed & Chop & $\begin{array}{l}\text { Thin } \\
\text { over- } \\
\text { story }\end{array}$ & $\begin{array}{l}\text { Cut } \\
\text { Over- } \\
\text { story }\end{array}$ & $\begin{array}{l}\text { Establish } \\
\text { Plantation }\end{array}$ & Graze \\
\hline \multicolumn{9}{|l|}{ Destroy } \\
\hline Damage & & & & & & & & $\mathrm{X}$ \\
\hline $\begin{array}{l}\text { No Lasting } \\
\text { Effect }\end{array}$ & NA & & & & & & $\mathrm{NA}$ & \\
\hline $\begin{array}{l}\text { Beneficlal } \\
\text { if Done } \\
\text { Properly }\end{array}$ & & & & & $\mathrm{x}$ & $\mathrm{x}$ & & \\
\hline
\end{tabular}

\section{Other Couments:}

* Expected effect on the species is an estimate made by Dr. Robert Kral based on his knowledge of the habitat and on knowledge gained from personal field observations. Estimates are "rough" in many instances. Results of practices may be modified depending upon the degree of application, intensity of treatment, neamess to plant communities, etc. A management practice for which no entry is made indicates a lack of sufficient information from which to predict expected results. As observations are made in the field by users of the data, the expected effect will be refined. 
Papers 80

Test \& map 3y:

Robert REa?

HALORAGACERE

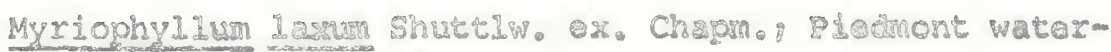

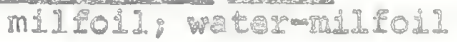

Technical Description

Perennial aquatics from submersed, ereeping and rooting bases. Stems.--The leafy shoots very elongate, slender, terece, smooth, greenish with tints of red.

Leaves, - The submexsed leaves mostiy in whoris of 3 or 4 , spreading, $2-3 \mathrm{~cm}$ long pinnately divided into spreading, haixlike segments, green or with tints of red; emergent parts of stems terairal, erect. The emergent leaves abruptly shorter, (at most to 5 mon. long), more shallowly pinnate with broader segments or ever entire, oblanceolate.

Inflorescence,-Flowers unisenul or bisasual, where unisezual, with the male borne above, small, greenish or with some readish tints, sessile in the whorls of emersed leaves, the inflorescence an evenly intermpted, slender spike. Flowers.--Sepals and petals each 4, snall, scale-1ike, the sepals about $0.5 \mathrm{~mm}$ long, the petals about $1 \mathrm{~mm}$ long. Stamens projecting beyond the perianth, 4-8, the filaments very slender, the anthers linear, yellowish green, about i.5 Inm long. Ovary inferior, the 4, shortooblong, undted carpels with recurved styles and stigmas.

Fruit,-Ripe fruit separating into \&. 1-seded, segments, the segment backs lonw warty.

Distribution and Flowering Season

Ponds and ditches, Coastai Plain, eastern North Carolina southward through South Carolina, Georgia, northem Florida and west into northwestern Florida and southerm Alabarna. Flowering from April through August.

Habitats and Management Impication

These plants, while considered rare, may be locally abundant in clear water of ditches and shallow ponds. In that they may be in situations that may be dry one year, filled with water another, they are abundant only during wetter periods. The ecology of most aquatic groups such as this is pooriy understood. Naturally, in areas where drainage of forest has lowered the water table and rendered standing water less avajlable, such species as M. Iasum become more rare. on the other hand they may also increase in areas where water is artindedaldy impounded. Some

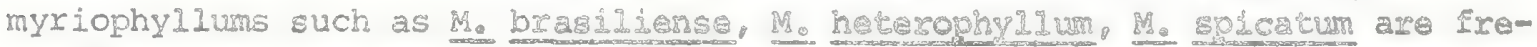
quenty dominant aquatics in such impoundruenes. Such, however, does not soem to be the case with this species.

References

Radford, A. E. et al. 1968. Manual of the vascular flora of the Carolinas, p. 758, Chapel Hitl, N.C.

SmaII, J. K. 1933. Manual of the southeastern flora, pp. 954-955. Chapel Hill, N.C. 
SPECIES: \#80 Myriophyllum laxum Shuttlw. ex. Chapm. Water-milfoil

\begin{tabular}{|c|c|c|c|c|c|c|c|c|}
\hline \multicolumn{9}{|c|}{ Management Practices } \\
\hline $\begin{array}{l}\text { Expected* } \\
\text { Effect on } \\
\text { the Spec1es }\end{array}$ & $\begin{array}{c}\text { Prescr1be } \\
\text { Burn }\end{array}$ & $\begin{array}{l}\text { Bulldoze } \\
\text { or } \\
\text { Root Rake } \\
\end{array}$ & Bed & Chop & $\begin{array}{l}\text { Thin } \\
\text { over- } \\
\text { story }\end{array}$ & $\begin{array}{l}\text { Cut } \\
\text { Over- } \\
\text { story }\end{array}$ & $\begin{array}{l}\text { Establish } \\
\text { Plantation }\end{array}$ & Graze \\
\hline \multicolumn{9}{|l|}{ Destroy } \\
\hline \multicolumn{9}{|l|}{ Damage } \\
\hline $\begin{array}{l}\text { No Lasting } \\
\text { Effect }\end{array}$ & & & & $\mathrm{NA}$ & & & & \\
\hline $\begin{array}{l}\text { Beneficial } \\
\text { If Done } \\
\text { Properly }\end{array}$ & & & & & & & & \\
\hline
\end{tabular}

\section{Other Comments:}

*Expected effect on the species is an estimate made by Dr. Robert Kral based on his knowledge of the habitat and on knowledge gained from personal field observations. Estimates are "rough" in many instances. Results of practices may be modified depending upon the degree of application, intensity of treatment, nearness to plant communities, etc. A management practice for which no entry is made indicates a lack of sufficient information from which to predict expected results. As observations are made in the field by users of the data, the expected effect will be refined. 
Myriophyl Tum Taxum Shuttiw. ex Chapm.

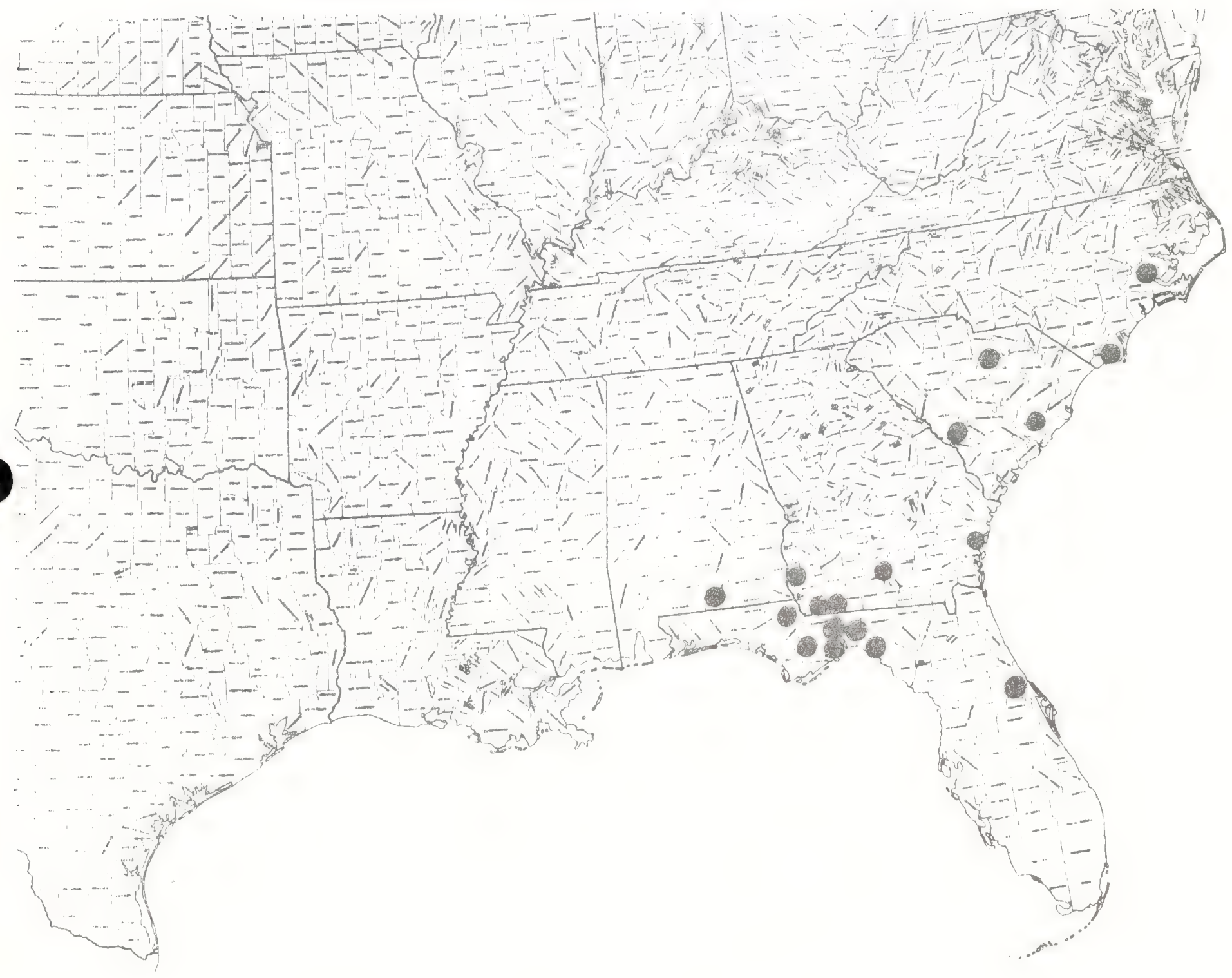


0

-

0 
Papez 82

Teste map bys

Robare Rad

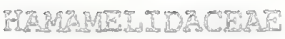

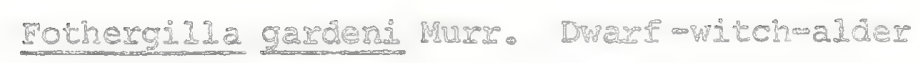

Techrical Doscription

Shrubs I meter or less tald simo le or profusely branched from the base. Stems,-Soboliferous: the erect or ascending prirnary shcots unbanched or with several ascenoing lateral branches. Shoots slender but stififish gray-brown or redish-brown, the older growth smooth, the thin outer bare cracking Iongituainally. the new shoot growth dersely tomentose with staldatomedged scales. Leaves, cmiternate, ascending, declduous, estipulate, numerous on shoots and on frequent spur shoots, 2.5 - $5.0 \mathrm{crn}$ Long, obovate, oblong or broady curseate. rather fim, the apices truncate or bro ally rounded, lowmoothed, the maxgims at least toward the base entrie or undulate, somewhat revolute, the base cuneate.

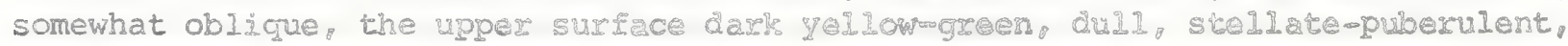
the lower surface palex, more densely stealatemadiry (2t least when young), orten stellate tomentose with blorde or redi:shabrow balrs: petioles short, round. stellate hairy。

Inflorescence. oblong white spikes $3-5 \mathrm{crn}$ long, the intornodes elongating as txitt develop, each flower subtended by a short, ovate, comertose bract.

Flowers. - sepals fused with receptacle into a short (3-4 mn ) campanulace, palem tomentose hypanthium, the calyg lobes very reduced, forming a more or less

scaly rim. Petals absent. Stamers numerous, the rilaments club-shapea, ca, 5 mm Iong very white, slightiy Elattened, the anthers smali, Jeliowish, reniform. Ovary halswinferior, densely tomentose, 2 carpellace, sigles 2 , filiform, Iater the carpel tips grading acurinately into 2 , spreaingo persistent beais.

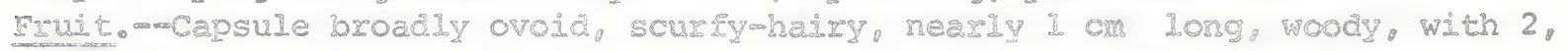
shiny brown, oblong seed to $5 \mathrm{~mm}$ long, all very similar to pamanelis.

Distribution and Iowering Season

Pineland bog margins, pocosirs, savannas, Coastal Plain Eron eastern North Carolina intermittently southward to north Forida, thence west Into nosthwest Florida and southerm Alabama. Flowering March into May.

Special Identifying Features

I. gardeni, mostiy a coastal plain species, is a lower shrub with more pubescence, smallex, narrower based leaves, smaler flowers, shorex stamens, smaller fruit than the more interior and montane E. major (sIms.) Iodd.

Habitats and Management Implication

E. gardeni is a plant of acidic, highly humified sands that are pemanently wet; a good place to look for it is in sparingly plue-fosested pocosins and on the shrubby edges of pitcher plant bogs. It is usually a part of dense shrubbery, associated with Myrica, various Vaccinium and Gaylussacla Persea Magnolia virginiana, gallberries, etc. In the easterr pats or its range there is usually some pond pine mingled witi longleat gine in the overstory. It is 
plainly part of a community in which fire was, and is, critical to its maintenance. It is a plant of full sunlight or very light shade, and probably increases with the reduction of competition through clear-cutting or burning. Any site preparation involving drainage, combined with bulldozing, rootraking, chopping, would elininate the species, with beding being the least undesireable.

References

Radford, A. E. et al. 1968. Manual of the vascular flora of the Carolina, pp. 530-531. Chapel Hill, N.C.

Small, J. K. 1933. Manual of the southeastern flora, p. 601. Chapel Hill, N.C.

Weaver, Richard E. 1969. Studies in the North American Genus Fothergilla

(Hammamelidaceae). Jour. Arnold Arb. 50:599-619. 
SPECIES: \#81 Fothergilla gardeni Mur. Dwasi witch-alder

\begin{tabular}{|c|c|c|c|c|c|c|c|c|}
\hline & \multicolumn{8}{|c|}{ Managerent Practicee } \\
\hline $\begin{array}{l}\text { Expected\% } \\
\text { Effect on } \\
\text { the Specles }\end{array}$ & $\begin{array}{c}\text { Prescoibe } \\
\text { Bura } \\
\end{array}$ & $\begin{array}{c}\text { Bulidoze } \\
\text { or } \\
\text { Root Rake }\end{array}$ & Bed & Chop & $\begin{array}{l}\text { Thir } \\
\text { over- } \\
\text { story }\end{array}$ & $\begin{array}{l}\text { Cur } \\
\text { over- } \\
\text { story } \\
\end{array}$ & $\begin{array}{l}\text { Establish } \\
\text { Dlantation }\end{array}$ & Graze \\
\hline Dastroy & & 83 & & $x$ & & & & \\
\hline Damage & & & $x$ & & & & $x$ & $?$ \\
\hline $\begin{array}{l}\text { No Lastirg } \\
\text { Effect }\end{array}$ & & & & & & & & \\
\hline $\begin{array}{l}\text { BeneELcial } \\
\text { Li Done } \\
\text { Properly }\end{array}$ & $x$ & & & & $x$ & $x$ & & \\
\hline
\end{tabular}

\section{Other Cormerts:}

* Expected effect on the species is an estinate made by Dr. Robert Kral based on his knowledge of the hableat and on knowledge galned from personal field observations. Estimes are "rough" In many Inetances. Results of practices may be modifled dependirg upor the degree of application, intensity of treatment, neamess to plant comunities, etc. A management practice for which mo entry 18 made indicates a lack of sufrictent information from which to predict expected results. As observacions are made in the field by users of the data, the expected effect will be reflned. 
Fothergilla gardeni Murr.

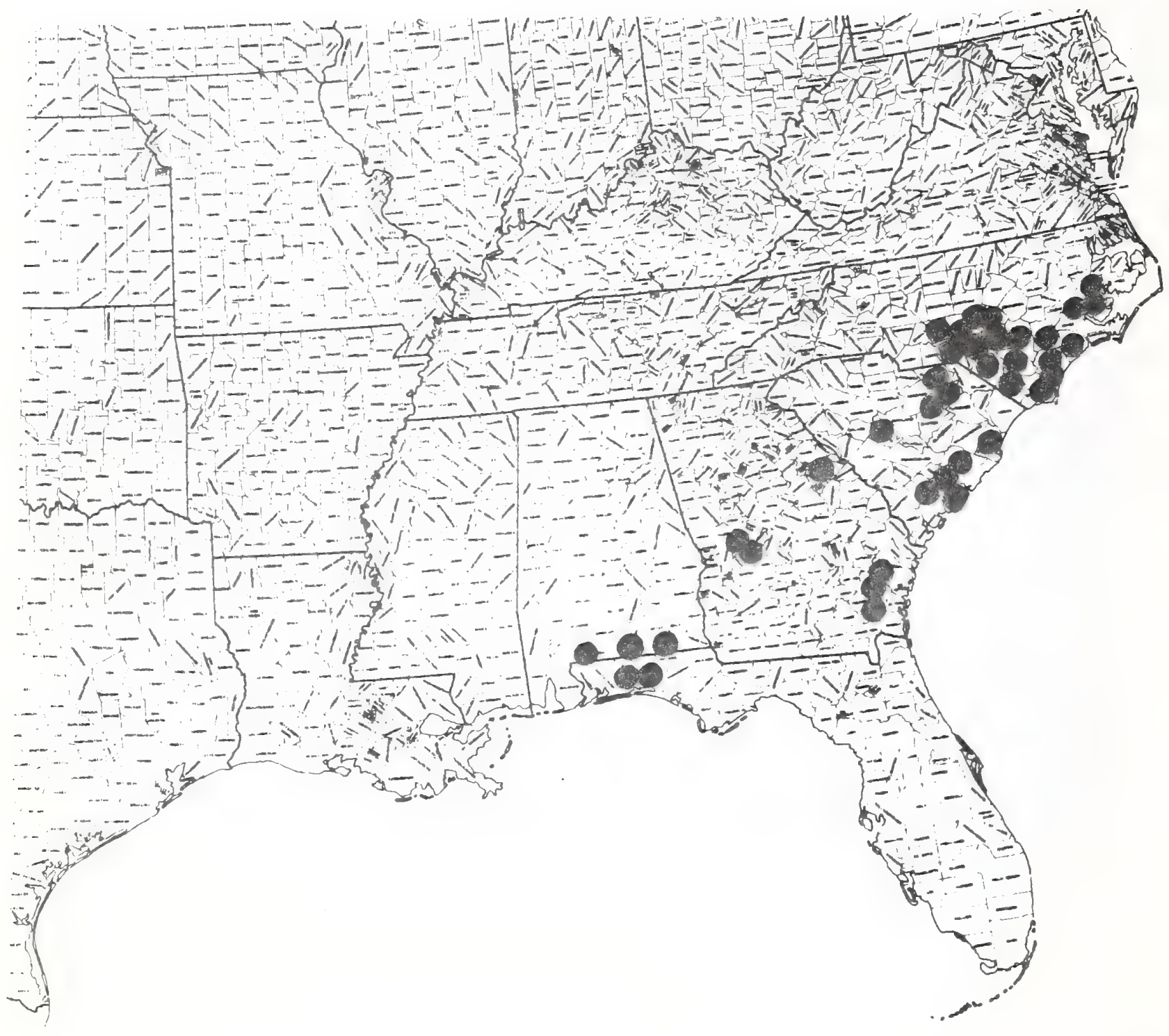


Paper 82

Text \& map by:

Robert Rral

\title{
HYDROPEXTIACEAS
}

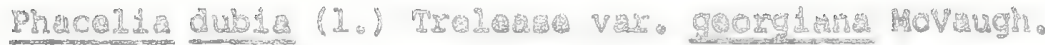

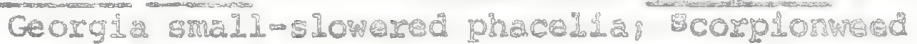

\section{Technical Description}

Annual taprooted herbs.

Stems. - The sterns solitary and erect or several and spreadingascending, or erect With several candelabralike bramches prom near the base, mosty $10-20$ (-30) cru Iong, slender but stifish, terete, reddishwirted with stifish. sharp, short. white, upwardy-directed hairs Elattened to the surface mised with spreadirg stalked glands.

Leaves. - Basal leaves in a rosecte, usually withering by flowering tine, distinctiy petiolate, odd pinnately compound, $2 a 4 \mathrm{~cm}$ long, with several pairs of learlets spreading in an oblong pattem, the terrinal and uppermost laterais largest. mostly elliptic or obovate, themselves scrutines deeply lobed, the laterals prominenty stalked, all surfaces pubescent as in stems stern leaves mostly erect, alternate, progressively shortening up the stem and becouing sessile, pinnately compound or divided.

Inflorescence.-Flowers in uncoiling teminal gacenes. beconing well separate as they mature to fruit on approssed-halry spraading stalks that olongato to nearly $1 \mathrm{~cm}$. In fruit.

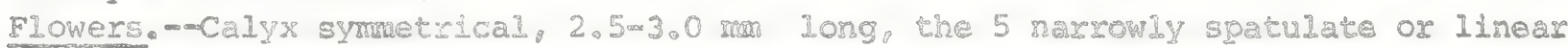
lobes nearly erect, separate neary to the base, greanigh, aporessed-hairy as in stems. Corolla symetrical, rotate (shaliowly cupghaped), mostly 5 m m across, the 5 lobes broadly ovate, rounded, nearly encire, about as long as the tube, pale blue with deeper blue veins, the "eye" near white, externally with a scattering of long whitish halrs, intemaly smooth. Stantw 5, atrached low in corolla aternating with lobes, spreadingmerect, the slender fidments 507 gnan long, pale blue with long spreaging withe hairs toward base, the anthers oblong, blue, about $1 \mathrm{~mm}$ long. Ovary superior, broady ovold and shorter than the sepals, with long, erect stirc hairs, the style linear with 2 slender branches about midlength. Capsule broady ovoid, 3-4ra long. stiffoinairy, 2ochambered, the seeds dark brown, irtegularly oblong, few, unutely pebsled, or foveate (pitted). angled with flattish interfaces.

Distribution and Flowering Season

On and around granite outcrops, in the Piedmont of Ceorgla and Alabame Flowering Apri1 and Mey.

Special Identifying Features

According to McVaugh (1943) this variety has more rosette leaflets (7-13, usually 9-11) than var. dubla (3-7) with the reminal segment not greatly larger than the upper laterals and the lateral segmente definitely stalked rather than sessile. The stem-leaves are prevalently oblong, rather than obovate or ovate as in var. aubia. 
Habitats and Management Implication

Typically the var. georgiana is on thin sandy-silty wash over granite, usually in shallow depressions or cracks. Also it is in the sandy solis surrounding granite or over shallowly underlying granite and frequently extends along sandy road shoulders or fields for several miles around the outcrop areas. It is altogether weedy, often an aspect dominant in such places, always in full sun or very light shade. Its sites, while often moist in winter and spring, invariably become quite dry. Obviously it thrives on the outcrops or in situations that match these, in other words artificial operings in the surrounding oak-pine. Quarrying of the granite is the major threat to this plant, but it will maintain abundantly so long as there are open sandy areas remaining.

References

McVaugh, Rogers. 1943. The vegetation of the granitic flat-rocks of the southeastern United States. Ecol. Monogr. 13 (2): 120-166.

Small, J. K. 1933. Manual of the southeastern flora, pp. 1097-1098. Chapel Hill, N.C. 
SPECIES: $\quad$ \#2 Phacelia dubia ( .) Trelease var. georgiana McVaugh Scorpion we

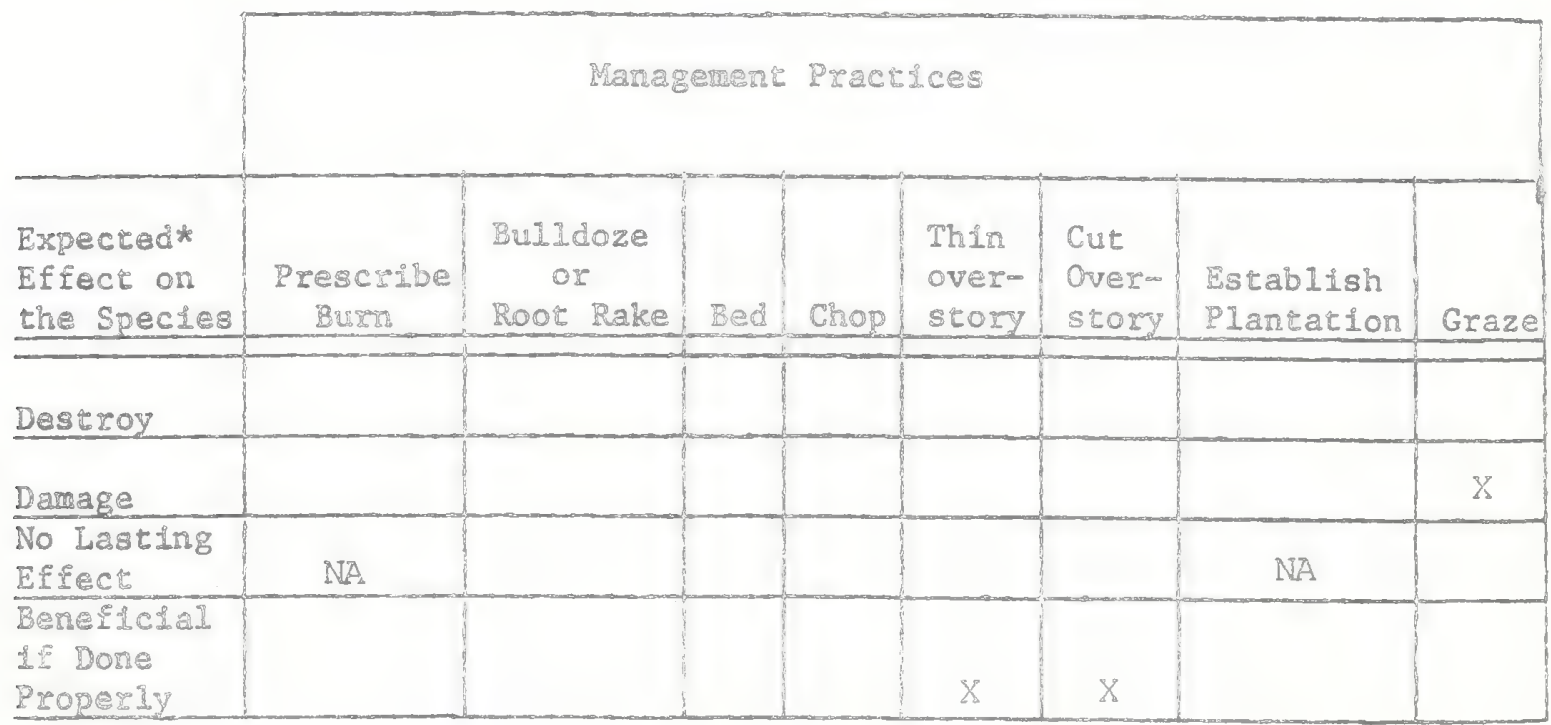

\section{Other Commerts:}

* Expected effect on the specier lo an estimate made by Dro Robert Kral based on his knowledge of the habltat and on knowledge gained from personal field observations. Estimates are "rough" in pany Instances. Results of practices may be modified deperding upon the degree of appllcation, intensity of treatment, neamess to plant comunitles, etc. A management practice for which no antry is made indicates a lack of sufficienc information from which to predict expected resuits. As observations are made in the field by users of the data, the expected efrect will be refined. 
Phacelia dubia (L.) Trel, var. georgiana McVaugh

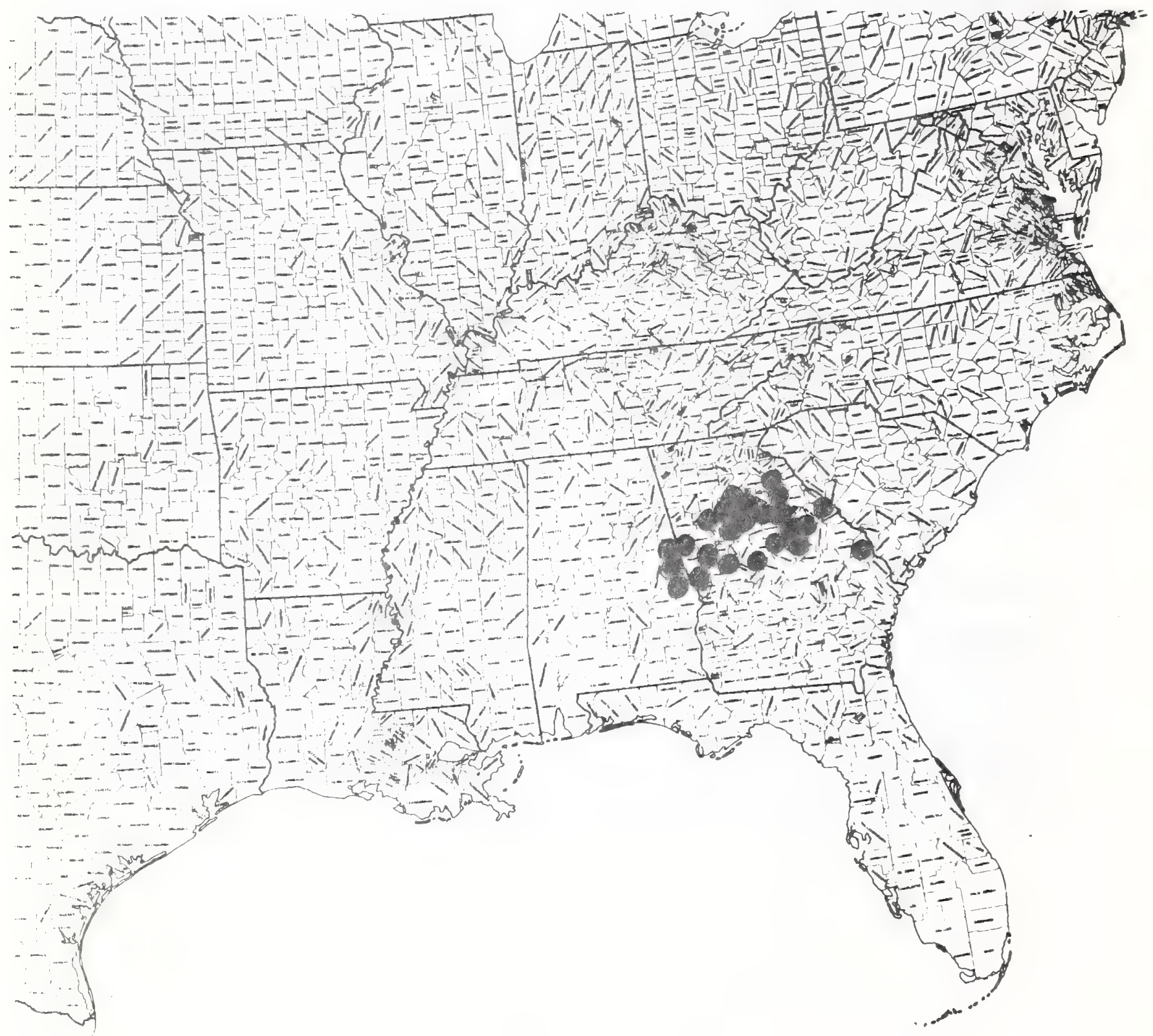




\section{HYPRRICACRAL}

Hypericun edisonianum (Sm21L) Ad \&us \& Robeson. Edison"s

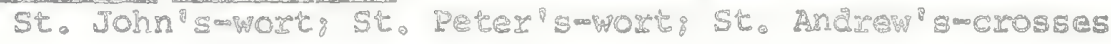
Ascyrum edisonianum Smal1

Technical Description

Shrubs to $1.5 \mathrm{dm}$ high, mostly erect at the base. Stems. - The base terete or nearly so, smooth, the bark pale brown repeatedly forkingmbanching above, but essentially leafless save for uppemost branches, there densely leary, all this from a woody, spreading, shallow root system. Ieaves.--opposite, sessile, leathery, smeotis, elliptic to oblong or brozdiy spatulate, mostly I-2 cm. long, ascending, acute, or shortmacurninate, entrire, the bases rounded, slightly clasping, the upper suriace glaucousagreen, the lower surface paler and yellow green, gland dotted, with a raised midrib; stipules present as large redishmbown glands at sides of blade bases. Inflorescence- -Flowers symetrical, terminating the numerous leary branch lets, often their bases hidcen by leaves, on erect or curved stalks 5010 ma long, bearing 2, small. narrowly-triangular, scaly bracts well below the calys base. Flowers.-Calyr of 2 series, the outer series of 2 largest, erect, broadiy elliptic or ovate, mostly 9-15 mm long, acute to short-acuminate, entire, the bases broadiy rounded or cordate, clasping: inner pair concealed by outer, shorter, narrower, Iinear-lanceolate. Petals 4 , subequal, $10-18 \mathrm{~mm}$ long, distinct obliquely obovate, yellow, spreading. Stamens numerous in a yellowish tuft, ovary superior, ovoid, the carpels $3-4$. styles $3-4$, slender. This plant foms thickets, developing shoots at intervals from the spreading shallow roots.

Distribution and Flowering season

Low prairies, sandy peaty shores, duneswales ilatwoods, southerr peninsular Florida. Flowers all year.

\section{Specal Identifying Features}

This species is distinguished from the closely related Mpericum stang (Michx.) Adams and robeson by its mainly narrower leaves and outer sepals and its mach bushier habit.

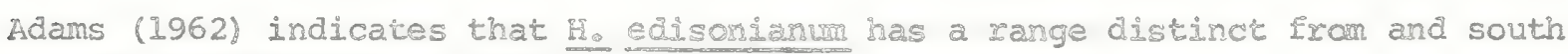
of. the widespread $\mathrm{H}_{0}$ stans.

Habitats and Management Inplication

I. edisonianum is restricted to a few counties in southern peninsular Florida (Highlands, Glade, Desoto), and typically is on high hydroperiod soils of prairies, pondshores and pineland grass sedge clearings. Here it is admixed with a large variety of grasses seciges, orchids, polygals, Ludwigla, etc. these amidst a scattering of palmetto. Periodic flring or these prairies and grassy clearings during dry seasons and drovghts has helped to maintain such 
spectes as this. Logging, if unaccompanied by drainage, increases $\mathrm{H}$. edisonianum. plantation level stocking shades it out. The plants, while not used by livestock are broken and trampled by them; improved pasture closes out their reproduction. This genus produces hypericin, a photosensitiser.

References

- 1957. A revision of the genus Ascyrum (Hypericceae). Rhodora 59(700):73-95.

Adams, P. 1962. Studies in the Guttiferae I. A synopsis of Hypericum section Myriandra. Contr. Gray Herb. 189: 3-51.

Small, J. K. 1933. Manual of the southeastern flora, pp. 867-868. Chapel Hiłl, N.C. 


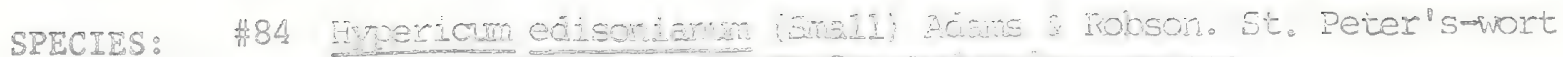

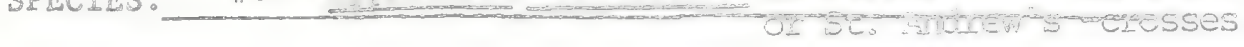

\begin{tabular}{|c|c|c|c|c|c|c|c|c|}
\hline & \multicolumn{8}{|c|}{ Maragenent Practces } \\
\hline $\begin{array}{l}\text { Expected\% } \\
\text { Effect on } \\
\text { the Specieg }\end{array}$ & $\begin{array}{c}\text { Prescribe } \\
\text { Bumn }\end{array}$ & $\begin{array}{c}\text { Bulldoze } \\
\text { or } \\
\text { Root Rake }\end{array}$ & Bed & chop & $\begin{array}{l}\text { Thin } \\
\text { over- } \\
\text { story }\end{array}$ & $\begin{array}{l}\text { Cut } \\
\text { over- } \\
\text { scory } \\
\end{array}$ & $\begin{array}{l}\text { Establish } \\
\text { Plantation }\end{array}$ & Graze \\
\hline Destroy & & $x$ & $x$ & x & & & $\mathrm{X}$ & \\
\hline Damage & & & & & & & & $\mathrm{X}$ \\
\hline $\begin{array}{l}\text { No Lasting } \\
\text { Erfect }\end{array}$ & & & & & & & & \\
\hline $\begin{array}{l}\text { BenerLCLI } \\
\text { IE Done } \\
\text { Properly }\end{array}$ & $\mathrm{x}$ & & & & $X$ & X & & \\
\hline
\end{tabular}

\section{Other Comenes:}

* Expected efrect on the species is an estronate made by Dr. Robert Kral based on kis knowledge of the habitat and on knowledge gained fron personal field observarions. Estimates are "rough" in many Lnstances. Results of practices may be nodified depending upon the degree of application, intensity of treatment, neamess to plant comunities, etc. A managewent practice for which no extry is made indicates a lack of sufficient information from winlch to predict expected results. As observations are made in the field by users of the data, the expected effect will be refined. 
Hypexicum edisonianum (Small)Adams \& Robs.

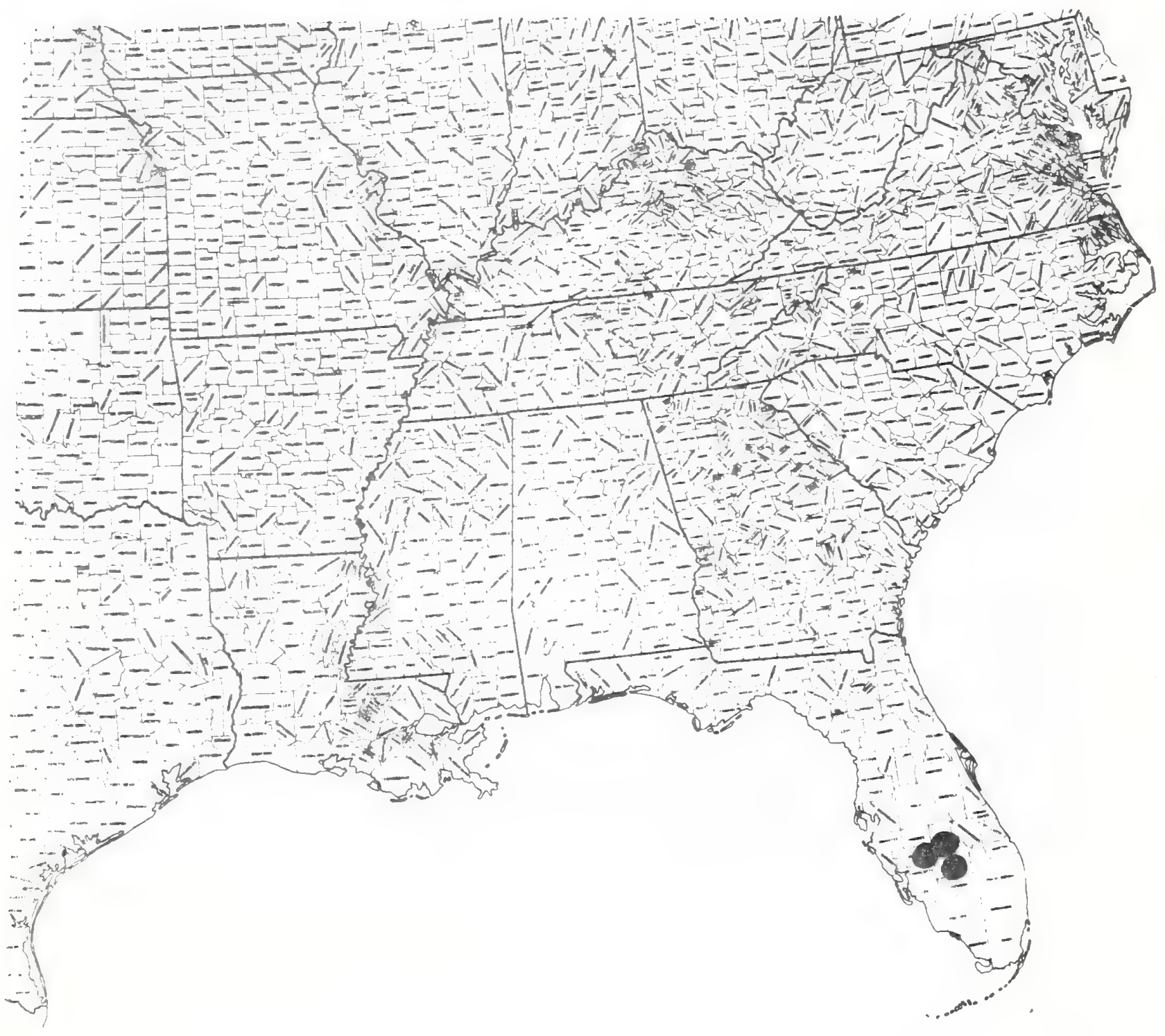


Technical Description

Tall (to 1.5 meters) slender, smooth erect or leaning, wandijke and grasslike plants from ovoid bulbs up to $2 \mathrm{~cm}$ broad. the outer scales dark reddishobrown, ovate, acurninate, the innermost scale leaves somewhat lorgerwtipped.

stems.--Terete, at most 4 man thick, can or pale yellow green glaucous, flecked with maroon, the nodes slightly swollen, few and distanto Ieaves.-Basal and lower stern leaves pale green very elongate-ihnear rarely more than $5 \mathrm{~mm}$ broad, to $7 \mathrm{an}$ lorg, narrowly attenuate involute at the tips, the margins entire, the blade bases broadening into open rather short sheathes. Inflorescence. - A teminal, narrowly and elongate-forking system of longow stalked spathes: spathes 2, overlapping, the lower one shorter, papery-margined, Iinear, concealing the flower stalks and perianth tubes.

Flowers,-Erect, nearly symetrical, the sepals and petals spreading horizontally. the flower fully $3.5-4.0$ crn broad, bluewiolet: perianth segmentes elliptic to narrowly obovate, the petals slightly smalex, Stamens 3, erect, the filaments very much shorter than the linear $(7-8$ m long) yellowish anthers whose tips are coiled. ovary inferior, short, the 6 style branches spreading, narrownconic, tapering to narrow stigmas. Eruit, - Capsule obovold, ca. $1.5 \mathrm{~cm}$ long, truncate, capped with the lobes of the persistent style branch bases: seeds nuerous, about $1.5-2.0$ man broad.

Distribution and Flowering Seasor

Iow sunny areas in Flatwoods, also swamp and marsh borders, eastern peninsular Elorida, mostly along the St. Johns River southward asd eastward. Flowering Bugust into october.

\section{Special Identicying Features}

This species is similar to the Iridaceous genus Sphenostigma, which see. The

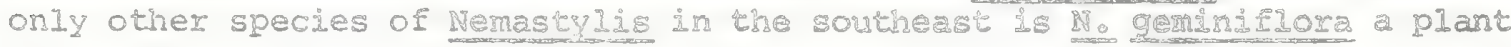
of heavy prairie earchs to the northsest, and which blooms in the morning. N. Eloridana has flowers which open at about fow $0^{\circ}$ clock in the aftemoon closing toward dusk.

Habitats and Management Inpl1caciong

$N_{\varphi}$ floridana is 1ocally abundant from Volusia county southward In wet, grassy. sandy peat or peatminck clearirgs in slash piremsaw paImetto, at edges of caboba paIm hamocks, or in broad rarshes. It is a plant mostly Found in full sun or the light shade or hamocks edges and savana plne. Much of the broad marsh along the St. Johns River is now pastured; the irnproved pasture does not favor the species in that li forms a closed mass or grass bases and rhizomes. Much of the pine flatwoods savanna where it formerly grew is converted to housing as a result of the space progran on Merritt Island and the subsequent expansion of Cocoa and Meloourne. Mhch of the savania and marsh has been 
systematically drained in any event, and drainage eliminates this species together with the grass-sedge complex it is a part of.

References

Small, J. K. 1931. The celestial lilies. Journ. N.Y. Bot. Gard. 32. 266 and Fig. 2.

1933. Manual of the southeastern flora, P. 326. Chapel Hill, N.C.

Mackiernan, Janice M. \& Elaine M. Norman. 1979, Reproductive

biology of Nemastylis floridana Small (Iridaceae). Florida Scientist $4: 229-236$. 
SPECIES: \#85 Nemastylis Eloridana Small Celestials or Celestial-Lilies

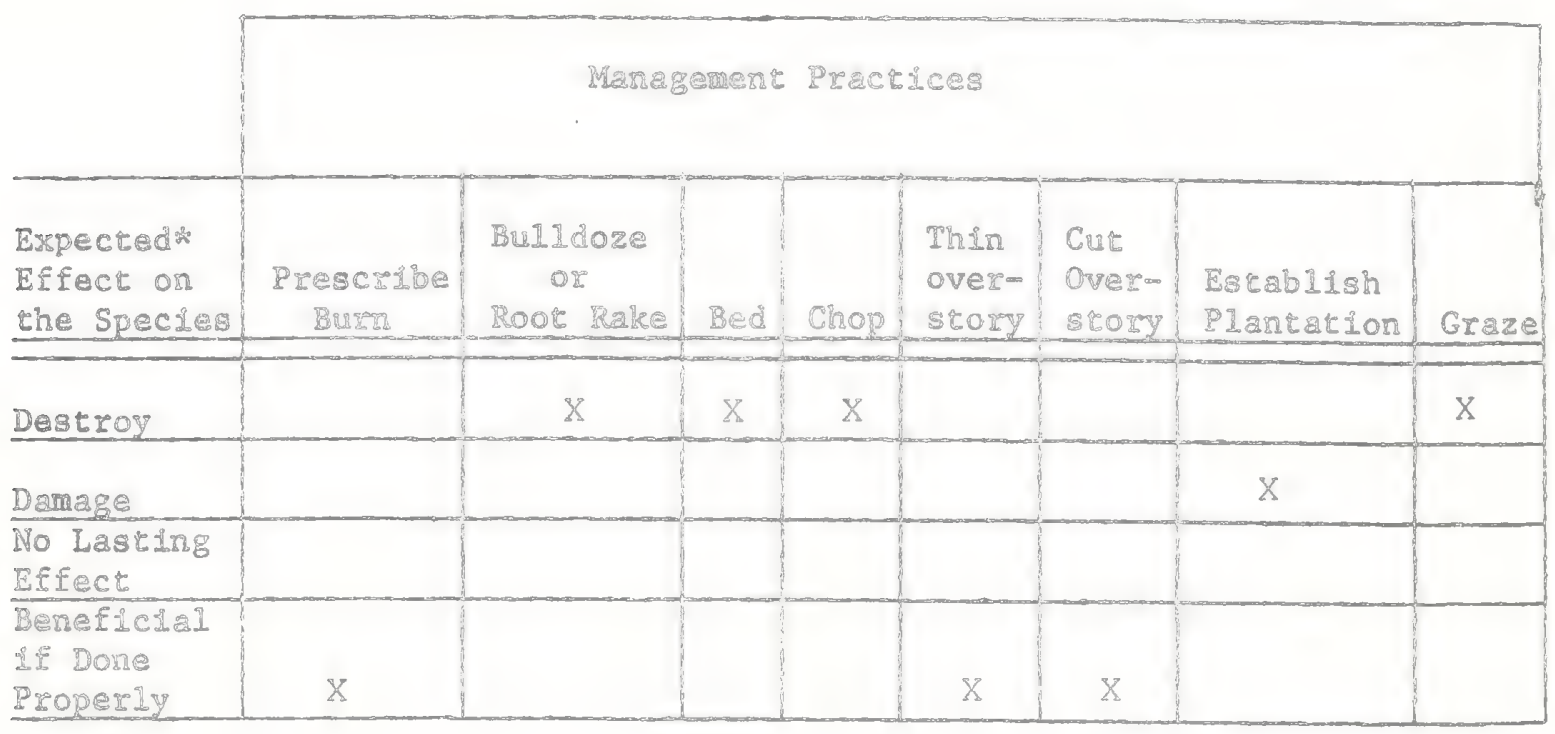

\section{Other Coments:}

*Eapected effect on the species is an estimate made by Dr. Robert Kral based on his knowledge of the habltat and on knowledge gained from personal fleld observations. Estimates are "rough" In many instances. Results of practices my be modifled depending upon the degree of application, Intensity of treatment, neamess ro plant comumites, etc. A managenent practlce for which no entry is made indicates a lack of sufflclent information from which to predict expected results. As observations are made in the field by users of the data, the expected effect will be refined. 
Nemastylis floridana Small

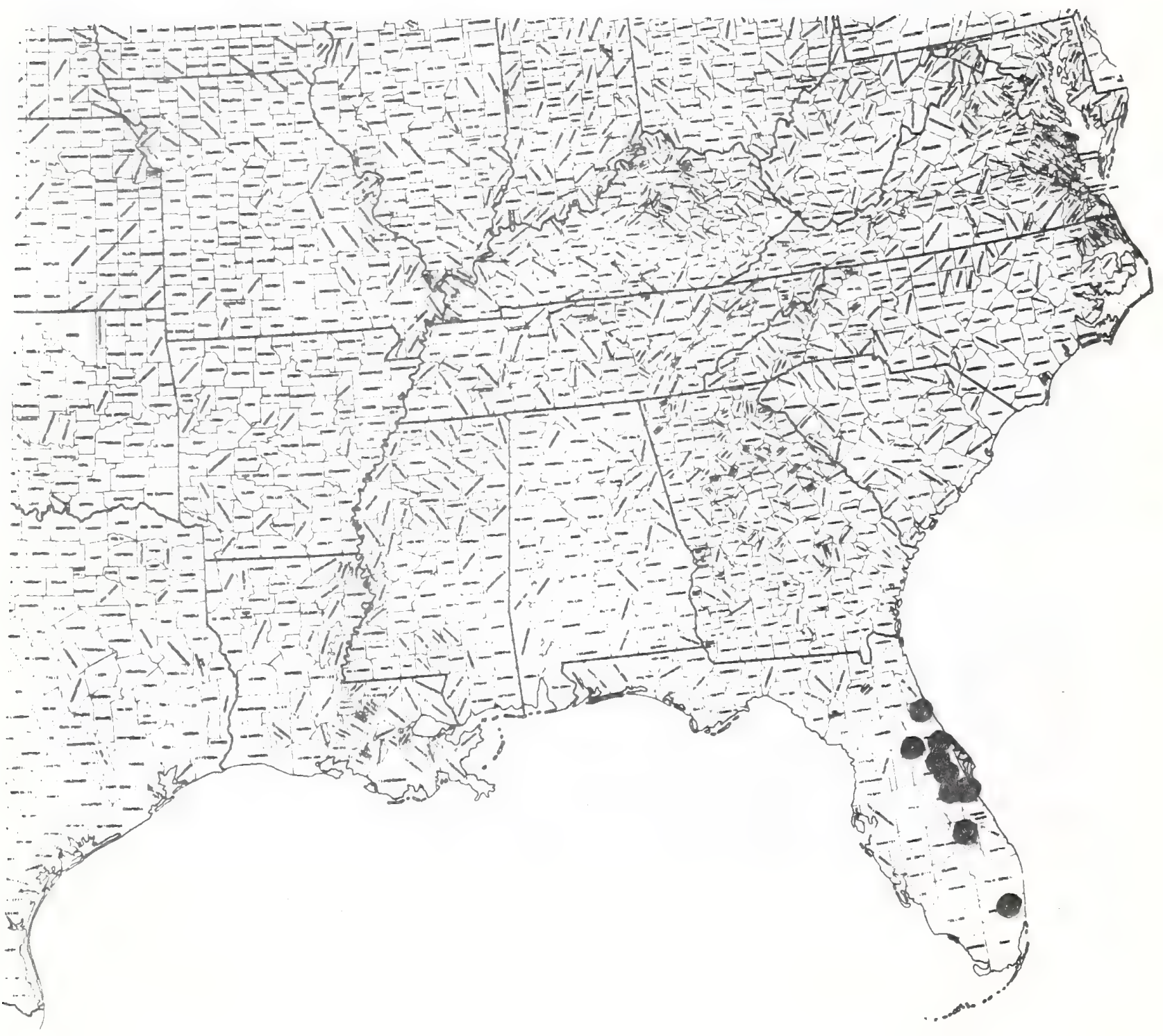




\title{
IRIDACERE
}

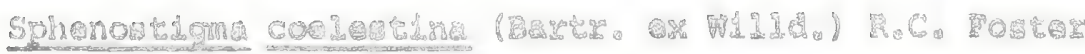 \\ Bartram is iriag $\mathbb{N}_{0} \mathrm{CON}_{0}$ \\ Isia coelestina batro

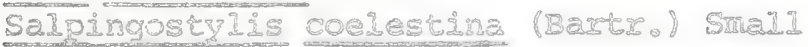

Technical Description

Erect, perennial, grass-like herto from an ovojd bujb $2.0-1.5$ crn broad, the outer bulb scales dark dujd brows.

Stems.-Very slender, usualiz unbranched, ofter bent at the sIIghty swoller nodes, greenish, low ribbed, slightiry compressed between the nodes, 2 ol dm long. Leaves.-Sheath leaves short, narzow, 1lnear, paler broan, erect, thin. BasaI leaves 1-3, shorter than the ster, razrowly alisptic-imiear, the tips attenuate, the blade somewhat pleated and ribbed, narrowing involutely to a short, mostly open sheath, the sheath bases orten strongly tinted with orangewellow as are the covered bulio scales. Stem leaves recuced, the bases sheathing, the blades to $9 \mathrm{~cm}$. Iong, 1 or 2 , ascending, distant on the stert.

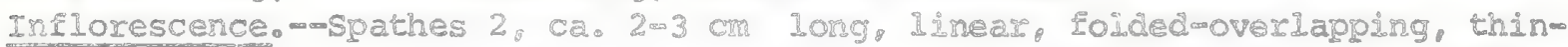
margined, greenish, acute, with narrow thin nartion tinted at the apes with maroon. Flowers nearly symetricals on very siencer (rarrowly linear) stalks hidden by the spathes, opening lateraliy to the spathe tip. Flowers.-merianth tube very slender. its tip sightig projecting beyond the spathes: perianth segments nearly equal spreading pale gentian biue paler toward the base, oblasceolate or obovate, the tips rounded or (usually) emarginate. the margins entire, the bases cuneace or attenute to a short claw or sessile at top of perianth tube, the whole rlower when rully open iully $5-6 \mathrm{~cm}$. broad. Stamens 3. filaments arising ar sumit of perianth tube, slender with abruptiy flaring thin bases, the anthers gellowish linoarmoblong, ca. bes mn long. ovary inferior, the very elongate slender ercor style with 3 narrow, ascending branchos

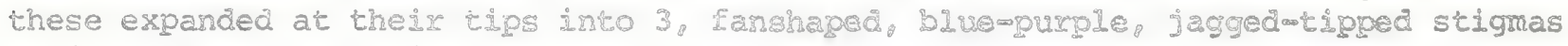
projected a cm or slightiy wore boyond the tip of the perianth tube. Eruit.-Capsule 1.5-2.0 cm long, erect, short oblong or marrowly obovate, greeniah, smooth. projected beyond the spathe tips or a thickened stali.

Distribution and Flowering Season

Low pine flatwoods, pineland savamas, northeastera Lordä. Flowering May, June.

Special Identifying Features

Tris species. First observed and illustrated by widiam Bartram is at a glance

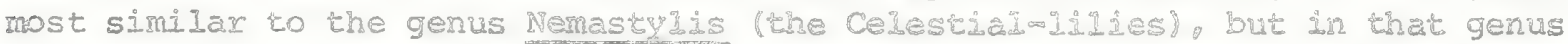
the anther tips are colled and the style branches nawow roward the taps. rather than flattened into fanshaped stignas. Whe orly Meriestylis Chat could possibiy

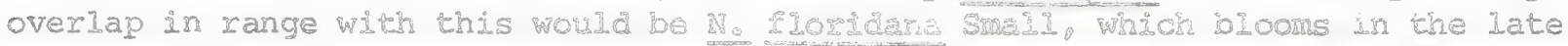

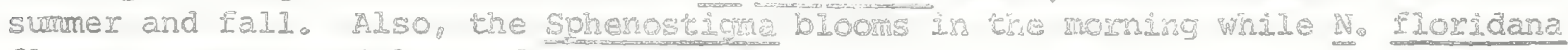
flowers open toward late afcenoon. 
Sphenostigma coelestina is in high hydroperiod, highly organic (usually black) fine textured sandy soils. It may be in full sun in savanna clearings or in open stands of flatwoods pines such as $P_{0}$ palustris, $P_{0}$ elliottii or $P_{0}$ serotina. Palmetto and gallberry, together with various heaths are common understory shrubs. The associated herbs are mostly grasses and sedges, with a scattering of Xyris, Eriocalaceae, orchids, Polygala etc. all indicative of the intermittently highly moist soil. Its bulbs, though rather shallowly set in a matrix of grass and sedge roots, seem not to be harmed by periodic fires. Most of the areas where the plants have been seen in abundance have had some recent fire. Occasionally the plants are seen in plantations of pine, usually in evidence where the trees have past the sapling stage and again where there has been a recent burn. Much of the former area of the species has been lost either through expansion of housing, rowcrop agriculture, nurseries, or improved cattle pasture. In most of these events, and in some of the managed tracts of pine, holdovers have probably been destroyed by the drying out resulting from construction of drainage ditches. These soils, on draining, lose much of their organic matter and become dry white sands. This species should be considered endangered rather than merely threatened. Most methods of site preparation involving soil disturbance will eliminate the species, the least objectionable method being bedding.

Interestingly, flowers of the species open at dawn, close at about 10:00 A.M. and during that period make one of the most beautifully conspicuous of mass floral effects. Yet, by late morning and afternoon, when the corollas have withered, the plants seem to disappear, blending into the mass of other grasslike herbs.

References

Foster, R. C. 1945. Contr. Gray Herb. 155:15.

Sma11, J. K. 1931. Bartram's Ixia coelestina rediscovered. Journ. N.Y. Bot. Gard. 32:161.

1931. Celestial lilies. Journ. N,Y, Bot. Gard, 32: 266. 1933. Manual of the southeastern flora, pp. 326-327. Chapel Hill, N.C. 
SPECIES: \#86 Sohenostigna coelestina (Barter. ex Wilido) R. Co Foster N.C.IN.

\begin{tabular}{|c|c|c|c|c|c|c|c|c|}
\hline & \multicolumn{8}{|c|}{ Management Practices } \\
\hline $\begin{array}{l}\text { Expected\% } \\
\text { Effect on } \\
\text { the Specles }\end{array}$ & $\begin{array}{c}\text { Prescrdbe } \\
\text { Bura }\end{array}$ & $\begin{array}{c}\text { Bulldoze } \\
\text { or } \\
\text { Root Rake }\end{array}$ & Bed & Chon & $\begin{array}{l}\text { Thin } \\
\text { over- } \\
\text { scory }\end{array}$ & $\begin{array}{l}\text { Cut } \\
\text { Over- } \\
\text { story }\end{array}$ & $\begin{array}{l}\text { Escablish } \\
\text { Plancarlon }\end{array}$ & Graze \\
\hline Destroy & & $\mathrm{X}$ & & $\mathrm{X}$ & & & & $x$ \\
\hline Damage & & & $\mathrm{X}$ & & & & $X$ & \\
\hline $\begin{array}{l}\text { No Lagting } \\
\text { Efrece }\end{array}$ & & & & & & & & \\
\hline $\begin{array}{l}\text { Berericial } \\
\text { If Done } \\
\text { Properly }\end{array}$ & X & & & & $x$ & $Z_{2}$ & & \\
\hline
\end{tabular}

\section{Other Comenes:}

*Erpected effect on the specles ls an estorate made by Dr. Robert Kral based on his knowledge of the habitat and on knowledge galned from personal field observations. Esthates are "rough" In many Lnstances. Results of practices mey be modifled depending upon the degree of application, intensity of treatment, rearsess to plant comunties, etc. A mansgement practice for which mo entry is made Indicates a lack of sufficient znformation from which to predict expected results. Ms observations are made in the field by users of the data, the expected erpect will be reined. 
Sphenostiqma coelestina (Bartr. ex Willd.)Foster

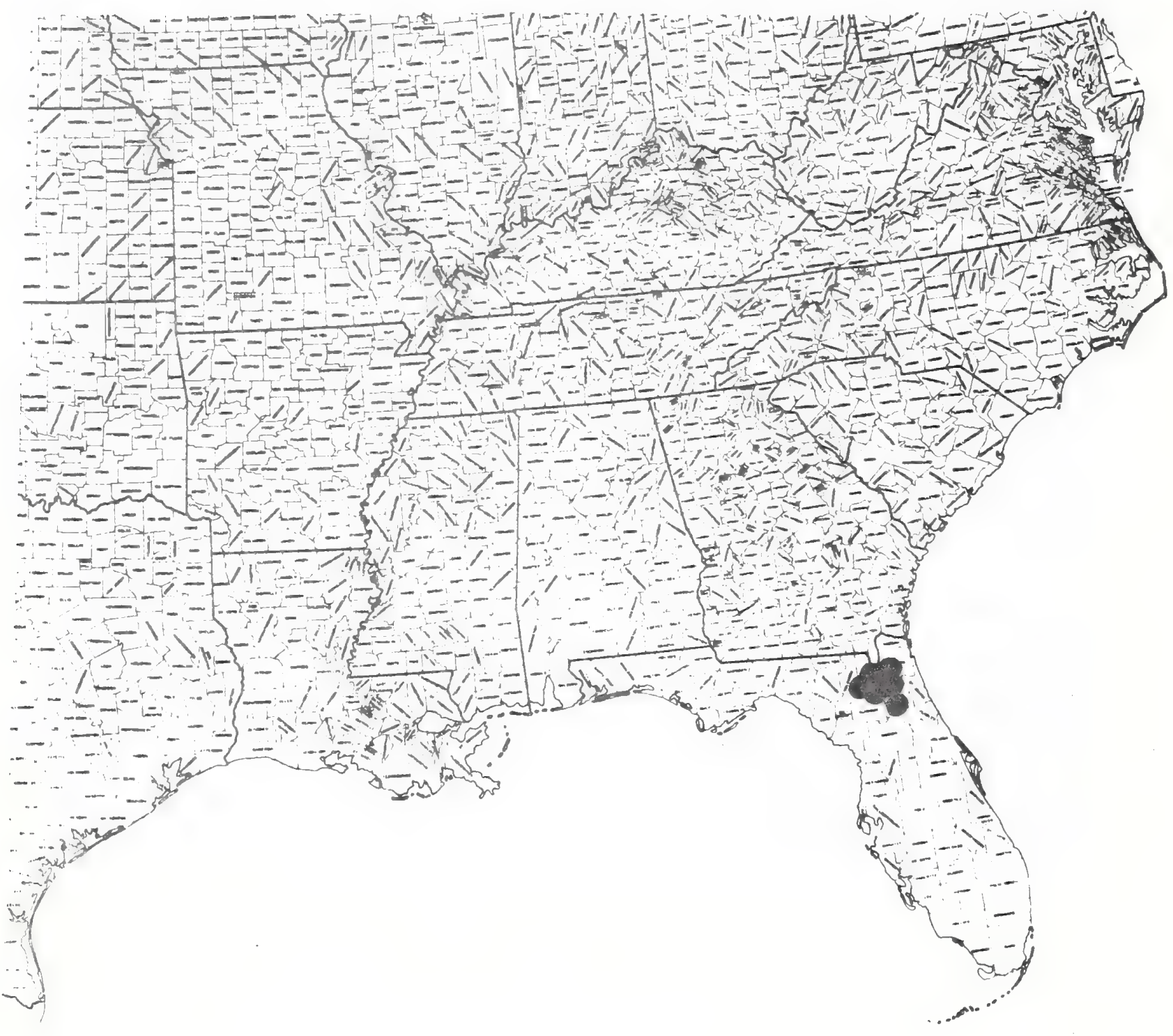


Raper 87

resce me by:

roberste resa

\section{JUACACEAE}

Juncus gymocaspus covidae: Covilie"s rusho mish S. Smithi Eragelrat. not runth.

Technicai Description

Perennial herbo

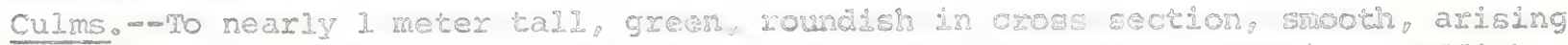
Iike closenet posts in a picket fence rrom a shallew. stout cropoing. redisho brown, SGQLY rhizome.

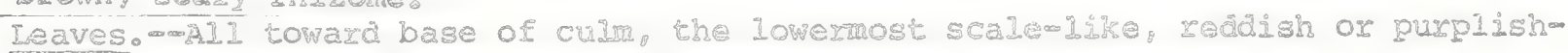
brown, the uppermost more tubular, upwardy greendis, acute.

Inflorescence, - Sessile or nearly so, the flowers urumly sererd in a diffuse system of cymes (often broader than high), appersing to arise Iatoraliy from the gradually capering culn tip. the branches or clusters oi branches axising from small clusters or scaiy, green midribbed, Lancenovace prophylds.

Flowers.--Symetrical with short prophylis imediately below, these mostly ovate. acute, with broad green midribs. Perianth spreading the sepais and petals each 3. greenish-brow, 2.0-2.7 m 10ng, much shorter than the mature fruit, the sepals lanceolate, acuminate, Ionger thas the ovate, roundwtipped, broady thin margined petals. Stanens 6 , anthers as long as filaments: ovary superior. Fruit, -Capsule when ripe with fim pale greenishobrows valves, ovoj., about $3 \mathrm{~mm}$ Iong, the valve edges sharply raised, bealsed. seeds ca, I ma long, unequally oblong. with short tails on both ends, manymizbed.

Distribution and Flowering season

Swamp woods, mountains of eastern Penssylyanda to the mountaing of North Carolina and Tennessee with disjunetions in Coastal Plain, namely northwest Florida, southeastem. Alabama, Southern Mississippl. In Borth, Flowering in August: In South, Flowering in aray Jure.

Special Identifying reatures

This species, which is being found rether frequently in sphagnous mountain swamp woods is much more rare in the GuIf coastal Plain. It is most similar to Juncus effusus and Jo coriacens. alfereng from the formex in its longer rhimones its perianth (in Jo effusus this is as long as or longer than the ripe capsule), and its thicher-walled capsules which narrow toward the tips rather chan being blunt. It differs rrom the latter again in its rhizomatous (rather then clupedy habit, its maller ovoid (rather than larger and round capsules, its more deilcate infiorescence with usually more flowers.

Habitats and Management Implication

Many Juncus are found in oper swamp or masches. Mhis one is usually in the shade, its xhizomes in peatmek or sandy peat rnuck, in the shade of bottomiand hardwoods

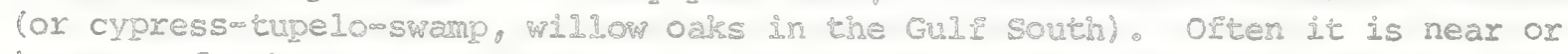
in mats of Sphagrum. not actually in the deepest swamp but rather the shallower margins。

Cutting of the swamp forests in which this grows may alter the habitat sufficiently to raise the water enough to obliterate this species. Opening up of the swamp 
forest tends to admit other plants of more sunny situations which will crowd out the species. Careful selective logging of the overstory should effect it little. References

Coville, F. V. 1894. Mem. Torr. Bot. Club 5: 106.

Engelmann, George. 1868. A revision of the North American species of the genus Juncus. Trans. Acad. Sci. St. Louis 2: 424-498

Small, J. K. 1933. Manual of the southeastern flora, pp. 281-286. Chapel Hill, N.C. 
SPECIES: \#87 Juncus Mrmocerys Covilie。 zushes

\begin{tabular}{|c|c|c|c|c|c|c|c|c|}
\hline & \multicolumn{8}{|c|}{ Mlanagement Practices } \\
\hline $\begin{array}{l}\text { Expected } \\
\text { Effect on } \\
\text { the Specieg }\end{array}$ & $\begin{array}{c}\text { Prescribe } \\
\text { Burn }\end{array}$ & $\begin{array}{l}\text { Bulldoze } \\
\text { or } \\
\text { Root Rake }\end{array}$ & Bed & Chop & $\begin{array}{l}\text { Thin } \\
\text { over- } \\
\text { scory }\end{array}$ & $\begin{array}{l}\text { Cut } \\
\text { Over- } \\
\text { scory }\end{array}$ & $\begin{array}{l}\text { Establish } \\
\text { Plancarton }\end{array}$ & Graze \\
\hline Destroy & & & & & & $\mathrm{X}$ & & \\
\hline Damage & & & & & & & & $\mathrm{X}$ \\
\hline $\begin{array}{l}\text { No Lasting } \\
\text { Effect }\end{array}$ & $\mathrm{NA}$ & & & & $x$ & & NA & \\
\hline $\begin{array}{l}\text { Beneficlal } \\
\text { 1E Done } \\
\text { Properly }\end{array}$ & & & & & & & & \\
\hline
\end{tabular}

\section{Other Contuenes:}

* Expected effect on the species is an estrmate made by Dr. Robert Kral based on hig knowledge of the habitat and on knowledge gafned from personal field observationa. Estinates are "rough" in many ingtances. Results of practices may be modified depending upost the degree of application, intensity of treatment, neamess to plant commities, etc. A management practice for which no entry is made indicates a lack of sufficlent information from mich to predict expected results. As obsevacions are made in the field by users of the data, the expected effect will be refined. 


\section{Juncus gymnocarpus Coville}

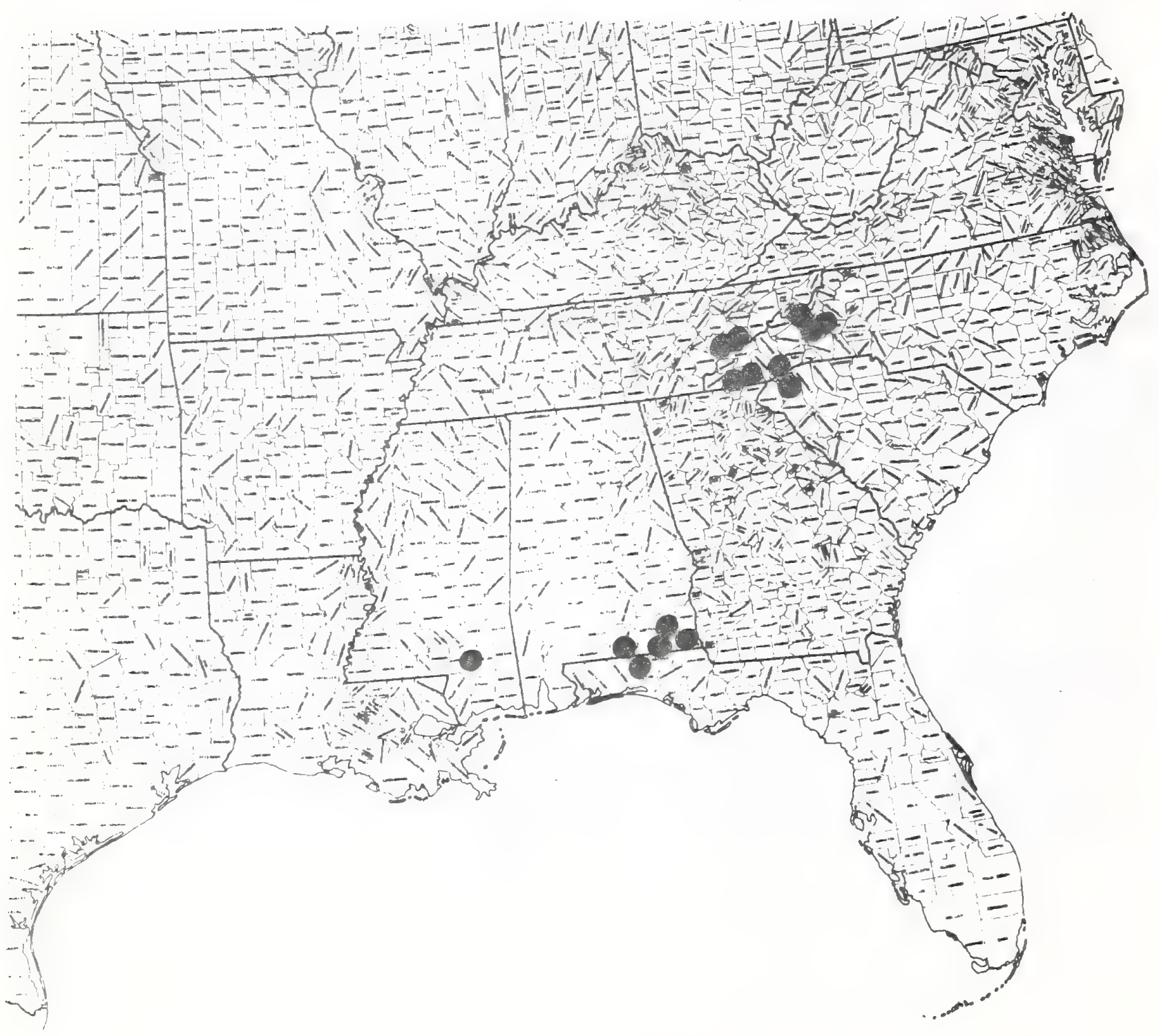




\title{
IARIACBRE
}

\author{
Calamintha ashe (Weatherby) Shinners. Ashos savory: Basil \\ Sacureja ashes weatherby \\ Clinopodium ashas: (Weatherby) Small
}

\section{Technical Description}

Bushy, pungently aromatic shrubs mostly 5 dm tall or dess, the loseveral primary shoots Irom a strong, branched taproot system. Stems, rom The older basal growth with shallowly cracked, pale gray brown bark that peels away in thin strips, the newer shoots numerous, ascending or erect, slender but stiffish, slightly if at ald angled, dowy with muerous fine short hairs, greenish or greenish-brow.

Leaves, - Of lower older sterns absent by flonering time, those of the newer shoots mostly numerous, opposite from nodes 1 ch or thereabouts apart, spreading or erect, linear to narrouly obovate, mosty $1 \mathrm{~cm}$ long or somewhat less, acute. the margins entire, strongly revolute, the bases mostly acute or cuneate, the surfaces grayogreen with a down of fine hairs, with srall glistening glands. Inflorescence. - wl lowers produced oppositely from the ardis of all or most upper leaves on ascending, downy hairy stalks about $3 \mathrm{mam}$ long, these with a pair of Iinear-Ianceolate bracts at their bases.

Flowers.-Calyx in flower about $6 \mathrm{~mm}$ long, the narcowly campanuate-cylindrical tube dull green, downy, lomibbed, about $3 \mathrm{~mm}$ long, the limb 2olipped, the upper Iip broady oblong, maroon, truncately 3mlobed, the lower lip of 2 somewhat longer, narrowly acute, slender tipped, upwardly arching teeth, the rim with a strong turt of erect, white hajrs. Corolia strongly bilabiate, about 1 cm. long, the tube and thxoat rather slender, $6-7$ m long, whiths to pale lavendera-rose, the upper Iip short-oblong, projecting slight Iy usward. roundedwernarginate. lavender-rose, the lower lip orojecting downard, 3 wobed with the midale lobe largest. lavender rose toward the tip, toward the base paler with darker mottings, the corolla surface finely hairy outside. Stamens 4 , in 2 lengths of 2 , the filaments arching up under the upper corolla lobe but not beyond it, the anthers shortoblong, daris purple.

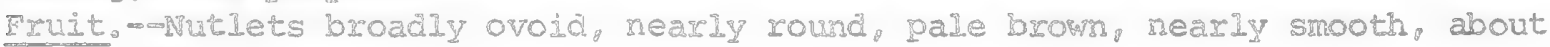
$\overline{1.5 \mathrm{man}}$ long.

Distribution and Flowering Season

Clearings in sandhilis scrü, the fortal central highlands for lakes country): southeastern Georgåa. Flowexing internittently from January to Erost.

\section{Special Identifying reatures}

Most similar to $C_{0}$ dentata a very rans smelling shrub conined to northwestem Florida and which has broader. somewhat larger, 15 wally cumeate-obovate leaves that have at least some teeth toward the apes. 
Habitats and Management Implication

This species, while local, may be extremely common where found. In the sandhills around Reidsville, Georgia (where it was reported by Roland Harper early in the Century) it may form masses in open stands of longleaf pine-scrub oak. There it frequently invades abandoned sandy fields or powerline clearings. It may also seed into young plantations of pine, being shaded out later as the crowns close. In peninsular Florida, the area from which it was first described by weatherby, it is endangered primarily because of housing development and increasing acreages of orange groves.

References

Shinners, L. H. 1962. Calamintha (Labiatae) in the southern United States. Sida 1 (2) $69-75$.

Small, J. K. 1933. Manual of the southeastern flora, pp. 1168-1169. 
SPECIES:_. \$88 Calamintha Ashei (Weatherby) Sininers. Basil

\begin{tabular}{|c|c|c|c|c|c|c|c|c|}
\hline & \multicolumn{8}{|c|}{ Management Practices } \\
\hline $\begin{array}{l}\text { Expected\% } \\
\text { Effect on } \\
\text { the Spectes }\end{array}$ & $\begin{array}{c}\text { Prescribe } \\
\text { Bura }\end{array}$ & $\begin{array}{l}\text { Bulldoze } \\
\text { or } \\
\text { Roor Rake }\end{array}$ & Bed & Chop & $\begin{array}{l}\text { Thin } \\
\text { over- } \\
\text { scory } \\
\end{array}$ & $\begin{array}{l}\text { Cur } \\
\text { Over- } \\
\text { stozy }\end{array}$ & $\begin{array}{l}\text { Estabilsh } \\
\text { Plantacion }\end{array}$ & Graze \\
\hline Destroy & & & & & & & X(shade $)$ & \\
\hline Damage & & & $x$ & $x$ & & & & \\
\hline $\begin{array}{l}\text { No Last1Rg } \\
\text { Effect }\end{array}$ & & & & & & & & $?$ \\
\hline $\begin{array}{l}\text { Benericial } \\
\text { LE Done } \\
\text { Properly }\end{array}$ & $N D$ & $x$ & & & X & $\mathrm{X}$ & & \\
\hline
\end{tabular}

\section{Oeher Corments:}

*Expected effect on the species is an estrmate uade by Dr. Robert Kral based on his knowledge of the habitat and on knowledge gained rom personal field observations. Estlmates are "rough" In mary Instances. Results of practices ray be modified depending upon the degree of appleation, incensity of ereat-

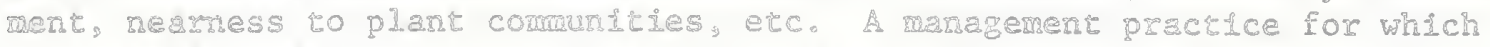
no entry 18 made 1ndicates a lack of sufficlent lnemathon from which to predict expected results. As observations are made in the field by users of che data 3 the expected effect wil be refined. 


\section{Calamintha ashei (Weatherb.) Shinners}

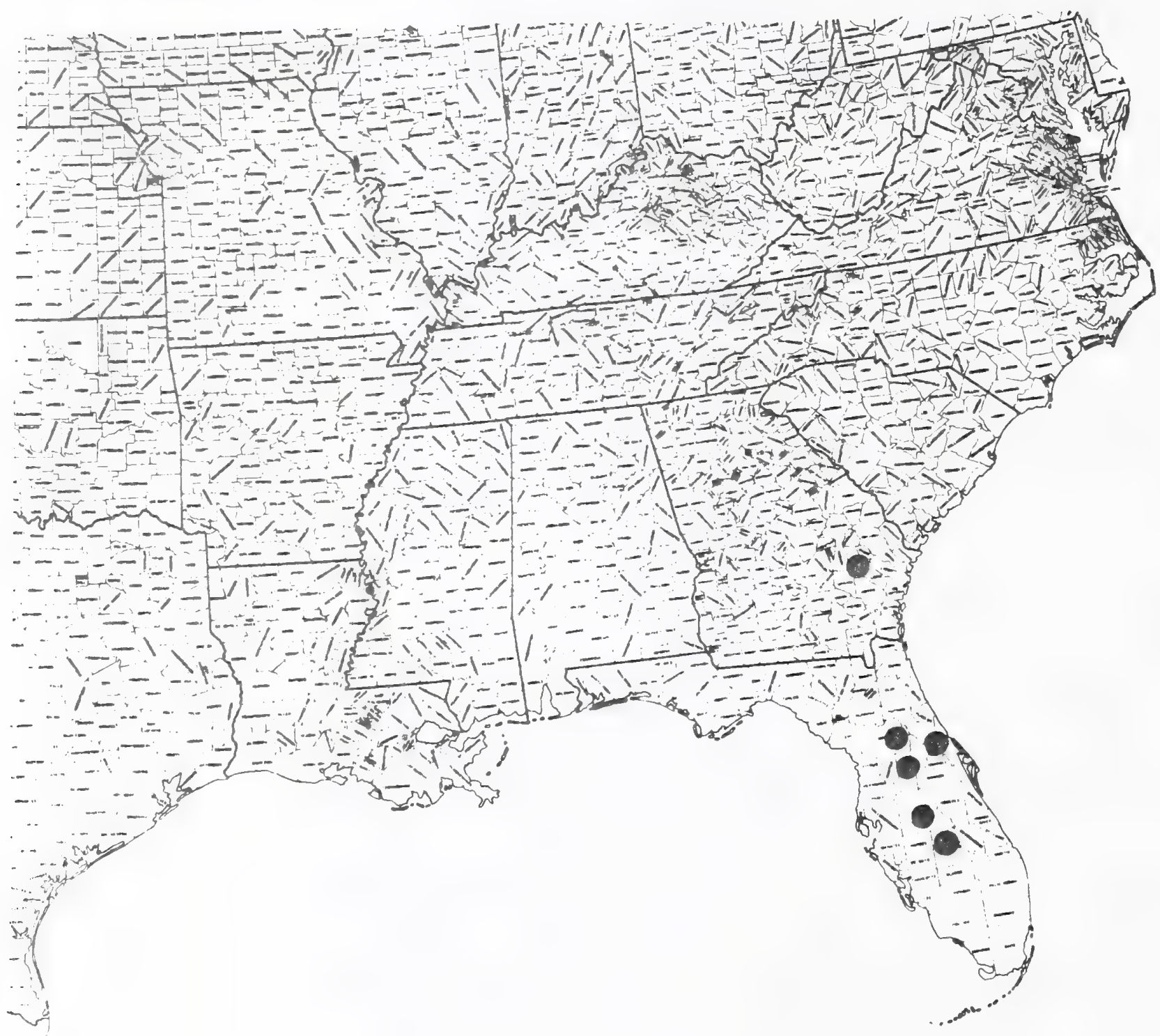




\title{
IAMIRCERE
}

\author{
Calamintha dentata Chapm: toothec savory: Basil \\ Clinopodium dentaturn (Chapm.) Kuntre \\ Sacureja dentata (cham,) Brig.
}

Technical Descriotion

Pungently aromaric shrubs to 5 dm tall, either simole below or profusely branched even from near the base, usually wh dense, fuld deafy crows, these frequently as broad as high, and Irom a woody simple or branched taproot system. Stems.--Nain shoots erect or ascending, graypbrown, the bark thin, cracing, exfoliating, with numerous, opposite, slender but stiflish and brittle, upwardiy ascending branchiets, all but the older surfaces dusted with fine short hairs. Leaves.-Lowest leaves absert by flowering tine: leaves of branchlecs opposite, spreading or ascending bxoadly oblanceolate to obovate, mostiy around 1 cri long. the apex rounded and dentate, the margin revolute and lowmentate toward the apex or completely entire, the base broady to narrowly cuneate, the uppor surface yellow-green, dusted with fine gray hairs, glazd-dotted, the lower surrace paler, prominently dotted with dask glands, the midrib strongly raised ard fine-hairy, the petiole very short or absent. Inflorescence,- Flowers opposite or paired in the axils of most upper leaves, on 2-bracted puberulent stalks to $3 \mathrm{~mm}$ long. Flowexs. - Calyx around 6-7 gm long, the tube about $4 \mathrm{~nm}$ long, cylindrical, 10-12ribbed, puberuient and with sessile clear glends, green with tints of maroon on the ribs, with a strong ring or erect white hairs around the rim inside, 2-lipped, the upper lip shorter, upcurved, with 3 triangular, maroon lobes, the lower Iip of 2 slender, upcurved, very siender-tipped maroon teeth. Corolia about $15 \mathrm{~mm}$ Iong, strongly bilabiate, the tube and throat narrowiy funmel shaped, $7 \mathrm{~m} 8 \mathrm{~mm}$ Iong, the upper Iip shorter than the Lowex oblong, arching forward, the lower Iip spreading and directed dowrward. 3-lobed, the lateral lobes spreading and low, the middle lobe obcordate: outer suriace of corolla laverder rose, palest toward the base, all puberulent: inner surface of corolla with upper iip lavender rose and lower lip with a pale median zone, this marked with daris pumpish flecks and Iines. Stamens 4 o of 2 lengths, axching upward under the upper corolla lip, not projecting beyond. Style slender, 2obrasched at apex. Eruit.-ivutlets usually 4 , broady ovolo or nearly rourd, about 1.5 min long, brown, nearly smooth.

\section{Distribution and Flowering Season}

Deep ary pineland sands, noxthestern lorida and southwestern Georgia. Flowering from Aprì to Frost。

Eabitats and Management Implication

This is perhaps the weediest shrub in the genus, doubtiuly threatened within its rather small range. It appears to be equally at home in longleap pinemaeciduous scrub sandhilis, dryish longlea pine flats, sandy open abandoned fields and roadsides, occasionally it iss found along the upper edges or ravines forested with beach-magnolia. In such places it has larger, broader leaves and a more slender 
habit. Taxonomically it is closest to C. ashei (Weatherby) Shinners, which has smaller flowers and narrower, more involute, entire leaves.

C. dentata, while most abundant in longleaf pine-turkey oak barrens, appears to maintain itsolf where there has been clear-cutting or this accompanied by all sorts of aite preparation. It 18 common in slash pine plantations locally within its range, being winnowed out only where the shade and litter become too dense.

References

Shinners, L. H. 1962. Calamintha (Labiatae) in the southern United States. Sida 1 (2) 69-75.

Small, J. K. 1933. Manual of the southeastern flora, pp. 1168-1169. 
SPECIES:

\#89 Calamintha dentata Chapm. Basil

\begin{tabular}{|c|c|c|c|c|c|c|c|c|}
\hline & \multicolumn{8}{|c|}{ Management Practices } \\
\hline $\begin{array}{l}\text { Expected* } \\
\text { Effect on } \\
\text { the Species }\end{array}$ & $\begin{array}{c}\text { Prescribe } \\
\text { Buren }\end{array}$ & $\begin{array}{l}\text { Bulidoze } \\
\text { or } \\
\text { Root Rake }\end{array}$ & Bed & Chop & $\begin{array}{l}\text { Thin } \\
\text { over- } \\
\text { scory }\end{array}$ & $\begin{array}{l}\text { Cut } \\
\text { Over- } \\
\text { story }\end{array}$ & $\begin{array}{l}\text { Establish } \\
\text { Plantation }\end{array}$ & Graze \\
\hline Destroy & & & & & & & $x$ & \\
\hline Damage & & & & & & & & $?$ \\
\hline $\begin{array}{l}\text { No Lasting } \\
\text { Effect }\end{array}$ & & $x^{x}$ & NIA & $x^{x}$ & & & & \\
\hline $\begin{array}{l}\text { Benericial } \\
\text { IE Done } \\
\text { ProperIy }\end{array}$ & $\mathbb{N A}$ & & & & is & X & & \\
\hline
\end{tabular}

\section{Other Commenes:}

*Expected effect on the species is an estirate made by Dr. Robert Kral based on his knowledge of the habitat and on knowledge gained from personal field obeervations. Estrinates are "rough" in many instances. Results of practices mey be modfied depending upon the degree of application, intensity of treatment, neamess to plant commultes, etc. A management practice for which mo entry is made indicates a lack of sufficient information from which to predict expected resultr. As observations are made in the field by users of the data, the expected erfect will be refined. 
Calamintha dentata Chapm.

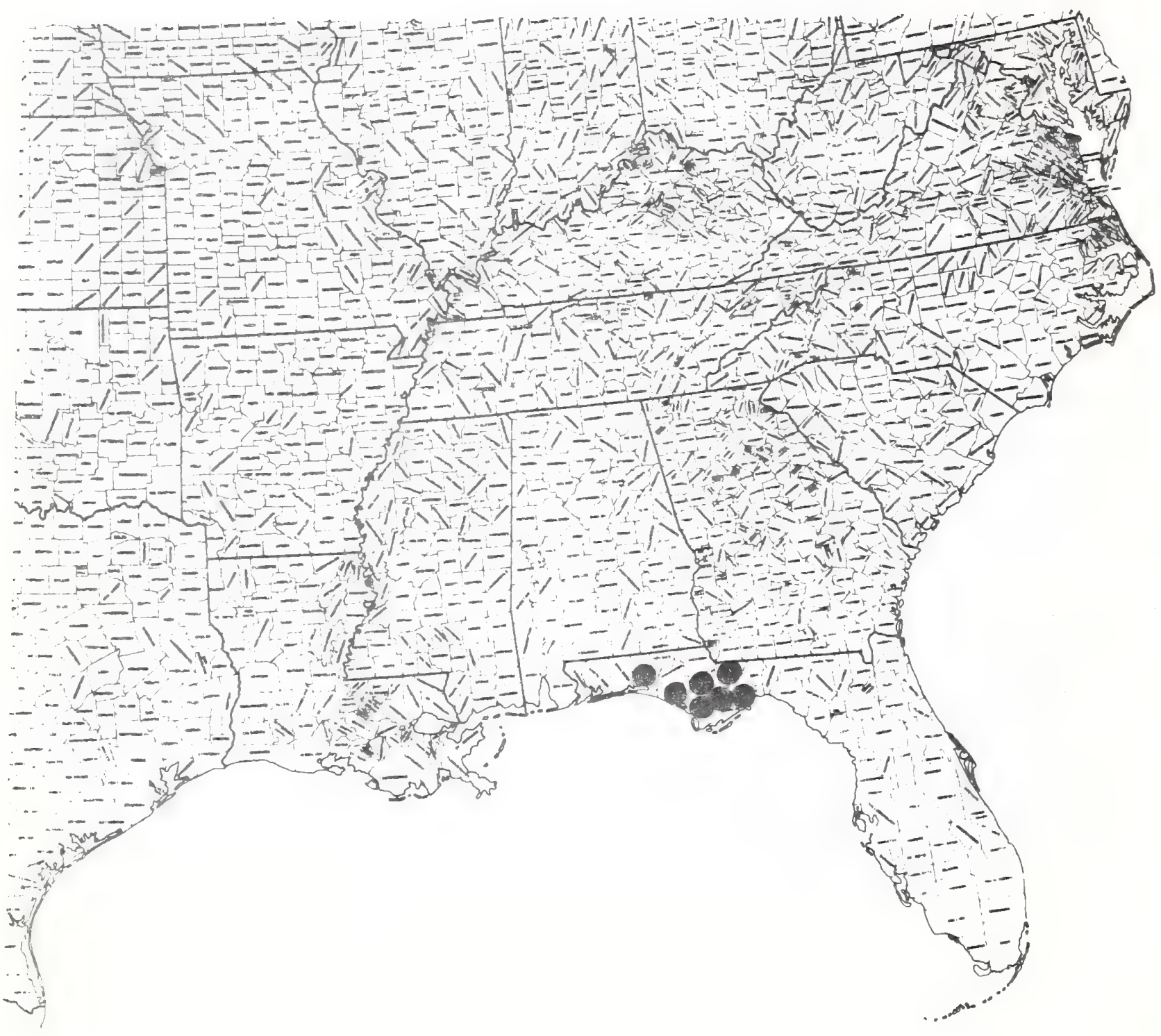


Paper 90

Text map Dy:

Robert Real

\section{IAMPACEAE}

Conradina grandifore Smadi IargewIowered roserary: N.C.N.

\section{Technical Description}

Pungently aromatic shrubs mostig $1.0-1.5$ meters tall for meters from rather shallow root systerns.

Stems, - -Shrub base mostly simple, terets, the bark graylsh, thing, the outer Iayer of braided expoliating strips: branches few to several g preading ox arching, rebranching irregulariy, the shrulb crom usualdy broader than long. Branchlets short to elongate, slender but stife, browash or readish brown. quadrangular, canescent (Censely shortwhairy) soith pale hairs.

Leaves.m-Persiscent, opposite, Inear, needie-like, nostip 1.001.5 cm long, spreading, the tips blunt, the margins Eleshyoinvolute, the base acrte to a short. redaish, terete petiole, the upper sureace graymgreen, glandwototed, shortappressed-hairy, the lower surface densely tomertulose with a somewhat less hairy. raised nidrib; all leaves producing in their axis short shoots with leaves of nomal length, thus the plants appearing quite whorled-lealy.

Inflorescence--iplowers produced in short-stalked cymles from the upper leaf axils, the inflorescence thus short-cylindric.

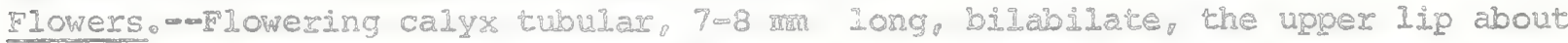
$3 \mathrm{~mm}$ long. short-oblong, 3-toothed apically, the lower lip of 2 , narrow, sharptipped, rigid, Eorward-andwupward arching teeth about 3 min long, the tube 4 m man. long, 10-12-ribbed, greenish with the ribs maroon, puberulent and glandodotted, the tooth margins ciliate. Corolla mostly fuliy $2 \mathrm{~cm}$ long, the raxrow tube bent just above the level of the caly\% tube opening. the chroat broady funnel fom, the Iinb strongly bilabiate, the upper Iip arching forward, oblong, emarginate. somewhat shorter than the downwedly arching and spreading, 3olobed, lower $11 p$

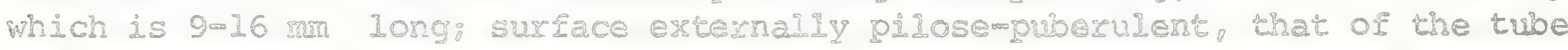
and throat pale lavender, that of the lips deeper lavender-biue the lower lobe medialy nearly white with strong blotches of deep lavenderwblue. Stamens 4. of 2 lengths, axching on long slender smooth filaments up and under the upper corolla 1ip and projecting the short anthers beyond its tip. Style arching as in the stamens, slender, snooth, Lorking at its apex into 2 short, spreading lobes. Fruit.m-Nutlets nearly zound, nearly black, smoothish, the attachnent scar basallateral.

Distribution and Elowering Seasors

Sandy Elats or sandhilis, mostig with sand pine, easters peninsular Florida from Volusia County southward to Palm Beack County. Flowering all rear.

Special Identifying Features

There are but 5 species in chis genus, all southeastern, all but 1 considered rare or 1ocal. Co grandiflora differs from the others in having the largest flowers, these in cymes of $1 \rightarrow 12$ on evident stalks.

Halbitats and Mamagenent Implication

This species is always on deeg, Eine sands, usually on or in the vicinity of ancient dunes of shores, typically in or around stands of Pinus clausa and ad- 
mixed with Iyonia, Ilex, various evergreen scrub oaks, Ceratiola, Polygonella. Opuntia, Saw-palmetto. It responds vigorously to fire, being released in this way from competing shrubs, and from overstory shade. It is an invader of mechanically disturbed sands within its range, but is winnowed out in fully stocked plantations of sand pine. Most of its area is in the coastal dune country along the coast, thus it is endangered primarily through the conversion of these sandhilis to housing developments, resourt developments, commercial developments, and orange groves.

References

Shinners, L. H. 1962. Synopsis of Conradina (Labiatae). Sida I (2): 84-88.

Sma11, J. K. 1933, Manual of the southeastern Flora, pp. 1166-1167. 
SPECIES: \#90 Conradina grandiflora Smali. N.C.Is.

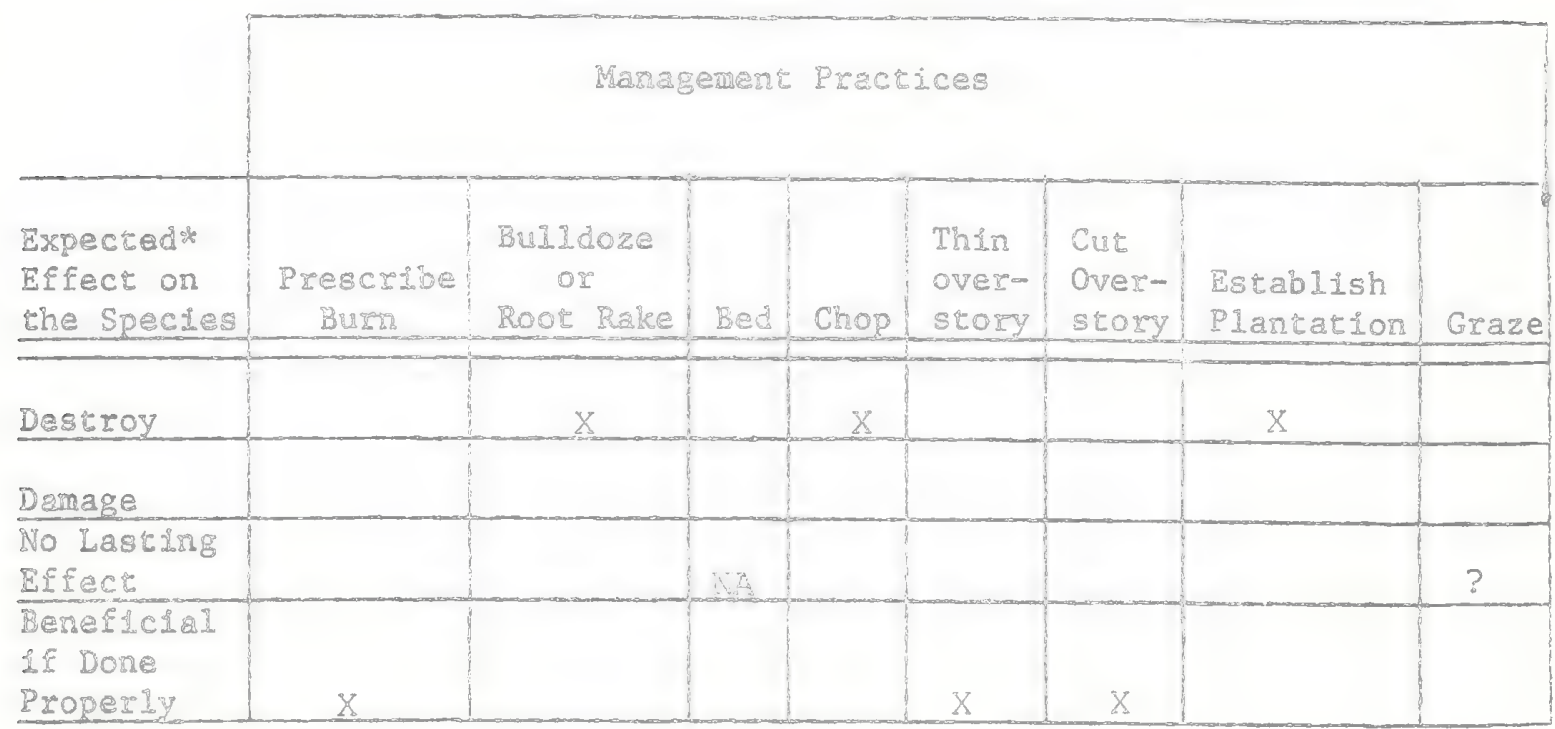

\section{Other Comenes:}

* Expected effect on the species is an estimate made by Dr. Robert Kral based on his knowledge of the habitat and on knowledge galned from personal field observations. Estrimates are "rough" in many Instances. Results of practices may be modified deperding upon the degree of application, intersity of treatment, neamess 60 plant commities, etc. A management practice for which no entry 18 made indicates a lack of sufficlent infomation from which to predict expected results. As observations are made in the field by users of the data, the expected effect will be refined. 
Conradina grandiflora Small

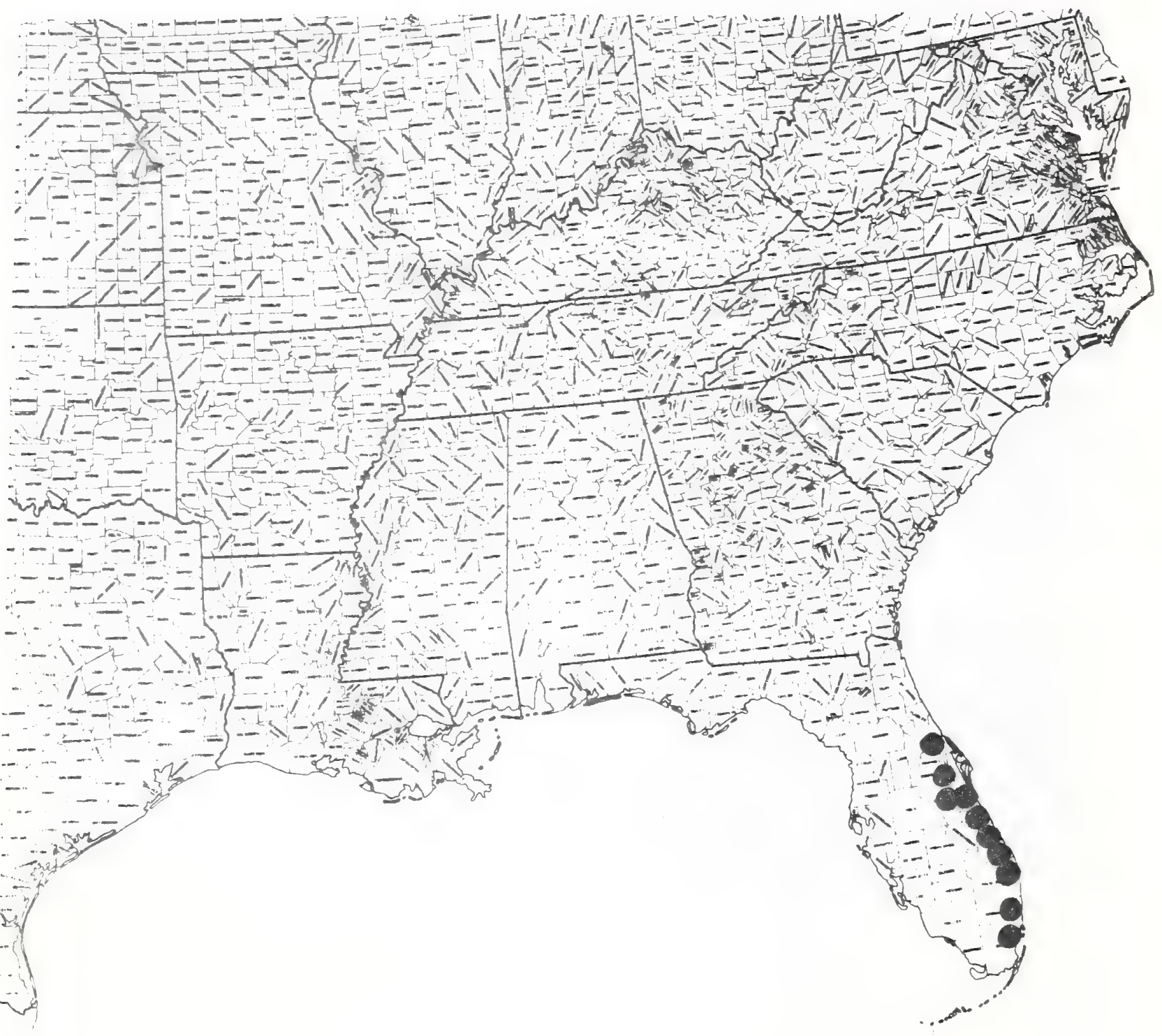


Paser 9 I

Text a map by:

20bert grel.

\section{IAPIIBCEAE}

Dicerandra odoratisina Raroer. Rose dicerandrag NoC.R.

Technical Description

Strongly aromatic anmul hezlo to 4 dn tall from a taproot that is

often thickened by gall Eomatios.

Stems.--Exect, simple or branching from near the base from all or most of the main nodes and thus producing a bushy crown lower part of stem brownish with thin, exfoliating bars, nearly terete, beconing upwardy quadrazgular, readish tinted, scabrous or puberuient with stoutish. Incurved short pale hairs, and also glandwdotted.

Ieaves. -Opposite, evenIy distributea along the stem, erect, spreadirg or recurved, often with auxillary Ieafy short shoots: leaf blades narrowly Iinear, lthe lowemost, preflowering ones may be broader), to $4 \mathrm{~cm}$ long, bIunt the margins scalorid, Fleshy, strongly inrolied, the bases nearly sessile, the suriaces above scabid, greenish or maroon tinted, gland-dotted, medialIy grooved, bereath palex, smoothish or puberulent, strongiy glandmotted, with a single strongly raised median, scabrid vein. Largest leaves toward base, gradually narrowing and shortening upward into the inflorescence.

Inflorescence.w Flowers single or in few inlowered, mearly sessile cymules from Iear axils mostiy from midstem upward, in colorful "Iiatrislike cylinarical systems. Flower stalks shorter than the calyses, spreadingascending, maroon with a strong dusting of short whitened hairse

Flowers.-Calys cylindrical, around 8 mu long in sower, strongly lberibbed, greenish with the ribs maroon, or strongly maxoon tinted, bilabiate, the upper Iip 1.5-2.0 mm long, arching slightly upward, low triangular, ciliate, the lower lip about $3 \mathrm{~mm}$ long, cleft nearly to its base to form 2 very narrowly triangular, subulate, stiffish teeth that project forward, curve slght Iy uprard. calprs tube surface strongly gland-öotted between the ribs, otherwise smooth, the nerves appressed-puberulent, the tooth edges ciliate, the tube orifice thin bearing within a ring of whitisin, erect haizs (an anrulus), and externaliy whitened or rose. Corolla strongly bilabiate, $2.0-2.5 \mathrm{crn}$ Long, the tribe and throat rarrowly funnelform, about $1.5 \mathrm{cr}$ long. Iavendermyse or somewhat paler toward the base, the upper lip oblongmovate, arching Forward, about 5 man long, its tip rounded or slightly emarginate or with 3 low, rounded teeth, its back keeled, shortwhiry, the lower directed downward, 7 m 8 mu long, strongly 3-lobed, the lobes obovate. the lateral ones slightiy shorter and rounded, the medin emarginate; outer corolia surfaces a brigh lavenderurose, softly puberulent externaly. the lower lip lined within with gellowish or paler lines also Freckled with dark purplish spots. Stamens $\Delta_{0}$ on slender filaments arising from near che throat apes, arching upward under the upper cololia lip, the anthers concealed just below its tigi anthers nearly round, each with a prominent spur, style slerder, elongate, projecting upward under the upper corolla lip with the stamens, its tip short pubescent, 2mbranched.

Ervit motlets nearly round, about 1 mom long, pale to deep brows, nearly smooth or minutely pieted. 
Distribution and Flowering Season

Local in sandhills in the lower Coastal Plain, eastern South Carolina southward to southeastern Georgia. Flowering from september to frost.

Special Identifying Features

There are but six species of Dicerandra, all in the southeastern United States. Three are shrubs restricted to Florida. This, together with the remaining 2 is annual, and distinguished from the other annuals by the fact that its stamens do not project beyond the upper corolla lip, by its much longer lower calyx lip which is divided nearly to the base, and by its non-geniculate corolla.

Habitats and Management Implication

All the Dicerandra are plants of deep, nearly pure sands. This species is always in pine (longlear and glash), usually on sand ridges sandy fields, or sandy rises in or bluffs along rivers. It is a plant of light shade or full sun. It readily invades such disturbed areas as dryish sites prepared for pines, abandoned sandy fields, roadsides, etc. Fire (not recommended as a management tool for sandhills but a natural factor there!) increases it by decreasing competing shrubs (scrub oak, Ceratiola, Persea, Calamintha) and grass-sedge competition, as well as the shade of the pine or oak-pine overstory. The plants, as mentioned above, come in strongly after any site preparation involving exposure of the sands; however, they disappear as the pines establish and close crowns.

References

Shinners, L. H. 1962. Synopsis of Dicerandra (Labiatae). Sida $I(2): 89-91$.

Small, J. K. 1933. Manual of the Southeastern Flora, pp. 1169-1170. Chapel Hill, N.C. 
SPECIES: $\quad$ \#91 Dicerandra odoratissima Happer。 IJ.C.N.

\begin{tabular}{|c|c|c|c|c|c|c|c|c|}
\hline & \multicolumn{8}{|c|}{ Management Practices } \\
\hline $\begin{array}{l}\text { Espected* } \\
\text { Effect on } \\
\text { the SpecLes }\end{array}$ & $\begin{array}{c}\text { Prescribe } \\
\text { Bura }\end{array}$ & $\begin{array}{l}\text { Bulldoze } \\
\text { or } \\
\text { Root Rake }\end{array}$ & Bed & Chop & $\begin{array}{l}\text { Thin } \\
\text { over- } \\
\text { story }\end{array}$ & $\begin{array}{l}\text { Cut } \\
\text { Over- } \\
\text { story }\end{array}$ & $\begin{array}{l}\text { Establish } \\
\text { Plantation }\end{array}$ & Graze \\
\hline Destroy & & & & & & & $\mathrm{X}$ & \\
\hline \multicolumn{9}{|l|}{ Damage } \\
\hline $\begin{array}{l}\text { No Lasting } \\
\text { Effect }\end{array}$ & & & NA & & & & & $?$ \\
\hline $\begin{array}{l}\text { Beneifcial } \\
\text { Lf Done } \\
\text { Properly }\end{array}$ & $x$ & $X$ & & & X & $x$ & & \\
\hline
\end{tabular}

\section{Other Comenes:}

* Expected effect on the species is an estlmate made by Dr. Robert Kral based on his knowledge of the habitat and on knowledge gained from personal ifield observations. Escimates are "rough" In many instances. Results of practices mey be modified depending upon the degree of application, intensity of treatment, neamess to plant commities, etc. A management practice for which no entry is made indicates a lack of sufficient information from which to predict expected results. As observations are made in the field by users of the data, the expected effect will be refined. 
Dicerandra odoratissima Harper

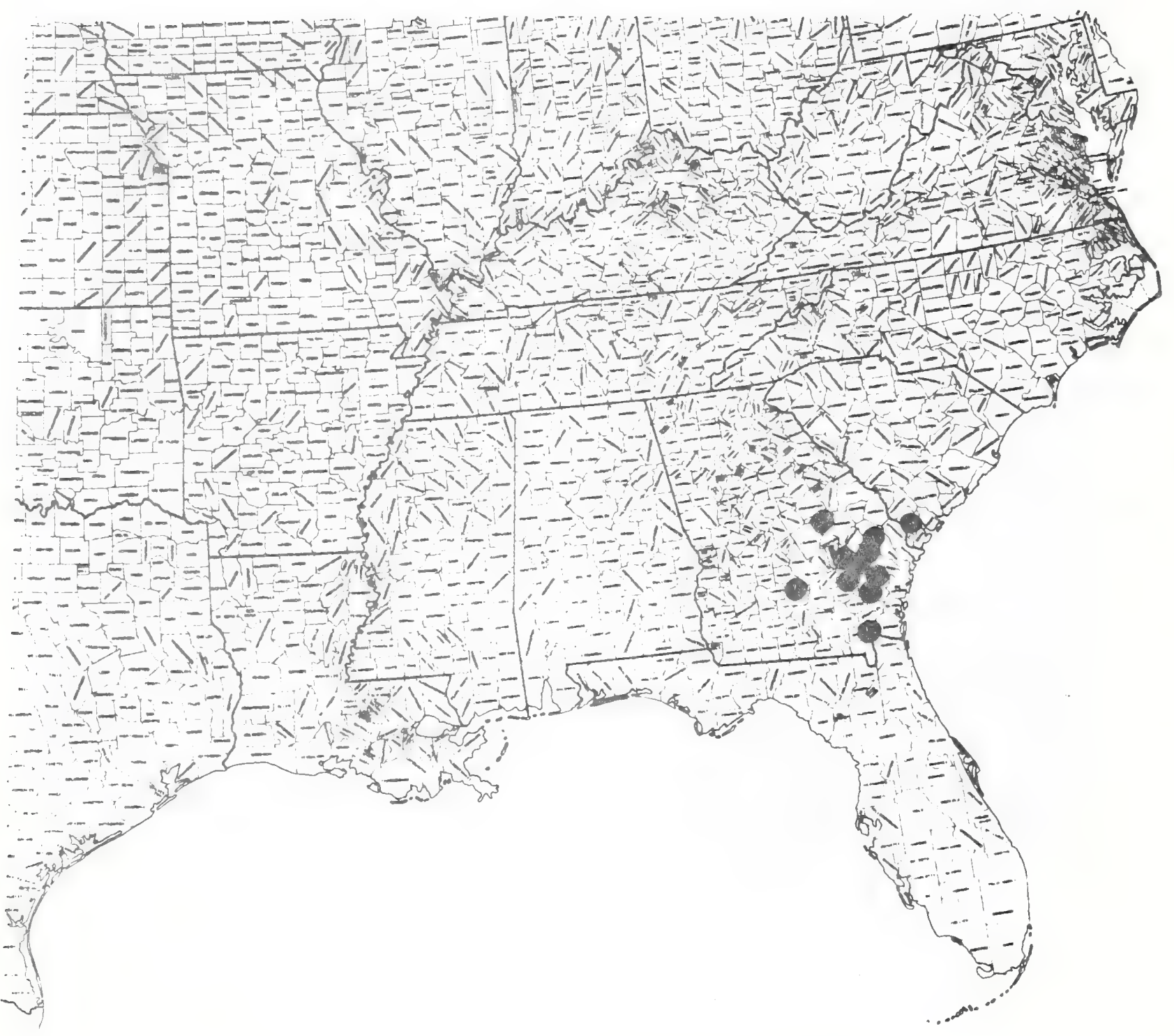


Paper 92

Text \& mep by:

Robiszo Rra 1

\section{ZRMIECERE}

Physostegia Veroniciformis Small. Veronica dragonm

head: ralse dragonnisad or ebediert plarit

Dracocephalum verondei formis Sxild

Technical Description

Perennial hexos mosty $6-8$ car tad, from stout, exect or ascending, simple or forking rhizomes。

Stems. - Solitary or Few, stifrgy erect or ascending, yet slender quadrangular with the angles rounded. the interfaces ilat or concave, toward base smooth. pale green, toward the tips, spreading puberlent and tirted with maroon.

Ieaves.- opposite, on widely separated nodes, ascrnding or erect, the basal ones Iong-petiolate, the blacies elyiptic or lanceolate, those toward micistem nearly sessile, spatulate or oblanceolate, most?y $304 \mathrm{~cm}$ long, the aper biumt, the margins entire to sinuate ox salierty low tooched with teeth distant and coward the blade apex, somewhat revolute, the base narrowly cuneate or attenute, nearly sessile, the surfaces pale yellow grear, swooth, minutely dotted, the upper surface grovved along the midrib. the lower surface with midrib strongly radsed: Leaves gradually diminishing in size upward becoming completely sessile, lanceolate, grading into lanceolate inflorescence bracts less than 1 cin long. Inflorescence, momers born in open, erect, spikelike racanes (intermodes elongate during and after flowering), ascending on spreadingmuberulent stalks 2 mm or less long.

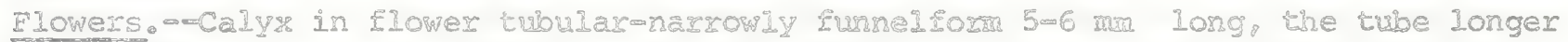
than the 5. triangular, short-acuruinate nearly equal teeth, the surece externally greenish with tints of maroon, spreading puberulent, corolla very bilabiate, slightly less than $2 \mathrm{~cm}$ Lorg, the tube pale, tubulax, 5ow into a broadiy funnelform throat $6 \mathrm{~cm}$ m long, the upper IIp broadly obovate. about $3 \mathrm{~mm}$ long, projecting foward and sight2y upward its back sightly keeled. the lower lip directed downard, 3 lobed, the laterals spreading, short-oblong, round tipped, the midale Iongest, oblong, eragginate surface of throat and Iips externally lavender rose, puberulent, lined with deeper purple veins, the inner surface of the lower Iip Iongitudinlly 1 ired ard dotred with deep purple (pollina tion guides). Stamens 4 o or 2 lengths, epipetalous, the Eilaments cursing upward under the upper corolla lip, the anthers short, darf. nearly round: siyle elongate, curving upward with the stamens and about as long, slightiy forked apically.

Fruit, malNits 2 an long, ovate, smooth, brownish, the outer face convex, the inner 2 races concave.

Distribution and Flowering season

Hiliside bogs, ditches, seeps, wet open pinelands, southern Georgia southwestward co northem and northwestern Florida. Flowering May into July.

Special Identifying Features

This has the smilest flowers of the southeastern species of Physostegia, the corolla being less than $2 \mathrm{~cm}$ long (the other species have corollas over $2 \mathrm{~cm}$ long), 
the calyx proportionately smaller. The plants are also smaller than are the other species.

Habitats and Management Implication

optimum habitat for $\mathrm{P}$. veroniciformis consists of high hydroperiod, mucky, sphagnous bogs where it mingles with pitcher plants, sundews, butterworts, various eriocauls, xyris, sedges and grasses, usually in full sunlight or light shade, often in clearings of wax myrtle, Magnolia, Persea, Nyssa (ogeche, biflora), Pinkneya, etc. The most important overstory species would be Pinus palustris, $P_{0}$ serotina, $P$. elliottil. Clear cutting would effect it little, perhaps increase it, providing this is not accompanied by mechanical site preparation or arainage, which in either case would eliminate this plant. As is true of most pineland bog forbs, it is increased by burning of competing shrub, tree, or grass competition. It is now being reduced over its range mainly by conversion to drained plantations of pine (which first dries the habitat, later shades it) or improved pasture which usually also involves drainage.

Reference

Small, J. K. 1903. Flora of the Southeastern United States, pp. 1028-1337. New York - 1933. Manual of the southeastern flora, pp. 1156. Chapel Hill, N.C. 
SPECIES:_ \#92 Physosteqia veronjciformis Smail False Dragon-head or Obedient

\begin{tabular}{|c|c|c|c|c|c|c|c|c|}
\hline & \multicolumn{8}{|c|}{ Management Practices } \\
\hline $\begin{array}{l}\text { Expectod* } \\
\text { Effect on } \\
\text { the Species } \\
\end{array}$ & $\begin{array}{c}\text { Prescribe } \\
\text { Burs }\end{array}$ & $\begin{array}{c}\text { Bulldoze } \\
\text { or } \\
\text { Root Rake }\end{array}$ & Bed & Chop & $\begin{array}{l}\text { Thin } \\
\text { over- } \\
\text { story }\end{array}$ & $\begin{array}{l}\text { Cut } \\
\text { Overoo } \\
\text { story }\end{array}$ & $\begin{array}{l}\text { Establish } \\
\text { Plantation }\end{array}$ & Graze \\
\hline Destroy & & $x$ & & $x$ & & & $\mathrm{X}$ & \\
\hline Damage & & & $\mathrm{X}$ & & & & & \\
\hline $\begin{array}{l}\text { No Lasting } \\
\text { Effect }\end{array}$ & & & & & & & & ? \\
\hline $\begin{array}{l}\text { Beneflcial } \\
\text { If Done } \\
\text { Properly }\end{array}$ & $\mathrm{X}$ & & & & $x$ & $\mathrm{X}$ & & \\
\hline
\end{tabular}

\section{Other Cowmenes:}

* Expected effect on the species is an esclmate made by Dr. Robert Kral based on his kmowledge of the habitat and on knowledge gained from personal field observations. Estimates are "rough" in many instances. Results of practices my be modified depending upon the degree of application, intenstty of treatment, neazress to plant comunities, etc. A management practice for which no entry is made indicates a Iack of sufficlent information from which to predict expected resules. As observations are made in the field by users of the data, the expected effect will be refined. 
Physostegia veroniciformis small

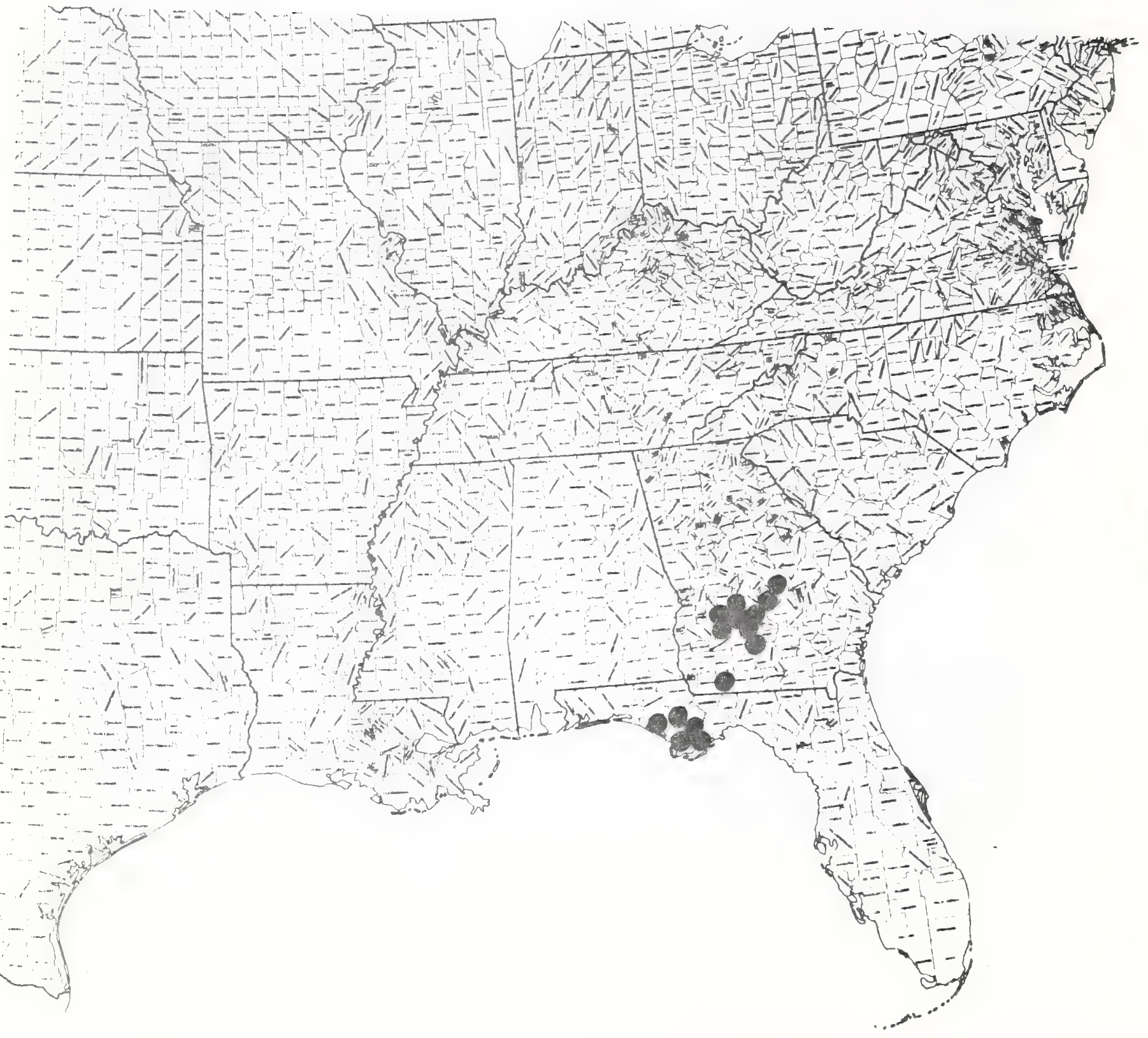




\title{
ZAMIACERE
}

\author{
Eycnanthemusn Floridanum Nash eq Grant \& Epling F Forida \\ mountainmmint: mourstain mist \\ Pycnanthemum Elordenum Nash (Mash 2259 . nom。 nud.)
}

Technical Description

Powerfully aromatic perenrial Irom a short stout caudes and several shallow spreading stout and Iongwtapering rootsp increasing by means or shallow or surface creeping. slender, stolons.

Stems -Usually solitary exect, sometimes to fuldy 2 meters tall profusely upwaraly arching-branched above, the lowest part woody sometimes to 1 cm thick. the bark thin, redash-brown, smooth, breaking and peeling, above becoming quadrangular, yellowgreen, with short downewed hajrs along the angles, the in terfaces flat, smoothish to hirsute and pubarulent, more densely so toward branch and shoot tips.

Leaves.--Lowest leaves absant by rlowering time the Largegt at about midmstem. opposite in numerous pairs, spreadirg. ovate or lanceolate. on hirsutulous short (usually under $4 \mathrm{~mm}$ long) petioles, the tips short acuminate or acute, the margins ascending-toothed fcoarsely low gerratel the bases acute. rounda or broadiy cuneate, both surfaces green and sparingly harsute to smooth, hirsute along the veins beneath. both surfaces copiousdy glandodotted. Ieaves gradualy getting smalier, more sessile, upward toward the inflosescenee, their upper surfaces whitened by dense tomentum as are those of the bracts and bractlets. Inflorescences minde up of dense clusters of shortstulfed bracted cymules, these clusters axillary to the uppentost pairs of bratead leaves. hemi spiaerical in outine, broader than high, about 2 cm agross. lowemost bracts of flower clusters narrowly ovate those subtending Elowers rarsower al densely tomentosepuberulent with a scattering of pale longer hairs the whole irfiorescence thereFore appearing pale grayogresio

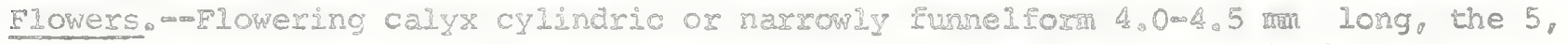
triangularacuminate teeth approsinately equal (chrough the calyx rim is obliquel. axound $1 \mathrm{~mm}$ long, the calys suriace gland aotted and also densedy appressed purberulant and hirsute extennaly. Corolda s.5 min long. strongly bilabiare. the short tube broadening into a Longer, Emanelerm throat, the upper Iip shortwoblong, projecting forward, itts back rourded, its apex rounded, shallowly emarginate, the lower 1 ip directed downard, 3 wobed the lobes roumded. corolia

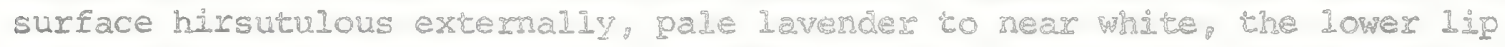
mottled with purplish bioches. Stanens 4 in 2 lergths but nearly equal, che iliments arching upord under the upper corolda lip. Style elongate. siender. slightly Forking at the apex.

Distribution and Flowering season

Pine-palnetto Elatwoods, pineland savannas, midde and northern peninsular Elorida: flowering JuIy and August. 
Special Identifying Features

This species resembles $\mathrm{P}$. muticum vegetatively, particularly in regard to the nearly smooth lower leaves and in general appearance of the plant. In its calyx lof subequal members) it is most similar to $P$. incanum. Where this writer has collected it there appeared no other Pycnanthemum species mixed with it.

Habitats and Management Implication

The habitat of $P_{\text {. }}$ floridanum varies from quite wet swales or ditches in pine flatwoods and open rangeland to open shrub-grass sedge-pine savanna, the soil being usually a black sandy peat. The overstory is usually a dotting of slash pine, pond pine, Iongleaf pine or a mixture of the three with a shrub understory of gallberry, Iyonia, Myrica, Saw-palmetto. The plants may appear abundantly in interspersed clearings of grass-sedge, and distinct because of their tendency to form large clones, the very whitened upper surfaces of their upper leaves making them visible from a considerable distance.

Clear cutting would increase the species in that it reduces shade. All methods of site preparation save beding would reduce it. Drainage would eliminate it. It is part of a complex of shrubs and herbs which is maintained through fire, thus fire as a management tool would probably increase it. Such plants as I have seen in pastures do not appear to be browsed by livestock, the main damage to them being by trampling.

References

Grant, Elizabeth and Carl Epling, 1943. A study of Pycnanthemum (Labiatae). University of California Publications in Botany 20(3): 195-240.

Sma11, J. K. 1933. Manual of the southeastern flora, pp. 1171-1175. Chapel Hill, N.C. 
SPECIES: \#93 Pycnanthemum floridanum Nasi ex Grant \& EpIing Mountain-mint

\begin{tabular}{|c|c|c|c|c|c|c|c|c|}
\hline & \multicolumn{8}{|c|}{ Maragement Practices } \\
\hline $\begin{array}{l}\text { Expected* } \\
\text { Effect on } \\
\text { the Specles }\end{array}$ & $\begin{array}{c}\text { Prescribe } \\
\text { Burra }\end{array}$ & $\begin{array}{l}\text { Bulldoze } \\
\text { or } \\
\text { Root Rake }\end{array}$ & Bed & Chop & $\begin{array}{l}\text { Thin } \\
\text { over- } \\
\text { story }\end{array}$ & $\begin{array}{l}\text { Cut } \\
\text { over- } \\
\text { story }\end{array}$ & $\begin{array}{l}\text { Establish } \\
\text { Plantation }\end{array}$ & Graze \\
\hline Destroy & & $x$ & & $\mathrm{X}$ & & & $x$ & \\
\hline Damage & & & $\mathrm{X}$ & & & & & \\
\hline $\begin{array}{l}\text { No Laeting } \\
\text { Effect }\end{array}$ & & & & & & & & ? \\
\hline $\begin{array}{l}\text { Beneficial } \\
\text { If Done } \\
\text { Properly }\end{array}$ & $\mathrm{X}$ & & & & $\mathrm{x}$ & $\mathrm{X}$ & & \\
\hline
\end{tabular}

\section{Other Coments:}

*Expected effect on the species is an estimare made by Dr. Robert kral based on hio knowledge of the habltat and on knowledge gained from personal field observations. Estimates are "rough" in many instances. Results of practices may be modified depending upon the degree of appilcation, intensity of treatrent, neamess to plant comanities, etc. A management practice for which no entry is made indicates a lack of sufficient infomation from which to predict expected resulte. As observations are made in the field by users of the data, the expected efrect will be retined. 
Pycnanthemum floridanum Nash ex Grant \& Epling

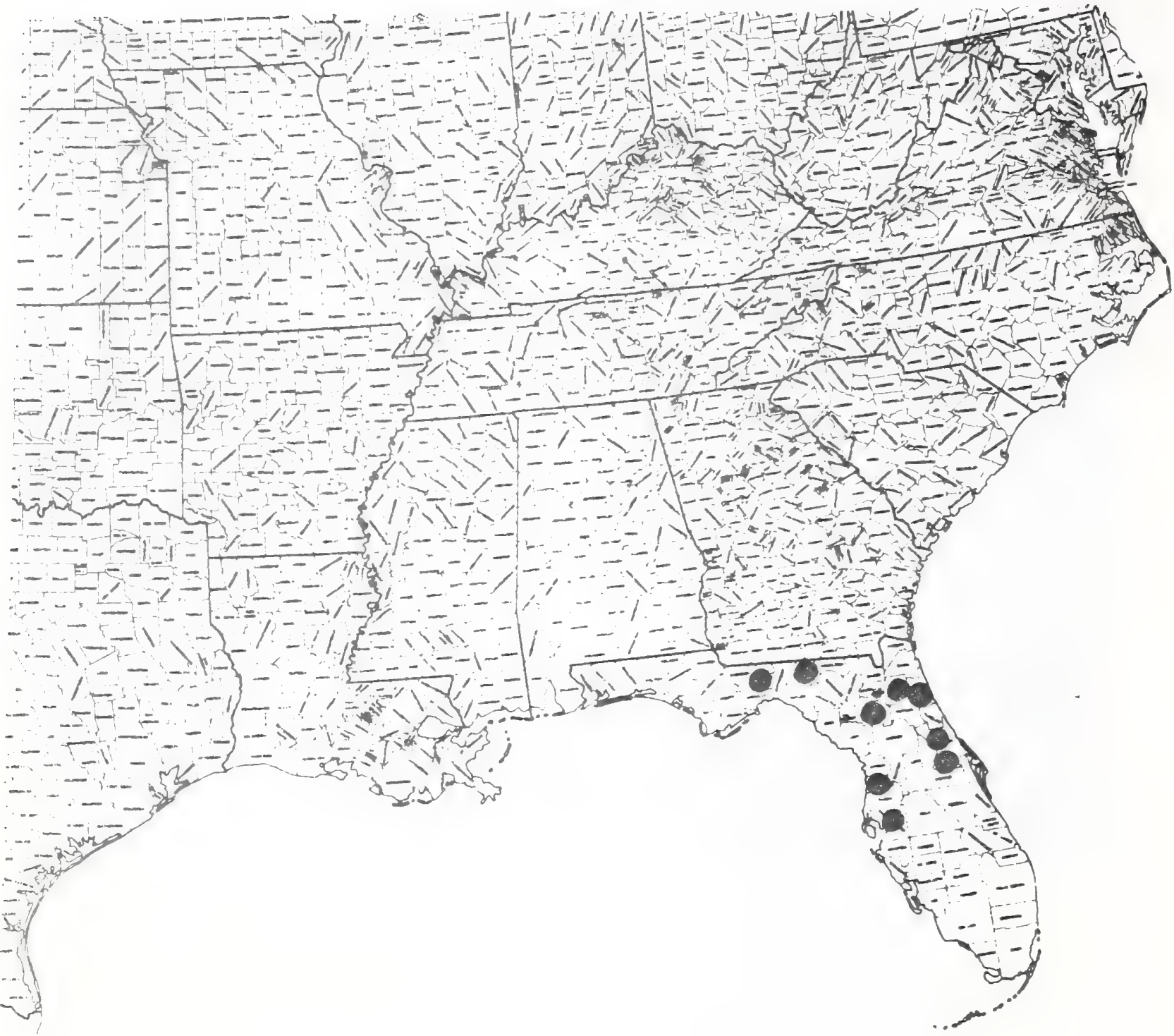


Paper

Test \& rap by:

Roberc Rral

\section{ERMIACMBS}

Scureilarda Eloridasa Chapa Florida skudicap: \$kuIlcaps or nelmet-Ilowers

\section{Technical Description}

Perennial, odorless hexb at most to 4 dmo tell trom a forking system of fleshy but slender,yellowish thizomes these at intervals developing fascicies of swollen-linear unbranched storage roots. Stems.--Solitary or few, nostly erect or ascending, simple or sparingiy and oppositely branched, quadrangular, the argles rounded and finm 20wmscabid, the interfaces flat or concave, mostly smooth, purglish toward the base, greenish upward.

Leaves.--opposite, distant on intemodes Ionger than themselves, erect or somew what spreading, the largest at about midosten, 1 inear, $204 \mathrm{~cm}$ long, narrowing to blunt, callused, purplish tipg, the mexgirs strongly inrolied (revoluto. the bases sessile or nearly so, acute, tire blade surface strongly gland dotted, pale yellow green, only the mid-nexve evident as a shallow groove above, strongly raised beneath, the upper surface smooth or minutely scabrid. Inflorescence. -Filowers well separated, solitary in the arils of bracteal leaves that are short-linear (mostiy I cm or less long) in variously elongate teminal racemes. Flower stalks $5 \mathrm{~mm}$ long or less, somewhat spreading-ascending, puberulent, rigię,

Elowers.-Calys expanding in fruit, in flower about 4 mu Iong, campanulate, shallowly 2-w lobed, bearing on its upper side near the apex a "Cap" or "scutellum" the outer surface greenish with tinges or maroon or purple, gland-dotted, also minutely puberulent. Corolla fuly $2.5 \mathrm{cr}$ lorg, strongly bilablate, the short tube beaxing within an oblique annulus (ring of hairs) and there bent upward into a funelform throat about $1 \mathrm{~cm}$ long: upper corolla lip arching forward. strongly keeled, 3-lobed with the median lobe longest, shortwoblong, retuse, the laterals shorter, projecting forward and spreading outward, rounded; lower lip directed somewhat downward and spreading, brozily ovate, emarginate, wavy margined; corolla surface a bright lavenderwbive, the throat beneath whitish, the inner face of the lower lip with a prominent white median patch that is mottled with deep lavender-biue flecks and guidelines. Stanens 4 of 2 dis tinct lengths, their filaments arching upward under the upper corolla lip but sot beyond, the short anthers with their backs longoristiy hairy. Style elongatecurved as in the filaments but longer and projecting beyond the corolla to curve downward at the forked tip. Fruit.--Nutlets nearly round, about 1.5 mw long, dark brown, strongly pebiblea (muricate).

Distribution and Flowering Season

Pine-palmetto flatwoods, savannas, northwest Florida in Franklin, Iiberty and Gulf Counties: flowering May, June.

Special Identifying Features

This is the rarest of the southeastern Scutellariag being estremely local within its small range. It is most similar to narrow leaved froms of Se integrifolia 
and to S. glabriuscula. However it is a smoother plant and all its leaves in addition to being either scale-like or linear, are entire and are usually shorter than either of those two species.

Habitats and Management Implication

A typical habitat for this species would be the nearly black, humus enriched, high hydroperiod sands of the lower coastal plain terraces around Apalachicola or not far inland. The overstory is usually a dotting of slash and longleaf pine, the shrub understory mainly a mixture of palmetto, gallberry, Lyonia, Myrica, The scutellaria grows in grass-sedge dominated clearings that are maintained in this type by periodic burng, often in association with other endangered species such as Verbesina chapmanil, Justicia angustifolia, Aclepias viridiflora, Euphorbia telepholdes, Macbridea aljba, Cuphaea aspera, etc.

Present land management policy within the range of this plant clearly is reducing the species. Some of the range has been cleared for improved pasture. This usually means drainage, which eliminates the scutellaria even before the introduced Bermuda or Pensacola grass crowds it out. Or, it means clearcutting of the pine, site preparation involving drainage, mechanical site preparation (the least objectionable method involving beding) and establishment of plantations of pine. Eventually the Scutellaria and most associated species are either lost through drying of the habitat or through the dense shade of the pines. The plants appear to hold over vegetatively for long periods in the rough under stands of large pine, abundantly sprouting and blooming shortly after these areas are burned. It is simply another species which is a part of fire maintained pineland savanna. unless management practice in the area is changed this plant will completely disappear.

\section{References}

Epling, Carl. 1942. The American species of Scutellaria. Univ. Calif. Publ. in Bot. 20 (1): $1-146$.

Sma11, J. K, 1933. Manual of the southeastern flora, pp. 1149-1153. Chapel Hill, N.C. 
SPECIES: \#94 Scuteliaria floridana Chapm: Shullcap or Helmet-flower

\begin{tabular}{|c|c|c|c|c|c|c|c|c|}
\hline & \multicolumn{8}{|c|}{ Management Practices } \\
\hline $\begin{array}{l}\text { Expected* } \\
\text { Eifect on } \\
\text { the Species }\end{array}$ & $\begin{array}{c}\text { Prescribe } \\
\text { Burrs }\end{array}$ & $\begin{array}{l}\text { Bulldoze } \\
\text { or } \\
\text { Roor Rake }\end{array}$ & Bed & Chop & $\begin{array}{l}\text { Thin } \\
\text { over- } \\
\text { story }\end{array}$ & $\begin{array}{l}\text { Cut } \\
\text { Over- } \\
\text { story }\end{array}$ & $\begin{array}{l}\text { Establish } \\
\text { Plantation }\end{array}$ & Graze \\
\hline Descroy & & & & $x$ & & & $x$ & $\mathrm{X}$ \\
\hline \multicolumn{9}{|l|}{ Damage } \\
\hline $\begin{array}{l}\text { No Lasting } \\
\text { Effect }\end{array}$ & & & & & & & & \\
\hline $\begin{array}{l}\text { Beneficlal } \\
\text { if Done } \\
\text { Properly }\end{array}$ & $x$ & & & & $\mathrm{X}$ & $x$ & & \\
\hline
\end{tabular}

\section{Other Comments:}

*Expected effect on the species is an estimate made by Dr. Robert Kral based on his knowledge of the habitat and on knowledge galned from personal field observations. Estimates are "rough" in many knstances. Resuits of practices may be modified depending upon the degree of application, intensity of treatment, neamess to plant commuties, etc. A management practice for which no entry is made indicates a lack of sufficient information from which to predict espected results. As observations are made in the field by users of the data, the expected efrect will be refined. 


\section{Scutellaria floridana Chapman}

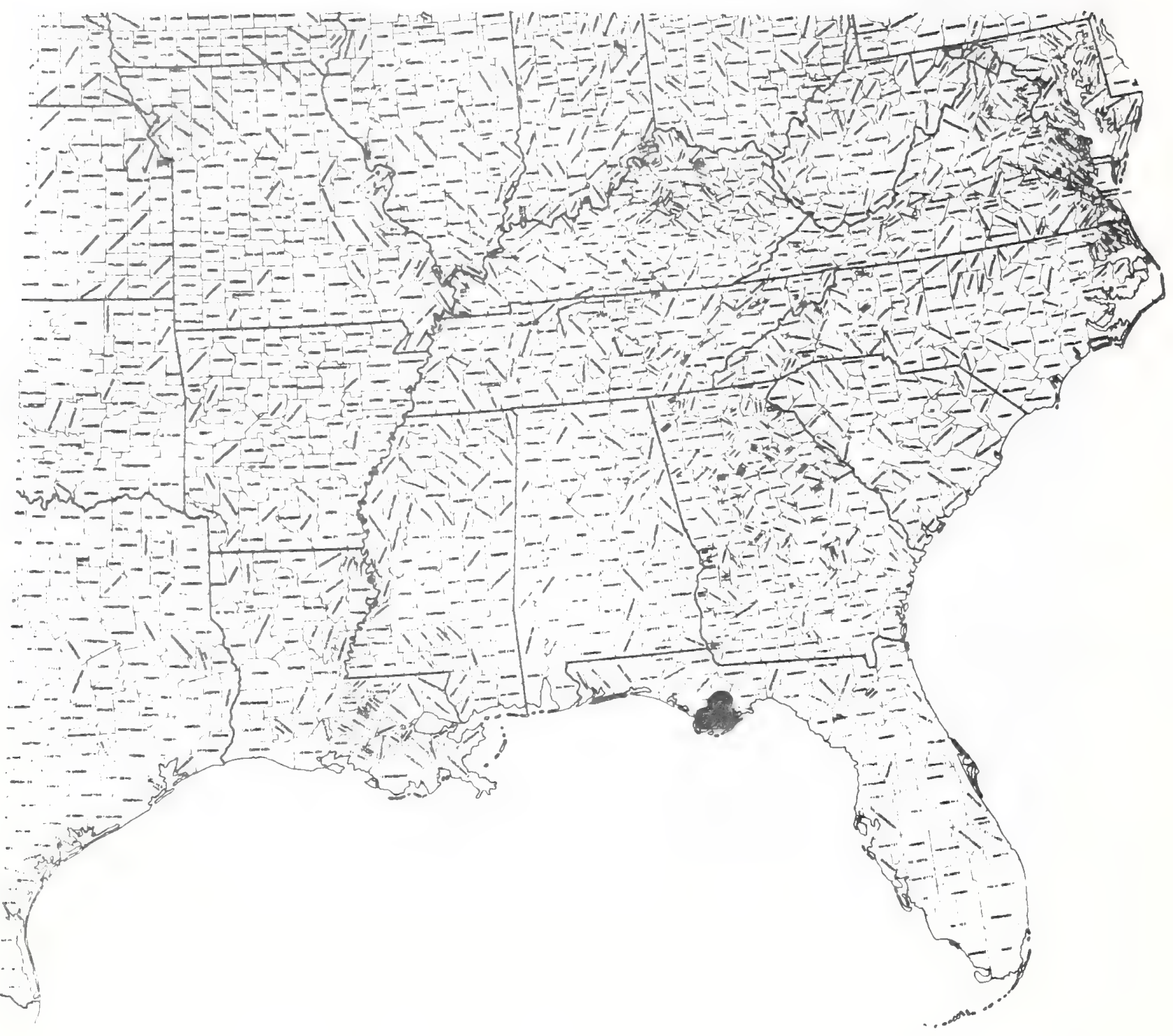


Paper 95

Test \& Map Dy:

Robert Rrad

\section{I.MIMCENG}

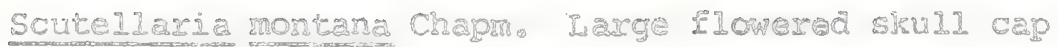
sku1160\% or helmet - fower

Technical Descriotion

Perennial, odorless, at most to 6 dr tal. Erom a short erect caudes, Erom which arise numerous blickisho simple primary roots.

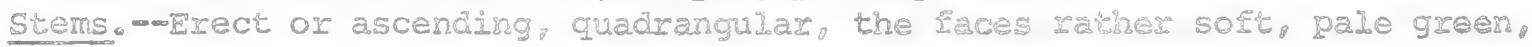
Epreadingmilose with whitish ofter gland-ippea hajrs.

Leaves. - Lowemost stem Leaves usual My smalest, long petodateg the blades triangularovate: median or uppernost stem Leaves Largest. spreaing on shorter.

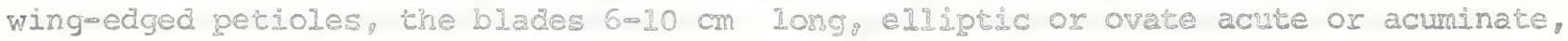
coarsely serrate, the bases attenuated gradualdy or abrupty dnco the petiole wings: leaf surfaces dark green above pith scatiered, appressed, weak hairs. paler and softmappressed hairy beneath. pilose along the raised veins. Inflorescence. - Flowers few to severa racemes. Flower stalks spreading, slexder but stifisho pilose, up to 5 mm long, the lowermost stalks subterded by petiolate leafy bracts, the uppermost with bracts smaller but still longer than the flower stadks.

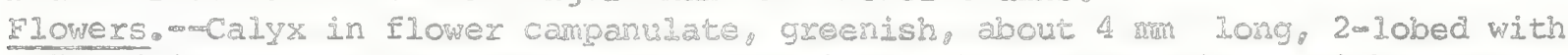
a "Cap" just above the base of the upper lobe the surface plise with gland tipped hairs, also puberulent, Corolla sirongly bilabiate. Iuly 3 cm lorg. the short tube benc upward at calyg surnit into a narrowig Eunne 1 form throatg the 2 Iips less than $1 / 2$ the corolla, the upger one arching Lowara somewhat keeled, 3 - lobed, the ceminal largest and emarginate the laterals shorter. spreading Forward, rounded, ine lower lip directed somewhat downard, broady ovate. slightly enarginate, the edges entire or exose corolda surace pilose externaly. pale blue at the upper throat and Iips shading to near white toward the base, the lower lip internaly bearing bluewprole splotelses and gudelines. stamens 4. of 2 lengths, the Eilanests arching upward under the uppor corolia lip. the anther backs plise. Style elongated beyord the stamens and exsertea sijghtly at the level of its forking apes.

Distribution and Flowering seasor

Mixed hardwoodwine forest at southern end of Blue Ridge northwestern Georgia and southeastern midle Tennessee: Elowering May, arly June.

Special Identifying geatures

This species, with its large, pale blue flowers ds closest to So pgeudoserrata. another rare species of the southern Appadachians but aiffers from 1 in that its Lower leaf surfaces are pubescent throught fin S. pseudoserrata the haIrs are con Iined to the lear veins).

Habitats and Management Implidcalion

S. montana is in rocky ravine-slopes and stream bottoms that have gravelly fine sandy loams. usually quite well drained. The overseory is of hardwoods miged with 
some yellow pine, thus these plants receive considerable shade. It is not known how this species responds to heavy logging of the overstory but it is likely that clearcutting would promote the increase of competing undesireable shrubs (Ionicera, Rubus) and vines (Pueraria, Ionicera, Smilax) which would tend to crowd them out. The steepness of the terrain this species is in precludes mechanical site preparation.

References

Collins, Ieo. 1976. A revision of the annulate species of Scutellaria (Labiatae). Unpublished $\mathrm{PhD}$. thesis, Vanderbilt University.

Epling, Carl. 1942. The American species of Scutellaria. Univ. Calif. Publ. Bot. 20 (1) : 1-146.

Small, J. K. 1933. Manual of the southeastern flora. pp. 1149-1153. 
SPECIES: $\$ 95$ Scutellaria montana Chalm. Skulicap or ilelmet-flower

\begin{tabular}{|c|c|c|c|c|c|c|c|c|}
\hline & \multicolumn{8}{|c|}{ Management Practices } \\
\hline $\begin{array}{l}\text { Expected* } \\
\text { Effect on } \\
\text { the Spectes }\end{array}$ & $\begin{array}{c}\text { Prescribe } \\
\text { Burm }\end{array}$ & $\begin{array}{c}\text { Bulldoze } \\
\text { or } \\
\text { Root Rake }\end{array}$ & Bed & Chop & $\begin{array}{l}\text { Thin } \\
\text { over- } \\
\text { erory }\end{array}$ & $\begin{array}{l}\text { Cut } \\
\text { over- } \\
\text { story } \\
\end{array}$ & $\begin{array}{l}\text { Establish } \\
\text { Plantacion }\end{array}$ & Graze \\
\hline Destroy & & & & & $\mathrm{X}$ & $\mathrm{X}$ & & \\
\hline Damage & $x$ & $I I A$ & & & & & & \\
\hline $\begin{array}{l}\text { No Lasting } \\
\text { Effect }\end{array}$ & & & & $x$ & & & & $?$ \\
\hline $\begin{array}{l}\text { Beneficlal } \\
\text { if Done } \\
\text { Properly }\end{array}$ & & & & & & & & \\
\hline
\end{tabular}

\section{Orher Comruents:}

*Expected effect on the species is an estlinare made by Dr. Robert Kral based on his knowledge of the habitat and on knowledge gained from personal field observations. Estinates are "rough" in many instances. Results of practices may be modified depending upon the degree of application, intensity of treatment, neamess to plant comunties, etc. A management practice for which no entry is made indicates a lack of sufficient infomation from which to predict expected results. As observations are made in the field by users of the data, the expected effect will be refined. 
Scutellaria montana Chapm.

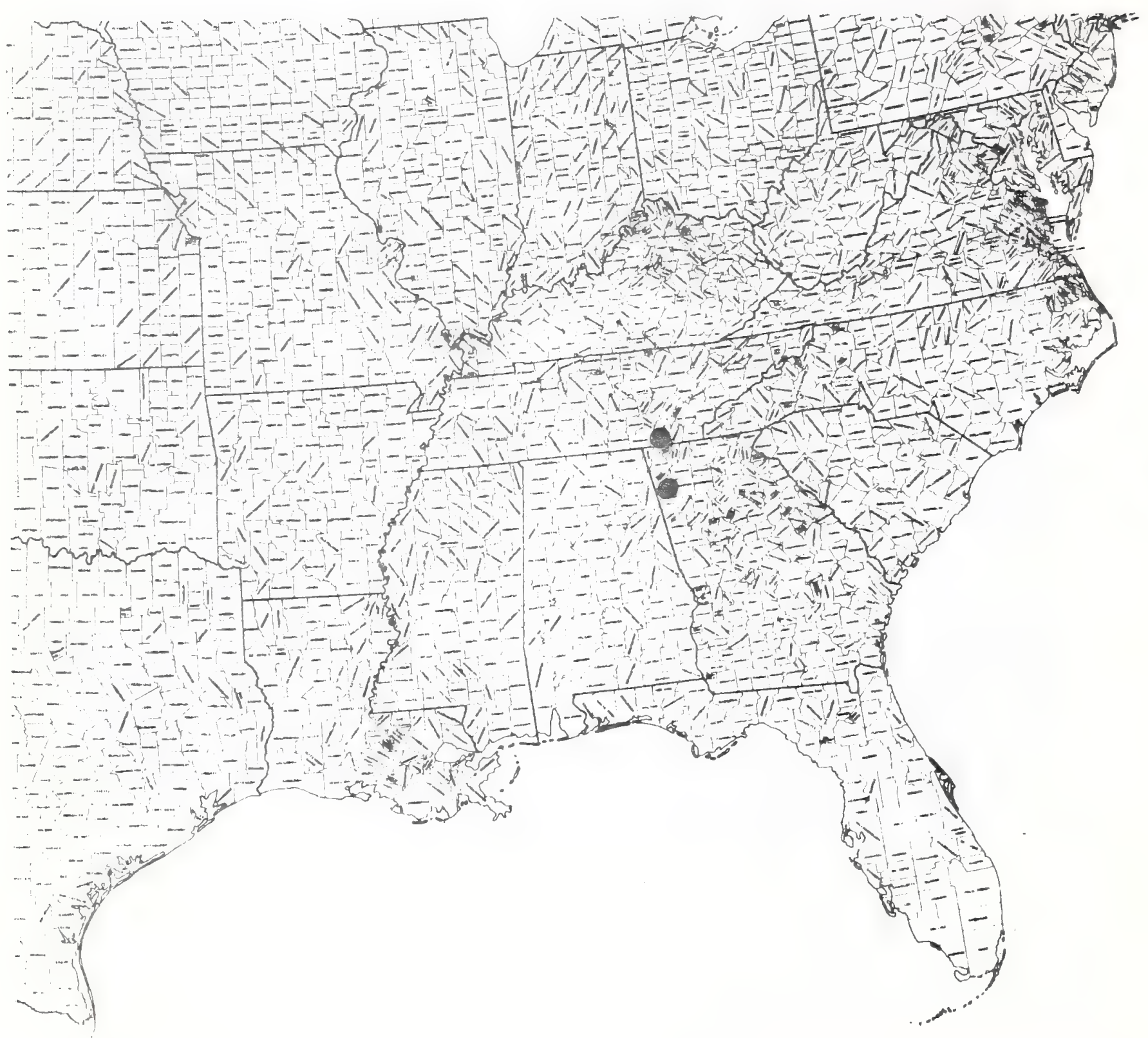




\section{IANIACEAE}

Scuteliaria thieretil Shimers o Thieret's skuilcap:

skullcap or helmet flowers

Technical Description

An annual herb from a taproot.

Stems.-Erect or erect with shortacurving bases, single or few rarely branching, rarely longer than $6 \mathrm{dm}$ pale green, spreading white-wairy.

Ieaves.--In several pairs, opposilee, shortwstalked, spreading, the blades mostIy ovate, rarely longer than $2 \mathrm{~cm}$ roundmipped, the margins unevenly low-crenate or low serrate, the bases attenuate, the surfaces pale green, softly short-hajry. Inflorescence.-Fiowers solitary in axils ox mid and upper leas pairs, spreading, on short, spreadingwhiry stadks.

Flowers.--Calyx about 4 min long (elongetiny in fruit) glandular shortwaixy and ciliate mostly marcon. Corolla strongly 2 wipped, 7 w $14 \mathrm{~mm}$ Iong, the tube (fused part) near white, the lips bluish, the lower lip with a whitish center. Fruit. - -Nutlets nearly round, about 1.001.5 min long, pebbled, dark brown.

Distribution and Flowering Season

This species is found only in the lower parishes of Louisiana, on shell sand or shell ridges, or in sandy meadow like clearings, these usualig not far from brakish marsh. It blooms from Aprid to Jurse.

Special Identifying Features

It is closest taxonomicaily to So drumonai. Bentho a species whose lower leaves are smallex and longerwstalked, and whose upper (bracteal) leaves axe conspicuously shorter than the flowers. In S. thioreti the leaves are hardly if at all reauced in aize upward on the stem and the lowers are thus shorter than the leaves.

Habitats and Ranagement Implication

S. thieretii has sore weedy tendencies, appears to frequent small clearings, on moist but well drained sands, where the forest is dominated by Locust (Gleditsia) and Southem Hackberry (Celtis laevigata). Cutting of species would probably not effect it much, so long as the solls were not radicaliy disturbed. Nothing is known about the response of this plant to graming.

References

Shinners, I. H。 1963. Sida I, NO. 3: 251-252. 
SPECIES: \#96 Scutellaria thieretii Shinners, Skullcar or llelmet-flower

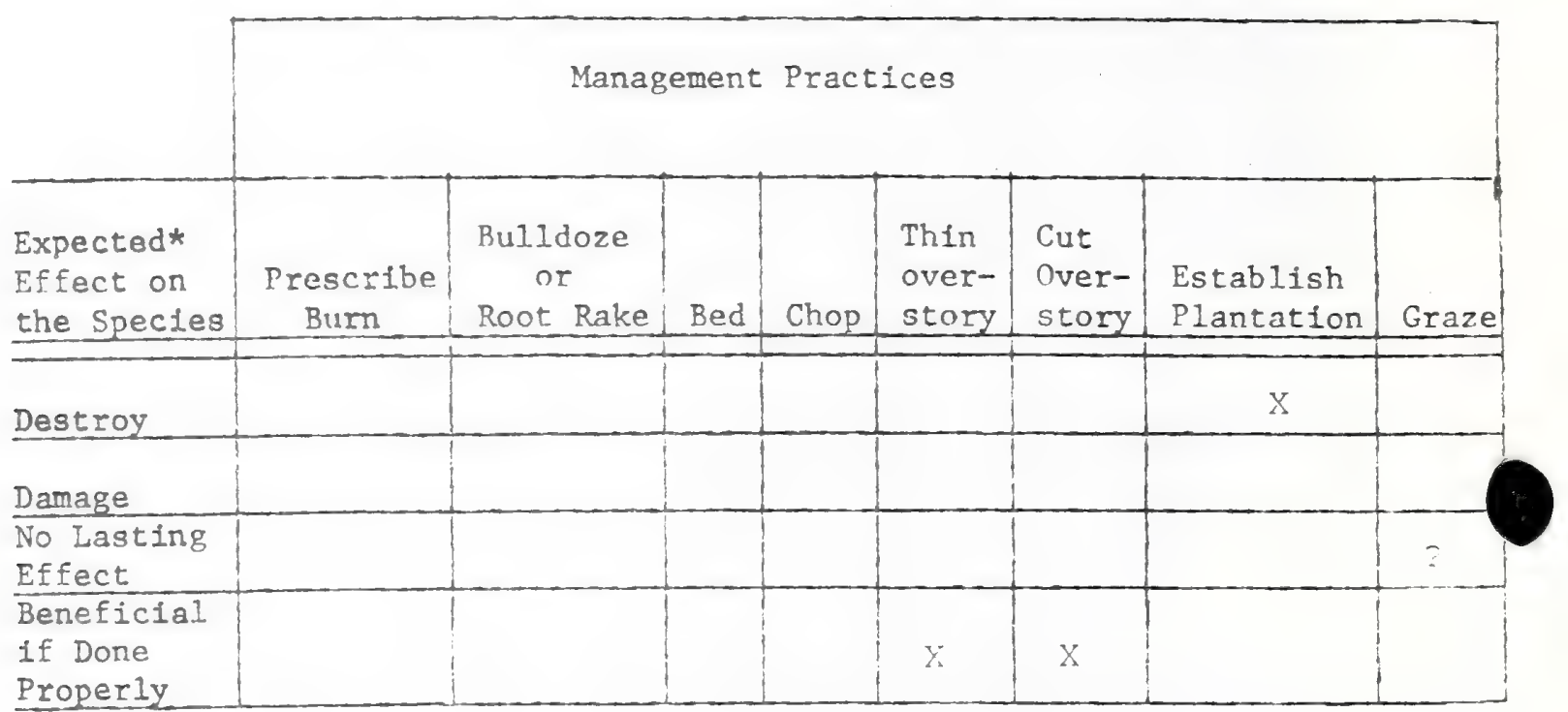

\section{Other Comments:}

* Expected effect on the species is an estimate made by Dx. Robert Kral based on his knowledge of the habitat and on knowledge gained from personal field observations. Estimates are "rough" in many instances. Results of practices may be modified depending upon the degree of application, intensity of treatment, neamess to plant comunities, etc. A management practice for which no entry is made indicates a lack of sufficient information from which to predict expected results. As observations are made in the field by users of the data, the expected effect will be refined. 
Paper 97

Text \& map by:

Robert Kral

\section{LAMIACEAE}

Stachys lythroldes Small. hedge-nettles

\section{Technical Description}

A rather slender but tall (to nearly 1 meter) perennial herb, spreading vegetatively by elongate, whip-like slender stolons.

Stems.--Erect often with numerous, opposite, slender ascending branches, strongly 4-angled, the angles sharp or rounded, the interfaces concave, each a strong groove, the stem surfaces pale green or with touches of red below, smoothish or with scattered, stiff, spreading or reflexed pale hairs and spreading-bristly at the nodes.

Leaves.-- Opposite, oblong, elliptic-oblong, or lanceolate the longest $6 \mathrm{~cm}$. 1ong, slightly broader than $1 \mathrm{~cm}$; blades subsessile or on stalks no longer than $3 \mathrm{~mm}$., spreading, in numerous pairs on the stem and branches, acute, low-toothed, the bases narrowly rounded or acute, the surfaces smooth.

Inflorescence: Flowers nearly sessile, spreading appearing whorled in the axils of the upper leaf-pairs, in bloom slightly longer than $1 \mathrm{~cm}$.

Flowers--Calyx narrowly bell-shaped, about $5 \mathrm{~mm}$. Iong the sepal bases fused, the lobes 5, triangular-acuminate, erect, about as long as the tube, the surfaces with a few spreading stiff hairs. Corolla strongly 2-1ipped, about $1 \mathrm{~cm}$. 1ong, pink, the lips somewhat shorter than the tube (fused part), the upper one projecting forward, oblong, the lower directed downward, 3-lobed; outer surface of upper lip with short, bristly hairs, that of lower lip sparsely so, that of the corolla tube scattered-short-hairy. Stamens 4, the dark anthers with spreading locules, projected beyond the corolla tip on slender, flattish, hairy filaments. Fruit:- - Nutlets about $2 \mathrm{~mm}$. long, broadly obovoid.

Distribution and Flowering Season

This hedge-nettle is confined to low sandy or sandy-peaty areas of bottomland hardwoods, usually near streams and in shade or full sun. So far it is known only from northern Florida. It blooms in mid and late summer.

\section{Special Identifying Features}

It is closest in appearance to S. hyssopifolia, but that species has very narrow sharp, stiff sepal tips and entire leaves. It also bears a resemblance to $S_{\text {. }}$ ambigua, but that species is more pubescent and has more strongly serrate, hairy leaves. The genus is currently under revision, so that all these might ultimately be considered subspecies.

\section{Habitats and Management Implication}

S. Iythroides appears to react, within its narrow range, almost as a weed to such disturbance as clear-cutting. An R. K. Godfrey collection (73824) from Leon County north of Tallahassee (the county which the species was first found) is 
from a clear-cut area of bottomland hardwoods from which all slash and stumps were removed. Here the plants were abundant, quite possibly responding through removal of shade and woody plant competition. Under normal conditions such a species probably maintains itself in small natural clearings in such forest. However, drainage of bottoms would probably eliminate the species from the habitat. References

Sma11, J. K. 1933. Manual of the Southeastern Flora: pp. 1159-1161. Chape1 Hill, North Carolina. 
Stachys Iythroides Small

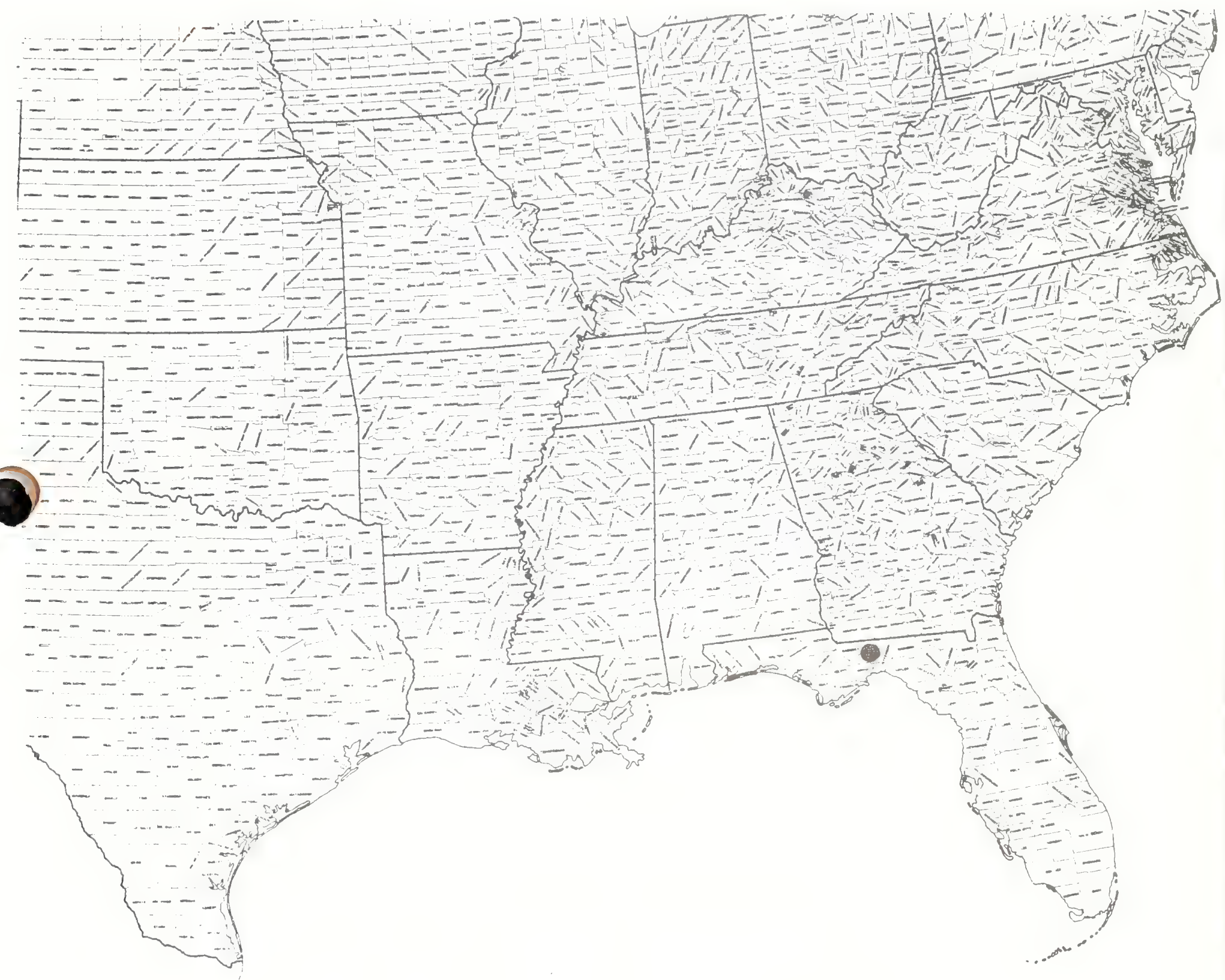




\section{LAMIACEAE}

Synandra hispidula (Michx.) Baill。; N.C.N.

S. grandiflora Nutt.

\section{Technical Description}

Annual or biennial herb bolting from overwintering rosettes. Stems:-Solitary or several, to $5 \mathrm{dm}$. long, erect or ascending, rather stout but soft, quadrate, pale green with a scattering of spreading soft hairs. Leaves--Rosette leaves present at flowering, on long, spreading-hairy stalks the blades broadly ovate, acute or acuminate, the margins crenate, the bases cordate, the surfaces appressed-hairy. Stem leaves opposite, crowded toward the base, distant toward mid-stem, also long-stalked and with blades similar to rosette leaves, those in the inflorescence becoming sessile and smaller. Inflorescence. Flowers in narrow, leafy-bracted racemes, solitary, erect and opposite in the bract axils, sessile, showy. Flowers:-Calyx bel1-shaped, about $1 \mathrm{~cm}$. long, the lobes triangular, ciliate subulate (with sharp narrow stiff points) longer than the tube (fused part), the surfaces villous (long-soft-hairy). Corolla strongly bilabiate, about 4 $\mathrm{cm}$. long, the tube and throat yellowish-white, narrowly funnelform, the upper lip arching forward, broad, the lower of 2 spreading narrower lobes and a central broader downward-pointing retuse lobe, this marked with purple guide-lines, the outer surface finely hairy. Filaments 4, of 2 lengths, hairy, projecting beyond corolla throat; fertile anthers 2, short-spurred.

Fruit:- Nutlets obovoid, smooth, ca. $3 \mathrm{~mm}$. long.

\section{Distribution and Flowering Season}

This species is found in rich, mixed-mesophytic forested ravines, usually in moist to even wet loams or clay loams and primarily over limestone parent material, often on and around rocky detritus. It occurs from southern Illinois and Ohio southward through Kentucky and Tennessee into northeastern Alabama and flowers in May and June.

\section{Habitats and Management Implication}

S. hispidula is definitely a shade plant, requiring soil that is highly loamy and permanently moist. Careful selective logging, which would limit danger from subsequent erosion or serious opening of the canopy, would probably not effect it adversely. Clear cutting in the steep situations it frequents would, through erosion, subsequent drying, and excess insolation eliminate the species. Grazing would similarly reduce or eliminate it, probably through disturbance of the plants and the soil by trampling; comparison of grazed versus ungrazed woodlands where this plant occurs shows no plants where cattle are allowed.

\section{References}

1. J. K. Sma11. 1933. Manual of the Southeastern Flora, pp. 1156-1157. Chape1 Hill, North Carolina. 
Synandra hispidula (Michx.) Baill.

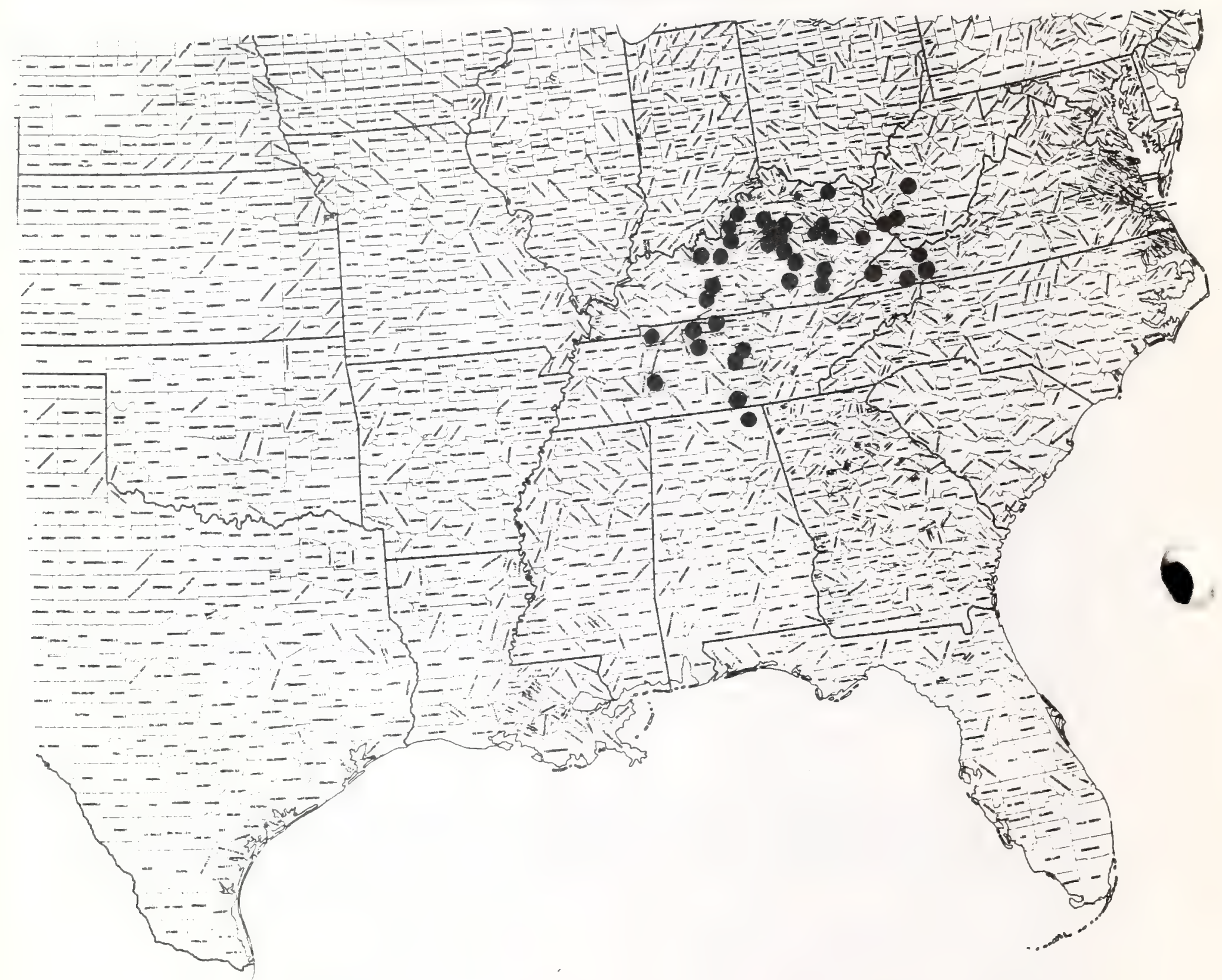




Paper 99

Text \& map by:

Robert kral

\title{
LAURACERE
}

\author{
Iindera melissaefolium (Walt,) Blune. Swamp spice bush; \\ Jove ${ }^{\circ} \mathrm{s}-\mathrm{Eruit}$ \\ Benzoin melissaefolium (Walt.) Nees
}

Technical Description

Low, aromatic, deciduous, thicket-forming shruo, rare?y to 1 meter tall. Stems.--Numerous; shoots erect or ascending, the young twigs hairy, the buds densely hairy. Leaves.--Altemate, drooping on short, slender, hairy petioles, the blades oblong, elliptic or narrowly ovace, thimnish, $50-16 \mathrm{~cm}$ long, $2-6 \mathrm{~cm}$ wide, acuminate, entire, the bases rounded, dark grees above, paler and pubescent beneath. Inflorescence: Plants unisesual. Nowers in short stalked umbels in the axils of the leaf scars, opening before the leaves, usually few to cluster on pedicels 9-12 $\mathrm{mm}$ long. Flowers.--Sepals 6, 0blong, about $2 \mathrm{~mm}$ long, bright yellow. Staminate flowers with 9 fertile erect or ascending stamens, the anthers opening by valves (flaps). Female flowers with numerous orangemyellow fleshy staminodes, the ovary superior, ovoid, with an elongate style. Fruit.-Fruiting pedicels stoutish, definitely thickened apicaldy. Drupes ellipsoidal or obovoid, 10-12 cm long, bright red when ripe.

Distribution and Flowering Season

Sandy sitty sink hole depressions and swamps, in the Coastal plain Erom North Carolina south to northern Florida, thence west to Loudsiana and north in the Mississippi Embayment to southeastern Missouri. One of our rarest shrubs.

Special Identifying Features

The observations of Dr. Julian steyermark (1949) are the best. He noted the following differences with the quite comon Spicebush. Io benzoirs (I.) Blume.

1. It is a shorter shrub. Io benzoin arows to mostly 1.604 .5 meters.

2. Crushed twigs and leaves have a sassafras odor in contrast to the strong benzine odor of $I_{\phi}$ berwoir.

3. The leaves of Io mellssaefolim droop: those of I. benzolin are spreading or ascending. Trose of the Eorner are densely hairy beneath: most $I$. benzoin (save for $I_{\odot}$ benzoin var. pubescens) tend to be smooth or smoothish. Bases of leaves of I. melissaerolium tend to be rounded; those of I. benzoin taper.

4. Fruiting pediceis are stouter, Ionger, more enlarged toward the tip: also they tend to persist on the shrubs until flowering time, while in $I_{0}$ benzoin taper.

Habitats and Management Implication

Both species frequent soils that never dry out, but I0 melissaefolium is strictly confined to swamp haräwood sites while I. benzoin is very often understory to mixed-mesophytic forest. 
The common species of overstory for I. melissaefolia are various swamp oaks $(0$. palustris, 8. phelos, Q. laurifolia, etc.) hickories, ash, Acer saccharinum, Arubrum. Steyermark (1.C.) found the shrubs in sandy potholes dominated by an overstory of Pin Oak and Pumpin Ash, with what remained of the surrounding higher forest being made up of Sugar Maple, Flowering Dogwood, Aralia, Asimina.

It is obvious that this shrub is a plant of high hydroperiod soils; it is Irequently found in standing water. Selective logging of the swamp hardwood overstory probably would effect it little. Clear cutting might raise the flood level to a dangerous degree.

Drainage of the swamps it frequents would eliminate the species. No comments are available as to whether livestock browse the twigs. In fact little recent information is available. In 1949 steyermark commented that material he borrowed from the four largest U.S. herbaria contained a total of only 19 herbarium sheets conprising but 10 different collections with most of these made more than one hundred years earlier.

References

Small, J. K. 1933. Manual of the Southeastern Flora.924。

Steyermark, Julian A. 1949。 Iindera Melissaefolia. Rhodora 51, no. 608: 153-162.

Tucker, G.E. 1974. Lindera mellissaefolium in Arkansas. Rhodora 76:525. 
SPECIES: \#99 Iindera melissaefoliura (walt.) Blume Jove's-fruit

\begin{tabular}{|c|c|c|c|c|c|c|c|c|}
\hline & \multicolumn{8}{|c|}{ Management Practices } \\
\hline $\begin{array}{l}\text { Expected* } \\
\text { Effect on } \\
\text { the Species }\end{array}$ & $\begin{array}{c}\text { Prescribe } \\
\text { Burn }\end{array}$ & $\begin{array}{l}\text { Bulldoze } \\
\text { or } \\
\text { Root Rake }\end{array}$ & Bed & Chop & $\begin{array}{l}\text { Thin } \\
\text { over- } \\
\text { story }\end{array}$ & $\begin{array}{l}\text { Cut } \\
\text { Over- } \\
\text { story }\end{array}$ & $\begin{array}{l}\text { Establish } \\
\text { Plantation }\end{array}$ & Graze \\
\hline Destroy & & 2 & & $x$ & & & & \\
\hline Damage & & & $\mathrm{Y}$ & & & $\mathrm{X}$ & & \\
\hline $\begin{array}{l}\text { No Lasting } \\
\text { Effect }\end{array}$ & $\mathrm{NA}$ & & & & $X$ & & $N A$ & ? \\
\hline $\begin{array}{l}\text { Beneficlal } \\
\text { if Done } \\
\text { Properly }\end{array}$ & & & & & & & & \\
\hline
\end{tabular}

\section{Oeher Comments:}

* Expected effect on the species is an estimate made by Dr. Robert Kral based on his knowledge of the habitat and on knowledge gained from personal field observations. Estinates are "rough" in many instances. Results of practices may be modified depending upon the degree of application, intensity of treatment, neamess to plant comunities, etc. A management practice for which no entry is made indicates a lack of sufficient information from which to predict expected results. As observations are made in the field by users of the data, the expected effect will be refined. 
Lindera melissaefolia (Walt.) Blume

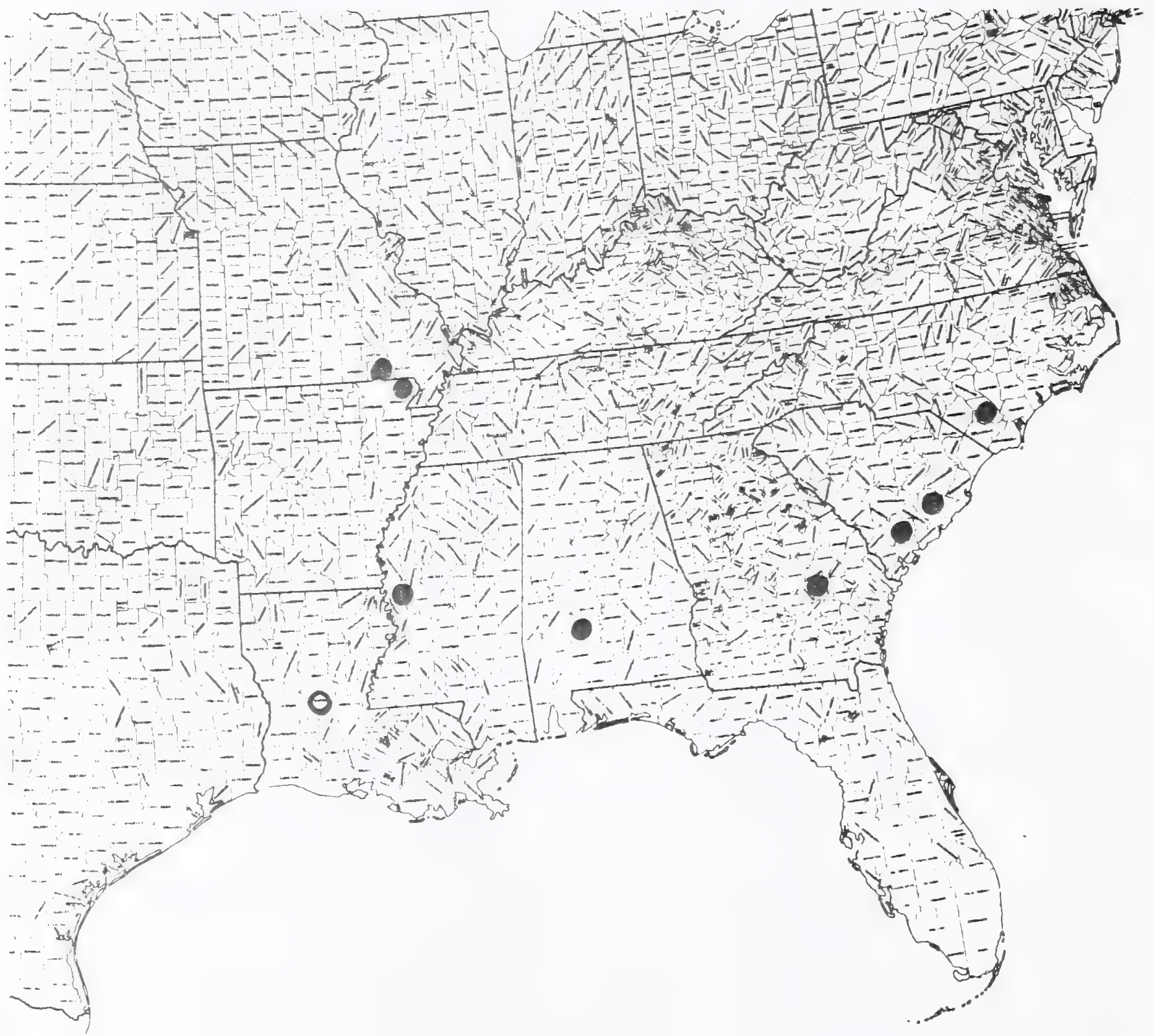


Raper 100

rexe \& maso by:

Robert Ral

\section{IIAURACERE}

Persea humils Nash. Dwar red bay peraed podbay porsaa P. borbonia $\left(I_{0}\right)$ Spreng, var. humi I is (so) Kopp

Technical Description

Evergreen shrub or small tree with purgently arometic twigs and foldage. Stems.--The ascending primary branches numerous and rebrasching fron near the base。 thus the plants bushy with full crowns. Things slender but stiffish, redilsh, densely appressedwairy. opcen iustrous.

Leaves. - -Spreading or ascending on angled, appressedwhiry petioles to 2 can long, the blades lanceolate to elliptse or (rarely) obovate, mostly $4-10 \mathrm{~cm}$ Iong, acute but the tips narrowly rounded, the margins slightly revolute and cartilaginous edged, entire, the bases cuneate, the upper surface yelloworeen and smooth, shining, the lower surface Iustrous, rediened or bronzed with thinte, appressed hairs. Inflorescence. - m lowers clustered in umbelalike tight cymes, the pedicels silky hairy, the cymes on stiffish, ascending, hairy stalks on new shoots. Flowers,-sepais 6 in 2 series, the surfaces silkywhiry. Outer sepals 3 , joined at base, ascending about $2 \mathrm{~mm}$ long, ovate: inner sepals nore spreading, oblong, ca. 3.0-3.5 m long, yelzowishmgreen. Stamens usually 9 , more or less erect, the Eilaments hadry, the anchers with o valves (flaps). Staminodes fleshy. Ovary 1 , superior with a single style and stigma button. Fruit.-mrupes broady ovoid or (mostiy) globose, nearly black when ripe and with a slight bloom, about $1 \mathrm{~cm}$. long.

Distribution and. Flowexing Season

Sandhilis scrub, peninsular Elorida, particularly in the central highlands with outliers north as far as southern Georgia. Flowering mostly in early summer, but intemittently all year.

Rabitats and Management Implication

This species is part of the sand-pine evergreen scrub oak forest type and is therefore found on deep. Fine-tertured sands these very often what remains of ancient dunes. Occasionally it is also to be found, with ceratiola, in open stands of longleaf pinewturkey oak. Associared shrubby species are shrub heaths (Lyonia) hollies, Ceratiole, palmetto, shrub oaks. Evergreen oaks. Florida hickory, Osmanthus, and sand pine mark the overgtomy where it is present. The sandhils it irequents have historICaIly been swbjected to Fire, but not as frequentIy as the often adjacent longlear pineland. In any event, most of the scrub species, of which this is a part, respond by prolific sprouting and often increase in contrast to the s and pirse and ceratiola which have to reseed such burned areas (the formar through opening of charred, serotinous cones)。

Clear cutting of the pine in the overstory without disturbance of the substratum would increase this species and other non-comatercial scrub evergreens. Root plowing, chaining, windrowing and other methods of site preparation for 
pine would of course eliminate scrub species such as $\underline{\underline{P}}$. humilis. Burning is not recommended in this forest site type.

The taxonomic distinctness of this species has long been debated, many workers considering it but a variety of $\mathrm{p}$. borbonia. Current work involving study of epidermal characters together with flavonoid analysis done by Dr. E. F. Wofford support the thesis that it is a taxon distinct from, though perhaps derived from, P. borbonia in recent geologic time.

\section{References}

1. Small, J. K. 1933. Manual of the Southeastern Flora. 921-922.

2. Wofford, E. P. 1974. The systematic significance of flavonoids in Persea of the southeastern United States. Biochem. Syst. and Ecol. 2 88-91.

3. 1975. An SEM study of leaf surface pubescence in the southeastern taxa of Persea. With R. W. Fearman, Sida 6 (1): 19-23. 
SPEUIES: \#100 Persea humilis Nash, Redbay persea

\begin{tabular}{|c|c|c|c|c|c|c|c|c|}
\hline & \multicolumn{8}{|c|}{ Management Practices } \\
\hline $\begin{array}{l}\text { Expected } \\
\text { Effect on } \\
\text { the Species }\end{array}$ & $\begin{array}{c}\text { Prescribe } \\
\text { Burm }\end{array}$ & $\begin{array}{l}\text { Bulldoze } \\
\text { or } \\
\text { Root Rake }\end{array}$ & Bed & Chop & $\begin{array}{l}\text { Thin } \\
\text { over- } \\
\text { scory }\end{array}$ & $\begin{array}{l}\text { Cut } \\
\text { Over- } \\
\text { story }\end{array}$ & $\begin{array}{l}\text { Establish } \\
\text { Plantation }\end{array}$ & Graze \\
\hline Destroy & & $x$ & & $\mathrm{X}$ & & & $\mathrm{X}$ & \\
\hline Damage & & & $\mathrm{X}$ & & & & & \\
\hline $\begin{array}{l}\text { No Lasting } \\
\text { Effect }\end{array}$ & NA & & & & & & & $? ?$ \\
\hline $\begin{array}{l}\text { Beneficial } \\
\text { if Done } \\
\text { Properly }\end{array}$ & & & & & $x$ & $\mathrm{X}$ & & \\
\hline
\end{tabular}

\section{Other Comonen:}

*Expected effect on the species is an estimate made by Dr. Robert Kral based on his knowledge of the habitat and on knowledge gained from personal field observations. Estimates are "rough" in many instances. Results of practices may be modified depending upon the degree of application, intensity of treatment, neamess to plant communities, etc. A managenent practice for which no entry is made indicates a lack of sufficient infomation from which to predict expected results. As observations are wade in the field by users of the data, the expected effect will be refined. 
Persea humilis Nash

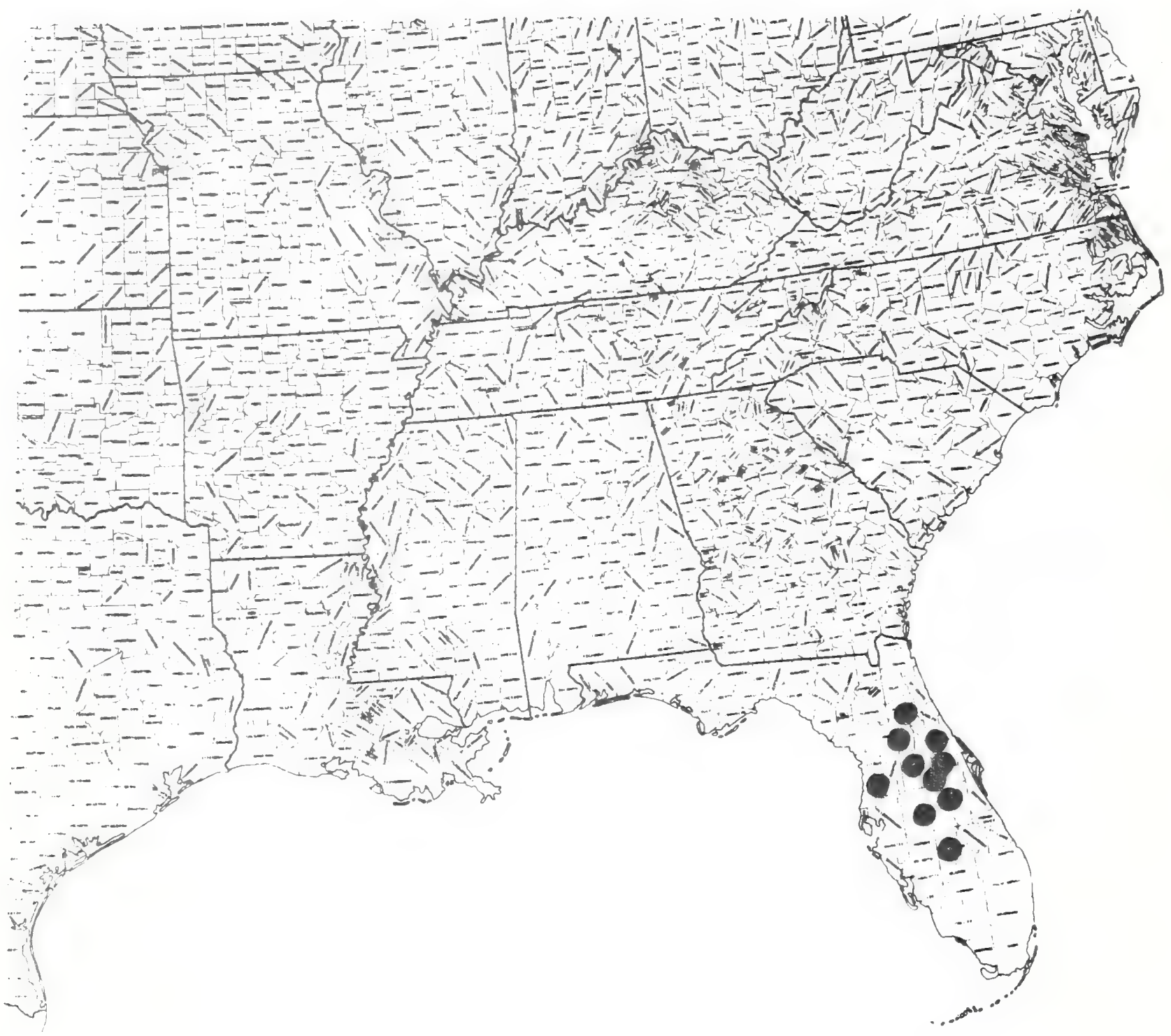


Paper 101

Test sag by

Robert Kral

\section{DAURACEAE \\ Litsea aestivalis (to) Ferr. Pond spice: pond bush Glabraria genaculata (waltol Bricton}

Technical Description

Glabrous, deciduous shrub to 3 meters tall.

Stems. - The twigs slender, palembrow, zigmag, the branches spreading, the bark of new shoots reddish-brown, sometimes tornertese at first.

Leaves.-Alternate, spreading on short slender petioles $5 \mathrm{~mm}$ Iong or less, the blades leathery (somewhat like small leaves of willowoak). lanceolate to oblong or oblanceolate, mostiy $1.5-4.0 \mathrm{~cm}$ long, rare ${ }^{2}$ wider than $1.0 \mathrm{~cm}$ the tips acute to narrowly or broadly rounded, the margiss entire, slightly thickened, the bases acute or acuminate, yellow-greer and stooth save for villosity (spreading, long. crisped hairs) along the midrit beneath (sometlnes also on the petiole). Winter buds ovoid, valvate, to about 3 rm long, stalked, solitary or paired at the branch tips or from spur tips, these expanding to form cup-like involucres below the small umbels of maie or female rlowers. Flowers.-With mostly 6 , spreading, yellow sepals, these broadly ellipticuoblong or obovate ca. 3.0-3.5 mm long. Stamens mostiy 9 , the anthers with 4 valves (flaps), opening inward or laterally. Fernale flowers with I superior ovary, this surrounded by usually 9 short, rleshy staminodes. Fruit,--One to four, on stalks (pedicels) to $4 \mathrm{~mm}$ long, these jointed to peduncles (inflorescence stalks) about as long: body of drupe nearly round, $4-6$ mm long, minutely roughenea, red.

\section{Distribution and Flowering Season}

Bay heads, edges of sandy sinks, meteor ponds, and pocosins, very uncomon, in the Coastal Plain from North Carolina south to northern Elorida and southwestern Georgia.

Special Identifying Features

Superficially similar to Iindera spp. but differing in having 4 anther flaps (versus 2 for lindera), in its smaller, rounder fruit, and in its much smaller and more leathery, narrower leaves. The twigs and foliage lack spicy odor.

Habitats and Management Implication

This is denfinitely a species of wet, sandy or peaty, quite acid soils. Like Iindera, it may form thickets and thus, while spotty in distribution, may be abundant locally. Common associated woody species would be Red Bay, Virginia Bay, Galiberry, Myrtle, various heaths, Pond Pine, Pond Cypress, Ioblolly Bay. Clear cutting of the mercantible species would probably favor this plant. Burning would not effect it adversely in that. like most species of bogs and pocosins, it would respond vigorous ly with new shoots. Site preparation involving removal of brush would of course eliminate it, unless done in strips. Greatest difficulty for a species with high soil moisture requirements such as this one is through drainage of the habitat. 


\section{References}

Small, J. K. 1933. Manual of the Southeastern Flora. 921, 923.

Britton, N. I. \& A. Brown. 1913. Illustrated flora of North eastern U. S.

Canada \& British Possessions. Vol. II: p. 135.

Fernald, N. I. 1945. Botanical specialities of the seward Forest and adjacent areas of Southeastern Virginia. Rhodora 47: 94-142. 
SPECIES: HIOI Iitsea aestivalis (I.) Fem. Pond spice; pond bush

\begin{tabular}{|c|c|c|c|c|c|c|c|c|}
\hline \multicolumn{9}{|c|}{ Management Practices } \\
\hline $\begin{array}{l}\text { Expected* } \\
\text { Effect on } \\
\text { the Specles }\end{array}$ & $\begin{array}{c}\text { Prescribe } \\
\text { Burre }\end{array}$ & $\begin{array}{c}\text { Bulldoze } \\
\text { or } \\
\text { Root Rake }\end{array}$ & Bed & Chop & $\begin{array}{l}\text { Thin } \\
\text { over- } \\
\text { story }\end{array}$ & $\begin{array}{l}\text { Cut } \\
\text { Over- } \\
\text { story }\end{array}$ & $\begin{array}{l}\text { Establish } \\
\text { Plantation }\end{array}$ & Graze \\
\hline Destroy & & $\mathrm{x}$ & & $\mathrm{X}$ & & & $\mathrm{x}$ & \\
\hline Damage & & & $\mathrm{X}$ & & & $\mathrm{X}$ & & \\
\hline $\begin{array}{l}\text { No Lasting } \\
\text { Effect }\end{array}$ & $\mathrm{x}$ & & & & & & & $?$ \\
\hline $\begin{array}{l}\text { Beneficial } \\
\text { if Done } \\
\text { Properly }\end{array}$ & & & & & X & & & \\
\hline
\end{tabular}

\section{Other Coments:}

*Expected effect on the species is an estimate made by Dr. Robert Kral based on his knowledge of the habitat and on knowledge gained from personal field observations. Estimates are "rough" in many Instances. Results of practices may be modified depending upon the degree of application, intensicy of treatment, nearness to plant commuities, etc. A management practice for which no entry is made indicates a lack of sufficlent information from which to predict expected results. As observations are made in the field by users of the data, the expected effect will be refined. 
Litsea aestivalis (L.') Fern.

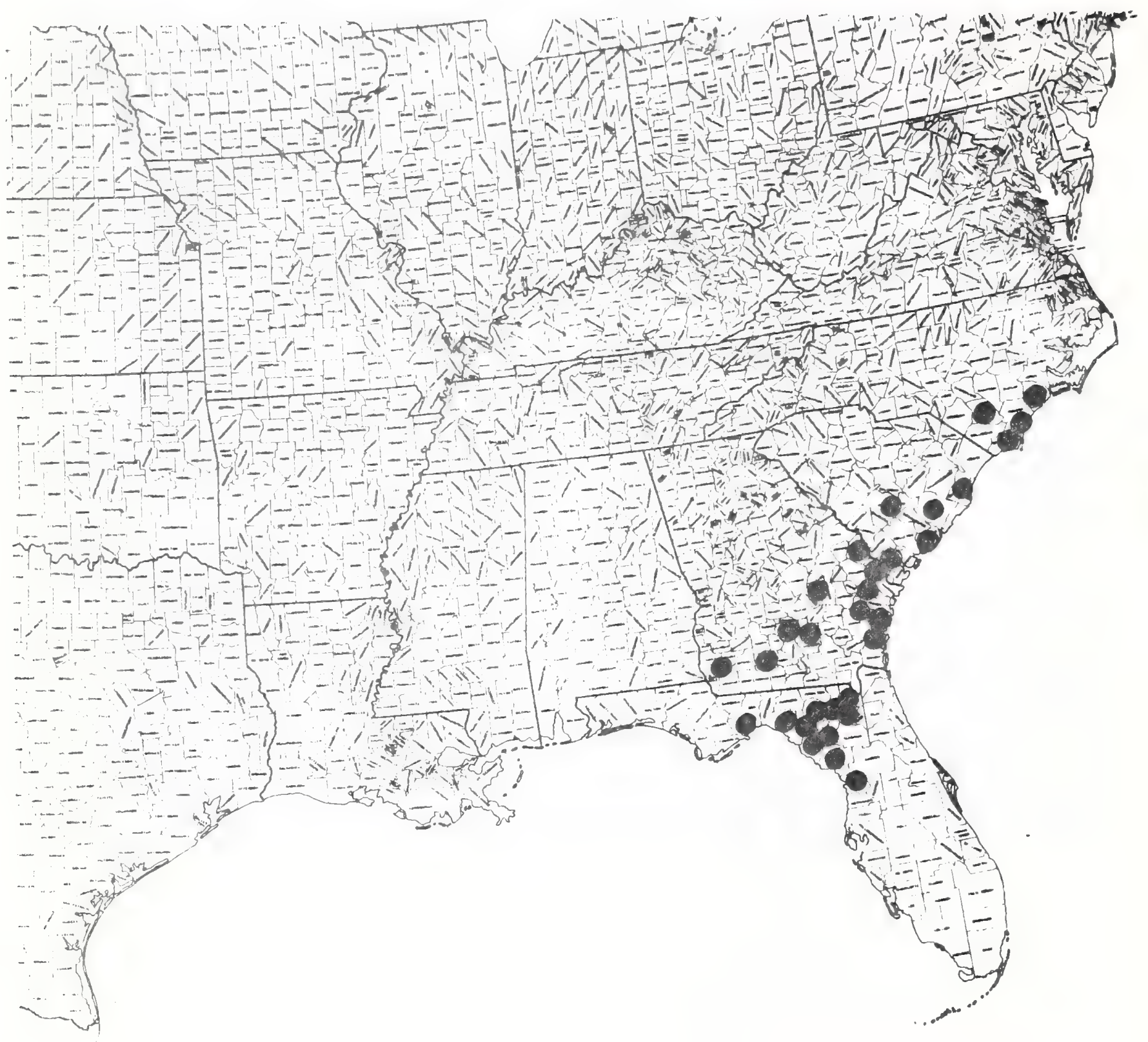


Paper 203

Trese \& man Dy:

RObore Kres

\section{ASTREACEAE}

\section{Aster pumosug Sinal: plumose aster: Aster}

\section{Technical Description}

Peremial herb, from a round, knotry caudes.

Stems,-me stems wand-like, to a meter or more long, ascending, arching or even sprawling on other vegetation: epidemis of lower stem grayisho with shallow vertical, pale brown cracks, the upper ster redàdshbrown or tan, puberulent with pale spreadirg haris.

Leaves - Lower leaves absent by flowering thme, those of mid and upper stem numerous, alternate, sesside, rigid, the largest Iowest, mostiy ellipticoblong or lance oblong, about $1-2 \mathrm{~cm}$ long, erect, spinulosemtipged, the margin scabromciliate, the surfaces villouswoberulent with incurved hairs. Stem leaves gradually smaller upward on the sten, grading into the involucral bräts.

Inflorescence. -mieads nunerous, closemset or scattered along the upper part of the stem on short, asconding. pllosompuberulent lateral branches or solitary on short and shortwbracted laterals thus the whole irfiorescence rather narrowy. Involucres broady turbirate, about $1 \mathrm{~cm}$. across, the numerous bracts in several, loosely appressed series: involueral. bracts linear. acuminate, pale greer with purpish tips, these usually somewhat spreading, the surfaces covered with longisho pale, soft hairs.

Elowers, - Ray corollas about 10 12, the bIades IIneal, spreadirng, showy, a deep blueviolet, the ray florets about $1.5 \mathrm{~cm}$ long. DLsc Elcwers yellowish. Eruit. -wikenes oblong, about $2 \mathrm{~mm}$ long, rLbbed lengthrise, densely silkyhairy with erect hairs: pappus about $5 \mathrm{~mm}$ long, capillary, yellowishwhite.

\section{Distribution and Flowering Season}

This aster is found in deep sands of longlear pinemeciduous scrublands in northwestern Florida, particularly above the Apalachicola River and associm ated drainages: flowering september through November.

\section{Special Identifying Features}

Taxonomically it most closely resembles the comon wpland aster. A. concolor I. which is like it in habit, leaf, ray lowers and akene, but which has somewhat broader involucral bracts that tend to be more tightly imbricated and having shorter hairs. In fact, the status of this as a species distinct from A. concolor could be questioned.

Fabitats and Management Implication

A. plumosus is most often found, as mentioned above, in longleaf pine-decidusous scrub oak woods, and invariably on deep, dryish to moist sands. Its maintenance and increase is related to periodic burning and therefore fire protection, encouraging increase of overstory, would tend to reduce its 
numbers. It will occupy areas that have been clearcut of pine and subsequent scarified and will persist in such areas, growing between the planted or seedling pines, until such time as the crowns close.

Referenceg

Smal1, J. K. 1924. Plant novelties from Florida. Bull. Torr. Bot. Club. 51: $379-393$

- 1933. Manual of the southeastern flora, p. 1384. 
SPECIES: H103 Aster plumosus Small. Aster

\begin{tabular}{|c|c|c|c|c|c|c|c|c|}
\hline & \multicolumn{8}{|c|}{ Management Practices } \\
\hline $\begin{array}{l}\text { Expected* } \\
\text { Effect on } \\
\text { the Species }\end{array}$ & $\begin{array}{c}\begin{array}{c}\text { Prescribe } \\
\text { Burn }\end{array} \\
\end{array}$ & $\begin{array}{l}\text { Bulldoze } \\
\text { or } \\
\text { Root Rake } \\
\end{array}$ & Bed & Chop & $\begin{array}{l}\text { Thin } \\
\text { over- } \\
\text { story }\end{array}$ & $\begin{array}{l}\text { Cut } \\
\text { Over- } \\
\text { story }\end{array}$ & $\begin{array}{l}\text { Establish } \\
\text { Plantation }\end{array}$ & Graze \\
\hline Destroy & & $\mathrm{X}$ & & $x$ & & & $\mathrm{X}$ & \\
\hline Damage & & & $\mathrm{X}$ & & & & & \\
\hline $\begin{array}{l}\text { No Lasting } \\
\text { Effect }\end{array}$ & & & & & & & & ? \\
\hline $\begin{array}{l}\text { Beneficlal } \\
\text { if Done } \\
\text { Properly }\end{array}$ & $x$ & & & & $\mathrm{X}$ & $\mathrm{X}$ & & \\
\hline
\end{tabular}

\section{Other Comments:}

*Expected effect on the species is an estimate made by Dr. Robert Kral based on his knowledge of the habitat and on knowledge gained from personal field observations. Estimates are "rough" in many instances. Results of practices may be modified depending upon the degree of application, intensity of treatrent, neamess to plant comunities, etc. A management practice for which no entry is wade indicates a lack of sufficient information from which to predict expected results. As observations are made in the field by users of the data, the expected effect will be refined. 


\section{Aster plumosus small}
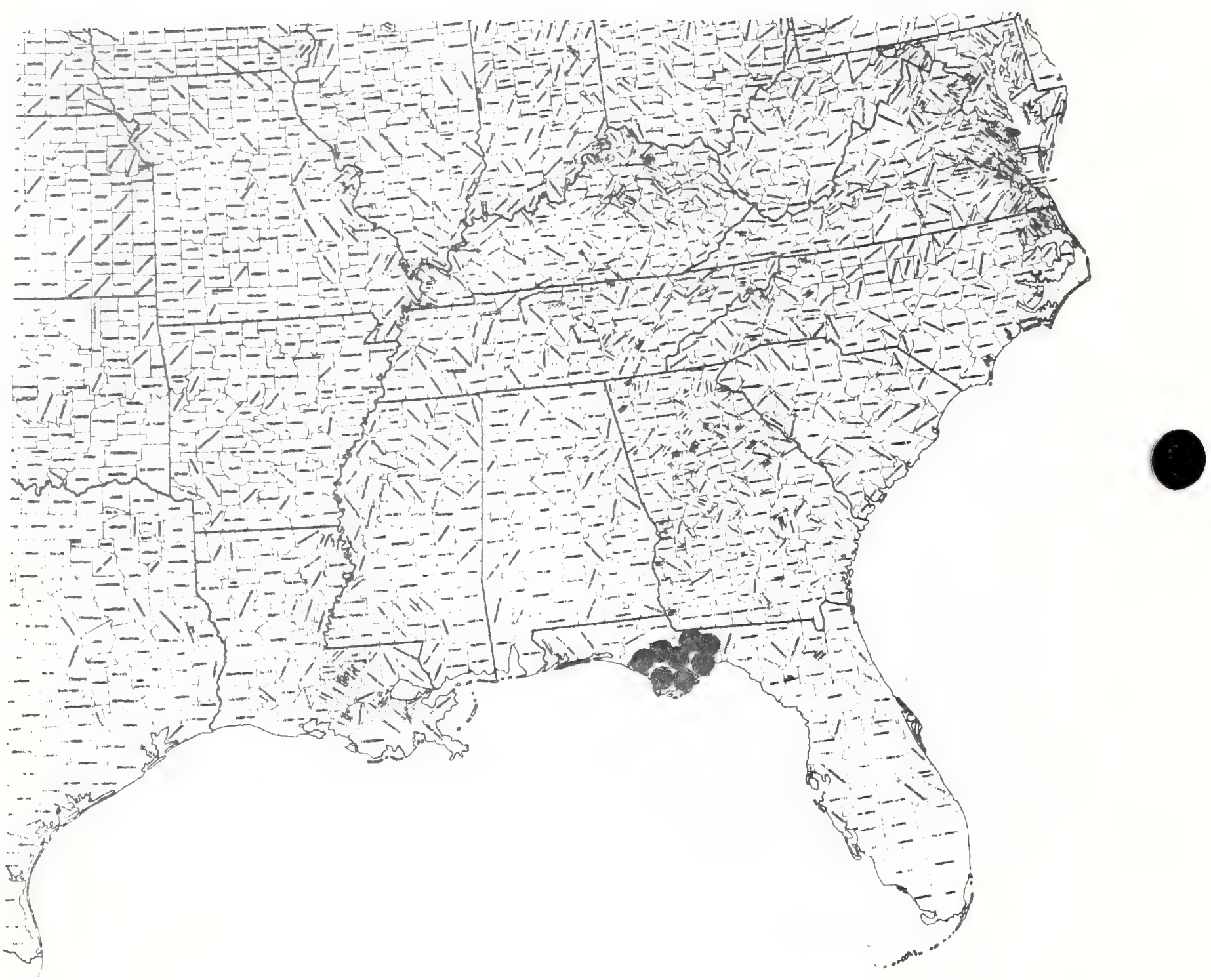
Paper 104

Test \& gap by:

Reverec Rral

\section{ASTERACEAE}

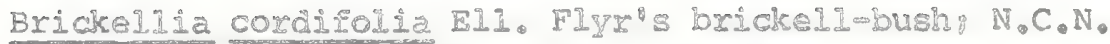
Coleosanthus cordifolius (EII.) Kuntere

Technical Description

Erect perennial herb from an erect, cylindrically chickened rhizome (caudex). Stems. - Solitary or few. erect or ascending, unbranched, most1Y $1.0-1.5$ meters tall, terete. Iongitudinally rany- Low ribbeop. puberilent.

Leaves.--Confined to stem, the lowest gone by flowering tine, the largest at midstem opposite, spreading on slender long petioles, mosty triangular, mostiy $6-10 \mathrm{~cm}$ long, acuminate, the margins crenate-dentate, the bases broadiy rounded or truncate, shortwattenuate to the petiole: upper surface of blade dark green, smoothish: lower surface puberulent and glanddotted. Inflorescence.--Rather few-headed, either a single cyme or a cluster of a few cymes, the puberulent peduncles stifily erect or ascending, the bracts few, mostly lanceolate. Heads exclusively discoid, broadiy topmshaped, $1.5-2.0 \mathrm{~cm}$ broad, the bracts in several. loosely overlapping series, the outer few shortest, narrowly or broadiy triangular, the inner larger ones larger ones narrowly oblong, 6-8 mim long, strongly parallel-ribbed. obtuse to acuminate, the margins and backs with small wooly hairs. Receptacle of head slightly ele vated.

Flowers--Disc florets very many, cubular, the corolla base whitish, toward the tip purplish, the corolla lobes low triangular, slighily spreading. Fruit.-Akenes cylindrical or slightly compressed, about 5 m long, strongly ribbea, brownish, puberulent; pappus of many, purplish-brown upwardly barbellate bristies, these projecting above the tips of the bracts.

Distribution and Flowering Season

Rich sandy loamy soil of high hamucks in the Coastal Plain, Georgia south to peninsular Florida and west into southern Alabama. Flowering from August to october.

Habitats and Management Implication

This species is to be looked for on well-drained fine sandy loams usually in mature forest of upland hammocks. The overstory is usually comprised of a mixture of pines such as $P_{\text {. taeda }}$. 9 gabra with hardwoods such as livemoak, willowoak (complex), beech, magnolia Mo grandiflora) etc. Frequent in the understory would be such shrubs as Myrica Cerifera Zaccinium spp. Rhododendron (particularly canescens). Osmanthus Kalmia Sebastiana Arunainaria. In foliage and in general appearance of the plant, it most Iy closely resembles the "Snake-root" type of Eupatorium, and is often in association with two of these species.

Selective logging of the pine-mixed hardwood overstory would probably not create an adverse situation for this species of open woodlands. Heavy logging 
on the other hand would tend to produce a scrub or shrub response that might provide a problem in competition. Clear cutting and mechanical site preparation for row crops of pine would eliminate this species by changing the habitat. Pine plantations are devoid of this plant and most other high mixed-hamock species of forbs.

References

Small, J. K. 1933. Manual of the Southeastern Flora: 1328. 
SPECIES: \#I04 Brickeliia cordifolia Ell. N.C.M.

\begin{tabular}{|c|c|c|c|c|c|c|c|c|}
\hline & \multicolumn{8}{|c|}{ Management Practices } \\
\hline $\begin{array}{l}\text { Expected* } \\
\text { Effect on } \\
\text { the Specieg }\end{array}$ & $\begin{array}{c}\text { Prescribe } \\
\text { Burn } \\
\end{array}$ & $\begin{array}{c}\text { Bulldoze } \\
\text { or } \\
\text { Root Rake }\end{array}$ & $\mathrm{Bed}$ & Chop & $\begin{array}{l}\text { Thin } \\
\text { over- } \\
\text { story }\end{array}$ & $\begin{array}{l}\text { Cut } \\
\text { Over- } \\
\text { story }\end{array}$ & $\begin{array}{l}\text { Establish } \\
\text { Plantatlon }\end{array}$ & Graze \\
\hline Destroy & & $\mathrm{x}$ & $x$ & $2:$ & & & $\mathrm{X}$ & \\
\hline Damage & (IIA) $x$ & & & & & $\mathrm{X}$ & & $\mathrm{X}$ \\
\hline $\begin{array}{l}\text { No Lasting } \\
\text { Effect }\end{array}$ & & & & & & & & \\
\hline $\begin{array}{l}\text { Beneficial } \\
\text { ff Done } \\
\text { Properly }\end{array}$ & & & & & X & & & \\
\hline
\end{tabular}

\section{Other Coments:}

*Expected effect on the species is an estimate made by Dr. Robert Kral based on his knowledge of the habitat and on knowledge gained from personal field observations. Estimates are "rough" in many instances. Results of practices may be modified depending upon the degree of application, incensity of treatment, neamess to plant comunities, etc. A management practice for which no entry is made indicates a lack of sufficient information from which to predict expected results. As observations are made in the field by users of the data, the expected effect will be refined. 
Brickellia cordifolia Ell.
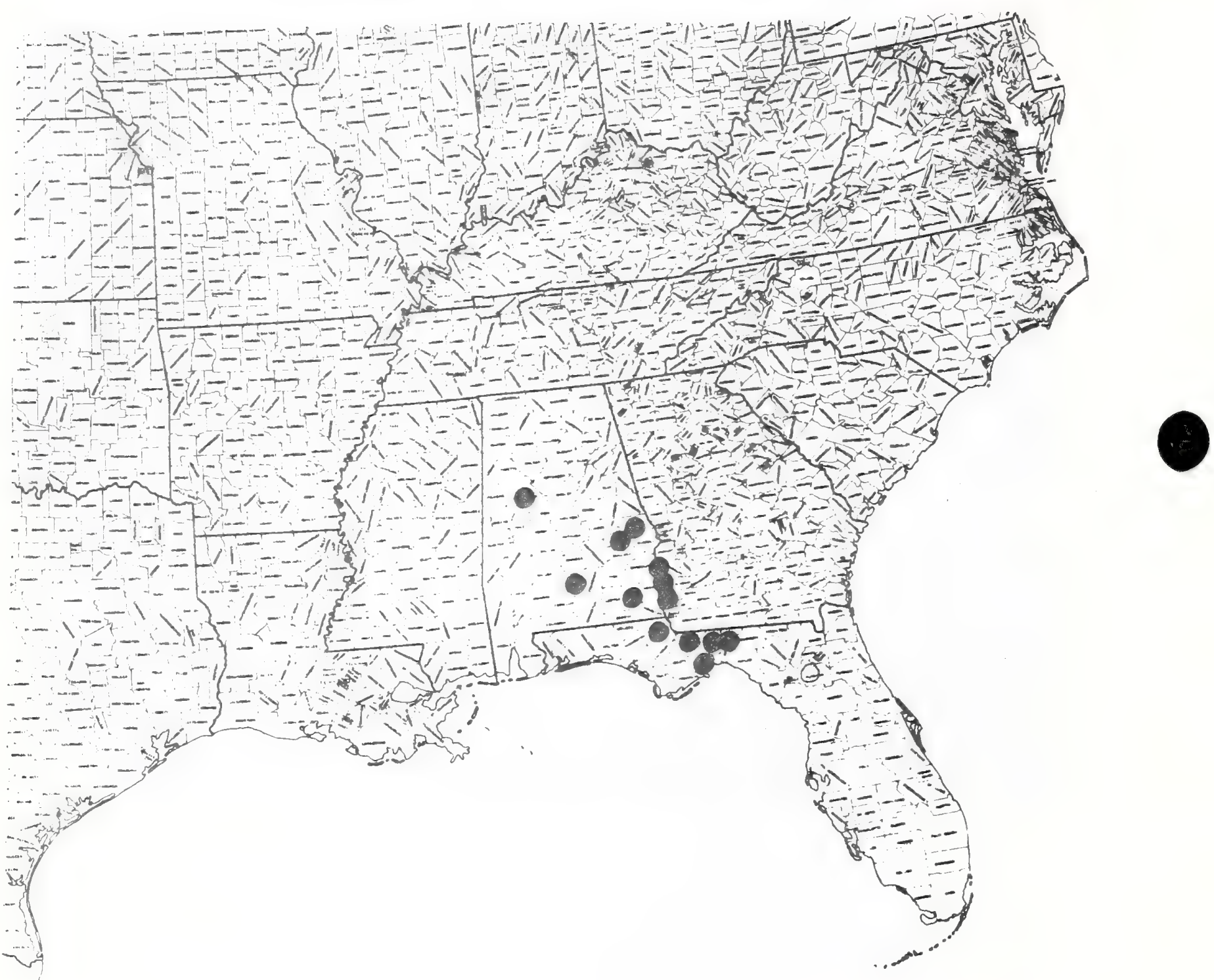
Peper 105

Text \& ma: by:

Robert Erad

\section{ASTERACDAE}

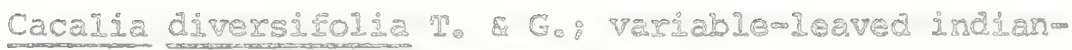

plantain: Indian-Plentain

Mesaderia diversisolia (T. \& Go) Greare

Technical Description

Smooth perennial herbs with thickened roots from a short-thickened erect caudex.

Stems, - - Usually single, sinole (unbanched) below the inflorescence, stiffly

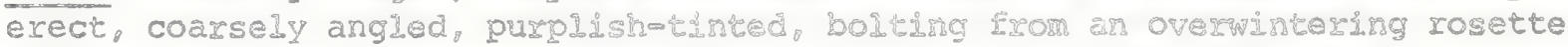
of long-petiolate, ovate, coargely toothed or shallowly lobed leaves. Ieaves.--Several toward the stem base, scatrered upward alterm nate, the lowest largest, longmetiolate, the upper short petiolate or nearly sessile, the largest blades $10-15 \mathrm{~cm}$ long, ovate, acure, the margins from sinuate and distantly dentate to shallowly triangulariy lobed. the bases abruptly attenuated to the wirged petiole. Rosette leaves similar. Inflorescence. - A many headed Elattishmtopped or concave cyme the branches of which arch upward from the upper stem nodes. Heads narrowly bell whaped or cylindric, the bracts in 1 series, Iirear with a winged midrib, yellowish or greenish-white.

Flowers.m.corollas all discoid, the corolla lobes linear, pale or bright lavender.

Fruits,-akenes Eusiform, $45 \mathrm{~m}$ m Long, dark brown, inconspicuously ribbed and somewhat flattened, the pappus of fine white bristles about as long as the akene body.

Distribution and Floworing season

Banks of streams through low hardwood hamnocks, Prom southeastern Rlabama and southwesterm Georgia southward through west Florida 1 rto northwestem peninsular Florida. Flowering from late May through June. August.

Habitats and Management Implication

This Cacalia is always on sandyesilt or mek in river bottor woodlands. It particularly abounds where there are natural or artdriclal clearings in such woods, there foming almost pure stands, its large cymes of whitish heads making a conspicuous sight. conmon associated species of herbs are Juncus spp. Sagittaria spp. Scippus cyperinus. S. divaricatus. Peltardra virginica. In the overstory are Betula nigra Nyssa aquatica No biflora Erasinus caroliniana, various oaks, particulariy o lypata, Q. michausis various willow oaks, Carya aquacica Loquidambar and occasional Taxodiun. It is usually in bottoms that overile massive limestone.

Selective logging of the botcoms frequented by this species would IIkely favor its increase through creation or smali oponings that would admit the partial light it needs. Heavy logging of the same areas would likely increase other herbaceous or shrubby vegetation to competitive disadvantage. Also, while this species is in bottoms, it is not favored in situations where water 
covers the ground through the entire season. Heavy logging of such bottoms often results in a rising of the water table and subsequent flooding out of some bottomland species such as this.

References

Small, J. K. 1933. Manual of the Southeastern Flora, pp. 1475-1476.

Kral, R. and R. K. Godfrey. 1958. Synopsis of the Florida species of Cacalia (Compositae). Quart. Journ. Fla. Acad. Sci. 21 (3): 193-206. 
SPECIES: \#105 Cacalia diversifolic I. \& G. Indian-Plantain

\begin{tabular}{|c|c|c|c|c|c|c|c|c|}
\hline & \multicolumn{8}{|c|}{ Management Practices } \\
\hline $\begin{array}{l}\text { Expected* } \\
\text { Effect on } \\
\text { the Species }\end{array}$ & $\begin{array}{c}\text { Prescribe } \\
\text { Burn }\end{array}$ & $\begin{array}{l}\text { Bulldoze } \\
\text { or } \\
\text { Root Rake } \\
\end{array}$ & Bed & Chop & $\begin{array}{l}\text { Thin } \\
\text { over- } \\
\text { story }\end{array}$ & $\begin{array}{l}\text { Cut } \\
\text { Over- } \\
\text { story }\end{array}$ & $\begin{array}{l}\text { Establish } \\
\text { Plantation }\end{array}$ & Graze \\
\hline Destroy & & $\mathrm{X}$ & $x$ & $X$ & & $\mathrm{X}$ & & \\
\hline \multicolumn{9}{|l|}{ Damage } \\
\hline $\begin{array}{l}\text { No Lasting } \\
\text { Effect }\end{array}$ & $\mathrm{NA}$ & & & & & & & \\
\hline $\begin{array}{l}\text { Beneficial } \\
\text { if Done } \\
\text { Properly }\end{array}$ & & & & & $\mathrm{X}$ & & & \\
\hline
\end{tabular}

\section{Other Cowments:}

*Expected effect on the species is an estimate made by Dr. Robert Kral based or his knowledge of the habitat and on knowledge gained from personal field observations. Estinates are "rough" in many instances. Results of practices may be modified depending upon the degree of application, intensity of treatment, neamess to plant comunities, etc. A management practice for which no entry is made indicates a lack of sufficient information from which to predict expected results. As observations are made in the field by users of the data, the expected effect will be refined. 
Cacalia diversifolia T. \& G.

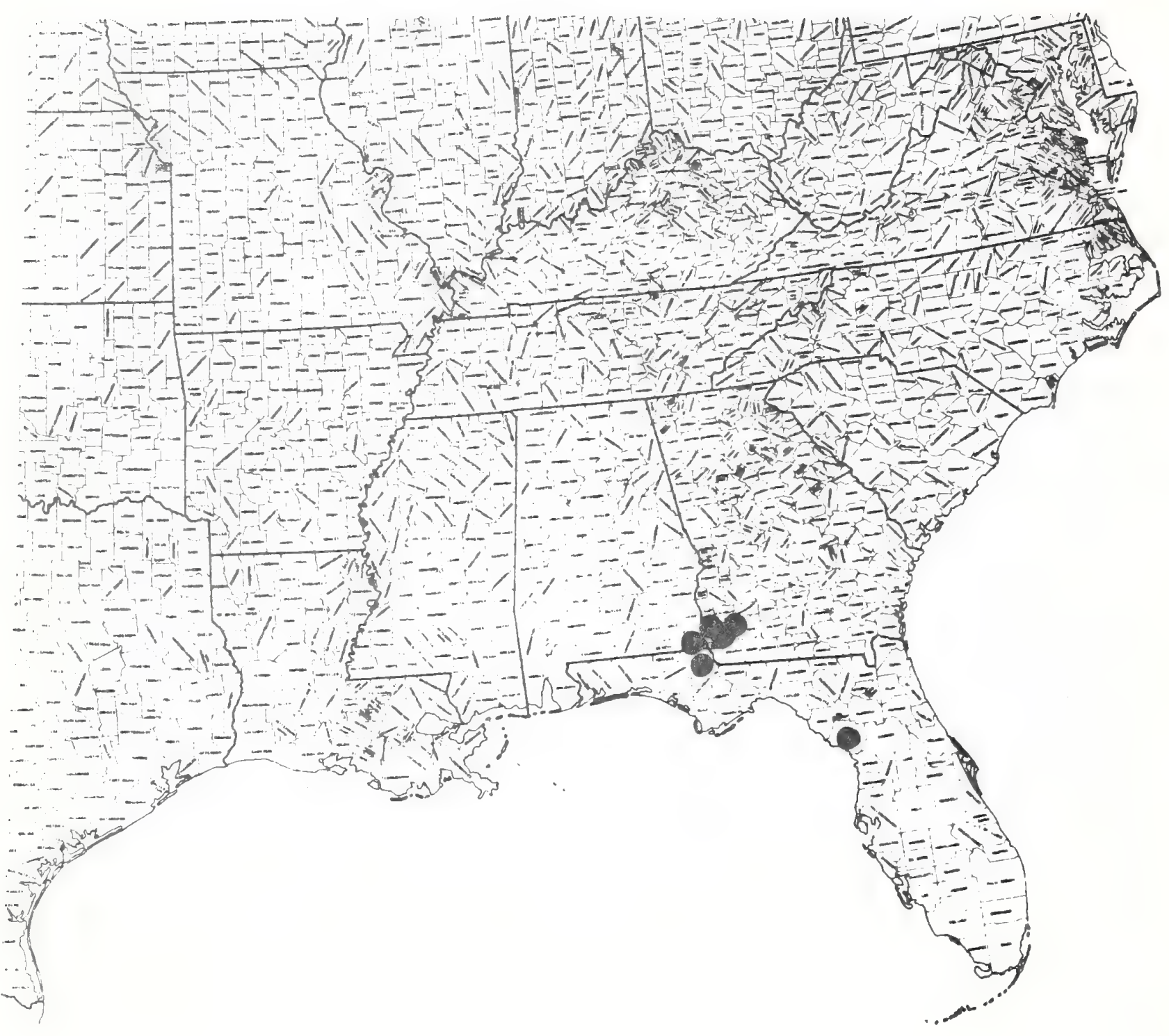




\section{RNPONRCEAE}

Deeringothamnus pulchelivs Sma1.: SIimperal pawpaw: N.C.N. Asimina pulchella (Simal) Rehder \& Dayton

\section{Technical Description}

Similar in root stock, stem, Iesf and fruit to Deeringotharnus rugeidi, differing only in its narrower petals which are more recurved and in its white to pale pink flower color. The odor of the flower is faint but very pleasant.

Distribution and Flowering season

Similarly rare, this shrub is found oniy toward the coast in southwestern peninsular Florida, mostly in Iee and Charlotte counties. It is probably most abundant on Big Pine Island near Fort Myers.

Habitats and Management Implication

It is always in open stands of slash pine with the moody understory being mostly saw palmetto, together with some Iyoria, Asimina, grows oak, etc. As is the case with D. rugellit this is a plant of high hydroperiod sandy soils and its response to logging and site preparation methods is the same.

Rererences

Kral, R. 1960. A revision of Asimina and Deeringothamnus (Annonacoae) Brittonia $12(4): 233-278$

Rehder, A. and W. Dayton, 1944, A new combination irs Asimina. Joum, Arn. Artb. 25: 84.

Smali.J.D. 1924. Planc novelities from Florida, Bull. Torr. Bot。 Club 51: 390. p. 369.

- 1926. Deerirgothamnus pulche1dus. Addisonia 11: 33-34,

- 1933. Manual of the southeastern flora, Pp. 531-432. Chapel Hill. 
SPECIES: \#109 Deeringotharmus pulchellus Small. N.C.N.

\begin{tabular}{|c|c|c|c|c|c|c|c|c|}
\hline & \multicolumn{8}{|c|}{ Management Practices } \\
\hline $\begin{array}{l}\text { Expected* } \\
\text { Effect on } \\
\text { the Species }\end{array}$ & $\begin{array}{c}\text { Prescribe } \\
\text { Burn }\end{array}$ & $\begin{array}{c}\text { Bulldoze } \\
\text { or } \\
\text { Root Rake }\end{array}$ & Bed & Chop & $\begin{array}{l}\text { Thin } \\
\text { over- } \\
\text { story }\end{array}$ & $\begin{array}{l}\text { Cut } \\
\text { Over- } \\
\text { story }\end{array}$ & $\begin{array}{l}\text { Establish } \\
\text { Plantation }\end{array}$ & Graze \\
\hline Destroy & & & & & & & $\mathrm{X}$ & \\
\hline Damage & & & & & & & & \\
\hline $\begin{array}{l}\text { No Lasting } \\
\text { Effect }\end{array}$ & & $\mathrm{X}$ & $x$ & $Y$ & & & & $\mathrm{X}$ \\
\hline $\begin{array}{l}\text { Beneficial } \\
\text { if Done } \\
\text { Properly }\end{array}$ & $x$ & & & & $x$ & $\mathrm{X}$ & & \\
\hline
\end{tabular}

\section{Other Comments:}

*Expected effect on the species is an estimate made by Dr. Robert Kral based on his knowledge of the habitat and on knowledge gained from personal field observations. Estimates are "rough" in many instances. Results of practices may be modified depending upon the degree of application, intensity of treatment, nearness to plant communities, etc. A management practice for which no entry is made indicates a lack of sufficient information from which to predict expected results. As observations are made in the field by users of the data, the expected effect will be refined. 
Deeringothamnus pulchellus small

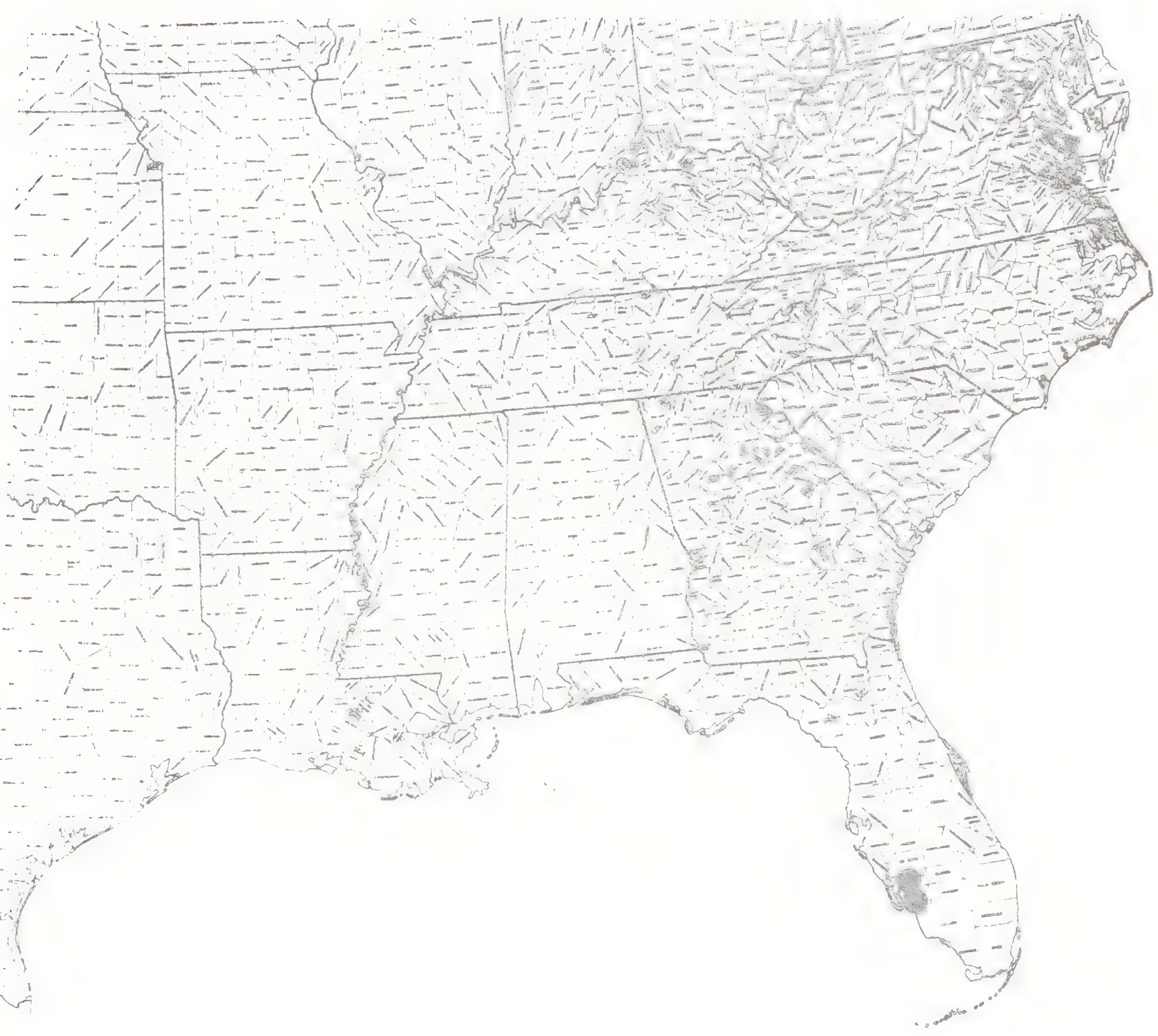


0

0

0 
Eaver 230

trose \& mas bys

robert Res

RNDONACERS

\author{
Deeringothamnes rugelid (Robins, is Srail. Rugel's \\ pawpaw: N.C.N.

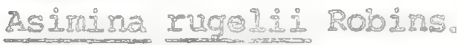

Technical Description

A low, sparingly branched, pungentraneling shruis, rarely to 0.5 meters tall, from a stout taproot.

Stems,--shoots slender, pale brom, smoothish, arching or erect, seldom branchea.

Ieaves. - Altemate, erect, leathery but declduous, to $7 \mathrm{~cm}$ Iong but mostly

around $4 \mathrm{~cm}$, mostly oblong, blunt, entire and sigglity dincolied, on very

short stalks, smooth, dark greer above, paler asd raisednetwieined beneath. Inflorescence. - Flowers solitary in lear asils, sproadirg or nodding on slender stalks.

Flowers.--Sepals 3, oblong, about $1 / 2 \mathrm{~cm}$ long, green. petals 6 , nearly equal, narrowly oblong, abovt $1.5 \mathrm{crn}$ lorg, canary yellow. Stamens many, in flat-topped cluster shorter than the petals. Carpels spindile-shaped several, rifening into usually 5 , peanut shaped berries.

Fruit.--Berries smootrs and yellowmgeen wher xipe and botween 3 and 6 cm long. seeds about the stze and shape of brown beans.

Distribution and Flowering Season

This rare shrub occurs naturally only in nottheastern peninsular Florida (Volusia, Seminole, Cos,). It bloom extaticaliz from April throughour the growing season.

Mabitats and Managenent Implications

D. rugelii is always found in slash pine-san palmetio ilatwoods on deep. Fine-textured, poorly drained sands or sandy peats. Comonly its shrubby associates are Befaria, Iyonia Eerruginea. Io Iucida. Vaccirium and Iex of the gallberry group. wiregrass. Banjcgrass and Andropogon together with several sedges, Eriocauls and syrids are common heriaceous associates.

It is mosty found in the serni-shade of slash pine woodlands, frequently in areas where logging of this plant is extensive, and Its increase riay be favored where natural regeneration is allowed. Cleas cutting, if the natural understory is not disturbed, would not erfect it. Ground fires tend to increase it, the plants actulily losing ground duxing lorg pexiods of no fire and being stimulated to produce vigorous flowering shoots from their large storage roots by fire. Any site preparation method that would involve shearing at the ground level would tend to increase it, havirg an effect similar to fire in reducing competition. Discing has been demonstrated to increase this sort of species in that new shoots can arise adventitiously from the cut roots, but deep plowing or mounding or the bulldozing of all 
vegetation into windrows would eliminate the species. Drainage would ultimately remove it, as it is high hydroperiod dependent. Grazing has little effect, in that cattle find this shrub unpalatable.

In nature this species is fire dependent, thus any sort of management that would exclude fire would at the same time encourage the competitive shrub and hexbaceous vegetation to take over.

References

Gray, A. and S. Watson. 1895 Asimina in Synoptical Flora of North America, Vol. I, Pt. $\overline{1, p .64}$.

Kral, R. 1960 A revision of Asimina and Deeringothamnus (Annonaceae). Brittonia 12 (4) 233-278

Robinson, B.I. 1897. Suppl. Syn. Flora of North America, Vol. I, pt. 1, p. 465

Small, J.K. 1930. Deeringothamnus rugelii. Addisonia 15: 17-18; pl. 
SPECIES: \#110 Deeringotharmus rugelii (Robins.) Small IJ.C.N.

\begin{tabular}{|c|c|c|c|c|c|c|c|c|}
\hline \multicolumn{9}{|c|}{ Management Practices } \\
\hline $\begin{array}{l}\text { Expected* } \\
\text { Effect on } \\
\text { the Species }\end{array}$ & $\begin{array}{c}\text { Prescribe } \\
\text { Bum }\end{array}$ & $\begin{array}{l}\text { Bulldoze } \\
\text { or } \\
\text { Root Rake } \\
\end{array}$ & Bed & Chop & $\begin{array}{l}\text { Thin } \\
\text { over- } \\
\text { story }\end{array}$ & $\begin{array}{l}\text { Cut } \\
\text { Over- } \\
\text { story }\end{array}$ & $\begin{array}{l}\text { Establish } \\
\text { Plantation }\end{array}$ & Graze \\
\hline Destroy & & & & & & & $x$ & \\
\hline \multicolumn{9}{|l|}{ Damage } \\
\hline $\begin{array}{l}\text { No Lasting } \\
\text { Effect }\end{array}$ & & $\mathrm{X}$ & $\mathrm{X}$ & $x$ & & & & $\mathrm{X}$ \\
\hline $\begin{array}{l}\text { Beneficial } \\
\text { If Done } \\
\text { Properly }\end{array}$ & $\mathrm{X}$ & & & & X & $\mathrm{X}$ & & \\
\hline
\end{tabular}

\section{Other Comments:}

*Expected effect on the species is an estimate made by Dr. Robert Kral based on his knowledge of the habitat and on knowledge gained from personal field observations. Estimates are "rough" in many instances. Results of practices may be modified depending upon the degree of application, intensity of treatment, neamess to plant comunities, etc. A management practice for which no entry is made indicates a lack of sufficient information from which to predict expected results. As observations are made in the field by users of che data, the expected effect will be refined. 
Deeringothamnus rugelii (Robins.) Small
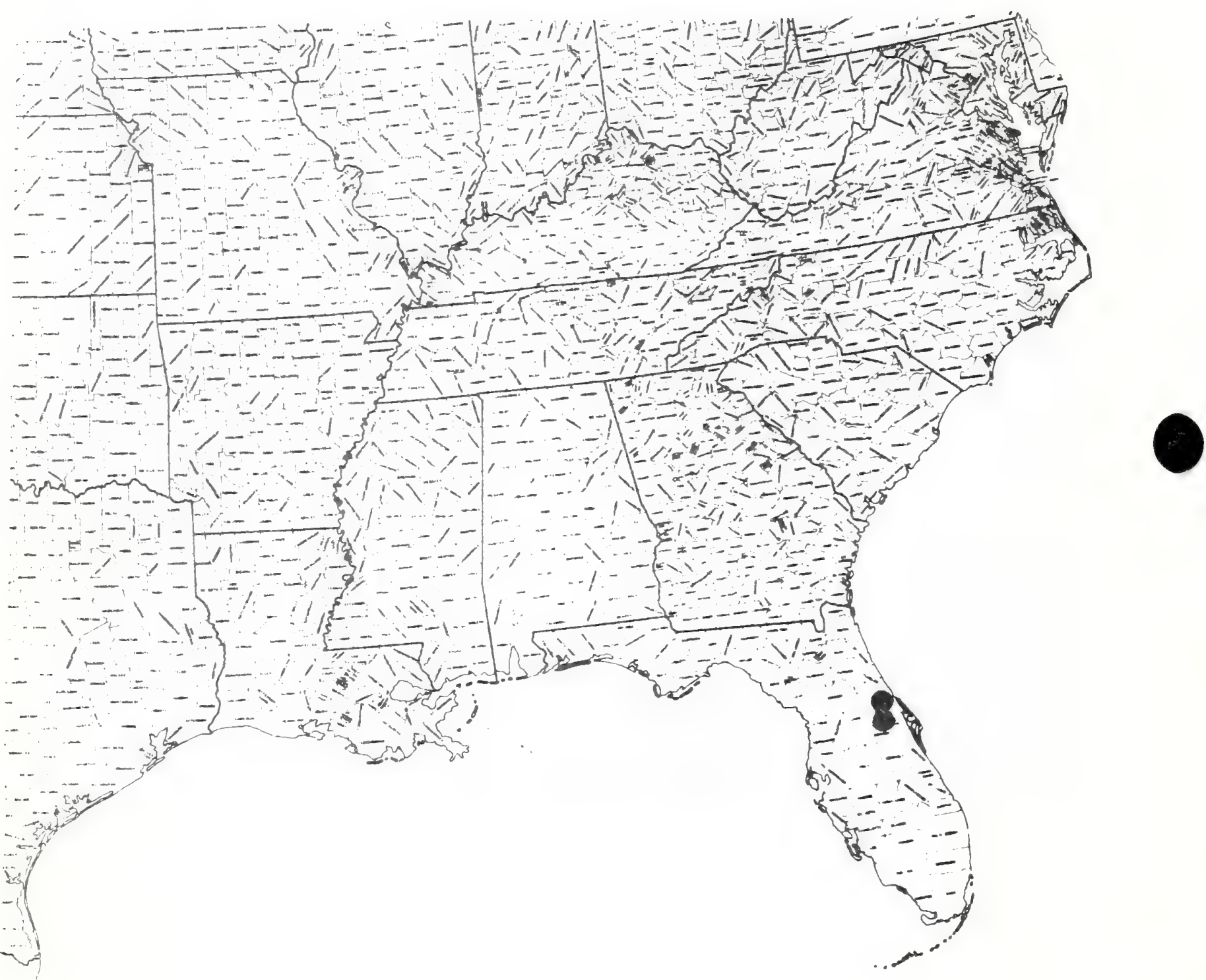
Paper 131

Text map by:

Robasc RYad

\section{BPIACEAE}

Exyngium cuneifolium Small. Wedge-leaved button snake roots: eryngos or button-srake roots

Technical Description

An exect smoothish perennial herb to $1 / 2$ meter tali, the foliage aromatic. froin a woody, elongate, stoutish rootstock.

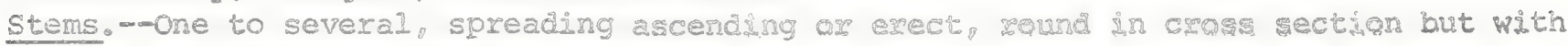
several distinct longitudinal ribs.

Ieaves,--Basal leaves in strong turts, long-stalked, the blades wedgemapha,

ca. $4 \mathrm{~cm}$ long, divided above into $3=5$ aplcal, thick-margined, bristle-tipped

teeth. Stem leaves numerous, spreading-ascending, also with bristle-tipped teeth, gradually lessening in sire to the flower clusters.

Inflorescence.-Flowers in bristlyo Looking heads, these mostly greenish

white, later tinged with pale blue, each head about $0.701 .0 \mathrm{crr}$ broad, on a stalk about as long or longer, in open, cywose clusters, and each with an involucre of spreading, usually 3-segmented, bristle-tipped bracts, these spreading and thus involucre broader thas heads, greenish, or greenish-white. Surface of receptacle or head elevated, flowers many, each with a 3usegmented, greenish white, sharp-tipped bract.

Elowers, -sepals 5, linear, about $2 \mathrm{~mm}$ long, exect, thichmargined, gharptipped, pale blue with tints of green and white: getals 5 . acact, narow.

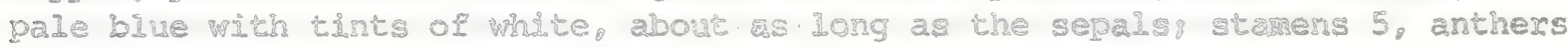
yellowighwhite: ovary inferior, with a pebily or wery surface, broally obovate or round, about $1.5 \mathrm{~mm}$ long iss reuit.

Distriobution and Flowering Season

This species occurs naturaliy in the few counties of the southern central. righlands of perinsular Forida in what ds called the lase region. It is locally abundant on the deep. finewtertured white sands of the scrub-forested sandhilis of that region, and blooms from July to January.

Habitats and Management Implications

The area is largely eorested with sandwine and evergreen scrub oak, mixed with shrubby members of the holly family, the heach family (particularly Lyonia), and palmetto species, various Polygonella. In areas where the scrub and overstory pine is cut away, such species as this Exyrgium will spread. They also increase after heavy buxns have cut the overstory and understory competition. probably because of the durable, large, subterranean rootstocks. Reproduction by seed is heavy. Mechanical disturbance of the sort brought about by heavy logging, ever scrapirg away of surface shrubby vegetation, provides sandy clearings that promote such species. Meavy development of overstory pire tends to reduce lto:

The greatest hazard the species probably faces at present is land development for housing. The plant itsels is not high priority grazing, its major Qanage Erom cattie would be irom tramping. 
References

Small, J.K. 1933. Manual of the Southeastern Flora: p 964, Chapel Hill.N.C. Mathias, Mildred E. and Constance, L. 1941. American Midland Naturalist 25: pp. $361-387$. 
SPECIES: \#III Ergngium cuneifolium Small. Frrngos or button-snake roots

\begin{tabular}{|c|c|c|c|c|c|c|c|c|}
\hline \multicolumn{9}{|c|}{ Management Practices } \\
\hline $\begin{array}{l}\text { Expected* } \\
\text { Effect on } \\
\text { the Species }\end{array}$ & $\begin{array}{c}\text { Prescribe } \\
\text { Bum }\end{array}$ & $\begin{array}{c}\text { Bulldoze } \\
\text { or } \\
\text { Root Rake }\end{array}$ & Bed & Chop & $\begin{array}{l}\text { Thin } \\
\text { over- } \\
\text { story }\end{array}$ & $\begin{array}{l}\text { Cut } \\
\text { Over- } \\
\text { story }\end{array}$ & $\begin{array}{l}\text { Establish } \\
\text { Plantation }\end{array}$ & Graze \\
\hline Destroy & & & & $x$ & & & $\mathrm{x}$ & \\
\hline Damage & & $x$ & NIA & & & & & \\
\hline $\begin{array}{l}\text { No Lasting } \\
\text { Effect }\end{array}$ & & & & & & & & $?$ \\
\hline $\begin{array}{l}\text { Beneflc1al } \\
\text { if Done } \\
\text { Properly }\end{array}$ & (NA) $Z$ & & & & $X$ & 3 & & \\
\hline
\end{tabular}

\section{Other Comments:}

* Expected effect on the species is an estimate made by Dr. Robert Kral based on his knowledge of the habltat and on knowledge gained from personal field observations. Estimares are "rough" in many instances. Results of practices may be modified depending upon the degree of application, intensity of treatment, neamess to plant commuties, etc. A management practice for which no entry is made indicates a lack of sufficient information from which to predict expected results. As observations are made in the field by users of the data, the expected effect will be refined. 
Eryngium cuneifolium Small

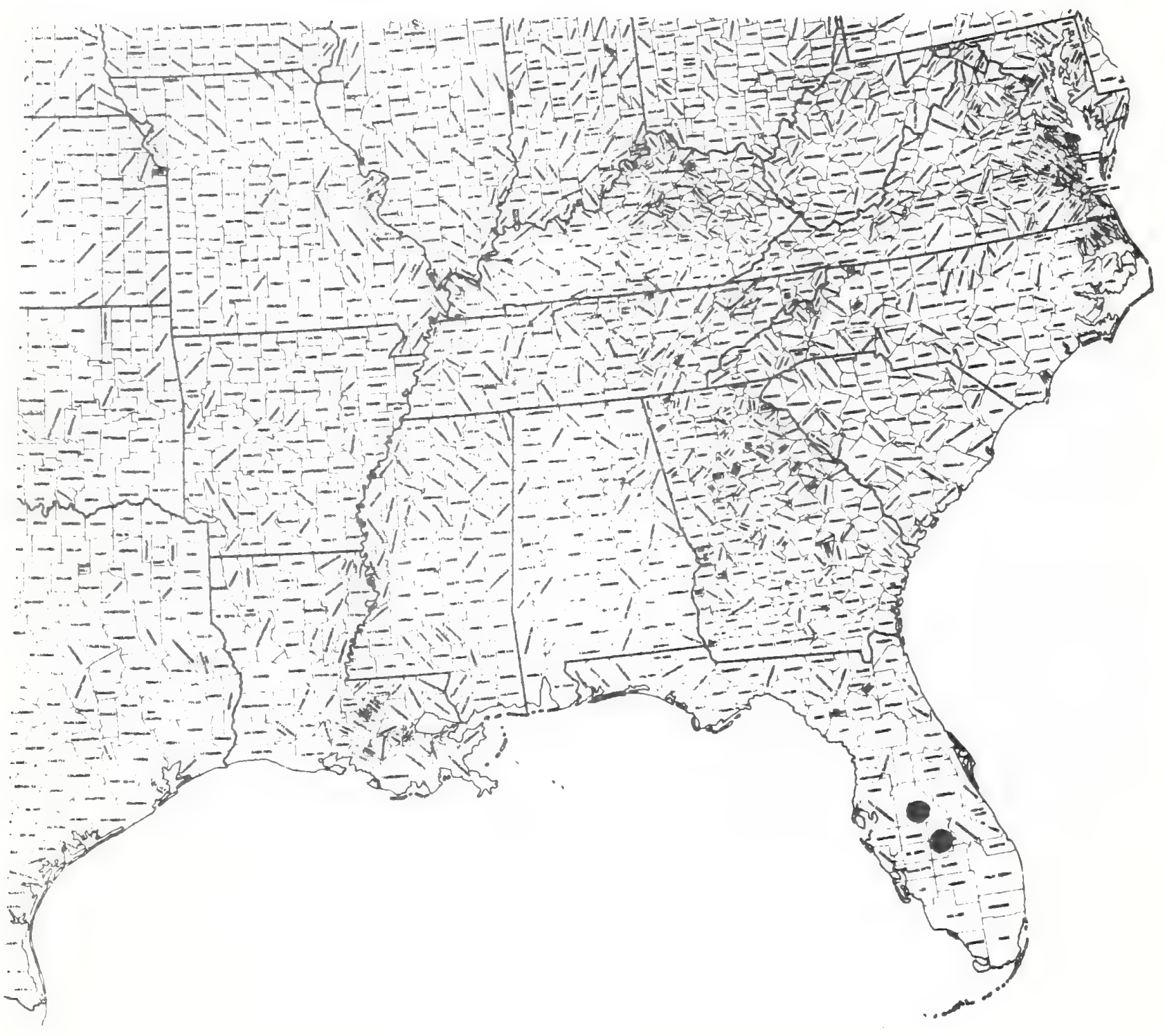


SPECIES: \#III Eryngium cuneifolium Small. Eryngos or button-snake roots

\begin{tabular}{|c|c|c|c|c|c|c|c|c|}
\hline & \multicolumn{8}{|c|}{ Management Practicas } \\
\hline $\begin{array}{l}\text { Expected* } \\
\text { Effect on } \\
\text { the Species }\end{array}$ & $\begin{array}{c}\text { Prescribe } \\
\text { Burn }\end{array}$ & $\begin{array}{c}\text { Bulldoze } \\
\text { or } \\
\text { Root Rake }\end{array}$ & Bed & Chop & $\begin{array}{l}\text { Thin } \\
\text { over- } \\
\text { story }\end{array}$ & $\begin{array}{l}\text { Cut } \\
\text { Over- } \\
\text { story }\end{array}$ & $\begin{array}{l}\text { Establish } \\
\text { Plantation }\end{array}$ & Graze \\
\hline Destroy & & & & $x$ & & & $\mathrm{X}$ & \\
\hline Damage & & $x$ & NA & & & & & \\
\hline $\begin{array}{l}\text { No Lasting } \\
\text { Effect }\end{array}$ & & & & & & & & ? \\
\hline $\begin{array}{l}\text { Beneflclal } \\
\text { If Done } \\
\text { Properly }\end{array}$ & (NA) $x$ & & & & $X$ & $\therefore$ & & \\
\hline
\end{tabular}

\section{Other Comments:}

*Expected effect on the species is an estimate made by Dr. Robert Kral based on his knowledge of the habitat and on knowledge gained from personal field observations. Estimates are "rough" in many instances. Results of practices may be modified depending upon the degree of application, intensity of treatment, neamess to plant comunities, etc. A management practice for which no entry is made indicates a lack of sufficlent information from which to predict expected results. As observations are made in the field by users of the data, the expected effect will be refined. 
Eryngium cuneifolium Small

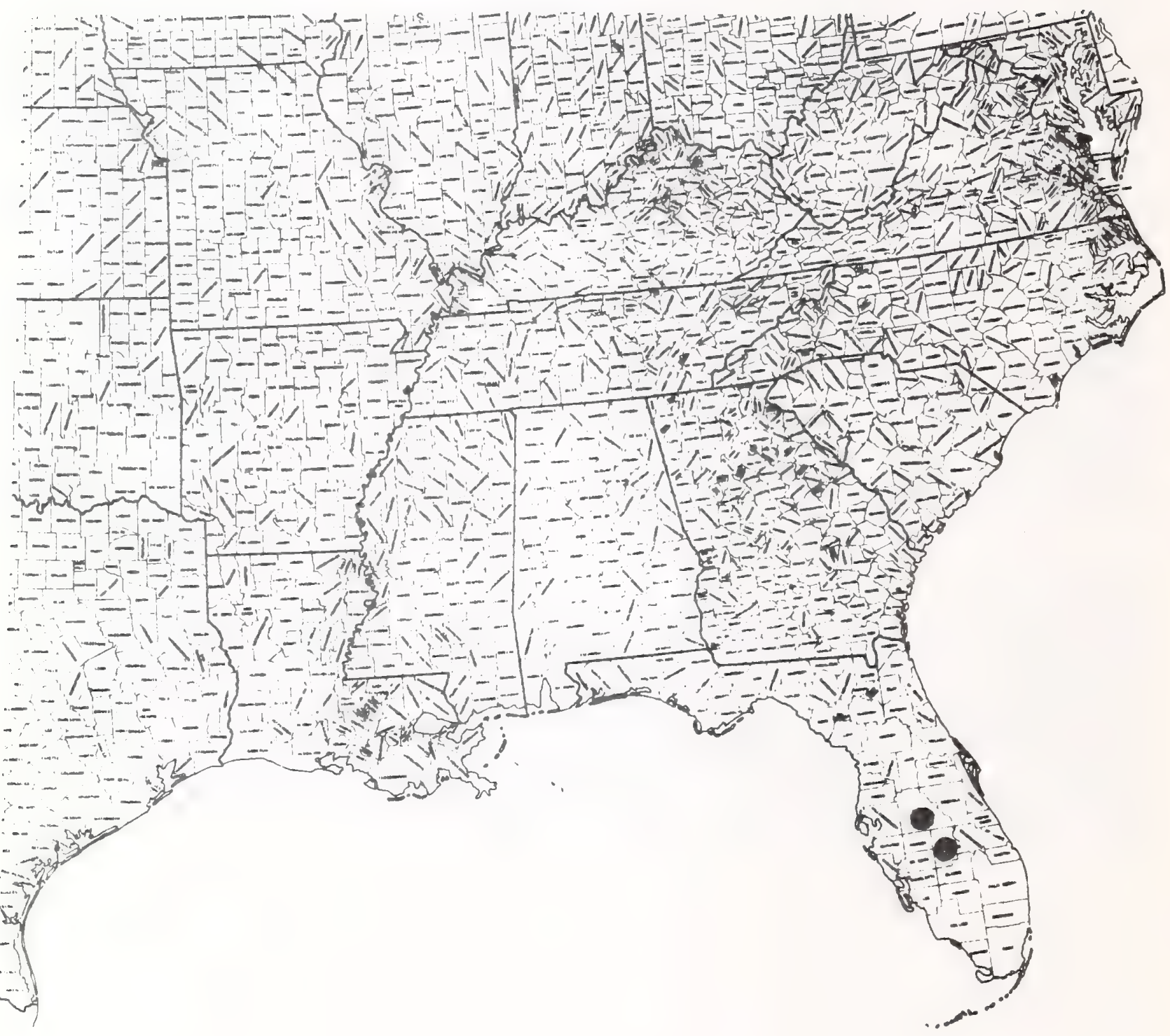




Paper $114^{\circ}$

Time \&

Robert incaI

\section{AQUTFOTIACEAE}

Ilex amelanchier M. Curtis. Service berry holly holly

Technical Description

Tall shrubs, mostly $2-3$ ( -4 ) meters tali, with few to several erect or ascending stems from the root.

Stems.-Whe bark tight, smooth, graymbrown. Twigs slender but stiffish, spreading or ascending, seldom foming spur-shoots, the bark of new shoots mostly gray-brown, at first with scattered pale puberulence, later that season smooth and with a scattering of pale lenticels.

Leaves.-Deciduous, alternate, estipulate, oblong, elliptic, ovate or narrowly obovate, mostly $4-10 \mathrm{~cm}$ long, acute, rounded or short-acuminate, the margins toward the base usually entire, toward the apex ascending-Iowtoothed, the bases mostly broady rounded cn slender, spreading, puberulent stalks to $1.2 \mathrm{~cm}$ long: upper surface smoothish, dark green: lower surface rather rugose, vilious-puberulent.

Inflorescence.--Flowers solitary or in small, shortwstalked, cymes, the slender puberulent pedicels to 1 cra long.

Flowers.-Female flowers with 405 tomentulose, triangular sepals and the same number of oblong, whitish petals ca. $3.5-4.0$ m long, in full bloom in April.

Fruit.-Maturing in september, rourd, fully $1 \mathrm{~cm}$ broad on stalks to 1.5 $\mathrm{cm}$ long, the skin a deep, opague red, the seods (merlcarps) with the outer face shargly few ridged.

\section{Distribution and Manageruent Impli.eation}

Banks of streams through pine rlatwoods, hardwood hamocks " titi swarus, and bogs, lower Coastal Plair, southeastern North Carolina southward to northem Elorida, thence west into the Florida parishes of Louisiana.

\section{Special Identifying Features}

This rare species has fruit of a size and color comparable to Ilex opaca, largish leaves comparable to those of I. montana on twigs similar to those of I. ambigua. Its staminate flowers arise Erom a common pedurcle (stalk) unilike those of related species.

Habitats and Management Inplication

Management of the low forest or savanna Io ame lancher rreguents if it involved selective logging of the hardwood astd pine overstory complex would probably effect this species very little. However, it is definitely a part of a high hydroperiod comples of woody plants. so that any scheme involving drainage would eliminate I. amelanohier along with its associates such as Myrica, Ilex myrtifoldi. Cyrilla, ClIftonia, Persea and Magnolia virginiana. 
References

Chapman, A.W. 1860. Flora of the southern U.S.: 270. Cambridge, Mass.

Small, J.D. 1933. Manual of the southeastern flora, pp. 813-815. Chapel Hill, N.C.
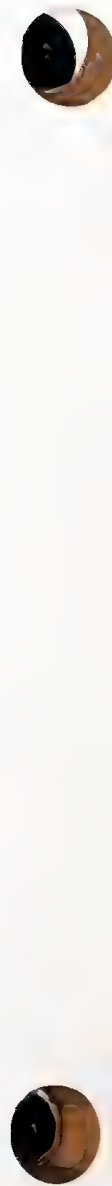
SPECIES: \#114 Ilex amelanchier M.A. Curtis Holly

\begin{tabular}{|c|c|c|c|c|c|c|c|c|}
\hline \multicolumn{9}{|c|}{ Management Practices } \\
\hline $\begin{array}{l}\text { Expected* } \\
\text { Effect on } \\
\text { the Spectes }\end{array}$ & $\begin{array}{c}\text { Prescribe } \\
\text { Burs }\end{array}$ & $\begin{array}{c}\text { Bulldoze } \\
\text { or } \\
\text { Root Rake }\end{array}$ & Bed & Chop & $\begin{array}{l}\text { Thin } \\
\text { over- } \\
\text { story }\end{array}$ & $\begin{array}{l}\text { Cut } \\
\text { Over- } \\
\text { story }\end{array}$ & $\begin{array}{l}\text { Establish } \\
\text { Plantation }\end{array}$ & Graze \\
\hline Destroy & & $\mathrm{X}$ & $\mathrm{x}$ & $x$ & & & & \\
\hline \multicolumn{9}{|l|}{ Damage } \\
\hline $\begin{array}{l}\text { No Lasting } \\
\text { Effect }\end{array}$ & $\mathrm{NA}$ & & & & & & & \\
\hline $\begin{array}{l}\text { Beneficial } \\
\text { If Done } \\
\text { Properiy }\end{array}$ & & & & & $x$ & & & \\
\hline
\end{tabular}

\section{Other Comments:}

*Expected effect on the species is an estlmate made by Dr. Robert Kral based on his knowledge of the habltat and on knowledge gained from personal field observations. Estimates are "rough" in many instances. Results of practices may be modified depending upon the degree of appiication, intensity of treatment, neamess to plant comunities, etc. E management practice for which no entry is made indicates a lack of sufficient information from which to predict expected results. As observations are made in the field by users of the data, the expected effect will be refined. 


\section{Ilex amelanchier M.A. Curtis}
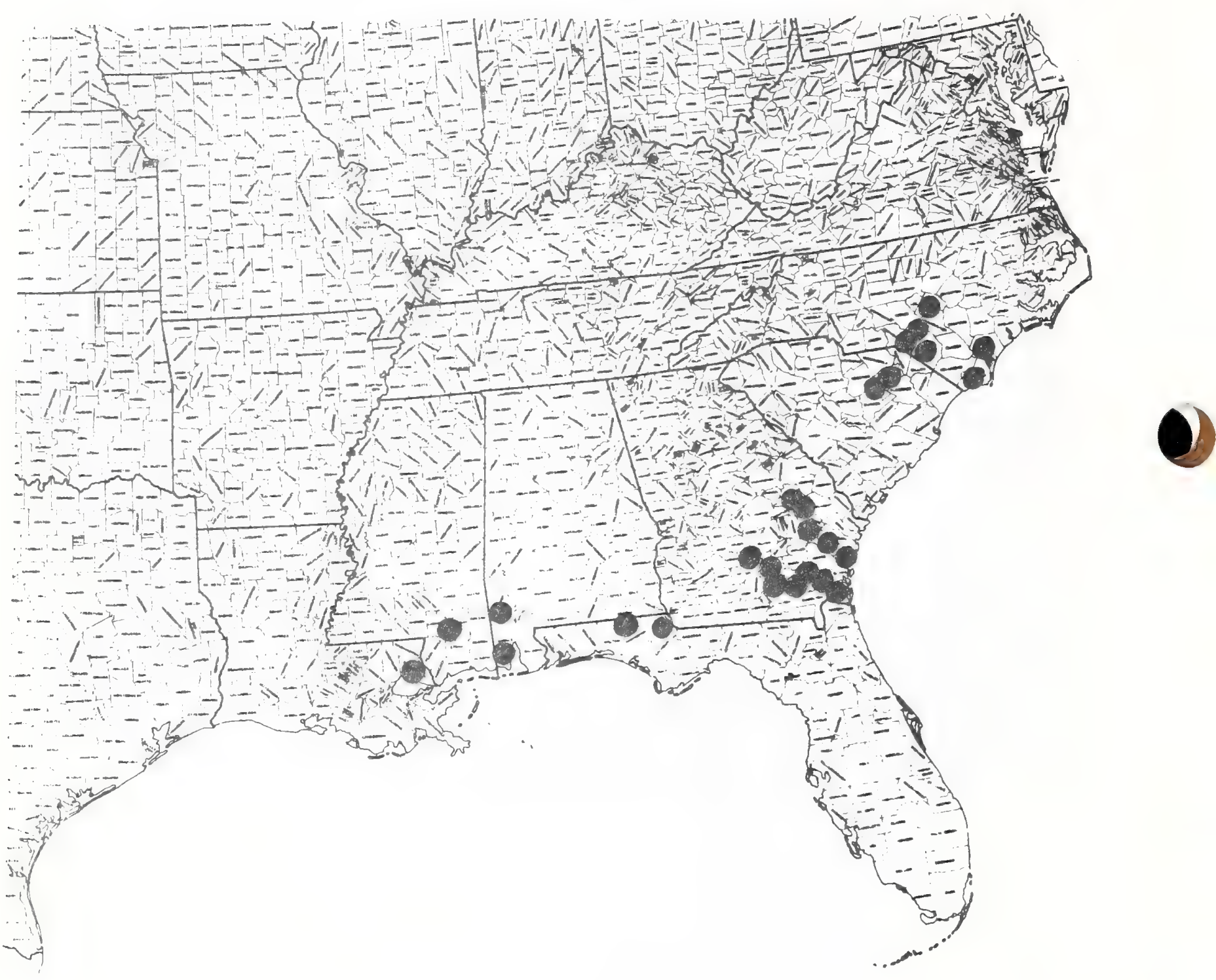
Iles opace Io var arenicola (Ashe) Kshe. Sandw loving American ho.lyg Holly

I. cumulicole Small

\section{Technical Description}

Shrub or small tree, rarely reaching 20 feet and a dob.ho of $8^{\circ 0}$. Stems, - The bark smooth, thin, tight, pale gray, the crom narrowish or broad, of usually ascending branches. TwIgs with older bark gray, that of newer shoots gray or reddish-brown, stoutish, stifi, somewiar angulate. Buds ovoid-triangular, about 3 4 m Iong, imbricate, the few scales redishbrown, gray-appressed-hairy.

Leaves.-Persistent, altemate, mostly ascending on short, stiffish, puberulent stalks, the blaces rarely longer than $0 \mathrm{~cm}$ long, oblong or obovate, rarely entire, more often with 304 pairs of strong, ascending spines above the middle, the margins strongly revolute the upper suriaces lustrous, yellowish-green, the lower surfaces paler, more yellowish. Inflorescence.--Trees unisexwal, the male flowers sma11, in smail clusters on wood of the previous year, the fernale similar but in smaller clusters (solitary or up to 3 ). Flowers.--Sepals of female flowers forming a 4-5 low-toothed cup, the margins entire of lowociliate. Fruit.mme largest of our hollies, on stout, puberulent stalks shorter than themselves, round, ofter ruldy $1 \mathrm{~cm}$ broad, a deep, opaque red when ripe, the nutlets (like hard segments of an orange) with backs having several low, rounded ridges.

\section{Special Identifing Features}

The var. arenicola is distinguished from var opaca mostly by the more yellowish tints of the foliage, by the more ascending, more revolute leaves, the spines of which are dirested forward, by the somewhat larger fruit, and by the less sharply ridged pyrenes (seeds, nutlets).

Distribution and Elowering Seasor

Ihis small tree, blooming in late spring and early sumer, is a component of the Sand Pinemevergreen scrub of the penjnsular Florida highlands, and was most abundant there in the southermost part of the highlands. Kurz and Godfrey (1962) indicate that it occurs occasionally in high sandy scrub in northeastern Florida, yet this may be a part of an extrene of I. opaca var. opaca. The same argument exists as to the northem Iirnts of Osmanthus megacarpa. Carya floridana and other scmb trees comprising species pairs with more wideranging sclerophylous species, The tasonomy is still not resolved. 
Habitats and Management Implication

I. opaca var. arenicola in the strict sense has had a range that coincides fairly closely with the hardiness zone for citrus. Therefore, much of its former area has been converted to row culture of citrus and more is being converted annually. This, and the continuing conversion of south Florida highlands to retirement estates and other housing, make up the greatest hazard to the specles. It was never abundant, never a stand former, but rather a minor element of the scrub. Its continuance is further risked by the dioecious character of the species, and the handsome follage and fruit which makes it subject to vandalism.

References

Sma11, J,K. 1929. Plant novelties for Florida. Bull. Torr Bot. Club 51: $\quad 379-393$.

Small, J.K. 1933. Manual of the Southeastern Florida Flora, p. 816. Chapel Hill, N.C. 
SPECIES: \#II5 Ilex opaca I. var. arenicola (Ashe) Ashe: Iiolly

\begin{tabular}{|c|c|c|c|c|c|c|c|c|}
\hline & \multicolumn{8}{|c|}{ Management Practices } \\
\hline $\begin{array}{l}\text { Expected* } \\
\text { Effect on } \\
\text { the Species }\end{array}$ & $\begin{array}{c}\text { Prescribe } \\
\text { Burr. }\end{array}$ & $\begin{array}{c}\text { Bulláoze } \\
\text { or } \\
\text { Root Rake }\end{array}$ & Bed & Chop & $\begin{array}{l}\text { Thin } \\
\text { over- } \\
\text { story }\end{array}$ & $\begin{array}{l}\text { Cut } \\
\text { Over- } \\
\text { story }\end{array}$ & $\begin{array}{l}\text { Establish } \\
\text { Plantation }\end{array}$ & Graze \\
\hline \multicolumn{9}{|l|}{ Destroy } \\
\hline Damage & & & & & & & $\mathrm{X}$ & \\
\hline $\begin{array}{l}\text { No Lasting } \\
\text { Effect }\end{array}$ & $\mathrm{NA}$ & & & $\rightarrow$ & & & & \\
\hline $\begin{array}{l}\text { Beneficial } \\
\text { if Done } \\
\text { Properly }\end{array}$ & & & & & $\mathrm{X}$ & $\mathrm{x}$ & & \\
\hline
\end{tabular}

\section{Other Comments:}

*Expected effect on the species is an estimate made by Dr. Robert Kral based on his knowledge of the habitat and on knowledge gained from personal field observations. Estimaces are "rough" in many instances. Results of practices may be modified depending upon the degree of application, intensity of treatment, nearness to plant comunlties, etc. A management practice for which no entry is made indicates a lack of sufficient information from which to predict expected results. As observations are made in the field by users of the data, the expected effect will be refined. 
Ilex opaca L. var. arenicola (Ashe) Ashe

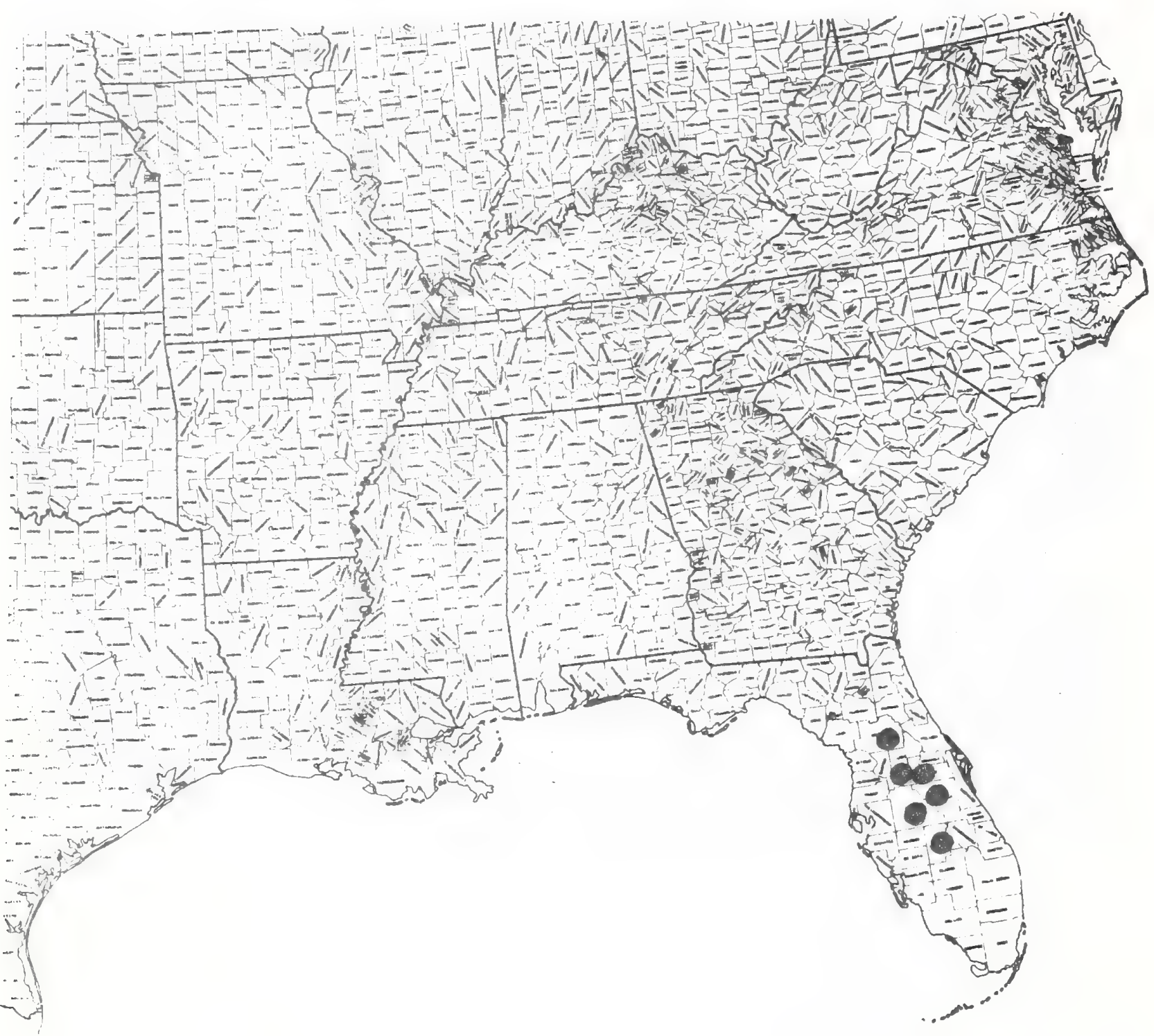


Paper 118

Text and map by:

Robert Kral

\section{ASTERACEAE}

Echinacea laeviqata (Boynt. \& Beadle) Blake. Cone-flower Brauneria laeviqata Boynt. \& Beadle in Small

Echinacea purpurea var. laeviqata (Boynt. \& Beadle) Cronq.

Technical Description

Tall glabrous perennials from stout, erect, simple or branched rhi zomes.

Stems. - $U_{1}$ to 1.5 meters talI, rarely (then sparingly) branched, stiffly erect, terete or somewhat angled, below greenish-brown or purplish-tinted, above greenish or purplish.

Leaves.--Rosette leaves or offshoot leaves largest, long-petiolate, with lanceolate or narrowly ovace blades to $15 \mathrm{~cm}$ long, apices acute, margins entire or distantly low-loothed, the bases attenuate to petioles nearly as long as or longer than blades, these clasping-based. Lower stem leaves approximate, similar to rosette leaves, those of mid-stem and above increasingly smaller, shorter petioled, more distant, the upper part of the stem forming an elongate, naked peduncle. Inflorescence.--Heads short-conic, mostly $2.0-2.5 \mathrm{~cm}$ broad, usually solitary at peduncle tip, or occasionally stems producing $2-3$ additional, erect peduncles. Bracts of involucre several, greenish, the bases imbricated in several series, the acute tips spreading or recurved. Surface of receptacle conic, covered with abundant, erect, smooth, linear, sharp, purple-tipped chaff (pales), each pale keeled, partly enfolding the base of a flower, the whole head looking bristly. Flowers.--Ray flowers with rays mostly 6-7 cin long, lineal, pale purple, spreading downward. Disc flowers with corollas tubular, purple, about $5 \mathrm{~mm}$ long, the teeth mostly erect, short-triangular. Fruit.--Akenes oblong-prismatic, usually 4-angled, gray-brown, about 4-5 mm long, the pappus a low, thin crown of triangular teeth.

Distribution and Flowering season

Meadows, open woodlands, glades, usually over calcareous parent material, southwestern Virginia (Valley \& Ridge, Blue Ridge and Piedmont) southward to northeastern Georgia: reported from northeastern Alabama.

Special Identifying Features

Taxonomically this is closest to the common eastern purple coneflower E. purpurea, but is by comparison smooth, with longer and narrower ray corolias. The awn of the chaff is usually $1 / 4$ as 1 ong as the pale body, while that of $\underline{\underline{Z}}$. purpurea is longer, mostly $1 / 2$ as long as the pale body. E. purpurea also tends to be a more robust plant with somewhat larger heads and a less erect rootstock. 
This species forms small stands in open, grassy woodlands. My own experience with it has been in low-grade upland hardwoods such as mixed oak-hickory-juniper where it occupies small clearings. Selective removal of the trees would little alter the habitat and in fact would promote the development of gladeplants such as this. Burning (not recommended for this sort of forest) would probably not harm these plants in that they are cormophytes. Conversion to grazed woodlot would not favor the species in that it is taken by cattle or sheep, yet gastroenteritis is reported from the ingestion by cattle or sheep of Rudbeckia, a closely related genus. It is possible that the plants are lost from grazed habitat more because of mechanical damage to them by trampling. Woods fires favor the increase of this species.

\section{References}

McGregor, R. L. 1968. The taxonomy of the genus Echinacea (Compositae). Univ. Kansas Sci. Bull. XIVIII (4): 113-142.

Small, J. K 1933. Manual of the southeastern flora, pp. 1420-1421. Chapel Hill, N. C. 


\begin{tabular}{|c|c|c|c|c|c|c|c|c|}
\hline \multirow[b]{2}{*}{$\begin{array}{l}\text { Expected* } \\
\text { Effect on } \\
\text { the Species }\end{array}$} & \multicolumn{8}{|c|}{ Management Practices } \\
\hline & $\begin{array}{c}\text { Prescribe } \\
\text { Burn }\end{array}$ & $\begin{array}{l}\text { Bulldoze } \\
\text { or } \\
\text { Root Rake }\end{array}$ & Bed & Chop & $\begin{array}{l}\text { Thin } \\
\text { over- } \\
\text { story }\end{array}$ & $\begin{array}{l}\text { Cut } \\
\text { over- } \\
\text { story } \\
\end{array}$ & $\begin{array}{l}\text { Establish } \\
\text { Plantation }\end{array}$ & Graze \\
\hline Destroy & & & & & & & $x$ & \\
\hline Damage & & NA & NA & NA & & & & $x$ \\
\hline $\begin{array}{l}\text { No Lasting } \\
\text { Effect }\end{array}$ & & & & & & & & \\
\hline $\begin{array}{l}\text { Beneficial } \\
\text { if Done } \\
\text { Properly }\end{array}$ & $x$ & & & & $x$ & $x$ & & \\
\hline
\end{tabular}

Other Comments:

*Expected effect on the species is an estimate made by Dr. Robert Kral based on his knowledge of the habitat and on knowledge gained from personal field observations. Estimates are "rough" in many instances. Results of practices may be modified depending upon the degree of application, intensity of treatment, nearness to plant communities, etc. A management practice for which no entry is made indicates a lack of sufficient information from which to predict expected results. As observations are made in the field by users of the data, the expected effect will be refined. 
Echinacea laevigata (Boynt. \& Beadle) Blake

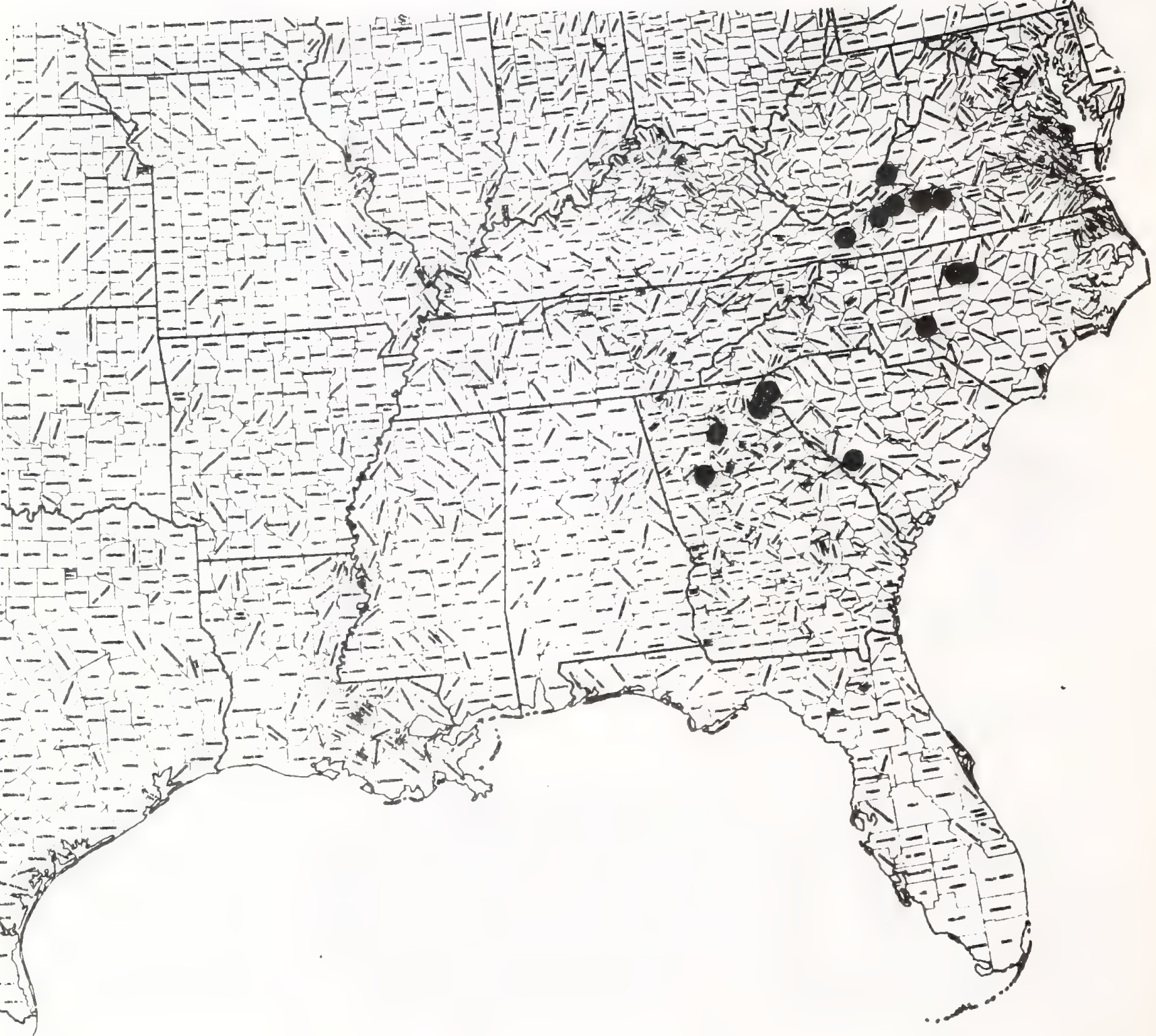




Raper 120

rext \& map by:

Robext Rrai

ASTERACEAE

HeIianthus camosus Small. Iake side sunflower: sunflowers

Technical Description

Perennial herb from a short caudex, the roots fleshy, increasing by short lateral offshoots, these foming overwintering rosettes. Stems.--One to few, to a meter long, erect or with bases slightly arching to the root, rouna in cross section or low ribbed, reddish brown. glabrous or with a few distant multiceliular hairs toward the tip. Leaves.--Rosette and lower leaves Iineai, mostiy elliptic-1inear, oblanceolate-linear, or spatulate, most $1 y$ $8-15 \mathrm{~cm}$ long, rarely more than 1.5 $\mathrm{cm}$ broad, obtuse to acute, scanetimes calluswtiped, the margirs entire, the base attenuate to a short petiole or sessile, the surfaces smooth, yellow green, and only the mid-rib evident, stem leaves ascending, scattered, the lowest opposite, progressively shortening and narrowing upward, sessile, the uppemost ones the most distant and the very upper decimeter or so of stem naked. Inflorescence.--lieads usually solitary or 2 at the stem tip, about $3 \mathrm{~cm}$ broad across the phyllaries, wp to $8 \mathrm{~cm}$ broad from ray thp to ray tip. Phyllaries firm, flat, but loosely imbrlcated, the longest about $1.5 \mathrm{~cm}$ or less, mostly narrowly ovate, oblong or lanceolate, with acurinate to spinulose tips, entire, glabrous, mostly sanerved. Receptacle slightly elevated, the charf strongly bowed at base, strongly nerved, acuminate, yellowish, smooth or minutely and distantly spreadingpuberulent.

Flowers.m.-Ray corollas spreading, bright yellow. Disc corolias a deeper, dull yellow, narrowly funnelform from a short, sometimes puberulent tube.

Fruit.- Akenes oblongmprismatic, somewhat narrowed proximally, about $4 \mathrm{~mm}$ long, somewhat compressed in a plane parallel to the head center, bearing $2-4$ narrow, chaffy deciduous scales but at maturity subtruncate, or with a pair of low thick teeth, smooth, gray-brown.

Distribution and Flowering Season

This species is restricted to northeastern Florida and flowers in late summer and fall.

Special Identifying Features

In size and generai aspect from a distance it resembles Helianthus heterophyllus Nutt. but that sunflower has a purplish brown disc and a scabrous stem and leaf.

Habitats and Management Implication

H. Carnosus is found in moist to wettish low pineland savannas, typically on black highly organic sandy peats and always in clearings. 
The comonest associate species are typical of bogs and low savannas, being mostly grasses, sedges, Lycopodium, Sarracenia, Xyris, Agalinis. In nature it is probably maintained by fire such as would eliminate or reduce overstory species such as slash pine, longleaf pine and gums, and shrub understory such as gallberry, palmetto, bay. Thus clearcutting would probably favor increase of this species; controlled burning certainly would favor it. So as well would any program that would reduce the shrub and palmetto layer and favor the increase of the grass-sedge conmunity this species is part of. However, the pinelands in which $\mathrm{H}$. carnosus grows are often being block cut, this followed by site preparation involving drainage which would eliminate all high hydroperiod soil grasses and forbs. I have seen the plants in slash pine plantings, again in areas where cleared areas are allowed to seed in with pine, but it does not seem to persist when the stand closes. I have observed it in pastured clearings and open pastured woodlands only where protected along fences.

References

Heiser, C. B. et al. 1969. The North American sunflowers (Helianthus). Mem. Torr. Bot. Club 22 (3): 1-218.

Small, J. K. 1902. A sea beach Helianthus from Florida. Torreya $2: 74$.

1933. Manual of the Southeastern Flora: p 1436. Chapel Hill, N.C. 
SPECIES: \#120 Helianthus Carnosus Small. Sunflowers

\begin{tabular}{|c|c|c|c|c|c|c|c|c|}
\hline & \multicolumn{8}{|c|}{ Management Practices } \\
\hline $\begin{array}{l}\text { Expected* } \\
\text { Effect on } \\
\text { the Species }\end{array}$ & $\begin{array}{c}\text { Prescribe } \\
\text { Burn }\end{array}$ & $\begin{array}{c}\text { Bulldoze } \\
\text { or } \\
\text { Root Rake }\end{array}$ & Bed & Chop & $\begin{array}{l}\text { Thin } \\
\text { over- } \\
\text { story }\end{array}$ & $\begin{array}{l}\text { Cut } \\
\text { Over- } \\
\text { story } \\
\end{array}$ & $\begin{array}{l}\text { Establish } \\
\text { Plantation }\end{array}$ & Graze \\
\hline Destroy & & $x$ & & $x$ & & & $X$ & \\
\hline Damage & & & $\mathrm{X}$ & & & & & \\
\hline $\begin{array}{l}\text { No Lasting } \\
\text { Effect }\end{array}$ & & & & & & & & \\
\hline $\begin{array}{l}\text { Beneflclal } \\
\text { 1f Done } \\
\text { Properly }\end{array}$ & $\mathrm{X}$ & & & & X & $\mathrm{X}$ & & \\
\hline
\end{tabular}

Other Coments: no not drain.

* Expected effect on the species is an estimate made by Dr. Robert Kral based on his knowledge of the habitat and on knowledge gained from personal field observations. Estimates are "rough" in many instances. Resuits of practices may be modified depending upon the degree of application, intensicy of treatment, neamess to plant comunities, etc. A ranagement practice for which no entry is made indicates a lack of sufficient information from which to predict expected results. As observations are made in the field by users of the data, the expected effect will be refined. 
Helianthus carnosus Small

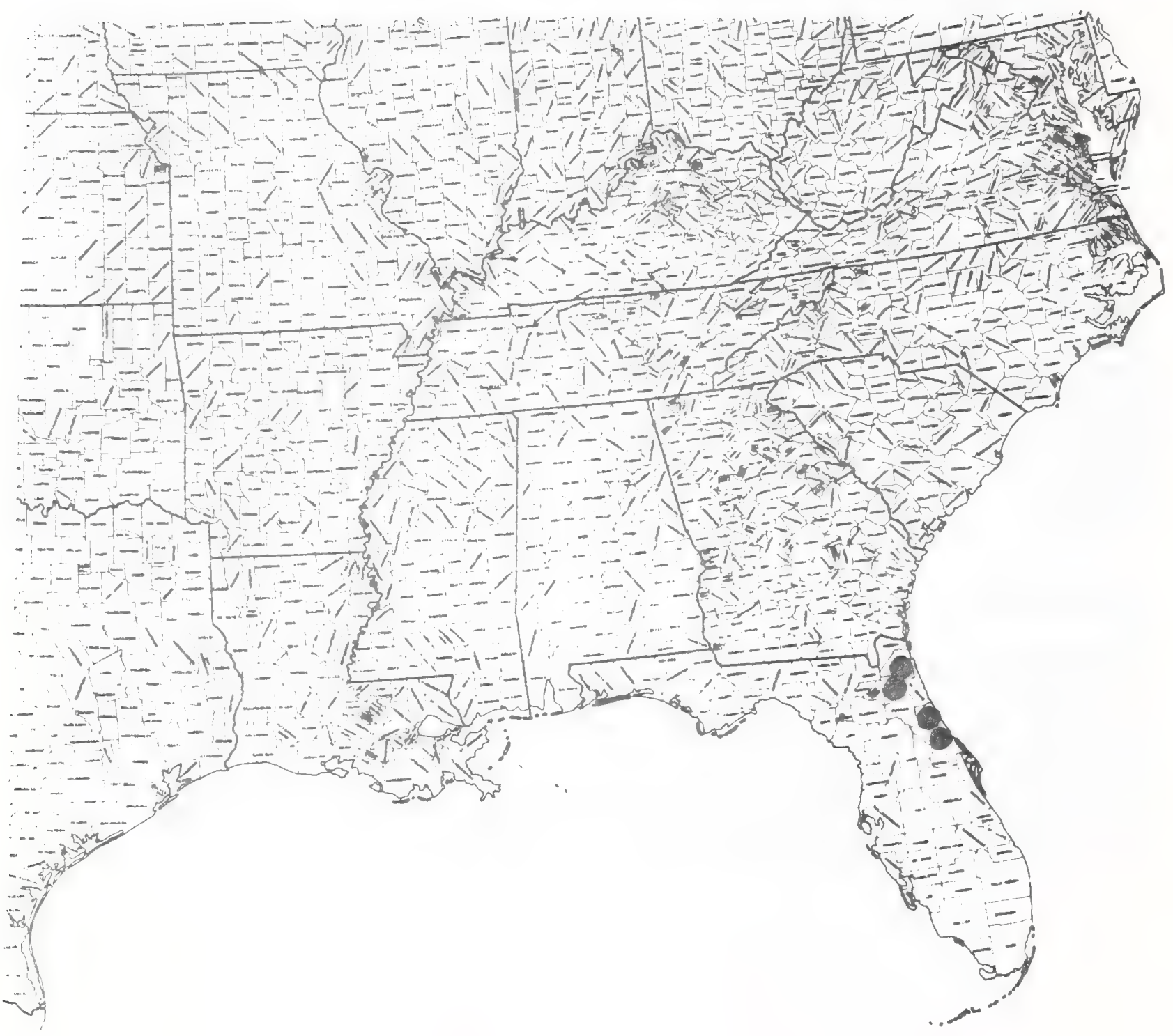

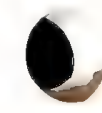




\title{
DROSERACERE
}

\author{
Dionaea muscioula Ellis. 3 Comon venus Elytrap: \\ Venus'-Flytrap
}

Technical Description

Perennial, smooth, forming rosettes mostiy $1.0-1.5$ din across from shallowly set "bulbs" made up of fleshy scale leaves, this bullb with a shallow diffuse root system。

Leaves.--Rosette leaves to $15 \mathrm{~cm}$ long, spreading in all directions from the contracted stem, numerous and spirally closewset: petioles green. mostly spatulate, Elattened, with broad clasping bases, abruptly narrowed above these, then broadening apically and with a short, very narrow constriction just below the blade: blades round when spread, or broader than long (thus reniform), $203 \mathrm{~cm}$ broad, the midrib acting as a hinge, the edges stirfly longmidiate, the surfaces green or strongly reditsh or maroon tinted particularly on the upper surface, which has a scattering of erect, very slender hairs (tactile hairs).

Inflorescence, - Flowers regular produced few or several in unbellike corymbs at summits of slender erect scapes to 3 dm long, the flower stalks elongating up to $2 \mathrm{~cm}$ subtended by elintical, narrowly ovate or lanceolate bracts. Flowers.-mSepals 5, lancemovate, 5-10 ming, long, greanish, with a scattering of minute simple or stellate, somewhat glandular hairs on backs and margins. petals 5 , distinct, cuneate-spatulate, spreading $1004 \mathrm{~mm}$ long, the tips rounded-marginate, the surface white strongly lined with green (sonewhat Iike 9 rass of Parnassus): stamens between 10 and 20 , usually around 15 , distinct, spreading, the filaments slender, 5-7 m long, the anthers 2-locular, neariy round: ovary superior, of 5 carpels, with 1 charber, the style slender, tufted-branched at its tip. Eruit. -mCapsule ovoid, to 4 m long, this irregularly splitting to reveal several black lustrous seeds.

Distribution and Flowering Season

Sphagnous bogs, shores, banks and seeps, Coastal plain, eastern North Carolina south to northeastern South Carolina. Flowering May, June.

Special Identifying Eeatures

This species, making up a genus, is unique, It is in the insectivorous family Droserceae and like the related genus Drosera uncoils its expanding leaves as in perns. Its leaf blades close, beartrap like, around insect "visitors" which produce a stimulus through contacting the slender tactile hairs on the upper leaf surface this communicated to motor cells along the hingelike midrib which 
quickly collapse; thus the halves of the blade fold rapidly together, the stiff fringe of cilia interlacing along the closed margins, 211 this often entrapping the insect. Enzymes are secreted from glands in the leaf, these breaking down the proteins, which are then assimilated.

Habitats and Management Implications

The Venus' Flytxap is a true bog plant, is usually in the full sun of bogs populated by other insectivorous plants, particularly Drosera and Sarracenia, together with a wealth of bog grasses, sedges, orchids and Iiliaceous species. The bases (bulbs) are shallowly set either in sphagnum or on highly organic black sandy peat wash. The species will not reproduce on substrates other than permanently moist ones, is not very tolerant of shade. Neither does it tolerate much competition in the way of other herbs, particularly taller herbs, grasses or sedges. Best situations for it are sunny "washes" or exposures of moist to wet sandy peat where it and sundews may form small mats of growth. It is commonest in openings in pocosins or in pineland savanna, the pine overstory being mainly longleaf and/orpond pine, the shrub layer being mainly gallberry, Lyonia, Andromeda, Kalmia, Magnolia, Myrica etc. Historically, area was probably maintained for it by periodic burning of the flatwoods and pocosins, thus removal of excess shade and other competing herbs and shrubs. Today, it frequently occupies areas where clearcutting or heavy logging has taken place so long as there are contiguous seed sources; it may also abound where there has been considerable soil disturbance either through site preparation or through road construction. However, it will not persist where pine plantations produce heavy shade nor will it survive the drainage that often accompanies site preparation. Some of the best places to look for it are along the road systems where seepage develops along the road shouldexs and ditchbanks, or where wet savanna has been recently burned.

This is one of the most exploited of southeastern plants, large populations being decimated or exterminated for the novelty plant trade. Thus the greatest threats to the species are exploitation, drainage for agriculture or pine plantation, and protection of wet habitat from fire.

References

Radford, A. E. et 21. 1968. Manual of the Vascular Flora of the Carolinas, P. 518. Chapel Hill, N.C.

Small, J. K. 1933. Manual of the Southeastern Flora, p. 580. Chapel Hill, N.C. 
SPECIES: \#127 Dionaea muscipula Eliis. Venus ${ }^{\circ}$-Elytrap

\begin{tabular}{|c|c|c|c|c|c|c|c|c|}
\hline \multicolumn{9}{|c|}{ Management Practices } \\
\hline $\begin{array}{l}\text { Expected* } \\
\text { Effect on } \\
\text { the Species }\end{array}$ & $\begin{array}{c}\text { Prescribe } \\
\text { Burn }\end{array}$ & $\begin{array}{c}\text { Bulldoze } \\
\text { or } \\
\text { Root Rake }\end{array}$ & Bed & Chop & $\begin{array}{l}\text { Thin } \\
\text { over- } \\
\text { story }\end{array}$ & $\begin{array}{l}\text { Cut } \\
\text { Over- } \\
\text { story } \\
\end{array}$ & $\begin{array}{l}\text { Establish } \\
\text { Plantation }\end{array}$ & Graze \\
\hline Destroy & & $\mathrm{x}$ & & $\ddot{z}$ & & & X (eventuall & (y) \\
\hline Damage & & & & & & & & $x$ \\
\hline $\begin{array}{l}\text { No Lasting } \\
\text { Effect }\end{array}$ & & & & & & & & \\
\hline $\begin{array}{l}\text { Beneflcial } \\
\text { if Done } \\
\text { Properly }\end{array}$ & $\mathrm{X}$ & & $x$ & & $x$ & $\mathrm{x}$ & & \\
\hline
\end{tabular}

Other Comroents:

*Expected effect on the species is an estimate made by Dr. Robert Kral based on his knowledge of the habitat and on knowledge gained from personal field observations. Estimates are "rough" in many instances. Results of practices may be modified depending upon the degree of application, intensity of treatment, neamess to plant commities, etc. A management practice for which no entry is made indicates a lack of sufficient information from which to predict expected resulis. As observations are made in the field by users of the data, the expected effect will be refined. 
Dionaea muscipula Ellis

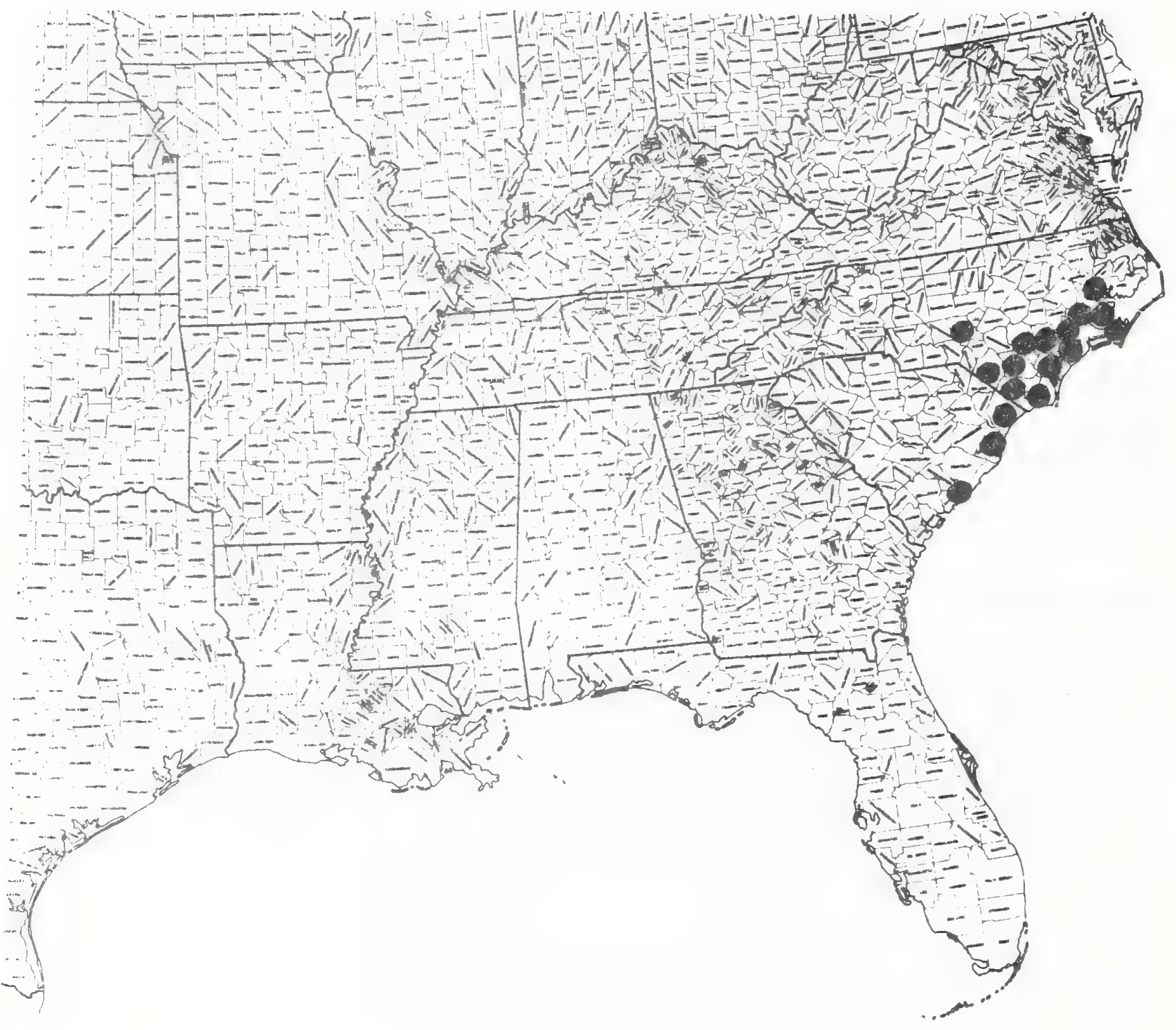




\title{
ERICACEAE
}

\author{
Rhododendron prunitolium (Smali) RLIIaiss. Rlumleas \\ azajea: azalea \\ Aralea prundolia Smad
}

Technical Description

Tall shrub, reaching 3 meters, often quite irregularly brasched but with branchlets in pseudo-shoris as in the genus. Stems.-Bark of older shoots mostly gray, smooth, ultimately exfoliating in thin strips, that of new shoots usually readishobrown, mostly smooth. Overwintering flowerwister buds narrowly ovold. the imoricate scales tan, strongly whiteciliate, meronate. Leaves.-Fully emerged and hardened by flowering time, spreading on short (3-9 mm) reddish-brown, smooth or sparingly appressed-stiffhairy shoots, the blades mostly elliptio to obovate or oblanceolate, mostly 4.5-8.0 cm long, acute and mucronulate, ciliate with erect hairs, also minutely serrulate, the bases cuneate, the upper surfaces dark green and smooth except for short. incurved hairs along the miarib, sometimes the lateral veins, the lower surface paler and with longer, appressed hairs along the midrib. Inflorescence. -Flowers in a cluster few to several, spreading on hirsute, redish or orangish pedicels to 1 cra long. calyr a shallow, strongly and broadlywtriagularlyolobed cup, the lobes $1.0-2.5 \mathrm{~mm}$ long, the backs smooth or stiffwairy, the margins strongly ciliate with long stiffish hairs. Flowers - Corollas rearly salverform, $300 \mathrm{~cm}$ long, $3.003 .5 \mathrm{~cm}$. broad, deep red, the tube and lobes with a scattering of spreading.

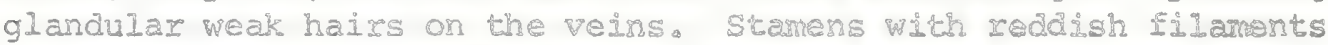
projecting far beyond the corolla tip. Style similarly exserted. Fruit. -Capsule about $2 \mathrm{~cm}$ long, cylindrical, usualiy with a mixture of short-incurved and longer erect hairs.

Distribution and Fowering Season

R. prunifolium is scatterea, mostiy in beech-maplemagrolia ravines, in southwestern Georyla and southeastern Alabama along the Chattahoochee River and its tributary valleys. It blooms in July and early August.

Special Identifying Eeatures

The nearest redowlowered azaleamtyperhododendrons to it geographically are of species austrinum. from which it is readliy digtinguished by its much later blooming time, its more glabrous flowers, its even taller habit. Also, the ilowers appear well after the leaves.

Habitats and Management Implication

This azalea is in somewhat dry, to moist, but always mesic situations. In the overstory there may be some pines, particularly P. taeda, . glabra, but much more often beech, white ash, various southern red oaks, signut hickory, hard maple, Southem magnolia. 
Commonly associated shrubs are Kalmia latifolia,Hydrangea quercifolia, Ilicium, Sebastiana various high-bush blueberries, Symplocos. The soil types it is found on vary from sandy clay loams through fine sandy loams, and (as is true for any soil supporting heaths) are quite acid.

In that this species is primarily one of ravine slopes and the soils of these within the range of the azalea are highly erodable, logging of the overstory species of pines and hardwoods should necessarily be selective. The wreckage and erosion found in areas where clear-cutting has been practiced quite plainly demonstrate that $\underline{R}$. prunifolium would be at a distinct disadvantage. Such areas generally go over to weedy shrubs, particularly blackberry, vines such as Smilax, Japanese honeysuckle, and Kudzu (where present), all of which would swamp out the original shrub understory that would have survived the logging operation. It therefore appears that this shrub is maintained only through maintenance of the forest soils and a selectively logged overstory. Such areas are sometimes converted to pasture after logging, again with poor results because sites are too steep and erodable for good pasture. There is no information available as to the toxicity to livestock of the foliage of this species, but toxicologists such as Kingsbury (1964) opine that most species of Rhododendron are to be considered toxic.

This azalea is one with considerable ornamental value, has been cultivated comercially to a limited extent. It is definitely in danger even in places where the habitat is maintained, because of the temptation to vandals and bad amateur gardeners.

\section{References}

Small, J.K. 1933. Manual of the Southeastern Flora p.997. Chapel Hill, N.C. Wilson, G.H. \& A. Rehder 1921. A monograph of Azalea. Univ. Press, Cambridge. $219 \mathrm{pp}$. 
SPECIES: \#129 Rhododendron prunifolium (SmaIl) ilillais Azalea

\begin{tabular}{|c|c|c|c|c|c|c|c|c|}
\hline & \multicolumn{8}{|c|}{ Management Practices } \\
\hline $\begin{array}{l}\text { Expected* } \\
\text { Effect on } \\
\text { the Species }\end{array}$ & $\begin{array}{c}\text { Prescribe } \\
\text { Burn }\end{array}$ & $\begin{array}{c}\text { Bulidoze } \\
\text { or } \\
\text { Root Rake }\end{array}$ & Bed & Chop & $\begin{array}{l}\text { Thin } \\
\text { over- } \\
\text { story }\end{array}$ & $\begin{array}{l}\text { Cut } \\
\text { Over- } \\
\text { story }\end{array}$ & $\begin{array}{l}\text { Establish } \\
\text { Plantat1on }\end{array}$ & Graze \\
\hline Destroy & & $\mathrm{X}$ & & $\mathrm{x}$ & & & & \\
\hline Darnage & $\mathrm{X} \quad(\mathrm{NA})$ & & $\mathrm{X}$ & & & $\mathrm{X}$ & $\mathrm{X}$ & \\
\hline $\begin{array}{l}\text { No Lasting } \\
\text { Effect }\end{array}$ & & & & & & & & \\
\hline $\begin{array}{l}\text { Beneficlal } \\
\text { if Done } \\
\text { Properly }\end{array}$ & & & & & $x$ & & & \\
\hline
\end{tabular}

\section{Other Commenes:}

* Expected effect on the species is an estimate made by Dr. Robert Kral based on his knowledge of the habltat and on knowledge gained from personal field observations. Estimates are "rough" in many instances. Results of practices may be modified depending upon the degree of application, intensiry of treatment, nearness to plant comunities, etc. A management practice for which no entry is made indicates a lack of sufficlent information from which to predict expected results. As obsexvations are rade in the field by users of the data, the expected effect will be refined. 
Rhododendron prunifolium (small)Millais

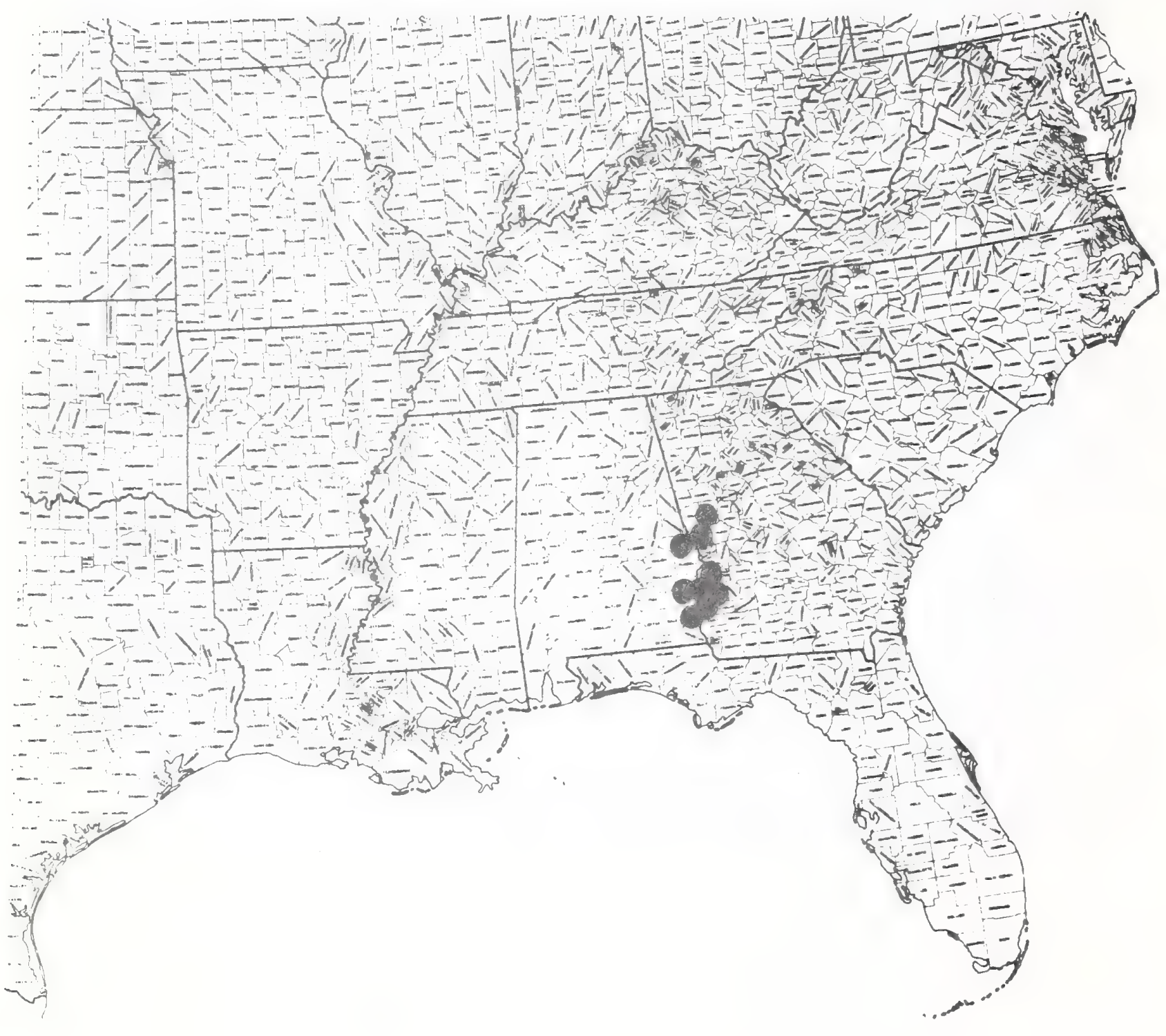


Eaper 130

Test \& snap by:

Robert Kral

EABACEAE

Baptisia calycosa Canby: pineland wildaindigo

or wis Indigo

Technical Description

Bushy, densely leafy, smoothith, peremial herbs ixom stout rootstocks. Stems.-Usually with 1 erect central axis, this pale green, somerhat glaucous between 5 and 10 m thick this with several spreading or ascending branches Irom near the base to the suanits these rebranching from nearly every node to fom a roundish dense crown fully as broad as higin or broader. the whole plant 5-10 an tall. Ieaves.-Alternate, trifoliate, near sessile, stipulate, the stipules 1-2 cm long, elliptic inear, elliptic or lanceolate; leaflets 3. oblanceolate, mostiy $2 \mathrm{~cm} \mathrm{~cm}$ long, nearly equal, pale yallow green (turning black on dryirgy, obtuse to rounded, the margins entire. ciliate with a scattering of long white spreading hairs, the bases narrowly cuneate, the surfaces smooth or nearly so, very rinely reticulate. Inflorescence-milowers arising singly from the axils or simple narrowly ovate or lanceolate bracts, numerous in ratier open, elongating racemes on slender spreadingmascending stalks 205 cm long, these stalks with a pair of opposite, smaller bracts shortly below the elower. plowers.m. Calys in bloom about $1.5 \mathrm{~cm}$ Iong, 9 reen. the cube campanulate. about 3 man long, the lobes uneguad, leafy spreadingmacending, broady oblanceolate, broadiy acute, with short ucros, usually ciliate, cureatebased. Petals clear yeliow, the corolla about 1 crn. Iong, the standard somewhat shorter than the wirgs and keel, nearly round, the wings oblanceolate, the keel petals bent upward alorg the keol. Stamens 10. all fillarents djstinct, all smooth. ovary smooth, with a slencer, upswept style.

Fruit, - Ovoid, the body with the valve edges forming keals, clagped by the sepals, abort I cmo long on a stipe about 3 mmo long and with a perm sistent slender style beak, black whers ripe, srooth.

Distribution and Elowering Seasor

Sandy longleaf pirelands, particularly low sandy rises in pine rlatwoods, northeastern Florida. Flowering late June and July.

Special Identifying Features

This particular widuindigo looks at flrst glance inge B. Lecontei in flower and leaf, but its calyx lobes are much larger and follaceous while those of B. Ieconte 1 are no longer than the calyx tube. It 2 s nearest $B$. hirsuta, a plant of northwestern Floxida, In calys character, but that plant is much more

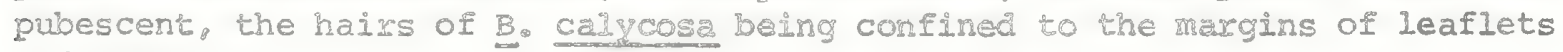
and sepals.

Habitats and Managenent Implication

B. calycosa is found always on deep sands. usualdy amidst a scattering 
of longleaf pine, scrub oak (particularly o. laevis), saw palmetto and associated. with numerous dry soil grasses and sedges, particularly Andropogon, Aristida, Panicum (Dichanthelium) Bulbostylis, Cyperus (C. filiculmis, C. retrorsus, C. plukenenetil. It may be found in sandy exposures transitional to pine flatwoods. In any event, it is part of longleaf pine savanna or longleaf pine-deciduous scrub oak types, both associations constituting fire disclimas. Within its small range (mostly in Clay, St. Johns counties) it appears to be most abundant and vigorous in recently burned over pinelands, least abundant where forest is heaviest. It will persist in pastures and on the edges of pine plantations. Clear cutting would favor its increase, as would any site preparation which would reduce shrub or tree competition without severely altering the soil. Prescribed burning would of course favor its increase.

References

Lairsey, Mary M. 1940. A monograph of the genus Baptisia. Ann. Mo. Bot. Gard. 27: 119-224.

Small, J. K. 1933. Manual of the southeastern flora, p. 676. 
SPECIES: \#130 Bapt1sia celycosa Camby Walse Indigo or Wild Indigo

\begin{tabular}{|c|c|c|c|c|c|c|c|c|}
\hline \multicolumn{9}{|c|}{ 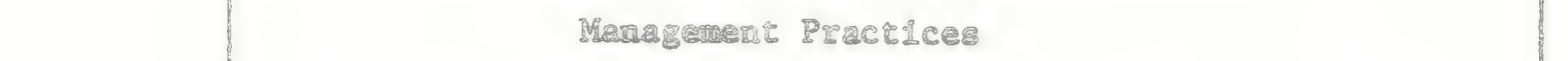 } \\
\hline $\begin{array}{l}\text { Expected* } \\
\text { Effoct on } \\
\text { the Specles } \\
\end{array}$ & $\begin{array}{c}\text { Prescribe } \\
\text { Burt }\end{array}$ & $\begin{array}{c}\text { Bulldoze } \\
\text { or } \\
\text { Boot Rage }\end{array}$ & Bed & Chop & $\begin{array}{l}\text { Thin } \\
\text { over- } \\
\text { grogz }\end{array}$ & $\begin{array}{l}\text { Cut } \\
\text { Over- } \\
\text { Beorg }\end{array}$ & $\begin{array}{l}\text { 2ecablish } \\
\text { Plantation }\end{array}$ & Graze \\
\hline Destroy & & $x$ & & $\mathrm{X}$ & & & & \\
\hline Derase & & & $x$ & & & & & \\
\hline $\begin{array}{l}\text { No Lremas } \\
\text { Ersect }\end{array}$ & & & & & & & $X$ & $\mathrm{x}$ \\
\hline 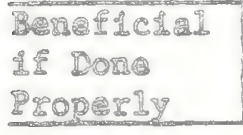 & $\mathrm{X}$ & & & & $\mathrm{x}$ & $x$ & & \\
\hline Ocher Comors & & & & & & & $\begin{array}{l}\text { Lif seed } \\
\text { source } \\
\text { mear }\end{array}$ & $\begin{array}{l}\text { ore are } \\
\text { uspected } \\
\text { olsons }\end{array}$ \\
\hline
\end{tabular}

HExpected offect on the species Is an estinste wade by Dr. Robert Kral based on ha knowledge of the habitat and on kwowledge galned from personal fleld

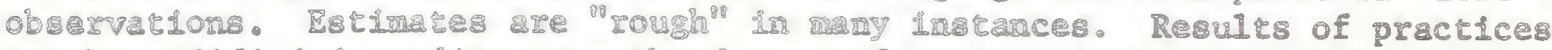
my be rodified dependirg upon the degree of aplicarion, Intensity of treat-

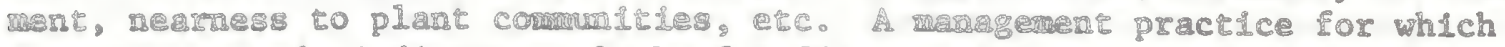
no entry 18 made IndICaces a lack of suflcient latomaton from which to predict espected results. As observations are wads lo the fleld by users of the dact, the expected erpect ufll be retined. 


\section{Baptisia calycosa Canby}

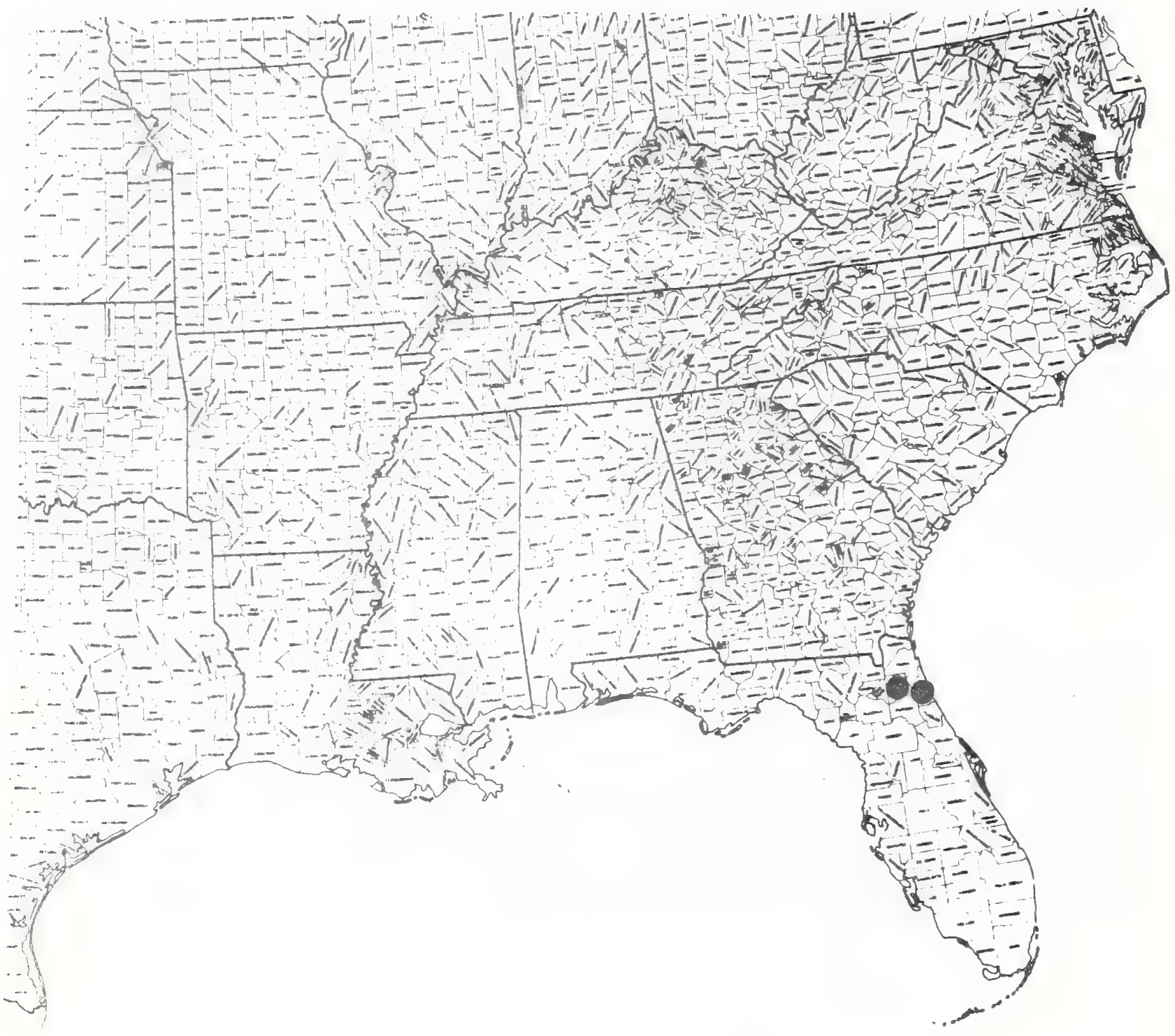


Papere 131

Teart \& Tato by:

Robers $\mathrm{Kra}^{\mathrm{M}}$

\section{EBACRA}

Iupinus mestianus Sinall. Banhandie Iupine: lupine

Technical Description

Shrubby evergreen herbs to a meter tall from strong, deep taproot systems. Stems. -Main stems 1 to few nearly erect Erom the rootg toward the base somerimes nearly I crn thick, terete, stillish, grayish or brownish with a dense matting of short tomentum, the Lower Leawes dosent by flowering time: secondary branches numerous, alternate, swopt mpward slencier at first and with the pubescence blonce or tan. sometrmes nearly redish brown, later the branches becoming stouter, fizmer, grayish-tomentose, the whole crown becoming quite Luld, leafy.

Ieaves.-Altemate, simple the stipules very rebuced, persisting as low, hairy scales, the petioles prominent, mostly $2-5$ cre long, densely short hairy, the blades ascenaing, mostly obovace or elifitic, $5-10 \mathrm{~cm}$. long, broady acute or obtuse angled, shortmucronate, entire, quite firm, the upper surface gray green, the lover surface nore brownish or orangish green, both surfaces matted mith close combrum.

Inflorescence-miowers in conspicuous, dense, sinnder, elongated racemes From 10 to 30 drm long. on stirfish ascencing pedicels to 3 man. long (elongating somewhat in fruit), chese and the calyz densely shortwtomentose. Plowers.-Calys about $1 \mathrm{~cm}$. Long, the culse broady bejlshaged, 2-10bed. the upper lobe very Iow and broas, the Lower Iip aweh longer than the calyr tube, Inear-criangular. Corolla boout $1 \mathrm{~cm}$. Iong, the standard slightly longer than the wings and ked, short claved, the blade broady ovate or nearly round, emarginate. Iingulate phe sides Eolded upward as in the tongue) a pale bright blue with a broad purplish band within along the middis wings shorteclawed, pale blue, the blades narrowiy obovate, Falcate, keel petals pale blue strongly curved ugward to narrow, yellowish-orange, firm tips. Scamens 10,211 ilianents fused from the midale dowward, I set of 5 longer, with short, rowd arthers, the shorter set with narrower, longer anthers. Ovary superior, narrow densely silky hairy, the long style curved rpward. Eruit.- - oblong-elliptic, nearly cylindric, beaked, mostly $2-3 \mathrm{~cm}$ long, pale brown trith ascending, pale, long, shaggy tomentum.

Distribution and Flowering Season

Sandridges toward and along the coast, northwegtexs Florida. Flowering in April and May.

Special Identifying Features

This distinctive species is the tallest, nost erect in habit of the simple leaved southeastern Lupinus with flowers of the same iolue as I. diffusus but having a purple "eye" spot quite unlike the white one of that species. I. Villosus, whose range overlags that of Io kpestianus also, has petals with more purple rather than bright blue tints. 
I. westianus is confined to dunal formations near the present coast, is locally abundant in windswept sandy clearings in dunescrub. This scrub is often densely or openly forested with Pinus clausa, this admixed. with evergreen scrub oaks, and Ceratiola, Osmanthus, Conradina, Calamintha etc. in the understory. The substrate is always a deep. rather fine sand that at the survace is a glaring white. The habitat is probably maintained naturally for the species by a combination of fire, to reduce woody competition and, wind. Clearcutting of the pine and removal of competing shrubby vegetation would probably increase the species by opening up the habitat, but subsequent establishment of pine plantations would eliminate this shade intolerant plant. Such species should probably be protected in that they tend to help stabilize an otherwise shifting sand. Unrestricted land development along the coast of northwest Florida for various sorts of housing and recreational use is probably the worst hazard to Lupinus westianus.

References

Small, J. K. 1926. A new lupine from northern Florida. Torreya 26: 91-93. 1933. Manual of the southeastern flora, p. 681.

Chapel Hill, N.C. 
SPECIES: \#131 Iupinus westianus Smallo Iupine.

\begin{tabular}{|c|c|c|c|c|c|c|c|c|}
\hline \multicolumn{9}{|c|}{ Management Practices } \\
\hline $\begin{array}{l}\text { Expected* } \\
\text { Effect on } \\
\text { the Species }\end{array}$ & $\begin{array}{c}\text { Prescribe } \\
\text { Bum }\end{array}$ & $\begin{array}{l}\text { Bulldoze } \\
\text { or } \\
\text { Root Rake } \\
\end{array}$ & Bed & Chop & $\begin{array}{l}\text { Thin } \\
\text { over- } \\
\text { story }\end{array}$ & $\begin{array}{l}\text { Cut } \\
\text { Over } \\
\text { story }\end{array}$ & $\begin{array}{l}\text { Establish } \\
\text { Plantation }\end{array}$ & Graze \\
\hline Destroy & & $X$ & & $x$ & & & $\mathrm{X}$ & \\
\hline \multicolumn{9}{|l|}{ Damage } \\
\hline $\begin{array}{l}\text { No Lasting } \\
\text { Effect }\end{array}$ & $\mathrm{NA}$ & & NA & & & & & \\
\hline $\begin{array}{l}\text { Beneficial } \\
\text { If Done } \\
\text { Properly }\end{array}$ & & & & & 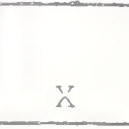 & $x$ & & \\
\hline
\end{tabular}

\section{Other Comments:}

Hexpected effect on the species is an estimare made by Dr. Robert Kral based on his knowledge of the habitat and on krowledge gained from personal field observations. Estimates are "rough" in many instances. Results of practices may be modified depending upon the degree of application, intensity of treatruent, neamess to plant comunities, etc. A management practice for which no entry is made indicates a lack of sufficient information from which to predict expected resulis. As observations are made in the field by users of the data, the expected effect will be refined. 
Lupinus westianus Small
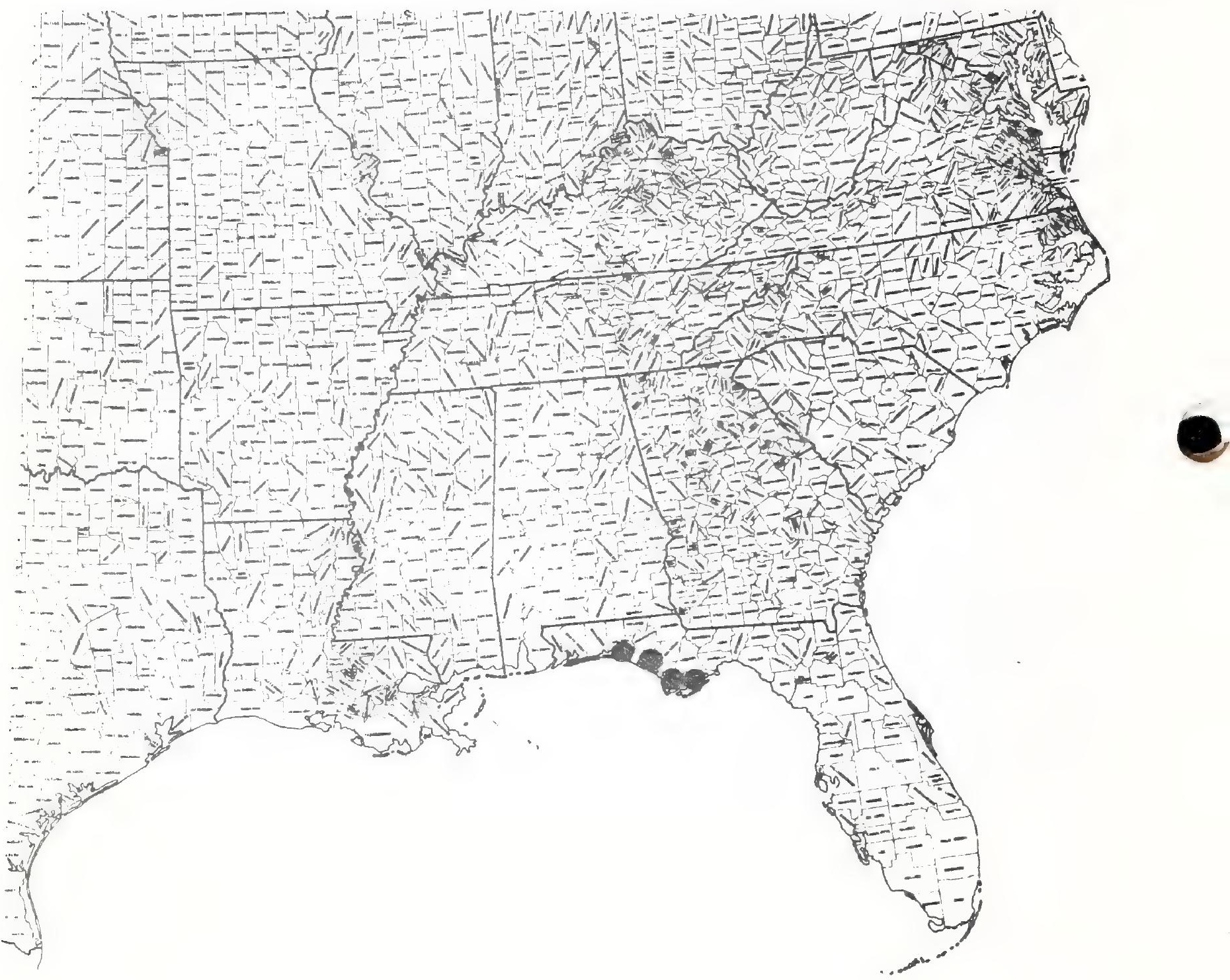
Paper 133

Text and map by:

Robert Kral

\section{LENTIBULARIACEAE}

Pinguicula planifolia Chapm. Butterwort

\section{Technical Description}

Perennial, forming rosettes to $15 \mathrm{~cm}$ broad from a very short stem and a shallow, diffuse rootstock.

Leaves.--Numerous, spreading, thinnish but succulent, somewhat involute, mostly elliptic to oblong, $4-10 \mathrm{~cm}$ long, rounded or acute, entire, cuneate to attenuate to a clasping base, greenish or more often strongly maroon-tinted, the surfaces covered with minute glands.

Inflorescence.--Stems (scapes, peduncles) 1 to several, arising singly progressively during flowering, erect or ascending, round in cross section, fleshy, to $2.5 \mathrm{dm}$ tall, with a scattering of short-stalked glands, each terminating in a single flower (rarely in twins).

Flowers.--Erect or slightly nodding, mostly $2-3 \mathrm{~cm}$ broad, showy, perfect and irregular. Sepals joined at the base, the calyx to tips $8-10 \mathrm{~mm}$ long, slightly 2-lipped, 5-lobed, the lobes oblong. rounded, the upper 3 lobs oblong and directed upward, the lower 2 spreading downward from the short bell-shaped but irregular calyx tube, dark green with a scattering of peg-shaped glandular hairs. Corolla with petal bases fused into a campanulate (bell shaped) spurred tube, this with the short-tubular spur directed downward and the corolla tube ca. $1.5 \mathrm{~cm}$ long, laterally attached to the receptacle and its opening directed upward; corolia lobes 5, spreading, lanceolate to oblanceolate, mostly fully 2-3 cm long, split often to near the middle into 2 , narrowly oblong lobes, the surfaces a lively pale blue-violet, the edges thickened and papillate. Inside of corolla tube just within the throat with a raised area (palate) hairy with capitate hairs. Stamens 2, arising from upper wall of corolla tube, the anthers on forward and inward short, thickish, arching filaments and nearly touching. Ovary superior, nearly round, covered with minute glandular hairs, the style very short, the stigma broader, irregularly 2-lobed. Placentation free-central, ovules numerous. Fruit.--Capsule round, ca. $5 \mathrm{~mm}$ broad, thin-walled, 2-valved, enfolded at the base by ascending calyx tube and its slightly spreading lobes. Seeds narrowly wedge-shaped, the surfaces honeycombed.

Distribution and Flowering Season

In bogs, cypress domes, depressions in flatwoods and savannas, often in shallow standing water, from northwestern Florida (about the longitude of Tallahassee) westward near the present coast into Mississippi. Flowering from February into May.

\section{Special Identifying Features}

This species is distinguished best from the other five southeastern Pinguicula by its large, narrow, forked purplish-violet petal lobes and by its strongly red or purplish-tinted rosettes.

Habitat and Management Implications

P. planifolia is a typical bog plant, being most abundant in full sunlight on very moist, acid, peat or peat-sand-muck, where the competition with the predominently grass-sedge vegetation is least. Merchantible species with which it is most associated would be slash pine, pond pine, longleaf pine and cypress, but 
it is never where crowns of such would close, except in the case of the deciduous cypress. It is part of a vegetational assemblage in which periodic fires historically occur, and which probably once favored its increase. clear cutting followed by any site preparation that did not involve strong alteration of or removal of the top soil layer would favor its increase. Ditches through bogs it frequents are usually lined with rosettes. However, once the drainage is complete enough to dry out the site, this plant disappears. Likewise, it may appear where plantations of pine are started, but disappaars when tree crowns close over it, and probably through reduction of soil water and crown closure to shade. The highly organic black bog earths which it grows on are often now converted through drainage and plowing to truck crop or row crop agriculture, this perhaps the largest hazard to the species. Similarly it is lost through conversion of boggy savanna to pasture, in this case mostly through a combination of trampling, drainage, and tre promotion of a closed-cover of grasses.

\section{References}

Godfrey, R. K. and H. Larry Stripling. 1961. A synopsis of Pinguicula (Lentibulariaceae) in the southeastern United States. Am. MidT. Nat. 66 (2): 395-409.

Sma11, J. K. 1933. Manual of the southeastern flora, pp. 1232-1233. Chapel Hill, N. C.

Wood, C. E. Jr. and R. K. Godfrey. 1957. Pinguicula (Lentibulariaceae) in the southeastern United States. Rhodora 59: 217-330. 
SPECIES

Pinguicula planifolia Chapm. Butterwort

\begin{tabular}{|c|c|c|c|c|c|c|c|c|}
\hline \multirow[b]{2}{*}{$\begin{array}{l}\text { Expected* } \\
\text { Effect on } \\
\text { the Species }\end{array}$} & \multicolumn{8}{|c|}{ Management Practices } \\
\hline & $\begin{array}{c}\text { Prescribe } \\
\text { Burn }\end{array}$ & $\begin{array}{l}\text { Bulldoze } \\
\text { or } \\
\text { Root Rake }\end{array}$ & Bed & Chop & $\begin{array}{l}\text { Thin } \\
\text { over- } \\
\text { story }\end{array}$ & $\begin{array}{l}\text { Cut } \\
\text { over- } \\
\text { story }\end{array}$ & $\begin{array}{l}\text { Establish } \\
\text { Plantation }\end{array}$ & Graze \\
\hline Destroy & & $x$ & & $x$ & & & $x$ & $x$ \\
\hline Damage & & & $x$ & & & & & \\
\hline $\begin{array}{l}\text { No Lasting } \\
\text { Effect }\end{array}$ & & & & & & & & \\
\hline $\begin{array}{l}\text { Beneficial } \\
\text { if Done } \\
\text { Properly }\end{array}$ & $x$ & & & & $x$ & $x$ & & \\
\hline
\end{tabular}

Other Conments: Drainage of site destroys this species!

*Expected effect on the species is an estimate made by Dr. Robert Kral based on his knowledge of the habitat and on knowledge gained from personal field observations. Estimates are "rough" in many instances. Results of practices may be modified depending upon the degree of application, intensity of treatment, nearness to plant communities, etc. A management practice for which no entry is made indicates a lack of sufficient information from which to predict expected results. As observations are made in the field by users of the data, the expected effect will be refined. 
Pinquicula planifolia Chapm.

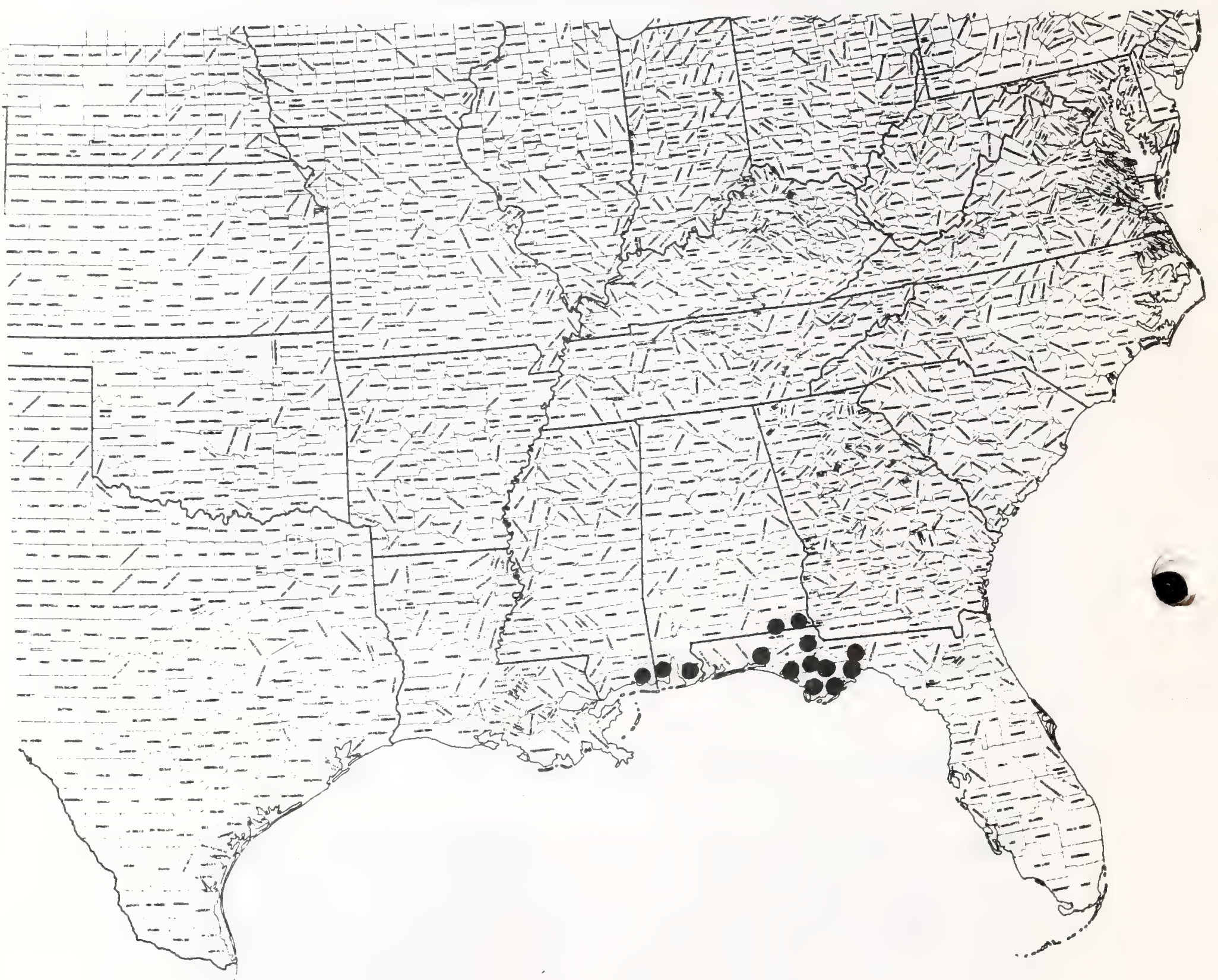






\section{TIIIACEAS}

Iilium grayii S. Wats. Gray"s Iily: Roan Iily or Orangew bell lily

Technical Description

Perennial herbs rooting both from the stem and from deep-sot suloglobose, scaly bulbs, these putting forth stolonifexous ofishoots that teminate in new bulbs.

Stems.--Solitary, erect to as much as 1.5 meters, usualdy lower, corete, pale green basally, upwardly often deeper green inted with naroon. Leaves.--Altemate toward stem base, toward stem midde in whoris of $4-6$ on fairly distant nodes, spreading, lance-Iinear, elliptico-Iinear to lanceolate or elliptic, mostly 5 -I0 cm long, acuminate, the margins finely scabrid with bluntish tubercles, the bases narrowly acute or attenuate to a short petiole or sessile, the upper surface dark green, the lower surface paler with the several raised and parallel nerves often minutely scabrid. Stem leaves gradually reduced to alternate bracteal leaves, these frequently crowded on larger specimens, under or on flower stalks longer than the flowers. Inflorescence,-Flowers 1-9. symetrical, somewhat nodding or spreading on ascending stalks, at anthesis campanulate. Flowers.--Tepals mostly $4-5 \mathrm{~cm}$ long, oblanceolate, mucronate, entire, the bases cuneate, all blades spreading but slightiy toward their tips, the outer surfaces a fire orange-red, with deeper (almost cimmamon) red midnerves, paler and with greenish tints basally, the inner surfaces orange red toward the tips, yellow medially and toward the base, liberally freckled with cinnamon-red splotches. stannens 6 , projecting forward, shorter than the tepals, the filaments slender, yellowish, broadenirg slightly toward the base, the anthers cinnamonmed, versatile, shortmoblong, about $5 \mathrm{~mm}$ long. Eruit. - Capsule (not seen by this writer) oblong, 3-4 cin long, erect.

Distribution and Flowering Season

Acidic clearings in shrub thickets, open woods, heath and grass balds, higher elevations in the Blue Ridge, along the rennesseemporth Carolina border and northward into southwest Virginia. Flowering late June, July.

Special Identifying Features

This species is closest to Io canadense, another bulb and stem rooter of acidic soils within the area. but has much smaller flowers, (the tepals of which are broader) shorter leaves (which have the lowest length-width ratio of southern Liliums), and a lower stature. The white bulb scale character mentioned by $J$. $\mathbb{R}$. Snall does not hold in that these may be found in both $\mathrm{L}$. canadense and I. Superburn.

Habitats and Management Implication

Lilium grayii has its bulbs deepset in moist, highly organic and siliceous black loams such as develop in grass-sedge meadows and clearings toward the mountain summits. Very often it is found in clearings amidst Rhododendron 
Catawbiense, other heaths, alder, willow, shadbush, etc. or along the edges of $r$ ed spruce-Fraser fir but never beneath them. Since most of its present habitat is within the boundaries of National parks, National forest or State parks, and since the plant has long been known to be rare and is protected, it may have some chance. The main threat to it today is not so much through habitat damage as through the gathering of the bulbs by professional or amateur gardeners or through vandalism.

References

Small, J. K. 1933. Manual of the southeastern flora, pp. 290-291. Chapel Hill, N.C. Watson, Sereno. 1879. Revision of North American Liliaceae. Proc. Am. Acad. Arts and Sci. 14:213-303. 
SPECIES: \#136 Iilium grayii S. Wats; Roan Iily or Orange-bell lily

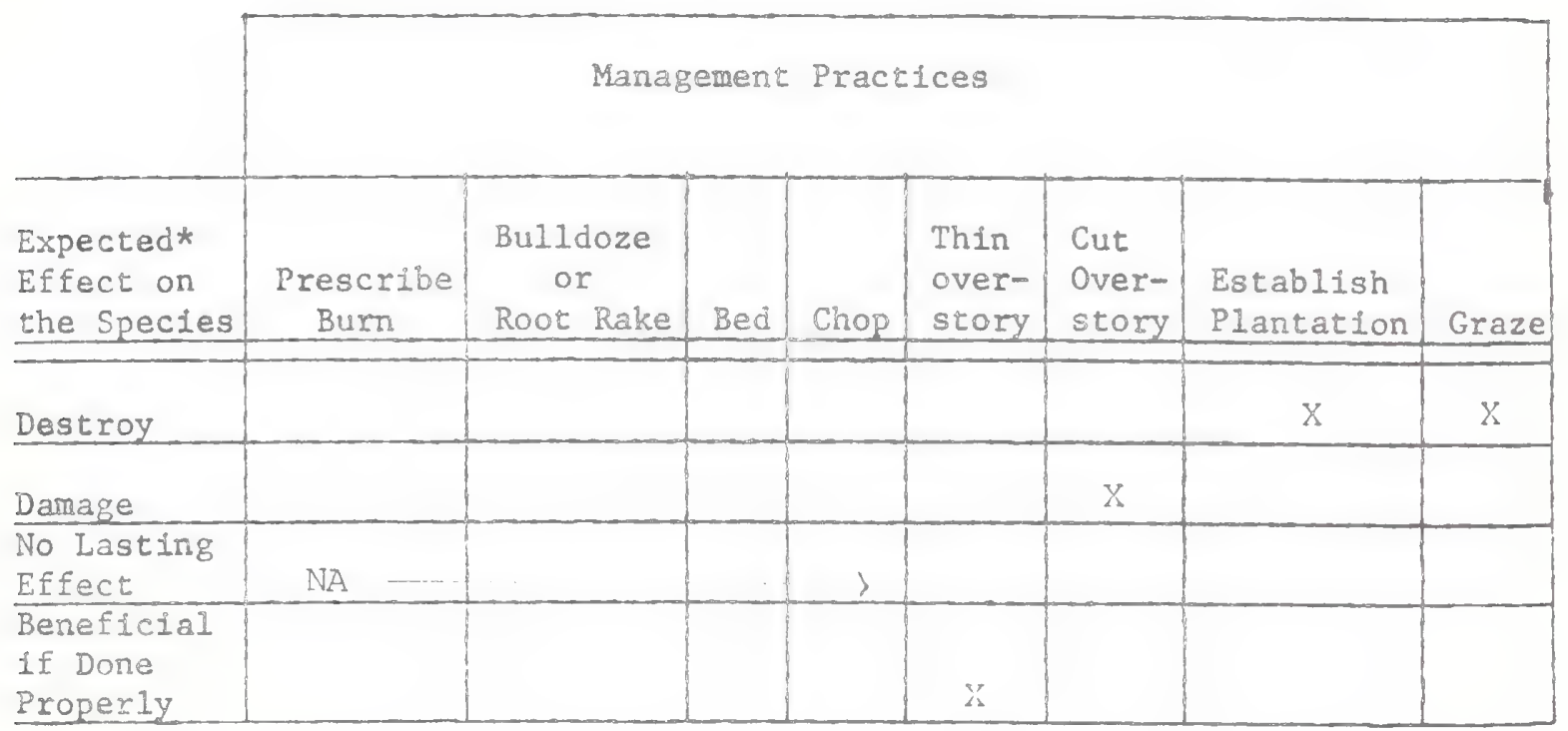

\section{Other Comments:}

*Expected effect on the species is an estimate made by Dr. Robert Kral based on his knowledge of the habitat and on knowledge gained from personal field observations. Estimates are "rough" in many instances. Results of practices may be modified depending upon the degree of application, intensity of treatment, nearmess to plant comunities, etc. A management practice for which no entry is made indicates a lack of sufficient information from which to predict expected results. As observations are made in the field by users of the data, the expected effect will be refined. 
Iilium grayii s. Wats.

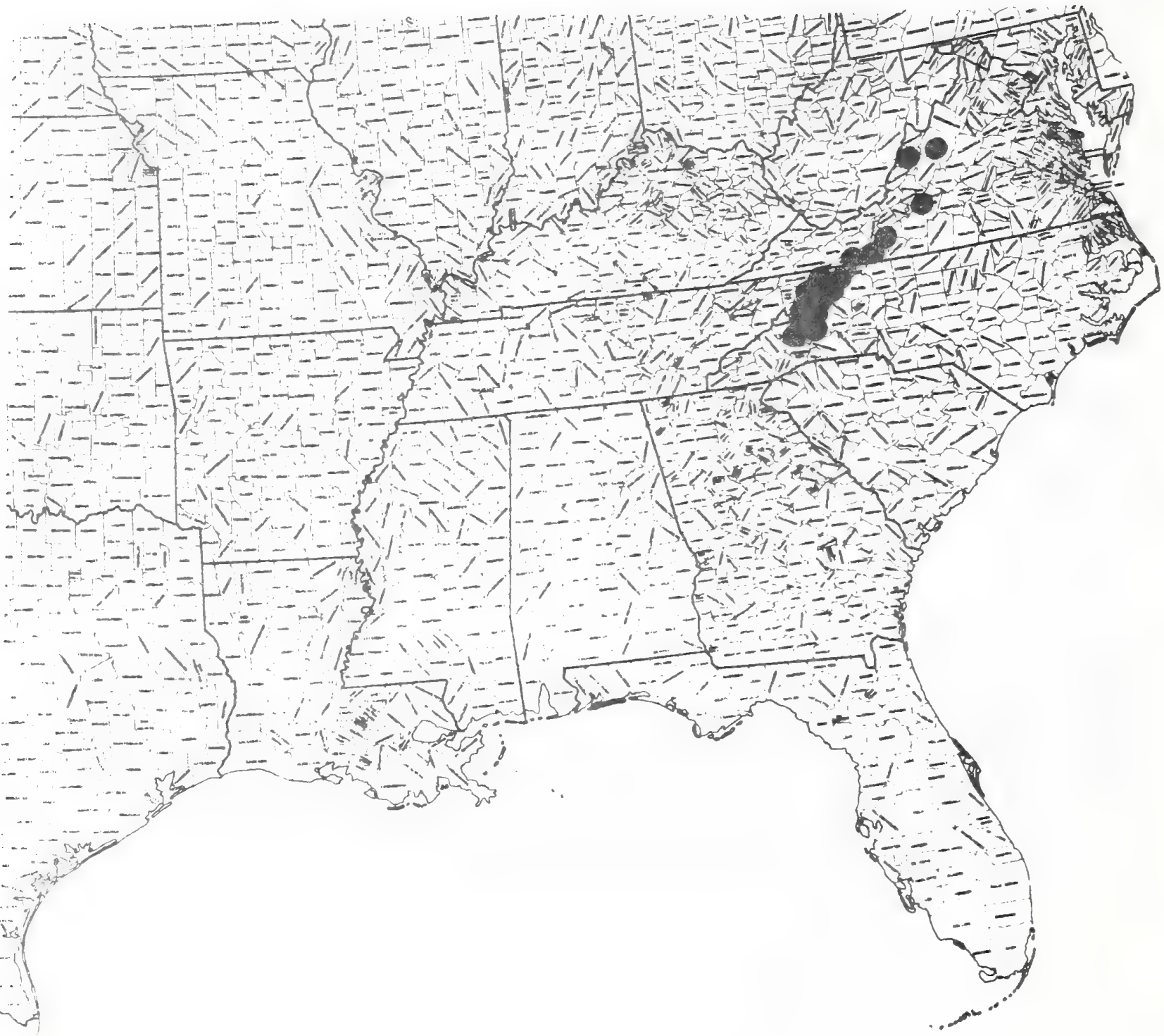


Paper 141

Text and map by:

Robert Kral

\section{IIIIA ACEAE}

Trillium texanum Buckley. Wake-robin

\section{Technical Description}

Strongly clonal, with clones of often several hundred shoots (many merely with leaves) arising from narrow, pale, deep-set, horizontal to ascending terete rhizomes 5-10 mm thick and often to $1 \mathrm{dm}$ long. Scapes.--Stiffly erect or ascending from a bowed base, mostIy 1-2 dm high to level of bracteal leaves, fleshy, often strongly tinged with red, smooth, terete with many low ribs, gradually tapering from a base ca. 4-5 mm thick, this sleeved by a thin, tan, erect rhizomal scale-leaf.

Bracteal leaves.--Mostly 3, spreading-ascending, oblong, lanceoblong or elliptic-oblong, $\mathrm{ca} .5-10 \mathrm{~cm}$ long, mainly $1.5-2.5 \mathrm{~cm}$ wide, apically usually broadly rounded, the bases narrowly cuneate to attenuate, often narrowed to short, petiole-like stalks, the surfaces grayish-green with stomates evident on the upper surfaces and with 5 longitudinal veins evident.

Flowers.--Solitary, ascending or nearly spreading horizontally on ascending, slender but stiff, greenish or reddish-green stalks 2-4 cm long; sepals spreading-ascending at anthesis, usually 3, lance-oblong, 2-3 cin long, blunt, with color and stomates as in bracteal leavies, becoming more erect by fruiting time; petals usually 3, at early anthesis white, ascending, at late anthesis more spreading and turning pink, ovate or lance-ovate, 2-3 cm long, narrowing to a narrow but blunt tip, the margins somewhat wavy, the base broadly cuneate or short-clawed; stamens 6, 10-12 mm long, the anthers oblong-linear, 6-8 mm long, introrse, with connectives purplishtinged, on somewhat flattened, ascending pale filaments; ovary pale green (with a few rows of stomates) ovoid, ca. $3 \mathrm{~mm}$ high, tapering to a deeper-green, erect, fleshy, lineal style ca. $2 \mathrm{~mm}$ long, the stigmas ascending, excurvate, lineal, ca. $3 \mathrm{~mm}$ long, pale green, the stigmatic surface granular.

Fruit.--Body of fruit ovoid, 7-8 mm long, yellow-green, with 6 low ribs evident at the narrow apex, the style persistent as a slightly tapering beak; seeds (fide Dr. Freeman!) 8-15.

Distribution and Flowering Season

Acid hardwood bottoms, sphagnous wooded seeps and branchbanks, northwestern Louisiana and eastern Texas; flowering from March into mid April.

Special Identifying Features

There are three other low, white-flowered trilliums native to the southeastern United states, these all placed by most specialists as varieties of T. pusillum Michx. Trillium pusillum var. pusillum and T. pusillum var. ozarkanum (Palmer \& steyermark) Steyermark 
range nearest $\underline{\text {. }}$ texanum, the former being found in the Coastal Plain of Mississippi, the latter mostly ozarkian but also found in the Ouachitas of southwestern Arkansas. Occasionally both of these varieties may form small clumps by means of rhizomal branching but neither develop the large "solid" patches that are formed by I. texanum, which also has a much longer and usually more slender rhizome. When living plants are compared, $\underline{T}$. texanum stands out even at a distance because of the paler green of its bracteal leaves and sepals, the "grayness" being imparted by the abundance of stomates on the upper as well as lower surfaces. The outline of bracteal leaves is also distinctive, those of T. texanum tending more toward oblong, sonetimes even broddest aboue the niddle, and with bases nore strong?y tapering. The petals of $\mathrm{T}$. ousillum tend after anthesis to deepen to deep purple, to becone very narrow and inrolute, are strongly recurved, pointing dowrinel jeswean the erect sepals; those of T. Texanlum do no terpen as nuch in color, often do not recurve. The fruit of $T$. pusillum is much more strongly ribbed than is that of $T$. texanum. In habitat $\underline{T}$. pusillum pusillum is mostly low rises in large bottomlands or, if upland, area where the soil is heavy. T. pusillum ozarkanum takes more upland, acidic soils, being commonest in area where chert gravel is predominant; when it is found in ravine bottoms or stream bottoms, usually the soils are well drained and cherty.

Habitat and Management Implications:

Trillium texanum is found invariably in moist to wet sites and is definitely a shade plant. Most known localities would be characterized as boggy, usually the seep borders of ravine streams with plenty of Alnus, Myrica, Cornus, Vaccinium, Itea in the shrub Iayer and with green and pop ash, red maple, bottomland oaks, mostly in the willow oak complex, also much red gum, black gum and lowland hickory and elm. Magnolia virqiniana is almost always present, some of merchantible size. of pines, $\underline{\text {. }}$ taeda is often present, sometimes abundant. Associated herbaceous species include a variety of lowland grasses and sedges, bog orchids (particularly rein-orchids), rushes, bog violets (particularly Viola primulifolia, sometimes Parnassia asarifolia. Lowland ferns in osmunda, Thelypteris, Athyrium, Woodwardia, Onoclea are frequent to abundant. Sphagnum species often mat the ground. The trillium may also occur in broader bottoms, usually on sandy-silty rises where there is some drainage but where the ground remains moist, such as would be found along the small tributaries to larger meandering streams.

The habitat of this trillium is threatened in two main ways. The larger bottoms, where this plant may be quite local, are being drained, clearcut, converted to pine. The soil disturbance, loss of soil water and admittance of too much light all are destructive of trillium habitat. Opening up such tracts for woodland pasture similarly destroys trillium. The other, and prevalent, danger is apparent when one visits the sandhills ravine habitat. Much of 
east Texas sandhilis is forested with low grade oak and hickory, or these mixed with pine. Huge tracts of sandhills are now being cleared, site prepped for pine plantation. Although this is

itself not trillium habitat, the erosion from such large preparations results in the small branch bottoms which are true trillium habitat being buried by sandy wash. This often kilis much of the bottomland hardwood reproduction and even larger trees; it also buries herbaceous cover to such an extent that nothing but a deep layer of wash is evident.

Thus preservation of Trillium texanum heavily depends on recognition of existing sites for it, preserving these from any logging save single tree selection, prevention of any drainage ditching, excluding any livestock use, recommending to those who log adjacent uplands that they leave a sufficient strip of undisturbed timber downslope so as to protect the small stream bottoms.

References

Buckley, S. B. 1860. Description of several new species of plants. Proc. Acad. Nat. Sci. Philad. I2: 443-445.

Correll, D.S. and M.C. Johnston. 1970. Manual of the vascular plants of Texas, p. 408. Renner, Texas. 


\begin{tabular}{|c|c|c|c|c|c|c|c|c|}
\hline \multirow[b]{2}{*}{$\begin{array}{l}\text { Expected* } \\
\text { Effect on } \\
\text { the Species }\end{array}$} & \multicolumn{8}{|c|}{ Management Practices } \\
\hline & $\begin{array}{c}\text { Prescribe } \\
\text { Burn }\end{array}$ & $\begin{array}{l}\text { Bulldoze } \\
\text { or } \\
\text { Root Rake }\end{array}$ & Bed & Chop & $\begin{array}{l}\text { Thin } \\
\text { over- } \\
\text { story }\end{array}$ & $\begin{array}{l}\text { Cut } \\
\text { over- } \\
\text { story } \\
\end{array}$ & $\begin{array}{l}\text { Establish } \\
\text { Plantation }\end{array}$ & Graze \\
\hline Destroy & $\mathrm{x}$ & $\mathrm{x}$ & $\mathrm{x}$ & $\mathrm{x}$ & & $\mathrm{x}$ & $\mathrm{x}$ & $\mathrm{x}$ \\
\hline Damage & & & & & $\mathrm{x}$ & & & \\
\hline $\begin{array}{l}\text { No Lasting } \\
\text { Effect }\end{array}$ & & & & & & & & \\
\hline $\begin{array}{l}\text { Beneficial } \\
\text { if Done } \\
\text { Properly }\end{array}$ & & & & & & & & \\
\hline
\end{tabular}

Other Comments: Draining the boggy habitat would destroy this trillium!

*Expected effect on the species is an estimate made by Dr. Robert Kral based on his knowledge of the habitat and on knowledge gained from personal field observations. Estimates are "rough" in many instances. Results of practices may be modified depending upon the degree of application, intensity of treatment, nearness to plant communities, etc. A management practice for which no entry is made indicates a lack of sufficient information from which to predict expected results. As observations are made in the field by users of the data, the expected effect will be refined. 
Trillium texanum Buckl.

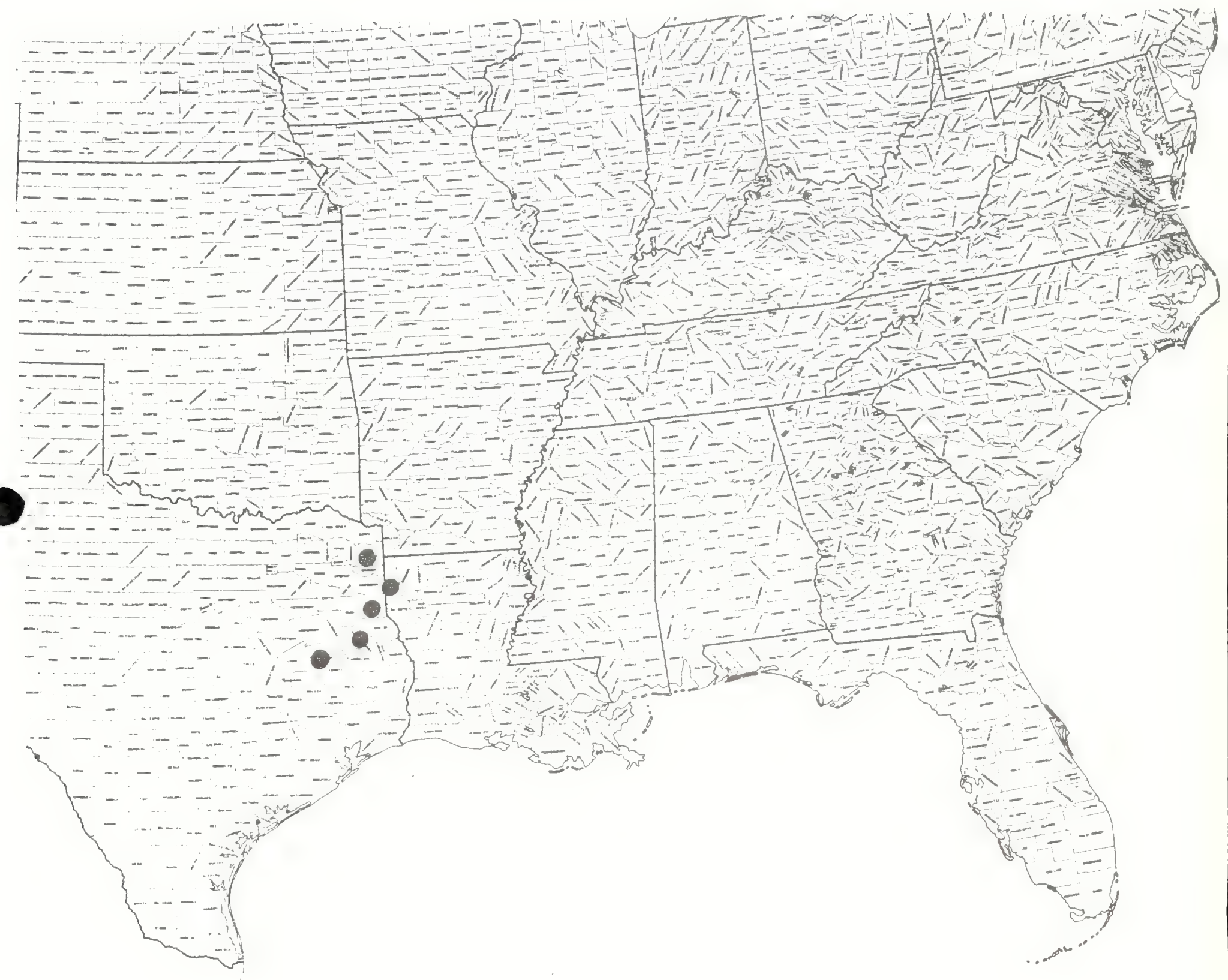


-

-

- 
Paper 142

Text \& map by:

Robert Kral

Zephyranthes simpsonit Chapm. Rain zephyr lity; Atamasco Ti Ty; zephyr li Ty

Atamasco simpsonit (Chapm.) Greene

\section{Technical Description}

Glabrous perennial herb at most to $3 \mathrm{dm}$. tall arising from a thinjacketed bulb (as in Narcissus).

Leaves.-- Linear, basa T, overlapping by sheathing bases, the blades elongate-linear, numerous, spreading, fleshy, a lustrous green, sometimes tinted with red, about $2 \mathrm{~mm}$. broad, around $2 \mathrm{dm}$. 1ong, the backs rounded, the edges rounded and smooth, the upper surface grooved.

Inflorescence.--Scapes 1 or few (the buibs solitary or in small clusters), erect or spreading, broader than the leaves and often appearing as they die, terete or somewhat flattened, pale green with tinges of red toward the apex and terminating in a tubular, reddish-purple bract which includes the single bud. The bract splits as the bud open, becomes darker red and is 2-cleft half its length or more.

Flowers-- Symmetrical, erect, showy, 5-10 cm. long, the tepals (the 3 petals and 3 sepais similar except in position) arising from a tubular base, oblong-lanceolate, short-acuminate, opening white, sometimes tinted with pink, aging through red to purple, spreading only slightiy, stamens 6 , erect, the elongate white filaments arising from the perianth tube apex, the oblong-linear anthers yellowish. Ovary inferior; style elongate, slender, branching at its summit into 3, short-linear stigmas at about the level of the anthers.

Fruit.--A 3-lobed capsule; seeds few, semicircular, a lustrous black.

Distribution and Flowering Season

Wet clearings in pine-saw palmetto flatwoods, savannas, pasture, roadsides, central and southern penisular Florida. Flowering February to Apri 1.

\section{Special Identifying Features}

There are but 3 native species of Zephyranthes in the southeast, of which the commonest and most widespread is the Atamasco Li ly, z. amatasco (L.) Herb. This is a clump former of rich bluffs and Tow rich woods with broader, longer leaves and larger, often broader and rounder tepals, and generally with less red pigments; its stigma branches arise at a level well above the anthers in the mature flower. The other species, also considered threatened, is Z. treatiae S. Wat. (Atamasco treatiae (S. Wats. Greene) which is in wet pine flatwoods from central peninsular Florida northward and westward to Gadsden Co., Florida. This is very similar to Z. simpsoni i in leaf and flower character, the leaves being but slightly broader, the tepals tending to spread apart further in full flower. A significant difference is in the level the stigma lobes are presented 


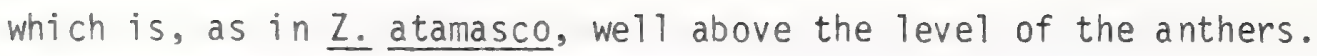

Habitats and Management Implication

Z. simpsoni 1 and Z. treatiae are both species of low pine flatwoods or pi ne dotted savannas, here Tocally abundant in black, highly organic sands. Both, in undisturbed flatwoods, flower sparsely as competing herbaceous or shrubby vegetation increases; both respond with vigorous flowering after fire disturbance. Both species are now more commonly seen on moist to wet mowed roadbanks or in pastures which were formerly pine flatwoods, here grazing or mowing appearing to operate effectively to reduce competition of other plants. In that both species appear to move to such artificial situations, and to increase dramatically there, they are less threatened than might appear from the abuse of their original habitat. However, efficient drainage will cause a decrease even of the roadside populations, these being plants of quite moist soils. Site preparation involving major soil disturbance or drainage ditching wi 11 reduce the populations. Clearcutting itself will at least temporarily increase both.

References

Godfrey, R.K. and J. Wooten. 197-. Aquatic and wetland plants of the southeastern United States. Zephyranthes, in unpublished Manuscript.

Sma 11, J.K. 1933. Manual of the southeastern flora, pp. 320-321. Chapel Hill, N.C. 
SPECrES: \#142 Denhrantines sirnsonii Chapm.

\begin{tabular}{|c|c|c|c|c|c|c|c|c|}
\hline \multicolumn{9}{|c|}{ Management Practices } \\
\hline $\begin{array}{l}\text { Expected* } \\
\text { Effect on } \\
\text { the Species }\end{array}$ & $\begin{array}{c}\text { Prescribe } \\
\text { Burn }\end{array}$ & $\begin{array}{c}\text { Bulldoze } \\
\text { or } \\
\text { Root Rake }\end{array}$ & Bed & Chop & $\begin{array}{l}\text { Thin } \\
\text { over- } \\
\text { story }\end{array}$ & $\begin{array}{l}\text { Cut } \\
\text { Over- } \\
\text { story } \\
\end{array}$ & $\begin{array}{l}\text { Establish } \\
\text { Plantation }\end{array}$ & Graze \\
\hline Destroy & & X & $\mathrm{X}$ & $\mathrm{X}$ & & & $\mathrm{X}$ & \\
\hline \multicolumn{9}{|l|}{ Damage } \\
\hline $\begin{array}{l}\text { No Lasting } \\
\text { Effect }\end{array}$ & & & & & & & & $\because$ \\
\hline $\begin{array}{l}\text { Beneficial } \\
\text { if Done } \\
\text { Properly }\end{array}$ & & & & & $z^{\prime}$ & $x$ & & \\
\hline
\end{tabular}

\section{Other Comments:}

* Expected effect on the species is an estimate made by Dr. Robert Kral based on his knowledge of the habitat and on knowledge gained from personal field observations. Estimates are "rough" in many instances. Results of practices may be nodified depending upon the degree of application, intensity of treatment, nearmess to plant comunities, etc. A management practice for which no entry is made indicates a lack of sufftctent information from which to predict expected results. As observations are made in the field by users of the data, the expected effect will be refined. 
Zephyranthes simpsonii Chapm.

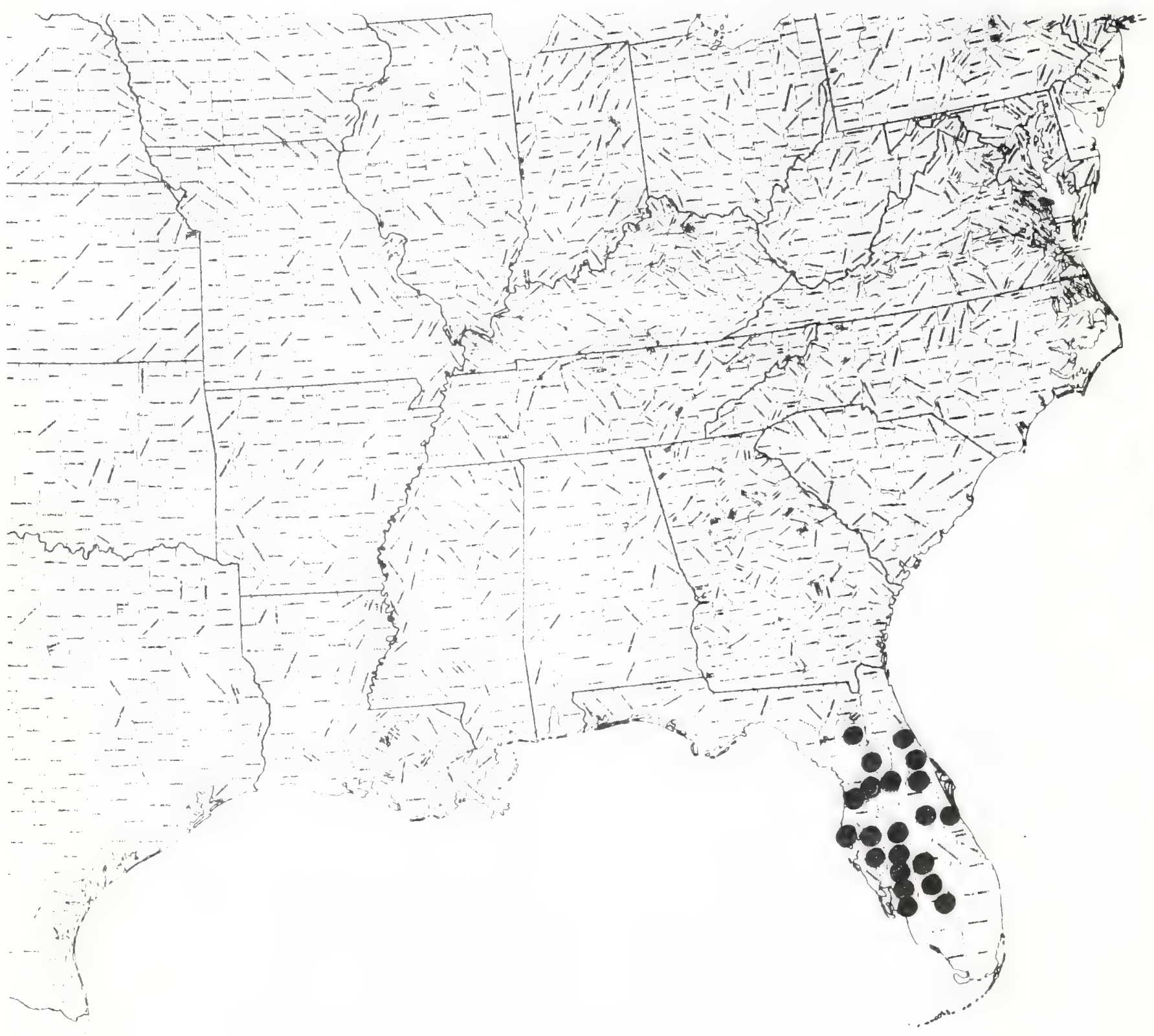


Paper IS4

Text \& map by:

Robere $\mathrm{RT}$ T3

\section{IIICIACERE}

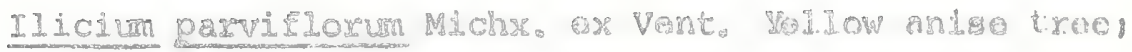
stax and ge

Technical Description

Large shrub or small tree to 7 meters erom a shallowil spreading root system.

Sterns.--The trunks single or several from the root, erect or leaning outward, the bark grayish-brown, smoothish, the fresh wood, twigs, leaves and flowers smelling of licorice. Branching slender and Forising, the newer shoots slender, smooth, greenishabrown or tan, leafy only toward the tips.

Ieaves.-Alternate in close spirals, persistent, spreading-ascending on greenish, grooved, slender petioles $2-3 \mathrm{~cm}$ long, the blades oblanceolate or elliptic, the largest mostly $10-15 \mathrm{~cm}$. long, leathery, acute but bIunt and rounded-tipped, the marging entire, very slightly erarginate, the base narrowly cuneate or attenuate, the upper surface a dark, glossy green, the lower surface paler, finely pale glandwotted, only the midrib prominently raised.

Inflorescence. -Flowers I-few, set in the teminal clusters of leaves on slender, pale, greenish spreading or erect stalks to $3 \mathrm{~cm}$ long, symetrical, about $2 \mathrm{~cm}$ across.

Flowers.--Sepals 3-6, ovate, greenish, under 1 cin long. petals numerous, ovate or oblong, about $1 \mathrm{~cm}$ long, yellowish, spreading, stamens numerous, ca. $3 \mathrm{~mm}$ long, the filanents broad as the anthers, linear, somewhat flattened, spreading to form a ring: anther sacs 2 shortwoblongo Carpels numerous, forming a ring, at first erect, tapering to narsow, outward pointing tips. Fruit.mollicles spreading like the rays of a star, the whole cluster about $2 \mathrm{~cm}$ broad, splitting along the upper edge each to release a single brown shiny seed.

Distribution and Flowering season

Low hammocks along streams, northeastern peninsular florida. Flowering in May, June.

Special Identifying Features

This unique tree is confined to the tributary systems of the lower st. Johns River. It is distinguished from the more widespread I. floridarum by its leaf tips which are blunt rather than sharply acute or acuminate, by its smaller, greenish-yellow flowers, by its somewhat smallex fruit.

Habitats and Management Implication

I. parviflorum is typically a plant of low hamocks on sandy loams or sandy peat mucks, in short on soils that are continuously moist. It is entirely within a karst country generally along sandyobottomed clear 
streams that arise from limesinks, usually in the shade of larger trees such a: Magnolia virginiana, willow oaks, occasionally cypress, gum and associated with waxmyrtle, Lyonia, cabbage and saw palmetto, Ilex cassine, Cyrilla, Persea, Gordonia, etc. and never reaches up into the contiguous stands of upland evergreen scrub oak, scrub pine or longleaf. It is thus an understory small tree, quite shade tolerant, its reproduction scant, succeeding on moist, highly organic, shaded soils, alth ugh it may be cultivated in full sun. Drainage or cutting, particularly clear-cutting, would be detrimental. The trees, sometimes sold as I. anisatum, have been conmercially exploited and are rare and local enough to comprise a truly endangered species.

References

Small, J. K. 1933. Manual of the southeastern flora, Pp. 533-534. Chapel Hill, N.C.

Stone, D. E. and Judith I. Freeman. 1968. Cytotaxonomy of Ilicium

floridanum and I. parviflorum (Iliciaceae). Journ. Arn. Arb. 49(I): 41-51. 
SPECIES: \#I44 Ilicium parviflorum Michr\%。 ex Vent。 Star-anise

\begin{tabular}{|c|c|c|c|c|c|c|c|c|}
\hline & \multicolumn{8}{|c|}{ Management Practices } \\
\hline $\begin{array}{l}\text { Expected* } \\
\text { Effect on } \\
\text { the Species }\end{array}$ & $\begin{array}{c}\text { Prescribe } \\
\text { Burn }\end{array}$ & $\begin{array}{c}\text { Bulldoze } \\
\text { or } \\
\text { Root Rake }\end{array}$ & Bed & Chop & $\begin{array}{l}\text { Thin } \\
\text { over- } \\
\text { story }\end{array}$ & $\begin{array}{l}\text { Cut } \\
\text { Over- } \\
\text { story }\end{array}$ & $\begin{array}{l}\text { Establish } \\
\text { Plantation }\end{array}$ & Graze \\
\hline Destroy & & $x$ & X & $x$ & & $\mathrm{X}$ & & \\
\hline Damage & & & & & & & NA & ? \\
\hline $\begin{array}{l}\text { No Lasting } \\
\text { Effect }\end{array}$ & INA & & & & $\mathrm{x}$ & & & \\
\hline $\begin{array}{l}\text { Beneficial } \\
\text { if Done } \\
\text { Properly }\end{array}$ & & & & & & & & \\
\hline
\end{tabular}

\section{Other Comments:}

*Expected effect on the species is an estimate made by Dr. Robert Kral based on his knowledge of the habitat and on knowledge gained from personal field observations. Estimates are "rough" in many instances. Results of practices may be modified depending upon the degree of application, intensity of treatment, nearmess to plant commities, etc. A management practice for which no entry is made indicates a lack of sufficient information from which to predict expected results. As observations are made in the field by users of the data, the expected effect will be refined. 
Ilicium parviflorum Michx. ex Vent.

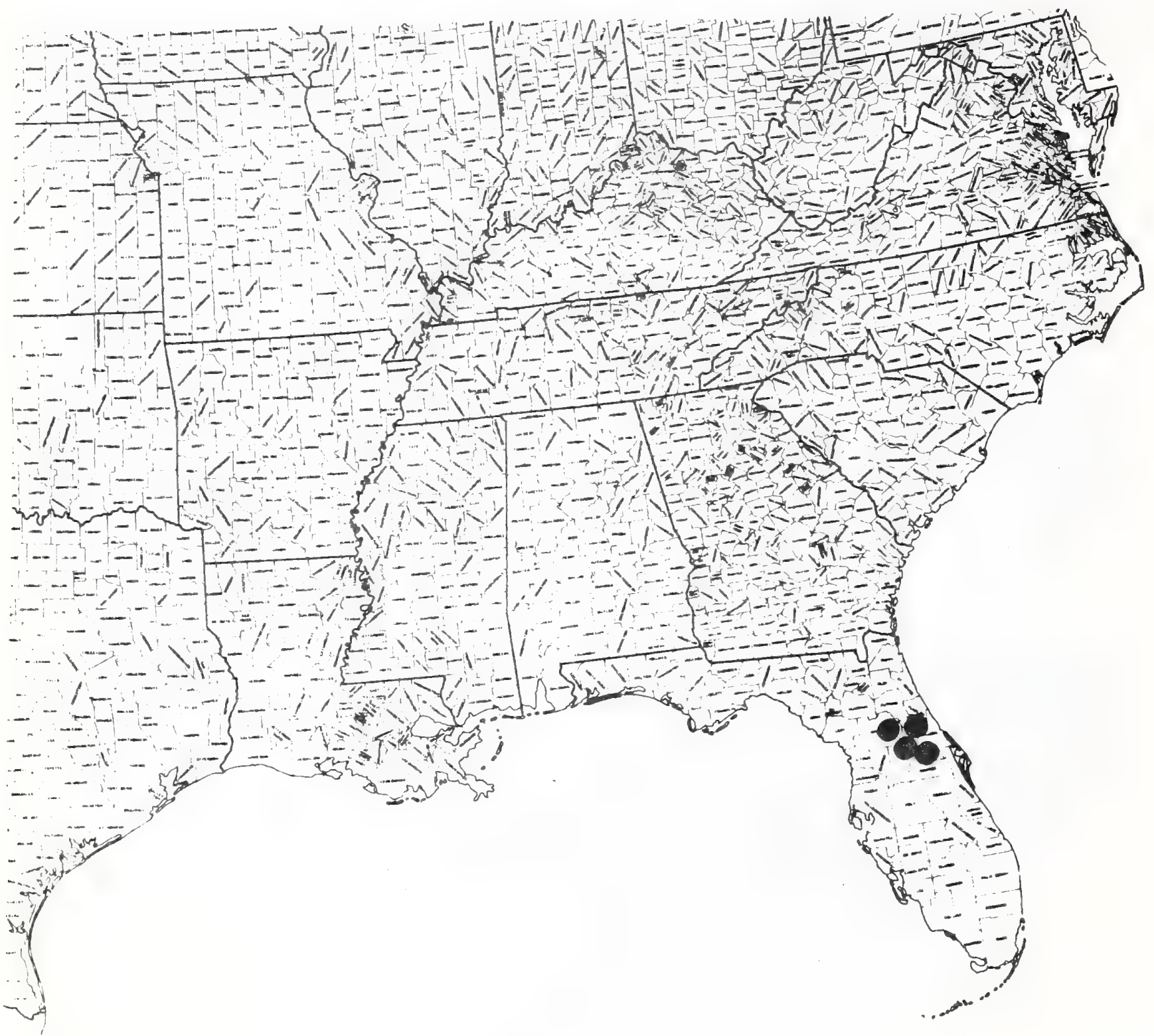


Paper 149

Taxt \& map by:

Robert Rral.

\section{PORYGONACEAE}

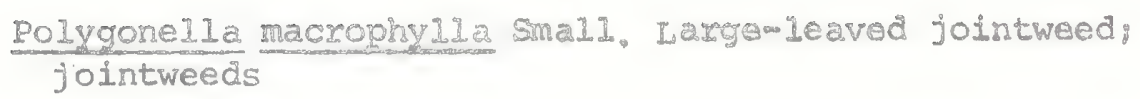

Technical Description

Shrublike perennial.

Stems.--The one to several shoots stiffly erect from a strong taproot, to more than a meter tall, glabrous, round in cross section, but finely ribbed, reddish-brown to gray-green, simple or with short erectish leafy lateral branches and branching in the inflorescence.

Leaves.-Numerous, alternate, ascending or exect, the lowest largest, mostly obovate, cuneate or broadly spatulate, mostly $2.5-6.0 \mathrm{~cm}$ long, $1.0-2.5 \mathrm{~cm}$ broad, flat, rather leathery, the tips rounded, the margins entire, often pale, the base cuneate, sessile or nearly so. Ocreae short-cylindric, firm, dark to pale brown, entire. Stem leaves gradually reduced in size upward, grading into bracts.

Inflorescence. - A dense to somewhat open system of ascending or spreading sessile racemes (sometimes branched), these short-oblong or ovate in outline, with broadly funnelform, overlapping ocreolae.

Flowers.-Mostly bisexual, on slender stalks projecting from the ocreolae, terminating in a narrow perianth tube that gradually expands upward, then flares into the 5 calyx segments (the longest about $3.0-3.5 \mathrm{~mm}$ long); the three outer sepal lobes broadest, with short claws and broadly ovate or obovate to suborbicular blades which are white at blooming time; inner sepal lobes narrower: all calys lobes erect or sIightiy spreading in bloom, spreading or even reflezed in fruit. Stamens 5, about as long as the sepals in bloom, the white filaments lineal, some broader than others, the anthers white or yellow roundish. Ovary lance-ovoid, trigonous, its tip producing 3 narrow district style branches and stigma buttoms. Fruit.--Akene lance-ovate, strongly trigonous, about $3 \mathrm{~mm}$ long, pale yellow brown, smooth, lustrous.

Distribution and Flowering Season

This species is local on the white sands of clearings in the sand pineevergreen scrub oak toward the coast of the Florida Panhandle and in Baldwin County Alabama. It flowers in late Fall (mostly October) and fruits in November.

Habitats and Management Implication

P. macrophylla is always on deep, white sands, either on clearings in the sand pine scrub or in open stands of overstory. It is associated with such shrubby genera as Ceratiola. Conradina (an aromatic, blueflowered, shrubby mint), Calamintha, and sandhilis herbs such as Balduina, Heterotheca, Andropogon, Panicum, Aristida, Acalinis. Much of this evergreen scrub complex is being leveled for the purpose of housing and such would of course eliminate the species. Some other areas of it are being clearcut and put to slash pine or longleaf pine, and the species may at first 
increase in these areas until such time as the crowns of the pines close. In nature the species probably maintained itself through fire disturbance sufficient to make clearings in the scrub.

References

Small, J.K. 1933. Manual of the Southeastern Flora, page 449. Chapel Hill, N.C. Horton, J.H. 1963. A taxonomic revision of Polygonella(Polygonaceae). Brittonia 15: $\quad 177-203$ 
SPECIES: \#I49 Ploygonella macroplyylla smaIl jointweed.

\begin{tabular}{|c|c|c|c|c|c|c|c|c|}
\hline & \multicolumn{8}{|c|}{ Management Practices } \\
\hline $\begin{array}{l}\text { Expected* } \\
\text { Effect on } \\
\text { the Species }\end{array}$ & $\begin{array}{c}\text { Prescribe } \\
\text { Burra }\end{array}$ & $\begin{array}{c}\text { Bulldoze } \\
\text { or } \\
\text { Root Rake }\end{array}$ & Bed & Chop & $\begin{array}{l}\text { Thin } \\
\text { overo } \\
\text { story }\end{array}$ & $\begin{array}{l}\text { Cut } \\
\text { Over- } \\
\text { story } \\
\end{array}$ & $\begin{array}{l}\text { Establish } \\
\text { Plantation }\end{array}$ & Graze \\
\hline Destroy & & $\mathrm{X}$ & & $x$ & & & & \\
\hline Damage & $\mathrm{X}$ & & $\mathrm{NA}$ & & & & $\begin{array}{r}\text { If } \\
\text { Sand }\end{array}$ & \\
\hline $\begin{array}{l}\text { No Lasting } \\
\text { Effect }\end{array}$ & & & & & & & $\begin{array}{l}\text { Pine } \\
\mathrm{OK}\end{array}$ & $?$ \\
\hline $\begin{array}{l}\text { Beneficial } \\
\text { If Done } \\
\text { Properly }\end{array}$ & & & & & $x$ & $X$ & & \\
\hline
\end{tabular}

\section{Other Comments:}

*Expected effect on the species is an estlmate made by Dr. Robert Kral based on his knowledge of the habitat and on knowledge gained from personal field observations. Estimates are "rough" in many instances. Results of practices may be modified depending upon the degree of application, Intensity of treatment, nearmess to plant comunites, etc. A management practice for which no entry 18 made indicates a lack of sufficient incormation from which to predict expected results. As observations are made in the field by users of the data, the expected effect will be refined. 
Polygonella macrophylla small

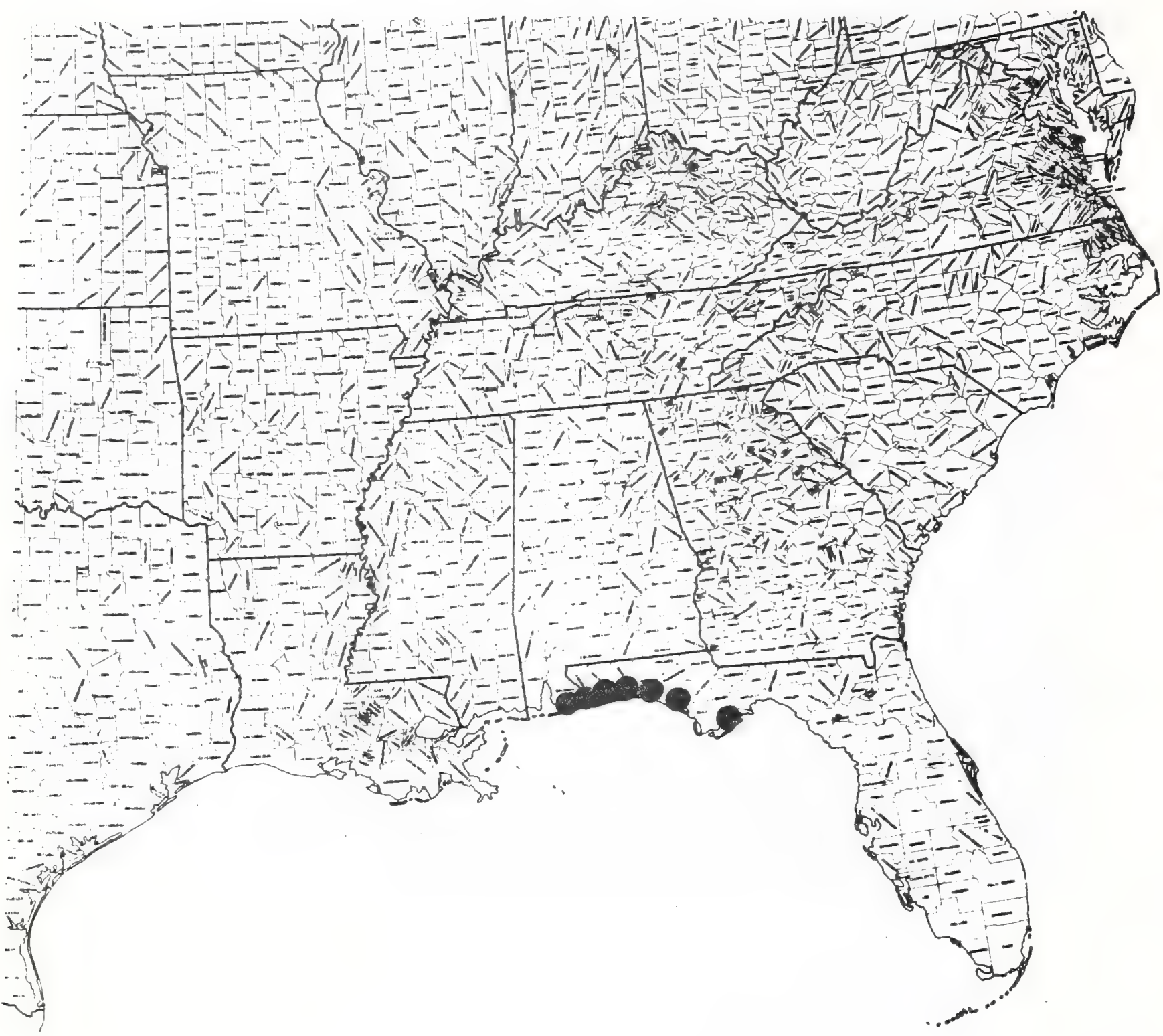


Paper 151

Test \& map by:

Robert Rral

\section{RANUNCUEACEAE}

Cimicifuga rubifolia Kearney. Appalachian bugbane: Bugbane

Technical Description

Tall, but rather slencier perennial herb, to 1.5 meters, the single.

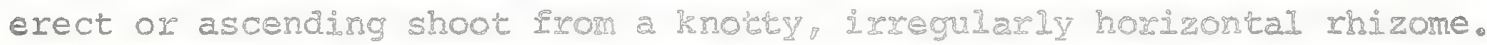

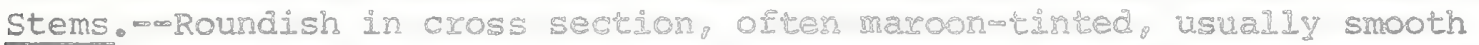
or with a villous-hairy line, usualy unbranched and wand-Iike in flower. Leaves.m-Few, concentrated toward the stem-base, the petioles elongate, sheathing the stembase, 3-branched, with each bramch again 3-branched (ternate), the leaflets symetrically or asymetrically ovate co orbicular prominentiy $3 \times 5(\infty 7)$ lobed (rich as in Red Maple is size and outine) to $1.2 \mathrm{dm}$ long on petiolules slightiy shorter, the lobe tips acuminate. the margins coarsely and irregularly serrate, the bases usualiy cordate, the upper surfaces deep green, smooth, the lower suriaces paler, smooth or with some long, crisped hairs on the raised veins. Inflorescence。m elongate, teminal openly cylindrical raceme of whitish flowers, the axis puberulent. Elowers.-Symetrical: sepals $2-5$, falling off when or shortly after the bud opens, ovatewsuborbicular. yellowishowhite, smooth, ciliate or entire. Petals absent. stamens numerous, on a slightly elevated receptacle, the filments white, filiform but slightly broadening upward, the anthers short, yellowishowhite. Carpels no more than 2, sessile on the receptacle.

Fruit,-Asymetrically oblong, $8010 \mathrm{gm}$ long, somewhat flattened, veiny, the numerous sma11 seeds charfy, irs 2, irsegular cows.

Distribution and Flowering Season

This species occurrs sporadically in the Ridgemand Jalley, Cumberland Plateau, and Eighland Rim in northeascern Llabama, Tennessee, and Virginia. It flowers mosty in the eariy fald.

Special Identifying Features

Taxonomically it is closest to C. racemosa in that it has no more than 2 carpels and its seeds are in more than one rono It is distinguished from that species by (a.) its much later Elowering habit (C. racemosa flowers in early sumer) (b.) its larger, broader, more 10bed leaflets which are strongly corbate- based (co) its shoreer fod m in contrast to $8 \mathrm{~mm}$ ) filaments and (2.) its longer (8-10 mm in contrast to $5-7 \mathrm{~mm}$ ) follicles.

Habitats and Management Implication

This rather rare species is found in rich, well-drained, loamy soils in open, mixedmesophytic, forested slopes. Mypically these are soils formed over limestones or calcareous shales and are moist, never wet, 


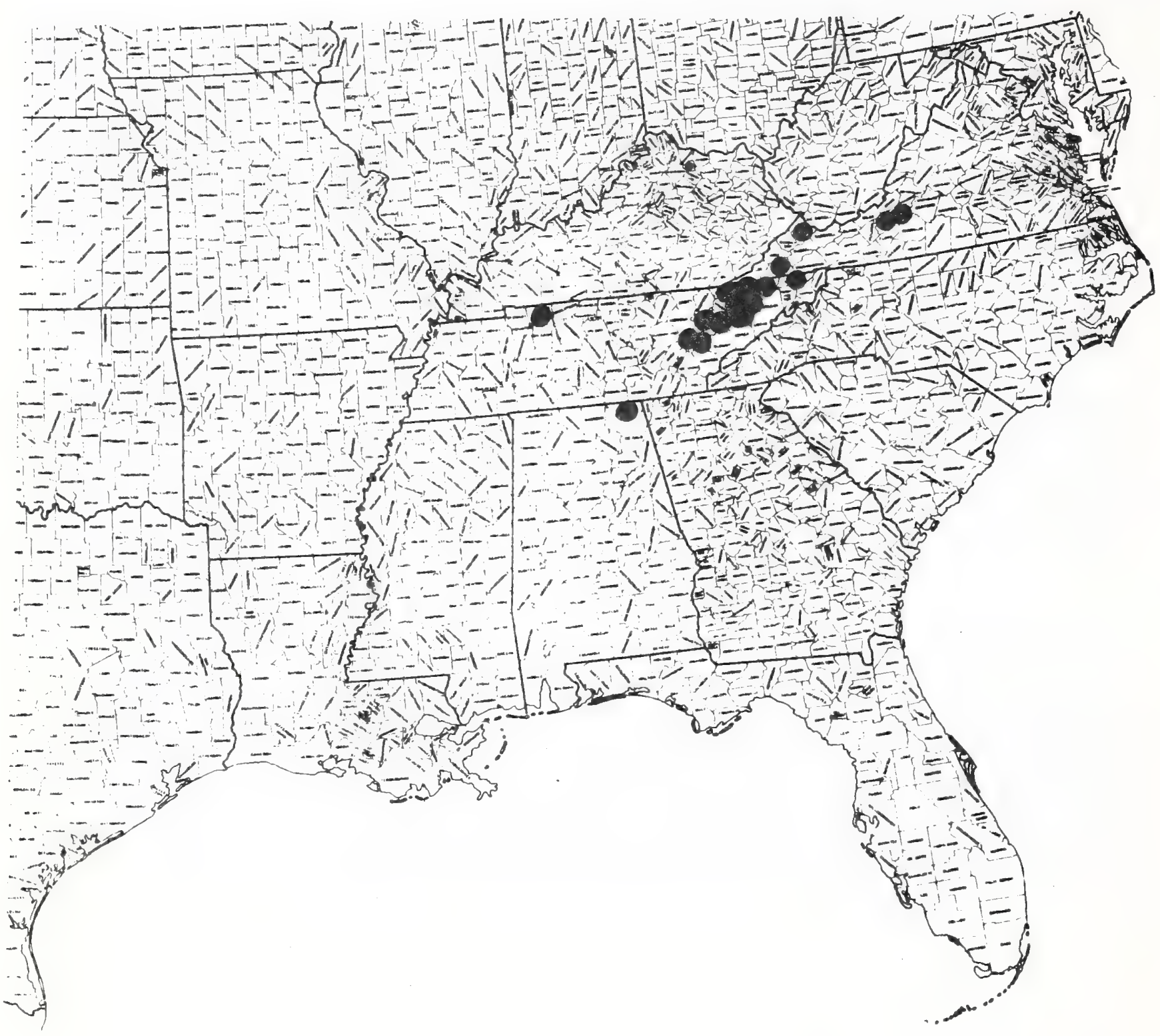


Paper 152

Text \& map by:

Robert Kral

\section{STEMONACEAE}

Croomia paucielora (Nutt.) Torr. few-flowered

croomia: Croomia

Technical Description

Smooth perennial herb forming large clones by means of shallow, pale, elongate rhizomes.

Stems.--Erect, terminating rhizomal branches, mostly $1.5-3.0$ dm tall, slender, round, about $3 \mathrm{rm}$ thick, greer, often with tints of red, the lower part loosely sheathed by scale-like leaves, otherwise leafless to near the sumit, there with $4-6$ spreading leaves.

Ieaves.-Alternate but often so close-set as to appear whorled (the plants look very much like some of the herbaceous smilax:!). Leaves spreading in all directions on petioles mostly $2-3 \mathrm{~cm}$ long, the blades ovate, elliptic or oblong, mostly $6-10 \mathrm{~cm}$ long, thin, yellowmgreen, acute or short-acuminate, entire, the bases cordate or auriculate, the veins palmate.

Inflorescence.-Flowers small, actinomorphic, about $0.5 \mathrm{~cm}$ across, usually I-2 cm toward the sumit of slender spreading or nodding stalks $2-3 \mathrm{~cm}$ long from the leaf axils, the stalk usually with I small, thin bract at or above its middle, this subtending the lower flower if there is one, this lower flower on a shortish pedicel $2-5 \operatorname{mm}$ long. Flowers.-mperianth greerish, of 2 sepals and 2 petals, these alike except for position, spreading horizontally, fused at their bases, narrowly ovate, 3.5-4.5 min long, acute, entire, stamens erect, 4, distinct, the filaments stout, oblong, 1.0-1.5 mm long, bowed slightly inward, the yellow anthers oblique on the filament sumits, short-oblong, their bases pointing inward. Ovary superior, ovoid, between 0.7 and $0.9 \mathrm{~mm}$ long, greenish, 1-celled with few ovules and with a fleshy sessile stigma. Fruit.--A somewhat fleshy, 2-valved ovoid, greenish capsule about $1 \mathrm{~cm}$. long or slightly longer, with the perianth persisting around its base. seeds few.

Distribution and Flowering Season

Rich loamy soils over limestone, usually in shade of mixed hardwoods, southern and western Georgia through most of the calcareous districts of Alabama in the Appalachian trend and southward infrequently into

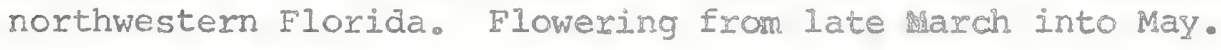

special Identifying Features

As mentioned in the description, Croomia plants vegetatively look much like some of the smaller herbaceous smilax but differ in having fewer perianth segments, fewer stamens, and having the fruit a capsule rather than a berry.

Habitats and Management Implication

Croomia plants are almost always found on moist, very humifiea, well drained circumeutral soils under rich deciduous forest, mostly in 
the mixed mesophytic type. They are invariably in association with such spring flowering herbs as Trillium, Hepatica, Sanquinaria, Erythronium, Actaea, Podophyllum, Dentaria. There they form scattered but quite large clones consisting often of hundreds of stems. Like so many other spring herbs of this type which flower before the overstory canopy is full they tend to die back to the root toward the summer.

Selective logging of the mixed mesophytic overstory would probably not much effect this species. Heavy logging or clear cutting with the attendant heavy soil disturbance and erosion, particularly also with the admission of more light with subsequent heating and drying of the soil would eliminate this plant. Such would either be through changing of the soil by lowering humus content as well as fertility, or through promotion of light tolerant woody weeds such as Smilax, Rubus, Ionicera, etc. which would crowd out the plants. The plants, probably more through trampling and subsequent erosion, do not hold up well when the forest is opened to grazing livestock. Thus, either through excessive timber cutting or conversion of woodlots to pasture, the distribution of Croomia within its range has been drastically reduced.

References

Small, J. K. 1933. Manual of the Southeastern Flora, p. 309. 
SPECIES: \#152 Croomia pauciflora (Tutt.) Torr.: Croomia

\begin{tabular}{|c|c|c|c|c|c|c|c|c|}
\hline & \multicolumn{8}{|c|}{ Management Practices } \\
\hline $\begin{array}{l}\text { Expected* } \\
\text { Effect on } \\
\text { the Spectes }\end{array}$ & $\begin{array}{c}\text { Prescribe } \\
\text { Burn }\end{array}$ & $\begin{array}{l}\text { Bulldoze } \\
\text { or } \\
\text { Root Rake }\end{array}$ & Bed & Chop & $\begin{array}{l}\text { Thin } \\
\text { over- } \\
\text { story }\end{array}$ & $\begin{array}{l}\text { Cut } \\
\text { Over- } \\
\text { story } \\
\end{array}$ & $\begin{array}{l}\text { Establish } \\
\text { Plantation }\end{array}$ & Graze \\
\hline Destroy & & & & & & $\mathrm{X}$ & & \\
\hline Damage & & & & & & & NA & \\
\hline $\begin{array}{l}\text { No Lasting } \\
\text { Effect }\end{array}$ & NA & & & $\rightarrow$ & $x$ & & & \\
\hline $\begin{array}{l}\text { Beneficial } \\
\text { if Done } \\
\text { Properly }\end{array}$ & & & & & & & & \\
\hline
\end{tabular}

\section{Other Comments:}

* Expected effect on the species is an estimace made by Dr. Robert Kral based on his knowledge of the habitat and on knowledge gained from personal field observations. Estimates are "rough" in many instances. Results of practices may be modified depending upon the degree of application, intensiry of treatment, nearness to plant comurities, etc. A management practice for which no entry is made indicates a lack of sufficient information from which to predict expected results. As observations are made in the field by users of the data, the expected effect will be refined. 
Croomia pauciflora (Nutt.) Torr.

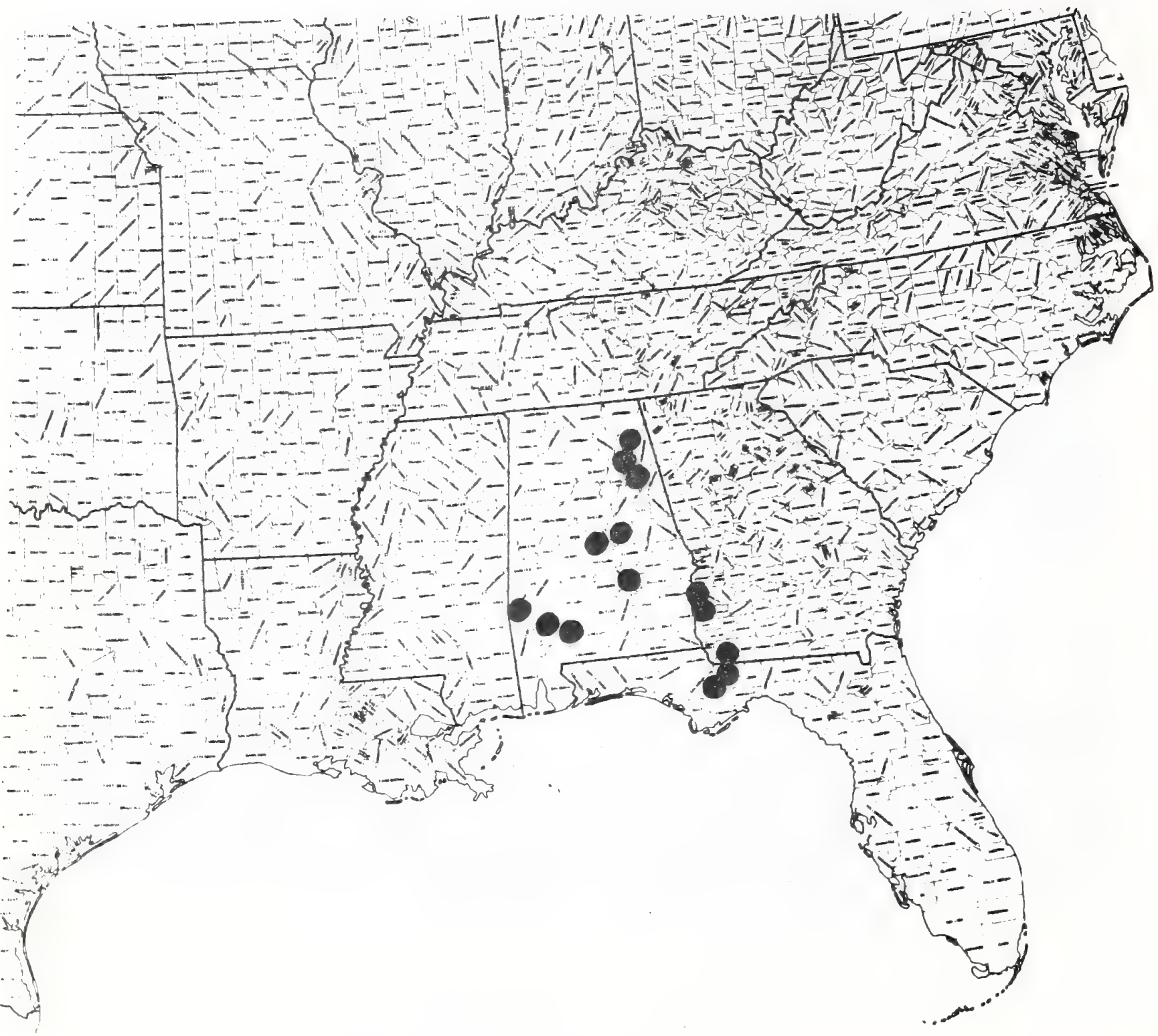


Paper 153

Test of map by

Roberts Rre

RYRTDRCERE

$\frac{\text { Byris }}{\text { Yellowmondi Reyed grass }}$

Technical Description

A Low, very tufced, herbaceous plant, usualy with the bases buried in peat or sand.

Ieaves.-Broadly Iinear or lanceolate, 3 - crin long, acute, mostiy entire, the blades greenish but each with a shaning dark brown "patch" at the base, and all arranged in a small far (resembing leaf arrangement in Iris but tiny!

Inflorescence - Scapes slendex (1inearofiliform) but stifily erect. 4-20 cm long, low wabed, the scape sheathes with learmike blades and about as long as mosi of the leaves, spikes manyw flowered, terminal and solitary on scapes, each resembling a small cone, lancemovoidg mostly 8 mi. long or slightly less, sharpotipped, somewhat laterally flattened. Bracts several, spiraliy arranged or in 2 ranks, the lowest sterile, sometimes with green narrow tips, the rest rextile, nearly round to obovate, keeled (appearing Eolded, the midmio along the angle) and each brownish with an elongated narrow Iy eldigtical ow lanceolate dorsal area (a greenish area different in cesture and along the midorib of the scalel.

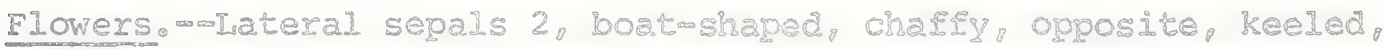
with the keel margir ciliace (there is a 3ra sepal, this a membrane that covers the flower in buc and falls orf when the petals expand) getals 3 , clawed, yellow, the biades spreacine in moming, obovate, about 3 mm long. staminodes 3. rlat and slender bolow, above branching and covered with a brush of slender, long, yellowigh hairs. stamens 3 atrached toward base of petal blades.

Fruit.-Capsule clasped by the lateral sepals, thirmwaled splitting Iongitudinally. Seeds numerous, attached in 3 longitudinal rones on inside of capsule, elipsoldal, about 0.3 man Long, Finely ribbed.

Distribution and Maragement Impication

Moist to wet acid sands or sandy peats of bogs and seeps in the coastal Plain Ixom southeast Georgie westwat through northmestern Forida and south Alabama to southern Mississippi and Louisiane Flowering Eron July through september.

Special Identifying Features

This is in a comples of litrie species such as and $x_{0}$ brevifolia which superficially look wuch idke ito However. those two species flower mostly in spring and early sumer while this one flowers in sumer and fald. Also this is the only one in the complex that has the distinctive, chegtrutabrown patch at the leaf base and the definitely laterally flattened spike. 
X. drumondii is always a plant of bogs or boggy places where the soil moisture is high. It is always in full sun and should be found usually where seepage has created exposures of wet fine sand and peat, there in association with other bog species of Dros ma, low Panicum. Eriocaulaceae (Pipeworts), Rhexia. Small pitcher plant bogs in slash longleaf and pond pine flats are ideal situations. In that such areas have histories of fire and in that fire tends to reduce overgrowth of shrub understory species of Ilex, Myrica etc. that would otherwise take the habitat, it is to be assumed that this is a part of the grass-sedgeforb complex that makes up fire disclimax. The species is often found in areas where clear-cutting of pine accompanied by considerable disturbance of soil has occurred in addition to (frequently) ground fire. However, in areas where clear-cutting or other logging or site preparation has occurred and also drainage, the species disappears. Obviously its major enemy is drainage, not logging of assiciated overstory or mechanical site preparation. However, while it will occur in plantations where the young trees are on elevated "strips", it will not persist after the crowns have closed.

Reference

Kral, R. 1966. Xyris of the continental United States and Canada, sida 2 (3): $17 \overline{7-260}$. 
SPECIES: \#153 Xyris drumondi Malme. Yellow eyed grass

\begin{tabular}{|c|c|c|c|c|c|c|c|c|}
\hline \multicolumn{9}{|c|}{ Managenent Practices } \\
\hline $\begin{array}{l}\text { Expected* } \\
\text { Effect on } \\
\text { the Species }\end{array}$ & $\begin{array}{c}\text { Prescribe } \\
\text { Burn }\end{array}$ & $\begin{array}{c}\text { Bulldaze } \\
\text { or } \\
\text { Root Rake }\end{array}$ & Bed & Chop & $\begin{array}{l}\text { Thin } \\
\text { over- } \\
\text { story } \\
\end{array}$ & $\begin{array}{l}\text { Cut } \\
\text { Overo } \\
\text { scory } \\
\end{array}$ & $\begin{array}{l}\text { Establish } \\
\text { Plantation }\end{array}$ & Graze \\
\hline \multicolumn{9}{|l|}{ Destroy } \\
\hline Darmage & & & & & & & & $\mathrm{X}$ \\
\hline $\begin{array}{l}\text { No Lasting } \\
\text { Effect }\end{array}$ & & $?$ & $x$ & $?$ & & & & \\
\hline $\begin{array}{l}\text { Beneficlal } \\
\text { Lf Done } \\
\text { Properly }\end{array}$ & $\mathrm{X}$ & & & & 8 & $\mathrm{X}$ & & \\
\hline
\end{tabular}

Other Coments: Drainage the problem

* Expected effect on the species is an estimate made by Dr. Robert Kral based on his knowledge of the habltat and on knowledge galned from personal field observarlons. Estimates are "rough" in nany instances. Results of practices may be modified depending upon the degree of application, intensity of treatment, neamess to plant comunlties, etc. A management practice for which no entry is made indicates a lack of surifientenformation from which to predict expected results. As observations are made in the field by users of the data, the expected efrect will be refined. 
Xyris drummondii Malme

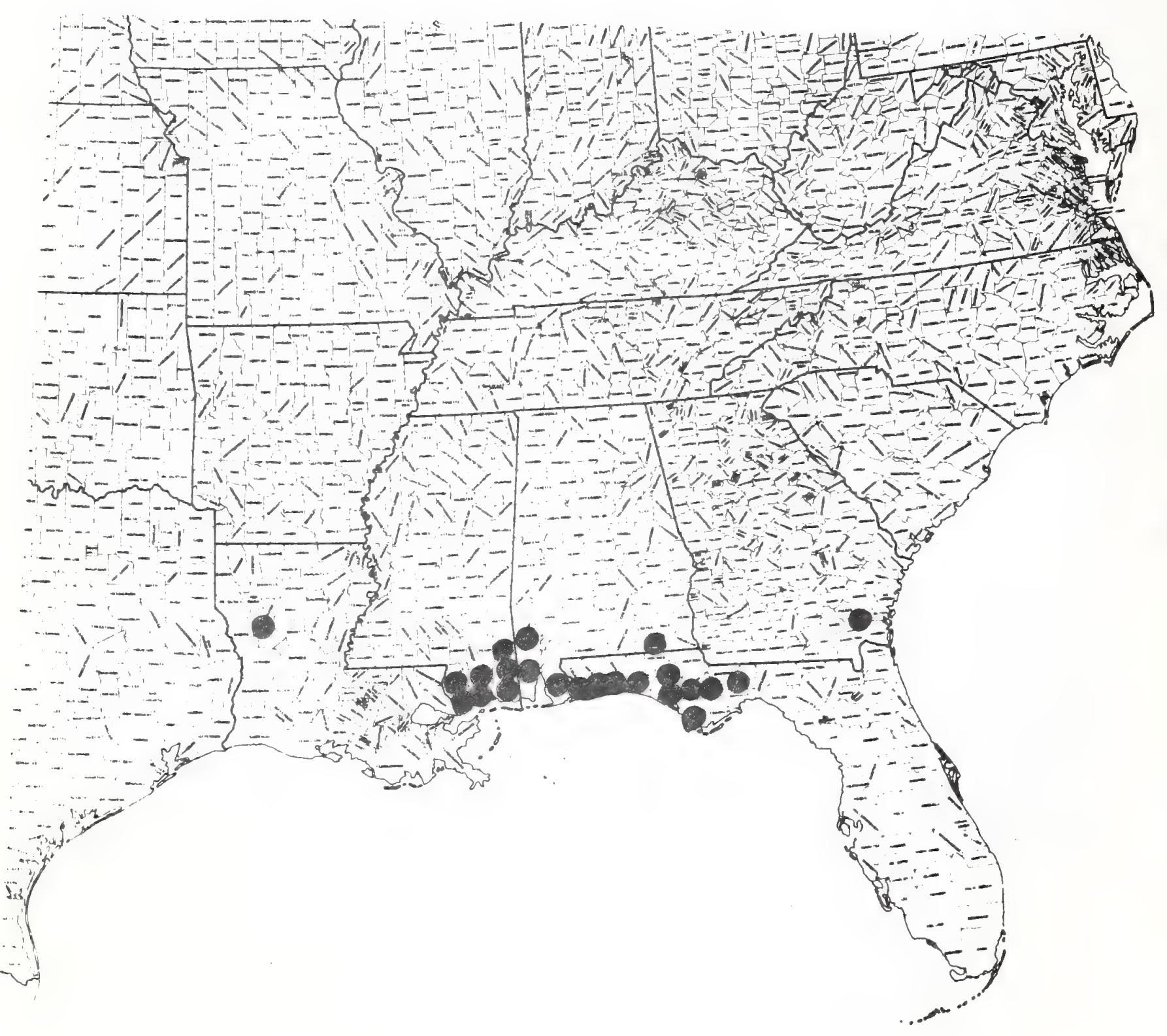


Baper 154

Tasse \& map by:

Rotiont Rised

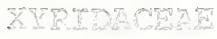

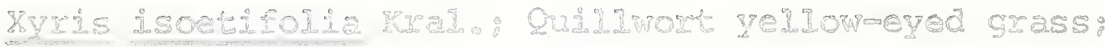
Yellowmesped grass
\end{abstract}

Technical Description

Similar to $x$ a drumondis but talisz.

Leaves mensley tuffed, very slender telidformi to $15 \mathrm{~cm}$ long, the narrow blades pale green, the bases broader. brownish

and chafey.

Inflorescence w whe Elowering stalke (scapes) are nasrowly Iinear, to $30 \mathrm{~cm}$. long, are stiffly erect, in cross section oval or round and each has a bladed sheath shorter than the leaves (the sheath biade similar to the leaf bladel. Each scape teminates in a single cone-like spike, this 4m m long, ovold or elilpsoldal, acnte or blunt, of many tightig overm lapping acaley, chatry bracts, the lower 203 sterale (without flowers in axils) the rest fertile. Fertile bracts orate or obovate, about $5 \mathrm{~m}$ m m long, scale-like, the apices rounded the rargins enire, che backs rounded. brown or reddish brown. wh dull green dorsal areas.

Flowers, whe lateral sepals, hidder by subtendirg bracts are similar to X. Irumondil, being boat-12ke, chafEY, the keels ciliate. Petals with blades projecting beyond the subtending bract: unfolding and spreading in the moming, yellow, obovate, ca. 4 ma long. Stamens and staminodia as in the preceding.

Fruit. - Capsule similar to the preceding. Seeds somewhat larger, about 0.5 min long, faintig ribbed.

Distribution and Flowering season

Moist sands or sandyomeats of savarma bogs, llatwoods pond maxgins, shores of limesink ponds and lakes, northwest Forida (Bay and GuIf Counties). Flowering from suly into septeriber.

Special Identifying Features

X. isoetifolia strongly resembles in its tufted habit, leaves and spikes

$X_{\text {. }}$ Ealdwiniana, a species widespread in the coastal. Plain from eastern

$\mathbb{N}_{*} C_{.}$sourh to Fla and weot into easterm Texas. It differs mostly in having ciliate keels on the lateral sepals and in having a beard of hairs on the staminodes (these are lacking in X. baldwini.ana).

Habitats and Management Implication

X. isoetifolia appears to be restricted to the karst country of northwest Florida, either directly around the ponds and lakes formed by "sinks" or in the poorly arained flatwoods surrounding. In either case it is comonly in full sun and associated with grass-sedge bog species of herbs. It may locally alound where wash has produced expanses of wet peaty sand and has been observed in abundance where plne flatwoods have been logged so as to 
create wet openings. It is another species of fire disclimax, probably incroased through reduction through fire of competing woody plant species and the rough they create, but definitely reduced or eliminated where drainage is created.

Reference

Kral, R. 1966. Xyris of the Continental United States and Canada, Sida 2(3): 177-260. 
SPECIES: \#154 Xyris isoetifolia Kral Yellow-eyed grass

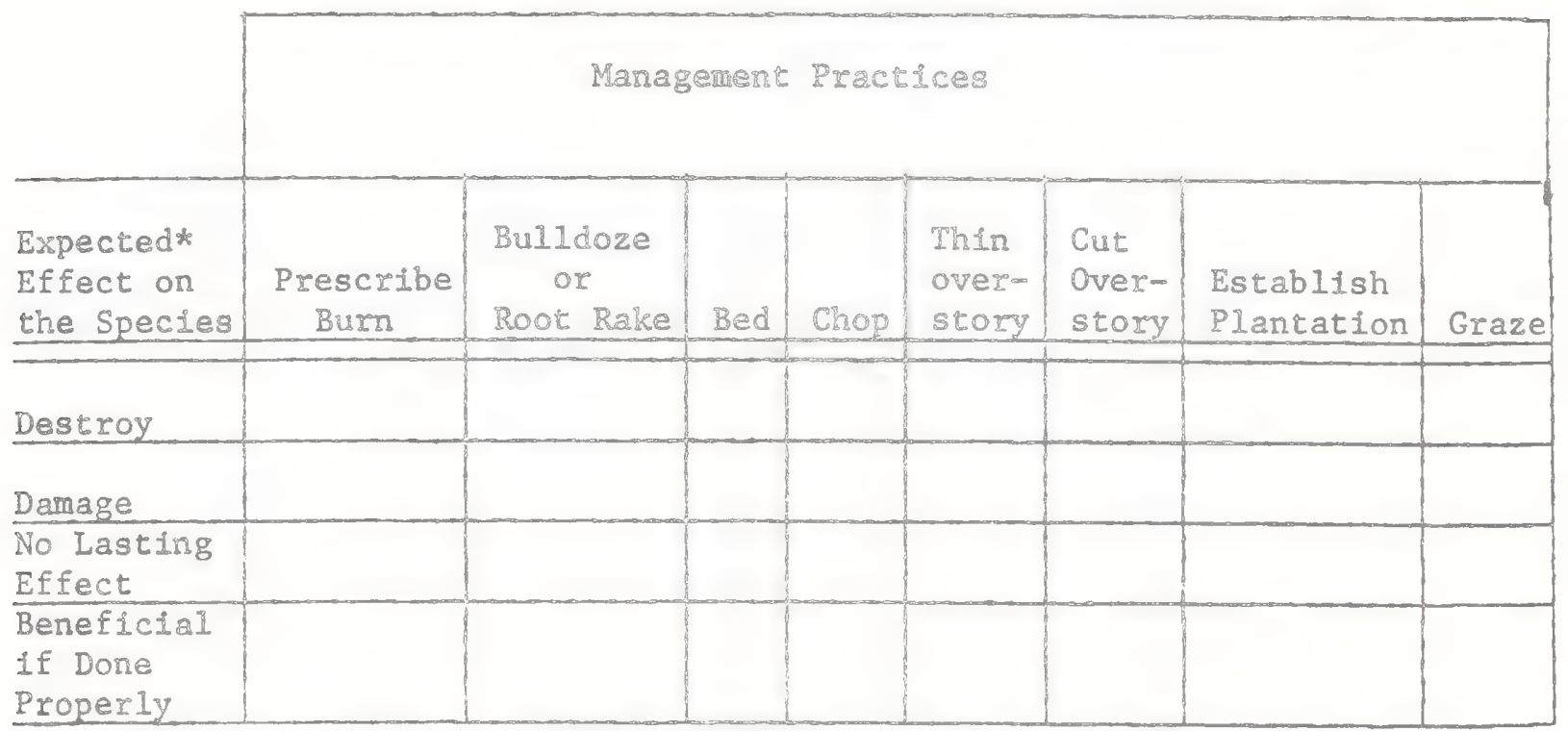

other Comments: Drainage the problem, also shade.

*Expected effect on the species is an estimate made by Dr. Robert Kral based on his knowledge of the habitat and on knowledge gained from personal field observations. Estimates are "rough" in many instances. Results of practices may be modified depending upon the degree of application, intensity of treatment, neamess to plant commities, etc. A management practice for which no entry is made indicates a lack of suficient information from which to predict expected results. As observations are made in the field by users of the data, the expected eifect will be refined. 


\section{Xyris isoetifolia Kral}

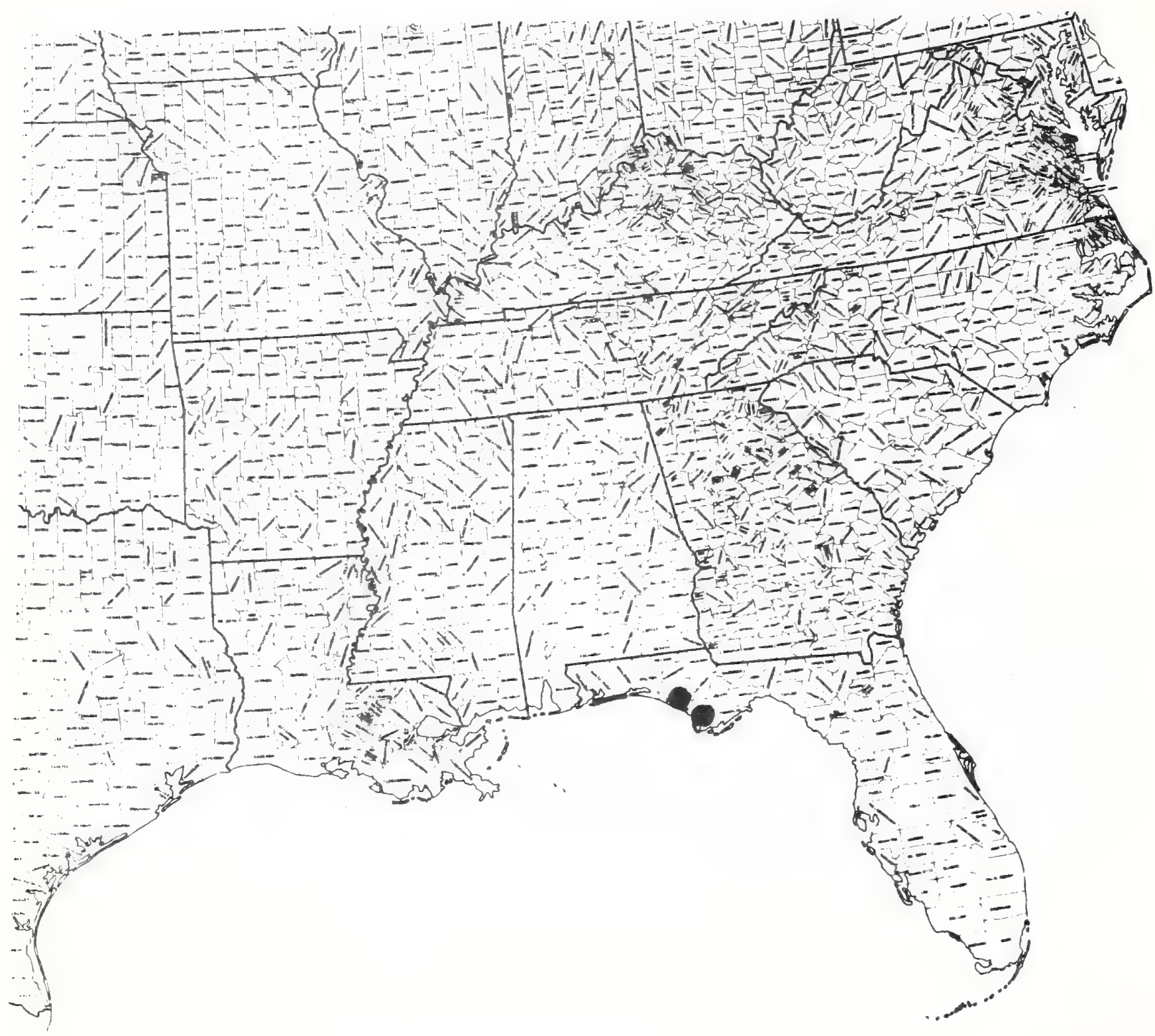


Paper 155

Tert \& map by:

Robert Rrad.

\section{KYRIDACRRE}

$\frac{\text { Xyris longisepale Rral. Rral's yelloweyed grass: }}{\text { Yelloweyed grass }}$

Technical Description

similar to the preceding but tallex, coasser. Less tusted. Leaves.--inear, to $25 \mathrm{~cm}$ long, 2 min broal, acute, mostly exect, smooth, the blades greenish, the sheathing bases usually with touches or pink or maroon.

Inflorescence maflowering stalks (scapes) mostly $4 m 8 \mathrm{~cm}$. tall, slenderly linear and sometimes twisted, toward the tips somewhat flattened and strongly l-edged. Scape sheathes shorter than the leaves, with shortish blades. Spikes ellipsoidal to oblong. $1.0-1.6 \mathrm{~cm}$ long, blunt, of many, loosely overlapping bracts. Fertile bracts broadiy oblong, 4-6 mm long, the tips rounded, the margins entire, the backs rounded, tan with a pale greenish or reddish-brown dorsal area. Flowers and Fruit.-materal sepals Iinearocurvate, silghtly longer than the subtending fertile bract and thus whth tips projecting beyond (exserted); keel narrowiy jagged (the edge irregularly siender toothed) or ciliate. The 3 blades of the corolla obovate, about 3.5 mmit long, unfolding in afternoon, yellow. staminodes and stamens as in the preceding. Seeds $0.400 .5 \mathrm{man}$ long, longitudinaliy low-ridged, amber.

Distribution and Elowering season

Moist to wet sandy shores of limesink lakes and ponds, northwest Florida and southeastern Alabama. Lowerirg from July through Septernber.

Special Identifying Features

X. Iongisepala is similax to x. smalliana a more widespread species of swamps in the coastal Plain from $\mathbb{N}_{\odot} J_{0}$ south to south Florida and west to southern Mississippi. However, \&. longisepala is a smaller plant of consistently different habitat, its spikes are smaller and more often oblong, its flowers have much shorter petals and the seeds are smaller, differently ribbed. Its flowers unfold raidmay, while those of $x$. smalliana unfold toward evening.

Habitats and Managerent Impilcation

This species is in little danger so long as the shorelines of the small lakes and ponds it frequents are not effecred physically by the management of surrounding forest. The only competitive vegetation of a woody sort is Hypericum. This, together with a large set of wetlands herbs, appears quite weIl adapted to the fluctuating waters typical of these karst areas. X. longisepala and associated species are present in great abundance some seasons, are virtually absent others, all depending on the frequency and timing of receding or raising of lake 
waters. Shore areas of some of the ponds have in some observed cases been mechanically disturbed so as to prepare for pine plantations. Where sucis is done these plants disappear as they do also when the smaller ponds are drained so as to increase area for pines and for pasture.

Reference

Kral, Ro 1966. Xyris (Xyridaceae) of the Continental United states and Canada. Sida $2(3):$ 177-269. 
SPECIES: \#155 Xyris Iongisepala Kral. Yellow-eyed grass

\begin{tabular}{|c|c|c|c|c|c|c|c|c|}
\hline \multicolumn{9}{|c|}{ Management Practices } \\
\hline $\begin{array}{l}\text { Expected* } \\
\text { Effect on } \\
\text { the Species }\end{array}$ & $\begin{array}{c}\text { Prescribe } \\
\text { Burn }\end{array}$ & $\begin{array}{c}\text { Bulldoze } \\
\text { or } \\
\text { Root Rake }\end{array}$ & Bed & Chop & $\begin{array}{l}\text { Thin } \\
\text { over- } \\
\text { scory } \\
\end{array}$ & $\begin{array}{l}\text { Cut } \\
\text { Over- } \\
\text { story }\end{array}$ & $\begin{array}{l}\text { Establish } \\
\text { Plantation }\end{array}$ & Graze \\
\hline Destroy & & $X$ & $\mathrm{X}$ & is & & & $\mathrm{X}$ & \\
\hline \multicolumn{9}{|l|}{ Damage } \\
\hline $\begin{array}{l}\text { No Lasting } \\
\text { Effect }\end{array}$ & $\mathrm{NA}$ & & & & & & & \\
\hline $\begin{array}{l}\text { Beneflclal } \\
\text { if Done } \\
\text { Properly }\end{array}$ & & & & & NA & - & & \\
\hline
\end{tabular}

\section{Other Coments:}

*Expected effect on the species is an estimate made by Dr. Robert Kral based on his knowledge of the habitat and on knowledge gained from personal field observations. Estimates are "rough" in many instances. Results of practices may be modified depending upon the degree of application, intensity of treatment, neamess to plant commities, etc. A management practice for which no entry is made indicates a lack of sufficient information from which to predict expected results. As observations are made in the field by users of the data, the expected effect will be refined. 
Xyris longisepala Kral

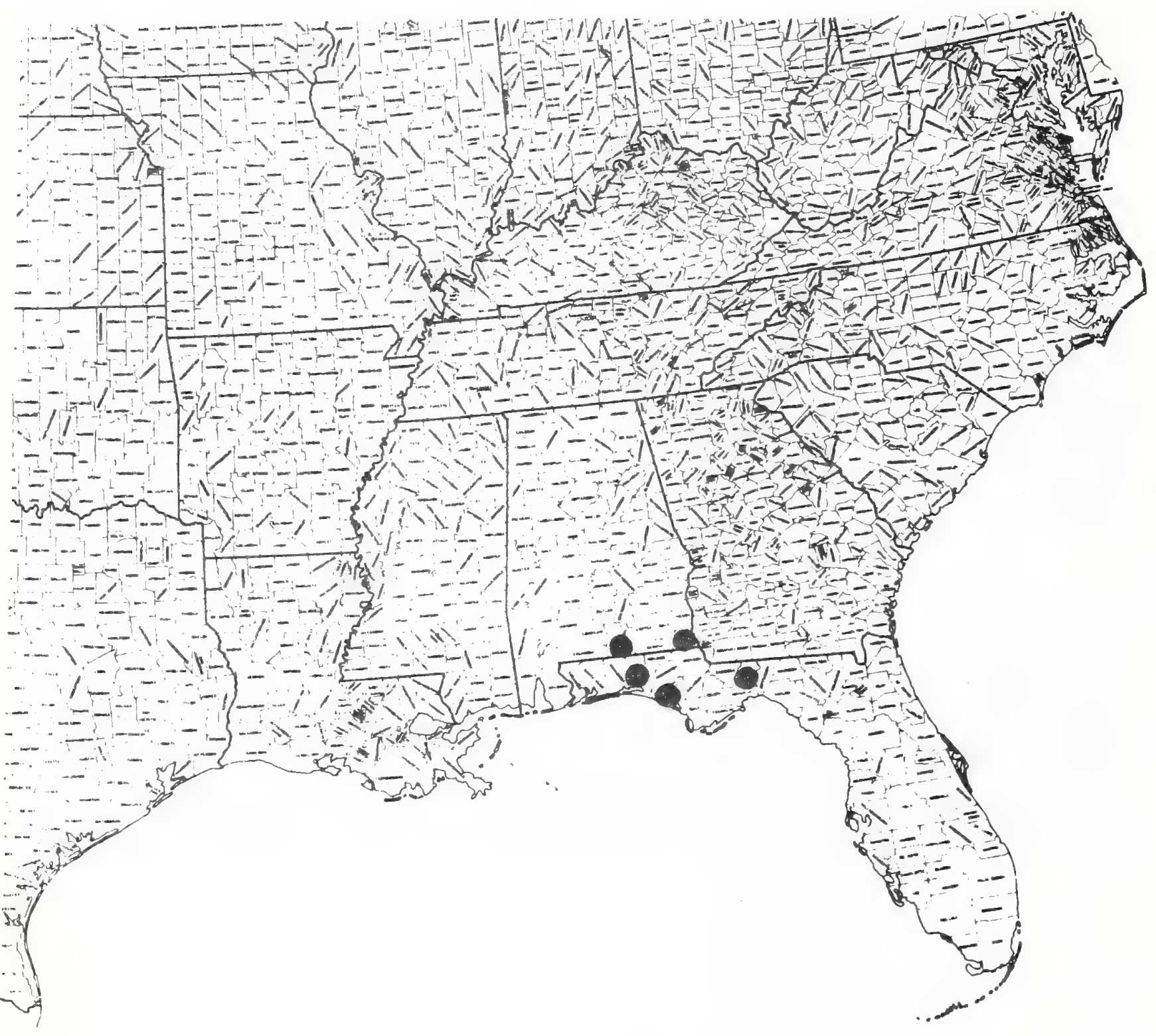




\section{KXIDIDACER}

XYris scabrifolia Herper. Harpor" selloweyed grass: Technical Description

$$
\text { yelloweyed grass }
$$

The plants solitary or in small tufts. sterns, The plant bases flsshy, bulbous, usualy tiated with pink or purple. Leaves.-Larger leaves Iinear, to $10 \mathrm{~cm}$ long $2385010 \mathrm{~mm}$ broad, twisted, the blades broadening abmptly at the sheathing bases. dul greenish. appearing glazed (examination under hand lens reveais suriaces that are covered by fine tubercles and are thus called papilioselo Sheathes of scapes shorter than leaves. the bases chestrut, the tips green like the lear blades.

Inflorescence-scapes 1 inear, stifrish, to 60 crn tall, twisted but erect, toward the tips 2 muridged and the surEaces glamed with papiliae as in the leaves. Spikes 10-20 ma long, obovola or allipsoidal, of many, spirally arranged and tightly overlapoing bracts, the tips blunt or acute. Fertile bracts obovate, $6-8$ ma long. rounded, nearly entire, the backs rounded, dark reddishmbrown or tar depending on age, the dorsal areas from pale green to pale brom. Flowers,-materal sepals hidden by the bracts, linear, the keel narrow, toward its base jagged with thin, irregular teeth and toward its tip fimbriate (draw out into slendex, hairmijke, long projections). Petal blades emerging in the afternoon, yellow, nearly round, about 5 m long. stamens and staminodes and fruit as in the preceding.

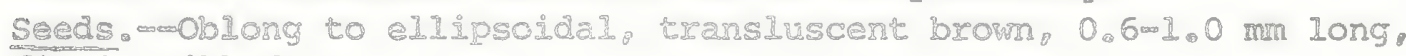
Finely ribbed.

\section{Distribution and Flowering Season}

Moist to wet sandy peats of acdd sphagnous bogs or sandy seeps, Coastal Plain, Georgia south to northern Forida thence west into southern Mississippi.

\section{Special Identifying Features}

This rare plant was first described from a smald bog in Meriwether County Georgia, where it has not been seen again. It is very similar in appearance to 8 olatylepis, but differs Erom it in having the foliage covered by fine tuberculae (barts) or papillae, in having rounder petals, and in having much larger, longer seeds.

Habitat and Management Implication

H. scabrifolia is to be looked for in the small hillside seeps and pitcher plant bogs within the stated area. It is never found on soils that ary out, is generally found rooted in sphagnous peat, mingled with pitcher plants, sundews and other wetland herbs. Its area is probably increased through loggirg of surrounding wetlands 
pines, so long as this is not accompanied by wholesale drainage. Fire increases it by eliminating competition of woody understory vegetation and the stronger grasses (as is true of most other fire and swamp disclimax forbs). It may persist for a time where the bogs and high hydroperiod savanna it frequents undergoes preparation for (mostly) slash pine plantation. It will disappear if drainage ditches are cut. If such are not made and the pines are strip nlanted, it will disappear as soon as the crowns close.

References

Kral, R. 1966. Xyris of the Continental United States and Canada, Sida 263: 177-260

Small, J. K. 1933. Manual of the Southeastern Florap. 254. Chapel Hill, N.C. 
SPECIES: \#156 Xyris scabrifolia Harper Yellow-eyed grass

\begin{tabular}{|c|c|c|c|c|c|c|c|c|}
\hline & \multicolumn{8}{|c|}{ Management Practices } \\
\hline $\begin{array}{l}\text { Expected* } \\
\text { Effect on } \\
\text { the Species } \\
\end{array}$ & $\begin{array}{c}\text { Prescribe } \\
\text { Burn }\end{array}$ & $\begin{array}{c}\text { Bulldoze } \\
\text { or } \\
\text { Root Rake }\end{array}$ & Bed & Chop & $\begin{array}{l}\text { Thin } \\
\text { over- } \\
\text { story }\end{array}$ & $\begin{array}{l}\text { Cut } \\
\text { Over- } \\
\text { story }\end{array}$ & $\begin{array}{l}\text { Establish } \\
\text { Plantation }\end{array}$ & Graze \\
\hline Destroy & & $\mathrm{X}$ & & 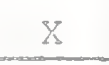 & & & 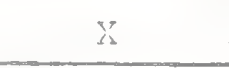 & \\
\hline Damage & & & $x$ & & & & & \\
\hline $\begin{array}{l}\text { No Lasting } \\
\text { Effect }\end{array}$ & & & & & & & & \\
\hline $\begin{array}{l}\text { Beneficlal } \\
\text { if Done } \\
\text { Properly }\end{array}$ & $x$ & & & & $\mathrm{X}$ & $\mathrm{X}$ & & \\
\hline
\end{tabular}

\section{Other Coments:}

* Expected effect on the species is an estimate made by Dr. Robert Kral based on his knowledge of the habitat and on knowledge gained from personal field observations, Estimates axe "rough" in many instances. Results of practices may be modified depending upon the degree of application, intensity of treatment, neamess to plant comunities, etc. A management practice for which no entry is made indicates a lack of sufficient information from which to predict expected results. As observations axe made in the field by users of the data, the expected effect will be refined. 
Xyris scabrifolia Haxper

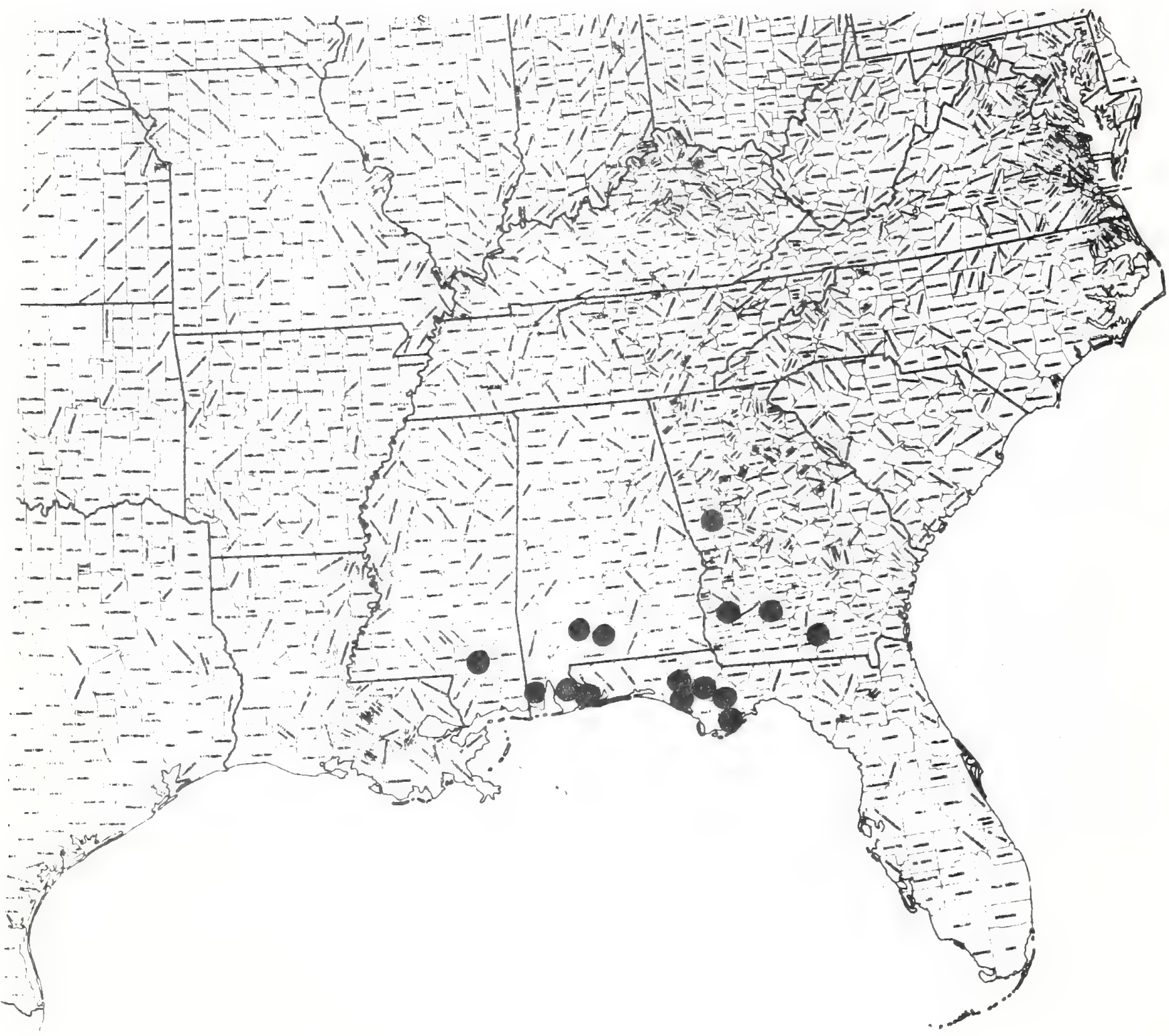




\section{ALISMATACEAE}

Sagittaria fasciculata E. O. Beal. bunched arrowhead S. graminea Michx. var. macrocarpa (J.G.Sm.) Bogin

Technical Description

Perennial, rosulate, smooth aquatic herbs, clonalizing by slender, pale, elongate, stoloniferous rhizomes.

Leaves.-- Alt basal, in flat spirals on a short, soft stem, with two extreme sorts produced; phyllodes appearing first in season, short-linear or slightly gladiate, erect or somewhat spreading, succulently stiff, arenchymatous (spongy-tissued), mostly $5-10 \mathrm{~cm}$ long, $0.7-2.0 \mathrm{~cm}$ wide, bluntly acute with the very tip callused, the margin entire, the surface evidently strongly multi-parellel-nerved with cross-partitions evident, toward the strongly clasping base pale, upwardly becoming a deep but bright green: leaves later in season progressively elongating to $15-35 \mathrm{~cm}$, becoming Jorate (still broadly Iinear toward base but dilating apjcaliy) or with elongate, broadly finear, flat petioles and el7iptic to lanceolate blades, these frequentiy $1.5-3.5(-4.0) \mathrm{cm}$ wide and $1 / 3-1 / 4$ as 1 ong as the petioles.

Inflorescence.- Verticellate raceme, 1 -several scapes arising from the rosette, erect, emergent, teretish, lineal-tapering, mostly $15-35 \mathrm{~cm}$ tall, the $2-3(-4)$ verticels arising coward the scape tip, the lowest producing female flowers, the upper ones male, the slender pedicels spreading or ascending, usual7y $3.5 /$ whorl. with female ones longest, to 3 or $4 \mathrm{~cm}$ long, each verticel subtended by 3 ovate, papery bracts ca. $4.5 \mathrm{~mm}$ long, boatshaped, spreading-ascending, joined at base into a cup.

Flowers.-. Regular, unisexual: sepals 3, ovate, distinct, in the female somewhat longer $(3.5-4.0 \mathrm{~mm}$ long) and spreading or reflexed in fruit, thin, pale green with pale, scarious borders sometimes tinged with pink; petais 3, distinct, spreading, obovate, white, ca. 4 mm long: stamens numerous, the broad, flattish filaments ca.0.3-0.4 mm long, glandular-short-puberulent, the oblong, yellowish anthers erect, ca. $0.8-1.0 \mathrm{~mm}$ long; carpels numerous, distinct on an elevated receptacle.

Fruit.-- Akene somewhat laterally compressed, asymmetrically wedge-shaped, $\overline{c a} \cdot 4 \mathrm{~mm}$ long, the oblong seed cavity longitudinally lined with prominent, reddish, resinous ridges, and surrounded by a broad chin pale wing, the persistent style projecting laterally as a winged "spur" to $1 \mathrm{~mm}$ Tong.

Distribution and Flowering Season.

Seeps, bogs and swamps, Blue Ridge and southern Blue Ridge escarpment, southwestern North Carolina and northwestern South Carolina: flowering in May, June.

Special Identifying Features.

This non-sagittate-leaved Sagittaria is distinguished from the others of its complex in the southeast (S. rigida, S. teres, S. platyphylla, S. graminea, S. isoetiformis) by a combination of flattened phyllodia, blades of emergent Teaves relatively broad but at the same time female pedicels not recurved 


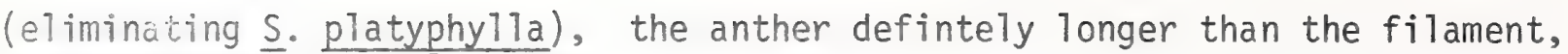
and the bracts strongly fused.

Habitat and Management Impications

S. fasciculata is presently known from but two counties $n$ North Carolina, one in South Carolina. It is always rooted in shallow water over siliceous and micaceous silty muck in freshwater swamps or bogs in or along shallow languid streams that course through such areas. It may be in full sun or full shade, in the latter case being under Red maple, Nyssa, Alder, Willow, Viburnum, Ilex, Aronia, Rosa. These seep swamps and bogs, often odorous with sulfides, are usually comparatively narrow zones in rises or hills forested by a mixture of hardwoods and pines (both hard and soft). The greastest present threat to the Sagittaria is a compound of such activity as drainage for industrial development, work along highway and railroad rights of way; much of its known habitat has been destroyed in this way. The sensitive habitat may also be threatened by excessive logging of the slopes draining into such bogs, with erosion and subsequent washing of sediments into the areas, thus burying the plants or effecting their supply of water.

\section{References}

Beal, E.0.1960. The Alismataceae of the Carolinas. Journ. Elisha Mitchell Soc. 76: 68-79.

- 1977. A manual of marsh and aquatic vascular plants of North CaroTina. North Car. Agric. Expt. Sta. Tech. Bu11. 247, pp. 60-69.

Radford, A.E., H.E. Ahles and C.R. Bell. 1968. Manual of the vascular flora of the Carolinas, pp. 51-54. Chapel Hi11, N.C.

Wooten, Jean W. 1973. Taxonomy of seven species of Sagittaria from eastern North America. Brittonia 25 (1): 64-74. 
SPECIES Sagittaria Easciculata E。 O. Beal。 bunched arrowhead

\begin{tabular}{|c|c|c|c|c|c|c|c|c|}
\hline \multirow[b]{2}{*}{$\begin{array}{l}\text { Expected* } \\
\text { Effect on } \\
\text { the Species } \\
\end{array}$} & \multicolumn{8}{|c|}{ Management Practices } \\
\hline & $\begin{array}{c}\text { Prescribe } \\
\text { Burn }\end{array}$ & $\begin{array}{c}\text { Bulldoze } \\
\text { or } \\
\text { Root Rake }\end{array}$ & Bed & Chop & $\begin{array}{l}\text { Thin } \\
\text { over- } \\
\text { story }\end{array}$ & $\begin{array}{l}\text { Cut } \\
\text { over- } \\
\text { story }\end{array}$ & $\begin{array}{l}\text { Establish } \\
\text { Plantation }\end{array}$ & Graze \\
\hline Destroy & NA & $x$ & $x$ & $x$ & & $x$ & $\mathrm{NA}$ & $?$ \\
\hline \multicolumn{9}{|l|}{ Damage } \\
\hline $\begin{array}{l}\text { No Lasting } \\
\text { Effect }\end{array}$ & & & & & $\mathrm{z}$ & & & \\
\hline $\begin{array}{l}\text { Beneficial } \\
\text { if Done } \\
\text { Properly }\end{array}$ & & & & & & & & \\
\hline
\end{tabular}

Other Comments: site drainage or daming would destroy plants!

*Expected effect on the species is an estimate made by Dr. Robert Kral based on his knowledge of the habitat and on knowledge gained from personal field observations. Estimates are "rough" in many instances. Results of practices may be modified depending upon the degree of application, intensity of treatment, neamess to plant communities, etc. A management practice for which no entry is made indicates a lack of sufficient information from which to predict expected results. As observations are made in the field by users of the data, the expected effect will be refined. 
Sagittaria fasciculata E. O. Beal

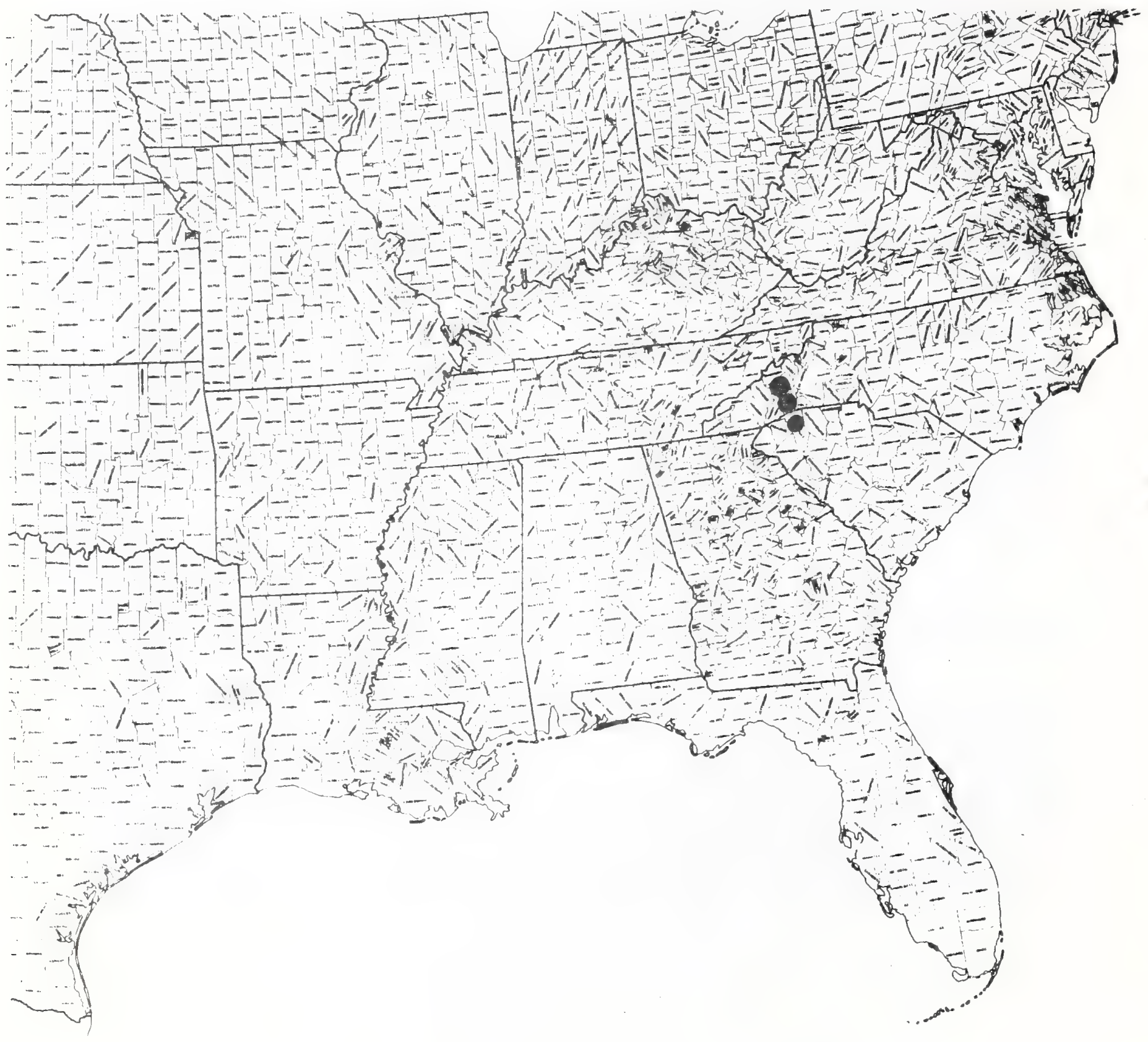




\section{APIACEAE}

\section{Sium floridanum sma71. Florida water-parsnip}

\section{Technical Description}

Perennial, smooth, tuberiferous and rhizomatous herbs.

Stems... Strongly decumbent, the stem bent upward to a height of $3-9 \mathrm{dm}$ from a pale, elongate-rhizomatous base (this often producing fusiform tuberiferous rhizomes later in season) arising from a contracted caudex, the lower nodes rooting, the aerial part of the scem somewhat zig-zag, deep green, sulcate (strongly ribbed and grooved).

Leaves..- Alternate, rather distant, spreading-ascending, the largest lowest, 1-odd-pinnately compound, mosily $1-2 \mathrm{dm}$ long, the lateral leaflets mostly 2-4 pairs, spreading, elliptic, Tinear-elliptic, or lanceolate, mostly $4-8 \mathrm{~cm}$ long, acute, Tow-serrate, sometimes falciform, the bases sessile or nearly so, oblique, usually acute, the lowest pair much smaller, the terminal leaflet often largest, broadest, on a stalk $1 \mathrm{~cm}$ or more long: upper leaf surface deep green, the lower surface paler; petiole elongate, strongly ribbed, expanding to a broad, scarious-margined, clasping base. Lowermost leaves usual7y withered by flowering time; leaves grading smaller in size progressively into the inflorescence, where mostly much smaller, simple.

Inflorescence.- Umbels arising from most upper leaf axi]s, spreading on primary peduncles of various lengths, the lowermost maturing first; primary rays of umbel subtended by $3-5$ reflexed, linear-lanceolate, scarious-edged bracts $1 \mathrm{~cm}$ long or less, secondary rays mostiy $1-2 \mathrm{~cm}$ long, spreading. terminating in involucres of bracts similar to those of primary rays, together with the spreading, stiff but slender pedicels, these mostly $5 \mathrm{~mm}$ long or less.

Flowers... Slightly irregular, bisexual; sepals 5, reduced to minute tubercles less than $1 \mathrm{~mm}$ long; petals 5, distinct, the corolla rotate, white, spreading to a width of $2.5-3.5 \mathrm{~mm}$, the blades ovate, somewhat unequa 7 , the largest $2.5-3.0 \mathrm{~mm}$ long, acuminate-incurved, the margin somewhat revolute, at base abruptly narrowed to a very short claw. Stamens 5, the filaments at first arched inward, then at anthesis spreading horizontally, slender, terete, ca. $1 \mathrm{~mm}$ long, the broadly elijpsoidal anthers ca. 0.3 mm long, yellowish, basifixed, the connective below forming a short-triangular spur: ovary inferior, 2-carpellate, with 2 distinct, spreading, Tinear styles.

Fruit... - A smooth schizocarp, the body broadly oblong-ellipsoidal, ca. $3 \mathrm{~mm}$ Tong, $2 \mathrm{~mm}$ wide, sometimes curvate, slightly compressed parallel to inflorescence (dorsiventra 7 y), each mericarp strongly 5-ribbed, stylopodium 2-lobed, the lobes forming a low cone, the styles persistent and spreadingrecurved, slender, ca. $1 \mathrm{~mm}$ long.

\section{Distribution and Flowering Season}

Alluvial woodlands, southwestern Georgia, northwestern Florida and contiguous southeastern Alabama. Flowering in June and July.

Special Indentifying Features

S. floridanum is treated by Radfore et al. (1968) as a part of $S$. suave Walt. (S. cicutaefolium Schrank。), and may indeed represent but a radiate 
extreme or a variety. Whatever the case, $S$. suave is a much taller, coarso: plant, usually erect rather than decumbent-based. Its leaves are larger, the leaflets more saliently (projecting) toothed, its inflorescence much broader and with broader involucral bracts, its fruits broader, often longer.

Habitat and Management Implications

S. floridanum forms local populations on sandy-silt of alluvium of rivers and stream bottoms, usually in full shade. The overstory is a mixture of Salix, Fraxinus pensylvanica and F. caroliniana, Planera, various of the willow oaks, overcup oak, basket oak, shumard oak, cherrybark oak, red maple, sycamore, etc. It is amongst understory shrubs such as Hypericum gilioides, Myrica carifera, Cephalanthus, Sebastiana, Amorpha. Herbaceous associates include Elytraria caroliniensis, Justicia ovata, Commelina virginica, Micromeria pi Tosiuscula, Vernonia gigantea, Pluchea, various Panicum, Sagittaria, Peltandra, Rhynchospora miliacea, etc. Logging of the hardwood overstory would, if involving clearcutting, have an adverse effect in that it would elevate the water table, admit too much light, disturb the sandy alluvium in which the rhizomes are found. single tree or groups selection would, if mechanical disturbance were kept to a minimum, probably not effect adversely.

\section{References}

Radford, A.E., H.E. Ahles and C.R. Bel1, 1968. Manual of the vascular flora of the Carolinas, p. 783. Chapel Hill, N.C.

Sma11, J.K. 1933. Manual of the southeastem flora, pp. 975-976. Chape] Hi11, N.C. 
SPECTES Sium floridanum Small。 Florida water parsnip

\begin{tabular}{|c|c|c|c|c|c|c|c|c|}
\hline \multirow[b]{2}{*}{$\begin{array}{l}\text { Expected* } \\
\text { Effect on } \\
\text { the Species }\end{array}$} & \multicolumn{8}{|c|}{ Management Practices } \\
\hline & $\begin{array}{c}\text { Prescribe } \\
\text { Burn }\end{array}$ & $\begin{array}{l}\text { Bulldoze } \\
\text { or } \\
\text { Root Rake }\end{array}$ & Bed & Chop & $\begin{array}{l}\text { Thin } \\
\text { over- } \\
\text { story } \\
\end{array}$ & $\begin{array}{l}\text { Cut } \\
\text { over- } \\
\text { story }\end{array}$ & $\begin{array}{l}\text { Establish } \\
\text { Plantation }\end{array}$ & Graze \\
\hline Destroy & $\mathrm{NA}$ & $\mathrm{NA}$ & $\mathbb{N A}$ & $N A$ & & $X$ & & $\begin{array}{l}\text { see } \\
\text { note }\end{array}$ \\
\hline \multicolumn{9}{|l|}{ Damage } \\
\hline $\begin{array}{l}\text { No Lasting } \\
\text { Effect }\end{array}$ & & & & & & & & \\
\hline $\begin{array}{l}\text { Beneficial } \\
\text { if Done } \\
\text { Properly }\end{array}$ & & & & & & & & \\
\hline
\end{tabular}

Other Comments: Site drainage harmful! So suave, a related species, is a suspected stock-poisoner.

*Expected effect on the species is an estimate made by Dr. Robert Kral based on his knowledge of the habitat and on knowledge gained from personal field observations. Estimates are "rough" in many instances. Results of practices may be modified depending upon the degree of application, intensity of treatment, nearness to plant communities, etc. A management practice for which no entry is made indicates a lack of sufficient information from which to predict expected results. As observations are made in the field by users of the data, the expected effect will be refined. 


\section{Sium floridanum Small}

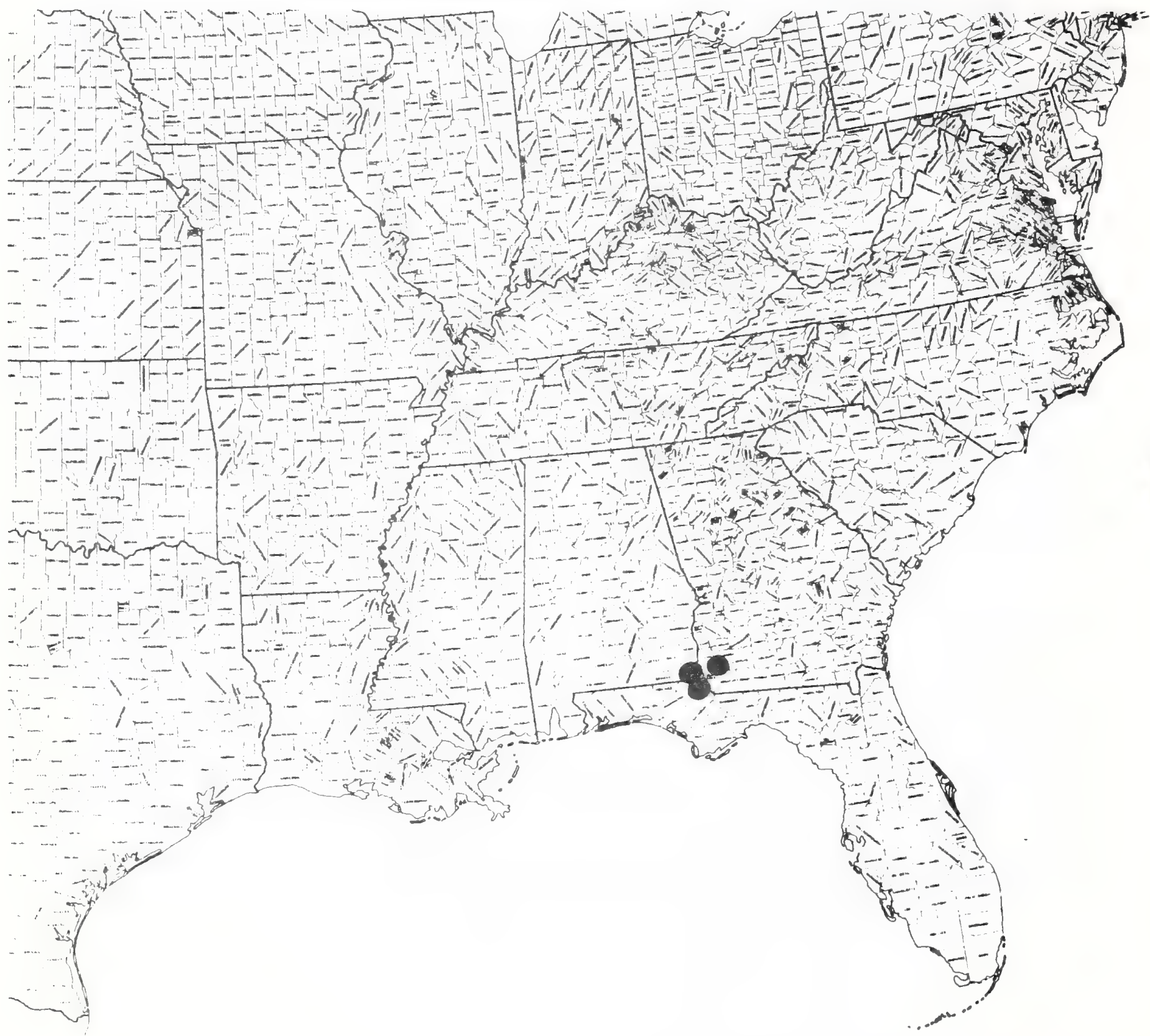




\title{
ARISTOLOCHIACEAE
}

\author{
Hexastylis naniflora Blomquist. dwarf-flowered heartleaf
}

\section{Technical Description}

Tufted, smooth, rosulate, spicy-smelling herbs from shallow, thick-rooted rhizomes, these pale, with thin, ovate, scaley bracts, few to several ascending from a more or less erect caudex.

Leaves.-- Alternate, essentially basal from rhizome tips, evergreen (new ones developed toward end of flowering period as old ones die), usually forming a dense, spreading rosette, the blades leathery, orbicular to reniform or broadiy ovate, mostly $4.6 \mathrm{~cm}$ long, rounded or emarginate, slightly revolute, the bases strongly cordate-auriculate, the upper surface dark glossy green, often reticulately mottled with paler green, the lower surface a dul7, pale green; petioles much longer than leaf blades, up to $1.5 \mathrm{dm}$ long, slender, teretish, distally greenish or maroon, proximally paler (when under litter), expanding to clasping pale bases.

Flowers... Regular, bisexual, produced singly toward tips of rhizome branches from axils of folded, ovate, scale peduncles mostly $3-6 \mathrm{~cm}$ long. Sepals 3 , joined into a flask-like tube, this short ovoid-cylindric, $0.7-1.0 \mathrm{~cm}$ long, slightly broader at its base, there 0.6-0.9 mm wide and cream lined with maroon, distally becoming mostly maroon; calyx lobes ca. $1 \mathrm{~cm}$ long, broadly ovate-triangular, spreading. ascending, arching concavely upward, obtuse, the margins broadly revolute, the bases auriculate, the upper surface cream mottled with maroon, puberulent, the backs paler, raised-reticulate. Throat of calyx pilosulous within at its rim, the tube within inconspicuously ridged-reticulate, smooth. Stamens 12, in 2 close-set whorls of 6 , erect on very short, stout, pale, fleshy filaments attached to carpel walls or between, the anthers of the set opposite the carpels set somewhat lower, all anthers extrorse, marginal to a broad somewhat flattened connective, the locules 4 , each pair 7inear, $1.5-2.0 \mathrm{~mm}$ long, purplish. Carpels 6, lancesovoid, ca. 1/2 inferior to superior, ca. $5 \mathrm{~mm}$ long, joined into a ring from a level just below the fleshy styles downward, the few ovules attached axially at base of locules, the fleshy styles erect, oblong, ca. $2 \mathrm{~mm}$ long, bearing round stigmas on the outside at the bases of apical notches.

Fruit.- Capsules ovoid, few-seeded (usually but 1 ovule/locule), retained in the fleshy calyx tube base and usually released through rotting of the entire structure.

\section{Distribution and Flowering Season}

Acidic sandy loam of wooded ravine slopes, Piedmont North Carolina and South Carolina. Flowering in Aprit and May.

\section{Special Identifying Features}

H. naniflora has the smallest flowers of any species of its complex in North America, and it might be added, also produces longer peduncles than most. As Blomquist (1957) has stated, its taxonomic affinities are with the "virginica" group, but it differs from any of these in that it lacks a "flare" in the calyx tube which also differs in that it narrows rather than broadens distally. 
H. nasiflora is found on moist to rather dry north-facing slopes of ravines in the Piedmont, usually in the oak-hickory-pine type. The oak species are mostly $\underline{Q}$. velutina, $\underline{Q}$. falcata, $\underline{Q}$. prinus, $\underline{Q}$. stellata, $\underline{Q}$. alba, $\underline{Q}$.

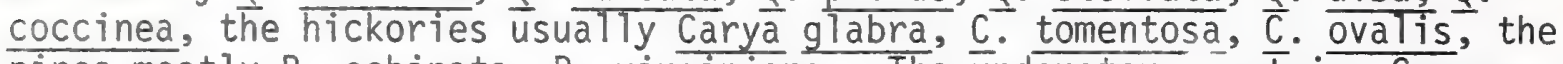
pines mostly $\underline{P}$. echinata, $\underline{P}$. virginiana. The understciy contains Cornus, Cercis, oxydeñdrum, but is mostly ericaceous, with Kalmia predominant.

Associated herbace ous species are Hepatica americana, Chimaphila, Epigaea, Uvularia, Sanguinaria, Viola, Polygonatum, Polystichum, etc. The Hexastylis plants range in size from a few branching rhizomes to several, the older clumps producing large round tufts of leaves and 20 or more flowers, with the rhizomes and petioles of leaves, usually also the flower stalks buried in unincorporated, moist duff. Generally the plants are around tree bases or under the Kalmia, on steepish slopes along streams. Clear cutting of such slopes would result in considerable mechanical damage to the soils, particularly erosional damage. Also, too much light would be admitted, destroying through bacterial action the organic fraction, drying out and heating up the substrate. No Hexastylis of this species has been observed in continguous cleared areas. Adjacent pastured woodlands of the same type show few or no plants, probably because of damage done through trampling and subsequent erosion of the slope more than through the plants actually being eaten by livestock.

\section{References}

Blomquist, H.L. 1957. A revision of Hexastylis of North America. Brittonia, $8(4): 255-282$.

Radford, A.E., H.E. Ahles and C.R. Bell, 1968. Manual of the vascular flora of the Carolinas, pp. 400-402. Chapel Hill, N.C. 
SPECIES HexastyIs naniflora Blomqui sto dwatw flowered heartieaf

\begin{tabular}{|c|c|c|c|c|c|c|c|c|}
\hline \multirow[b]{2}{*}{$\begin{array}{l}\text { Expected* } \\
\text { Effect on } \\
\text { the Species }\end{array}$} & \multicolumn{8}{|c|}{ Management Practices } \\
\hline & $\begin{array}{c}\text { Prescribe } \\
\text { Burn }\end{array}$ & $\begin{array}{c}\text { Bull doze } \\
\text { or } \\
\text { Root Rake }\end{array}$ & $\mathrm{Bed}$ & Chop & $\begin{array}{l}\text { Thin } \\
\text { over- } \\
\text { story }\end{array}$ & $\begin{array}{l}\text { Cut } \\
\text { over- } \\
\text { story }\end{array}$ & $\begin{array}{l}\text { Establish } \\
\text { Plantation }\end{array}$ & Graze \\
\hline Destroy & $X$ & $X$ & $X$ & $x$ & & $\mathrm{X}$ & & $\mathrm{X}$ \\
\hline Damage & & & & & $x$ & & & \\
\hline $\begin{array}{l}\text { No Lasting } \\
\text { Effect }\end{array}$ & & & & & & & & \\
\hline $\begin{array}{l}\text { Beneficial } \\
\text { if Done } \\
\text { Properly }\end{array}$ & & & & & & & $\begin{array}{c}\bar{X} \\
\text { see note }\end{array}$ & \\
\hline
\end{tabular}

Other Comments: overplanting with trees would probably involve considerable soil disturbance, and in such a case

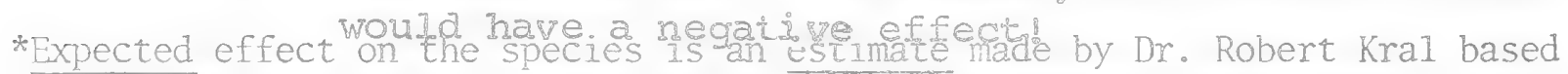
on his knowledge of the habitat and on knowledge gained from personal field observations. Estimates are "rough" in many instances. Results of practices may be modified depending upon the degree of application, intensity of treatment, nearness to plant commities, etc. A management practice for which no entry is made indicates a lack of sufficient infomation from which to predict expected results. As obsemations are made in the field by users of the data, the expected effect will be refined. 
Hexastylis naniflora Blomqui st

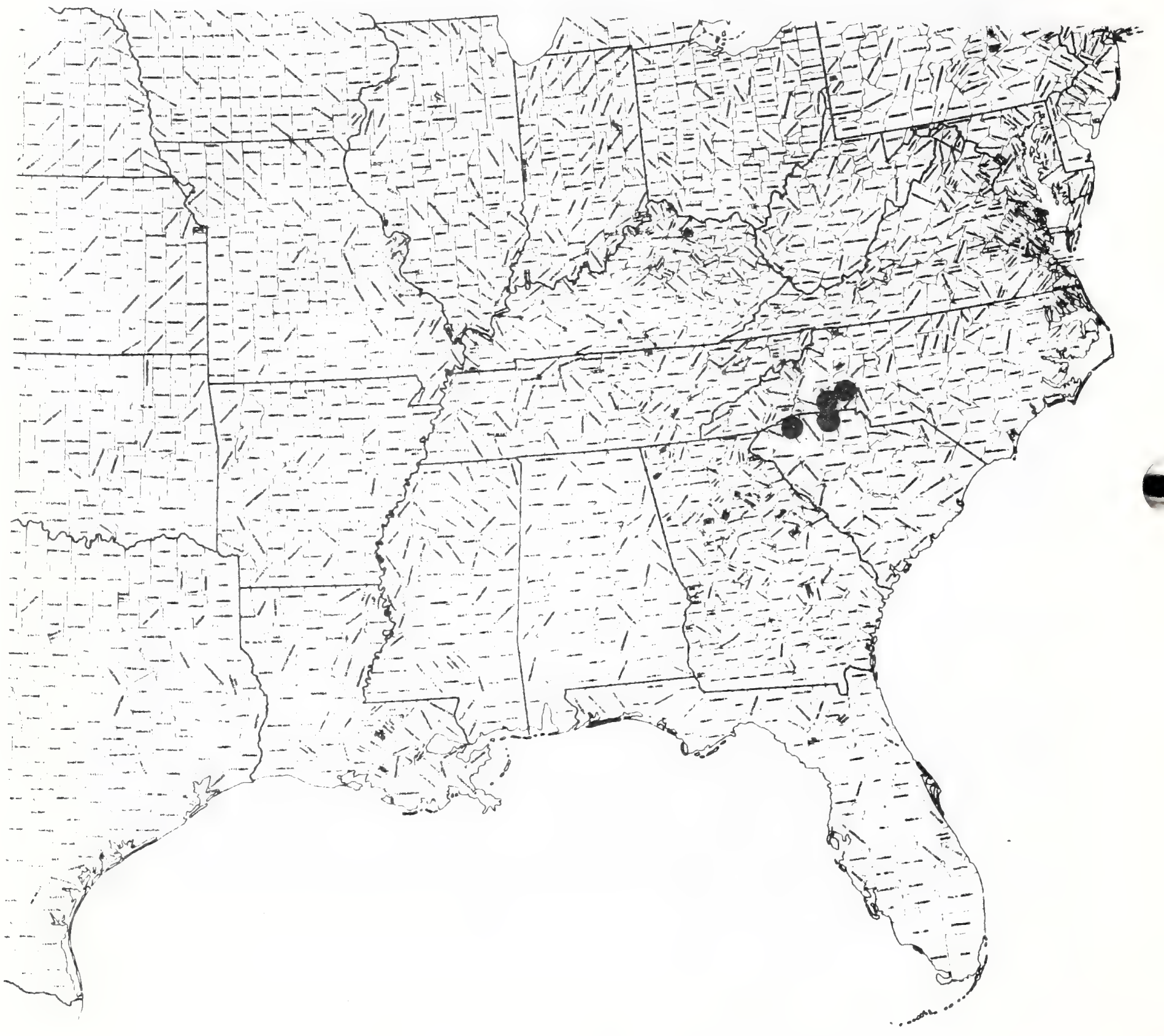




\section{ASCLEPIADACEAE}

Matelea alabamensis (Vail) Woodson. Alabama milkvine
Vincetoxicum alabamense Vail
Cyclodon alabamense (Vail) Small

\section{Technical Description}

Perennial, milky-juiced, twining herbaceous vine from a fibrous rootstock.

Stems.-. 1-3 from a stout, erect, fibrous-rooted rhizome, prostrate or twining on shrubs or trees, to several meters long, simple or branching. terete, pale green or tinged with maroon, from nearly smooth to hirtellous, sometimes with a scattering of long, spreading, yellowish trichomes, the newer growth often also with an admixture of short-stalked to sessile, reddish glands.

Leaves.-- Opposite, the petioles stiffly spreading, mostly $3-5 \mathrm{~cm}$ long, slender, the upper side somewhat concave, the lower side rounded, the surface yellow-green or maroon, scattered-hirsute, also with a scattering of shorter eglandular and glandular hairs mixed with some sessile glands; blades ovate to suborbicular, $5-10(-15) \mathrm{cm}$ long, apically acuminate or acute, rarely narrowly rounded or even emarginate, encire, the base cordate or auriculate with the sinus narrow or closed, the upper surface deep yellowgreen, sparingly to copiously hirtellous, the short, erect hairs swollenbased, the lower surface usually more copiously hirtellous, particularly along the veins, and also along the veins often with sessibe or short-stalked glands.

Inflorescence.-- Umbels usually $1 /$ node from the upper nodes, subtended by an involucel of a few, small, lance-linear, hirtellous, green bractiets, on spreading, strongly ribbed, hirtellous and glandular peduncles $1.0-1.5$ $\mathrm{cm}$ long, the slender rays (pedicels) usually few (mostly 2-5), spreading, slender but stiff, hirtellous and glandular.

Flowers.- Bisexual, regular, rotate, flattish, $\mathrm{ca} .2 .5 \mathrm{~cm}$ wide across the petals; sepals 5, joined at very base, the triangular lobes spreading, ca. 3 mm long, acute, pale green, hirtellous, also with sessile and stalked glands; corolla lobes 5 , spreading, flat, ca. $8.9 \mathrm{~mm}$ long, elliptical or narrowly ovate, the tips narrowly rounded, sometimes slightly emarginate, the margins entire, the surface greenish yellow with a reticulum of deeper green, above glabrous, beneath hirtellous and glandular; gynostegium (a weld of stamen and female parts) surrounded at base by a fleshy, orangish disc, this with 5 conical, suberect horns opposite the 5 calyx lobes and forming peripherally a thinnish, irregularly and shallowly 5-lobed, strongly erose fringe; gynostegium elevated above the perinath base ca. $1 \mathrm{~mm}$, yellow-green, the truncate apex ca. $3 \mathrm{~mm}$ wide, obscurely pentagonal, nearly covered by 5, thin broadly triangular, inflexed flaps of anther tissue; anther apparatus consisting of 2 saclike pollinia (masses of pollen) connected by a yokelike pair of arms (translocator) spreading from a lenselike "chitinous" gland (corpusculum) located at the apex of a vertical slit (the interstaminal slit); ovularjes 2 , superior, connivent to form a single style apically, this expanded distally to form a peltate stigma (most of the gynostegial head!) which is receptive in 5 radial lines beneath 
and oppcsite the glands.

Fruit.-- Follicles yellowish-green, lance-ovoid, muricate, ca. $10 \mathrm{~cm}$ long;

seeds numerous, flattish, obovate in outline, brownish, erose-margined, bearing a white "coma" of long, thin hairs at the narrow end.

Distribution and Flowering Time

Wooded, steep or gradual ravine slopes, Coastal Plain, southwestern Georgia, northwestern Florida, and southestern Alabama; flowering from late May into June.

\section{Special Identifying Features}

The above description of the floral structure is adapted from the excellent treatment of southeasterm Matelea done by Dr. D. Drapalik (1970), the undisputed authority on these species. Of the 9 taxa found in the southeast only 2 have the corona and coronal appendage tips at a level below the gynostegial head; these 2 are $\mathbf{M}$. alabamensis and $\mathbf{M}$. gonocarpa, which have very different looking flowers, with the strongly reticulate, broader petals of the former in strong contrast to the narrower, not evidently reticulated petals of the latter; the coronal apparatus is entirely different. The ovary and fruit of the former are muricate, those of the latter smooth. Superficially, flowers of M. flavidula are very like those of $M$. alabamensis, the petals being strongly spreading, flat, similar in outTine, yellow green with dark green reticulation as in $\mathrm{M}$. alabamensis and the fruit similar. However the corona and appendages of M. flavidula extend to a level above the gynostegial head.

\section{Habitat and Management Implications}

M. alabamensis is perhaps one of the rarest herbs in the southeastern U.S., with less than 10 localities ever having been known, and not now found at most of these. Therefore information about precise localities is kept confidential.

The plants, in the one area where they are fairly numerous today, are found on gentle east, south and west slopes in what is, or was, part of a beech-magnolia-maple system. In addition to these the overstory has oaks such as Q. . hemisphaerica, Q. nigra, Q. alba, Prunus serotina, Nyssa, Carya cordiformis, C. glabra, Tilia, Liquidambar, with a scattering of Pinus echinata, $P$. Taeda. In the understory are Cornus florida, Ostrya, Carpinus, Prunus umbellata, Rhus copallina, with Vaccinium elliottii, $V$. arboreum, Sebastiana, Rhus toxicodendron and lianas such as Parthenocissus, Vitis, Rhus radicans, Anisostichus, Campsis are common. The soil is a fine sandy loam and is usually moist, definitely not wet. Such herbs as Hexastylis arifolia, Trillium underwoodii, T. catesbaei, Spigelia, Carex, Polygonatum, Sanguinaria are present. The Matelea vines appear to occupy the edges of the deeper stands of forest or where the trees are well spaced, or where there has been some evidence of recent logging or other disturbance. This appears to agree with information on labels of specimens collected from other localities. It also appears that as such disturbed areas are gradually overgrown by returning woody vegetation the Matelea vines quit flowering, under increasing shade gradually lose vigor, and finally are supressed entirely.

From this it might be assumed that selective logging of the sort that did little damage to the understory or to the substrate might actually benefit. Controlled light burning might be beneficial. However, these plants are so rare that recommendations for their monitoring and management ought best to come from Dr. Drapalik himself. 


\section{References}

Drapalik, Donald. 1970. A biosystematic study of the genus Matelea in the southeastern United States. Unpublished Ph.D. Thesis, University of North Carolina at Chapel Hill.

Sma17, J.K. 1933. Manual of the southeastern flora, pp. 1075-1076, Chape1 Hi] 1, N.C.

Vai1, Anna M. 1899. Studies in the Asclepiadaceae, Bu71. Torr. Bot. Club 26: $423-431$.

1903. Studies in the Asclepiadaceae VII. A new species of Vincetoxicum from Alabama. Bu17. Torr. Bot. Club 30: 178-179.

Woodson, R.E. 1941. The north American Asclepiadaceae I. Perspective of the genera. Ann. Mo. Bot. Gard. 28: 193-244. 
SPECIES Matelea alabamensis (Vail) Woodson. Alabama milkvine

\begin{tabular}{|c|c|c|c|c|c|c|c|c|}
\hline \multirow[b]{2}{*}{$\begin{array}{l}\text { Expected* } \\
\text { Effect on } \\
\text { the Species }\end{array}$} & \multicolumn{8}{|c|}{ Management Practices } \\
\hline & $\begin{array}{c}\text { Prescribe } \\
\text { Burn }\end{array}$ & $\begin{array}{c}\text { Bulldoze } \\
\text { or } \\
\text { Root Rake }\end{array}$ & Bed & Chop & $\begin{array}{l}\text { Thin } \\
\text { over- } \\
\text { story }\end{array}$ & $\begin{array}{l}\text { Cut } \\
\text { over- } \\
\text { story }\end{array}$ & $\begin{array}{l}\text { Establish } \\
\text { Plantation } \\
\end{array}$ & Graze \\
\hline Destroy & & $\mathrm{X}$ & $\mathrm{X}$ & $\mathrm{X}$ & & & $\mathrm{X}$ & \\
\hline Damage & & & & & & $\mathrm{x}$ & & \\
\hline $\begin{array}{l}\text { No Lasting } \\
\text { Effect }\end{array}$ & & & & & & & & \\
\hline $\begin{array}{l}\text { Beneficial } \\
\text { if Done } \\
\text { Proper } 1 y\end{array}$ & $\mathrm{X}$ & & & & $\mathrm{x}$ & & & \\
\hline
\end{tabular}

plants not used by stock, but can be damaged

Other Comments: by them.

*Expected effect on the species is an estimate made by Dr. Robert Kral based on his knowledge of the habitat and on knowledge gained from personal field observations. Estimates are "rough" in many instances. Results of practices may be modified depending upon the degree of application, intensity of treatment, nearness to plant communities, etc. A management practice for which no entry is made indicates a lack of sufficient information from which to predict expected results. As observations are made in the field by users of the data, the expected effect will be refined. 
Matelea alabamensis (Vaii) Woodson

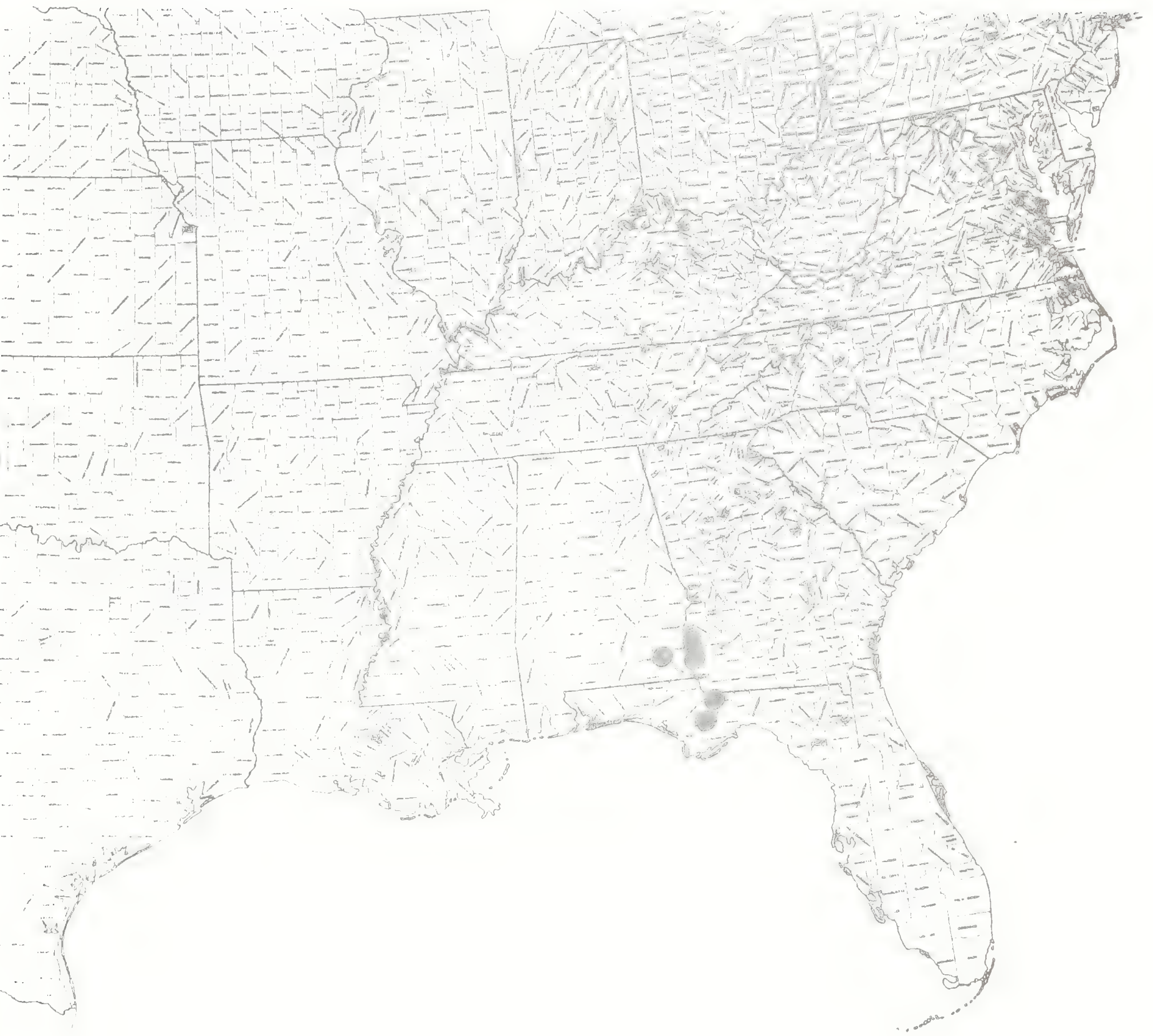


-

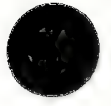

- 


\section{ASPIDIACEAE}

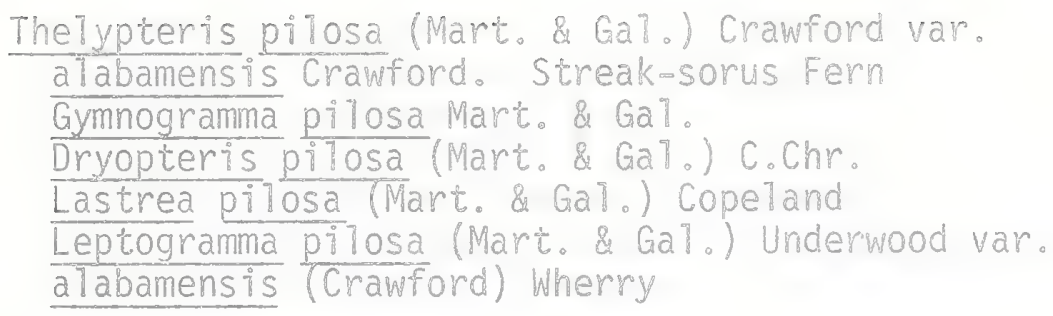

\section{Technical Description}

Rather delicate, lowish fern from a slender, short, yellow-pilosulous and reddish-brown-scaley rhizome, the rhizome scales reddish-brown, lustrous, scattered pilosulous toward base, $1 \mathrm{~cm}$ or less long, lanceolate, attenuate.

Fronds.-. Close-set on the short rhizome, usually appearing clustered, the stipe slender, erect to ascending or spreading, brownish toward base, upwardly becoming green, slightly angulate, pilose throughout, $1-3(4-8) \mathrm{cm}$ Tong; blade $3.5-10.0(-15) \mathrm{cm}$ long, $1.5-3.0 \mathrm{~cm}$ broad, ovate-lanceolaate to lance-or-elliptic-oblong, usually broadest at middle or below, l-pinnate, the lower pinnae separate, short-stalked, narrowly to broadly ovate, elliptic or suborbicular, rounded-tipped, entire to sinuate or sinuately toothed or lobed, upward becoming sessile, then fused basally so that toward tip the frond is pennately lobed, at very tip shallowly lobed or serrate-dentate; upper surface of blade yellow-green, dul7, scattered strigose-pilose, densely so along the veins and midrib; lower surface of blade slightly paler, similarly pilose: venation of pinnae pinnate, a central vein extending to pinna-tip, laterals to each lobe (tooth) tip as well as to each sinus; sori short to elongate-linear, the sporangia rather loosely and medially arranged along the branch veins of the pinnae.

Distribution

Shaded bluffs along the West Fork of the Sipsey River, Bankhead National Forest, Winston County, Alabama; also Chihuahua, Mexico.

\section{Special Identifying Features}

This species differs from the other Thelypteris of the southeast in having no indusium. It differs from T. pilosa var.pilosa, a widespread species in Mexico and Central America in being an overall smaller plant, the pinnule tips rounded (rather than acute!), the sinuses of pinnule margins reached by but 1 latera? vein (rather than by 2 ).

Habitat and Management Implications

I. pilosa var. alabamensis grows on shaded moist ledges of Pottsville Sandstone which forms massive bluffs in places along the sipsey River. For several years it was presumed extinct in that it had been known only from the type locality $5 \mathrm{mi}$. east of Double Springs on the Sipsey and this locality had been destroyed by bridge construction. Recently however, it has been found in a few, isolated localities along the same stream, the populations generally sma71, consisting of few plants each. In that the area where the ferns have been found is in National Forest and the river itself 
is there protected, this fern, because of its small size, because of the steepness of its habitat, should escape much damage save by overactive collectors of ferns. These plants are usually much smaller than dimensions given them by Wherry (1964), usually are scattered in moss and liverwort mats in the crevices of the bluffs. Shade is provided $r$ a bluff and ravine forest of hemlock, various cove-type hardwoods including Quercus rubra, Q. alba, ash, tulip poplar, elm, maple. Betula lenta, etc. Habitat for this rare fern is maintained by a combination of high humidity, high substrate moisture, and shade, the humidity provided by evaporation from the stream, the substrate moisture by seepage over the sandstone and bryophyte mats, the shade by overhanging branches of trees which also tend to trap the moist air. Danger to the fern could come from logging of the bluff woodlands, this admitting too much light, reducing humidity, thus generally contributing to a drying out and destruction of the habitat.

\section{References}

Copeland, E.B. 1947. Genera Filicum, the genera of ferns. Chronica Botanica Company, Waltham, N.Y.

Crawford, L.C. 1951. A new fern for the United States. Amer. Fern. Journ. 41: 15-20.

Dean, Blanche E. 1969. Ferns of Alabama, rev. ed. pp. 105-106. Southern University Press.

Knobloch, I.W. and D.S. Corre11. 1962. Ferns and fern allies of Chihuahua, Mexico. Renner, Texas.

Wherry, E.T. 1964. The southern fern guide, p. 86. New York. 
SPECIES Theirpteris pilosa (Mart, \& GaI,) Crawford var.

alabamensis crawford。 streak-sorus ferr

\begin{tabular}{|c|c|c|c|c|c|c|c|c|}
\hline \multirow[b]{2}{*}{$\begin{array}{l}\text { Expected } \\
\text { Effect on } \\
\text { the Species }\end{array}$} & \multicolumn{8}{|c|}{ Management Practices } \\
\hline & $\begin{array}{c}\text { Prescribe } \\
\text { Burm }\end{array}$ & $\begin{array}{l}\text { Bulldoze } \\
\text { or } \\
\text { Root Rake }\end{array}$ & Bed & Chop & $\begin{array}{l}\text { Thin } \\
\text { over- } \\
\text { story }\end{array}$ & $\begin{array}{l}\text { Cut } \\
\text { over- } \\
\text { story }\end{array}$ & $\begin{array}{l}\text { Establish } \\
\text { Plantation }\end{array}$ & Graze \\
\hline Destroy & $\mathrm{x}$ & NA & $\mathbb{N A}$ & $\mathbb{N A}$ & 8 & $x$ & NA & NA \\
\hline \multicolumn{9}{|l|}{ Damage } \\
\hline $\begin{array}{l}\text { No Lasting } \\
\text { Effect }\end{array}$ & & & & & & & & \\
\hline $\begin{array}{l}\text { Beneficial } \\
\text { if Done } \\
\text { Properly }\end{array}$ & & & & & & & & \\
\hline
\end{tabular}

Other Comments:

*Expected effect on the species is an estimate made by Dr. Robert Kral based on his knowledge of the habitat and on knowledge gained from personal field observations. Estimates are "rough" in many instances. Results of practices may be modified depending upon the degree of application, intensity of treatment, neamess to plant communities, etc. A management practice for which no entry is made indicates a lack of sufficient information from which to predict expected results. As observations are made in the field by users of the data, the expected effect will be refined. 
Thelypteris pilosa (Mart. \& Gal.) Crawford var. alabamensis Crawford

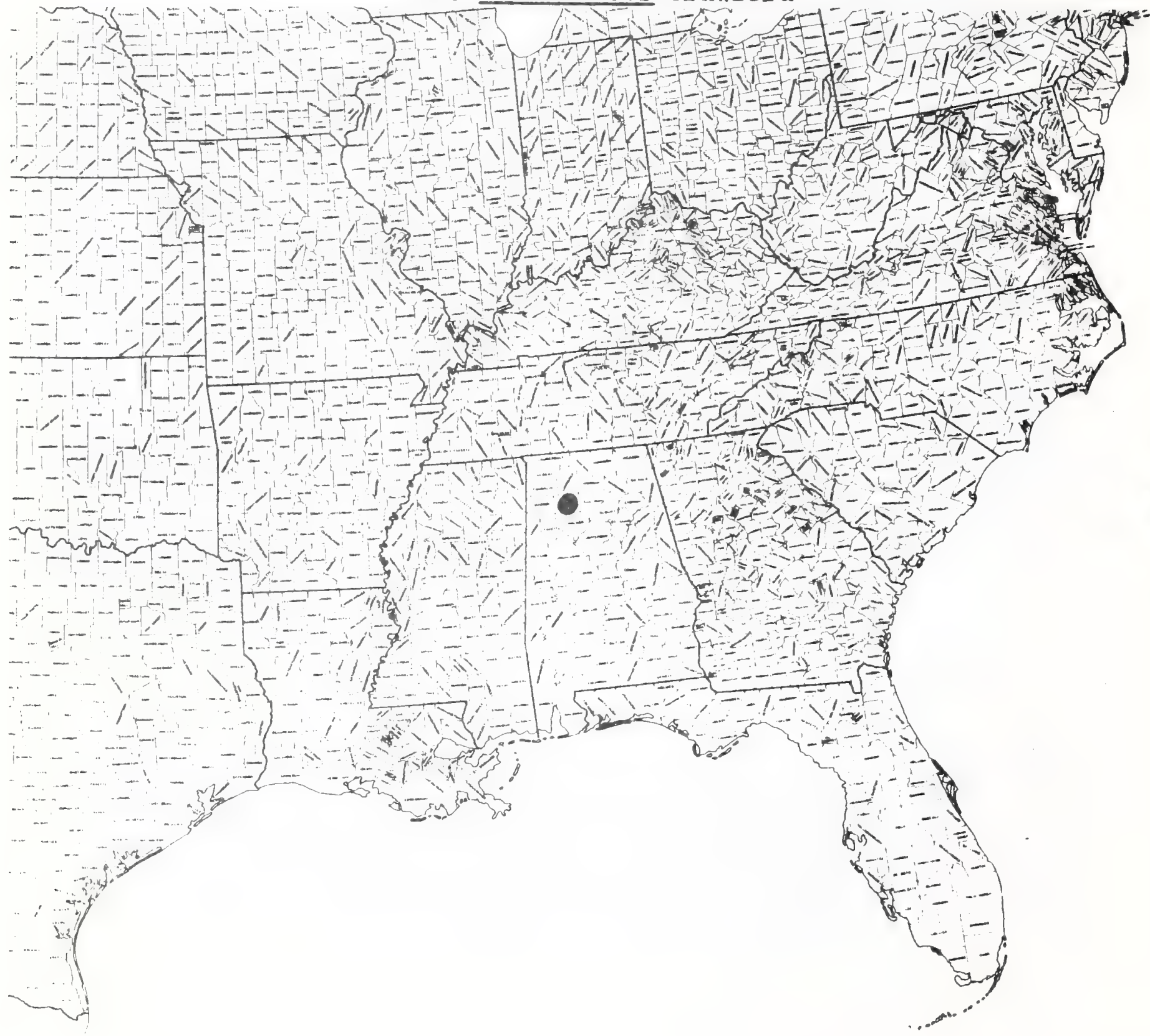


Paper 162

Text \& Map by:

Robert Kral

\section{ASPLENIACEAE}

Phylittis scolopendrium (L.) Newn. American hart's-tongue fern Scolpodendrium vulgare Sm.

Phyllitis scoTopendrium var. americana Fern

\section{Technical Description}

Perennial, evergreen fern from a shortish, stout, ascending caudex-like rhizome.

Fronds... Few to several, closely and spirally clustered at rhizomal crown, simple-bladed, the blades spreading or ascending in a rosette, strap-like (oblong-linear to Tinear-panduriform), mostly 1-3 dm long, mostly 2-5 cm wide, apically short-acuminate, acute or rounded, rarely bifurcated, in any case the tips bluntish, the margin thin, somewhat revolute, entire or sinuate, the fresh surface pocketed-crispate, the blade base usually prominently auriculate; surface above a glossy deep green, beneath paler, duller; veins pinnate, few-forking, free, their tips entarged to form linear "foveolae" (visible on upper surface) extending to ca. $1 \mathrm{~mm}$ from margin; stipe dark glossy brown, stoutly linear, between $1 / 3$ and $1 / 4$ as long as the blade, with a brush of reddish-brown, narrowly-triangular-attenuate scales, these longest and most abundant at stipe base, reduced in size and patchy upward, denser again on the lower surface of the frond along base of midrib of blade, sometimes to near its apex; sorj 7 inear, double but each pair so close as to appear one, the "pairs" regularly and pinnately arranged from near blade base to near sumit or on the distal 1/2-1/3, mostly $0.5-1.5 \mathrm{~cm}$ long, shorter often alternating with longer; indusia palemembranous, lateral to each of a sorus "pair", I flap usually slightly overlapping the other over the crest of the compound sorus.

\section{Distribution}

Cool, moist to dryish shaded faces of calcareous rock or shade, in North America very rare and local from New Brunswick and Ontarjo southward to central New York state; in the southeastern area known now only from Marion County, Tennessee, Northern Alabama and Mexico.

Special Identifying Features

P. scolopendrium is monotypic, perhaps may be distinct as a variety of the more abundant European entity (this infrequently naturalized in eastern North America), which tends to be in all ways a larger plant with scales of stipe more uniformly disposed along the stipe, the larger ones admixed with smaller, narrower ones, and with longer, broader sori. Uni ike the American example, the European plants are said to be abundant in many parts of Europe, almost weedy, on rock fences, in rocky pastures and hedgerows.

Habitat and Management Implications

At one time there were only 2 known stations for the hart's-tongue fern in the southeast, both in Tennessee, in Marion and Roane counties, the latter 
now destroyed. In that the only recent observations of it have been made in thi Marion County locality, a limesink and falls near South Pittsburg, the following habitat observations are confined to the writer's experience with that locality. The Phyllitis juts from the steep sides and overhang of a narrow deep sinkhole in limestone. The substrate is almost always moist, is often wet, covered with a mat of bryophytes. $\therefore d$ is usually both shaded and cool, consisting either of rockface or the sticky clay weathered from it. The visible sporophytes are usually few, most of them now confined to the most inaccessible part of the sinkhole, namely the lower part of and overhang adjacent to the lip of a waterfall. Fortunately for the fern the only way a collector could reach the few plants would be by his being lowered by rope or rope ladder. There are several previous reports of this South Pittsburg population, beginning with the late 1800's and the earliest indicate that it was then much more abundant, extending even to the floor of the sink. Since then, reported numbers of sporophytes have varied widely, but in general show a decline. None are now seen on the sink floor or toward its rim. Complicating matters still further is the fact that Mr. E.W. Graves (according to MS. Eleanor McGilliard, 1936) spread spores of Ontario plants in the area so that at least some of the specimens now seen may have developed from that source. However, the hart's-tonuge fern still exists in one southeastern locality. It is maintained there by the unique habitat which provides a combination of shade of mixed hardwoods, high and nearly constant moisture of substrate, and high humidity created by the spray from falling and seeping water. There is relatively little fluctuation of the cool temperature in summer. This habitat is so sensitive that any type of human activity in the immediate area involving mining or logging machinery would doubtless trip the balance toward extirpation.

\section{References}

Fernald, M.L. 1950. Gray's manual of botany, ed. 8, p. 42. New York.

Graves, E.W. 1911. The hart's-tongue in Tennessee, 1878-1935. Amer. Fern Jour. 26 (4): 113-122.

McGilliard, E. 1936. The hart's-tongue in Tennessee, 1878-1035. Amer. Fern. Journ. 26 (4): 113-122.

Shaver, J.M. 1954. Ferns of Tennessee, pp. 105-112. Nashville, TH

Sma11, J.K. 1938. Ferns of the southeastern United States, pp. 148-150. New York. 
SPECIES Phylitis scolopendrium (I, ) Newn' American hart's-tongue

\begin{tabular}{|c|c|c|c|c|c|c|c|c|}
\hline \multirow[b]{2}{*}{$\begin{array}{l}\text { Expected* } \\
\text { Effect on } \\
\text { the Species }\end{array}$} & \multicolumn{8}{|c|}{ Management Practices } \\
\hline & $\begin{array}{c}\text { Prescribe } \\
\text { Burn }\end{array}$ & $\begin{array}{l}\text { Bulldoze } \\
\text { or } \\
\text { Root Rake }\end{array}$ & Bed & Chop & $\begin{array}{l}\text { Thin } \\
\text { over- } \\
\text { story }\end{array}$ & $\begin{array}{l}\text { Cut } \\
\text { over- } \\
\text { story }\end{array}$ & $\begin{array}{l}\text { Establish } \\
\text { Plantation }\end{array}$ & Graze \\
\hline Destroy & NA & $\mathbb{N A}$ & $\mathbb{N A}$ & $\mathbb{N} A$ & $x$ & $x$ & & \\
\hline \multicolumn{9}{|l|}{ Damage } \\
\hline $\begin{array}{l}\text { No Lasting } \\
\text { Effect }\end{array}$ & & & & & & & & \\
\hline $\begin{array}{l}\text { Beneficial } \\
\text { if Done } \\
\text { Properly }\end{array}$ & & & & & & & & \\
\hline
\end{tabular}

Other Comments: known localities should be "insulated" by a wide totally protected zoned

*Expected effect on the species is an estimate made by Dr. Robert Kral based on his knowledge of the habitat and on knowledge gained from personal field observations. Estimates are "rough" in many instances. Results of practices may be modified depending upon the degree of application, intensity of treatment, nearness to plant communities, etc. A management practice for which no entry is made indicates a lack of sufficient information from which to predict expected results. As observations are made in the field by users of the data, the expected effect will be refined. 
Phyllitis scolopendrium (L.) Newm.

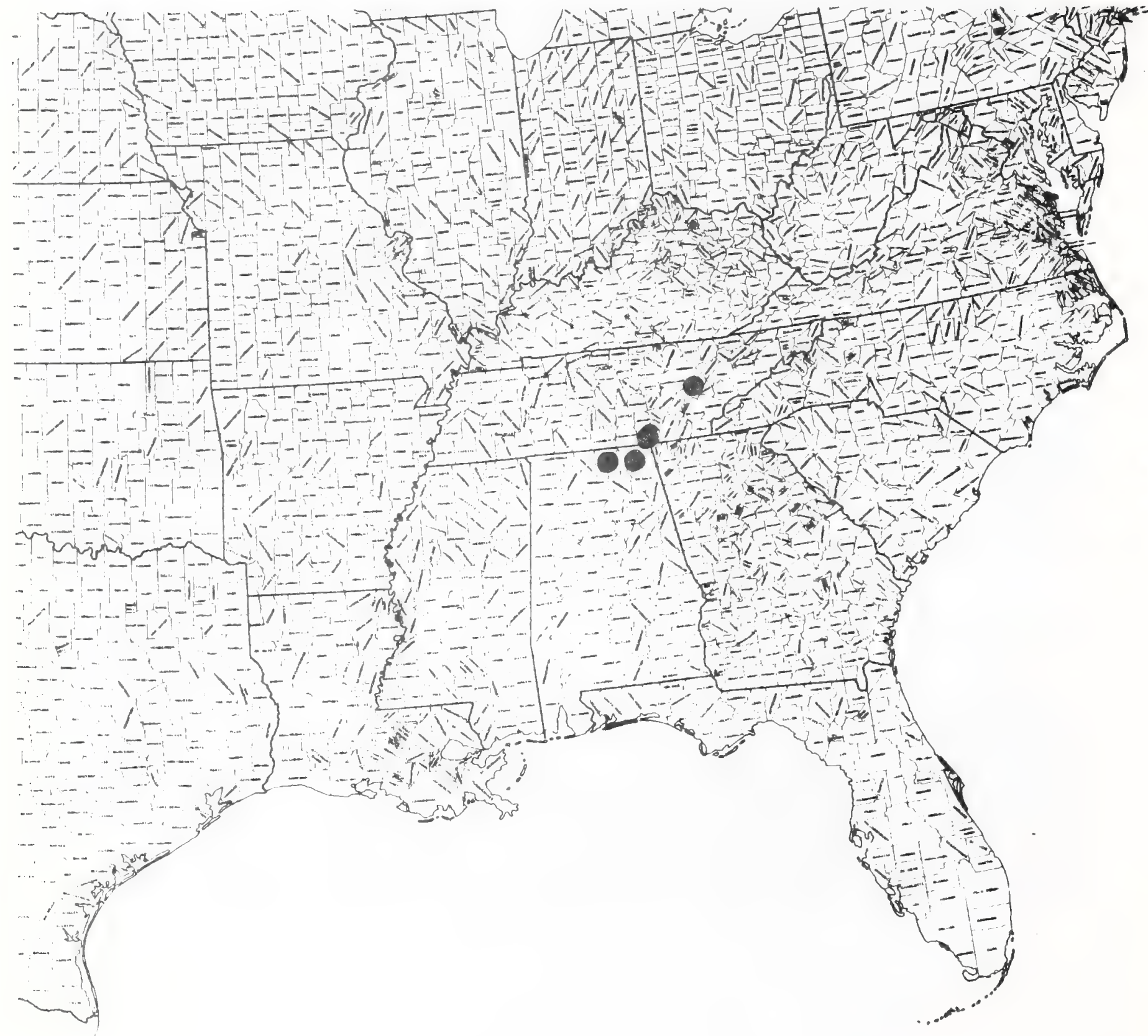


Paper 163

Text \& Map by:

Robert Kral

\section{ASTERACEAE}

\section{Coreopsis intermedia Sherff. golden-wave tickseed}

\section{Technical Description}

Thick-rooted perennial herb increasing by Tateral shoot buds from a stout caudex.

Stems.-- 1-several, erect or ascending, mostly 6-10 (-15) dm long, stiffish and brittle, toward base nearly terete, pale brown or purplish-brown, sparsely puberulent or hirsutulous, upwardly becoming greenish, the internodes strongly ribbed or sulcate, simple or sparingly branched below the inflorescence. Leaves.- Opposite; lowest leaves usually withered by flowering time, closeset, simple (or trilobed with terminal lobe largest), as long or longer, slender, but clasping-based; leaves higher on stem becoming sessile or short-petiolate, all simple and unlobed, the largest at about midstem, spreading, rather distant, firm (slightly fleshy), elliptic, oblong, lanceolate or oblanceolate, to $7 \mathrm{~cm}$ long, the tips obtuse or rounded, the margin with a somewhat paler, thickened, puberulent, entire edge, the base shortattenuate, broadly cuneate or rounded-clasping, the upper surface yellowgreen, puberulent to nearly smooth, the lower surface paler, puberulent to smooth; leaf size diminshing gradually to the inflorescence base, thence rather abruptly smaller, the bracts distant or absent in the inflorescence. Inflorescence.- Heads rather few, solitary at tips of upwardly arching to erect, smooth to slightly puberulent, strongly ribbed peduncles, these mostly $6-20 \mathrm{~cm}$ long and usually bractless or with bracts only at very base. Heads (involucres) at anthesis broadly campanulate, mostly about 1.5-2.0 $\mathrm{cm}$ wide across the phyllaries, ca. $1.5 \mathrm{~cm}$ high (from base to tips of inner phyllaries), the phyllarias essentially in 2 series with the outermost distinct, lanceolate, $8-10 \mathrm{~mm}$ long, greenish and multinerved, with narrow but firm, cartilaginous and bristly tips, marginally pale-banded, ciliate, the backs smooth; inner phyllaries broadly lanceolate or narrowiy ovate, erect, mostly 12-15 mm long, orange-yellow, the tips narrowly rounded, minutely ciliate, the margins entire, thin, the surfaces smooth; chaff of elevated receptacle mostly $6-8 \mathrm{~mm}$ long, firm-papery, Iinear-lanceolate, whitish, with subulate, brownish tips, the backs sightly convex, with 1-2 brown, medial bands.

Flowers..- Ray florets 8-10, the corollas spreading, clear yellow, the tube $\overline{\mathrm{ca} .2 \mathrm{~mm}}$ long, the blade broadly obovate-cuneate, $2.5-3.0 \mathrm{~cm}$ long, the broad apex irregularly and rather coarsely toothed; ovary apparently infertile, oblong-linear, $\mathrm{ca}$. $4 \mathrm{~mm}$ long, flattened, bearing at apex a pair of low, lacerate pappus scales; disc florets numerous, fertile, the tubular-narrowly campanulate corollas ca. $5 \mathrm{~mm}$ long, the tube and throat ye? lowish-white, with 5 reddish 7 ines, and 5 short-triangular, slightly spreading, deeper yellow, red-margined lobes. Style branches short-spreading, apically minutely glandular-bristly with short, narrowly conic appendages. Pappus consisting of 2 (sometimes more) sma 71 , erect, pale, triangular, 3-winged, acutish scales. Fruit.- - Akenes mostly broadly ovoid to nearly round, mostly $2.5 \mathrm{~mm} 7 \mathrm{ong}$ and nearly as broad or broader, inwardly curvate, deep reddish-brown, the 
convex backs strongly tuberculate, the inner face forming a membranous entiremargined cup around the obovate seed cavity whose surface is strongly tuberculate and which bears marginally a strong, broad, purplish-brown, thin, entire, erose or pectinately fringed wing-border.

\section{Distribution and Flowering Season}

Sands or sandy Toams of open woods, sandy fields and roadsides, northeastern Louisiana and northeastern Texas. Flowering mostly in May and June.

\section{Special Identifying Features}

C. intermedia is closest taxonomically to $C$. pubescens Ell., a widespread species mostTy of the interior provinces in the southeastern U.S. and in the Ozarks. However, the range of the former is nested within, does not overlap, that of the latter (so far as present records indicate). It is to be distinguished from $C$. pubescens by its fleshier, firmer leaves, which tend toward the plant base to be entire, less often pinnate, and by its longer range of peduncle lengths. Hybrids between it and $C$. pubescens have been synthesised by $D r$. E. Smith, as have hybrids between it and $C$. grandiflora (with highest pollen stainability) and $\underline{C}$. nuecencis (Smith, 1976).

Habitat and Management Implications

C. intermedia is most abundant on deep sand soils, in open oak-hickory or oak-hickory-pine woods or on sandy clearings in such woods. The soil, if not a nearly pure sand, is but slightly humified, and generally rather dry. The oaks are majnly Q. stellata, Q. margaretta, Q. marilandica, Q. falcata, Q. incana, the hickories Carya texana, C. tomentosa, the pines $\underline{\text { P. echinata, }}$ $\bar{P}$. Eaeda, the understory mostTy of Cornus florida, Vaccinium arboreum, Sassafras, Tow bush blueberry, etc. Sandhills herbaceous species such as Froelichia, Poronychia, Berlandiera, Tetragonatheca, Stillingia, Cenchrus, Cnidoscolus, Penstemen (murrayanus) are common. The hardwood forest is of relatively Tow quality, being best suited for growth of pine, which is plantation managed through much of the area. Clear cutting, even accompanied by considerable soil disturbance, would favor increase of this species through creating more light. The region has a history of fire, this probably the disturbance factor which has over time created openings for $\underline{C}$. intermedia to occupy.

References

Sherff, E.E. 1926. New or otherwise noteworthy Compositae III. Bot. Gaz. 88: 285-309.

Smith, E.B. 1976. A biosystematic survey of Coreopsis in eastern United States and Canada. Sida (3): 123-215. 
SPECIES Coreopsis intermedia Sherfe". goldenwave tickseed

\begin{tabular}{|c|c|c|c|c|c|c|c|c|}
\hline \multirow[b]{2}{*}{$\begin{array}{l}\text { Expected* } \\
\text { Effect on } \\
\text { the Species }\end{array}$} & \multicolumn{8}{|c|}{ Management Practices } \\
\hline & $\begin{array}{c}\text { Prescribe } \\
\text { Burn }\end{array}$ & $\begin{array}{l}\text { Bulldoze } \\
\text { or } \\
\text { Root Rake }\end{array}$ & Bed & Chop & $\begin{array}{l}\text { Thin } \\
\text { over- } \\
\text { story }\end{array}$ & $\begin{array}{l}\text { Cut } \\
\text { over- } \\
\text { story }\end{array}$ & $\begin{array}{l}\text { Establish } \\
\text { Plantation }\end{array}$ & Graze \\
\hline Destroy & & & & & & & $\mathrm{x}$ & \\
\hline \multicolumn{9}{|l|}{ Damage } \\
\hline $\begin{array}{l}\text { No Lasting } \\
\text { Effect }\end{array}$ & & $\mathrm{x}$ & $x$ & $x$ & & & & \\
\hline $\begin{array}{l}\text { Beneficial } \\
\text { if Done } \\
\text { Properly }\end{array}$ & $x$ & & & & $\mathrm{X}$ & $x$ & & \\
\hline
\end{tabular}

Other Comments:

* Expected effect on the species is an estimate made by Dr. Robert Kral based on his knowledge of the habitat and on knowledge gained from personal field observations. Estimates are "rough" in many instances. Results of practices may be modified depending upon the degree of application, intensity of treatment, neamess to plant communities, etc. A management practice for which no entry is made indicates a lack of sufficient information from which to predict expected results. As observations are made in the field by users of the data, the expected effect will be refined. 
Coreopsis Intermedia therff

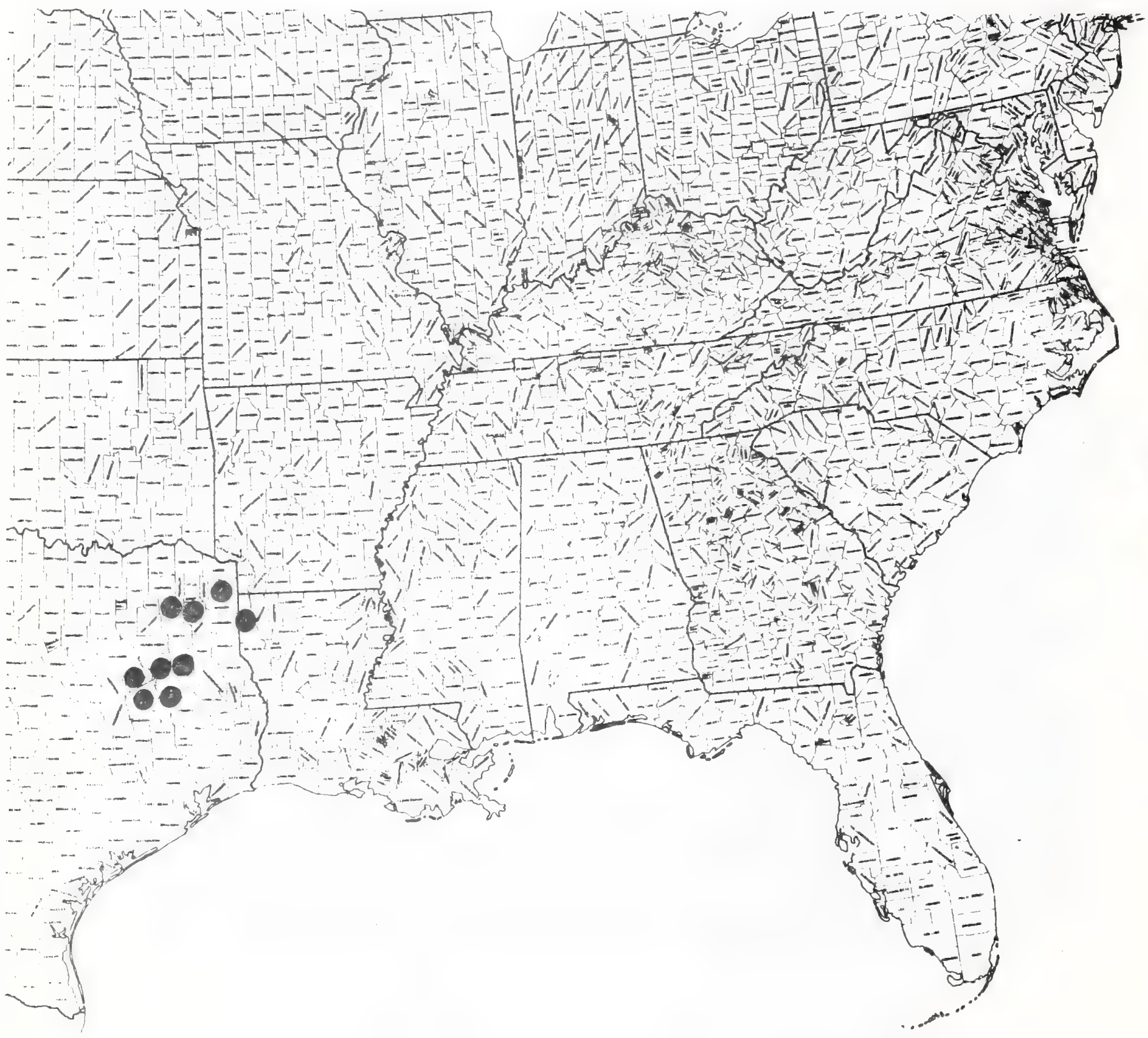




\title{
ASTERACEAE
}

\author{
HeTianthus smithil Heiser. Smith's sunflower \\ H. parvifTorus var. attenuatus A. Gray
}

\section{Technical Description}

Perennial, fleshy-rooted, from short, ascending rhizomes and from crown buds.

Stems.-- Erect, solitary or few, simple or sparingly branched below the inflorescence, terete or s7ightly ribbed, mostly $8=15 \mathrm{dm}$ high. ca. $5 \mathrm{~mm}$ thick at base, mostly smooth save in inflorescence branches, glaucous, purplish or reddish-brown, brittle.

Leaves.-- Lowermost usual7y absent by flowering time, of those present the lower ones opposite, rarely alternate, upward on stem becoming alternate, with the largest at about mid-stem, the blades mostly narrowly to broadly lanceolate, firm, narrowiy acuminate, the margins entire, often revolute, the bases cuneate, then attenuated on spreading petioles $1.5 \mathrm{~cm}$ long or less; upper blade surface deep yellow-green, harsh, the lower surface paler, densely golden-gland-dotted, the midrib strongly raised, strigose, the lateral veins pinnate, less conspicuous, less strigose, the surfaces between major veins usually smooth or with a wide scattering of short, appressed hairs. Inflorescence... Heads numerous, in cymes, the major inflorescence brances slender, elongate, arching upward from axils of most upper leaves and with most heads produced on hairy peduncles toward the strigillose branch tips; heads mostly campanulate, ca. $1 \mathrm{~cm}$ high and nearly as broad across the phyllaries, the phyllaries several, loosely imbricated in several series, foliaceous, the smallest outermost and loosest, the tips often spreading, lance-linear, attenuate, the larger ones oblong-lance-ovate, narrowly nerved, smoothish: receptacle conic, the phyllaries grading into pales of similar length but oblong, firmer, browner, more strongly ribbed and apically often tridentate, the upper margins ciliate, the backs villosulous distally. Flowers.-- Ray florets mostly $6-10$, the Tigules $1.0-1.5 \mathrm{~cm}$ long, spreading, pale yellow, elliptic-linear, ciliate. Disc florets numerous, the corollas yel7ow, ca. $4.5 \mathrm{~mm}$ long, the short tube abruptly expanded to a narrowly campanulate throat, thence into 5, spreading-ascending, short-triangular teeth. Fruit.- Akenes oblong-obovoid, somewhat flattened parallel to phyllaries, ca. $4 \mathrm{~mm}$ long, $2 \mathrm{~mm}$ wide, dark brown, bearing at the truncated apex 2 pale, Tance-subulate, ciliate, pale scales to $2 \mathrm{~mm}$ long.

\section{Distribution and Flowering Season}

Dry sands or sandy clays of upland oak-pine-hickory woods, southern Appalachians, southeastern Tennessee, southwestern North Carolina, northeastern Georgia and in Alabama in the eastern mountain ranges south along the east side of the state through the Pjedmont into the upper Coastal Plain. Flowering from August to frost.

\section{Special Identifying Features}

H. smithii most resembles, in fact produces intermediates with, $\underline{H}$. microcephalus, 
a common small-headed sunflower of dry sunny uplands throughout the southeast. However, that species has longer petioles (1.5 cm or more), with heavily to lightly puberulent lower leaf surfaces. In appearance $\mathrm{H}$. smithii is actually closest to $\mathrm{H}$. laevigatus, a rather rare sunflower of the inner Piedmont and eastern BTue Ridge of the Carolinas, also western Virginia. That species, so similar in leaf and head, however lacks the resin atoms on the lower surfaces of its leaves, whose upper surfaces are nearly smooth, rather than scabrid.

\section{Habitat and Management Implications}

H. smithii, according to Dr. Heiser in his recent monograph of the genus T1969), is quite rare. However, Cronquist (1977) has turned up several more specimens from recent collections of Helianthus from the southeast; it actually may be relatively abundant locally in the mountains of eastern Alabama, It is a plant of well drained, dryish, sands, sandy loams, or sandy clay loams, usually in open oak-hickory-yellow pine uplands. The pine species are usualiy $\underline{P}$. echinata, $P$. taeda, $P$. palustris, $P$. virginiana, the oaks Q. prinus, Q. coccinea, Q. velutina, Q. falcata, the hickories Carya tomentosa, C. glabra, C. ovalis, C. pal7ida. Understory is usually made up of Cornus fTorida, Running oak (Q. stellata var.), Viburnum, with an admixture of both high and low bush blueberries, Rubus, Smilax. Herbaceous associates are the usually dry upland summer and faTl flowering Desmodium, Lespedeza, Stylosanthes, Strophostyles, Potentilla, Lechea, Scutellaria, Agalinis, etc. In areas where cutting of the overstory has been extensive, H. smithii behaves as a weed as do other perennial sunflowers in the same

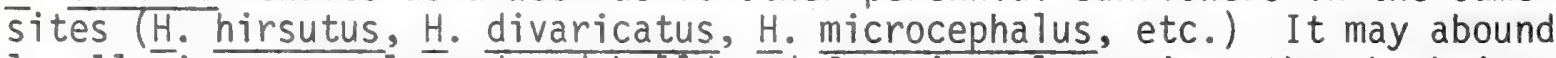
locally in areas cleared and bulTdozed for pine plantation, though, being a sun plant, it is most likely shaded out as crowns close. It is in such disturbed sites that it is producing hybrids with $\underline{H}$. microcephalus. Fire is a historical factor in the forest types $H_{\text {. smithii- It frequents and }}$ probably tends to increase the species by reducing woody competition.

\section{References}

Cronquist, A. 1977. Notes on the Asteraceae of the southeastern United States. Brittonia 29 (2): 217-225.

Heiser, C.B. with D.M. Smith, S.B. Clevenger and W.C. Martin. 1969. The North American sunflowers. Mem. Torr. Bot. Club 22 (3). 218 pp. illust. Durham, N.C. 
SPECIES HeIianthus smithi Hei ser'". Smith ${ }^{B}$ s sunflower

\begin{tabular}{|c|c|c|c|c|c|c|c|c|}
\hline \multirow[b]{2}{*}{$\begin{array}{l}\text { Expected* } \\
\text { Effect on } \\
\text { the Species }\end{array}$} & \multicolumn{8}{|c|}{ Management Practices } \\
\hline & $\begin{array}{c}\text { Prescribe } \\
\text { Burn }\end{array}$ & $\begin{array}{c}\text { Bulldoze } \\
\text { or } \\
\text { Root Pake }\end{array}$ & Bed & Chop & $\begin{array}{l}\text { Thin } \\
\text { over } \\
\text { story }\end{array}$ & $\begin{array}{l}\text { Cut } \\
\text { over- } \\
\text { story }\end{array}$ & $\begin{array}{l}\text { Establish } \\
\text { Plantation }\end{array}$ & Graze \\
\hline Destroy & & & & & & & $x$ & \\
\hline Damage & & & & & & & & $x$ \\
\hline $\begin{array}{l}\text { No Lasting } \\
\text { Effect }\end{array}$ & & $\mathrm{X}$ & $x$ & $x$ & & & & \\
\hline $\begin{array}{l}\text { Beneficial } \\
\text { if Done } \\
\text { Properly }\end{array}$ & $x$ & & & & $X$ & $x$ & & \\
\hline
\end{tabular}

Other Comments: ¿nvades mechanicaldy disturbed areas!

*Expected effect on the species is an estimate made by Dr. Robert Kral based on his knowledge of the habitat and on knowledge gained from personal field observations. Estimates are "rough" in many instances. Results of practices may be modified depending upon the degree of application, intensity of treatment, neamess to plant communities, etc. A management practice for which no entry is made indicates a lack of sufficient information from which to predict expected results. As observations are made in the field by users of the data, the expected effect will be refined. 
Helianthus smithii Heiser

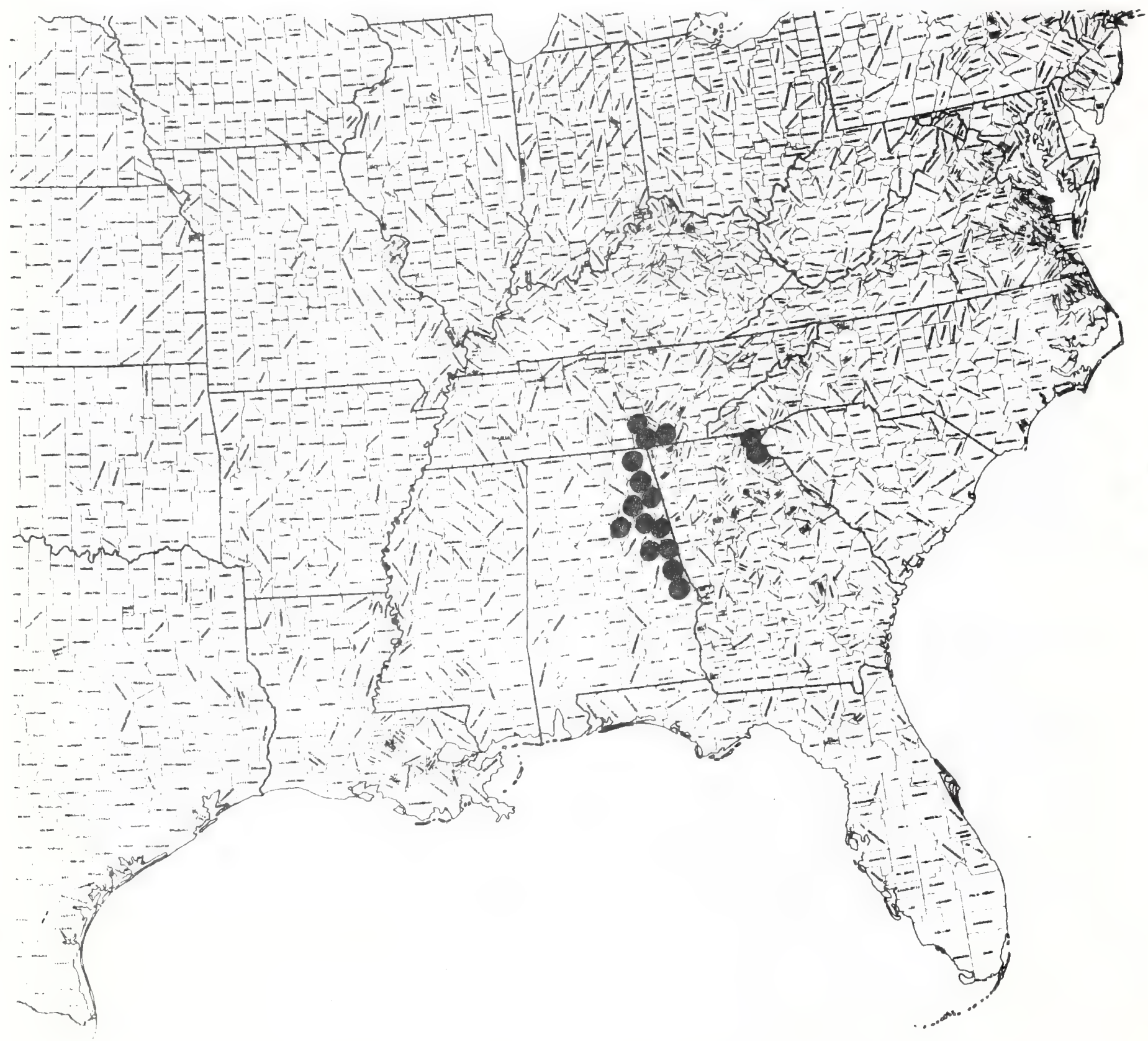




\title{
ASTERACEAE
}

\author{
Heterotheca ruthi i (Sma17) Harms. Ruth's golden-aster \\ Chrysopsis ruthio Small \\ Pityopsis ruthii (Sma11) Small
}

Technical Description

Tufted perennial herbs with slender, stoloniferous rhizomes.

Stems.-- Few to several, erect to ascending or decumbent, stiffish, terete, the bases with brownish, scaly, old leaf bases, throughout silvery-white with copious, long, appressed hairs, these admixed above on stem with short, spreading, peg-like, glandular hairs; branches few to several, upwardly arching, departing from mid-stem upward.

Leaves.-- Numerous, overlapping, in tight spirals, linear-lanceolate or gladiate, ascending or erect, mostly $2-5 \mathrm{~cm}$ long, narrowly acute or acuminate, entire, the bases attenuate, clasping, the surfaces silvered with long, appressed hairs.

Inflorescence.-- Of few to several heads in a cyme, the peduncles usually longer than the heads, upwardly arching, copiously spreading-glandular-hairy; heads broadly campanulate, about $1 \mathrm{~cm}$ high (from base to tip of disc), about $1 \mathrm{~cm}$ broad across top of involucre: involucral bracts lance-linear, the Tongest 7-8 mm long, attenuate-tipped, Toosely overlapping in several series, the outermost shortest, al7 green with broad, pale, ciliate margins, the backs sessile-glandular.

Flowers.-- Ray florets most7y 10-15, the pappus of numerous capi7tary du 71white bristles, $4-5 \mathrm{~mm}$ long, the corollas yellow, with flattish claws ca. $3 \mathrm{~mm}$ long and spreading, 7inear-el7iptic or oblanceolate blades 6-7 mm long: disc florets numerous, the pappus similar to that of rays, the corollas yellow, tubular, ca. $5 \mathrm{~mm}$ long, the slightly expanded throat divided into 5, triangular, erect or slightly spreading lobes.

Fruit.-- Akene lance-fusiform, 3.5-4.0 mm long, slightly ribbed, slightly compressed, the base and middle silvery-hairy, the narrowed apex smooth, the surface pale brown.

Distribution and Flowering Time

Rocky sunny bars and banks, also exposed ledges, along the Hiwassee River in Polk County, Tennessee; flowering from September to frost.

Special Identifying Features

Heterotheca ruthii is distinguished from the other grass-leaved members of its section (Pityopsis) by a combination of characters including the comparatively short, overlapping leaves which show little gradation in size from base to apex of stem, together with the glandular nature of the pubescence of peduncles, inflorescence branches, and involucral bracts. H. aspera, of the lower Guif Coastal Plain has a similar glandular pubescence but has 
longer bas 1 leaves, a taller habit, and narrower heads.

Habitat and Management Implications

This very localized endemic grows only on exposures of phyllitic rock in and along the Hiwassee River upstream from Reliance and Trally along the Ocoee in the same county. Usually it is in shallow moist soil pockets in cracks of the rock, associated with grasses and sedges in full sun. It is often on rocky bars in the stream itself. Damage to the habitat must have been already done by construction of a railroad along the south banks of the stream. Fluctuating stream levels because of sporadic releases from upstream damming on both streams have probably also served to reduce it through "flushing" away plants or inundating them. Logging of the cove hardwoods, hemlock, and scattered soft and hard pine of the ravines and slopes along the river has probably not been as disastrous as has the water "management" in the area.

Plants have been cultivated successfully from seed by Dr. R.E. Farmer (1977) who regards $H$. ruthii, when grown under artificial conditions, a good horticultural species.

References

Bowers, F.D. 1972. The existence of Heterotheca ruthii (Compositae) Castanea 37: 130-132.

- A toxonomic revision of Heterotheca sect. Pityopsis. Unpublished Ph.D. Thesis, Univ. of Tennessee.

Farmer, R.E. 1977. Seed propagation of Heterotheca ruthii. Castanea $42(2): 146-149$.

Harms, V.L. 1969. A preliminary conspectus of Heterotheca sect. Pityopsis. Castanea 34: 402-409.

Sma11, J.K. 1897. Studies in the botany of the southeastern United States XII. Bu11. Torrey Bot. Club 24: 493.

- 1933. Manual of the southeastern flora, pp. 1340-1342. ChapeT Hi11, N.C. 
SPECIES Heterotheca ruthi i (SmaI) Hams. Ruth s goldenwaster

\begin{tabular}{|c|c|c|c|c|c|c|c|c|}
\hline \multirow[b]{2}{*}{$\begin{array}{l}\text { Expected* } \\
\text { Effect on } \\
\text { the Species }\end{array}$} & \multicolumn{8}{|c|}{ Management Practices } \\
\hline & $\begin{array}{c}\text { Prescribe } \\
\text { Bumn }\end{array}$ & $\begin{array}{l}\text { Bulldoze } \\
\text { or } \\
\text { Rook Rake }\end{array}$ & Bed & Chop & $\begin{array}{l}\text { Thin } \\
\text { over- } \\
\text { story }\end{array}$ & $\begin{array}{l}\text { Cut } \\
\text { over- } \\
\text { story }\end{array}$ & $\begin{array}{l}\text { Establish } \\
\text { Plantation }\end{array}$ & Graze \\
\hline Destroy & NA & $\mathbb{N A}$ & $N A$ & $N A$ & & & $x$ & \\
\hline \multicolumn{9}{|l|}{ Damage } \\
\hline $\begin{array}{l}\text { No Lasting } \\
\text { Effect }\end{array}$ & & & & & & & & \\
\hline $\begin{array}{l}\text { Beneficial } \\
\text { if Done } \\
\text { Properly }\end{array}$ & & & & & $x$ & $x$ & & \\
\hline
\end{tabular}

\section{Ocher Corments:}

Fxpected effect on the species is an estimate made by Dr. Robert Kral based on his knowledge of the habitat and on knowledge gained from personal field observations. Estimates are "rough" in many instances. Results of practices may be modified depending upon the degree of application, intensity of treatment, nearness to plant communities, etc. A management practice for which no entry is made indicates a lack of sufficient information from which to predict expected results. As observations are made in the field by users of the data, the expected effect will be refined. 
Heterotheca ruthii (Small) Harms

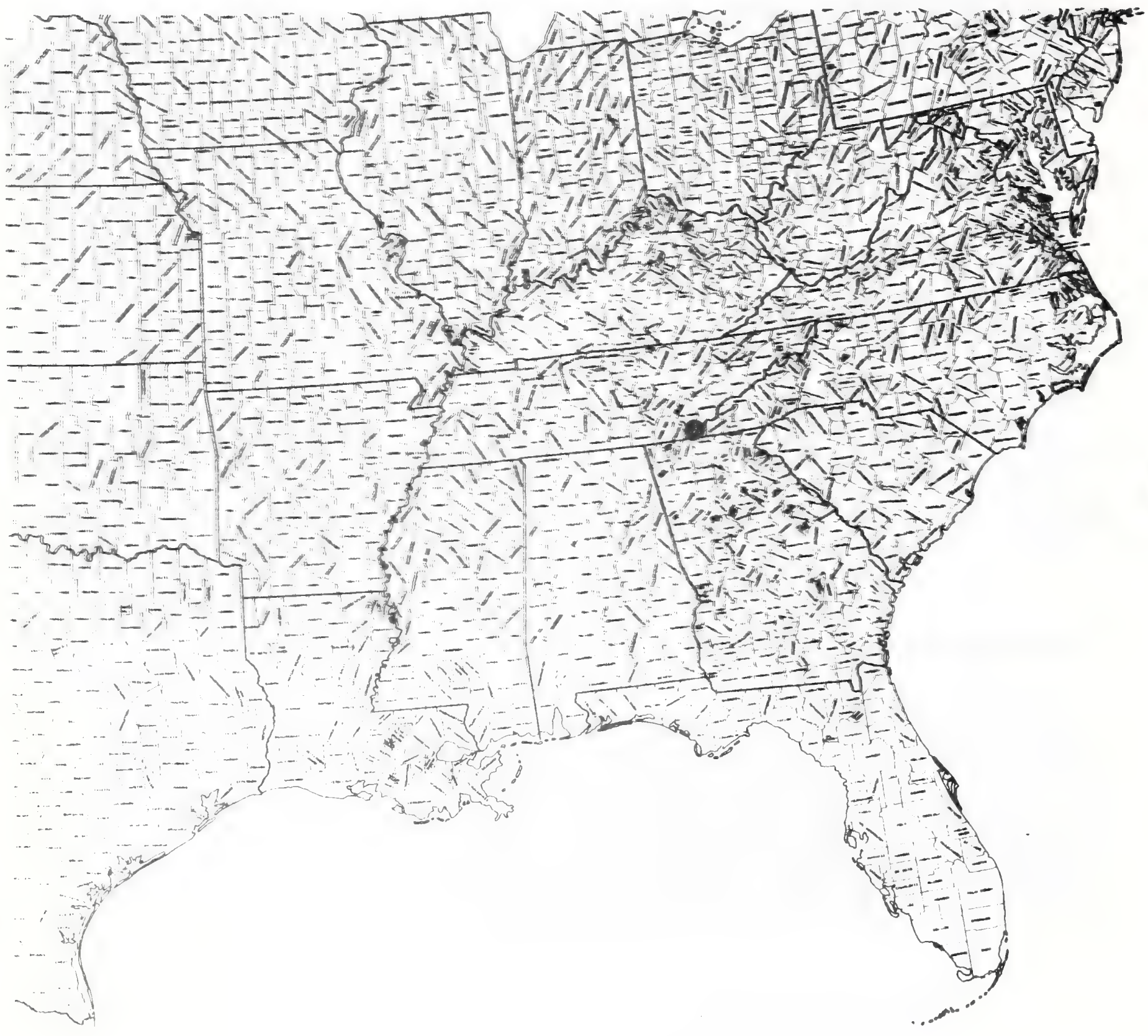




\title{
BRASSICACEAE
}

\author{
Draba aprica Beadle. open-ground whitlow-grass
}

Technical Description

Taprooted winter annual.

Stems.-- 0.3-3.5 dm high, rarely branched below the middle, soft, slender but stiffly erect, terete, low-ribbed, toward the base purplish, at midstem and above greenish, throughout stellate-pubescent, the hairs whitish. Leaves..- Both rosette and cauline produced. Basal leaves spatulate to el7iptic, ovate or suborbicular, the tips obtuse to rounded, the margins entire to few-and-low toothed (2-4 pairs), the bases gradually or abruptly attenuated to definite, spreading petioles; stem leaves alternate, spirally arranged, distant or slightly overlapping, erect, sessile or short-petiolate, the blades mostly oblong, elliptic-i inear or broadly inear, the largest (to $2.5 \mathrm{~cm}$ long) toward the stem base, gradually reduced in size and tending to be entire upward toward and in the inflorescence.

Inflorescence.- Racemose, often with short indeteminate racemes born from axils of most upper leaves but the longest terminal, elongating (in robust plants) to $3-5 \mathrm{~cm}$; pedicels at anthesis $\mathrm{ca} .2-3 \mathrm{~mm}$ long, spreading-ascending, elongating in fruit to $4-5 \mathrm{~mm}$, and becoming rather distant as the raceme elongates.

Flowers.-- Regular, bisexual; sepals 4 , erect, distinct, oblong-cymbiform $\overline{0.8-1.0} \mathrm{~mm}$ long, yellowish-green, tending to fall early from the young fruit, the backs stellate-pubescent; petals 4, erect to somewhat spreading, 2.2-2.5 $\mathrm{mm}$ long, clawed, white, the blades broadly ovate or obovate, the apex rounded, the base attenuated gradually or abruptly to the claw: stamens 6,2 shorter, all shorter than the petals, the filaments white, slender, the nearly round anthers yellow: ovary 2-carpellate, oblong, latera 7 y flattened parallel to the partition, superior, green, stellate-pubescent, the style to $0.2 \mathrm{~mm}$ long. Fruit. - Sitiques Tinear-elliptic, $4-6$ mm long, stellate-hairy. Seeds (2-) (4-6) (-8), flat, asymmetrically trjangular, brown, ca. $1 \mathrm{~mm}$ long, borne in 2 (opposite) rows.

Distribution and Flowering Time

Shallow, usually highly sandy soils over arenaceous (siliceous) rock, very Tocal, Piedmont South Carolina and Georgia; Ozarks of Arkansas; southeastern Missouri, eastern Oklahoma. Flowering April into June.

Special Identifying Features

D. aprica is taxonomically nearest D. brachycarpa Nutt. ex $T$. \& G. but differs in the dense stellate-hairiness of its fruit. The two species grow together on the summit of Kennesaw Mountain in Georgia (the type locality) and it can be seen there that D. brachycarpa is first to bloom, mostly being in full fruit by the time flowers of D. aprica are full. As is true of several Draba, D. aprica flowers are petaTiferous during the early period of flowering but tend to Tack them later in the flowering season. 
Habitat and Management Implications

D. aprica frequents organic sands of shallow soils over siliceous rock

(mostly granites or sandy shales). These soils are subject to rapid drying, are often covered by mosses, 1 ichens annual grasses and annual forbs such as Krigia virginica, Viola rafinesquii, Arabidopsis, Pla..ago virginica, etc. The plants are either in full sun or are in the light shade of Rhus, Forestiera, Prunus, Juniperus, certainly not in closed forest. The overstory is primarily oak-hickory-pine, with oaks (Q. stellata, Q. marilandica, $\underline{Q}$. falcata, Q. coccinea, Q. prinus)predominant. Soils on which this Draba succeeds are usually too thin to support large trees, the cover thus being being a scattering of shrubs including (in addition to those already mentioned) Amorpha, Vaccinium arboreun, Chionanthus, Celtis tenuifolia, etc. While fire is part of the vegetatinoal history of this type, no observations have been made as to how this factor would effect the abundance of $D$. aprica. Evidently succession to total forest cover would shade it out. The species is small, perhaps its small size and the very local nature of its populations being the reasons for its declared rareness. Whenever this species has been observed over time it persists, even though annual, but appears to spread very little.

\section{References}

Fernald, M.L. 1934. Draba in temperate northeastern America. Rhodora 36: $361-363$

Sma11, J.K. 1913. Flora of the southeastern U.S., ed. 2 1136-1375

1933. Manual of the southeastern Flora, pp. 565-566, Chapel Hil 1, N,.C.

Radford, A.E., H.E.Ahles and C.R. Bell, 1968. Manual of the vascular flora of the Carolinas, pp. 489-490. Chapel Hill, N.C. 
SPECIES Draba aprica Beadie." open groma whi Low grass

\begin{tabular}{|c|c|c|c|c|c|c|c|c|}
\hline \multirow[b]{2}{*}{$\begin{array}{l}\text { Expected* } \\
\text { Effect on } \\
\text { the Species }\end{array}$} & \multicolumn{8}{|c|}{ Management Practices } \\
\hline & $\begin{array}{c}\text { Prescribe } \\
\text { Burn }\end{array}$ & $\begin{array}{l}\text { Bulldoze } \\
\text { or } \\
\text { Root Rake }\end{array}$ & Bed & Chop & $\begin{array}{l}\text { Thin } \\
\text { over- } \\
\text { story }\end{array}$ & $\begin{array}{l}\text { Cut } \\
\text { over- } \\
\text { story }\end{array}$ & $\begin{array}{l}\text { Establish } \\
\text { Plantation }\end{array}$ & Graze \\
\hline Destroy & & $N A$ & NA & $\mathrm{NA}$ & & & $X$ & not \\
\hline Damage & & & & & & & & obs. \\
\hline $\begin{array}{l}\text { No Lasting } \\
\text { Effect }\end{array}$ & & & & & & & & \\
\hline $\begin{array}{l}\text { Beneficial } \\
\text { if Done } \\
\text { Proper } 1 y\end{array}$ & ? & & & & $x$ & $\mathrm{x}$ & & \\
\hline
\end{tabular}

Other Comments:

*Fxpected effect on the species is an estimate made by Dr. Robert Kral based on his knowledge of the habitat and on knowledge gained from personal field observations. Estimates are "rough" in many instances. Results of practices may be modified depending upon the degree of application, intensity of treatment, nearness to plant communities, etc. A management practice for which no entry is made indicates a lack of sufficient information from which to predict expected results. As observations are made in the field by users of the data, the expected effect will be refined. 
Draba aprica Beadle

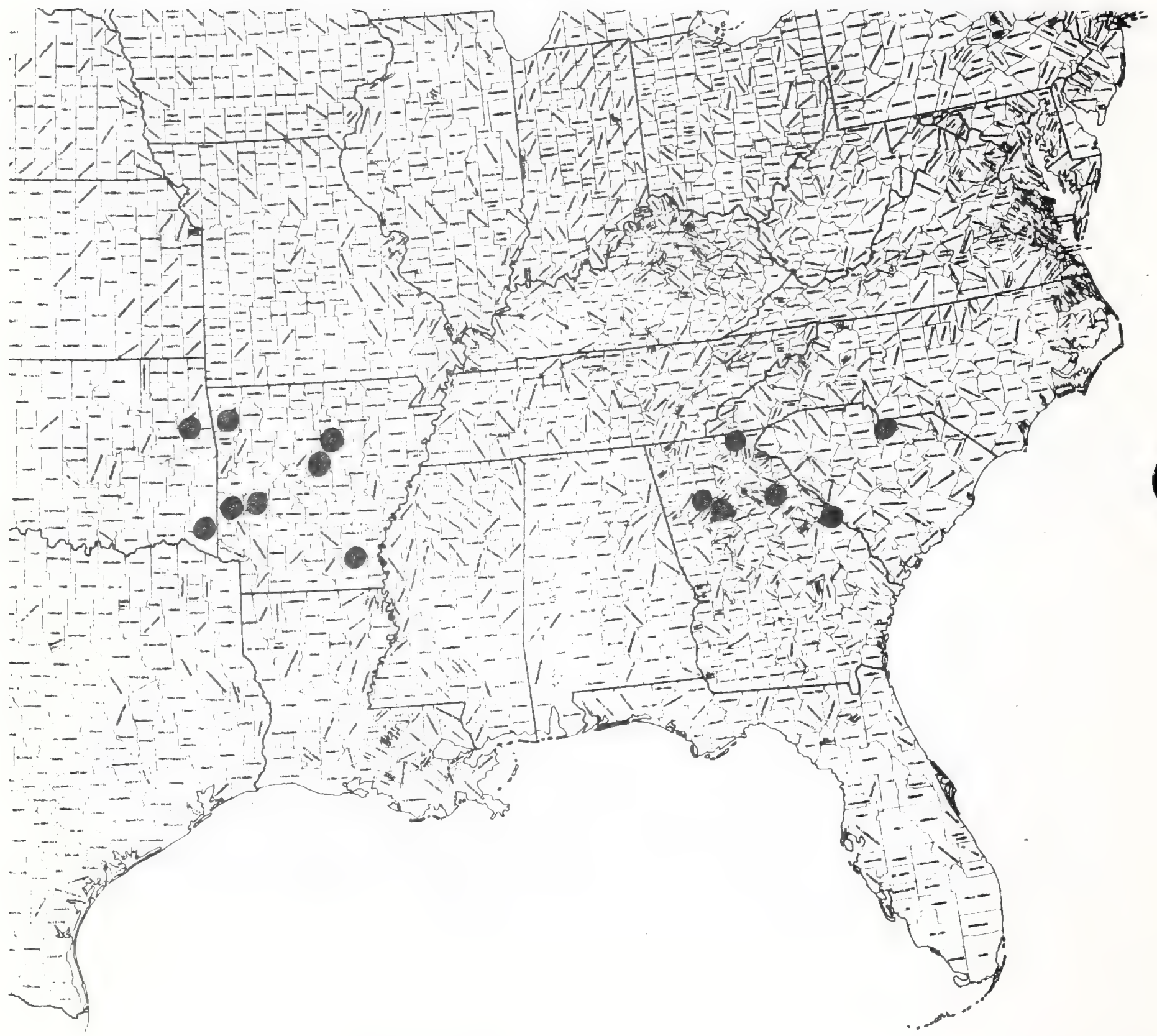




\section{CISTACEAE}

Hudsonia ericoides L. ssp. montana (Nutt.) Nickerson \& Skog. golden mountain heather

H. montana Nutt.

\section{Technical Description}

Low, much-branched shrub from a short, chick crown, the roots thickish.

Stems.-- Numerous, decumbent-based, often rooting at lower nodes, producing abundant spur shoots, the side branches arching upward, the whole plant forming a dense, often circular mat, the old shoot growth with bark dark reddish-brown, with numerous irregular narrow cracks revealing paler inner bark, the newer shoots with epidermis more reddish, the newest growth pale reddish-brown or can, pilose.

Leaves.-- Atternate, ascending and overlapping in tjght spirals from base to tip of shoots and spur shoots, linear, mostly $3-8 \mathrm{~mm}$ long, sometimes curved, greenish, firm, somewhat thickened, toward the base above somewhat concave, toward the apex thicker, the tips with a conic callus, the surfaces at first pilose, later nearly smooth.

Inflorescence.- Flowers few to several, solitary from the tips of shoots and spur shoots, on slender, erect or ascending, pilose-tomentose peduncles mostly $5-10 \mathrm{~mm}$ long.

Flowers.-. Bisexual, regular: calyx turbinate, $5-7 \mathrm{~mm}$ long, the 5 sepals unequal, fused at base to a cup, the 2 longest lobes Tinear-subulate, the others lance-ovate, acuminate, the outer surface pilose-tomentose; petals 5, distinct, pale yellow, spreading, twice as long as the sepals; stamens distinct, smooth, up to 25, ca. $3 \mathrm{~mm}$ long, the anthers broadly ellipsoidal, ca. $0.3 \mathrm{~mm}$ long. Ovary superior, 3-carpellate, pilose.

Fruit.-. Capsule ovoid, ca. $3 \mathrm{~mm}$ long, pilose to base, splitting into 3 firm valves, 1 with the persistent, elongate style; seeds few, usual7y 2-3, asymmetrically oblong-ellipsoidal or ovoid, ca. $1 \mathrm{~mm}$ long, the surface covered with low, papiliose, gray-white bumps.

Distribution and Flowering Time

Heath balds on granitic ledges and cliffs, Blue Ridge, western North Carolina (Burke County); flowering mostly in June and July.

\section{Special Identifying Features}

This differs from the subspecies "ericoides" (another mat-former on sandy soils, mostly in pinelands but sometimes on rocky mountain summits from Newfoundland south through New England and intermittently south into Delaware with an outlier in Chesterfield County South Carolina) in its broader calyx, the lobe tips of which are narrower, and in its somewhat shorter leaves.

Habitat and Management Implications

H. ericoides ssp. montana occupies small granitic clearings and ledges in the heath balds along the rim of Linville Gorge. It is usually rooted in 
the shallow sandy soil of shallow depressions or cracks in the rock, is often at edges of growths of growths of Leiophy $71 \mathrm{ym}$ buxifolium, Hypericum densiflorum, Rhododendron catawbiense, Gaylussacia, Vaccinium, Lyonia, Leucothoe. It is normal7y at the edge of, or barely under, forest of pinus strobus, $P$. rigida, $P$. virginiana, P. pungens, Tsuga caroininiana, T. $\overline{\text { can- }}$ adensis, Quercus prinus, Q. coccinea, Carya ova Tis. Freyuent sprouts of Castanea dentata are in evidence. Fire was probably the main disturbance factor al Towing periodic reduction of competition by both heath species and trees. The forest adjacent to the Hudsonia sites, even in its primal state was, because of the poorness of the soils and the difficulty of topography, probably not of a high potential for timber. Presently, the main threat to survival of these rare plants is the damage done them by trampling feet of rock climbers and hikers.

\section{References}

Bozeman, J.R. and J.F. Logue, 1968. A range extension for Hudsonia ericoides in the southeastern U.S. Rhodora 70: 289-291.

Nutta11, Thomas. 1818. Genera of North American Plants II: p. 4.

Radford, A.E., E. Ahles and C.R. Bell. 1968. Manual of the vascular flora of the Carolinas, p. 718. Chapel Hi11, N.C.

Sma11, J.K. 9133. Manual of the southeastern flora, pp. 880-881. Chapel Hill, N.C. 
SPECIES Fudsonia ericoides $L_{0}$ ssp. montana (Nutt, ) Nickerson \& Skog. golden mountain heather

\begin{tabular}{|c|c|c|c|c|c|c|c|c|}
\hline \multirow[b]{2}{*}{$\begin{array}{l}\text { Expected* } \\
\text { Effect on } \\
\text { the Species }\end{array}$} & \multicolumn{8}{|c|}{ Management Practices } \\
\hline & $\begin{array}{c}\text { Prescribe } \\
\text { Burn }\end{array}$ & $\begin{array}{l}\text { Bulldoze } \\
\text { or } \\
\text { Root Rake }\end{array}$ & Bed & Chop & $\begin{array}{l}\text { Thin } \\
\text { over- } \\
\text { story }\end{array}$ & $\begin{array}{l}\text { Cut } \\
\text { over- } \\
\text { story }\end{array}$ & $\begin{array}{l}\text { Establish } \\
\text { Plantation }\end{array}$ & Graze \\
\hline Destroy & & $\mathrm{NA}$ & NA & $\mathrm{NA}$ & & & $\mathrm{NA}$ & \\
\hline \multirow{2}{*}{\multicolumn{9}{|c|}{$\begin{array}{l}\text { Damage } \\
\text { No Lasting } \\
\text { Effect } \\
\text { Beneficial }\end{array}$}} \\
\hline & & & & & & & & \\
\hline $\begin{array}{l}\text { Beneficial } \\
\text { if Done } \\
\text { Properly }\end{array}$ & ? & & & & $x$ & $x$ & & \\
\hline
\end{tabular}

Other Comments: effect of grazing not observed, but likely to be detrimental

*Expected effect on the species is an estimate made by Dr. Robert Kral based on his knowledge of the habitat and on knowledge gained from personal field observations. Estimates are "rough" in many instances. Results of practices may be modified depending upon the degree of application, intensity of treatment, neamess to plant communities, etc. A management practice for which no entry is made indicates a lack of sufficient information from which to predict expected results. As observations are made in the field by users of the data, the expected effect will be refined. 
Hudsonia ericoides L. ssp. montana (Nutt.)Nickers. \& Skog

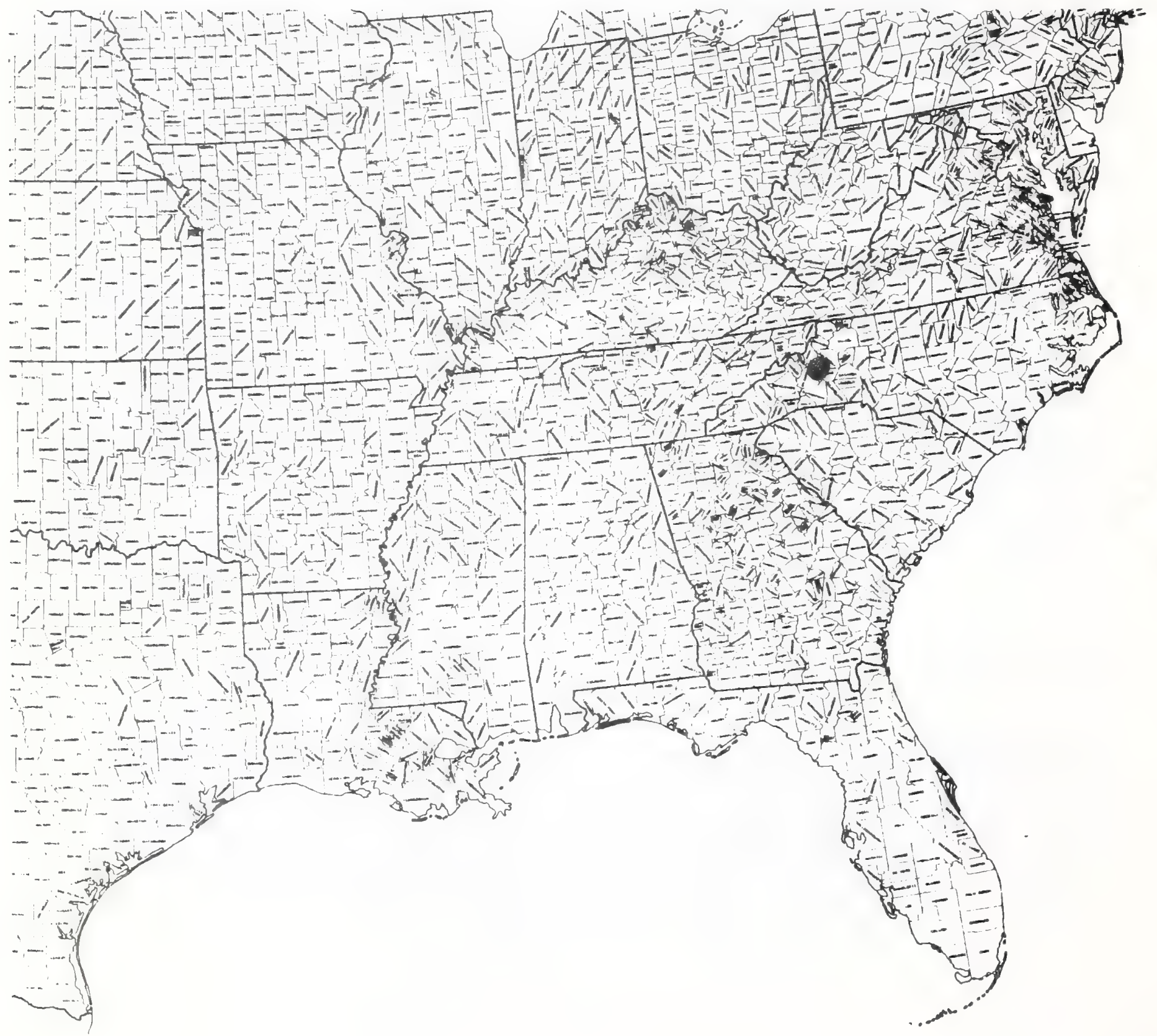




\title{
CISTACEAE
}

\author{
Lechea maritima Legg. var. virginica Hodgdon. Virginian pinweed
}

\section{Technical Description}

Short-7ived shrub, the branches from a short, erect or ascending caudex and a strong, irregularly branched rootstock.

Stem.-- Woody, 1-several, stoutish, stiff, erect or decumbent based or leaning with branches erect and unilateral, the bark dark reddish-brown, longitudinally shallowly cracked, the main axis frequently and diffusely branched to below the middie, usualiy also producing 1 or more pseudowhorls of basal shoots. Newer shoots and basal shoots with axis pilose-tomentose with whitish hairs.

Leaves.-- Alternate and opposite or whorled (particularly on basal shoots), sessite, usually close-set, those of the basal (overwintering) shoots narrowly eliptic or lanceolate, mostiy $5 \mathrm{~mm}$ long or less, acute, entire, pilose-ciliate, the upper surface green, nearly smooth, the lower surface pilose-tomentose, thus whitened; leaves of fertile shoots (lower ones absent by flowering time) eliptic-7inear, $1 \mathrm{~cm}$ or less long, $1 \mathrm{~mm}$ wide or less, the tips acute, cal7used, the margins entire, the bases acute, sessile or short-petiolate, the upper surface yellow-green, smooth, the lower surface strigose-plilose with white hairs.

Inflorescence.- Flowers numerous, arising singly from the axils of most middle and upper leaves of the abundant shoots, thus producing a leafybracted, compound, broadly triangular, panicle.

Flowers.-- Nearly regular, bisexual, obovoid to nearly round or ovoid, 1.5-2.0 mm Tong; sepals 5 in 2 series, the outer series of 2 Tinear, the inner 3 scale-like, ovate, cupped around the ovary and fruit, longer than the outer pair, 271 on the backs pilosulous-tomentose; pedicels stiffly erect or outcurved, tomentose, mostly $1-2$ mm long, dilated at summit; petals 3, papery, reddish, shorter than inner sepals, withering and persistent around the fruit; stamens 3-25, about as long as the inner sepals, arising from the receptacle, distinct, the filaments slender, the short anthers nearly round, yellowish; ovary superior, 3-carpellate, smooth, ovoid, the stigmas 3, nearly sessile, fimbriate, reddish.

Fruit.-- An ovoid, 3-valved, smooth capsule ca. $1.5 \mathrm{~mm}$ long; seeds $2(-3) /$ capsule, ca. $1 \mathrm{~mm}$ long, smooth, brown, narrowly ovoid, the backs convex, the inner surface flattish or broadly angled.

Distribution and Flowering Time

Sands of dunes and clearings close to seacoast, southeastern Virginia: flowering from August to frost.

Special Identifying Features

This plant is distinguished from other pinweeds by a combination of the following characters:

1. Outer sepals shorter than inner.

2. Basal leaves (lower overwintering shoot leaves) more than three times 
as long as broad; basal shoots present at and past anthesis.

3. Fertile branches from main shoot from well below the middle to apex (often unilateral on spreading main stems!)

4. Capsule hardly as long as inner sepals; seeds usually 2/capsule.

It is distinguished as a variety of $L$. maritima by its fewer seeds ( $L$. maritima usually has 4/capsule), its tendency to branch from a lower stem Tevel, and by its more shrubby habit (branches remaining alive for more than 1 year!)

Habitat and Management Implications

L. maritima virginica occupies a narrow zone along the coast in eastern Maryland and southeastern Virginia; it was most abundant on sandy clearings and coastal dunes from Fort Henry south to the area of Virginia Beach and Back Bay. It is either on shifting sands of the dunes, or in sandy clearings in oak-pine scrub (the oak often scrub quercus virginiana), or on sandy rises in brackish marsh. The main danger to the plants is from extensive development of areas along beaches for housing and recreational sites.

References

Fernald, M.L. 9150. Gray's manual of Botany, ed. 8, pp. 1018-1022. Boston, Mass.

Hodgdon, A.R. 1938. A taxonomic study of Lechea. Rhodora $40(470,471)$, $131 \mathrm{pp} ., \mathrm{pl}$. 
SPECIES Lechea maritima Iie vas'" virginica Hodgöon' Virginian

pinweed.

\begin{tabular}{|c|c|c|c|c|c|c|c|c|}
\hline \multirow[b]{2}{*}{$\begin{array}{l}\text { Expected* } \\
\text { Effect on } \\
\text { the Species }\end{array}$} & \multicolumn{8}{|c|}{ Management Practices } \\
\hline & $\begin{array}{c}\text { Prescribe } \\
\text { Burn }\end{array}$ & $\begin{array}{l}\text { Bulldoze } \\
\text { or } \\
\text { Root Rake }\end{array}$ & Bed & Chop & $\begin{array}{l}\text { Thin } \\
\text { over- } \\
\text { story }\end{array}$ & $\begin{array}{l}\text { Cut } \\
\text { over- } \\
\text { story }\end{array}$ & $\begin{array}{l}\text { Establish } \\
\text { Plantation }\end{array}$ & Graze \\
\hline Destroy & & $\bar{x}$ & $\mathrm{X}$ & $x$ & & & $\mathrm{X}$ & $\mathrm{NA}$ \\
\hline \\
\hline $\begin{array}{l}\text { No Lasting } \\
\text { Effect }\end{array}$ & & & & & & & & \\
\hline $\begin{array}{l}\text { Beneficial } \\
\text { if Done } \\
\text { Properiy }\end{array}$ & $x$ & & & & $x$ & X & & \\
\hline
\end{tabular}

Other Comments:

*Expected effect on the species is an estimate made by Dr. Robert Kral based on his knowledge of the habitat and on knowledge gained from personal field observations. Estimates are "rough" in many instances. Results of practices may be modified depending upon the degree of application, intensity of treatment, nearness to plant communities, etc. A management practice for which no entry is made indicates a lack of sufficient information from which to predict expected results. As observations are made in the field by users of the data, the expected effect will be refined. 
Lechea maritima Legg. var. virginica Hodgdon

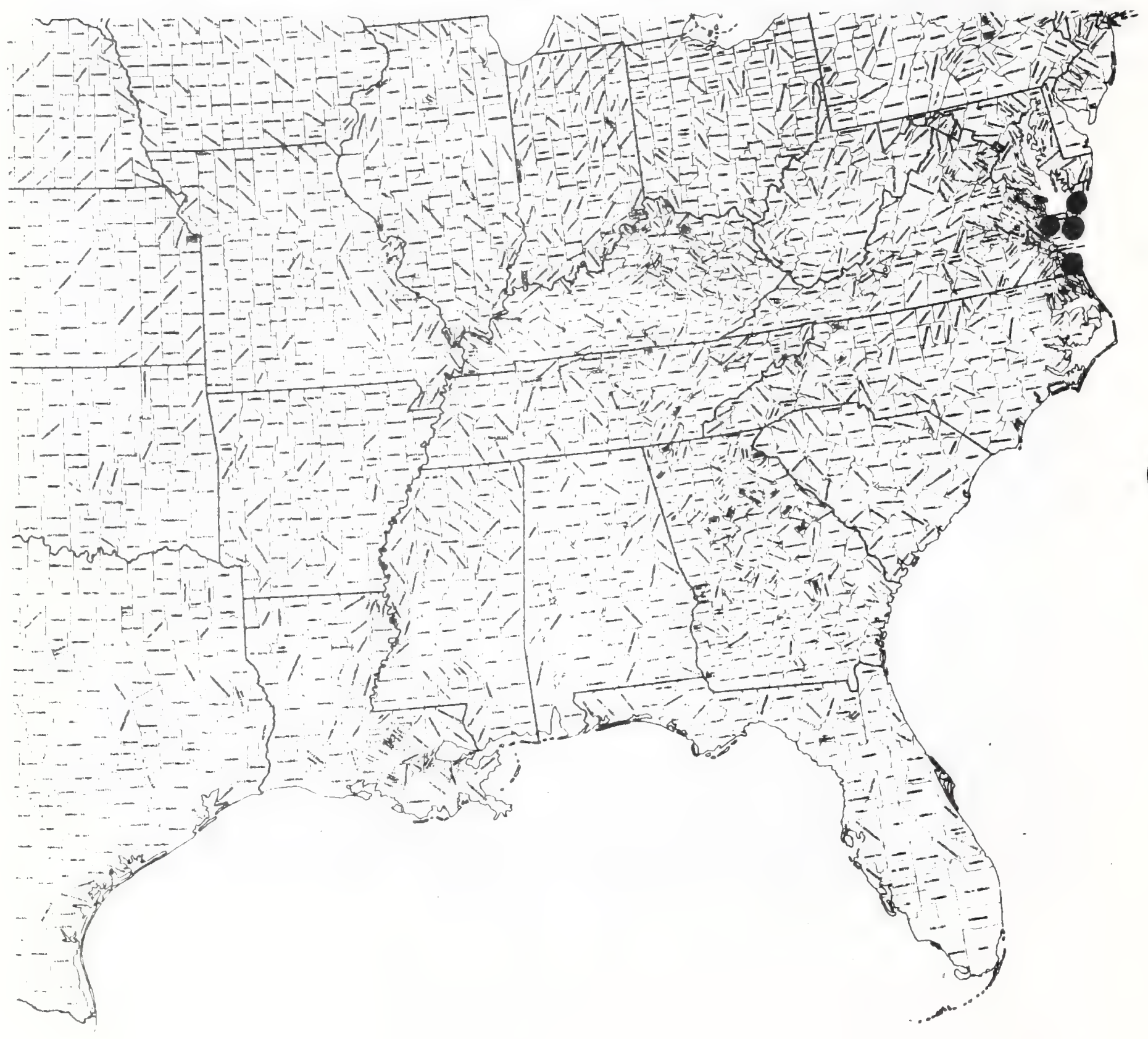




\section{CYPERACEAE}

Rhynchospora crinipes Gale. Alabama beakedorush

Technical Description

Strongly tufted, smoothish, perennial sedge.

Culms.-- Ca.7.0-7.5 dm tal1, slender, subtriangular, erect or spreading, 1eafy.

Leaves.-- Sheathes closed, narrowly cylindrical, ventrally brownish-

scarious; blades spreading or erect, Tinear, flat, elongate, toward apex narrowed to triangular, scabrid tips, the margin minutely scabrid; blade width to $2 \mathrm{~mm}$.

Inflorescence.-- Clusters of spikelets distant toward culm tips, the erect peduncles exserted from the closed sheathes of subtending bracteal leaves, the clusters 4-5, compact, turbinate, somewhat lobed, the uppermost exceeded by 2 or more setaceous, minutely scabrid, bracts.

Spikelets.-- Lanceolate, ca. $5 \mathrm{~mm}$ long, usually with 2 fertile florets and 1 sterile apical; scales lanceolate, aristulate, loosely imbricate, scarious, reddish-brown; perianth bristles 6 , rigidly erect, antrorsely barbellate, reaching tubercle tip: akene body pyriform, $1.4 \mathrm{~mm}$ Tong, ca. $1 \mathrm{~mm}$ broad, lustrously smooth, biconvex, the somewhat flattened edges and center of akene face pale, the surface otherwise brownish, the akene base narrowed to a terete stipe ca. $0.6 \mathrm{~mm}$ long, this covered by white villous hairs; tubercle of akene compressed-triangular, to $0.8 \mathrm{~mm}$ long, grayish, its edges scabridhispid.

\section{Distribution}

Known only from two localities near Mobile, Mobile County, Alabama, where collected by Dr. C. Mohr in June of 1968. Has not been observed since.

\section{Special Identifying Features}

Examination of the type material at the U.S. National Museum shows, as Shirley Gale (1944) indicates, a resemblance to R. filifolia Gray, of the same complex in the genus but this last lacks the prominent long, villous stipe to its akene. Extreme specmens of R. curtissif Britt. ex Sma 11 and R. harperi Small may have some development of stipe and stipe hairs; however none of the above tend to have leaves as broad, stipes of akenes as long and as hairy. The difficulty remains now with the distinctness of the material identified as R. crinipes but with the sparse available evidence for it in that no material has been found outside the type collection.

Habitat and Management Implications

R. crinipes was collected from "dry places, roadsides (exsiccated), Mobile," and "ditches, borders of ponds, Mobile". One may infer from this, and from visiting the Mobile area, that the original habitat was pineland (slash and longleaf) savanna, probably sandy-peat soil of high hydroperiod. A71 
species of this complex of beakrush are found to be a part of grass-sedge bog communities whose abundance and perpetuation depend upon periodic burning to reduce forest and shrub competition together with a continuance of high levels of soil water.

\section{References}

Gale, Shirley. 1944. Rhynchospora, section Eurhynchospora in Canada, the United States and the West Indies. Contribs. Gray Herb. CLI, pp. 89-278. 
SPECIES Rhynchospora crinipes Gale. Alabama beaked-rush

\begin{tabular}{|c|c|c|c|c|c|c|c|c|}
\hline \multirow[b]{2}{*}{$\begin{array}{l}\text { Expected* } \\
\text { Effect on } \\
\text { the Species }\end{array}$} & \multicolumn{8}{|c|}{ Management Practices } \\
\hline & $\begin{array}{c}\text { Prescribe } \\
\text { Bum }\end{array}$ & $\begin{array}{c}\text { Bulldoze } \\
\text { or } \\
\text { Root Rake }\end{array}$ & Bed & Chop & $\begin{array}{l}\text { Thin } \\
\text { over- } \\
\text { story }\end{array}$ & $\begin{array}{l}\text { Cut } \\
\text { over- } \\
\text { story }\end{array}$ & $\begin{array}{l}\text { Escablish } \\
\text { Plantation }\end{array}$ & Graze \\
\hline Destroy & & $x$ & & $x$ & & & $x$ & \\
\hline Damage & & & & & & & & $x$ \\
\hline $\begin{array}{l}\text { No Lasting } \\
\text { Effect }\end{array}$ & & & & & & & & \\
\hline $\begin{array}{l}\text { Beneficial } \\
\text { if Done } \\
\text { Properly }\end{array}$ & $3 x$ & & & & $x$ & $x$ & & \\
\hline
\end{tabular}

Other Comments: Drainage of habitat would destroy this species!

*Expected effect on the species is an estimate made by Dr. Robert Kral based on his knowledge of the habitat and on knowledge gained from personal field observations. Estimates are "rough" in many instances. Results of practices may be modified depending upon the degree of application, intensity of treatment, nearness to plant commuities, etc. A management practice for which no entry is made indicates a lack of sufficient infomation from which to predict expected results. As observations are made in the field by users of the data, the expected effect will be refined. 


\section{Rhynchospora crinipes Gale}

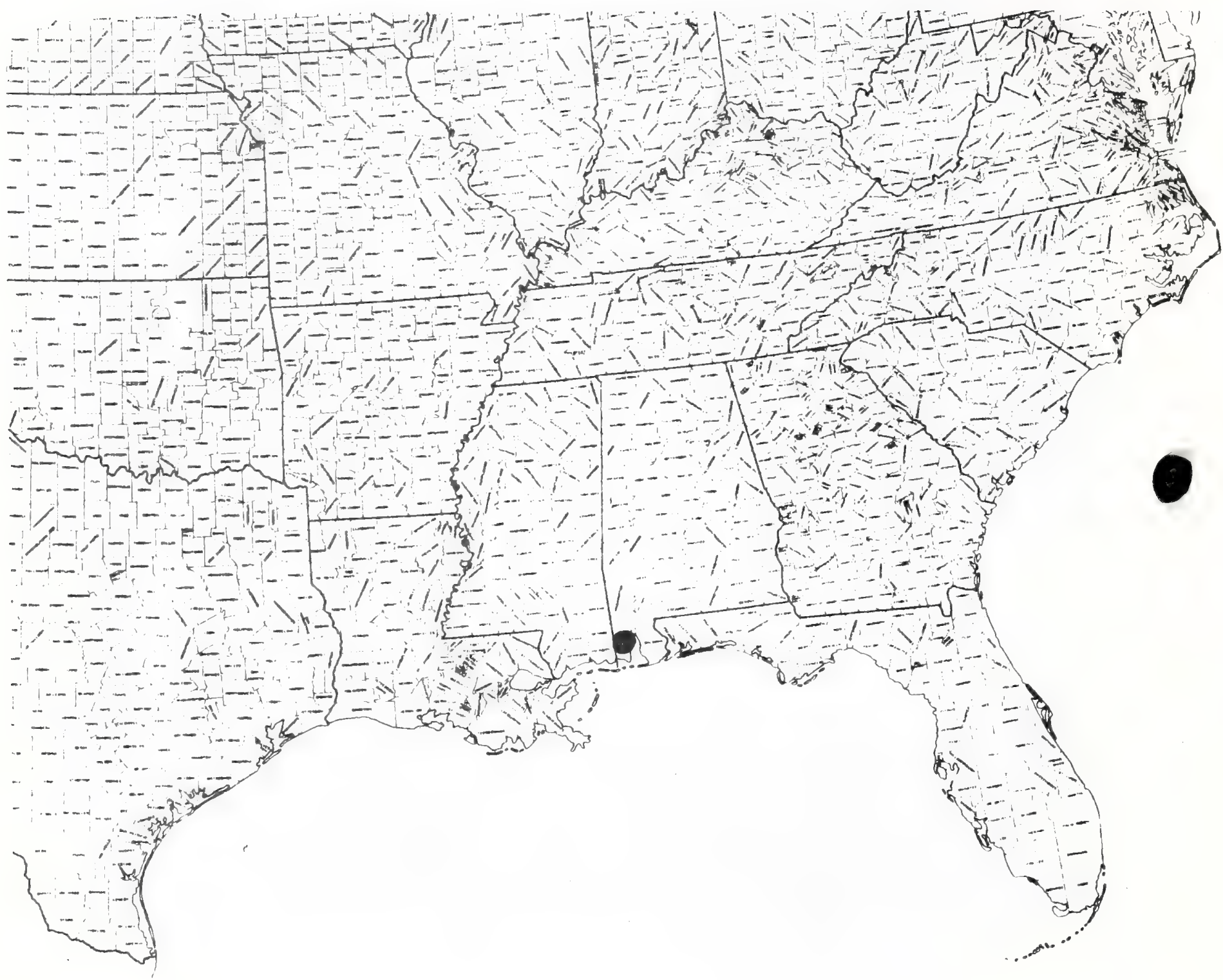




\title{
DIAPENSIACEAE
}

\author{
Shortia galacifolia $T$ \& \& G. Oconee bells \\ Sherwoodia galacifolia (T。\&.G.) House \\ Shortia galacifolia var. brevistyla P.A. Davies
}

\section{Technical Description}

Smooth, evergreen perennial herb or subshrub forming mats by shallow, short or elongate, stoloniferous and creeping rhizomes.

Leaves.-- Alternate, close-set and developing in rosettes from nodes at various intervals along the creeping or arching rhizomes, forming from solitary or clustered imbricate-scaley buds, these scales not persisting through the season, lance-ovate, usually $1 \mathrm{~cm}$ or less long, acuminate, entire, subtending either axillary buds of 1-3 (-4) flowers or sterile shoot leaves; leaves of floriferous shoot buds consisting of scales only; leaves of sterile shoots numerous, the lowest above the scales much reduced in petiole, the short blades broadly elliptic to suborbicular, marginally denticulate, the denticles gland-tipped, the larger leaves several, mostly 10-20 cm long, 2/3-3/4 petiole, the petioles green, iinear, narrowly winged, the blades broadly ovate, obovate, broadly oblong or (mostly) suborbicular, mostly $4-8 \mathrm{~cm}$ long, apically rounded, subtruncate, or broadly retuse, the margin crenate-sinuate, crenate-dentate or dentate, each 'tooth' tipped by a short-excurrent vein tip, the base cordate or rounded; upper blade surface a deep glossy green, the lower surface pale green; venation pinnate, reticulate.

Flowers.-- Regular, bisexual, mostly $1-3(-4)$ from a bud, solitary at erect, spreading or slightiy nodding tips of slender, erect or ascending, pinkish or reddish peduncles $5-20 \mathrm{~cm}$ long, these bearing at or toward their apices 3-4 lanceolate, acuminate, entire and narrowly scarious-white margined, red to pink or pale green, scaley bracts $5-10 \mathrm{~mm}$ long, the uppermost ones directly subtending the flower; sepals 5, distinct, imbricate, greenish, lanceolate, oblong or ovate-lanceolate, mostly 5-8 mm long, acute, emarginate or rounded, the margin entire, the surface green or tinged with red, the edge narrowly white-scarious; petais 5, fused at base, the corolla 1-2 cm long, campanulate, the lobes obovate, the rounded apex jagged or erose, the surface white or faintly pink; stamens 5, epipetalous, alternating with petals, departing about midway up the corolla tube, the 7 inear-flattened, yellowish-white filaments ca. $5 \mathrm{~mm}$ long, crooked apically, the yellowishwhite anthers basifixed, ovoid, pointed inward to touch the style, ca. 0.5 $\mathrm{mm}$ long, the anther sacs slightly divergent; staminodes 5, opposite petals at base of corolla, the filaments flattened, short, ca. $0.5 \mathrm{~mm}$ long, the blades ovate, flat, yellowish-whice, ca. $3 \mathrm{~mm}$ long, acute, villosulous-edged; ovary superior, broadly ovoid, 3-carpellate, the style single, erect, linear, elongate (mostly 1.0-1.5 cm long), the stigma capitate, obscurely 3-lobed. Fruit.-- A greenish, ovoid, 3-locular, Toculicidal capsule 5-6 mm long, invested by the persistent calyx and ripening in summer; seeds numerous on axile placentae. 
Cool, acidic ravines of the Blue Ridge Escarpment, mostly in the drainages of the Horsepasture, Toxaway and Keowee Rivers of South Carolina and North Carolina; also northeastern Georgia; flowering from late February through March into early Aprit.

\section{Special Identifying Features}

There are no other New World species of Shortia, though the genus is found in Asia. Nearest to it in the family in the southeast is the common Galax, G. aphyl7a, which occupies similar habitat or drier sites, and which produces its much smaller, whitish flowers numerously in elongate, spike-like racemes; in Galax the staminodia are longer than the stamens.

\section{Habitat and Management Implications}

This plant, while very local in distribution, is usually quite abundant in the few localities left to it after the wholesale damming up of streams within its area. A typical site would be a deep stream cut through granitic rock where the overstory is comprised of a mixture of cove hardwoods, hemlock, and white pine, the understory made up mainly of heaths such as Leucothoe, Rhododendron (mostly maximum, minus), Kalmia, various Vaccinium, Galyussacia. The soiT is usualty a strongly humus-enriched moist sand, very acidic. In such sites Shortia may cover the steep slopes along the streams, sometimes to the exclusion of other ground cover, often forming clones several meters across and even extending along old windfallen trunks or over stumps of trees. It appears to be most abundant where shade is heavy, where soil does not dry out and the atmosphere where it grows best is both cool and humid, being kept that way by the insulating effect of the forest and steep ravine slopes. The species has been extirpated over most of its former range by wholesale damming up of streams and rivers, most of its best habitat now under the waters of either Lake Jocasee or Lake Toxaway, only the upper reaches of the streams of these areas now supporting Shortia. other populations have been endangered through land development or excessive logging of the steep ravines such plants frequent. In that the species depends on a stable, humus-enriched, cool, shaded habitat it should be obvious that logging within its area be kept to a minimum, this being done on a basis of single tree selection if at all.

\section{References}

Davies, P.A. 1952. Geographical.variations in Shortia galacifolia. Rhodora 54: 121-124.

- 1955. Distribution and abundance of Shortia galacifolia. Rhodora 57: 189-201.

- 1956. Type location of Shortia galacifolia. Castanea 21: 107-113.

- 1959. Remarks on the Virginia location of Shortia galacifolia. Rhodora 61: 297-301.

Duncan, W.H., H. Venard, and G.W. McDowe11. 1950. Shortia galacifolia from Georgia, Rhodora 52: 229-232. 
Gray, A. 1841. Notes of a botanical excursion to the mountains of North Carolina. Am. Journ. Sci. 42: 1-149.

House, H.D. 1908. The genus Shortia. Torreya 7: 233-235.

Radford, A.E., H.E. Ahles, and C.R. Bell. 1968. Manual of the vascular flora of the Carolinas, p.818. Chapel Hir\}, N.C.

Redfield, J.H. 1879. Notes on a botanical excursion into North Carolina. Bu71. Torrey Bot. Club 6: 331-339.

Rhoades, M.H. 1966. Seed germination of Shortia galacifolia T.\& G. under controlled conditions. Rhodora 68: $\overline{147-154 .}$

Sma17, J.K. 1933. Manual of the southeastern flora, pp. 1018-1020. Chapel HiT7, N.C.

Vivian, V.E. 1967. Shortia galacifolia, its life history and microclimate requirements. BuT7. Torr. Bot. Club 94: 369-387. 
SPECIES Shortia galacifolia T. \& G. Oconee bells

\begin{tabular}{|c|c|c|c|c|c|c|c|c|}
\hline \multirow[b]{2}{*}{$\begin{array}{l}\text { Expected* } \\
\text { effect on } \\
\text { the Species }\end{array}$} & \multicolumn{8}{|c|}{ Management Practices } \\
\hline & $\begin{array}{c}\text { Prescribe } \\
\text { Burn }\end{array}$ & $\begin{array}{l}\text { Bulldoze } \\
\text { or } \\
\text { Root Rake }\end{array}$ & Bed & Chop & $\begin{array}{l}\text { Thin } \\
\text { over- } \\
\text { story }\end{array}$ & $\begin{array}{l}\text { Cut } \\
\text { over- } \\
\text { story }\end{array}$ & $\begin{array}{l}\text { Establish } \\
\text { Plantation }\end{array}$ & Graze \\
\hline Destroy & & NA & NA & NA & & $\mathrm{X}$ & NA & \\
\hline Damage & $\mathrm{X}$ & & & & $\mathrm{x}$ & & & \\
\hline $\begin{array}{l}\text { No Lasting } \\
\text { Effect }\end{array}$ & & & & & & & & \\
\hline $\begin{array}{l}\text { Beneficial } \\
\text { if Done } \\
\text { Properly }\end{array}$ & & & & & & & & \\
\hline
\end{tabular}

Other Comments:

*Expected effect on the species is an estimate made by Dr. Robert Kral based on his knowledge of the habitat and on knowledge gained from personal field observations. Estimates are "rough" in many instances. Results of practices may be modified depending upon the degree of application, intensity of treatment, nearness to plant communities, etc. A management practice for which no entry is made indicates a lack of sufficient information from which to predict expected results. As observations are made in the field by users of the data, the expected effect will be refined. 
Shorcia calacifolia $T_{*}$ \& $G$

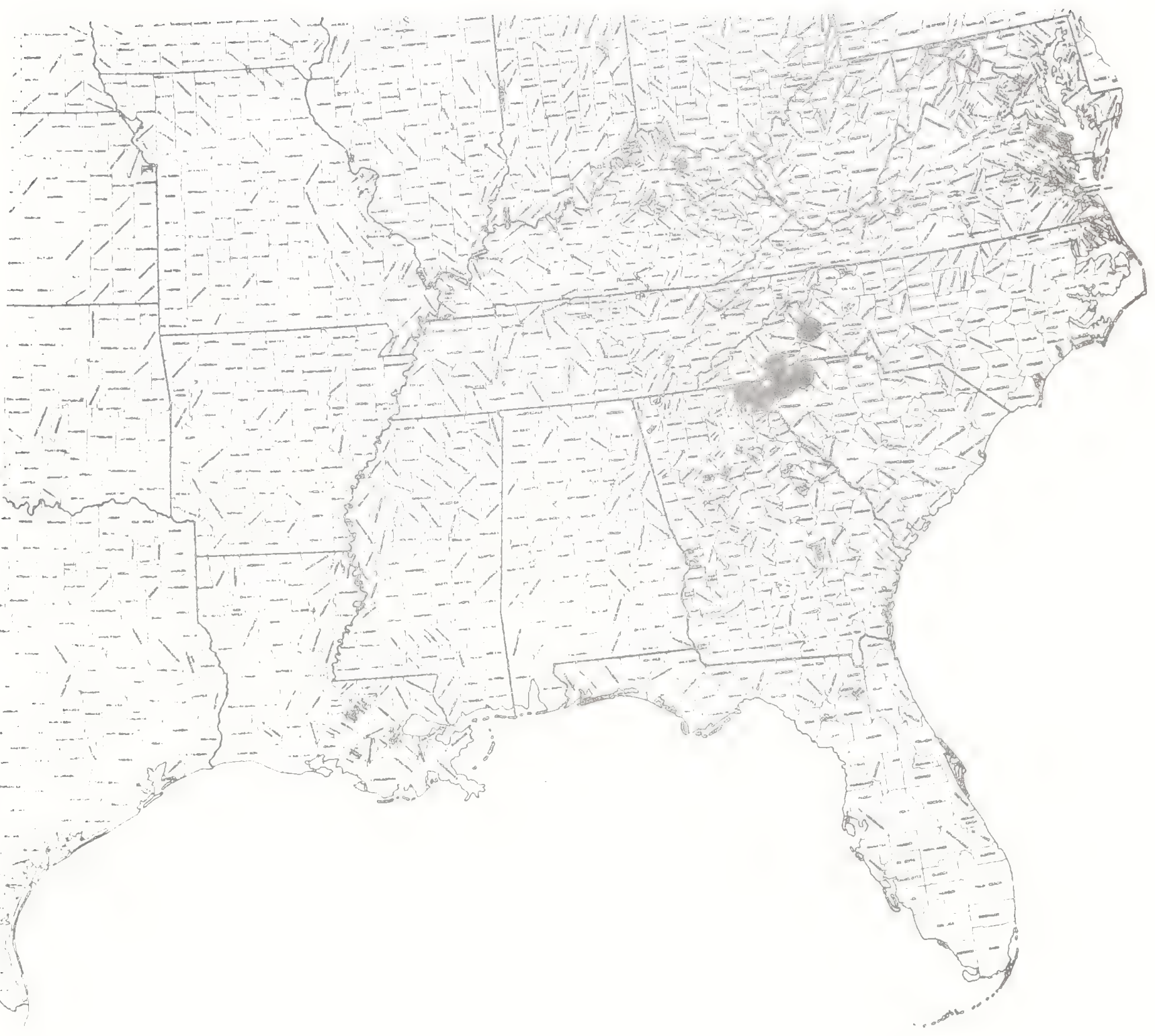


0

• 
Paper 171

Text \& Map by:

Robert Kral

\section{ERICACEAE}

\section{KaImia cuneata Michx。 white-wicky laural \\ Chamaedaphne cuneata 0 . Ktze.}

Technical Description

Soboliferous deciduous shrub.

Shoots.--Solitary or few from the crown, the primary shoots slender, erect or leaning on other shrubs, sparingly branched save above, the older wood terete, with bark gray or gray-brown, thin with shallows irregular, longitudinal cracks, the branching ascending, the new shoots slender, reddishbrown, the internodes sonewhat ridged, puberulent, the short hairs mixed with longer, spreading, gland-tipped hairs.

Leaves.--Alternate, erect or ascending, overlapping in spirals, the blades mostly oblanceolate, 3-6 cm long, apically acute to obtuse-angled, sometimes mucronulate, the margin entire, somewhat revolute, the base cuneate then attenuate to make a narrow wing on the short petiole; upper surface smooth, pale yellow-green; lower surface stipitate-glandular. Inflorescence.--Flowers in contracted, umbel-like racemes from axillary, ovoid, imbricate-scaley buds toward tips of previous season's growth, expanding shurtly after the new shoot leaves.

Flowers.--Complete, rotate on slender, spreading, pale green, glandular pedicels $1.5-3.0 \mathrm{~cm}$ long; sepals 5 , joined at very base, ovate, calyx 7-8 nim brodd, somewhat spreading in bloom, firm, acute, entire, green with pale Illargins, the backs sparsely stalked-glandular; petals 5 , joined into a saucer-shaped, shallowly 5-Tobed structure, $1.5-2.0 \mathrm{~cm}$ broad, the $1 \mathrm{imb}$ of which is 10-pouched opposite the 10 stamens (which in bud are outwardly bent with anthers fitting into the pouches), white with a narrow red band just outside the stamen ring, the inner surface puberulent inside toward the base, the outer surface sparingly stipitate-glandular; stamens 10, 5-6 mm long, the filaments spreading at anthesis, white, linear, somewhat flattened, the bases broadened where atiached to a disc, there sparsely hairy, the anthers oblong, pale brown, ca. 0.5 min long, introrse-poricidal; ovary superior, depressed-globose, ylandular-hairy, slightly 5-lobed, the style simple, straight-linear, ca.7-8 mun lony.

Fruit.--Capsule depressed-globose, 4-5 mm long, the dehiscence septicidal; seeds numerous, pale brown, oblong-cuneiform, 0.6-0.7 mm long.

Distribution and Flowering Times

Moist to wet sandy peats or peats of shrub bogs, savarinas and sandhills swales, inner Coastal Plain, North Carolina and South Carolina. Flowering from late May into June.

Special Indentifying Features

K. Cuneata is most similar to, often in mixed populations with, K. angustifolia var. caroTiniana (Smill) Fern., but differs in being deciduous, rather than evergreen, in its consistently alternate, cuneate-based leaves (rather than 
whorled, elliptic or elliptic-lanceolate), and in its flowers which are white with a red-bordered "eye" (rather than pinkish).

Habitat and Management Implications

K. cuneata is a shrub of high hydroperiod, highly organic soils. It Tocally abounds in the shrub bogs or pocosins so common in the pinelands and sandhills of the inner Coastal Plain of the Carolinas. Associated with it in the shrub layer are such general as Myrica, Ilex (glabra, coriacea), Lyonia, Gaylussacia, etc. The overstory, often sparse, is comprised of Pinus serotina, P. taeda, sometimes Chamaecyparis, Magnolia virginiana, Gordonia, (often shrubby), Acer rubrum, Nyssa sy Tatica biflora, Liquidambar, etc. It is a part of a fire disctiniax, and increases as a result of burns. It does not compete well with other shrub bog species, ultimately being over-topped and suppressed by them. Logging of the overstory, by admitting more light, would increase this species so long as the logging was not accompanied by drainage or radical soil disturbance. Any of the conventional mechanical means of site preparation would eliminate the species. Its main enemies up till now have been management schemes which involve mechanical clearing of the shrub layer, this usually accompanied by digging of drainage ditches, discing and plowing. Even if it survives the mechanical site preparation it is subsequently shaded out by the rows of pine as their crowns close. Some populations in the sandhills have been damaged or destroyed by ponds formed by dams built on the streams it grows along.

References

Ebinger, J.E. 1974. A systematic study of the genus Kalmia. Rhodora 76: 315-398.

Michaux, A. 1803. Flora Boreali Americana, p. 257. Paris.

Radford, A.E., H.E. Ahles and C.R. Bell. 1968. Manual of the vascular flora of the Carolinas, pp. 802-804. Chapel Hill, N.C.

Sina 11, J.K. 1933. Manual of the southeastern flora, pp. 999-1000. Chapel Hill, N.C. 
SPECIES KaImia cuneata Michs. white-wicky laurel.

\begin{tabular}{|c|c|c|c|c|c|c|c|c|}
\hline \multirow[b]{2}{*}{$\begin{array}{l}\text { Expected* } \\
\text { Effect on } \\
\text { the Species }\end{array}$} & \multicolumn{8}{|c|}{ Management Practices } \\
\hline & $\begin{array}{c}\text { Prescribe } \\
\text { Burn }\end{array}$ & $\begin{array}{c}\text { Bulldoze } \\
\text { or } \\
\text { Root Rake }\end{array}$ & Bed & Chop & $\begin{array}{l}\text { Thin } \\
\text { over- } \\
\text { story }\end{array}$ & $\begin{array}{l}\text { Cut } \\
\text { over- } \\
\text { story }\end{array}$ & $\begin{array}{l}\text { Establish } \\
\text { Plantation }\end{array}$ & Graze \\
\hline Destroy & & $x$ & & $x$ & & & $x$ & \\
\hline Damage & & & $x$ & & & & & $\begin{array}{l}\text { see } \\
\text { note }\end{array}$ \\
\hline $\begin{array}{l}\text { No lasting } \\
\text { Effect }\end{array}$ & & & & & & & & \\
\hline $\begin{array}{l}\text { Beneficial } \\
\text { if Done } \\
\text { Properly }\end{array}$ & $x$ & & & & $x$ & $x$ & & \\
\hline
\end{tabular}

Other Comments: Site drainage destroys this species! Foliage is toxic to livestock.

*Expected effect on the species is an estimate made by Dr. Robert Kral based on his knowledge of the habitat and on knowledge gained from personal field observations. Estimates are "rough" in many instances. Results of practices may be modified depending upon the degree of appication, intensity of treatment, neamess to plant commities, etc. A management practice for which no entry is made indicates a lack of sufficient information from which to predict expected results. As observations are made in the field by users of the data, the expected effect will be refined. 
Kalmia cuneata Michx.

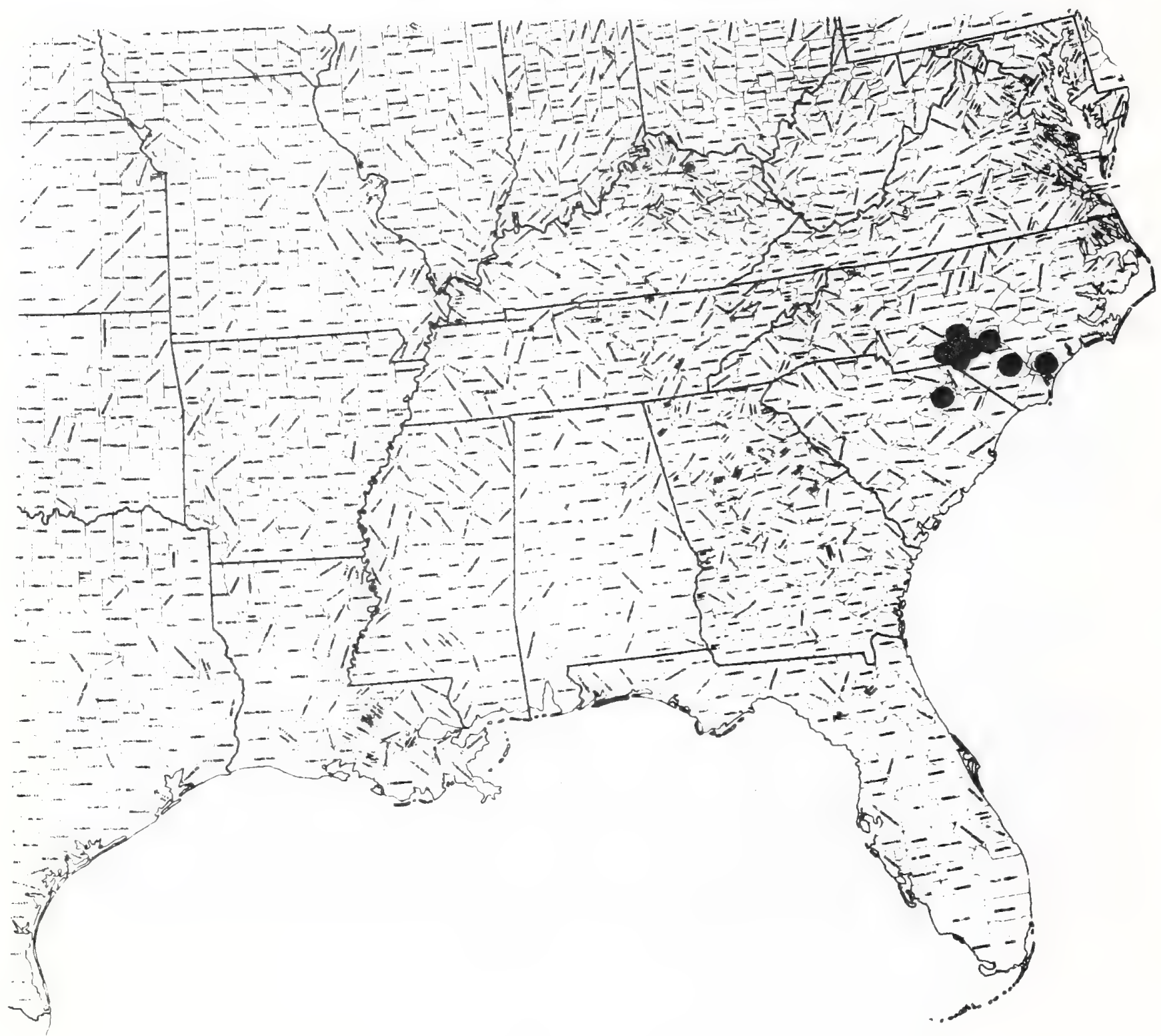


Paper 172

Text \& Map by:

Robert Kral

\section{EUPHORBIACEAE}

Croton elijottio Chapm. Elliott's croton

\section{Technical Description}

Taprooted, stellate-pubescent, annuai herb.

Stems.-- Main stem erect, (1-) $2-6$ (-10) dm high, mostly simple, branching only in the inflorescence or sometimes (when luxurious on sites good for i†) bushy-branched from near the base, terete, greenish or yellowish-green, the color determined by the trichomes which range from white to blondish or brown; branches upwardly arching, several main ones usually arising at inflorescence base and giving a "whorled" appearance, these usually elongate and toward tips again rebranching in pseudowhorls, the branches toward their tips increasingly tomentose.

Leaves.- - Basal usually absent by flowering time, usually those toward base of primary branches largest, there "pseudowhorled" on elongated portions of stem and branches rather distant, spreading or ascending, the blades mostly narrowly lanceolate, linear-elliptic, or narrowly oblong, (2-) 3-6 (-8) cm long, firm, acute, entire, the bases rounded to broadly cuneate, only the midrib prominent, the upper surface yellow-green, stellate-puberulent, the lower surface paler, silvered or blondish with stellate tomentum; petioles slender, terete, ca. $1 / 3-1 / 2$ as long as the blades, stellatepubescent. Inflorescence.-. Flowers in nearly sessile to short-pedunculate, compact, erect, indeterminate, spikelike racemes, the female fewer and basal, the more numerous males abcissing as the inflorescence elongates, each floret subtended by a tomentose, narrowly linear bractlet slightly longer than the pedicel.

Flowers.- Regular or nearly so: male globose, ca. $2 \mathrm{~mm}$ broad, on stiffish, spreading-ascending pedicels ca. $1 \mathrm{~mm}$ long, the sepals (usually) 5, distinct, ovate, strongly arched inward and cupped, 1.5-2.0 mm long, blunt, the backs stellate-pubescent, the petals narrower, distinct, mostly oblong, scarious (very thin), flatter, ascending, alternating with small fleshy glands, the stamens mostly 10-12, erect or incurved, the short (ca. $0.5 \mathrm{~mm}$ ), slightiy divergent anther sacs basifixed, on pale, villous-based filaments ca. 1.5 $\mathrm{mm}$ long; female flowers at anthesis nearly $2 \times$ as long as the male, slightly irregular, the 6-8 sepals joined at base into a shallow cup, mostly obovate or oblong-spatulate, fleshy, backs tomentose, apex fleshy, dilated, cuplike, strongly incurved, the ovary sessile, obovoid-globose, densely paletomentose, the short style spreading-branching into short-linear segments, these again forking, then reforking to form a cotal of 12 linear stigma Tobes.

Fruit.-- Ripe capsule obovoid-globose, greenish, stellate-hairy, ca. $5 \mathrm{~mm}$ long, clasped by the slightly enlarged sepals, 3-loculed, 3-valved, 3-seeded, the seeds ca. $4 \mathrm{~mm}$ long, in outtine broadly ellipsoidal, the backs rounded, smoothish (minutely cancellate), dark gray, lustrous, the inner faces flattish, forming a broad angle, bearing at very base below the attachment scar a yellowish, fleshy, transverse, ellipsoidal caruncle.

Distribution and Flowering Time

Moist to rather dry sands or sandy peats of fields, flatwoods, roadsides and 
pondshroes in the Coastal Plain, eastern South Carolina, (according to Sma11, 1933), southwestern Georgia, and southern Alabama; flowering from July into September.

\section{Special Identifying Features}

Of the entire-leaved species occurring within the range of $\underline{c}$. elliottii, and possibly in its habitat, there are but three, namely $c$. capitatus, $\underline{C}$. engelmani $i$, and $C$. monanthogynus. The first is a larger plant throughout, with broader 7 eaves, flatter female sepals, and a darker pubescence. The second, in addition to having flatter sepals, has shorter petioles and broader leaves. The third has smaller leaves, broader leaf outlines, is branched near the ground, has smaller male flowers which nod on the pedicels, and a different fruit and seed.

Habitat and Management Implications

C. elliottii frequents moist to dryish sands, sandy peats and peats. It is commonest on the drying shores of permanent to temporary ponds, lakes, and pools in karst topography. It is intolerant of shade. Considered rare and endangered, this species has not shown up much (if at a11) in collections since the early 1940's. However, during the 1977 season it has been found to be abundant around nearly every limesink pond in southwestern Georgia, adjacent northwestern Florida, and in southeastern Alabama. Where found it forms nearly pure stands, and is also often locally abundant in thosecrop fields and pine plantations adjacent to the ponds, and is not infrequent along roadside ditches in these same areas. Thus it would seem that the rarity of this species is only during those long periods in which the complex of requirements for germination of its abundant seed are not met. 1977 was a drought year, exposing large areas in which normally would be underwater or wet, and it is evident that the seed of c. elliotti i lie dormant during wet periods. Hardly any other stôy explains the sudden occurrence of these large stands of the Croton. Mechanical disturbance of the soils in which its seeds lie dormant also appears to promote its increase, the most luxuriant plants being found in places where spoil banks have been created or where pond edges have been plowed.

\section{References}

Chapman, A.W. 1860. Flora of the southern states, p. 430. Cambridge.

Sma11, J.K. 1933. Manual of the southeastern flora, pp. 780-783. Chapel Hil1, N.C. 
SPECIES Croton elIiotwi Chapmi Elitote's croton

\begin{tabular}{|c|c|c|c|c|c|c|c|c|}
\hline \multirow[b]{2}{*}{$\begin{array}{l}\text { Expected* } \\
\text { Effect on } \\
\text { the Species }\end{array}$} & \multicolumn{8}{|c|}{ Management Practices } \\
\hline & $\begin{array}{c}\text { Prescribe } \\
\text { Burn }\end{array}$ & $\begin{array}{c}\text { Bulldoze } \\
\text { or } \\
\text { Root Rake }\end{array}$ & Bed & Chop & $\begin{array}{l}\text { Thin } \\
\text { over- } \\
\text { story } \\
\end{array}$ & $\begin{array}{l}\text { Cut } \\
\text { over- } \\
\text { story }\end{array}$ & $\begin{array}{l}\text { Establish } \\
\text { Plantation }\end{array}$ & Graze \\
\hline Destroy & & & & & & & $x$ & NA \\
\hline Damage & & & & & & & & \\
\hline $\begin{array}{l}\text { No Lasting } \\
\text { Effect }\end{array}$ & $\mathrm{X}$ & * & $\%$ & $\%$ & & & & \\
\hline $\begin{array}{l}\text { Beneficial } \\
\text { if Done } \\
\text { Properly }\end{array}$ & & & & & & & & \\
\hline
\end{tabular}

Other Comments: *dependent on time of year:

*Expected effect on the species is an estimate made by Dr. Robert Kral based on his knowledge of the habitat and on knowledge gained from personal field observations. Estimates are "rough" in many instances. Results of practices may be modified depending upon the degree of application, intensity of treatment, neamess to plant communities, etc. A management practice for which no entry is made indicates a lack of sufficient information from which to predict expected results. As obsemvations are made in the field by users of the data, the expected effect will be refined. 
Croton elliottii Chapm.

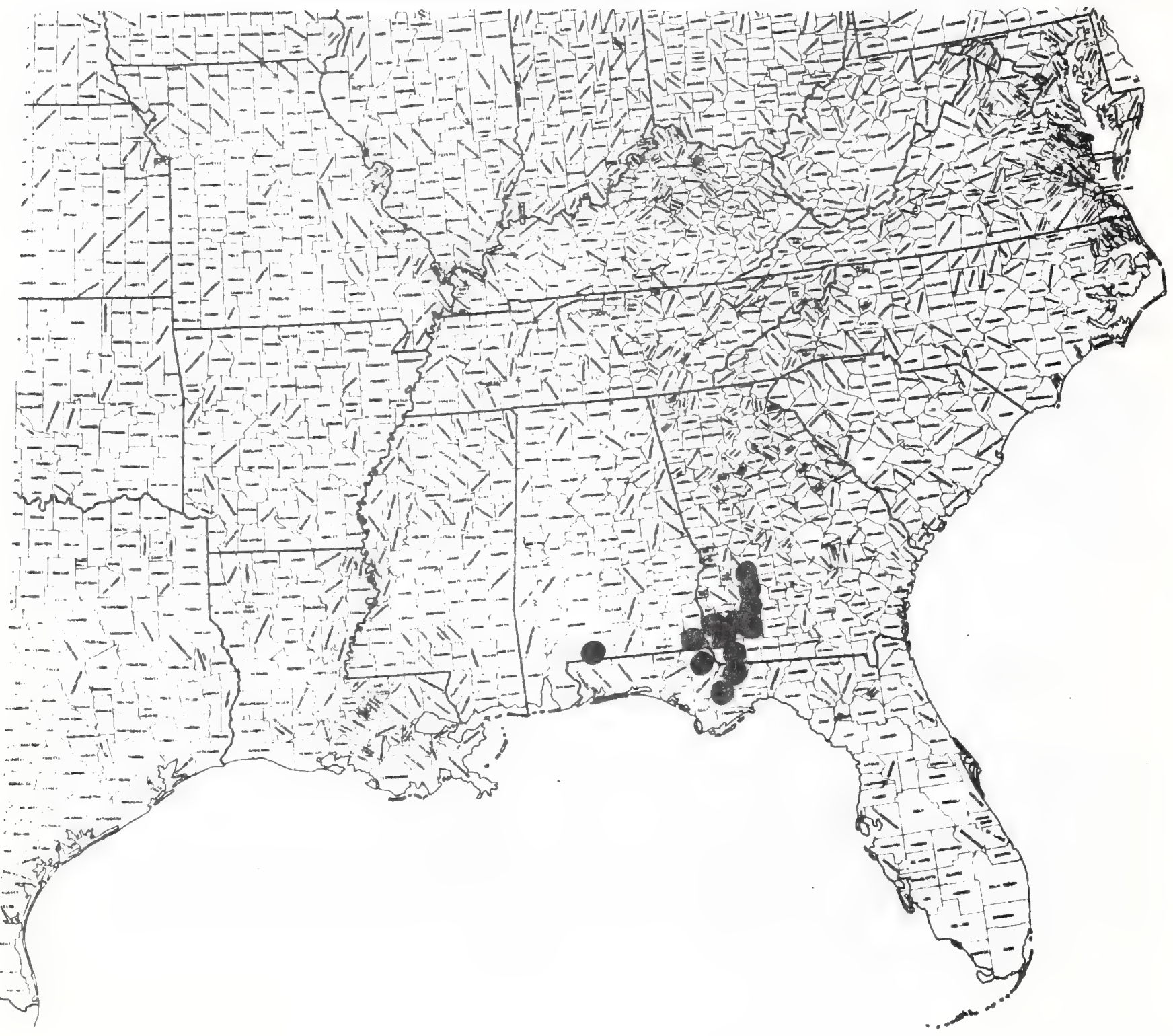


Paper 173

Text \& Map by:

Robert Kral

\section{HYMENOPHYLLACEAE}

Hymenophy 7 um cunbridgense (L.) Smith. tunbridge fern Trichomanes tunbridgense $L$.

Technical Description

Perennial, delicate, smooth, low fern, creeping by filiform, terete, smooth rhizomes, forming dense mats.

Fronds.-- Erect, produced at frequent intervals along the elongate rhizomes, actually drooping from the usually vertical substrate, no longer than $5 \mathrm{~cm}$; stipe (petiole) most7y $1-2 \mathrm{~cm}$ long, smooth, terete, dark brown, minutely Tongitudinally striate; blade simple to 2-pinnate, 1 cell layer thick save for brown mid-nerve, in outline lance-ovate or oblong, $1-2 \mathrm{~cm}$ wide, the pinnae most?y 4-6 per side, slightly ascending, in outine cuneate to obovate, asymmetrical, deeply divided into linear or oblong ultimate segments these ascending and somewhat spreading fanlike on the upper side of each pinna, marginally spinulose-serrulate, apically rounded or blunt; mid-vein of blade winged to about the width of the ultimate segments the veins simple, forking only into ultimate segments of their tips; sori enclosed in a cuplike, bi-lobed, obovoid, apically denticulate involucre (modified ultimate segment) ca. 1.0-1.2 mm long at tip of a Jower vein of the lowermost pinnule of a pinna, the sporangia in a single cluster, concealed within, borne on a bristle.

\section{Distribution}

Moist ledges, caves, ravines in full shade, in North America found only in one ravine in Pickens County, South Carolina; essentially tropical in the New World, in the Old World and Asia extending north to Norway and Japan.

\section{Special Identifying Features}

H. tunbridgense in the southeastern area is most similar to Trichomanes, $\overline{o f}$ the same fern family. Trichomanes may be distinguished by its funnet form or tubular involucres, their tips not toothed, the bristly bearing the sporangia projecting beyond the tip of the involucre (rather chan concealed within).

\section{Habitat and Managment Implications}

This fern grows only in one humid ravine, this a steep-sided streamcut through metamorphosed granite. It is in deep shade of mixed hardwoods, hemlock and white pine, with an understory of Rhododendron maximum and KaImia. It forms mats of pendant fronds on shaded ledges and surfaces of the rock along the ravine base which slopes, sometimes sheerly, into a swift, cold, rock-bedded stream. The atmosphere is often charged with mist from the stream, probably is saturated most of the time, thus the habitat is highly humid, che substrate almost constantly moist, always shaded. It is obvious that continuance of this rare fern depends on maintenence of the streambank and the stream and absolutely no admittance of light such as would occur with any sort of logging. 
References

Radfort, A.E. Ahles, H.E. and C.R. Bel1, 1968. Manual of the vascular flora of the Carolinas, pp. 14-15. Chapel Hill, N.C.

Copeland, E.B. 1947. Genera filicum. Chronica Botanica Co., Waltham, N.Y. 
SPECIES Hymenophy Ium tunlondogerse (I0) Snith" Tunbridge fern

\begin{tabular}{|c|c|c|c|c|c|c|c|c|}
\hline \multirow[b]{2}{*}{$\begin{array}{l}\text { Expected* } \\
\text { Effect on } \\
\text { the Species }\end{array}$} & \multicolumn{8}{|c|}{ Management Practices } \\
\hline & $\begin{array}{c}\text { Prescribe } \\
\text { Bum }\end{array}$ & $\begin{array}{c}\text { Bulldoze } \\
\text { or } \\
\text { Root Rake }\end{array}$ & Bed & Chop & $\begin{array}{l}\text { Thin } \\
\text { over- } \\
\text { story }\end{array}$ & $\begin{array}{l}\text { Cut } \\
\text { over- } \\
\text { story }\end{array}$ & $\begin{array}{l}\text { Establish } \\
\text { Plantation }\end{array}$ & Graze \\
\hline Destroy & NA & $N A$ & $\mathrm{NA}$ & $\mathrm{NA}$ & X. & $x$ & NA & $?$ \\
\hline \multicolumn{9}{|l|}{ Damage } \\
\hline $\begin{array}{l}\text { No Lasting } \\
\text { Effect }\end{array}$ & & & & & & & & \\
\hline $\begin{array}{l}\text { Beneficial } \\
\text { if Done } \\
\text { Properly }\end{array}$ & & & & & & & & \\
\hline
\end{tabular}

Other Comments: logging of any sort would be detrimental!

*Expected effect on the species is an estimate made by Dr. Robert Kral based on his knowledge of the habitat and on knowledge gained from personal field observations. Estimates are "rough" in many instances. Results of practices may be modified depending upon the degree of application, intensity of treatment, neamess to plant communities, etc. A management practice for which no entry is made indicates a lack of sufficient information from which to predict expected results. As observations are made in the field by users of the data, the expected effect will be refinea. 
Hymenophyllum tunbridgense (L.) Smith

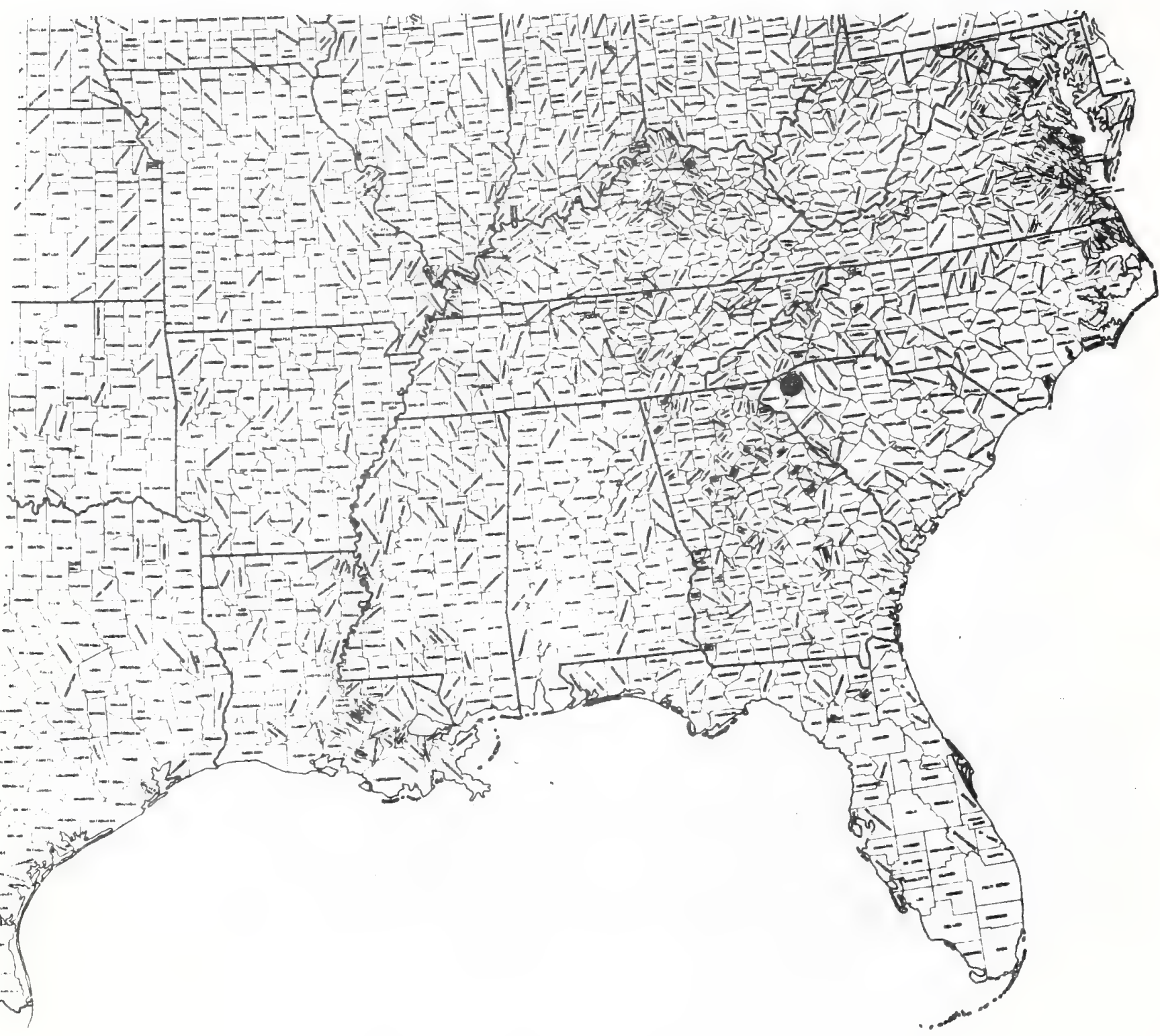




\section{ISOETACEAE}

Isoetes louistanensis Thieret. Louisiana quiliwort.

Technical Description

Grasslike, mostly submersed-aquatic herb from a 2-10bed corm.

Leaves.- Numerous, arising in tight spirals around the apex of the contracted corm, erect or ascending, $1.5-4.0 \mathrm{dm} 70$ ng (Jength depending on water depth, the Ionger-ieaved specimens from deeper water), the abruptly dilated bases serving as sporangia, with outer leaves producing megaspores, inner ones producing microspores; blades above sporangia narrowly tinear, deep yellow-green, tapering gradually to the apex, proximally flattened at inner face, and thin-margined, toward the apex with backs more convex, or triangular in cross-section, spongy and longitudinally chambered; stomata present; ligule triangular to ovate, $2-3 \mathrm{~mm}$ long: peripheral strands 0-28. Sporangia.- Oblong-elliptic, the thin wall pale, with dots or short lines of red-brown, particularly on the inner face, $6.5-8.0 \mathrm{~mm} 70 \mathrm{ng}, 3.0-4.0 \mathrm{~mm}$ broad, the inner face covered from $1 / 3-1 / 2$ by the velum (a membranous outgrowth of the sporangium apex and sides).

Spores.-- Megaspores nearly round, white, irregularly and sharply ridgedreticulate, 0.500-0.625 mm in diameter: microspores brownish, densely and finely spinose, $0.25-0.35 \mathrm{~mm}$ in diameter.

Distribution and Phenology

Banks and shallows of clear streams, Washington Parish, Louisiana. Produces spores in May and June.

Special Identifying Features

This extremely rare quil7mort is most similar to engelmanij var. caroliniana (according to Dr. Thieret, describer of the species) in vegetative character and in nature of megaspores. It differs from that plant by the brown-spotted sporangial walls,

Habitat and Management Implications

I. louisianensis has so far been found only in and along one stream in the Forida parishes of Louisiana. This stream is clear, relatively shallow and swift, and flows through a pine (P. taeda)-bottomiand hardwood (mostly Quercus of the willow oak complex) type. There it may be found with its corms shallowiy buried in silty sandy substrate, either on banks or bars, or in the stream itself. Thus the plants appear to thrive either submersed or emergent, but obviously require a wet substrate. Logging operations of the sort that would disturb the stream bed or banks would have a disastrous effect on this Iseotes.

References

Thieret, J.W. 1973. Isoetes louisianensis (Isoetaceae), a new species from Louisiana. Sida $\overline{5(2):} \overline{129}$.

Reed, C.F. 1965. Isoetes in southeastern United States. Phytologia 12: 369-400. 
SPECIES Isoetes louisianensis Thieret

\begin{tabular}{|c|c|c|c|c|c|c|c|c|}
\hline \multirow[b]{2}{*}{$\begin{array}{l}\text { Expected* } \\
\text { Effect on } \\
\text { the Species }\end{array}$} & \multicolumn{8}{|c|}{ Management Practices } \\
\hline & $\begin{array}{c}\text { Prescribe } \\
\text { Burn }\end{array}$ & $\begin{array}{l}\text { Bulldoze } \\
\text { or } \\
\text { Root Rake }\end{array}$ & Bed & Chop & $\begin{array}{l}\text { Thin } \\
\text { over- } \\
\text { story }\end{array}$ & $\begin{array}{l}\text { Cut } \\
\text { over- } \\
\text { story }\end{array}$ & $\begin{array}{l}\text { Establish } \\
\text { Plantation }\end{array}$ & Graze \\
\hline Destroy & NA & NA & NA & NA & & & NA & $\mathrm{x}$ \\
\hline Damage & & & & & & $\mathrm{x}$ & & \\
\hline $\begin{array}{l}\text { No Lasting } \\
\text { Effect }\end{array}$ & & & & & $\mathrm{x}$ & & & \\
\hline $\begin{array}{l}\text { Beneficial } \\
\text { if Done } \\
\text { Properly }\end{array}$ & & & & & & & & \\
\hline
\end{tabular}

Other Comments: grazing stock would trample banks and disturb stream bottom!

*Expected effect on the species is an estimate made by Dr. Robert Kral based on his knowledge of the habitat and on knowledge gained from personal field observations. Estimates are "rough" in many instances. Results of practices may be modified depending upon the degree of application, intensity of treatment, nearness to plant communities, etc. A management practice for which no entry is made indicates a lack of sufficient information from which to predict expected results. As observations are made in the field by users of the data, the expected effect will be refined. 
Isoetes 1oui sianensis Thi eret

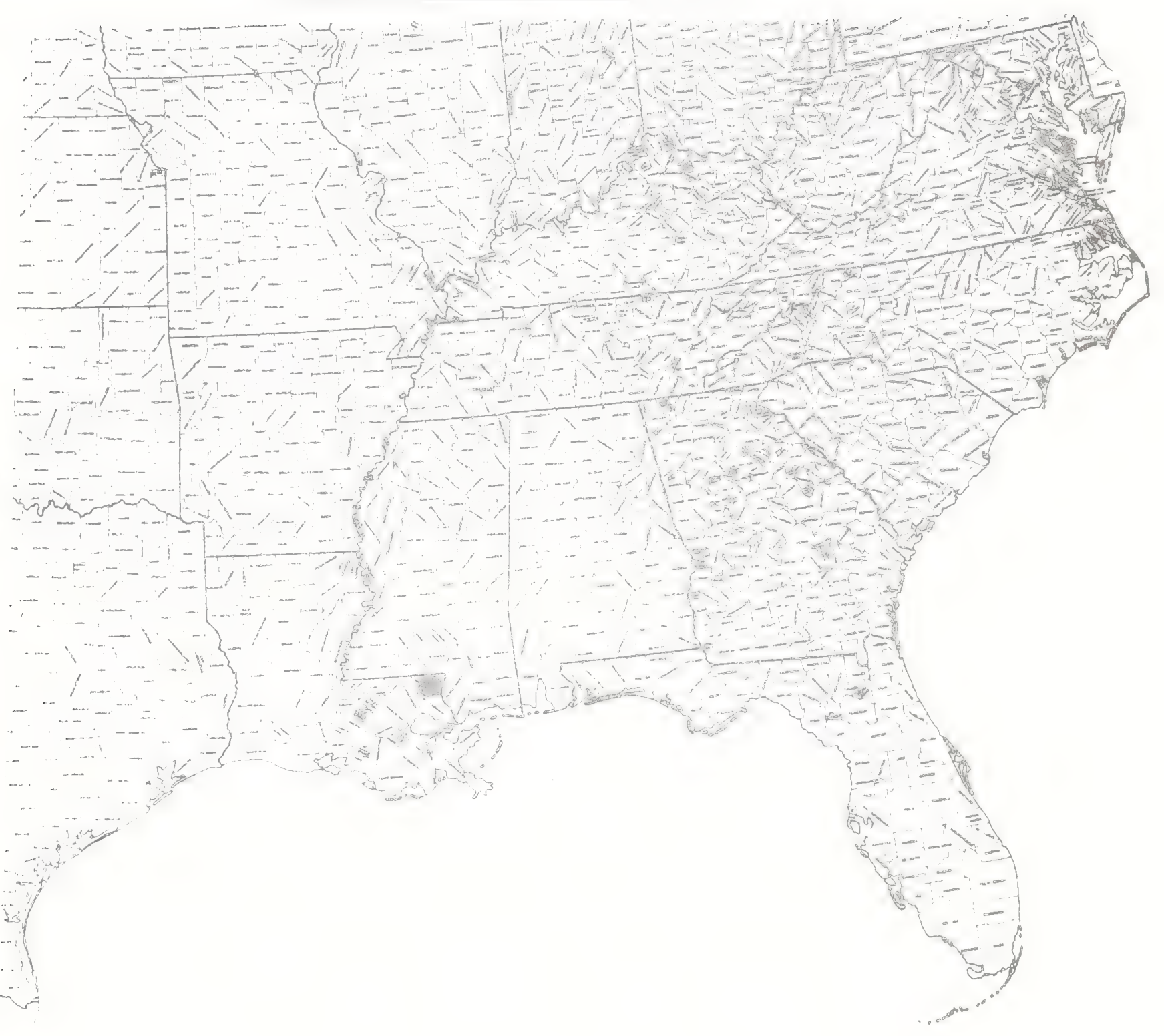


-

- 
Paper 175

Text \& Map by:

Robert Kral

\title{
LAMTACEAE
}

\author{
Pycnanthemum curvipes (Greene) Grant \& Epling. Tennessee mountain-mint \\ Koellia curvipes Greene \\ K. multiflora Sma 17
}

\section{Technical Description}

Stiffish, aromatic perennial herbs from coarse rhizomes or a knotty rootstock, also producing slender pale stoloniferous mizomes from rootstocks and stem bases.

Stems.-- Erect, solitary or few, to 1.5 meters tail, quadrangular save at very base, the lower stem with reddish-brown, thin bark, usually smooth but sometimes canescentapuberulent, toward the middle and above densely canescent-puberulent with whitish, incurved hairs, rarely mixed with a few longer, spreading hairs.

Leaves.-- Opposite, the lowermost usually absent by flowering time, the largest at mid-stem or lower, the blades mostly ovate to ovate-lanceolate, mostly 3-6 cm long, acute, the margins subentire to low-serrate, the base mostly broadly rounded, less often broadly cuneate, the upper surface pale yellow-green, gland-dotted, smooth or nearly so (becoming hairier in the inflorescence), the lower surface whitened with pale, incurved trichomes, the petioles 5-15, mostly $8 \mathrm{~mm}$ long, spreading, densely pale puberulent. Inflorescence.- Flowers grouped into small cymes, these intermingled with small, linear, canescent bracts, the cymules grouped into dense, hemishperical cymes, these usually teminal and solitary but sometimes in vigorous growth produced also from the next node beneath; all leaves of inflorescence branches similar in shape to main stem leaves but smaller, with upper surfaces whitened.

Flowers.-. Zygomorphic, complete. Calyx 3.0-3.0 mi long, short-cylindric, externally densely white-puberulent, the 5 teeth nearly equal, triangular, the lower 2 longest (comprising the lower calyx 7ip), ca. $1 \mathrm{~mm}$ long, the upper divided nearly to base, all tooth tips short-acuminate or mucronate, often slightly recurved; corolla bilabiate, externally puberulent, the tube ca. 2.503.5 mm long, che upper 3 ip erect, $1.5-3.5 \mathrm{~mm}$ 7ong; corolla surface pale lavender, the Tips spotted with deep purple.

Fruit.-. Nutlets usually 4 , oblong, brown, 1.2-1.4 mm long, the rounded tips hairy.

\section{Distribution and Flowering Season}

Dryish, upland woods and clearings or outcrops, in the Southern Appalachians from western North Carolina southward into the Piedmont of Georgia, west of the mountains from middle Tennessee southward chrough eastern Alabama to the upper Coastal Plain. Flowering from July through August.

Special Identifying Features

This "species" is hardly distinguishable from P. albescens, a plant of similar 
sites whose distribution centers in the Gulf Coastal Plain from eastern Texas eastward into northern Florida and inland into Oklahoma and Arkansas. Only the most minor characteristics, such as leaves tending to be rounded at base (instead of cuneate), pubescence of upper stem tending to be consistently incurled-puberulent (rather than often having longer, spreading ha irs admixed), calyx teeth broader, shorter, abruptly acuminate with tips tending to recurve, the upper divided nearly to base (ratıer than narrower and longer, less abruptly acuminate, usually acute, with tips erect, the upper more fused). Actually, inspection of a farily large series of specimens of $P$. albescens, there are specimens which have a mix of characteristics of $\underline{P}$. curvipes, $\underline{P}$. albescens, and the closely related $\underline{P}$. incanum. The limits of species in this complex are not yet defined clearly.

\section{Habitat and Management Implications}

The habitat of $P$. curvipes is variable. It may be found at edges of upland woods or in open oak-hickory or oak-pine woods on sandy loams, sandy clay loams, or clay loams. Also it may be found on shallow soil pockets on outcrops of shale, phyllite, or granite (the type locality is Stone Mountain, Georgia). The site is in any event sunny and dry. Plants of this complex of Pycnanthemum exhibit weedy characteristics, rather rapidly occupying abandoned clearings, succeeding in areas where there is fire and/or logging disturbance. Succession to closed-canopy forest, or closure of crowns of plantation pine, would eliminate the species by shading it out.

\section{References}

Grant, E. and C. Epling. 1943. A study of Pycnanthemum (Labiatae) Univ. of Calif. Publ. Bot. 20 (3). 195-240.

Greene, E.L. 1911. P. curvipes in Leafl. Bot. Obs. and Crit. 2: 140.

Sma11, J.K. 1933. Manual of the southeastern flora, pp. 1171-1175. Chapel Hill, N.C. 
SPECIES Pycnanthermum curypes (Greene) Grant \& EpIing.

Tennessee mouncainmint

\begin{tabular}{|c|c|c|c|c|c|c|c|c|}
\hline \multirow[b]{2}{*}{$\begin{array}{l}\text { Expected* } \\
\text { Effect on } \\
\text { the Species }\end{array}$} & \multicolumn{8}{|c|}{ Management Practices } \\
\hline & $\begin{array}{c}\text { Prescribe } \\
\text { Bum }\end{array}$ & $\begin{array}{l}\text { Bulldoze } \\
\text { or } \\
\text { Root Rake }\end{array}$ & Bed & Chop & $\begin{array}{l}\text { Thin } \\
\text { over- } \\
\text { story }\end{array}$ & $\begin{array}{l}\text { Cut } \\
\text { over- } \\
\text { story }\end{array}$ & $\begin{array}{l}\text { Establish } \\
\text { Plantation }\end{array}$ & Graze \\
\hline Destroy & & & & & & & $x$ & \\
\hline Damage & & & & & & & & \\
\hline $\begin{array}{l}\text { No Lasting } \\
\text { Effect }\end{array}$ & & $\mathrm{X}$ & 罣 & $\mathrm{x}$ & & & & \\
\hline $\begin{array}{l}\text { Beneficial } \\
\text { if Done } \\
\text { Properly }\end{array}$ & $x$ & & & & $\mathrm{x}$ & $x$ & & \\
\hline
\end{tabular}

Other Comments: effects of grazing not observed

*Expected effect on the species is an estimate made by Dr. Robert Kral based on his knowledge of the habitat and on knowledge gained from personal field observations. Estimates are "rough" in many instances. Results of practices may be modified depending upon the degree of application, intensity of treatment, neamess to plant commities, etc. A management practice for which no entry is made indicates a lack of sufficient information from which to predict expected results. As observations are made in the field by users of the data, the expected effect will be refined. 
Pycnanthemum curvipes (Greene) Grant \& Epling

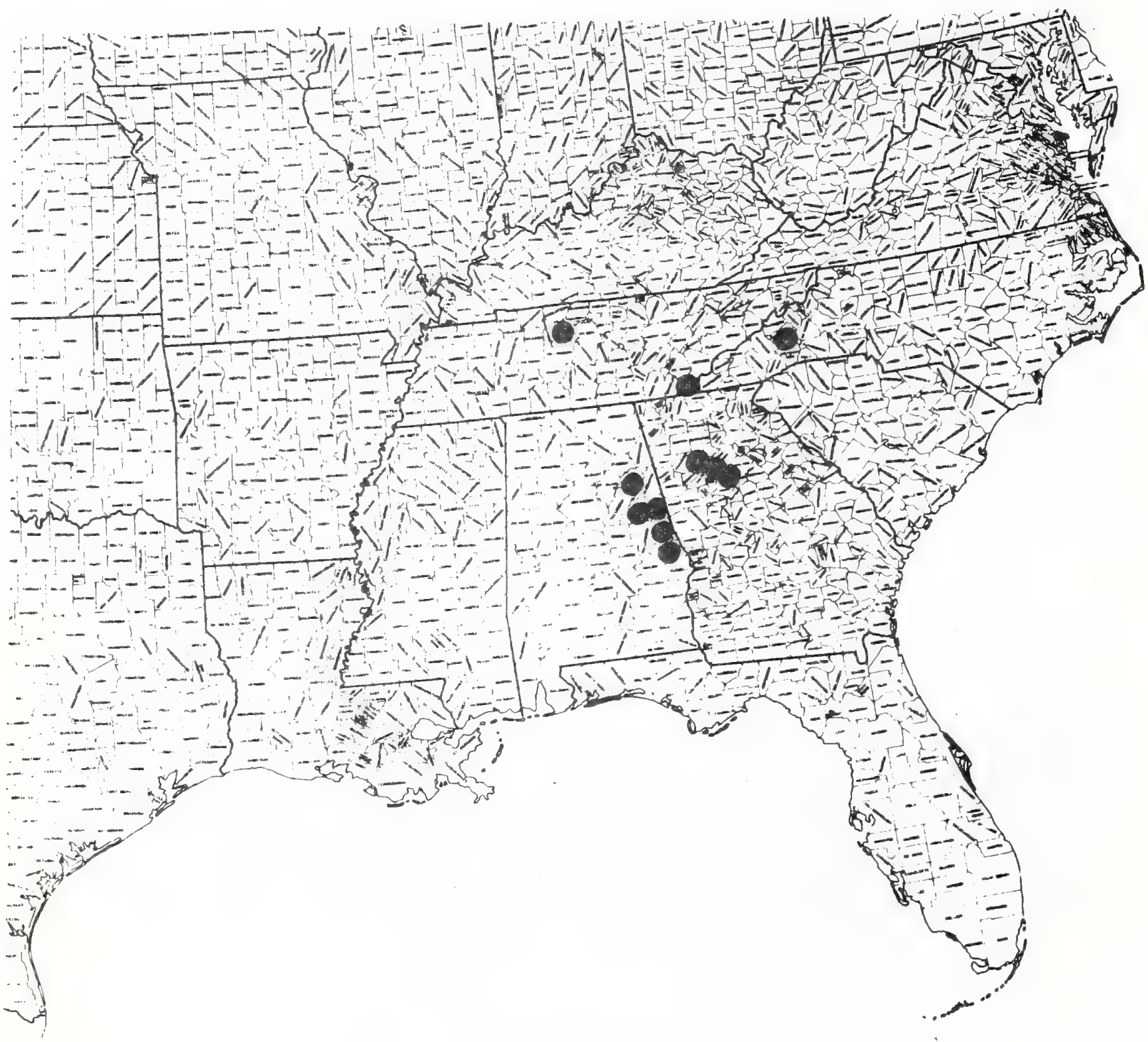


Paper 176

Text \& Map by:

Robert Kral

\section{LILIACEAE}

\section{Schoenolirion wrightio Sheman. Texas sunnyber? \\ S. texanum (Scheele) Gray}

\section{Technical Description}

Perennial, grass-ijke, smooth herb, the bulbous base capping a vertical, thick-rooted rhizome.

Leaves.-. All basal and sheathing-based, the outermost strictly scale-like, forming a thin, brownish jacket, the longer ones $2-5 \mathrm{dm} 7$ ong, the blades lineal. mostly $3-5 \mathrm{~mm}$ wide, tapering to a narrow but bluntish, angulate apex, with several raised nerves, greenish, the margins minutely papillose; blades toward base gradually widening, straw-colored or near white, their borders thin and broad, clasping.

Inflorescence.- Scapes erect, mostly 3-6 dm tall, smooth, terete, simple or branching at middle or above, the brances ascending to erect, each subtended by a short-lineal, green, erect bract, and terminating in an elongate, multiflowered, narrow, indeterminate raceme, the slender pedicels upwardarching, in flower mostly $1-2 \mathrm{~cm}$ long, each subtended by an ascending, linea] green bract from 1 to $2 \mathrm{~cm}$ long (the shortest toward raceme tips). Flowers.- Regular, bisexual, nearly $1 \mathrm{~cm}$ broad: sepals and petals each 3 , distinct, spreading at anthesis, nearly equal (thus perianth tepaloid), elliptic or oblong, ca. $4.0-4.5 \mathrm{~mm}$ long, the tips rounded, bluntish, concave, shomewhat fleshy, the margins entire, the surfaces medially with 3-4 longitudinal green 7 ines and with broad, greenishowhite borders; stamens 6 , the erect filaments ca. $3 \mathrm{~mm}$ long, lineal but dilating and flattening toward base, the anthers oblong, but with anther pairs sijghtly divergent, versatile, ca. $2 \mathrm{~mm}$ long, yellowish: ovary superior, subglobose, green, the 3 styles united into a lineal, erect slender column ca. $2.5 \mathrm{~mm}$ long.

Fruit.- Capsules trilobed, $4-5 \mathrm{~mm}$ broad; seeds globose, $2-3 \mathrm{~mm}$ broad, glossy black.

Distribution and Flowering Time

Grassy savannas, swales, northeastern and north-central Alabama, southern Arkansas, eastern Texas. Flowering from late Apriz to early June.

Special Identifying Features

S. wrightij has whitish flowers which, together with its leaves being usually shorter than the inflorescence, distinguish it from S. croceum, a wideranging yellow-flowered species whose rangeit is nested within. The onty other white-flowered species is $S$. albiflorum; this plant of the lower Coastal Plain lacks a rhizome and also has a much more branched inflorescence.

Habitat and Management Implications

S. wrightit is found always on high-hydroperiod, sandy soils, these usually highly organic. It is almost always in full sun, associated with grasses and sedges. Generally it is a part of savanna, the trees being either pines or a mixture of various species of southern yellow pine with hardwoods, 
particularly oak and hickory. Such savannas have been maintained over time by fire. The "bog" soils it grows in are eliminated by drainage and the various mechanical site preparation techniques are likewise destructive. Planting with pine likewise is destructive in that ultimate closure of crowns would shade out the herbaceous cover.

\section{References}

Corre11, D.S. and M.C. Johnston. 1970. Manual of the vascular plants of Texas. Renner.

Sherman, H.L. 1969. A systematic study of the genus Schoenolirion (LiTiaceae). Unpublished Ph.D. Thesis, Vanderbilt University.

Sma11, J.K. 1933. Manual of the southeastern flora: 293-294. 
SPECIES Schoenolixion wrightid Sherman. Texas surnylo I I

\begin{tabular}{|c|c|c|c|c|c|c|c|c|}
\hline \multirow[b]{2}{*}{$\begin{array}{l}\text { Expected* } \\
\text { Effect on } \\
\text { the Species }\end{array}$} & \multicolumn{8}{|c|}{ Management Practices } \\
\hline & $\begin{array}{c}\text { Prescribe } \\
\text { Burn }\end{array}$ & $\begin{array}{l}\text { Bulldoze } \\
\text { or } \\
\text { Root Rake }\end{array}$ & Bed & Chop & $\begin{array}{l}\text { Thin } \\
\text { over- } \\
\text { story }\end{array}$ & $\begin{array}{l}\text { Cut } \\
\text { over- } \\
\text { story }\end{array}$ & $\begin{array}{l}\text { Establish } \\
\text { Plantation }\end{array}$ & Graze \\
\hline Destroy & & z & $x$ & $x$ & & & $\mathrm{x}$ & \\
\hline Damage & & & & & & & & $\mathrm{x}$ \\
\hline $\begin{array}{l}\text { No Lasting } \\
\text { Effect }\end{array}$ & & & & & & & & \\
\hline $\begin{array}{l}\text { Beneficial } \\
\text { if Done } \\
\text { Properly }\end{array}$ & $x$ & & & & $x$ & $x$ & & \\
\hline
\end{tabular}

Other Comments: drainage of siote destroys these plants!

*Expected effect on the species is an estimate made by Dr. Robert Kral based on his knowledge of the habitat and on knowledge gained from personal field observations. Estimates are "rough" in many instances. Results of practices may be modified depending upon the degree of application, intensity of treatment, nearness to plant communities, etc. A management practice for which no entry is made indicates a lack of sufficient information from which to predict expected results. As observations are made in the field by users of the data, the expected effect will be refined. 


\section{Schoenolirion wrightii Sherman}

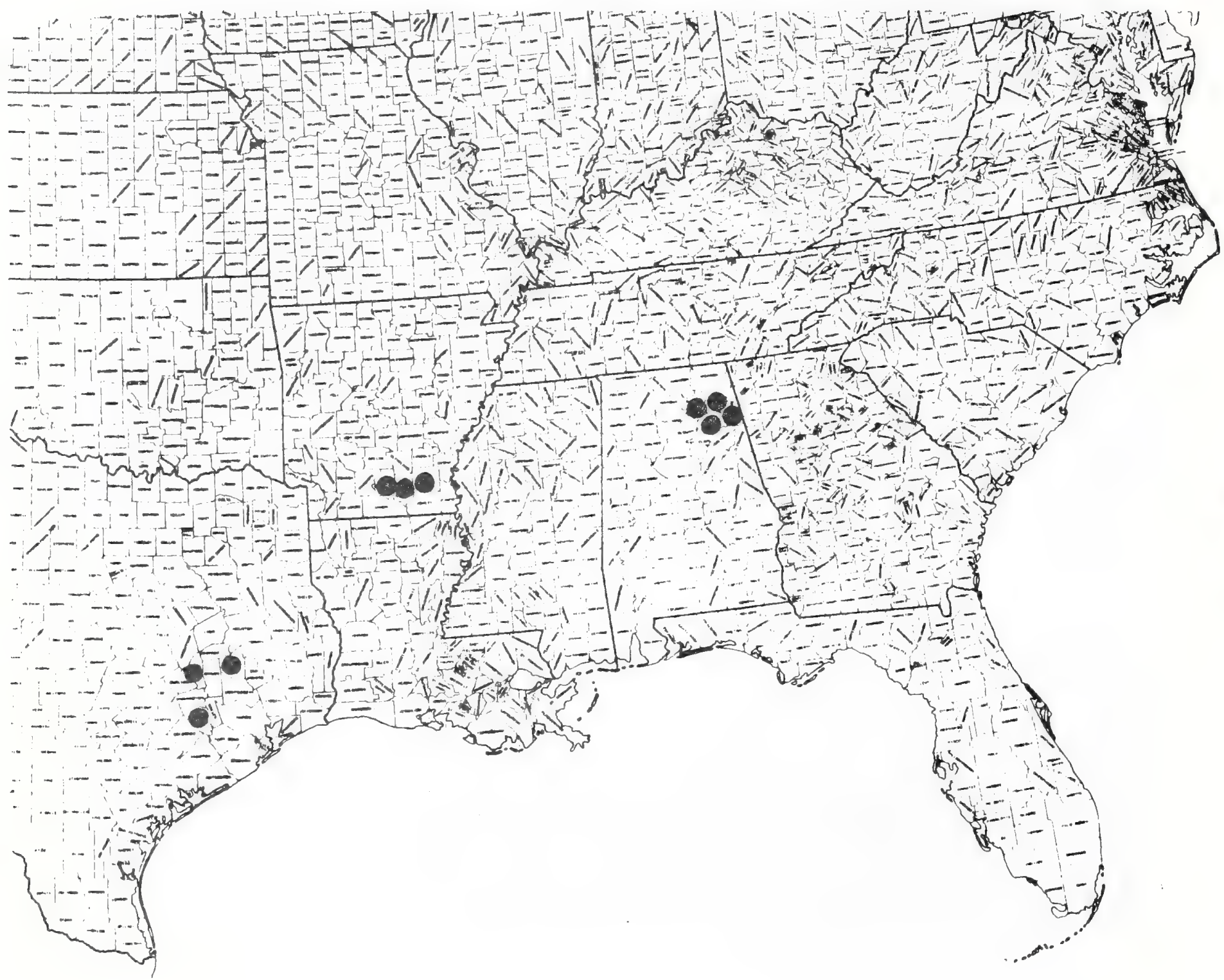




\section{LILIACEAE \\ Triltium persistens Duncan。 persistent tril7ium}

Technical Description

Perennial herbs from stocky, short, erect, horizontal or declinate rhizomes.

Stems.-- Solitary (rarely paired) from the whizome tip, erect from sheathing, scale-like basal leaves, terete, mostly $1-2(-3) \mathrm{dm}$ long, toward the base pale, upwardly becoming dark green or maroon, or green suffused with maroon, tapering slightly into the bracts.

Bracts. - 3 (rarely 4 ), lanceolate to ovate - lanceolate, rarely elliptical, mostiy $3-5 \mathrm{~cm}$ long $(-8), 1.5-2.5 \mathrm{~cm}$ wide $(-3.5 \mathrm{~cm})$, spreading or slight7y declined, usually somewhat folded concavely along the midrib, the apex narrowly acute, to acuminate, the margin minutely papillate-scabrid, the base cuneate, nearly sessile, the midrib accompanied by $1-2$ fainter, arcuate pairs of Taterals, the upper surface dark green, the Jower surface paler, in living specimens slightly glaucous.

Flowers.-- Solitary on a slender, erect or slightly spreading peduncle 1.2-3.0 cm long; sepals 3, distinct, ascending or slightly spreading, lanceolate to elliptic, linear or oblong, $1.0-2.5 \mathrm{~cm}$ long, $0.3-0.8 \mathrm{~cm}$ wide, apically acute to rounded, edged with a thin, pale band. the bases slightly fused, acutish, the surfaces greenish; petals 3, ascending, Jinear to oblong, oblanceolate or spatulate, $1.5-3.0 \mathrm{~cm}$ long, $0.3-1.0 \mathrm{~cm}$ wide, apica $77 \mathrm{y}$ acute, sometimes bluntish, somewhat longitudinally folded so that the upper surface is concave ( Iingulate), the margin entire but somewhat crispate (as in Tri7lium grandiflorum), the surfaces yellowish-white when young, aging to pink: stamens 6, ascending, mostly 10-11 mm long, the yellowish anthers innear, $5 \mathrm{~m} 6 \mathrm{~mm}$ long, dehiscing laterally, on Tinear, flattish, white filaments about as long as the anthers; ovary broadly obovoid, ca. $3.0-3.5 \mathrm{~cm}$ long, the wall grooved along the sutures, abruptly pointed into the $(2-3 \mathrm{~mm}$ long) style, this parted into 3 linear, slightly spreading styles which are $4.5 \mathrm{~mm}$ long. Fruit not observed.

Distribution and Flowering Time

Acidic, moist to rather dry hemlock-pine-hardwood coves and ravines usually around Rhododendron, northeast Georgia (Rabun and Habersham Counties) and northwestern South Carolina (Oconee County): flowering from mid-March to midAprit.

\section{Special Identifying Features}

As stated by Duncan (1971), this species bears resemblances both to T. catesbaei, a common acidic woodland pedicellate trillium of the southern Appalachians and Piedmont, as well as to I. pusillum, a low-growing pedicellate trillium more often found in hardwood bottoms of the Coastal PJain. However, I. catesbaei is usually a taller plant, with much larger and broader leaves, larger flowers whose petals are of a broader outline and strongly recurved. On the other hand it differs from the similar sized T. pusitlum in its differently shaped bracts (more often broadest toward the base rather than elliptic or oblong), its more ascending (rather than spreading) petals which tend to be broadest 
at mid-point and above (rather than toward the base), and by its ovary which is obcvoid (rather than ovoid), and strongly grooved and winged along the sutures (rather than obscurely angled).

Habitat and Management Implications

T. persistens is an acidic, humified sands derived from metamorphosed granites. The sites are steep, at least strongly sloping, bouldery, shaded by an over story of white, shortleaf and Virginia pine, Red oak, Chestnut oak, White oak, Sweet gum, Yellow poplar, Hickory, Magnolia tripetala. Hemlock is locally abundant toward ravine bases. The understory toward ravine heads is mainly Kalmia, Rhododendron minus, with R. maximum lower down and interspersed with Hydrangea arborescens. Low bush biueberries are abundant on the drier, opener sites, common herbaceous associates include Hexastylis, Galax, Epigaea, Viola hastata, $V$. pallens. The forest has a scattering of merchantible-sized pine (particularly shortTeaf), oak, Yellow poplar. Sweet gum, but the steepness of the terrain together with the erodibility of the soils would preclude any but selective logging. Areas where clearing has been done to provide power Tine rights-of-way, etc., show heavy erosion, together with a dense overgrowth of Rubus, Hydrangea, Sambucus, Lonicera japonica and Pueraria. Where these clearings have been made through trillium populations, no trillium is in evidence.

\section{References}

Duncan, W.H., J.F. Garst and G.A. Neece. 1971. Trillium persistens (Liliaceae), a new pedicellate-flowered species from northeastern Georgia and adjacent Southe Carolina. Rhodora 73 (794): 244-248. 
SPECIES Tril1ium persistens Duncano persistent trid 1ium

\begin{tabular}{|c|c|c|c|c|c|c|c|c|}
\hline \multirow[b]{2}{*}{$\begin{array}{l}\text { Expected* } \\
\text { Effect on } \\
\text { the Species }\end{array}$} & \multicolumn{8}{|c|}{ Management Practices } \\
\hline & $\begin{array}{c}\text { Prescribe } \\
\text { Burn }\end{array}$ & $\begin{array}{c}\text { Bul ldoze } \\
\text { or } \\
\text { Root Rake }\end{array}$ & Bed & Chop & $\begin{array}{l}\text { Thin } \\
\text { over- } \\
\text { story }\end{array}$ & $\begin{array}{l}\text { Cut } \\
\text { over- } \\
\text { story }\end{array}$ & $\begin{array}{l}\text { Establish } \\
\text { Plantation }\end{array}$ & Graze \\
\hline Destroy & & $\mathbb{N A}$ & $\mathbb{N A}$ & $N A$ & & $\mathrm{X}$ & $N A$ & \\
\hline Damage & $\mathrm{X}$ & & & & $X$ & & & $\mathrm{x}$ \\
\hline $\begin{array}{l}\text { No Lasting } \\
\text { Effect }\end{array}$ & & & & & & & & \\
\hline $\begin{array}{l}\text { Beneficial } \\
\text { if Done } \\
\text { Properly }\end{array}$ & & & & & & & & \\
\hline
\end{tabular}

Other Comments:

*Expected effect on the species is an estimate made by Dr. Robert Kral based on his knowledge of the habitat and on knowledge gained from personal field observations. Estimates are "rough" in many instances. Results of practices may be modified depending upon the degree of application, intensity of treatment, nearness to plant commities, etc. A management practice for which no entry is made indicates a lack of sufficient information from which to predict expected results. As observations are made in the field by users of the data, the expected effect will be refined. 
Trillium persistens Duncan

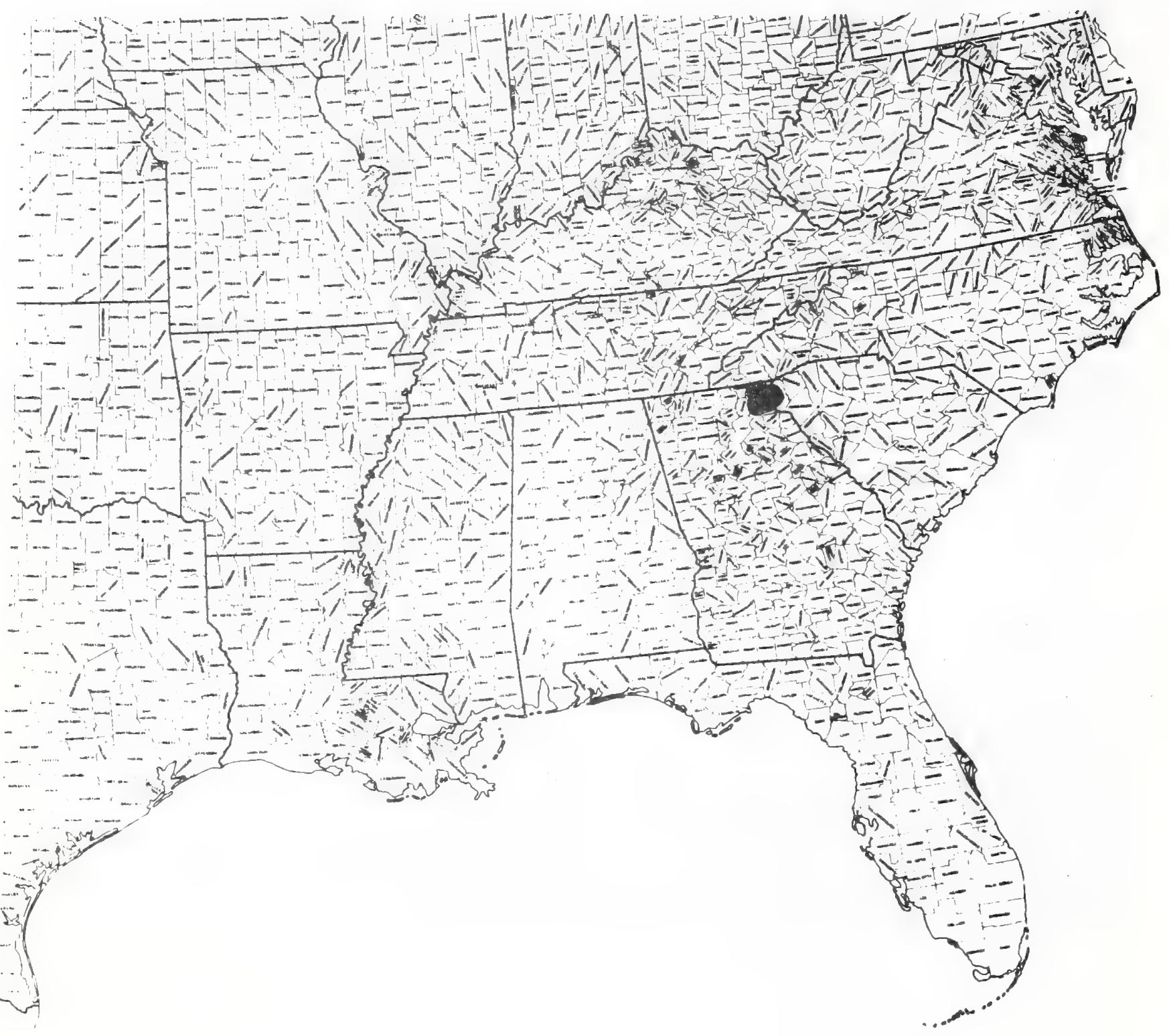




\section{LILIACEAE}

Veratrum woodif Robbins in Wood. Woods" false helleborne

Technical Description

Perennial herb from a thick-rooted, stout, bulbous rootstock.

Stems.-- Erect, single from the bulb, at base to $2 \mathrm{~cm}$ thick, usualiy encased in 07d, brown fibrous, overlapping leaf bases, the exposed portions terete, pale yellow-green, with a scattered pubescence of weak, fascicled hairs, gradually narrowing upward, there terete or somewhat angled, also slightly ribbed, scattered-pubescent.

Leaves.-- Rosette leaves arising from lateral shoots buds, emerging in winter or early spring, most7y 5-6 am long, with half the length petiole, the blades mostly elliptical or broadiy oblanceolate, mostly $4-8 \mathrm{~cm}$ broad, acute, entire, attenuated to the long, clasping-based petiole, strongly parallel-veined, the upper surface toward the base numerous, overlapping, spreading, the lowermost similar to rosette leaves, all spirally arranged, lowest often withering by flowering time, upward on the stem narrowing, mostly linear, shortening and more distant, in the inflorescence short-linear or lanceolate, each subtending an inflorescence branch.

Inflorescence.-- Flowers very numerous in an erect panicle of racemes, the whole structure narrow, up to 1 meter long, each branch ascending, sharply ribbed, puberulent with pale weak hairs and with numerous flowers from near base to tip, each pedicel subtended by a papery, boat-shaped, ovate, scalelike bract ca. 3.0-3.5 mm long, this ciliate and with puberulence along its ribs on the back; pedicels to $5 \mathrm{~mm}$ long, crisped-puberulent, ascending. Flowers..- Regular, bisexual or some in a plant strictiy male; tepals 6, the petals somewhat longer, all spatulate or oblanceolate, the backs crisped pale-puberulent, the surfaces maroon; stamens 6 , filaments slender, maroon, erect or ascending, to $5 \mathrm{~mm}$ long, the anthers broadly ovoid, short; ovary superior, 3-carpellate, ovoid, 3-4 mm high, 3-lobed, the acute carpel tips distinct, the styles distinct, lineal, spreading or spreading-recurved. Fruit.-- Capsule lanceolate, erect, ful7y $1.5 \mathrm{~cm}$ long, strongly $3-10 \mathrm{bed}$ and angled, dark reddish-green, externally with a scattering of fascicled hairs; seeds several, strongly wing margined.

\section{Distribution and Flowering Season}

Rich sandy mesic woodlands, in the Southeast from the Cumberlands of Kentucky southward through the Cumberlands and Blue Ridge of Tennessee thence intermittently through various provinces of Georgia into southwestern Georgia and northwestern Florida: wooded summits and coves in the Interior Highlands of Missouri and Arkansas; Iowa: I17inois; Indiana.

Special Identifying Features

$V$. woodii is closest to $V$. parviflorum Michx. of similar habitats but more confined to the Appalachians from southwestern Virginia southward into northern 
Georgia and Alabama. This last tends to have broader leaf blades, smaller flowers (the petals rarely much longer than $5 \mathrm{~mm}$ ) whose perianth is greenish on pedicels more than two times as long as the subtending bracts. Also the inflorescence branches in $V$. parviflorum tend to be more spreading, the inflorescence therefore broader, more diffuse. Both of these species, but particularly $\mathrm{V}$. woodij, are sporadic-flowering, so that almost every population has but few fTowering shoots, none at all some seasons. Tome confusion as to flower color for $V$. woodii exists, in that while the freshly emerged perianth is maroon, it does often change to green later, particularly in fruiting speciments.

\section{Habitat and Management Implications}

$V$. woodii is invariably in rich mesic woodlands, its bulbs rather deeply set in moist, well-drained, sandy loams, In Kentucky, Tennessee, and in north Georgia the overstory is often hemlock-hardwood, the hardwoods being a mixture of Quercus such as Q. rubra, Q. alba, Liriodendron. Aesculus, Tilia, Fraxinus, Carya (cordiformis), etc. In the hightands of Missouri and Arkansas the overstory is mainly mixed oak-hickory. In southwestern Georgia and northwestern Florida the plants are found under a mixture of Magnolia grandiflora, Fagus grandifolia, Acer, with a scattering of Spruce pine or Loblolly pine. The herbaceous associates are those usually found in rich deciduous woodlands and include species in the genera Hepatica, Ranunculus, Polemonium, Lilium, Sanguinaria, Polygonatum, Smilacina, Erythronium, Tradescantia, Thaspium, Phlox, etc., together with several genera of woodland ferns including Adiantum, Polystichum, Asplenium, Athyrium, Woodsia. The Veratrum if often in populations of hundreds of plants but the populations may be extremely local. The plants appear to be intolerant of full sun, so that areas contiguous to good populations and which doubtless contained Veratrum But were clearcut now lack the species. Veratrum are considered poisonous and it is to be assumed that they are not eaten by livestock.

\section{References}

Fernald, M.L. 1950. Gray's manual of botany, ed. 8 pp. 427-428. Boston, MASS

Sma11, J.K. 1933. Manual of the southeastern flora, pp. 276-277. Chapel HiT T, N.C.

Wood, A. 1855. Classbook of botany, ed. 41, p. 557. New York, N.Y. 
SPECIES Veratrum woodii Robbins. Nood's faIse hellebore

\begin{tabular}{|c|c|c|c|c|c|c|c|c|}
\hline \multirow[b]{2}{*}{$\begin{array}{l}\text { Expected* } \\
\text { Effect on } \\
\text { the Species }\end{array}$} & \multicolumn{8}{|c|}{ Management Practices } \\
\hline & $\begin{array}{c}\text { Prescribe } \\
\text { Burn }\end{array}$ & $\begin{array}{c}\text { Bulldoze } \\
\text { or } \\
\text { Root Rake }\end{array}$ & Bed & Chop & $\begin{array}{l}\text { Thin } \\
\text { over- } \\
\text { story }\end{array}$ & $\begin{array}{l}\text { Cut } \\
\text { over - } \\
\text { story }\end{array}$ & $\begin{array}{l}\text { Establish } \\
\text { Plantation }\end{array}$ & Graze \\
\hline Destroy & & $x$ & $x$ & $x$ & & $\mathrm{X}$ & X (if pin & e) * \\
\hline Damage & $\mathrm{X}$ & & & & & & . & \\
\hline $\begin{array}{l}\text { No Lasting } \\
\text { Effect }\end{array}$ & & & & & $\mathrm{X}$ & & & \\
\hline $\begin{array}{l}\text { Beneficial } \\
\text { if Done } \\
\text { Properly }\end{array}$ & & & & & & & & \\
\hline
\end{tabular}

Other Conments:*plants mechani. cally damaged by trampling: plants considered poisonous!

*Expected effect on the species is an estimate made by Dr. Robert Kral based on his knowledge of the habitat and on knowledge gained from personal field observations. Estimates are "rough" in many instances. Results of practices may be modified depending upon the degree of application, intensity of treatment, nearness to plant commities, etc. A management practice for which no entry is made indicates a lack of sufficient information from which to predict expected results. As observations are made in the field by users of the data, the expected effect wil1 be refined. 
Veratrum woodii Robbins in Wood

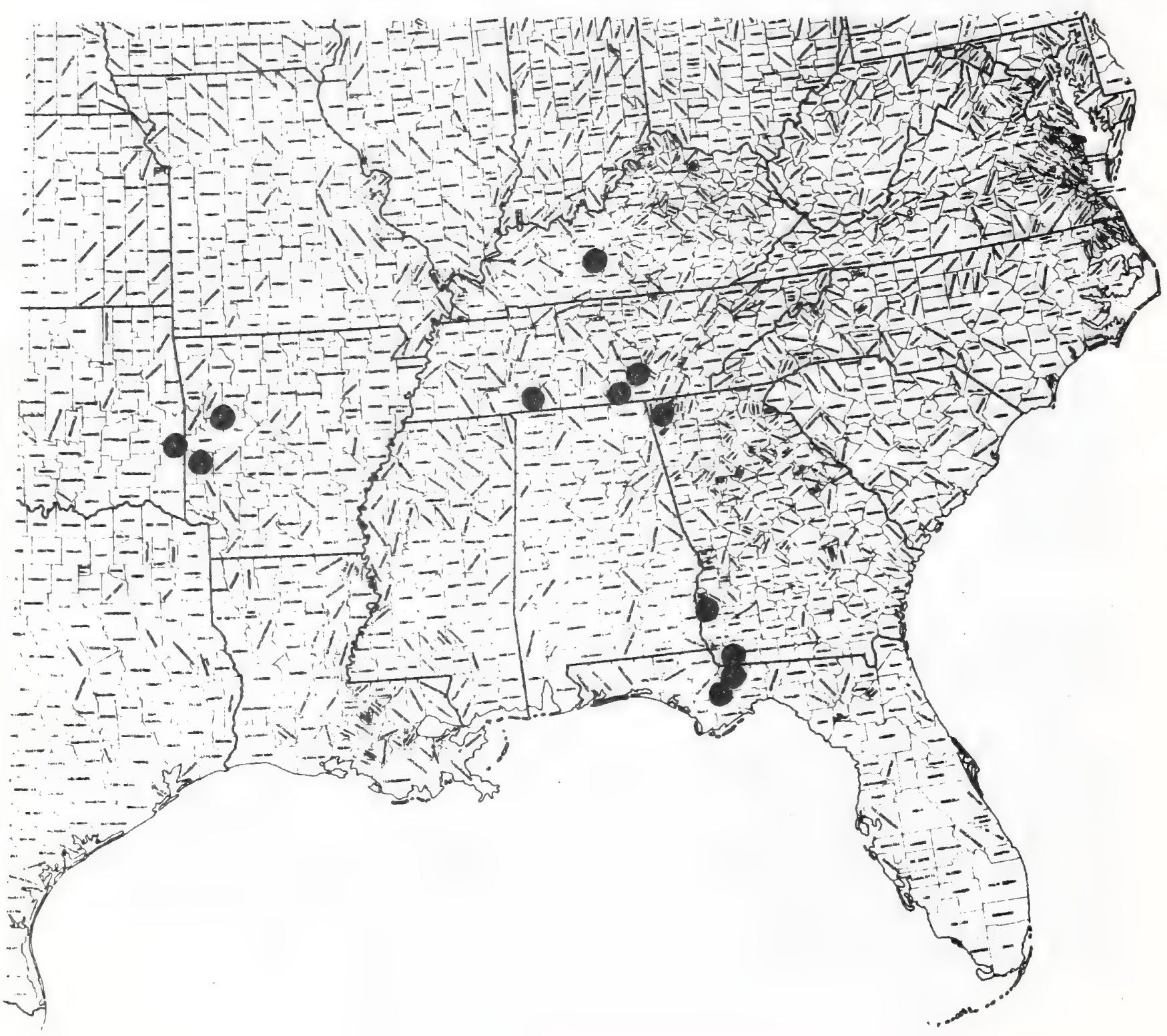




\section{LINACEAE}

Linum carteri Small var. smallif Rogers. Carter's Targe-flowered flax Cathartolinum carteri (Sma17) Sma17, in part Linum rigidum Pursh var. rigidum sensu Rogers (1963).

Technical Description

Annual smoothish herb from a taproot.

Stems.-- Erect, stiffish but slender, (1-), 2-4 (-6) dm tal7, simple or with simple, spreading-ascending branches from base, proximally purplishbrown and terete, papillose in lines, upwardly greenish with internodes narrowly wing-angled below midribs of the numerous leaves, branching only in inflorescence.

Leaves.-- Linear, linear-oblanceolate, or el7iptic-7inear, erect or ascending, spiral and overlapping, small and more spreading toward stem base, largest in lower $1 / 3$ of stem, gradually diminishing into the inflorescence, the largest $1.5-2.5 \mathrm{~cm}$ long, acute, entire and somewhat involute, sessile, only the mid-nerve evident, this raised beneath, the surface green.

Inflorescence.-- A cyme, obtrianguiar in outitine, the stiff primary branches usually few, sparingly rebranched, strongly wing-angled, the bracteal leaves and bracts lance-subulate, keeled, marginally glandular-ciliate, the pedicels usually inwardly (upwardiy) second, to $1 \mathrm{~cm}$ long, usually shorter, wingangled, axillary, imperceptibly "jointed" I mm below calyx.

Flowers.-- Regular, bisexual, opening in morning; sepals 5, distinct. lanceolate, greenish or tinted with maroon, distinct, seemingly in 2 series with the outermost set of 3 longer than the inner 2, deciduous from fruit, all subulate-tipped and glandular-ciliace, triple-nerved with the median nerve raised as a keel: petals 5, distinct, falling by mid-day, golden yellow, spreading, obovate-obtriangular, ca. $15-17 \mathrm{~mm}$ long, apically shallowiy emarginate, the base broadly cuneate, at very base with a nectariferous "pouch" and there also pilosulous; stamens 5, hypogynous, ascending, the slender white filaments ca.8-10 mm long, the basifixed, oblong, yellow anthers ca. $1.5 \mathrm{~mm}$ long; ovary superior, ovoid, pale green, ca. 3.0-3.5 mm long; style 5-8 mm long, erect. branching just below the 5 yellowishpapil1ose stigmas.

Fruit.-- An ovoid, greenish-tan capsule ca. $5 \mathrm{~mm}$ high, the 5 carpels ultimately separating into 10 1-seeded segments.

Distribution and Flowering Season

Sandy peat over limestone baserock, moist clearings, cleared areas or pineland savanna, southern peninsular Florida; flowering Feb.-Apr.

\section{Special Identifying Features}

This and the var. carteri were at first treated by Dr. Rogers (1963), monographer of the genus, as a part of $L$. rigidum Pursh whose nearest populations are nearly 1000 miles distant in Texas. Later work (1968) involving cytology as well as morphology confirmed the distinctness of the Florida plants, these 
being tetraploid with different corolla pigmentation and different fruit character. There is no problem with identification of L. carteri smallii; it and var. carteri are the only southeastern Linum in which the styles are united to nearly the level of the stigma. L. sulcatum (which occurs no nearer than Georgia) has smaller flowers, styles joined only below the middle, and has persistent sepals. The var. smallii is disting ished from the var. carteri by its smooth stems, taller habit, overall larger flowers (var. carteri has puberulent or scabrid stem angles, shorter habit, smaller flowers). While var. smallit is in the southernmost counties it does extend northward as far as southern Charlotte County; on the other hand var. carteri is confined to the oolites of the Miami area of Dade County.

Habitat and Management Implications

L. carteri smallii grows on sands and sandy peats, usually moist, over a Timestone baserock. It is locally abundant on highway shoulders, disturbed areas in the slash pine-saw palmetto type, or where roads and clearings cross cypress. Thus it is on soils which, while moist, are usually not inundated and it would have a preference for disturbance. It is a plant of full sunlight, thus by inference it would increase in areas where trees and brush were removed, decrease where these form a canopy. The pine flatwoods of southern Florida have a history of the Linum. The greatest present threat to this plant is from overdevelopment of much of its former area for the purpose of housing and industrial development.

\section{References}

Rogers, C.M. 1963. Yellow-flowered species of Linum in eastern North America. Brittonia 15 (2): 97-122.

1968. A reassessment of Linum rigidum and $\underline{L}$. carteri (Linaceae) Floridá, Sida 3(4): 209-210.

Sma11, J.K. 1905. Additions to the flora of subtropical Florida. Bul1. N.Y. Bot. Gard. 3: 416-440.

Sma11, F.K. 1933. Manual of the southeastern flora, pp. 750-752. Chapel Hi1 , N.C. 
SPECIES Iinum carteri. SmaI rar. smalidi Rogers

Carter"s large-flowered flass

\begin{tabular}{|c|c|c|c|c|c|c|c|c|}
\hline \multirow[b]{2}{*}{$\begin{array}{l}\text { Expected* } \\
\text { Effect on } \\
\text { the Species }\end{array}$} & \multicolumn{8}{|c|}{ Management Practices } \\
\hline & $\begin{array}{c}\text { Prescribe } \\
\text { Burn }\end{array}$ & $\begin{array}{c}\text { Bulldoze } \\
\text { or } \\
\text { Root Rake }\end{array}$ & Bed & Chop & $\begin{array}{l}\text { Thin } \\
\text { over- } \\
\text { story }\end{array}$ & $\begin{array}{l}\text { Cut } \\
\text { over- } \\
\text { story }\end{array}$ & $\begin{array}{l}\text { Establish } \\
\text { Plantation }\end{array}$ & Graze \\
\hline Destroy & & & & & & & $\mathrm{X}$ & \\
\hline Damage & & $?$ & ? & $?$ & & & & $\mathrm{X}$ \\
\hline $\begin{array}{l}\text { No Lasting } \\
\text { Effect }\end{array}$ & & & & & & & & \\
\hline $\begin{array}{l}\text { Beneficial } \\
\text { if Done } \\
\text { Properly }\end{array}$ & $\mathrm{X}$ & & & & $x$ & $x$ & & \\
\hline
\end{tabular}

Other Comments: Site drainage is detrimental!

*Expected effect on the species is an estimate made by Dr. Robert Kral based on his knowledge of the habitat and on knowledge gained from personal field observations. Estimates are "rough" in many instances. Results of practices may be modified depending upon the degree of application, intensity of treatment, nearness to plant commuities, etc. A management practice for which no entry is made indicates a lack of sufficient information from which to predict expected results. As observations are made in the field by users of the data, the expected effect will be refined. 
Linum carteri Small var. smallii Rogers

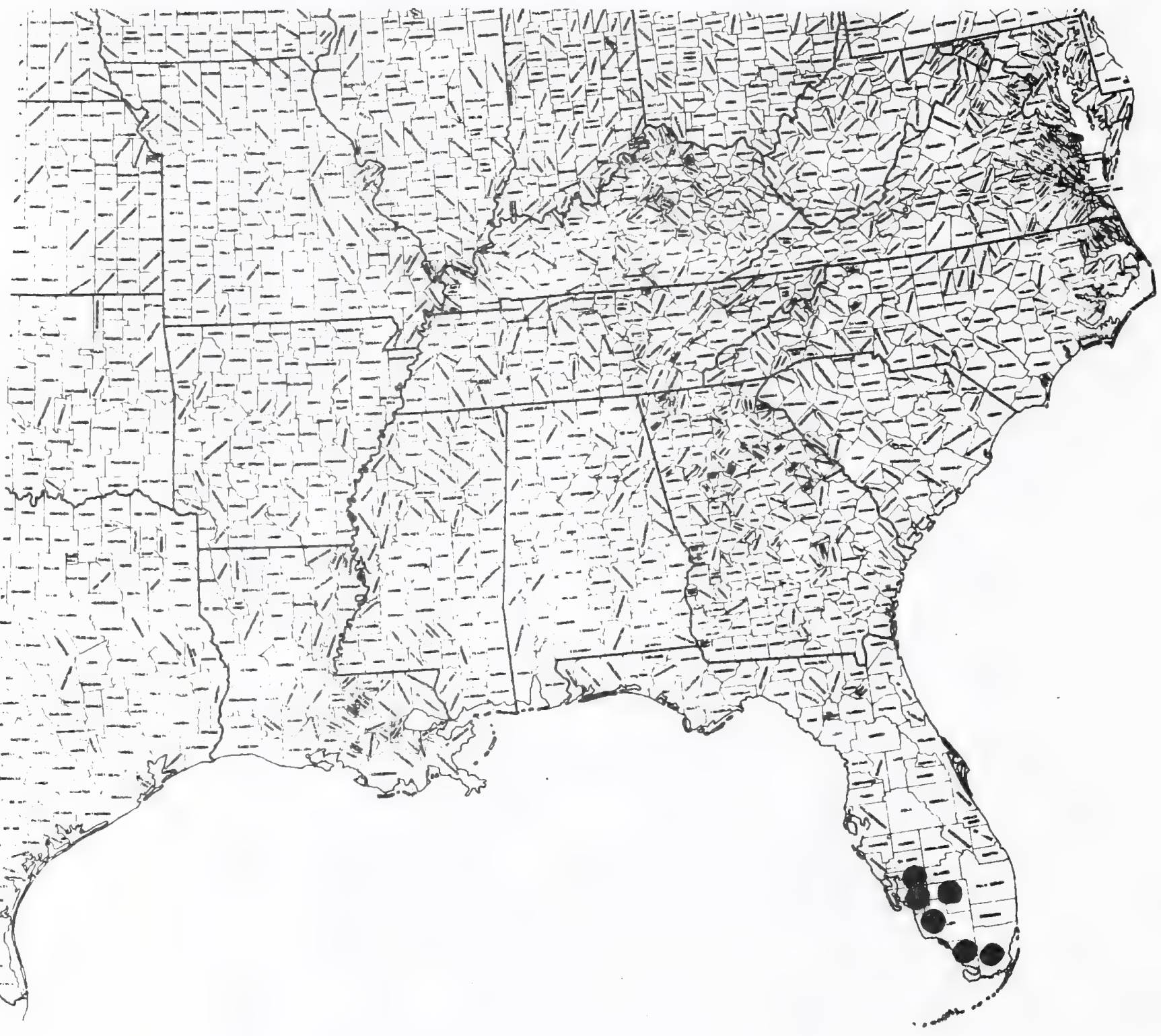




\section{LOGANIACEAE}

Spigeila gentianoides Chapm. gentian pinkroot

Technical Description

Smoothish, delicate perennial from a shallow, jointed, ascending rhizome.

Stems.-- Usualiy single, erect, slender but stiff, mostly 1-3 dm tall, toward base terete, maroon, ca. 1 mm thick, upwardly becoming green, the internodes sharply ridge below leaf margins, the ridges scabrid.

Leaves.-- Opposite, decussate, sessile-clasping, with minute, fimbriate stipules; lowermost pairs smallest, often scale-7ike, grading sharply to the largest which are from midstem to inflorescence spreading, the blades mostly el7ipicical, narrowly ovate or lanceolate, 3-5 cm long, 1-2 $\mathrm{cm}$ broad, acute, the margins scarbid, the base acute, the venation pinnatearcuate, the upper surface deep green, scaberulous, the lower surface paler, minutely scabrid only along the veins.

Inflorescence.-- A short, few-flowered, erect, terminal, spikelike raceme, the raceme axis angulate, the angles scabrid.

Flower.-- Regular, bisexual: pedicel stout, rarely longer than $1.5 \mathrm{~mm}$, a slight contraction of the calyx; calyx of 5 sepals, these fused only at base, Tinear-7anceolate, 4-6 mm long, erect, greenish, minutely scabrid, particularly along margins; corolla gamopetalous $2.5-3.0 \mathrm{~cm}$ 7ong, of 5 petals, the tube tubular-funnelform, ca. I cm long, broadening to a broadly cylindrical throat which narrows slightiy distally just below the base of 5, trianguTar, erect, acute, scabrous edged lobes 5-6 mm 7ong; corol1a surface pale pink, the tint somewhat deeper along edges of the lobes; stamens 5, epipetalous, the filaments projecting inward at a level ca. 1 $\mathrm{cm}$ above corolla base, fleshy, ca. $2 \mathrm{~mm}$ long, the anthers linear-oblong, ca. $3 \mathrm{~mm}$ long, yellow, basifixed, erect, connivent around the style apex; ovary superior, carpels 2, style 1, erect, terete, $1.4-1.5 \mathrm{~mm}$ long, minutely pilose, the stigmatic tip truncate, Fruit.-- A strongly bilobed capsule, this exceeded by the erect, persistent separs; seed not seen.

Distribution and Flowering Time

Sandy loam of upland woods, northwestern Florida: flowering in May and June.

Special Identifying Features

S. gentianoides overlaps the range of but one other species of Spigelia, namely the wide-ranging and commoner S. marilandica, a taller, larger-leaved, lump former with corollas crimson outside, yellow within, and with stamen tips protruding from the corolla throat rather than being included.

Habitat and Management Implications

This species has been observed but twice since the time Chapman described it, and in both cases was found in oak-pine woods. The soil is a moist or 
seasonally dry sandy loam, topped by a thin layer of dark, unincorporated humus. The plants are in light to heavy shade of an overstory of pine (usually a mixture of $\underline{P}$. taeda, $\underline{P}$. palustris) and hardwoods consisting mainly of Quercus nigrā, Q. hemisphaerica, Q. falcata, Nvssa sylvatica, with the understory layer and shrub layer comprised mainiy of Cornus florida, Vaccinium arboreum, Rhododendron canescens, Gaylussacia frondosa, G. dumosa, Rubus spp., SmiTax spp., Rhus toxicodendron, both high and lowbush Vaccinium. Among herbaceous associates are Mitchella repens, Gentiana villosa, Scutellaria elliptica, Polygala polygama, Pedicularis canadensis, Agrimonia, Chasmanthium, Amianthium. However, none of the herbaceous associates are abundant, and the Spigelia plants are seldom around the bases of the shrubs. More often they appear singly or in small groups beneath the oaks and pines, usually with nothing around them but leaf litter in various stages of decay. Clearcut areas adjacent to the Spigelia show no plants. The area shows some history of fire, none of cultivation. It is doubtful that such a species as this would survive clear cutting which would admit too much light, the result being a drying out and reduction of the humus fraction of the soil. Certainly the Spigelia would not survive mechanical site preparation and the overstory species substitution involved with pine monoculture.

\section{References}

Chapman, A.W. 1860. Flora of the Southern United States, pp. 200-201. Cambridge, MASS.

Sma11, J.K. 1933. Manual of the southeastern flora, pp. 1045-1046. Chapel Hill, N.C. 
SPECIES Spigelia gentianoides Chapmo gentian pirkroot

\begin{tabular}{|c|c|c|c|c|c|c|c|c|}
\hline \multirow[b]{2}{*}{$\begin{array}{l}\text { Expected* } \\
\text { Effect on } \\
\text { the Species }\end{array}$} & \multicolumn{8}{|c|}{ Management Practices } \\
\hline & $\begin{array}{c}\text { Prescribe } \\
\text { Bum }\end{array}$ & $\begin{array}{l}\text { Bulldoze } \\
\text { or } \\
\text { Root Rake }\end{array}$ & Bed & Chop & $\begin{array}{l}\text { Thin } \\
\text { over- } \\
\text { story }\end{array}$ & $\begin{array}{l}\text { lut } \\
\text { over- } \\
\text { story }\end{array}$ & $\begin{array}{l}\text { Establish } \\
\text { Plantation }\end{array}$ & Graze \\
\hline Destroy & & $\mathrm{x}$ & $\mathrm{x}$ & $\mathrm{X}$ & & $x$ & $x$ & \\
\hline Damage & & & & & & & & $\mathrm{X}^{*}$ \\
\hline $\begin{array}{l}\text { No lasting } \\
\text { Effect }\end{array}$ & & & & & & & & \\
\hline $\begin{array}{l}\text { Beneficial } \\
\text { if Done } \\
\text { Properly }\end{array}$ & & & & & $x$ & & & \\
\hline
\end{tabular}

Other Comments: plants are poisonous to stock, may not be taken, but tramiling of habitat would likely be injurious.

*Expected effect on the species is an estimate made by Dr. Robert Kral based on his knowledge of the habitat and on knowledge gained from personal field observations. Estimates are "rough" in many instances. Results of practices may be modified depending upon the degree of application, intensity of treatment, nearness to plant comminities, etc. A management practice for which no entry is made indicates a lack of sufficient information from which to predict expected results. As observations are made in the field by users of the data, the expected effect will be refined. 
Spigelia gentianoides Chapm.

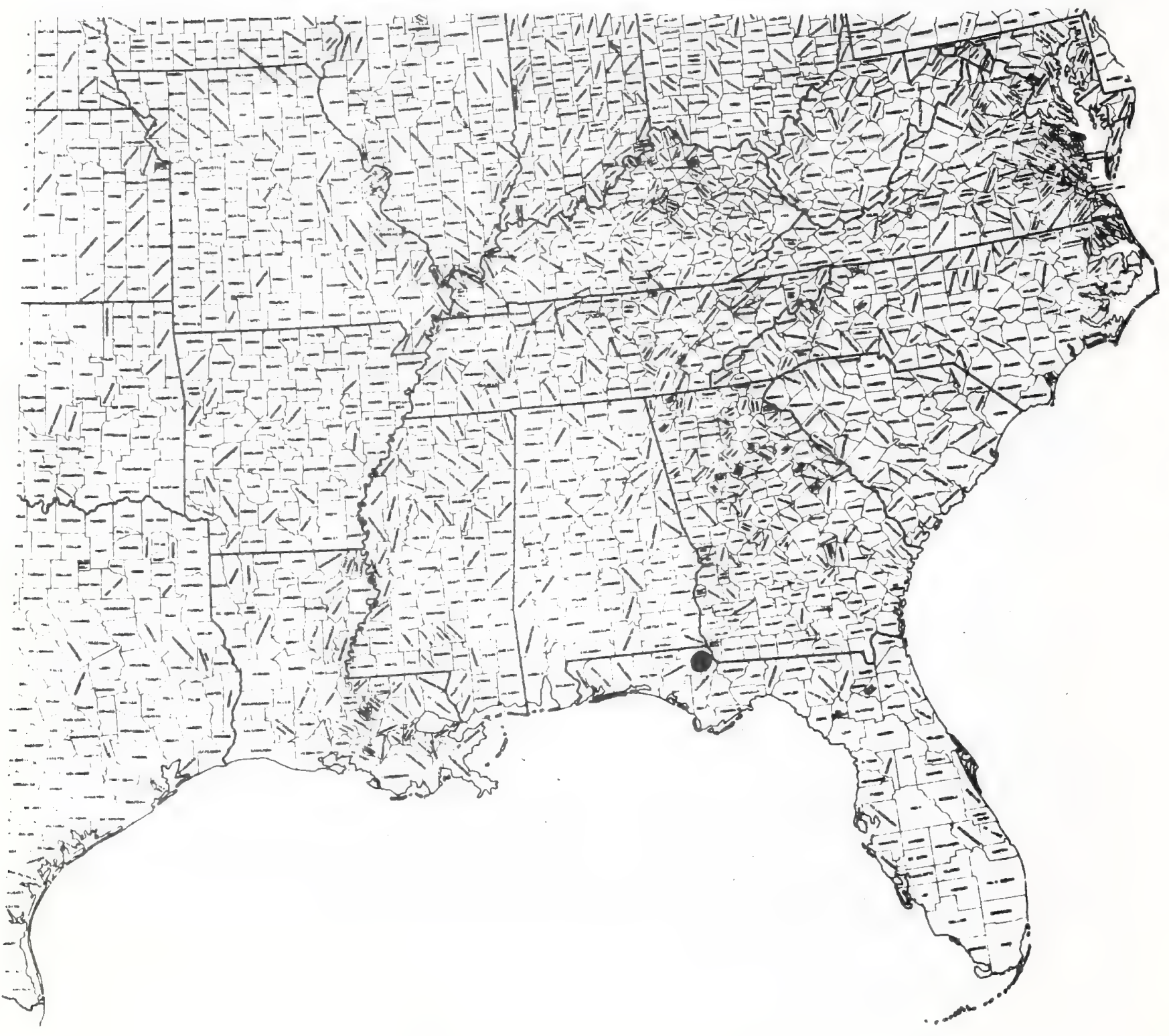


Spigelia loganioides (T.\& G. ex Engl.) A.DC. Florida pinkroot Coelosiylis Toganioides T.\& G. ex Engl.

Technical Description

Smooth perennial herb from a slender, short-stoloniferous rhizome.

Stems.-- Erect or decumbent, simple or sparingly branched from near base, 1-4 dm tal1, frequently rooting from nodes of decumbent base, slender, ca. $1 \mathrm{~mm}$ thick, proximally subterete, purplish, upwardly becoming greenish, somewhat quadrangular or ridged between nodes below bases of leaf margins, these ridges sparsely scabrid just below nodes.

Leaves.-- Opposite, spreading or ascending, producing erect, iriangular, scale-like stipules, sessile, the outermost pairs short, scale-like, mostly distant, grading to largest at midstem or above, these narrowly ovate to elliptic or oblanceolate, $2-4 \mathrm{~cm}$ long, mostly bluntly acute or shortacuminate, marginally entire and minutely scabrid, the base cuneate or shortattenuate, pinnately veined with few pairs of laterals, these arcuate, the upper surface deep green, smooth or nearly so, the lower surface paler, minutely papillate along the raised veins: blades gradually or not at all reduced in the inflorescence.

Inflorescence. - Flowers solitary or few (2-3) in erect, nearly sessile spikelike racemes, these alternate from each pair of upper leaves (bracts). Flowers.-- Regular, bisexual, erect on short, green scabrous pedicels or nearly sessile, the pedicels often with $1-3$ lance-linear bracteoles no longer than $1 \mathrm{~mm}$, the uppermost directly under the calyx; sepals 5, fused at very base, erect, narrowly triangular, greenish, $3.0-3.5 \mathrm{~mm}$ long, narrowly acute, the margins minutely scabrid; corolla of 5 strongly fused petals, 1.2-1.5 $\mathrm{cm}$ long, white, the narrowly funnelform throat ca. $5 \mathrm{~mm}$ long, the throat broadly cylindrical, ca. $4-5 \mathrm{~mm}$ long, the lobes spreading in late morning, triangular, 3-4 mm long, bluntly acute, slightly involuted; stamens 5, a 7 ternating with petals, epipetalous, the Iinear, terete, white filaments ca. $1 \mathrm{~mm}$ long, directed inward from base of corolla throat the erect, basifixed, yellow anthers linear-oblong, ca.1.0-1.3 mm long; ovary superior, subtended by a prominent disc, ovoid, 2-carpellate, the style greenish, erect, stoutly Tinear, ca. $2.5 \mathrm{~mm}$ long, continuous with a Tinear, hispidulous, acute stigma $4.0-4.5 \mathrm{~mm}$ long.

Fruit. - A strongly bilobed capsule, the lobes (locules) nearly round, 3.0$\overline{3.5 \mathrm{~mm}}$ high, few-seeded.

Distribution and Flowering Season

Very local in calcareous hammocks and rises in river bottoms, northern peninsular Florida: flowering from May into July.

Special Identifying Features

This species is distinguished from the other 3 southeastern spigelia as follows:

1. When stems branch, the branches are produced from the plant base.

2. Flowers are produced from axillary racemes. 
3. The corolla is white, smaller than either $\mathbf{S}$. marilandica or $\mathbf{S}$. gentianoides; the style is about as long as the linear hispidulous stigma.

Habitat and Management Implications

S. loganioides is on moist, well-drained, sandy silt-loa:.:j of calcareous woodlands, usually in deep shade of Cabbage palm, Live oak, Willow oak, Sweet gum, Loblolly pine hammock, or in river bottom forest of the same type where it appears on high water banks or low natural levees, areas that would be inundated rarely, even though contiguous to real swamp forest. Frequent herbaceous associates are Dyschoriste humistrata, Ruellia, Elytraria, Arisaema, Mitche11a, Carex, Chasmanthium, Panicum (Dichantheliums such as D. commutatum), etc. The habitat is sensitive, ecotonal; the plants appear not to react well to logging or pasturing disturbance. Several localities where it was once observed have now been destroyed by either clear-cutting for agriculture and forestry, or by conversion to pasture. The genus is known to be poisonous to livestock, but trampling by livestock surely eliminates this species.

\section{References}

Chapman, A.W. 1897. Flora of the southern United States, pp. 200-201. Cambridge, MASS.

Sma11, J.K. 1933. Manual of the southeastern flora, 1044-1045. Chapel Hill, N.C. 
SPECTES Spigelia loganioides (T. \& Gö ex Engï) A.DC:

Florida pirakroot

\begin{tabular}{|c|c|c|c|c|c|c|c|c|}
\hline \multirow[b]{2}{*}{$\begin{array}{l}\text { Expected* } \\
\text { Effect on } \\
\text { the Species }\end{array}$} & \multicolumn{8}{|c|}{ Management Practices } \\
\hline & $\begin{array}{c}\text { Prescribe } \\
\text { Burn }\end{array}$ & $\begin{array}{l}\text { Bulldoze } \\
\text { or } \\
\text { Root Rake }\end{array}$ & Bed & Chop & $\begin{array}{l}\text { Thin } \\
\text { over- } \\
\text { story }\end{array}$ & $\begin{array}{l}\text { Cut } \\
\text { over- } \\
\text { story }\end{array}$ & $\begin{array}{l}\text { Establish } \\
\text { Plantation }\end{array}$ & Graze \\
\hline Destroy & $\mathrm{X}$ & $\mathrm{x}$ & $x$ & $x$ & & $x$ & $x$ (if pine & $\mathrm{X}$ \\
\hline \multicolumn{9}{|l|}{ Damage } \\
\hline $\begin{array}{l}\text { No lasting } \\
\text { Effect }\end{array}$ & & & & & $x$ & & & \\
\hline $\begin{array}{l}\text { Beneficial } \\
\text { if Done } \\
\text { Properly }\end{array}$ & & & & & & & & \\
\hline
\end{tabular}

Other Conments: Site drainage is detrimental Grazing detrimental in that stock trample plants (which are suspected of being poisonous)'

* Expected effect on the species is an estimate made by Dr. Robert Kral based on his knowledge of the habitat and on knowledge gained from personal field observations. Estimates are "rough" in many instances. Results of practices may be modified depending upon the degree of application, intensity of treatment, nearness to plant comminities, etc. A management practice for which no entry is made indicates a lack of sufficient information from which to predict expected results. As observations are made in the field by users of the data, the expected effect will be refined. 
Spigelia loganioides (T.\& G.) A.DC.

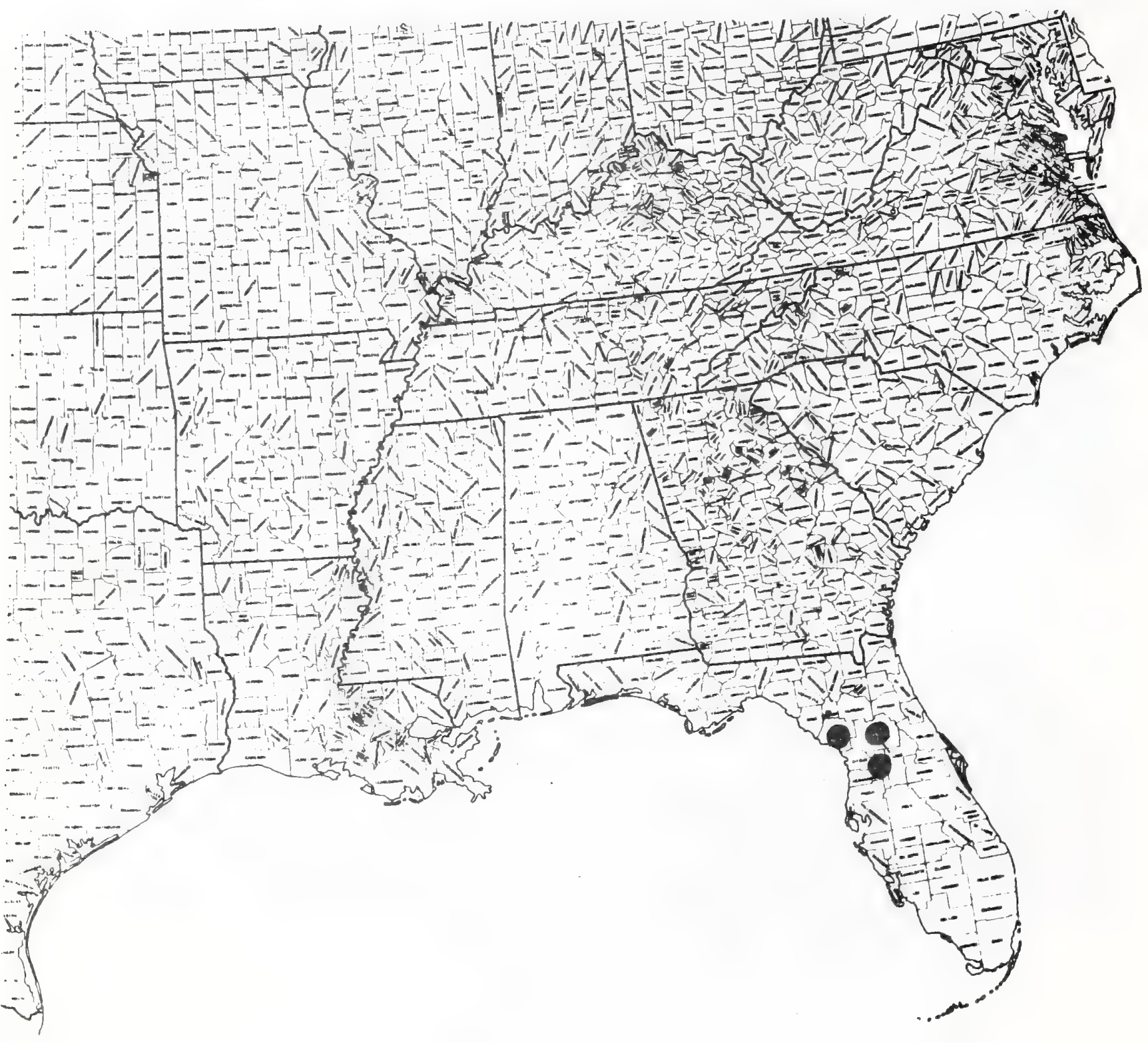




\section{PLANTAGINACEAE}

Plantago cordata Lam. heart-leaved plantain

Technical Description

Rosulate, glabrous perennial from a thick $(2-3 \mathrm{~cm})$ caudex with spongy, thick, shallow, simple or branched roots, these up to $1 \mathrm{dm}$ or more long.

Leaves.-- Numerous at plant base, erect or spreading, (1-) 2-6 dm long, $1 / 5-1 / 3$ petiole, the blades, elliptic to (mostly) ovate, the larger ones mostly 1-2 dm long, to $1.5 \mathrm{dm}$ wide, the tips acute to obtuseangled, the margins entire to undulate, sinuate, or coarsely and irregularly saliently dentate, the base cordate to truncate, then attenuated on the upper petiole; petioles strongly ribbed, though spongy, pale green or tinged with maroon, toward base somewhat equitant, the margins thin, broadening to a broadly clasping base; leaf surfaces a dullish green, the prominent nerves mostly 5-7, parallel on the petiole, the laterals spreading arcuately in the blade. Scapes.-- Erect, or ascending, 1-4 per plant, mostly 2-6 dm long, stiff but spongy, terete, fistulose (hollow), pale green often with tinges or purple toward base, the flowers borne in the upper 1/2-1/3.

Inflorescence.- Spikes narrowly linear, erect, many-flowered, the flowers irregularly, somewhat looselys arranged (interrupted) along the fleshy axis, each clasped by a broadly ovate, green, scarious-margined, rounded bract about as long as the calyx (ca. 3 mm long).

Flowers.- Sepals 4, distinct, erect, scale-like, oblong or ovate, $2-3$ $\overline{\mathrm{mm}}$ long, rounded-tipped, medialiy green with broad, pale, scarious margins; petals 4, fused, papery, the corolla salverform, the tube ca. $3 \mathrm{~mm}$ long, the spreading, broadly ovate-triangular lobes ca. 1 mm long; stamens usually 4, epipetalous, alternating with petals, the slender filaments exserted, the reddish-brown, short-oblong, apjculate, short-spurred anthers basifjxed, ca. $1.5 \mathrm{~mm}$ long; ovary superior, carpels 2, style simple, linear, exserted. Fruit.-- Capsule ovoid, smooth, thin-walled, ca. $4 \mathrm{~mm}$ long, 2-chambered circumsessile; seeds 2-4/capsule, ellipsoidal, 3.0-3.5 mm long, dark brown.

Distribution and Flowering Time

Swamps, shallows and banks of creeks, various provinces in eastern North America from southern Ontario, Michigan and wisconsin southward, extremely rare in the southeastern area, being scattered in western and Piedmont Virginia, Kentucky, North Carolina (Piedmont), northwestern Georgia, norhtern Alabama, southwestwardiy to Louisiana; in southeastern area flowering mostly in April.

\section{Special Identifying Features}

In the southeastern area, $\underline{P}$. cordata is most similar to $\underline{P}$. major, $\underline{P}$. rugellij, differing from both in its much greater size, stoutness of caudex, fistulose scapes, more scattered-flowered spike. Seeds are shed and spikes dying back by the time the other two species are producing their long-persistent spikes. 
P. cordata is a species of very wet, usually shaded sites, generally being found in and along shallow streams of ravines or swamp woodlands. It is normally rooted in muck or wet, silty-sandy or gravelly substrates, these often accumulated over slates, shales, sandstones or limestones. The streams in or along which it grows are clean and healtny, the plants appearing not to persist in polluted situations. Steyermark (1963) notes that the foliage is edible, thus pasturing of the wooded banks it frequents must have a negative effect. Clearcutting of the hardwood overstory would likely produce an adverse effect through altering runoff patterns, aggravating flooding and siltation, and otherwise distrubing the substrate.

\section{References}

Godfrey, R.K, 1961. Plantago cordata still grows in Georgia. Castanea 26: 119-120.

Harper, R.F. 1944. Notes on Plantago with special reference to $\underline{P}$. cordata. Castanea 9: 121-130.

Lamarck, J and J. Poiret. 1791. Tableau encycolpedique et methodique des trois regnes de la nature. Botanique. I: 338. Paris.

Sma11, J.K. 1933. Manual of the southeastern flora, pp. 1244-1247. Chapel Hill, N.C.

Steyermark, J.A. 1963. Flora of Missouri, pp. 1380-1386. Ames. 
SPECIES Plantago cordata wam. heartm leaved plantain

\begin{tabular}{|c|c|c|c|c|c|c|c|c|}
\hline \multirow[b]{2}{*}{$\begin{array}{l}\text { Expected* } \\
\text { Effect on } \\
\text { the Species }\end{array}$} & \multicolumn{8}{|c|}{ Management Practices } \\
\hline & $\begin{array}{c}\text { Prescribe } \\
\text { Burn }\end{array}$ & $\begin{array}{c}\text { Bulldoze } \\
\text { or } \\
\text { Root Rake }\end{array}$ & Bed & Chop & $\begin{array}{l}\text { Thin } \\
\text { over- } \\
\text { story }\end{array}$ & $\begin{array}{l}\text { Cut } \\
\text { over- } \\
\text { story }\end{array}$ & $\begin{array}{l}\text { Establish } \\
\text { Plantation }\end{array}$ & Graze \\
\hline Destroy & NA & NA & NA & NA & & $x$ & $\mathrm{NA}$ & $x$ \\
\hline \multicolumn{9}{|l|}{ Damage } \\
\hline $\begin{array}{l}\text { No Lasting } \\
\text { Effect }\end{array}$ & & & & & $x$ & & & \\
\hline $\begin{array}{l}\text { Beneficial } \\
\text { if Done } \\
\text { Properly }\end{array}$ & & & & & & & & \\
\hline
\end{tabular}

mechanical site preparation may effect indirectly Other Comments: if raw substrate exposed by such methods washes down into the small streams, unless a "Jouffer"

*Expected effect on zhe spectes is alo estimatemade by Dr. Robert Kral based on his knowledge of the habitat and on knowledge gained from personal field observations. Estimates are "rough" in many instances. Results of practices may be modified depending upon the degree of application, intensity of treatment, nearness to plant communities, etc. A management practice for which no entry is made indicates a lack of sufficient information from which to predict expected results. As observations are made in the field by users of the data, the expected effect will be refined. 
P lantago cordata Lam.

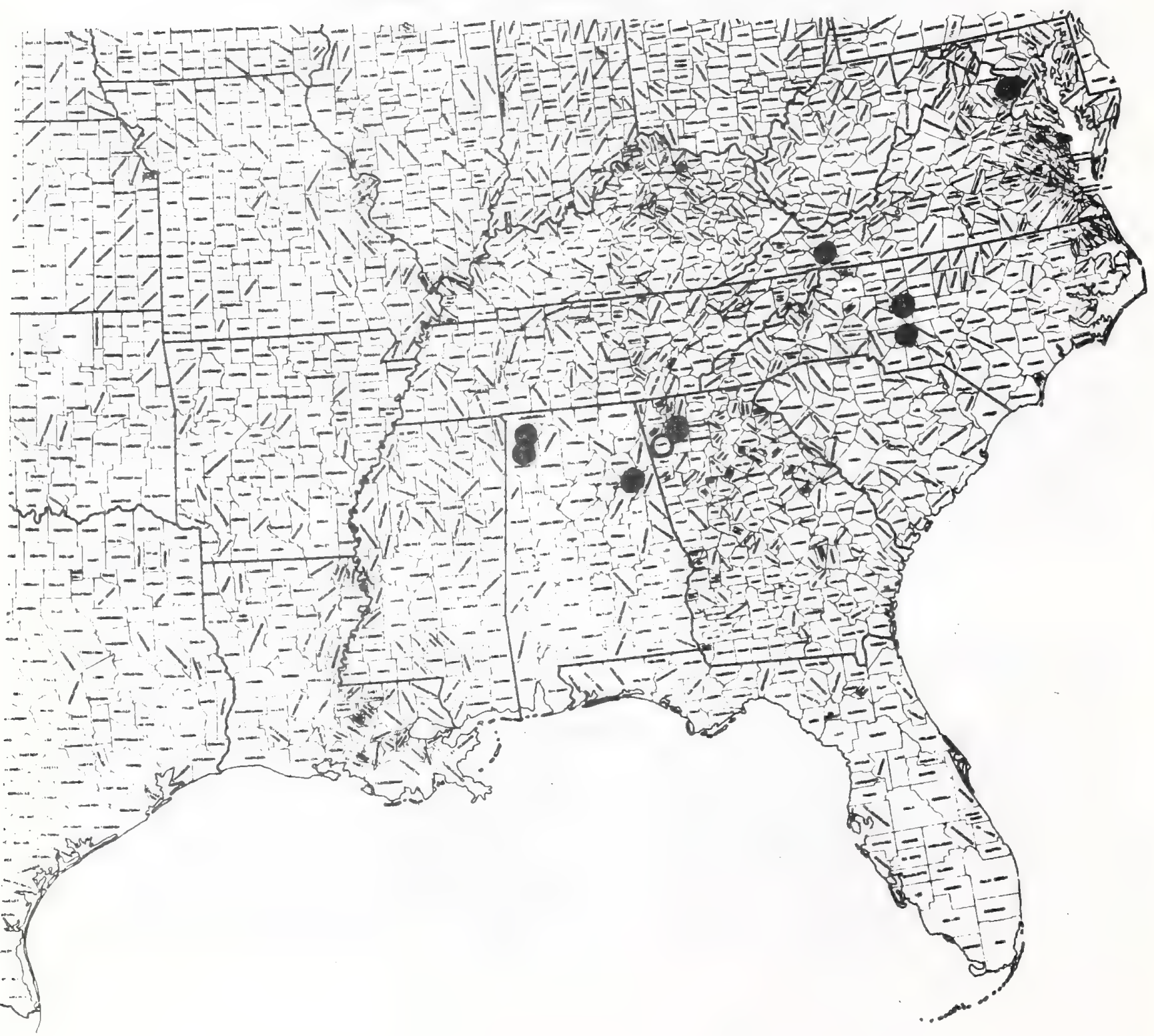


Paper 183

Text \& Map by:

Robert Kral

\section{POACEAE}

Andropogon arctatus Chapm. pinewwoods bluestem

Sorghum arcitatum Kuntze

\section{Technical Description}

Diffuse-rooted, tufted perennial.

Culms.-- Few to several in a tuft, to 1.5 meters tall (mostly lower), slender, wand-Tike, smooth, brancting in the upper half, the branches ascending. Leaves. The longest basal, up to $1 / 3$ the culm length, the sheathes strongly overlapping, sharply folded, pale green or pale purplish, with scattered long pale hairs or strongly pale pilose along the margins and shaggy pilose toward the open apex, strongly multinerved; ligule a low glabrous scale; collar long-pale-hairy; blade flattened, to $4 \mathrm{~mm}$ wide, narrowly and rigidly acute or acuminate, the margin scabrid, the midnerve strongly raised beneath, the surface mostly smooth, in length progressively reduced upward, grading into spathes.

Inflorescence.- - Spikelets in racemes, these usually paired, straight, linear when expanded, about $4-5 \mathrm{~mm}$ wide (exclusive of spreading awns), $3-5 \mathrm{~cm}$ long, and on a common, slender peduncle $5-12 \mathrm{~cm}$ long, its villous apex projecting well beyond the narrow, inrolled subtending spathe, the tip of which is attenuate, the margins and apex inside long-white ascending-hairy.

spikelets.-- Sessile (fertile) spikelet ca. $4.5 \mathrm{~mm}$ long (exclusive of awn), on a rachis joint that is flattened, ca. $2 \mathrm{~mm}$ long, copiously pilose-ciliate from near base to apex; glumes 2, longer than the fertile and sterile floret, lanceolate, firm, the first glume with a strong median groove, thus concave, there smooth, the base pilose, the cartilaginous edges scabrid, the apex bifid, the second glume sharply keeled, the keel scabrid, the surfaces otherwise smooth, the apex acuminate and purplish. Sterile and fertile lemma thin, transluscent, shorter than glumes, the narrow apex of the fertile lemma terminating in a yellowish, twisted, hispidulous awn 8-10 mm long. Stalked spikelet vestigial or absent, on an outward-bending, flattened, pilose pedicel 2-3 $\mathrm{mm}$ long. Frujt not observed.

Distribution and Flowering Time

Moist, low, grass-sedge clearings in pine flatwoods and savanna, northwest Florida and southeastern Alabama; flowering from late September to frost.

Speical Identifying Features

This species most resembles A. ternarius, a common species throughout the south usually of drier sites, but differs from it in its shorter spikelets, narrower and tawnier racemes (hairs on A. ternarius racemes make these silverywhite by contrast). The first glume of $\bar{A}$. arctatus is much more deeply longitudinally grooved.

Habitat and Management Implications

This rare species roots in moist sandy peat of open pine flatwoods and savannas, 
there being found in sunny, grass-sedge communities bordering titi, shrub bog, or pitcher plant bog. The dominant trees of the area are Longleaf pine and Pond pine, with other species often being Nyssa biflora, Taxodium ascendens. As is true of other moist pineland savanna species, this one is maintained by fire, lost through drainage. It has not been observed under closed canopies of pines either in natural regenerated stands or plantations. Its reaction to soil distrubance has not $b$ - an observed, but it doubtlessly invades clearings if ground is not drained.

\section{References}

Chapman, A.W. 1878. An enumeration of some plants chiefly from the semitropical regions of Florida. Bot. Gaz. 3: 2-6, 9-13, 17-21.

Hitchcock, A.S. and A. Chase. 1950. Manual of the grasses of the United States, ed. 2 (revised by A. Chase). U.S.D.A. Misc. Publ. 200. 
SPECIES Andropogon arctarus Chapm. pinewoods bluestem

\begin{tabular}{|c|c|c|c|c|c|c|c|c|}
\hline \multirow[b]{2}{*}{$\begin{array}{l}\text { Expected* } \\
\text { Effect on } \\
\text { the Species }\end{array}$} & \multicolumn{8}{|c|}{ Management Practices } \\
\hline & $\begin{array}{c}\text { Prescribe } \\
\text { Burn }\end{array}$ & $\begin{array}{l}\text { Bulldoze } \\
\text { or } \\
\text { Root Rake }\end{array}$ & Bed & Chop & $\begin{array}{l}\text { Thin } \\
\text { over- } \\
\text { story }\end{array}$ & $\begin{array}{l}\text { Cut } \\
\text { over- } \\
\text { story }\end{array}$ & $\begin{array}{l}\text { Establish } \\
\text { Plantation }\end{array}$ & Graze \\
\hline Destroy & & & & & & & $x$ & \\
\hline Damage & & & & & & & & $\mathrm{X}$ \\
\hline $\begin{array}{l}\text { No Lasting } \\
\text { Effect }\end{array}$ & & & & & & & & \\
\hline $\begin{array}{l}\text { Beneficial } \\
\text { if Done } \\
\text { Properly }\end{array}$ & $X$ & & & & $\mathrm{X}$ & $\mathrm{X}$ & & \\
\hline
\end{tabular}

Other Comments: drainage of site is detrimental: mechanical disturbance of sice may. if disturbed tracts are not arainea. be beneficial

* Expected effect on the species is an estimate made by Dr. Robert Kral based on his knowledge of the habitat and on knowledge gained from personal field observations. Estimates are "rough" in many instances. Results of practices may be modified depending upon the degree of application, intensity of treatment, nearness to plant communities, etc. A management practice for which no entry is made indicates a lack of sufficient information from which to predict expected results. As observations are made in the field by users of the data, the expected effect will be refined. 
Andropogon arctatus Chapm.

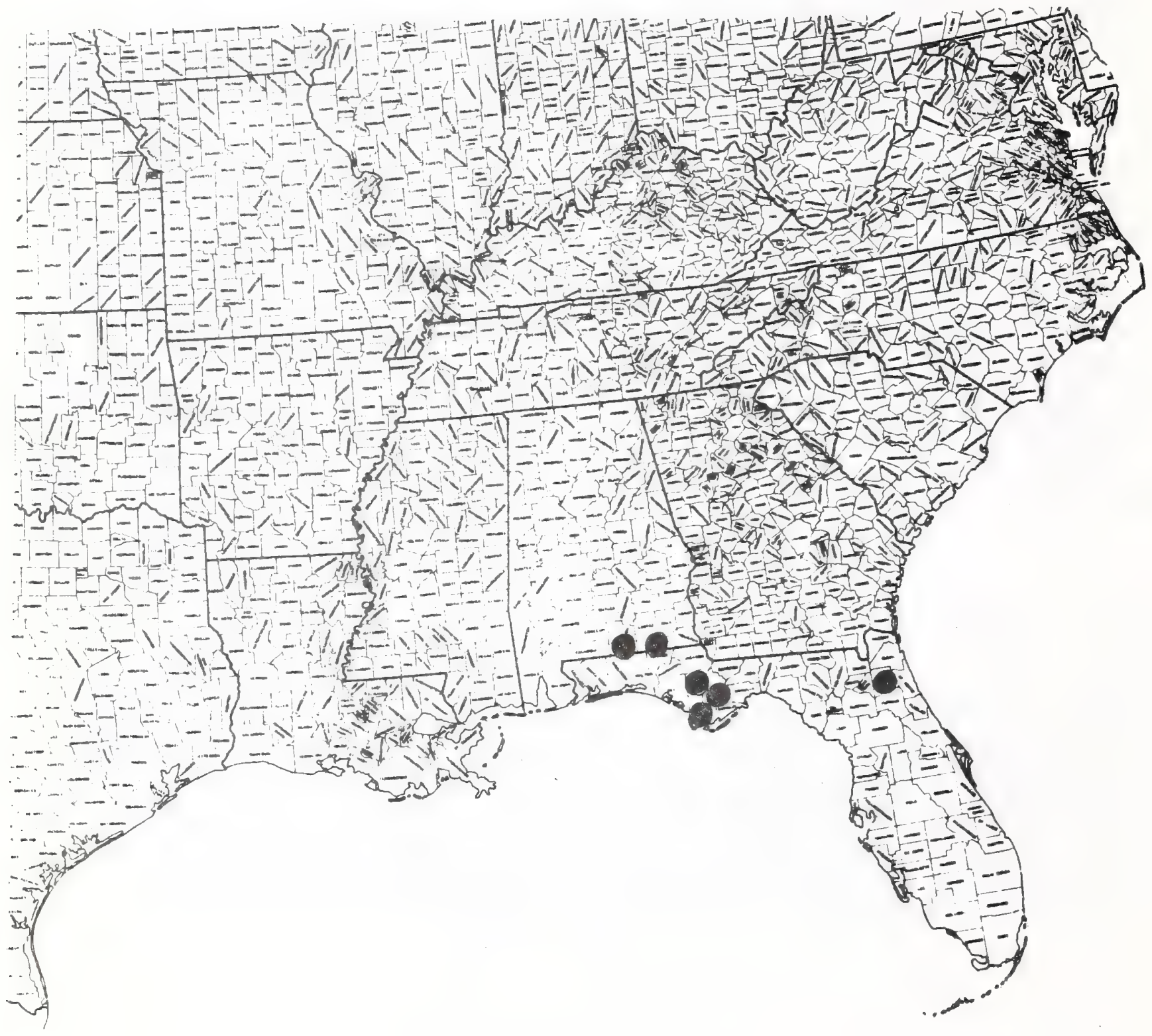




\section{POACEAE}

Calamovilfa curtissii (Vasey) Vasey. Curtis' reed-grass. Ammophita curtissii vasey

Technical Description

Perennial, tufted, slender but rather coarse grass, mostiy 1.0-1.5 (-1.8) meters ta17, with culms arising termina $71 y$ from spreading or ascending, thick and thick-rooted, knotty rhizomes, these covered by imbricated chaff of old sheath bases.

Culms.-- Erect or ascending, 1-few from a rhizome, stiffish, toward base ca. $5 \mathrm{~mm}$ thick, a lustrous yellow-green, brownish in the region of the swollen nodes, the lowermost internodes sometimes excurved.

Leaves.-- Up to $9 \mathrm{dm}$ long: lowermost sheathes strongly overlapping, fully 1 cm broad at the gray-brown base, backs rounded, upwardiy becoming stramineous and lustrous; median and upper sheathes more cylindrical, usual7y as long as or longer than the internodes, stramineous, lustrous; all sheathes apically rounded-auriculate, here entire or sparingly pilose; ligule a low, puberulent and ciliolate ridge; blades duil green to $5 \mathrm{~mm}$ wide, very firm, the lowermost sometimes flat, but most usually strongly involute even at base, tapering to very elongate, spreading-recurved, flexuous, filiform, scabrid tips, the margins scabrid.

Inflorescence.-- A narrow, rather dense panicle 3-5 dm long, at first concealed in the uppermost subtending leaf, later well exceeding it, the spikelets numerous on the overlapping, erect or ascending panicle branches on smooth erect peduncles mostly $3-10 \mathrm{~mm}$ long, the panicle branches terete, smooth. producing spikelets nearly their whole length or as much as the lower $1 / 2$ naked.

Spikelets.-- In outline lanceolate, pale green with maroon tints, 4-5 mm Tong; glumes 2, Tanceolate, keeled, smooth, acuminate to acute, the single scabrid nerve often excurrent as a short mucro, the first glume 3.0-4.0 mm long, the second ca. $4.0-5.0 \mathrm{~mm}$ long: floret solitary on a short rachilla joint, this at its apex pilose with silvery-silky erect hairs; lemma and palea thin, pale green lanceolate, narrowly acute or acuminate, sebequal, ca. $5 \mathrm{~mm}$ long, the lemma mostly crisped-white-pilose toward its base, the palea similarly pilose at least along the 2 keels. Stamens 3.

Distribution and Flowering Season

Moist sands or sandy peats of slash and Tongleaf pine-saw palmetto flatwoods and flatwoods savanna, northeastern and eastern peninsular Florida; flowering in summer.

\section{Special Identifying Features}

The genus Calamovilfa, and particularly this species, bears particular resemblance to some Calamogrostis and Ammophila. It differs from the former in its glumes not being longer than the Temma, from the latter in its shorter

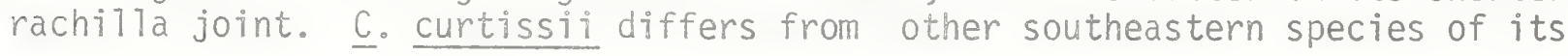


genus by its combination of very thick rhizome and very narrow panicle, togetiner with the pilosity of the lemma and palea backs.

Habitat and Management Implications

C. curtissii is an inhabitant of pine flatwoods, its thick rhizomes rooted in moist, usually organic sand, this usually with a high hydroperiod. The overstory is usually a scattering of both Slash and Longleaf pine, the understory predominantly Serenoa repens intermixed with ericads such as Lyonia, Befaria. It is a savanna plant, maintained by fire, and its herbaceous associates include several Andropogon. Panicum, Aristida, Polygala, Xyris, Rhexia cubensis, Eriocaulon, Lachnocaulon, Eryngium aromaticum, etc. Cutting of the trees opens up area for this type, as does burning. Drainage destroys it, as does fire on the drained land. Overplanting with pine has a negative effect, such grasses as $\underline{C}$. curtissij being shaded out as the crowns close.

\section{References}

Godfrey, R.K. and R. Kral. 1958. Observations on the Florida flora. Brittonia 10: 166-177.

Hitchcock, A.S. 1950. Manual of the grasses of the United States, ed. 2 (revised by A. Chase). U.S.D.A. Misc. Publ. 200 pp. 329-332. Washington.

Scribner, F.L. 1899. American grasses II. U.S.D.A. Div. Agrost. no 17: 7-349.

Vasey, G.V. 1884. A new grass. Bul1. Torr.Bot. Club 11:7.

1892. Monograph of the grasses of the U.S. and British America. Contrib. U.S. Nat. Herb: 1-89. 
SPECIES Calamovi Ifa curtissid (Vasey) Vaseÿ Curtiss ${ }^{\circledR}$ reedgrass

\begin{tabular}{|c|c|c|c|c|c|c|c|c|}
\hline \multirow[b]{2}{*}{$\begin{array}{l}\text { Expected* } \\
\text { Effect on } \\
\text { the Species }\end{array}$} & \multicolumn{8}{|c|}{ Management Practices } \\
\hline & $\begin{array}{c}\text { Prescribe } \\
\text { Bum }\end{array}$ & $\begin{array}{c}\text { Bulldoze } \\
\text { or } \\
\text { Root Rake }\end{array}$ & Bed & Chop & $\begin{array}{l}\text { Thin } \\
\text { over- } \\
\text { story }\end{array}$ & $\begin{array}{l}\text { Cut } \\
\text { over- } \\
\text { story }\end{array}$ & $\begin{array}{l}\text { Establish } \\
\text { Plantation }\end{array}$ & Graze \\
\hline Destroy & & $X$ & & $\mathrm{X}$ & & & $\mathrm{x}$ & $?$ \\
\hline Damage & & & $\mathrm{X}$ & & & & & \\
\hline $\begin{array}{l}\text { No Lasting } \\
\text { Effect }\end{array}$ & & & & & & & & \\
\hline $\begin{array}{l}\text { Beneficial } \\
\text { if Done } \\
\text { Properly }\end{array}$ & $X$ & & & & $X$ & $x$ & & \\
\hline
\end{tabular}

Other Comments: drainage of site is detrimental!

*Expected effect on the species is an estimate made by Dr. Robert Kral based on his knowledge of the habitat and on knowledge gained from personal field observations. Estimates are "rough" in many instances. Results of practices may be modified depending upon the degree of application, intensity of treatment, nearness to plant communities, etc. A management practice for which no entry is made indicates a lack of sufficient information from which to predict expected results. As observations are made in the field by users of the data, the expected effect will be refined. 
Calamovilfa curtissii (Vasey) Vasey

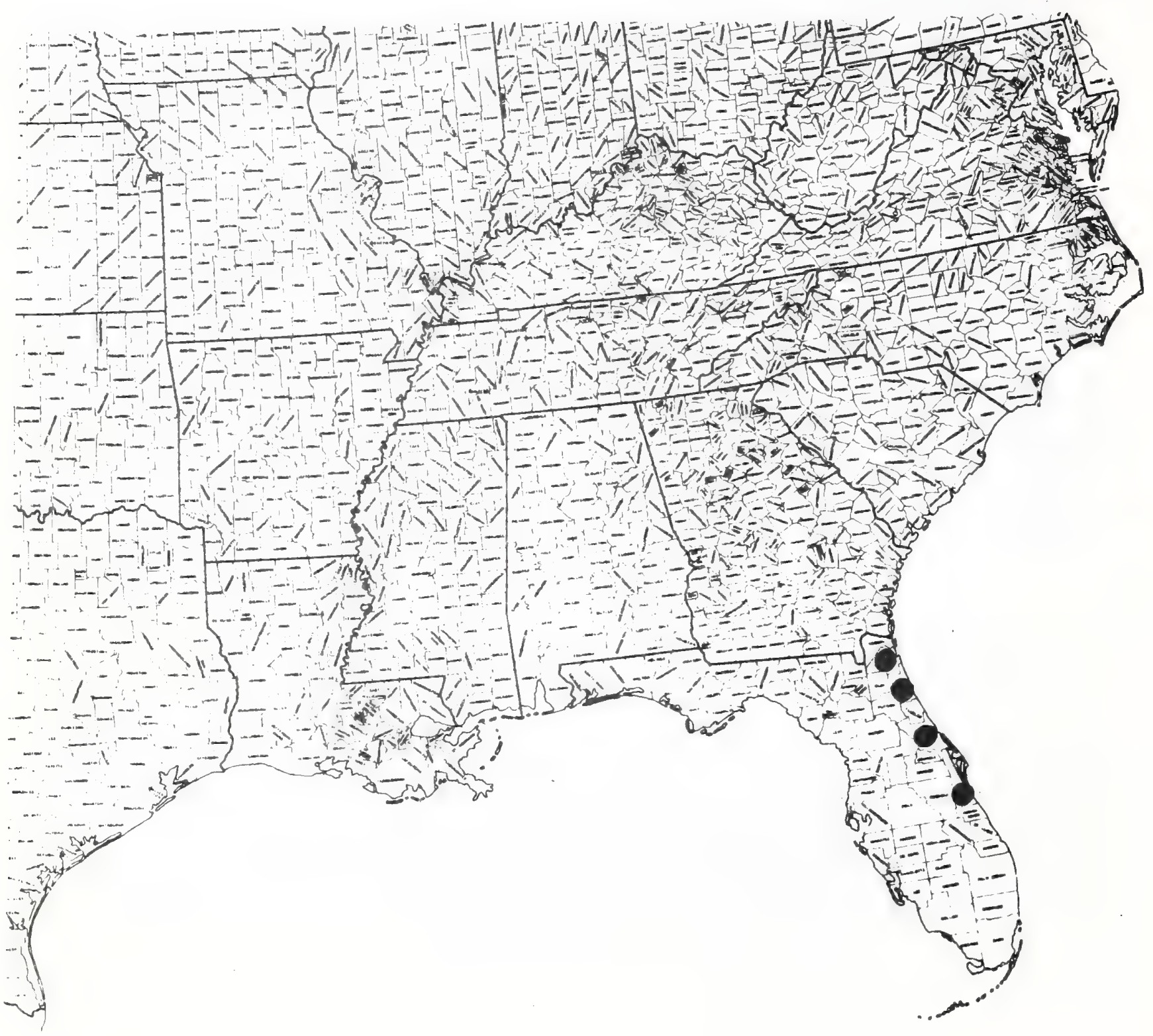


POACEAE

Glyceria nubigena Anders. Smoky Mountain manna-grass

Technical Description

Tufted, smooth, short-rhizomatous, perennial grass.

CuIms.-- Erect or ascending, decumbent-based, to 1.5 meters tal1, often rooting from the lower nodes, rather soft, toward base $2-4 \mathrm{~mm}$ thick, the nodes brown or reddish-brown, the internodes multiribbed, pale green. Leaves.-- Sheathes opening distally, multinerved, green-tinted often with red or purple, at mid-cuim much shorter than the subtended internode; ligule a thin erect scale to $4 \mathrm{~mm}$ long; blades rather soft, green, ascending, linear, 5-10 mm wide, tapering to a narrowly acute tip, the margins scabrid, the larger blades 2-3 dm long becoming shorter, usually less than $1 \mathrm{dm}$ toward the inflorescence, both surfaces scabrid along the many prominent veins.

Inflorescence.-- Spikelets numerous in an open, diffuse, lax panicle, the panicle branches spreading or drooping toward the tips, very slender, scabrid, naked toward base, rebranched at middle or above (very rarely floriferous to nearly base), the ultimate branches bearing scattered, rarely overlapping, stalked spikelets; spikelet stalks $3-10 \mathrm{~mm}$ long, capillary, scabrid. Spikelet.- At maturity elliptic or oblong, ca. $5 \mathrm{~mm}$ long; glumes 2, ovate or broadly lanceolate, acuite or narrowly rounded, the first (lowermost) ca. 1.0-1.5 mm long, shorter than the second which is ca. $1.5-2.0 \mathrm{~mm}$ long, the backs pale green, that of the second usually with 3 strongly raised nerves, the margins broad, pale scarious; florets mostly 4, the larger lemmas ca. $3 \mathrm{~mm}$ long. lance-elliptic, narrowed to white, scarious, somewhat erose tips, the backs with 7 strongly raised, parallel nerves, the nerves stopping short of the apex, the green surface bordered by a narrow purplish band, this internal to a broad, scarious margin; palea about equal in length to lemma, the 2 nerves sublateral, strongly scabrid; grain ellipsoidal, dark reddish-brown, ca. $2 \mathrm{~mm}$ long.

Distribution and Flowering Season

Seep swamps and bogs at higher elevations in the Blue Ridge, western North Carolina and eastern Tennessee; flowering in June and July.

Special Identifying Features

G. nubigena, within the complex of Glyceria that have 7-nerved 1emmas, and in general aspect, is closest to $G$. grandis but that more northern species has much more purplish florets and has subequal glumes.

Habitat and Management Implications

G. nubigena is in boggy places, either in full sun or shade, in the higher mountainous areas of the Blue Ridge, Surrounding forest is usually in the fir or spruce-fir type, or is Hemlock-hardwood. It may also be in seep 
areas in high elevation grass balds. In either event it is part of a wetland complex of grass-sedge. Draining the site would eliminate the species; logging in or around the seeps would not only alter the drainage but the substrate as well.

References

Anderson, W.A. 1933. A new species of Glyceria from the Great Smoky Mountains. Rhodora 35: 321.

Hitchcock, A.S. 1950. Manual of the grasses of the United States, 2nd ed. (revised by A. Chase). U.S.D.A. Misc. Publ. 200: 81-93.

Radford, A.E., H.E Ahles and C.R. Bell. 1968. Manual of the vascular flora of the Carolinas, pp. 80-82. Chapel Hill, N.C. 
SPECIES GIyceria nubigena Anders. Smoky Mountain manna-grass

\begin{tabular}{|c|c|c|c|c|c|c|c|c|}
\hline \multirow[b]{2}{*}{$\begin{array}{l}\text { Expected* } \\
\text { Effect on } \\
\text { the Species }\end{array}$} & \multicolumn{8}{|c|}{ Management Practices } \\
\hline & $\begin{array}{c}\text { Prescribe } \\
\text { Burn }\end{array}$ & $\begin{array}{l}\text { Bulldoze } \\
\text { or } \\
\text { Root Rake }\end{array}$ & Bed & Chop & $\begin{array}{l}\text { Thin } \\
\text { over- } \\
\text { story }\end{array}$ & \begin{tabular}{|l} 
Cut \\
over- \\
story
\end{tabular} & $\begin{array}{l}\text { Establish } \\
\text { Plantation }\end{array}$ & Graze \\
\hline Destroy & $\mathrm{NA}$ & NA & NA & $\mathrm{NA}$ & & $\mathrm{X}$ & NA & $\mathrm{x}$ \\
\hline Damage & & & & & $\mathrm{X}$ & & & \\
\hline $\begin{array}{l}\text { No Lasting } \\
\text { Effect }\end{array}$ & & & & & & & & \\
\hline $\begin{array}{l}\text { Beneficial } \\
\text { if Done } \\
\text { Properly }\end{array}$ & & & & & & & & \\
\hline
\end{tabular}

Other Comments: site drainage is detrimental!

*Expected effect on the species is an estimate made by Dr. Robert Kral based on his knowledge of the habitat and on knowledge gained from personal field observations. Estimates are "rough" in many instances. Results of practices may be modified depending upon the degree of application, intensity of treatment, nearness to plant communities, etc. A management practice for which no entry is made indicates a lack of sufficient information from which to predict expected results. As observations are made in the field by users of the data, the expected effect will be refined. 


\section{Glyceria nubigena Anders.}

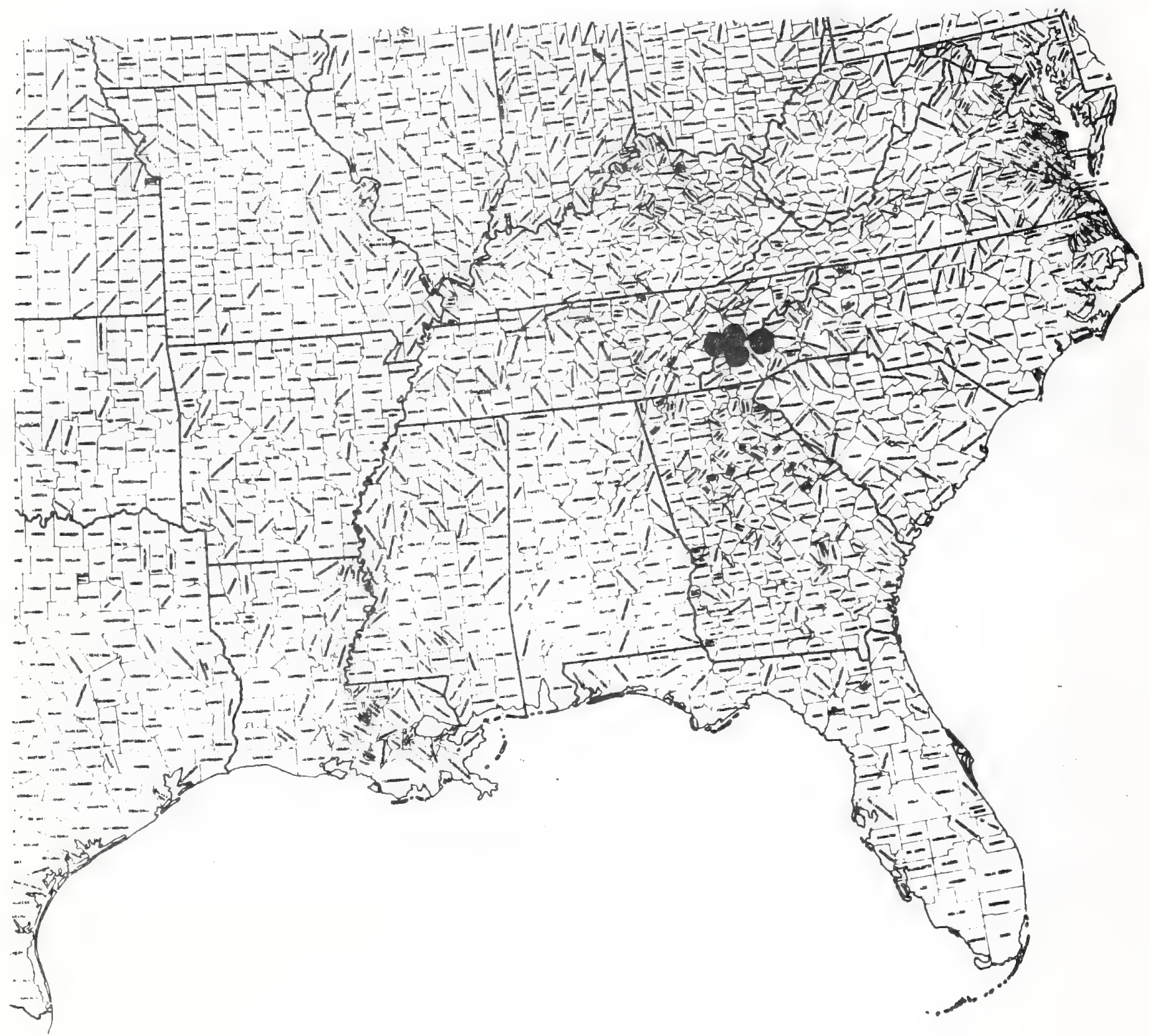


Paper 186

Text \& Map by:

Robert Kral

\section{POLYGALACEAE}

\section{Polygala lewtonii Sma71. Lewton's milkwort.}

\section{Technical Description}

Biennial (or short-1ived perennial?), smooth, the stems strongiy tufted around summit of a stout, deep taproot.

Stems.-- Both sterile and fertile shoots produced, these spreading, ascending or erect, slender but stiffish, usually decumbent-based, angulate, no longer than $2 \mathrm{dm}$, the primary shoots often rebranched with short, usually erect or ascending branches, the internodes decurrently ridged below the leaves or their scars, thus the internodes narrowly angled, new growth of ten glanddotted.

Leaves.-- Simple, usually erect and overlapping in spirals, sessile, yellowish or grayish-green or tinted with maroon, rather succulent, linear, spatulate or oblanceolate, the lowest smallest, those toward midstem largest, mostly 1.0-1.5 cm long, acute, sometimes apiculate, entire, the surface somewhat granular, the venation not evident.

Inflorescence.-- Racemes loosely flowered, oblong-cylindrical, 1-5 cm long, erect, the pedicels spreading or ascending, slender, angulate, gland-dotted, most7y 2.0-2.5 mm long, each subtended by a scarious, whitish, early-deciduous, narrowly triangular bract ca. $1 \mathrm{~mm}$ Tong, the fruit and pedicels dropping soon after maturity; cleistogamous flowers produced on separate shoots at plant base, more scattered in narrower, longer, usual7y leafless, racemes. Flowers.-- Two sorts produced, chasmogamous and cleistogamous, the former at tips of elongate, leafy shoots, ca. $5 \mathrm{~mm}$ long, irregular, bisexual, the calyx of 5 sepals projecting forward, distinct or nearly so, the 2 lowermost and the 1 uppermost smallest, greenish, scale-like, narrowly ovate, boatshaped, 2.0-2.5 mm long, the 2 laterals (wings) petaloid, ca. $5 \mathrm{~mm}$ long, short-clawed, the blades oblong or lanceolate, bright pink; petals 3, joined at base and also with the fused filaments of the stamens, projecting forward, pinkish, the lowest distally forming a cuplike, fimbriate-tipped keel (the whole structure ca. $3.5 \mathrm{~mm}$ long), the ascending stamens enfolded by the cupped sides of its auriculate-lobed base, at base joined to the 2 asymmetrically oblong lateral petal lobes; stamens 8, not evidently diadelphous, the filaments basally joined, the free whitish filament tips upwardly bent, terminating in short yellowish, cylindric-oblique, 2-locular, poricidal anthers; ovary superior, bilocular, with 1 ovule/locule, the style terminal, bent as in Viola, its truncate stigmatose tip forming a cup. Fruit.-- Capsule short-cylindrical, somewhat angulate, also bilobed, ca. $5 \mathrm{~mm}$ long, the seeds cylindric, ca. $3 \mathrm{~mm}$ long, strongly carunculate.

\section{Distribution and Flowering Season}

Deep sands of clearings in sandscrub and sandy high savanna, lakes region of peninsular Florida; flowering from February and March intermittently through summer. 


\section{Special Identifying Features}

This species is closest to $P$. polygama, which is widespread on a variety of soils through the eastern̄ U.S. However, it has a much larger root, tends to form larger clumps, the leaves tend to be narrower, the wing sepals more rhombic (inequilateral rather than obovate, and are shortor than the capsule (rather than equal to it or longer) which is of a narrower outline.

Habitat and Management Implications

P. lewtonii is extremely local in the Florida sandhills in the highlands of the peninsula and is mostly to be found in the Sand pine-evergreen scrub oak type or in high sandy lakeside savannas which are dotted with longleaf pine and low scrub oaks. The sites are usually quite dry, the vegetation sparse. Occasionally the species comes in on powerline clearings or along new roads. It is threatened most by the construction of large housing developments or wholesale clearing for orange groves. Cutting of pine and removal of competing oak scrub would tend to favor this species. Its reaction to fire has not been observed, but it is part of a type in which fire has had an historic role.

\section{References}

Sma11, J.K. 1898. Studies in the botany of the southern United States, p. 140. BuT1. Torr. Bot. Club 25: 140.

. 1933. Manual of the southeastern flora, pp. 768-773. Chapel Hil1, N.C. 
SPECIES Polygala lewtonii SmaIl. Lewton's milkwort

\begin{tabular}{|c|c|c|c|c|c|c|c|c|}
\hline \multirow[b]{2}{*}{$\begin{array}{l}\text { Expected* } \\
\text { Effect on } \\
\text { the Species }\end{array}$} & \multicolumn{8}{|c|}{ Management Practices } \\
\hline & $\begin{array}{c}\text { Prescribe } \\
\text { Burn }\end{array}$ & $\begin{array}{l}\text { Bulldoze } \\
\text { or } \\
\text { Root Rake }\end{array}$ & Bed & Chop & $\begin{array}{l}\text { Thin } \\
\text { over- } \\
\text { story }\end{array}$ & $\begin{array}{l}\text { Cut } \\
\text { over- } \\
\text { story }\end{array}$ & $\begin{array}{l}\text { Establish } \\
\text { Plantation }\end{array}$ & Graze \\
\hline Destroy & & & & & & & $\mathrm{X}$ & \\
\hline Damage & & $\mathrm{x}$ & $\mathrm{x}$ & $\mathrm{x}$ & & & & \\
\hline $\begin{array}{l}\text { No Lasting } \\
\text { Effect }\end{array}$ & & & & & & & & \\
\hline $\begin{array}{l}\text { Beneficial } \\
\text { if Done } \\
\text { Properly }\end{array}$ & $?$ & & & & $\mathrm{x}$ & $\mathrm{X}$ & & \\
\hline
\end{tabular}

Other Comments:

* Expected effect on the species is an estimate made by Dr. Robert Kral based on his knowledge of the habitat and on knowledge gained from personal field observations. Estimates are "rough" in many instances. Results of practices may be modified depending upon the degree of application, intensity of treatment, nearness to plant communities, etc. A management practice for which no entry is made indicates a lack of sufficient information from which to predict expected results. As observations are made in the field by users of the data, the expected effect will be refined. 
Polygala lewtonii small

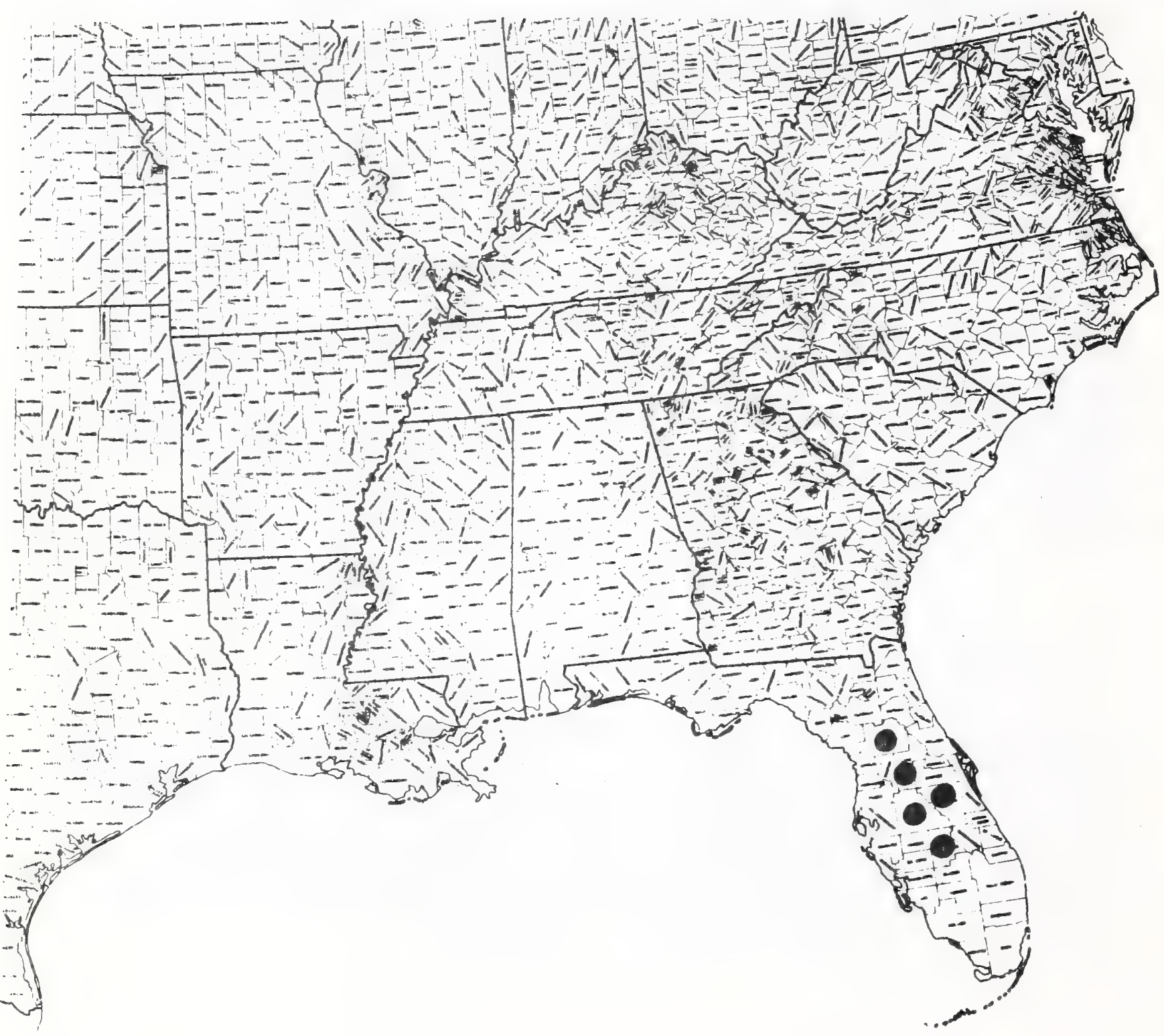




\section{POLYGONACEAE}

Eriogonum harperi Goodman. Harper's wild-buckwheat E. Tongifolium Nutt. var. harperi (Goodman) Reveal

\section{Technical Description}

Biennial from a strong, woody, deep taproot.

Stems.-- Erect, unbranched, often to 2 meters tal1, bolting the second season from strong rosettes, brittle, toward base to $2 \mathrm{~cm}$ thick, lanatetomentose with long, sordid hairs, toward and in inflorescence with hairs shorter, more spreading, and admixed with puberulence. Leaves.-- Rosette leaves with blades mostly oblanceolate, fully 3-4 dm Tong, to $7 \mathrm{~cm}$ broad, spreading or ascending on broadly linear, claspingbased petioles to 2-3 dm long, stem leaves ascending, numerous and overlapping in a spiral, progressively reduced in size and shorter petiolate into the inflorescence, the uppermost sessile, usually lanceolate; leaf apices mostly acute to short-acuminate, the margin entire to slightly crispate-sinuate, the base (of lower leaves) attenuate; upper leaf surface becoming smooth, deep yellow-green; lower surface densely white, silky-tomentose.

Inflorescence.-- An elongate but spreading, profusely branched panicle of cymes, up to $6 \mathrm{dm}$ long, this broadest at its concave summit. Major branches upwardly arching, tomentose, subtended by lanceolate to linear bracteal leaves, the branching cymosely branched again, these secondary branches with nodes bi-bracteolate, producing nearly sessile to stalked flower clusters; each flower cluster a small umbel, the florets on short stalks subtended and concealed by a turbinate, 5-triangular-toothed tomentose involucre ca. $4-5 \mathrm{~mm}$ long, the receptacle of this bearing reduced florets and tomentose scales as well pedicels mostly $1.5-3.0 \mathrm{~mm}$ long, linear-angulate, villous.

Flowers.-- Symmetrical, either male or bisexual in the same cluster, at anthesis narrowly turbinate, ca. $5 \mathrm{~mm}$ long (in fruit nearly doubling in length). Perianth 6-parted, of sepals only, these nearly equal in 2 sets, oblong-linear, pale yellow-green and tomentose with silvery long hairs, spreading at anthesis, erect in bud and fruit, joined at base into an attenuate, pale-tomentose tube which is jointed inconspicuously to the pedicel. Stamens 6 , attached along the rim formed by the bases of the perianth lobes, about as long as the perianth lobes, the slender yellow-green filaments long than the short-oblong, 2-celled, reddish, versatile anthers; ovary superior, 1-celled, white-tomentose, styles 3 , separate and linear.

Fruit.-- A utricle, the ovary much enlarged in fruit, becoming 5-6 mm long, oblong and strongly 3 -angled, the angles produced at the retuse summit into short-triangular teeth; seed lanceolate, ca. $5 \mathrm{~mm}$ long, obscurely triangular, smooth, a lustrous, deep, reddish-brown.

Distribution and Flowering Time

Very local on thin soil over limestone of bluffs, ledges and barrens, 
northwestern Alabama and east central Tennessee; flowering in July and August.

\section{Special Identifying Features}

E. harperi is sympatric with no other species of rice inum, of which there are but 3 other species in the southeastern U.S. Its nearest re]atives would be E. floridanum a species of the sandhills in southern Florida, and E. Tongifolium, of rocky or sandy woods in poor open woods from Louisiana, Missouri and Arkansas west or southwest. E. harperi is a taller plant with much larger leaves, the stem leaves numerous and gradually reduced upward on the stem into the inflorescence. E. floridanum and E. longifolium have fewer, much more distant and reduced, stem Teaves, the upper part of the stem thus appearing naked. Neither of these has the same fruit shape, and there are distinct perianth differences.

\section{Habitat and Management Implications}

E. harperi growns on thin, heavy soils over limestones or dolomites, these mostly of Mississippian age. In such habitats it is scattered, usually in clearings in forest made up of Juniperus virginiana, Quercus muhlenbergi i, Q. shumardi 1 , Carya carolinae-septentrionalis, Cercis, UTmus rubra, U. americanca, U. Serotina, etc. Undersotry shrubs are Symphoriocarpos, Hypericum frondosum, Viburnum rufidulum, various Prunus. As the overstory increases the eriogonum is shaded out. Occasional natural fire would probably tend to increase this species, as it would release through clearing of overstory species. However, logging would have to be selective (such sites, through their difficult terrain almost necessitating this) with every care taken to prevent excessive mechanical disturbance of soil. Effects upon the plants of grazing have not as yet been observed. The steepness or rockiness of the habitat is such that the forage is often unsuitable for any but goats or sheep.

References

Goodman, G.J. 1947. A new Eriogonum from the southeast. Bu11 Torrey Bot. Club 74 (4): 329-331.

Revea1, J.L. 1968. Notes on the Texas Eriogonum. Sida 3: 195-205. 
SPECIES Eriogonum harperi Goodman. Harper's wi. Id-buckwheat

\begin{tabular}{|c|c|c|c|c|c|c|c|c|}
\hline \multirow[b]{2}{*}{$\begin{array}{l}\text { Expected* } \\
\text { Effect on } \\
\text { the Species }\end{array}$} & \multicolumn{8}{|c|}{ Management Practices } \\
\hline & $\begin{array}{c}\text { Prescribe } \\
\text { Burn }\end{array}$ & $\begin{array}{l}\text { Bulldoze } \\
\text { or } \\
\text { Root Rake }\end{array}$ & Bed & Chop & $\begin{array}{l}\text { Thin } \\
\text { over- } \\
\text { story }\end{array}$ & $\begin{array}{l}\text { Cut } \\
\text { over- } \\
\text { story }\end{array}$ & $\begin{array}{l}\text { Establish } \\
\text { Plantation } \\
\end{array}$ & Graze \\
\hline Destroy & & NA & NA & $N A$ & & & & \\
\hline Damage & & & & & & $\mathrm{X}$ & & $X$ \\
\hline $\begin{array}{l}\text { No Lasting } \\
\text { Effect }\end{array}$ & & & & & & & & \\
\hline $\begin{array}{l}\text { Beneficial } \\
\text { if Done } \\
\text { Properly }\end{array}$ & $\mathrm{X}$ & & & & $x$ & & & \\
\hline
\end{tabular}

Other Comments:

* Expected effect on the species is an estimate made by Dr. Robert Kral based on his knowledge of the habitat and on knowledge gained from personal field observations. Estimates are "rough" in many instances. Results of practices may be modified depending upon the degree of application, intensity of treatment, nearness to plant conmunities, etc. A management practice for which no entry is made indicates a lack of sufficient information from which to predict expected results. As observations are made in the field by users of the data, the expected effect will be refined. 


\section{Eriogonum harperi Goodman}

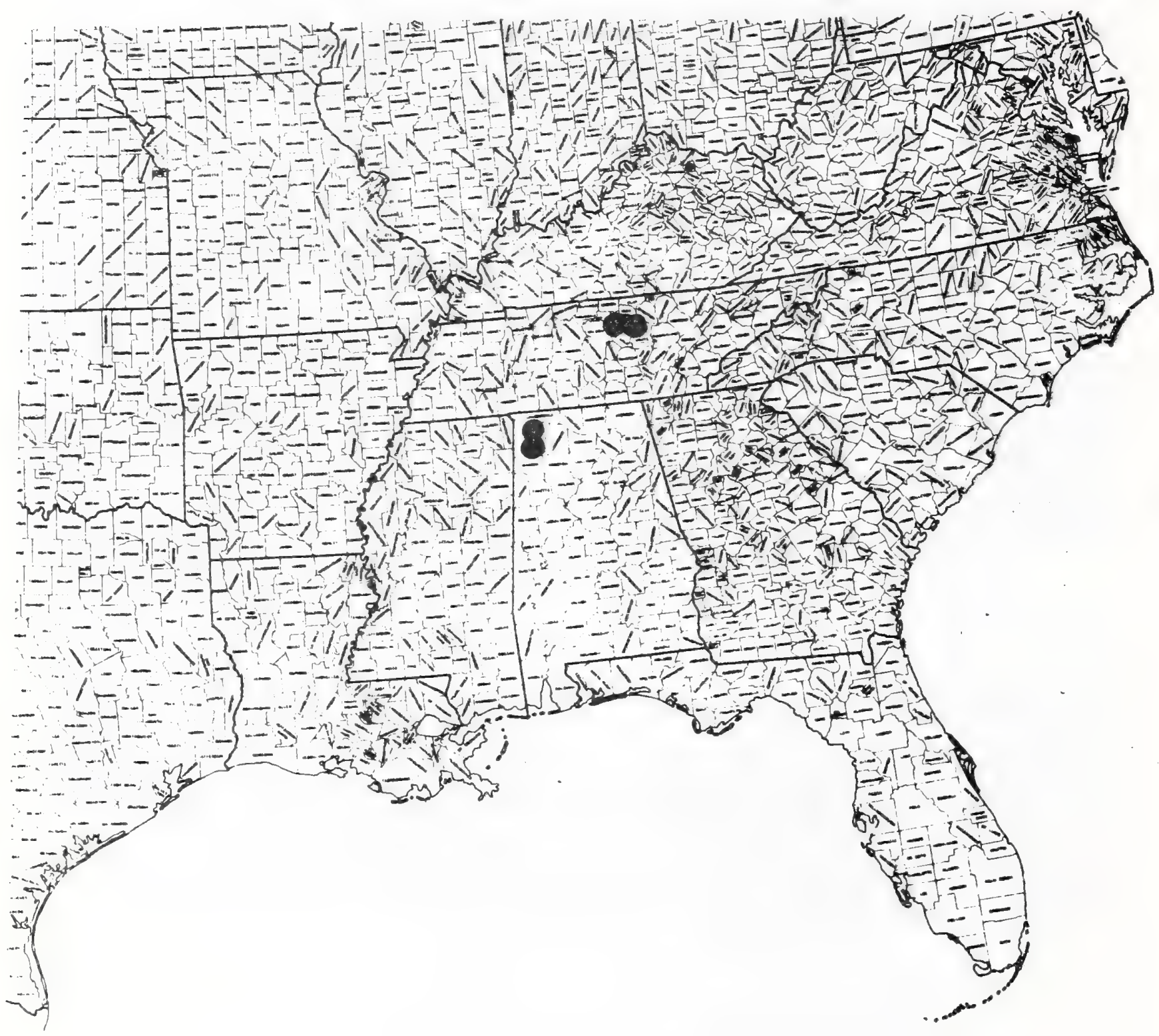


Paper 188

Text \& Map by:

Robert Kral

\section{PORTULACACEAE}

Talinum appalachianum W. Wolf. Appalachian fame-flower.

Technical Description

Succulent, smooth perennial herb from a fleshy, elongate but thickish, terete, simple or apically forking, Justrous, pale brown, taproot-like caudex, this bearing toward its apex a scattered, spiral system of narrowly triangular-inear scale leaves.

Leaves.-- Toward base of stem and on caudex narrowly Tinear-iriangular, scale-like; foliage leaves crowded toward shoot tips, terete, linear ascending, the larger ones $3-4 \mathrm{~cm}$ long, 2-3 mm thick, short-subulatetipped, dull green, the sessile bases slightly clasping, appearing "jointed" to stem.

Inflorescence.-- Mostiy 5-10 cm long; peduncles 1 or 2, axillary to shoot leaves toward shoot apex, erect, linear-filiform, terete, straw-colored, branching above the middie to form an open, few-flowered cyme, the branches and pedicels subtended by opposite pairs of narrowly triangular, scarious bracts $3-4 \mathrm{~mm}$ long.

Flowers.-- Regular, bisexual, rotate; sepals 2, distinct, broadly ovate, ca. $2 \mathrm{~mm}$ long, thin, pale green suffused with pink, reticulately veined; petals 5, distinct, spreading, oblong, ca. $5 \mathrm{~mm}$ long, $3 \mathrm{~mm}$ broad, roundedtipped, a Tively lavender-rose; stamens $5(-6-8)$, usually alternating with petals, distinct, the ascending filaments filiform, deep pink, $2.5-3.0 \mathrm{~mm}$ long, the bright yellow anthers oblong, $0.7-0.8 \mathrm{~mm}$ long; ovary superior, 1-locular, ovoid, ca. $1.5 \mathrm{~mm}$ high, style simple, narrowly linear, erect, pink, 1.0-1.2 mm long at anthesis, the stigma at first appearing buttonlike but actually with 3, involute-margined, pale, papillose lobes.

Fruit.-- Capsule ovoid, $4 \mathrm{~mm}$ long, green, smooth, splitting into $3-4$ thin valves, ; seeds cochleate (snail-shaped), several from a free central placental columella, dark reddish-brown, lustrous though minutely roughened.

Distribution and Flowering Time

Southwestern tip of Appalachians along Coosa River in Chilton and Coosa Counties, Alabama; flowering from May into July.

Special Identifying Features

This Talinum, according to an Alabama student of the genus, Dr. W. Wolf

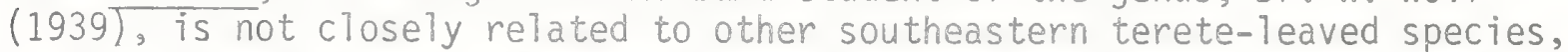
the erect and forking caudex habit being in distinct contrast to the more irregular habit of $T$. mengesii and $T$. teretifolium. Also this is the smallest of the Alabama species in size of plant and size of flower. The stamens are consistently less in number also, there being 12 or more in $\mathrm{T}$. teretifolium, 40 or more in I. mengeisii. Its flowers open toward dusk, thus Tater than in the other two arenaceous-outcrop species. 
T. appalachianum grows on the thin soil that accumulates in the rubble of of schistaceous granite covering outcrops of same, with the erect caudexes hidden by the gravel, only the green leaves and inflorescences protruding. The habitat is quite dry, usually clearings in oak-pine forest, the pines being a mixture of Shortleaf and Loblolly with an occasional Longleaf, the oaks primarily Quercus stellata, Q. coccinea, Q. falcata, Q. nigra, Q. coccinea, Q. velutina. Hickories such as Carya tomentosa, C. pallida, C. glabra are scattered throughout. Understory shrubs in the area are Vaccinium arboreum, V. stamineum, V. elliotti i and low bush Vaccinia, Forestiera, Bumelia, Rhus, Smilax, etc. Herbaceous associates include Opuntia, Delphinium carolinianum, Sporobolus, Aristida, Danthonia, Andropogon, Dichanthelium, Panicum, etc. The forest, because of the thin soils is of a generally poor quality and unsuitable for conventional mechanical methods of site preparation. There is history of fire in the area, this probably aiding in slowing down herbaceous and shrub competition on the sunny clearings the Talinum occupies. The only presently known locality is threatened, since a part of it is often used or traversed by heavy highway equipment or powerline maintenance crews.

\section{References}

Sma11, J.K. 1933. Manual of the southeastern flora, pp. 403-404. Chapel Hill, N.C.

Wolf, W. 1936. The status of Talinum in Alabama, Amer. Mid1. Nat. 22: 315-332. 
Talinum appalachianum W. Wolf. Appalachian fame-flower

\begin{tabular}{|c|c|c|c|c|c|c|c|c|}
\hline \multirow[b]{2}{*}{$\begin{array}{l}\text { Expected* } \\
\text { Effect on } \\
\text { the Species }\end{array}$} & \multicolumn{8}{|c|}{ Management Practices } \\
\hline & $\begin{array}{c}\text { Prescribe } \\
\text { Bum }\end{array}$ & $\begin{array}{c}\text { Bulldoze } \\
\text { or } \\
\text { Root Rake }\end{array}$ & Bed & Chop & $\begin{array}{l}\text { Thin } \\
\text { over- } \\
\text { story }\end{array}$ & $\begin{array}{l}\text { Cut } \\
\text { over- } \\
\text { story }\end{array}$ & $\begin{array}{l}\text { Establish } \\
\text { Plantation }\end{array}$ & Graze \\
\hline Destroy & & $\mathrm{NA}$ & NA & $N A$ & & & $\mathrm{X}$ & \\
\hline \multicolumn{9}{|l|}{ Damage } \\
\hline $\begin{array}{l}\text { No Lasting } \\
\text { Effect }\end{array}$ & & & & & & & & \\
\hline $\begin{array}{l}\text { Beneficial } \\
\text { if Done } \\
\text { Properly }\end{array}$ & ? & & & & $X$ & $\mathrm{x}$ & & \\
\hline
\end{tabular}

Other Comments:

*Expected effect on the species is an estimate made by Dr. Robert Kral based on his knowledge of the habitat and on knowledge gained from personal field observations. Estimates are "rough" in many instances. Results of practices may be modified depending upon the degree of application, intensity of treatment, nearness to plant communities, etc. A management practice for which no entry is made indicates a lack of sufficient information from which to predict expected results. As observations are made in the field by users of the data, the expected effect will be refined. 
Talinum appalachianum W. Wolf

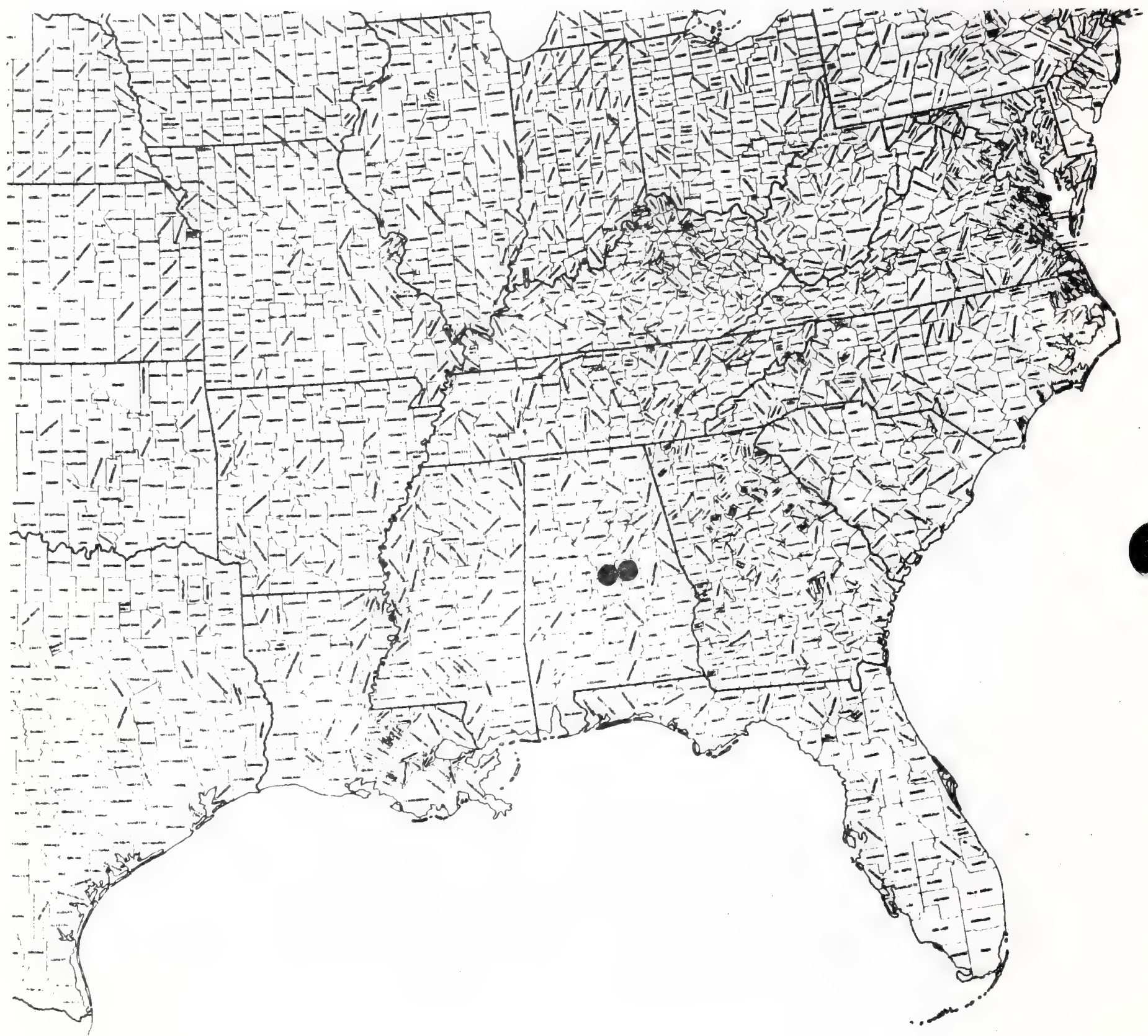


Aquilegia canadensis L. var. australis (Sma77) Munz. southern columbine A. australis Small

Technical Description

Perennial herb from a stout caudex.

Stems.-- Erect, usualiy solitary, slender, 3-10 dm tall, terete, sparseiy pilose or nearly glabrous, pale yellowish-green, branching only in the inflorescence.

Leaves.-- Rosette leaves numerous, mostly 1-3 dm long, 2/3 petiole, these slender, ascending or spreading from abruptly dilated, scarious-margined, clasping bases, terete, pale green or tan, sometimes maroon-tinted, pilose, the blades broadly ovate or triangular, 2-3-ternately compound, the leaflets reniform to suborbicular or obovate, $1.5-3.0 \mathrm{~cm}$ ' long, usually deeply 3-cleft-and-7obed, the Tobes 2-3-rounded-7obed at tips, the margins usually entire, the bases cuneate to rounded or truncate, with the lateral leaflets generally inequilateral; upper surfaces dark yellow green, lower surfaces glaucous; stem leaves progressively shorter-petioled and more distant upward on stems, grading into 3-1obed, simple, bracteal leaves.

Inflorescence.-- An open paniculate compound of cymes, the long-peduncled branches ascending from all or most upper (bracteal) leaves: flowers nodding. Flowers.-- Regular, bisexual; sepals 5, distinct, erect, lanceolate or ovateTanceolate, $1.2-1.5 \mathrm{~cm}$ long, acute, entire, rounded-cordate, reddish with green tips; petals 5 , distinct, $3-4 \mathrm{~cm}$ long, each for most of its length joined into a narrowly conical-tubular spur, the open end ca. 6-7 mm across, flaring obliquely, yellowish, the tubular part reddish, gradualiy then abruptly narrowed, then broadening at its tip into a small, nectar-filled bulb, with all spurs directed backward (upward) on the inverted flower; stamens numerous, the pale slender filaments flattened and somewhat dilated proximally, projecting the yellow, basifixed, objong, $1.5 \mathrm{~mm}$ long, anthers well beyond the perianth tips; carpels 5, erect, lance-linear, distinct, weakly pilose, the styles linear, $1.0-1.5 \mathrm{~cm}$ long.

Fruit.-- Follicles erect, lance-cylindrical, $1.5-2.0 \mathrm{~cm}$ long. glabrescent, the acuminate tips but stightly spreading.

Distribution and Flowering Time

Calcareous bluffs and outcrops, northwestern Florida; flowering in March and Apri1.

\section{Special Identfying Features}

This variety is distinguished from the wide-spread north American type variety by a combination of more glaucous foliage, somewhat larger flowers with the sepals narrower and slightly longer, the spurs stouter, and follicle tips less spreading. The type locality is in the calcareous outcrop areas at 
Mariana, Florida, a considerable disjunction from the area of A. canadensis var. canadensis. Munz (1946) treats Texas material named A. australis by SmalT (1898) as part of another variety (latiuscula (Gréene) Munz) which is a lower plant with narrower spurs. A problem in identification and rank of these taxa still exists in that specimens of $A$. canadensis var. canadensis show such a wide range of variation as to include most, ir not all, the characters used by Munz (1.C.) for the other varieties.

Habitat and Management Implications

A. canadensis australis grows in the shallow soil mantles of ledges of or in crevices in Timestone of 01 igocene age in the area of Mariana, Jackson County Florida. Particularly fine examples of it are to be found on shaded limerock outcrops along the Chipola River in Mariana Caverns State Park, these usually in association with such herbaceous genera as Trillium, Sanguinaris, Isopyrum, Lithospermum (tuberosum), Senecio (obovatus), PhTox (divaricata), etc. in light to dense shade of mixed mesophytic forest characterized by mixed oaks, hichories, ash, maple and elm. Normally it is rooted in a humified sand. The only cutting of overstory that should be recommended for this type would be selective in that clearcutting would admit intolerable amounts of light and heat. Opening such woodlands to grazing would have a negative effect more through trampling of plants and physical damage to the thin soils than from an actual use by livestock.

References

Munz, P.A. 1946. Aquilegia, the cultivated and wild columbines. Gentes Herbarum VII (1): 1-150. Ithaca, NY.

Sma11, J.K. 1898. Studies in the botany of the southeastern United States. Bul1. Torr. Bot. Club 25: 466.

- 1933. Manual of the southeastern flora, pp. 514. Chapel Hill, NC. 
SPECIES

Aquilegia canadensis I' var australis (Small) Munz•

Southern columbine

\begin{tabular}{|c|c|c|c|c|c|c|c|c|}
\hline \multirow[b]{2}{*}{$\begin{array}{l}\text { Expected* } \\
\text { Effect on } \\
\text { the Species }\end{array}$} & \multicolumn{8}{|c|}{ Management Practices } \\
\hline & $\begin{array}{c}\text { Prescribe } \\
\text { Burn }\end{array}$ & $\begin{array}{l}\text { Bulldoze } \\
\text { or } \\
\text { Root Rake }\end{array}$ & Bed & Chop & $\begin{array}{l}\text { Thin } \\
\text { over- } \\
\text { story }\end{array}$ & $\begin{array}{l}\text { Cut } \\
\text { over- } \\
\text { story }\end{array}$ & $\begin{array}{l}\text { Establish } \\
\text { Plantation }\end{array}$ & Graze \\
\hline Destroy & $\mathrm{NA}$ & $\mathrm{NA}$ & $\mathrm{NA}$ & NA & & $\mathrm{x}$ & $\mathrm{NA}$ & \\
\hline Damage & & & & & & & & $x$ \\
\hline $\begin{array}{l}\text { No Lasting } \\
\text { Effect }\end{array}$ & & & & & * & & & \\
\hline $\begin{array}{l}\text { Beneficial } \\
\text { if Done } \\
\text { Properly }\end{array}$ & & & & & * & & & \\
\hline
\end{tabular}

Other Comments: *selection, group selection

* Expected effect on the species is an estimate made by Dr. Robert Kral based on his knowledge of the habitat and on knowledge gained from personal field observations. Estimates are "rough" in many instances. Results of practices may be modified depending upon the degree of application, intensity of treatment, nearness to plant communities, etc. A management practice for which no entry is made indicates a lack of sufficient information from which to predict expected results. As obsemations are made in the field by users of the data, the expected effect will be refined. 
Aquilegia canadensis L. var. australis (small) Munz

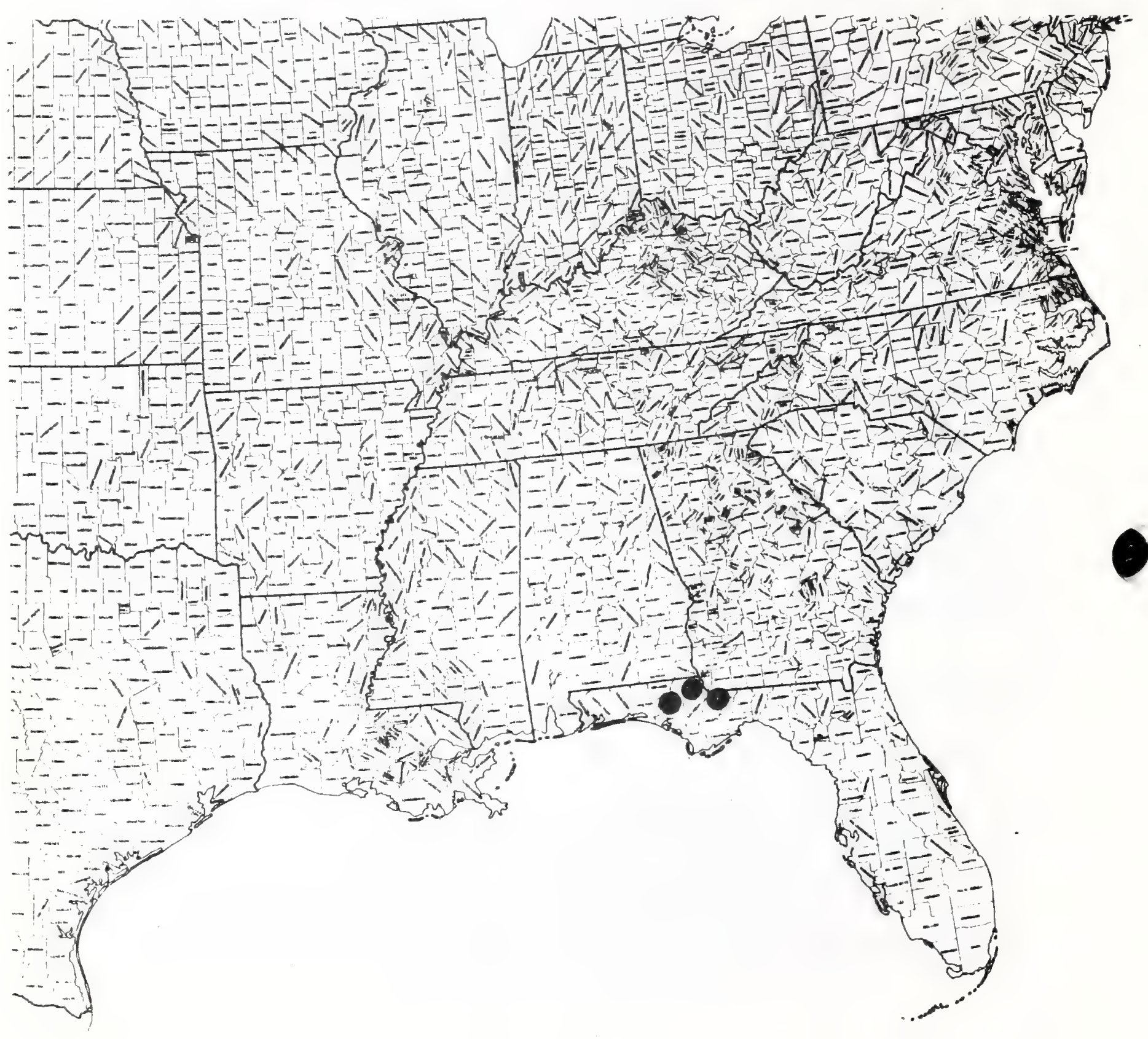


Paper 190

Text \& Map by:

Robert Kral

\title{
RANUNCULACEAE
}

\author{
Clematis addisonit Britt. Addison's leather-flower \\ Viorna addisonit (Britt.) Small
}

\section{Technical Description}

Perennial, semishrubby, glabrous vine from a stoutish short caudex. Shoots.-- At first erect, by fruiting time often arching or leaning, usually single from the woody rootstock, brittle, terete, purplish and glaucous, either simple or branching from the middle and upper nodes.

Leaves.-- Opposite, the lowermost pairs very short, 7 ineal to obovate, erect, the largest at mid-stem or above, mostly ovate, $8-12(-15) \mathrm{cm} 7 \mathrm{ng}$, 6-10 cm broad, acute to rounded or emarginate, rarely deeply retuse or bilobed, entire, narrowly revolute, the bases rounded, cordate, sometimes obliquely so, sessile or with very short, clasping based petioles, the upper surface deep green, obscurely palmately veined, the lower surface glaucous, noticeably reticulate; bracteal leaves of main axis indistinguishable from main shoot leaves in shape or size, those of later growth, particularly of side branches, much smaller, often divided into 1-2 pairs of leaflets, or these modified to tendrits.

Flowers.-- Regular, bisexual, usually nodding, arising singly or doubly from shoot tips or oppositely from axils of shoot and branch on spreading, bibracteate, purplish-glaucous peduncles, the pedicels $3-8 \mathrm{~cm}$ long, their tips recurved; sepals 4-5, valvate in the ovoid bud, later forming a campanulate calyx, distinct, thickish and leathery, Tanceolate, ca. $2.5 \mathrm{~mm}$ long, the tips recurved and short-acuminate, the backs reddish-purple, smooth, parallelveiney, the inner surface tomentose, densely so along the margin; stamens numerous, erect, ca. $2 \mathrm{~cm}$ long, the filaments pilose, linear, the anthers basifixed, linear, yellowish, 4.0-4.5 mm long, the connective and its protruding narrow tip pilose: carpels numerous, at anthesis reaching about to the level of the erect anthers, erect, the carpe\} body ovoid, 1-ovuled, densely serecious-tomentose, the styles elongate, densely silky-hairy to stigma tip, the hairs yellowish-white, the stigmas short-linear.

Fruit.-- Ripe akene body laterally flattened, with a few slightly raised veins, in outline broadly ovate, ca. $6 \mathrm{~mm}$ 7ong, $4.5 \mathrm{~mm}$ broad, short acuminate into the persistent style, brown with pale, appressed soft hairs, the style densely yellowish-plumose-hairy, fuTly $4 \mathrm{~cm}$ long, usually strongly spreading or recurved.

Distribution and Flowering Time

Rocky wooded bluffs and ravines or ledges, Valley and Ridge, southwestern Virginia; flowering from May into early July.

Special Identifying Features

This leather flower is the least viney of its complex, usually the shoots erect and fairly short by first flowering time, only later leaning, and often 
producing no tendrils; typically the leaves are simple, mostly sessile, only those of lateral branches sometimes compound.

Habitat and Management Implications

C. addisonii is scattered on thin soils over limestone or dolomite, either on open outcrops or under light to moderate shade of mixed hardwood-Juniperus, the substrate moist to rather dry. The overstory when present is comprised of a mixture of Quercus, primarily Q. muhlenbergii, Q. rubra, Q. alba, hickories such as Carya ovalis, $\underline{C}$. glabra, $\underline{C}$. cordiformis, JugTans, Acer saccharum, Ulmus, Celtis, Fraxinus americana, etc. Juniperus virginiana is interspersed. The steep topography and highly erodable nature of the thin soils would suggest that logging of the overstory should be confined to single tree selection, if any is recommended at all on these difficult and sensitive areas.

References

Erikson, R. 1943. Taxonomy of Clematis Sect. Viorna. Ann. Mo. Bot. Gard. 30: $1-60$.

Fernald, M.L. 1950. Gray's manual of botany, ed. 8, pp. 663-666. Boston, MA

Keener, Carl S. 1967. A biosystematic study of Clematis subsection Integrifoliae (Ranunculaceae). Journ. Elisha Mitchel1 Sci. Soc. 83(1): 1-41.

- 1975. Studies in the Ranunculaceae of the southeastern

United States III. Clematis. Sida $6(1):$ 33-47.

Sma11, J.K. 1933. Manual of the southeastern flora, pp. 526-528, Chapel Hill, NC Wherry, E.T. 1937. Clematis addisoni Britton, Claytonia 3: 42-43. 
SPECIES Clematis addisonii Britt. Addison's leather-flower

\begin{tabular}{|c|c|c|c|c|c|c|c|c|}
\hline \multirow[b]{2}{*}{$\begin{array}{l}\text { Expected* } \\
\text { Effect on } \\
\text { the Species }\end{array}$} & \multicolumn{8}{|c|}{ Management Practices } \\
\hline & $\begin{array}{c}\text { Prescribe } \\
\text { Burn }\end{array}$ & $\begin{array}{l}\text { Bulldoze } \\
\text { or } \\
\text { Root Rake }\end{array}$ & Bed & Chop & $\begin{array}{l}\text { Thin } \\
\text { over- } \\
\text { story }\end{array}$ & $\begin{array}{l}\text { Cut } \\
\text { over- } \\
\text { story } \\
\end{array}$ & $\begin{array}{l}\text { Establish } \\
\text { Plantation }\end{array}$ & Graze \\
\hline Destroy & & NA & $\mathrm{NA}$ & $\mathrm{NA}$ & & & $\mathrm{x}$ & \\
\hline Damage & $\mathrm{X}$ & & & & & $\mathrm{x}$ & & \\
\hline $\begin{array}{l}\text { No Lasting } \\
\text { Effect }\end{array}$ & & & & & & & & \\
\hline $\begin{array}{l}\text { Beneficial } \\
\text { if Done } \\
\text { Properly }\end{array}$ & & & & & $\mathrm{X}$ & & & \\
\hline
\end{tabular}

Other Comments:

*Expected effect on the species is an estimate made by Dr. Robert Kral based on his knowledge of the habitat and on knowledge gained from personal field observations. Estimates are "rough" in many instances. Results of practices may be modified depending upon the degree of application, intensity of treatment, nearness to plant communities, etc. A management practice for which no entry is made indicates a lack of sufficient information from which to predict expected results. As observations are made in the field by users of the data, the expected effect will be refined. 
Clematis addisonii Britt.

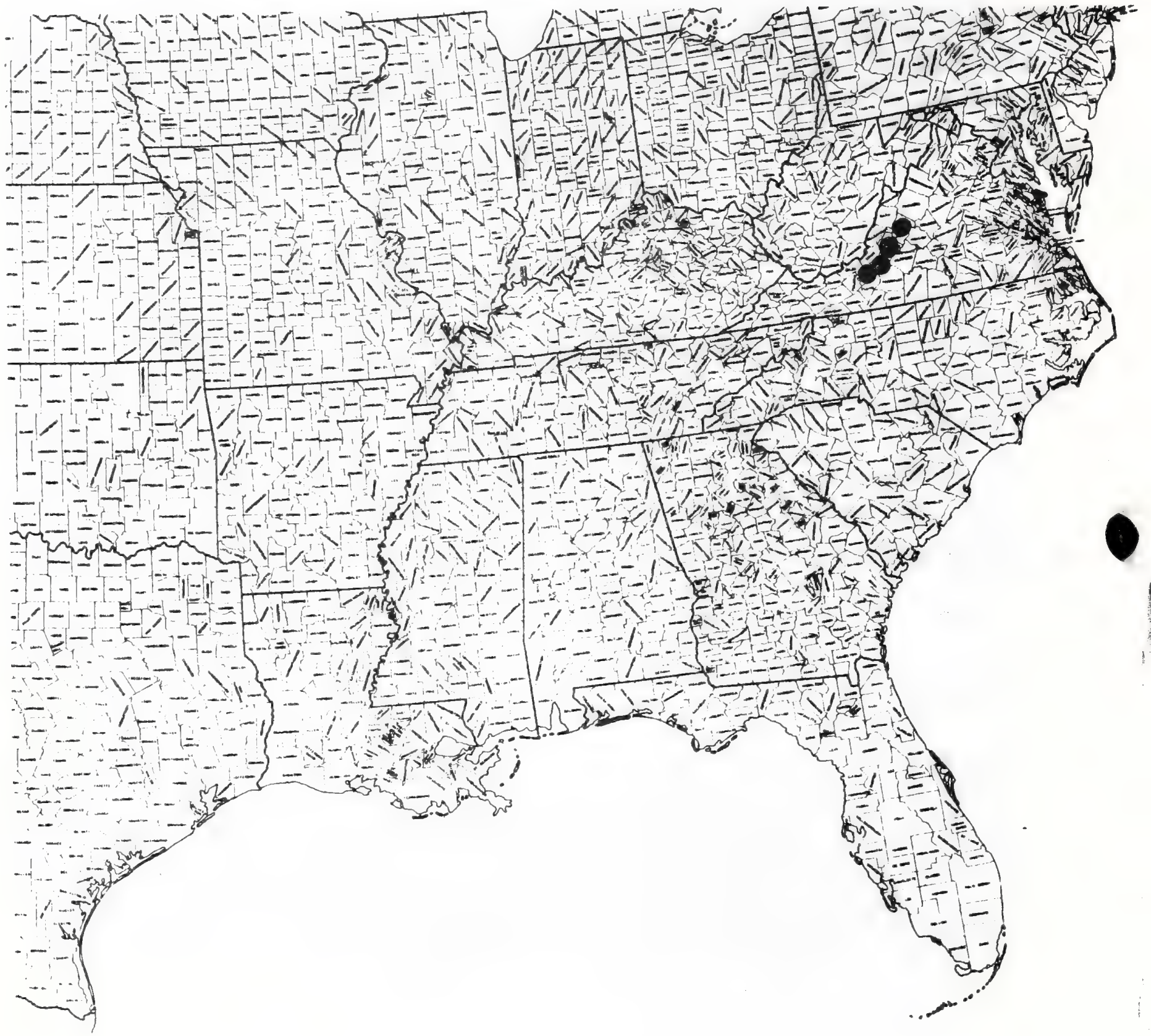


Paper 191

Text \& Map by:

Robert Kral

\section{RANUNCULACEAE}

\section{Clematis viticaulis steele. grape leather-flower}

\section{Technical Description}

Perennial herb from an erect or ascending, subligneous rhizome.

Stems.-- Erect, mostly 3-5 dm ta 17, terete or very slightly angled, brownish, the surface proximally brown, retrorsely strigose, upwardly crisped-palepuberulent (sometimes againg smooth) and reddish-brown, branching oppositely or in whorls from all or most nodes.

Leaves.-- Opposite (rarely whorled), all simple, the lowermost scale-like, usualTy gone by flowering time the largest at about mid-stem, ovate or lanceovate, mostly 5-8 cm long, acute, usually mucronulate, the margin entire, or rarely with a pair ( -3 prs.) of low teeth, the base rounded or broadly cuneate, nearly sessile on short $(2-5 \mathrm{~mm})$ crisped-puberulent petioles, leathery, the upper surface yellowagreen, smooth, somewhat reticulate, the lower surface paler, arcuately and pinnately veined, strongly reticulate, aging smooth save for puberulent vein bases and axils.

Flowers.-- Regular, bisexual, 1.5-2.0 cm long, erect on erect or upwardly curved, pale-puberulent peduncles $4-6 \mathrm{~cm}$ long (these much elongating in fruit); calyx campanulate, the 4 sepals valvate in bud, on expansion lanceolate or oblong-lanceolate, thickish, the acute tips slightly recurved, externally greenish with tints of blue and maroon, strongly parallel-nerved, palepilosulous, the thick edges pale-tomentulose; petals absent; stamens numerous, 1.3-1.5 cm long, the flattish filaments distinct, erect, Tinear, 7-8 mm long, distally pilose, the anthers scarecely broader, the broad connectives appressed-pilose with pale hairs, particularly toward the tip; carpels numerous, distinct, about the length of the sepals at anthesis, erect, the lance-linear, pale-tomentose ovary tapering into slender, appressed pilose style, this with a 7 inear-recurved stigma tip.

Fruit.-- Akenes at maturity aggregated into a loose head at summit of fruiting stalks to $5 \mathrm{~cm}$ long; akene body broadly ovate, flattened, ca. $5 \mathrm{~mm}$ Tong, silky with appressed whitish hairs, the persistent slender styles $2-3 \mathrm{~cm}$ long densely plumose-hairy from base to stigma base, the hairs reddish-brown.

Distribution and Flowering Time

Shale barrens, Bath and Rockbridge Counties, western Virginia; flowering in June.

\section{Special Identifying Features}

C. viticaulis is in the complex of Clematis consisting of erect plants which are non-viney and whose leaves are always simple, usually sessile or shortpetiolate, It is nearest C. albicoma wherry, another shale barren plant, but differs in its puberulent (rather than villose) sepal backs and its reddishbrown plumose styles (rather than whitish-pubescent). 
Habitat and Management Implications

Keener (1971), recent monographer of this complex of Clematis, has stated that $C$. viticaulis is a strict shale barren endemic and is confined to shales of Upper Devonian age. It is usually on a southern exposure, on steep slopes, particularly toward slope bases, usually where these are undercut by stream action. The vegetation is sparse, much of it on weathered rock flakes in a matrix of thin, yellow-brown soil which has an acid reaction. Such genera as Sedum, Hedyotis, Viola, Senecio, Phlox, Eriogonum, Allium, Trifolium, Paronychia, Denothera, Scutel Taria, Melica, Aster, Antennaria, etc., these of ten a Tso endemic representatives, are associated. The overstory is either absent or rather thin, comprised of low grade specimens of Pinus virginiana, P. rigida, $P$. pungens, Juniperus virginiana, various dry site Quercus such as $\bar{Q}$. ilicifolia, $\bar{Q}$. velutina, Q. coccinea, Q. stellata, Q. alba, etc., Nyssa sylvatica, severa Carya species and such shrubs as Vaccinium, Ilex, Ka Imia, Rhododendron, Qxydendrum, etc. Fire and mechanical erosion (slippage of the fracturing, thin-bedded shales) have doubtless been the historical factors providing open space for the Clematis. Conventional methods of mechanical site preparation are not applicable on this sort of topography. Increase of forest, particularly pine, on such sites would, through shading, eliminate this species.

\section{References}

Erickson, R.0. 1943. Taxonomy of Clematis, sect. Viorna. Ann. Mo. Bot. Gard. 30: $1-60$.

Fernald, M.L. 1950. Gray's manual of botany, 8th ed., pp. 663-666, New York.

Keener, C.S. 1967. A biosystematic study of Clematis subsection Integrifoliae (Ranunculaceae). --Journ. El isha Mitchell Soc. 83 (1): 1-41.

- 1971. The natural history of the mid-Appalachian shale barren

flora. In P.C. Holt (ed.) the distributional history of the biota of the southern Appalachians, part II. Flora. Research Div. Monogr. 2. Virginia Polytechnic Institute and State University, Blacksburg.

Steele, E.S. 1911. New or noteworthy plants from the eastern U.S. Contr. Nat. Herb. 13: 359-374.

Wherry, E.T. 1935. Fifteen notable shale barren plants. Claytonia 2: 19-21. 
SPECIES Clematis viticaulis steele. Grape leacher-flower

\begin{tabular}{|c|c|c|c|c|c|c|c|c|}
\hline \multirow[b]{2}{*}{$\begin{array}{l}\text { Expected* } \\
\text { Effect on } \\
\text { the Species }\end{array}$} & \multicolumn{8}{|c|}{ Management Practices } \\
\hline & $\begin{array}{c}\text { Prescribe } \\
\text { Burn }\end{array}$ & $\begin{array}{l}\text { Bulldoze } \\
\text { or } \\
\text { Root Rake }\end{array}$ & Bed & Chop & $\begin{array}{l}\text { Thin } \\
\text { over- } \\
\text { story }\end{array}$ & $\begin{array}{l}\text { Cut } \\
\text { over- } \\
\text { story } \\
\end{array}$ & $\begin{array}{l}\text { Establish } \\
\text { Plantation }\end{array}$ & Graze \\
\hline Destroy & NA & NA & $\mathrm{NA}$ & NA & & & NA & \\
\hline Damage & & & & & & & & $\mathrm{x}$ \\
\hline $\begin{array}{l}\text { No Lasting } \\
\text { Effect }\end{array}$ & & & & & & & & \\
\hline $\begin{array}{l}\text { Beneficial } \\
\text { if Done } \\
\text { Properly }\end{array}$ & & & & & $\mathrm{X}$ & $\mathrm{x}$ & & \\
\hline
\end{tabular}

Other Comments:

*Expected effect on the species is an estimate made by Dr. Robert Kral based on his knowledge of the habitat and on knowledge gained from personal field observations. Estimates are "rough" in many instances. Results of practices may be modified depending upon the degree of application, intensity of treatment, nearness to plant communities, etc. A management practice for which no entry is made indicates a lack of sufficient information from which to predict expected results. As observations are made in the field by users of the data, the expected effect will be refined. 
Clematis viticaulis Steele

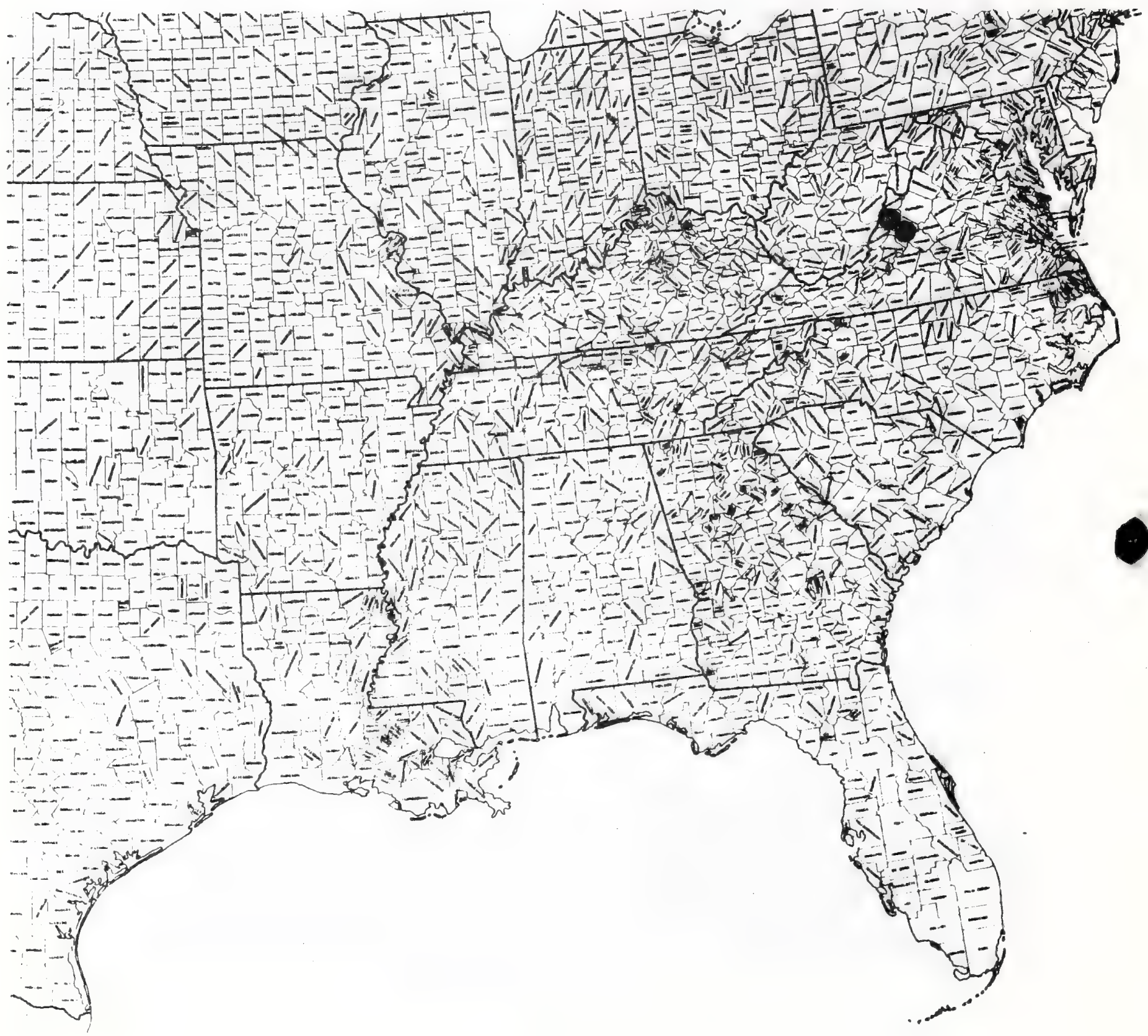


Paper 192

Text \& Map by:

Robert Kral

RANUNCULACEAE

Thalictrum cooleyi Ahles Cooley's meadow-rue

Technical Description

Perennial, smooth herb from a slender, erect caudex.

Stems.-- Erect or leaning on other plants, slender, greenish, to 1 meter tall or slightly more, teretish but with a few low, minutely scabrid ridges. Leaves.-- Both basal and cauline, the lowermost cauline leaves and basal leaves petiolate, ternately compound, the ultimate leaflets lanceolate to lance-linear or ovate (highly variable in shape and length), mostly 1-2(-5) $\mathrm{cm}$ long, $0.3-1.0 \mathrm{~cm}$ broad, the laterals nearly sessile or on slender petiolules to $5 \mathrm{~mm}$ long, the terminal one often longer-stalked, leaflet apices rounded to acute, the margins entire or (in larger leaflets) often 1-3 lobed or with a strong pair of lateral teeth, the venation of larger leaflets ternate or subpalmate, the bases rounded or acute; larger petioles 0.4-1.0 dm long, ascending, slender but with broadly scarious-auriculate clasping bases; stem leaves progressively smaller, shorter-petioled, more distant upward on stems, in the inflorescence sessile or nearly so. Inflorescence.-- Flowers few, in an open panicle on slender pedicels to 2 cm long.

Flowers.-- Regular, unisexual (the species is dioecious); sepals most7y obovate, 4-5, distinct, early deciduous, the staminate ones yellowish to white, ca. $2 \mathrm{~mm}$ long, broadiy rounded or bluntly acute, apiculate, slightly longer than the greenish pistillate ones; petals absent; stamens with slightly clavate, lavender filaments ca. 5-7 mm long, the yellowish anthers ca. $2 \mathrm{~mm}$ long, apiculate; carpels several, fusiform, distinct, short-stipitate, many-ribbed, smooth save for the minutely hairy, linear stigmas. Fruit.-- Akenes narrowly el7ipsoidal, ca. 5-6 mm 7ong, 1.5-2.5 mm wide, many-ribbed, the stigmas persisting, straight but bent somewhat inward at base.

Distribution and Flowering Season

Moist to wet savanna-bogs, Coastal Plain, eastern North Carolina; (Northwest Florida; Georgia (a possible hybrid according to Dr. Rayner!)

Special Identifying Features

According to Ahles (1939), describer of the species, T. cooleyi differs from all others of its section (Leucocoma) in its lavender (instead of white) filaments, its much narrower leaflets (narrowly lanceolate instead of oblong to ovate) and its fewer leaf divisions.

Habitat and Management Implications

T. cooleyi is in high hydroperiod soils of pineland savanna or pocosin clearings where it is scattered in grass-sedge, where associated with such 
genera as Dichromena, Zigadenus, Calopogon, Dionea, Habenaria, Sarracenia, Parnassia, Eryngium, oxypolis, Rhexia, Asclepias (lanceolata, rubra) Cacalia, Eriocauton, etc. The clearings are in a shrub type made up of Myrica, Ilex (glabra, coriacea), Vaccinium, Lyonia, Andromeda, Zenobia, Rhododendron, etc. and usually the scattered overestory is comprised of $\underline{P}$. pa ustris, $\underline{P}$. taeda, Taxodium ascendens, Liriodendron, Acer rubrum, Nyssa bifiora, etc. - Visits to previously known Tocalities in 1976 and again in 1977 revealed no plants, but Stephen Leonard and Douglas Rayner have since (1980) relocated populations. A11 these areas were either in plantation pine (Slash) or in various states of site preparation involving drainage, plowing, discing or bulldozing plus raking. The ecological history of this species is probably similar to that of other wet savanna species, clearings being largely maintained through removal of competing woody vegetation by fire. It is obvious that this very rare plant has become even more rare through the extensive drainage, site preparation and planting to pine done within its small known range.

\section{References}

Ahles, H.E. 1959. Thalictrum cooleyi, sp. nov. Brittonia 11: 68-70.

Radford, A.E., H.E. Ahles and C.R. Bell. 1968. Manual of the vascular flora of the Carolinas. Chapel Hill, N.C. 
SPECIES Thalictrum cooleyi Ahles: Cooley's meadow-rue

\begin{tabular}{|c|c|c|c|c|c|c|c|c|}
\hline \multirow[b]{2}{*}{$\begin{array}{l}\text { Expected* } \\
\text { Effect on } \\
\text { the Species } \\
\end{array}$} & \multicolumn{8}{|c|}{ Management Practices } \\
\hline & $\begin{array}{c}\text { Prescribe } \\
\text { Burn }\end{array}$ & $\begin{array}{l}\text { Bulldoze } \\
\text { or } \\
\text { Root Rake }\end{array}$ & Bed & Chop & $\begin{array}{l}\text { Thin } \\
\text { over- } \\
\text { story }\end{array}$ & \begin{tabular}{|l} 
Cut \\
over- \\
story \\
\end{tabular} & \begin{tabular}{|l} 
Establish \\
Plantation
\end{tabular} & Graze \\
\hline Destroy & & $\mathrm{x}$ & $\mathrm{X}$ & $\mathrm{X}$ & & & $\mathrm{x}$ & \\
\hline Damage & & & & & & & & $\mathrm{x}$ \\
\hline $\begin{array}{l}\text { No Lasting } \\
\text { Effect }\end{array}$ & & & & & & & & \\
\hline $\begin{array}{l}\text { Beneficial } \\
\text { if Done } \\
\text { Properly }\end{array}$ & $\mathrm{x}$ & & & & $\mathrm{x}$ & $\mathrm{x}$ & & \\
\hline
\end{tabular}

Other Comments:

*Expected effect on the species is an estimate made by Dr. Robert Kral based on his knowledge of the habitat and on knowledge gained from personal field observations. Estimates are "rough" in many instances. Results of practices may be modified depending upon the degree of application, intensity of treatment, nearness to plant communities, etc. A management practice for which no entry is made indicates a lack of sufficient information from which to predict expected results. As observations are made in the field by users of the data, the expected effect will be refined. 
Thalictrum cooleyi H. Ahles

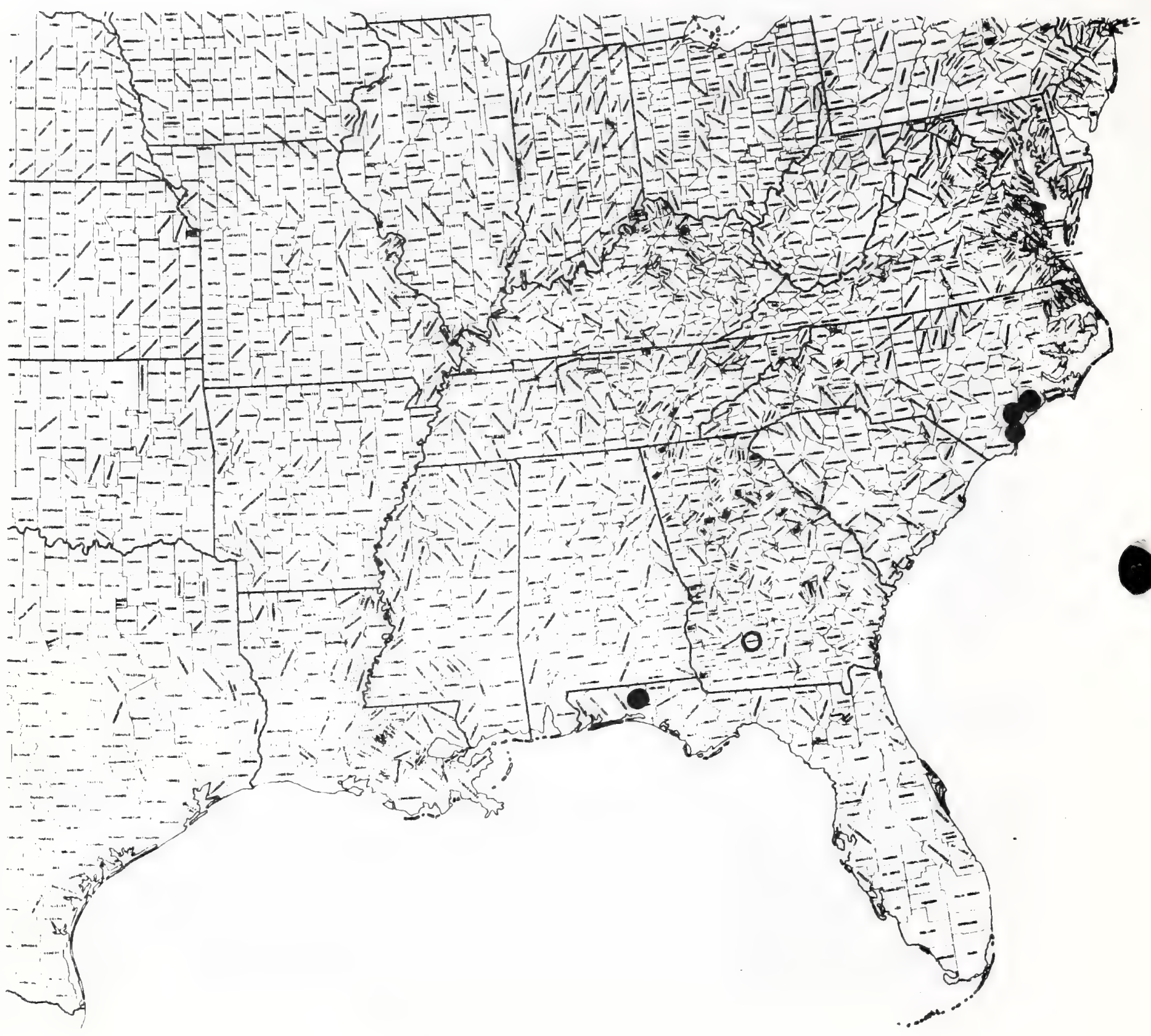


Paper 193

Text \& Map by:

Robert Kral

\section{ROSACEAE}

Geum radiatum Michx. Spreading avens

Sieversia radiata (Michx.) Greene

\section{Technical Description}

Perennial, the older plants forming large, dome-like tufts from lateral, ascending rhizomes that are thick, brown-chaffy and fibrous.

Stems.-- Usually arising singly from rhizome tips and from strong rosettes, $\overline{\text { to } 5} \mathrm{dm}$ tall, hirsute or hispid-hirsute.

Leaves.-- Basal rosette leaves by far the largest, on luxuriant specimens

fully $3 \mathrm{dm}$ long, the petiole usually 3-4 times as long as the blade, terete, pale green, hispid-hirsute with yellowish hairs, its base abruptiy dilated, clasping, with broad, thin margins, the blade either simple or lyratepinnate, the terminal segment much the largest, suborbicular to reniform, (5-) 10-15 (-20) cm broad, irregularly and many-toothed, often narrowly and deeply incised, the lateral pairs of leaflets (when present) of few to several pairs, mostly $1.5 \mathrm{~cm}$ long or Tess, distant, spreading, variously toothed and incised, usually inequilateral, cuneate-based; the upper surface deep yellow green, scattered-strigose, the lower surface paler, strigose-hirsute, particularly along the several palmate, major veins, the petiolar surface coarsely hirsute; stem leaves abruptly smailer, ascending, mostly ovate, obovate or rhombic, lacerately serrate, often also deeply incised-lobed. Inflorescence.-- A few-flowered, rather narrow cyme or a raceme, the slender, erect, villous and hirsute pedicels at anthesis longer than the flower. Flower.-- Showy, regular, bisexual; hypanthium at anthesis saucer-shaped, $\overline{\mathrm{ca} \cdot \mathrm{6}}-8 \mathrm{~cm}$ broad, green, villosulous and strigose-hirsute; calyx lobes 5, spreading, triangular, acuminate, 6-8 mm long, green, the tips thickened and blunt, alternating with 5, short-linear, blunt-tipped sinus appendages, a11 stigose-hirsute externally, lanulose above toward the tips; petals 5, obcordate, spreading, mostly 1.0-1.5 mm long. a deep, clear yellow grading to orange at the cuneate base and often bearing medially below the petal "notch" a short, ridgelike appendage within; stamens numerous around hypanthial rim, spreading and erect, 4-5 mm long, the filaments pale yellow, ca. $4 \mathrm{~mm}$ long; carpels numerous, erect, distinct, the narrowly fusiform-ellipsoidal ovaries silvery-silky-tomentose, ca. $4 \mathrm{~mm}$ long, tapering into narrow, erect, pale green, smooth styles fully as long or longer.

Fruit.-- Akenes erect, the body lanceolate in outline, somewhat compressed, silvery pilose, ca. $5 \mathrm{~mm}$ Tong, tapering into a persistent erect smooth style fully $1 \mathrm{~cm}$ or more long.

Distribution and Flowering Time

Clearings in mountain heath balds at summit elevations, southern Appalachians, western North Carolina and eastern Tennessee; flowering from June into August.

\section{Special Identifying Features}

There is no other Geum in the southeastern area that remotely resembles this

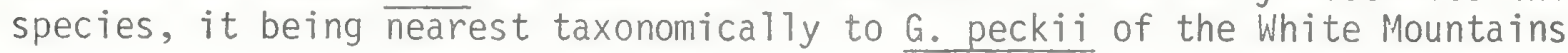


of New Hampshire and north into Nova Scotia. There are no other southern species in this section (Sieversia)which is distinguished in part by its persistent, straight or but slightly bent, non-jointed styles. G. radiatum is the most ornamental of southeastern area geums, its flowers by far the largest.

Habitat and Management Implications

G. radiatum is usually found rooted in dark, highly humified moist sandy Toams in crevices in granitic rocks or in grass balds or grassy clearings in heath balds at summits of the higher mountains in the Appalachians along the North Carolina-Tennessee border, thus usually at elevations of 5000 feet or more. The forest at these elevations is normally Picea rubens-Abies fraseri, but the Geum is never under these trees. It is definitely a plant of fult sun and $1 \overline{\text { oses }}$ ground to increasing clones of Rhododendron catawbiense, Alnus, other shrubs, or forest reproduction. The Rhododendron is usually the prime culprit in crowding or shading it out. It is locally abundant in a few 10calities, most of which are public land. Much of its endanderment apart from its being shaded out by competing shrubby vegetation, comes from irresponsible construction of park or forest facilities such as parking lots, trails or public buildings within its area.

\section{References}

Chapman, A.W. 1897. Flora of the southern states, ed. 3, p. 135. Cambridge, Mass.

Michaux, A. 1803. Flora Boreali-Americana, p. 300. Paris.

Radford, A.E., H.A. Ahles and C.R. Bell, 1968. Manual of the vascular flora of the Carolinas, pp. 542-545. Chapel Hill, N.C.

Sma11, J.K. 1933. Manual of the southeastern flora, p. 618. Chapel Hill, N.C. 


\begin{tabular}{|c|c|c|c|c|c|c|c|c|}
\hline \multirow[b]{2}{*}{$\begin{array}{l}\text { Expected* } \\
\text { Effect on } \\
\text { the Species }\end{array}$} & \multicolumn{8}{|c|}{ Management Practices } \\
\hline & $\begin{array}{c}\text { Prescribe } \\
\text { Burn }\end{array}$ & $\begin{array}{c}\text { Bulldoze } \\
\text { or } \\
\text { Root Rake }\end{array}$ & Bed & Chop & $\begin{array}{l}\text { Thin } \\
\text { over- } \\
\text { story }\end{array}$ & $\begin{array}{l}\text { Cut } \\
\text { over- } \\
\text { story }\end{array}$ & $\begin{array}{l}\text { Establish } \\
\text { Plantation }\end{array}$ & Graze \\
\hline Destroy & $\mathrm{NA}$ & $\mathrm{NA}$ & $\mathrm{NA}$ & NA & & & $\mathrm{X}$ & \\
\hline \multicolumn{9}{|l|}{ Damage } \\
\hline $\begin{array}{l}\text { No Lasting } \\
\text { Effect }\end{array}$ & & & & & & & & \\
\hline $\begin{array}{l}\text { Beneficial } \\
\text { if Done } \\
\text { Properly }\end{array}$ & & & & & * & * & & \\
\hline
\end{tabular}

Other Comments: *Removal of shrub and reproduction competition would benefit this plant.

*Expected effect on the species is an estimate made by Dr. Robert Kral based on his knowledge of the habitat and on knowledge gained from personal field observations. Estimates are "rough" in many instances. Results of practices may be modified depending upon the degree of application, intensity of treatment, nearness to plant communities, etc. A management practice for which no entry is made indicates a lack of sufficient information from which to predict expected results. As observations are made in the field by users of the data, the expected effect will be refined. 
Geum radiatum Michx.

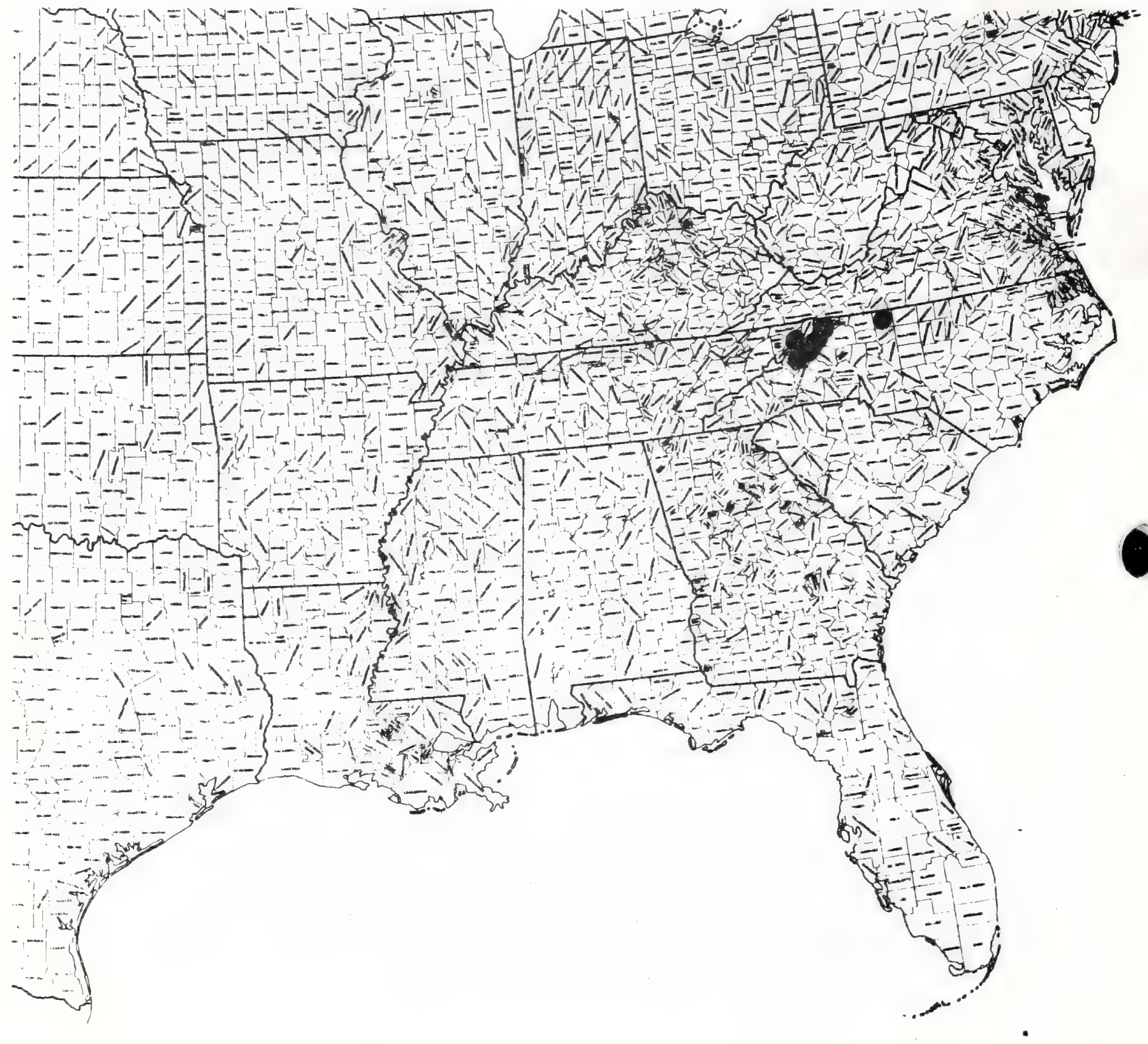


Paper 194

Text \& Map by:

Robert Kral

ROSACEAE

Prunus geniculata Harper. scrub plum

Technical Description:

Non-soboliferous, scraggy, heavily but irreguiarly branched, broad crowned shrub to 2 meters tall, the bark of older stems thin, gray (usually lichenencrusted), cracking into irregularly rectangular or squarish plates.

Twigs.-- Twigs of young or normal growth strongly zig-zag, the lateral branches either forming short, stubby spur shoots or strongly tapering, spine-like; bark of new shoots lustrous reddish-brown or purplish, often at first puberulent, becoming smooth toward end of season; bark of older growth a lustrous gray, cracking longitudinally into a braided pattern revealing a reddish inner bark; terminal bud absent, laterals ovoid-triangular, ca. $2 \mathrm{~mm}$ long, the scales reddish-brown with smooth backs and ciliate margins. Leaves.-- Alternate, smooth, appearing crowded on spur shoots, rather distant, spreading or ascending on norma? shoot growth: stipules linear-subulate, ca. $5 \mathrm{~mm}$ long, pectinately fringed with reddish glands, green, smooth; leaf blades ovate to obovate or eliptic, mostly $1-3 \mathrm{~cm}$ long, short-acuminate, regularly serrulate with teeth tipped by redish glands, the base rounded or broadly cuneate, on a redish, slender petiole $1 / 3-1 / 2$ as long as the blade.

Flowers.-- Regular, bisexual, developing singly from buds lateral to axillary buds, appearing before leaves, rather crowded on spur shoots, more distant on spine bases or along vigorous shoots, spreading on short, smooth green pedicels slightly if at all exserted beyond subtending bud scales (thus appearing sessile); hypanthium funnelform, green-tinted with maroon or red, ca. 3 mm long, smooth; calyx lobes 5, spreading-ascending, triangular, acute, sparsely ciliate, reddish or green, the backs smooth, the upper surface white-tomentulose; petals 5, spreading, ca. $5 \mathrm{~mm}$ long (flower at anthesis ca. $1.0-1.3 \mathrm{~cm}$ broad), white, the ovate to obovate blades with rounded tips, their bases attenuated to short, ciliate-margined claws; stamens numerous, more or less erect on hypanthial rim, ca. $5 \mathrm{~mm}$ long, the slender, terete, linear filaments white, smooth, tapering to nearly round, versatile, yellow anthers $0.5 \mathrm{~mm}$ long; ovary superior, lance-ovoid, ca. $3 \mathrm{~mm}$ long, smooth, tapering apically to a linear, smooth style $5-6 \mathrm{~mm}$ long, this teminating in a buttonlike stigma.

Fruit.-- On stalks to $3 \mathrm{~mm}$ long: drupe ovoid or el7ipsoida $1,1.2-2.5 \mathrm{~cm}$ long, duT7 reddish, the stone but slightly flattened, but with a groove ventral7y, the flesh tin and bitter.

Special Identifying Features

Prunus geniculata differs from a 11 other plums of Florida in the sessile appearance of its sma 17, fragrant flowers. As its discoverer Dr. Harper (1911) has stated, its affinities appear to be with the common and widespread, soboliferous Chickasaw Plum, but this shrub does not appear to form thickets, and its fruit in character is more like that of P. umbellata, the Sloe. 
Also, the mature leaf blades are not folded peachlike as they are in $\underline{P}$. angustifolia. In short, this little species is very distinct from the other florida plums.

Habitat and Management Implications

P. geniculata occurs on deep "yellow" sands of longleaf pine-turkey oak sandhil Ts as weTT as on "white" sands of sandscrub dominated by evergreen scrub oak, various ericads, and sand pine. As in true of many other woody species frequenting sandhills in the longleaf pine type, it responds vigorously to fire disturbance and historically was probably fire maintained. The primary threat to the species now is through the development of much of its habitat into housing and orange groves.

References

Harper, R.M. 1911. A new plum from the lake region of Florida Torreya 11: 67. Sma11,J.K. 1933. Manual of the southeastern flora, pp. 646-650. 


\begin{tabular}{|c|c|c|c|c|c|c|c|c|}
\hline \multirow[b]{2}{*}{$\begin{array}{l}\text { Expected* } \\
\text { Effect on } \\
\text { the Species }\end{array}$} & \multicolumn{8}{|c|}{ Management Practices } \\
\hline & $\begin{array}{c}\text { Prescribe } \\
\text { Burn }\end{array}$ & $\begin{array}{c}\text { Bulldoze } \\
\text { or } \\
\text { Root Rake }\end{array}$ & Bed & Chop & $\begin{array}{l}\text { Thin } \\
\text { over- } \\
\text { story }\end{array}$ & $\begin{array}{l}\text { Cut } \\
\text { over- } \\
\text { story }\end{array}$ & $\begin{array}{l}\text { Establish } \\
\text { Plantation }\end{array}$ & Graze \\
\hline Destroy & & $\mathrm{X}$ & $x$ & $x$ & & & $X$ & \\
\hline Damage & & & & & & & & * \\
\hline $\begin{array}{l}\text { No Lasting } \\
\text { Effect }\end{array}$ & & & & & & & & \\
\hline $\begin{array}{l}\text { Beneficial } \\
\text { if Done } \\
\text { Properly }\end{array}$ & $x$ (moder & ate) & & & $x$ & $x$ & & \\
\hline
\end{tabular}

Other Comments: *Some Prunus are toxic to livestock!

*Expected effect on the species is an estimate made by Dr. Robert Kral based on his knowledge of the habitat and on knowledge gained from personal field ohservations. Estimates are "rough" in many instances. Results of practices may he modified depending upon the degree of application, intensity of treatment, nearness to plant commities, etc. A management practice for which no entry is made indicates a lack of sufficient infomation from which to predict expected results. As obsemations are made in the field by users of the data, the expected effect will be refined. 
Prunus geniculata Harper

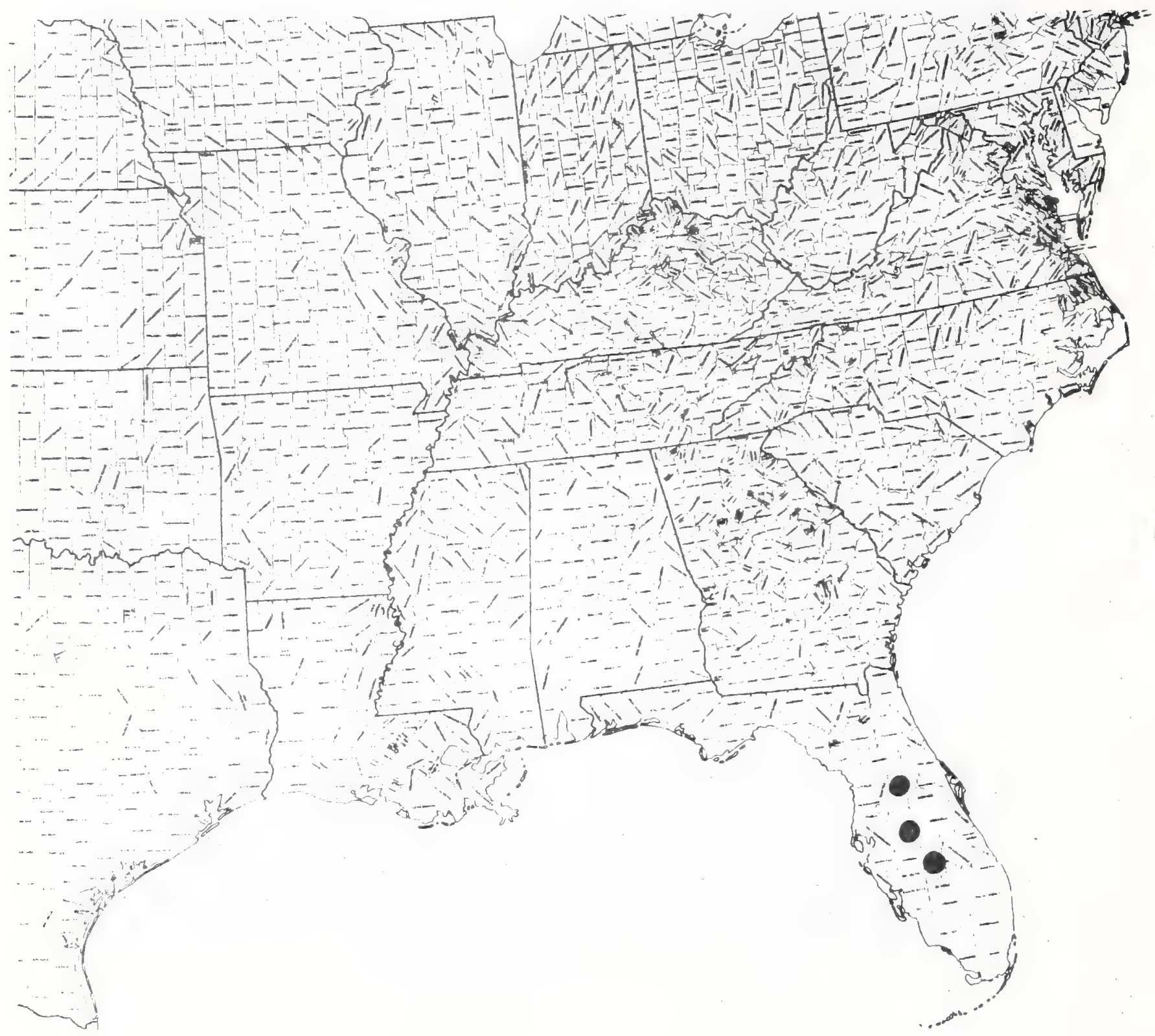


Paper 795

Text \& May by:

Robert Kral

\section{RUBIACEAE}

Hedyotis nigricans (Lam.) Fosb. var. pulvinata (Sma77) Fosb.

Mat-forming narrow-leaved bluets

Houstonia puTvinata Small

Houstonia nigricans (Lam.) ern. var pulvinata (Sma71) ern.

Technical Description

Low, compact, much-branched, essentially smooth perennial herb, forming circular mats from a woody, branched rootstock.

Stems.-- Mostly 1.0-1.5 dm high, numerous, low-spreading or arching, prolifically branching from sub-woody older stem bases, pale green, lustrous, angled or quadrangular (longitudinally narrowly grooved below the stipules). Leaves.-- Opposite, stipulate, the stipule an erect, scarious, triangular erose or laciniate scale ca. $1 \mathrm{~mm}$ high: blades spreading or ascending, sessile, linear, linear-oblanceolate, or elliptic-1inear, $0.8-1.2 \mathrm{~cm}$ long, mostly 1-2 mm wide, acutish, the margins revolute, the upper surface pale green, the lower surface paler, only the medial vein evident; leaves largest at midstem, gradually reduced up the stem into inflorescence.

Inflorescence.-- A compound system of smal1, pedunculate cymes arising from most of the upper leaf axils, thus the whole plant at anthesis because of its many branches a cushion of lavender bloom.

Flowers.-- Regular, bisexual, erect on short, stiffish, often maroon-tinted pedice Ts to $1.2 \mathrm{~mm}$ long; calyx at anthesis funnelform, ca. $1.5 \mathrm{~mm}$. high, the 4 lobes lance-ovate, ca. 6-7 mm long, erect, acute, the calyx surface green, smooth or sparsely strigose; corolla about $5 \mathrm{~mm}$ long, narrowly somewhat funnelform, bright lavender, the cylindrical tube ca. $2 \mathrm{~mm}$ long, expanding to the short, funnelform throat ca. $1 \mathrm{~mm}$ long, the 4 lobes 57 ightly spreadingtriangular, 2.0-2.5 mm long; inner corolia surface densely villosulous, outer surface smooth or sparesly strigose on the throat; stamens 4, epipetalous, the anthers oblong, ca. $7 \mathrm{~mm}$ long, alternating with the corolla lobes, nearly sessile ca. $1 \mathrm{~mm}$ below the corolla sinus; ovary nearly round, part inferior, smooth, ca. $0.5 \mathrm{~mm}$ high, 2-carpellate, the style erect, 1inear, ca. $5 \mathrm{~mm}$ long, densely minutely puberulent.

Fruit.-- Calyx tube enlarging in fruit to $2 \mathrm{~mm}$, thus Tonger than the calyx Tobes; capsule ca. $2.5 \mathrm{~mm}$ long, projecting slightly beyond calyx tips, obovoid, nearly $3 \mathrm{~mm}$ long, somewhat compressed, 2-lobed, and keel-margined; seeds several/7ocule, ca. $0.5 \mathrm{~mm}$ long, irregularly elliptic-oblong, nearly black, muciculate.

Distribution and Flowering Time

Sandy clearings, dunes, coquina reefs along the coast, eastern peninsular Florida; flowering from May intermittently through summer.

Special Identifying Features

This variety is to be distinguished from the other varieties of this widespread, polymorphic species by its consistently lower, mat-forming habit. The dense 
hairiness of the inner surface of its corolla sets it off from its nearest variety, var. filifolia, a taller, more erect, more sparse plant with longer, narrower leaves which is from sand dunes and coastal sandy areas from the tip of Florida along the Gulf of Mexico to Texas.

Habitat and Management Implications

"Typical" var. pulvinata is found on and near the east coast of Florida, usually on or around coquina sands or old limestone reefs. If inland it is never far inland and there usualiy around coquina rock outcrops or sandy clearings near these outcrops. The habitat is dry, may have various Opuntia, Monarda punctat, Gaillardia pulchella, Ipomops is rubra, Phyllanthus, Cenchrus, Helianthus debilis, etc. Overstory, of forest, surrounding clearings or nearby, is mostly pine, in some places sand pine mingling with various live oak species, in others longleaf pine mixed with slash pine, generally with an understory mostly of ericads and palmetto. The main threat facing the variety at present is from overdevelopment of the coastal areas for retirement and vacation housing and for commerce. Inland where the plants are found in small clearings, the management of pine is usually clearcutting followed by mechanical site preparation and planting to slash pine. This destroys the small clearings in which the Hedyotis grows.

\section{References}

Fosberg,F.R. 1954. Notes on plants of the eastern U.S. Castanea 19: 25-37.

Sma11,J.K. 1899. Undescribed species from the southern U.S. Bu11. N.Y. Bot. Gard. 1: 278-290.

, 1933. Manual of the southeastern flora, pp. 1253-1256. Chapel Hill. 
SPECIES Hedyotis nigricans (Lam。) Fosb. var. puIvinata (SmaII) Fosb. Matw forming naserow deaved bluet

\begin{tabular}{|c|c|c|c|c|c|c|c|c|}
\hline \multirow[b]{2}{*}{$\begin{array}{l}\text { Expected* } \\
\text { Effect on } \\
\text { the Species }\end{array}$} & \multicolumn{8}{|c|}{ Management Practices } \\
\hline & $\begin{array}{c}\text { Prescribe } \\
\text { Bumn }\end{array}$ & $\begin{array}{c}\text { Bulldoze } \\
\text { or } \\
\text { Root Rake }\end{array}$ & Bed & Chop & $\begin{array}{l}\text { Thin } \\
\text { over- } \\
\text { story }\end{array}$ & $\begin{array}{l}\text { Cut } \\
\text { over- } \\
\text { story }\end{array}$ & $\begin{array}{l}\text { Establish } \\
\text { Plantation }\end{array}$ & Graze \\
\hline Destroy & $N A$ & $x$ & $x$ & $\mathrm{X}$ & & & $\mathrm{x}$ & \\
\hline \multicolumn{9}{|l|}{ Damage } \\
\hline $\begin{array}{l}\text { No Lasting } \\
\text { Effect }\end{array}$ & & & & & & & & \\
\hline $\begin{array}{l}\text { Beneficial } \\
\text { if Done } \\
\text { Properly }\end{array}$ & & & & & $X$ & $\mathrm{X}$ & & \\
\hline
\end{tabular}

Other Comments:

*Expected effect on the species is an estimate made by Dr. Robert Kral based on his knowledge of the habitat and on knowledge gained from personal field observations. Estimates are "rough" in many instances. Results of practices may be modified depending upon the degree of application, intensity of treatment, neamess to plant communities, etc. A management practice for which no entry is made indicates a lack of sufficient information from which to predict expected results. As obsemations are made in the field by users of the data, the expected effect will be refined. 
Hedyotis nigricans (Lam.) Fosb. var, pulvinata (Small) Fosb.

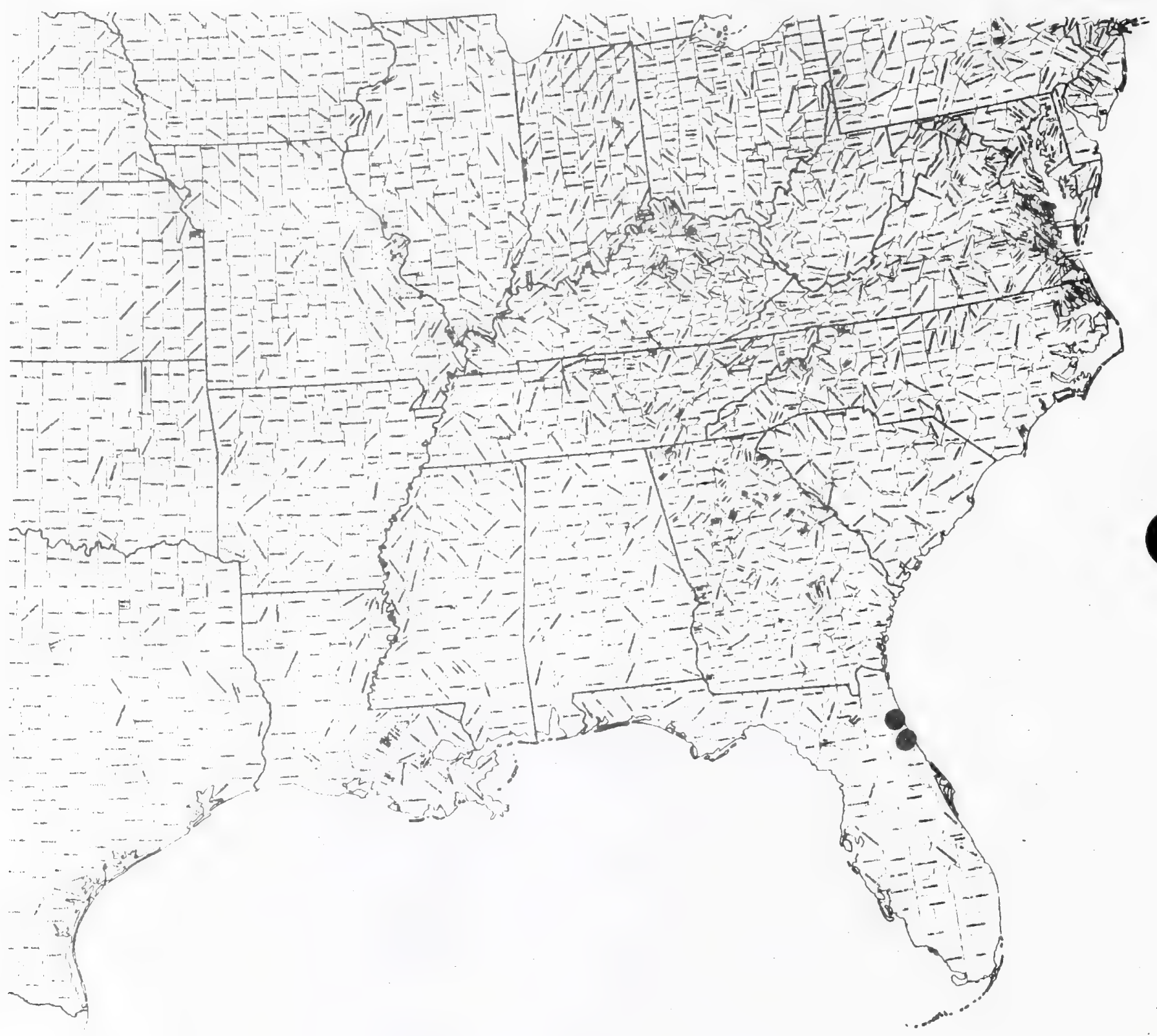


Paper 196

Text \& Map by

Robert Kral

\section{SALICACEAE}

Salix floridana Chap. Florida Willow

S. chapmanij Sma I]?

\section{Technical Description}

Shrub or tree, in the former with several ascending trunks and a broad bushy crown; in the latter with 1 or few trunks from a single diffuse root, diameters of up to $40 \mathrm{~cm}$, heights to 30 meters (fide R. K. Godfrey); bark grayish, braided in long, flat interlacing ridges, the furrows rather shallow, revealing a reddishbrown inner bark.

Twigs.-- Brittle, rather stiff, the new shoot growth greenish-brown pilosulous; year-old shoots reddish or purplish-brown, sparsely pubescent with usually appressed hairs or glabrous; winter buds erect, lance-ovoid, greenish or reddishbrown, ca. $4 \mathrm{~mm}$ Tong, glabrous.

Leaves.-- Alternate, spirally arranged, deciduous, stipulate with stipules persisting on some shoots, variable in shape but usually broad, often reniform, bilobed, glandular-denticulate; leaf blades rather variable in shape and size, mostly (5.5-) 8-15 cm long, $2.5-5.0 \mathrm{~cm}$ broad, broadly lanceolate, ovate, elliptical, oblong or even obovate, rather firm, flat, bright yellow-green and smooth above, very glaucous beneath with the surfaces or at least the midrib and veins villosulous, apically acute, often mucronulate, the margin irregulariy serrulate or serrulate-denticulate, each denticle with its tip producing a yellowish or reddish gland, the base rounded; largest leaves usually toward shoot apex, smallest but often broader outlined ones toward shoot base; petioles ascending or erect, greenish, smooth or finely pubescent, $0.5-7.5 \mathrm{~cm}$ Tong.

Inflorescence and Fruit.-- Plants unisexual, the linear and somewhat pendulous catkins produced at time of leaf emergence, the carkin axis villosulous with white hairs, densely so at pedicel nodes and there often also glandular, the pedicels spreading, slender, smooth, to ca. 2 mm long, the ovary developing into an ovoid, greenish, papillose capsule 3-4 mm long, this contracted rather abruptly to a beaklike apex bearing the persistent, short, bilobed style; capsule splitting at maturity from apex to base into 2 spreading valves revealing numerous, white-comose seeds.

\section{Distribution and Flowering Season}

Floodplain woods in scatiered localities, Coastal Plain from central and southwestern Georgia southward into northwestern and northern peninsular Florida; flowering in March, fruiting in Aprit.

Special Identifying Features

Some doubt must stili exist as to the identity of this species. Dr. Chapman, who collected and described S. floridana from the Chipola River bottoms near Marianna, Florida, indicated that it has a shrubby habit, while Drs. Godfrey (pers. comm.) indicates that it can become a tree reaching 75 feet 
and wore than a foot in diameter. Specimens exhibit a perplexing gradation toward S. caroliniana Michx. (S. Tongipes Shuttlw.), a true species sharing the same habitat and often occurring with $S$. floridana. This last tends also to produce hairs on the lower surfaces of its mature leaves, has similar floral and fruit characters, ranges from a shrub to tree: ize, has similar twigs. However, it must be admitted that trees and shrubs answering to the original description and type of $S$. floridana are to be found today and Georgia and Florida. These exhibit a range toward a larger, broader leaf than shown by any other southeastern willow and have very white lower leaf surfaces which are quite hairy beneath even in maturity. In willow taxonomy this is an admission of a describable morphology, though the true rank and relationships of this entity would still seem open to various interpretation.

\section{Habitat and Management Implications}

S. floridana is an inhabitant of floodplain woodlands in calcareous districts where it is usually on the sandy-silty or limerocky banks of streams and rivers. As is true of most willows in the southeast, its seeds requite a wet, sunny substrate for germination and its growth is intolerant of much shade. Thus, while the larger trees are often found in dense swamp forest, these are ultimately shaded out by longer-lived, more shade tolerant, or taller species and the younger specimens are usually found where sun may reach them such as in blowdowns or cleared areas, sunny banks or bars. Associate species may include Taxodium distichum, Sabal, Quercus hemisphaerica, Q. Tyrata, Q. muhlenbergi i, Q. michauxi i, Carya aquatica, UTmus, Celtis, Magnolia virginiana, Persea, Plantanus, Liquidambar, Nyssa, Forestiera, Fraxinus caroliniana, F. pensylvanica, Myrica, Cephalanthus, etc. The soil is a sandy silt, often inundated, usually at least moist. This particular willow, if seed stock from adjacent area is available, will move into disturbed areas along streams and therefore thinning of competing hardwoods would promote its increase.

\section{References}

Chapman, A.W. 1883. Flora of the southern United States, pp. 452-454. Cambridge.

Kurz,H. \& R.K. Godfrey. 1962. Trees of northern Florida, pp. 27-32. Gainesville.

Sma11,J.K. 1933. Manual of the southeastern flora, pp. 412-415. Chapel Hi11 
SPECIES Salix floridana Chapman. Florida wh1 low

\begin{tabular}{|c|c|c|c|c|c|c|c|c|}
\hline \multirow[b]{2}{*}{$\begin{array}{l}\text { Expected* } \\
\text { Effect on } \\
\text { the Species }\end{array}$} & \multicolumn{8}{|c|}{ Management Practices } \\
\hline & $\begin{array}{c}\text { Prescribe } \\
\text { Burn }\end{array}$ & $\begin{array}{l}\text { Bulldoze } \\
\text { or } \\
\text { Root Rake }\end{array}$ & Bed & Chop & $\begin{array}{l}\text { Thin } \\
\text { over- } \\
\text { story }\end{array}$ & $\begin{array}{l}\text { Cut } \\
\text { over- } \\
\text { story }\end{array}$ & $\begin{array}{l}\text { Establish } \\
\text { Plantation }\end{array}$ & Graze \\
\hline Destroy & $\mathrm{NA}$ & $\mathrm{X}$ & $x$ & $x$ & & & $x$ & \\
\hline Damage & & & & & & & & $x$ \\
\hline $\begin{array}{l}\text { No Lasting } \\
\text { Effect }\end{array}$ & & & & & & & & \\
\hline $\begin{array}{l}\text { Beneficial } \\
\text { if Done } \\
\text { Properly }\end{array}$ & & & & & $x$ & $x$ & & \\
\hline
\end{tabular}

Other Comments: Drainage of site would destroy this species!

*Expected effect on the species is an estimate made by Dr. Robert Kral based on his knowledge of the habitat and on knowledge gained from personal field observations. Estimates are "rough" in many instances. Results of practices may be modified depending upon the degree of application, intensity of treatment, nearness to plant communities, etc. A management practice for which no entry is made indicates a lack of sufficient information from which to predict expected results. As observations are made in the field by users of the data, the expected effect will be refined. 
Salix floridana Chapm.

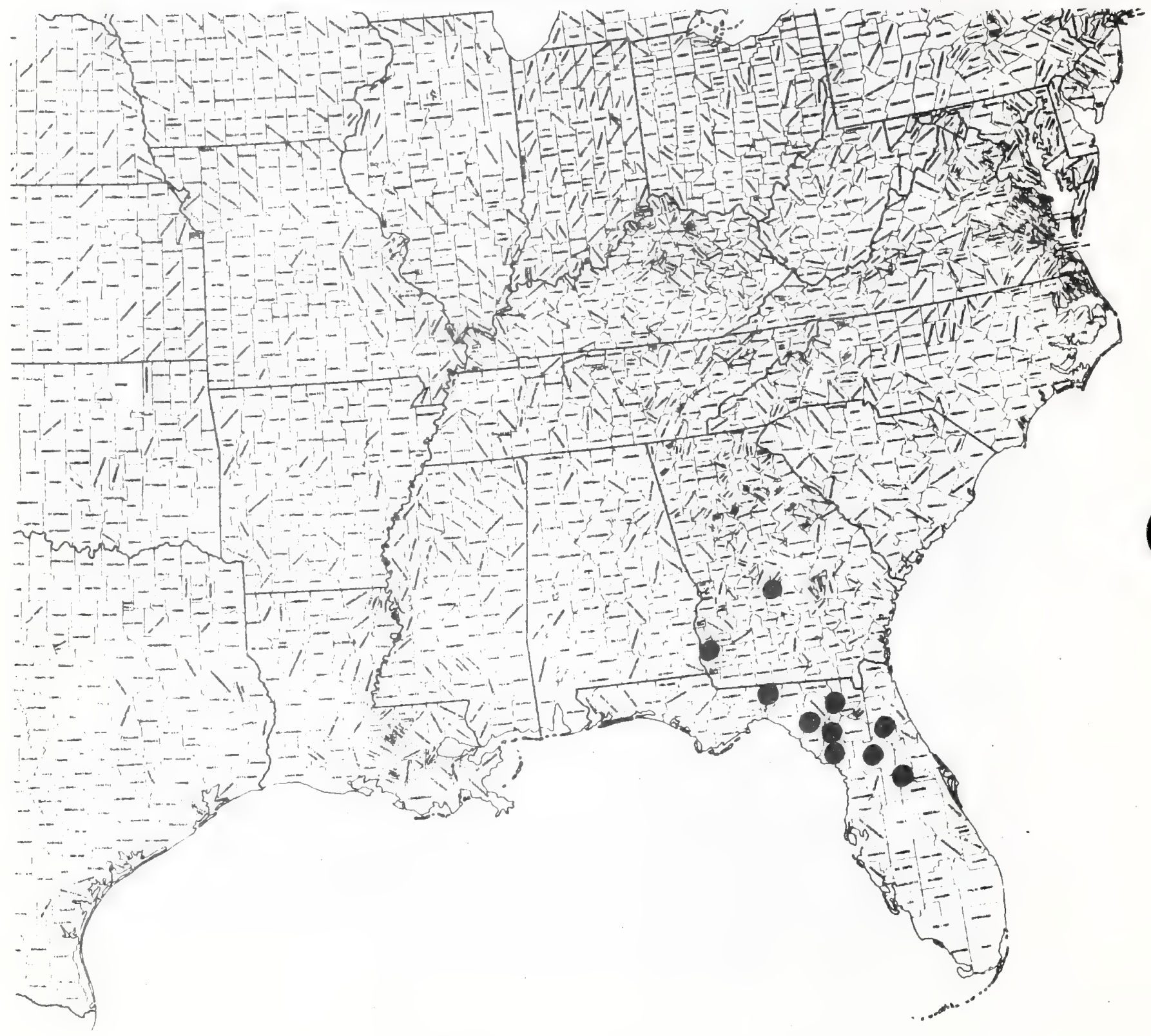


Paper 197

Text \& Map by:

Robert Kral

\section{SARRACENIACEAE}

Sarracenia alabamensis Case \& Case. Alabama cane-break pitcher-plant

\section{Technical Description}

Strongly tufted, rosulate, perennial insectivorous herb.

Leaves.-- Trimorphic, producing persistent phyllodia similar to those of $\mathrm{S}$. oreophila (which see!), followed later by two sorts of pitcher leaves; vernal (earliest) pitcher leaves appearing with flowers, in size and color as well as shape comparable to those of $S$. rubra, $0.8-5.0 \mathrm{dm}$ long, erect, greenish, soft7y pubescent, the hood cordate, suberect, $1.9-8.0 \mathrm{~cm}$ 10ng, $1.7-6.0 \mathrm{~cm}$ broad, pale green, toward the apex of the pitcher and on the hood surface reddish-reticulate-veiney; late season leaves largest, some fully to $6 \mathrm{dm}$ long, dilating gradually from the clasping base, somewhat alate (winged) ventral7y, at orifice $3-7 \mathrm{~cm}$ broad, the orifice rim recurved, the hood blade ca. 4-10 cm long, $3.5-6.6 \mathrm{~cm}$ wide, reniform or cordiform, acutish, erect or slightly arching forward over the orifice, reddishveiney, often toward apex of pitcher near orifice faintly whitish-areolate. Flowers.-- Solitary at nodding tips of stiffly erect peduncles 3.5-5.7 dm high, frequently in vigorous plants two scapes (rather than one as in most forms of pitcher plant) being produced from a rhizome tip, each scape at its summit directly under flower producing an involucre of 3 bracts, these usually recurved, triangular, firm, 4.5-6.0 mm long; sepals ovate, $1.7-2.6 \mathrm{~cm}$ long, most $y$ ovate or lance ovate, to $2.2 \mathrm{~cm}$ broad, inwardly bent, reddish or greenish tinted with red or maroon; petals 5 , distinct, panduriform, $3.5-4.5 \mathrm{~cm}$ long, external7y blood red, inner surfaces largely pale green, the broadened base narrowed to a short claw attaching petal to receptacle, the blade above the constriction broadly obovate, hanging downward around the broadened style apex; stamens numerous, distinct, the anthers deep yellow; ovary superior, warty, 5-carpellate, nearly round, the style bearing an umbrella-like, peltate disc 3.5-4.2 cm broad, the 5 stigmas borne just below the bifid tips of the 5, recurved disc angles. Fruit and seed not seen.

\section{Distribution and Flowering Time}

Fall-line sandhilis seeps, swamps and bogs, Autauga, Chilton and ETmore Counties, Alabama; flowering late April into early June.

\section{Special Identifying Features}

This plant is described by Case as different on the basis of its productian of spreading-recurved, falcate phyllodia (like S. oreophila), reddish flowers as in S. rubra and with similar but sigmoidally curved earty pitchers but differing from it in having larger, velvety-puberulent summer leaves. Hybrids between S. rubra and S. alata from Washington County, southwestern Alabama are enough like the Case description as to be placed in this, his new species. As Case and Case (1974) have indicated, S. rubra is extremely variable. McDaniel (1971) states that at least 3 geographical extremes of it exist, and accounted for the S. "alabamensis" populations as one of these. It would thus appear that 
furtner investigation is required before the distinctness of $\underline{S}$. alabamensis as a species is accepted.

\section{Habitat and Management Implications}

This pitcher plant grows in full sun or light shade, on highly saturated, boggy sphagnous soils, usually in association with various grasses, sedges, bod orchids such as Pogonia, Calopogon, Cleistes, Xyris, Eriocaulon, Lachnocaulon. Polygala, Rhexia, etc. Usual7y it is in clearings amongst shrubs such as Myrica, Alnus, Rhus vernix, Vaccinium; Smilax and Arundimaria are abundant, often dominate this Tayer. Overstory when present is a mixture of Magnolia virginiana, Ainus taeda, Acer rubrum, Liquidambar, various willow oaks, Nyssa. Reports by case the first discoverer of the popuTations, Dr. R. Harper (1927) indicate that the Sarracenia populations were usually in more or less open sites, the shrub competition Tittle and scattered and Case (op. cit.) states that this condition prevailed in the 1950's when he first visited the localities. The same areas today have, presumably through protection from fire, become much more shrubby, to the disadvantage of the Sarracenia. Much of its former area is being invaded by Lonicera japonica which enguTfs everything. Other area has been either cleared or drained, converted to pasture or other agriculture. Thus the known localities from S. alabamensis. (or these $S$. rubra!) have become fewer. Adding to the difficulty is the fact that plant "poachers" have visited remaining populations frequently for purpose of getting plants to sell. Areas where this pitcher plant remains should be kept undrained, free from trampling from cattle, periodically moderately burned to release the plants from shrub competition and, if logged, this done selectively with minimal mechanical disturbance.

\section{References}

Case,F.W. \& R.B. Case, 1974. Sarracenia alabamensis, a newly recognized species from central Alabama. Rhodora 76 (808): 650-665.

Harper,R.M. 1922. Some pine-barren bogs in Central Alabama, Torreya 22: 57-59.

McDaniel,S.T. 1966. A toxonomic revision of Sarracenia (Sarraceniaceae) Bu11. Tal1 Timbers Res. Sta. 9: 1-36.

Sma11,J.K. 1933. Manual of the Southeastern flora, pp. 580-583. Chapel Hill. 
SPECIES Sarracenia alabamensis Case \& Case. Alabama cane $-j$ rake

\begin{tabular}{|c|c|c|c|c|c|c|c|c|}
\hline \multirow[b]{2}{*}{$\begin{array}{l}\text { Expected* } \\
\text { Effect on } \\
\text { the Species }\end{array}$} & \multicolumn{8}{|c|}{ Management Practices } \\
\hline & $\begin{array}{c}\text { Prescribe } \\
\text { Burn }\end{array}$ & $\begin{array}{l}\text { Bulldoze } \\
\text { or } \\
\text { Root Rake }\end{array}$ & Bed & Chop & $\begin{array}{l}\text { Thin } \\
\text { over- } \\
\text { story }\end{array}$ & $\begin{array}{l}\text { Cut } \\
\text { over- } \\
\text { story }\end{array}$ & $\begin{array}{l}\text { Establish } \\
\text { Plantation }\end{array}$ & Graze \\
\hline Destroy & & $x$ & $\mathrm{X}$ & $\mathrm{X}$ & & & $x$ & \\
\hline Damage & & & & & & & & $\mathrm{X}$ \\
\hline $\begin{array}{l}\text { No lasting } \\
\text { Effect }\end{array}$ & & & & & & & & \\
\hline $\begin{array}{l}\text { Beneficial } \\
\text { if Done } \\
\text { Properly }\end{array}$ & $\mathrm{X}$ & & & & $\mathrm{X}$ & $\mathrm{X}$ & & \\
\hline
\end{tabular}

Other Comments: Drainage of site destroys this species!

*Expected effect on the species is an estimate made by Dr. Robert Kral based on his knowledge of the habitat and on knowledge gained from personal field observations. Estimates are "rough" in many instances. Results of practices may be modified depending upon the degree of application, intensity of treatment, nearness to plant communities, etc. A management practice for which no entry is made indicates a lack of sufficient infomation from which to predict expected results. As observations are made in the field by users of the data, the expected effect wil be refined. 
Sarracenia alabamensis Case \& Case

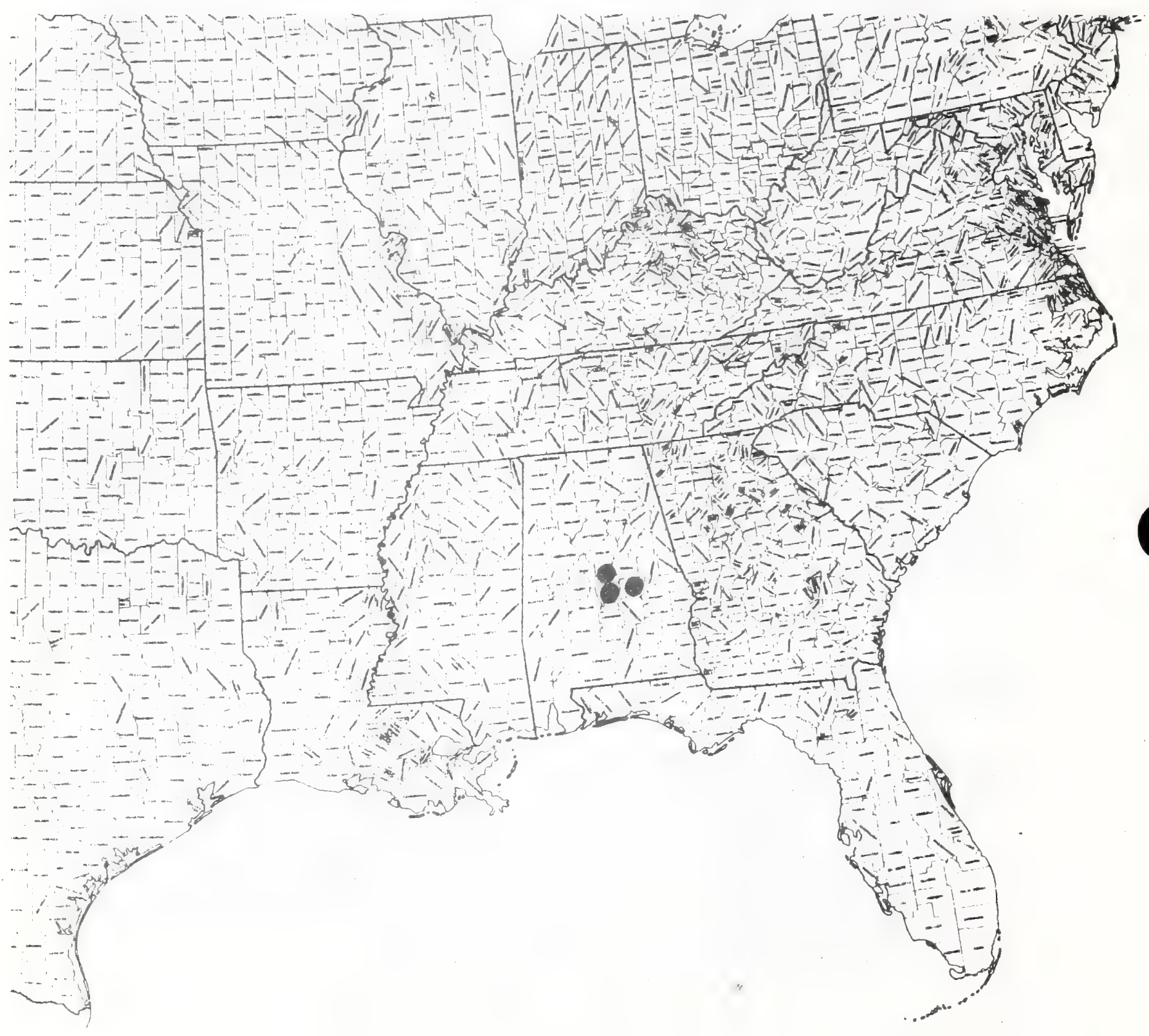


Paper 198

Text \& Map by:

Robert Kral

\section{SARRACENIACEAE}

Sarracenia oreophila (Kearney) wherry. green pitcher-plant S. flava L. var. oreophila Kearney, nom. nud.

\section{Technical Description}

Perennial, insectivorous, rosette-forming herb from at stoutish, horizontal rhizome to $1.5 \mathrm{~cm}$ thick, this covered by a scaly, brown chaff of old clasping leaf bases plus triangular, acuminate scale leaves.

Leaves.-- Two sorts produced: phyllodial (non-pitcher) type mostly falciform (curved as in a scimitar or sickle), $4-15 \mathrm{~cm}$ long, mostly $1-2 \mathrm{~cm}$ broad, flattish, attenuated to an abruptly broadened, thin, clasping, pale or reddish base, spreading, more numerous than the tubular (insectivorous) leaves, persistent, developing before and after flowers; tubular type much longer than phyllodes, to $7.5 \mathrm{dm}$ long, dilating gradually from base to rim which is $5-6 \mathrm{~cm}$ in diameter and with a narrow, recurved flange, che main veins parallel with the dorsal (midrib) and ventral (zone where margins have fused) ones somewhat raised into low wings; lid of larger pitchers $4-10 \mathrm{~cm}$ long, constricted and revolute at its base, widening to an ovate or reniform blade $5-10 \mathrm{~cm}$ broad which arches slightly forward above the constriction, is broadly acute or obtuse, sometimes apiculate, with sides broadly rounded at base, there revolute; pitcher body externally yellow-green, the major veins toward orjfice often maroon, the lid also green but with principal veins and reticulate side veins particularly within, dark maroon.

Scapes.-- Usualiy solitary, 3-4 mm thick, green, stiffly erect, 4-7 dm high, terete, fistulose, crooked at tip, thus the flower nodding.

Flowers.-- Reguiar, bisexual, solitary at nodding scape ijps, subtended by an involucre of 3 , spreading or recurved, lanceolate or triangular-ovate, yellowish or whitish-green, thin-edged bracts $\mathrm{ca} .1 \mathrm{~cm}$ long, the tips rounded; sepals 5, distinct, lance-ovate, $4.5 \mathrm{~cm}$ long, spreading, then arching downward, apically narrowed but rounded, the backs toward apex somewhat concave, yellowgreen, toward the narrowed base reddish; petals 5, distinct, clear yellow, pandurate, ca. $5 \mathrm{~cm}$ long, 1/3 from base (attachment) hooked over the broad stigma rim, thus the elliptic to oblong or obovate blade pendulous, its apex rounded; stamens numerous, hypogynous, the filaments slender, smooth, the anthers oblong, versatile, ca. $4 \mathrm{~mm}$ long; ovary superior, 5-carpellate, warty, nearly round, abruptly constricted to a short linear style base, this abruptly expanded into a broad, convex, peltate, round (parasol-like), yellowgreen style disc $4.0-5.5 \mathrm{~cm}$ broad, this radiately 5 -nerved, each nerve reddish, terminating in a recurved, bifid-tipped lobe, the stigmatic area located just below the slit within.

Fruit.-- A tardily dehiscent, 5-lobed, nearly globose, warty capsule 1.5$\overline{2.0} \mathrm{~cm}$ broad; seeds numerous, ca. $2 \mathrm{~mm}$ long, irregularly obovoid, warty and foveate.

Distribution and Flowering Time

Bogs, Blue Ridge streambanks and seeps, northeastern Alabama, northeastern 
Georgia and an 0ld, doubtful record from coastal Plain Georgia (Taylor Co.); flowering late April into June.

\section{Special Identifying Features}

This species is distinguished from the other yellow-flowered pitcher plants by its falcate-recurved phyllodes. The other two species which look like it in pitcher leaf and flower are S. flava L. and S. alata (Wood) Wood, whose phyllodia (when present) are erect and gladiate. $\bar{S}$. oreophila has a range apart from any other species save possibly $S$. rubra ( . alabamensis?) which is red-flowered, has more erect, sigmoidly bent phyllodes.

Habitat and Management Implications

S. oreophila is always on wet, sphagnous sites such as seepy depressions in oak or oak-pine barrens, hillside bogs, or stream and river banks. Its herbaceous associates are mostly grass-sedge, with an admixture of bog orchids, Xyris, Eriocaulon, Lachnocaulon, Drosera, Schoenolirion, Polygala, Utricularia, etc. Shrubs such as Ilex verticillata, Viburnum cassinoides, ATnus, high bush Vaccinium, Itea, etc. are often present, usually increasing and tending to crowd or shade out the pitcher plants and other forbs. In some localities the plants may also be in light shade of open stands predominantly of oak or of oak and pine. The species was once much more widespread in the Blue Ridge and Cumberland Plateau of northern Alabama but has been largely extirpated there due to conversion of boggy areas to crop or pasture land through drainage and plowing, or through creation of farm ponds from bog streams. Light use of areas as cattle pasture appears to have little adverse effect, the main damage appearing to be from trampling rather than browsing. The boggy clearings $S$. oreophila frequents are usually in various stages of occupation by both shrub and overstory species, so that populations may be observed in various stages of being crowded and shaded out. This is definitely a firesuccessional herb (as are most of the other Sarracenia!) and probably was maintained over time by periodic moderate natura fires. Fortunately for $\underline{S}$. oreophila, there are several small populations in the relatively inaccessible floor of the Little River canyon, much of which is state-owned.

\section{References}

Komarek, E. V. Sr. 1965. Fire-ecology--grasslands and man. Proc. 4th Annual Ta11 Timbers Fire Eco1. Conf., 169-220.

McDanie1, S. 1971. The genus Sarracenia (Sarraceniaceae). Bu11. Ta11 Timbers Res. Sta. (9): 1-36.

Sma11, J. K. 1933. Manual of the southeastern flora, pp. 580-583. Chape1 Hill.

Wherry, E. T. 1933. The Appalachian relative of Sarracenia flava. Bartonia 15: 7-8. 
SPECIES Sarracenia oreophila (Kearney) Wherry. Green pitcher-plant

\begin{tabular}{|c|c|c|c|c|c|c|c|c|}
\hline \multirow[b]{2}{*}{$\begin{array}{l}\text { Expected* } \\
\text { Effect on } \\
\text { the Species }\end{array}$} & \multicolumn{8}{|c|}{ Management Practices } \\
\hline & $\begin{array}{c}\text { Prescribe } \\
\text { Burn }\end{array}$ & $\begin{array}{l}\text { Bulldoze } \\
\text { or } \\
\text { Root Rake }\end{array}$ & Bed & Chop & $\begin{array}{l}\text { Thin } \\
\text { over- } \\
\text { story }\end{array}$ & $\begin{array}{l}\text { Cut } \\
\text { over- } \\
\text { story }\end{array}$ & $\begin{array}{l}\text { Establish } \\
\text { Plantation }\end{array}$ & Craze \\
\hline Destroy & & $\mathrm{X}$ & $\mathrm{x}$ & $\mathrm{x}$ & & & $x$ & \\
\hline Damage & & & & & & & & $\mathrm{X}$ \\
\hline $\begin{array}{l}\text { No Lasting } \\
\text { Effect }\end{array}$ & & & & & & & & \\
\hline $\begin{array}{l}\text { Beneficial } \\
\text { if Done } \\
\text { Properly }\end{array}$ & $\mathrm{X}$ & & & & $\mathrm{X}$ & $\mathrm{X}$ & & \\
\hline
\end{tabular}

Other Comments: Site drainage destroys this species!

*Expected effect on the species is an estimate made by Dr. Robert Kral based on his knowledge of the habitat and on knowledge gained from personal field observations. Estimates are "rough" in many instances. Results of practices may be modified depending upon the degree of application, intensity of treatment, nearness to plant commuities, etc. A management practice for which no entry is made indicates a lack of sufficient information from which to predict expected results. As observations are made in the field by users of the data, the expected effect will be refined. 
Sarracenia oreophila (Kearney) Wherry

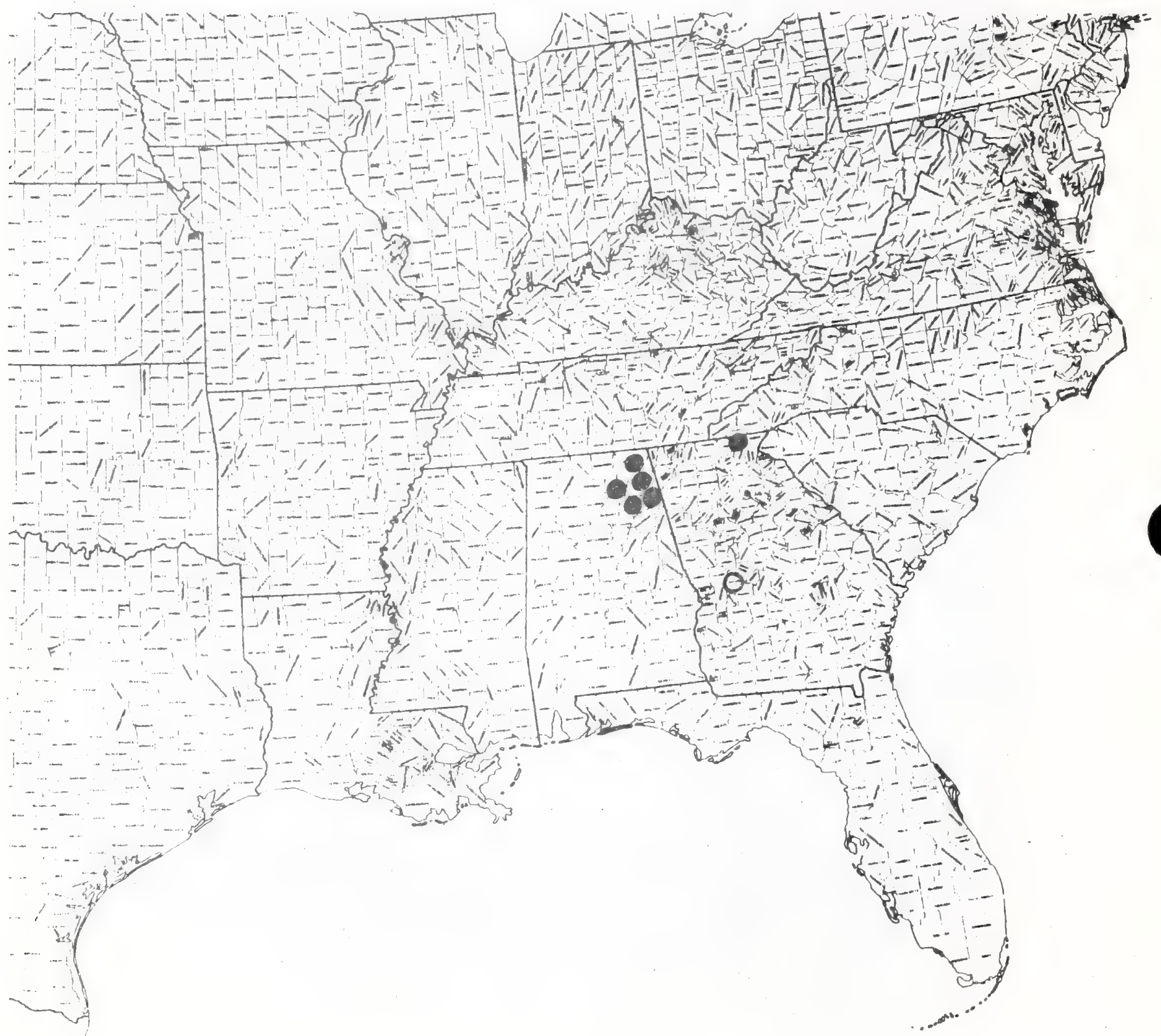


Paper 199

Text \& May by:

Robert Kral

\section{SAXIFRAGACEAE}

\section{Ribes echinellum (Covil7e) Rehder. Florida gooseberry} Grossularia echinella Coville

\section{Technical Description}

Spreading, irregularly branched shrubs to 1.5 meters ta 17.

Shoots.-- Usually several from a knotty, shallow crown, the branches spreading, arching, often rooting at tips where these touch ground, the bark thin, pale gray-brown, on older wood broadly cracking longitudinally to reveal reddishbrown inner bark; new shoots slender, spreading, somewhat zig-zag, pale graybrown, bearing 1-3 spreading nodal spines to $7.5 \mathrm{~cm}$ iong, and decurrently ridged from the sides of the leaf scars the length of the internodes; shoot buds ovoid, ca. $4 \mathrm{~mm}$ long, the scales imbricate, thin, reddish-brown, ciliate. Leaves.-- Alternate, close-set on abundant spur shoots or distant on elongated shoots, orbicular on slender, greenish, hirsute to pilose petioles $1-3 \mathrm{~cm}$ long, these with abruptly broadly clasping, elongate-glandular-ciliate bases; blades suborbicular, $7-3 \mathrm{~cm}$ wide, mostly palmately $3-5$ parted, the sinuses mostly sharp, shallow to deep, the lobes cuneate to oblong, their tips dentately or crenately few-toothed, the margins ciliate, the upper surface dark green, smooth or pilose along the veins, the lower surface paler, appressed-hairy.

Flowers.-- Axillary to new shoot leaves, perfect, regular, on slender, spreading or ascending peduncles about as long as the subtending petiole and bearing a white tomentum of villous (crisped) hairs mixed with stiffish, spreading, gland-tipped hairs, bearing also just below the flower a pair of ovate-oblong, green, clasping-based, pilose bracilets: perianth tube narrowly campanulate, its base around the ovary with a dense coating of stiffish, glandular-capitate hairs (these Tater becoming spines on the fruit), above pilosulous, then spreading into 5 oblong or spatulate, puberulent, greenish, erect calyx lobes ca. $5 \mathrm{~mm}$ long which at anthesis become sharply reflexed; petals 5, erect, broadly oblong, 3.0-3.5 m long, strongly inrolled, widest at the truncate apex, there erose, the bases arising from an hypanthial rim; stamens 5, alternating with the petals, erect, the slender, terete filaments lengthening to $0.8-1.5 \mathrm{~cm}$, the base fixed, oblong, 2-1ocular anthers ca. $2 \mathrm{~mm}$ long, at first cinnamon-red, later purplish; ovary inferior, the style slightly shorter than the stamens, cleft to below the middle. Fruit.-- A globose to ellipsoidal or ovoid, greenish berry $7.0-7.5 \mathrm{~cm}$ long, the surface beset with numerous, spreading, stiffish and gland-tipped prickles, these yellow-green, $3.0-3.5 \mathrm{~mm}$ long.

Distribution and Flowering Time

Sandy loams of mixed deciduous forest, Piedmont, South Carolina (McCormich Co.) and northern Florida (Jefferson Co.); flowering from late February into early Apriti. 


\section{Special Identifying Features}

This species differs from the only other bristly-fruited Ribes of the southeastern area, R. cynosbati, by its smoother leaves (in $k$. cynosbati the leaves are pilose above), its gland-tipped or capitate ovary and fruit prickles (in R. cynosbati these are not capitate!).

Habitat and Management Implications

R. echinellum is a freely shoot-rooting species of we 17 -drained sandy loams of rich woods in two widely separate localities. In the Florida area it is on southern and southwestern facing lake bluff with an overstory of hardwoods such as Liquidambar, Nyssa, Tilia, UTmus, live oak, water oak, white oak, shumard oak, and pignut hickory. The understory is Cornus florida, Cercis, Palmetto, Forestiera, Viburnum, Sambucus. Logged areas of the Florida population show an increase of weedy shrubs, particularly Rubus, Sambucus, Smilax, and a reduction of the Ribes. Probabiy single tree or group selection would not effect the shrubs adversely, so long as theis was kept from much mechanical disturbance of the soil. The shrubs are not found in full sun and it is thus quite likely that clearcutting would eliminate or seriously reduce them.

\section{References}

Covilele, F. 1924. Grossularia echinata, a spiny-fruited gooseberry from Florida. Journ Agric. Res. 28: 71-74.

Radford, A.E., H. E. Ahles and C. R. Bel1. 1969. Manual of the vascular flora of the Carolinas: 519-520. Chapel Hill.

Rehder, A. E. 1926. Ribes echinellum (Cov.) Rehder in "New species, varieties and combinations from the Herbarium and the collections of the Arnold Arboretum." Journ. Agric. Res. 28: 71.

Sma17, J. K. 1933. Manual of the Southeastern flora, pp. 602-604. Chapel $\mathrm{Hi}$ ll. 
SPECIES Ribes echinellum (Cov,) Rehd。 Florida gooseberry

\begin{tabular}{|c|c|c|c|c|c|c|c|c|}
\hline \multirow[b]{2}{*}{$\begin{array}{l}\text { Expected* } \\
\text { Effect on } \\
\text { the Species }\end{array}$} & \multicolumn{8}{|c|}{ Management Practices } \\
\hline & $\begin{array}{c}\text { Prescribe } \\
\text { Bumn }\end{array}$ & $\begin{array}{c}\text { Bulldoze } \\
\text { or } \\
\text { Root Rake }\end{array}$ & Bed & Chop & $\begin{array}{l}\text { Thin } \\
\text { over- } \\
\text { story }\end{array}$ & $\begin{array}{l}\text { Cut } \\
\text { over- } \\
\text { story }\end{array}$ & $\begin{array}{l}\text { Establish } \\
\text { Plantation }\end{array}$ & Graze \\
\hline Destroy & $\mathrm{X}$ & $\mathrm{X}$ & $\mathrm{x}$ & $\mathrm{X}$ & & & NA & \\
\hline Damage & & & & & & & & $\mathrm{x}$ \\
\hline $\begin{array}{l}\text { No Lasting } \\
\text { Effect }\end{array}$ & & & & & $\mathrm{x}$ & $\mathrm{X}$ & & \\
\hline $\begin{array}{l}\text { Beneficial } \\
\text { if Done } \\
\text { Properly }\end{array}$ & & & & & & & & \\
\hline
\end{tabular}

Other Comments:

*Expected effect on the species is an estimate made by Dr. Robert Kral based on his knowledge of the habitat and on knowledge gained from personal field observations. Estimates are "rough" in many instances. Results of practices may be modified depending upon the degree of application, intensity of treatment, nearness to plant commities, etc. A management practice for which no entry is made indicates a lack of sufficient information from which to predict expected results. As observations are made in the field by users of the data, the expected effect will be refined. 
Ribes echinellum (Coville) Rehder

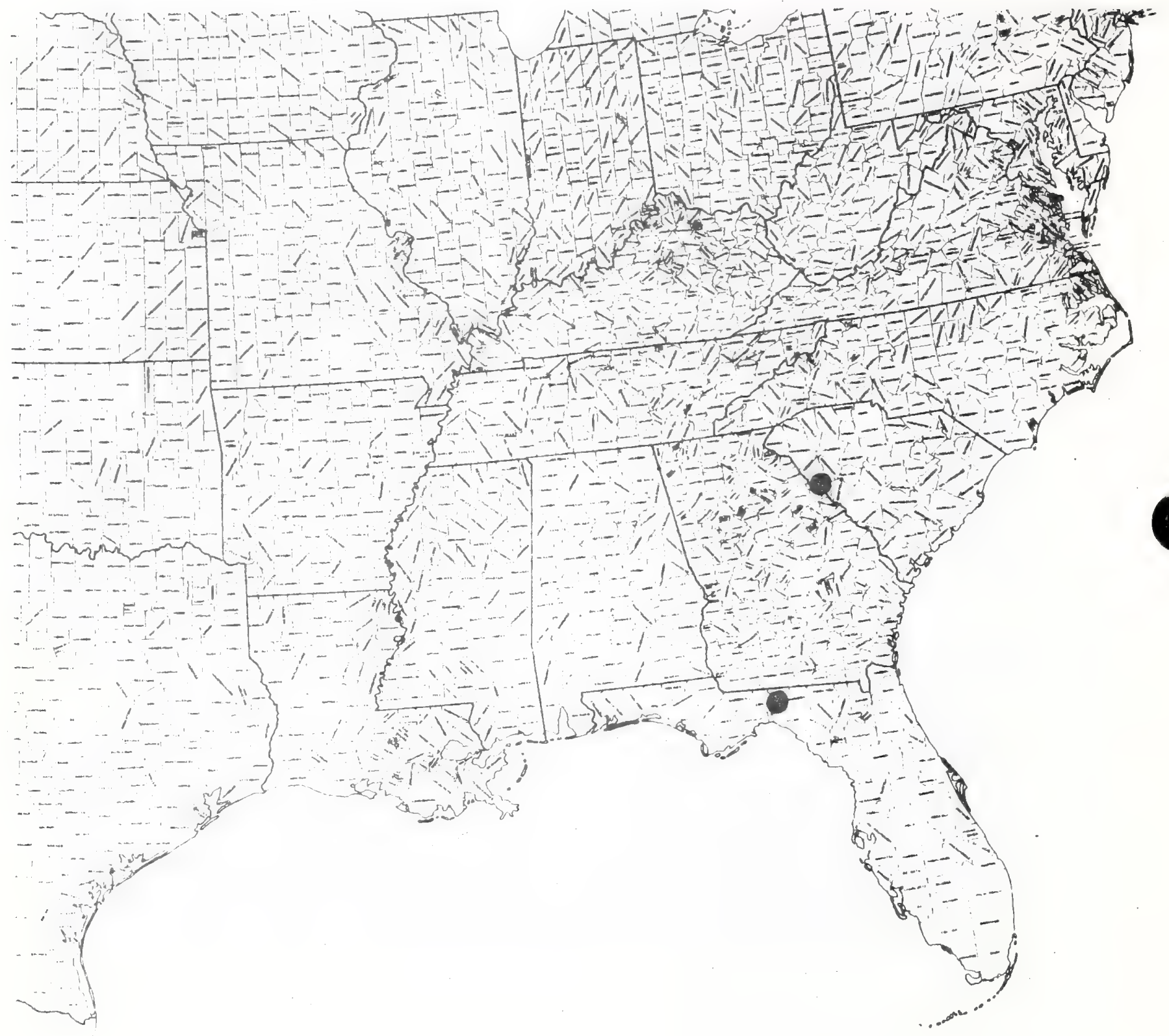


Paper 200

Text \& Map by:

Robert Kral

\section{SCHROPHULARIACEAE}

\section{Amphianthus pusillus Torrey. Tittle amphianthus}

\section{Technical Description}

Delicate or diminutive, shallow-and-fibrous-rooted annual.

Stems.-- Main axis erect, short (mostly 2-5 mm high), greenish or purplish, the single internode ca. 1 mm wide, Iongitudinally 4-ridged, at its summit bearing a pair of oppositely spreading, linear-triangular leaves (bracts?) which subtend a central floret which terminates the main axis; primary branches (peduncles?) 2 or more, arising around the central floret, the bases telescciped, ranging from but a few millimeters long to fully 2 decimeters long, depending on water depth, all actually inflorescence branches in an open cyme, al1 terminating in a pair of spreading, broadish bracts which subtend solitary flowers and which float like pads in the vernal pools.

Leaves.-- Opposite, decussate. Lowermost leaves (those subtending the first flower), linear-triangular, ascending or spreading to $5 \mathrm{~mm}$ long, those of the branch bases usually in 2, overlapping pairs and slightly shorter, those terminating the variously elongated terminal internode (inflorescence branch?) spreading, obovate, broadly ovate, or elliptic, mostly 3-5 mm long, rounded to slightly retuse, entire, the bases broadly or narrowly acute, sessile or nearly so, green, often with maroon edges, inconspicuously veined, minutely glandular-punctate.

Flowers.-- Zygomorphic, bisexual, solitary in axils of bracteal leaves, at anthesis erect on short pedicles mostly 0.1-0.2 mm 1ong, these after anthesis recurving and elongating; calyx campanulate, ca. $1.5 \mathrm{~mm}$ long, the tube short, the limb oblique, spreading in fruit, the lobes 5, slightly unequal, oblong, ovate or suborbicular, ascending at anthesis, the lowest smallest, narrowest, al1 blunt or rounded-tipped, greenish or maroon-tinted; corolla white, at anthesis ca. 3-4 mm long, the tube and throat ca. $2 \mathrm{~mm}$ long, the 5 lobes nearly erect or slightly spreading, nearly equal, short-oblong, rounded or emarginate, the lower one slightly larger, emarginate; stamens 2, epipetalous $1 / 2$ way up the corolla tube, the filaments capillary, short, ca. $0.3 \mathrm{~mm}$ long, the anthers yellowish, nearly round, the sacs slightly divergent, $0.5 \mathrm{~mm}$ long; staminodia absent; ovary superior, bilobed, ca. $1 \mathrm{~mm}$ high, the style erect, ca. $1 \mathrm{~mm}$ long, the stigmatic apex bilobed, the lobes flat.

Fruit.-- An obcordate, tumidly bilobed, 2-locular capsule ca. $3 \mathrm{~mm}$ high, carinate along the valve margins, the stalk of the mature fruit usually strongly recurved; seeds numerous, short-cylindrical and curvate (banana - shaped) ca. $1 \mathrm{~mm}$ long, dark brown, with numerous prominent longitudinal ridges and slightly less distinct cross lines.

Distribution and Flowering Time

Vernal pools in granite outcrop areas of Piedmont Alabama, Georgia and South Carolina; flowering from late March into April. 


\section{Special Identifying Features}

A. pusil7us, a monotypic genus, is perhaps in floral character most similar to the genus Gratiola. Certainly in Gratiola there are species which show

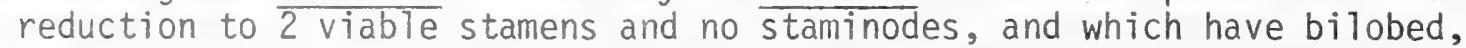
laminal stigmas and similar (though larger) corollas. Seed character in the two general is similar. However, Amphianthus differs from all other southeastern area Scrophulariaceae as follows:

1. The leaves are stronly dimorphic. The Tower pairs are subulate, yet from the shoots above the first node of branches a variously elongated (depending on depth of pools) internode develops which terminates in a pair of opposite, much broader leaves that float, padlike, as in Callitriche heterophyl7a. These elongated internodes have been referred to as pedicels, the floating, opposite leaves as bracts. However Smal1 (1933) and Pennell (1935) refer to them as branches and leaves. In any event, this small plant, above the level of its comparatively stocky first internode, could be said to be mostly inflorescence.

2. The corollas are very small, smaller than in any other southeastern member of the Scrophulariaceae, and are similar to Gratiola or Bacopa, this in contrast to the tumid, obcordate capsules which are similar to those of Veronica.

Habitat and Management Implications

Amphianthus grows in full sun in and around edges of vernal pools on granite, its roots in the shallow, s dy-silty wash that accumulates there. In dry seasons it often does not appear, the seeds appearing to lie dormant until favorable winter moisture conditions develop. Length of elongate, roundbracted pedicels varies depending on water depth. Associated species in and around the pools are usually Isoetes spp., Diamorpha cymosa, Arenaria uniflora, A. glabra, Lindernia monticola, Juncus georgianus, Agrostis, Panicum, etc. Where there is sufficient soil depth over the granite an oakyellow pine forest community usually forms, this generally with an understory of Rhus, Vaccinium, Chionanthus, Calamintha, Hypericum, etc. The vine Gelsemium sempervirens is common, as are Smilax, Anisochistus, Campsis, Vitis. Only the deeper, more permanent pools support Amphianthus and such poots are rare even in the best localities. Shade eliminates this plant. The main threat to known populations appears to be a combination of destruction of the granite outcrops by quarrying and damage done to the smalt pools by hickers and motorcycitists.

\section{References}

McVaugh, R. and J.H. Pyron. 1937. The distribution of Amphianthus in Georgia. Castanea 2: 104-105.

McVaugh, R. 1943. The vegetation of the granite flat rocks. Ecol. Monogr. 13: $120-166$.

Penne11, F.W. 1935. The Scrophulariaceae of eastern temperate North America. Acad. Nat. Sci. Philadelphia, Monogr. 1: 110-112. 
Torrey, J. 1837. An account of several new genera and species or North American plants. Ann. Lyc. Nat. Hist. N.Y. 80-94.

Sma11, J.K. 1933. Manual of the southeastern flora, pp. 1193-1194. Chapel Hi71, N.C. 


\begin{tabular}{|c|c|c|c|c|c|c|c|c|}
\hline \multirow[b]{2}{*}{$\begin{array}{l}\text { Expected* } \\
\text { Effect on } \\
\text { the Species }\end{array}$} & \multicolumn{8}{|c|}{ Management Practices } \\
\hline & $\begin{array}{c}\text { Prescribe } \\
\text { Burn }\end{array}$ & $\begin{array}{l}\text { Bulldoze } \\
\text { or } \\
\text { Root Rake } \\
\end{array}$ & Bed & Chop & $\begin{array}{l}\text { Thin } \\
\text { over- } \\
\text { story }\end{array}$ & \begin{tabular}{|l} 
Cut \\
over- \\
story
\end{tabular} & $\begin{array}{l}\text { Establish } \\
\text { Plantation }\end{array}$ & Graze \\
\hline Destroy & $\mathrm{NA}$ & $\mathrm{NA}$ & $\mathrm{NA}$ & IN A & & & NA & \\
\hline Damage & & & & & & & . & $\mathrm{x}$ \\
\hline $\begin{array}{l}\text { No Lasting } \\
\text { Effect }\end{array}$ & & & & & & & & \\
\hline $\begin{array}{l}\text { Beneficial } \\
\text { if Done } \\
\text { Properly }\end{array}$ & . & & & & $\mathrm{x}$ & $\mathrm{X}$ & & \\
\hline
\end{tabular}

Other Comments:

*Expected effect on the species is an estimate made by Dr. Robert Kral based on his knowledge of the habitat and on knowledge gained from personal field observations. Estimates are "rough" in many instances. Results of practices may be modified depending upon the degree of application, intensity of treatment, nearness to plant communities, etc. A management practice for which no entry is made indicates a lack of sufficient information from which to predict expected results. As observations are made in the field by users of the data, the expected effect will be refined. 
Amphianthus pusilius Torrey

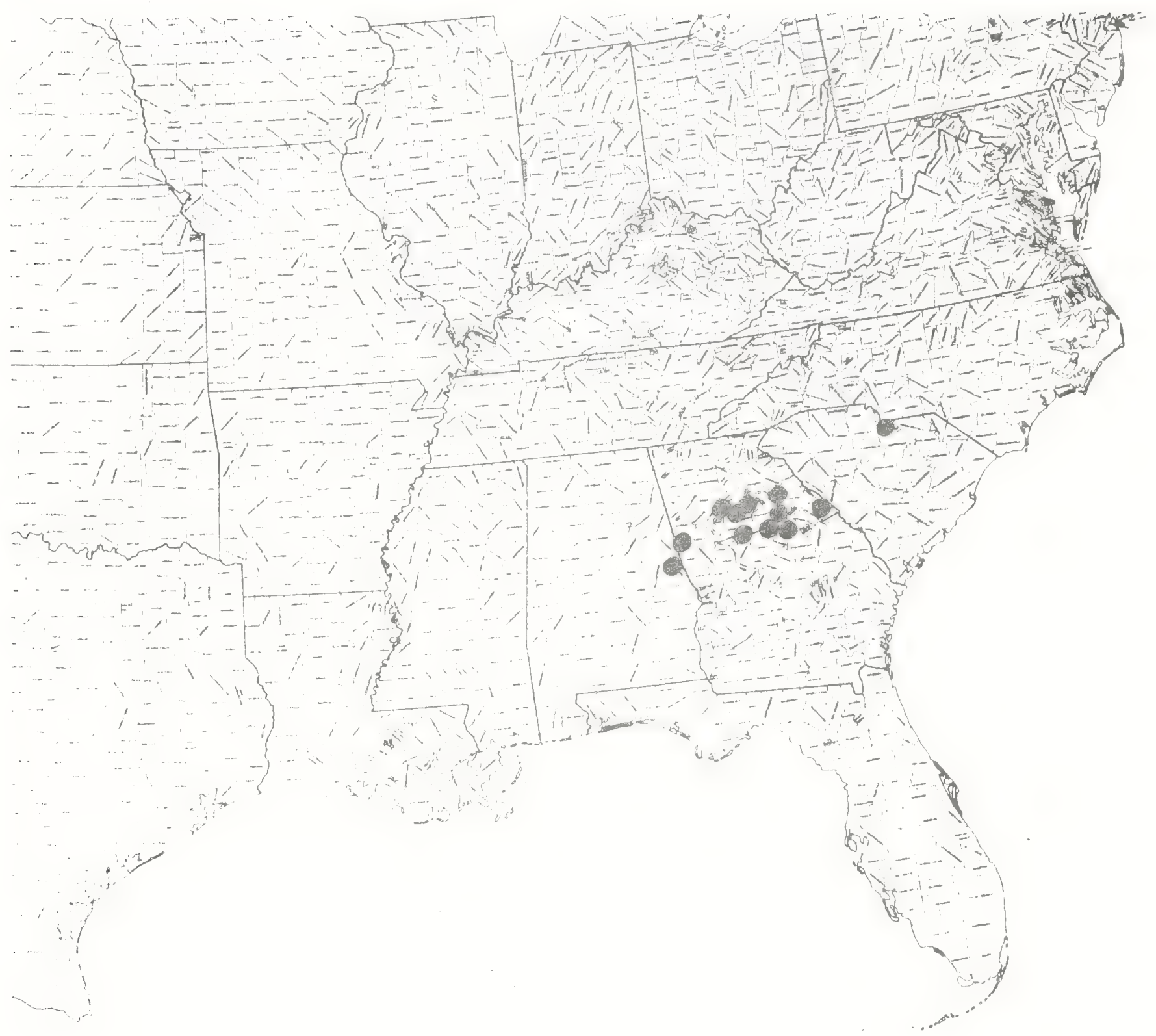


0

0

0 
Paper 201

Text \& Map by:

Robert Kral

\section{SOLANACEAE}

Solanum carolinense L. var. floridanum Chapm. Florida horse-nettle S. floridanum Shuttiw. ex Dun. in DC. non S. floridanum Raf.

S. godfreyi Shinners

\section{Technical Description}

Woody-based, monoecious perennial herb from a deep-set tuberous rootstock.

Stems.-- Erect or spreading, simple to copiously branching, 2-6 (-10) dm ta11, terete, yellow-green save for thin, cracking brownish bark at stem base, the surface smooth toward stem base, upwardly with scattered stellate haris, (these most abundant toward shoot tips) also sparingly to copiously armed with stiff, stoutbased, spreading yellow spines to $1 \mathrm{~cm}$ long.

Leaves.-- Alternate, simple, petiolate, the lowermost usually absent by flowering time, those toward middle of main axis largest, the blades deeply pinnately lobed, mostly $8-15 \mathrm{~cm}$ long, the lobes ranging from oblong to triangular, their tips rounded to acute, symmetrical or oblique, the sinuses broad; upper leaf surface deep yellow-green, with scattered steliate pubescence; lower surface paler, more copiously stellate-hairy, also spine-armed at least along the prominent mid-vein, sometimes along the major branch veins.

Inflorescence.-- Racemes developing between all or most upper leaf nodes, spreadingascending, mostly 6-12-flowered, coiled toward their tips, much elongating during the long flowering season, the female flowers lowermost, the axis spinose and stellate-hairy.

Flowers.-- Regular, unisexual on spreading (in femail becoming refluxed) slender, stellate-hairy pedicels reaching ca. $1 \mathrm{~cm}$ by anthesis; sepals 5, united, the calyx campanulate, green, stellate-hairy, the tube 2.0-2.5 mm long, the 5 ascending or spreading lobes subequal, narrowly triangular-subulate; petals 5, united, the corolla rotate, $3-4 \mathrm{~cm}$ wide, the spreading lobes $1.0-1.5 \mathrm{~cm}$ 1ong, triangular, the surface from white to lavender, the lobes stellate-purerulent medially on the backs, otherwise smooth; stamens 5, epipetalous toward corolla base, the stocky pale filaments ca. $1 \mathrm{~mm}$ long, the basifixed, linear-oblong, erect anthers yellow, ca. $1 \mathrm{~cm}$ long, opening by terminal pores; ovary superior, broadly ovoid, smooth or with scattered simple hairs, the style short-linear.

Fruit.-- Berries born on stiffly recurved stalks to $2 \mathrm{~cm}$ long, these gradually dilated toward apex, the calyx not enlarged but persistent around fruit base; body of fruit globose, $1.0-1.5 \mathrm{~cm}$ thick, gummy-meated, ripening yellow or orange-yellow; seeds numerous, flattened, nearly round, $2.5 \mathrm{~mm}$ broad.

Distribution and Flowering Time

Sandy clearings and open woodlands, northern Florida and adjacent south Georgia; flowering intermittently from late spring through the growing season.

Special Identifying Features

S. carolinense var. floridanum is distinguished from S. carolinense proper by its deeper pinnatifid leaves, but because of the frequency of intermediate leaf forms between the varieties, should perhaps be considered merely a form. 
Habitat and Management Implications

This Solanum is found on sandy soils, usually in clearings in disturbed, open hammocks, in fields or along roads. Sometimes it is found in swamp woodlands, but there only on sandy rises, usually where there has been some soi? cisturbance. This is usually where there has been some soil disturbance. This is plainly a weed, sometimes invades gardens or cultivated fields. Its tendency to grow along railroads, or highways, or in gardens, old fields and empty lots in towns would appear an indication that it would persist, even increase in numbers, with disturbance.

\section{References}

D'Arcy, W.G. 1974. Solanum and its close relatives in Florida. Ann. Mo. Bot. Gard. 61: $\overline{819-867 .}$

Chapman, A.W. 1860. Flora of the southern United States, p. 349. Cambridge, MASS.

Shinners, L.H. 1962. Solanum godfreyi Shinners, nom. nov. Sida 1: 108.

Sma11, J.K. 1933. Manual of the southeastern flora, pp. 1112-1116. Chapel Hill, N.C. 
SPECIES Solanum carolinense L。 var. floridanum Chapm.

Florida horse-nettle

\begin{tabular}{|c|c|c|c|c|c|c|c|c|}
\hline \multirow[b]{2}{*}{$\begin{array}{l}\text { Expected* } \\
\text { Effect on } \\
\text { the Species }\end{array}$} & \multicolumn{8}{|c|}{ Management Practices } \\
\hline & $\begin{array}{c}\text { Prescribe } \\
\text { Burn }\end{array}$ & $\begin{array}{c}\text { Bulldoze } \\
\text { or } \\
\text { Root Rake }\end{array}$ & Bed & Chop & $\begin{array}{l}\text { Thin } \\
\text { over- } \\
\text { story }\end{array}$ & $\begin{array}{l}\text { Cut } \\
\text { over- } \\
\text { story } \\
\end{array}$ & $\begin{array}{l}\text { Establish } \\
\text { Plantation }\end{array}$ & Graze \\
\hline Destroy & & & & & & & $\mathrm{X}$ & \\
\hline \multicolumn{9}{|l|}{ Damage } \\
\hline $\begin{array}{l}\text { No lasting } \\
\text { Effect }\end{array}$ & & $\mathrm{X}$ & $\mathrm{X}$ & $\mathrm{X}$ & & & & $x$ \\
\hline $\begin{array}{l}\text { Beneficial } \\
\text { if Done } \\
\text { Properly }\end{array}$ & $X$ & & & & $\mathrm{X}$ & $\mathrm{x}$ & & \\
\hline
\end{tabular}

Other Comments:

* lixpected cffect on the species is an estimate made by Dr. Robert Kral based on his knowledge of the habitat and on knowledge gained from personal field observations. Estimates are "rough" in many instances. Results of practices may he modified depending upon the degree of application, intensity of treatment, nearness to plant communities, etc. A management practice for which no cntry is made indicates a lack of sufficient information from which to prodict expectcd results. As observations are made in the field by users of the data, the expected effect will be refined. 
Solanum carolinense L. var. floridanum Chapm.

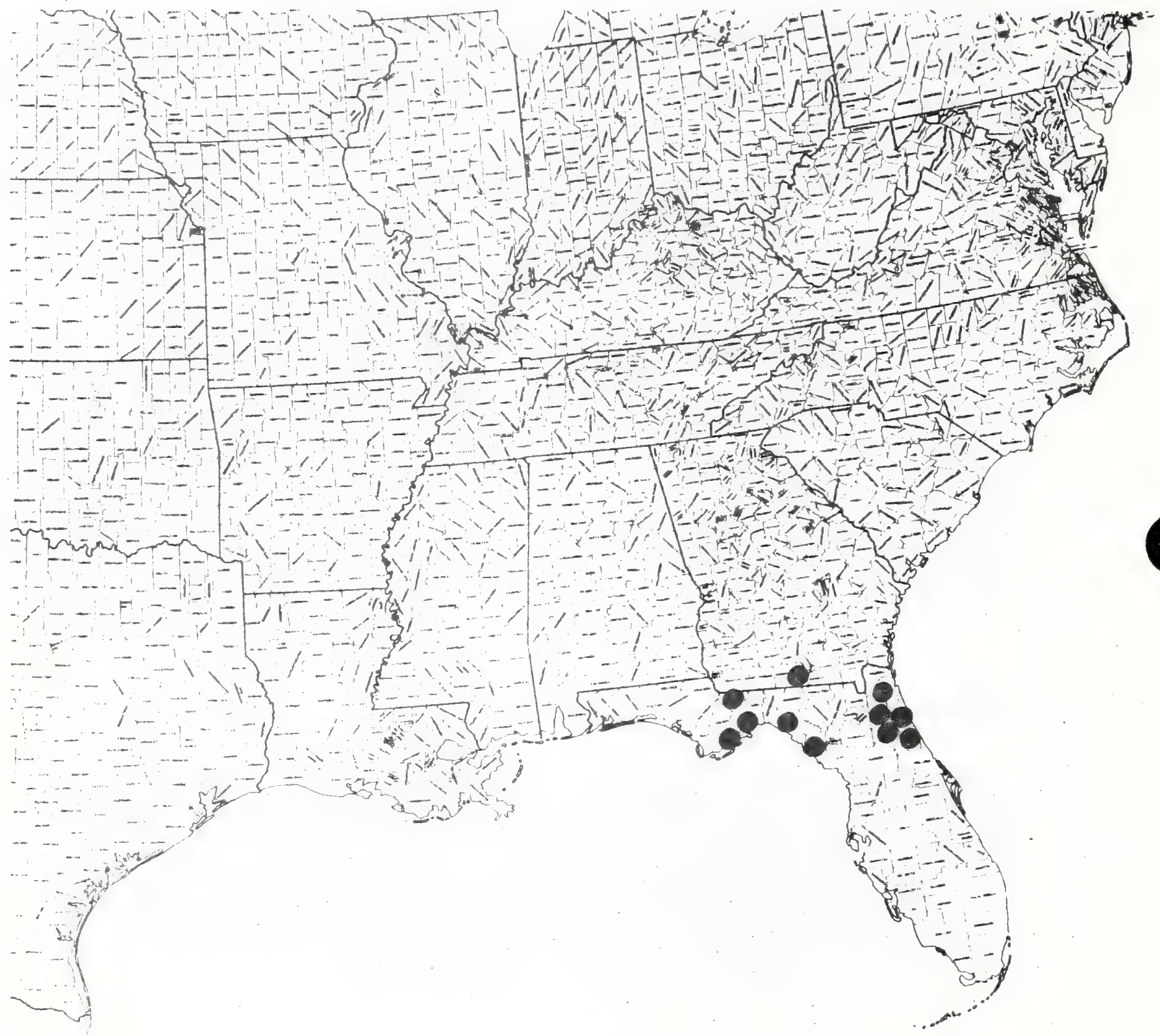


Paper 202

Text \& Map by:

Robert Kral

\section{TAXACEAE}

Taxus floridana Cahpm. Florida yew

Technical Description

Faint7y but pleasant7y aromatic, broad-and-flattish-crowned, smooth, mostly dioecious shrub or small tree at most to 8 meters tal7, the trunk usually leaning, usually asymmetrical, the bark thin, purplish-brown or gray-brown, separating into sma 11 plates.

Branchlets.-- Slender, often spreading, the newest growth pale green, covered with the flattened, spiralled, adherent sterigma bases, these later turning brownish or reddish-purple as the bark forms.

Leaves.-- Spirally arranged but twisted on the "petiole" so as to form flattened sprays or a broad " $v$ " trough, linear, mostly $1.0-2.5 \mathrm{~cm}$ long, soft, ca. $2 \mathrm{~mm}$ broad, short-acuminate to a sharp but weak point, entire and concavely revolute, the upper surface a deep, lustrous green, the lower surface much paler, yellow-green, with 2 strong stomatiferous bands one on each side of the raised midrib, the blade narrowing to an ascending or erect, petiole-like constriction ca. $1 \mathrm{~mm}$ long, this articulated to the decurrent, flattened sterigma base.

Male Reproductive Structure.-- Male cones subglobose, yellowish roundish, ca. $3 \mathrm{~mm}$ broad, projecting on short, erect stalks slightly beyond the tips of acuminate tips of axillary, imbricate-scaley "flower buds", the sporangia borne under heads of tack-7ike sporophyl1s, these produced in a few whor is in each cone. Fema le Reproductive Structure.-- Ovules erect, solitary, each enclosed in a small, imbricate-scaley, pale green axillary bud (which much resembles an ordinary shoot bud), with only the micropylar end of the aril protruding. Ripe oval ovoid or obovoid, ca. 5-7 mm long, in a globular fleshy, red aril cup nearly $1 \mathrm{~cm}$ broad.

Distribution and Flowering Time

Understory to mesic (or swamp) forest species in steep ravines (rarely swamps) mostly along the east bank of the Apalachicola River in Gadsden and Liberty Counties, Florida (also in a Chamaecyparis swamp ca. 8 mi. southeast of Bristol). Pollen shed and received during March.

\section{Special Identifying Features}

T. floridana is unlike any other gymnosperm within its smali range, its nearest eastern North American relative being $T$. canadensis, a lower species of the north and northeast, locally into the southern Appalachians but still removed in range several hundred miles. In some ways it superficially resembles Torreya, but has shorter, narrower, softer foliage and a much different aril character (for details consult information under Torreya taxifolia!) 
Habitat and Management Implications

I. floridana is usually in the same habitat as Torreya taxifolia (which see!), though, as noted above, it has one anomalous habitat. It is a shade requiring species so that logging disturbance of the overstory would create a much drier, sunnier, warmer site than it or its reproduction would tolerate. The largest numbers of this rare species are now found within the boundaries of Torreya State Park. Outside the Park, on private lands, the main danger faced by the species is from excessive cutting of overstory species of pine and hardwood, this admitting too much 1 ight and heat and also accelerating soil erosion on the steeper sites.

References

Kurz,H. \& R.K. Godfrey. 1962. Trees of northern Florida, pp. 1-2. Gainesville. Nutta11, T. North American Sylva III: 92.

Sargent,C.S. 1921. Trees of North America, Dover Press ed., pp. 95-95.

Sma 11,J.K. 1933. Manual of the southeastern flora, p. 12. Chapel Hill. 
SPECIES Taxus floridana Nutt. Florida yew

\begin{tabular}{|c|c|c|c|c|c|c|c|c|}
\hline \multirow[b]{2}{*}{$\begin{array}{l}\text { Expected* } \\
\text { Effect on } \\
\text { the Species }\end{array}$} & \multicolumn{8}{|c|}{ Management Practices } \\
\hline & $\begin{array}{c}\text { Prescribe } \\
\text { Burn }\end{array}$ & $\begin{array}{l}\text { Bulldoze } \\
\text { or } \\
\text { Root Rake }\end{array}$ & Bed & Chop & $\begin{array}{l}\text { Thin } \\
\text { over- } \\
\text { story }\end{array}$ & $\begin{array}{l}\text { Cut } \\
\text { over- } \\
\text { story }\end{array}$ & $\begin{array}{l}\text { Establish } \\
\text { Plantation }\end{array}$ & Graze \\
\hline Destroy & $x$ & $\mathrm{x}$ & $\mathrm{x}$ & $\mathrm{x}$ & & $X$ & & \\
\hline Damage & & & & & $\mathrm{x}$ & & & * \\
\hline $\begin{array}{l}\text { No Lasting } \\
\text { Effect }\end{array}$ & & & & & & & & \\
\hline $\begin{array}{l}\text { Beneficial } \\
\text { if Done } \\
\text { Properly }\end{array}$ & & & & & & & & \\
\hline
\end{tabular}

Other Comments: Taxus is one of the most deadly stock poisons!

*xpected effect on the species is an estimate made by Dr. Robert Kral based on his knowledge of the habitat and on knowledge gained from personal field observations. Estimates are "rough" in many instances. Results of practices may be modified depending upon the degree of application, intensity of treatment, nearness to plant communities, etc. A management practice for which no entry is made indicates a lack of sufficient information from which to predict expected results. As observations are made in the field by users of the data, the expected effect will be refined. 
Taxus floridana Chapman

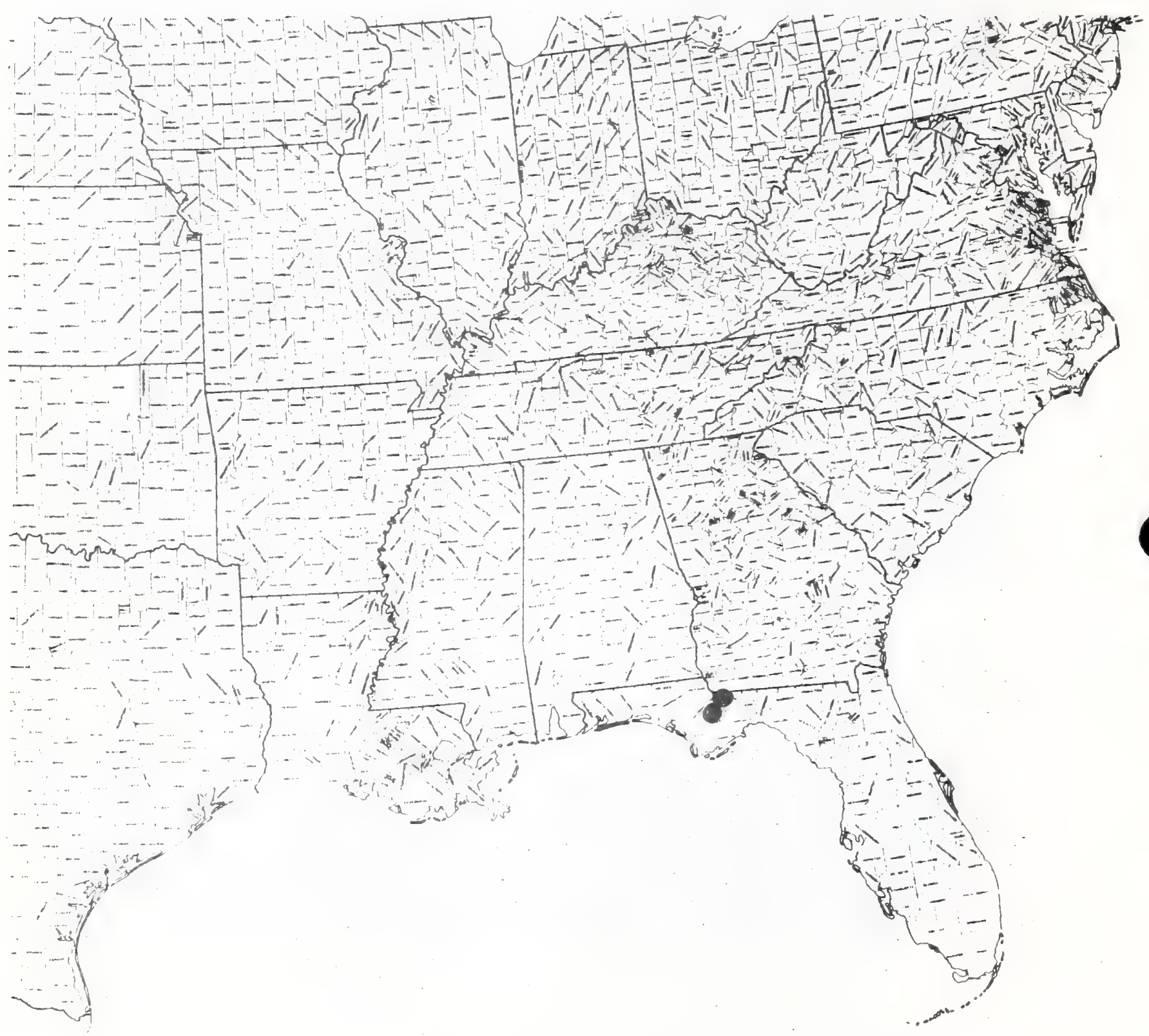


Paper 203

Text \& Map by:

Robert Kral

\title{
TAXACEAE
}

\author{
Torreya taxifolia Arn. Florida correya \\ Tumion taxifoTium (Arn.) Greene
}

Technical Description

Sma 11, dioecious tree (formerly to ca. 18 meters ta $17,6 \mathrm{dm}$ dbh), usually with but a single, evenly tapering bole, the bark thin, grayish or graybrown, braided and shredding cedar-iike, the inner bark orangish, the fresh-cut wood unpleasantly pungent. Crown broadly pyramidal, the main branches whorled, spreading or slightly declined, the ultimate branching plane, stiff. Branchlets smooth, arising mostly oppositely from scaley shoot buds developing from swollen branch tips and branch nodes, green, smooth, narrowly grooved between the elongate, flattened, spirally arranged sterigma bases.

Leaves.-- Evergreen, smooth, persistent 3-4 years, spirally arranged but by a "petiolar" twist appearing distichous (in 1 plane) much as in the yews, rigid, lance-linear, 2-4 cm long, ca. 3-4 mm broad, rigidly subulatetipped, concavely revolute, narrowed at base to a petiole-like constriction ca. I mm long which includes the "joint" connecting it to the jutting sterigma apex which in turn flares to a flattened sterigma base adherent to the branchlet; upper leaf surface a dark lustrous green; lower leaf surface dull pale green with a broad pale stomatiferous band on either side of the raised midrib.

Male Reproductive Structure... Microsporangia clustered, pendulous on sporangiophores clustered in round, sma 17, yel7owish cones ca. $5 \mathrm{~mm}$ long, on stiffly spreading stalks from tips of stramineous ovoid, imbricatescaley axillary buds.

Female Reproductive Structure.-. Ovules arising singly and terminally from imbricate axillary buds, erect, nearly sessile, only the micropyle projecting from the enfolding bud scale tips; ripe ovule in size and shape comparable to a green olive, ellipsoidal, smooth, $3-4 \mathrm{~cm}$ long, green and glaucous, later turning purple, the aril (fleshy covering of seed) fleshy, later leathery, somewhat thin, the seed coat within woody.

Distribution and Anthes is

Rich wooded slopes or rises in calcareous bottoms, Apalachicola River basin, northwestern Florida and southwestern contiguous Georgia with a presently known range including but 3 counties in Florida, 1 in Georgia. Shedding and receiving pollen in March and Aprit.

\section{Special Identifying Features}

This small tree, whose nearest relative is Torreya californica, a species confined to the western slopes of the Sierra Nevada and coast ranges of California, bears no resemblance to any other southeastern area gymnosperm unless it be Taxus floridana, a species of yew with a similar habitat and range. The yew differs in having a lower, more spreading corwn, shorter, 
softer leaves; and a much smaller ovule surrounded by a fleshy, cuplike, bright red aril.

Habitat and Management Implications

T. taxifolia grows as understory in rich hardwood hammock forest. The soil is a rich, dark, moist sandy loam, the best stands once on steep sides of ravines at and below Chattahoochee southward to Bristol along the east side of the Apalachicola River. Overstory species include Magnolia grandiflora, several species of Quercus (particularly Q. alba, Q. nigra, Q. shumardi , Q. falcata, Q. hemisphaerica), Carya, Fraxinus, Acer saccharum subspecies, Acer rubrum, Pinus glabra, $\mathrm{P}$. taeda, etc. Associated understory species include Cornus fTorida, Cercis, Magnolia pyramidata, M. ashei, Persea, Myrica, etc. clearcutting of the hardwoods and pine, some of which are Targe and valuable has in the past had an adverse effect on the Torreya trees which are intolerant of much light. One of the best areas for the trees was Torreya State Park where the main danger to them (as in other areas) was once the rampant rooting up of seedlings and young speciments by uncontrolled numbers of wild hogs. This trouble could have been overcome, but in the early 1960's the trees throughout their small range were attacked by a root rot organism which destroyed all of the larger specimens. Today there are but few survivors, these, in the main, widely scattered young trees or suckers from root systems of older individuals. The prognosis for this species in the wild is bad. There are a few large speciments still undamaged in cultivation in botanical gardens or nurseries from which cuttings are occasionally rooted but moving of these back to original localities will be difficult.

\section{References}

Arnott, G. 1838. On the genus Torreya. Ann. Nat. Hist. 1: 126-132.

Kurz, H. and R.K. Godfrey. 1962. Trees of northern Florida, pp. 2-3. Gainesville, FLA.

Sargent, C.S. 1921. Trees of North America, Dover Press ed., pp. 91-92.

Sma11, J.K. 1933. Manual of the southeastern flora, pp. 11-12. Chapel Hil1, N.C. 
SPECTES Torreya taxifolia Arn. Florida torreya

\begin{tabular}{|c|c|c|c|c|c|c|c|c|}
\hline \multirow[b]{2}{*}{$\begin{array}{l}\text { Expected* } \\
\text { Effect on } \\
\text { the Species }\end{array}$} & \multicolumn{8}{|c|}{ Management Practices } \\
\hline & $\begin{array}{c}\text { Prescribe } \\
\text { Burn }\end{array}$ & $\begin{array}{c}\text { Bulldoze } \\
\text { or } \\
\text { Root Rake }\end{array}$ & Bed & Chop & $\begin{array}{l}\text { Thin } \\
\text { over- } \\
\text { story }\end{array}$ & $\begin{array}{l}\text { Cut } \\
\text { over- } \\
\text { story }\end{array}$ & $\begin{array}{l}\text { Establish } \\
\text { Plantation }\end{array}$ & Graze \\
\hline Destroy & $\mathrm{X}$ & $\mathrm{x}$ & $\mathrm{X}$ & $\mathrm{X}$ & & $\mathrm{X}$ & & \\
\hline Damage & & & & & $\mathrm{X}$ & & & \\
\hline $\begin{array}{l}\text { No Lasting } \\
\text { Effect }\end{array}$ & & & & & & & & \\
\hline $\begin{array}{l}\text { Beneficial } \\
\text { if Done } \\
\text { Properly }\end{array}$ & & & & & & & & \\
\hline
\end{tabular}

\section{Other Comments:}

*lixpected effect on the species is an estimate made by Dr. Robert Kral based on his knowledge of the habitat and on knowledge gained from personal field observations. Estimates are "rough" in many instances. Results of practices may be modified depending upon the degree of application, intensity of treatment, nearness to plant communities, etc. A management practice for which no entry is made indicates a lack of sufficient information from which to predict expected results. As observations are made in the field by users of the data, the expected effect will be refined. 
Torreya taxifolia Arn.

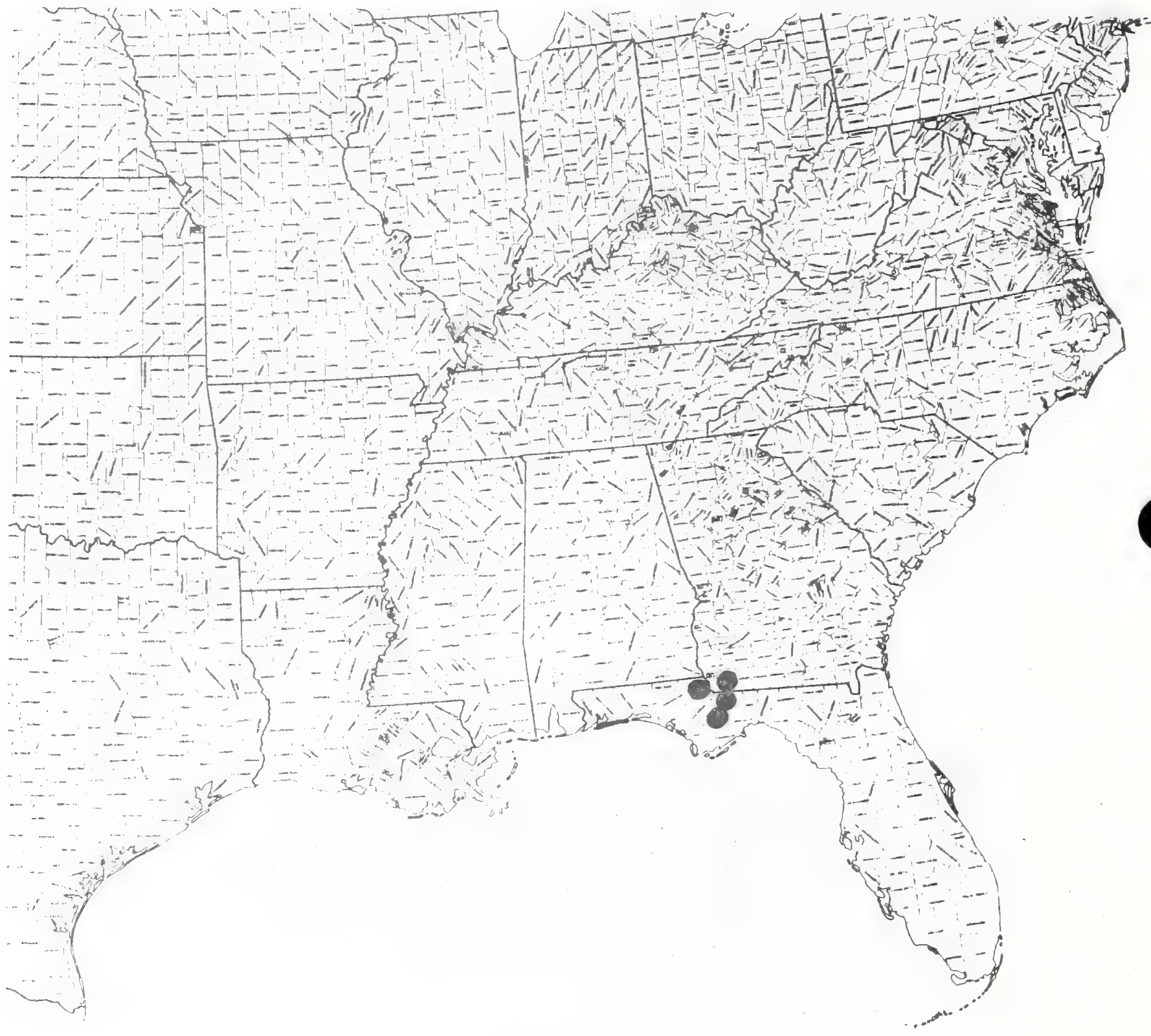


Paper 204

Text \& Map by:

Robert Kral

\section{VERBENACEAE}

Verbena tampensis Nash. Tampa vervain
GTanduTaria tampensis (Nash) Smal1

\section{Technical Description}

Perennial herb from a short shallow rhizome or from short lateral offshoots. Stems.-- Few to several, erect to ascending, but usually decumbent, often rooting from lower nodes, mostly 3-6 dm long, sometimes leaning on other vegetation, quandrangular, sparingly to copiously strigillose from base to inflorescence, usualiy purplish or purplish-green.

Leaves.-- Opposite, the basal smallest, the largest usually at or about mid-stem, these grading gradually smaller upward to an essentially leafless, variously elongate peduncle; blades mostly ovate, acute, mostly $4-6 \mathrm{~cm}$ long, the margin unevenly coarsely serrate, rarely incised-parted below the middle, the base broadly cuneate, then abruptly attenuated, the prominent (1-3 cm) petiole thus wing-margined to near its base; upper leaf surface dark green, strigillose; lower leaf surface paler, strigose along the veins, strigose-puberulent between.

Inflorescence.-- A more or less prominently pedunculate indeterminate bracteate spike, this at first compact, nearly as wide as long, later elongating to as much as $1 \mathrm{dm}$, with the lower flowers (by then fruit) scattered; bracts linear-lanceolate, corasely ciliate, strigillose, shorter than the calyx. Flowers.-- Slightly zygomorphic, bisexual; calyx tubular, ca. $1 \mathrm{~cm}$ long, the tube 5-ribbed, greenish, strigillose, the ribs purplish, prolonged to become the midribs of the 5, narrowly triangular-subulate, unequal calyx lobes: corolla slightly zygomorphic, salverform, the pale tube to $1.5 \mathrm{~cm}$ long, puberulent, the spreading $1 \mathrm{imb} 1.5-1.8 \mathrm{~cm}$ broad, the lobes shortoblong or obovate, usually apically notched, the lowest largest, the rim dinesely coated with short, white, glandular hairs, the upper surface a deep lively lavender, the lower surface pale; stamens 4, diadelphous, attached high in the corolla tube; ovary superior, short-oblong, shallow 4lobed, the style elongate, linear, shorter than corolla tube, apically dilated into a 2-lobed concave, glandular stigma.

Fruit.-- of 4 oblong-linear nutlets ca. $4 \mathrm{~mm}$ long, toward the rounded apex ridged-reticulate, toward the somewhat broadened base longitudinally ridged, the inner (contact) faces toward apex with fine, white papillae.

\section{Distribution and Flowering Time}

Sandy coastal hammocks, clearings, middle and southern peninsular Florida; flowering all year, but mostly March to June.

\section{Special Identifying Features}

Some problems exist in distinguishing this from the widespread (extending southward into northern peninsular Florida) V. candensis, and southern

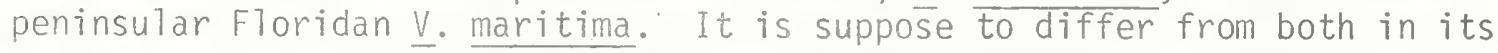


shorter corolla tube which is but little (7ess than 1/2 1onger) longer than the calyx, and the tendency for its leaves to be less parted or deeply incised. Its corollas are broader-limbed than is true norm 71 y for $\mathrm{V}$. maritima. However, where $V$. canadensis overlaps in range, there are morphological intermediates, particuTarly with V. maritima. Even "good" V. tampensis will show some range in length of coroTla tube on the same plant, thus the strongest character is perhaps not consistent.

Habitat and Management Implications

$\underline{V}$. tampensis is a species of well drained sandy clearings or open hammocks, mostly of the cabbage palmetto-live oak type or in slash or longleaf pinesaw palmetto flats, generally not far from the present seacoast or at least along tidally influenced rivers inland. It is often found in disturbed areas, is often in or by recent clearings. Drainage may increase its area; as may soil disturbance to create sandy openings, and its presence in firedisturbed pinelands would indicate that it is not negatively responding to fire.

\section{References}

Long, R.W. and 0. Lakela, 1971. A flora of tropical FTorida, pp. 740-742. Miami, FLA.

Perry, L. 1933. A revision of the North American species of Verbena. Ann. Mo. Bot. Gard. 20: 239-363.

Sma11, J.K. 1905. Bul1. N.Y. Bot. Gard. 3: 436.

- 1933. Manual of the southeastern flora, pp. 1128-1129. 
SPECIES Verbena tampensis Nash. Tampa vervain

\begin{tabular}{|c|c|c|c|c|c|c|c|c|}
\hline \multirow[b]{2}{*}{$\begin{array}{l}\text { Expected* } \\
\text { Effect on } \\
\text { the Species }\end{array}$} & \multicolumn{8}{|c|}{ Management Practices } \\
\hline & $\begin{array}{c}\text { Prescribe } \\
\text { Burn }\end{array}$ & $\begin{array}{c}\text { Bulldoze } \\
\text { or } \\
\text { Root Rake }\end{array}$ & Bed & Chop & $\begin{array}{l}\text { Thin } \\
\text { over- } \\
\text { story }\end{array}$ & $\begin{array}{l}\text { Cut } \\
\text { over- } \\
\text { story }\end{array}$ & $\begin{array}{l}\text { Establish } \\
\text { Plantation }\end{array}$ & Graze \\
\hline Destroy & & $\mathrm{X}$ & $\mathrm{X}$ & $\mathrm{X}$ & & & $\bar{X}$ & \\
\hline Damage & & & & & & & & $\mathrm{X}$ \\
\hline $\begin{array}{l}\text { No lasting } \\
\text { Effect }\end{array}$ & $x$ & & & & & & & \\
\hline $\begin{array}{l}\text { Beneficial } \\
\text { if Done } \\
\text { Properly }\end{array}$ & & & & & $\mathrm{x}$ & $\mathrm{x}$ & & \\
\hline
\end{tabular}

Other Conments:

* Expected effect on the species is an estimate made by Dr. Robert Kral based on his knowledge of the habitat and on knowledge gained from personal field observations. Estimates are "rough" in many instances. Results of practices may be modified depending upon the degree of application, intensity of treatment, nearness to plant communities, etc. A management practice for which no entry is made indicates a lack of sufficient information from which to predict expected results. As obsemations are made in the field by users of the data, the expected effect will be refined. 


\section{Verbena tampensis Nash}

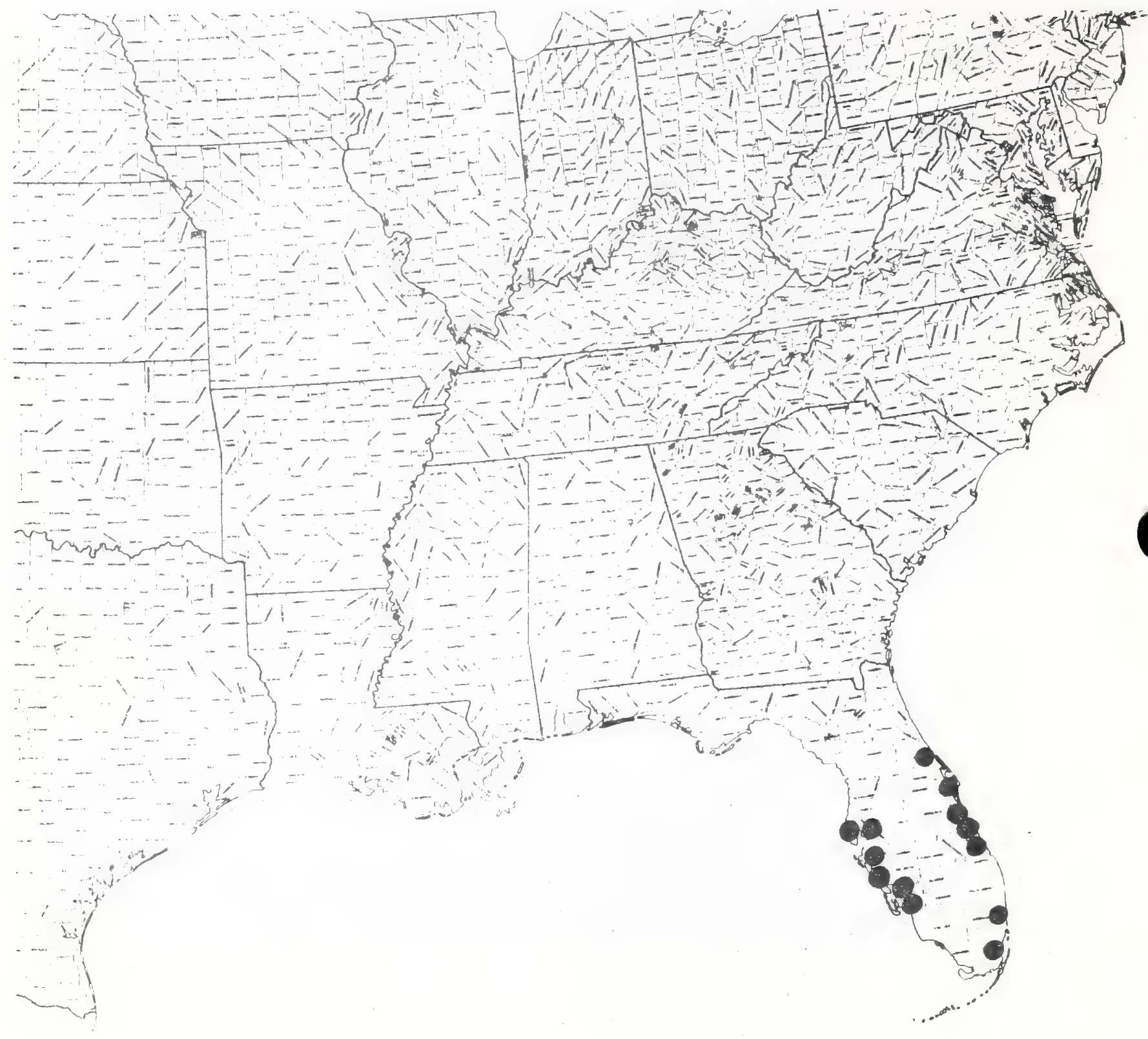


Paper 205

Text \& Map by:

Robert Kral

\title{
SARRACENIACEAE
}

\author{
Sarracenia psitticina Michx. parrot pitcher-plant
}

\section{Technical Description}

Rhizomatous, rosette-forming, smooth, scapose, perennial, insectivorous herb. Stems.-- Short, usually ascending, densely covered by spirally arranged Teaf bases, arising from stoutish, variously elongate, shallowly set rhizomes. Leaves... Of two sorts, one scale-like (squamelloid), deltoid, acuminate, overtapping, on the rhizome, the other ascidiform (joined by the margins to form a "pitcher") mostly $8-15(-20) \mathrm{cm}$ long, making up the rosette, the bases clasping, overlapping, in a tight spiral, spreading-ascending, viewed from the side sigmoid with the apex incurved, the petiole gradually widening distally, on the ventral (upper, in) side flattening and dilating into a broad wing, this broadest in the upper $1 / 3$ and narrowing more abruptly into the pitcher rim, the pitcher tube very narrowly funnelform, toward the apex purplereticulate, the areolae pale, transluscent, the pitcher hood saccate-ovoid, "bubble-like", acute, incurved over the pitcher orifice, its inflated back purple-reticulate, also with transluscent, pale areoles.

Inflorescence.-- Flowers solitary, nodding at apex of terete, fistulose, scales mostly $15-30 \mathrm{~cm}$ long, perfect, regular; bracts 3 , whorled, oblong-triangular, blunt, reddish-green or maroon, ca. 5-8 mm long, spreading or reflexed; sepais mostly 5, bluntly ovate-triangular, 2-3 cm long, spreadingincurved, the backs maroon, the upper surfaces paler, usually greener; petals mostly $5,2.0-4.5 \mathrm{~cm}$ long, the short, pale claws hooked over the peltate stylar apex, the oblong-ovate, panduriform (like violin body) blades reddish-maroon, flat, pendulous; stamens numerous, the sigmoid or straight, slender pale filaments fascicled, of various lengths, the anthers dorsifixed, horseshoe-shaped ca. $2 \mathrm{~mm}$ long, 2-locular, extrorse, these and the filaments concealed by the umbrella-shaped, pale yellow-green stylar apex; ovary superior, 5-locular, the stigmas "teat-jike" at and below the bific apex of the angles of the style lobes.

Fruit.-- A subglobose, loculicidal capsule ca. $1 \mathrm{~cm}$ broad, moderately tuberculate; seeds bluntly obtriangular, $1.5-2.0 \mathrm{~mm}$ long.

\section{Distribution and Flowering Time}

Bogs and margins of acid flatwoods ponds and streams, clearings in titi swamps, Coastal Plain, southeastern Georgia south to northeastern Florida and westward through the Gulf Coastal Plain into the Florida parishes of Louisiana; flowering from late March through May.

\section{Special Identifying Features}

This pitcherplant is the only one in the southeastern area to combine small size of pitcher with the odd "bubble-like" pitcher hood, broad pitcher wing, small purplish-maroon flowers (similar superficially to those of $S$. rubra), and an areolar pattern similar to that of $S$. leucophylla and $S$. minor. It hybridizes in nature with $S$. purpurea ( $\bar{S}$. $\overline{\text { catesbaei) }}$, with $\underline{S}$. $\overline{\text { alata }}$ (ac- 
cording to Dr. S. McDaniel, whose treatment is consulted in preparation of this report).

Habitat and Management Implications

S. psittacina, as is true of the other Sarracenia, is a plant of boggy, high-hydroperiod, peaty or sphagnous sites such as are found in flatwoods depressions, seep slopes, acidic swamps, wet savannas, or bogs. It is usually in full sun or light shade, is part of a grass-sedge formation, tends to be crowded and shaded out by invading shrub or tree complexes, and tends to increase when this is reduced either by clear-cutting or fire. It is totally eliminated or drastically reduced by any form of mechanical site preparation, either in the first process, which usually also involves drainage ditching of the wetlands or later, when the planted or seeded pine closes over the grasssedge formation and shades it out. This sma11, interesting species is also much abused by those who dig up the plants for sale. Management to maintain it and other pitcher plant species has to involve controlled burning to retard forest successional pressures, together with a light enough stocking of pine (preferably longleaf or slash) to insure that enough light reaches the plants, and an absolute adherence to a high soil moisture regimen.

\section{References}

Harper, R.M. 1918. The American pitcher plants. J. Elisha Mitchell Sci. Soc. 34: 110-125.

MCDaniel, Sidney. 1971. The genus Sarracenia (Sarraceniaceae). Bull Ta11 Timbers Res. Sta. 9: 1-26.

Sina11, J.K. 1933. Manual of the southeastern flora, pp. 580-583. Chapel HiT1, N.C. 
SPECIES Sarracenia psittacina Michs. Parrot pitcher-plant

\begin{tabular}{|c|c|c|c|c|c|c|c|c|}
\hline \multirow[b]{2}{*}{$\begin{array}{l}\text { Expected* } \\
\text { Effect on } \\
\text { the Species }\end{array}$} & \multicolumn{8}{|c|}{ Management Practices } \\
\hline & $\begin{array}{c}\text { Prescribe } \\
\text { Burn }\end{array}$ & $\begin{array}{c}\text { Bulldoze } \\
\text { or } \\
\text { Root Rake }\end{array}$ & Bed & Chop & $\begin{array}{l}\text { Thin } \\
\text { over- } \\
\text { story }\end{array}$ & $\begin{array}{l}\text { Cut } \\
\text { over- } \\
\text { story }\end{array}$ & $\begin{array}{l}\text { Establish } \\
\text { Plantation }\end{array}$ & Graze \\
\hline Destroy & & $x$ & $x$ & $\mathrm{x}$ & & & $\mathrm{x}$ & \\
\hline Damage & & & & & & & & $\mathrm{x}$ \\
\hline $\begin{array}{l}\text { No Lasting } \\
\text { Effect }\end{array}$ & & & & & & & & \\
\hline $\begin{array}{l}\text { Beneficial } \\
\text { if Done } \\
\text { Properly }\end{array}$ & $\mathrm{X}$ & & & & $\mathrm{X}$ & $\mathrm{X}$ & & \\
\hline
\end{tabular}

Other Comments: Site drainage destroys this species!

*Expected effect on the species is an estimate made by Dr. Robert Kral based on his knowledge of the habitat and on knowledge gained from personal field observations. Estimates are "rough" in many instances. Results of practices may be modified depending upon the degree of application, intensity of treatment, neamess to plant communities, etc. A management practice for which no entry is made indicates a lack of sufficient information from which to predict expected results. As observations are made in the field by users of the data, the expected effect will be refined. 
Sarracenia psittacina Michx.

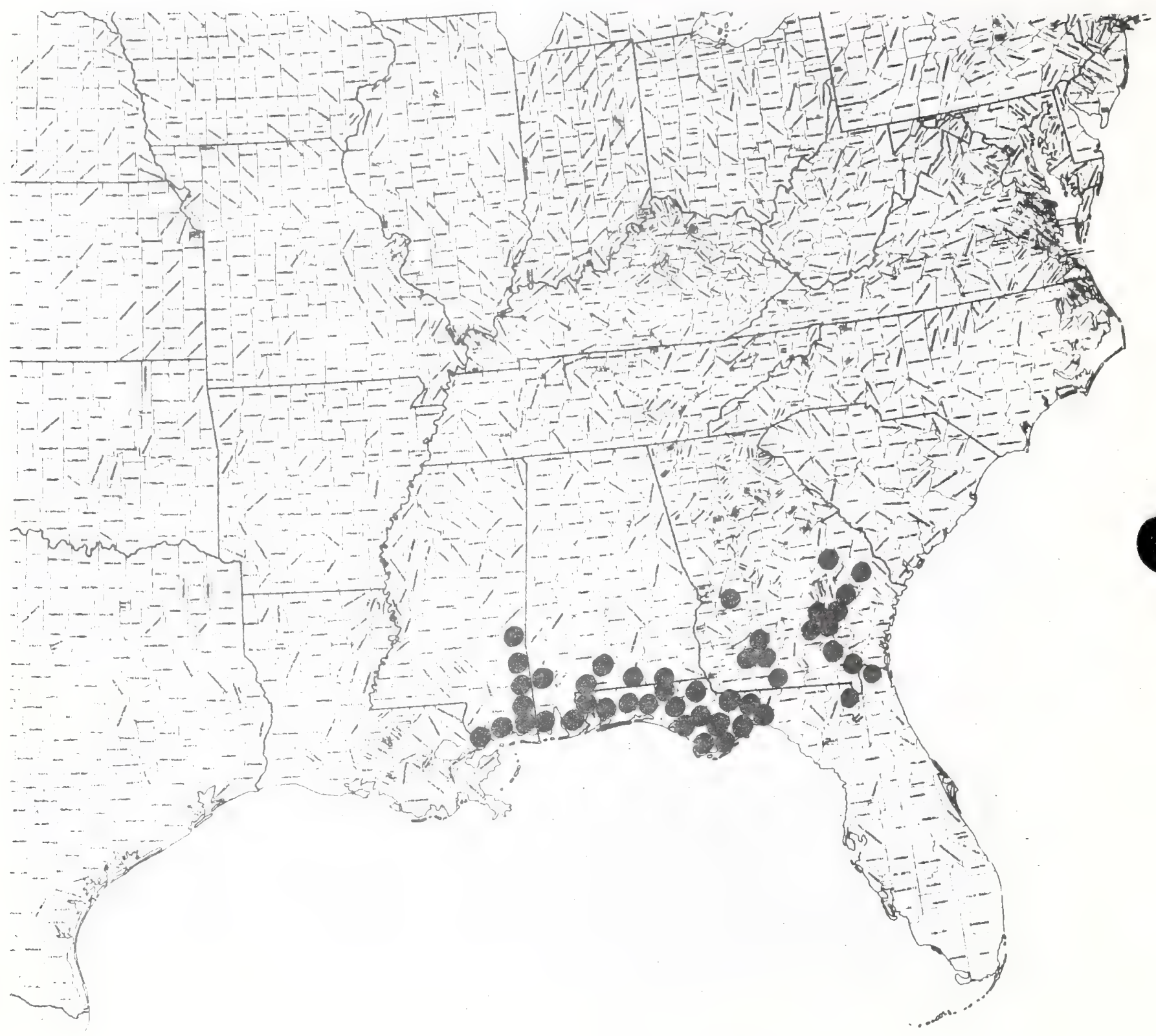




\title{
OPHIOGLOSSACEAE
}

\author{
Ophioglossum parmatum L. hand adder's-tongue fern \\ Cheiroglossa palmata (L.) Pres]
}

\section{Technical Description}

Epiphtic perennial fern from a round-iuberous rhizome, the rhizome surface covered by a wooly chaff of narrow scales, the roots fleshy, containing endophytic fungus.

Fronds.-- Glabrous, usually 2 or 3 from the rhizome, the "petiole" fleshy but flattened, narrowly strap-like, dilating distally into a pendulous, handlike, similarly fleshy but flat blade, this broad, I-4 dm long (nearly as wide or wider), dissected into 2-9, oblong or broadly linear, erect or flabellately spreading lobes, these narrowed acutely, acuminately or rounded, truncate or even retuse, and varied in length (rarely undivided as in the "normal" adders - tongue species), often reminiscent of Laminaria type kelp, the frond base attenuated co the stalk, the venation areolate (anastomosing, closed); fertile segments (1-) 2-many (-16) arising from the upper rachis or from the blade base, the massive, rounded sporangia many in 2 continuous rows in linear spikes, these mostly 7 inear-oblong, $2.5-5.0 \mathrm{~cm}$ long, on narrower ascending stalks as long as the spikes or longer.

Distribution and Sporing Season

Epiphytic, in the "wickerwork" of old petiolar bases of cabbage palm, moist rich hammocks, peninsular Florida; producing spores all year.

\section{Special Identifying Features}

The family Ophioglossaceae is distinguished from other ferns by a combination of tuberous rhizome, sporangia massive, in spikes or panicle-like clusters from stipe or leaf. Two genera are native. Ophioglossum is distinguished by the anastomosing (closed) frond venation, the simple or less-dissected leaf, the sporangia borne in spikes (in Botrychium the usually more dissected frond has open venation, the sporangia are produced in branched (panicled) systems). All other Ophioglossum in North America have vegetative leaves simple, unlobed, and are smaller plants than 0. palmatum, which is also distinguished by its unique ecological niche and exclusively epiphytic habit.

Habitat and Management Implications

0. palmatum almost invariably is found on Sabal palmetto, is commonly associated with various Bromeliaceae, ferns such as Polypodium aureum, Vittaria lineata. However, the Ophioglossum has a unique $\bar{n}$ che on the palm in that its fleshy, fuzzy rhizome is imbedded in the detritus that collects within the large persistent petiole bases of the palm. The stipes of the frond grow upward and out from behind the palm petiole bases, protruding and bending downward apically, thus the "hand-7ike" blade droops. The plants are most abundant in the moister hammocks, thus are more abundant where there is often shallow standing or flowing water a good part of the year, less abundant 
on palms of hammock edges or in open or dryer hammock. Since the "wickerwork" of palm petiole bases ultimately breaks away from the bole, the fern falls with these old petioles and dies. Thus, the greatest threat to this once (according to Smal1) abundant fern comes. with fire which, while it may not kill the palm, will burn away the old leaf bases which are the habitat of the fern. Since most of the original cabbage palm hammock of Florida has been burned severely at least once, protection of what is left of this habitat is mandatory. Some hammocks are still being burned to "open". up area for livestock. Other hammock habitat has been lost through drainage and subsequent industrial and/or residential development; still more has been drained for conversion to Citrus culture.

References

Sma17, J.K. 1938. Ferns of the southeastern states, pp. 346-379. Lancaster, $\mathrm{Pa}$. 
SPECIES Ophioglossum palmatum L。 Hand adder ${ }^{\circ}$ s-tongue fern

\begin{tabular}{|c|c|c|c|c|c|c|c|c|}
\hline \multirow[b]{2}{*}{$\begin{array}{l}\text { Expected* } \\
\text { Effect on } \\
\text { the Species }\end{array}$} & \multicolumn{8}{|c|}{ Management Practices } \\
\hline & $\begin{array}{c}\text { Prescribe } \\
\text { Burn }\end{array}$ & $\begin{array}{c}\text { Bulldoze } \\
\text { or } \\
\text { Root Rake }\end{array}$ & Bed & Chop & $\begin{array}{l}\text { Thin } \\
\text { over- } \\
\text { story }\end{array}$ & $\begin{array}{l}\text { Cut } \\
\text { over- } \\
\text { story }\end{array}$ & $\begin{array}{l}\text { Establish } \\
\text { Plantation }\end{array}$ & Graze \\
\hline Destroy & $\mathrm{X}$ & $\mathrm{X}$ & $x$ & $\mathrm{X}$ & & $x$ & $X$ & \\
\hline Damage & & & & & $x$ & & & $\mathrm{x}$ \\
\hline $\begin{array}{l}\text { No lasting } \\
\text { Effect }\end{array}$ & & & & & & & & \\
\hline $\begin{array}{l}\text { Beneficial } \\
\text { if Done } \\
\text { Properly }\end{array}$ & & & & & & & & \\
\hline
\end{tabular}

Other Comments: Burning over of cabloage palm hammock has destroyed this species over much of its range.

*Expected effect on the species is an estimate made by Dr. Robert Kral based on his knowledge of the habitat and on knowledge gained from personal field ohservations. Estimates are "rough" in many instances. Results of practices may be modified depending upon the degree of application, intensity of treatment, nearness to plant communities, etc. A management practice for which no entry is made indicates a lack of sufficient information from which to predict expected results. As observations are made in the field by users of the data, the expected effect will be refined. 
ophioglossum palmatum $L$.

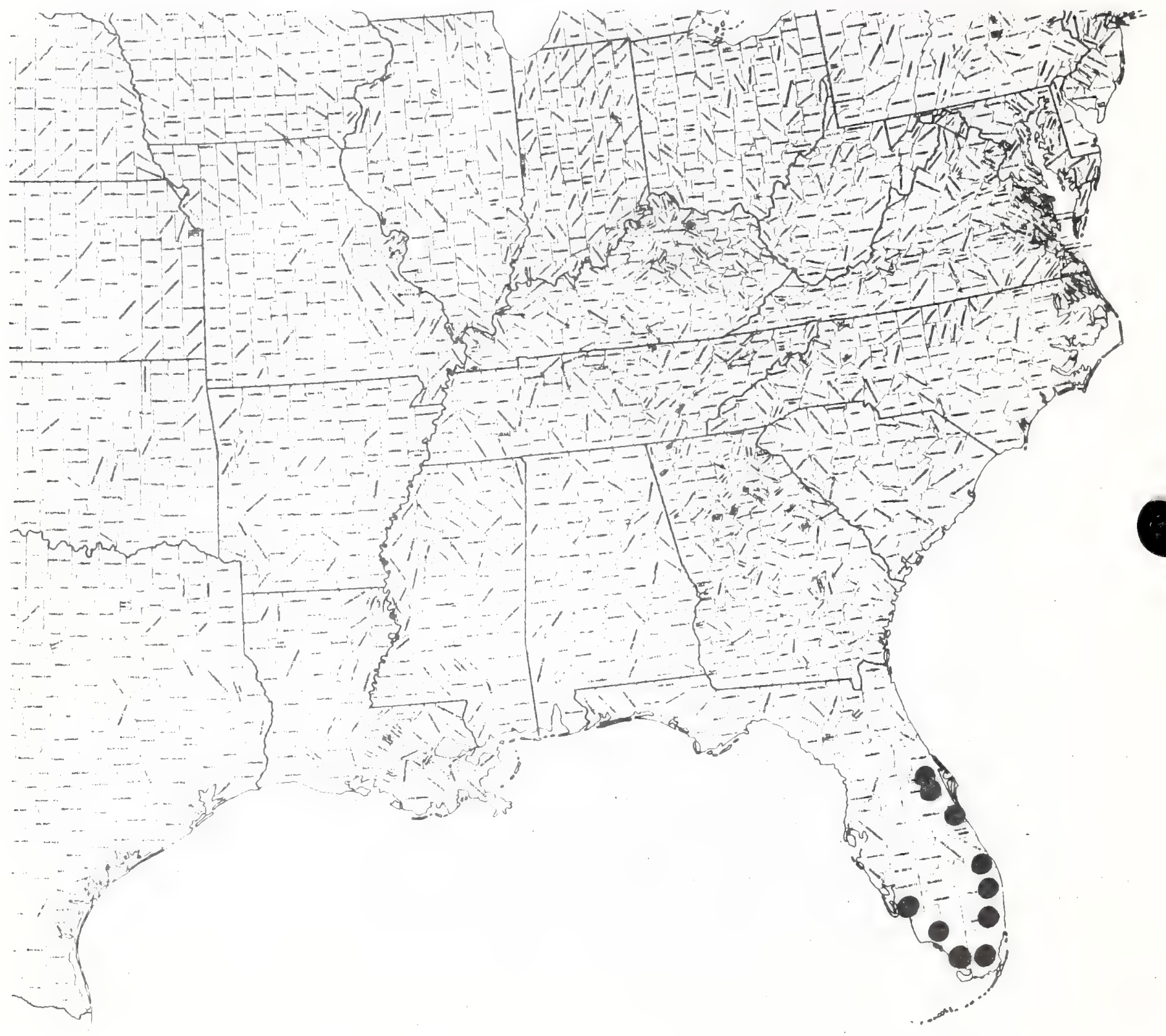




\title{
ASCLEPIADACEAE
}

\author{
Matelea floridana (Vail) Woodson. Florida milkvine. \\ Vincetoxicum fToridanum Vail \\ Odontostephana floridana (Vail) Alexander
}

\section{Technical Description}

Perennial, milky-juiced, herbaceous, twining vine from a stout-rooted rootstock.

Stems.-- Slender, terete, but faintly longitudinally ribbed, prostrate unTess there is something to climb on, always a twiner when there is, variable in length, vigorous growth to several meters long, simple or intermittently branched, the surface yellowish-green, but often strongly maroon-tinted, pubescence a mixture of long spreading hairs (hirsute) mixed with short hairs, some of these tipped with red glands.

Leaves.-- Opposite, the petioles stiffly spreading, strongly ribbed, mostly $\overline{2}-6 \mathrm{~cm}$ long, the longest lowest, pubescent as in stems; blades cordiform, ovate to suborbicular, apically acuminate, the margin entire and bristlyciliate, the base cordate or often auriculate with the sinus narrowly rectangular or closed, the whole blade often to $1.5 \mathrm{dm}$ long but usually much shorter upward on stem; upper surface dark yellow-green, puberulent, sometimes sparsely hirsute along the veins, the lower surface paler, soft puberulent, along the strongly raised veins puberulent and hirsute, with some of the short hairs red-glandular.

Inflorescence.-- A simple, axillary, pedunculate, few-to-many-flowered umbel, the peduncle ca. $1 \mathrm{~cm}$ long, slightly shorter than the rays, ribbed, puberulent, maroon-tinted, the pedicels slender, stiffly spreading, mostly $1.0-1.5 \mathrm{~cm}$ long, glandular-puberulent, each usually subtended by a narrowly linear, green, hirsute bract ca. $5 \mathrm{~mm}$ long.

Flowers.-- Perfect, regular, between 1.0 and $1.5 \mathrm{~cm}$ across; sepals $5,2.5-3.0$ $\overline{m m}$ Tong, spreading, triangular-ovate, narrowly acute, green or maroon, faintly reticulate-venose, hirtellous; petals 5, spreading, joined at very base, flat, 0.7-1.0 cm long. deep to pale maroon or yellowish-green, narrowly ovate, boradly acute, entire, the backs inequilaterally puberulent, the margins this, a narrow, entire, pale band, the upper surface smooth: crown thin, maroon, broadly low-triangular-lobed, each tip tridentate, each sinus with 2 narrowly triangular teeth' gynostegium flat-topped, Tow, greenish, the truncate summit 5-obtuse-angled, each interval bearing an inward-projecting, thin, pale scale" ovary superior, bicarpellate, the two ovoid, apically incurved, distinct carpels hidden and developing under the peltate gynostegium and the corona.

Fruit.-- Follicles 2, lance-cylindric, apically attenuated, ca. 7-10 cm long, yellowish when ripe, strongly fleshy-spined; seeds flattish, numerous, ca. $5 \mathrm{~mm}$ long, ovate, dark brown, each with a strong tuft of white, silky capillary hairs.

Distribution and Flowering Time

Hammocks, open dry woodlands, northern and central peninsular, rarely panhandle Florida; flowering from late May to July. 


\section{Special Identifying Features}

There are no more difficult plants to work with than the asclepiads, in that much of the taxonomy is based on complex floral appendage: . The perianth is rather straight forward in most genera, being made up mainly of 5, usually nearly distinct, sepals and of 5, similarly nearly distinct, spreading or incurved petals, Problems come with parts internal to these, first with what is termed "corona" which in Matelea is made up of a disc-like, usually thin, outgrowth from the summit of the short corolla tube; this may also involve some tissue from the stamen. Only in a few general (these primitive) are the 5 stamens distinct: instead they are usually adnate to (pressed against) the gynoecium and produce a short to long columnar truncate-headed structure called a gynostegium (much as in orchids), and in ours the anthers are 2-celled, bilocular, the pollen sticking together in waxy masses (pollinia) in each anther Sac, and each anther connected in a stamen by an inverted slender "V" of tissue called the "translocator", the arms of which terminate in a pollinium and are joined by a chitinous, small, usually dark brown zone. called "gland". The glands, 5 in number, are usually visible at anthesis at the angles of the gynostegial head at the tips of longitudinal slits in the gynostegium. The gynoecium is made up of 2 superior ovaries, these joined apically by their styles and at the very stigmatic tips forming most of the truncated, 5-angled surface of the gynostegium. I think that the discussion above indicates what the problem is, in that most of the taxonomy with these plants involves knowing the character, size and appendages of the abovedescribed parts. Matelea is distinguished from other viney milkweeds by its bearing a corona at the gynostegial base, this forming 1-2 series, the rims of which are variously toothed or lobed. In fruit these "Bristlepods" look like milkweeds, usually with but one ovary of a pair ripening. Not all Bristlepods have bristly ovaries and fruit, thus such species as M. gonocarpa, M. suberosa may be eliminated from confusion with $M$. floridana, which does. $\bar{M}$. floridana is distinguished from its nearest relative, $M$. carolinensis TJacq.) Woods in that it has somewhat smaller flowers, each with an apparentiy 5 -lobed crown, the surfaces of which are predominantly nearly black. The larger flowers of $M$. carolinensis have a 10 -lobed crown.

Habitat and Management Implications

M. floridana grows in a variety of wooded habitats which may be quite mesic, as in and around wooded limesink areas or relatively dry, as in open oakhickory or oak-hickory-pine uplands. The substratum is usually a moist to dryish sandy loam. In the moister "hammock" sites the overstory may be an admixture of Magnolia grandiflora, beech, maple, Liquidambar, Quercus in the willow oak group, water oak, live oak, various hickory, ash, etc., sometimes with cabbage plam admixed, often with palmetto, various Ilex, Corius, Asimina parviflora, in the understory. In the drier sites the overstory is usually a mixture of Tongleaf pine, live oak, scrub live oak, deciduous scrub oaks including Q. laevis, Q. margaretta, Q. velutina, Q. falcata, etc., and the understory of various heaths, particularTy Vaccinium, Gaylussacia, Lyonia, running oaks such as $\underline{Q}$. pumila, Q. minima, saw palmetto, Zamia, Asimina, etc. Sometimes the sites are dry enough to support large patches of Chrysobalanus oblongifolius. Herbaceous associates are often suggestive of dryish savanna woodlands, include wiregrass, various upland Andropogon, Dichanthelium, Panicum, Polygala incarnata, P. polygama, Rhynchosia, Baptisia, Desmodium, Lespedeza, Stillingia, Asclepias tuberosa, Amsonia ciliata, Paronychia, many Asteraceae including various Aster, Solidago, Heterotheca, Tetragonatheca, etc. I have now seen many populations and note (as has the far more experienced Dr. Drapalik, the authority on the genus!) that most of these are largely non-flowering 
and that this is where the overstory and understory is most complete in development. The best flowering populations appear to be where there has been recent disturbance, usually involving woods fires or logging or a combination thereof.

Thus, within the rather narrow range of this species, its management would be in line with practice for natural stands of longleaf pine, which is a common overstory species, The mechanical distrubance of the soil involved with most site preparatory techniques would probably have an adverse effect, except where contiguous seeds sources might be available to colonize bare areas. There is considerable risk here, however, in that (as mentioned above) populations are often sterile. Where these milkweeds are in rich hammock, selective logging may create small openings suitable for them; clear cutting would, however, promote weedy understory plants, particularly Pueraria, Lonicera, Smilax, Rubus, which would tend to crowd out these vines.

\section{References}

Drapalick, D.J. 1970. A biosystematic study of the genus Matelea in the southeastern United States. Unpublished Ph.D. dissertation, University of North Carolina, Chapel HiTl.

Shinners, L.H. 1964. Texas Asclepiadaceae other than Asclepias. Sida 1 (6) : $358-367$.

Sma11. J.K. 1933. Manual of the southeastern flora, pp. 1076-1078. Chapel Hi11, N.C.

Vail, Anna M. 1899. Studies in the Asclepiadaceae. Bull. Torr. Bot. Club 26: $423-431$.

Woodson, R.E. 1941. The North American Asclepiadaceae I. Perspective of the genera. Ann. Mo. Bot. Gard. 28: 193-244. 
SPECIES Matelea floridana (Vail) Woods. Florida milkvine

\begin{tabular}{|c|c|c|c|c|c|c|c|c|}
\hline \multirow[b]{2}{*}{$\begin{array}{l}\text { Expected* } \\
\text { Effect on } \\
\text { the Species }\end{array}$} & \multicolumn{8}{|c|}{ Management Practices } \\
\hline & $\begin{array}{c}\text { Prescribe } \\
\text { Burn }\end{array}$ & $\begin{array}{l}\text { Bulldoze } \\
\text { or } \\
\text { Root Rake } \\
\end{array}$ & Bed & Chop & $\begin{array}{l}\text { Thin } \\
\text { over- } \\
\text { story }\end{array}$ & $\begin{array}{l}\text { Cut } \\
\text { over- } \\
\text { story }\end{array}$ & $\begin{array}{l}\text { Establish } \\
\text { Plantation }\end{array}$ & Graze \\
\hline Destroy & & & & & & & $\mathrm{X}$ & \\
\hline Damage & & $\mathrm{x}$ & $\mathrm{X}$ & $\mathrm{x}$ & & & & $\mathrm{X}$ \\
\hline $\begin{array}{l}\text { No lasting } \\
\text { Effect }\end{array}$ & & & & & & & & \\
\hline $\begin{array}{l}\text { Beneficial } \\
\text { if Done } \\
\text { Properly }\end{array}$ & $x$ & & & & $\mathrm{x}$ & $\mathrm{x}$ & & \\
\hline
\end{tabular}

Other Comments:

*Expected effect on the species is an estimate made by Dr. Robert Kral based on his knowledge of the habitat and on knowledge gained from personal field observations. Estimates are "rough" in many instances. Results of practices may be modified depending upon the degree of application, intensity of treatment, nearness to plant communities, etc. A management practice for which no entry is made indicates a lack of sufficient information from which to predict expected results. As observations are made in the field by users of the data, the expected effect will be refined. 
Matelea floridana (Vai I.) Woodson

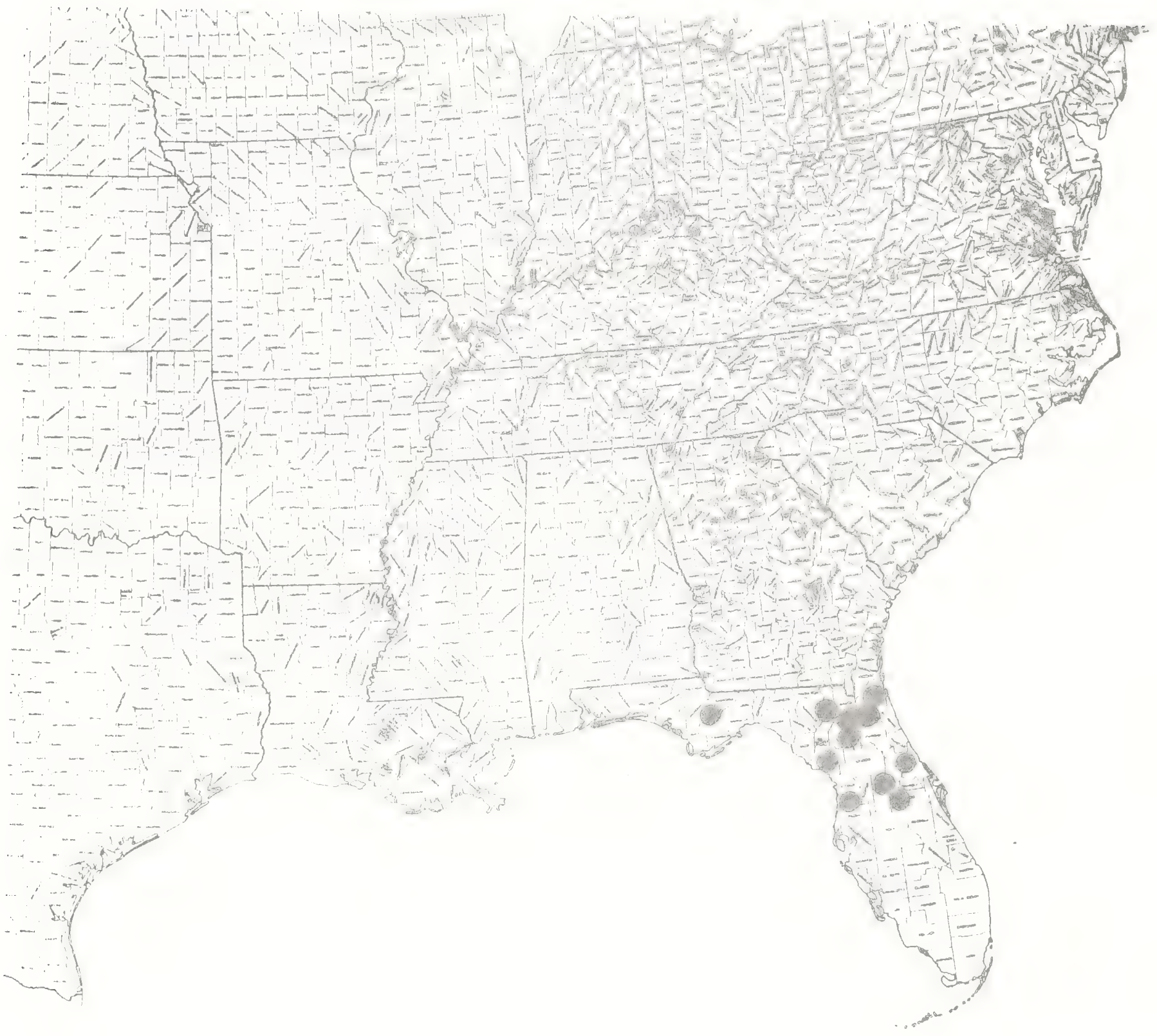


○

0

- 
Paper 209

Text \& Map by:

Robert Kral

\title{
ASTERACEAE
}

\author{
Cacalia rugelia (Shuttiw, ex Chapm.) Barkley \& Cronq. Rugel's indian- \\ plantain \\ Senecio rugelia A. Gray
}

\section{Technical Description}

Perennial, soft and britcle-foljaged herb, essentially rosulate, perennating by stout, ascending, rhizomatous offshoots.

Stems.-- Rhizomes stout, variously elongate, shallowly set in the duff, ascending, toward apex densely cloaked in the overlapping old scale leaves, these densely spirally imbricate, grading abruptly into rosetce leaves at rhizomal apex.

Leaves.-- Principally and largest in the rosette, very much in size and outline reminiscent of Plantago major, $P$. rugellii or $P$. cordata, namely spreading or erect, mostily 10-20 $\mathrm{cm}$ Tong, sightly over half of the flat but thickish-succulent petiole, the blades broadly ovate, soft, flat, acute or short-acuminate, the margins distantly but regularly denticulate, the denticles callus-tipped, the base rounded, truncate, even slightly cordate, in any event then abruptly decurrent on the petiole to its base, the upper surface deep green, sparsely appressed-floccose, much paler and somewhat more floccose on lower side and petiole.

Inflorescence.-- Scapes rigidly erect, usualiy 1 , rarely $2 / p l a n t$, mostly 20-40 cm ta71, cerete, longitudinally low-ribbed, glandular-pilosulous, dull green, with several small, distant, alternate, spreading bracteal leaves, these sessile or short-petiolate (the lower ones sometimes approaching rosette leaves in shape, but much smaller), narrowly ovate to broadiy lanceolate or elliptical, with pubescence as in rosette leaves and grading into even smaller peduncular bracts. Heads mostly 3-6, in a short, determinate, bracteate raceme, terminating long, erect peduncles usually much longer than the heads so that all approach one another to form an elliptical or oval pattern, at anthesis broadly campanulate, from base of receptacle to tip of florets ca. $2 \mathrm{~cm}$ high, and about as wide across the pappus tips, the receptacle naked, somewhat concave, the phyllaries chin, greenish, erect, in essentially 2 series, fused toward their bases, ca. $1 \mathrm{~cm}$ long, lance-linear, with the inner series somewhat broader, acute to acuminate, boradiy scariousmargined apically, inconspicuously parallel-nerved, smooth or scatteredpuberulent on the backs; florets numerous, all discoid, perfect, the corolla cream, ca. 8-9 mm high, its base narrowly tubular, expanding to a broadly tubular upper half, the 5 triangular lobes spreading at a level about even with the tips of the numerous capillary, white pappus bristles, the anther cylinder narrow, purplish, definitely exserted at an angle beyond the corolla orifice, the 2 somewhat flattened style branches apically subcapitate, truncated, bristly-tipped.

Fruit.-- Akenes columnar, smooth, ca. 4-6 mm 7 ong, $0.8 \mathrm{~mm}$ wide, with many, Tow Tongitudinal ribs, pale brown; pappus as described above.

Distribution and Flowering Time

Rich, moist coniferous woods at high elevations in the Blue Ridge Mountains of Tennessee and North Carolina; flowering Tate June to September. 
C. rugelia differs from the other southeastern Cacalia in its essentially rosulate habit, in being pubescent (the other Cacalia arm smooth), in its larger, yet fewer, more floriferous, heads. As the synonymy indicates, it was once placed in Senecio, removed from it partly because of its atypical chromosome number, but certainly does not bear much resemblance to any southeastern Senecio either in leaf or in flower color.

Habitat and Management Implications

C. rugelia may local7y form populations of thousands of individuals amongst granite boulders and on ledges, rooted in moist, highly acidic duff under spruce or fir toward or on summit elevations of some of the higher ridges in the Blue Ridge (Haywood, Swain, Macon counties in N.C., Sevier Co. in Tennessee). It is a shade plant, preferring a continuously cool, moist substratum, and would be damaged by any removal of the essentially coniferous overstory. Much of its territory lies within National Park or National Forest, but its choice of summit forest makes it susceptible to trampling by backpackers who travel the ridge trails. Irresponsible private or public development for recreational-vacational purposes of the high ridge country also poses a threat to this species. The plant is certainly rare enough in occurrence, and narrow enough in range to be monitored carefulty in future.

\section{References}

Barkley, T.M. and A. Cronquist. 1974. Cacalia rugelia, a new combination for a North American Senecionoid. Rhodora 76: 48-50.

Sma11, J.K. 1933. Manual of the southeastern flora, pp. 1475-1480. Chape1 Hi11, N.C. 
SPECIES Cacalia rugelia (Shuttiw.es Chapm.) Barkley \& Cronq. Rugel's indianmplantain

\begin{tabular}{|c|c|c|c|c|c|c|c|c|}
\hline \multirow[b]{2}{*}{$\begin{array}{l}\text { Expected* } \\
\text { Effect on } \\
\text { the Species }\end{array}$} & \multicolumn{8}{|c|}{ Management Practices } \\
\hline & $\begin{array}{c}\text { Prescribe } \\
\text { Bum }\end{array}$ & $\begin{array}{c}\text { Bulldoze } \\
\text { or } \\
\text { Root Rake }\end{array}$ & Bed & Chop & $\begin{array}{l}\text { Thin } \\
\text { over- } \\
\text { story }\end{array}$ & $\left\{\begin{array}{l}\text { Cut } \\
\text { over- } \\
\text { story }\end{array}\right.$ & $\begin{array}{l}\text { Establish } \\
\text { Plantation }\end{array}$ & Graze \\
\hline Destroy & $\mathrm{x}$ & & & & & $\mathrm{x}$ & & \\
\hline Damage & & $\mathrm{NA}$ & $\mathrm{NA}$ & $\mathrm{NA}$ & $\mathrm{X}$ & & $N A$ & \\
\hline $\begin{array}{l}\text { No Lasting } \\
\text { Effect }\end{array}$ & & & & & & & & \\
\hline $\begin{array}{l}\text { Beneficial } \\
\text { if Done } \\
\text { Properly }\end{array}$ & & & & & & & & \\
\hline
\end{tabular}

\section{Other Comments:}

*Expected effect on the species is an estimate made by Dr. Robert Kral based on his knowledge of the habitat and on knowledge gained from personal field observations. Estimates are "rough" in many instances. Results of practices may be modified depending upon the degree of application, intensity of treatment, neamess to plant commuities, etc. A management practice for which no entry is made indicates a lack of sufficient information from which to predict expected results. As observations are made in the field by users of the data, the expected effect will be refined. 


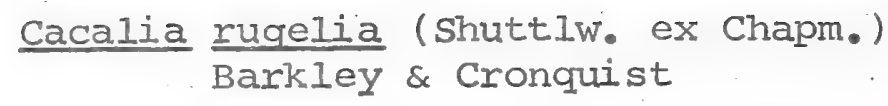

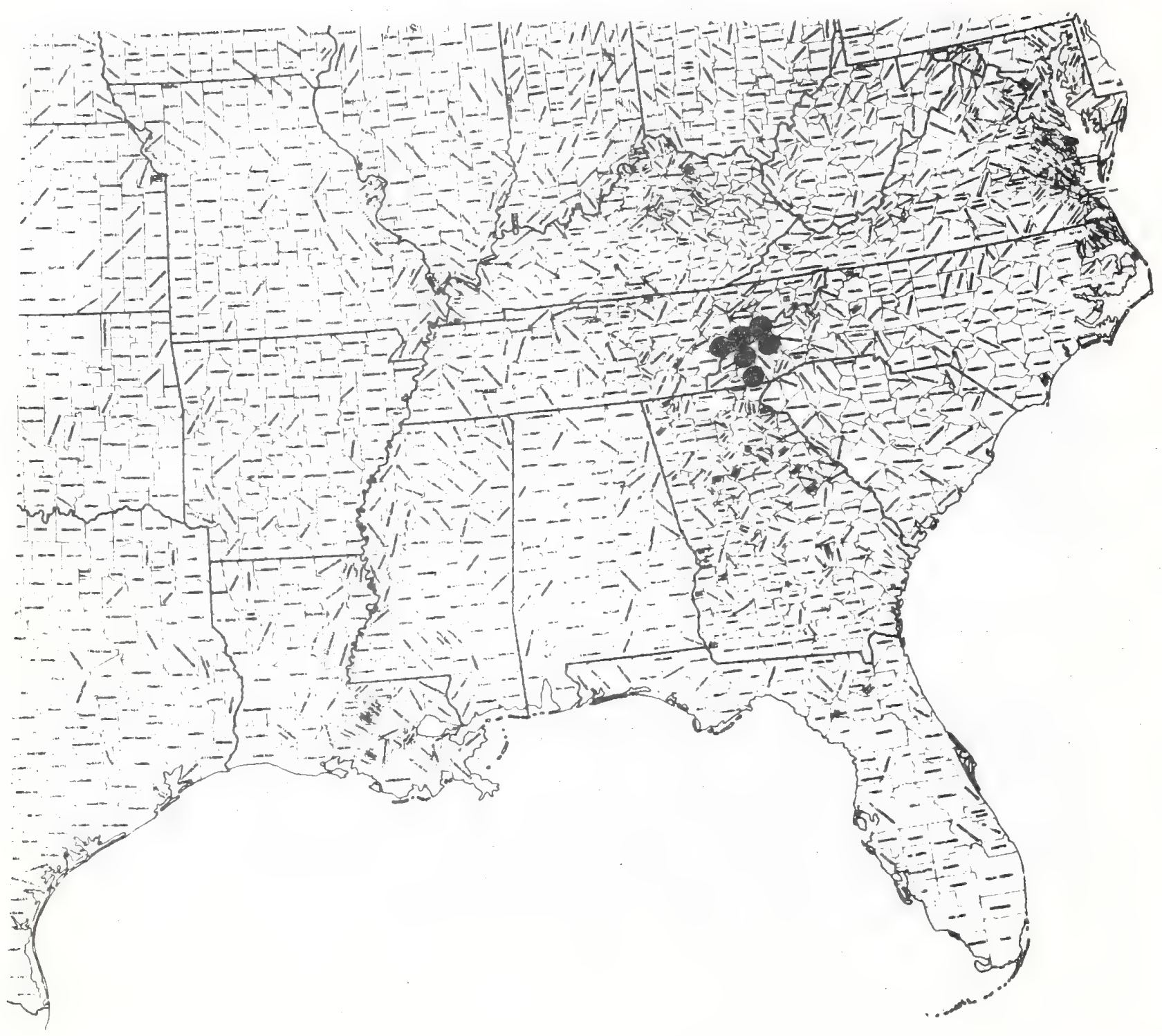


Paper 210

Text \& Map by:

Robert Kral

\section{ASTERACEAE}

Coreopsis latifolia Michx. broad-leaved tickseed

\section{Technical Description}

Perennial herbs from short, knotty rhizomes.

Stems.-. Erect or ascending, solitary or clumped, the stem bases often decumbent and rooting from lowermost nodes, upwardly abruptly bent, erect or nearly so, to 1.5 meters ta 17 , smooth, green, terete, low-ribbed, the ribs pale green, most prominent distally, the axis usually unbranched below the inflorescence.

Leaves.-- Mostly opposite, ascending or spreading, on petioles $1-3 \mathrm{~cm}$ long, the blades thin, mainly boadly lanceolate to ovate, the lowermost absent by flowering time, the largest generally about mid-stem, $10-20 \mathrm{~cm}$ long, 5-10 cm broad, acuminate, coarsely serrate or serrate-dentate, the teethtips apiculate, the blade bases cuneate to attenuate, usually entire, the upper surface a deep yellow-green, smooth, the lower surface markely paler, smooth to sparsely sofi-puberulent: blades abruptly or gradually diminishing in size into the inflorescence, there mostly lanceolate, lower-toothed, remaining petiolate.

Inflorescence.- - A few-to-many-headed, rather open but narrowish cyme, the primary branches with long, naked bases, arching stiffly upward, the ultimate branches (peduncles) usually villosulous, general7y longer than the heads subtended, subtended by or bearing narrowly elliptic or short-linear bracts. Heads..- At anthesis ca. $1 \mathrm{~cm}$ high, campanulate, the receptacle low-convex, the bracts in 2 series, the outer ones 5, spreading ascending or reflexed, linear-spatulate or oblong-linear, green, blunt-tipped, smooth, mostly 5-10 $\mathrm{mm}$ long, the inner series erect, broadly oblong, apically obtuse angled, also ciliate, to $1 \mathrm{~cm}$ long, firm-chaffy, enlarging with age, the margin pale, scarious, the surfaces at anthesis yellow-green, smooth, narrowly ribbed longitudinally with reddish resin vescicles; pales (chaff) about the length of the inner cracks, similar in cexture and veining, but grading narrower inward on receptacle, the scarious margins sparsely ciliate.

Florets.-- Ray florets 4-5, sterile, the corollas yellow, the tubular base sparsely villous, the ligules spreading, broadly oblong-elliptic, mostly $1.5-2.0 \mathrm{~cm}$ long, clear yellow, the parallel veining narrow, orange; disc florets many, dult yellow-green or orangish, the base greenish, ca. $1.5 \mathrm{~cm}$ long, expanding to a cylindrical throat ca. $5 \mathrm{~mm}$ long, the 5 triangular lobes at anthesis slightly spreading, ca. 1.5 long; anther tube at anthesis long-exsert, dark purple-brown; stigma apices yellow, narrowly conic-subulate.

Fruit.-- Akene oblong-el7iptic, dorsiventrally flactened (flattened parallel to the bracts), mostly $7-9 \mathrm{~mm}$ long (frequently ranging in length in the same head!), 2-edged and medially ribbed, occasionally with $1-2$ additional ribs, dark brown, smooth, the pappus obsolete.

Distribution and Flowering Season

Rich, hardwood forested mountain coves and slopes, Blue Ridge, western North Carolina southward into South Carolina and northeastern Georgia; very local; 
flowering from September to frost.

\section{Special Identifying Features}

This species looks more like a Helianthus or Heliopsis at first glance than it does a Coreopsis. In fact, it is invariably associated with species in both these genera, particularly Helianthus decapetalus, $\underline{H}$. divaricatus, and Heliopsis helianthoides. Of course, its double and dimorphic bract series with inner bracts not overlapping and its flattened fruit help to distinguish it at close range. Within the opposite-leaved Coreopsis there is nothing else like it, particularly in leaf, in that all the other species have leaf or leaflet blades entire, usually much firmer, certainly smaller. c. latifolia has another peculiar quirk in that usually all of its rays do not deve Top equally, this giving a "lopsided" aspect to the heads at anthesis.

\section{Habitat and Management Implications}

C. latifolia is a species of rich, moist, deep, we11-drained, shaded sandy Toams such as are found in the Blue Ridge mountain coves; I have not seen it above altitudes of 4,000 ft. It is invariably in or at the edges of open or dense forest, this mostly hardwoods such as Liriodendron. Aesculus octandra, Tilia, Quercus rubra, Q. alba, Acer saccharum, A. rubrum, BetuTa lenta, etc., sometimes with White pine, Hemlock. The understory is mostly Cornus florida, Rhododendron, Clethra, Viburnum, Sambucus and the herbaceous associates are those common to rich Southern Appalachian coves, in late summer and fall being mosly various Eupatoria (mainly E. rugosum, E. sessilifolium), Aster, Solidago (particularly S. caesia, S. curtissii, S. arguta) Elephantopus, Helianthus, Verbesina, Heliopsis, many ferns, Cimicifuga, Actaea alba, Campanula americana, Pycnanthemum (particularly P. montanum, P. pycnanthemoides), Monarda, (didyma, fistulosa, c7inopodia), Phys̄ostegia, Stachys, Agastache, MuhTenbergia, Chasmanthium, panicum, etc. The site, white rich, is often rocky, the deep soil around or pocketed in a jumble of acidic rock, this from upslope and frequently overlying basic rock. In that $C$. latifolia is a shade plant or at best an edge plant, it is supposed that such a plant would not succeed or compete well in clearcut areas, though the precise reasons for this are not known. Clearcutting, attempted in steep areas such as these, would likely have a disastrous effect in admitting too much light and along with it, weedy herbs and woody plants (such as Lonicera, Rubus, Smilax, Pueraria) which would put stress on this species: erosion and drying out of the substrate would also occur. On the other hand, selection or group selection would probably have no lasting effect, were this done with minimum impact to the soil.

\section{References}

Radford, A.E., H.E. Ahles, and C.R. Bell. 1968. Manual of the vascular flora of the Carolinas, pp. 1120-1125. Chapel Hill, N.C.

Sma11, J.K. 1933. Manual of the southeastern flora, pp. 1446-1450. Chapel Hill, N.C.

Smith, E.B. 1976. A biosystematic study of Coreopsis in eastern United States and Canada. Sida 6 (3): 123-215. 
SPECIES Coreopsis latifolia Michx. Broadmleaved tickseed

\begin{tabular}{|c|c|c|c|c|c|c|c|c|}
\hline \multirow[b]{2}{*}{$\begin{array}{l}\text { Expected* } \\
\text { Effect on } \\
\text { the Species }\end{array}$} & \multicolumn{8}{|c|}{ Management Practices } \\
\hline & $\begin{array}{c}\text { Prescribe } \\
\text { Burn }\end{array}$ & $\begin{array}{c}\text { Bulldoze } \\
\text { or } \\
\text { Root Rake }\end{array}$ & Bed & Chop & $\begin{array}{l}\text { Thin } \\
\text { over- } \\
\text { story }\end{array}$ & $\begin{array}{l}\text { Cut } \\
\text { over- } \\
\text { story }\end{array}$ & $\begin{array}{l}\text { Establish } \\
\text { Plantation }\end{array}$ & Graze \\
\hline Destroy & $\mathrm{X}$ & $\mathrm{x}$ & $x$ & $x$ & & $\mathrm{x}$ & & $x$ \\
\hline \multicolumn{9}{|l|}{ Damage } \\
\hline $\begin{array}{l}\text { No Lasting } \\
\text { Effect }\end{array}$ & & & & & $x$ & & & \\
\hline $\begin{array}{l}\text { Beneficial } \\
\text { if Done } \\
\text { Properly }\end{array}$ & & & & & & & & \\
\hline
\end{tabular}

Other Comments:

*Expected effect on the species is an estimate made by Dr. Robert Kral based on his knowledge of the habitat and on knowledge gained from personal field observations. Estimates are "rough" in many instances. Results of practices may be modified depending upon the degree of application, intensity of treatment, nearness to plant commuities, etc. A management practice for which no entry is made indicates a lack of sufficient information from which to predict expected results. As obsemations are made in the field by users of the data, the expected effect will be refined. 
Coreopsis latifolia Michx.

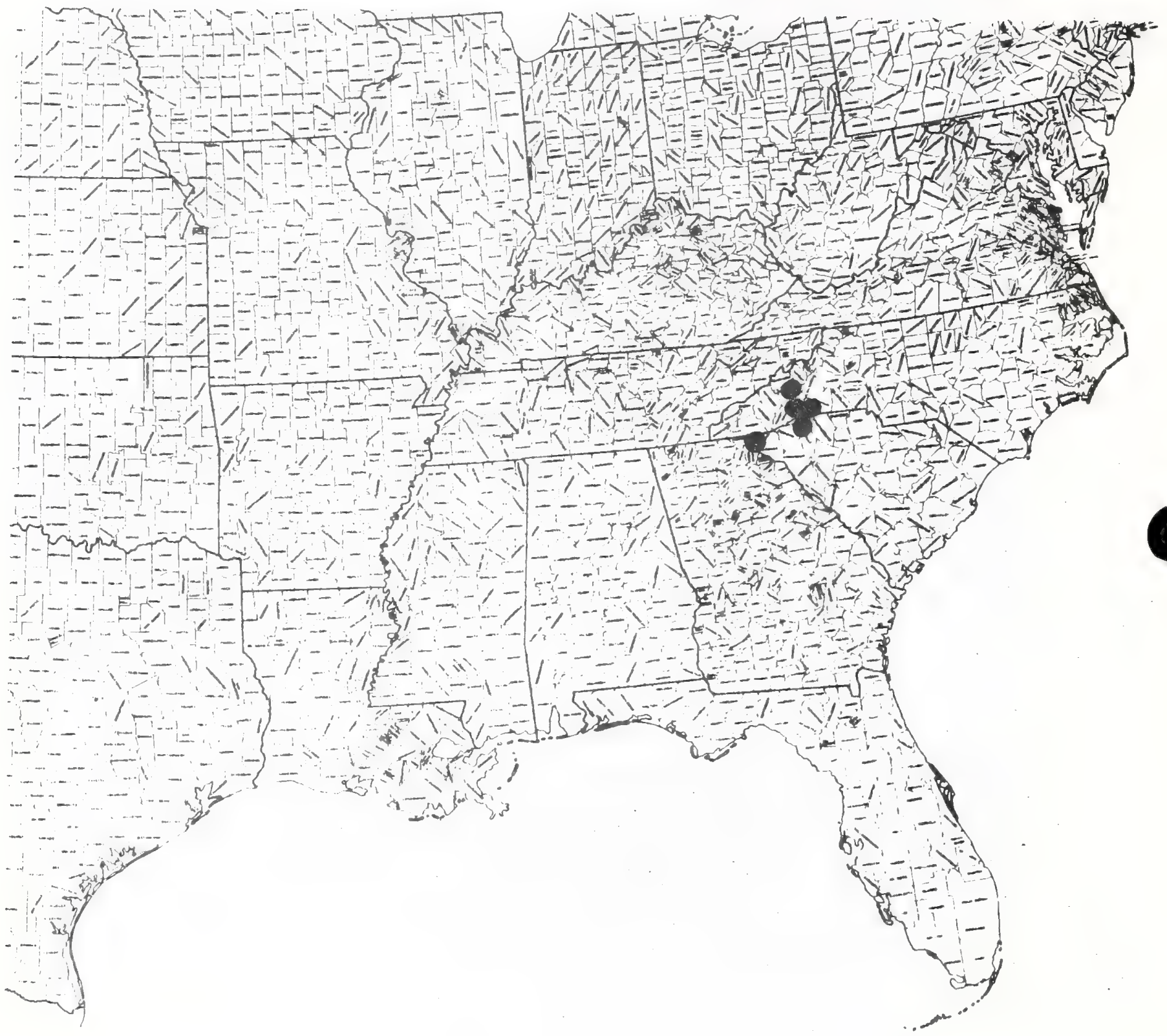


Paper 211

Text \& Map by:

Robert Kral

\section{ASTERACEAE}

Helianthus debilis Nutt. ssp. vestitus (Wats.) Heller. hairy cucumber-leaf sunflower

$H$. vestitus Wats.

\section{Technical Description}

Low, coarse, annual sunflower from a diffuse root, forming circular mats of procumbent or decumbent shoots that sometimes root at lower nodes.

Stems.-- Mostly 5-8 dm long, terete and ridged, much branched to form mats or trailing with only the tips ascending, the bases dull gray-brown, roughened and relieved by the white, persistent strumose bases of hairs, distally pale yellow-green, whitened by moderate to heavy white-villous, strumose (thickened-based) pubescence.

Leaves..- Alternate and opposite on same shoot, spreading or ascending on slender, strumose-hirsute petioles $2-4 \mathrm{~cm}$ long, the blades somewhat fleshy, essentially triangular, toward the acute apex entire, the mid and lower margin coarsely, saliently and irregularly toothed, the base truncate to broadly cordate or auriculate, slightly attenuated to the petiole, the surfaces equally yellow-green, strigose or hispidulous-scabrid.

Inflorescence.-- Heads solitary from leaf axils toward tips of shoots on stiffly upwardly arching, hispid-hirsute peduncles at first shorter than Teaves, later elongating to become $7-20 \mathrm{~cm}$ long; head diameter at full anthesis (across the rays) most7y $5-6 \mathrm{~cm}$; involucre and disc at anthesis hemispheric, ca. $2 \mathrm{~cm}$ broad, from base to convex tip of disc ca. $1.5 \mathrm{~cm}$; phyllaries in several series, coarsely herbaceous, loosely imbricated, green, narrowly lance-triangular, the longest $1.0-1.5 \mathrm{~cm}$ long, spreading or even recurved toward the slender tips, the margins coarsely scabrid-ciliate, the backs ribbed, granular and scaberulous; phyllaries abruptly grading to chaffy pales, these firm, folded, boat shaped, oblong, the body 5-7 mm long, the outer ones obtuse, truncate, or trilobate apically, those upward in head with tips scabridulous, tridentate, the central tooth subulate, or simply subulate, this imparting a somewhat bristly look to the disc in fruit; ray florets at least 10, often 12-14, sterile, the short, tubular base erect, the ligule bright yellow, spreading, elliptical, 2.5-3.0 cm long; disc purplishbrown, the corolla symmetrical, erect, $4-5 \mathrm{~mm}$ long, the pale tube base inverted cupuliform, hirtellous, joined by a constriction to the swollen base of the upper tube, this cylindrical, reddish-purple, externally granular, terminating in 5, triangular-spreading-ascending, purplish lobes, these with backs scaberulous; style branches 2, the purplish, hispidulous stigma tips spreading, exserted beyond the corolla at fult anthesis.

Fruit.- - Akene oblong, quadrangular, 3.5-4.0 mm long, dark gray, the faces pale-hirtellous, parituclarly toward the truncate summit, the pappus obsolete.

Distribution and Flowering Time

Sandy clearings in coastal hammock, dunes along the coast, beaches, southwestern peninsular Florida; flowering all year. 
Special Identifying Features

Oniy two decumbent, petiolate-leaved, dark-disced sunflowers inhabit the sandy coasts of peninsular Florida; the one on the east r ast is ssp. debilis and from a distance it appears identical. However, a close look shows that the east coast subspecies lacks the shaggy white pubescence that marks so well the west coast subspecies, and its leaf margins are not as coarsely toothed.

Habitat and Management Implications

As mentioned above, ssp. vestitus forms mats on deep exposures of sand toward and along the Gulf coast of southern Peninsular Florida. Usually it is in full sun, but occasionally it moves inland to sandy clearings in open slash pine-saw palmetto or into coastal tropical hammock formations, so that it can be said to be forest related at least on a successional basis as a pioneer of disturbed sandy sites. Its usual associates are those typical of sea coasts, i.e. Panicum amarum, P. amarulum, Uniola paniculata, various Cenchrus, Aristida, Dichanthelium Panicum, Eragrostis oxylepis, various dry ground Cyperus, Opuntia, Scaevola, Ipomoea pes-caprae, I. Sagittata, Phyllanthus amarus, Lippia, etc. This sort of habitat is maintained by development of sandy shorelines (particularly offshore bars) by offshore sea current combined with wind and wave action to form expanses of shifting sand, or by disturbance of coastal sandy hammock to provide same. These habitats are, over time, altered and the Helianthus suppressed, by invasion of stabilizing woody vegetation, in some cases pines such as $\underline{P}$. elliotti $\underline{\text { el }}$. clausa, or by evergreen scrub hammock and always saw palmetto or Sabal. Originally the plants were probably more confined to the beaches but because of the bulldozer and other land-altering machines, now occurs at greater distances inland on disturbed sands. Most of the original shoreline habitat of ssp. vestitus has been destroyed by residential and recreational development of same.

\section{References}

Heiser, C.B. et. al. 1969. The North American sunflowers (Helianthus). Mem. Torr. Bot. Club 22 (3.): 1-218.

Sma11, J.K. 1933. Manual of the southeastern flora, pp. 1431-1441. 
SPECIES Helianthus debilis Nutt. ssp. vestitus (wats.) Heller Hairy cucumber-leaf sunflower

\begin{tabular}{|c|c|c|c|c|c|c|c|c|}
\hline \multirow[b]{2}{*}{$\begin{array}{l}\text { Expected* } \\
\text { Effect on } \\
\text { the Species }\end{array}$} & \multicolumn{8}{|c|}{ Management Practices } \\
\hline & $\begin{array}{c}\text { Prescribe } \\
\text { Burn }\end{array}$ & $\begin{array}{l}\text { Bulldoze } \\
\text { or } \\
\text { Root Rake }\end{array}$ & Bed & Chop & $\begin{array}{l}\text { Thin } \\
\text { over - } \\
\text { story }\end{array}$ & $\begin{array}{l}\text { Cut } \\
\text { over- } \\
\text { story }\end{array}$ & $\left\{\begin{array}{l}\text { Establish } \\
\text { Plantation }\end{array}\right.$ & Graze \\
\hline Destroy & & $x$ & & & & & $\mathrm{x}$ & \\
\hline Damage & & & $\mathrm{NA}$ & $N A$ & & & & $\mathrm{X}$ \\
\hline $\begin{array}{l}\text { No Lasting } \\
\text { Effect }\end{array}$ & & & & & & & & \\
\hline $\begin{array}{l}\text { Beneficial } \\
\text { if Done } \\
\text { Properly }\end{array}$ & & & & & $x$ & $\mathrm{x}$ & & \\
\hline
\end{tabular}

Other Comments:

*Expected effect on the species is an estimate made by Dr. Robert Kral based on his knowledge of the habitat and on knowledge gained from personal field observations. Estimates are "rough" in many instances. Results of practices may be modified depending upon the degree of application, intensity of treatment, neamess to plant communities, etc. A management practice for which no entry is made indicates a lack of sufficient information from which to predict expected results. As obsemvations are made in the field by users of the data, the expected effect will be refined. 
Helianthus debilis Nutt. ssp. vestitus (Wats.) Heller

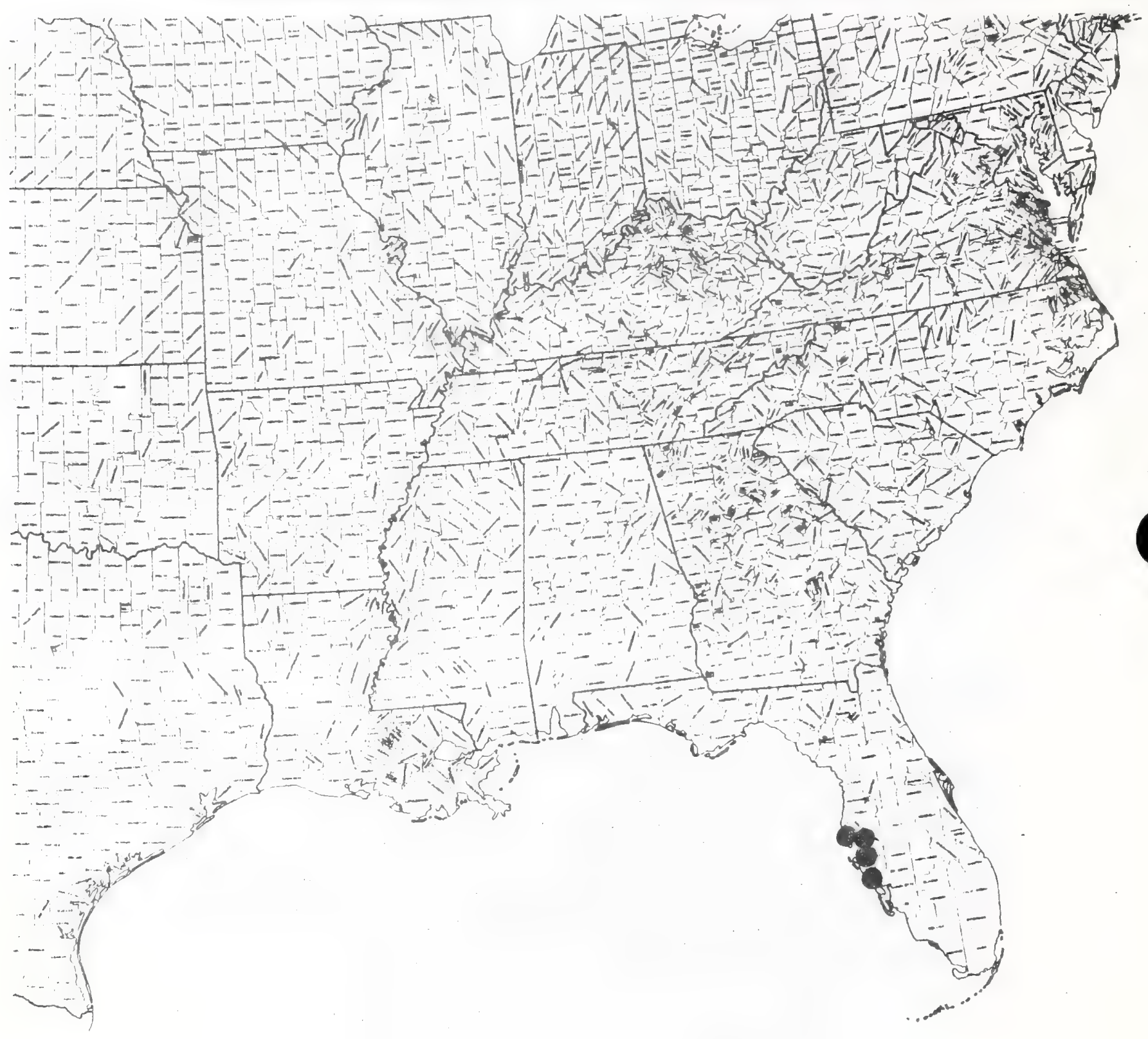


Paper 212

Text \& Map by:

Robert Kral

\title{
ASTERACEAE
}

\author{
Helianthus schweinitzii T.\&G. Schweinitz's sunflower
}

Technical Description

Perennial sunflower from a fascicle of slenderly carrot-like tuberous roots. Stems.-- Erect, solitary or few, terete and multistriate-ribbed, proximally nearly smooth and a dull brown or pale dull green, at very base $5-8 \mathrm{~mm}$ thick, distally becoming increasingly antrorsely strigillose, reddish, simple and leafless below by anthesis, branching only at or above mid-stem, the branches upwardly arched, candelabra-7ike.

Leaves.-- Opposite, the largest at abou'c midstem (grading gradually below, where early deciduous, and above to widely scattered rameal pairs) spreadingascending on short, strigose, clsaping-based petioles $5 \mathrm{~mm}$ long or less, the blades narrowly lanceolate up to $14 \mathrm{~cm}$ long and $2 \mathrm{~cm}$ wide, narrowly acute, the margins somewhat revolute, entire or distantly very low serrate, the base cuneate or attenuate, the upper surface deep yellow-green, triple nerved, harsh, the lower surface strigose-tomentose with white hairs, thus paler, the midrib and laterals strongly raised.

Inflorescence.-- Heads several to many in a rather open system of upwardly arching, sparingly leafy-bracted primary peduncles these terminating in a single head or branching again in a cymose pattern, the ultimate peduncles varying in length from very elongate to a few times longer than the heads subtended; head diameter across the rays mostly $\mathrm{ca} .4 \mathrm{~cm}$, the involucre and disc at anthesis broadly campanulate, ca. $2 \mathrm{~cm}$ broad, $1.0-1.5 \mathrm{~cm}$ high from base to tip of convex disc: receptacie convex, chaffy; phyllarles very firm, green, herbaceous, in several loosely imbricate series, spreading-erect. ovate-lanceolate to narrowly lanceolate, narrowly acute or long-acuminate, the larger ones ca. $1 \mathrm{~cm}$ long, the margins harsh, the upper surfaces scabrid, the backs strigose-tomentose; phyllaries grading rather abruptly to oblong, keeled, apically tridentate, firm chaff $5-8 \mathrm{~mm}$ long, the apex hirsute-ciliate, the backs strongly multiribbed, yellow-green, smooth save for a green and white-pubescent midrib; ray florets $8-10$, sterile, the ligules ellipticoblong, ca. $2.0-2.5 \mathrm{~cm}$ long, spreading, Tight yellow, puberulent; disc corollas ca. $5 \mathrm{~mm}$ high, tubular, constricted just above the inverted, pale, discoid base, the limb broadly tubular, greenish-yellow, the 5 erect or slightly spreading yellowish lobes triangular, ca. $1 \mathrm{~mm}$ long, the spreading, linear, tapering, hispidulous stigmatic branches barely exserted at anthesis. Fruit.-- Akenes in outline oblong, somewhat widened upward, dorsiventrally somewhat flattened (in plane parallel with phyllaries), ca. $5 \mathrm{~mm}$ long, dark gray-brown, distally strigillose; pappus of 2-4, early deciduous, scarious, narrowly lanceolate or triangular scales.

Distribution and Flowering Time

Clearings in and edges of upland woods, local in the Piedmont of North and South Carolina, very rare in the Coastal Plain of the Carolinas; flowering from september to frost. 
Special Identifying Features

This sunflower, save for its unique, fascicled-tuberous, roots most resembles, in its small, yellow-flowered heads, sympatric populations of $\mathrm{H}$. laevigatus $T$. \& G. and narrow-leaved extremes of $H_{\text {. microcephaluc }}$. \& \& G. However it differs from both these last in its harsh upper stems.

Habitat and Management Implications

H. schweinitzii prefers moist to dryish clays, clay-loams or sandy clay loams, these often with a high gravel content and all moderately podzolized. It is a plant of full sun or the light shade of open stands of oak-pine-hickory, the oaks being primarily upland species such as Q. montana, Q. coccinea, Q. velutina, Q. marilandica, Q. stellata, etc. the pines mainly $\underline{P}$. virginiana, $\bar{P}$. taeda, $\bar{P}$. echinata, $\underline{P} . \overline{\text { palustris }}$ this last in the Coastal Plain sites), the hickories mostly Carya glabra, $\underline{C}$. tomentosa, $\underline{C}$. pallida. The clearings and "edges" this sunflower frequents support a wide upland grass flora composed of general Andropogon, Aristida, Panicum, Gymnopogon, Danthonia, Stipa avenacea, Erianthus, Sorghastrum, etc. many Tegumes, particuTarly in Lespedeza, Desmodium and an abundance of composites in genera Heterotheca, Liatris, Solidago, Aster, Silphium. Patches of bracken fern are abundant, admixed with large clones of Vaccinium.

Woods fires are part of the history of the vegetation of this area; many of the herbs (including the Helianthus) are cormophytic and are sun plants, thus their abundance depending on a factor such as fire reduce the shade and competition of woody plants. The greatest risk faced by this local species is that of pine monoculture, in that the stands of planted pine when properIy spaced for high production are too dense, admit too little light. Areas in which there has been mechanical site preparation to the point of bare mineral earth may be colonized readily by $H$. schweinitzii if a seed source of that species is conveniently nearby. The problem is that, this being a very localized species, and in that site prep areas are often so very large, such seed sources are usualiy themselves destroyed; therefore large tracts of the former range of $\underline{H}$. schweinitzii now lack it.

\section{References}

Heiser, C. B. et al 1969. The North American sunflowers (Helianthus). Mem. Torr. Bot. Club 22 (3): 1-218.

Sma11, J. K. 1933. Manual of the southeastern flora, pp. 1431-1441. Chape] $\mathrm{Hi} 11$. 
SPECIES Helianthus schweinitzii T。 \& G。 Schweinitz ${ }^{8}$ s sunflower

\begin{tabular}{|c|c|c|c|c|c|c|c|c|}
\hline \multirow[b]{2}{*}{$\begin{array}{l}\text { Expected* } \\
\text { Effect on } \\
\text { the Species }\end{array}$} & \multicolumn{8}{|c|}{ Management Practices } \\
\hline & $\begin{array}{c}\text { Prescribe } \\
\text { Burn }\end{array}$ & $\begin{array}{l}\text { Bulldoze } \\
\text { or } \\
\text { Root Rake }\end{array}$ & Bed & Chop & $\begin{array}{l}\text { Thin } \\
\text { over- } \\
\text { story }\end{array}$ & $\begin{array}{l}\text { Cut } \\
\text { over- } \\
\text { story }\end{array}$ & $\begin{array}{l}\text { Establish } \\
\text { Plantation }\end{array}$ & Graze \\
\hline Destroy & & $\mathrm{x}$ & & $\mathrm{x}$ & & & $\mathrm{x}$ & \\
\hline Dannage & & & $\mathrm{x}$ & & & & & $\mathrm{X}$ \\
\hline $\begin{array}{l}\text { No Lasting } \\
\text { Effect }\end{array}$ & & & & & & & & \\
\hline $\begin{array}{l}\text { Beneficial } \\
\text { if Done } \\
\text { Properly }\end{array}$ & $\mathrm{x}$ & & & & $\mathrm{x}$ & $\mathrm{X}$ & & \\
\hline
\end{tabular}

Other Comments: Note remark about problems with site preparation!

*ixpected effect on the species is an estimate made by Dr. Robert Kral based on his knowledge of the habitat and on knowledge gained from personal field observations. Estimates are "rough" in many instances. Results of practices may be modified depending upon the degree of application, intensity of treatment, nearness to plant communities, etc. A management practice for which no entry is made indicates a lack of sufficient information from which to predict expected results. As observations are made in the field by users of the data, the expected effect will be refined. 
Helianthus schweinitzii T. \& G.

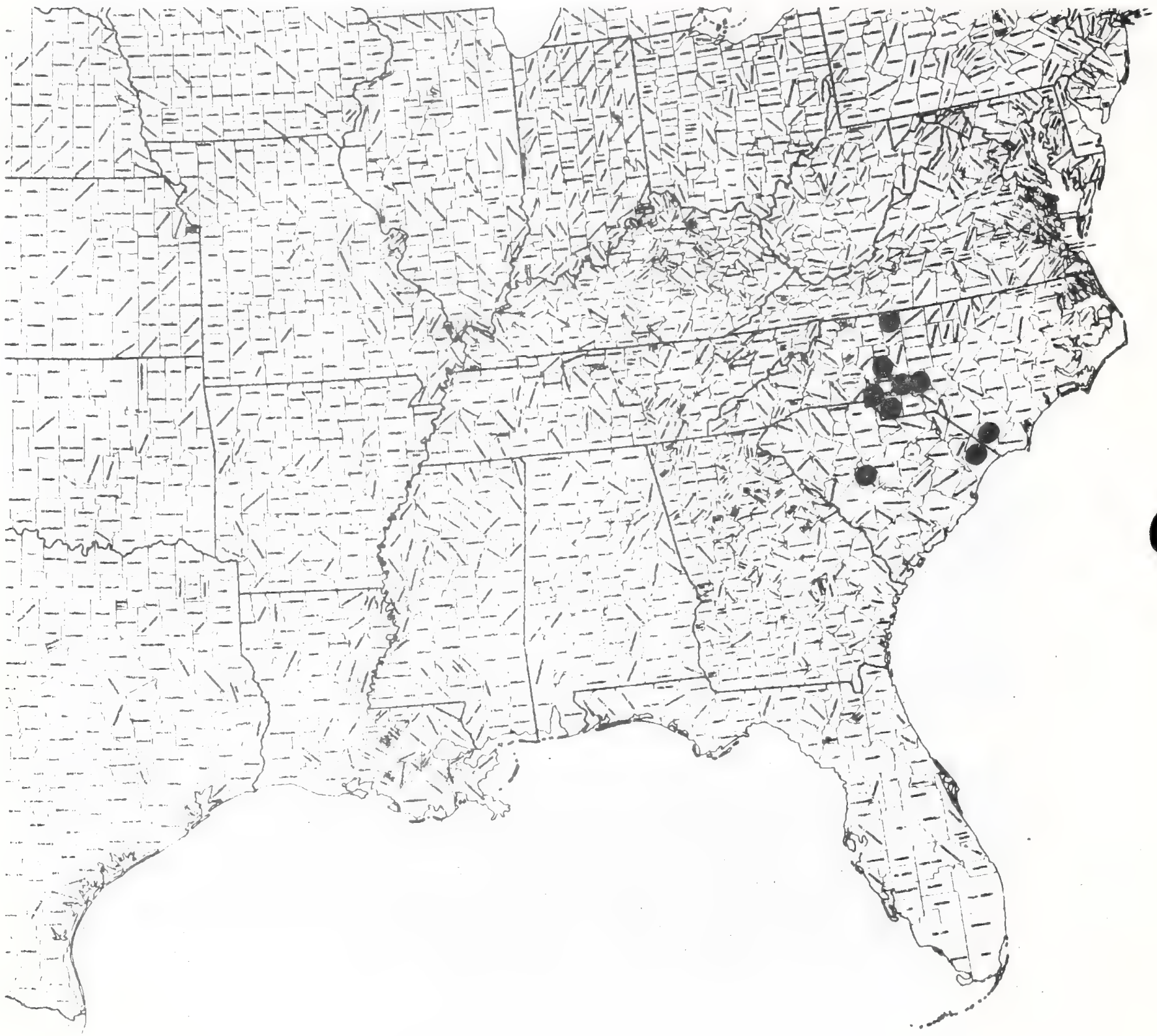


Paper 273

Text \& Map by:

Robert Kral

\section{ASTERACEAE}

Liatris helleri T. C.Porter. Heller's gay-feather Laciniaria helteri (Porter) Porter

Technical Description

Smoothish perennials from depressed-globose cormose rootstocks $2-5 \mathrm{~cm}$ broad. Stems.--Stiffly erect, 1-several, arising from a short crown tufted with basal leaves plus fibrous-shreddy remains of old leaf bases, to $4 \mathrm{dm}$ high but usually lower, proximaliy purplish, distally green, strongly ribbed, angulate.

Leaves.-- Both basal and cauline, numerous, those at stem base and on short offshoots iongest, often 2-3 dm long, the flat blades linear-oblanceolate, elliptic-linear or linear, acute, entire, tapering gradually to slender, erect, ribbed petioles, the surfaces scatteringly punctate, equally pale green, only the midrib prominent: leaves upward on stem erect, gradually reduced in their length and width, with the petioles shortening and winged, often sparsely ciliate, grading into linear bracteal leaves of the inflorescence.

Inflorescence.-- Heads somewhat scattered to approximate, axillary singly to lineal bracts, sessile or nearly so in an elongate, showy, narrow determinate spike or spikelike raceme $7-20 \mathrm{~cm}$ long, individually campanulate, from base to tip of florets $1.0-1.3 \mathrm{~cm}$ long; receptacle naked, somewhat elevated; involucral bracts thinnish, imbricated in several series, the largest ones inner or medial, ca.7-8 mm long, oblong or obovate, apically rounded, marginaliy ciliolate, the backs slightly rounded, longitudinally ribbed, green proximally, maroon distally and with a broadish, scarious, rosy border; all flowers discoid, symetrical, perfect, $7-10 /$ head, corolla pale to deep lavender rose, from tube base 60 orifice ca. $5 \mathrm{~mm}$ long, the tube scattered-pilose within, the lobes narrowly triangular, spreading, 2.0-2.5 mm long, the 2 stigma lobes long-7inear, terete, well exserted and spreading, deep lavender-rose, papillose.

Fruit.-- Akene narrowly cuneifoms, sirongly angled and ribbed, ca. $5 \mathrm{~mm}$ 1ong, the intervals shallowly to deeply concave, the surface nearly black, hispidulous along the ribs; pappus of numerous, rigidly erect, slender, pale purple, antrorsely barbed, bristles, these extending only $1 / 2-2 / 3$ way to corolla throat.

Distribution and Flowering Season

On and around outcrops of granitic rock, very local, northern Blue Ridge of North Carolina; flowering from July chrough September.

Special Identifying Features

$L$. helleri in general apperance is most like high altitude races of $L$. spicata (var. typica, forma montana fide Gaiser, 1946) differing primarily in its internally pilose (rather than smooth) corolla tube, and its ciliate (versus entire) petioles. Within its own complex, which has corolla tubes 
hairy within, it is nearest L. graminifolia, differing (dubiously) from it primarily by its much shorter pappus (which in L. graminifolia extends nearly to the disc corolla apex), and lower, stockier habit.

Habitat and Management Implications

L. helleri is found on the shallow, acid soils of ledges in outcrops of granitic rock in a few, scattered sumits of the Northern Blue Ridge in North Carolina. It is a plant of full sun, usually found mixed with mountain grasses, sedges and composites in shallow depressions in the outcrops or right around them. Other common associates are Selaginella tortipila, Arenaria groenlandica, Paronychia argyrocoma, Sedum telephoides, Potentilla Saxifraga michauxii, Heuchera villosa, etc. Depending on elevation the succession is toward yellow pine-hardwood (at lower summits), spruce-fire (at higher elevations), but this is a slow process. Greatest damage to the plants has actually come from commercial, recreational and/or residential development of some of the open sumit country, as has been the case on Blowing Rock and Grandfather Mountain. Open areas where these plants grow should probably be fenced off to avoid needless trampling by hikers, though there would still be the question of enforcement. Since these plants are confined to outcrops or their environs, where the soil is very thin, such trees as do provide a little shade are of a poor quality, and the sites generally are unsuitable for managed forest.

References

Gaiser, L. 0. 1946. The genus Liatris Rhodora 48: (nos. 572-576).

Sma11, J. K. 1933. Manual of the southeastern flora, pp. 1331-1335. Chape1 $\mathrm{Hi} 11$. 
SPECIES Liatris helleri T. Co Porter. Heller"s gay-feather

\begin{tabular}{|c|c|c|c|c|c|c|c|c|}
\hline \multirow[b]{2}{*}{$\begin{array}{l}\text { Expected* } \\
\text { Effect on } \\
\text { the Species }\end{array}$} & \multicolumn{8}{|c|}{ Management Practices } \\
\hline & $\begin{array}{c}\text { Prescribe } \\
\text { Burn }\end{array}$ & $\begin{array}{l}\text { Bulldoze } \\
\text { Or } \\
\text { Root Rake }\end{array}$ & Bed & Chop & $\begin{array}{l}\text { Thin } \\
\text { over- } \\
\text { story }\end{array}$ & $\begin{array}{l}\text { Cut } \\
\text { over- } \\
\text { story }\end{array}$ & $\begin{array}{l}\text { Establish } \\
\text { Plantation }\end{array}$ & Graze \\
\hline Destroy & & $N R_{3}$ & $\mathbb{N A}$ & NA & & & NA & \\
\hline Damage & & & & & & & & $\mathrm{X}$ \\
\hline $\begin{array}{l}\text { No lasting } \\
\text { Effect }\end{array}$ & & & & & & & & \\
\hline $\begin{array}{l}\text { Beneficial } \\
\text { if Done } \\
\text { Properly }\end{array}$ & $x$ & & & & $\mathrm{x}$ & $x$ & & \\
\hline
\end{tabular}

Other Comments:

*Expected effect on the species is an estimate made by Dr. Robert Kral based on his knowledge of the habitat and on knowledge gained from personal field observations. Estimates are "rough" in many instances. Results of practices may be modified depending upon the degree of application, intensity of treatment, nearness to plant comminities, etc. A management practice for which no entry is made indicates a lack of sufficient information from which to predict expected results. As observations are made in the field by users of the data, the expected effect will be refined. 
Liatris helleri T:C. Porter

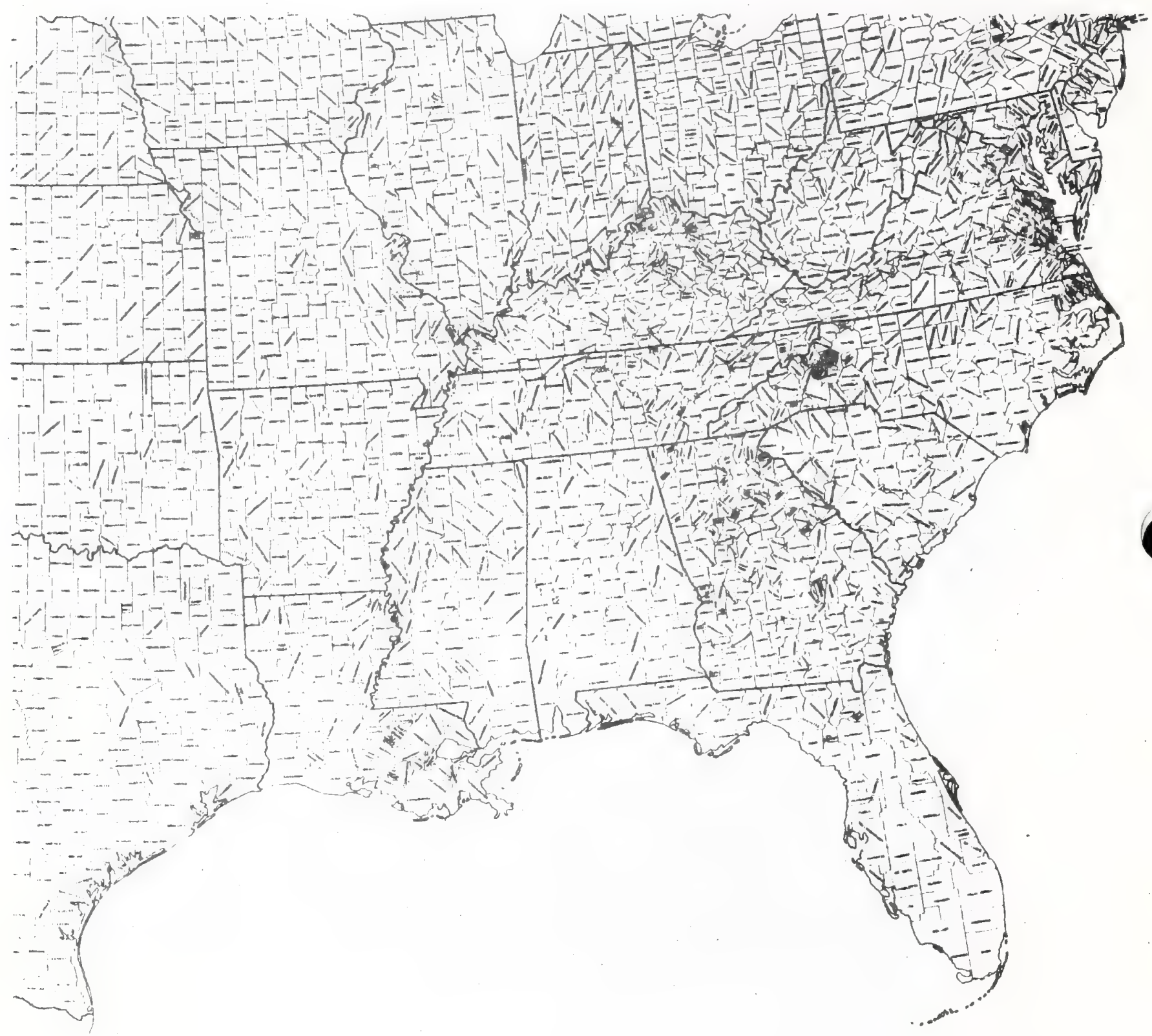


Paper 274

Text \& Map by:

Robert Kral

\section{ASTERACEAE}

Rudbeckia triloba L. var. pinnatiloba T. \& G. pinnate-lobed black-eyed susan

R. pinnatiloba (T.\& G.) Beadre

\section{Technical Description}

Taprooted, annual herbs.

Stems.-- Erect or ascending, to 1 meter tall but usualiy lower, terete, simple below the inflorescence or prolifically branched with branches ascending, terete, strongly reddish-purple-tinged, multiribbed often with heavy spreading or retrorse shaggy pilosity at least on the lowemost nodes and internodes, at mid-stem and above softly hirsute and/or strigillose.

Leaves.-- Rosette leaves usually withered by flowering time, spreading, to $7 \mathrm{dm}$ Tong, pinnately lobed, the few segments spreading or ascending, mostly oblong or lanceolate, pale yellow green, hirsute; stem leaves alternate, spreading, the lower ones similar to rosette leaves and strongly petiolate, then progressively smaller upward on stem, becoming sessile, elliptic or elliptic Jinear, acutish, entire or serrate, the bases cuneate, the surfaces pale yellow-green, beneath both hirsute and hirtellous, above hirsute and hispid-hirsute.

Inflorescence.-- Heads several to very many (depending on luxuriance of plants) usually one or few, strongly pedunculate on the arching-spreading-ascending, stiffish inflorescence branches, thus the heads in broad or narrowish panicles. Receptacle of head conic, $1.0-1.5 \mathrm{~cm}$ broad on a strigose peduncle longer than the head; involucral bracts green stiffly spreading, broadly Tinear or narrowly triangular or lanceolate. $0.7-1.0 \mathrm{~cm}$ Iong, acute, entire, strigillose or even with bases beneath shaggy-hirsute with pale hairs; chaff stiff, transluscent, oblanceolate, strongly subulate-tipped, these tips dark purplish-maroon, the body bearing submarginally on each side a strong maroon or purple band.

Flowers.-- Ray florets sterile, most7y 8-10, the ligules above the short corolla tube flat, spreading. elliptic or oblong-el7iptic, mostly $1.0-1.5 \mathrm{~cm}$ long, a rich orange-yellow, papillose: disc florets very many, shorter than the bristly tips of the chaff, tubular, ca. $3 \mathrm{~mm}$ long, the pale tube dilating gradually into the throat, the throat and the 5 erect, triangular lobes deep maroon; stigma tips blunt, covered with clavate, purplish-brown trichomes.

Fruit.-- Akene broadly wedge-shaped, quadrate, ca. 2 mm long, deep reddishbrown, smooth, the truncate apex with pappus a low, short-lacerate crown, this producing a short cusp at each of the 4 angles.

Distribution and Flowering Season

Thin soils over calcareous rock, glades, clearings, open calcareous woodlands, very local but locally abundant, northwestern Florida, inner Coastal Plain Alabama and western North Carolina: flowering from late July to frost.

Special Identifying Features

The species R. triloba is distinguished from other sympatric Rudbeckia by its 
annual character combined with short, blunt style tips and subulate chafftips. The variety is distinguished by its 5-7-lobed pinnation of its rosette and lower stem leaves and to a lesser degree by the pale, dense, usually spreading or somewhat reflexed pubescence of the lower sam (this last not a constant character!).

\section{Habitat and Management Implications}

Rudbeckia triloba pinnatiloba prefers basic soils, these usually shallow, dryish, we 7 T-drained, derived from chalks, marls, limestones, and usually sunny. Thus, it is generally found in open woodlands or in small natural or artificial clearings, The surrounding forest is often a mixture of Juniperus, calciphilic oaks such as Quercus shumardii, Q. muhlenbergii, Q. durandi, etc. UTmus americana, U. rubra, U. alata, Bumelia, Rhus (particularly R. aromatica), Rhamnus, Cercis, Carya ovata, C. carolinae-septentrionalis, etc. In the clearings it is often associated with Thaspium pinnatifidum, Zizia, Delphinium carol inianum, Lithospermum canescens, L. tuberosum, PhTox pilosa, various Sporpbolus, Panicum. Melica, Bromus, ETymus. In the open woodlands it is with such spring woodTand herbs as Sanguinaria, Hepatica, Polymnia, (in Florida this is P. Taevigata) Aquilegia, Sedum (in Alabama this may be $\underline{S}$. nevii), Arenaria lanuginosa, Euphorbia commutata, various sessile-flowered TriTlium, etc. The sites, being thin soils over Timerock and often very rocky, produce some, but not much quality, oak, hickory, juniper. They are definitely unsuitable for plantation forestry or for mechanical site preparation methods. Since the Rudbeckia is on thin soils or on and around rock outcrops and in clearings where there is often a good exposure of mineral earth it would follow that admitting more light through removal of timber and competing understory woody growth would not harm, and probably would promote an increase of, this plant (frequently it escapes to road shoulders where the road building exposes calcareous ground!).

\section{References}

Beadle, C.D. 1898. Notes on the botany of the southeastern states. Bot. Gaz. 25: 276-280.

Perdue, R.E. 1957. Synops is of Rudbeckia subgenus Rudbeckia. Rhodora 59 (708): 294-299.

Sma11, J.K. 1933. Manual of the southeastern flora, pp. 1422-1427. Chapel Hill, N.C.

Torrey, J. and A. Gray. 1842. Rudbeckia in North American Flora 2: 308. 
SPECIES Rudbeckia triloba I. var. pinnatiloba T. \& G. Pinnate-lobed black-eyed susan

\begin{tabular}{|c|c|c|c|c|c|c|c|c|}
\hline \multirow[b]{2}{*}{$\begin{array}{l}\text { Expected* } \\
\text { Effect on } \\
\text { the Species }\end{array}$} & \multicolumn{8}{|c|}{ Management Practices } \\
\hline & $\begin{array}{c}\text { Prescribe } \\
\text { Burn }\end{array}$ & $\begin{array}{l}\text { Bulldoze } \\
\text { or } \\
\text { Root Rake } \\
\end{array}$ & Bed & Chop & $\begin{array}{l}\text { Thin } \\
\text { over- } \\
\text { story }\end{array}$ & $\begin{array}{l}\text { Cut } \\
\text { over- } \\
\text { story }\end{array}$ & $\begin{array}{l}\text { Establish } \\
\text { Plantation }\end{array}$ & Graze \\
\hline Destroy & & NA & $\mathrm{NA}$ & $\mathrm{NA}$ & & & $\mathrm{NA}$ & \\
\hline Damage & & & & & & & & $\mathrm{x}$ \\
\hline $\begin{array}{l}\text { No Lasting } \\
\text { Effect }\end{array}$ & $x$ & & & & & & & \\
\hline $\begin{array}{l}\text { Beneficial } \\
\text { if Done } \\
\text { Properly }\end{array}$ & & & & & $\mathrm{x}$ & $\mathrm{x}$ & & \\
\hline
\end{tabular}

Other Comments: This plant locally is as much of a weed as the common variety!

*Expected effect on the species is an estimate made by Dr. Robert Kral based on his knowledge of the habitat and on knowledge gained from personal field observations. Estimates are "rough" in many instances. Results of practices may be modified depending upon the degree of application, intensity of treatment, nearness to plant communities, etc. A management practice for which no entry is made indicates a lack of sufficient information from which to predict expected results. As observations are made in the field by users of the data, the expected effect will be refined. 
Rudbeckia triloba L. var. pinnatiloba T. \& G.

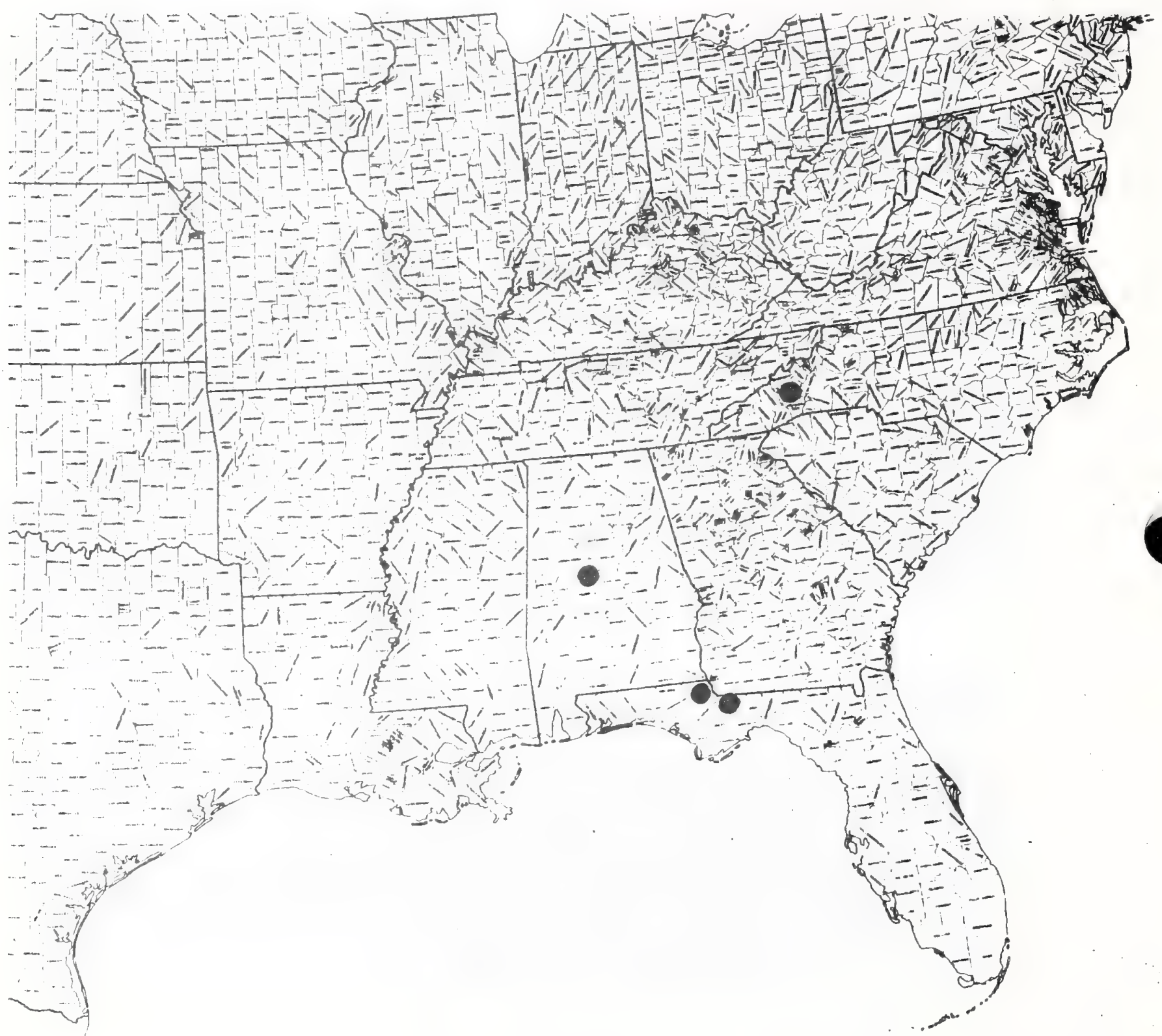


Paper 215

Text \& Map by:

Robert Kral

\section{ASTERACEAE}

\section{Senecio millefolium T.\& G. Piedmont ragwort} S. memingeri Britt.

Technical Description

Solitary or caespitose, rosulate and caulescent perennia1, from a stout cardex, increasing by ascending, short-rhizomatous, offshoots.

Stems.-- Ascending to erect, fistulose, mostly 5-8 dm high, proximaliy and on the nodes white-wooly-hairy, strongly ribbed, often sulcate, branching from the middle or above, the slender branches arching upward, terminating in inflorescence branchlets.

Leaves.-- Rosette leaves numerous, spreading to erect, these and the lower stem leaves crowded, mostly 1-3 dm long, strongly petiolate, the slender petiole bases abruptly and broadly clasping, the blades smooth, mostly oblong or cuneate or narrowly obovoid, $1-3 \mathrm{~cm}$ long, divided into few to many, short-to-elongate-1ineal segments, in all giving a "parsley" aspect to the foliage; stem leaves alternate, becoming more scattered, shorter, more sessile, and generaliy less dissected upward on stem, grading into scattered, short-linear-triangular bracteal leaves in the inflorescence.

Inflorescence.-- A single or compound system of cymes, the primary and lower branches upcurved, variously elongate, the ultimate, crowded peduncles of various lengths but usually much longer than heads, very slender, smooth, each branchlet subtended by a short-linear-triangular villosulous bract and with few to many bractlets, some usually directly subtending the head; heads campanulate, ca. $1 \mathrm{~cm}$ high, the receptacle shallowly convex, chaffless; phyllaries usually in 2 series, the outer irregular, of a very few short, Tinear-triangular, erect or incurved bractlets mostly $1 \mathrm{~mm}$ long or less, or these lacking, the inner series of very many narrowly linear-triangular, subequal, thin, green phyllaries, these ca. 5-8 mm long, fused below the middle into a cup, their suberect tips triangular, acute, with broad, pale, scarious margins.

Flowers.-- Of two sorts, ray and disc, the former pistillate, the latter perfect; ray florets ca. 10, the Iigules spreading, 5-9 mm long, linearelliptic, bright yellow, apically 3-5-toothed; disc florets with corolla ca. $4 \mathrm{~mm}$ high, erect, deeper yellow, the slender tube broadening into a narrowly campanulate throat, the 5 erect to spreading Tobes short-triangular.

Fruit.-- Akenes linear ellipsoidal, ca. $2.5 \mathrm{~mm}$ long, 5 ribbed, the ribs strongly raised, densely short-hairy with pale hairs, the intervals pale to dark brown; pappus white, of very many distinct, capillary bristles.

Distribution and Flowering Season

Open to lightly shaded granitic outcrops, Blue Ridge and inner Piedmont, North Carolina southward into northeastern Georgia and northwestern South Carolina. Flowering in May. 
S. millefolium is taxonomically closest to $\underline{S}$. anonymuc uod (s. smallii Britt.) and intergrades with it in some localities. The onty real difference between the two appears to be the much more dissected foliage of the former. Intergrades, or somewhat more dissected-7eaved $\underline{S}$. anonymus may account for S. memmingeri and a range of S. millefolium extended to northeastern Alabama by some authors. However, the real $\underline{S}$. millefolium, whatever its true biological status, appears to be found only in the Blue Ridge and upper Piedmont of three states.

Habitat and Management Implications

S. millefolium grows on thin soils over granitic rock, usualiy on and around outcrops. Usual7y it is in full sun on steep granite domes or ledges, in shallow depressions or cracks therein, but occasionally may be found in light shade of an oak-hickory-pine-juniper overstory. The soil is prevalently sandy, acid and poor, and some associated herbaceous plants are in genera Danthonia, Panicum, Aristida, Bulbostylis, Carex (such as $\underline{\text { C. nigromarginata, }}$ C. physorhyncha), Arenaria, Sedum, Thermopsis, Baptisia, various dry site Solidago, Aster, Coreopsis. Elevations range from 2,000 ft. to 4,000 ft. In the vicinity of Caesar's Head, S.C. are seen several small populations, many in the process of being shaded out by encroaching woody vegetation, evidence that this plant occupies a niche below climax. It is endangered over its small range primarily by development of the rocky and scenic land for vacation or retirement housing.

References

Barkley, T.M. 1978. Senecio in North American Flora, Ser. II (10): 50-139. New York Botanical Garden.

Radford, A.E., C.R. Bell and H. Ahles. 1968. Manual of the vascular flora of the Carolinas, pp.1034-1037. Chapel Hi17, N.C.

Sma17, J.K. 1933. Manual of the southeastern flora, pp. 1478-1480. Chapel Hill, N.C.

Torrey, John and Asa Gray. 1843. Flora of North America 2: 444. 
SPECIES Senecio millefolium T. \& $G_{\odot}$ Piedmont ragwort

\begin{tabular}{|c|c|c|c|c|c|c|c|c|}
\hline \multirow[b]{2}{*}{$\begin{array}{l}\text { Expected* } \\
\text { Effect on } \\
\text { the Species }\end{array}$} & \multicolumn{8}{|c|}{ Management Practices } \\
\hline & $\begin{array}{c}\text { Prescribe } \\
\text { Burn }\end{array}$ & $\begin{array}{l}\text { Bulldoze } \\
\text { or } \\
\text { Root Rake }\end{array}$ & Bed & Chop & $\begin{array}{l}\text { Thin } \\
\text { over- } \\
\text { story }\end{array}$ & $\begin{array}{l}\text { Cut } \\
\text { over- } \\
\text { story }\end{array}$ & $\begin{array}{l}\text { Establish } \\
\text { Plantation }\end{array}$ & Graze \\
\hline Destroy & & NA & $\mathrm{NA}$ & $\mathrm{NA}$ & & & NA & \\
\hline Damage & & & & & & & & $\mathrm{x}$ \\
\hline $\begin{array}{l}\text { No Lasting } \\
\text { Effect }\end{array}$ & & & & & & & & \\
\hline $\begin{array}{l}\text { Beneficial } \\
\text { if Done } \\
\text { Properly }\end{array}$ & $x$ & & & & $\mathrm{x}$ & $\mathbf{X}$ & & \\
\hline
\end{tabular}

Other Comments:

*Expected effect on the species is an estimate made by Dr. Robert Kral based on his knowledge of the habitat and on knowledge gained from personal field observations. Estimates are "rough" in many instances. Results of practices may be modified depending upon the degree of application, intensity of treatment, nearness to plant communities, etc. A management practice for which no entry is made indicates a lack of sufficient information from which to predict expected results. As observations are made in the field by users of the data, the expected effect will be refined. 


\section{Senecio millefolium T. \& G.}

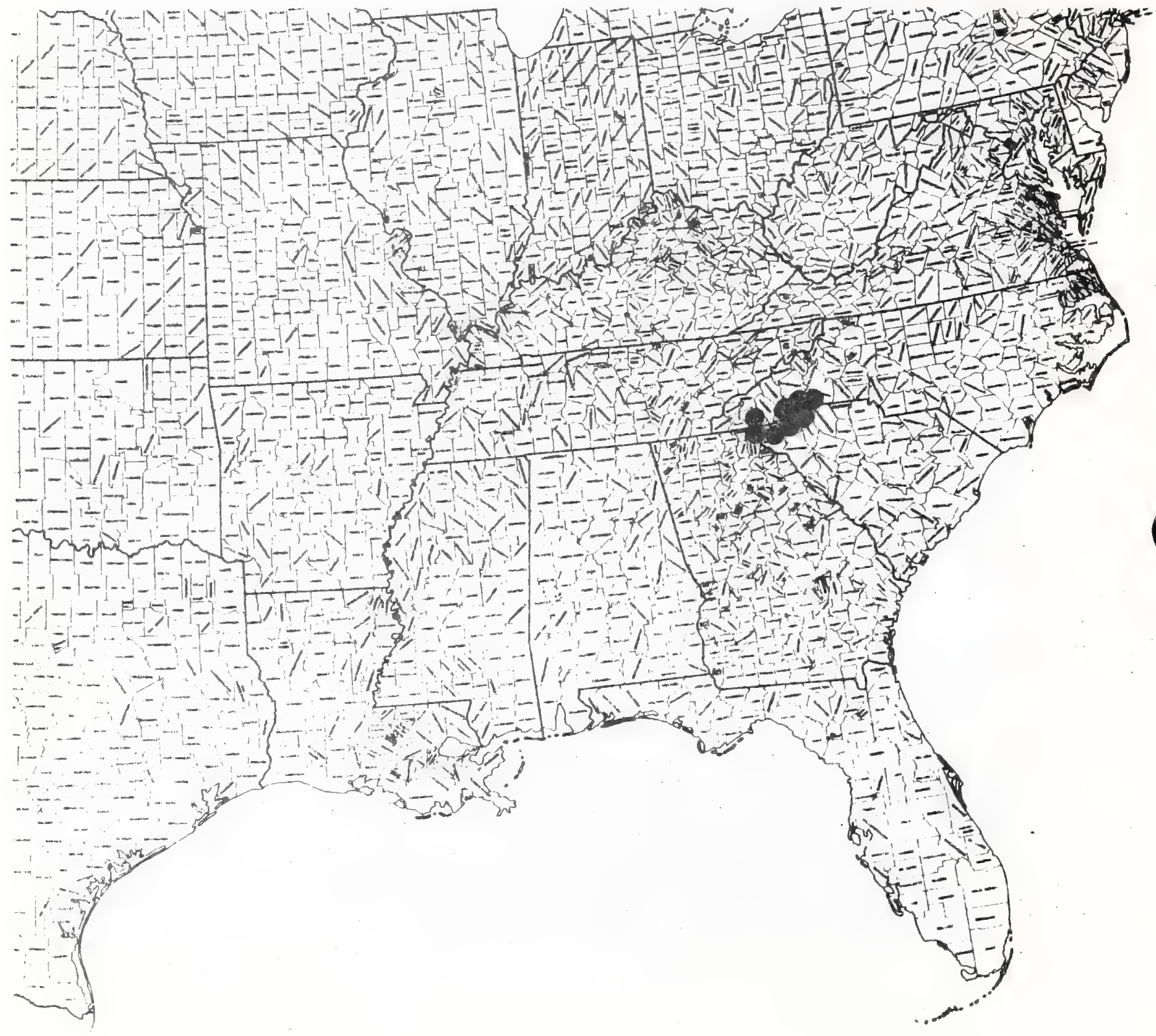


Paper 216

Text \& Map by:

Robert Kral

\section{ASTERACEAE}

\section{Solidago spithamea Curtis Blue Ridge goldenrod}

\section{Technical Description}

Stocky perennial goldenrod from a stoutish, erect, or ascending rhizome, this cloaked above by the brown bases of old leaves, often $1 \mathrm{~cm}$ thick.

Stems.-- Solitary or in small tufts, erect or nearly so, siender but stiffish, very leafy and compact, 1-2 (-3) dm tal1, terece and longitudinally striate, greenish - brown proximally, distally becoming more strongly ribbed and reddish, sparsely to moderately strigillose, or strigose-tomentose with whitish hairs, usually simple below the inflorescence.

Leaves.-- Smooth, the offshoot and basal cauline leaves the largest and longest, ascending or erect, mostly $8-15 \mathrm{~cm}$ long, oblanceolate or spatulate, acute, the broader portions coarsely ascending-serrate, to $3 \mathrm{~cm}$ wide, the bases long-attenuate, providing a wing to the clasping, petiole, the upper surface deep yellow green, inconspicuously reticulate, the lower surface paler, finely but conspicuously reticulate; cauline leaves gradually reduced upward into the inflorscence, ascending to spreading, approximate, progressively more sessile.

Inflorescence.-- A compact, symmetrical, broader than long, convex, terminal grouping of stiffly ascending, leafy-bracted cymes, $3-10 \mathrm{~cm}$ broad; heads campanulate, at full anthesis $7-9$ m high from base to tip of florets, 6-7 $\mathrm{mm}$ wide across the pappus tips; receptacle slightly elevated, chaffless; phyllaries rather tightly imbricated in several series, erect, ca. $5 \mathrm{~mm}$ long, lance-linear, acute to acuminate, cillolate, the bases outbowed, white chartaceous, the surface toward the tip smooth, green, the apparent venation consisting of a single strong midrib; ray florets pistiliate, 8-10 (some transitional to disc), the corollas with ligules spreading clear yellow, to $3 \mathrm{~mm}$ long, from narrowly elliptic to broadly cuneate-obovate, apically rounded bi-or-trilobate; disc florets numerous, erect, perfect, regular, the corolla ca. $4 \mathrm{~mm}$ long, the tube slender, abruptly broadening to a cylindrocampanulate throat and 5 triangular, spreading lobes ca. 1 mm long; style branches erect or spreading, lance-linear, flattened ventrally, well exserted beyond the corolla at anthesis.

Fruit.-- Akene columnar, 3.5-4.0 min long, strigitlose, pale brown; pappus ca. 3.5 mm long, of numerous, white, antrorsely barbellate capillary bristles.

\section{Distribution and Flowering Season}

Rock outcrops, ledges, balds at high elevations, Blue Ridge, North Carolina and Tennessee; flowering from late July to September.

\section{Special Identifying Features}

This goldenrod is distinguished from the other cymose-corymbose southeastern species by its low stature, smoothish foliage, toothier non-clasping (in comparison with S. rigida, a tall plant essentially of prairie - savanna)stem leaves. 
Habitat and Management Implications

S. spithamea is indeed a rare plant, being confined to a few rocky, granitic summits in the Blue Ridge, not being known ficii elevations under 4,000 ft. Typically it is rooted shallowly in dark humified fine sands that accumulate in cracks or pockets on acid rock, or on bluff ledges, usually in full sun. Sometimes it is with grasses and sedges on the grass balds contiguous to rock outcrops. Common associate herbs are plants such as Deschampsia flexuosa. Danthonia compressa, Poa spp., many high bald Carex, Potentilla tridentata, Prenanthes roanensis, Arenaria groenlandica, Paronychia argyrocoma, Hedyotis montana, Geum radiatum, etc. Thus it is basically a grass bald species, in a rare and sensitive system that contains many other. rare species of herbs. Two risks to it are posed. The first is natural succession, in that shrubby ericads gradually invade balds, finally suppressing most herbs, then these heaths later are overgrown by Picea or Abies. This natural succession is very slow; is comparable to that taking place on granitic rock in the boreal forest formations to the north. The second is the impact of humans on the site; high Blue Ridge balds are extremely scenic, of great interest to tourists and local recreators and thus National Forest, National and State Park, and private developers alike wish to provide road access to some of the most scenic places. This means (in the case of Grandfather Mountain, Roan Mountain, Banner Elk, etc.) development of parking, lodge, or shelter facilities at the summits and thus the habitat for the goldenrod and other rarities is reduced. Excessive trail building and road construction to overlooks have taken their toll, either through the actual construction process or by trampling later by sighyseers. In that most of the known habitat for $S$. spithamea is "protected" either by public or private ownership, and in that the philosophy of all at present is away from the logging of summit forest, forest practices pose no threat to this species.

\section{References}

Radford, A.E., C.R. Bell and H.E. Ahles. 1968. Manual of the vascular flora of the Carolinas, pp. 1084-1098. Chapel Hi11, N.C.

Sma11, J.K. 1933. Manual of the southeastern flora, pp. 1344-1360. Chapel Hill, N.C. 
SPECIES Solidago spithamea Curtis. Blue Ridge goldenrod

\begin{tabular}{|c|c|c|c|c|c|c|c|c|}
\hline \multirow[b]{2}{*}{$\begin{array}{l}\text { Expected* } \\
\text { Effect on } \\
\text { the Species }\end{array}$} & \multicolumn{8}{|c|}{ Management Practices } \\
\hline & $\begin{array}{c}\text { Prescribe } \\
\text { Burn }\end{array}$ & $\begin{array}{c}\text { Bulldoze } \\
\text { or } \\
\text { Root Rake }\end{array}$ & Bed & Chop & $\begin{array}{l}\text { Thin } \\
\text { over- } \\
\text { story }\end{array}$ & $\begin{array}{l}\text { Cut } \\
\text { over- } \\
\text { story }\end{array}$ & $\begin{array}{l}\text { Establish } \\
\text { Plantation }\end{array}$ & Graze \\
\hline Destroy & & $\mathrm{NA}$ & NA & $N A$ & & & NA & \\
\hline Damage & & & & & & & & $x$ \\
\hline $\begin{array}{l}\text { No Lasting } \\
\text { Effect }\end{array}$ & $\mathrm{X}$ & & & & & & & \\
\hline $\begin{array}{l}\text { Beneficial } \\
\text { if Done } \\
\text { Properly }\end{array}$ & & & & & $\mathrm{x}$ & $\mathrm{x}$ & & \\
\hline
\end{tabular}

Other Conments:

*Expected effect on the species is an estimate made by Dr. Robert Kral based on his knowledge of the habitat and on knowledge gained from personal field observations. Estimates are "rough" in many instances. Results of practices may be modified depending upon the degree of application, intensity of treatment, nearness to plant communities, etc. A management practice for which no entry is made indicates a lack of sufficient information from which to predict expected results. As observations are made in the field by users of the data, the expected effect will be refined. 
Solidago spithamea Curtis

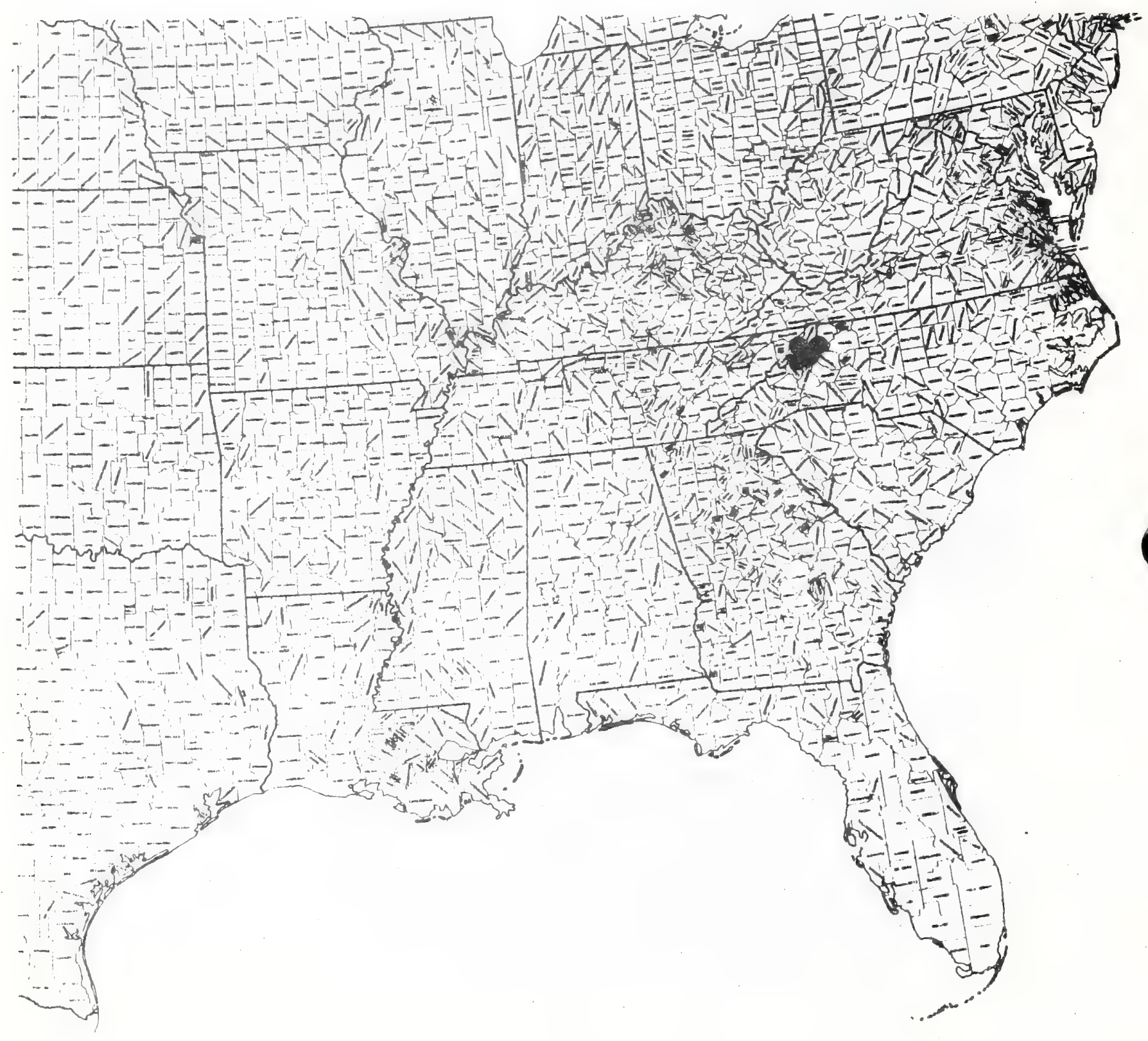




\section{BETULACEAE}

Betula uber (Ashe) Ferm. Virginia round-ieaf birch B. Tenta L. var. ubber Ashe

\section{Technical Description}

Tree to ca. 30 feet tall and $12^{\prime \prime} d . b . h$., the growth pleasingly aromatic, smelling of wintergree the trunk erect to ascending, the bark dark reddishbrown, this, shallowly furrowed, cross-checking, forming thin, appressed scales, the branching profuse, spreading, pendulous toward tips, forming a roundish crown.

Twigs.-- Slender, zig-zag, dark red-brown or paler, with pale, somewhat raised lenticles, smooth; winter buds ovoid or lance-ovoid, acute, ca. 5-7 $\mathrm{mm}$ long, the numerous scales imbricate, the rounded backs reddish-brown, ciliate, somewhat resinous; spur shoots abundantly produced.

Leaves.-- Deciduous, alternate, stipulate, the stipules deciduous early, the petioles spreading, slender, 8-10 mm long, adaxially pilose, particularly near junction with blade: blades membranaceous, broadiy ovate to suborbicular, $1.5-3.0(-3.5) \mathrm{cm}$ long, $1.5-2.5 \mathrm{~cm}$ wide, rounded, the margin serrate-dentate, the tooth tips sharp, the venation ascending-pinnate, with 4-5 pairs of laterals, the upper surface glabrous, dark green the lower surface appressedpilose along the midrib and toward the base of larger lateral veins. Inflorescence.-- Flowers unisexual, male and female catkins produced on same tree, the former preformed the previous year, narrowly cylindrical, elongating and drooping at anthesis, fully $8-10 \mathrm{~cm}$ long, the bracts reddishbrown essentially as in $B$. lenta, the female catkins mostly erect, single and terminal on the spur and short shoots of a season in late spring, ripening during summer and persisting through the season, ovoid-cylindric, $1.4-1.8 \mathrm{~cm}$ long.

Flowers.-- Male flowers not seen; female flowers "naked", 2-styled in axils of numerous, imbricated, 3-Jobed bracts, these with lobes subequal, broadened distally, the central one erect, the laterals bowed outward, all raised abaxially, veiny distally, the venation impressed adaxially along median and all somewhat glutinous.

Fruit.-- Akene ca. $2 \mathrm{~mm}$ long, 1.8-2.0 mm wide, the body elliptic or obovate, winged, the thin wing narrow toward the base, broadening distally and there $0.5 \mathrm{~mm}$ wide.

\section{Distribution and Flowering Time}

Gravelly banks and bottoms of Cressy Creek, at elevation of ca. $3800 \mathrm{ft}$., Blue Ridge, Western Virginia; flowering in late spring, fruit maturing in June and persisting through summer.

\section{Special Identifying Features}

This rare tree is in al1 ways similar to Black Birch except in its rounder, smaller, leaf blades which have less pairs of lateral veins, and in its more 
pilose petioles. It does not really appear to act as a species and research is now being conducted to determine its true biological status. Its seed germination is poor, only about 1\%. In an experiment where 300 seedlings were finally gotten only 3 were true to type, the rest exhisiting characters of $B$. lenta. However, of numerous attempts to graft stock, only two have succeeded thus far (Dr. Sharik, 1979).

Habitat and Management Implications

The round-leaved birch, as mentioned above, is known from only one locality. This is the rocky, gravelly bottom of Cressy Creek, a shallow, swift mountain stream south of Marion. The trees are genuinely rare with less than 50 plants known from the area, most of these seediings, and most of the specimens on private land, only 14 large enough to produce fruit. Of these "mature" specimens only one is on Forest Service land. Betula lenta is abundant in the same area. Associate species of trees on the gravelTy or sandy alluvium of the creek bottom include Acer saccharum, A. rubrum, Quercus rubra, Prunus serotina, $P$. americana, Platanus occidentalis, Robinia pseudoacacia, Fraxinus pensylvanica, with Ostrya virginiana, Carpinus caroliniana, Cornus florida, C. amomum, Alnus serrulata, Amelanchier laevis, Crataegus flabellata, $\underline{\text {. }}$. crusgalli, Malus coronaria in the understory. Tsuga canadensis, Pinus strobus, P. echinata, and P. virginiana are scattered throughout or form small stands. Much of the bottom floods and much of the area along Cressy Creek has been cleared for pasture or is pastured woodland. The forest generally shows a history of logging and probabiy had been logged over by the time W.W. Ashe found the trees there in 1914. The birch appears to occupy (as does B. lenta) a disclimax role in forest succession. At present, in spite of (and perhaps because of) considerable effort on the part of conservationists, etc., communication is poor between the Government and the private land owners in the area, to the point where continued survival of the less than 50 individuals is uncertain. There has already been considerable abuse of the plants, not only by locals but also by professional people who should have known better. The single large tree that is on U.S. Forest land is now well protected by high wire fencing although (and this seems strange!) the site is marked by a roadside sign.

The future of the tree in cultivation appears to be assured, in that many cuttings have been rooted or will be rooted. But the future of this doubtful taxon in nature remains questionable.

References

Ashe, W.W. 1918. Notes on Betula, Rhodora 20:64.

Ferna 1d, M.L. 1945. Notes on Betula in eastern North America, Rhodora 47: 325-326.

Johnson, A.G. 1954. Betula lenta var. uber Ashe. Rhodora 56: 129-131. Ogle, D.W. and P.M. Mazzeo. 1976. Betula uber, the Virginia round leaf birch, rediscovered in southwestern Virginia, Castanea 41: 248-256.

Reed, C.F. 1975. Betula uber (Ashe) Fernald rediscovered in Virginia. Phytologia 32 (4): $3 \overline{05-3} 11$. 
Sharik, T. 1979. The endangered Virginia round-leaf birch (Betula Uber (Ashe) Fernald): an example of the challenges in the management of rare and local tree populations. Paper presented in the Conference at V.P.I. "Dendrology in the Eastern Deciduous Forest Biome", 11 September 1979, Blacksburg, Virginia. 
SPECIES Betula uber (Ashe) Fernald. Virginia round-leaf birch

\begin{tabular}{l|c|c|c|c|c|c|c|c|}
\hline & \multicolumn{7}{|c|}{ Management Practices } \\
\cline { 2 - 9 } $\begin{array}{l}\text { Expected* } \\
\begin{array}{l}\text { Effect on } \\
\text { the Species }\end{array}\end{array}$ & $\begin{array}{c}\text { Prescribe } \\
\text { Burn }\end{array}$ & $\begin{array}{c}\text { Bulldoze } \\
\text { or } \\
\text { Root Rake }\end{array}$ & Bed & Chop & $\begin{array}{l}\text { Thin } \\
\text { over- } \\
\text { story }\end{array}$ & $\begin{array}{l}\text { Cut } \\
\text { over- } \\
\text { story }\end{array}$ & $\begin{array}{l}\text { Establish } \\
\text { Plantation }\end{array}$ & Graze \\
\hline Destroy & & $\mathrm{X}$ & $\mathrm{NA}$ & $\mathrm{NA}$ & & & $\mathrm{X}$ & \\
\hline $\begin{array}{l}\text { Damage } \\
\text { No Lasting }\end{array}$ & $\mathrm{X}$ & & & & & $\mathrm{X}$ & & $\mathrm{X}$ \\
\hline $\begin{array}{l}\text { Effect } \\
\text { Beneficial } \\
\text { if Done } \\
\text { Properly }\end{array}$ & & & & & $\mathrm{X}$ & & & \\
\hline
\end{tabular}

Other Comments:

*Expected effect on the species is an estimate made by Dr. Robert Kral based on his knowledge of the habitat and on knowledge gained from personal field observations. Estimates are "rough" in many instances. Results of practices may be modified depending upon the degree of application, intensity of treatment, nearness to plant communities, etc. A management practice for which no entry is made indicates a lack of sufficient information from which to predict expected results. As observations are made in the field by users of the data, the expected effect will be refined. 
Betula uber (Ashe) Fern。

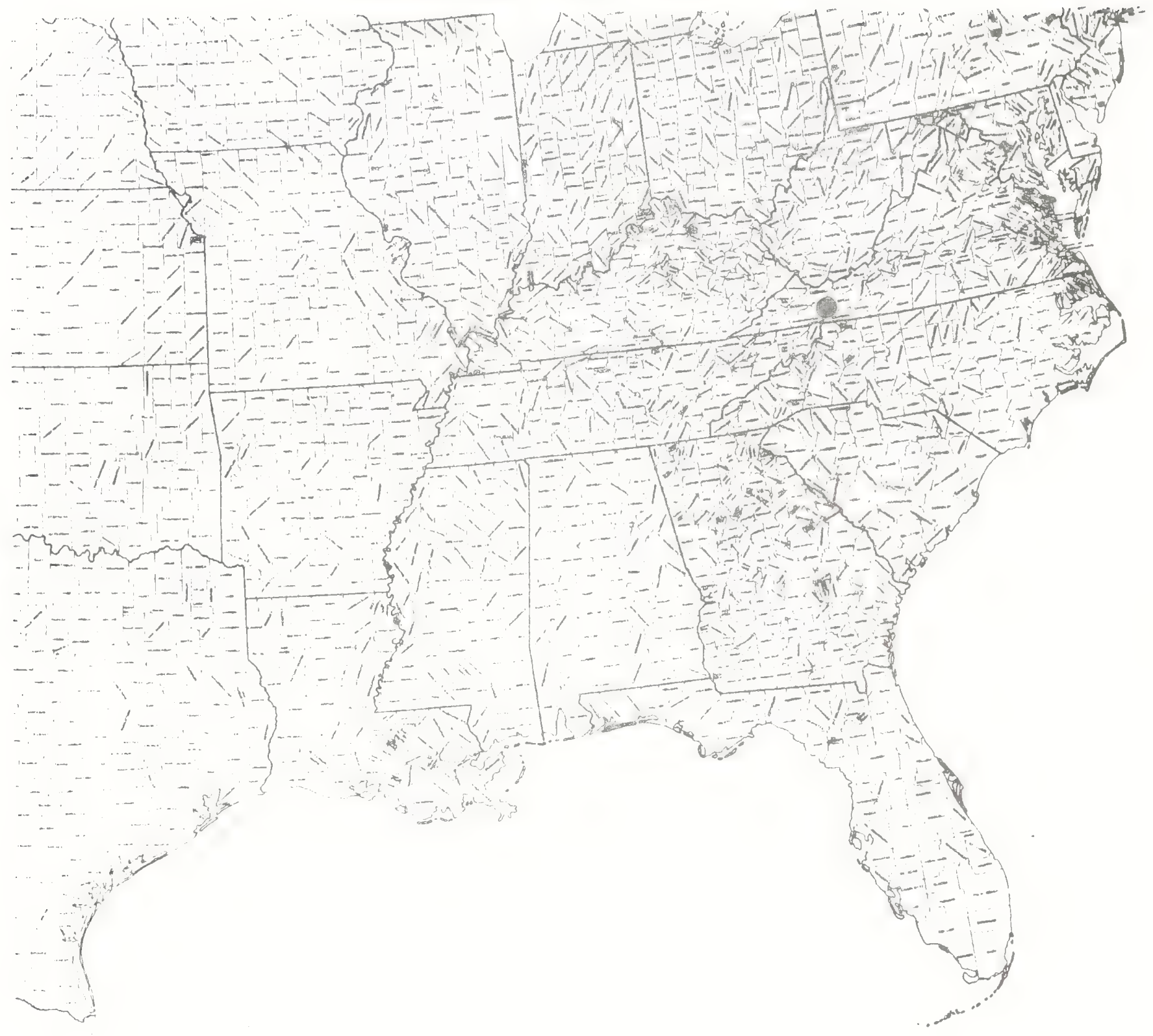


6

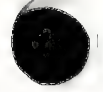

• 
Paper 218

Text and map by:

Robert Kral

\section{BORAGINACEAE}

Onosmodium molle Michx. Softwhairy falsemgromweli.

Technical. Description

Taprooted perennial bolting from an overwintering rosette the second season.

Stems.--Solitary or clumped, $5 m 8$ ( -10$)$ dm tali, terete, pale yellow-green, strigose and hirsute, stiffly erect or ascending, branching only from midmstem or above, the branches stiffly ascending, branching only from mid-stem or above, the branches stiffly ascending, then spreading distally.

Leaves.--Rosette and lower stem leaves mostly oblanceolate, often withering by anthesis, the largest $10-20 \mathrm{~cm}$ long, those upward on stem becoming much smaller, ascending, often overlapping, spirally arranged, oblong to elliptic or lancemovate, acute, entire, very firm, the base sessile, rounded or broadly cuneate: leaf surfaces gray-green, the pinnatemarcuate venation strongly raised beneath, the upper surface pale tomentose with upwardly appressed hairs, also often pilose with longer, scattered hajrs, the lower surface densely appressed palemtomentose, sometimes hirsute on the raised veins. Inflorescence. $-{ }^{\mathbb{A}}$ compound of elongating (indeterminate), strongly bracteate, scorpioid racemes, the bracts grading evenly larger downward on branches to stem leaves, gradually smaller upward in the inflorescence, overlapping, with shape and pubescence similar to that of uppermost foliage leaves, the flowers single in bract axils on ascending, stiff, strigose and palemtomentose pedicels shorter than the flowers.

Flowers.--Regular, perfect: sepals 5, joined at very base, the lobes erect, Iinear, ca. $5 \mathrm{~m} 7 \mathrm{~mm}$ long (Iengthened in fruit), green, but paler because of silvery strigose tomentum: petals 5 , the gamopetalous corolla tubularmurceolate (rarrowly urm-shaped). ca. I cm long, the tube gradually didating to the throat, the 5 greenish, ovate-triangular, villosulouswbaked lobes ca. $2.5 \mathrm{~mm}$ long, pointing inward around the exserted style, the whole corolla in outline oblanceolate and pale save toward the greenish tips: stamens 5, epipetalous, included in corolla, the anthers longer than the short filaments, oblongwinear, apiculate, basifised, the filaments arising toward sumit of corolla tube: ovary superior, 2-carpellate, deeply 4-lobed, the style strongly elongate, slender, erect, its tip projecting far beyond the corolla lobe tips.

Fruit.--Nutlets per flower $2 \mathrm{~m}$, asymetrical1y ovoid or ellipsoidal, 3.0-3.5 mm long. slightIy naxrowed below to a broad, concave, round basal attachment scar, the surface whitish to grayish or greenishwhite, glassy, noticeably pitted.

Distribution and Flowering season

Iimestone glades prairies, calcareous open woodlands, mostly of juniper, middle Kentucky southward through middle Tennessee into 
The Highland Rim of northwestern Alabama; flowering in May and June.

Special Identifying Features

This species, while usually in pure populations within its rather narrow range, is sympatric with two others, namely $\underline{0}$. hispidissimum Mack. and 2. subsetosum Mack. \& Bush. It differs from the former in its softer (to touch), denser leaf and bract tomentum, in its nutlet bases, which are far less narrowed. It differs from the latter in having a greener, hairier stem (‥ subsetosum has a yellowish. lustrous stem that toward its base is quite smooth). However, the outstanding difference is in the combination of the dense coating of appressed, pale, strigose but softish tomentum of its leaf and bract surfaces with the pale color of the tomentum which gives the plants even from a distance a distinctive pale green aspect.

Habitat and Management Implications

O. molle is calciphilic, prefering the heavy clay soils derived from limestones and dolomites. It may be found in open stands of juniper, or juniper mixed with oak (mostly Quercus shumardii, 2. muhlenberqii. ․ stellata, ․ imbricaria), hickory (mostly Carya carolinae-septentrionalis, C. ovata, C. cordiformis), Ulmus (particularly U. serotina), white ash, blue ash, etc., and with an understory made up of Cercis, Cornus drummondii, Rhus (particularly R. aromatica), Bumelia lycioides, Rhamnus caroliniana, R. Ianceolata, etc. In such sites however it can be seen that the onosmodium is on its way out, being both shaded and crowded out by the woody plants. Its best habitat is in open Iimestone glees where it roots in the shallow heavy soils overlying the rock, or in depressions or cracks in the rock where some soil has accumulated. Common associated heribs are in the genera opuntia, Sporobolus, Delphinium, Silphium, Petalostemon (particularly . gattingeri. in Tennessee!), Ratibida (pinnata), Iithospermum (canescens), Viola (often V. egqlestoni $i$ ), Fsoralea (subacaulis), Leavenworthia, Senecio, Penstemon calycosus, Phlox (bifida), Verbena (canadensis, simplex), etc., in short, limestone glade herbs, many of which are narrow endemics. These open glades have been maintained historically primarily by natural fires accompanied by erosive forces that would tend to create openings. Such habitat, when left undisturbed, succeeds to junipers, then hardwoods, which ultimately crowd out or shade out the herbs. While the onosmodium is a coarse herb not much taken by livestock, it vanishes from pastured glades, probably because of trampling by the stock. Removal of the juniper and hardwoods, if unaccompanied by radical soil disturbance, promotes increase of this species. The main threat to the existing 
populations, most of which are found in middle Tennessee, comes mainly through the conversion of glades into industrial and residential developments.

\section{References}

Fermald, M. L. 1950. Gray"s manual of botany, ed. 8, pp. 1200-1201. American Book Company.

sma11. J. K. 1933. Manual of the southeastern flora, pp. 11261127. Chapel Hill, N.C.

Steyermark, J. A. 1963. Flora of Missouri, pp. 1244-1246. Ames, Ia. 
SPECIES Onosmodium molle Michx. soft-hairy false-gromwell

\begin{tabular}{|c|c|c|c|c|c|c|c|c|}
\hline \multirow[b]{2}{*}{$\begin{array}{l}\text { Expected* } \\
\text { Effect on } \\
\text { the Species }\end{array}$} & \multicolumn{8}{|c|}{ Management Practices } \\
\hline & $\begin{array}{c}\text { Prescribe } \\
\text { Burn }\end{array}$ & $\begin{array}{c}\text { Bulldoze } \\
\text { or } \\
\text { Root Rake }\end{array}$ & Bed & Chop & $\begin{array}{l}\text { Thin } \\
\text { over- } \\
\text { story }\end{array}$ & $\begin{array}{l}\text { Cut } \\
\text { over- } \\
\text { story }\end{array}$ & \begin{tabular}{|l} 
Establish \\
Plantation \\
\end{tabular} & Graze \\
\hline Destroy & & NA & NA & NA & & & $\mathrm{X}$ & \\
\hline Damage & & & & & & & & $\mathrm{x}$ \\
\hline $\begin{array}{l}\text { No Lasting } \\
\text { Effect }\end{array}$ & & & & & & & & \\
\hline $\begin{array}{l}\text { Beneficial } \\
\text { if Done } \\
\text { Properly }\end{array}$ & $\mathrm{x}$ & & & & $\mathrm{x}$ & $\mathrm{x}$ & & \\
\hline
\end{tabular}

Other Conments:

*Expected effect on the species is an estimate made by Dr. Robert Kral based on his knowledge of the habitat and on knowledge gained from personal field observations. Estimates are "rough" in many instances. Results of practices may be modified depending upon the degree of application, intensity of treatment, nearness to plant communities, etc. A management practice for which no entry is made indicates a lack of sufficient information from which to predict expected results. As observations are made in the field by users of the data, the expected effect will be refined. 
Onosmodium molde Michx.

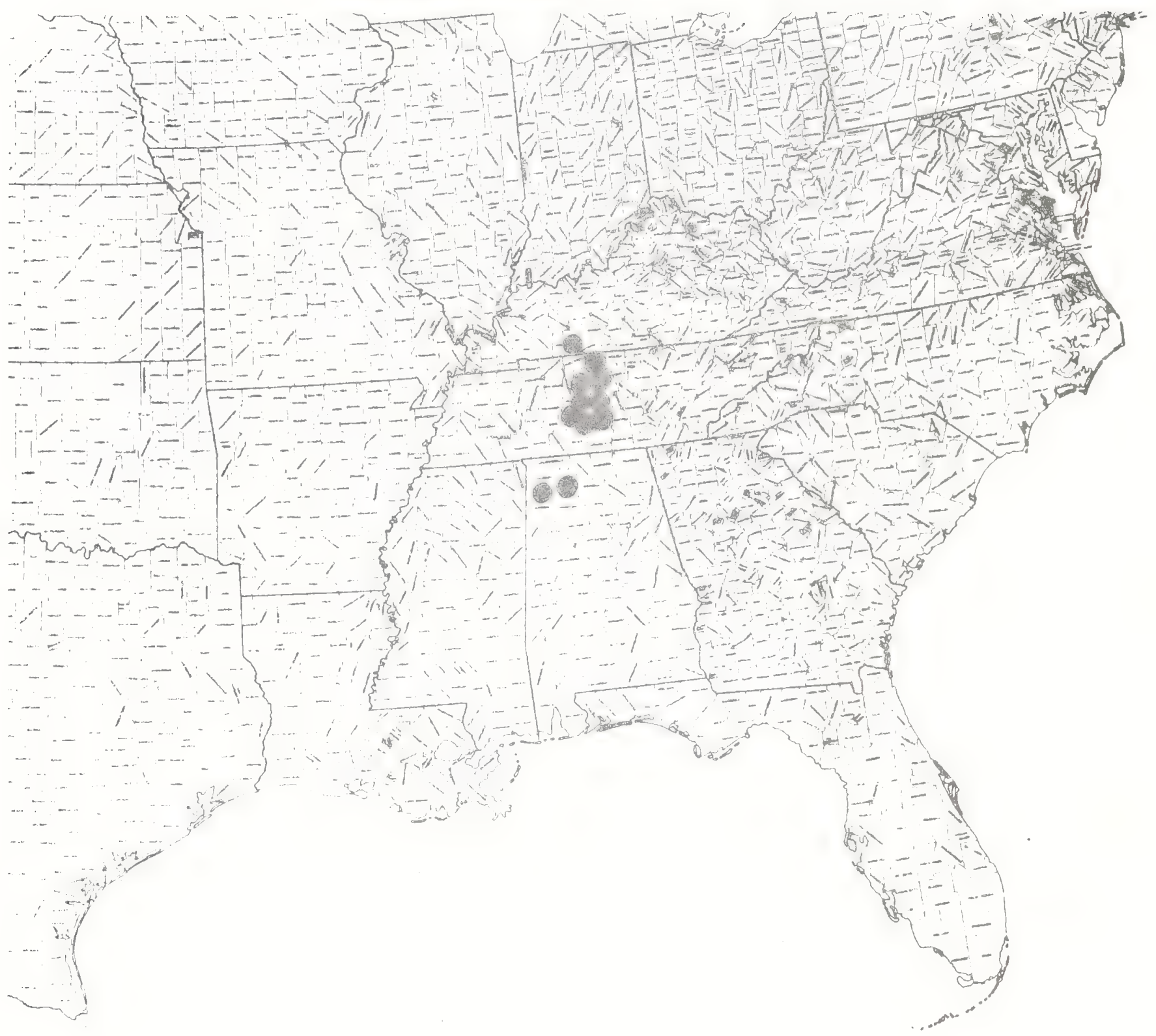




\section{BRAS STCACFR}

Leavenworthia aurea Tors. Golden gladewcress

Technical Description

Glabrous, rosulate, taprooted winter anzual.

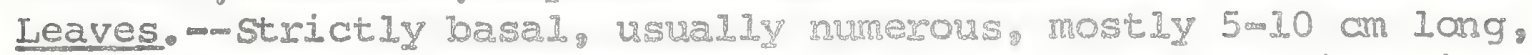
spreading, the slendex elongated petioles often purplish-tinged toward the abruptIy di lated clasping base. the blades rather fleshy, either simple. broady eldipticad to ovate. subosbidular or

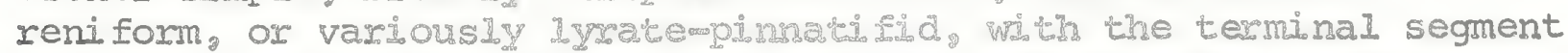
similar to the simple blade, elge lateral segments sew to many.

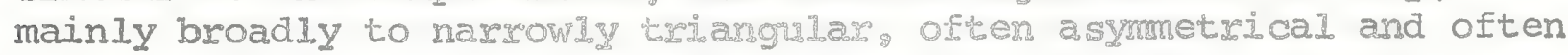
decurrent to form a vasoous I bsoadened wing between segments; blade or segment margins entire to lowwentate or angulate: leaf surfaces pale green on both sides.

Inflorescence, - scapes erect os spreadingmascending, terminating in a single flower or loosely racemose, ln total length from $8-20$

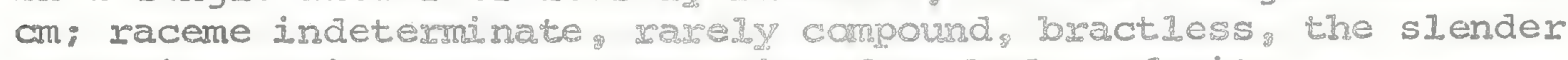
ascending pedicels much elongating from bud to frut. Flowers.-Regular, bisexual, vexy sweetly fragrant, opening fully only on sunny days, closing at nigh or when shaded sepals 4 , distinct, cymbiform (boatmskaped) ca, 4 mm losgs erect or ascending, pale yellow-orange, somerimes masoon widined toward base: petals 4 , distinct, 7-8 (-10) mm long, the exect claw $2-3 \mathrm{~mm}$ long, the obtriangular, shal lowly emagginate blade spreadingmascending, clear yellow, tinged with orange towal ebe base: stamens 6, distinct, erect, strongly tetradynamous (2 diswnctsy shorter), the Ionger ones ca. $5 \mathrm{~mm}$ long, the fillaments sturgaly Elattened yellow, tapering into basifixed, dikxorse, ellipsoidal, yellowish anthers ca. $1 \mathrm{mn}$ long: gynoecium ab anchesis ca. 5 mon long, the narrowly ellipsoidal cylinaric ovary ca. $3 \mathrm{~mm}$ long, the style fleshy, the stigma narrowly discoid, papd dose.

Fruit.-Siliques strongly flatcened, parallel to a complete septum,

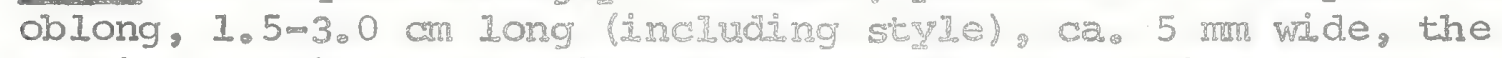
margins straight or at drbervas somewhat corstricted, the persistent style ca. 3 mm long, the mpe valpes straw-colored, raisedreticulateveined. seeds $5 \mathrm{~m}$ 1/fterit. strongly flattened, dark brown, ca, $4 \mathrm{~mm}$ wide, suborbi cular, but tramcated at the funicular end, otherwise narrowiy winged with a wing ca. 0.5 mm broad.

Distribution and Flowering season

Seasona.1y wet limestone glades, southeastewn oklahoma and eastem Texas (San Augustine Co.): Flowering from late Feloruary into April. 
Leavenworthia aurea is taxonomically closest to I. exiqua lutea, a resemblance strikingly apparent to any who have seen both in the field. Both have small yellow flowers, the petals of which are shallowly emarginate: both have flattened fruit and very similar foliage. The essential differences are that I. aurea has a somewhat thicker fruit with strong margins and a longer style, and terminal leaf segments that are more rounded, fleshier. I. aurea has a haploid chromosome number of 24; I. exiqua lutea has $n=11$.

Habitat and Management Implications

I. aurea is a typical open limestone glade plant, thus is part of an ecological system very similar to that occupied by most of the other species of Leavenworthia that range east of the Mississippi. It abounds locally on thin, clay or clay loam sites over flat-bedded limestone, usually in areas where shallow water flows or pools in winter and spring, but which tend to dry by late spring or sumer. Nostoc balls are frequent over the surface of the substrate, and the associated genera (often species) are much the same as those of eastern Leavenworthia, namely Arenaria (mostly patula), Iescuerelua, Talinum, Sedum (mostly s.. pulchellum). Senecio. Delphinium (mostly D. virescens), Penstemon, Satureja (mostly s. arkansana), Euphorbia, Scutellaria, Iinum (frequently I. pratense), Verbena, Baptisia (mostIY B. australis, B. sphaerocarpa), Nothoscondum, Allium, etc. Opuntia is common. Zygadenus nuttallii is frequent, as are Iindheimera texana, Stipa Ieucotricha. Isoetes butleri is frequent in the shallow pools, together with Callitriche, Gratiola, Iindernia. Succession is much the same as it is in eastern glades, early stages involving reproduction of Juniperus with a scattering of UImus (mostly U. crassifolia), Rhamnus, Forestiera, quercus, Diospyros, etc. Ultimately the Juniperus gives way to the hardwoods which make up the climax forest. Historically such glades (as in Tennessee) were probably kept open through natural fires, periodic drought, which would reduce woody competitors and promote exposure of limestones by erosional forces.

I. aurea is primarily threatened by real estate development as the numerous towns within its range expand, by conversion of some of its area to "improved" pasture or to crop agriculture, both these latter activities usually involving alteration of the intermittent flow of water over the glades in winter or spring. Since the plants are sun plants, any land development that promotes successional direction toward forest will reduce their suitable area.

References

Rollins, R. C. 1963. The evolution and systematics of 
Leavenworthia (Cruciferae). Contribs. Gray Herb. of Harvard Univ. No. CXCII: 1-98.

Torrey, John. 1837. An account of several new genera and species of North American plants. Ann. Lyc. Nat. Hist. 4: 80-94. 
SPECIES Leavenworthia aurea Torr.' golden glade-cress

\begin{tabular}{|c|c|c|c|c|c|c|c|c|}
\hline \multirow[b]{2}{*}{$\begin{array}{l}\text { Expected* } \\
\text { Effect on } \\
\text { the Species }\end{array}$} & \multicolumn{8}{|c|}{ Management Practices } \\
\hline & $\begin{array}{c}\text { Prescribe } \\
\text { Burn }\end{array}$ & $\begin{array}{l}\text { Bulldoze } \\
\text { or } \\
\text { Root Rake }\end{array}$ & Bed & Chop & $\begin{array}{l}\text { Thin } \\
\text { over- } \\
\text { story }\end{array}$ & $\begin{array}{l}\text { Cut } \\
\text { over- } \\
\text { story }\end{array}$ & $\begin{array}{l}\text { Establish } \\
\text { Plantation }\end{array}$ & Graze \\
\hline Destroy & & $N A$ & NA & NA & & & $\mathrm{X}$ & \\
\hline \multicolumn{9}{|l|}{ Damage } \\
\hline $\begin{array}{l}\text { No Lasting } \\
\text { Effect }\end{array}$ & & & & & & & & $\mathrm{x}$ \\
\hline $\begin{array}{l}\text { Beneficial } \\
\text { if Done } \\
\text { Properly }\end{array}$ & $\mathrm{x}$ & & & & $\mathrm{x}$ & $\mathrm{x}$ & & \\
\hline
\end{tabular}

Other Comments: drainage of the seasonally moist sites would be deleterious

*Expected effect on the species is an estimate made by Dr. Robert Kral based on his knowledge of the habitat and on knowledge gained from personal field observations. Estimates are "rough" in many instances. Results of practices may be modified depending upon the degree of application, intensity of treatment, nearness to plant communities, etc. A management practice for which no entry is made indicates a lack of sufficient information from which to predict expected results. As observations are made in the field by users of the data; the expected effect will be refined. 
Leavenworthia aurea Torr.

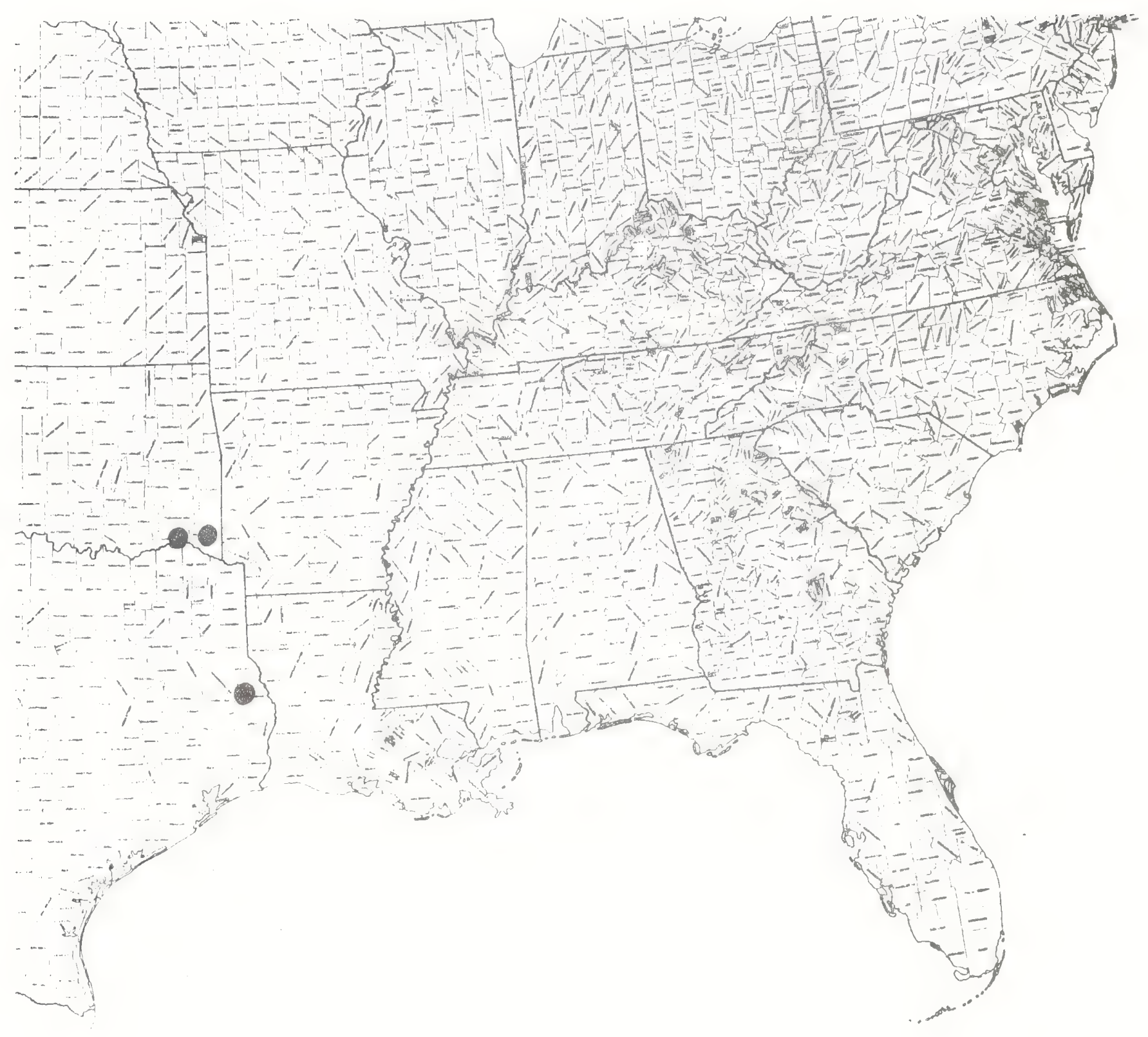


6

0

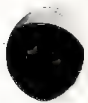


Papers 220

Test and map by:

Robert Kral

BRASSICACEAE

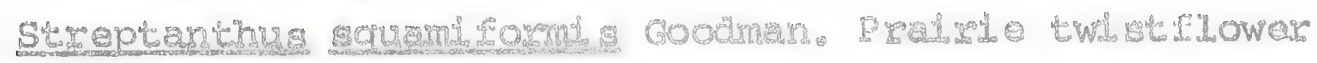

Technical Description

Taprooted annual herbs fuom winter nosetes.

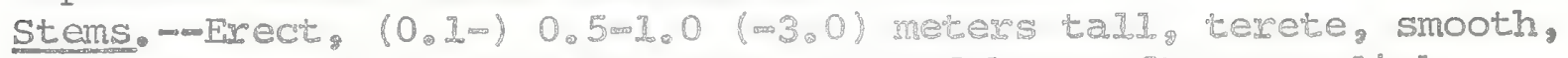
pale green and slightIy glancous. boward base ofter. prrepish

or redaish tinged. usual. II simple. cometimes spaxingly ascendingbranched.

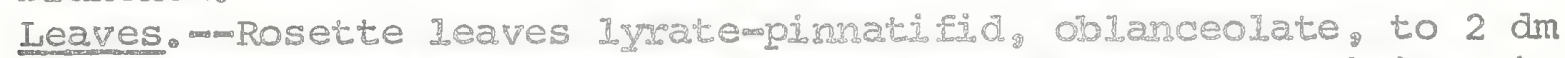
long, Iongmptiolate: cauline leaves toward stem base siomiar in size and outline to those of tosette, but progressively shorten-

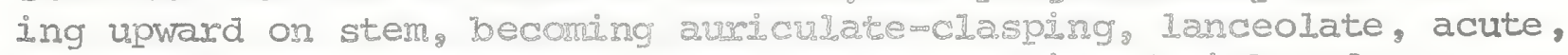
entire: leaf surfaces smooth, pale green or tringed with red or maroon or purple.

Inflorescence An elongatiog (indeteminate) bractiess raceme resembling that of Larjsprg in fuld fower erect, cylindrical, the pedicels in bud shorts apposimate, in full flowes erect or strongly ascending, so ca $1 \mathrm{~cm}$ stiffish, though slender, hirsute with flattish, white trolchomes, in frolt over I cm long and rather distant on the elongared raceme aski.

Flowers. - Merfect, wegular. showy: calyx at anthesis cylindriccampanulace, fuIIy $1 \mathrm{~cm}$ long the A distinct sepals lance-oblong, strongly tinged with rose or pryple their narewed tips spreadingrecurved even in the bua, bhed backs soumded, strongly hirsute with flattened, white haiss, cheix matogins broady white-scarious;

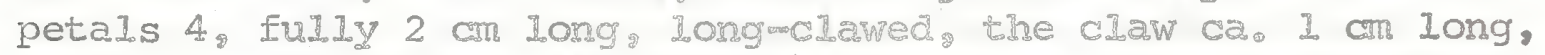
erect, the blade broadiy obovate; spreading, abmut Iy narrowed to and attenuated on the clawg the distal margin exose, surface purplish or lavender rose toward blade center. paler marginally:

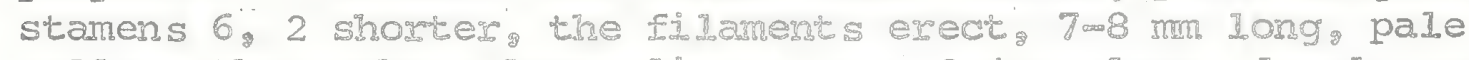

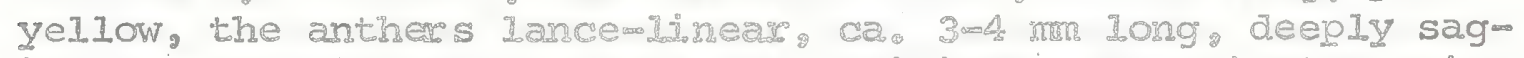
jttate, purpli sholue, exect and basidro. excurved ovary at anthesis superios. puppish. Iinear. shorter tha the stamens.

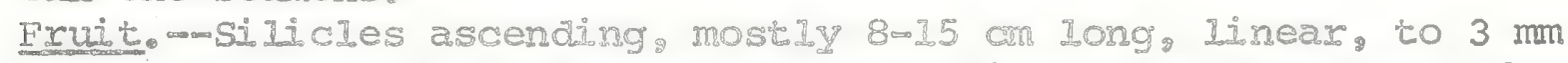
broad, flattened with the septur perpendicular to the plane of

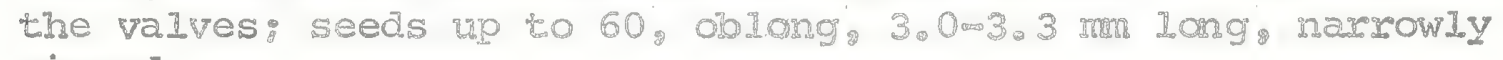
winged.

Distribution and Flowering Season

Dry to moist uplads or cavine slopes in dense to open woodIands or in clearings, Ouachita Monntajas of southeastern Oklahoma and southwestem Arkan sas: flowering from late Aprid through May. 
Streptanthus squamiformis is at once distinguished from other species of its geographical area by the copious pubescence of its pedicels and sepal backs, these hairs prominent, whitish, spreading and flattened (hence "squamiform"). The densely hirsute buds are broadly ovoid, with sepal tips prominently excurvate, this feature very noticeable in the field.

Habitat and Management Implications

This Streptanthus actually occurs in a wider variety of habitat than its describer indicated. It is abundant in open, sloping to quite steep, mesic though rocky, woodlands, there growing under a mixture of oaks, elms, maples and Iuniperus, and associated with such spring woodland herbs as Hepatica, Dentaria, sessile Trillium, Sanquinaria, Senecio obovatus, Thaspium, Zizia, various violets including $\mathrm{V}$. pensylvanica, Dodecatheon, several carices including the endangered Carex latebracteata Waterfal1" the local Valerianella palmeri, grasses such as Bromus purcans, Poa sylyestris, Festuca versuta, many Panicum. In such sites it may be rooted in deep.moist, well drained sandy loams or clay loams. It may also be found in open stands of upland oak-hickory-shortleaf pine, where the understory is primarily connus and Vaccinium, the herbaceous associates quite different, with more Phacelia, Phlox pilosa, Monarda misseliliana, Silene virqinica, Kricia, Oenothera, Valerianella Iongifiora, V. nuttallii, V. radiata, Antennaria, Tradescantia, coreopsis, and various upland grasses and carices. Here the soil may be shallow or deep, a sandy loam or clay loam, frequently droughty. Still another sort of haitat may be completely open, often cliffs or ledges, outcrops of shale, novaculite or even calcareous rock, the plants rooted either in cracks or depressions in the more massive rock or directly in shaley talus or broken rock. Large plants are often found along new roads or in powerline clearings where there has been recent mechanical disturbance of the soil; similarly they often show up in areas that have been clearcut and site prepared either by burning or mechanical treatment or a combination of these. In nature the plants probably maintained either in outcrop areas or open barrens and probably (just as they do today!) acted as pioneers in areas where fire and/or slope erosion had occurred. One may visit sites in various stages of succession after fire and mechanical disturbance, and see how this streptanthus is reduced in vigor and numbers over time. The species is definitely weedy, persisting in mesic sites where the steepness of the site allows erosional foreces to create openings of mineral earth, persisting in open uplant sites or in areas of talus, cliff or outcrop, invading freshly disturbed contiguous area. 
Thus, clearcutting, burning, or mechanical site preparation pose no real threat providing contjguous area of seeding plants is available. The plants will not persist in pine plantations.

References

Goodman; G. J. 1956. A new species of Streptanthus. Rhodora 58: 354-355. 
SPECIES Streptanthus squamiformis Goodman. Goodman's twistflower

\begin{tabular}{|c|c|c|c|c|c|c|c|c|}
\hline \multirow[b]{2}{*}{$\begin{array}{l}\text { Expected* } \\
\text { Effect on } \\
\text { the Species }\end{array}$} & \multicolumn{8}{|c|}{ Management Practices } \\
\hline & $\begin{array}{c}\text { Prescribe } \\
\text { Burn }\end{array}$ & $\begin{array}{l}\text { Bulldoze } \\
\text { or } \\
\text { Root Rake }\end{array}$ & Bed & Chop & $\begin{array}{l}\text { Thin } \\
\text { over- } \\
\text { story } \\
\end{array}$ & $\begin{array}{l}\text { Cut } \\
\text { over- } \\
\text { story }\end{array}$ & \begin{tabular}{|l} 
Establish \\
Plantation
\end{tabular} & Graze \\
\hline Destroy & & & & & & & $x$ & \\
\hline Damage & & & & & & & & $x$ \\
\hline $\begin{array}{l}\text { No Lasting } \\
\text { Effect }\end{array}$ & & & & & & & & \\
\hline $\begin{array}{l}\text { Beneficial } \\
\text { if Done } \\
\text { Properly }\end{array}$ & $\mathrm{x}$ & $\mathrm{x}$ & $\mathrm{x}$ & $\mathrm{X}$ & $\mathrm{x}$ & $\mathrm{x}$ & & \\
\hline
\end{tabular}

Other Comments:

*Expected effect on the species is an estimate made by Dr. Robert Kral based on his knowledge of the habitat and on knowledge gained from personal field observations. Estimates are "rough" in many instances. Results of practices may be modified depending upon the degree of application, intensity of treatment, nearness to plant communities, etc. A management practice for which no entry is made indicates a lack of sufficient information from which to predict expected results. As observations are made in the field by users of the data, the expected effect will be refined. 
Streptanthus squami formis Goodman

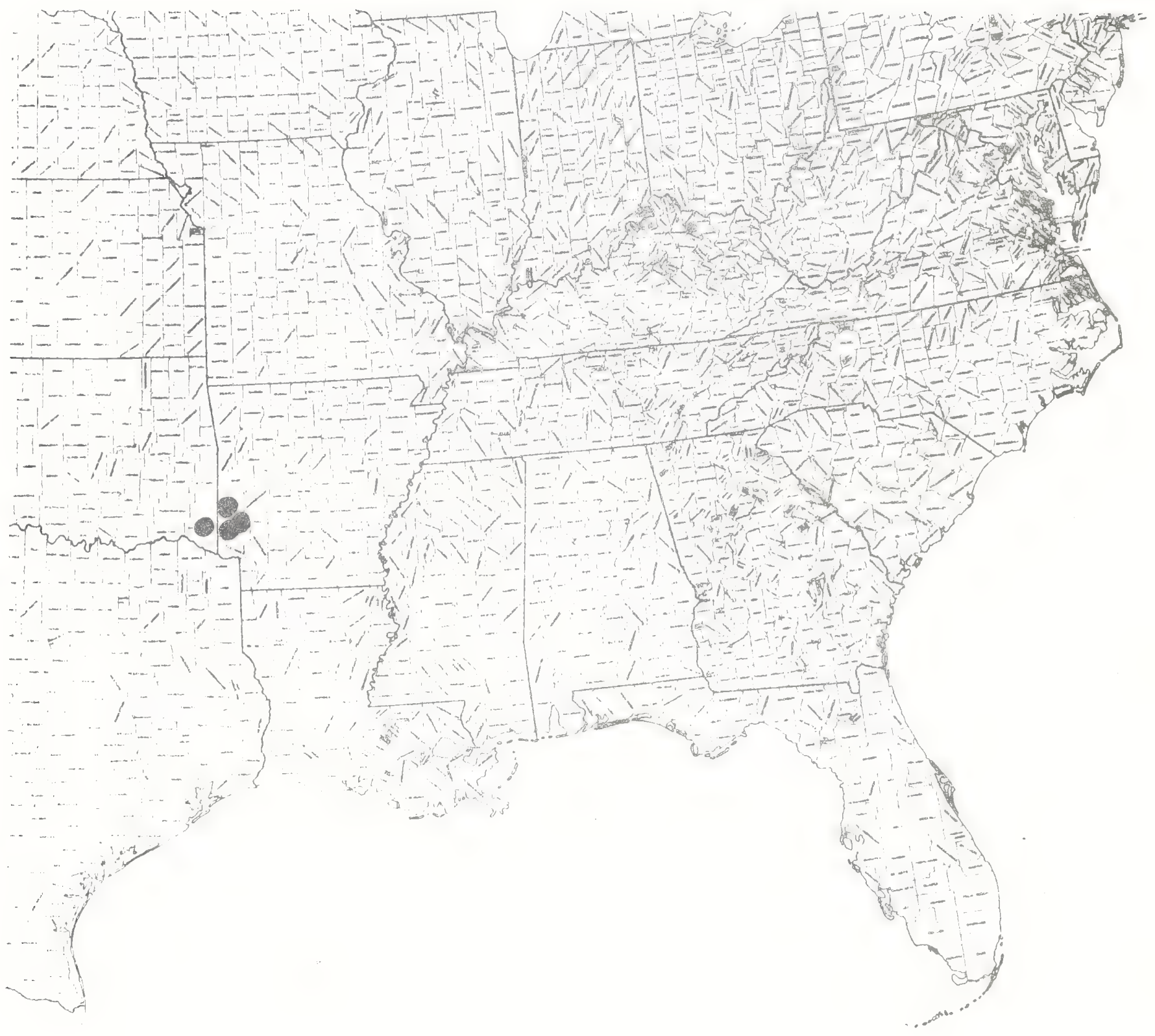




\section{BRASSICACEAE}

Warea carteri Small. Casteren's warea

Technical Description

Taprooted, glabrous, sIender annuals mosteIy $2 \mathrm{~m}$ I0 dm kigh.

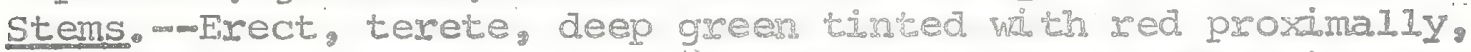
becaming pale green distalizy simple ore (moxe comonIy) ascendingbranched from midmstem up to form an openg pourdish crown. Leaves. $-\mathrm{A}$ Iternate, estipulate, simple, those of the lower stem absent by anthesis, the largest at flowering time lowemost on stem and branches, on siender, spreading petioles to 1 cm Iong, the blades mostly $2-5$ cm long. nasrowly eldiptical to oblanceolate or spatulate, rounded, entise, the bases cureace or atcenuate, the surfaces pale yellow-green, inconspicuonsly reticulate, only the midrib prominent, the foliage gradualdy dimisishng in size upward on stem, grading to scattered, lineal broacts. Inflorescence. - An indeteminate, tinyowacteate raceme, the flow-

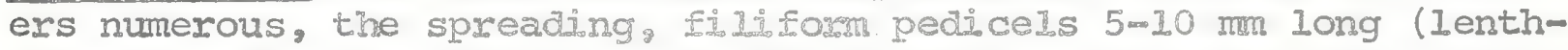
ening somewhat in frutt), subtended by triangular, scalelike bracts ca. I mm Iong, the raceme outline broadly short ovoidmoblong to nearly round.

Flowers.--Perfect, somewhat zygomomphicg buds obovold wyriform, the

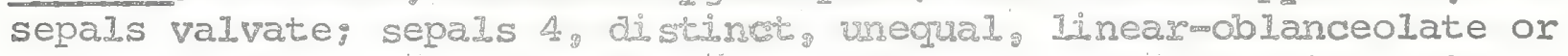
narrowly spaulate, $3 \mathrm{~m}$ m long, apicaldy recurved, greenish-white: petals 4, spreading, distinct and distinctiy urequal, the Iongest 8-9 mm long with more than half the length a slender, strongly

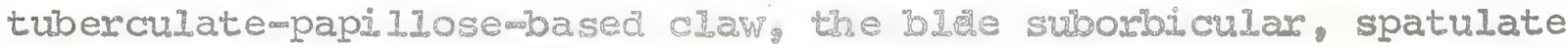
to obovate or reniform, erosemang gined whitce stamens 6 , erect to spreading, somewhat unequad, distinct, hyoogynous, the slender white filaments to $6 \mathrm{~mm}$ Iong the anthers basifixed, narrowly oblong, ca. $2 \mathrm{~mm}$ long, pale sellow: ovary superior. Iineal, subterete, ca. $2 \mathrm{~mm}$ long, raised on a slender gynophore to $2 \mathrm{~mm}$ long, the strongly bilobed stigna sessile os nearly so.

Fruit.--Siliorues on spieadirg pedicels to $1.5 \mathrm{~cm}$ 1.0ng, continuous with straight slender gyophores 5 m6 m long. the fruit body Iineal, spreadingmrecurved, $46 \mathrm{~cm}$ long, ca. $1 \mathrm{~mm}$ wide, slightIy compressed laterally the septum compressed parallel to the valves; seeds numexous, oblong, smooth. ca. 0.6 mm Long.

Distribution and Flowering season

Sandy clearings in sandscrib and sandhills, southern perinsular Florida; flowering all yearo but particular II from late Sept-m ember through October. 
Warea carteri is one of four specles endemic to the southeastern area. It is most similar to W. cumeifolia, di.fiering in the stronger pubescence of its petal claws and in the consistentIy white corolla. It is also geographically distinct, being confined to southern Florida; while W. cuneifolia ranges from northern Florida northward in sandhilis to the carolinas. The only

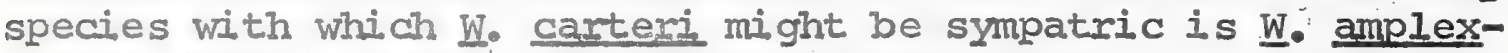
ifolia (Nutt.) Nutt. a consistently ovate-amplexicaul-leaved species of sandhilis; flowers of the latter are pinkish or lavender.

Habitat and Management Implications

W. carteri frequents both yellow and white sand sandscrub sites, where pine is scattered in the overstory and made up of pinus

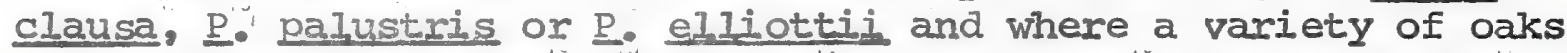
such as Quercus laevis, 2. incana, ․ geminata, l. myrtifolia, ‥ chapmanij, etc. Carya floridana. Bumelia tenax, Asimina obovata, Chionanthus, Iyonia ferrucinea, Ilex ambioua, etc., make up the scrubby understory. The saw palmetto, Serenoa repens is frequent to common. The sandy substratum is moist to quite dry, varying in color from yellow to nearly white, depending on the clay content. The Warea is normally found where the scrub is of low density or where, through a combination of fire and wind action' open patches of sand have developed. It may be associated with Selaginelia arenicola, Pteridium, opumtian various Galactia, Paronychia hernarioides, P. chartacea, Lupinus cumulicola, Clitoria, several Euphorbia, Eryngium, Berlandiera subacaulis, many species of Aristida, Andropogon, Dichanthelium Panicum, Bulbostylis warei, B. ciliatifolia, in other words species that are typical of sandy scrubland clearings or high pineland. As is true of most other annual herbs that inhabit this system, this is a plant of full sun or light shade, it is a poor competitor, and was probably maintained by woods fires that kept scrub vegetation reduced or by creation of small blowouts and sandy exposures through wind action.

The greatest threat to this particular species is urban expansion, with much of its former area now converted to residential lots, together with a repleement of scrub habitat by orange groves.

\section{References}

Channel1, R. B. \& C. W. James 1964. Nomenclatural and taxonomic corrections in Warea (Cruciferae). Rhodora 66 $(765): 18-26$.

Sma11, J.K. 1933. Manual of the southeastern flora, pp. 573574. Chapel Hili, N.C. 
SPECIES

Warea carteri SmaII: Carter"s warea

\begin{tabular}{|c|c|c|c|c|c|c|c|c|}
\hline \multirow[b]{2}{*}{$\begin{array}{l}\text { Expected* } \\
\text { Effect on } \\
\text { the Species }\end{array}$} & \multicolumn{8}{|c|}{ Management Practices } \\
\hline & $\begin{array}{c}\text { Prescribe } \\
\text { Burn }\end{array}$ & $\begin{array}{c}\text { Bul1doze } \\
\text { or } \\
\text { Root Rake }\end{array}$ & Bed & Chop & $\begin{array}{l}\text { Thin } \\
\text { over- } \\
\text { story }\end{array}$ & $\begin{array}{l}\text { Cut } \\
\text { over- } \\
\text { story }\end{array}$ & $\begin{array}{l}\text { Establish } \\
\text { Plantation }\end{array}$ & Graze \\
\hline Destroy & & & & & & & $\mathrm{x}$ & \\
\hline Damage & & & & & & & & $x$ \\
\hline $\begin{array}{l}\text { No Lasting } \\
\text { Effect }\end{array}$ & & $x$ & $X$ & $x$ & & & & \\
\hline $\begin{array}{l}\text { Beneficial } \\
\text { if Done } \\
\text { Properly }\end{array}$ & $x$ & & & & $\mathrm{X}$ & $\mathrm{X}$ & & \\
\hline
\end{tabular}

Other Comments:

*Expected effect on the species is an estimate made by Dr. Robert Kral based on his knowledge of the habitat and on knowledge gained from personal field observations. Estimates are "rough" in many instances. Results of practices may he modified depending upon the degree of application, intensity of treatment, nearness to plant communities, etc. A management practice for which no entry is made indicates a lack of sufficient information from which to predict expected results. As observations are made in the field by users of the data, the expected effect will be refined. 
Warea carteri Small

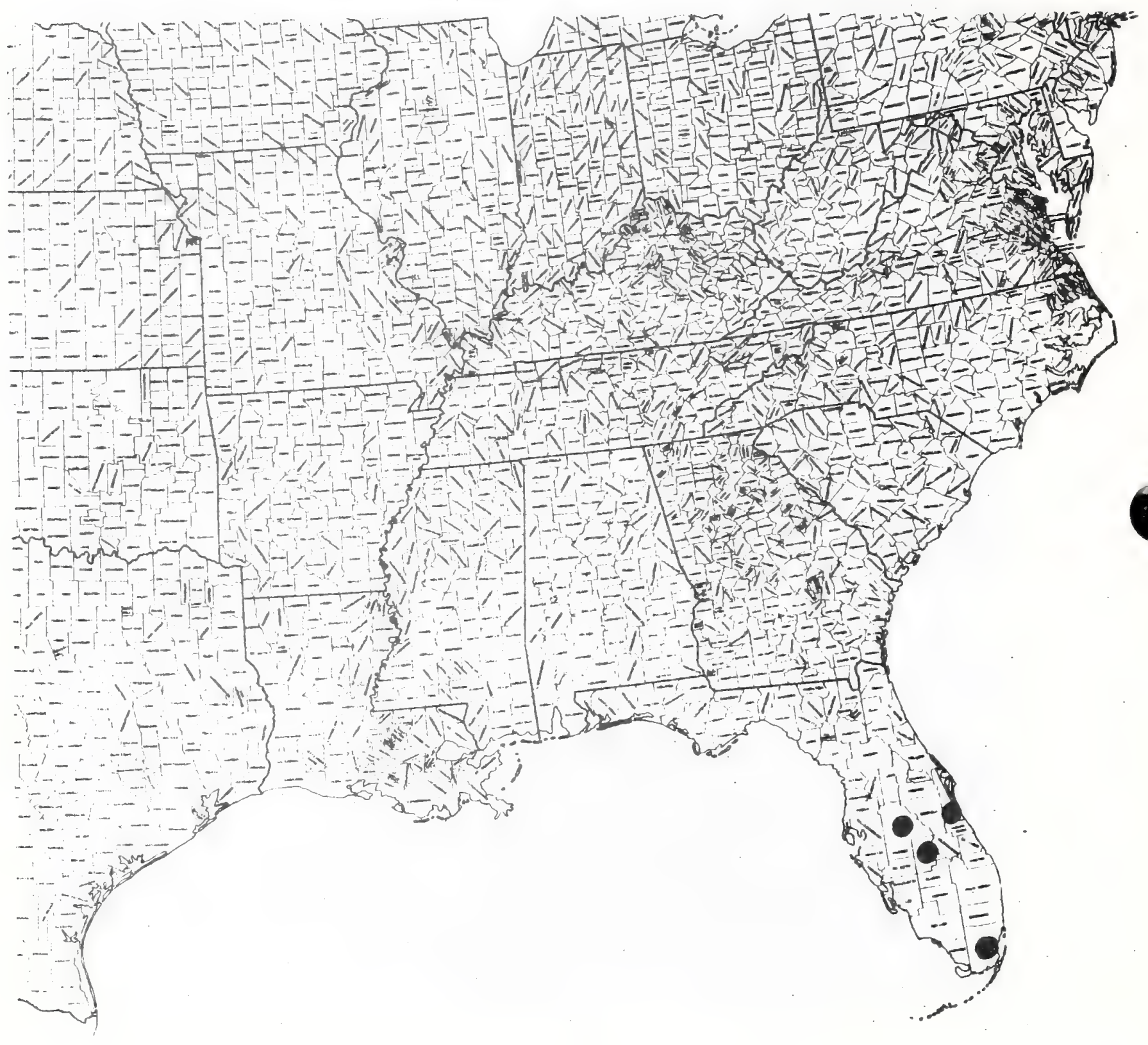




\section{CAPRIFOIIACEAE}

\section{Viburnum bracteatm Reho. Sovtheastern Fibumum}

Technical. Description

Tighti sh-barked shrub to 3 meters. the losanches spreading-arching, the branchlets tan, terete, slexdes. smooth. aging to gray brown.

Leaves.-Deciauous, opposite, che peloioles short, usually less than $2 \mathrm{~cm}$, spreadingwascending greeni shworown or reddishmorow, sparingly hirsute with glandular hairs. che stipules persistent, pale red-brown, Iinear, clitate, 3 mo m long, the blades elliptic to

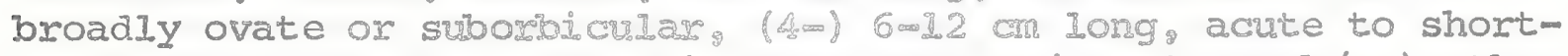
acuminate, rather remotely sinuaremdextate (ca. 1 tooth/cm), the base rounded or cordate, the upper surace a rich. dask green, smooth, the lower surface paler, pilosewhidrste along the pinnate veins, otherwise smooth or glabsescent.

Inflorescence m-Cymes exect temina on giandular peduncles $5-6$ cm long, the primary cymal branches several, glandular, at junction with branchlets producing conspicrous greenish bracts, these narrowly oblong to Iineas, $6 \mathrm{~m}$ 2 m Iong, glandular, ciliate, the whole inflorescence $4.6 \mathrm{~cm}$ broad. showp. white. Flowers.-Regular, bisexnal gracteolate, the bracteoles scarious, triangular, paie, ca. I.0mi.5 ma long, the calyx Iimb cupuliform,

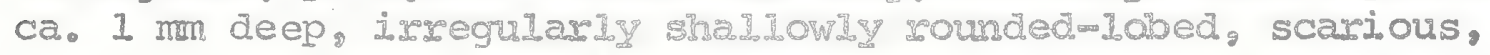
sparingly ciliate: corolda, rotate. cas 8 mm wide across the limb,

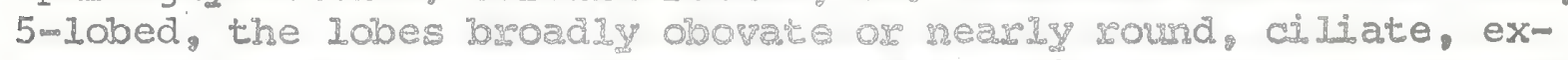
ternally spaxsely puberklert: stamens 5 epipetalous the rounded. pale yellow anchexs loxgmexserted ovary diferior, the body with its covering perianth at anthesis elipsoidal, greenish, granular. Frui.t. - Drupes when plpe bluemback, opal or ovoid, ca. I cm Iong, the sparingly grooved, somewhat flattened stone ca. $8 \mathrm{~mm}$ Iong.

Distribution and Flowering Season

Calcareousmocky bluffs, ledges, cliffs along the coosa River, northwestern Georgia, northeastern Alabama: flowering most Iy in May.

Special Identifying Feacures

In the southeast, this shrub is most similar to two species, V. rafinesquianum SchuIt. ard V molle Midnx. and is probably most closely allied to the former. differing from it mainIy in its somewhat longer petioles, dis leapes with hairs beneath confined to the main veins lin V. pafinescrianum the whole lower 
surtace is pubescent, save in var. affine (bush) House) It differs from $V$. molle in its usually smaller, more remotely toothed leaves, smoother foliage, it persistent and more conspicuous bracts and stipules, and in its tighter bark (in V. molle the bark exfoliates in small plates!).

Habitat and Management Implications

V. bracteatum is part of the shrub understory in open deciduous woodland foresting the steep, calcareous bluffs along the coosa River. The overstory dominants include Quercus muhlenbergii, $\mathrm{Q}$. shumardii, Q. mira, Ulmus americana, U. rubra, carya ovata, C. cordiformis. C. carolinae-septentrionalis, Acer saccharum, Eraxinus americana, F. quadranorilata, etc. Understory and shrub species include Caminus, Ostrya. Cercis, Amorpha fruticosa, Comus Elorida, Hamamelis, Philadelphus, Ilex decidua, Bumelia lycioides, etc. Rooted in the deeper pockets of soil are such herbs as Hepatica, Sanguinaria, Thaspium barbinode, T. trifoliata, Zizia aptera, Thalictmm dioicum. Heuchera americana (with 店. vililosa on the rocks). Coreopsis auriculata, Triljium cuneatum. Phlox divaricata, etc. Upslope the overstory becomes one of oakhickory-pine, with an understory primarily of comus florida and Vaccinium arboreum. Three other viburnum, $\mathrm{V}$. mufidulum, V. acerifolium and $V$. rafinesonianum are present, the latter two with a slight overlap in flowering time, but the peak of flower for V. bracteatum is definitely after the others.

The timber comprising the overstory is merchantable and some has been cut, but the steep terrain tends to protect these woods from intense use and certainly prohibits crop agriculture or foraging except by goats. The main threat to this shrub is from quarrying of the dolomitic limestones. This has destroyed most of the type locality along the Coosa at the southern outskirts of Rome, Georgia, and has wiped out the Alabama locality known to Roland Harper. Perpetuation of the species depends on the setting aside of some of the bluff country this shrub is known to frequent. Since there are many localities of steep limestone bluffs along and near the Coosa River where the plants should be found, further search for it should be conducted and likely areas purchased and preserved.

References

Rehder, A. 1903. Vibumum, in Sargent's Trees \& Shrubs, Vol. I. - 1904. Preliminary lists of New England plants. Rhodora 6: 54-61.

- 1940. Manual of cultivated trees and shrubs hardy in North America. New York.

Sma11,J.K. 1933. Manual of the southeastern flora,pp. 1270-1272 Chapel Hill. 
SPECIES Viburnum bracteatum Reha.' southeastern viburnum

\begin{tabular}{|c|c|c|c|c|c|c|c|c|}
\hline \multirow[b]{2}{*}{$\begin{array}{l}\text { Expected* } \\
\text { Effect on } \\
\text { the Species }\end{array}$} & \multicolumn{8}{|c|}{ Management Practices } \\
\hline & $\begin{array}{c}\text { Prescribe } \\
\text { Burn }\end{array}$ & $\begin{array}{l}\text { Bulldoze } \\
\text { or } \\
\text { Root Rake }\end{array}$ & Bed & Chop & $\begin{array}{l}\text { Thin } \\
\text { over- } \\
\text { story }\end{array}$ & $\begin{array}{l}\text { Cut } \\
\text { over- } \\
\text { story }\end{array}$ & $\begin{array}{l}\text { Establish } \\
\text { Plantation }\end{array}$ & Graze \\
\hline Destroy & $\mathrm{NA}$ & NA & NA & NA & & & $\mathrm{NA}$ & \\
\hline Damage & & & & & & & & $\mathrm{X}$ \\
\hline $\begin{array}{l}\text { No lasting } \\
\text { Effect }\end{array}$ & & & & & & $\mathrm{X}$ & & \\
\hline $\begin{array}{l}\text { Beneficial } \\
\text { if Done } \\
\text { Properly }\end{array}$ & & & & & $x$ & & & \\
\hline
\end{tabular}

Other Comments:

* Expected effect on the species is an estimate made by Dr. Robert Kral based on his knowledge of the habitat and on knowledge gained from personal field observations. Estimates are "rough" in many instances. Results of practices may be modified depending upon the degree of application, intensity of treatment, nearness to plant commuities, etc. A management practice for which no entry is made indicates a lack of sufficient information from which to predict expected results. As observations are made in the field by users of the data, the expected effect will be refined. 
Viburnum bracteatum Rehd:

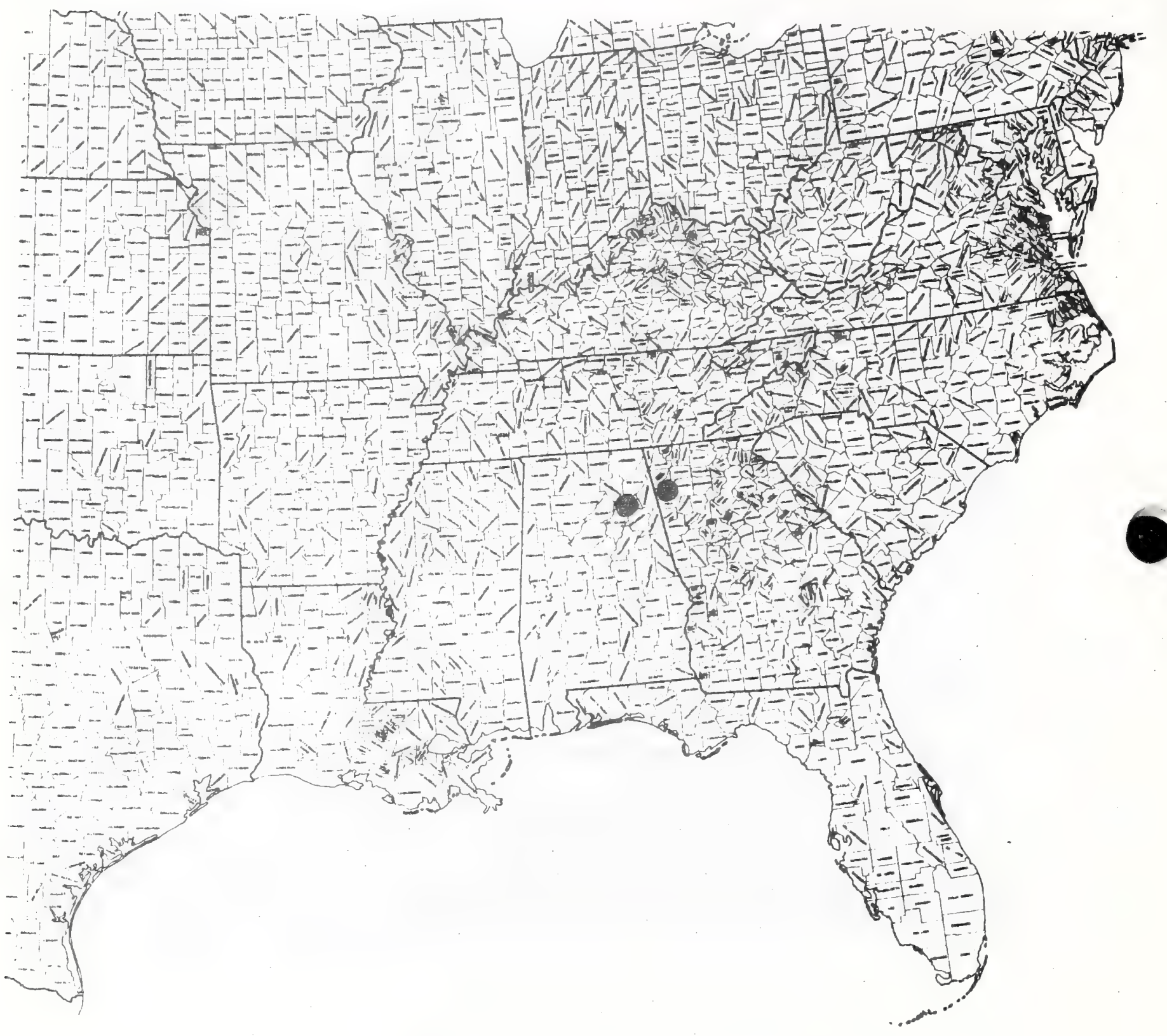




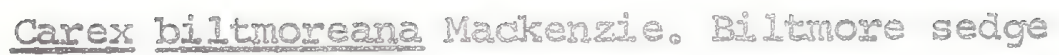

Technical Description

Fibrous-rooted, LooseIy short-steloniferous, mookl, caespitose perennial sedge.

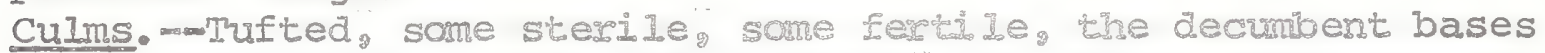
often stoloniferous, usually purplish. cloaked by numerous overlapping sheaths, the older ones (and those of previous years) fibrillose, the fertile ones $3009 \mathrm{dm}$ high by leaf tips, the bases stoutish (to $5 \mathrm{~mm}$ thick) but distally slender, sharply angulate, the angles scabroid. Leaves. -Numerous, strongly oper lapping toward culm base, more distant upward on culm, the lowest scale-like ox mostly sheath. often fibrillose with age, the longest wth sheaths prominent, the rounded backs strongly raboed greeng purplish proximally, the ventral side scarious, whiteg terucate or oblique at apex; larger leaf blades flat or slifihty revolute, lineal, the widest 5-7 mm broad, strongly nerped scabrid along the larger nerves and on the margin, the apex strong?y taperaing" harsh. Spikes.-Male (staminate) spilse lineal. 2 - 3 cm long" overtopping the uppermost (fenale) spike, the densely over lapping bracts scarious, oblong, 4-5 m long, apically obtuse or rounded marginally pale, submarginally with a broad seddishworown basd, medially around the midrito pale or greenish: anthers pale, ellipsoidal, ca. I mm long, exserted on filiform fidamers. Female spikes 2 or 3 , rather distant, the ultimate one whth few florets, thus short, directly subtending the short to elongate $(2-3 \mathrm{~cm})$ pedurcle of the male spike and subtended by a short-sheathed, setaceousmbladed bract, the lowest spike longest, narrowly Ifrear brt erect, mostly $2-4 \mathrm{~cm}$ long, the numerous florets crowded at spise tip. scattered and distant toward its base, the peduncle $2-3 \mathrm{~cm}$ long" mostIy invested by the sheath of the subtending bract this with sheath and blade similar to upper foliage leaves and often exceeding the staminate inflorescence: female scales scar: ous broadiy elliptic or oblongelliptic, ca. 3 mm long, the naspow edge pale, whitish the convex back otherwise reddishwlorown save for a greenish midzone made up of 3 nerves, the apex rounded or obtuse: perdgynim obovoid, tightly filled below the apes by the tumid asene, strongly raisednerved, smooth, green, the very short beas bent abruptIy back and appressed to the periogyial sumity its orifice entire, oblique. Akene. - - I I mply troigonous, 2,0-3.3 mang, tone rounded angles pale, the intervals somewhat conves, reddishobrown, smooth. 
Distribution and Flowering season

Seeps over and moist rocky woods around granite extrusions, Blue Ridge, southem North Carolina and adjacent Geow jia and South Carolina: flowering in April; fruiting in May.

Special Identifying Features

C." biltmoreana, by a combination of several spikes/culm, the female below the single male, prominent bract sheaths, trigonous fruit with perigynes raised-nerved and perigynial beak short, bent, entire, fits well into the section Paniceae, which is stoloniferous unlike most of the related section laxiflorae. Within the paniceae. c. biltmoreana is closest to the rare and montane C. woodii (c. tetanica var. woodii) but that plant has far more slender stolons, much narrower leaf blades, smaller perigynes, and tends to form very large clones, even turfs. Actually there is no other Appalachian Carex that quite resembles C. biltmoreana, which in the field exhibits strong tufts of purplish-based, erect leaves, these arising fram mats of browning old leaves and leaf bases of previous seasons, and the somowhat spreading, even nodding leafy fertile culms with their redish-brown-tinted male and female bractlets.

Habitat and Management Implications

C. biltmoreana is usually found in very steep, granitic sites. Commonly it grows in fulI sun or slight shade in seeps over masses of extruding granite, thus its roots are almost always wet. Common associated grasses and sedges are carex mumicata." C. atlantica, C. scabrata, scimpus polunhylius, S. expansus, Eleocharis, Rhymchospora (mostly R. capitellata), Poa, Trisetum", Sphenopholis. Glyceria. Juncus is common.' Sphagnum and other wet ground mosses form part of the mat it roots in. Hedyotis serpyllifolia, Krigia montana; Rhexia vircinica, Iudwigia are frequent herbaceous associates, together with numerous rosettes of wetland Aster and Solidago. The overstory, where present, is mostly oak-pine-hemlock and the understory heavy with Rhododendron maximum; $\underline{R}$ catawbiense, $R$. minus, $\underline{R}$ calendulaceum, Gaylussacia ursina, Ieucothoe, Iyonia, Vaccinium, etc. C. biltmoreana is perhaps the most rare of southern Appalachian carices, but within its small range is often overlooked because of the difficult terrain it grows in. I have seen it in places where a climbing rope is necessary to reach the plants with any feeling of security.

The species probably is rare, but nonetheless safer than are many other more abundant species in that the steep country in 
which it grows is not easily dogged the sites are poor for timber overall, the opporturity for explattation of the rugged landscape for forestry or for residerind or comercial purpose is

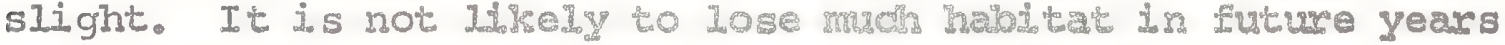

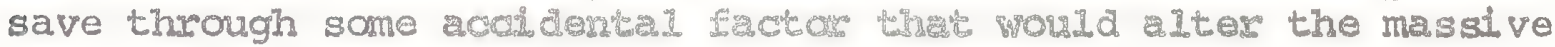
granites it grows upon.

\section{References}

Mackenzie. K. K. 1940" North Amer. can casoiceae, Vol. II. nos. 277-278.' New Yor's Botand cal Garden.

Sma1I, J.K. 1933. Manual of the southeastern flora, pp. $214-215$. ChapeI HiII, N.C. 
SPECIES Carex bil Itmoreana Mackenzie. Biltmore's sedge

\begin{tabular}{|c|c|c|c|c|c|c|c|c|}
\hline \multirow[b]{2}{*}{$\begin{array}{l}\text { Expected* } \\
\text { Effect on } \\
\text { the Species }\end{array}$} & \multicolumn{8}{|c|}{ Management Practices } \\
\hline & $\begin{array}{c}\text { Prescribe } \\
\text { Burn }\end{array}$ & $\begin{array}{l}\text { Bulldoze } \\
\text { or } \\
\text { Root Rake }\end{array}$ & Bed & Chop & $\begin{array}{l}\text { Thin } \\
\text { over- } \\
\text { story }\end{array}$ & $\begin{array}{l}\text { Cut } \\
\text { over- } \\
\text { story }\end{array}$ & $\begin{array}{l}\text { Establish } \\
\text { Plantation } \\
\end{array}$ & Graze \\
\hline Destroy & & NA & $\mathrm{NA}$ & NA & & & $\mathrm{NA}$ & \\
\hline Damage & & & & & & & & $\mathrm{x}$ \\
\hline $\begin{array}{l}\text { No Lasting } \\
\text { Effect }\end{array}$ & & & & & & & & \\
\hline $\begin{array}{l}\text { Beneficial } \\
\text { if Done } \\
\text { Properly }\end{array}$ & $\mathrm{x}$ & & & & $\mathrm{x}$ & $\mathrm{x}$ & & \\
\hline
\end{tabular}

\section{Other Corments:}

*Expected effect on the species is an estimate made by Dr. Robert Kral based on his knowledge of the habitat and on knowledge gained from personal field observations. Estimates are "rough" in many instances. Results of practices may be modified depending upon the degree of application, intensity of treatment, nearness to plant communities, etc. A management practice for which no entry is made indicates a lack of sufficient information from which to predict expected results. As observations are made in the field by users of the data, the expected effect will be refined. 
Carex bi Itmoreana Mackenzio

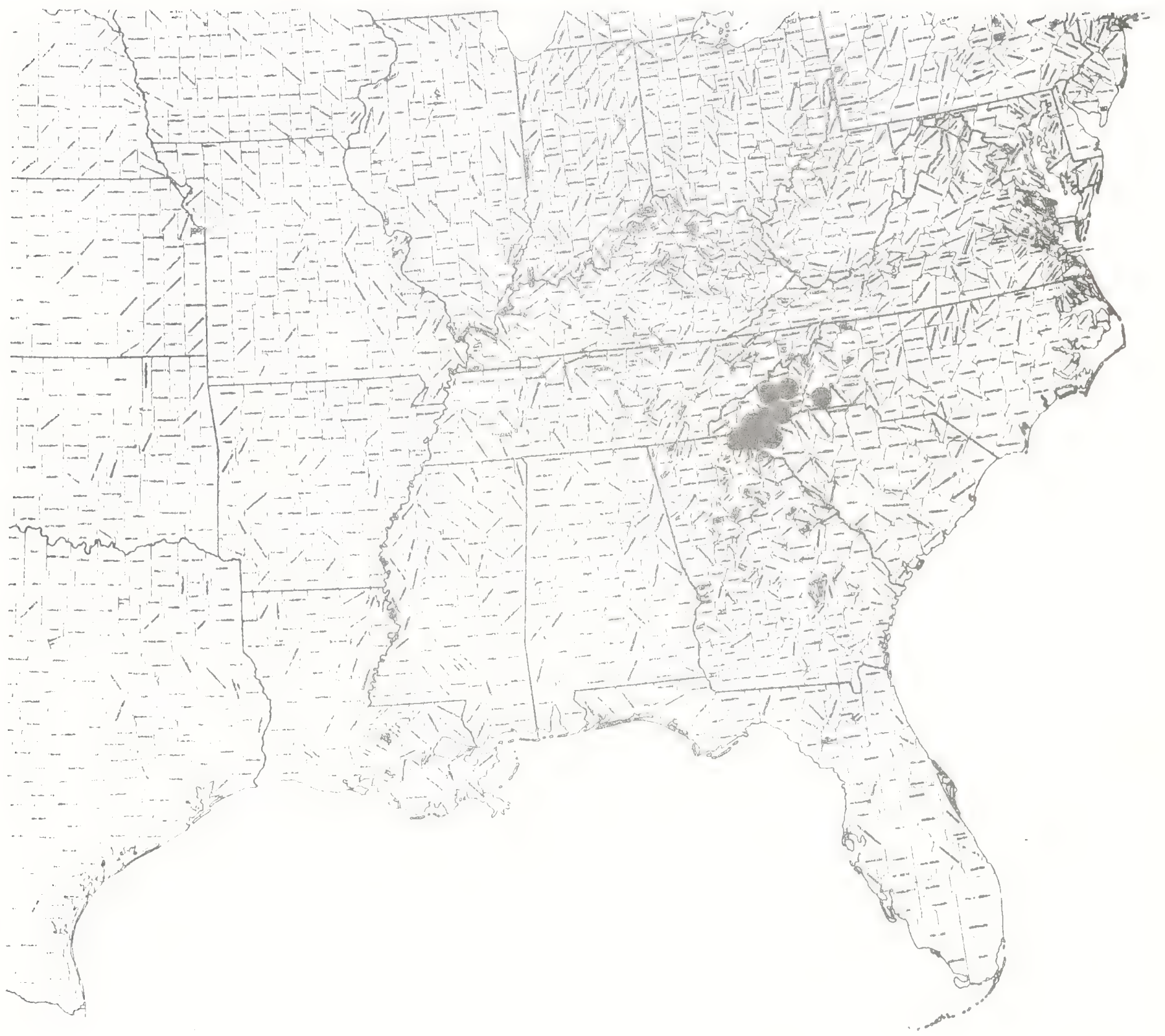


6

- 
paper 224

Text and map by:

Roberot Kral

\section{CXPERACEA E}

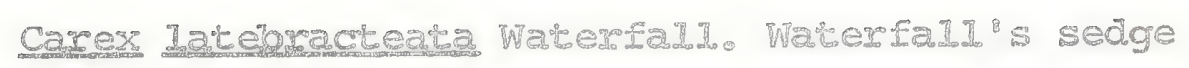

Techni cal Descrà pton

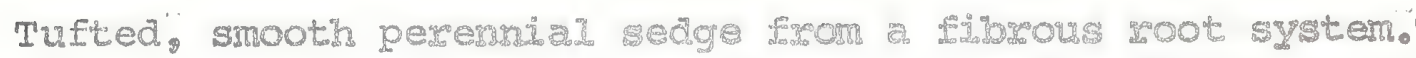

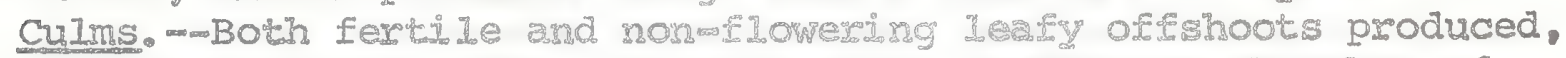
usua.Iy in Iarge tufis. phe culm bases covered by sheathes of the erect leaves, the pedurclle strongly tromgulaw, strong Iy

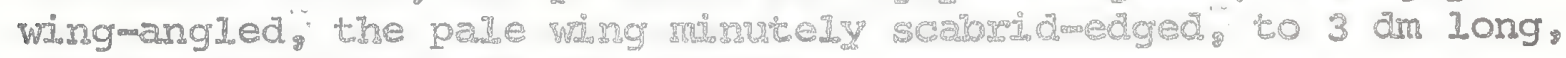
usually overopoed by ghe leaves.

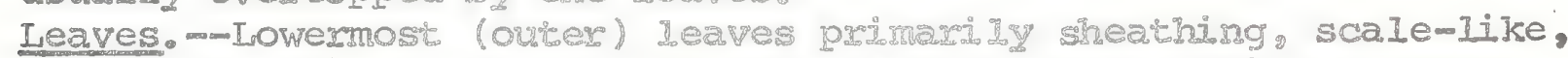
straw-colored, essentidally bladeless. full sioged foljage leaves 3-5 dm long, exect ox ascending, hlue sheaks pale grean, soft, the margins broad, scandons, apically to form a scanong prominent. obkuse to acutish Iigule,

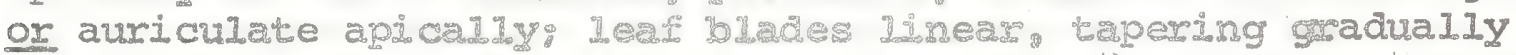
at the apex, the lasgex ores 5uIIY 1 cri broadg pale green, blue-

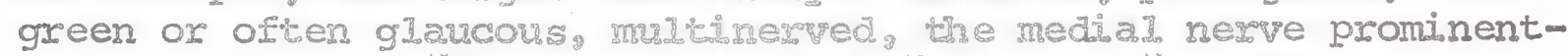

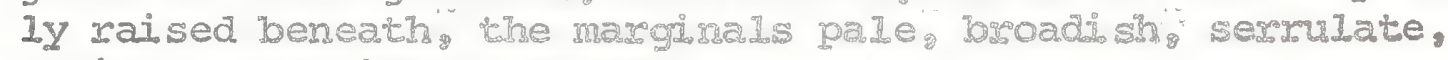
making a conspicuors bordes"

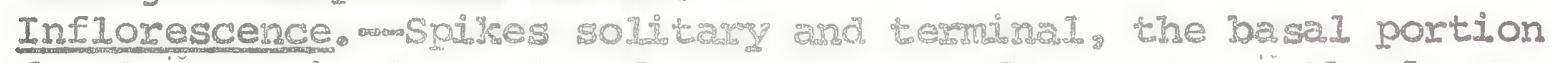

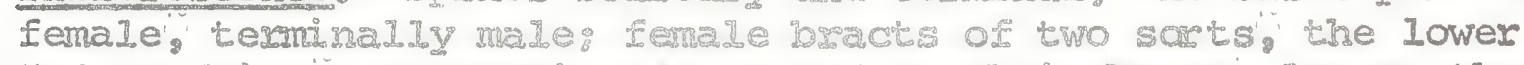

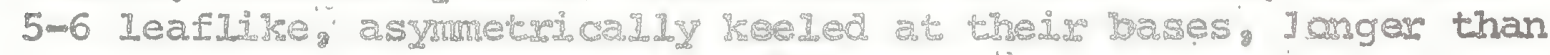

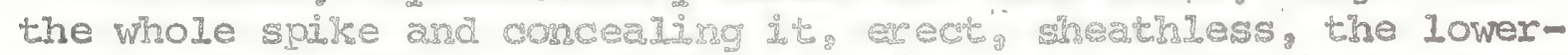

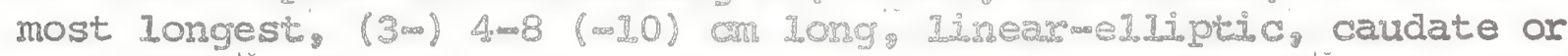
cuspidate, sini

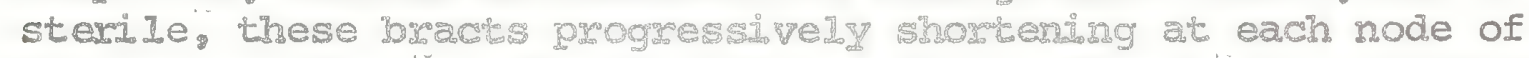
the spike rachis. each sulorending a Eemale floreb thence abrupt-

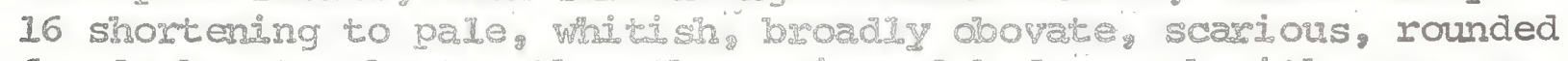
female bracts shotter than the pergyga gody each whth a narrow, asced, transverse band distaldy and ca. $2.5 \mathrm{~m} .0$ mm long: male bracts few, tightly imbri categ simi $12 \%$ to upper female bracts.

Florets. - wenale flowet with style Longmexserced. reddish-brown,

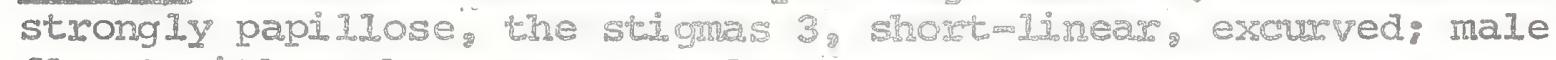
floret with anthers ca 2 mo long. Fruit. $5 \mathrm{~mm}$ long, tight II filled by the akene, somewat triangular at the naxrowed base, obscure Iy so or entwing ly trmid above, smooth;

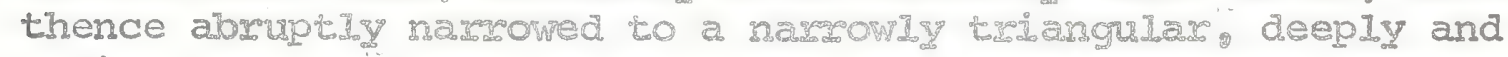

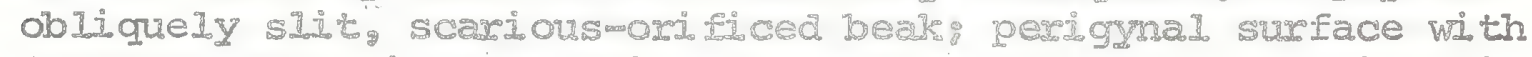
I-3 strongly raised contiruous newes several Iesswaised in-

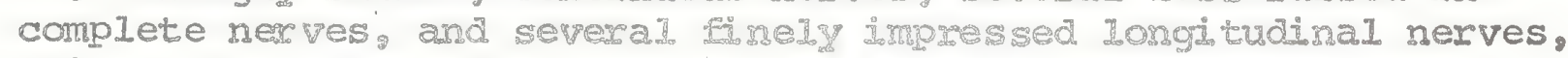
white. Asene broad1Y obovoid, obscryel ty trononous, ca. $3 \mathrm{~mm}$

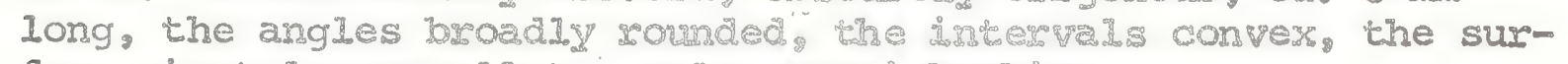
face minutely canceldate pale greenishurithe

Distribution and Fowering Seascon

Rocky' open-forested, hardwood slopes and wavines' bluffs, south- 
eastern Oklahoma and southwestern Arkansas: flowering in April and May.

Special Identifying Features

The single androgynous spike concealed by large, spathelike bracts, combined with mooth perigynes, basally joined male bracts, and the style base jointed directly to a blunt akene apex all place this carex in section Phyllostachyae, which in North America has but four other species. Only two of these, $\underline{c}$. jamesii Schw. and C. willdenovij schk, are widespread in the southeasterm U.S.: both are narrower leaved and lack the broad, strongly concealing, lower female bracts. Thus this species is more similar to c. backii Boott and C. saximontana Mackenzie, the former inhabiting dryish woods and clearings from New England and southem Canada westward to British Columbia and Wyoming, the latter on aryish hillsides, usually under pines, fram western Minnesota and Manitoba westward to Oregon and British Columbia. However, C. latebracteata has only the lower female bracts leafIike, while in C. backili alI are leaflike. Therefore C." latebracteata is closest to C. saximontana but differs (a.) in having much larger perigymes (b.) in its more robust habit and (c.) in its longer, broader leaves.

Habitat and Management Implications

Carex latebracteata is locally abundant along the stream systems of the Ouachita mountain area of southeastern oklahoma and south western Arkansas. It may be found usually on steep slopes and bluffs under Pinus echinata-mixed hardwood, mesic hardwood, oakhickory, or in natural or artificial clearings thereof. The soil is shallow to deep; the common parent materials being from shale, calcareous rock, ar novaculite" is usually a sandy loam" clay loarn; or sandy clay loam." The overstory may range fran dense forest to quite open stands and some common woodland herbaceous associates are Dentaria, Hepatica, Sanquinaria, Corydalis flarula, Thaspium barbinode, other carices, Dodecatheon meadia, Valerianella palmeri. Streptanthus scuarniformis. Phlox pilosa, Monarda musselliana. M- bradouriana; Scutellaria parvula, Penstemon arkansana, Silene vircoinica, Phacelia hirsuta; etc. In evidence are also many Panicum, Melica, Bromus purgans. Thus, some herbaceous associates are those of open dry woodlands and clearings, others of moist, rich, loamy woodlands, an indication that this sedge is rather ample ecologically. While the plants are best developed in shade, they appear to persist in artificial clearings such as male for powerlines or roads, or in very open steep poor woodlands over thin-bedded shale talus. They are eliminated by mechantcal site preparation methods where the soil is radically disturbed, and none are seen where the forest was a mixed type but has become plantation pineland. The principal threat to the species appears to be in the conversion of woodlands to plantation pineland, or with the cutting down of hardwood 
or pine-hardwood for convexsion of the land to crop agriculture or grazing. However the sceepness of the terrain inhabited by much of this species and the relatively low quality of the tirnber, plus much of its acerage beirg in state park or National forest, give it a good chance of survingl.

\section{References}

Hemann, F.J. 1970. Manual of the Carices of the rocky mountains and Colorado Basix. U. S. D. A. Agric. Handb. 374.

Waterfal1, U. T. 1954. A rew sperios of Carex (Sect. Phyllostachyae) from Oklahoma. Rhoolora $56: 21=23$. 


\begin{tabular}{|c|c|c|c|c|c|c|c|c|}
\hline \multirow[b]{2}{*}{$\begin{array}{l}\text { Expected* } \\
\text { Effect on } \\
\text { the Species } \\
\end{array}$} & \multicolumn{8}{|c|}{ Management Practices } \\
\hline & $\begin{array}{c}\text { Prescribe } \\
\text { Burn }\end{array}$ & $\begin{array}{l}\text { Bulldoze } \\
\text { or } \\
\text { Root Rake }\end{array}$ & Bed & Chop & $\begin{array}{l}\text { Thin } \\
\text { over- } \\
\text { story }\end{array}$ & $\begin{array}{l}\text { Cut } \\
\text { over- } \\
\text { story }\end{array}$ & $\begin{array}{l}\text { Establish } \\
\text { Plantation }\end{array}$ & Graze \\
\hline Destroy & & & & & & & $\mathrm{x}$ & $\mathrm{x}$ \\
\hline Damage & & $\mathrm{x}$ & $\mathrm{x}$ & $\mathrm{x}$ & & $\mathrm{x}$ & & \\
\hline $\begin{array}{l}\text { No Lasting } \\
\text { Effect }\end{array}$ & $\mathrm{X}$ & & & & $\mathrm{x}$ & & & \\
\hline $\begin{array}{l}\text { Beneficial } \\
\text { if Done } \\
\text { Properly }\end{array}$ & & & & & & & & \\
\hline
\end{tabular}

Other Comments:

*Expected effect on the species is an estimate made by Dr. Robert Kral based on his knowledge of the habitat and on knowledge gained from personal field observations. Estimates are "rough" in many instances. Results of practices may be modified depending upon the degree of application, intensity of treatment, nearness to plant communities, etc. A management practice for which no entry is made indicates a lack of sufficient information from which to predict expected results. As observations are made in the field by users of the data, the expected effect will be refined. 
Carex latebracteata Waterfall

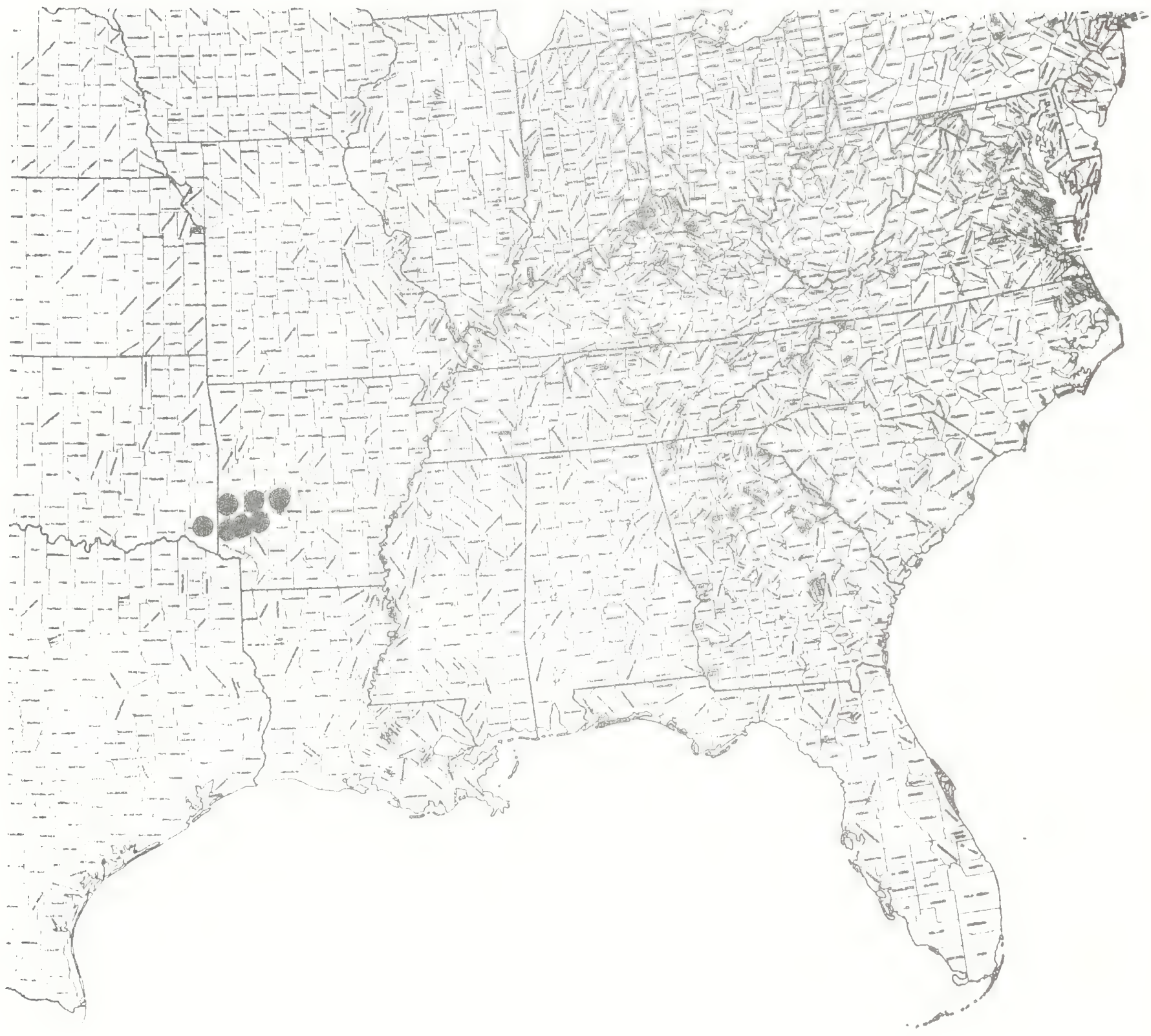


raper $\angle \angle 2$

Text and map by:

Robegt Kral

\section{CYPERA CEA E}

Carex misera Buchi. Wretched sedge

Technj.cal Descre prinon

Densely tufted' perenhial sedge, incges sidg by short. scaly lateral offshoots.

Culms.-Both sterile and Eextide present In a clump; the growth slender, at first erect. them las and dyooping mosity 2-4 dm long, proximally enFolded by sheaches aloove these narrowly Iinear, sharply triangular, scabrid whispidulous along the edges, dark green, ribbed in the intervals.

Leaves.-Numerous, crowded coward shook base, the lowest scale-like, most Iy sheath, pryplishmed zoligge leares with sheaths elongatetubular, closed, the backs spassely to copiously hirtellous, strongIy ribbed, pale green, towad base seddish the vestmal (inner) side thinner, palerg and smoothish: Ijgude nawrow, erect, scarious,

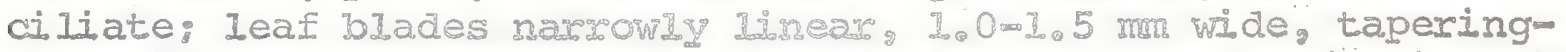
tipped, the upper surface, perticularoly towera the base, pilctulous, the lower surface less so or smoothi"

Inflorescence. mpikes ustaIdy 3 or $A$ the uppermost exclusively male, the lower 2 or 3 esclusioly femade, the lowest subtended. by a sheathless blade sinilas to a folgage leaf but shorter, its tip reaching to just below or just beyond the tip of the male spike;

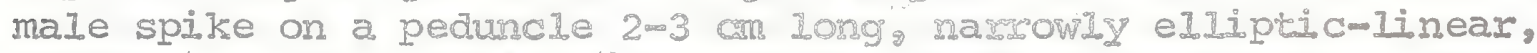
reddish, 1.5-2.0 cm long: the bracts tightdy over lapping: female spikes narrowly Ilnear the uppermost shortest and most compact," the florets over lapping in a loose spiral the lowermost longpedunculate, more elongated, to $2.5 \mathrm{~cm}$ long, with the lowermost florets distant.

Florets.-Male flore with bsacts oblong. ca. 4 m long, apically obtuse or narrowly rounded, sometimes apiculace, scarious, reddishbrown, the midnerve and medial band green ore dark, duIl brown; female bract: eliptical to banceolate or lancemovate, $2.5-3.5 \mathrm{~mm}$ Iong, acute to acuminace, scurous, seddishowown and with or without a pale border. the midnexve asd medial zone green; peri-

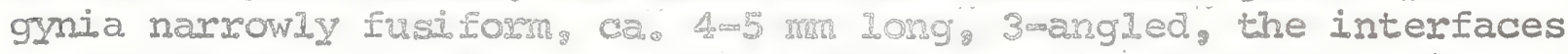
nearly flat and asgles rousdea, prif Eew neveres only 2 continuous

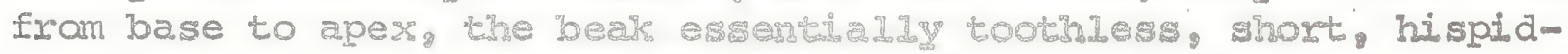

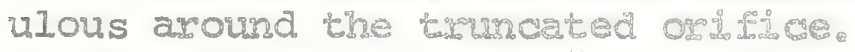

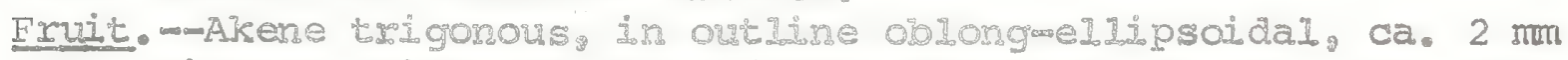
long, with an apical apiculus (style base) ca. $0.3 \mathrm{~mm}$ long, the interfaces slightly conver, the sigrace smooth pale brown, the base nasrowed glot definitely nor stipitaice. 
Shaded or (rarely) sunny granitic rock faces and cliffs, Blue Ridge, eastern Tennessee and western North Carolina south into northern Georgia: fruiting (and this is the oni. time one collects Carex for detemination!) in May and June.

\section{Special Identifying Features}

This species is distingui shed from other "Gracillimae" by its combination of lax habit, hairy, narrow leaves, reddish-tinted male and female scales, and its exclusively male teminal spike, together with the sheathless lower inflorescence bract.

Habitat and Management Implications

Carex misera is usually found in moist to wet, shaded, mosscarpeted seeps over acid rock, this usually granite or metamorphosed granite. Usually it is not far from sumit elevations in the BIue Ridge, thus may be under evergreens such as red spruce, balsam, white pine, hemlock, or under a mixture of hardwoods, particularly oaks, yellow-birch, red and sugar maple, buckeye, basswood, etc. The understory is mainly occupied by ericaceous shrubs, particularly various Bhododendron (both evergreen and "Azalea" types): Iyonia, Gaylussacia (most Iy G. ursina), Menziesia, etc. Generally, on the rock faces its associates other than bryophytes are many ferns, other Carex, grasses, various saxtifrages, Mitchella; Kriqia montana, etc. I have been informed that sometimes tufts of this species may develop on seepage over rock that has been exposed in process of road cutting, but have experience with it only from shaded, undisturbed sites. Removal of the forest overstory that helps to keep the rock faces shaded, cool and moist is bound to have a traumatic effect on such plants as C. misera. at the very least tending to dry out the habitat to the point where it would be detrimental.

\section{References}

Mackenzie, K. K. 1940. North American Cariceae II : caption and plate 332. New York Botanical Garden."

Sma11, J. K. 1933. Manual of the southeastern flora, pp. 191235. Chapel Hill, N.C. 
SPECIES Carex misera Buckley'. Wretched sedge

\begin{tabular}{|c|c|c|c|c|c|c|c|c|}
\hline \multirow[b]{2}{*}{$\begin{array}{l}\text { Expected* } \\
\text { Effect on } \\
\text { the Species }\end{array}$} & \multicolumn{8}{|c|}{ Management Practices } \\
\hline & $\begin{array}{c}\text { Prescribe } \\
\text { Burn }\end{array}$ & $\begin{array}{l}\text { Bulldoze } \\
\text { or } \\
\text { Root Rake }\end{array}$ & Bed & Chop & $\begin{array}{l}\text { Thin } \\
\text { over- } \\
\text { story }\end{array}$ & $\begin{array}{l}\text { Cut } \\
\text { over- } \\
\text { story }\end{array}$ & $\begin{array}{l}\text { Establish } \\
\text { Plantation }\end{array}$ & Graze \\
\hline Destroy & $\mathrm{x}$ & NA & NA & $\mathbb{N A}$ & & & NA & \\
\hline Damage & & & & & $x$ & $\mathrm{x}$ & & $\mathrm{x}$ \\
\hline $\begin{array}{l}\text { No Lasting } \\
\text { Effect }\end{array}$ & & & & & & & & \\
\hline $\begin{array}{l}\text { Beneficial } \\
\text { if Done } \\
\text { Properly }\end{array}$ & & & & & & & & \\
\hline
\end{tabular}

Other Comments:

*Expected effect on the species is an estimate made by Dr. Robert Kral based on his knowledge of the habitat and on knowledge gained from personal field observations. Estimates are "rough" in many instances. Results of practices may be modified depending upon the degree of application, intensity of treatment, nearness to plant commities, etc. A management practice for which no entry is made indicates a lack of sufficient information from which to predict expected results. As observations are made in the field by users of the data, the expected effect will be refined. 
Carex misera Buckley

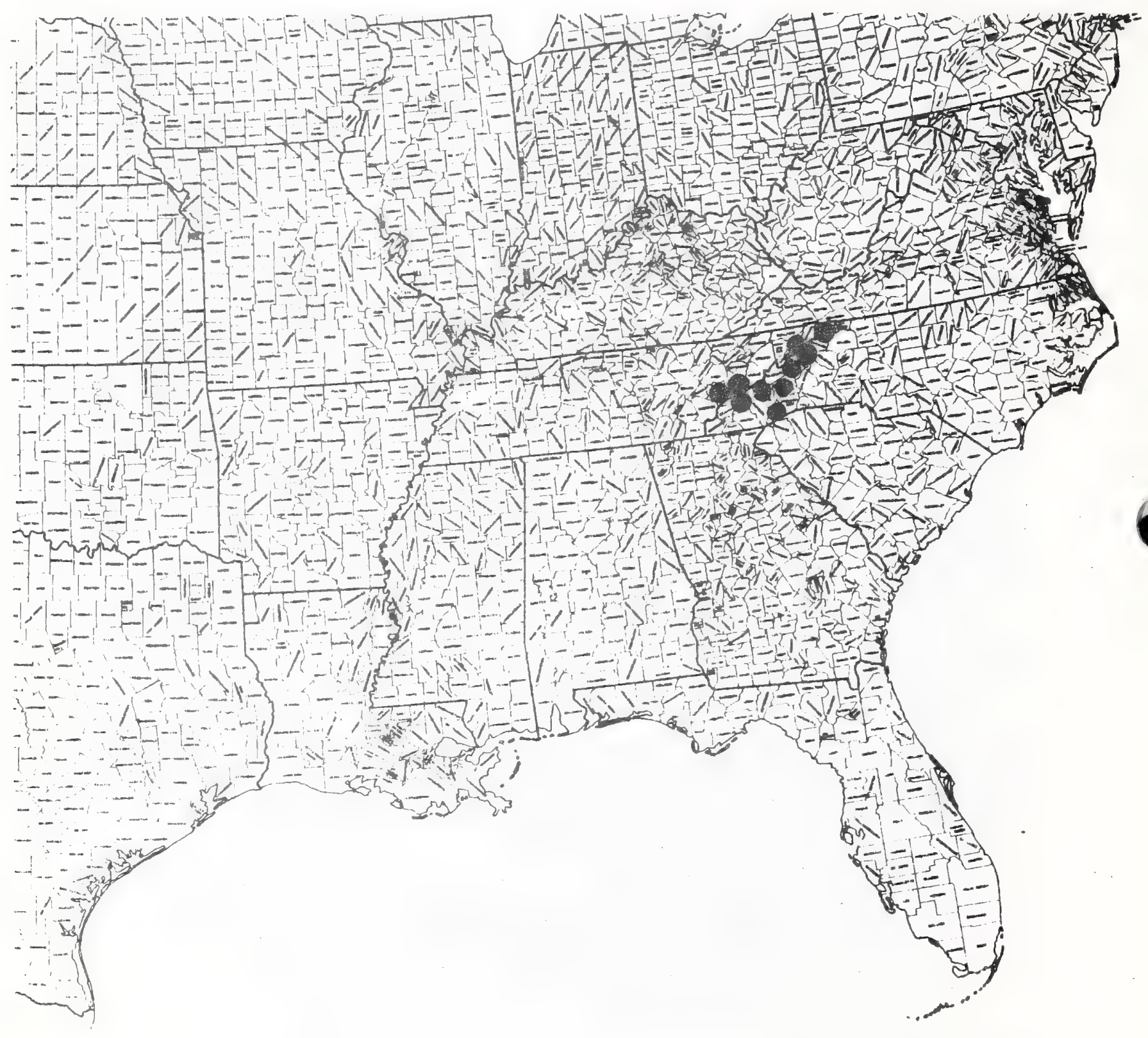


Paper 226

Text and map by:

Robert Kral

\section{DIAPENSIACEAE}

Pyxidanthera brevifolia wells. We11"s pixiemoss

P. barbulata Michx. var. brevifolia (Wells) Ahles

Technical Description

Mosslike, muchmbranched, creeping evergreen subshrub forming dense low mats.

Stems.-molder shoots slender, with a thin, retangular-anastomosing gray-brown bark: newer shoots cloaked densely by spirally imbricated scale-like remnants of foliage leaves, the more recent growth with the short, pale green internodes densely white-tomentulose. Leaves.-Mosslike, set in close spirals, spreading or ascending, mostly narrowly elliptic to oblanceolace or lanceolate, mostly 3-5 $\mathrm{mm}$ long, somewhat fleshy, firm, acute to narrowly acute or shortacuminate, the tip callusmapiculate, the margin thick, entire, the base acute or attenuate, sessile or nearly so, pale green or sometimes tinged with maroon. the upper surface white-villouspilosulous, the lower surface essentially smooth or sparsely villous proximally. Inflorescence.-mlowers solitary and terminal on numerous short branches, closely subtended and surrounded by spreading, closely spiralled leaves of shoot tips and reminding one of the antheridial heads of polytrichum. Flowers.-Perfect, regular: sepals 5 (mb), joined at very base, ca. 3-4 mm long, the lobes broady obovate, rounded, imbricated in bud, reddish-pink, ciliolate: petals usually 5 , fused at base, the spreadingmascending lobes broadly spatulate or narrowly obovate, ca. 3-4 mm long, apically broadly rounded, slightly erose, white: stamens 5, alternating with petal lobes, adnate to short corolla tube, the filaments linear, flattened, stiffly ascending, 1.5 - $2.0 \mathrm{~mm}$ long, the truncated apex inflesed, bearing a pair of white, divergent anther sacs slightly longer than $1 \mathrm{~mm}$, each tapering downward to a sharp, conic spur, opening by a transverse slit: ovary superior, ovoid, 3-locular, the style straight, exect, simple, terminating in an obscurely $3-1$ lobed stigma.

Eruit.-mapsule smooth, ovoid, ca. $2 \mathrm{~mm}$ long, loculicidally dehiscent; seeds axile, dark lorow, reticulate,ca. $0.700 .8 \mathrm{~mm}$ long.

Distribution and Elowering Season

Deep dry sands of open woods inner Coastal Plain of North Carolina and adjacent south Carolina: flowering in March and April.

Special Identifying Feacures

P. brevifolia has been considered by many recent workers to be 
merely a variant of the commoner Pixie-moss which occurs in dryish pineland barrens, bog edges, from New Jersey southward to eastern south Carolina. Primack \& Wyatt (1975) contend that the plants of the high sandhills of the inner Cosstal Plain represent a part of a clinal system. The material as represented in the type locality is, however, different in being shorter leaved, with villous tomentum abundant on the upper leaf surfaces, and with smaller flowers. Material from Chesterfield county (Sugarloaf Mt.) South Carolina appears to exhibit characteristics of both. My comments about $\underline{P}$. brevifolia are confined to the comparatively "pure" populations of Harnett County, North Carolina.

Habitat and Management Implications

The ideal habitat for $\underline{\underline{P}}$. brevifolia is deep, dryish, coarse sand with a scattering of longleaf pine and turkey oak dominant in the overstory and in the understory Vaccinium, Gaylussacia, other ericads, these becoming most abundant in the swales. Selaginella arenicola, Stipulicida setacea, Arenaria caroliniana, Baptisia (several species), Euphorbia, Lithospermum carolinense, Tradescantia (especially T. rosea), opuntia, Heterotheca (particularly the local $\mathrm{H}$. pinifolia), grasses such as Aristida, Sporobolus, Andropogon, Leptoloma, Panicum, populate the sands together with several sorts of lichen and dryland bryophytes, but the overall effect is one of considerable bare patches of substrate. The pixie-moss forms large clumps, often around the bases of the trees, tending to be more compact in habit on the driest sites, on slightly moister substrates more trailing in habit. Mechanical site preparation techniques would be devestating to these shallow-rooted mat formers, though single tree removal or clear cutting would probably not effect them adversely. These sandhills have had a history of fire, thus as a factor it has probably tended to maintain a vegetational type favorable to the pixie-moss.

At present the major threat to Well's pixie-moss has come from development of some of the sandhills for residential purposes. The largest patch (type locality) has actually been largely destroyed through the construction of a large mobile home sales part (at spout springs).

\section{References}

Ahles, H. E. 1964. New combinations for some vascular plants of the southeastern United States. Journ. Elisha Mitchell Sci. Soc. $80: 172-173$.

Primack, R. B. \& R. Wyatt. 1975. Variation and taxonomy of Pyxidanthera (Diapensiaceae). Brittonia 27 (2): 115-118. 


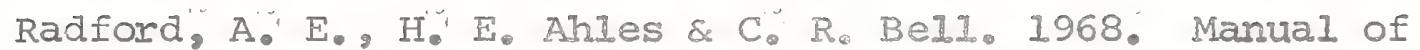
the vascular flora of the Carolinas, pp. 817-819. Chapel Hill, N. C.

Sma11; J. K. 1933. Manual of the southeastern flora, pp. 1018-1020. Chapel Hill, N.C.

WeIls, B. W. 1929. A new pixie from North Carolina. Journ. Elisha Mitchell Sci. Soc. 44: $2380-239$. 
SPECIES Pixidanthera brevifolia Wells. Well's pixie-moss

\begin{tabular}{|c|c|c|c|c|c|c|c|c|}
\hline \multirow[b]{2}{*}{$\begin{array}{l}\text { Expected* } \\
\text { Effect on } \\
\text { the Species }\end{array}$} & \multicolumn{8}{|c|}{ Management Practices } \\
\hline & $\begin{array}{c}\text { Prescribe } \\
\text { Burn }\end{array}$ & $\begin{array}{c}\text { Bulldoze } \\
\text { or } \\
\text { Root Rake }\end{array}$ & Bed & Chop & $\begin{array}{l}\text { Thin } \\
\text { over- } \\
\text { story }\end{array}$ & $\begin{array}{l}\text { Cut } \\
\text { over- } \\
\text { story }\end{array}$ & $\begin{array}{l}\text { Establish } \\
\text { Plantation }\end{array}$ & Graze \\
\hline Destroy & & $\mathrm{x}$ & $\mathrm{X}$ & $\mathrm{x}$ & & & $\mathrm{x}$ & \\
\hline Damage & & & & & & & & $\mathrm{X}$ \\
\hline $\begin{array}{l}\text { No Lasting } \\
\text { Effect }\end{array}$ & & & & & & & & \\
\hline $\begin{array}{l}\text { Beneficial } \\
\text { if Done } \\
\text { Properly }\end{array}$ & $\mathrm{X}$ & & & & $\mathrm{x}$ & $\mathrm{x}$ & & \\
\hline
\end{tabular}

Other Comments:

*Expected effect on the species is an estimate made by Dr. Robert Kral based on his knowledge of the habitat and on knowledge gained from personal field observations. Estimates are "rough" in many instances. Results of practices may be modified depending upon the degree of application, intensity of treatment, nearness to plant communities, etc. A management practice for which no entry is made indicates a lack of sufficient information from which to predict expected results. As observations are made in the field by users of the data, the expected effect will be refined. 
Pyxidanthera brevifolia Wells

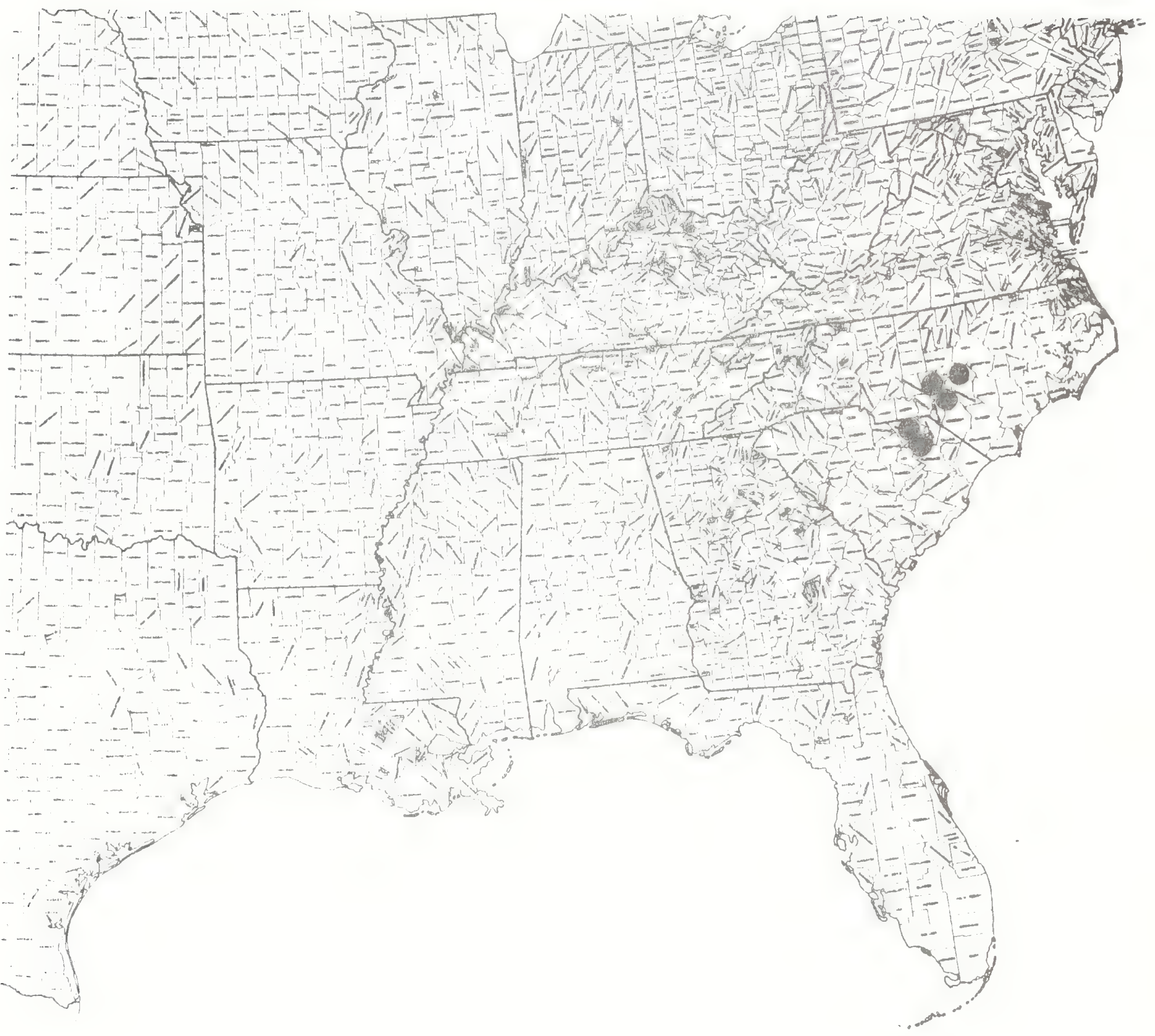


6

6

0 
Paper. 227

Text and map by:

Robert Kral

\section{ERTCACEAE}

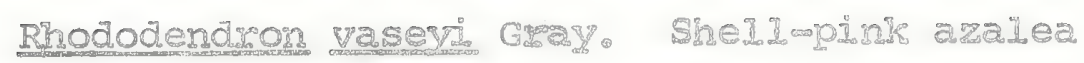

\section{Biltia vaseris (Gray) Smal}

Technical Descripotion

Deciduous shmb I-3 (-5) m taII, with few to severals exect to ascending prirnary shoots, the bark grays sts or greaybrown, thin, tending to crack longitudinaldy and exfoliace.

Twi.gs. Branching deliguescent. often psenclowhorled (as in most Rhododendron), the bark of older wood grays she or gray brown, cracking and exfoliating In long thin plates that of new shoots more reddish, sessi.lemglandularg the buds ovace, Imbricate, the bud scales glandular-ciliate with backs glasdularopunctate. Leaves. - Alternate, estipulate, spreading on short, glandular petioles, the blades elliptic to obovate, 4 m 7 (-15) cm long, acute,

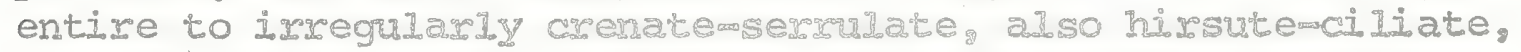
cuneate, the surfaces daw greeng che upper surface scattered-

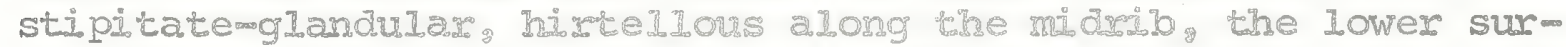
face scatteredwingute, the long haj as admised with a scattering

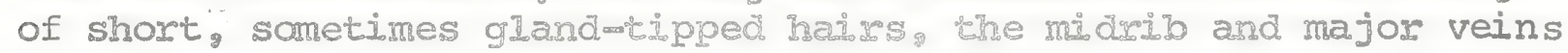
often hissute.

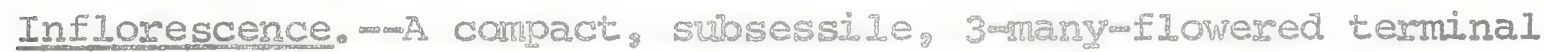
raceme reaching anthesis as the leafy shoots expand and forming a showy, ball-1ike mass $5-10$ cm broad of woodsy meloing flowers, these on slender, spreading, reddishg glandular pedicels ca. 2 cm long.

FIowers. Irregular, perfect: calyz gamosepalous, ca. 2 mm high, 5-parted, oblique, comoram 1ske, the Lobes unequal, lowtriangular, glandularmargined, green: corolla gamopetalous rotate, $2.5-3.0$ cm Iong, the 5 spreaulng, botod. Iy oblong to ovace, rounded Iobes much longer than the campanulate bases somewhat uneornal, the lowest largest and the lower lacenas next largest, all smooth, shel1 pink, grading to pale pink mottled whin deep rose flecks or streaks towaro the throat whinds. particulas ly on the lower and lateral petals: stamens 5 7. Myoogyrous. the filaments unequaI, but all slexder paleg axchng outwat and forward, thus upswept, exserted beyond the corolly the longest often 3-4 cm Iong,

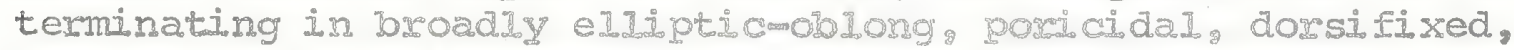
rosy or dull purple. smooth. anthers ca. 2 m long: ovary superior, lancemovoid, green, sti. pidacemormsessilemglandular, ca. $4 \mathrm{~mm}$ longs the style outwasdIn and rpwasdy swept as are the filaments, often exceeding them, slender, pinkish, stipicatemglandular, the stigma capitate, 5 - 10 bed.

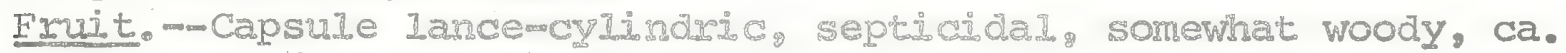
I.5 cm long, brownish. stipitatemlandular, ofter with the style persisting. 
Moist to wet, acid swamps and bogs, at elevations of over 3000 ft. Blue Ridge of North Carolina from Ashe County south to Macon and Transylvania counties; flowering in May and June.

\section{Special Identifying Features}

R. vaseyi is very distinctive in that it is the only deciduous Rhododendron in the Southeasterm Area that regularly has more than five stamens, yet less than the 10 that consistently are found in the evergreen species ( $\underline{R}$. minus, $\underline{R}$. catawbiense, $\underline{R}$. maximum) which also have entire, rather than serrate, leaf margins. Unlike the rest of the "azaleas", the corolla tube of R. vaseyi is much less than $1 / 2$ as long as the corolla limb and the corolla surface is smooth rather than pubescent or glandular-pubescent. One is reminded, on seeing this species in nature, of a deciduous $\underline{R}$. minus.

Habitat and Management Implications

R. vaseyi is always shallowly rooted in moist to wet, acidic, fern-dappled substrates, generally springy sites along mountain streams or in mountain bogs. the overstory may contain Tsuga, Pinus strobus, Picea, mixed with Acer mbrum and other maples, Aesculus, Quercus rubra, Tilia. The understory is mostly heath, being various species of Rhododendron, most ly $\underline{R}$. maximum, Leucothoe editorum, Vaccinium, etc., Sambucus, Viburnum (mostly $\underline{\text {. }}$ cassinaides), etc. The overstory, being composed of several valuable species, has a history of logging. The mechanical disturbance accompanying this however appears to have had little adverse impact", the $R$. vaseyi often increasing in the artificial clearings and also along rights of way by roads. The main danger facing this particular species comes from the irresponsible and uncontrolled development of vacation and retirement housing in this scenic part of North Carolina, which often results in total habitat destruction. Damming of small mountain streams along which $\underline{R}$. vaseyi grows has destroyed some habitat. Drainage has destroyed some bogs. The plants are extremely beautiful in bloom, thus are dug and hauled away by nurserymen and others, mostly amateur gardeners. This last activity is not necessary, since all Rhododendron root easily from cuttings.

\section{References}

Radford, A. E', C. R. Bell \& H. Ahles. 1968. A vascular flora of the Carolinas, pp. 797-801. Chapel Hill, N.C.

SmaII; J. K. 1933. Manual of the southeastern flora, pp. 993-998. Chapel Hill, N. C. 
Wilson, E. H. and A. Rehder. 1921. A monograph of Azaleas. Cambridge, Mass. 
SPECIES Rhododendron vaseyi Gray. shell-pink azalea

\begin{tabular}{|c|c|c|c|c|c|c|c|c|}
\hline \multirow[b]{2}{*}{$\begin{array}{l}\text { Expected* } \\
\text { Effect on } \\
\text { the Species }\end{array}$} & \multicolumn{8}{|c|}{ Management Practices } \\
\hline & $\begin{array}{c}\text { Prescribe } \\
\text { Burn }\end{array}$ & $\begin{array}{l}\text { Bulldoze } \\
\text { or } \\
\text { Root Rake } \\
\end{array}$ & Bed & Chop & $\begin{array}{l}\text { Thin } \\
\text { over- } \\
\text { story }\end{array}$ & $\begin{array}{l}\text { Cut } \\
\text { over- } \\
\text { story }\end{array}$ & $\begin{array}{l}\text { Establish } \\
\text { Plantation }\end{array}$ & Graze \\
\hline Destroy & & NA & NA & NA & & & & \\
\hline Damage & $\mathrm{X}$ & & & & & & & . \\
\hline $\begin{array}{l}\text { No Lasting } \\
\text { Effect }\end{array}$ & & & & & & & & $\mathrm{X}$ \\
\hline $\begin{array}{l}\text { Beneficial } \\
\text { if Done } \\
\text { Properly }\end{array}$ & & & & & $\mathrm{x}$ & $\mathrm{x}$ & & \\
\hline
\end{tabular}

Other Comments: site drainage would be deleterious!

*Expected effect on the species is an estimate made by Dr. Robert Kral based on his knowledge of the habitat and on knowledge gained from personal field observations. Estimates are "rough" in many instances. Results of practices may be modified depending upon the degree of application, intensity of treatment, nearness to plant communities, etc. A management practice for which no entry is made indicates a lack of sufficient information from which to predict expected results. As observations are made in the field by users of the data, the expected effect will be refined. 


\section{Rhododendron vaseyi Gray}

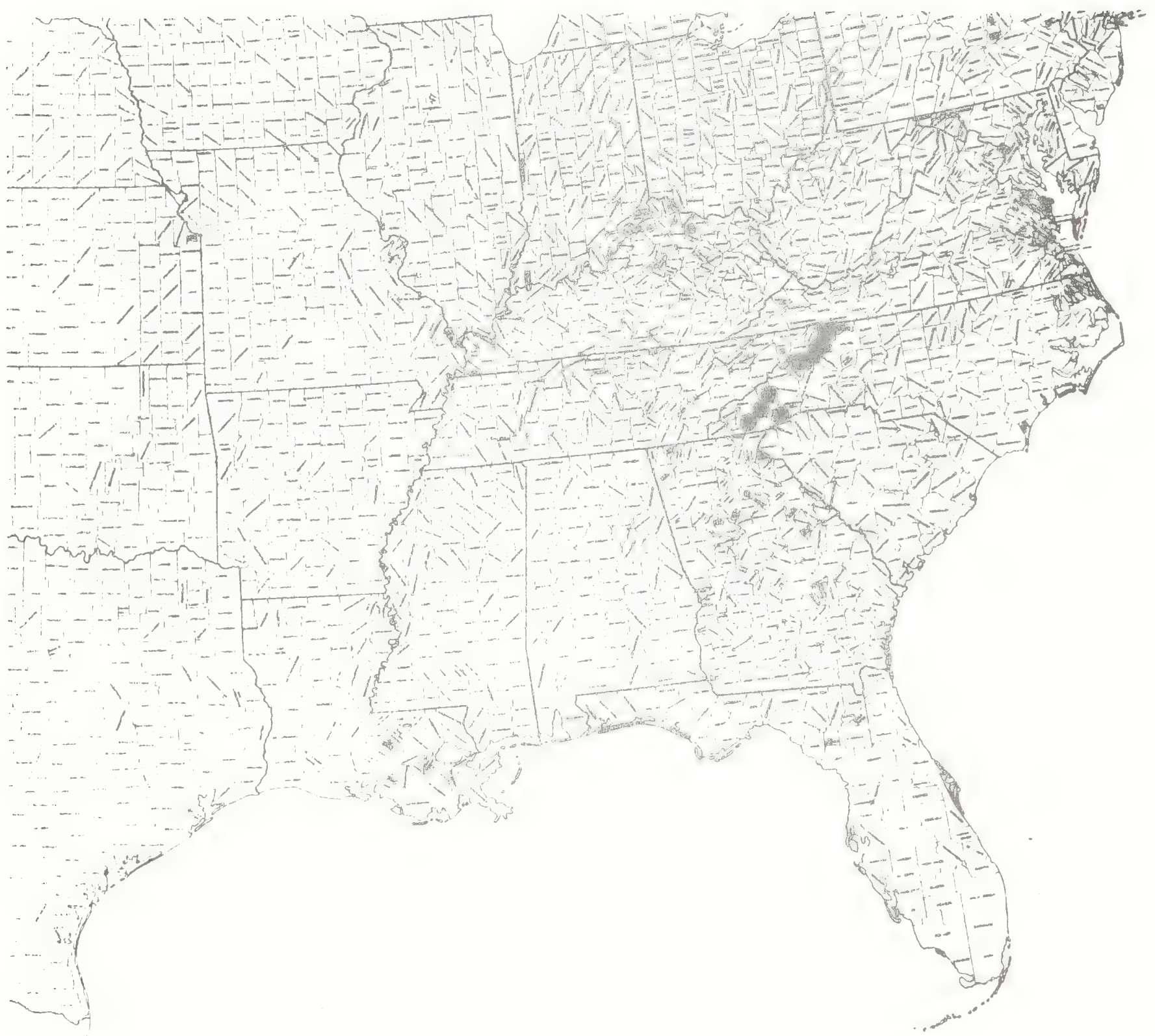


6

6

0 
Euphorbia discoidalis Chapman

E. curtisi Engelm. in part

Tithymalopsis discoidalis (Chapm.) Sma11

I. apocynifolia Sma11, in part

Status: Threatered?

Technical Description:

Perennial, milky-juiced, from an elongate simple or branched, deepset, fleshy rootstock, the lower part of the stems and lower branches often deeply buried.

Stems: erect or ascending, arising from below the ground line so that a single plant may look like a clump, above the ground line reaching mostly $3.7 \mathrm{dm}$ high, simple toward base or branching throughout, with branches at each level successively shorter, wltimately very short, this producing a profusely forkingmbranched crown of scattered involucres; axis near the ground terete, developing a thin, dullubrown, anastomosing bask with narrowly diamond shaped or 1 inear cracks, upwardy terete with several low, rounded ribs, greenish or sometimes tinged with red, smooth or with a scattering of soft, pale hairs, particularly on nodes and ultimate branchlets. Leaves: mostly alternate on lower main axis, becoming whorled at the first branch node, opposite along most of the primary and secondary branches, sessile ol petiolate, minutely hairywstipulate, those of the main stem often lost by flowering time; blades ascending to reflexed, ranging from filiform through linear to narrowly oblong, eliiptic, ovate or even oblanceolate or obovate, 2 m $5 \mathrm{~cm} 1$ ong, apically narrowly to broadly rounded, the margin entire, strongly revolute, the base rounded to acute or cureate, the petiole $3 \mathrm{~mm} 10 \mathrm{ng}$ or less or absent, if present pilose or hirsute, the upper blade surface yellowgreen, impressed veiney, rarely with a scattering of hairs, the lower surface paler, smooth or densely to sightly pilose, in narrower leaves with only the raised midrib evident, in broader leaves with pinnate laterals also raised leaves of inflorescence often abruptly smaller above the lowest pair or whor 1, usually present as pairs or in whor 15 of 3 at levels of branching, common1y linear or oblong, less often elliptic or broader, usually spreading, smooth or pubescent, as in lower leaves. Inflorescence: a dichotomously forking compound of cymes bearing cupuliform glands in the branch axis, the branches slender, smooth or pilose; involucres (cyathia) sma11, campanulate, most1y 1.0-1.5 $\mathrm{mm}$ high from base to rim of cup. pale green. pale red or yellow green, appressedwwite-hairy, the 5 reniform glands at margin of cup with broadly obovate, reniform or rectangular or squarish, white, pink, or ye11owish-white petaloid appendages, these mostly 1.5-2.0 mm 1ong, spreading, broadly rounded, entire or wavy-margined. Flowers: as in Euphorbia, namely with several singlemstamened male florets and 1 remale floret/cyathium, the androphore and filament of a stamen projecting the anthers to about the mouth of the cyanthium, the female stalk projecting the strongly 3 lobed ovary siightly beyond the cyathial rim at anthesis, still furcher as the fruit forms, the 
ovary body subglobose, strongly 3-1obed, the style 3-branched, with each branch rebranched into short-linear excurved stigmas. Fruit: Capsule globose or depressed globose, strong1y 3-1obed, most1y $2.5-3.0 \mathrm{~mm}$ high, the fruit stalk $3-5 \mathrm{~mm}$ 1ong; capsule valves yellowish-green, rarely reddish-green at murity, externally smooth; seed nearly round to broadly obovoid or ellipsoidal, pale gray, smooth, with minute rows of shallow pits, ca. $2 \mathrm{~mm}$ long, the rounded backs with a low medial ridge, the inner side with the raphe forming a longitudinal low groove.

\section{Distribution and Flowering Season:}

Open sandy woodlands, sandy clearings, sandhil1s, Coastal Plain, southwestern Georgia, northern Florida, southern Alabama; flowering from late August to frost.

\section{Special Identifying Features:}

This species was thought by its original author to be confined to the pinelands of northwestern Florida, and the earlier descriptions of it call for a narrow-leaved plant. Dr. Michael J. Huft, current monographer of this part of Euphorbia (Tithymalopsis,Agaloma) has seemingly much broadened the concept of the species so as to include several other "taxa" (including E. curtisii Engelm. in part) that have smal1ish cyathia but proportionately larger petaloid appendages and a common seed character. If this broadened description is accurate, E. discoidalis then ceases to be the rare narrow-leaved entity of the Florida pinelands and becomes a rather weedy plant that is frequent in much of southern Alabama and Georgia as we 11 as Florida. It, in this broadened sense, is distinguishable from others of the complex by a combination of profuse branching, compar atively low level of red pigmentation of cyathia, hairy nodes, petioles and cyathia, and relatively short-peduncled cymules, the short, ultimate brachlets terminating in but a single cyathium.

Habitat and Management Implications:

E. discoidalis is ecologically more ample than is the definitely more rare E. exserta. It is commonest in the Longleaf Pine-deciduous scrub oak type but may be encountered also in oak-hickory-yellow pine uplands, wherever the soils are sandy. Some common associates are Aristida (particularly A. stricta), Andropogon (ternarius,virginicus, gyrans), Gymnopogon ambiguus, Tridens, Triplasis, Sorghastrum secundum, Paspalum, many dichanthelium Panicum, Exianthus, Cyperus filiculmis, C. retrorsus, C. plukenetii, Rhynchospora grayii, Bulbosty ciliatifolia, Tradescantia, Commelina erecta, other euphorbiaceous plants such as Tragia, Acalypha, Crotonopsis, Cnidoscolus, many legumines including many Lespedeza and Desmodium, Galactia, Crotalaria, Petalostemon carolinianum, Astragalus, Lupinus (particulariy L. nuttallii, L. villosus), Tephrosia, and many composites including species of Eupatorium, Liatris (L. tenuifolia, L. gracilis, L. elegans), Helianthus, Heterotheca, Verbesiña aristata, Vernonia angustifolia, Aster (particularly A. adnatus, A. concolor, A. patens, A. dumosus), and Silphium.

This plant appears to have increased as a result of disturbance. Areas in various stages of site preparation have an abundance which continues until the crowns of plantation pine close. In naturally stocked uplands it increases as a result of wooss fires which 


\section{reduce competing woody vegetation. \\ References:}

Chapman, A.W. 1897. Flora of the southern United States, ed.3, pp. 422-426。

SmaL1,J.K. 1933. Manual of the southeastern f1ora, pp. 798-800. 
SPECIES: Euphorbia discoidalis Chapman

\begin{tabular}{|c|c|c|c|c|c|c|c|c|}
\hline $\begin{array}{l}\text { Expected } \\
\text { Effect on } \\
\text { Habltat }\end{array}$ & $\begin{array}{c}\text { Preacribo } \\
\text { Burn }\end{array}$ & $\begin{array}{l}\text { Doze or } \\
\text { Root } \\
\text { Rake }\end{array}$ & $\mathrm{Bed}$ & Chop & $\begin{array}{l}\text { Thin } \\
\text { over- } \\
\text { story }\end{array}$ & $\begin{array}{l}\text { Cut } \\
\text { over- } \\
\text { story }\end{array}$ & $\begin{array}{c}\text { Over Plant } \\
\text { with } \\
\text { treet }\end{array}$ & Graze \\
\hline Deseroy & & & & & & & $x$ & \\
\hline Damage & & & & & & & & \\
\hline $\begin{array}{l}\text { No Lasting } \\
\text { Effact }\end{array}$ & & & & $X$ & & & & \\
\hline $\begin{array}{l}\text { Benaficial } \\
\text { if Dore } \\
\text { Proporly }\end{array}$ & & & & & & & & \\
\hline
\end{tabular}

\section{Other Commenta:}

*Est1mated effect 1 a an estimate of the author baed on his book knowledge of the habltat and on knowledge galned from personal field observations. Estimates are "rough" in many Instances. Results of practices may vary in degree of application, intensity, nearness to plant communitles, etc. A column left "blank" indicates a lack of sufficient information from which to predict expected results. As observations are made in the fleld by users of the data, predictions should be reflned by area and by intensity of forestry practices. 
Approximate Range of:

Euphorbia discoidalis Chapman

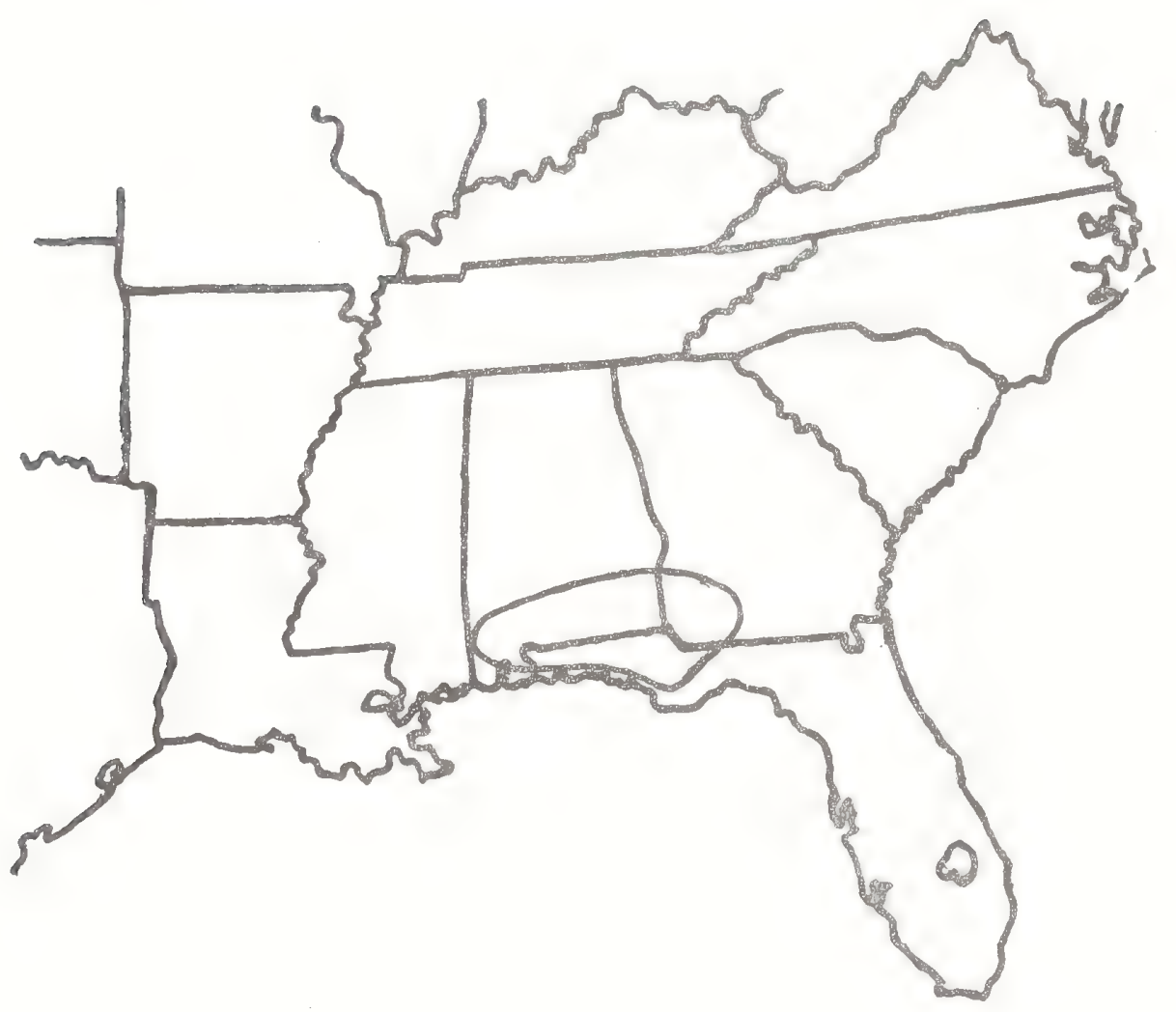


6

6

- 
raper $2 \angle y$

Text and Map by:

Robert Kral

\section{FABACEAE}

Baptisia megacarpa Chapm. ex Torr. Streamside wild indigo

?B. riparia Lairsey

Technical Description

Perennial legume from tough, fibrous, deep rootstock. Stems.- Solitary or several from the crown to fuldy I meter Iong ( -1.5 meters), the leafless stem base usuady stout, terete, smooth, pale green, often glaucous. dis var.cately branching, ziguzag and rebranching distally, thus forming a broad, yet shallow crown.

Leaves. - Palmately bionomtri- foliolate on spreadingmascending petioles, these passely hissute at very base, and much shorter than the leaflets: leaflets spreading, obovate to narrowly or broadiy elliptic or rarely ovate, most $1 y$ - $55 \mathrm{~cm}$ long. apically narrowly rounded or acute, extires the bases mostly cuneate, the upper surface dark yel.1owmgreen, smooth, the lower surface very pale, maxkedIy reticulate, smooth or sparingly hissute along the midrib and main lateral veins: stipules early deciduous. Inflorescence.-Flowes few to many in both terminal and axillary indeteriminate racemes on slender peduncles longer than the petioles of subtending leaves. usually spreading drooping, the spreading ascending pedicels Losing their narow, scale-like, bracts by anthesis. Racemes including peduncle, highly variable in length, mostly $5 \mathrm{~m} 15 \mathrm{~cm}$ long.

Flowers. - Regular. zygomorphic, fuldy $2 \mathrm{~cm}$ Iong on siender, smooth pedicels at anthesis ca. 1 cm Iorg. ir frut to $2 \mathrm{~cm}$ the calyx at anthesis ca. $1 \mathrm{~cm}$ long or slighty less, campanulate, the orifice slightIy oblique, the limb slight Iy bilabiate, the teeth 4 , triangular, shorter than the tube, the upper tooth shorter and broader than the lower 3 , apicaliy bidentate, the outer surface pale green, mooth, raised-peiney, the inner surface villosulous; corolia papillionaceous, cream the petals 5, projecting forward, clawed, the banner ca. $1.5 \mathrm{~cm}$ long. orbicular, retuse, the wing petals slightly longer with oblong, round tipped blades, the keel pecals longest, ca. $2.0 \mathrm{~cm}$, their blades excentricaly oblong, aplicaly roumded, proximally auricled; stamens 10, distinct, ca. 1.5 cm long, the slender but flattened pale filaments projected forwasa arourd the ovary, hidden in the curvate keel, the yellow, edijpsoidal, basifixed arthers ca. 1 mm long: ovary superior, including the long style about as long as the stamens. the body lancem 1inear, sLithII Laterally compressed, nearly smooth to hintellous strongly stipitate. Fruit - we gume broadly obovoid. broadly eldipsoidal or broady short - Cy Iindric, pexy bladderyminflated, mostiy $3-5 \mathrm{~cm}$ long, the valves thin. pale brown glabous, the veins foming a raised fine reticule, the stipe hider in the pess stent calyx, the slender style persistent, ca. 1 cm long. seeds sumerous dis outidre elilptical. 
somewhat compressed laterally, smooth, ca. $3 \mathrm{~mm}$ long.

Distribution and Flowering Season

Moist shaded ravine slopes, streambanks, bluffs and rises in sandy bottoms, northwest Florida, southwest Georgia and southeast Alabama: flowering from late April to early June.

Special Identifying Features

This tallish, broad-crowned, woodland species has a somewhat confused taxonomy; extremes of it may be actually what has been called B. riparia Lairsey and $\underline{B}$. riparia var. minima Lairsey. These, described from flowering, not fruiting material are supposed to be distingui shed by their narrower leaflets and hairier ovaries, but such characters appear to blend into extremes of $B$. megacarpa. It is probably best to refer to all cream-petaled, short-racemed, smoothish, trifoliate Baptisia which have thin-walled, inflated legumes, if they are from riparian systems of that area, as $\underline{B}$. meqacarpa.

Habitat and Management Implications

B. megacarpa grows in light to deep shade, or at edges of woods, is rooted in fine sands, sandy loams or sandy alluvium, sometimes on sandy rises in large bottoms. The overstory may range from mixed mesophytic to pine-hardwood with the common pines being loblolly or spruce pine, the commoner hardwoods being willow oaks, elm, hickory, ash, bull bay, yellow poplar and sweet gum. It is in sites that rarely dry, but which at the same time would rarely flood. It is normally associated with spring woodland herbs that require well drained, moist, loamy substrates and which tend to di sappear when the overstory is removed. The rich sites in which this plant grows are excellent for quality hardwoods and pine and as a consequence are being, or have been, heavily logged; this may in part explain the comparatively rare occurrence of B. megacarpa, though some good localities may support hundreds, even thousands, of plants. Selective logging, if this does not result in severe mechanical disturbance or erosion of the sloping sites, probably has no adverse effect. Clear cutting poses a danger for several reasons, even if there is not mechanical site preparation. First, full sun and subsequent drying and loss of humus from such sites, would be detrimental. Second, the advent of Lonicera japonica, Rubus, Smilax, Pueraria, all of which tend to crowd out original ground cover in such disturbed habitat, would eliminate this species.

\section{References}

Lairsey, Mary M. 1940. A monograph of the genus Baptisia. Ann. Mo. Bot. Gard. 27: 119-244.

Sma11, J.K. 1933. Manual of the southeastern flora,pp. 674-678. 
SPECIES Baptisia megacarpa Chapm. ex mopuc streamside wi ld indigo

\begin{tabular}{|c|c|c|c|c|c|c|c|c|}
\hline \multirow[b]{2}{*}{$\begin{array}{l}\text { Expected* } \\
\text { Effect on } \\
\text { the Species }\end{array}$} & \multicolumn{8}{|c|}{ Management Practices } \\
\hline & $\begin{array}{c}\text { Prescribe } \\
\text { Burm }\end{array}$ & $\begin{array}{l}\text { Bulldoze } \\
\text { or } \\
\text { Root Rake }\end{array}$ & Bed & Chop & $\begin{array}{l}\text { Thin } \\
\text { over- } \\
\text { story }\end{array}$ & $\begin{array}{l}\text { Cut } \\
\text { over- } \\
\text { story }\end{array}$ & $\begin{array}{l}\text { Establish } \\
\text { Plantation }\end{array}$ & Graze \\
\hline Destroy & NA & $X$ & $x$ & $\mathrm{X}$ & & $x$ & & \\
\hline Damage & & & & & & & & $\mathrm{x}$ \\
\hline $\begin{array}{l}\text { No Lasting } \\
\text { Effect }\end{array}$ & & & & & $\mathrm{x}$ & & & \\
\hline $\begin{array}{l}\text { Beneficial } \\
\text { if Done } \\
\text { Properly }\end{array}$ & & & & & & & & \\
\hline
\end{tabular}

Other Comments:

* Expected effect on the species is an estimate made by Dr. Robert Kral based on his knowledge of the habitat and on knowledge gained from personal field observations. Estimates are "rough" in many instances. Results of practices may be modified depending upon the degree of application, intensity of treatment, nearness to plant communities, etc. A management practice for which no entry is made indicates a lack of sufficient information from which to predict expected results. As observations are made in the field by users of the data, the expected effect will be refined. 
Baptisia meqacarpa Chapm. ex Torr.

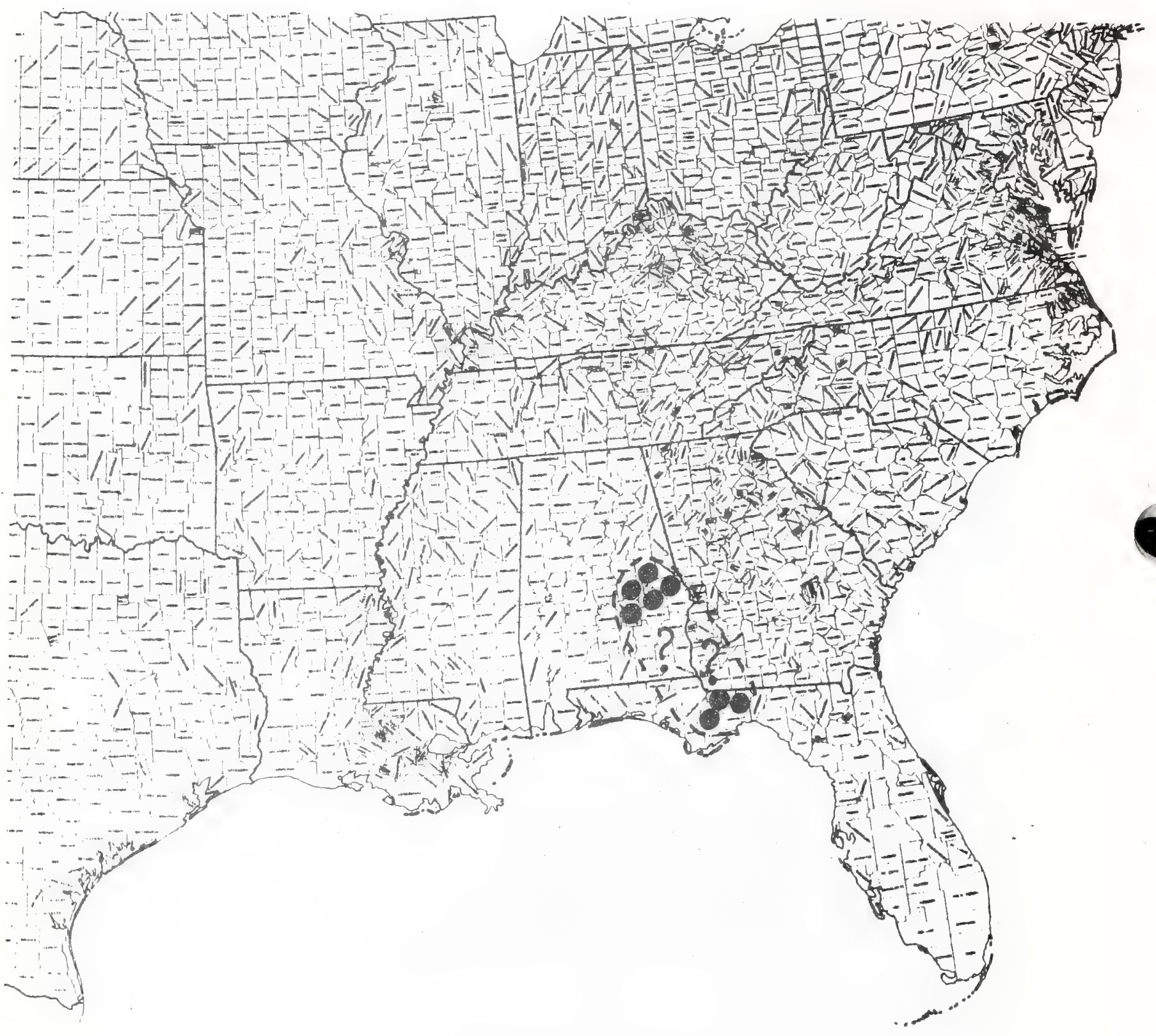


Paper 230

Text and map by:

Robert Kral

\section{FABACER}

\section{C1itoria Exagrans Smal. Sweet-scented butterfy-pea}

\section{Martiusia Exagrans. Smad}

\section{Technical, Descriptotion}

Subshrubby perennid. I smoothish dherbs from a stowt. woody caudex,

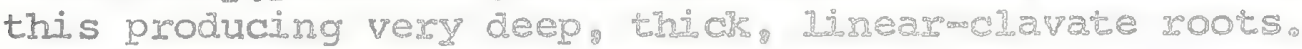

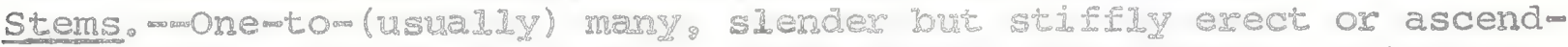

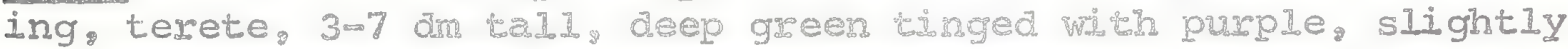
glaucous, usually leafless toward the base at flowering time, only the paired, triangulas ovates, scalewide stejpules persisting, simple or sparingly ascendingmbrached from midmstem up there very slender and zigomag, minute zy puberulous.

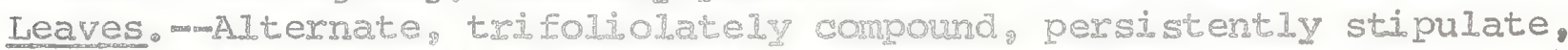
the stipules scalew Bike, naw reddishmbrown, ca. 3 mm long (smaler coward sterm tips): petioles colored as in stems, slendes. spreadingascending, minutely pubemlous, the length various but usually about as long as the lateral leaflets subtended: Leaflets 3 , plonate, the larger ones mostly 2-5 cm long, Eim. Innear to ablong. nawowly eldiptical or narrowIy lanceolate, wounded to obruse os shalowly masginate. mucron-

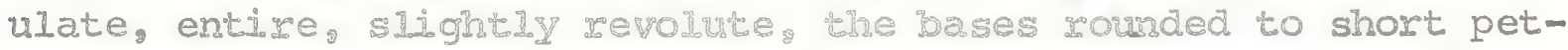
iolules, these subtended loy short, trongular-1ndoar, purplish stipels: upper surface daro green. strongly reticulate with a

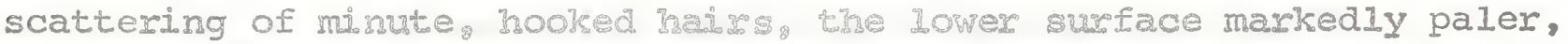
raised-reticulate, mooth or spadodigly strigose along the major veins.

Inflorescence. man Lowers Doth chasmogamous and cleistogamous, the former showy. (Im) $2(-3)$ on spreadingwascending, axillary, stout, purpIish peduncles slightII shorter than subtendirg petioles, apically bearing 2 pairs of pusplish narsowlywicrangular scale-1ike bracts $2-3$ m. Iong. these swbteroing stiffish erect or ascending, puberulent, pale green pedicels $3 \mathrm{~mm}$ mong.

Elowers.mperfect, zygomorohic. spreading: chamogamous flowers large, showy, with a faine roaghande subtended by a pair of purp-

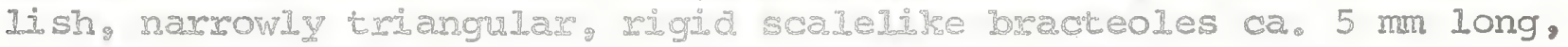

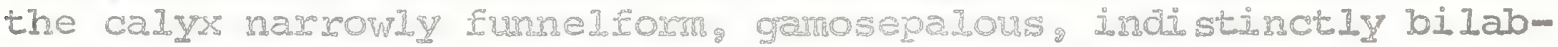
iate, ca. I an long to the base of the deepest sinus, the lower lip

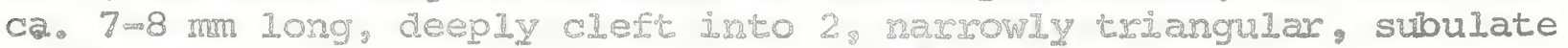
teeth, the mppex lip deeply cleft into 3 mose broadly triangular

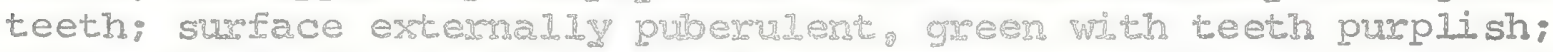
petals 5 , distinct the banner Mali moonshaped in bud and folding sharply over the rest of the petals, wher expanded 4 m5 an long, obovate or even rhomioj. $\mathrm{C}_{\mathrm{g}}$ the bulk of the blade bent mpward, pale bIue with purplish prominest pelns and a broad, whitish basalmedial "eye": whing petals mach shorter binan the banner projecting 
forward and largely concealing the 2 keel petals, oblanceolate or spatulate, yellowish-white: keel petals shorter still, strongly clawed, the small, broadly ablong blades very curved on the lower margin: stamens 10, smooth, diadelphous, pro, zcting forward and upward, 1.5-1.8 cm long, the 9 fused filaments joined to above the middle, the basifixed pale yellow anthers ca. I mm Iong, erect: ovary superior, smooth or minutely hooked-hairy, linearupcurvate, ca. $1 \mathrm{~cm}$ long, prominently stipitate, the style more slender, upcurved, ca. 7-8 mm long, distally pilose, the stigma very small, capitate.

Fruit.--Ripe legumes oblong, somewhat flattened laterally, 3-5

cm long (exclusive of persistent style base or "beak"), 7-9

$\mathrm{mm}$ broad, exserted beyond the calyx on an uncinate-puberulent stipe fully $1.0-1.5 \mathrm{~cm}$ long, splitting along both sutures to expose a row of 3-9 broadly oblong to subglobose or angular, dark brown, smooth beans 3-4 mm long and broad.

Distribution and Flowering season

Very local in sandscrub, central part of southern peninsular Florida; showy flowers (chasmogamous) produced mostly in May and June; cleistogamous flowers intermittently produced later in season.

Special Identifying Features

This Clitoria is distinguished from others of the southeastern area by its more consistently erect (versus viney) habit, its much narrower, usually lineal or oblong, leaflets, and particularly by the very long stipe of the ovary and fruit (in $\underline{\text { c. mar- }}$ iana, the southeastern species nearest it taxonomically, the stipe of the fipe fruit does not protrude beyond the calyx).

Habitat and Management Implications

C. Eragrans consists now of a very few, scattered populations in the sandy scrublands of two counties in southern Florida. It is deeply rooted in deep, yellow or white, sands, the primary roots and branch roots much like very long, spatulate fingers. Most of the time it is found in sandy clearings in the scrub; sometimes it occurs in very open scrub. The overstory, where present, may be of scattered longleaf pine, slash pine or sand pine, these associated with both evergreen and deciduous scrub oaks, several ericaceous shrubs and a scattering of saw-palmetto. Associate herbaceous species on these dryish sites include selaginella arenicola, many Dichanthelium Panicum, Cenchrus, Andropogon, Aristida, Stipa avenacea, Sporobolus junceus, Cyperus retrorsus, C. Filiculmis, Bulbostylis warei, B. ciliatifolia, Helianthemum, several Lechea including I. patula, In deckentii, I. divaricata. 
Hypericum cumulicola. Paronychia chartecea, E. herrariaides. Polygonel1a basinamea, Pireoreta, Bonamia grandifilora, several

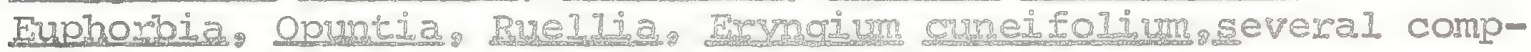

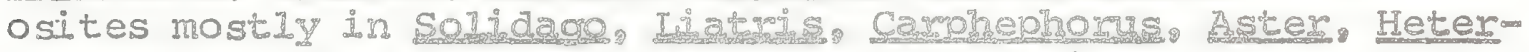
otheca, Balduins ancustifolig Severa species of zare shrubs, including prunus geniculata Conredina brevifolias Calamintha

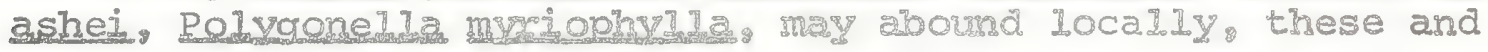
several of the herbs being typical of the now endangered flora of scrublands and sharing many of the same ecological quirks. The Clitoria and its associates were probably maintained by a combination of natural woods firses which tended to reduce woody plant competition, together with erosional forces, particularly wind, would would tend to creace the sandy clearings favored by the Clitoria. Most of the scrub homeland of C. Eragrans has been converted either to housing or to commercill property as the south Florida towns expand, or to orange groves. Such plants as this one do not seem to return qujckly to abandoned fammand or to neglected orange gropes. On the other hand, those areas of scmib that are still relatjovely incact (and they are fewl) are now kept from fire and thus thexe is a shift ir them toward an ever denser woody growth; this means that C. fregreans is losing ground even there! It should be considesed endangesed rather than threatened.

References

Fantz, P. R。 1977. A revision of Clitoria (unpublished Ph,D. Thesis, University of Florida, Gainesville).

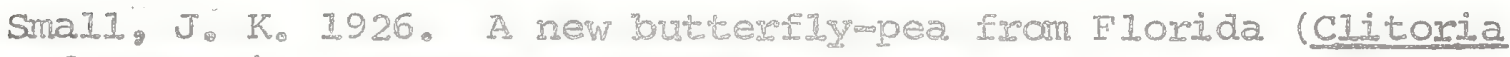
fraqrans). Torreya $26: 56057$. - 1933. Mamual of the southeastern flora, pp. 721-722. CrapeI EIII, N。C. 
SPECIES Clitoria fragrans Small. Sweet-scented butterfly-pea

\begin{tabular}{|c|c|c|c|c|c|c|c|c|}
\hline \multirow[b]{2}{*}{$\begin{array}{l}\text { Expected* } \\
\text { Effect on } \\
\text { the Species }\end{array}$} & \multicolumn{8}{|c|}{ Management Practices } \\
\hline & $\begin{array}{c}\text { Prescribe } \\
\text { Burn }\end{array}$ & $\begin{array}{c}\text { Bulldoze } \\
\text { or } \\
\text { Root Rake }\end{array}$ & Bed & Chop & $\begin{array}{l}\text { Thin } \\
\text { over- } \\
\text { story }\end{array}$ & $\begin{array}{l}\text { Cut } \\
\text { over- } \\
\text { story }\end{array}$ & $\begin{array}{l}\text { Establish } \\
\text { Plantation }\end{array}$ & Graze \\
\hline Destroy & & $\mathrm{x}$ & & $\mathrm{x}$ & & & $\mathrm{x}$ & \\
\hline Damage & & & $\mathrm{x}$ & & & & & $\mathrm{x}$ \\
\hline $\begin{array}{l}\text { No Lasting } \\
\text { Effect }\end{array}$ & & & & & & & & \\
\hline $\begin{array}{l}\text { Beneficial } \\
\text { if Done } \\
\text { Properly }\end{array}$ & $x$ & & & & $\mathrm{x}$ & $\mathrm{x}$ & & \\
\hline
\end{tabular}

Other Comments:

*Expected effect on the species is an estimate made by Dr. Robert Kral based on his knowledge of the habitat and on knowledge gained from personal field observations. Estimates are "rough" in many instances. Results of practices may be modified depending upon the degree of application, intensity of treatment, nearness to plant communities, etc. A management practice for which no entry is made indicates a lack of sufficient information from which to predict expected results. As observations are made in the field by users of the data, the expected effect will be refined. 
Clitoria fracrang smal1

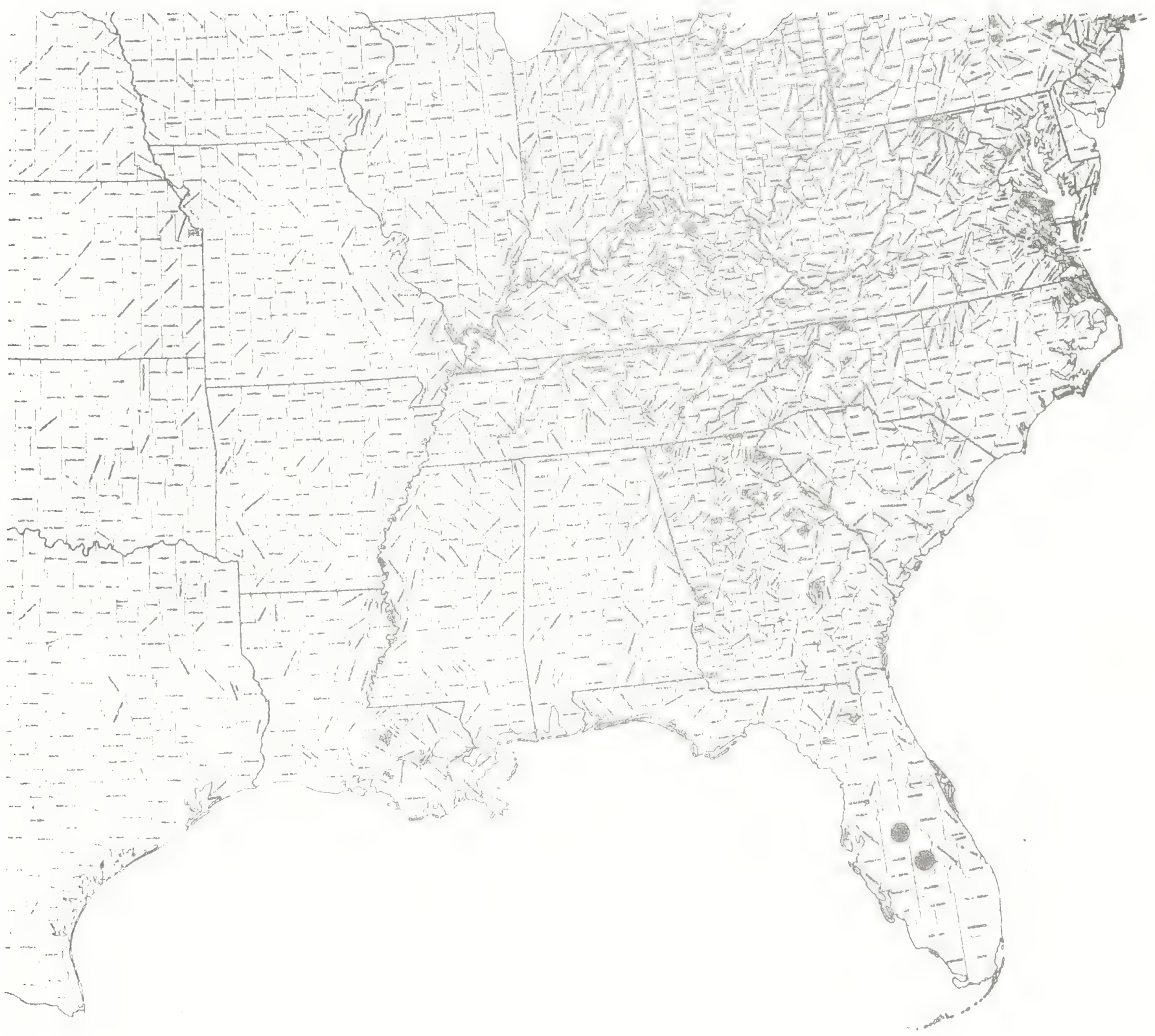




\section{Juncus caesariensis Cov. New Jersey rush}

\section{Technical Description}

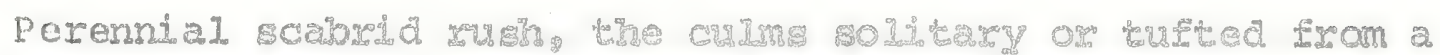

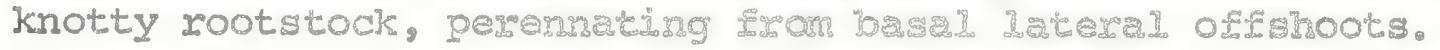

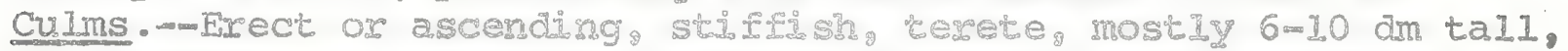
multiribbed, the surfaces roughened by papidae and tubercles, thus dull pale green.

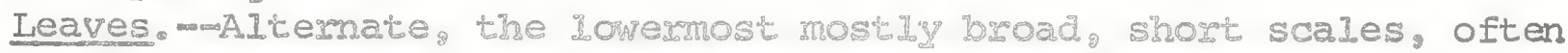
persisting as fibrils. the folidge leaves scacrered up the stem and gradialIy reduced in length the larger ones lowest with sheathes cylindrical, to $10 \mathrm{~cm}$ long, slit from apex to near joase on ventral side, there broadly scaw ousmargined distaldy ard producing a pair of scarious, triangulas , exect anndeles ce. 3 mo high the multi-

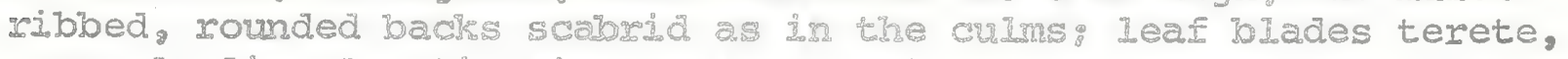
narrowly Iireal-cylindric, nargowly pointed, nodosemseptate, I-3 dm Long, "viloer culate- scalorido

Inflorescence. com compourd of cymules, these on primary peduncles of various length that ascend rison the upper nodes, the ultimate

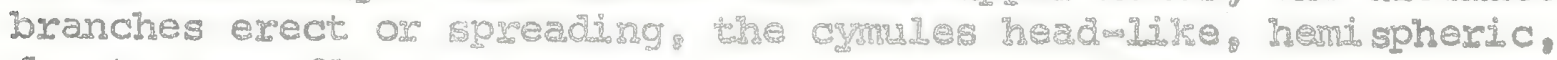
few tomany E I owered.

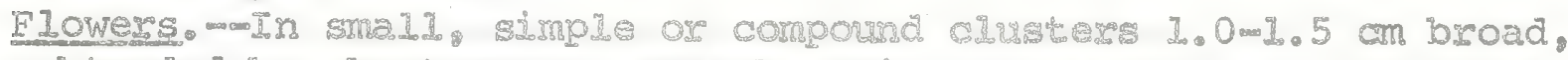
subtended by chartaceors, smooth tro. angular. acute to acuminate bractlets ca. 30an m long: perdanth tepaloid (aII similar), the 6 segments narrowly trongularmsuloulate, $4-5$ mang the inner cycle

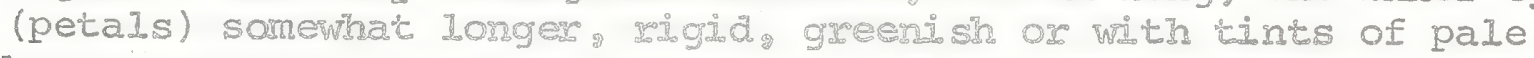
brown, nawowly acte: scamens 6 , slsorter than the perianth, erect, the anthers basifixed: ovary superiog. 3meapeldate, lancemovoid, the body trigonors. the styles exserted. 3mbranched. Fruit.-Capsude ca. $5.0 \mathrm{~m} .5 \mathrm{~mm}$ Iong somewhat exserted beyond the persistent perianth. Lancemopoid. bhe apex subulate, the surface a glossy redmorown: seeds numbroms, a lustrous pale brown, narrowly fusiform, strongly bicaudate, ca, 2 man long.

Distribution and Fiowerding seasor

Sphagnous seep areas in swamps. Doggy areas in flatwoods, ravines, Coastal Plain. souchern New Jersey eastern Maryland, eastem Virginia: Elowering in Juzy and Amgust.

Special Identifying Features

I. caesariensis is most similar to I. canadensis differing from it in having 6 , rather than 3 , stamens, but particularly in its conspicuous Iy papi I.temibuerulate foliage, this last feature an exclusive one for southeasters area Juncus of the complex 
This distinctive rush is always rooted in moist to wet, highly organic, acidic, usually sphagnous, substrate. Usually it is in sphagnous seeps in boggy flats in hardwood swamps or pine barrens, also seep slopes in ravines, thus its associates are primarily grasses and sedges, admixed with other rushes, Xyris, many Rhexia, Lobelia, Aster, Soltdace. Eupatorium (particularly E. dubium, E. maculatim), Vemonia, etc. The Virginia localities are seeps around rises in hardwood swamps or seep slopes in ravines. The swamps have cypress in the wettest areas, some loblolly pine on low xises, overall with many lowland oaks, including guercus Iyrata, 2. michauxil, 2. phelios, ‥ nigra, ․ shumardii, 2. hemisphaerica, etc., Maonolia viroiniana, UImus, Populus heterophylla. Acer morum, Eraxinus pensylvanica,etc. The rush may be along sphagnous rivulets in the shade, but is usually most abundant in small clearings. These same small streams may drain into deep swamp, where Fraxinus caroliniana, F. tomentosa, Salix, Populus, Nyssa are abundant, but the Juncus there is replaced by other species, particularly J: effusus, many robust Carex, scinpus, Saumums, Typha, etc. In the hillside seep areas the uplands are primarily oak-hickory-pine with an ericaceous understory, breaking downshope into mixed hardwoods (with much beech and maple) having a plentitude of Macmolia virciniana; and an understory of Vaccinium, Gayiussacia Iyonia, Leucothoe, deciturous Bhodiodendron, Clethra alnifolia, Myrica, Alnus. I. caesariensis is found where breaks in the overstory and thin spots in the understory allow enough sun to reach the seeps. Again, herbaceous associates are mostly grasses and sedges.

I have not seen Juncus caesariensis except in Virginia, the only state in the southeastern area it is known from. It may persist more abundantIy in New Jersey, the state for which it is named, but the very specialized habitat makes this doubtful. In Maryland the one known area is presumed destroyed. In virginia it is aefinitely rare with but three stations presently noted. Two of these are now being impacted adversely by a combination of such activities as residential lot construction, road building, chemical spraying of rights of way. Selective cutting of swamp species or of ravine slope species would probably not have an adverse effect providing mechanical disturbance of the wet substrate was not extreme.

\section{Referenoes}

Covilie, F, V. 1894. Juncus caesariensis Cov. (J. asper Engelm. non Sauze \& Maillard) in Mem. Torr. Bot. Club $5: 106$.

Fernald, M. I. 1950: Gray's manual of botany, ed. 8, pp. 397416. Boston. Mass. 
SPECIES Juncus caesariensis Cov. New Jersey rush

\begin{tabular}{|c|c|c|c|c|c|c|c|c|}
\hline \multirow[b]{2}{*}{$\begin{array}{l}\text { Expected* } \\
\text { Effect on } \\
\text { the Species }\end{array}$} & \multicolumn{8}{|c|}{ Management Practices } \\
\hline & $\begin{array}{c}\text { Prescribe } \\
\text { Burn }\end{array}$ & $\begin{array}{l}\text { Bulldoze } \\
\text { ox } \\
\text { Root Rake }\end{array}$ & $\mathrm{Bed}$ & Chop & $\begin{array}{l}\text { Thin } \\
\text { orer- } \\
\text { story }\end{array}$ & $\begin{array}{l}\text { Cut } \\
\text { over- } \\
\text { story }\end{array}$ & $\begin{array}{l}\text { Establish } \\
\text { Plantation }\end{array}$ & Graze \\
\hline Destroy & & $X$ & $x$ & $x$ & & & $\mathrm{X}$ & \\
\hline Damage & & & & & & $x$ & & $\mathrm{X}$ \\
\hline $\begin{array}{l}\text { No Lasting } \\
\text { Effect }\end{array}$ & $\mathrm{X}$ & & & & $\mathrm{X}$ & & & \\
\hline $\begin{array}{l}\text { Beneficial } \\
\text { if Done } \\
\text { Properly }\end{array}$ & & & & & & & & \\
\hline
\end{tabular}

Other Comments: site drainage would eliminate this species!

* Fxpected effect on the species is an estimate made by Dr. Robert Kral based on his knowledge of the habitat and on knowledge gained from personal field observations. Estimates are "rough" in many instances. Results of practices may be modified depending upon the degree of application, intensity of treatment, neamess to plant communities, etc. A management practice for which no entry is made indicates a lack of sufficient information from which to predict expected results. As observations are made in the field by users of the data, the expected effect will be refined. 


\section{Juncus caesariensis Cov.}

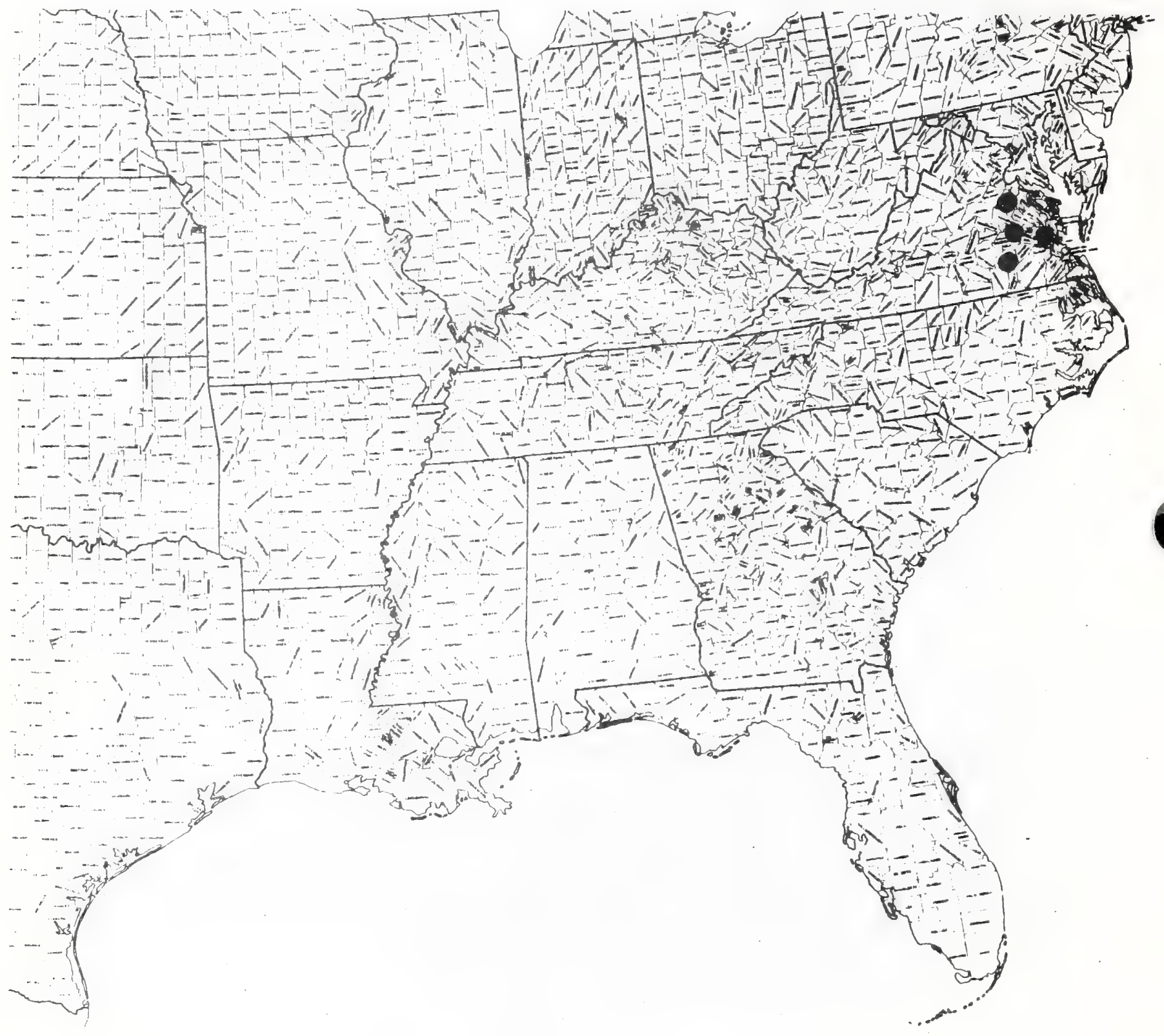




\section{JUNCACEAE}

Juncus georgianus Covinie. Georgia rustz

Technical Description

Densely tufted, diffusemandibrousmrooted, smooth, pexennial rush. Culms.--Erect or ascending, slender but stiffish, terete, strongly ribbed and grooved, pale green, mostly 2 a dm tallg the bases often hidden by remnants of tufts of old leaves. Leaves.--Crowded toward culm base, the outemost and Iowest scale Iike, the longest with overlapping sheaths from longer than to much shorter than the erect or spreading blades, their backs rounded, prominently ribbed, pale green, their involuted margins broad, white, subscarious, distaldy lovwauricled; larger lear blades 1/4$2 / 3$ as long as the culms, narrowly linears pale green, proximally flat, ca. I mm wide, the backs strongly ribbed, the upper surface shallowly concave, the margin a narrow, cartilaginous border, the tip narrowly tapering, halfuterete.

Inflorescence. - - f ften $1 / 3-1 / 2$ the total plant length, a cymose compound of secund racemes, the few promary branches of various Iengths, usually dichotomously branched, the erect florets nearly sessile or on short pedicels, rather distant on the ultimate branches, the whole inflorescence longer than and subtended by, 1-2 leafIike, short-sheathd bracts, these bearing also in their axils narrowly triangular, scalewijke scajousmargined prophylls. Flowers.-mIndividual flowers prophy late, the lowest one subtending the pedicel, and (usmaly) two mose directiy urder the perianth, scarious, broadIy tro.angu das, ca. 2 m long, acute to rounded, sometimes apiculate or muronate: periant tepalojd chaffy, the 6 segments erect, lancemsubulate, ca. $406 \mathrm{~mm}$ long, broady palescarious-margined, medially green with a narrow border of yellow or maroon: stamens 6, hypogynous, erect, the inneal, pale yellow, basifixed anthers much Ionger than the filaments: ovary superior, ovoid, ca. $3 \mathrm{~mm}$ long, green, smooth, the style reddish, ca. 1.0$1.5 \mathrm{mn}$ long, the stigmas 3.12 rear, redaish, papilose. Fruit.m-Capsule oblongmovold, Loculicidal, obscurely trigonous, ca. $3 \mathrm{~mm}$ long, Iustrous, pale olivaceous, the numerous seed asymetrically oblong, excentrically shortwbicaudate, ca. $0.5 \mathrm{~mm}$ long, pale redish-brown, irregularly longitudinaldy finewriged.

Distribution and Flowering season

Moist sunny depressions on and around granite outcrops, Piedmont, Erom North Carolina south and southwest through South Carolina and Georgia into eastern Alabama. Flowerong mostly from late May into late JuIy. 
Of the e-septate-leaved, prophyllate Juncus in the southeastern area, J. georgianus is distinguished by its flat (in contrast to terete or strongly involuted) leaf blades, its shortish involucral bracts, its long $(4-6 \mathrm{~mm})$ flowers with the perianth segments very erect even in fruit.

Habitat and Management Implications

I. georgianus is locally abundant on granite outcrop areas, usually the tufts rooted in the shallow in-wash of edges of shallow pools. Herbaceous associates are such plants as Isoetes, Rhymchospora globularis (vars.). R. capitellata, Bulbostylis, EimbristXlis, Aarostis elliottiana, cyoerus granitophilus, Eleocharis tenuis, E. obtusa, Panicum flexile, P. lithophilum, various other Panicum, Diamorpha, Sedum, Arenaria species, Talinum, Gratiola, Iindernia monticola, I. anacallidea, Rhexia mariana, B. virginica, Utricularia comuta, Viquiera, oenothera fruticosa, Schoenolirion croceum, Senecio tomentosus, etc. The substrate is a highly organic sand, with the granitic substrate not far below, and the abundance of the herbaceous plants around the temporary pools is largely dependent on quantity of winter and early spring rainfall in that the sumers are usually droughty. Slowly invading the granite are the surrounding, usually poor quality, stands of oaks such as quercus georqianus, Q. stellata, Q. falcata, \&. nigra, l. hemisphaerica, 2. montana, l. rubra, Q. velutina, Q. marilandica, etc. Jumiperus, Pinus virqiniana, P. echinata, P. taeda, Diospysos, UImus alata, Prunus, Sassafras. As these invade, the herbaceous cover so characteristic of open granite glades disappears. This rush, together with its often rare and local associates, is endangered mostly by quarrying of the granite outcrops and to a lesser degree by development of some of these areas for residential lots or for public recreation. Increasing numbers of people are drawn to the larger outcrops, this often involving much needless trampling of granite pool vegetation or destructive driving over it by various recreational vehicles.

\section{References}

Radford, A. E., C. R. Bell \& H. E. Ahles. 1968. Manual of the vascular flora of the Carolinas, pp. 273-280. Chapel Hill, N.C.

Small, J. K. 1933. Manual of the southeastern flora, pp. 281286. Chapel Hill, N.C. 
SPECIES Juncus georgianus Covile. Georgia Lush

\begin{tabular}{|c|c|c|c|c|c|c|c|c|}
\hline \multirow[b]{2}{*}{$\begin{array}{l}\text { Expected* } \\
\text { Effect on } \\
\text { the Species }\end{array}$} & \multicolumn{8}{|c|}{ Management Practices } \\
\hline & $\begin{array}{c}\text { Prescribe } \\
\text { Burm }\end{array}$ & $\begin{array}{l}\text { Bulldoze } \\
\text { or } \\
\text { Root Rake }\end{array}$ & Bed & Chop & $\begin{array}{l}\text { Thin } \\
\text { over- } \\
\text { story }\end{array}$ & $\begin{array}{l}\text { Cut } \\
\text { over- } \\
\text { story }\end{array}$ & $\begin{array}{l}\text { Establish } \\
\text { Plantation }\end{array}$ & Graze \\
\hline Destroy & & NA & $N A$ & $\mathbb{N A}$ & & & $N A$ & \\
\hline Damage & & & & & & & & $x$ \\
\hline $\begin{array}{l}\text { No Lasting } \\
\text { Effect }\end{array}$ & $x$ & & & & & & & \\
\hline $\begin{array}{l}\text { Beneficial } \\
\text { if Done } \\
\text { Properly }\end{array}$ & & & & & $\mathrm{X}$ & $\mathrm{X}$ & & \\
\hline
\end{tabular}

other Comments:

* Expected effect on the species is an estimate made by Dr. Robert Kral based on his knowledge of the habitat and on knowledge gained from personal field observations. Estimates are "rough" in many instances. Results of practices may be modified depending upon the degree of application, intensity of treatment, nearness to plant communities, etc. A management practice for which no entry is made indicates a lack of sufficient information from which to predict expected results. As observations are made in the field by users of the data, the expected effect will be refined. 
Juncus georgianus Coville

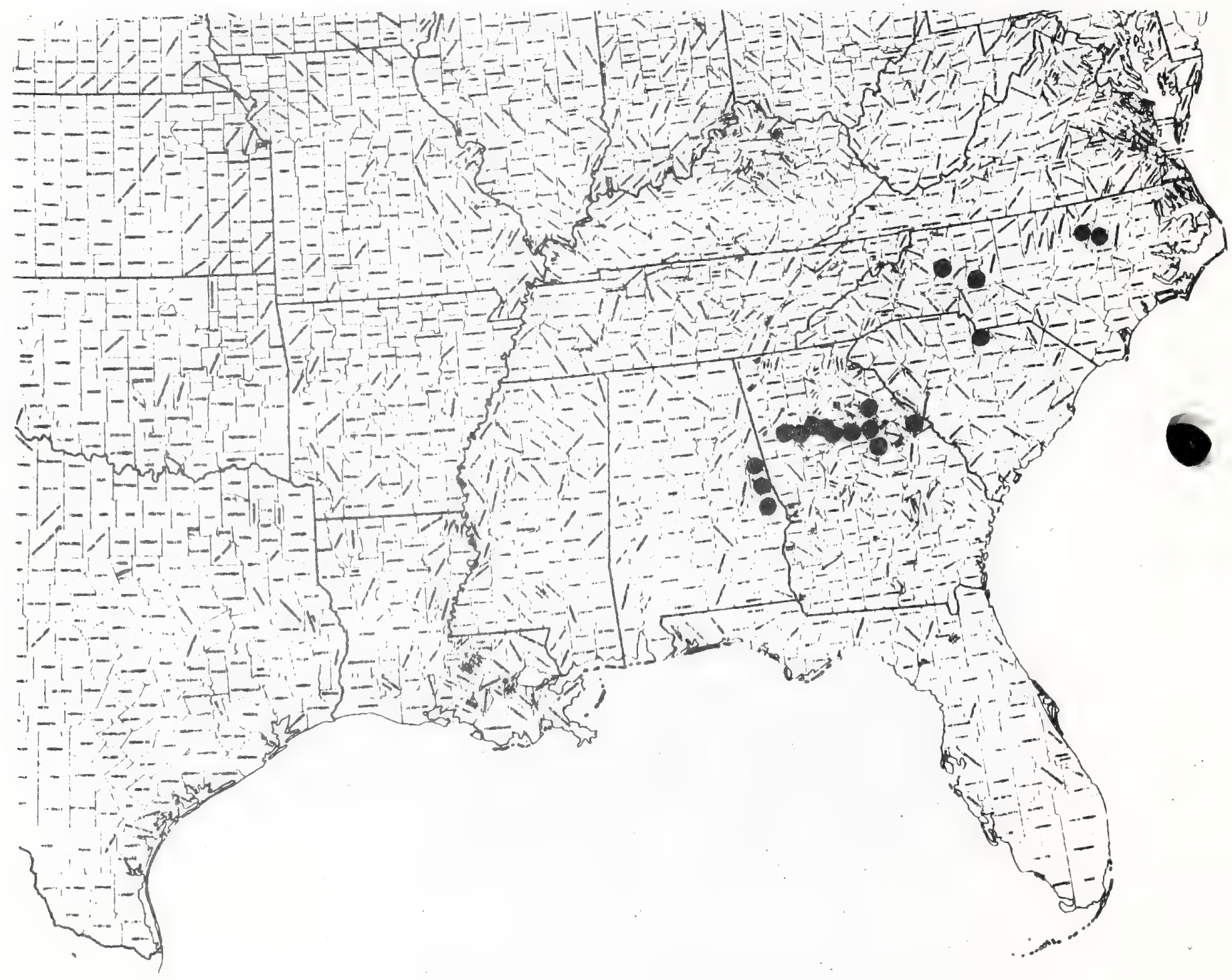


Paper 233

Text and map by:

Robert Kral

\section{IAMIACEAE}

\section{Consadina olabra shinners. panhandle rosenary}

Technical Description

Aromatic, copiously branched, often clonal shrub to 2 meters tall from a woody, diffuse root.

Shoots.--Primary shoots usually several from the woody rootstock, spreading or ascending silffyy coward base between 1 and $3 \mathrm{~cm}$ thick, subterete, the thin outer bark grayish or gray-brown, forming flat, anastomosing (braiding) strips. these often breaking and exfoliating: branchlets abund thosgh usually more aggregated toward primary branch tips, slender but stiffish, spreading-ascending, quadrate, light graymbrow or light reddishmbown. minuteIy gland-dotted, also sometimes minutely and sparsely pilosulous. Leaves.-Opposite, though appearing Eascicilate because of presence of short shoots in axi. Is persistert, estipulate, linear

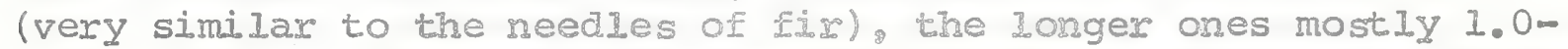
$1.5 \mathrm{~cm}$ Iong, 1.0-1.5 mm wide, usudIy sightly and evenly widening from just above a basal constridton to the tip. thus generally Iinear-oblanceolate), apicaldy obtuse, marginaliy strongly revolute, very shortmpetiolate. Imserved the nerve strongly raised on the lower surface: upper surface deep gellow green. glandularpunctate, the lower surface paler minte 3 s strigillosemtomentose. Inflorescence. - m F lowers solitary or (Usually) 2 or 3 in spreading cymules from most upper leaf axils. the short (ca. I mm) glabrous peduncles apically bibracteate the bracis green, linear-subulate, ca. $3 \mathrm{~mm}$ long, the pedicel.s glerder, smooth pale green or tinged with maroon, mostly $2 \mathrm{~m} 3 \mathrm{~mm}$ long.

Flowers.--Perfect, zygomorphic: calyzs fused bilabiate, 6-7 mm $10 \mathrm{ng}$, the tube cylindromcampanulate. ca. $3.5 \mathrm{~mm}$ lorg (to base of deepest sinus), apicaliy pidosemangulate witbing the limb bilabiate, the upper lip with 3 , slighty upcurved, nasorow triangular, ciliate teeth and sightly shorter than the lower which is deeply cleft to 2 sienderIy linear-trangularmsubulate, upcurved, ciliate teeth, the calyx body strongly wibbed, glandadotted, green or maroontinged: corolla from base to tip of lorgest lobe $1.5-2.0 \mathrm{~cm}$ Iong, strongly bilabiate: tube slenderly cubular. ca. $5 \mathrm{~mm}$ long, at its apex dilating and bent dowmard (geniculate) to form a funnelform throat ca. $5 \mathrm{~mm}$ long: upper lip oblong, somewhat hooded, arching upward and forward, Lower lip Elatter, longeng bent downward, strongIy 3-1obed, che midlobe most prominent, usually aboordate; surface pilose extemally the cube and lower part of the throat near white, deepening to lavender-blue at lobe and lip tips, this interrupted by a pale purplemotted medial band on the inside of the lower lip; stamens 4, didynamous paired toward aper of throat just below the lip sinuses, the siender which sis fidaments ca. $1 \mathrm{~cm}$ long, arching upward under the upper corolda Iip asd projecting the short, horseshoe-shaped (ca. 0.7 Im long) vidLousmbacked anthers we11 
beyond the corolila throat, the anther sacs parallel, the connective short, broad; ovary deeply 4-lobed, superior, the slender style exserted beyond the anthers, its tip bifurcated into 2 Iinear, acute, spreading, purplish-blue stigmas. Fruit.--Nutlets 4 (usually but 2 perfecting), er.ased in the persistent calyx, broadIy rounded-obovoid, slightly longer than I ma, pale reddish-brown, the surface faintly raised-reticulate with brown lines.

Distribution and Flowering season

Sandy high pineland, very local, northwest Florida; flowering mainly from March into June, intermittently to frost.

Special Identifying Features

The genus conradina is made up of but five species, all confined to the southeastern area, all shrubby in habit. 'Two (C. canescens, C. brevifolia) have cinereous-puberulent upper leaf surfaces and persistently puberulent pedicels. Of the three which have smooth upper leaf surfaces, C. glabra has the smoothest calyx tube, the palest corollas, the longest hairs on the anthers, and the most erect habit.

Habitat and Management Implications

C. glabra has developed a few, in some cases large, populations on the high sandy land east of the Apalachicola River below the town of Chattahoochee in Iiberty County, Florida. Far to the west, in Santa Rosa County near Milton a single collection was made years ago but later efforts to relocate this population have not proved out. The Iiberty County land was forested originally by either mixed hardwoods and pine, or by longleaf pinedeciduous scrub oak with occasional live oak in the uplands where the Conradina grew: these areas are deeply dissected by steep sided, densely forested, moist ravines in which presumaloIy the Conradina did not and does not grow except in the ecotones. C. glabra was and is understory in open woodlands or in small clearings therein. Most of its original small area has been heavily logged, particularly for the longleaf pine, or has been cleared for agriculture. Crop faming is mostly poor in this area, but some former habitat is pastured woodland or has been cleared for pasture; in either event, the impact of clearing for crop farming has eliminated suftable habitat and pasturing badly damages the shrubs. The sotl is a deep yellow sand, this overlying a conglomerate that has a high clay fraction which itself overlies limestone. In paces, where there has been subsidence because of solution of underlying limestone, the 
shallow sandy swales that pesult do not wet enough to develop bog vegetation, may support the Consadina. Associate shrub species that might be expected for this type ase cheysoloalanus, Vaccinium, running oaks, Rhus toxicodendrong R. copa11ina Crataeous. Rubus. Smilax, with dry sitce herbs such as mang Desmodium and Iespedeza, Cassia, Baptisia (Ianceolata, lecontei simplicifolia), Iupinus (I.

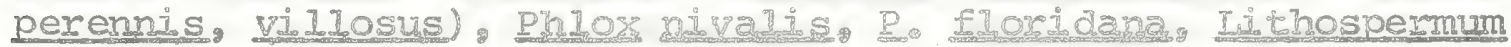
caroliniense, onomodium 17. theca, Aster, Solidago, Liacm.

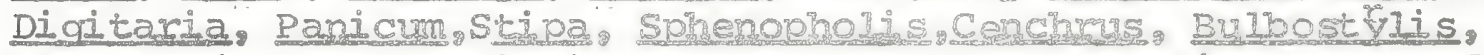
Cyperus (upland species), etc. Much of the coneadina area, after the original hastesting of $10 n g l e a f$ pine has been planted to slash pine. In such cases C. Llagsa along with Calamintha dentata. (its common associate) appears to be dreseasing in the plantation rows, but it may be prematrife to state that this will be a stable system in that (1.) the side growth tends to be more oper thar amay have been intended (2.) the plantations when oldew may provide more shade and more competation than is good for the conredina. since fire his historical in the maintenence of stands of longleaf pine and Conradina qlabra was a part of these original stands. it is reasonalole to assume that this shruby mint is increased. not decreased, in the case of fire. Fire protection to faror the sash pine may be detrimental in the case of this shrubby minc.

\section{References}

Gray, T. C. 1965. A monograph of the genus Consadina (Iabiatae).

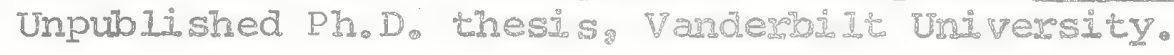

Sma11, J. K. 1933. Manual of the sortheastern flora, pp. 1166-I167. Chape1 Hi II, N. C.

Shinners. I. I. 1962. Symopsis of Corgadira (Iabiatae). Sida

I. (2): $84-88$. 
SPECIES Conradina glabra Shinners." panhandle rosemary

\begin{tabular}{|c|c|c|c|c|c|c|c|c|}
\hline \multirow[b]{2}{*}{$\begin{array}{l}\text { Expected* } \\
\text { Effect on } \\
\text { the Species }\end{array}$} & \multicolumn{8}{|c|}{ Management Practices } \\
\hline & $\begin{array}{c}\text { Prescribe } \\
\text { Burn } \\
\end{array}$ & $\begin{array}{c}\text { Bulldoze } \\
\text { or } \\
\text { Root Rake }\end{array}$ & Bed & Chop & $\begin{array}{l}\text { Thin } \\
\text { over- } \\
\text { story }\end{array}$ & $\begin{array}{l}\text { Cut } \\
\text { over- } \\
\text { story }\end{array}$ & $\begin{array}{l}\text { Establish } \\
\text { Plantation } \\
\end{array}$ & Graze \\
\hline Destroy & & & & $\mathrm{x}$ & & & & \\
\hline Damage & & $\mathrm{x}$ & $\mathrm{x}$ & & & & & $\mathrm{x}$ \\
\hline $\begin{array}{l}\text { No Lasting } \\
\text { Effect }\end{array}$ & & & & & $\mathrm{x}$ & $\mathrm{x}$ & $?$ & \\
\hline $\begin{array}{l}\text { Beneficial } \\
\text { if Done } \\
\text { Properly }\end{array}$ & $\mathrm{x}$ & & & & & & & \\
\hline
\end{tabular}

Other Comments:

*Expected effect on the species is an estimate made by Dr. Robert Kral based on his knowledge of the habitat and on knowledge gained from personal field observations. Estimates are "rough" in many instances. Results of practices may be modified depending upon the degree of application, intensity of treatment, nearness to plant communities, etc. A management practice for which no entry is made indicates a lack of sufficient information from which to predict expected results. As observations are made in the field by users of the data, the expected effect will be refined. 


\section{Conradina glabra shinners}

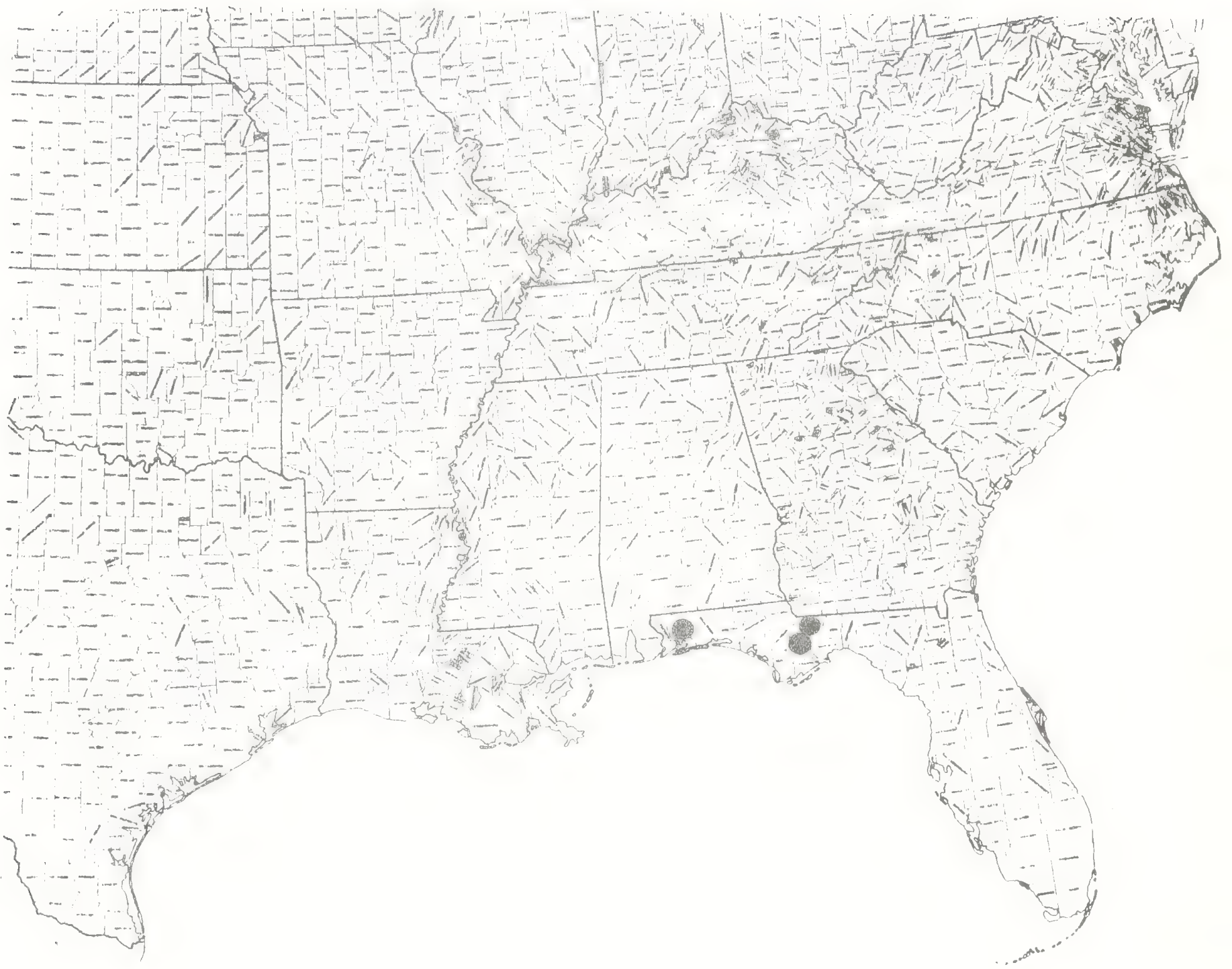


6

6

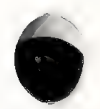


Paper 234

Text and map by:

Robert Kral

\section{LYTHRACEAE}

\section{Lythrum curtissit Fernald。 Curtiss" Iythrum}

Technical Description

Subshrubby, smooth, perennial herb from a shallowly spreading, diffuse rootstock, the larger roots often spongyowickidened Stems.--Solitary or in small clumps, bowed outward at base, but ascending or ereut, the bark toward stem base thin. gray-brown or reddishmbrown, cracking and anastomosing longitudinaliy to reveal paler inner bark, proximally terete, often spongy (if submersed), distally becoming quadrangular narrowly winged, the lower part of the stem usually leafless by flowering time. the branching abundant from about the mid-stem up, slender, ascending, the lower branches often rebranched in the same way. Leaves.-Numerous, altemate, subsessile, estipulate, ascending or spreading, those of main stem by far the largest, (but by flowering time usually deciauous from just below the inflorescence to stem base), mostly oblong to narrowly elliptic, acute, entire, mostly $1.503 .0 \mathrm{~cm}$ long, the upper sureface deep green or tinged with purple, the lower surface markedly paler, the principal venation pinnate, the lateral veins arcuate: leaves of branches and upper portion of main axis grading maller, more numerous, alternate to suoopposite, mostly ascending or erect.

Inflorescence.-mlowers borne singly in axis of most leaves of branches and upper axis on stiff, ascending pedicels rarely as long as $1 \mathrm{~mm}$.

Flowers.--somewhat aygomorphic, bisexualjcalyx at anthesis forming a cylindromclavate tube 3 mon mong this green wi.th $10-12$ purplish ribs and ceminating ${ }^{n} 4 \times 6$, low-triangular-subulatetipped lobes, these alternating with narrow. spreading appendages from the sinuses: petals (4⿻) 6 , distinct, ari sing and spreading from the calyr tube orifice, a lively lavender-rose, somewhat unequal, ca. $2 \mathrm{~mm}$ long, obovate to oblong or eldiptic, acute at both ends: stamens most1y $6-12$ of various lengths, the elongate, slender slightIy flattened filaments arising from calyr tube base and extending well beyond its orificeg terminating in cimamon, broadIy ellipsoidal or oblong. versatile arthers ca.0.4 ming: ovary superior, shortmcylindrics included in calyr. bicarpellate, terminating in a filiform, exserted, capitate stigma.

Fruit.-Capsule cylindro-clavate, ca. $3 \mathrm{~mm}$ long, smooth, pale redaishwrown, 2mloculed: seeds numerous, pale brown, oblong, concave-flattened, ca. $0.5 \mathrm{~mm}$ long.

Distribution and Flowering season

Bogs, seeps, clearings in and edges of acid or calcareous swamps, 
northern Florida and southwestern Georgia; flowering July into september or October.

\section{Special Identifying Features}

L. curtissi is most similar to $\underline{L}$. alatum var. lanceolatum, and is nested within its range. It differs mainly in its smaller calyx tubes (4-5 mm versus $6-8 \mathrm{~mm}$ ), its thinner, longer leaves of main stem, and its more remote rameal (branch) leaves.

Habitat and Management Implications

L. curtissii is a plant of high hydroperiod soils, usually silts, fine sands, or peat-muck. Its accepted range falls within the karst country of northwestern Florida and southwestern Georgia, where it may be found around the shallow porids, in shallow boggy depressions in flatwoods, in roadside ditches, or in bays and river or creek swamps. Usually it is either in light shade or full sun, the surrounding overstory ranging from longleaf and slash pine with saw palmetto and gallberry in the understory to cypress-tupelo or titi. Sometimes it is at the edges of Hypericum ponds. In any event, the substrate is seasonally very wet. Commonest herbaceous associates are grass-sedge-rush, with an admixtuxe of Xyris, Exiocaulon, Rhexia, Bacopa, Ludwigia, Polygala.

The greatest danger facing this very local species is the conversion of large parts of its former range to slash pine, this preceded by clearcutting, mechanical site preparation, and especially by cutting of drainage ditches. A permanent drying out of the site destroys $\mathrm{L}$. curtissii even before crown closure of planted pine would shade it out. In such pine plantations the Lythrum pexsists only along these ditches.

\section{References}

Fernald, M. L. 1902. Some little known plants from Florida and Georgia. Bot. Gaz. 33: 154-157.

Small, J. K. 1933. Manual of the southeastern flora, pp. 930931. Chapel Hill, N.C. 
SPECIES Iythrum curtissì Fernala' Curtiss Iythrum

\begin{tabular}{|c|c|c|c|c|c|c|c|c|}
\hline \multirow[b]{2}{*}{$\begin{array}{l}\text { Expected* } \\
\text { Effect on } \\
\text { the Species }\end{array}$} & \multicolumn{8}{|c|}{ Management Practices } \\
\hline & $\begin{array}{c}\text { Prescribe } \\
\text { Burm }\end{array}$ & $\begin{array}{c}\text { Bulldoze } \\
\text { or } \\
\text { Root Rake }\end{array}$ & Bed & Chop & $\begin{array}{l}\text { Thin } \\
\text { over- } \\
\text { story }\end{array}$ & $\begin{array}{l}\text { Cut } \\
\text { over- } \\
\text { story }\end{array}$ & $\begin{array}{l}\text { Establish } \\
\text { Plantation }\end{array}$ & Graze \\
\hline Destroy & & $x$ & $X$ & $x$ & & & $\mathrm{X}$ & \\
\hline \multicolumn{9}{|l|}{ I)amage } \\
\hline $\begin{array}{l}\text { No Lasting } \\
\text { Effect }\end{array}$ & $\mathrm{X}$ & & & & & & & \\
\hline $\begin{array}{l}\text { Beneficial } \\
\text { if Done } \\
\text { Proper } 1 y\end{array}$ & & & & & $\mathrm{x}$ & $\mathrm{X}$ & & \\
\hline
\end{tabular}

Other Comments: arainage of this habitat is detrimental.

*Expected effect on the species is an estimate made by Dr. Robert Kral based on his knowledge of the habitat and on knowledge gained from personal field observations. Estimates are "rough" in many instances. Results of practices may be modified depending upon the degree of application, intensity of treatment, nearness to plant commuities, etc. A management practice for which no entry is made indicates a lack of sufficient information from which to predict expected results. As obsemations are made in the field by users of the data, the expected effect will be refined. 


\section{Lythrum curtissii Fernald}

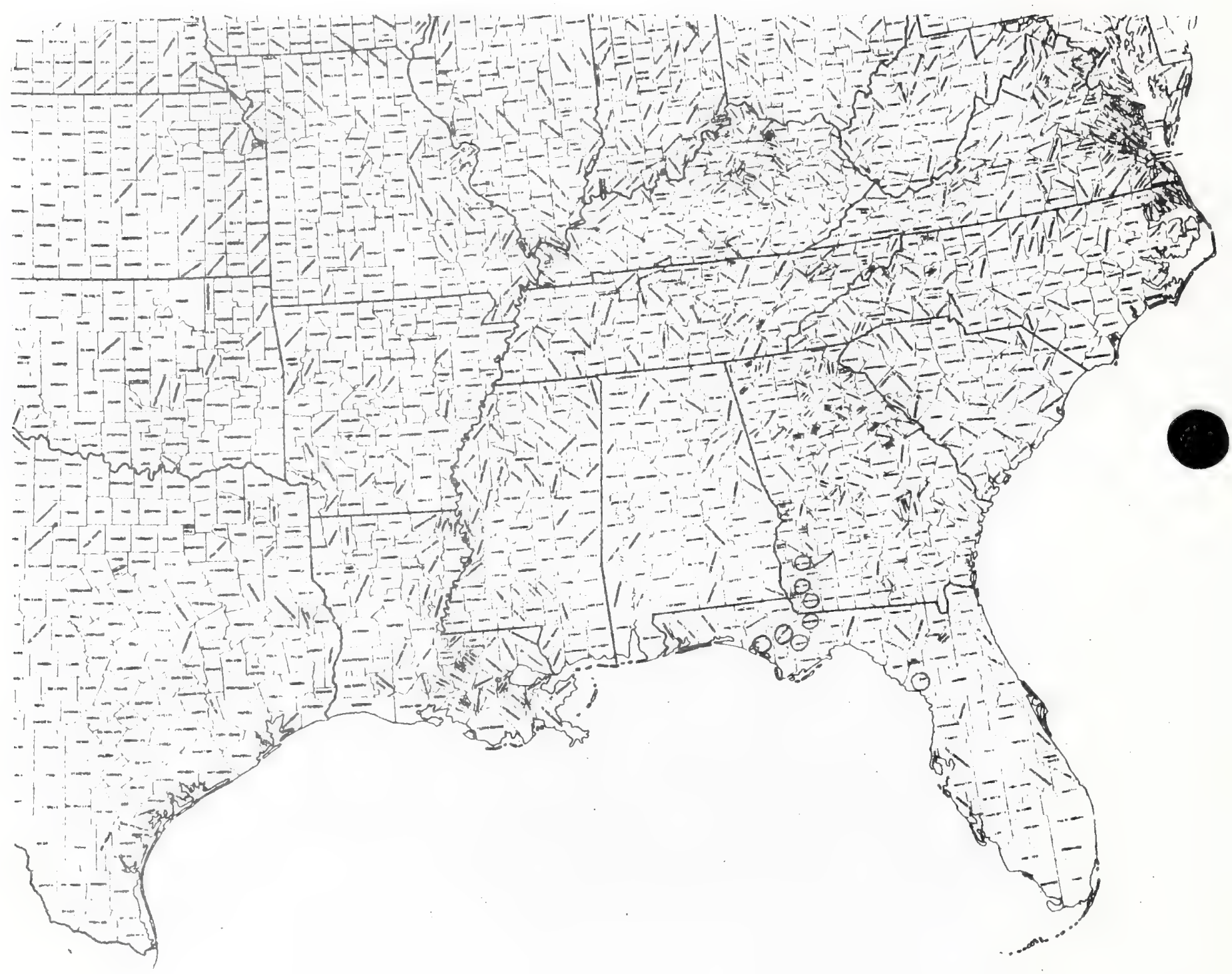




\section{ISTITRA CEAE}

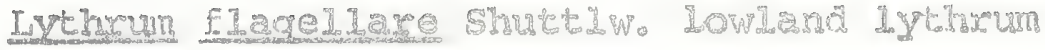

Technical Description

Perennial, creeping, matw foming; smooth herb. Stems.-0lder stems entirely prostrate, slerder, wiry, dark brow, the thin bark cracking longitudinally. sametimes extoliating: newer shoots ascending, arching or prostrate, wiry quadrate, very narrowly winged, mostly deafy co the base.

Leaves. -opposite, estipulate, simp $2 e_{8}$ spreading and often upright (thus appeacing secund) on medals petjoles $1.5 \mathrm{~mm}$ long or less, or sessile, the blades oblorg to ellopic or even suborbicular (these usually the lowest ores on a shoot), most.y 0.7-I.3 cm Iong, apically rounded or obtusemangled, the masgin entire, glassy-papil lite the base rourded or broady cureate. the surfaces uniformly green. orly the midnerve evident. Flowers.-Solitary in the axis of most shoot leaves. with ascending, clavate, short pedicels slightly longer than subtending petioles, bearing at apex just below the flower 1 - 2 lanceolate-acute, scale-like bracteoles ca. I m long: calfz tube cylindro-clavate, at anthesis ca. 4 mm long. the 5 wo Jobes triangular. ca. I m long,

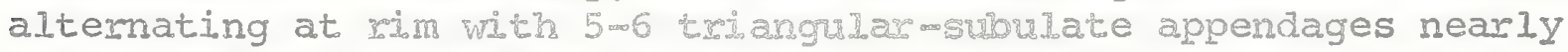
as long, the tube surface greenish, tisged with maroon, the midnerve of the calys lobes decureent as naspow ribs: petals distinct, equalling sepals, bright laverder, obovate, ca, 5 mi long, broady rounded or slightly retrse entires cruedce: stamens equal to or more than the sepals, aro sirg at djeferent levels in the calyx tube, the slender, deep lavender EI lanents thasting the elifpsoidal dorsifixed anthers beyond the calyr mouth: ovary superiors oblong, ca. $3 \mathrm{~mm}$ long, the style teminalo exect, ceminating in a capitate stigna at about the morth of ihe calsy.

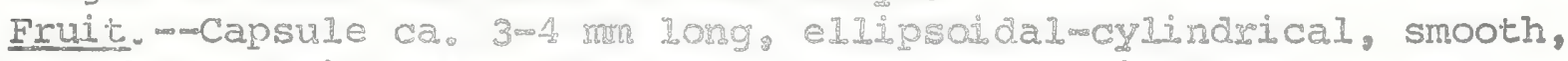
pale brown, bilocular, the seeds mumexous, reticulate.

Distribution and Flowering season

Margins of ponds, ditchbanks, edges of cypress swamps, southern peninsular Flowda flowering all year.

Special Identi fying Fearures

I. Elagellare is the only lychoum of the southeastem area to have an almost exclusively creeping mtoloniferous habit. Leaf length/ wiath ratios are lower thar in ary okner southeastern species. 
I. flagellare is confined to mucky or sandy-peat-muck soils, thus is a plant of high hydroperiod systems. Its best habitat is in the intermittentIy inundated margins of shallow pineland sloughs or at edges of cypress domes. These types in south Florida may be seasonally dry but over most of the nomnal year are distinctly wet. The pine flatwoods are usually slash pine, with an understory of saw palmetto interspersed with Myrica, Ilex and ericaceous shrubs, all growing not far above underlying calcareous rock. During the dry periods these areas frequently burn, this promoting a savanna formation composed of grass-sedge with other monocots such as Eriocaulon, Xvris, Juncus, Sagittaria and dicots in general Utricularia, Sabatia, Polygala, Iippia, Hydrocotyle, Iudwiqia, Mecardonia, Iindernia, Campanula, Lobelia, Buchnera, Proserpinaca, Rhexia, with wetland representatives of Liatris, Coreopsis, Carphephorus, Bigelowia. Most collections of I. $\underline{\text { flag- }}$ ellare come from the flatwoods and cypress dome borders of a zone along the Florida gulf coast from sarasota southward, and much of this same region was ranch country between the major torms (i.e. Sarasota to Punta Gorda, Punta Gorda to Ft. Myers and south) where the flatwoods savannas continued to be bumed as they were historically. In more recent years these same tracts have been drained increasingly, this resulting in a reduction of the shallow wetlands habitat supporting the Iythrum. Much former habitat is now uniformly dry except during wettest periods and the plants are now mainly to be looked for only along drainage ditches. I. flagellare,it appears, is another fire-related species of wet savanna and will not persist where woody plants, protected from occasional fire, increase or where the substrate is dried out by construction of drainage ditches.

\section{References}

Chapman, A. W. 1897. Flora of the southern states, ed. 3, p. 158. Cambridge, Mass.

sma11, J. K. 1933. Manual of the southeastern flora, pp. 930931. Chapel Hill, N. C. 


\begin{tabular}{|c|c|c|c|c|c|c|c|c|}
\hline \multirow[b]{2}{*}{$\begin{array}{l}\text { Expected* } \\
\text { Effect on } \\
\text { the Species }\end{array}$} & \multicolumn{8}{|c|}{ Management Practices } \\
\hline & $\begin{array}{c}\text { Prescribe } \\
\text { Burn }\end{array}$ & $\begin{array}{l}\text { Bulldoze } \\
\text { Or } \\
\text { Root Rake }\end{array}$ & Bed & Chop & $\begin{array}{l}\text { Thin } \\
\text { over- } \\
\text { story }\end{array}$ & $\begin{array}{l}\text { Cut } \\
\text { over- } \\
\text { story }\end{array}$ & $\begin{array}{l}\text { Establish } \\
\text { Plantation }\end{array}$ & Graze \\
\hline Destroy & & $\mathrm{X}$ & $x$ & $\mathrm{x}$ & & & $\mathrm{X}$ & \\
\hline Damage & & & & & & & & $x$ \\
\hline $\begin{array}{l}\text { No Lasting } \\
\text { Effect }\end{array}$ & & & & & & & & \\
\hline $\begin{array}{l}\text { Beneficial } \\
\text { if Done } \\
\text { Properly }\end{array}$ & $\mathrm{x}$ & & & & $x$ & $\mathrm{X}$ & & \\
\hline
\end{tabular}

Other Comments: drainage of habitat is detrimental!

*Expected effect on the species is an estimate made by Dr. Robert Kral based on his knowledge of the habitat and on knowledge gained from personal field observations. Estimates are "rough" in many instances. Results of practices may he modified depending upon the degree of application, intensity of treatment, nearness to plant comminities, etc. A management practice for which no entry is made indicates a lack of sufficient information from which to predict expected results. As observations are made in the field by users of the data, the expected effect will be refined. 
Iythrum flagellare Shuttlw.

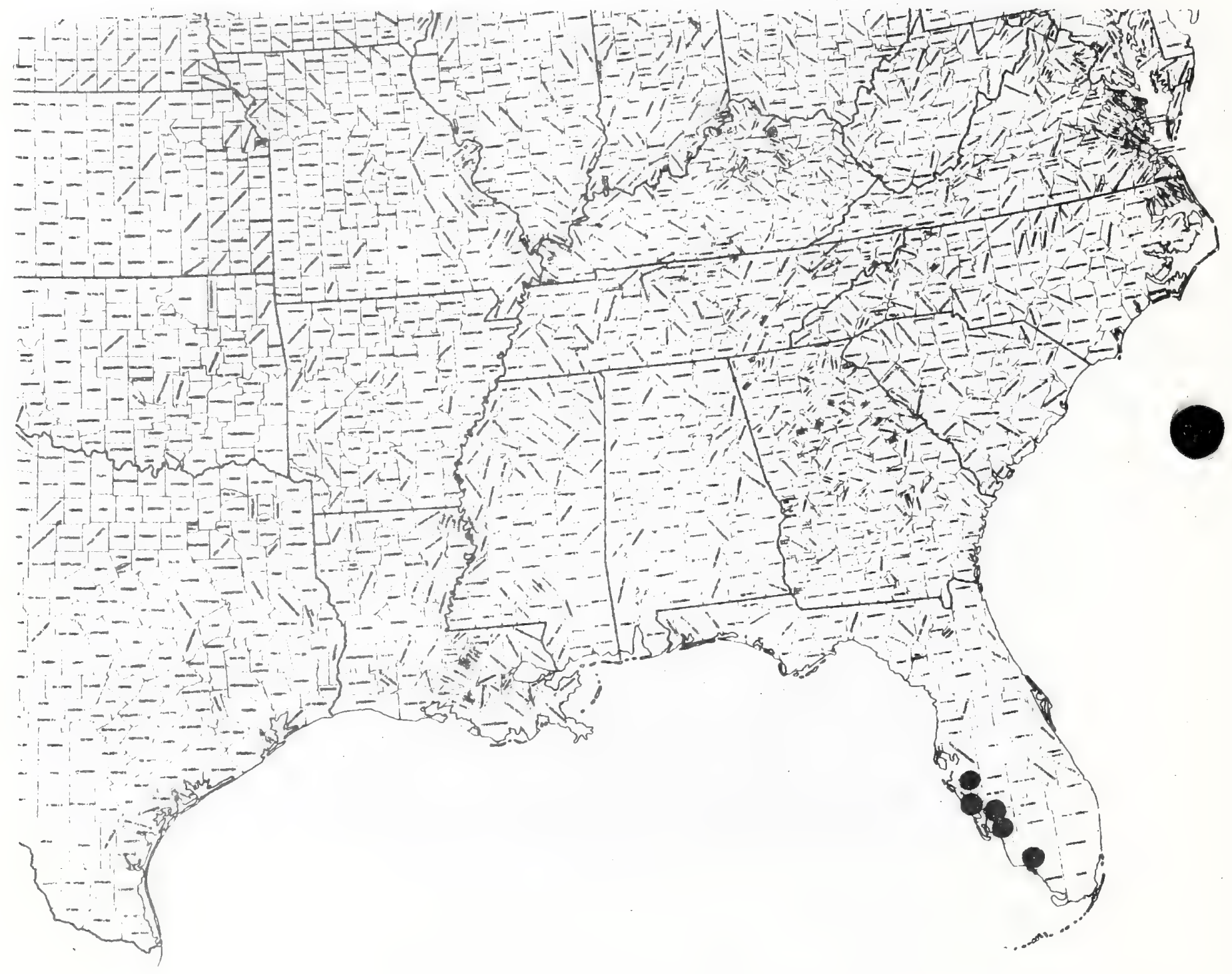


raper <so

Torte and map by:

Robert Kral.

\section{MACNOTIACEAE}

\section{Macrolia ashei Weatherby Ashe magnolia}

Techrical Descriplion

A small tree or large slamilo ard masely to 30 ft. tall, the trunk single, ascendirg, ravely straights or trunks several and spreading-ascending freon a common moot.

Bark - -Beechlike, Exom a short distance appearog. smooth. grayish or pale gray-browh close up minutedy wastymowghenedg thin, on oldest specimens sometines drecking

Twigs. -stoutish. the new shooks freguenty to I cm thick, terete, gray-green, sericeous with shorte appressed, sillvery hairs, the leaf scars nearly round, bundle traces muerous the stipule scars girdling the shoot: tewinal bud (usully containing a flower) lance cylindric, conicutipped, fuldy 4 mb em long, densely appressedsi Iverymtamentose.

Leaves.--Conspicuous Iy layge. fyeguently $6 \mathrm{~m}$ dm 1 ong those of a season frequent ly rather crowded in close spirals toward shoot tips, ascending to spreading on steont. sh terete, appressedwihite-tomentose petioles $5-9 \mathrm{~cm}$ Iong. the blades obovate, the abrupty narrowed tip narrowly romded or emarginate, the margin entire, crispateundulate, the base evidertly avsed culate, the mpper leaf surface deep green, at matur.ty mooth. the lower surface very glaucous, chalk-white with appressed and spoeadingmididous haids. Flowers.-Solitary at tips of expanding shoots. usualdy approaching anthesis shortIy after svotending leaves have begun to harden in late spring. symetri.cad. bosesual. the seceptacle very elevat-

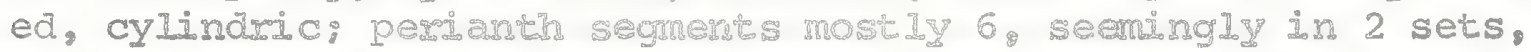
mostly oblong obovate, rather fleshy crearmwhice with purplishred blotches toward thei bases, at first exect with tips only spreading, foming a fragreanc "tuling" fully $1 \mathrm{dm}$ high, later spreading into a flower fuldy between 2 and 3 dm broad soon thereafter abcissing: stamens numerous, sp: raly arranged, the short filaments erect, the connective broad. cream the Yelowow sh archer sacs linear; carpels numerous, distinct, spirally ascanged, whit sh-puberulent, the stigmas Iinear, Lateral on the excureved styles.

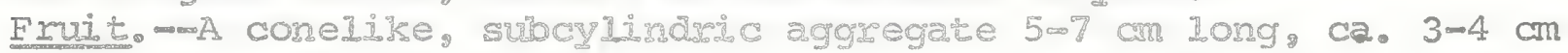
thick of woody, shortwberjed follidiles ca. $1.3 \mathrm{~m} 2.0 \mathrm{~cm}$ long, externaIIy roseate at first maturity Iates becoming brownish, splitting

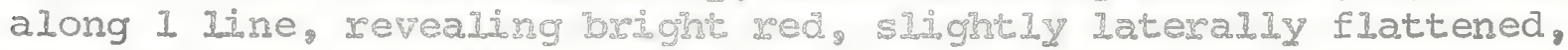
bean-shaped seed, these dangling ort on long furicular strands.

Distribution and Flowering season

Ravines in hardwood forests or in oakcoine hills, western Florida from Leon to walton Counties: flowering in April and May. 
Magnolia ashei is thought by some to be merely a variant of M. macrophylla, a taller taxon with a mach wirier range, and which has a rounder, often shorter, definitely broader aggregate of follicles. Dr. R. K. Godfrey, an authority on trees of northern Florida, states (1962) that M. macrophylla does not occur in Florida. If, as is now believed, the early report of $\mathrm{M}$. ashei from eastern Texas is based on $M$. macrophylla. M. ashei is indeed a geographically distinct entity.

Habitat and Management Implications

M. ashei is rooted in the moist sandy loams of ravine slopes and narrow creek bottoms of western Florida. Associate species are mesophytic and include M. grandiflora, M. virginiana, Persea, Acer barbatum, A. Ieucoderme, Ilicium floridanum, Faqus, various willow oaks, Asimina parviflora, Ilex, Halesia, etc. Pines such as $\underline{P}$. taeda, $\underline{P}$ qlabra may be frequent in the overstory.

Such ravines often have trees of high value and many within the narrow range of $M$. ashei have been logged heavily, usually clearcut. These kinds of operations, usually involving tractors and other heavy equipment, if they do not kill the scattered magnolias outright by breaking or otherwise damaging crowns and roots, create openings, increase soil erosion, and in general reduce the quality of the site for M. ashei, which seems to be an obligate understory species. Therefore it generally gives way to weedier species over time. In short, this species (or variety?) is in considerable danger.

\section{References}

Kurz, H. \& R. K. Godfrey. 1962. Trees of northern Florida. Univ. of Florida Press, Gainesville.

Miller, R. F. 1975. The deciduous magnolias of west Florida. Rhodora $77: 64-75$.

Sma11, J. K. 1933. Manual of the southeastern flora, pp. 535-536. Chapel Hill, N. C.

Weatherby, C. A. 1926. A new magnolia from west Florida. Rhodora $28: 35-36$. 
SPECIES Magnolia ashei Weatherby. Ashe magnolia

\begin{tabular}{|c|c|c|c|c|c|c|c|c|}
\hline \multirow[b]{2}{*}{$\begin{array}{l}\text { Expected* } \\
\text { Effect on } \\
\text { the Species }\end{array}$} & \multicolumn{8}{|c|}{ Management Practices } \\
\hline & $\begin{array}{c}\text { Prescribe } \\
\text { Burn }\end{array}$ & $\begin{array}{l}\text { Bulldoze } \\
\text { or } \\
\text { Root Rake }\end{array}$ & Bed & Chop & $\begin{array}{l}\text { Thin } \\
\text { over- } \\
\text { story }\end{array}$ & $\begin{array}{l}\text { Cut } \\
\text { over- } \\
\text { story }\end{array}$ & $\begin{array}{l}\text { Establish } \\
\text { Plantation }\end{array}$ & Graze \\
\hline Destroy & $\mathrm{X}$ & $\mathrm{X}$ & $X$ & $X$ & & $x$ & $\mathrm{X}$ & \\
\hline Damage & & & & & $X$ & & & $\mathrm{X}$ \\
\hline $\begin{array}{l}\text { No Lasting } \\
\text { Effect }\end{array}$ & & & & & & & & \\
\hline $\begin{array}{l}\text { Beneficial } \\
\text { if Done } \\
\text { Proper } 1 y\end{array}$ & & & & & & & & \\
\hline
\end{tabular}

Other Comments:

* Expected effect on the species is an estimate made by Dr. Robert Kral based on his knowledge of the habitat and on knowledge gained from personal field observations. Estimates are "rough" in many instances. Results of practices may be modified depending upon the degree of application, intensity of treatment, nearness to plant communities, etc. A management practice for which no entry is made indicates a lack of sufficient information from which to predict expected results. As observations are made in the field by users of the data, the expected effect will be refined. 
Magnolia ashei Weatherby

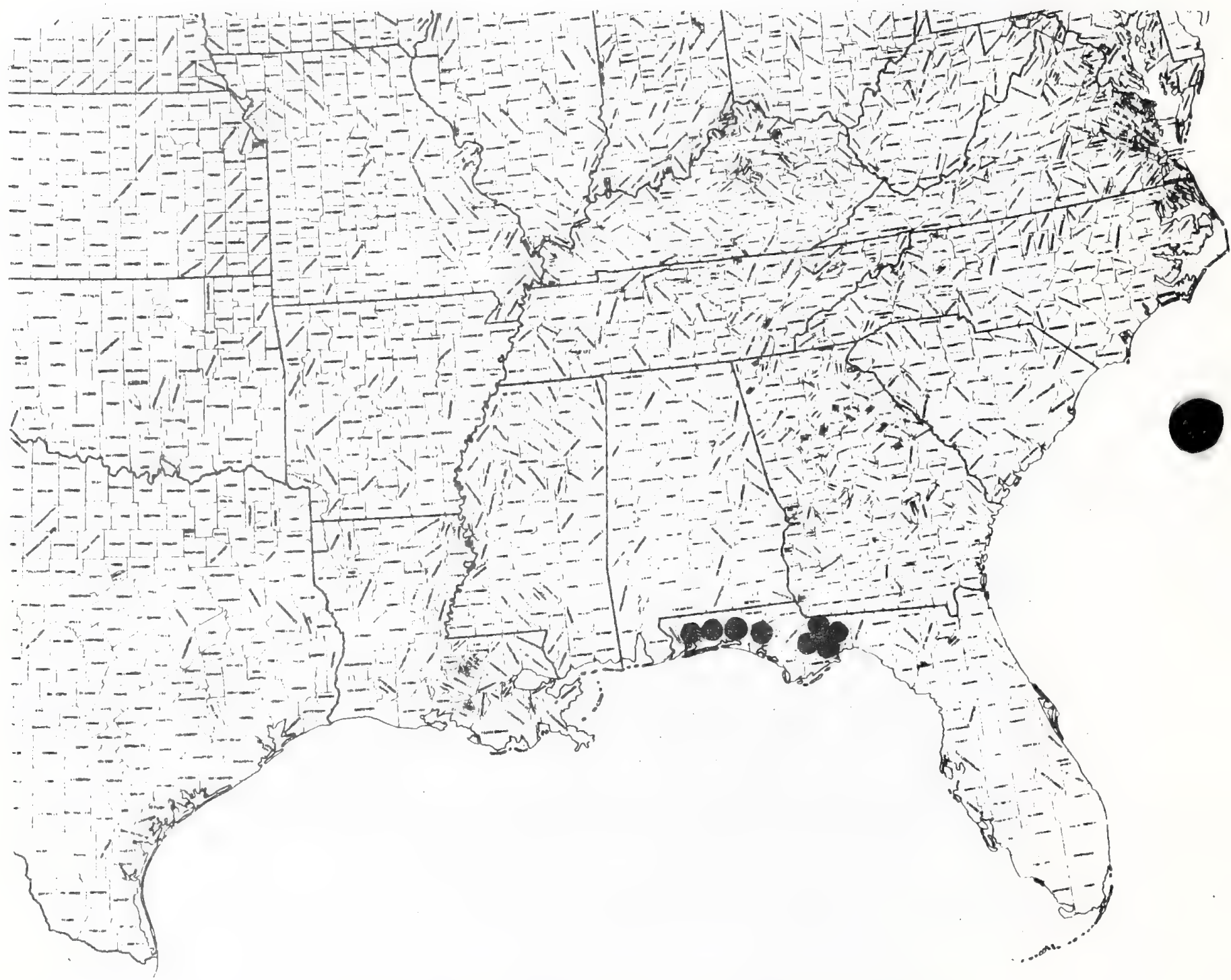




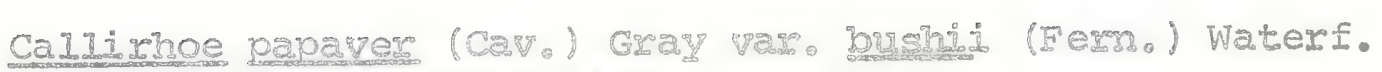
Bushs's wood: popgy, mallow

C. bushid Fermo

C. involucrata (W. of G.) Gray vas. bushid (Forno) Martin

Technical Description on

Perennial herios from carrotminge rootstooks.

Stems. - Stems solitary or fewy erect or ascending or sprawling. mostly 5-8 dm tald, terete or (2istadiy) subangulate, proximaliy purpli sh-tinged, distally pale green. simple to above the middle or sparingly branched rrom rear base, the bsanches ascending, the surfaces with a scattering of appressed. stellate trichomes and, toward stem base these admixed whth spreading or reflexed pilosity. Leaves. - Both basal and carline, altersate, stoprlate, the rosette and lower stem leaves usualy dryirg by anthesis, strongly petiolate, those at about midnstern os Just below 2t the largest: stipules ovate-triangular or naysowly ovate. acter, most Iy I-2 cm long, entire or sparsely toothed towas aper. strumosemis sute marginally, the bases clasping, the Iower sristace sometimes prberulent: petioles much longer than blades on lower leaves, progressively shortening upward on stem, ascendirg, slender but stiff, hirsute; blades suborbicular to broadIy ovate or renz form, $5-8 \mathrm{~cm}$ long, $5-10 \mathrm{~cm}$ wide, deeply and palmately lobed and parted into fram 3-ol oblong to cuneate, rareIy narrow ty triangulas, segments, these ascendingtoothed from above the middie to the acure segment apes, the sharp -based sinuses cutting $1 / 2 \cos 2 / 3$ of the way to the leaf base, which ranges fram truncate to broadII or nasrowly cordate: upper leaf surface deep yellowmgreen. pilose whirsure? the lower surface somewhat paler. piloseminirsute.

Inflorescence.mofilowers wswalIy few per branch, loosely racemose, axillary to uppermost leaves, the peduncles $1-$ fllowered, erect to ascending, at fixst barely lorgers than the flowers, in frut elongating to ca. I dra, hirsutemand mte Ilatem wairy. Flowers, megular, perfect, showy, each subtended by an involucel of 3 , lance- linear to ovate, green, stmusmewci Ifate, upcurved bracts 1.0-1.5 cm long: sepals 5, greeng united at base into a broadly campanulate cup $6 \mathrm{~m}$ m mm high, the lobes linearowtriangular, to $2 \mathrm{~cm}$ long, slenderiy taperingwtipped, the masgins coarsely strumosehirsute, the surface extemal.ly hissute from lobe base to base of calyx, intemalIy villosulouswtomentose: petals 5, jojned at very base, ascendingmspreading, a lively pale rosempurple, paler toward base, broadly obovate, $3.0-3.5 \mathrm{~cm}$ Iong, apically broadly rounded or tuncate, erose, the short-clawed base internally pilose: stamens numerous, monodelphous, the staminal tube plus the free filaments and anthers ca. $1_{1} 5-2.0$ cn long, the tiny anthers dorsifixed, yellow: carpels 100020 , forming a rang, the style parting above its base into a like number of Linear branches, these narrowIy stigmatic on the insers side. 
Fru.t.-Dry, the mature carpel becoming a firmly papery-walled (Chartaceous) mericarp, these arranged in a ring around the center of the receptacle, each shaped much like the segment of an orange or tanerine, ca. $4 \mathrm{~nm}$ long, apically short-pointed, the backs coarsely raised-reticulate, 3-nerved, sí, apically bidentate with narrowly triangular teeth, the sides flat, peripherally rugose-reticulate, the attachment toward the base of the narrow inner angle; seeds reniform, ca. $3 \mathrm{~mm}$ long, somewhat laterally flattened, I/mericarp.

Distribution and Flowering Season

Dryish, rocky open woodlands or glades, southwestern Missouri, northwestern Arkansas, eastern oklahoma. Flowering from May into August.

Special Identifying Features

The species $C$. papaver is distinguished from other 1obed-leaved sympatric callirhoe by its combination of erect habit, pseudocalyx of 3 subfloral bractlets, deeply colored petals and conspicuous stipules. The nearest species to it is C. involucrata, which has procumbent or decumbent stems, and leaf divisions that are coarsely serrate. Var. bushii is distinguished from $\underline{\text { C. }}$ papaver proper by the spreading or retrorse, longer stem hairs, often by the broader leaf segments, these few-toothed toard the apex.

Habitat and Management Implications

C. papaver bushij is found in open calcareous or cherty-rocky woodlands, rocky banks and bluffs of ravines and streams, or at edges of limestone glades and barrens. Its tuberous rootstocks are usually rooted in clay.' Overstory species in the area are characteristic of ozarkian uplands, namely Quercus alba, 2. stellata, 2. muhlenbercii, 2. mubra, ․ velutina, etc. carya tomentosa, C. texana, C. glabra, C. ovalis, UImus rubra, U. americana, U. alata, Fraxinus americana, Acer sacchamm, etc. Stands of juniper are cammon, pure or admixed with the hardwoods. Shrubs such as Rhamnus caroliniana, Rhus aromatica, Cornus, Andrachne, Hypericum are often present. Herbaceous associates include Delphinium, Arenaria; Sedum, Onosmodium, Talinum,oenothera, Satureja, etc. in the more open areas, mostly indicators of rather basic soils.

The upland system into which this variety fits is being radically changed. Several of the major streams have been dammed, floodIng out much of the bluff, dry bank, and glade habitat; expansion of the mall towns in this region of heavy touriam has resulted in the loss of still more area as residential and recreational development moves outward. Much of the forest has been cut or poisoned away, so as to open up the rocky woodlands or so as totally to clear for pasture. Thus, with such a recent and 
drastic alteration of mul of the formas hablat of this attractive plant, it should isdeed be consdered threatened.

References

Martin, R. F. 1938. MisceIlaneous notes on U. S. plants. Rhodora $40: 459-4.61$.

Robinson, B. I. \& M. I. Fema1d. I909.' Emendations of Gray's manual I. Rhodora 11: 33001 .

Steyermark, J. A. 1963. Flor2 of Missori. pp. 1048-1051. Ames, Iowa.

Waterfal1, U. T. 1959. C. papaver (Cav.) Gray var. bushii (Fern.) Waterfali, comb. nov. Sorthwestern Nat. 3: 215-216. 
SPECIES Callirhoe papaver (Cav॰) Gray var. bushii (Fern॰) Waterf.

Bush's woods poppy-mallow

\begin{tabular}{|c|c|c|c|c|c|c|c|c|}
\hline \multirow[b]{2}{*}{$\begin{array}{l}\text { Expected* } \\
\text { Effect on } \\
\text { the Species }\end{array}$} & \multicolumn{8}{|c|}{ Management Practices } \\
\hline & $\begin{array}{c}\text { Prescribe } \\
\text { Burn }\end{array}$ & $\begin{array}{l}\text { Bulldoze } \\
\text { or } \\
\text { Root Rake }\end{array}$ & Bed & Chop & $\begin{array}{l}\text { Thin } \\
\text { over- } \\
\text { story }\end{array}$ & $\begin{array}{l}\text { Cut } \\
\text { over- } \\
\text { story }\end{array}$ & $\begin{array}{l}\begin{array}{l}\text { Establish } \\
\text { Plantation }\end{array} \\
\end{array}$ & Graze \\
\hline Destroy & & $\mathrm{X}$ & $\mathrm{x}$ & $\mathrm{x}$ & & & $\mathrm{x}$ & \\
\hline Damage & & & & & & & & $\mathrm{x}$ \\
\hline $\begin{array}{l}\text { No lasting } \\
\text { Effect }\end{array}$ & & & & & & & & \\
\hline $\begin{array}{l}\text { Beneficial } \\
\text { if Done } \\
\text { Properly }\end{array}$ & $\mathrm{x}$ & & & & $\mathrm{X}$ & $\mathrm{X}$ & & \\
\hline
\end{tabular}

Other Comments:

*Expected effect on the species is an estimate made by Dr. Robert Kral based on his knowledge of the habitat and on knowledge gained from personal field observations. Estimates are "rough" in many instances. Results of practices may be modified depending upon the degree of application, intensity of treatment, nearness to plant communities, etc. A management practice for which no entry is made indicates a lack of sufficient information from which to predict expected results. As observations are made in the field by users of the data, the expected effect will be refined. 
Callirhoe papaver (Cav,) Gray var. bushii (Fern。) Waterf.

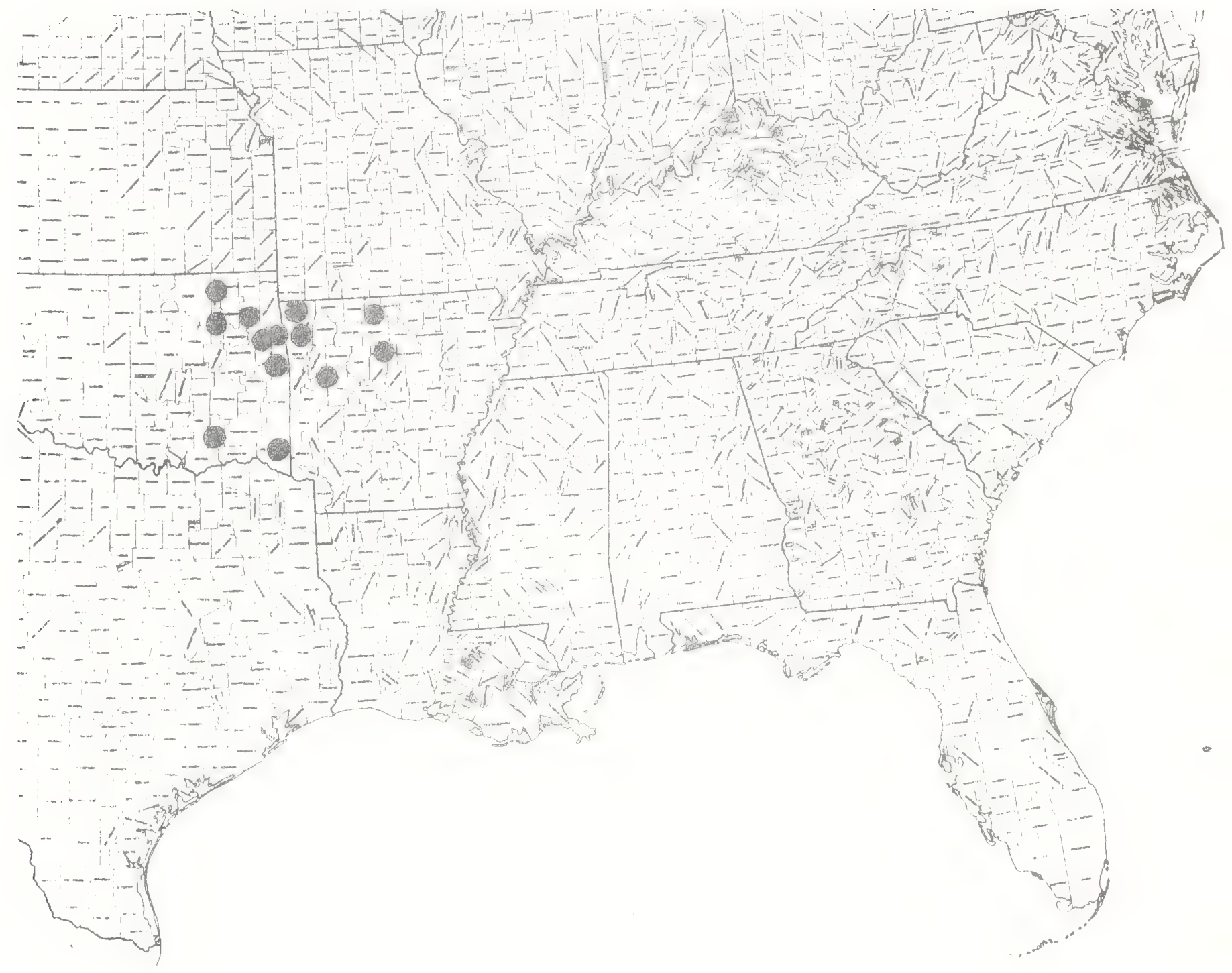


- 
5apex 238

Text and map by:

Robert KraI

\section{MNMPHACEA E}

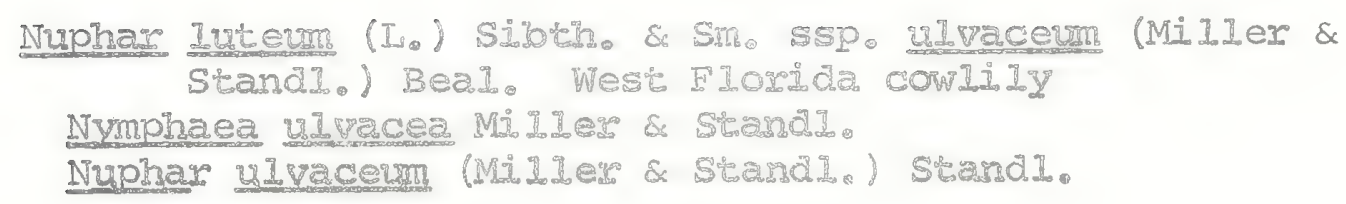

Technical. Description

Coarse, smooth, aquatic perennial, the deaves arising directIy from a stout, subrersed, shallowly set, elongate soluzome to $5 \mathrm{~cm}$ thick.

Leaves.-Alternate, on variously elongate (depending on water depth) terete, spongy green petioles to I meter long (usualIy less); submersed blades thin, the entire margins strongly undulatemcrispate, often tinged with red; floating Leaves sini Lar to submersed anes but thicker, deeper green, flas, lancewovate to lancemoblong, most Iy 2-4 dm long, the tips narsowly rounded, the margin entire, the auriculate base with lobes over lapping or closing the naryow sinus, this less than 1/5 the blade Length: upper Ieaf surface lustrous, deeper green chan the dus ler lower surface. Flowers.- Solitary at bips of Flesldy bactiess pecuncles that arise directly from the shid zome and are simi lar la length and shape to petioles of subtendirg leaves, pegulas, perfect, subglobose, ca. $2.5 \mathrm{~cm}$ high, $3.5-4.0 \mathrm{~cm}$ broad: sepals 6 in 2 apparent sexies, the outer 3 erect, broadly oblong, cupuliform. gxeens ca. 3 cm long, the tips broadIy rounded, the base abruptIy constricted at the receptacle; irner sepals clear yeldow, trainner g roundedwobovate, short-clawed cupping the cercen of che flowed stamens numerous, incurved-overlapping in 4 w Jlat spirals, yel low, the flattened filaments shorter than the Iinear moright anthess: ovary superior, at anthesis ca. 2 cm high. the mas? campels fused into a broady ovoidmglobose body. this constricted just below the apex, then abruptiy dilated, forning a concave disc, I.2m1.5 cm broad, the numerous nasrowly elipeical stigmatic lines wadiating spokelike from the center.

Fruit. - A green, subglobose, sporgy beyry ca. $2.5 \mathrm{~cm}$ high, the apex truncated by a persistent stigmatic disc, the numerous seeds imoedded in spongy placental tissue, round ca. 4 m broad, smooth, pale brown.

Distribution and Flowering season

Swift Iy to sIowly Elowing shallows of streans, northwestern Florida, Chipola system westward: flowering intemictentIy from May to frost.

Special Identifying Features

This subspecies (accoraing to Beal ald are subspecies of N. ulvaceum!) is, in its narrow floating leares, most similar to ssp. sagittifolia, 
a taxon of the Atlantic Coastal Plain, but tends to have broader foliage. It is also supposed to be distinguished from it by the pattem of its stigmatic rays (lines) which is narrowly elliptic (rather than linear). Differences between these subspecies are best consulted on plants which $z$;e in normal depths and currents of water, the narrower leaved ones appearing it seems where currents are swiftest. When specimens of $N$. luteum ssp. ulvaceum are exposed, as when the river level drops for long periods, the leaves become mach shorter-petioled; with blades having much lower length/width ratios. On the other hand, submersed leaves also tend to have blades with lower Iength/ width ratios.

Habitat and Management Implications

N.' Iuteum Ulvaceum has its rhizames shallow embedded in the sands or silty sands of bottoms and shallows of swift flowing, clear or tannic-acid-tinted streams. Here it may be associated with various Potomogeton. Najas, Sparganium, scirpus (such as S. etuberculatus); Sagittaria, etc. At low river stages it may be exposed or in very shallow water and reacts to produce much different looking plants (see previous section!) The bank forests are typical of bottams in the region, containing a mixture of planera, Forestiera, Ulmus, Salix, willow oaks, Sycamore, Carya aonatica, Nyssa, Taxodium, Acer momm, etc. Much of this timber is valuable and considerable acerages of bottomland for est in the range of this Nuphar have been cut over. The threat to the Nuphar is predictable; clearcutting of the hardwoods alters the drainage pattern", promotes excessive flooding, excessive sedimentation, reduces water quality and clarity, all negative factors for this plant. Single tree or groups selection, providing the logging is done with minimal disturbance to the substrate, probably has the least effect.

\section{References}

Beal, O. E. 1956. A taxonanic revision of the genus Nuphar Sm. of North America and Europe. Journ. Elisha Mitchell Sci. Soc. 72 : $317-346$.

Fernald, M. I. 1942. Additions to the flora of Virginia." Rhodora $44: 396-397$ :

Miller, G. S. \& P. C. Standley. 1912. The north American species of Nymphaea. Contribs. U. S. Nat. Herb. 16 (3): 63-108.

Sma11; J. K. 1933. Manual of the southeastern flora; pp. 540-542. Chapel Hill, N. C. 
SPECIES Nuphar Iutea (I') Sibth. Ssp. uIvaceum (MiIIer \& StandI.)

Beal. West Elorda cowling

\begin{tabular}{|c|c|c|c|c|c|c|c|c|}
\hline \multirow[b]{2}{*}{$\begin{array}{l}\text { Expected* } \\
\text { Effect on } \\
\text { the Species }\end{array}$} & \multicolumn{8}{|c|}{ Management Practices } \\
\hline & $\begin{array}{c}\text { Prescribe } \\
\text { Burn }\end{array}$ & $\begin{array}{c}\text { Bulldoze } \\
\text { or } \\
\text { Root Rake }\end{array}$ & Bed & Chop & $\begin{array}{l}\text { Thin } \\
\text { over- } \\
\text { story }\end{array}$ & $\begin{array}{l}\text { Cut } \\
\text { over- } \\
\text { story }\end{array}$ & $\begin{array}{l}\text { Establish } \\
\text { Plantation }\end{array}$ & Graze \\
\hline Destroy & $N A$ & $X^{\circ}$ & $x^{*}$ & $X^{\%}$ & & $\mathrm{X}$ & $\mathrm{NA}$ & \\
\hline Damage & & & & & & & & $x$ \\
\hline $\begin{array}{l}\text { No Lasting } \\
\text { Effect }\end{array}$ & & & & & $x$ & & & \\
\hline $\begin{array}{l}\text { Beneficial } \\
\text { if Done } \\
\text { Properly }\end{array}$ & & & & & & & & \\
\hline
\end{tabular}

Other Comments: * referring to adjacent bottoms

*Expected effect on the species is an estimate made by Dr. Robert Kral based on his knowledge of the habitat and on knowledge gained from personal field observations. Estimates are "rough" in many instances. Results of practices may be modified depending upon the degree of application, intensity of treatment, nearness to plant commities, etc. A management practice for which no entry is made indicates a lack of sufficient information from which to predict expected results. As observations are made in the field by users of the data, the expected effect will be refined. 
Nuphar luteum (L。) Sibth. \& Sm. ssp. ulvaceum (Miller \& Standl.) Beal

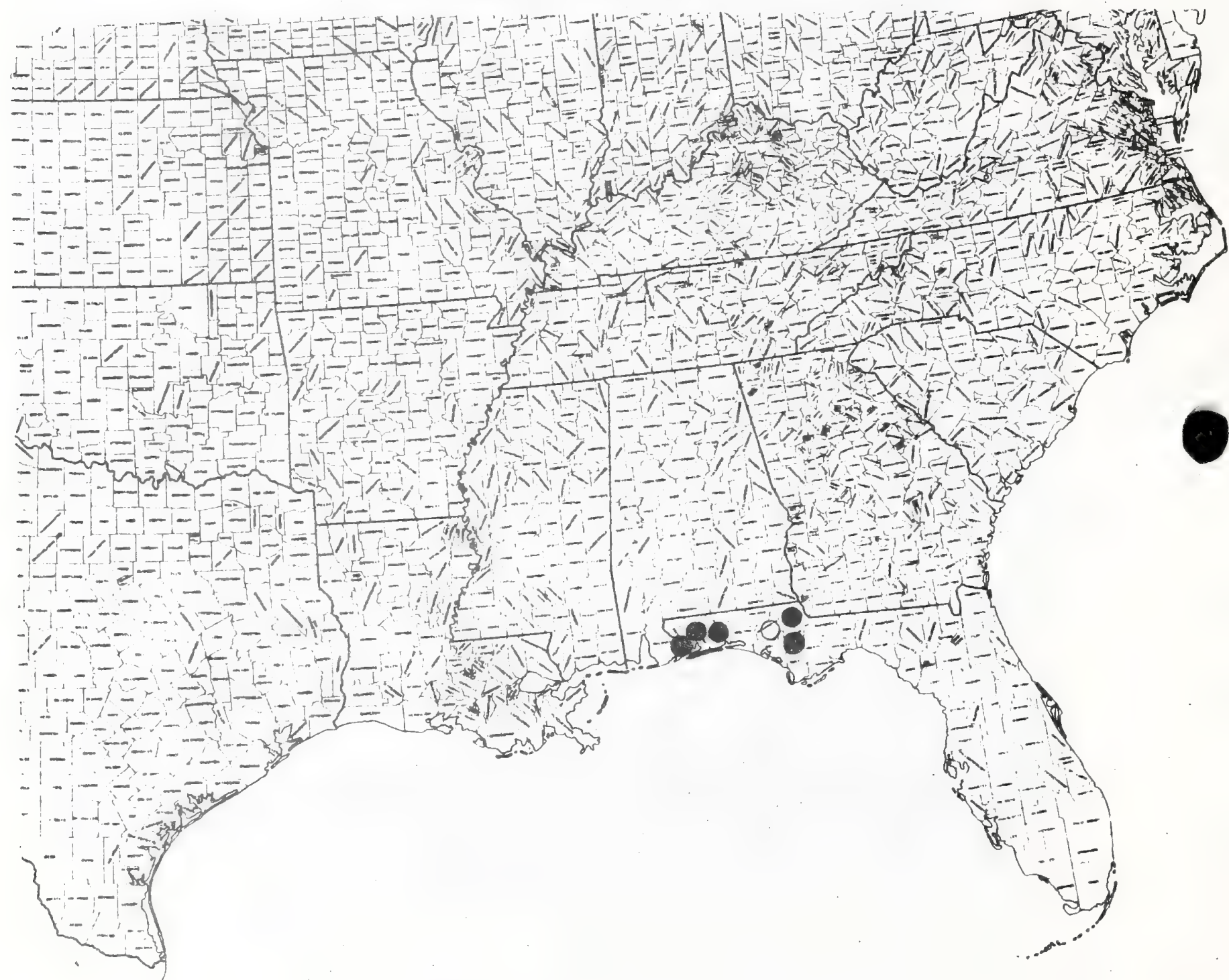




\section{OLEACEAE}

\section{Chionanthus pyomaeus Smal1. Pygmy fringemtree}

Techrical Description

Shrub or small tree to ca. 15 feet tall, the bark gray-jorown, thinnish, longitudinally cracking.

Twiqs.-mpposite or subopposite, stiffish, grayish or gray-brown, on newer shoots often with 4 low ribs along the internodes below the sides of the semicircular. concave leaf scars: leaf scars mostIy opposite, sometimes a.ternate: terminal bud ovate-triangular, ca. $4 \mathrm{~mm}$ long, the several scales imbicate, reddishmbrown, ciliolate; axillary buds similar but smaller.

Leaves.-opposite or alternate, estipulate, simple, spreading or ascending, mostly $3-10 \mathrm{~cm}$ long, the petioles short, the blades somewhat Ieathery, ovate to elliptic or obovate, acute to rounded, entire, attenuated to the petiole, the upper surface dark yellowgreen, smooth, the lower surface paler, glabrescent (becoming smooth), reticulate.

Inflorescence.--Showy, appearing with the new shoots from the axils of most leaf scars of the previous season, a leafy-bracted panicle, the larger bracts opposite, spreading or ascending, mostly elIiptic or oblong, becoming similar to but smaller than foliage leaves, proximally on the axis, but reduced upward in the inflorescence to linear, 3-4 mm long, the peduncle rather short, its opposite branches numerous, spreading, slender, drooping, terminating in 3-6-flowered cymules, the whole inflorescence multiflowered and. feathery.

Flowers.--Regular, perfect, very pleasingly fragrant: sepals 4, green, ca. 1.5-2.0 mm Iong, united at base, the lobes triangular; petals 4, white, united at base to a short, campanulate throat, the lobes narrowly Iinear, $1.0-1.5 \mathrm{~cm}$ long, somewhat spreading, stamens 2, opposite, adnate to corolla base and falling with it, the erect greenish filaments ca. $2 \mathrm{~mm}$ long, the yellowish basifixed anthers oblong, blunt-tipped, ca, $2 \mathrm{~mm}$ long: ovary superior, ovoid, slightIy over $1 \mathrm{~mm}$ long, the single erect, terminal style somewhat shorter, apically with a bilobed stigma.

Eruit.-Drupes 2.0-2.5 cm long, oval, green becoming purplishbrown when ripe.

Distribution and Flowering season

Sandhills and sandy scrulo, lakes region of southern central peninsular Florida: flowering from March into April.

Special Identifying Features

If this is a species it shares the southeastem area with but one 
other of the genus, namely the common fringetree C. virginicus $I_{\text {. }}$ which does occur in northern and middle peninsular Florida. However, this last often becomes a small tree whose leaves are thinner, whose petals are longer (mostly with lobes 2-4 cm long), shoe anthers have apiculate or acuminate tips, and whose fruit is seldom as large. C. pyomaeus, as is so often the case with woody plants in sandhills, often looks shrubbier than it really is, in that blowing, drifting sands build up around it to the point that only the upper branches are exposed.

\section{Habitat and Management Implications}

This rare woody plant is confined to the deep, yellow or white sands of the peninsular Florida scrub. Usually it is on sandhills, either under longleaf pine-deciduous scrub oak or in the denser growth of the sand pine-evergreen oak type. In the latter type, if the sands have become stabilized by the various scrub species, its growth may become quite spindly and elongated, thus plants may reach as much as 15 feet. In the more exposed sites it is much more compact, lower, shrubby. Common associates in the sandscrub are guercus myrtifolia, o. chapmanii, o. geminata Carya floridana, Persea humilis, Lyonia ferruginea, I lex ambiqua, Bumelia tenax, Garberia, Ximinea, Osmanthus megacarpa, Ceratiola, etc. The scrub has had a long history of fire, some of the severe ones burning such plants back to the base, eliminating such as Ceratiola. However, most sandhills species are biologically adapted to fire, many sprouting vigorously afterward. The sparse overstory of pines has been cut or burned often and, in that most understory woody species of shmubs or small trees are Iess dense or absent from dense stands of pine in the overstory, it is assumed that reduction of the overstory favors increase of such species as c. pyomaeus.

The main problem with $C$. pygmaeus is not from the fire or logging, but instead is the "suitability" of the sandhills for cultivation of orange trees which now occupy the bulk of the former range of this showy rarity. Also, much of the scrub has been converted to housing lots for the rapidly expanding towns and communities of the south Florida highlands. It is suggested, in fact, that the status of C. pygmaeus be changed from "threatened" to "endangered".

\section{References}

Hardin, J. W. 1974. Studies of the southeastern United States flora.IV. Oleaceae. Sida 5: 274-285.

Small, J. K. 1933. Manual of the southeastern flora, pp. 104l1042. Chapel Hill, N. C. 
SPECIES Chionanthus pygmaeus Small, pygmy fringe-tree

\begin{tabular}{|c|c|c|c|c|c|c|c|c|}
\hline \multirow[b]{2}{*}{$\begin{array}{l}\text { Expected* } \\
\text { Effect on } \\
\text { the Species }\end{array}$} & \multicolumn{8}{|c|}{ Management Practices } \\
\hline & $\begin{array}{c}\text { Prescribe } \\
\text { Burn }\end{array}$ & $\begin{array}{l}\text { Bulldoze } \\
\text { or } \\
\text { Root Rake }\end{array}$ & Bed & Chop & $\begin{array}{l}\text { l'hin } \\
\text { over- } \\
\text { story }\end{array}$ & $\begin{array}{l}\text { Cut } \\
\text { over- } \\
\text { story }\end{array}$ & $\begin{array}{l}\text { Establish } \\
\text { Plantation }\end{array}$ & Graze \\
\hline Destroy & & $\mathrm{x}$ & $\mathrm{x}$ & $\mathrm{x}$ & & & $\mathrm{x}$ & \\
\hline \multicolumn{9}{|l|}{ Damage } \\
\hline $\begin{array}{l}\text { No lasting } \\
\text { Effect }\end{array}$ & $x$ & & & & & & & \\
\hline $\begin{array}{l}\text { Beneficial } \\
\text { if Done } \\
\text { Properiy }\end{array}$ & & & & & $\mathrm{X}$ & $\mathrm{x}$ & & \\
\hline
\end{tabular}

Other Comments:

* Expected effect on the species is an estimate made by Dr. Robert Kral based on his knowledge of the habitat and on knowledge gained from personal field observations. Estimates are "rough" in many instances. Results of practices may he modified depending upon the degree of application, intensity of treatment, nearness to plant communities, etc. A management practice for which no entry is made indicates a lack of sufficient information from which to predict expected results. As observations are made in the field by users of the clata, the expected effect will be refined. 


\section{Chionanthus pygmaeus Small}

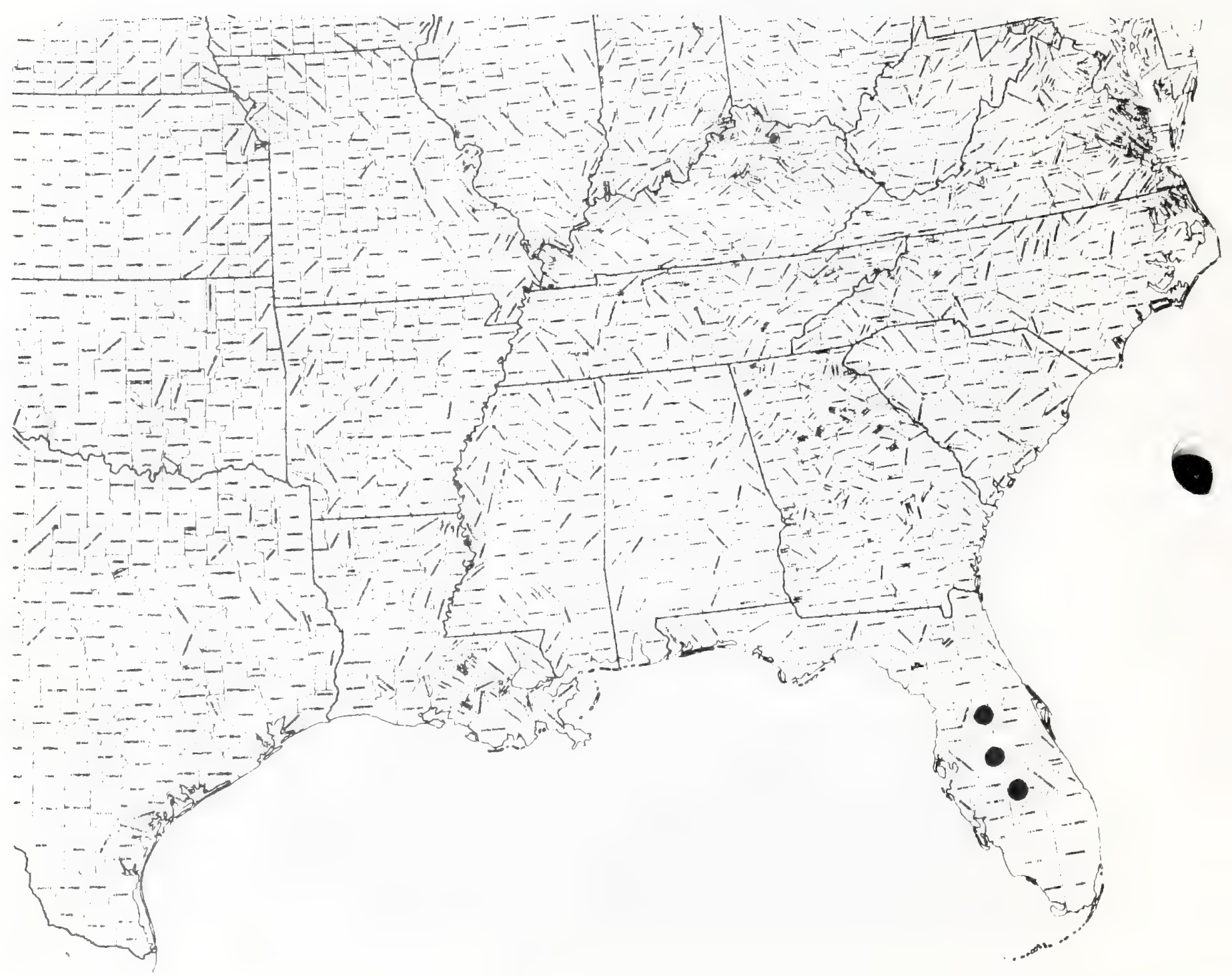


Paper 240

Text and map by:

Robert Kral

\section{POACEAE}

Ctenium floridanum (Hitchc。) Hitchc. Florida orange-grass Campulosus floridanus Hitchc。

Technical Description

Perennial grass from scaly rhizomes.

culms.--Solitary or clumped, terete, slender and wand-Iike, to 1.5 meters tall, proximally smooth, distally scabro-puberulent or cinereous.

Leaves. - - Rhizomal leaves tightly overlapping, scale-like, scariousmargined, strawmcolored; basal leaves crowded, the sheathes open and strongly overlapping, the lowermost ones short-bladed. and grading into rhizomal ones, the uppermost ones becoming greener, often tinged with maroon and with narrowly linear, green blades 5-30 cm long, mostly 3-5 $\mathrm{mm}$ wide, frequently involute, strongly multiverved, the uppex surface scabro-puberulent on the nerves: ligule a narrowly triangulas, pale, scarious, acute, laceratefimbriate scale to $5 \mathrm{~mm}$ long; mid-and-upper culm leaves few, scattered, the sheathes shorter than the internodes and closed proximally, the blades shorter, narrower and more involute than those of culm base.

Inflerescence.--Spikelets unilateral in a terminal spike, numerous, close-set, sessile, alternating in 2 rows along the concave side of and perpendicular to a single, slender, slightly excurved, greenishpurple, convexwbaked spike rachis $4-15 \mathrm{~cm}$ long, this sometimes also spiralled, the whole inflorescence laterally quite flattened, when viewed from the side resembling a narrow comb, with reduced spikelets narrowing it at each end. First glume narrowly triangular, 1.5-2.0 m long, scarious, keeled, the single nerve excentric, greenish, scaberulous, the glume base dorsally with a conspicuous, spongy,pulvinas swelling; second glume lanceolate, narrowly acute, 4-5 mm Iong, scarious with 3 strong (but not complete) longitudinal green nerves, the median one bearing midway up an excentrically spreading, rigid, swollen-based awn $3-4 \mathrm{~mm}$ long, the lateral ones bearing (or lacking) a scattered row of inconspicuous, yellowish glands; rachilla base (callus) bearing a strong tuft of slender, erect, white bristles; first lemma empty, scarious, ca. $3 \mathrm{~mm}$ long, oblong-eliiptic, the apex emarginate, the single green nerve dorsal, excurrent as a straight awn, the edges plumose-ciliate; second lemma staminate or empty, similar in awning and shape to the first, but ca. $3.5 \mathrm{~mm}$ long and containing a slender, reduced linear palea $2.5 \mathrm{~mm}$ long; 3rd lemma like the others, the body ca. $3.5 \mathrm{~mm}$ Iong and similarly awned, the palea nearly as long, apically bifid; additional lemmas 2 or 3, reduced, subtended by a rachilla joint ca. I mm long.

Fruit.--Grain narrowly cylindrical, dark brown, ca. $2 \mathrm{~mm}$ long, 
Sandy, moist to quite dry ecotones between longleaf pine scrub or wiregrass, and pine flatwoods ponds or depressions, northern peninsular Florida north into southeastern Georgia; flowering and fruiting from August to frost.

\section{Special Identifying Features}

Of the 12 species in this small genus only two are native to the U.S.A. and C. floridanum is nested into but a small part of the range of $\underline{C}$. aromaticum, which is widespread in savannas and flatwoods clearings in the Coastal Plain from Virginia south to Florida and west into Louisiana. The two are easily distinguished in that the former blooms and fruits later in the year, has prominent scaly rhizomes (lacking in C. aromaticum, a much more tufted plant), has a much longer ligule, takes a generally drier habitat, and either has less prominent glands along the midrib of the 2nd glume or lacks these glands entirely.

Habitat and Management Implications

C. floridanum appears to take a distinctly drier habitat than does C. aromaticum, and rarely dominantes its landscape. The plants are generally scattered in savanna-like sites on dryi sh sandy soils and are in association with several species of uplant. Aristida (mainly A. stricta), Andropogon, Sporobolus, Anthaenantia villosa, Digitaria villosa, many Dichanthelium Panicum, Heterotheca (gossypina, microcephala, scabrella, etc.), Helianthus floridanus, Liatris gracilis, I. tenuifolia, Aqalinis setacea, etc. It is usually in what appears to be a transitional zone between longleaf pine-turkey oak scrub, or live oakpine savanna and pine-saw palmetto-gallberry flats or pineland ponds. In the same parts of Florida and Georgia, $\underline{\text { c. aromaticum }}$ occupies a distinctly wetter habitat, being particularly abundant on the black sandy peat of pineland savanna or even in bogs.

Much of the habitat of $C$. floridanum is being destroyed through residential-industrial developments on the one hand, and through mechanical site preparation for plantation pine on the other. This grass was probably maintained in nature by periodic natural woods fires which would have tended to reduce competition by woody plants, favoring the dryish savanna systems.

\section{References}

Hitchcock, A. S. 1915. New or noteworthy grasses. Am. Journ. Bot. $2: 306-307$.

- \& Agnes Chase. 1950. Manual of the grasses of the United States, ed. 2, pp. 515-516. U.S.D.A. Misc. Publ. 
no. 220 , Washington, D.C.

Small, J. K. 1933. Manual of the southeastern flora, p. 114. Chapel Hill, N. C. 
SPECIES Ctenium floridanum (Hitchc.) Hitchc. Florida orangegrass

\begin{tabular}{|c|c|c|c|c|c|c|c|c|}
\hline \multirow[b]{2}{*}{$\begin{array}{l}\text { Expected* } \\
\text { Effect on } \\
\text { the Species }\end{array}$} & \multicolumn{8}{|c|}{ Management Practices } \\
\hline & $\begin{array}{c}\text { Prescribe } \\
\text { Burn }\end{array}$ & $\begin{array}{l}\text { Bulldoze } \\
\text { or } \\
\text { Root Rake }\end{array}$ & Bed & Chop & $\begin{array}{l}\text { Thin } \\
\text { over- } \\
\text { story }\end{array}$ & $\begin{array}{l}\text { Cut } \\
\text { over- } \\
\text { story }\end{array}$ & $\begin{array}{l}\text { Establish } \\
\text { Plantation }\end{array}$ & Graze \\
\hline Destroy & & $\mathrm{x}$ & & $\mathrm{X}$ & & & $\mathrm{X}$ & $\mathrm{x}$ \\
\hline Damage & & & $\mathrm{x}$ & & & & & \\
\hline $\begin{array}{l}\text { No lasting } \\
\text { Erfect }\end{array}$ & & & & & & & & \\
\hline $\begin{array}{l}\text { Beneficial } \\
\text { if Done } \\
\text { Properly }\end{array}$ & $\mathrm{X}$ & & & & $\mathrm{x}$ & $\mathrm{x}$ & & \\
\hline
\end{tabular}

\section{Other Comments:}

*Expected effect on the species is an estimate made by Dr. Robert Kral based on his knowledge of the habitat and on knowledge gained from personal field observations. Estimates are "rough" in many instances. Results of practices may be modified depending upon the degree of application, intensity of treatment, nearness to plant communities, etc. A management practice for which no cntry is made indicates a lack of sufficient information from which to predict expected results. As observations are made in the field by users of the data, the expected effect will be refined. 
Ctenium floridanum (Hitchc。) Hitchc.

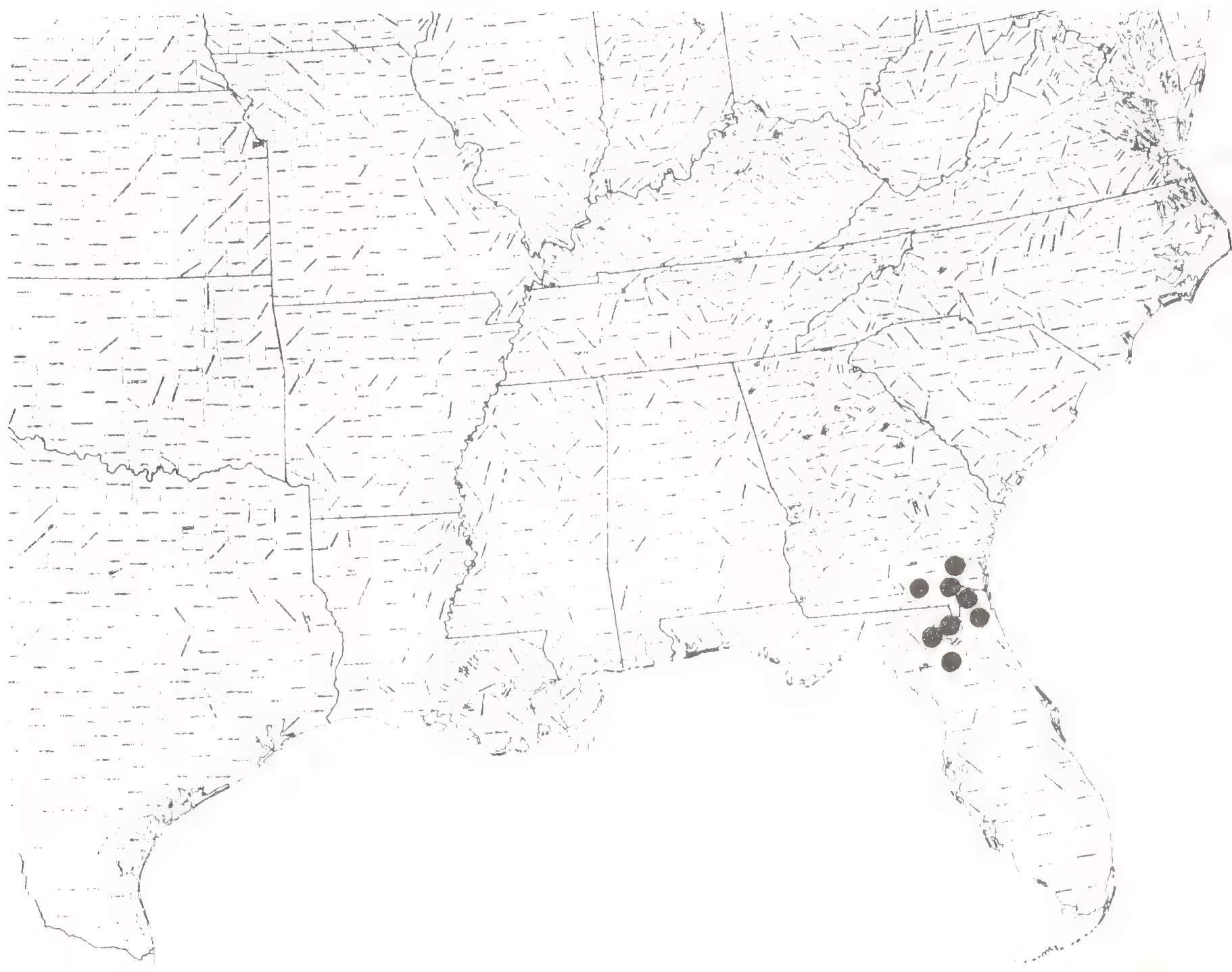


6

6

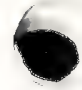


Paper 241

Text and map by:

Robert Kral

\section{POACEAE}

Panicum hirstii Swallen. Hirst's panic-grass

Technical Description

Perennial grass in sect. Dichanthelium, the culms usually in small tufts from overwintering rosettes.

CuIms.--Erect or leaning, slender, to $8 \mathrm{dm}$ tall, longitudinally ribbed, smooth, at mid-culm with internodes longer than subtending sheaths.

Leaves.--Rosette leaves spreading, broadly lance-linear, acuminate, mostly 3-4 cm long, smooth, strongly nerved, the margins thin; culm leaves several, gradually reauced in length from ca. mid-culm both upward and downward on culm, narrowly lance-linear-bladed, the sheathes mostly shorter than internodes, purplish-tinged, strongly ribbed, smooth, save for the pilose margins, the longest blades mostly 8-14 cm long, smooth, in the vernal culms flattish, inrolied only toward the narrowed tips, in the autumnal culms strongIy inrolled, always erect or ascending, firm.

Inflorescence.--Spikelets several to very many in a panicle, this 3-7 cm long, in outline narrowly elliptical, the numerous panicle branches thus strongly ascending, all branches smooth, the primary ones sinuously contorted, the stiffish, ascending lateral peduncles shorter than the spikelets, mostly secund (unilateral on branches), Spikelet.s.--Narrowly to broadly obovoid, ca. $2 \mathrm{~mm}$ long, asymetrical, often obpyriform, strongly ribbed, smooth (or pilosulous), pale green, bluntish; first glume scarious, pale, broadly rounded or obtuse, nerveless, 0.5-0.8 mm long; second glume about as long as the fertile lemma, toward its tip often purple-tinged; sterile lemma slightly longer than the fertile (thus ca. $2 \mathrm{~mm}$ long), otherwise similar to the second glume; fertile lemma with a short, incurved, hispidulous point, the strongly convex back whitish, shining, minutely and distantly papillate.

Distribution and Flowering Season

Wet savanna and pine barren ponds, Coastal Plain, southern New Jersey and southwestern Georgia. Vernal culms in May, June; autumnal culms from Auguist to frost.

Special Identifying Features

This Dichanthelium Panicum is placed in the sect. "Angustifolia" on the basis of the stiffish, erect, narrow blades which tend to taper from near base to apex, the obpyriform, conspicuously 
or inconspicuously pustular spikelet which is usually strongly nerved and blunt-tipped, and the bushy-branched (distally) autumnal habit. Tentatively, R. Harper placed it in $\underline{P}$. roanokense on the basis of small spikelets, smooth foliage, s smooth nodes, which thus means he interpreted it as being in sect. "Dichotoma", but the inflorescence branching in P. hirstii forms a narrower system. Greatest difficulty comes with $\underline{P}$. neuranthum Griseb., which in no way differs from the type description or the type material other than in the spikelet being "finely papillose-pubescent". ‥ neuranthum is found mostly in wet savanna, edges of islands in everglades, moi st open swales, in Cuba, British Honduras, southern Florida northward locally to southern Alabama, southern Mississippi and Texas. In that there are frequent instances of species of "Dichanthelium" varying widely from smooth to pubescent in spikelet, it would seem to me that $\underline{P}$. hirstii is certainly a weak species and probably is a glabrous variant of $\underline{p}$. neuranthum Griseb. This last, by Gould and overconservatively, has been placed in the synonymy of Dichanthelium anqustifoliun (Ell.) Gould.

Habitat and Management Implications

Panicum hirstii, if it is a species, is found in areas that are at least intermittently wet, usually in full sun or light shade. It is to be looked for around and in shallow, intermittent or fluctuating pineland ponds, the plants rooted in sandy-peat-muck and mostly associated with grass-sedge bog species. These systems frequently bum or are bumed over during dry cycles, and this is probably a significant management factor in keeping woody reproduction from closing over the herbaceous cover and shading or crowding it out. The forest overstory around $\mathrm{P}$. hirstii ponds in southwest Georgia is primarily Taxodium-Nyssa, with varying admixtures of Pinus serotina, P. palustris, elliottii, Acer rubrum, Fraxinus (in southern New Jersey Taxodium is absent but Chamaecyparis present, and the dominant pinus is $\underline{p}$. rigida). Management to protect $\underline{p}$. hirstii would have to exclude drainage, excessive soil disturbance including any methods of mechanical site preparation. Controlled burning would favor the species.

\section{References}

Gould, F. W. 1975. The grasses of Texas. College Station, Texas.

Hitchcock, A. S. \& Agnes Chase. 1950. Manual of the grasses of the United States. U.S. Govt. Printing Office, Washington.

Swallen, J. R. 1961. A new species of Panicum from New Jersey. Rhodora 63 (752): 235-236. 
SPECIES Panicum hirstii Swallen. Hirst"s panic-grass

\begin{tabular}{|c|c|c|c|c|c|c|c|c|}
\hline \multirow[b]{2}{*}{$\begin{array}{l}\text { Expected* } \\
\text { Effect on } \\
\text { the Species }\end{array}$} & \multicolumn{8}{|c|}{ Management Practices } \\
\hline & $\begin{array}{c}\text { Prescribe } \\
\text { Burn }\end{array}$ & $\begin{array}{c}\text { Bulldoze } \\
\text { or } \\
\text { Root Rake }\end{array}$ & Bed & Chop & $\begin{array}{l}\text { Thin } \\
\text { over- } \\
\text { story }\end{array}$ & $\begin{array}{l}\text { Cut } \\
\text { over- } \\
\text { story }\end{array}$ & $\begin{array}{l}\text { Establish } \\
\text { Plantation }\end{array}$ & Graze \\
\hline Destroy & & $x$ & $\mathrm{x}$ & $\mathrm{x}$ & & & $\mathrm{x}$ & \\
\hline llamage & & & & & & & & $\mathrm{X}$ \\
\hline $\begin{array}{l}\text { No lasting } \\
\text { Effect }\end{array}$ & & & & & & & & \\
\hline $\begin{array}{l}\text { Beneficial } \\
\text { if Done } \\
\text { Properly }\end{array}$ & $X$ & & & & $\mathrm{X}$ & $\mathrm{X}$ & & \\
\hline
\end{tabular}

Other Comments: drainage of habitat would be detrimental!

*ixpected effect on the species is an estimate made by Dr. Robert Kral based on his knowledge of the habitat and on knowledge gained from personal field observations. Estimates are "rough" in many instances. Results of practices may he modified depending upon the degree of application, intensity of treatment, nearness to plant communities, etc. A management practice for which no entry is made indicates a lack of sufficient information from which to predict expected results. As observations are made in the field by users of the lata, the expected effect will be refined. 


\section{Panicum hirstii Swallen}

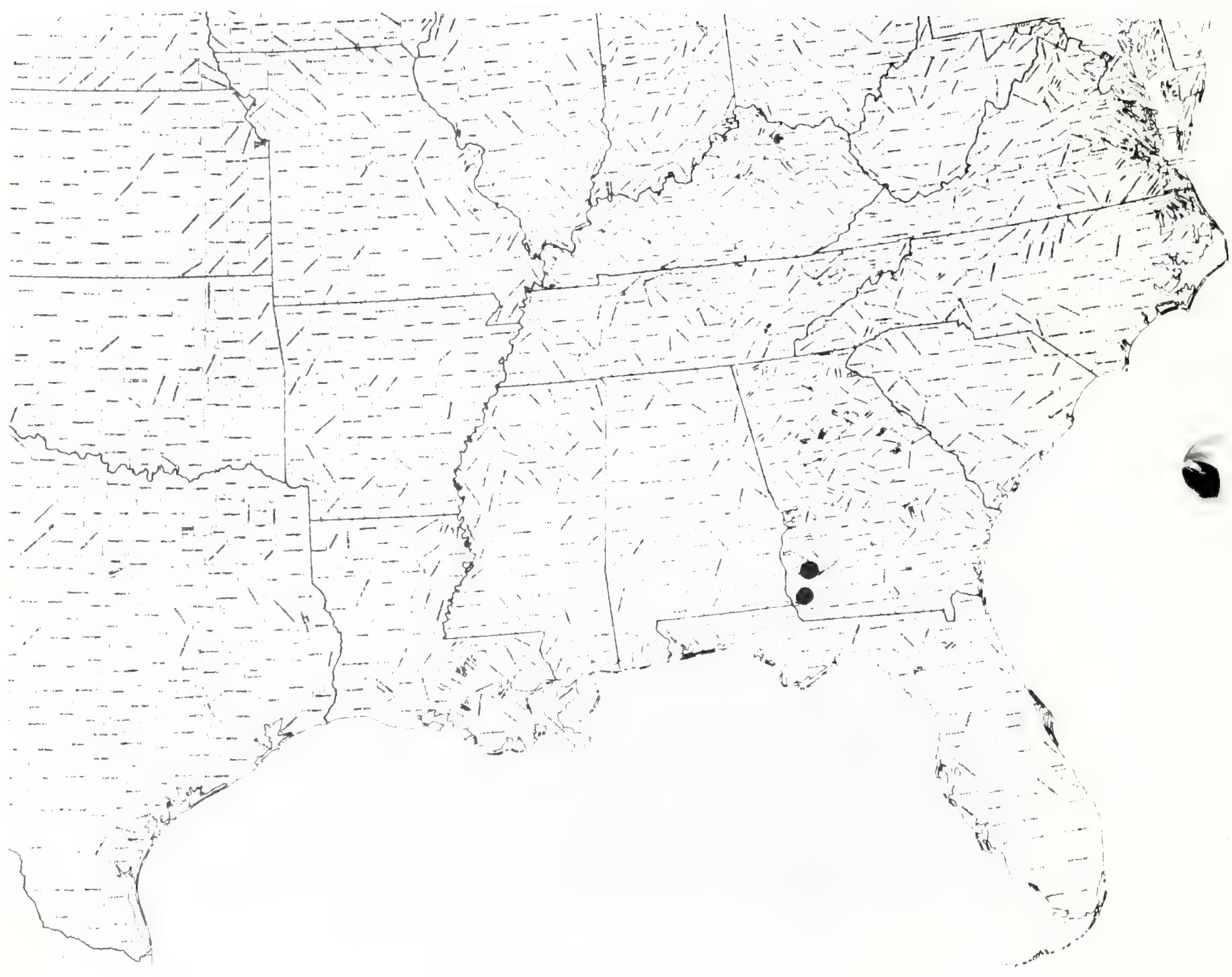


Paper 242

Text and map by:

Robext Kral

\section{POACEAE}

Panicum Iithophilum Swallen. Swallen's panic-grass

Technical Description

Annual, often tufted, panic-grass with a shallow, diffuse root system.

Culms.--Highly variable in height, depending on fertility of site, moisture, ranging from 1.5-6.0 dm tall, few-to-several per clump, erect to ascending or spreading, slender, teretish, low-ribbed, purplish-tinted proximaliy, pilose at the nodes.

Leaves.--Concentrated toward the culm base, but none forming overwintering rosettes, the lowest smallest, usually withered by flowering time, the largest with sheathes 3-4 cm long, these narrowIy tubular, strongly ribbed, pilose, with hair bases on ribs strmose, splitting apically; ligule a ring of hairs ca. $3-4 \mathrm{~mm}$ Iong; blades ascending to erect, mostly 6-10 cm long, 3-5 mm wide, linear, flat, and tapering vary gradually from below the middle to the narrowly pointed apex, the margin proximally strmose-ciliate, the surface yellow-green or strongly maroon-tinged, the upper side pilose, the lower surface smooth or pilose toward the base.

Inflorescence.--Spikelets eliipsoidal, acute, ca. 1.9-2.3 mm Iong, smooth, green, variously tinted with maroon or purple, arranged diffusely in an eliipsoidal or ovoid panicle $1 / 3$ or less the total plant length, on shortish, ascending or erect stalks toward the tips of the slender, purplish, minutely scabrid panicle branches. First glume ca. I mm Iong, acute, somewhat keeled at the midnerve; second glume ovate, ca. $2 \mathrm{~mm}$ long, the short acute tip slightly excurved or erect, the rounded back strongly ribbed; sterile lemma similar in shape to the second glume.

Fruit.--(in this case the hard fertile lema and palea!) planoconvex, ellipsoidal, apiculate, pale green, shining, ca. $2 \mathrm{~mm}$ long or nearly equaliing spikelet, not pointed beyond it.

Distribution and Flowering Season

Granite outcrops and their immediate surroundings, Piedmont South Carolina, Georgia, Alabama. Flowering from August to frost.

Special Identifying Features

P. Iithophilum is in that part of the sect. "Capillaria" that has spikelets under $2.5 \mathrm{~mm}$ long and panicles that rarely exceed $1 / 3$ of the plant length. This thus relates it to $\underline{P}$. gattingeri, $\underline{P}$. philadelphicum in the southeastern U.S.A. It is distinguished from the former by its less plump spikelets, 
its narrower leaf blades; it is distingui shed from the latter by its longer spikelets and purplish-tinged foliage.

Habitat and Management Implications

P. Iithophilum often forms stands on and around granite outcrops in full sun or light shade, usually where there have been vernal pools or inwash depressions. Thus its new leaves are arising at the time when Diamorpha, Sedum, Arenaria, Isoetes, Agrostis elliottiana. Juncus, Iindernia and other ephemerals are carpeting such places. By the time the Panicum is fruiting it is us ua.lly admixed with such plants as Viquieria porteri, crotonopsis elliptica, Cyperus granitophilus, Talinum, Hypericum gentianoides Bulbostylis capiliaris, etc., and in some instances may be the dominant plant. In nature it falls well within that class of pioneer species that invades the granite, ultimately giving way to perennial herbs and finally to invading shrubs and trees, these last at first being mostly gymnosperms such as Juniperus, Pinus echinata, $\underline{\text { p. virginiana, }}$. taeda, which in turn give way to upland hardwood species. The site quality for pines or hardwoods is usually poor until the underlying granite is covered by considerable depth of soil, and fire has been a historical factor in helping keep granite glades open. Mainly the threat to this particular grass is from quarrying of the granite, together with careless trampling or driving over the outcrop pools. However, this is a weedy species which can resist such pressures better than most of its associates. Much of it now exists in protected state land in Georgia.

\section{References}

Hitchcock, A. S. \& Agnes Chase. 1950. Manual of the grasses of the United States, ed. 2, pp. 687-689. U.S.D.A. Misc. Publ. 200. U. S. Govt. Printing Office, Washington, D.C.

Radford, A. E., C. R. Bell \& H. E. Ahles. 1968. Manual of the vascular flora of the Carolinas, pp. 142-159. Chapel Hill,N.C. 
Panicum Iithophilum Swallen. Swallen's panic-grass

\begin{tabular}{|c|c|c|c|c|c|c|c|c|}
\hline \multirow[b]{2}{*}{$\begin{array}{l}\text { Expected* } \\
\text { Effect on } \\
\text { the Species }\end{array}$} & \multicolumn{8}{|c|}{ Management Practices } \\
\hline & $\begin{array}{c}\text { Prescribe } \\
\text { Burn }\end{array}$ & $\begin{array}{c}\text { Bulldoze } \\
\text { or } \\
\text { Root Rake }\end{array}$ & Bed & Chop & $\begin{array}{l}\text { Thin } \\
\text { over- } \\
\text { story }\end{array}$ & $\begin{array}{l}\text { Cut } \\
\text { over- } \\
\text { story }\end{array}$ & $\begin{array}{l}\text { Establish } \\
\text { Plantation }\end{array}$ & Graze \\
\hline Destroy & & $\mathrm{NA}$ & $\mathrm{NA}$ & $\mathrm{NA}$ & & & $\mathrm{NA}$ & \\
\hline Damage & & & & & & & & $\mathrm{X}$ \\
\hline $\begin{array}{l}\text { No lasting } \\
\text { Effect }\end{array}$ & & & & & & & & \\
\hline $\begin{array}{l}\text { Beneficial } \\
\text { if Done } \\
\text { Properly }\end{array}$ & $\mathrm{X}$ & & & & $\mathrm{X}$ & $\mathrm{X}$ & & \\
\hline
\end{tabular}

Other Comments:

*fixpected effect on the species is an estimate made by Dr. Robert Kral based on his knowledge of the habitat and on knowledge gained from personal field observations. Fstimates are "rough" in many instances. Results of practices may he modified depending upon the degree of application, intensity of treatment, nearness to plant communities, etc. A management practice for which no cntry is made indicates a lack of sufficient information from which to predict expected results. As observations are made in the field by users of the data, the expected effect will be refined. 


\section{Panicum Iithophilum Swallen}

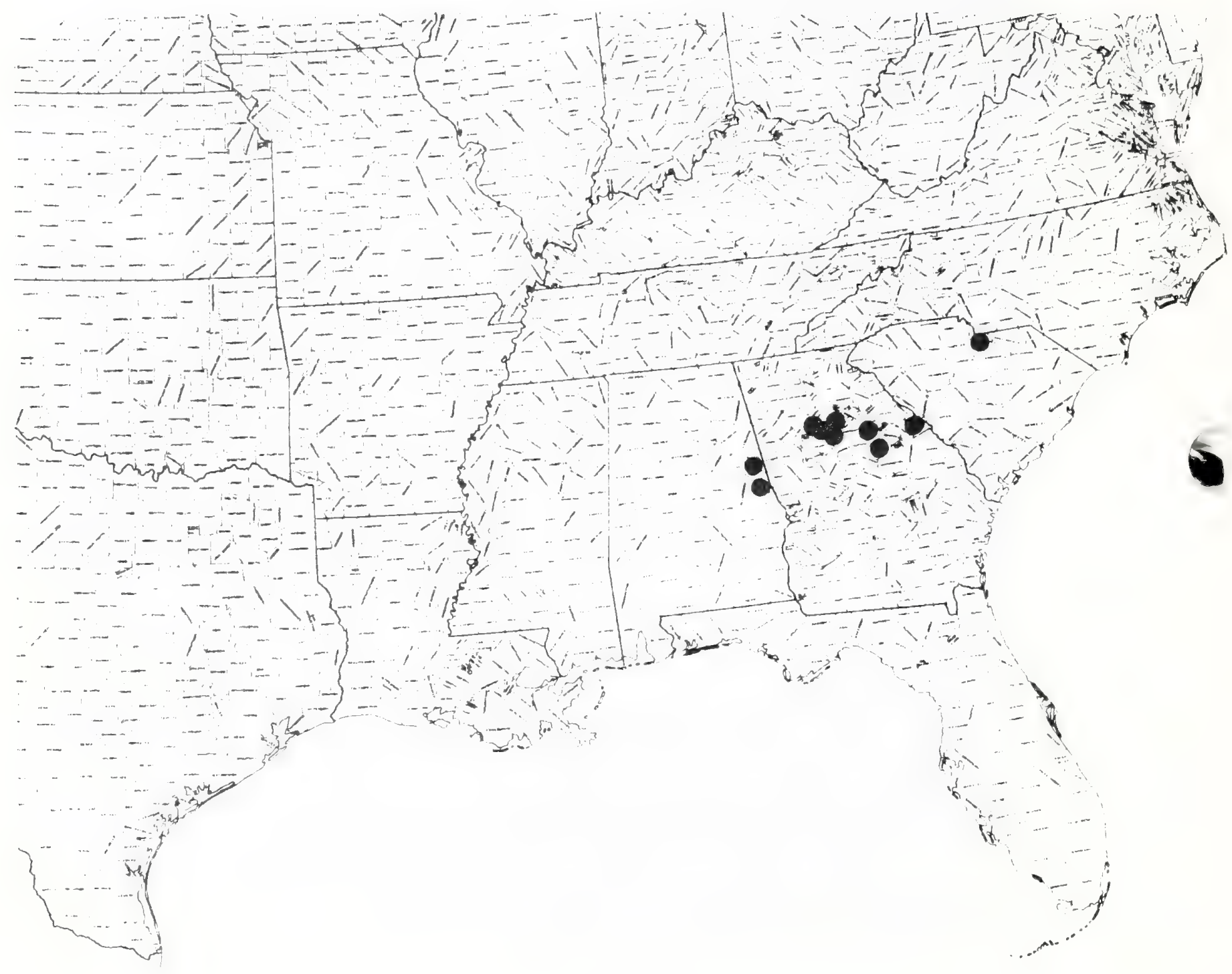


SPECIES Portulaca sinaliii P. Wilson. Small's purslane

\begin{tabular}{|c|c|c|c|c|c|c|c|c|}
\hline \multirow[b]{2}{*}{$\begin{array}{l}\text { Expected* } \\
\text { Effect on } \\
\text { the Species }\end{array}$} & \multicolumn{8}{|c|}{ Management Practices } \\
\hline & $\begin{array}{c}\text { Prescribe } \\
\text { Burn }\end{array}$ & $\begin{array}{l}\text { Bulldoze } \\
\text { or } \\
\text { Root Rake }\end{array}$ & Bed & Chop & $\begin{array}{l}\text { Thin } \\
\text { over- } \\
\text { story }\end{array}$ & $\begin{array}{l}\text { Cut } \\
\text { over- } \\
\text { story }\end{array}$ & $\begin{array}{l}\text { Establish } \\
\text { Plantation }\end{array}$ & Graze \\
\hline Destroy & & $\mathrm{NA}$ & NA & $\mathrm{NA}$ & & & $\mathrm{NA}$ & \\
\hline Damage & & & & & & & & $\mathrm{X}$ \\
\hline $\begin{array}{l}\text { No lasting } \\
\text { Effect }\end{array}$ & $\mathrm{X}$ & & & & & & & \\
\hline $\begin{array}{l}\text { Beneficial } \\
\text { if Done } \\
\text { Properly }\end{array}$ & & & & & $x$ & $\mathrm{X}$ & & \\
\hline
\end{tabular}

Other Comments:

*Expected effect on the species is an estimate made by Dr. Robert Kral based on his knowledge of the habitat and on knowledge gained from personal field observations. Estimates are "rough" in many instances. Results of practices may he modified depending upon the degree of application, intensity of treatment, nearness to plant communities, etc. A management practice for which no entry is made indicates a lack of sufficient information from which to predict expected results. As observations are made in the field by users of the data, the expected effect will be refined. 
Portulaca smallii P. Wils.

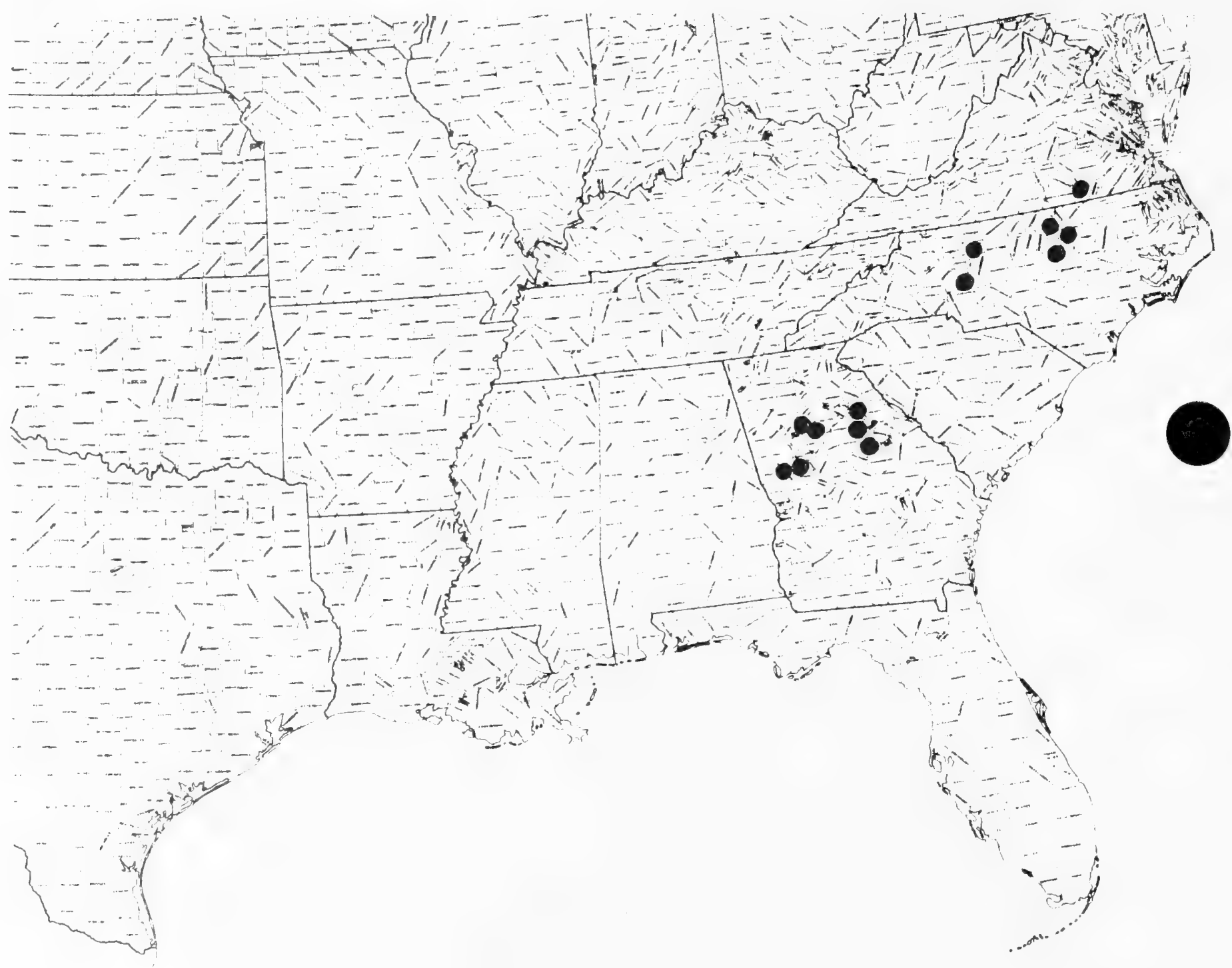


Paper 244

Text and map by:

Robert Kral

\section{RANUNCULACEAE}

Clematis catesbyana Pursh. Uld man's beard virgin bower C. virginiana L. var. catesbyana (Pursh) Britton

C. micrantha small?

Technical Description

Rambling, sprawling or climbing perennial, herbaceous vine, sometimes forming masses several meters high or broad.

Stems.--Lower stems with thin, dull-brown, exfoliating bark, distally strongly ribbed, often white-appressed-villosulous, the newer shoots and branchlets villous-tomentulose with whitish or yellowi sh hairs.

Leaves.--Main shoot leaves ternately-pinnately compound, alternate, estipulate, sometimes to $2 \mathrm{dm}$ long, usually shorter, the spreading or ascending petiole 5-10 cm long, ribbed, reddish-brown or greenish brown, appressed villous, distally 3-branched, each branch toward apex with 3-5 (-7) mostly 3, leaflets, the largest terminal, reniform, suborbicular or ovate, 3-5 cm long, coarsely toothed, the tooth tips acuminate or cuspidate, often also prominently 2-3-1obed, the base rounded or cordate, the upper surface dark, duII green or yellowish-green, smooth to sparsely strigillose, more heavily so along the impressed main veins, the lower surface paler, sericeous or soft-puberulent.

Inflorescence.--Main axes and lateral shoots terminating in an elongated panicle of cymes, the lower nodes of which produce compound leaves similar to those of main shoots but smaller, more sessile and with fewer, smaller leaflets, these gradually reduced upward along the main axis and upward on the inflorescence branches to become smaller still, the blades simple or trilobate, tomentose; inflorescence branches cymose, 2-6-flowered, the spreading rays tomentose, bracteolate, or the flowers solitary at peduncle tips (toward inflorescence tip).

Flowers.--Regular, perfect, 1.0-1.3 cm broad across the spreading sepals; sepals elliptic to lanceolate or obovate, ca. $5-7 \mathrm{~mm}$ Iong, acute, both surfaces densely white-sericeous-tomentose, the backs often tinged with purple, or pink, or pale green; stamens numerous, erect or spreading, ca. 5-6 mm long, the filaments broadly linear, very flattened, broader than the short-linear, $1 \mathrm{~mm}$ long, erect, yellowish anthers or some not as broad and others dilated only distally, thus more spatulate; carpels many, distinct, appressedhairy, the elongated erect styles strongly white-pilose save at the short-linear stigmatic apex.

Fruit.--Akenes ellipsoidal, $3.0-3.5 \mathrm{~mm}$ long, pubescent, the elongated styles silvery-spreading-pilose.

Distribution and Flowering season

Fencerows, borders of high and low hammocks, waste places, western peninsular Florida and northwestern Florida; flowering August into september (the range given is for the entity $\underline{c}$. micrantha Small; 
that for $\underline{C}$. catesbyana proper is much broader and is coastal Plain from South Carolina south into Florida, west into Louisiana!)

\section{Special Identifying Features}

As Dr. Keener (1975) points out, C. micrantha appears simply to be a smaller-flowered variant of C. catesbyana, but has broader sepals and shorter stamens. Specimens called C. micrantha do appear to be few, with same geographic fidelity, thus the taxonomy may be undetermined. In such a case it is advisable to attempt to preserve a doubtful taxon at least until the facts are in.

\section{Habitat and Management Implications}

The habitat in Florida of the extreme named c. micrantha Small appears to be the sunny edges of high and low hammock, where the vines may form rambling, climbing patches. The hammocks of the Brooksville area (the type locality) overlie deep Eocene limestones and are characterized by Magnolia grandiflora, willow and water oaks, live oak, red maple, green ash, red bay, etc., sometimes with a scattering of loblolly pine (which reaches its southem extremes here), longleaf pine. Sabal palmetto is throughout. The country is typical karstland, with high hills of sandy loam or sandy silt loam overlying reddish sandy clays, often dotted with outcropping limestones, the highlands interrupted by sinkholes, sinkhole lakes and ponds, or extensive bottoms. The Clematis grows along the edges of forest, in brushy cleared areas, or in places where the underlying limestone forms local outcrops (this last is particularly the case in the Mariana area of northwest Florida). The vines are never in dense shade, nor are they ever rooted in saturated soil. As is true of the closely related C. virginiana, such plants may be disturbance related, coming in where there have been recent clearings, or frequenting fencerows and rights of way at edges of undisturbed woodlands. I have observed weedy growths of these plants in orange groves! They are of course lost in the case of totally destructive logging, clearing for improved pasture, or (and this may be the most destructive influence) herbicide spraying along rows, in groves or fencerows. Quarrying of phosphate rock in the region is also a factor in endangerment.

\section{References}

Keener, C. S. 1975. Studies in the Ranunculaceae of the southeastern United States. Sida 6 (1): 33-47.

Pursh, Frederick. 1814. Flora Americana septentrionalis, Vol. II. 736. London.

Snall, J. K. 1933. Manual of the southeastern flora, p. 525. Chapel Hill, N.C. 
SPECIES

Clematis catesbyana Pursh (incl. C. micrantha Small)

old man"s beard virgin's bower

\begin{tabular}{|c|c|c|c|c|c|c|c|c|}
\hline \multirow[b]{2}{*}{$\begin{array}{l}\text { Expected* } \\
\text { Effect on } \\
\text { the Species }\end{array}$} & \multicolumn{8}{|c|}{ Management Practices } \\
\hline & $\begin{array}{c}\text { Prescribe } \\
\text { Burn }\end{array}$ & $\begin{array}{l}\text { Bulldoze } \\
\text { or } \\
\text { Root Rake }\end{array}$ & Bed & Chop & $\begin{array}{l}\text { Thin } \\
\text { over- } \\
\text { story }\end{array}$ & $\begin{array}{l}\text { Cut } \\
\text { over- } \\
\text { story }\end{array}$ & $\begin{array}{l}\text { Establish } \\
\text { Plantation }\end{array}$ & Graze \\
\hline Destroy & $x$ & $\mathrm{X}$ & $\mathrm{x}$ & $x$ & & & $\mathrm{X}$ & \\
\hline \multicolumn{9}{|l|}{ Damage } \\
\hline $\begin{array}{l}\text { No luasting } \\
\text { Effect }\end{array}$ & & & & & & & & \\
\hline $\begin{array}{l}\text { Beneficial } \\
\text { if Done } \\
\text { Properly }\end{array}$ & & & & & $\mathrm{X}$ & $X$ & & \\
\hline
\end{tabular}

Other Comments: plants are suspected to be dangerous to livestock!

*ixpected effect on the species is an estimate made by Dr. Robert Kral based on his knowledge of the habitat and on knowledge gained from personal field ohservations. Estimates are "rough" in many instances. Results of practices may he modified depending upon the degree of application, intensity of treatment, nearness to plant communities, etc. A management practice for which no entry is made indicates a lack of sufficient information from which to predict expected results. As observations are made in the field by users of the data, the expected effect will be refined. 


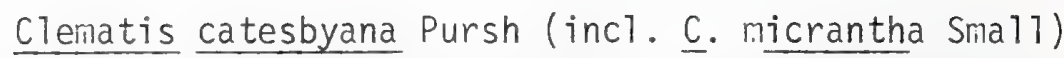

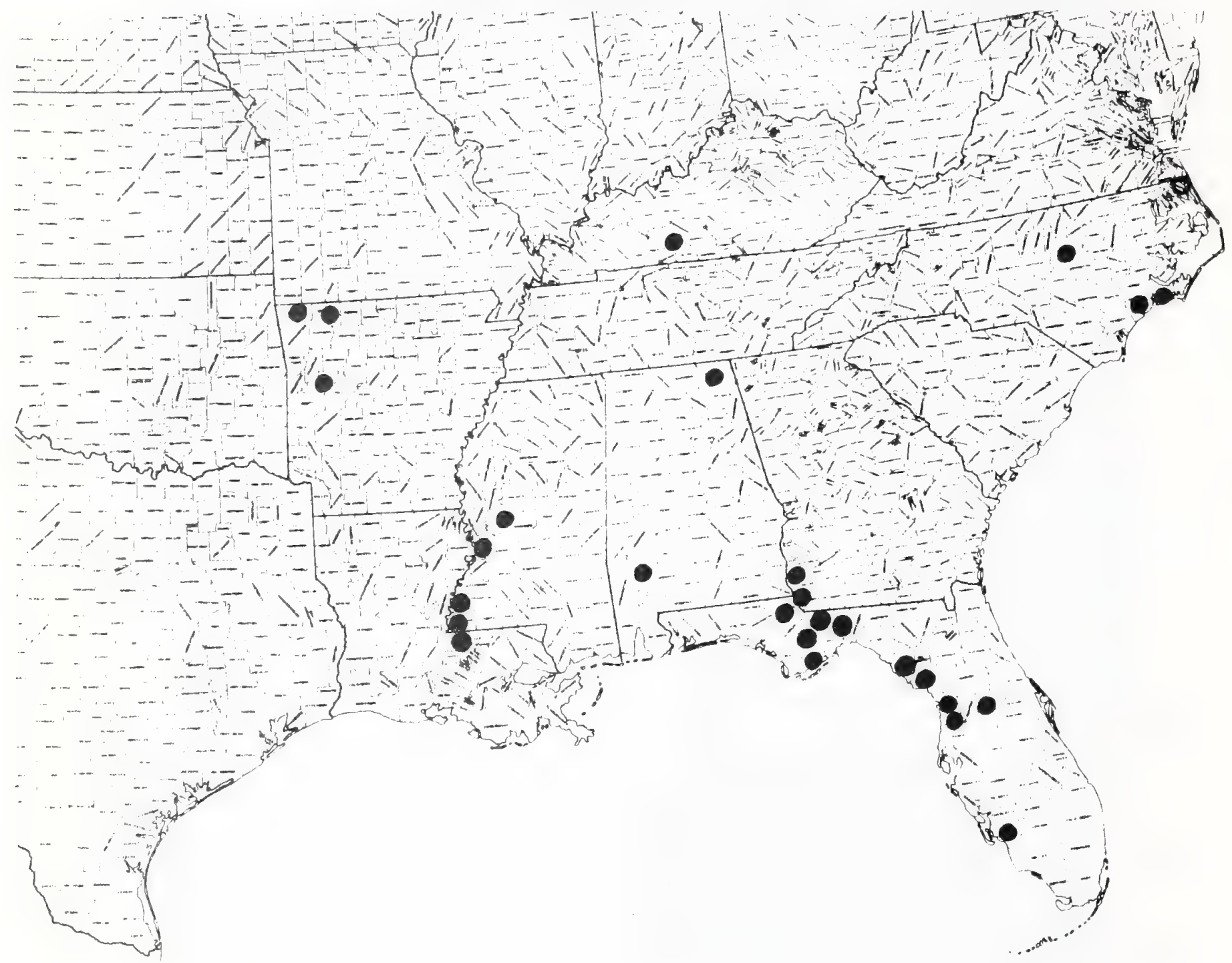


Perennial herb, the short caudex arising from a cluster of spindle-shaped roots.

Stems.--Usually solitary, erect, 5-10 (-15) dm long, by flowering time with basal nodes and internodes brownish, close-set, often leafless, above with internodes rather abruptly elongating, surfaces proximally often reddish-tinted, glabrous or pilosulous with hairs downcurved, upward on stem becoming pale yellow-green, sparsely to copiously recurved-puberulent or pilose, with an admixture of longer-spreading trichomes, in the inflorescence mostly densely recurved-puberulent and spreading-pilose, the plants unbranched or few-branched from the middle or upper nodes, or in the inflorescence, the branches ascending.

Leaves.--Rosette and lower stem leaves palmately deeply dissected, the segments spreading fanlike into a semicircular or orbicular outline on slender, pilose to nearly smooth petioles much longer than the blades; primary blade segments 3-5, mostly 3-6 cm long, joined only at very base, linear or oblong-linear, cuneate-based, bi-or-tri-branching into short to elongate-linear, spreading-ascending ultimate segments, these mostly acute, nipple-mucronate, the nipple whitish, apically depressed; blade surfaces yellowish-green, the upper smoothish, the lower with scattered pilosity and puberulence, this also along the margins. Leaves above mid-stem increasingly reduced, much shcrter than internodes, becoming sessile, mostIy 3-lobed, the uppermost linear.

Inflorescence. - Flowers either in a single terminal indeterminate raceme or a compound of a few, ascending racemes, the total inflorescence often fully $1 / 2$ the total plant length and of 15 or more flowers.

Flowers.--Perfect, irregular, showy, the pedicels spreading, arcuately ascending, slender, the lowest longest, often several cm long, all by anthesis longer than the flowers, most subtended by a single, linear, acute, viliosulous and hirsute bract and each with 2-3 short-linear, similarly hairy bracteoles distally, the pedicel surfaces with hairs both incurved-tomentulose and spreading-hirsute; sepals 5, an intense, deep, blue-violet, $2.5-3.0 \mathrm{~cm}$ broad and from tip of longest segment to tip of spur fully $3.0 \mathrm{~cm}$ long, the spur sepal (uppermost and longest) $3 \mathrm{~cm}$ long, the spur $1 \mathrm{~cm}$ long, the blade broadly oblong, apically acute or short-acuminate, spreading ciliolate, the inner surface smoothish, the outer surface spreadingpilose, the lateral sepals subequal, mostly oblong or obovate, ca. 1.5-1.7 cm long, acute to obtuse, broadly cuneate-based, the outer surfaces (backs) strongly strigose or hirtellous, particularly in the mid-zone; petals in 2 sets of 2, the upper pair connivent to produce a spur, this enclosed by the sepal spur, apically with 
short, shallowly notched blades, the lower pair clawed, about as long as the lateral sepals, the blades of a similar color and deeply notched, the spur petals ca. $3 \mathrm{~cm}$ long, the spur $1 \mathrm{~cm}$ long, blade pale blue to near white, ovate, marginally ciliate, backs pilosulous or pilose, the claw petals bluish, ca. $1.5 \mathrm{~cm}$ long, the claw ca. $0.5 \mathrm{~cm}$, bearing at its upper margin basally a spreading, short-oblong, erect auricle, the blade elliptical or ovate, ciliate-erose, narrowly and deeply cleft, the backs villous, the inner surfaces pilosulous; stamens numerous, ca. I cm long, the filaments flattened proximally, gradually narrowing and thickening toward the connective, smooth or sparsely hirsute, the anthers ellipsoidal, usually smooth; carpels narrowly lanceovoid, ca. $0.5 \mathrm{~cm}$ long, the ovary sericeous.

Fruit.--Follicles 5, the bodies oblong, ca. $1.5 \mathrm{~cm}$ long, slightIy spreading apically, pilose, the persistent styles ca. $0.5 \mathrm{~cm}$ long, arching outward; seeds somewhat asymmetrically obconic, obtuse-angled, truncate apically, $2 \mathrm{~mm}$ long, minutely soft-spreading-hairy, nearly black, the faces with irregular, shallow concavities.

Distribution and Flowering season

Calcareous clearings or open woodlands or prajries, Black Belt of middle Alabama and in the Highland Rim of northwestern

Alabama; flowering from may to mid-June.

Special Identifying Features

Delphinium alabamicum is in the range of two other species that somewhat resemble it, namely D. tricorne Michx., and D. carolinianum Walt. It differs from the former in being a taller plant, has narrower leaf segments, more erect follicles, and slightly longer, darker seeds. It differs from the latter in being a stouter plant, the flowers much larger and deeper in color, the follicles not as erect, the larger, darker seed not scaly.

Habitat and Management Implications

D. alabamicum thrives on basic soils derived from limestones, dclomites, chalks or marls. It is best developed on thin to deep, heavy clay soils, either in the full sun of prairies and glades or in open upland woods bordering such. If part of a prairie assemblage, this species is in association with such grasses as sporobolus, Panicum, Andropogon, Melica, caricoid sedges, particularly carex granularis, C. blanda, c. Ieavenworthii, $\underline{\text {. }}$ festucacea, C. albolutescens, scirpus lineatus, rushes such as Juncus interior, J. filipendulus, and a wide variety of prairie forbs in genera such as Silphium, Ratibida, Rudbeckia, Senecio, 
Aster, Solidago, Ranunculus (particularly R. fascicularis), Polygaenia, Verbena, Allium, Sisyrinchium, etc. This is the black belt prairie type in which D. alabamicum was once known to occur, but which appears to have di sappeared since. The largest extant populations are in northwestern Alabama in open and closing limestone glades, often in association with glade endemics such as petalostemon gattingeri, Psoralea subacaulis, Leavenworthia, Lesquerella, on shallow soils that in a growing season range from wet enough to support Isoetes, Juncus, Callitriche at certain times of year, dry enough during summer to support opuntia compressa, Agave virginica. Contiguous open woodlands, these often very limerocky, have this Delphinium. These woodlands are sometimes mostly Juniper, or have an admixture of upland hardwoods, particularly quercus muhlenbergii, Q. shumardii, 2. alba, 2. stellata, Carya carolinae-septentrionalis, C. ovata, C. ovalis, Ulmus americana, U. rubra, Celtis, Fraxinus americana, Acer saccharum, etc. with an understory of Rhus, Cornus, Cercis, Bumelia, Diospyros. In that the best specimens of D. alabamicum are definitely either in open areas or at edges of woodlands and are not present in dense, closed stands of juniper-hardwood, it has to be assumed that the Delphinium is seral to juniper-hardwood. Logging will create area for it, has done so locally. The main threat to it at present comes from urban, residential, and industrial expansion. The type locality is now a trailer factory. Conversion of glades to improved pasture admits introduced grasses such as fescue, orchard grass, bermuda grass, which crowd out the larkspur. Conversion of the deepr soils to row crops has also taken place. Therefore it is not logging, lout people and crop-oriented activity that makes D. alabamicum truly endangered.

References

Kral, R. 1976. A treatment of Delphinium for Alabama and Tennessee. Sida 6 (4): 243-265. 
SPECIES Delphinium alabamicum Kral. Alabama larkspur

\begin{tabular}{|c|c|c|c|c|c|c|c|c|}
\hline \multirow[b]{2}{*}{$\begin{array}{l}\text { Expected* } \\
\text { Effect on } \\
\text { the Species }\end{array}$} & \multicolumn{8}{|c|}{ Management Practices } \\
\hline & $\begin{array}{c}\text { Prescribe } \\
\text { Burn }\end{array}$ & $\begin{array}{l}\text { Bulldoze } \\
\text { or } \\
\text { Root Rake } \\
\end{array}$ & Bed & Chop & $\begin{array}{l}\text { Thin } \\
\text { over- } \\
\text { story }\end{array}$ & $\begin{array}{l}\text { Cut } \\
\text { over- } \\
\text { story }\end{array}$ & $\begin{array}{l}\text { Establish } \\
\text { Plantation }\end{array}$ & Graze \\
\hline Destroy & & $\mathrm{NA}$ & NA & NA & & & $\mathrm{x}$ & \\
\hline Damage & & & & & & & & $\mathrm{X}^{*}$ \\
\hline $\begin{array}{l}\text { No Lasting } \\
\text { Effect }\end{array}$ & $\mathrm{X}$ & & & & & & & \\
\hline $\begin{array}{l}\text { Beneficial } \\
\text { if Done } \\
\text { Properly }\end{array}$ & & & & & $\mathrm{x}$ & $\mathrm{X}$ & & \\
\hline
\end{tabular}

Other Comments: *while plants are toxic to stock, they are rarely eaten: however, stock may trample them.

*Expected effect on the species is an estimate made by Dr. Robert Kral based on his knowledge of the habitat and on knowledge gained from personal field observations. Estimates are "rough" in many instances. Results of practices may be modified depending upon the degree of application, intensity of treatment, nearness to plant communities, etc. A management practice for which no entry is made indicates a lack of sufficient information from which to predict expected results. As observations are made in the field by users of the data, the expected effect will be refined. 


\section{DeIphinium alabamicum Kral}

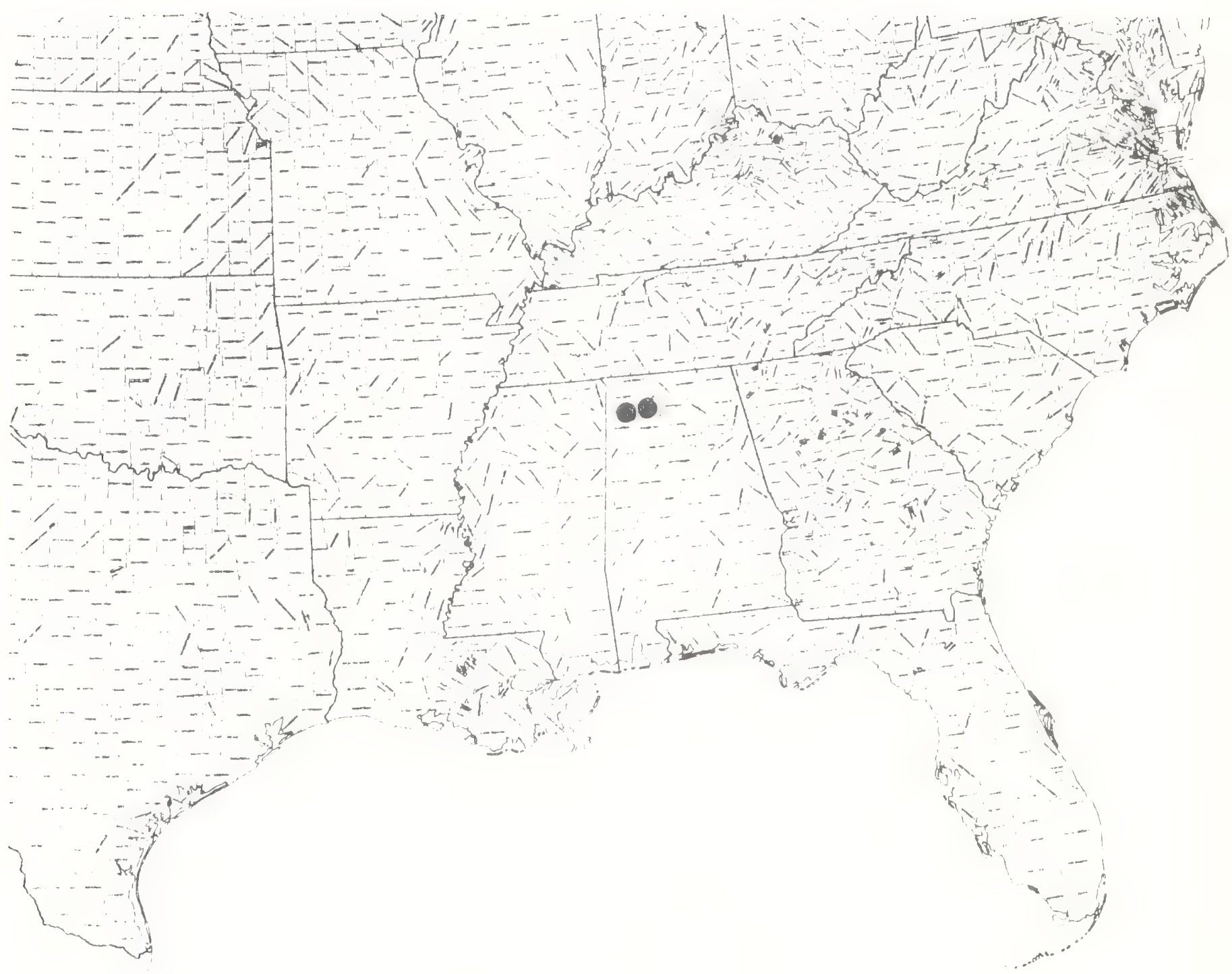


-

•

• 
Paper 246

Text and map by:

Robert KraI

\section{RANUNCULACEAE}

Delphinium newtonianum D. M. Moore. Newton larkspur

Technical Description

Slender perennial larkspur, the stems arising from a fascicle of fusiform-tuberous roots $2-5 \mathrm{~cm}$ long.

Stems.--Erect, branching only in the inflorescence, usually ari sing singly from the rootstock, stiff but slender and fistulous, proximally usually purple-tinted, retrorsely and sparingly strigillose, increasingly short-recurved-pubescent upward into the inflorescence. Leaves.--Altemate, both basal and cauline, the basal and lower cauline leaves long-pətiolate, absent by flowering time, the persistent cauline ones largest toward or below mid-stem, on slender ascending, ribbed, sparsely villous or glabrous, green petioles to $10 \mathrm{~cm}$ long (usually shorter, particularly the upper ones), the blades in outline semicircular or reniform, mostly 8-15 cm wide, 4-7 cm long, deeply cleft-and-parted, the principal segments 3-7, spreading fanlike, mostly narrowly cuneate or oblanceolate, acutetipped, upwardly ciliate, entire or themselves apically deeply 2-3-lobed, the blade base usually truncate; leaf surfaces above yellow-green, smooth or sparsely hirsute along the main veins, beneath much paler, hirsute along the main veins. Inflorescence. - Few-to-many-branched, the branches spreading from the axils of the gradually reduced, simple or fewer-lobed, short-petioled upper stem leaves, recurved-puberulent, terminating in linear-bracteolate, open cymose racemes; pedicels slender, divaricate, mostly I-3 cm long, bibracteolate, puberulent. Elowers.--DistinctIy zygomorphic, perfect, very showy; sepals 5, distinct, strongly unequal, the uppermost largest, spurred, the spur near white, ca. $2 \mathrm{~cm}$ long, projecting back, the blade spreading upward, ovate, similar to the pair of laterals and lower ones, all blades a very pale but bright blue, the margins ciliate, the surfaces nearly smooth save for a villosulous, yellowish-green subapical-distal thickened area (nectary?); petals 4, unequal, the blades projecting forward but shorter than the sepals, the upper pair with spurs projecting backward into the sepal spur, apically short-ovate-bladed, the blade bifid, hispid-hirsute, pale blue or near white, the lower pair with reduced spurs, strongly clawed, the broader, larger, pale blue blades deeply cut, hispid-hirsute; stamens numerous, distinct, projecting forward, the long filaments blue, somewhat flattened, apically slender, terminating in deep brownish, ellipsoidal, asymmetrical, basifixed anthers; carpels 3, lance-ovoid, distinct, smooth, each tapering apically into purplish blue, slender styles shorter than the stamens and each terminating in a truncate-papillose stigma. Fruit.--Follicles usually 3, smooth, pale green, cylindricalfalciform, without the persistent style ca. $1.0-1.3 \mathrm{~cm}$ long, somewhat arching outward apically at maturity; seeds broadly ellipsoidal, pale brown, ca. $2 \mathrm{~mm}$ long, minutely and uniformly puberulent. 
Dense to open upland woods over limestones; north-central and northwestem Arkansas; Elowering from late May nearly through July.

\section{Special Identifying Features}

Its inflorescence is basically cymose, thus is determinate. That of the others (D. virescences, D. treleasil, D. carolinianum, D. tricorne) is an indeterminate raceme. D. virescens, D. treleasii and D. carolinianum all have narrower, longer inflorescences and all are plants of full sun or at most light shade, all have smaller flowers. The only other woodland larkspur in Arkansas is D. tricorne, which has a similar ruotstock but which is a much lower, stouter-stemmed plant having (usually) a deeper violet-blue color of flowers, which are produced much earlier in the season.

Habitat and $M$ agement Implications

D. newtonianum prefers light to heavy shade of hardwoods, a moist loamy clay or sandy clay loam. It may be seen on the edge of such woodlands (as Dr. Moore himself first saw it!) but the large healthy stands are always in shade, and rooted in moist soils. Usually the site is sloping, sometimes steeply so, and it is often over calcareous rock or dotted with boulders of calcareous rock or sandier rock dislodged from above. In the overstory are such hardwoods as red oak, shumard oak, white oak, black oak, etc., red hickory, mockernut, pignut, hard maple, white ash, various elms, hackberry, etc., in short a facies of mixed mesophytic forest. The herbaceous cover is largely that of rich deciduous forest, namely Ranunculus, Hepatica, Anemonella, Phlox divaricata, Arisaema, Sanguinaria, Actaea, etc., mostly long past flowering. Cimicifuga racemosa, Campanula americana, Galium arkansanum are usually present and overlappin in flower and several woodland grasses in genera Bromus, Elymus, Festuca, Panicum, Chasmanthium may be abundant.

The habitat is sensitive, easily erodible, and this is the problem. If the valuable species of hardwoods that make up the overstory are heavily logged, the slopes erode, the soils dry out, and several noxious species of weedy shrubs and vines move in, crowding out whatever Delphinium might survive the shock of the logging operation. The Delphinium is a definite sciophyte favoring moist, rich substrates, and thus would stand little chance of survival. Since a good part of the known area for this rare plant is still in private ownership, it is hoped that these owners are influenced to practise selective logging of their timber tracts. 


\section{References}

Moore, D. M. 1939. Delphinium newtonianum, a new species from the Arkansas ozarks. Rholora 41: 193-197.

Keener, C. S. 1976. Studies in Ranunculaceae of southeastern

U.S. IV. Genera with zygomorphic flowers. Castanea 41: 12-20. 
SPECIES Delphinium newtonianum D.M. Moore. Newton County larkspur

\begin{tabular}{l|c|c|c|c|c|c|c|c|}
\hline & \multicolumn{7}{|c|}{ Management Practices } \\
\cline { 2 - 10 } $\begin{array}{l}\text { Expected* } \\
\begin{array}{l}\text { Effect on } \\
\text { the Species }\end{array}\end{array}$ & $\begin{array}{c}\text { Prescribe } \\
\text { Burn }\end{array}$ & $\begin{array}{c}\text { Bulldoze } \\
\text { or } \\
\text { Root Rake }\end{array}$ & Bed & Chop & $\begin{array}{l}\text { Thin } \\
\text { over- } \\
\text { story }\end{array}$ & $\begin{array}{l}\text { Cut } \\
\text { over- } \\
\text { story }\end{array}$ & $\begin{array}{l}\text { Establish } \\
\text { Plantation }\end{array}$ & Graze \\
\hline \begin{tabular}{l} 
Destroy \\
\hline Damage
\end{tabular} & $\mathrm{X}$ & $\mathrm{X}$ & $\mathrm{X}$ & $\mathrm{X}$ & & $\mathrm{X}$ & $\mathrm{NA}$ & \\
\hline $\begin{array}{l}\text { No Lasting } \\
\text { Effect }\end{array}$ & & & & & & & & $\mathrm{X}$ \\
\hline $\begin{array}{l}\text { Beneficial } \\
\text { if Done } \\
\text { Properly }\end{array}$ & & & & & & & & \\
\hline
\end{tabular}

Other Comments: *plants are toxic to livestock and often are untouched by them, but may be drmaged by trampling.

*Expected effect on the species is an estimate made by Dr. Robert Kral based on his knowledge of the habitat and on knowledge gained from personal field observations. Estimates are "rough" in many instances. Results of practices may be modified depending upon the degree of application, intensity of treatment, nearness to plant communities, etc. A management practice for which no entry is made indicates a lack of sufficient information from which to predict expected results. As observations are made in the field by users of the data, the expected effect will be refined. 


\section{Delphinium newtonianum D. M. Moore}

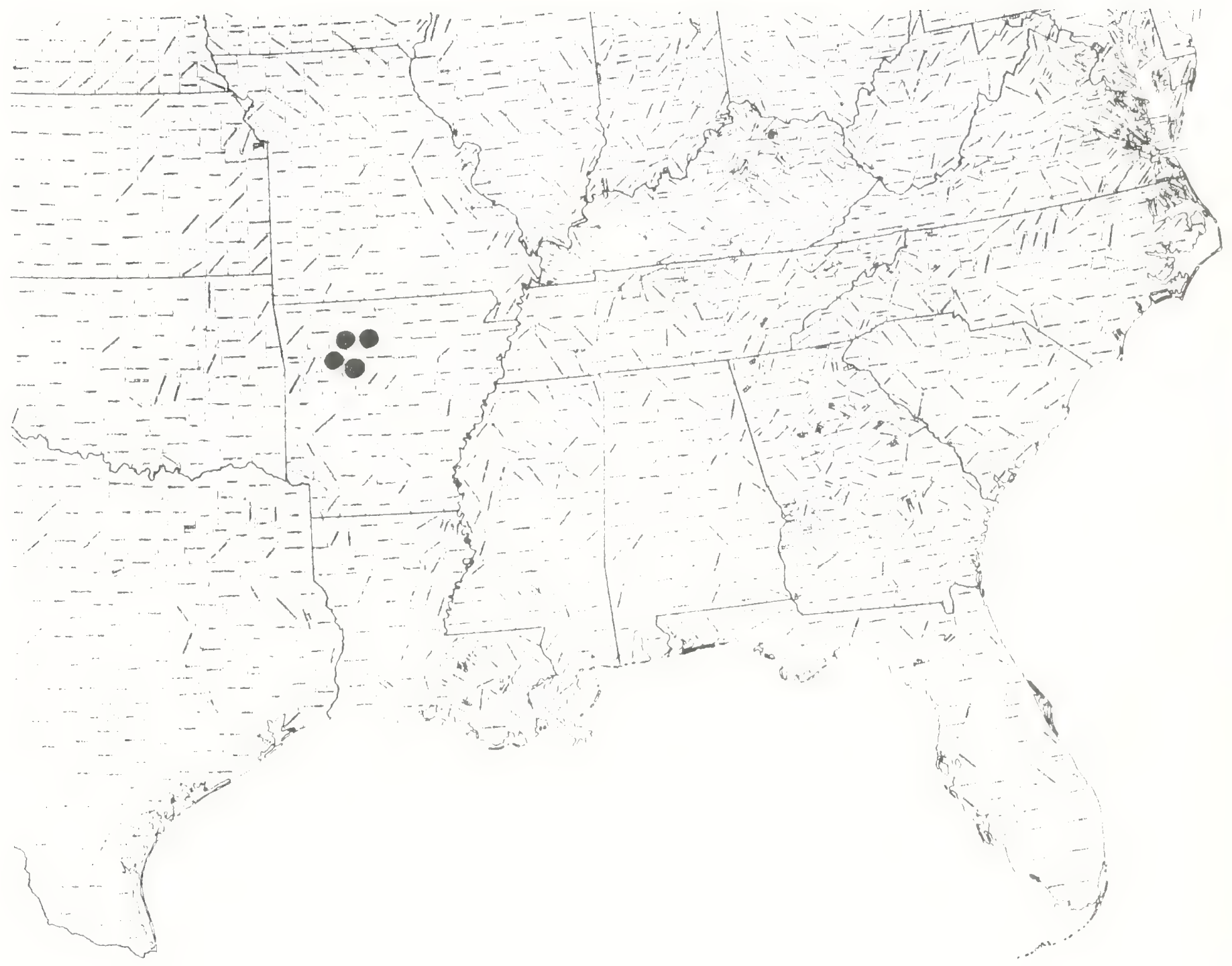



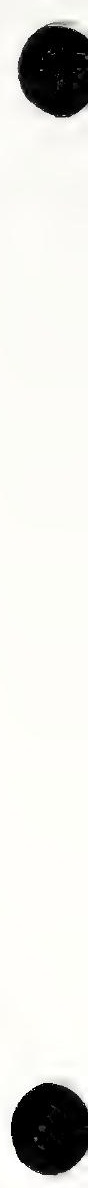

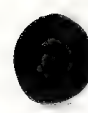


Paper 247

Text and map by:

Robert Kral

\section{RHAMNACEAE}

Saceretia minutiflora (Michx.) Trel. Tiny-leaved buckthorn

Technical Description

Diffusely branching, arching, sprawling, evergreen, leaning or even viney shrub, often climbing into crowns of overstory. Stems.--oldest growth terete, with bark grayish, thin, tending to exfoliate in narrowly rectangular plates; more re ent growth with bark smooth, reddish-brown, or brown with anastomosing shallow longitudinal cracks; branchlets numerous, some spur shoots modified to straight, spreading thorns, the leafy shoots also spreading (often in 2 ranks), slender, villous-puberulous with sordid hairs, tan or reddi sh-brown.

Leaves.--Opposite or nearly so, distichous, simple, stipulate, the stipules linear-triangular, $1.0-1.5 \mathrm{~mm}$ long, reddish-brown, early deciduous, the petioles spreading, I-2 mm long, puberulous, the blades mostly broadiy ovate to oblongmovate, mostly $1.5-4.0 \mathrm{~cm}$ long, acute, crenate-denticulate, the narrowly triangular denticles directed upward, glandular, the base rounded or cordate, the texture firm but thin, the surface above dark green, glossy, conspicuously reticulated, the lower surface slightly paler, strongly reticulate, the midnerve and stronger laterals, sometimes the entire surface, puberulent.

Inflorescence.--Terminal on leafy branches, usually a system of elongated spikes from all or most axils of reduced upper shoot leaves, the spike axis puberulous, $3-4 \mathrm{~cm}$ long, the many small flowers sessile, distant toward the spike base, more crowded towared its tip, each subtended by 2-several small, unequal, narrowly triangular, villous-backed, reddish-brown, scale-like bracts. Flowers.--Perfect, regular, small, very sweetly fragrant, broadly campanulate, nearly round, from base to tip of calyx ca. $1.5 \mathrm{~mm}$ high, about as broad; hypanthium shallowly cup-shaped, broady rounded at base; calyx lobes 5, erect or with spreading tips, greenish-white, triangular, acute, ca. $0.5-0.6 \mathrm{~mm}$ long, rather fleshy, with I raised nerve above; petals 5, whitish, distinct, ascending, ca. $0.6 \mathrm{~mm}$ long, broadly oblong, short-clawed, retuse, apically somewhat cuppea; stamens 5, opposite the petals, the anthers cupped within the fleshy filaments ca. $0.3 \mathrm{~mm}$ long, the broady oblong anthers eiect, ca. $0.4 \mathrm{~mm}$ long, apiculate; hypogynous disc a strong, fleshy annulus; ovary superior, ovoid, trilobed, ca. $0.6 \mathrm{~min} \mathrm{high,} \mathrm{the} \mathrm{fleshy} \mathrm{style} \mathrm{ca.} 0.3 \mathrm{~mm}$ long, the stigma lobes short, 3.

Fruit.--A drupe-like berry subtended by the spreading calyx lobes and bracts, nearly round, $6-9 \mathrm{~mm}$ long, the fleshy part thin, anastomosing-venose, the nutlets shaped somewhat like corn grains (broadly wedge-shaped).

Distribution and Floweing season

Hardwood forest over limestone, sometimes on kitchen middens, 
beach borders, Coastal Plain, North Carolina south into peninsular Florida, west in the Gulf Coastal Plain into Mississippi.

Special Identifying Features

Sageretia minutiflora is the only species of this smajl,primarily Asian genus to occur in the United States. Of our own genera of Rhamnaceae it is most similar to Bhamnus, differing from it in its shallower calyx tube (hypanthium?), its more prominent interstaminal disc, its less prominent stigmatic lobes. Also the southeastern area Rhamnus lack the sprawling, viney habit of $\underline{S}$. minutiflora.

Habitat and Management Implications

This rather rare and local plant appears to prefer shade and a calcareous substratum. Optimal habitats are shaded shell sands, old kitchen middens, limesinks, low or high hammock with much limestone shallow or outcropping, usually along rivers or streams that flow through or over limestone. The plants in spite of their size are inconspicuous because of denseness of other understory vegetation, the primary shoots often reaching up into the crowns of lower trees so that only the exfoliating bark of the leafless lower parts of the Sageretia are evident. Associated overstory varies depending on the part of the range considered, to the north largely oak-hickory-maple, beech with Magnolia qrandiflora in the Florida and Gulf Coastal sites, much Sabal palmetto in some Florida sites. Sabal minor is often present, sometimes serenoa in the understory, together with frequent ostrya, Carpinus, Myrica, Sebastizna, Persea, Ilex, Viburnum, Cornus, Bumelia, Rhamnus, etc. in varying proportions.

The plant is endangered primarily by clearcutting, and by residential and recreational site building. Much of its former area in Florida has now been converted. Selective or group selective logging, providing there is not excessive damage by the operation, likely has little effect on Sageretia in that the plants may sucker readily and actually are not obligate shade types. Clearcutting and subxequent site preparatory activity would be destructive. Fire is not an historical factor in the development of hammock vegetation, hence would be a destructive factor. One thing is certain. These plants are local in occurrence and little is really known about their ecology. In such instances it pays to find out what niche they occupy. Fortunately there are several populations of Sageretia on state or Federal lands in Florida, so that relatively undisturbed habitat for it is likely to remain available. 


\section{References}

Small, J. K. 1933. Manual of the southeastem flora, pp. 830-834. Chapel Hill, N.C.

Radford, A. E., C. R. Bell, and H. E. Ahles. 1968. Manual of the vascular flora of the Carolinas, p. 694. Chapel Hill,N.C. 
SPECIES Sageretia minutiflora (Michx.) Trel. tiny-leaved buckthorn

\begin{tabular}{|c|c|c|c|c|c|c|c|c|}
\hline \multirow[b]{2}{*}{$\begin{array}{l}\text { Expected* } \\
\text { Effect on } \\
\text { the Species }\end{array}$} & \multicolumn{8}{|c|}{ Management Practices } \\
\hline & $\begin{array}{c}\text { Prescribe } \\
\text { Burn }\end{array}$ & $\begin{array}{c}\text { Bulldoze } \\
\text { or } \\
\text { Root Rake }\end{array}$ & Bed & Chop & $\begin{array}{l}\text { Thin } \\
\text { over- } \\
\text { story }\end{array}$ & $\begin{array}{l}\text { Cut } \\
\text { over- } \\
\text { story }\end{array}$ & $\begin{array}{l}\text { Establish } \\
\text { Plantation }\end{array}$ & Graze \\
\hline Destroy & $\mathrm{X}$ & $\mathrm{X}$ & $\mathrm{X}$ & $\mathrm{X}$ & & & & \\
\hline Damage & & & & & & $\mathrm{x}$ & & \\
\hline $\begin{array}{l}\text { No Lasting } \\
\text { Effect }\end{array}$ & & & & & $\mathrm{X}$ & & & \\
\hline $\begin{array}{l}\text { Beneficial } \\
\text { if Done } \\
\text { Properly }\end{array}$ & & & & & & & & \\
\hline
\end{tabular}

\section{Other Comments:}

*Expected effect on the species is an estimate made by Dr. Robert Kral based on his knowledge of the habitat and on knowledge gained from personal field observations. Estimates are "rough" in many instances. Results of practices may be modified depending upon the degree of application, intensity of treatment, nearness to plant communities, etc. A management practice for which no entry is made indicates a lack of sufficient information from which to predict expected results. As observations are made in the field by users of the data, the expected effect will be refined. 
Sageretia minutiflora (Michx.) Trel.

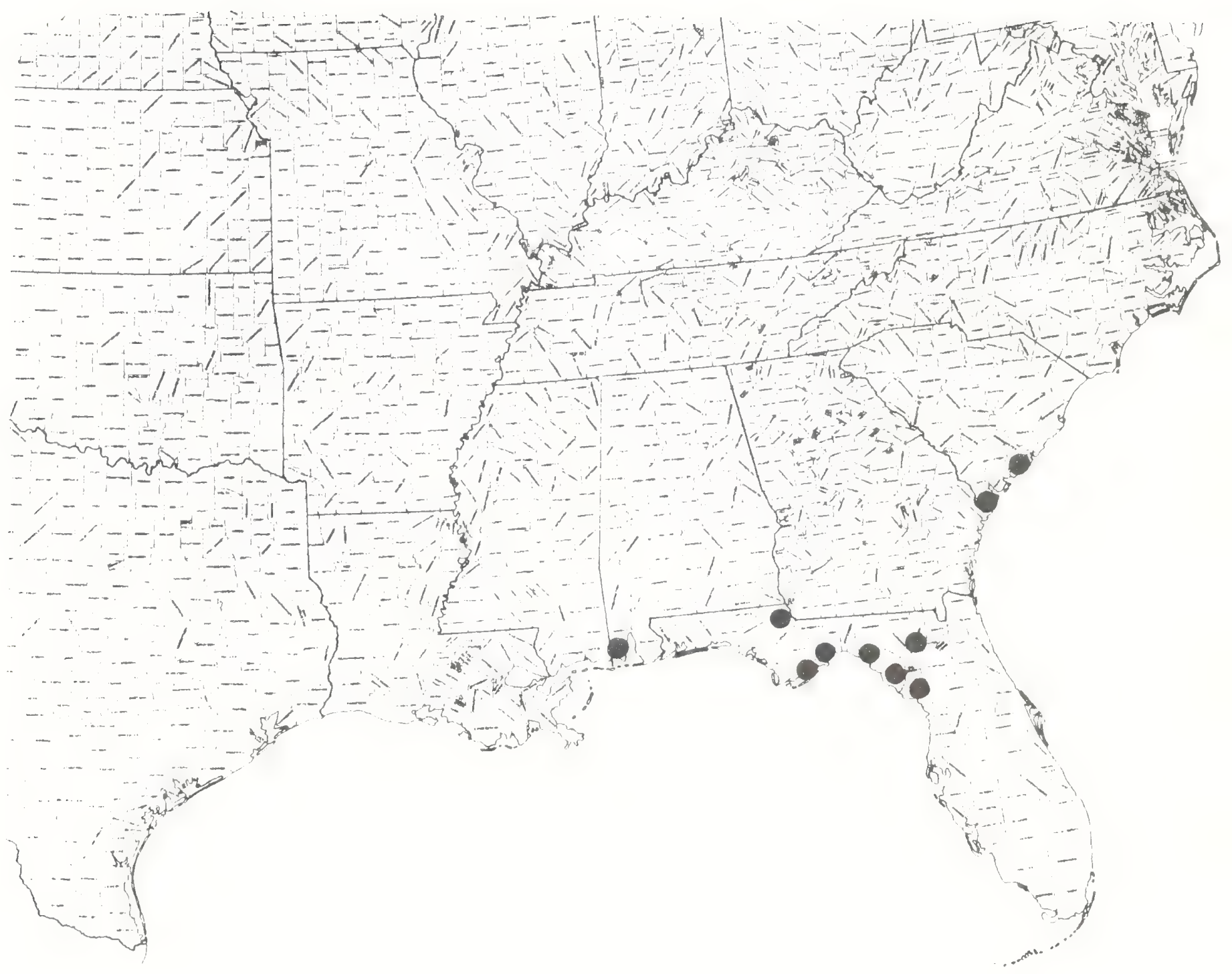


-

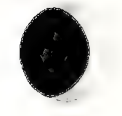

○ 
Paper 248

Text and map by:

Robert Kral

\section{ROSACEAE}

Geum geniculatum Michx. Bent avens

Technical Description

Rosulate and caulescent perennial herb from a stout, ascending caudex and a diffuse-fibrous root system.

Rootstock.--Caudex covered by chaffy, dark-brown remnants of old leaf bases and stipules, these bristly-ciliate.

Stems.--Erect or ascending, simple, branched only in the inflorescence, terete, to 1 meter tall, toward base purplish, retrorsely hirsute-hispid, upwardly becoming greenish or green tinged with purple, increasingly hirsute, the hairs more spreading and admixed with spreading puberulence, toward tips and in branches of inflorescence with hairs often gland-tipped.

Leaves.--Both basal and alternate on stem: rosette leaves persistent, spreading to erect, the stiffish petioles usually much longer than the blades, often purplish-tinted, spreading or retrorsely hispid-hirsute, proximally ribbed but terete, distally strongly grooved above, the blades reniform to suborbicular or obovate, simple to lyrate-pinnatifid or trifoliolate, the margin coarsely and irregularly sharp-toothed, the simple blades apically rounded, often incised, or shallowly trilobed (as in red maple), the bases rounded, truncate or cordate, the pinnately lobed blades with terminal blade much the largest, ovate to suborbicular or even reniform, often shallowly trilobed, the uppermost lateral divisions ranging from nearly as large to abruptly much smaller, inequilateral, the median and lower laterals in distant pairs, usually much smaller, inequilateral, acute, cuneate-based, the trifoliate blades with petiolules, the terminal leaflet again largest, the laterals spreading all usually obovate, unevenly serrate, sometimes also incisedlobed, cuneately based; stem leaves progressively shortening upward on stem, ultimately sessile, the stipules broadly ovate to lanceolate, foliaceous, acute, entire or serrate, the bases broadly to narrowly cuneate, the blades trilobate or trifoliolate, mostly ovate-lanceolate or ovate, unevenly serrate, also often incisedlobed, the bases cuneate, usually entire; upper leaf surfaces hirsute, deep yellow-green, lower leaf surfaces hispid-hirsute, sometimes also puberulent.

Inflerescence. - A strongly bracteate system of few-to-many-flowered cymes, the branches (on larger plants) stiffly ascending at ca. $45^{\circ}$ angles, rather densely hirsute and puberulent, with bracteal leaves progressively narrowed and smaller in the inflorescence, the stiffish, erect to ascending slender pedicels Ionger than the flowers.

Elowers.--Regular, perfect; hypanthium shallow, narrow, its margin bearing short-oblong bractlets $2-3 \mathrm{~mm}$ long just below the sharp calyx sinuses; receptacle convex, often white-pilose; calyx lobes persistent, 5, ca. 7-8 mm long, ovate-triangular, the backs green tinged with maroon, strigose-hirsute, also puberulent and glandular 
the margins ciliate, the upper surface smooth, green; petals 5 , distinct, obovate-cuneate, 0.7-10.0 mm long, ascending, the broad, wavy distal margin emarginate, the smooth surface white or white strongly suffused with broad bands of pink or purple, very veiney; stamens very many from the hypanthial rim, the greenish-white filaments dilating and flattened proximally, slightly shorter than the sepals, the ellipsoidal anthers reddish-brown, 1.0-1.2 mm long; carpel bodies numerous, distinct, oblanceolate in outline, green, dorsiventrally compressed, hirsute, apically slender, often glandular-hairy; style very elongate, fully I cm long, slender, the lower half smooth or proximally glandular-hairy, at its tip with one close loop, above this the slender erect upper half spreading pilose, teminating in a narrow, short-linear stigma.

Fruit.--Akenes ca. 0.4-0.5 mm long, the body ascending-pilosehirsute, somewhat margined, the style persistent (at least to the midale or to the coil).

Distribution and Flowering season

Moist rocky woodlands, edges of balds, local toward sumit elevations in the Blue Ridge of western North Carolina and eastern Tennessee; flowering from July to early september.

Special Identifying Features

Geum geniculatum, excepting G. radiatum, another rare species of the high southern Appalachians, is the largest flowered species of southeastern area Geum. G. radiatum however is at once distinguished by its very showy large yellow petals and its unbent style; the petals of G. geniculatum are white, greenish-white or pinkish-purple-tinted. G. geniculatum may be distinguished from all southeastem Geum by the length of its styles (fully I cm) which are at the middle coiled: the other southeastern Geum have styles coiled (geniculate) above the middle.

Habitat and Management Implications

This rare Avens is seemingly found above about 4,000 ft. altitude and only on a few summits. It is located under or around hardwood forests made up of Betula Iutea, B. Ienta, Sorbus americana, Aesculus octandra, Prunus pensylvanica, Faqus, Quercus rubra, Acer spicatum, … pensylvanicum, A. saccharum, etc., these species often admixed with red spruce and Fraser fir. The understory often has heavy growth of several heaths, but particularly Rhododendron catawbiense, R. maximum, R. calendulaceum, Iyonia, Vaccinium; other shrubs are Rubus odoratus, Ribes, Vibumum alnifolium, Sambucus pubens, Diervilla, etc. I have not seen this species unless it is heavily admixed with composites 
such as Aster acuminatus, Eupatorium rugosum, Prenanthes, other herbs such as Impatiens pallida, Iaportea. Many ferns and lycopods are present, along with the montane oxalis acetosella and dense carpets of mosses. The Geum, while often locally abundant, is often hard to see because of associated herbs and ferns, and often only the tops of it are visible. The substrate is moist, acidic, very well drained, but never drying out, always highly organic. Such soils accumulate amongst the granite-bouldery talus that has developed at oi toward the summit elevations. It must be emphasized that this Geum is a shade plant, while its rare neighbor, G. radiatum, is a plant of sunlight, thus the former is liable to increase as mature forest develops and the latter to decrease, particularly as Rhododendron enroaches on its area.

Over much of its narrow geographic range this plant is now protected, in that it is largely in either state or national forest or in protected private land (i.e. Grandfather Mountain, Bluff Mountain). Thus the overstory that is so essential to it is being preserved, as it should be since this shade dependent species would fast disappear if the cover were cut away, the openings resultantly being filled by grasses or more aggressive understory shrubs, and the soils drying excessively.

References

Chapman, A. W. 1897. Flora of the southern states, ed. 3: 135. Cambridge, Mass.

Gray, A. 1841. Notes of a botanical excursion to the mountains of North Carolina. Am. Journ. Sci. 42: 1-49.

Rydberg, P. A. 1913. Rosaceae, in North Am. FI. 22: 406.

Small, J. K. 1933. Manual of the southeastern flora, pp. 6.7-619. Chapel Hill, N. C. 
Geum geniculatum Michx. Bent avens

\begin{tabular}{|c|c|c|c|c|c|c|c|c|}
\hline \multirow[b]{2}{*}{$\begin{array}{l}\text { Expected* } \\
\text { Effect on } \\
\text { the Species }\end{array}$} & \multicolumn{8}{|c|}{ Management Practices } \\
\hline & $\begin{array}{c}\text { Prescribe } \\
\text { Burn }\end{array}$ & $\begin{array}{l}\text { Bulldoze } \\
\text { or } \\
\text { Root Rake } \\
\end{array}$ & Bed & Chop & $\begin{array}{l}\text { Thin } \\
\text { over- } \\
\text { story }\end{array}$ & $\begin{array}{l}\text { Cut } \\
\text { over- } \\
\text { story }\end{array}$ & $\begin{array}{l}\text { Establish } \\
\text { Plantation }\end{array}$ & Graze \\
\hline Destroy & $x$ & $\mathrm{NA}$ & $\mathrm{NA}$ & $\mathrm{NA}$ & & $\mathrm{x}$ & $\mathrm{NA}$ & $\mathrm{X}$ \\
\hline Damage & & & & & $\mathrm{x}$ & & & \\
\hline $\begin{array}{l}\text { No Lasting } \\
\text { Effect }\end{array}$ & & & & & & & & \\
\hline $\begin{array}{l}\text { Beneficial } \\
\text { if Done } \\
\text { Properly }\end{array}$ & & & & & & & & \\
\hline
\end{tabular}

Other Comments:

*Expected effect on the species is an estimate made by Dr. Robert Kral based on his knowledge of the habitat and on knowledge gained from personal field observations. Estimates are "rough" in many instances. Results of practices may he modified depending upon the degree of application, intensity of treatment, nearness to plant communities, etc. A management practice for which no entry is made indicates a lack of sufficient information from which to predict expected results. As observations are made in the field by users of the data, the expected effect will be refined. 
joum seniculatum lichr.

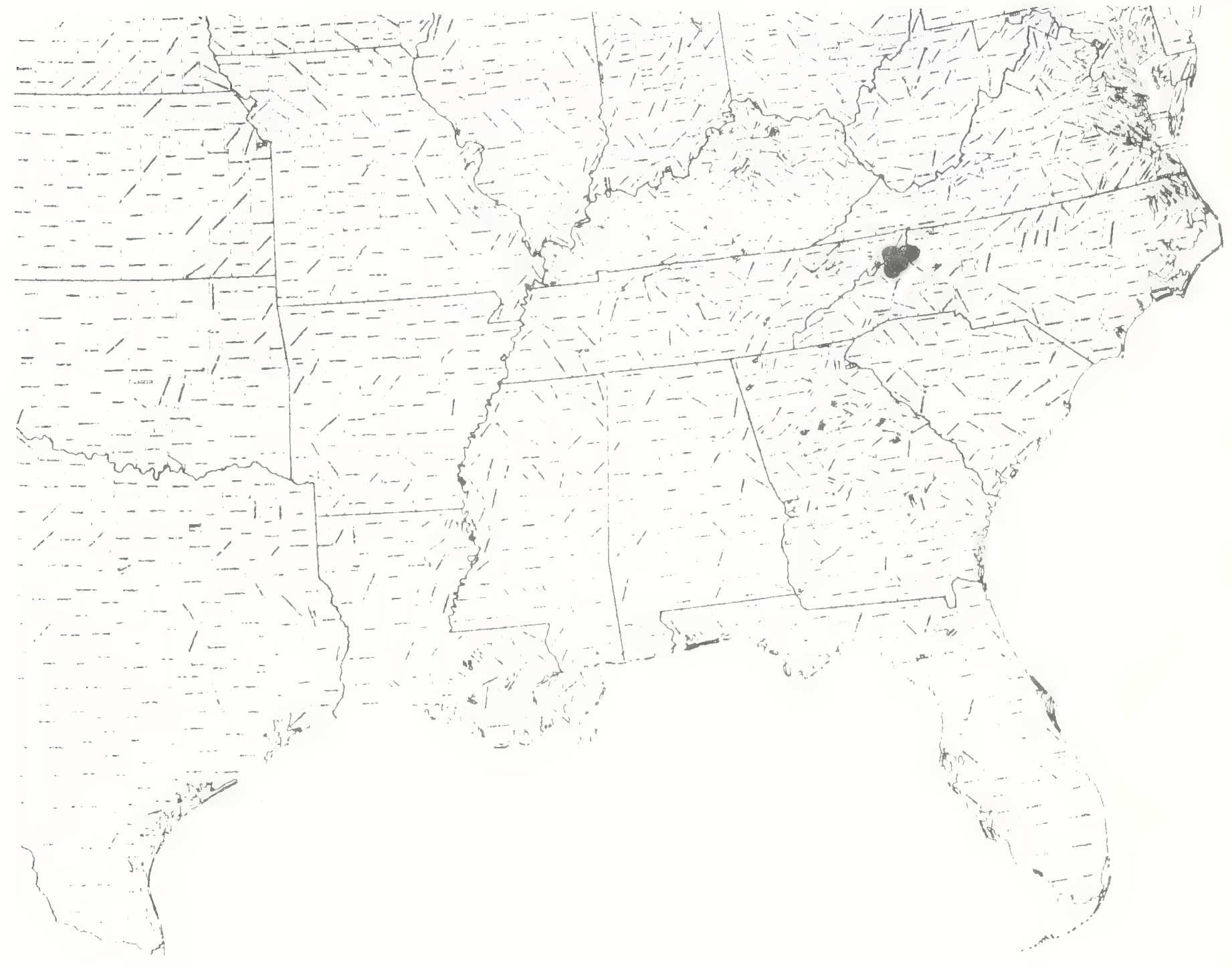


-

-

0 
Paper 249

Text and map by:

Robert Kral

ROSACEAE

Waldsteinia lobata (Baldw.) T. \& G. Piedmont strawberry

Technical Description

Perennial herb, producing rosettes at tips of very elongate, brownish, shallowly-set, forking rhizomes 2-5 mintck, or sometimes rhizomes producing flagelliferous and stoloniferous shoots along which the leaves are alternate, scattered.

Leaves.--AlI but oldest portions of rhizome covered by a densely overlapping "shag" of brownish or reddish-Jorown scale leaves; rosette leaves numerous, erect or spreading, $10-20 \mathrm{~cm}$ Iong, mostly petiole, the abruptly dilated, reddish petiolar bases clasping the abbreviated stem (rhizome) tip in a tight spiral, this usually subtended by spirals of reddish, hispid-hirsute and long-ciliate, narrowly triangular scale leaves $1.0-1.5$ cm long: petioles slender, hirsute, sometimes scattered-puberulent also, proximally reddish, distally greenish, terete, low-ribbed; leaf blades reminiscent of many Ribes, suborbicular to broadly ovate or reniform, mostly 3-8 cm long, deeply to shallowly incised-lobed, the principal divisions mostly 3-5, broadened distally, the sinuses very narrow, the segment margins variously incised, also rather coarsely and unevenly serrate-dentate; upper blade surface dark yellow-green, strigosehirsute and densely hirsute with shorter hairs along the veins, these often with a scattering of reddish, sessile glands; lower blade surface markedly paler, the pubescence heavier with some longstiff hairs, but mostly downy, and particularly dense along the major, palmately disposed, veins.

Inflorescence.--Peduncles equal to or slightly shorter than the petioles of foliage leaves, l-few per shoot, erect, axillary to chaffy, triangular, reddish-brown brats just below the foliage leaves at rhizomal tips, slender, terete and channelled, hispidhirsute, also puberulent with hairs spreading to somewhat retrorse, medially bearing 1 , linear bractlet, the flowers few to many, usually somewhat scattered along the axes of a variously spreading pair of indeterminate racemes mostiy 4-6 cm long, the slender spreading pedicels villosulous and hispid-hirsute, ca. I cm Iong, each subtended by a foliaceous, linear to oblong or spatulate, acute, sparingly low-toothed or entire, hispid-hirsute bract $0.5-2.0 \mathrm{~cm}$ long, these bracts gradually reduced toward raceme tips.

Flowers.--Regular, bisexual, at anthesis ca. I cm broad; receptacle strongly pilose-hispid; hypanthium green, funnelfomn, ca. $3 \mathrm{~mm}$ high, hispid-hirsute, glandular; calyx lobes 5, green, triangular, spreading, ca. $3 \mathrm{~mm}$ long, sparsely ciliate, the upper surface villosulous-cinereous, the backs hispid-hirsute and sparsely glandular; stamens very many, distinct, spreading or ereat from hypanthial rim, the slender filaments slightly flattened, yellowish, ca. $3 \mathrm{~mm}$ long, the dorsifixed anthers yellow, broadly oblong, ca. I mm long; petals 5, bright yellow, distinct, spatulate or oblance- 
eolate, spreading, equal to calyx lobes or slightly shorter; carpels 2-3, distinct, basally attached, the body compressedobovoid, ca. $2 \mathrm{~mm}$ long, villosulous, the slender style ca. $3 \mathrm{~mm}$ long, early deciduous, its base sparsely soft-hairy, jointed to the ovary apex and terminating in a narrowly capitate stigma. Fruit.--Akenes similar in shape to carpel bodies, ca. $3 \mathrm{rm}$ long, plumper, viliosulous-tomentose.

Distribution and Flowering Season

Acidic, shaded, rocky ravines and creek or river bluffs, Piedmont and Blue Ridge, Georgia and northwestern South Carolina; flowering from April into May.

\section{Special Identifying Features}

W. Iobata differs from the other 2-3 taxa of the southeastern area in its broader leaves which are merely incised rather than divided and in the pubescent (rather than smooth) style bases. This plant differs also in the extreme length of its rhizomes which often attain lengths of a meter or more.

Habitat and Management Implications

W. Iobata is a shade plant, growing on deep to shallow sandy loams in acid-rocky woods, often a part of the shallow mantle of moss and duff that covers boulders or bluff ledges. Common associated genera are Galax, Mitchella, Asplenium, Polystichum, Dryopteris, Hepatica, Sanquinaria, Hexastylis, Tiarella, Trillium (particularly T. cernuum, T. cuneatum, T. catesbaei), Polygonatum, Erythronium, etc. The substrate has a high sand fraction, is very well drained, usually moist (but seasonally becoming dry). The steep sites it frequents often have dense growths of Rhododendron (particularly R. maximum, R. minus) and Kalmia. The overstory varies, a reflection of the complex metamorphic geology of the region, in that calcareous rock (such as marble) may be nearby as well as acidic rock. Thus the dominant species may be oak-hickory-pine, oak-pine-juniper, or in the richest, deepest ravines, mixed mesophytic with much beech, hard maple, buckeye and ash.

This plant is too rare for many conclusions to be reached about its present abundance related to past occurrence. Small (1933) indicates a range that includes the Piedmont of the Carolinas but current listings of the flora of the Carolinas do not include W. lobata. I have seen it only in or near areas where marble is presently being quarried and can state that this activity is totally destructive of the habitat. In that the plants occupy rather shallow, at least seasonally moist, soils under light to heavy shade, it would follow tha heavy logging 
would be risky. This would be true particularly of Piedmont Georgia where clearcutting of the forest or even moderate logging is often followed by an invasion of noxious herbaceous and woody weeds such as Lonicera, Pueraria, Smilax, Rubus, etc., which tend to crowd out spring flowering herbs. It is suggested that this species be considered endangered rather than threatened.

\section{References}

Small, J. K. 1933. Manual of the southeastern flora, pp. 616-617. Chapel Hill, N. C.

Torrey, John and Asa Gray. 1838-1840. Flora of North America I, P. 426. New York. 
SPECIES Waldsteinia lobata (Baldw.) T. \& G. Piedmont strawberry

\begin{tabular}{|c|c|c|c|c|c|c|c|c|}
\hline \multirow[b]{2}{*}{$\begin{array}{l}\text { Expected* } \\
\text { Effect on } \\
\text { the Species }\end{array}$} & \multicolumn{8}{|c|}{ Management Practices } \\
\hline & $\begin{array}{c}\text { Prescribe } \\
\text { Burn }\end{array}$ & $\begin{array}{l}\text { Bulldoze } \\
\text { or } \\
\text { Root Rake } \\
\end{array}$ & Bed & Chop & $\begin{array}{l}\text { Thin } \\
\text { over- } \\
\text { story } \\
\end{array}$ & $\begin{array}{l}\text { Cut } \\
\text { over- } \\
\text { story }\end{array}$ & $\begin{array}{l}\text { Establish } \\
\text { Plantation }\end{array}$ & Graze \\
\hline Destroy & $\mathrm{X}$ & $\mathrm{x}$ & $\mathrm{X}$ & $\mathrm{x}$ & & $\mathrm{X}$ & & \\
\hline Damage & & & & & $\mathrm{X}$ & & & $\mathrm{X}$ \\
\hline $\begin{array}{l}\text { No Lasting } \\
\text { Effect }\end{array}$ & & & & & & & & \\
\hline $\begin{array}{l}\text { Beneficial } \\
\text { if Done } \\
\text { Properly }\end{array}$ & & & & & & & & \\
\hline
\end{tabular}

\section{Other Comments:}

* Expected effect on the species is an estimate made by Dr. Robert Kral based on his knowledge of the habitat and on knowledge gained from personal field observations. Estimates are "rough" in many instances. Results of practices may be modified depending upon the degree of application, intensity of treatment, nearness to plant communities, etc. A management practice for which no entry is made indicates a lack of sufficient information from which to predict expected results. As observations are made in the field by users of the data, the expected effect will be refined. 
Waldsteinia lobata (Baldw.) T. \& G.

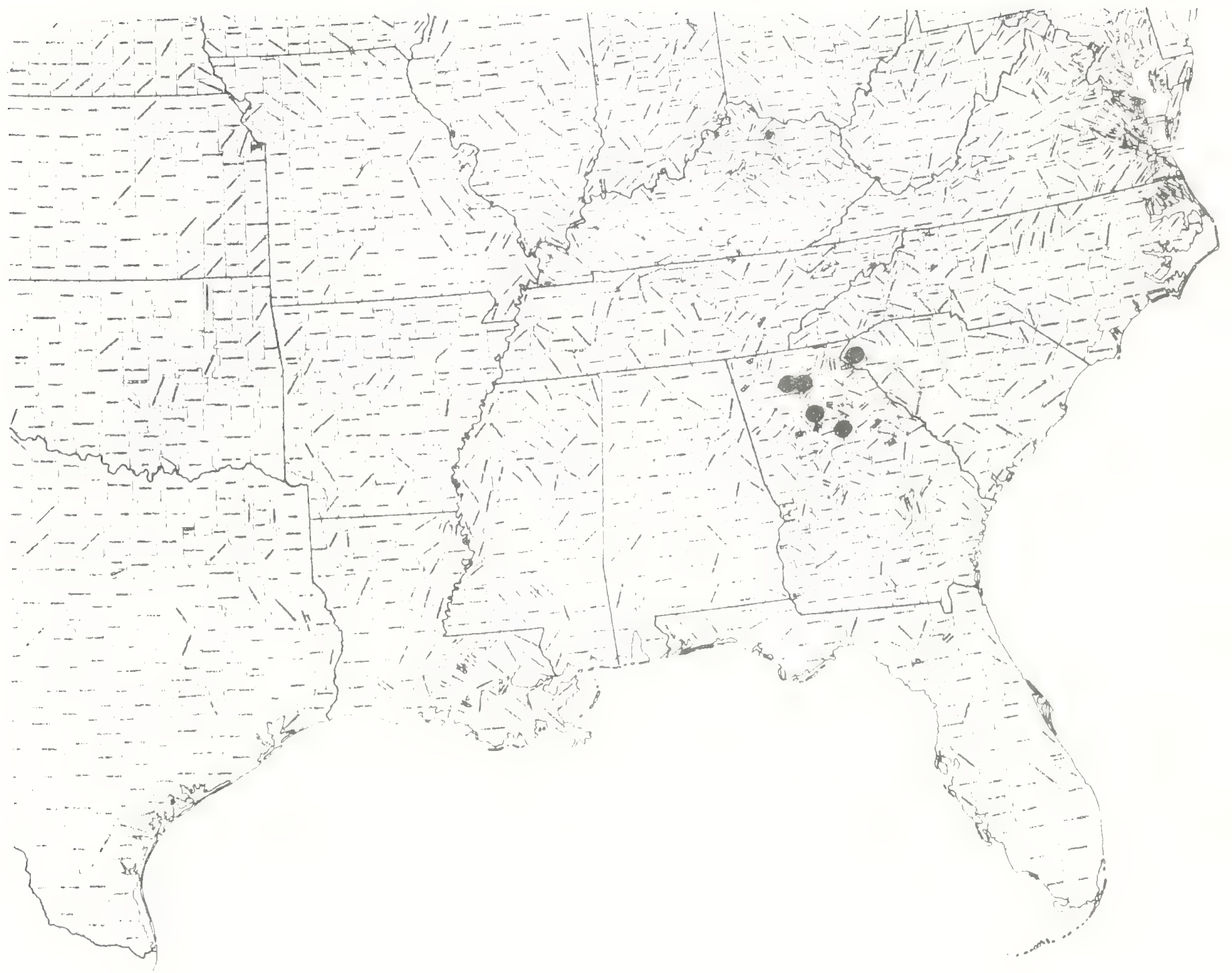


Paper 250

Text and map by:

Robert Kral

\section{SANTAIACEAE}

Nestronia umbellula Raf. Common nestronia

Technical Description

Strongly clonal, deciduous, smooth, dioecious shrubs mostly 3-10 dm tall, parasitic on roots of hardwoods or pines. Shoots.--Primary shoots mostly stiffly erect, broadmcrowned, terete, smooth, reddish-brown, the bark of older wood thin with a thin, pale, anastomosing exfoliating cuticle, the branching opposite, the new shoot growth greenish; winter buds triangular, imbricatescaly, the scale backs reddish-brown, smooth.

Leaves.--Opposite, subdistichous, simple, estipulate, spreading or ascending on short (2-3 mm) petioles, the blades mostly elliptic, oblong, lanceolate or broadly ovate, 2-6 cm long, acute, entire with narrow pale granular margins, the bases cuneate to short-attenuate, the upper surface dark dull yellowmgreen, the lower surface markedly paler.

Inflorescence.--Male plants with simple umbels produced on slender, erect or ascending, supra-axillary, bractless peduncles 1-2 cm long, the (mostly) 3-6 flowers spreading on very slender pedicels 2-4 mm long; female plants with larger flowers, these solitary, axillary, on stouter peduncles $5-7 \mathrm{~mm}$ long, and teminating in a joint, around the rim of which are 1-several, peg-like, reddishtipped appendages (bracts?), and to which the hypanthium is jointed. Flowers.--Regular; male flowers yellow-green, with the slender pedicels dilating apically and merging imperceptibly with the funnelform hypanthium; calyx lobes (3-) 4, triangular, 2.0-2.5 mm long, spreading-recurved, acute, the margins papillate, particularly distally: petals none; stamens 4, erect, ca. 1.5-2.0 mm long, opposite the sepals and projecting the anthers slightly above the calyx orifice, the filaments ca. $2 \mathrm{~mm}$ long, arising from the hypanthial rim just below the sepal sinus, their dilated bases tucked under the thin hypanthial edge, the dorsifixed anthers broady ellipsoidal, ca. $0.6 \mathrm{~mm}$ long, the connective appendaged with several very long, flattened, pale, reflexed trichomes that connect with opposing sepals. Female flowers with hypanthium narrowly obconic, mostly 6-7 mm long, maroon, the spreading-recurved sepal labes fleshier than in the male, ca. $3 \mathrm{~mm}$ long; stamens present, 4, erect, the anthers non-functional: ovary inferior, the single style stout-linear, erect, ca. $2 \mathrm{~mm}$ long, terminating in a 3-4 lobed stigma. Fruit.--Drupaceous, obovoid, ca. $1 \mathrm{~cm}$ long, the 4 sepal lobes erect, persistent on the truncated summit.

Distribution and Flowering season

Sandy, usually open woodlands, Piedmont and Coastal Plain, scattered from eastern Virginia southward to Georgia and Alabama; flowering in April and May. 
Nestronia is monotypic, different from other shmbby Santalaceae by the umbellate male florets (sharing this only with Buckleya), and the unique trichomal webbing between anthers and sepal bases. In Buckleya, a much taller shrub, the male inflorescence is terminal rather than axillary.

Habitat and Management Implications

N. umbellula is very local, but produces large clones, usually in deep, moist to quite dry sands, sandy loams or sandy clays. oddly, most clones, if in proximity are all of one sex or the other, with the female much more rare, often producing few flowers. The overstory varies. Some stands are found in sandhills ecotones to shrub bog, and are under various species of yellow pine, upland oaks and hickories, with abundant exicaceous shrub associates. Still other clones are found in open uplannd stands of oak-pine-hickory, others under mixed upland hardwoods. some authors indicate that the plants parasitize pines exclusively, whilst others comment that the hosts are exclusively hardwoods. A study is currently being run on this. However it can be concluded that the habitat is usually open woodland, rather dry, usually sandy, and that the substrate is typically quite acid.

In that the plants are root parasitic it follows that removal of the hosts through logging or clearing removes the parasite. Also, in that most of the forest types these shrubs are found in are fire disclimax or have fire in their history, it may be concluded that periodic woods fires have no adverse effect, so long as the hosts are not kilied.

\section{References}

Radford, A. E.,C. R. Bell and H. E. Ahles. 1968. Manual of the vascular flora of the Carolinas, pp. 396-397. Chapel Hill, N.C.

Rafinesque, C. S. 1836. New flora of North America 3, New Sylva, p. 12. Philadelphia, Pa.

Sma11, J. K. 1933. Manual of the southeastern flora, pp. 12481249. Chapel Hill, N. C. 
SPECIES Nestronia umbellula Raf. common nestronia

\begin{tabular}{|c|c|c|c|c|c|c|c|c|}
\hline \multirow[b]{2}{*}{$\begin{array}{l}\text { Expected* } \\
\text { Effect on } \\
\text { the Species }\end{array}$} & \multicolumn{8}{|c|}{ Management Practices } \\
\hline & $\begin{array}{c}\text { Prescribe } \\
\text { Burn }\end{array}$ & $\begin{array}{l}\text { Bulldoze } \\
\text { or } \\
\text { Root Rake }\end{array}$ & Bed & Chop & $\begin{array}{l}\text { Thin } \\
\text { over- } \\
\text { story }\end{array}$ & $\begin{array}{l}\text { Cut } \\
\text { over- } \\
\text { story }\end{array}$ & $\begin{array}{l}\text { Establish } \\
\text { Plantation }\end{array}$ & Graze \\
\hline Destroy & & $x$ & $\mathrm{x}$ & $\mathrm{x}$ & & & & \\
\hline Damage & & & & & & $X^{*}$ & & $x^{*}$ \\
\hline $\begin{array}{l}\text { No Lasting } \\
\text { Effect }\end{array}$ & $\mathrm{X}$ & & & & $\mathrm{X}$ & & & \\
\hline $\begin{array}{l}\text { Beneficial } \\
\text { if Done } \\
\text { Properly }\end{array}$ & & & & & & & & \\
\hline
\end{tabular}

Other Comments: if cutting means removal of host root system, then plants would be destroyed; family is poisonous to

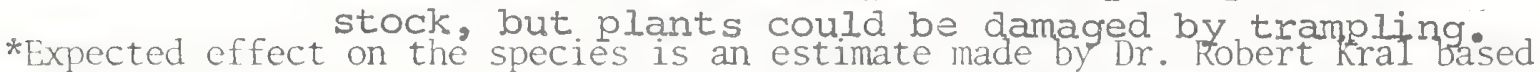
on his knowledge of the habitat and on knowledge gained from personal field observations. Estimates are "rough" in many instances. Results of practices may be modified depending upon the degree of application, intensity of treatment, nearness to plant communities, etc. A management practice for which no entry is made indicates a lack of sufficient information from which to predict expected results. As observations are made in the field by users of the data, the expected effect will be refined. 


\section{Nestronia umbellula Rafinesque}

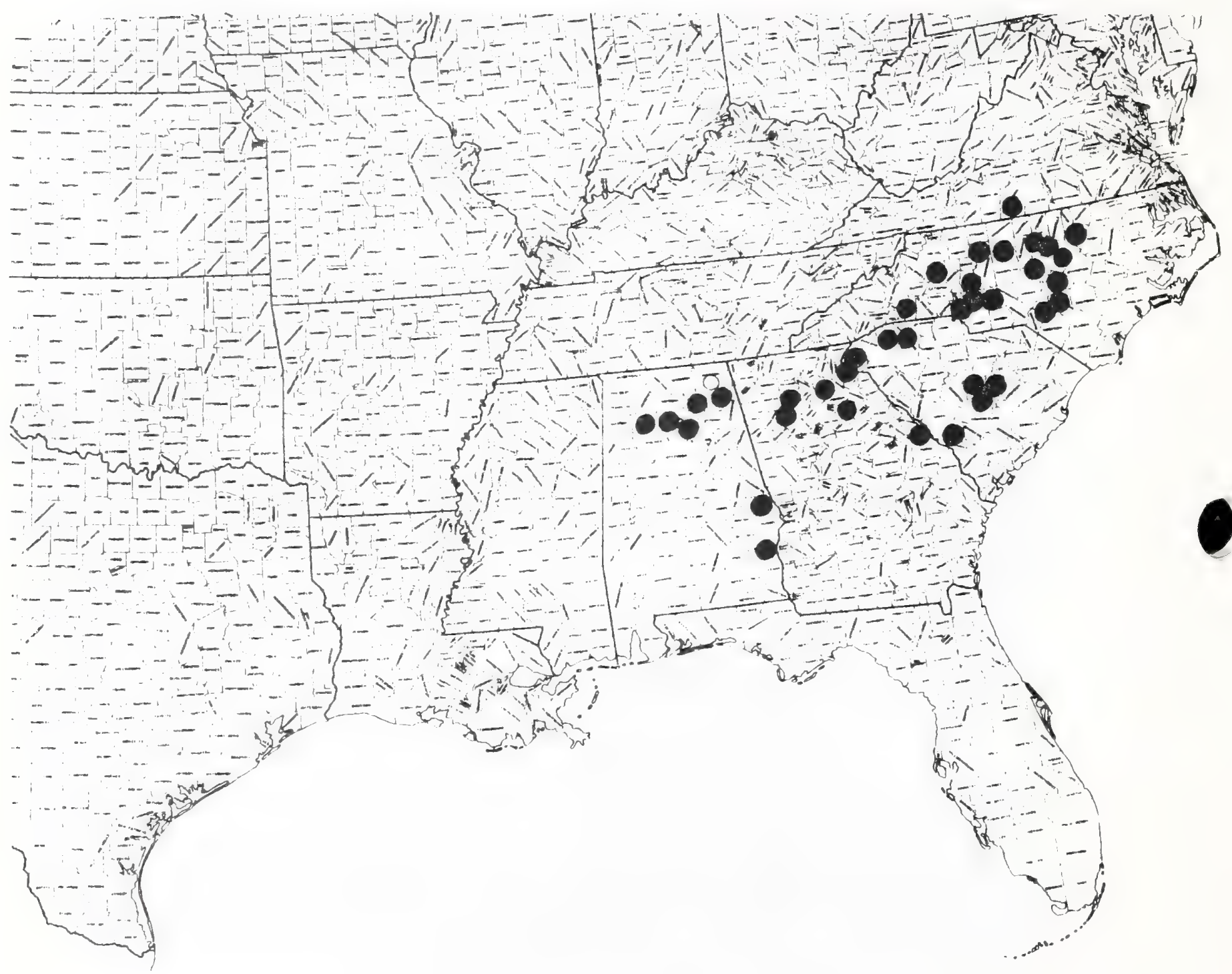


Paper 251

Text and map by:

Robert Kral

\section{SAXIFRAGACEAE}

Heuchera arkansana Rydb. Arkansas alumroot H. viliosa Michx. var. arkansana (Rydo.) E. B. smith

Technical Description

Rosulate perennial herbs from elongated, stoutish surficial or shallow, creeping rhizames with an exfoliating epidermis.

Leaves.--Numerous in the basal rosette, erect or spreading, highly variable in length, sometimes the "tufts" to $4 \mathrm{dm}$ high, the petioles to $3 \mathrm{dm}$ long; petioles slender, rigid but soct, terete, ribbed, pale green or tinged lightly with red, villous with most of the pale hairs gland-tipped, the petiole bases abruptly clasping; blades $1 / 2$ or less as long as the petioles, soft, renifom to suborbicular, angulately low-lobed, the 5-7 broad lobes rather coarseIy, somewhat unevenly dentate, the larger teeth tipped with a callused denticle, this bearing an elongate, gland-tipped trichome, the base shallowly to deeply cordate; upper leaf surface a dark dull green, viliousi-hirsute, the hairs gland-tipped, these hairs admixed with short-stipitate to sessile glands, the lower surface markedly paler, villous-hirsute-glandular.

Inflorescence.--Peduncles 1-several, from the axils of the leaves, erect or ascending, slightly shorter than to somewhat longer than the leaves, slender, with a few, distant, lance-linear, scariousbordered, villous-ciliate, scaly bracts, the lowest ca. $1.0-1.5 \mathrm{~cm}$ long, the main axis terete and ribbed or slightly angulate, villous-glandular, with the glands shorter-stalked in the inflorescence; panicle cylindrical, ca. $7-15 \mathrm{~cm}$ long, the numerous, slender primary branches ascending or spreading, from axils of scale-like bracts, simple or forking once, the few-to-several pedicels short, stipitate-glandular, scaly-bracteolate, in short, indeterminate racemes or corymbs, the whole inflorescence densest distally, more open toward the narrov base.

Flowers.--Hypanthium with 5 calyx lobes forming a campanulate outIine, from base to tip ca. $2 \mathrm{~mm}$ high, the whole surface stipitateglandular; calyx lobes slight Iy unequal, erect, thus calyx apex slightly oblique, the lobes narrowly ovate to oblong, ca. 1.0-1.3 $\mathrm{mm}$ long, apically rounded, marginally stipitate-and-glandularciliate, pale green; petals 5, distinct, arising from hypanthial rim, linear-spatulate or linear oblanceolate, lingulate, ca. $2 \mathrm{~mm}$ Iong, apically excurvate, white: stamens 5, unequal, distinct, arising from hypanthial rim, erect, the filaments linearterete, the longest to ca. $2.5 \mathrm{~mm}$, the nearly orbicular, pale yellow anther sacs dorsifixed, divaricate, with lateral dehiscence; ovary bicarpellate, nearly superior, fused to hypanthium only at very base, the body ovoid, ca. $1.5 \mathrm{~mm}$ high at anthesis, tapering gradually into the stiffish, somewhat divergent, stout-linear styles, these each tipped by a short, papillate stigma. Fruit.-Capsule broady ellipsoidal, 2-valved, from base to tip of persistent style ca. 6-7 mm long, the body fused to hypanthium 
ca. 1/3 its length; seeds pale brown, short-cylindrical, slightIy curvate, longitudinally with many muriculate lines, ca. 0.7 nm long.

\section{Distribution and Flowering season}

Shaded ledges of calcareous of acidic rock, the ozarks, north central to northwestern Arkansas; flowering from June to septamber.

\section{Special Identifying Features}

Recently Smith (1977) broke from tradition by making this another variety of $\underline{H}$. viliosa, a common and widespread plant of shaded or sunny cliffs and ledges throlyy much of the easteim. U.S. It is true that the Arkansas material differs in its somewhat shorter, broader-based flowers (these often appear "round"), its more compact inflorescence. It is usually a smaller version of $\mathrm{H}$. villosa macrorhiza, a very robust plant locally abundant in calcareous bluffs along the Cumberland and Tennessee Rivers in Kentucky and middle Tennessee. When $\underline{H}$. arkansana was first described it was considered an Ozarkian disjunction from $H$. villosa proper. Recent collections have closed the gap and even the variety is tenuous if a consistent taxonomy for Heuchera is sought.

Habitat and Management Implications

H. arkansana is confined to ledges of calcareous or sandy rock along the major stream and river systems. Usually these ledges are in the shade of mixed hardwoods, less often in full sun and, in the sunny sites, there is usually some seep water at least part of the year. Associated herbaceous plants are mostly ferns, a few carices, grasses such as Festuca, Bromus, and other saxifrages. Lianas are common over the rock, particularly Vitis, Parthenocissus, Ampelopsis, Rhus radicans, etc. The Heuchera is shallowly rooted in a shallow soil mantle, this often held together by various mosses and liverworts, all frequently breaking or slipping away fram the rock during rainy spells, or washing away from the Heuchera rhizomes, leaving them largely exposed. In that such habitat is so sensitive, clearcutting of the forest on the steep slopes and contiguous river and creek bottoms definitely would have an adverse effect on this rock plant. The greatest danger to the plants however has come from the excessive dam building within the range of the species, so that the lower reaches of many of the bluffs it used to frequent have been inundated by reservoirs.

References

Rosendahl, C. O.,F.K. Butters \& O. Lakela. 1936. A monograph 
on the genus Heuchera. Minn. Studies in Plant Sci. 2: 1-180. Rydberg, P. A. 1905. North American Flora 22 (1): p. 101. New York Botanical Garden. Bronx, New York.

Smith, E. B. 1977. Notes on the Arkansas Saxifragaceae. Proc. Ark. Acad. Sci. 3I: 100-102. 
SPECIES Heuchera arkansana Rydb. Arkansas alumroot

\begin{tabular}{|c|c|c|c|c|c|c|c|c|}
\hline \multirow[b]{2}{*}{$\begin{array}{l}\text { Expected* } \\
\text { Effect on } \\
\text { the Species }\end{array}$} & \multicolumn{8}{|c|}{ Management Practices } \\
\hline & $\begin{array}{c}\text { Prescribe } \\
\text { Burn }\end{array}$ & $\begin{array}{l}\text { Bulldoze } \\
\text { or } \\
\text { Root Rake }\end{array}$ & Bed & Chop & $\begin{array}{l}\text { Thin } \\
\text { over- } \\
\text { story }\end{array}$ & $\begin{array}{l}\text { Cut } \\
\text { over- } \\
\text { story }\end{array}$ & $\begin{array}{l}\text { Establish } \\
\text { Plantation } \\
\end{array}$ & Graze \\
\hline Destroy & $\mathrm{x}$ & NA & NA & $\mathrm{NA}$ & & $\mathrm{x}$ & NA & \\
\hline Damage & & & & & $\mathrm{x}$ & & & $\mathrm{x}$ \\
\hline $\begin{array}{l}\text { No Lasting } \\
\text { Effect }\end{array}$ & & & & & & & & \\
\hline $\begin{array}{l}\text { Beneficial } \\
\text { if Done } \\
\text { Properly }\end{array}$ & & & & & & & & \\
\hline
\end{tabular}

Other Comments:

*Expected effect on the species is an estimate made by Dr. Robert Kral based on his knowledge of the habitat and on knowledge gained from personal field observations. Estimates are "rough" in many instances. Results of practices may be modified depending upon the degree of application, intensity of treatment, nearness to plant communities, etc. A management practice for which no entry is made indicates a lack of sufficient information from which to predict expected results. As observations are made in the field by users of the data, the expected effect will be refined. 
Heuchera arkansana Rydb.

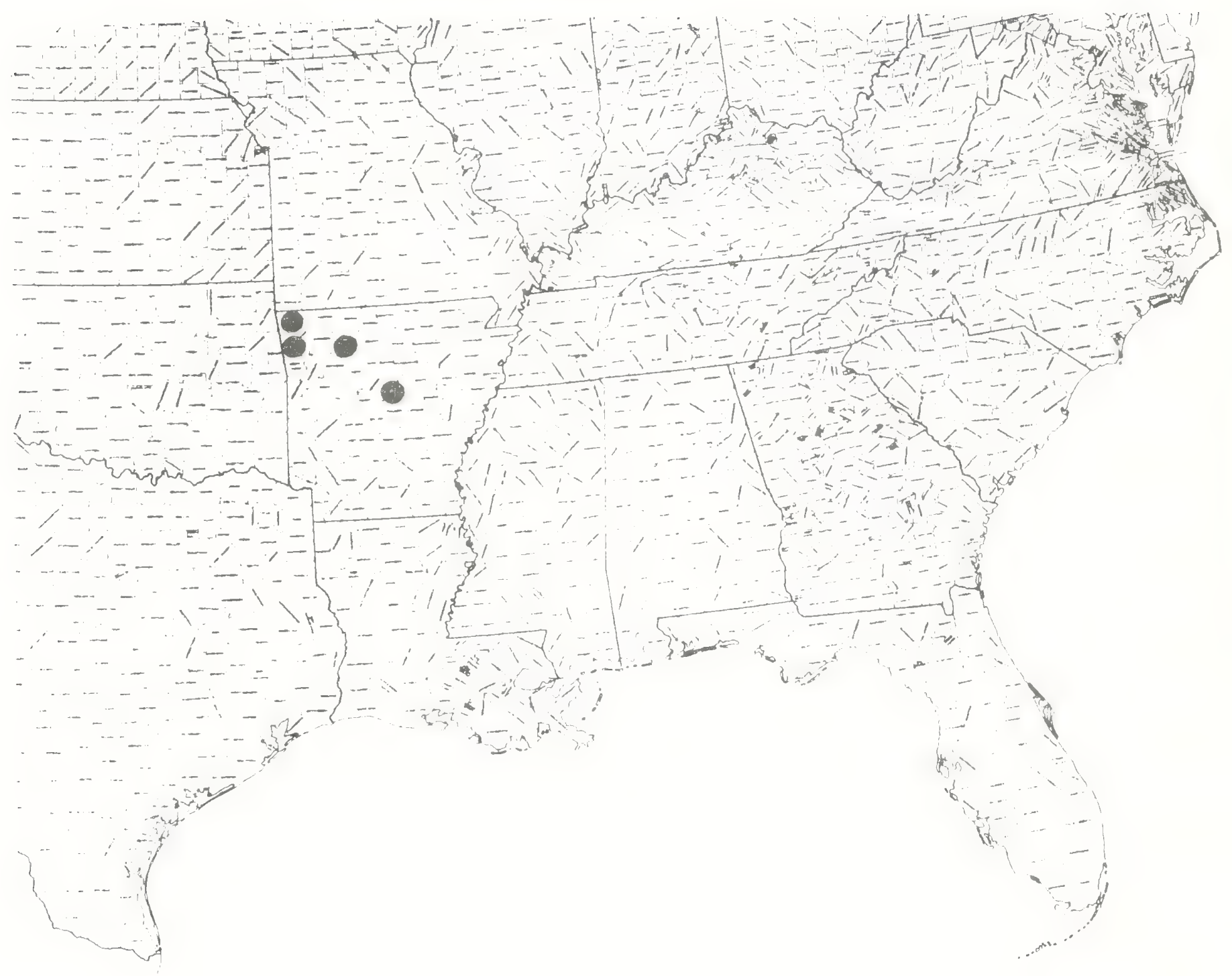


0

0

0 
Paper 252

Text and map by:

Robert Kral

\section{SAXIFRAGACEAE}

Saxifraqa careyana Gray. Golden-eye saxifrage Micranthes careyana (Gray) Small

Technical Description

Rosette-forming perennial heib from a short-fleshy caudex-like stem, perennating by short offsets from the erect crown. Leaves.--The largest all basel, numerous and spreading, rather fleshy and stiffish, highly variable in size, from 3-5 cm long, the petioles $\mathrm{ca}$. I/2-2/3 the total leaf length, broadly lineal, their backs broadly rounded, the upper side concave, proximally dilated abruptly to a clasping, reddish-villous-hairy, thinbordered, villous-ciliate-margined base, dilated more gradually distally into the blade base; leaf blades mostly of a broad type, suborbicular to reniform or broadly ovate, apically rounded, marginally low-dentate, prominently coarsely dentate, or serratedentate, villosulous with brownish-red hairs, the tooth-tips often callused-apiculate, the base entire or nearly so, truncate or rounded, abruptly attenuated on the petiole, the upper surface sparsely to densely villous with weak pale hairs, deep green, the lower surface often reddish, appressed-or-erect-villous with longer, browner hairs. Inflorescence.--Scapes mostly 15-30 cm high, erect, terete and ribbed, soft and brittle, pale green, spreading-villose with soft sordid hairs, these sometimes tipped with a red gland, bractless or with a few reduced, leaf-iike bracts proximally, regularly forking-branched and scattered-bracteolate distally to produce a many-flowered cyme, the slender ascending-divaricate cyme branches sparingly glandular-villose and stipitate glandular. Flowers.--Regular, bi sexual on slender, stipitate-glandular pedicels to I cm long, usually these subtended by a small, erect bracteole; hypanthium at anthesis very shallow: calyx lobes 5, triangular, green or tinged with red, ca. 1.5-2.0 mm long, acute, spreading, smooth; petals 5, spreading, distinct, elliptic or broady lanceolate, ca. $4 \mathrm{~mm}$ long, white or pale pink, toward the base bimaculate, the spots yellow; stamens usually 10, distinct, from the narrow rim of the hypanthium, spreading-ascending, the slender, fleshy, teretish filaments white or pink-tinted, ca. $3 \mathrm{~mm}$ long, the yellowish, nearly round, basifixed anthers ca. $0.7 \mathrm{~mm}$ long; ovary nearly superior, of 2 distinct, whitish carpels ca. $2.5 \mathrm{~mm}$ long, these with white, conical bodies tapering distally into short, fleshy, divaricate styles, each with a capitate stigma.

Fruit.--Ripe follicles similar in shape to carpels but from base to tip of style beak ca. $5 \mathrm{~mm}$ long, spreading, thin-valved, smoothish; seeds numerous, elliptic-bicaudate, translucent, yellowishbrown, ca. 0.7-0.8 mm long, longitudinally multiribbed, some ribs crested with papillae. 
Distribution and Flowering season

Rocky moist woods, moist outcrops of acidic rock, usually in shade, Appalachians, mostly Blue Ridge, western North Carolina, eastern Tennessee; flowering from March through April.

Special Identifying Features

Of the symmetrical-flowered southeastern saxifrages whose filaments taper from base to apex, this is but one of two in Tennessee and the Carolinas that have bimaculate (2-spotted) petal bases. The other species, S. caroliniana Gray has filaments dilating distally (rather than tapering), has strongly clawed petal bases, and larger fruit.

Habitat and Management Implications

S. careyana frequents the moss mantle of wet, acidic rocks ( phyllites, shales, granites, etc.) of steep slopes and cliff faces or ledges, is very often on the boulders and banks of plunging streams that empty into the larger streams and rivers. It may be in full sun of small clearings or areas of wet talus, but is always where moisture is high, nearly constant. Usually it is in the shade of a mixture of canada hemlock, white pine, various hardwoods such as red oak, white oak, chestnut oak, black ozk, hard maple, red maple, black locust, white ash, red hickory, bittermut hickory, various magnolia, yellow poplar, etc. The shrub layer is mostly ericaceous, containing Kalmia, Rhododendron, Ieucothoe, Vaccinium, etc. Associated herbs are mostly carices, Scirpus, grasses in genera Poa, Bromus, Festuca, Panicum, ana such forbs as Hepatica, sedum, Mitchella, Kriqia, Coreopsis, Senecio, Erigeron, Antennaria, etc. Many bryophytes, lichens, and ferms normally make up the surface of the thin mantle of soil or contribute the bulk of the organic matter the Saxifraga roots in. The habitat is steep, sensitive to exosion, thus it follows that heavy logging (where such is possible in that the terrain is often very steep) would, in addition to wrecking the slopes, open up the area to drying sun.

References

Radford, A. E., C. R. Bell \& H. E. Ahles. 1968. Manual of the vascular flora of the Carolinas, pp. 528-529. Chapel Hill, N.C.

Sma11, J. K. 1933. Manual of the southeastern flora, pp. 595596. Chapel Hill, N. C. 
SPECIES Saxifraga careyana Gray。 golden-eye saxifrage

\begin{tabular}{|c|c|c|c|c|c|c|c|c|}
\hline \multirow[b]{2}{*}{$\begin{array}{l}\text { Expected* } \\
\text { Effect on } \\
\text { the Species }\end{array}$} & \multicolumn{8}{|c|}{ Management Practices } \\
\hline & $\begin{array}{c}\text { Prescribe } \\
\text { Burn }\end{array}$ & $\begin{array}{c}\text { Bulldoze } \\
\text { or } \\
\text { Root Rake }\end{array}$ & Bed & Chop & $\begin{array}{l}\text { Thin } \\
\text { over- } \\
\text { story }\end{array}$ & $\begin{array}{l}\text { Cut } \\
\text { over- } \\
\text { story }\end{array}$ & $\begin{array}{l}\text { Establish } \\
\text { Plantation }\end{array}$ & Graze \\
\hline Destroy & $\mathrm{x}$ & NA & NA & $\mathrm{NA}$ & & $\mathrm{x}$ & $\mathrm{NA}$ & \\
\hline Damage & & & & & $\mathrm{x}$ & & & $\mathrm{x}$ \\
\hline $\begin{array}{l}\text { No Lasting } \\
\text { Effect }\end{array}$ & & & & & & & & \\
\hline $\begin{array}{l}\text { Beneficial } \\
\text { if Done } \\
\text { Properly }\end{array}$ & & & & & & & & \\
\hline
\end{tabular}

Other Comments:

* Expected effect on the species is an estimate made by Dr. Robert Kral based on his knowledge of the habitat and on knowledge gained from personal field observations. Estimates are "rough" in many instances. Results of practices may be modified depending upon the degree of application, intensity of treatment, nearmess to plant communities, etc. A management practice for which no entry is made indicates a lack of sufficient information from which to predict expected results. As observations are made in the field by users of the data, the expected effect will be refined. 


\section{Saxifraga careyana Gray}

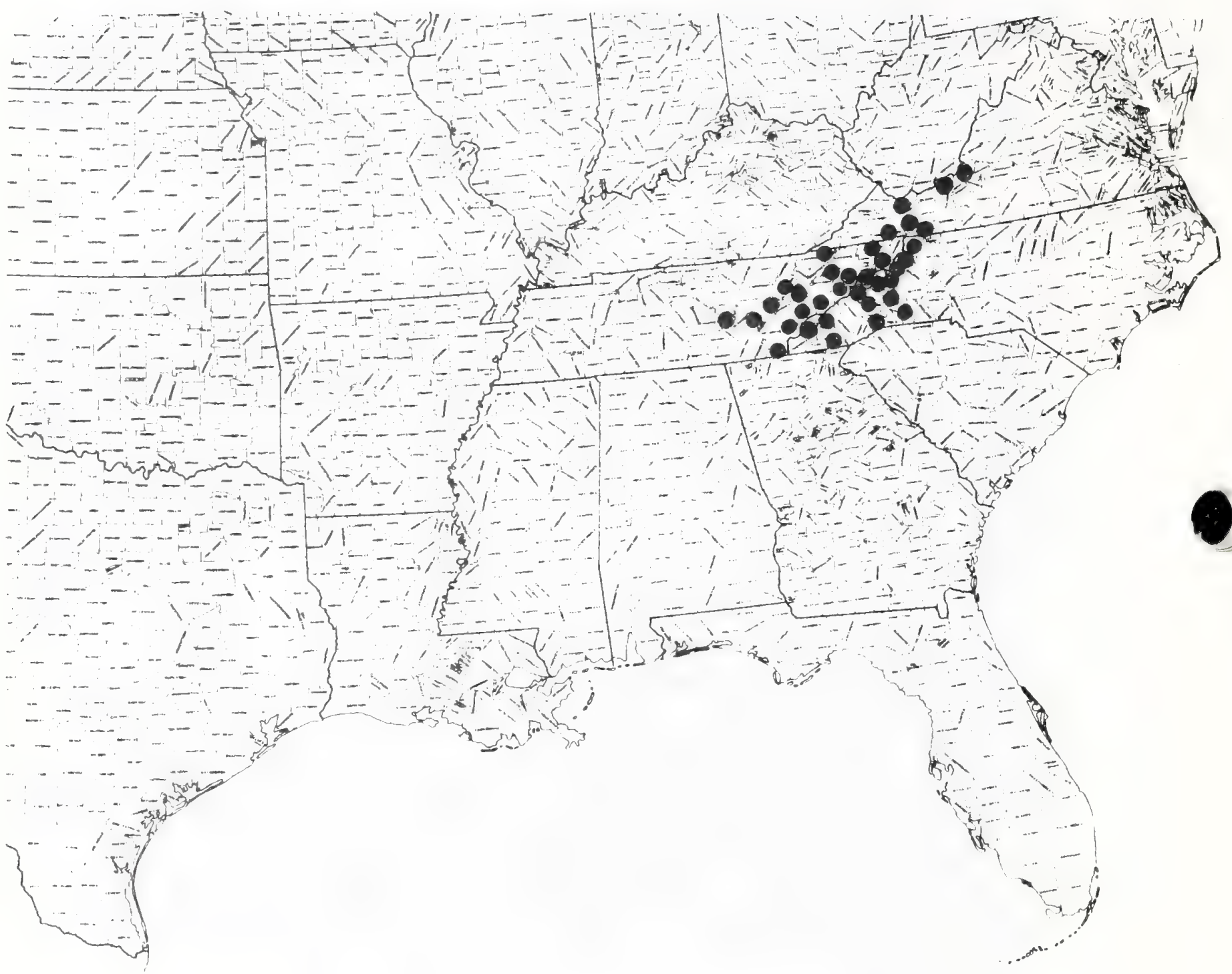


Paper 253

Text and map by:

Robert Kral

\section{SAXIFRAGACEAE}

Saxifraga caroliniana Gray. Carolina saxifrage Micranthes caroliniana (Gray) Sinall

Technical Description

Rosette-forming, perennial herbs from short, fleshy stems, perennating by crown buds.

Leaves.--AII larger ones basal, usually numerous, spreading, extremely variable in size (depending on depth, moisture and richmess of substrate), stiffish, to $15 \mathrm{~cm}$ long, the petioles broadly Iinear, I/3-2/3 the length of the blade, the backs broady rounded, the upper surface flat or concave, proximally abruptly dilated to a clasping, brownish-villous base, distally sllghtly dilating into the blade; leaf blades flattish, somewhat succulent, suborbicular to oblong, ovate, apically rounded, the margins usually coarsely dentate, the teeth low-triangular or more narrowly triangular, tipped by an inconspicuous callus, the upper surface deep green, sparsely appressed-pilose with flattened pale hairs, the lower surface often paler or reddened, nearly smooth or scatteredpilose.

Scapes.--Erect, rigid and brittle, as variable in length as leaves, but consistentIy longer, terete, glandular-villous-pilose or pilose-glandular, usually bractless proximally but the inflorescence branches subtended by greenish, spreading or ascending, narrow linear or narrowly cuneate, sometimes apically toothed, bracts, these diminishing in size upward within the inflorescence. Inflorescence. - - Iowers arranged in a regularly forking compound of cymes, the slender bronches spreading or slightly ascending, pilose-glandular, the whole compound usually oval in outline. Flowers.--Regular, bisexual, on slender, stipitate-glandular pedicels of various lengths but rarely longer than $1 \mathrm{~cm}$, each subtended by a small bracteole: hypanthium at anthesis very shallow; calyx lobes ca. $1.5 \mathrm{~mm}$ long, green, triangular, often reflexed in fruit, the narrow apex tipped by a reddish callus; petals 5, distinct, spreading, mostly $2.5-3.5 \mathrm{~mm}$ long, clawed, the blades narrowly oblanceolate or elliptic, white distinctiy yellow bimaculate just above the blade base inside; stamens 10, spreading or erect, the slender filaments slightly clavate: ovary superior, the 2 distinct carpel bodies white, narrowly conic or lance-ovoid, from base to tip of slender, divergent styles ca. 2.5-3.0 mm long. Fruit.-Foliicles mostly $5-6 \mathrm{~mm}$ long from base to tip of persistent spreading style beak, the body lance-ovoid, excurved; seeds plumply short-cylindrical or ellipsoidal, 1-or-2-caudate, ca. 0.6-0.7 mm long, pale reddish-brown, translucent, longitudinally multiribbed, the ribs minutely papiliate. 
Distribution and Flowering season

Shaded rocky ledges, slopes, cliffs, usually on acidic rocks, Blue Ridge and Valley and Ridge, western Virginia south into western North Carolina, northeastern Tennessee; flowering in May and June.

\section{Special Identifying Features}

S. Caroliniana most closely resembles $\underline{S}$. careyana, the only other species in the area that has yellow bimaculate petals (see writeup on $\underline{S}$. careyana). The essential differences are the more stipitate petals, the narro'sly clavate filaments of the stamens, and the larger fruit of the former.

Habitat and Management Implications

S. caroliniana is, like its close relative s. careyana, a plant of cool, shaded, surfaces of acidic rocks, and is usually rooted in a thin mantle of highly humified detritus mixed with moss. Most of its associate species are various carices, shade grasses, and a variety of ferns. The substrate is usually very moist, often misted with spray from plunging water, or variously supplied with seepage such as trickles down the shaded rocks. The terrain is invariably steep. The overstory varies somewhat, in some cases being primarily coniferous, usually with hemlock, white pine, mixed with hardwoods such as red oak, yellow birch, black birch, sugar maple, red maple, buckeye, basswood, magnolia, etc., and an understory largely ericaceous, composed of Rhododend-

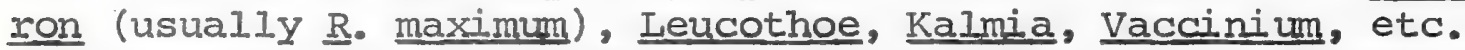
Clethra acuminata is often present, together with Rubus odoratus. However, in Valley and Ridge Virginia, the overstory may be largely of hardwoods, with very few conifers. In either event, the sites are steep, but locally may produce conifer and hardwood lumber of high quality. The slopes and soils are such that, if logging is heavy, much damage to the sensitive bluff habitat is done because of mechanical di sturibance of the highly erodable soils, admission of too much light together with several woody weeds. The end result is that the character of the herbaceous vegetation is changed.

\section{References}

Radford, A. E.,C.R. Bell \& H. E. Ahles. 1968. Manual of the vascular flora of the Carolinas, pp. 528-529. Chapel Hill,N.C.

Small, J. K. 1933. Manual of the southeastern flora, pp. 595596. Chapel HiII, N. C. 
SPECIES Saxifraga caroliniana Gray. Carolina saxifrage

\begin{tabular}{|c|c|c|c|c|c|c|c|c|}
\hline \multirow[b]{2}{*}{$\begin{array}{l}\text { Expected* } \\
\text { Effect on } \\
\text { the Species }\end{array}$} & \multicolumn{8}{|c|}{ Management Practices } \\
\hline & $\begin{array}{c}\text { Prescribe } \\
\text { Burn }\end{array}$ & $\begin{array}{l}\text { Bulldoze } \\
\text { or } \\
\text { Root Rake } \\
\end{array}$ & Bed & Chop & $\begin{array}{l}\text { Thin } \\
\text { over- } \\
\text { story }\end{array}$ & $\begin{array}{l}\text { Cut } \\
\text { over- } \\
\text { story }\end{array}$ & $\begin{array}{l}\text { Establish } \\
\text { Plantation }\end{array}$ & Graze \\
\hline Destroy & $\mathrm{X}$ & NA & NA & NA & & $\mathrm{x}$ & $N A$ & \\
\hline Damage & & & & & $\mathrm{X}$ & & & $\mathrm{x}$ \\
\hline $\begin{array}{l}\text { No lasting } \\
\text { Effect }\end{array}$ & & & & & & & & \\
\hline $\begin{array}{l}\text { Beneficial } \\
\text { if Done } \\
\text { Properly }\end{array}$ & & & & & & & & \\
\hline
\end{tabular}

Other Comments:

* Expected effect on the species is an estimate made by Dr. Robert Kral based on his knowledge of the habitat and on knowledge gained from personal field ohservations. Estimates are "rough" in many instances. Results of practices may he modified depending upon the degree of application, intensity of treatment, neamess to plant conmunities, etc. A management practice for which no entry is made indicates a lack of sufficient information from which to predict expected results. As observations are made in the field by users of the data, the expected effect will be refined. 


\section{Saxifraga caroliniana Gray}

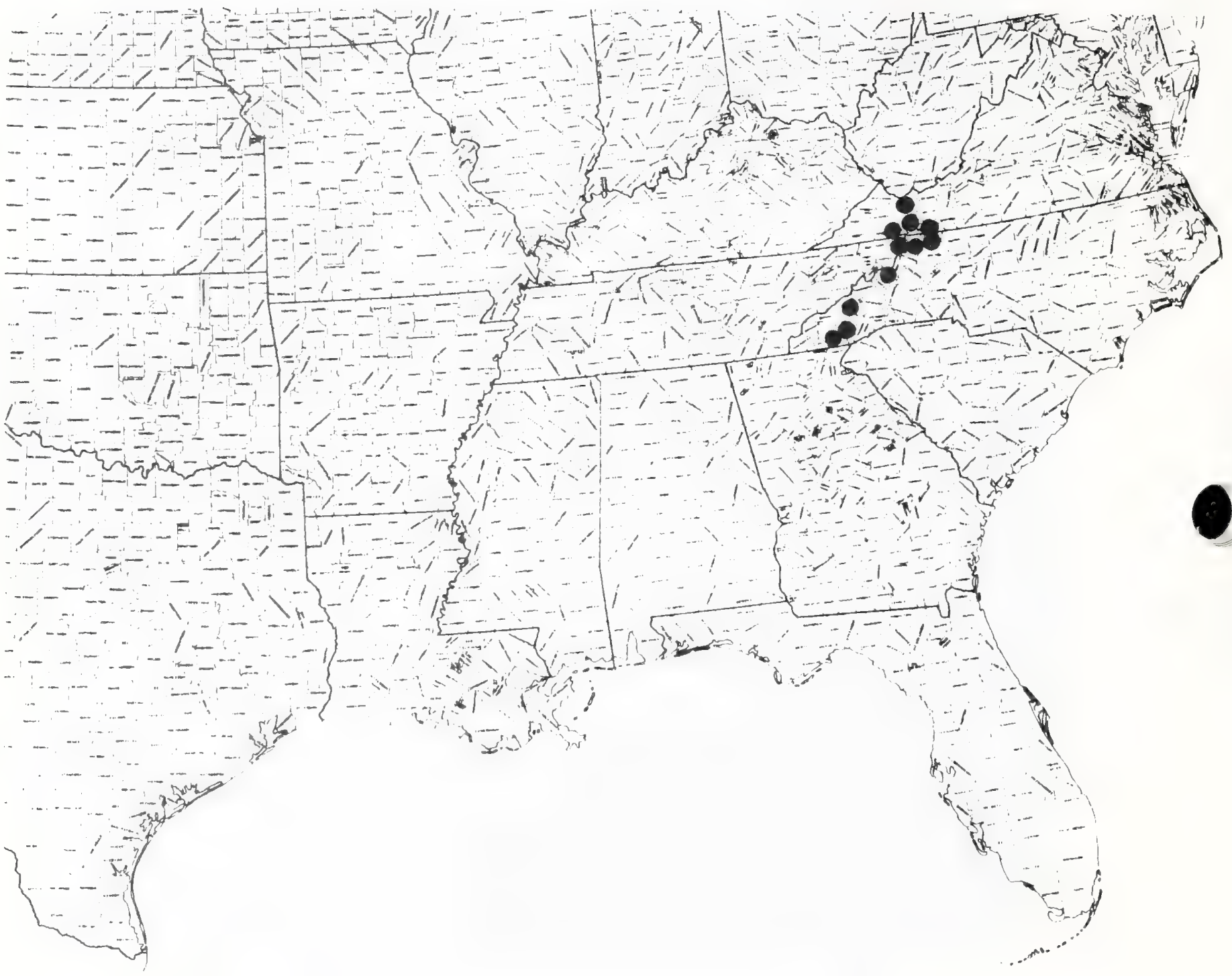


Paper 254

Text and map by:

Robert Kral

\section{SCROPHUIAARIACEAE}

Penstemon dissectus EII. Dissected beardtongue

Technical Description

Tufted perennial beardtongue from a fascicle of fleshy roots. Stems. - Of two sorts, the floriferous ones numerous, raliating from a short crown, mostly $306 \mathrm{dm}$ long, decumbent-based, then erect, stiffish, terete, minutely puberulent, proximally and distally purplish, at midmstem greenish, slightly glaucous, usually unbranched below the inflorescence: sterile offshoots produced also, these usually strongly decumbent or procumbent, with trimorphic leaves.

Leaves.--Opposite, estipulate, those lowest on flowering stems short, scalelike, their margins coarsely pectinately fringed, grading evenly upward to full-sized cauline leaves, these in outline broadiy oblong, ovate or even triangular, mostiy $3-6 \mathrm{~cm}$ long, sessile with a clasping base, spreading or ascenliry approximate, deepIy dissected into several lineal or linearmspatulate, spreading segments, these sometimes distally deeply lobed or pinnately lobed, the segment tips with a blunt, reddish callus, the primary segment bases merging with a broadly winged midrib: segment margins very revolute; leaf surface above deep yellow-green, puncticulate, below paler, punctate, only the midribs evident, these retrorsely scabropuberulent; leaves gradually diminishing in size, becoming more distant upward on stem, the longest internode comprising the peduncle. Leaves of sterile shoots trimorphic, the lowest scalelike, those of midshoots as in flowering stems, those distal (and overwintering) evergreen, linear, oblong or spatulate, usually sinuate or low toothed, raredy if at all narrowly lobed, mostly 3-6 cm long.

Inflorescence. - A teminal, stiffly erect, panicle on a leafless purplish, small-bracteate peduncle of varied length, but up to I dm long, the branching opposite and ascending, the lower branches longest, all branches naked at the base, toward tips producing asymmetrical, few-flowered cymes: pedicels slender, stiffish, terete, retrorsely puberulous, purplish, 5-15 nm long.

Flowers.--Perfect, zygornorphic, usually spreading horizontally or suberect: sepals 5, green rimmed with red, slightly unequal, the calyx broadly campanulate, ca. $5 \mathrm{~mm}$ long, the lobes ovate-triangular, the lowest longest, all acute, the margins glandular-ciliate, entire or denticulate apically, the surface externally stipitateglandular; corolla gamopetalous, zygomorphic, 2.5-3.0 cm long, the short tube ca. $5 \mathrm{~mm}$ Iong, $3 \rightarrow 4 \mathrm{~mm}$ broad, widening into a campanulate, oblique-orificed throat ca. $1.5 \mathrm{~cm}$ long, 1.0-1.2 cm wide at orifice, the 5 subequal, nearly round lobes aII nearly equalIy spreading, the lowest slightly longer, projecting more, the corolia Iively lavender-rose with deeper lines, externally stipitate-glandular, internally smooth save for a white-bristly pilosity at base of lower 3 lobes: stamens 5, the longest one a linear-clavate stamin- 
ode that is bristly-white-hirsute distally, all arising at the corolla tube, the fertile filaments arching downward, slender, terete, basifixed to ellipsoidal, divergent purplish anther sacs, these muriculate, sometimes with a few bristly hairs along the dehiscence line; ovary superior, 2-locular, lance-ovoid, smooth, about as long as the calyx, tapering into a linear, upcurved style, this terminating in a short stigma. Fruit.--Capsule lance-ovoid, tapering to an acuminate beak, ca. I cm long, smooth, brown, the valves somewhat woody; seeds numerous, asymmetrically broadly wedge-shaped and prismatic, ca. 2.0-2.5 mm long, dark brown, minutely alveolate (honeycombed).

Distribution and Flowering season

Gritty sands and gravels of outcrops and environs of same, Coastal Plain Georgia; flowering from late April to early June.

Special Identifying Features

This is the only Penstemon in the southeastern area that has deeply dissected leaves.

Habitat and Management Implications

P. dissectus appears to be confined to outcrops of siliceous rock or of sandy gravelly soils nearby. It may be abundant very locally on outcrops of the Altamaha Grit, a ferrugineous gravelly sand that is known to have on it several other rare endemics (including Elliottia, Marshallia ramosa, Physostegia veroniciformis, Rhynchospora punctata, Hypericum 1loydii, Arenaria uniflora, Talinum teretifolium, etc.) The aspect is savanna, the overstory on the outcrops and thin sandy soil around them being a scattering of longleaf pine, bluejack oak, sandhilis post oak, turkey oak, black oak, blackjack oak, persimmon, sassafras,dogwood, black cherry, etc. Among the shrubs present are many ericads such as Vaccinium arboreum, $\underline{V}$. floridanum, $\mathrm{V}$. myrsinites, V. stamineum, Gaylussacia dumosa, G. frondosa, and an abundance of Rubus cuneifolius, Smilax (several kinds). The sites are dry much of the year but have some seep areas or depressions in the rock where there is moist to wet inwash and thus some very localized bogs develop. The wiregrass Aristida stricta is common in the penstemon sites, which are dry, and most of the associate species of herbs are those that appear on dryish sands. The system is fire-disclimax and much of the Penstemon area shows a current to comparatively recent evidence of burning which tends to maintain the savanna. Protection from fire would of course increase the percentage of woody and herbaceous competition, which would both crowd and shade out the Penstemon. a plant of full sun or light shade. Some Penstemon areas I have visited have been planted to rows of slash pine, the result being that this 
beardtongue disappears as the pine crowns close.

References

small, J. K. 1933. Manual of the southeastern flora, pp. 1201-1205. ChapeI Hill, N. C. 
SPECIES Penstemon dissectus E11: dissected beardtounge

\begin{tabular}{|c|c|c|c|c|c|c|c|c|}
\hline \multirow[b]{2}{*}{$\begin{array}{l}\text { Expected* } \\
\text { Effect on } \\
\text { the Species }\end{array}$} & \multicolumn{8}{|c|}{ Management Practices } \\
\hline & $\begin{array}{c}\text { Prescribe } \\
\text { Burn }\end{array}$ & $\begin{array}{l}\text { Bulldoze } \\
\text { or } \\
\text { Root Rake }\end{array}$ & Bed & Chop & $\begin{array}{l}\text { Thin } \\
\text { over- } \\
\text { story }\end{array}$ & $\begin{array}{l}\text { Cut } \\
\text { over- } \\
\text { story }\end{array}$ & $\begin{array}{l}\text { Establish } \\
\text { Plantation }\end{array}$ & Graze \\
\hline Destroy & & $\mathrm{x}$ & & $\mathrm{X}$ & & & $\mathrm{x}$ & \\
\hline Damage & & & $\mathrm{X}$ & & & & & $\mathrm{x}$ \\
\hline $\begin{array}{l}\text { No Lasting } \\
\text { Effect }\end{array}$ & & & & & & & & \\
\hline $\begin{array}{l}\text { Beneficial } \\
\text { if Done } \\
\text { Properly }\end{array}$ & $\mathrm{x}$ & & & & $\mathrm{x}$ & $\mathrm{x}$ & & \\
\hline
\end{tabular}

Other Comments: in some localities this plant is on rock, thus mechanical site preparations cannot be applied

*Expected effect on the species is an estimate made by Dr. Robert Kral based on his knowledge of the habitat and on knowledge gained from personal field observations. Estimates are "rough" in many instances. Results of practices may be modified depending upon the degree of application, intensity of treatment, nearness to plant communities, etc. A management practice for which no entry is made indicates a lack of sufficient information from which to predict expected results. As observations are made in the field by users of the data, the expected effect will be refined. 
- onstanon dissectus 3.1 .

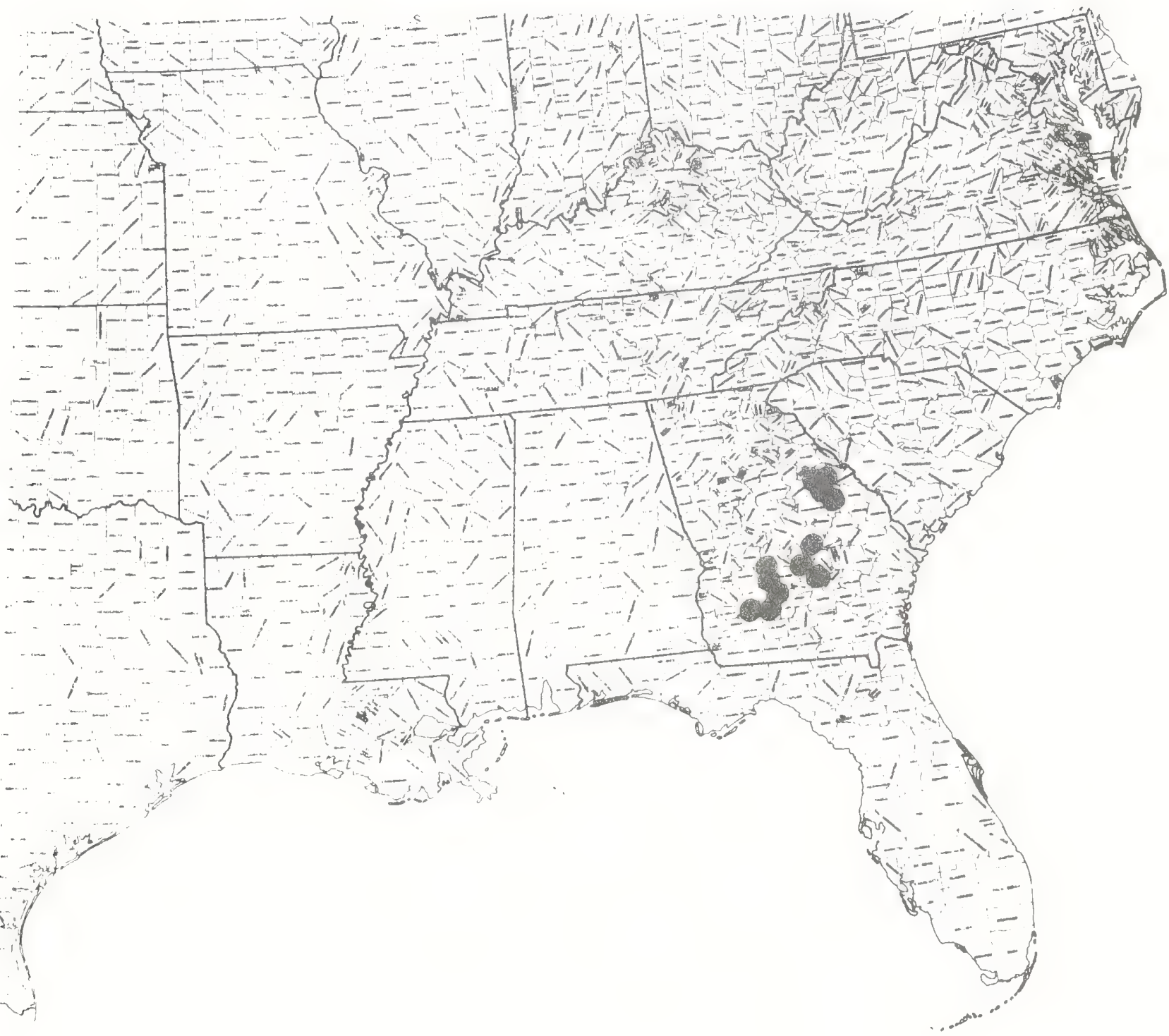


Paper 255

Text and map by:

Robert Kral

\section{VIOLACEAE}

Viola egqlestonii Brainerd. Eggleston"s violet

Technical Description

Perennial, rosulate, smoothish herbs from a fleshy, stoutishcylindrical, erect or ascending rhizome $0.5-1.0 \mathrm{~cm}$ thick.

Leaves.-AII basal; stipules linear-triangular, pale green tinted with pink, thin, entire or remotely ciliate: petioles various in. length, those of earliest leaves usually shorter than the blades, increasingly lengthening through the season and longer than the blades, smooth, or sparingly villosulous, fleshy, half-terete, the backs rounded and ribbed, the inner side (ventral) usually concave; blades mostly $1.5-6.0 \mathrm{~cm}$ Iong, pale green on both faces, the earliest ones mostly broadly ovate to suborbicular or reniform, broadly ac to obtuse or rounded, the margins crenate or crenate-serrate, the bases truncate or cordate, also attenuated on the petiole; later leaves becoming progressively more dissected, usually involving a seasonal series from triangular and more lacerate-serrate or incised, with bases truncate-hastate, to ovate and deeply palmatifid, the (5-) 7-11 segments narrowly oblanceolate or spatulate, or with the medial segment broadest, sometimes itself broady oblong, ovate or elliptic with the laterals few, basal, narrow, saliently spreading, the lobe margins low-serrate, the blade base cuneate to truncate, or with lower lobes reflexed; surfaces usualiy glabrous.

Inflorescence.--Flowers several per plant, solitary at peduncle tips and of two sorts, petaliferous ones (chasmogamous ") showy, appearing early in the season on ascenhing or erect peduncles, giving way later in the season to inconspicuous cleistogamous ones on horizontally oriented peduncles; peduncles of chasmogamous florets slender, about as long as the leaves, bibracteolate, the small, subulate, red-tinged bracts appearing about midway up, the peduncle apex bent to the flower.

Flowers.-Chasmogamous flowers zygomorphic, bisexual: sepals 5, distinct, narrowly triangular, slightly unequal, the longest ca. $9 \mathrm{~mm}$ long, broadly auricled at base, projecting forward in the flower, thinnish, pale green with maroon tints, in fruit with tips spreading-reflexed; petals 5, distinct, the lowest somewhat larger, ca. $1.5 \mathrm{~cm}$ long, basally with a saccate spur that projects backward between the bases of the lower pair of sepals, the blade obovate, projecting forward, the lateral petals narrower, projecting forward and outward, internally bearded medially toward blade base, the upper pair of petals broadest and apically most spreading; petal surfaces a lively blue-violet in the blade, grading to pale blue or nearly wite with deep blue-violet veins toward the base (this giving the flower a distinct "eye"): stamens 5, the filaments very short, broad, each projecting beyond a broadly oblong, pale, introrse anther to form a triangular scale, the whole structure 
forming a cylinder around the style; ovary superior, 3-locular, the single style apical, bent slightly above its base and distally dilated into the capitate stigma.

Fruit.--A broadly oblong, pale yellowish-green, loculicidal capsule 1.0-1.4 cm long, the numerous seeds narrowly obovoid, ca. $2 \mathrm{~mm}$ long, smooth, pale brown.

Distribution and Flowering season

Heavy, thin, soils over limestone, glades and clearings, Interior Low Plateau, middle Kentucky south through middle Tennessee into northwestern Georgia and northern Alabama. Chasmogamous flowers from early March into May; cleistogamous flowers from May to frost.

Special Identifying Features

The stemless blue violets probably comprise the most difficult taxonomic problem remaining in the southeastern U.S.A. There are several other "species" that have similar patterms of variation of leaf and some doubtlessly hybridize with $\mathrm{V}$. eqglestonii, particularly on disturbed habitat. The most likely contaminant is $\underline{V}$. palmata (including $\underline{V}$. triloba, $\underline{V}$. sororia in some

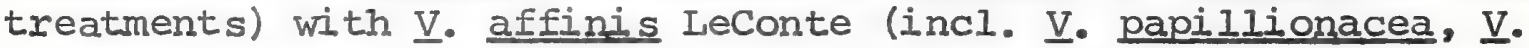
missouriensis, etc.) a close second. Taxonomically however, $\underline{V}$. egqlestoni $i$ is most like the palmatifid-leaved $\underline{v}$. pedatifida, a prairie species with wich it does not share range. The only consistent difference between the two is in the behavior of the peduncle of the cleistogamous flower, which in V. egglestoni is prostrate, sometimes buried shallowly in the substrate or creeping over the surface and which in $\underline{V}$. pedatifida is erect or suberect. It differs from most species in the $\underline{V}$. palmata camplex in that, in the latter the young leaves are generally somewhat pubescent, and there is usually some pubescence even in older foliage.

Habitat and Management Implications

V. egglestonif is frequent or fairly common in most of the open limestone glades of middle Tennessee, rather rare and local elsewhere in its small range. Its soil preferences are for a dark, humified clay, a product of the in-place and transported weathered limestones which always underlie the plants. Common herbaceous associates are those typical of limestone glades and include sporobolus, various Dichanthelium Panicum, Carex, Juncus filipendulus, Arenaria patula, Satureja, Scutellaria parvula, Delphinium virescens, Sedum pulchellum, various Leavenworthia, Lesquerella, Petalostemon gattingeri, Psoralea subacaulis, Astraqalus tennesseensis, Onosmodium molle, Iithospermum canescens, opuntia compressa, etc. The site ranges from very moist to quite dry in a single season. As do other species of open limestone 
glades,this violet tends to disappear as the surrounding woody vegetation invades, so that as Juniperus (the common first arborescent invader) close crows, V. egglestoni 1 becomes scarce and is totally absent by the time the overstory succession reaches climax. Thus, as is true also of other open glades plants, V. egqlestonii was probably maintained historically by a combination of natural woods fires and erosional forces that would tend to create either outcrops or shallow soils. In that the plants are comophytic and low, they tend to persist, even increase, under conditions of extreme disturbance such as lot development, high grazing intensity, etc.

References

Brainerd, Ezra. 1910. Five new species of Viola from the South. Bull. Torr. Bot. Club $37: 523-527$.

- 1921. Violets of North America. Vermont Agric. Expt. Sta. Bull. 224. 205 pp. Burlington, Vt.

Russell, N. H. 1965. Violets (Viola) of central and eastern United States: $a$ : introductory survey. Sida 2 (1): 1-113.

Small, J. K. 1933. Manual of the southeastern flora, pp. 884-894. Chapel Hill, N. C. 
SPECIES Viola egglestonii Brainerd. Eggleston's violet

\begin{tabular}{|c|c|c|c|c|c|c|c|c|}
\hline \multirow[b]{2}{*}{$\begin{array}{l}\text { Expected* } \\
\text { Effect on } \\
\text { the Species }\end{array}$} & \multicolumn{8}{|c|}{ Management Practices } \\
\hline & $\begin{array}{c}\text { Prescribe } \\
\text { Burn }\end{array}$ & $\begin{array}{l}\text { Bulldoze } \\
\text { or } \\
\text { Root Rake } \\
\end{array}$ & Bed & Chop & $\begin{array}{l}\text { Thin } \\
\text { over- } \\
\text { story }\end{array}$ & $\begin{array}{l}\text { Cut } \\
\text { over- } \\
\text { story }\end{array}$ & $\begin{array}{l}\text { Establish } \\
\text { Plantation }\end{array}$ & Graze \\
\hline Destroy & & NA & NA & NA & & & $\mathrm{x}$ & \\
\hline \multicolumn{9}{|l|}{ Damage } \\
\hline $\begin{array}{l}\text { No Lasting } \\
\text { Effect }\end{array}$ & & & & & & & & \\
\hline $\begin{array}{l}\text { Beneficial } \\
\text { if Done } \\
\text { Properly }\end{array}$ & $\mathrm{X}$ & & & & $\mathrm{X}$ & $\mathrm{X}$ & & \\
\hline
\end{tabular}

Other Comments:

*Expected effect on the species is an estimate made by Dr. Robert Kral based on his knowledge of the habitat and on knowledge gained from personal field observations. Estimates are "rough" in many instances. Results of practices may be modified depending upon the degree of application, intensity of treatment, nearness to plant communities, etc. A management practice for which no entry is made indicates a lack of sufficient information from which to predict expected results. As observations are made in the field by users of the data, the expected effect will be refined. 
Viola egglestoni Brainerd

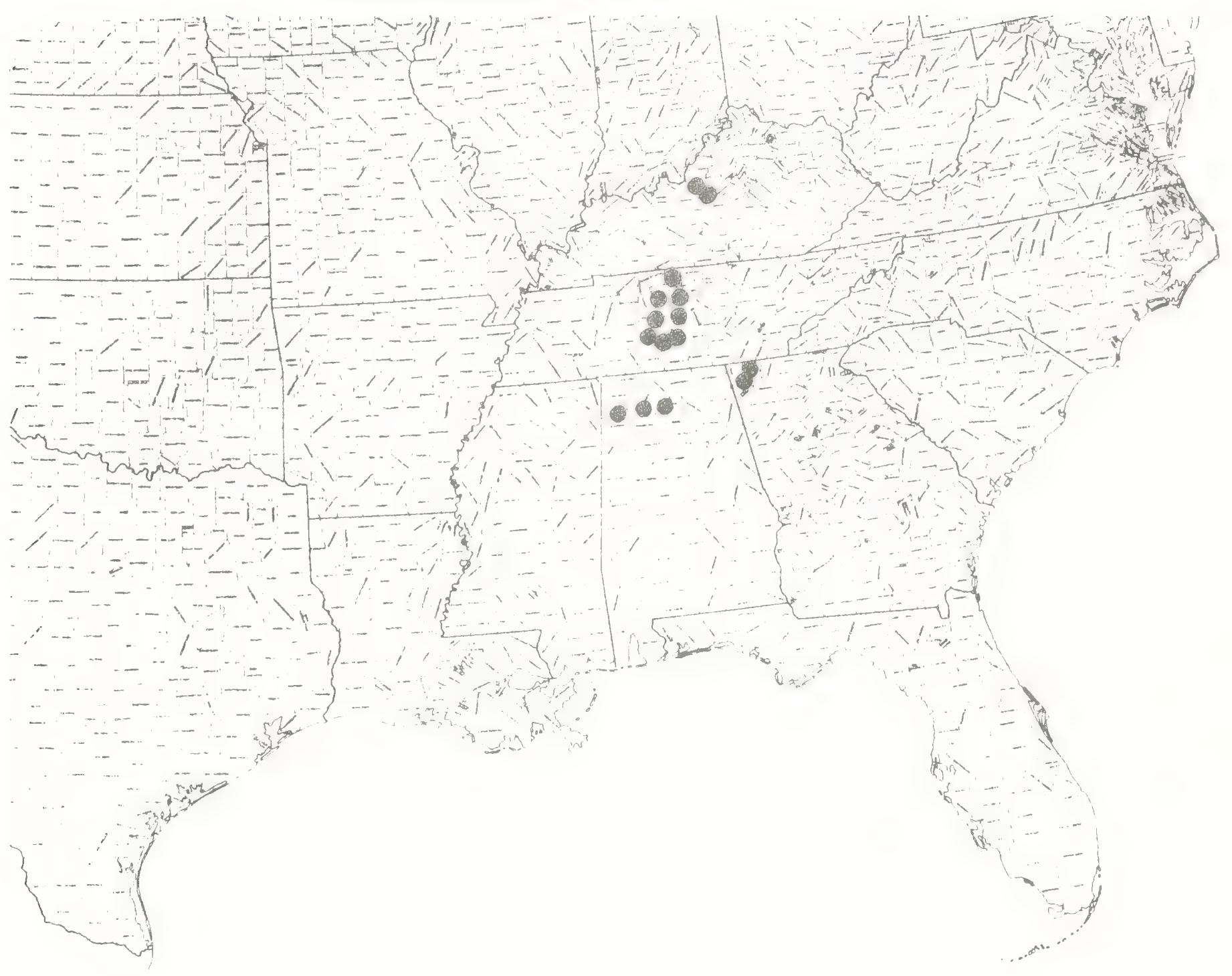



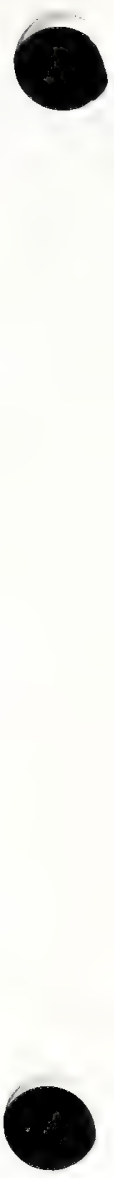
Justicia mortuifluminis Fernald

J. umbriatilis Fernald (1941), not S.Moore, Journ. Bot.1i: 216. (1913)

Status: Endangered?

Technical Description:

Perennial, strongly clonalizing herb, perennating by elongate, deepset, forking, pale-stoloniferous rhizomes, these at first ca. $3 \mathrm{~mm}$ thick, later thickening to $4-6 \mathrm{~mm}$.

Stems: erect or with short-decumbent bases, to $6 \mathrm{dm}$ tall, stiffish, simple or branching from lower nodes, slender, proximally with brown or purple tints, subterete, upwardly becoming angulately sharp-ridged, the ridges decurrent from the petiole bases, the surfaces light yellow-green, smooth save in inflorescence where ridges scabro-puberulent.

Leaves: opposite, on 7-11 nodes, estipulate, the lowermost smallest, more spreading, sessile or short-petiolate, the largest at mid-stem or above, erect or ascending, narrowly elliptic, oblanceolate or elliptic-oblong, narrowly acute or acuminate, the apex narrowly rounded, the margin entire or undulate, scabro-ciliate, the base attenuated nearly to petiole base, the surface smooth, dark green above, paler beneath, the venation pinnate-arcuate, the midrib above medially grooved, the veins below somewhat raised.

Inflorescence: Most mid and upper leaves bearing in their axils arching-erect peduncles, these slender, angulately ribbed, the lowest 1 ongest, $10-15 \mathrm{~cm}$ long, the uppe most as short as $3-4 \mathrm{~cm}$ long, bearing apically compact, subcapitate, strongly bracteate spikes, the bracts in pseudowhorls at base of flowers, triangular, greenish, shorter than the calyx tubes, the flowers suberect and strongly overlapping.

Flowers: bisexual, the corolla very zygomorphic; sepals 5, subequal, at anthesis ca. $1 \mathrm{~cm}$ long, joined at base into a short, subscarious tube, the lobes linear-eliiptic, erect or slightly spreading, narrowly and sharply acute, green with only midnerve evident, the margins narrow, pale, minutely scabrid; corolla variable in length and lobation but mostly ranging from $1.0-1.5 \mathrm{~cm}$ long, strongly bilabiate, the tube ca. $8 \mathrm{~mm}$ long, the upper 1 ip oblong, arching forward, 5-6 mm 1ong, apically broadly rounded, emarginate or subtruncate, the lower lip 7-9 mm long, broadly obtriangular, spreading downward, strongly 3-lobed, the central lobe slightly longest and widest, the laterals oblong-ovate or oblong-elliptic, diverging at a slight angle, the surface smooth, pale lilac with darker veins save for the nearly white tube base and the upper medial surface of the midlobe of the lower lip, this raised to a palate, which is white, strongly mottled peripherally with deep lilac spots and 1 ines; stamens 2, epipetalous, the white slender flattened filaments borne laterally on the corolla tube on line with the lip sinuses, arching somewhat up under the upper corolla lip, the anther connective very dilated, laterally flattened, lanceolate-curvate, the 2 anther sacs linear, one borne low on the connective edge and opening inward, the other borne supapically on the outer edge of the connective 
and opening away from the stigma; ovary superior, bicarpellate, narrowly lance-ovoid, the slender style terminal, arching up under the upper corolia lip and at the level of the anthers producing 2 low stigmatic lobes, 1 terminal and 1 subterminallatera1.

Fruit: Ripe capsule 1.2-1.4 cm 1ong, the base with a 1atera11y flattened stipe ca. $5 \mathrm{~mm}$ long, the body broadly oblong, dorsiventra11y flattened (paralle1 to partition), acuminate, the wall greenishbrown, firm, splitting into 2 valves loculicidally; seeds few, orbicular-reniform, laterally flattened, ca. $3 \mathrm{~mm}$ wide, dark brown, minutely pebbled, the funiculus with a narrow lateral extension curled about the lower edge of the seed.

Distribution and Flowering Season:

Alluvial woodlands, quiet backwater sloughs, Coastal Plain, southeastern Virginia; flowering from June through July.

Special Identifying Features:

Fernald's description of this "species" produces an image of what an ideal hybrid bwtween $\mathrm{J}$. americana and $\mathrm{J}$. ovata would be 1ike. The common water-willow, J. americana is taller (sometimes to 1 meter ta11), stouter-based, stouter rhizomed, the rhizomes shallow and producing slender surficial stolons, the leaves are narrower, the inflorescence is very dense, headlike, produced on very elongate peduncles, the corollas are smaller, with the upper lip somewhat spreading-recurved, the lower lip has the median lobe constricted toward its base, the laterals are more spreading; J. ovata on the other hand is lower, the rhizomes more slender, the Ieaves broader, most1y broad1y e11iptic, ovate or obovate, the inflorescences are fewer-flowered with the flowers more 1 oosely arranged, the lower blooms more distant as fruit forms. Seed characters appear to be intermediate. It is of some interest to note that $\mathrm{J}$. mortuifluminis has been found along the Blackwater and Nottoway Rivers in southeastern Virginia, the northernmost area for J. ovata, but also where some suitable habitat for J. americana, which is far the most ubiquitous of these wetland taxa. I have inspected several sites for what keys to J. mortuifluminis and note that some clones agree well with the original description whilst others grade toward either $\mathrm{J}$. americana or to J. ovata. The situation appears to be that, where J. americana and J. ovata come into contact along the slow, tidally influenced rivers of southeastern Virginia, intermediate morphologies have developed, and these appear to be back-crossing with parental types. This will make an interesting proof if such has not already been done. It is also worthy of note that morphologies similar to J. mortuifluminis appear in the Gulf Coastal Plain, where J. ovata and J. americana also overlap occasiona11y. It would seem that the taxon is weak.

Habitat and Management Implication:

J. mortuifluminis, as the name implies, is found in deadwater swamps. Particularly good sites for it are still to be found in the Nottoway system around Franklin. The river itself is typical of a rather slow flowing stream, sinuous, wine-tinted, in places with a broad floodplain with large shallow-bottomed sloughs interrupted by frequent natural levees as we 11 as by slow-flowing tributary streams. 
The substratum is in places silty muck, in others a fine silty sand, in any event overlying sandy alluvium. There are large beds of Saururus, Sagittaria, Scirpus, Rhynchospora, Pontederia, Sparganium, Leersia, Glyceria, Panicum, Peltandra, robust carices, Polygonum, Penthorum, etc. The overstory is prevalently cypresstupe1o, with Nyssa biflora, Acer rubrum, Liquidambar, Salix, Populus, Fraxinus caroliniana, E. pensylvanica, F. tomentosa, P1atanus, Carya aquatica, various willow oaks, Overercup Oak, Persimmon with an understory of Itea, Cephalanthus, Sambucus, Cornus, Viburnum, etc. The Justicia frequents frequent1y inundated first bottom, forms particular1y large stands where tributary streams course throgh the bottoms or along cutoff sloughs. It is definitely a shade plant.

This habitat suffers most from clearcutting of the cypress and hardwoods. Following a wholesale cut of such bottoms there is often a strong shift of species, evinced by a rapid increase of rank, weedy herbaceous and woody plants, turning such places into jungles in which the Justicia may no longer grow.

References:

Fernald, M.L. 1941. Another century of additions to the flora of Virginia. Rhodora 43: 635-659.

- 1942. Justicia mortuifluminis, in Rhodora 44:92. - 1950. Gray's manual of botany, ed. 8, pp. 1308-1309. 
SPECIES: Justicia mortuifluminis Fernald

\begin{tabular}{|c|c|c|c|c|c|c|c|c|}
\hline $\begin{array}{l}\text { Expected } \\
\text { Effect on } \\
\text { Hab1tat }\end{array}$ & $\begin{array}{c}\text { Preocribe } \\
\text { Burn }\end{array}$ & $\begin{array}{l}\text { Doze or } \\
\text { Root } \\
\text { Rake }\end{array}$ & Bed & Chop & $\begin{array}{l}\text { Th1n } \\
\text { Over- } \\
\text { etory }\end{array}$ & $\begin{array}{l}\text { Cut } \\
\text { over- } \\
\text { Story }\end{array}$ & $\begin{array}{c}\text { Over Plant } \\
\text { w } 1 \text { th } \\
\text { treeg } \\
\end{array}$ & Graze \\
\hline Destroy & $\mathrm{NA}$ & NA & $\mathrm{NA}$ & NA & & $\mathrm{X}$ & $\mathrm{NA}$ & \\
\hline Damsge & & & & & $\mathrm{X}$ & & & \\
\hline $\begin{array}{l}\text { No Lasting } \\
\text { Effect }\end{array}$ & & & & & & & & \\
\hline $\begin{array}{l}\text { Beneficial } \\
\text { if Done } \\
\text { properly }\end{array}$ & & & & & & & & \\
\hline
\end{tabular}

Other Commente:

* Est1mated effect 18 an est1mate of the author based on his book knowledge of the habltat and on knowledge galned from personal field observations. Estlmates are "rough" in many instances. Results of practices may vary in degree of application, intensity, nearness to plant communities, etc. A column left "blank" Indicates a lack of sufficient information from which to predict expected results. As observations are made in the fleld by users of the data, predictions should be reflued by area and by intensity of forestry practices. 
Approximate Range of:

Justicia mortuifluminis Fernald

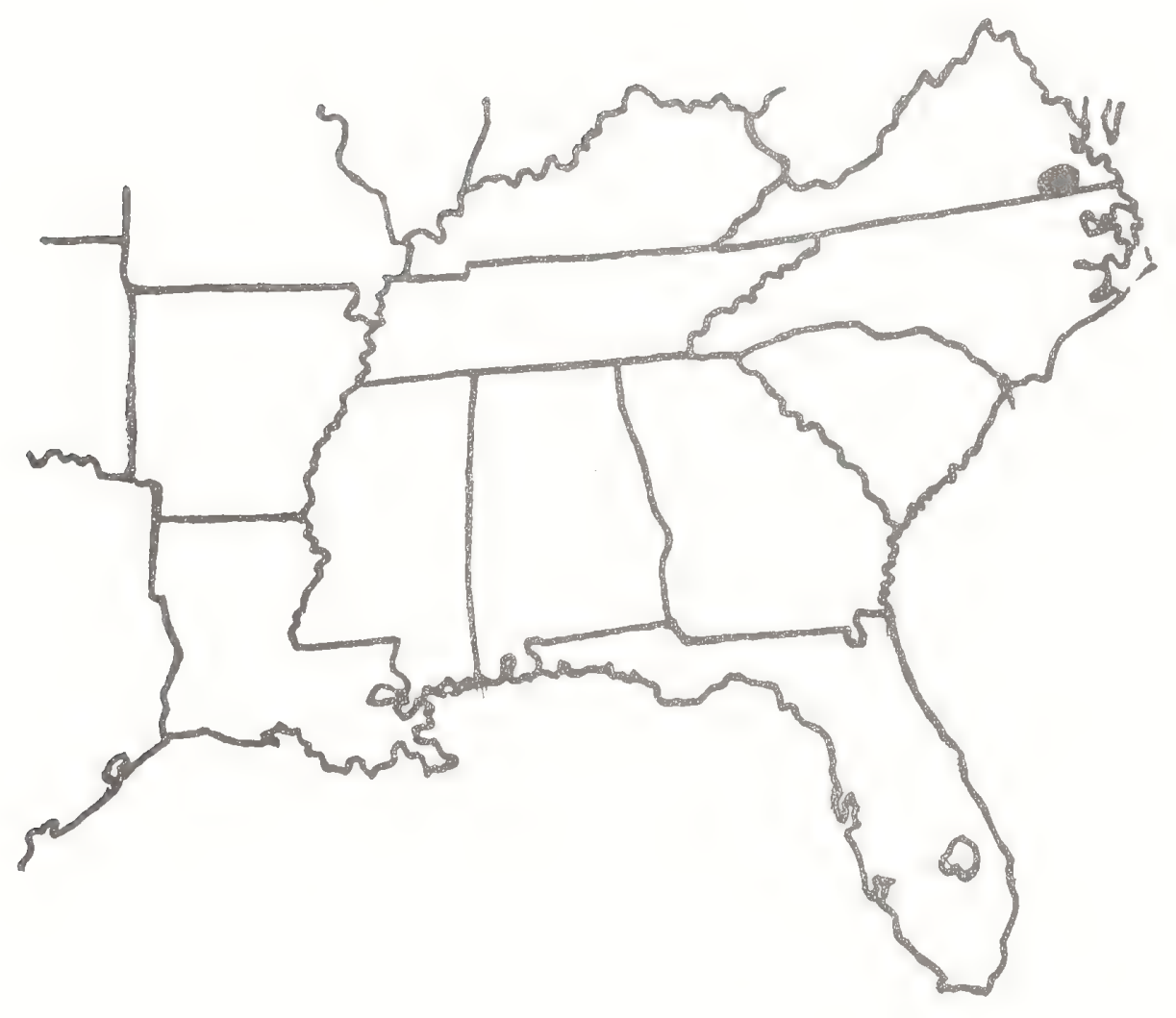


•

•

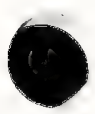




\section{Oxypo1is canbyi (Coult. \& Rose) Fern. \\ O. filiformis (Walt.) Britt. var. canbyi Coult.\& Rose}

Status: Endangered

Technica1 Description:

Perennial, smooth, aromatic (sme11ing faintly of dil1), strong1y clonalizing umbellifer, increasing by numerous fleshy, elongate, pale, stoloniferous rhizomes。

Stems: erect or ascending, slender but stiffish, terete, finely fluted, arising from scaley buds at tips of previous year's rhizomes, fistulose, to 1.5 meters tall, the decumbent base frequent1y rooting at nodes, the nodes there approximate, the internodes mostly 5-10 mm thick toward plant base, gradually tapering and more elongate upward into inflorescence, usually branching only well above mid-stem, the branches archingwascending, forking or ternately rebranching, forming a candelabralike narrow to broad compound of several to many umbels, the surface a pale green, toward stem base purplish or pinkish. Leaves: a1ternate, phyllodia1, terete, nodose-septate, the lower ones 1 ongest, frequent1y to 2 or $3 \mathrm{dm}$ long or more, narrowed abruptly from the broadly clasping base, then gradually tapering to the conical, acute apex, upwardly gradually diminishing in length into the inflorescence, there overtopped by umbels in anthesis, the surface finely fluted as in stems, dull green. Inflorescence: an indeterminate compound of compound umbels, the primary peduncles axillary, elongate, arching-ascending or erect, stiffish, terete, mostly $5-10 \mathrm{~cm}$ long, the secondary peduncles (primary rays) 7-12, slender but stiffish, most1y $2 \mathrm{~m} \mathrm{~cm} 1 \mathrm{ong}$, subtended by a whorl (involucre) of several, spreading, apically upcurved, linear-setaceous, green bracts $1.0-2.5 \mathrm{~cm}$ long, these usually grooved on the upper side; secondary umbels mostly ca. $1 \mathrm{~cm} \mathrm{high,} \mathrm{to} 1.5 \mathrm{~cm}$ broad, the slender, stiff pedicels numerous, 2-7 mm long, subtended by an involucel of green, linear - subulate bractlets 3-10 mm long; inner florets of some umbels strictly male, some outer florets strictly female.

Flowers: bisexual and/or unisexua1, regular; sepals 5, narrowly triangular-subulate, pale green or tinged with red or pink, spreading, mostly ca. $0.5 \mathrm{~mm}$ long, articulated to hypanthial rim and rarely persisting on ripe fruit; petals 5, white, ca. $1.2 .1 .3 \mathrm{~mm}$ long, short-clawed, the broadly ovate-orbicular blade strongly incurved with the back concave, the narrowd apex curved inward, nearly touching the strongly raised midmerve; stamens 5, alternating with petals on hypanthial rim, the filaments white, 1inearosubulate, terete, to $1.5 \mathrm{~mm}$ long, apically incurled so that, while anther is basifixed, the dorsal side of the connective lies against the filament apex, the anthers nearly round, ca. $0.5 \mathrm{~mm}$ long, pale yellowish-white or tinged with pink, bilocular; ovary inferior, bicaxpellate, the hypanthium at anthesis ca. 0.5-0.6 mm high, in out1ine narrowly campanulate, somewhat compressed laterally and indented along the edges of the commisure, 1ongitudinally low $r$ ibbed, green tinged with pink, the stylopodium (enlarged 
nectariferous style bases) fleshy, yellowish, conical, ca. 0.5 $\mathrm{mm}$ high, the short, fleshy style branches excurvate at anthesis, the stigmas slightly capitate.

Fruit: Schizocarp broadly obovate or ellipsoidal in outline, strongly compressed dorsiventra11y, mostly 4m6 mm 1ong, the apex strongly notched, the fruit often bowed inward through unequal and greater development of the outer mericarp, the outer face of each mericarp with 3 evident but narrow longitudinal ridges over the low-convex, elliptical seed cavity and with slender, longitudina1ly oriented, reddish, oil tubes in the broad intervals, a1so marginal1y thickened so as to make the border of the mericarp much thicker than the seed cavity (see plate!); medial surface over seed cavity often sparsely but evident1y muricate.

Distribution and Flowering Time:

Borders and shallows of cypress-Pond Pine ponds, sloughs, sha11ow savanna ponds and ditches, infrequent, Coastal Plain, Delaware (where probably extirpated), South Carolina, Georgia; flowering from late May through July.

Specia1 Identifying Features:

O. canbyi has been placed by some as a variety of o. filiformis (Wa1t.) Britt., a more widespread, superficially similar, species of the Atlantic and Gulf Coastal Plain, but this is probably because both species are often collected without getting the rootstock or the mature fruit. The former is at once distinguished by its strong1y clonalizing habit, in that it develops strong, spreading, fleshy rhizomes; O. filiformis produces no rhizome whatever. O. canbyi has much more slender, whiplike, elongated lower leaves, while those of $\mathrm{O}$. filiformis are stiffer, often stouter, tend to have a stronger taper, are more fleshy. 0. canbyi has a totally different looking fruit in that the edges of meach mericarp are strongly distended under the prominent ribs by thickenings of corky material so that the margins of each schizocarp are actually thicker than is the central area over the seed; on the other hand the fruit of $\mathrm{O}$. filiformis are thicker medially than marginally. In that there are such strong differences it would be far more consistent with the taxonomy of the genus to consider the two taxa as distinct species.

Habitat and Management Implication:

I have seen several populations in Georgia and the habitat is fair $1 y$ consistent, namely shallow ponds in pinelands or shallow, grassy-sedgey sloughs. Such are usually peat-muck-bottomed, rimmed with growth of Pond Cypress, Pond Pine, Swamp Black Gum, Ogeche Plum, with some undergrowth of Stillingia aquatica,

Cephalanthus, Crataegus, I1ex myrtifolia, Itea, Sambucus, Smilax, Rosa,etc. Grasses and sedges such as Panicum hemitomon, Manisuris, Rhynchospora inundata, $R$. macrostachya, $R \cdot$ perplexa, $R$ : microcarpa, R. tracyi, Eleocharis (several species) dominate, are interspersed with Eriocaulon compressum, sever al Xyris, Polygala cymosa, Hypericum denticulatum, Proserpinaca, Rhexia virginica, R. aristosa, various tu dwigia, Asclépias lanceolata, Hydrocotyle, Bacona caroliniana (with its odd turpentine stink!), various Sabatia, and many 
composites, some of the more consistent being Pluchea rosea, Sclerolepis, Coreopsis nudata. Shrubby Hypericum such as H. $_{\text {. }}$ fasciculatum, H. myrtifolium may sometimes form large patches.

A11 such plants are the sort that thrive on peat-muck substrates that usually are at least wet, but which may, during dry cycles be exposed for brief periods. During such dry perinds the former shallows may burn, this doubtless maintaining or increasing grassmsedge formations.

Several stations for 0 . canbyi have been lost in recent years. In many instances the shal10w pineland ponds hare been drained and converted to lowland pasture, with e remaining becoming dominated by pasture grasses. In other cases the ponds have been converted to stock tanks as well as reservoirs for irrigation water and under such management, which involves deepening by dredging as well as ditching, the Oxypolis is 1ost. In still other cases the drainage is done so as to provide drier sites either for cropland or for pine plantation, in either event resulting in total destruction of the habitat.

\section{References:}

Coulter, J.M. \& J. N. Rose. 1900. Monograph of the North American Umbe11iferae. Contribs.U.S. Nat.Herb. 7 (1): 1-256.

Fernald, M.L. 1939. Oxypolis canbyi (Coult. \& Rose) comb. nov. in Rhodora $41(484): 139$.

- 1950. Gray's manual of botany, ed. 8,pp. 11-2-1103. 
SPECIES: Oxypolis canbyi (Coult. \& Rose) Fernald

\begin{tabular}{|c|c|c|c|c|c|c|c|c|}
\hline $\begin{array}{l}\text { Expected } \\
\text { Effect on } \\
\text { Hab1cat }\end{array}$ & $\begin{array}{c}\text { Pracriba } \\
\text { Burn }\end{array}$ & $\begin{array}{l}\text { Doze or } \\
\text { Root } \\
\text { Rake }\end{array}$ & Bed & Chop & $\begin{array}{l}\text { Th1n } \\
\text { over- } \\
\text { etory }\end{array}$ & $\begin{array}{l}\text { Cut } \\
\text { Over- } \\
\text { Story }\end{array}$ & $\begin{array}{c}\text { Over Plant } \\
\text { w1 th } \\
\text { trees } \\
\end{array}$ & Graze \\
\hline Deecroy & & $X$ & $X$ & $X$ & & & $X$ & \\
\hline Damage & & & & & & $X$ & & $X$ \\
\hline $\begin{array}{l}\text { No Lasting } \\
\text { Effect }\end{array}$ & & & & & & & & \\
\hline $\begin{array}{l}\text { Banaficlal } \\
\text { If Done } \\
\text { Proporly }\end{array}$ & & & & & & & & \\
\hline
\end{tabular}

Other Commente: Drainage of site is fatal to this species!

\section{*Egt1mated effect 18 an eat1mate of the author based on his book knowledge of the habitat and on knowledge gained from personal field observations. Estimates are "rough" in many instances. Results of practices may vary in degree of application, intensity, nearness to plant communities, etc. A column left "blank" lndicates a lack of sufficient information from which to predict expected results. As observations are made 1 n the fleld by users of the data, predictions should be reflned by area and by intensity of forestry practices.}


Oxypolis canbyi (C. \& R.) Fern.

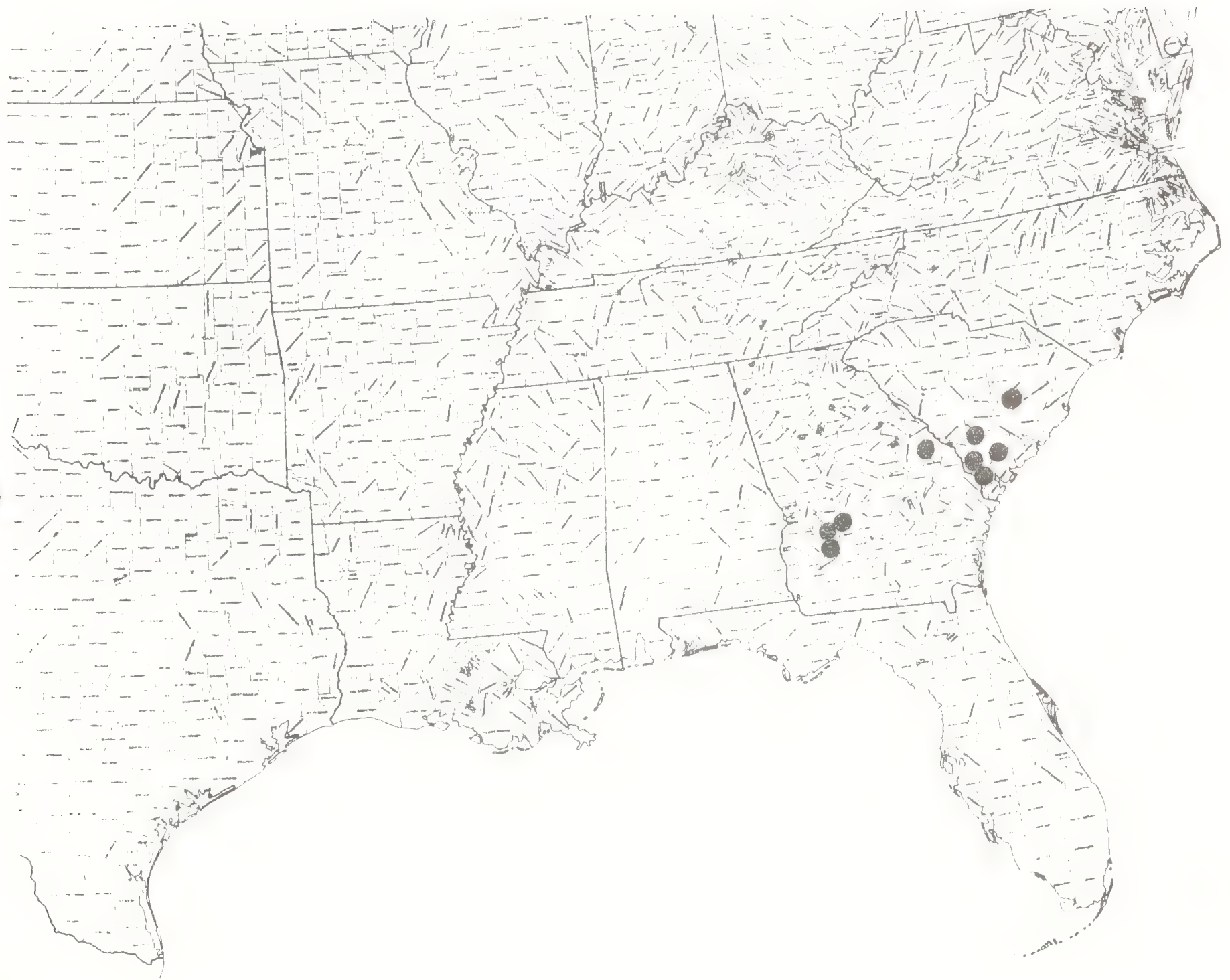


-

-

:

- 
Paper 258

Text and map by: Robert Kral

\section{APIACEAE}

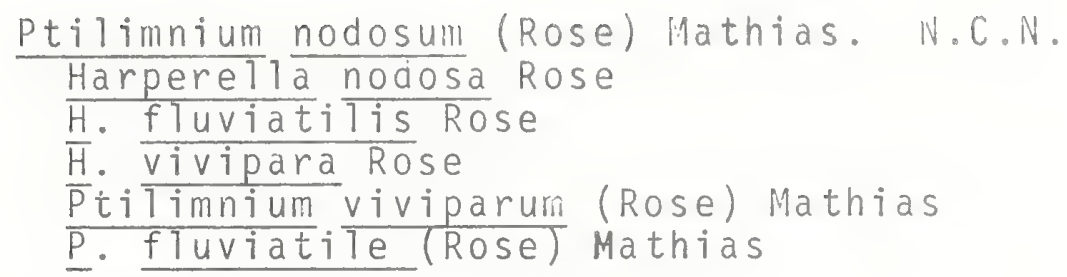

Technical Description

Mostly annual, sometimes producing roseties from buds off lower nodes, the roots shallow, diffuse-fibrolis, the plants with a faint scent of di11.

Stems. - - Erect from shori-aecumbent base, fistulose, froiii 1 to 12 dm high (size dependent on site and spacing of plants), stiffish or weak, solitary or tufted, the lower nodes numerous, often rooting, the erect portion toward base mostly 3-5 mm thick, subterete, multicostate, purplish-tinged, upwardiy becoming strongly angulately ribbed and green, toward base usually unbranched, from mid-stem up strict to near apex or alternately (rarely oppositely) branching, with branches arching-ascending to nearly erect.

Leaves.--Phyllodial (actually compound but reduced to a mere rachis), tubular, lineal with broadly clasping bases, the rosette and lower ones often 3-4 dm long, variable in width, some slenderly linear, some broader, fleshier, 3-5 mm thick, in any case cross-septate at regular intervals, sometimes constricted at septations in thicker leaves; phyllodia becoming shorter, more distant upward on stem, grading gradually to short-linear bracteal leaves. Inflorescence.--A compound of compound umbels, on the stricter plants these rather few and close together at tips of essentially axillary peduncles, these mostly erect, up to $1 \mathrm{dm}$ long, mostly shorter; primary rays 5-15, stiffiy erect or spreading, 5-20 mor long, subtended by an involucre of short, spreading, subulate or lance-subulate bracts rarely ionger than $0.5 \mathrm{~mm}$, the secondary rays (pedicels) mostly 5-15, 1-5 mm 1ong, subtended by a weak involucre, these bracts mostiy under $0.5 \mathrm{~mm} 7 \mathrm{ong}$. Flowers.--Bisexual or unisexual, regular, each small umbel containing both perfect and male florets the male usually toward center and shorter-pedicelled; hypanthium of bisexual florets at anthesis ca. 0.5 mm high, broadly campanulate, indented along the commisure, the round-backea siaes ionyituuild liy ribbeú; calyx lobes 5 , narrowly triangular-subulaie, green or tinged with rose, ca. $0.5 \mathrm{~mm}$ iong, spreading, sometimes incurved-tipped, persisting on fruit; petals white, short-clawed, the blades somewhat fleshy, suborbicular, strongly incurved, apically short-acuminate, the mid-nerve somewhat raised above; stamens 5, the spreading to incurved, white, tapering filaments 0.5-1.0 mm long, the ellipsoidal-oblong bilocular anthers yellowish to reddish, dorsifixed, introrse, to $0.5 \mathrm{~mm}$ long; ovary inferior, contained in perianth tube, crested by a bilobed, low-conic yellowish to pale pink stylopodium $0.2 \mathrm{~mm}$ high, the style branches slenderly linear, spreading, 0.3-0.4 mm long, Fruit.--Schizocarp broadly elliptical in outline, $1.5-2.0 \mathrm{~mm}$ long, slightly compressed laterally (broad plane of fruit perpendicular to commisural plane), thus fruit broadly oblong in cross section; mericarps in cross-section semicircular, along the comisural border with an elevated, spongy-thickened band, the rounded backs with 
3 strong, green or tan longitudinal ribs, the intervals broader, chin over the seed and with solitary oil tubes, dark-reddish-brown; commisural face of mericarp flat or slightly concave, escept for the pale spongy border a dark green or reddish-brown, the oil tubes double.

\section{Distribution and Flowering Season:}

Wet bars, shoals and seepy banks of rocky, fast-flowing streams, wet savanna, shallow pineland pools, ditches and ditchbanks, very local, inner and outer coastal plain, Piedmont, and locally in a few isolated Appalachian localities. Flowering mostly from May into July, intermittently to the end of the growing season.

\section{Special Identifying Features:}

In that populations of quill-leaved Ptilimnium fluviatile (Rose) Mathias show overlapping variation in all characters with equally variable populations of $P$. nodosum, and because many of these characters may vary because of external environment, (i.e. pond versus riverine habitat, substratum character, spacing of plants, amount and character of competing vegetation) and also because none of the characters supposed to distinguish the species have much geographical basis, it is suggested that the oldest available name be used for a complex formerly thought to coitain three species ( $P$. nodosum, $\underline{P}$. fluviatile, P. viviparum (Rose) Mathias). That name is $\underline{P}$. nodosum.

Habitat and Management Implications

The few existing localities known for P. nodosum in the coastal Plain appear to be shallow pineland poñds and Tow savanna meadow. The type locality of the species, a shallow pond near Ellaville, Schiey Co.,Georgia, no longer exists, and other habitat in the area of Unadilla in Dooly Co.,Georgia appears also to have been destroyed. In Aiken Co., South Carolina, two localities are still known; one an area of grassy savanna near Montmorenci is nearly destroyed and the other, a shallow pond (doline) near Monetta, while disturbed, is still in good condition. The central habitat seems to be what is called by the local people "high pond". such hign ponas are snallow, ringeu by willow oaks, swaiip black gurn, sweet gum, pond cypress, and sometimes pond pine. The sijl of the pond edges and b ottom is typically a peat-muck, this overlying fine black sand or sandy-silty-clay, which in turn overlies solution rock. Such ponds have unpredictable shorelines, with water sometimes extending into the bordering forest, at others retreating to the center of the ponds or altogether disappearing. The dominant grass is Panicum hemitomon, with an interspersion of other panicums, cut-grass, Sacciolepis, and sedges such as Rhynchcspora perplexa, R. microcarpa, R. tracyi, R. inundata, R. macrostachya, etc, carex walteri, C. lupulina, $\overline{\text { Eleccharis }}$ tríicostata, E. melanocarpa, E. microcarpa, E. baldwini i, Psilocarya, Dichromena 
colorata, Fimbristylis, admixed with xyris jupicaj, $\underline{x}$. smalliana, $\underline{x}$. fimbriata, Eriocaulon, Juncus, Sagittaria; dicots often include Hypericum fasciculatum, H. denticulatum, H. myrtifolium, Rhexia virginica, 只. mariana, R. aristosa, Proserpinaca pectinata, various Ludwigia such as L. spathulata, L. pilosa, L. sphaerocarpa, $L$. Tinearis, Centel1a, Hydrocotyle, Lindernia, Bacopa caroliniana, sabatia, Lobelia, Polygonum species. Composites may include Coreopsis nudata (in Georgia), c. rosea (in South Carolina), Rudbeckia mohrij, R. nitida (in Georgia). Sclerolepis is nearly always present and is abundant.

In the riverine sites of Alabama, upland North Carolina, Maryland, Kentucky and West Virginia it is either in or on the immediate banks of swift flowing, clear and rocky streams. In early spring its rosettes are reminiscent of those of some juncus. The substrate reaction is acidic, its associate species are often the same genera of herbs as found with it in the coastal plain. In some of the Alabama localities, particularly along the Little River, it may be abundant locally and may form nearly pure stands. It is never found in heavy shade, but the streams in whose shallows it grows all flow through mixed mesophytic or oak-hickory-pine forest. It is always found in wet soil situations thus it is not suprising that it thrives in spite of periodic flooding so long as its substrate is not washed away. Flooding in the sort of healthy streams it frequents, whose watersheds are usually well timbered, is usually of short duration. However neavy logging of the steep slopes and headwater ravine areas would do much to disrupt such short flood cycles and could reduce such populations by extending the amount and auration of flooding. Much of this riverine habitat has been destroyed through dam building. The coastal plain sites are, as stated earlier, much reduced. The pineland ponds and wet savanna habitats are everywhere being drained either in the process of preparation for pine plantation or row crop agriculture or "improved" pasture.

References

Easterly, N. W. 1957. A morphological study of Ptilimitum. Brittonia 9: $136-145$.

Krä T, R. 1981. Notes on some "quill"-leaved umbellifers. Sida $9(2): 124-734$.

Mathias, M. E. 1936. Studies in the Umbelliferae V. Brittonia $2(3): 239-245$.

Radford, A.E.H.E.Ahles \& C.R. Bell. 1968. Manual of the vascular flora of the Carolinas. Chapel Hill, iN.C.

Rose, J.N. 1905. Two new umbeli iferous plants from the coastal plain of Georgia. Proc. Nat. Mus. 29: 447-442.

1911. Two new species of Harperel1a. Contribs. ivat.

Herb. 13: 789-790.

Smal1, J.K. 1933. Manual of the southeastern fiora, pp. 977-978. Chapel Hill, iN. C. 
SPECIES Ptilimnium nodosum. (Rose) Mathias. N. C.N.

\begin{tabular}{|c|c|c|c|c|c|c|c|c|}
\hline \multirow[b]{2}{*}{$\begin{array}{l}\text { Expected* } \\
\text { Effect on } \\
\text { the Species }\end{array}$} & \multicolumn{8}{|c|}{ Management Practices } \\
\hline & $\begin{array}{c}\text { Prescribe } \\
\text { Burn }\end{array}$ & $\begin{array}{l}\text { Bulldoze } \\
\text { or } \\
\text { Root Rake }\end{array}$ & Bed & Chop & $\begin{array}{l}\text { Thin } \\
\text { over- } \\
\text { story }\end{array}$ & $\begin{array}{l}\text { Cut } \\
\text { over- } \\
\text { story } \\
\end{array}$ & $\begin{array}{l}\text { Establish } \\
\text { Plantation }\end{array}$ & Graze \\
\hline Destroy & NA & $x-\star$ & $x$ & $x$ & & & $x$ & $x$ \\
\hline \\
\hline $\begin{array}{l}\text { No Lasting } \\
\text { Effect }\end{array}$ & & & & & & & & \\
\hline $\begin{array}{l}\text { Beneficial } \\
\text { if Done } \\
\text { Properly }\end{array}$ & & & & & $x$ & $x$ & & \\
\hline
\end{tabular}

Other Comments: *any site preparative methods involving drainage or soil disturbance would eliminate this species. riverine habitat best protected by careful watershed

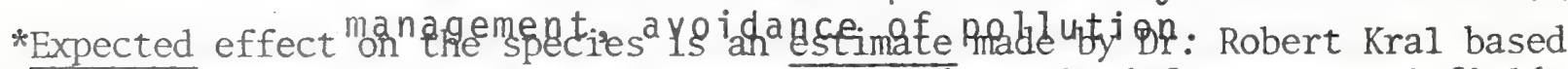
on his knowledge of the habitat and on knowledge gained from personal field observations. Estimates are "rough" in many instances. Results of practices may be modified depending upon the degree of application, intensity of treatment, nearness to plant conmunities, etc. A management practice for which no entry is made indicates a lack of sufficient information from which to predict expected results. As observations are made in the field by users of the data, the expected effect will be refined. 
Ptilimnium nodosum (Rose) Mathias

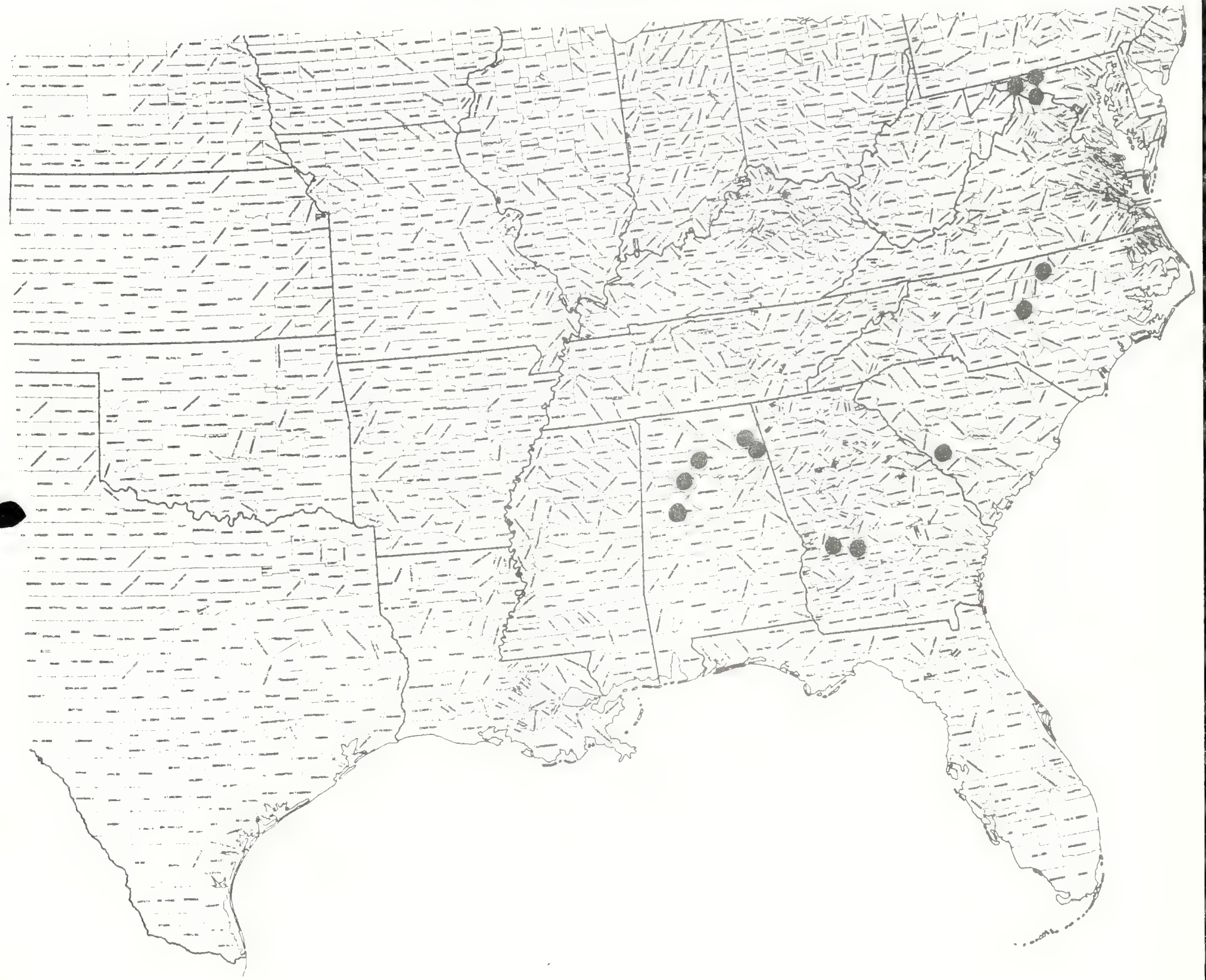


6

6

6 
Papex 258

Text \& map by:

Robert Kral

\title{
APIACEAE
}

\author{
Ptilimnium nodosum (Rose) Mathias \\ Harperel. La nodosál Roso
}

Status: Endangered

Technical Description:

Annual or short-lived perennial with a faint dill odor, perennating by buds from lower nodes, the roots shallow, diffusemibrous.

Stems: Erect from decumbent base, mostiy $6-9(-12)$ dm tal1, solitary or in tufts, the lower nodes numerous, often rooting the erect portion toward base most1y $305 \mathrm{~mm}$ thick, subterete, multicostate, fistulose, purplish-tinged, upwardly becoming strongly angulately ribbed and green, toward base usually unbranched, from mid-stem up strict to near apex or alternately (rarely oppositely) branching, the branches arching-ascending to nearly erect.

Leaves: Phyllodial, tubular, linear with broadly clasping bases, the lower often $3 \mathrm{~m} 4 \mathrm{dm}$ 1.ong, variable in width, some slenderly linear, some broader, fleshier, to $3 \mathrm{~mm}$ thick, in any case cross-septate at regular intervals, sometimes constricted at septations in thicker leaves; phyllodia becoming shorter, more distant upward on stem, grading gradually to short-linear bracteal leaves.

Inflorescence: a compound of compound umbels, on the stricter plants these rather few and close together at tips of essentially axillary peduncles, these most1y erect, from 5-10 cm 1ong; primary rays most 1y 10-15, stiffly erect or spreading, 5-20 mm long, subtended by an involucre of short, spreading, subulate or lance-subulate bracts rare 1 y longer than $0.5 \mathrm{~mm}$, the secondary rays (pedice $1 \mathrm{~s}$ ) most $1 y$ 10. 15, $\quad-5 \mathrm{~mm}$ long, subtended by a weak involucre, these bracts most $1 \mathrm{y}$ under $0.5 \mathrm{~mm}$ 1 ong.

Flowers: Bisexual or unisexua1, regular, each smal1 umbel containing both perfect and male florets, the male usually toward center and shorter-pedicelled; hypanthium of bisexual florets at anthesis ca. $0.5 \mathrm{~mm}$ high in outline broadly campanulate, indented along the commisure, the rounded backed sides longitudinally ribbed; calyx lobes 5, narrowly triangularosubulate, green or tinged with rose, ca. $0.5 \mathrm{~mm}$ long, spreading, sometimes incurvedwtipped, persisting on fruit; petals white, short-clawed, the blades somewhat fleshy, suborbicular, strongly incurved, apically shortwacusninate, the midmnerve raised above; stamens 5, the erect or incurvate, white, tapering filaments 0.5 0.7 $\mathrm{mm}$ long, the ellipsoidal-oblong bilocular anthers reddish, dorsifixed, introrse, ca. $0.3 \mathrm{~mm}$ long; ovary inferior, contained in perianth tube, crested by a bilobed, low conic, yellowish stylopodium $0.2 \mathrm{~mm}$ high, the style branches slenderly linear, spreading, ca. 0.3๓0.4 $\mathrm{mm}$ long, the stigmas capitate.

Fruit: schizocarp broadly el1iptical in out1ine, $1.5-2.0 \mathrm{~mm} 1 \mathrm{ong}$, somewhat compressed laterally (broad plane of fruit perpendicular to commisural plane), thus fruit broadly oblong in cross-section; mericarps in cross-section semicircular, along the commisural border with an elevated, broad, spongyothickened band, the rounded backs with 3 strong, green longitudinal ribs, the intervals broader, thin over the seed and with solitary oil tubes, dark-reddish-brown; commisural face of mericarp concave, except for the pale spongy border a dark reddish-brown, the oil tubes double. 


\section{Distribution and Flowering Season:}

Wet savanna, shallow pineland pools, ditches and ditchbanks, very local, inner Coastal Plain and lower Piedmont, North Carolina south to southwest Georgia; flowering mostly in May and June, intermittent $1 \mathrm{y}$ into Ju1y.

\section{Special Identifying Features:}

This species is very similar to the only other phyllodial-1eaved

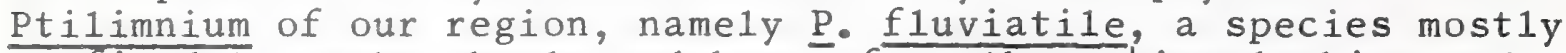
confined to rocky shoals and bars of southern Lppalachian and Piedmont streams. Transitional forms appear within what was once referred to . viviparum (Rose) Mathias, and it might be most logical to consider all as varieties. The main differences appear to be that $\underline{P}$. nodosum is a taller plant ( $P$. fluviatile rarely reaches $6 \mathrm{~d} \overline{\mathrm{m}}$ ) with the lower phyllodia longer. The number of umbels per compound, the number of pedicels per umbellet, is more, generally between 10 and 15 (usually 10 or less in P. fluviatile). The petals are slight1y larger. The commisural edge of each mericarp is a corky-thickened ridge in $\underline{\mathrm{P}}$. nodosum, whilst in $\underline{\mathrm{P}}$. fluviatile this area is taken up by a strong but narrow rib.

Habitat and Management Implication:

The few existing localities known for $\underline{p}$. nodosum appear to be shallow pineland ponds and low savanna meadows. The type locality of the species, a shallow pond near Ellaville, Schley Co.,Georgia, no longer exists, and other habitat in the area of Unadilla in Dooly County Georgia appears also to have been destroyed. In Aiken County, South Carolina, two localities are still known, one an area of grassy savanna near Montmorenci nearly destroyed; the other, a shallow pond (doline) near Monetta, while disturbed, is still in good condition. The central habitat seems to be what is called by the local people "high pond". Such high ponds are shallow, ringed by willow oaks, Swamp B1ack Gum, Sweet Gum, Pond Cypress, and sometimes Pond Pine. The soil of the pond edges and bottom is typically a peat-muck, this overlying black fine sand or sandy-silty-clay, which in turn overlies solution rock. Such ponds have unpredictable shorelines, with water sometimes extending into the bordering forest, at others retreating to the center of the ponds or altogether disappearing. The dominant grass is Panicum hemitomon, with an interspersion of other Panicum, Leersia, Sacciolepis, and sedges such as Rhynchospora perplexa, R. microcarpa, $\bar{R} \cdot$ tracyi, $\underline{R}$. inundata, $\underline{R}$. macrostachya, Carex walteri, C. lupulinā, Eleocharis tricostatā, E. melanocarpa,

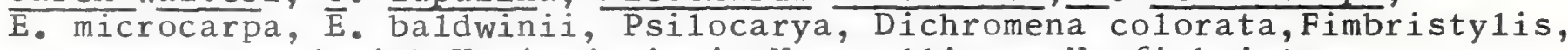
are encountered with Xyris jupicai, X. smalliana, X. fimbriata, Eriocaulon compressum; dicots often include Hypericum fasciculatum,

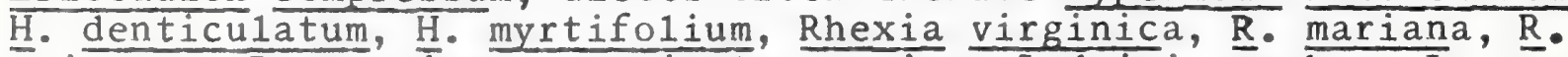
aristosa, Proserpinaca pectinata, various Ludwigia such as L. spathulata, L.: pilosa, L. sphaerocarpa, L. linearis, Centella, Hydrocoty $1 \mathrm{e}$, Lindernia, Bacopa carolinianā, Justicia angusta, Lobelia, Sabatia, Polygonum. Composites may include Coreopsis nudata (in Georgia), C. rosea (in South Carolina), Rudbeckia mohrii, R. nitida (in Georgia). Sclerolepis is nearly always present and abundant. 
Most of the few known localities have been destroyed. The main threat is either from use of the shallow ponds as stock tanks and as sources of irrigation water for adjacent fields, or from drainage preparatory to pine plantation. Another is from drainage followed by conversion to row crop agriculture.

\section{References:}

Radford, A.E., H.E. Ahles \& C. Ritchie Bel1. 1968. Manual of the vascular flora of the Carolinas, pp.784-786.

Rose, J.N. 1905. Two new umbelliferous plants from the coastal plain of Georgia. Proc. Nat. Mus. 29: 4411-442.

.1911. Two new species of Harpere11a. Contribs. Nat. Herb. 13: 789-790.

Sma11,J.K. 1933. Manual of the southeastern f1ora, pp. 977-978. 
SPECIES: $\quad$ Ptilimnium nodosum (Rose) Mathias

\begin{tabular}{|c|c|c|c|c|c|c|c|c|}
\hline $\begin{array}{l}\text { Expected } \\
\text { Effect on } \\
\text { Hab1tat }\end{array}$ & $\begin{array}{c}\text { Prescrlbe } \\
\text { Burn }\end{array}$ & $\begin{array}{l}\text { Doze or } \\
\text { Root } \\
\text { Rake }\end{array}$ & Bed & Chop & $\begin{array}{l}\text { Thin } \\
\text { over- } \\
\text { etory }\end{array}$ & $\begin{array}{l}\text { Cut } \\
\text { Over- } \\
\text { Story } \\
\end{array}$ & $\begin{array}{c}\text { Over Plant } \\
\text { wth } \\
\text { trees } \\
\end{array}$ & Graze \\
\hline Destroy & & $X$ & $X$ & $x$ & & & $x$ & K \\
\hline Damage & & & & & & & & \\
\hline $\begin{array}{l}\text { No Last1ng } \\
\text { Effect }\end{array}$ & $X$ & & & & $X$ & $x$ & & \\
\hline $\begin{array}{l}\text { Beneficlal } \\
\text { If Done } \\
\text { Properly }\end{array}$ & & & & & & & & \\
\hline
\end{tabular}

other Commente: Drainage destroys the habitat!

* Est1mated effect 18 an est1mate of the author based on h1s book knowledge of the habltat and on knowledge galned from personal field observations. Estimates are "rough" in many instances. Results of practices may vary in degree of application, intensity, nearness to plant communities, etc. A column left "blank" indicates a lack of sufficient information from whlch to predict expected results. As observations are made in the field by users of the data, predictions should be refined by area and by intensity of forestry practices. 
Known Distribution of:

Ptilimnium nodosum (Rose) Mathias

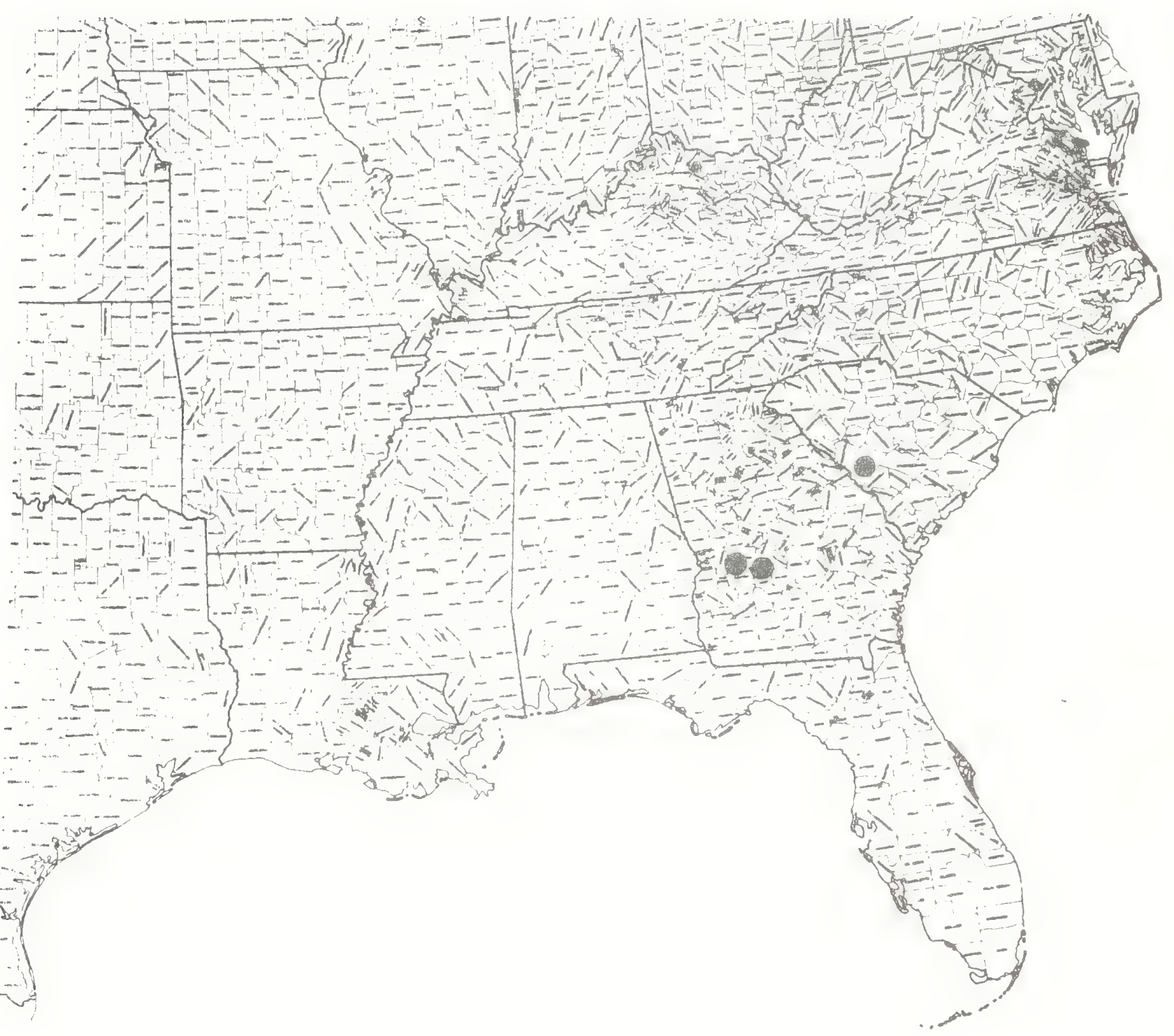




\section{ARISTOLOCHIACEAE}

\section{Hexastylis contracta B1omquist}

Status: Threatened

Technical Description:

Perennial, evergreen, ginger-smelling Heartleat, increasing by short, ascending, branching rhizomes, these with fascicles of fleshy, linear roots and with strongly raised leaf scars, the branches al1 floriferous, numerous enough on older plants to form densely leafy low domes. of leaves.

Leaves: alternate, of 2 sorts; scale leaves thin, nearly round but sharply folded, venose, tan, viewed from side semicircular, falciform, to $1 \mathrm{~cm}$ long, the hinge straight or curved, the margins entire but often villose, enfolding the tloral stalk base; foliage leaves of previous season persisting often beyond current season's flowers, new ones developing above scale leaves on tresh growth, erect or spreading on slender, elongate, claspingbased petioles 6-15 cm long, pale green or suffused with red pigments, the upper side grooved, all sides smooth or distally scabrompuberulent, the blades suborbicular to reniform or very broad1y ovate, 4-7 cm long, leathery, apical1y narrowly rounded, broadly rounded, obtuseangled, rarely emarginate, the margins entire, narrowly inrolled, thus there thickened, the bases cordate-auriculate, the broadly rounded auricles overlapping or presenting an acute or oblong outline sinus, smooth, the upper surface lustrous deep green, impressed veiney, rarely paler along the main veins, the lower surface somewhat paler, slightly raised veiney and quite pale along the main veins, sometimes also with suffusions of red pigment generally.

Flowers: solitary from axillae of scale leaves, but usually 2 or 3 per short rhizomal branch, thus often quite numerous on older plants and forming a compact clump of blooms, the slender, terete peduncles erect or ascending, $0.5-2.5 \mathrm{~cm}$ long, accrescent, usually hidden by scale leaves at early anthesis, much elongate by late anthesis or fruit, pale but often with much red or purple pigment distal1y; perianth comprised of sepals on 1 y, fleshy; sepals 3 , most $1 \mathrm{y} 1.5{ }^{2} .5 \mathrm{~cm}$ long, united to form a flaskmshaped tube, this narrowed at base, flaring at about the lower $1 / 3$ to form a low, rounded flange, then narrowing slightly to the rim, here with the lobes broadly triangular, spreading, $5 m 7 \mathrm{~mm} 10 \mathrm{ng}$, the apex obtuseangled, the sides rounded; external surface of perianth tube fleshtoned or pale green or pale lavender with dark, parallel nerves, these branching and anastomosing in the lobes; internal surface with lower $1 / 3$ of tube raised-purple-reticulate, the ridges low, above this with upper tube smooth and ridgeless, the lobes sparsely villose-puberulent with some hairs having swollen purplish-pigmented bases, some patches of cells red-pigmented, forming a scrobiculate and patch pattern of red or maroon; stamens 12 in 2 close cycles, united and aris $\mathrm{ng}$ on short,fleshy filaments from near ovary apex, the erect anthers oblong, ca. $3 \mathrm{~mm}$ long, with a short apiculus; ovulary 6-carpellate, inferior, producing apically a rim or ring of 6 , erect, hornlike,fleshy styles and their extensions, these extensions narrowing to a blunt tip of 2 connivent 1 obes $1 / 2$ as long as the extension, thence grooved externally down to the 
roundish stigma "button". Fruit: a berry like, subglobose capsule enclosed within the persistent calyx tube; seeds ca. 3/locule, wedge-shaped, compressed, brownish.

Distribution and F1owering Season:

Dryish to moist, acidic, shaded stream and river banks, ravine slopes, Cumberland P1ateau of Tennessee (Kentucky?) and 1ocal in the Blue Ridge of western North Carolina; flowering in April and May.

Special Identifying Features:

H. contracta appears to be a borderline species between the Iarge group "Virginica" (fide B1omquist, 1957) which have strong ridged-reticulations within the calyx tube base and pale areas along the veins of leaves which tend mostly to be roundish, and the "arifolia" group, which have leaves mostly triangular and a hypanthium which is flask-shaped, and which lacks ridged reticulation within toward base. The style extensions in $\mathrm{H}$. contracta (the hornlike portion of style above the stigma button) is for the apical $1 / 2$ bifid while all other reticulate-tubed species in the same complex have the extension entire or merely notched apica11y. While some other species have a rimlike flare on the calyx tube as does $\mathrm{H}$. contracta, these others develop it medially or distally, while $\overline{\mathrm{e}} \overline{\mathrm{t}}$ is usually well below the middle in ${ }_{\text {H. }}$ contracta.

Habitat and Management Implication:

H. contracta is 1 ocally abundant only in the Cumberlands of Tennessee, there being confined largely to steep, heavily forested streambluffs and ravine siopes that cut through sandstones of the plateau. The soils are thus quite sandy, usually a fine sandy loam, high1y acidic, otten shallow or overlying sandstone detritus, usual1y moist but not wet. In the overstory are gymnosperms such as Canada Hemlock, White Pine, Shortleaf Pine, Virginia Pine, mixed with hardwoods such as Quercus rubra, $Q$. velutina, Q. alba, $\mathrm{Q}$. coccinea, Carya cordiformis, C. tomentosa, Betula lenta, Tilia heterophy 11 a,Acer saccharum, A. rubrum, Liriodendron, the more mesic species increasing1y abundant toward bases of bluffs or ravines. The understory is predominant $1 y$ ericaceous, the commonest being Rhododendron maximum, Kalmia latifolia, various Vaccinium, Uxydendrum, with the Rhododendron most abundant in the ravine bases, sometimes forming almost impenetrable thickets. Associated herbaceous species may include Polystichum, Athyrium, Dennstaedtia, Osmunda, Thelypteris (particularly T. noveboracensis), Adiantum pedatum, many carices, Erythronium, Polygonatum, Medeola, Trillium erectum, stenandrium, Smilacinia, Uvularia, Ranunculus, Hepatica americana, Anemone quinquefolia, Sanginaria, Silene virginica, Stellaria pubera, Dentaria,Cimicifuga racemosa, Actaea, Viola blanda, $\underline{\text { V. hastata, }}$. conspersa,various Scutellaria, Zizia trifoliata, Thaspium, and several woodland composites, most notably Antennaria, Erigeron pulche1lus

These interesting habitats have been much reduced by coal stripmining in recent years, which ruins both streams and surrounding slopes. 
Another problem arises with the heavy cutting of the forests of ravines and streambluffs, with subsequent erosion, over insolation, and invasion by woody and herbaceous weed species. Sometimes this cutting is tollowed by mechanical site preparation which extends down even into some of the shallower ravines and branches. In any event, Hexastylis habitat is destroyed.

\section{References:}

Blomquist,H.L.1957. A revision of Hexasty1is of North America. Brittonia 8 (4): $255-281$.

Radford, A.E., H.E.Ahles \& C.Ritchie Bell.1968. Manual of the vascular flora of the Carolinas, pp. 400-402. 
SPECIES: Hexastylis contracta B1omquist

\begin{tabular}{|c|c|c|c|c|c|c|c|c|}
\hline $\begin{array}{l}\text { Expected } \\
\text { Effect on } \\
\text { Hab1eat } \\
\end{array}$ & $\begin{array}{c}\text { Preacribo } \\
\text { Burn }\end{array}$ & $\begin{array}{l}\text { Doze Or } \\
\text { Root } \\
\text { Rake }\end{array}$ & Bed & Chop & $\begin{array}{l}\text { Th1n } \\
\text { over- } \\
\text { otory }\end{array}$ & $\begin{array}{l}\text { Cut } \\
\text { Over- } \\
\text { Story }\end{array}$ & $\begin{array}{c}\text { Over Plant } \\
\text { with } \\
\text { trees } \\
\end{array}$ & Graze \\
\hline Descroy & & $x$ & $\mathrm{x}$ & $\mathrm{x}$ & & & $x$ & \\
\hline Damage & $\mathrm{x}$ & & & & $\mathrm{x}$ & $\mathrm{x}$ & & $\mathrm{x}$ \\
\hline $\begin{array}{l}\text { No Lasting } \\
\text { Effect }\end{array}$ & & & & & & & & \\
\hline $\begin{array}{l}\text { Beneficlal } \\
\text { If Done } \\
\text { properly }\end{array}$ & & & & & & & & \\
\hline
\end{tabular}

Other Commente: Unless substantial belts of timber along streams and branches are kept, site preparation in the uplands results in much of the erosion moving into ravine bases and stream bottoms,burying vegetation

* Est1mated effect is an est1mate of the authorbaed on hisbook knowledge of the habltat and on knowledge galned from personal fleld observat1ons. Estimates are "rough" 1n many 1nstances. Results of practices may vary in degree of application, Intensity, nearness to plant communties, etc. A column left "blank" indicates a lack of sufficient information from which to predict expected results. As observations are made in the fleld by users of the data, predictions should be refined by area and by intensity of forestry practices. 
Approximate Known Range of:

Hexastylis contracta Blomquist

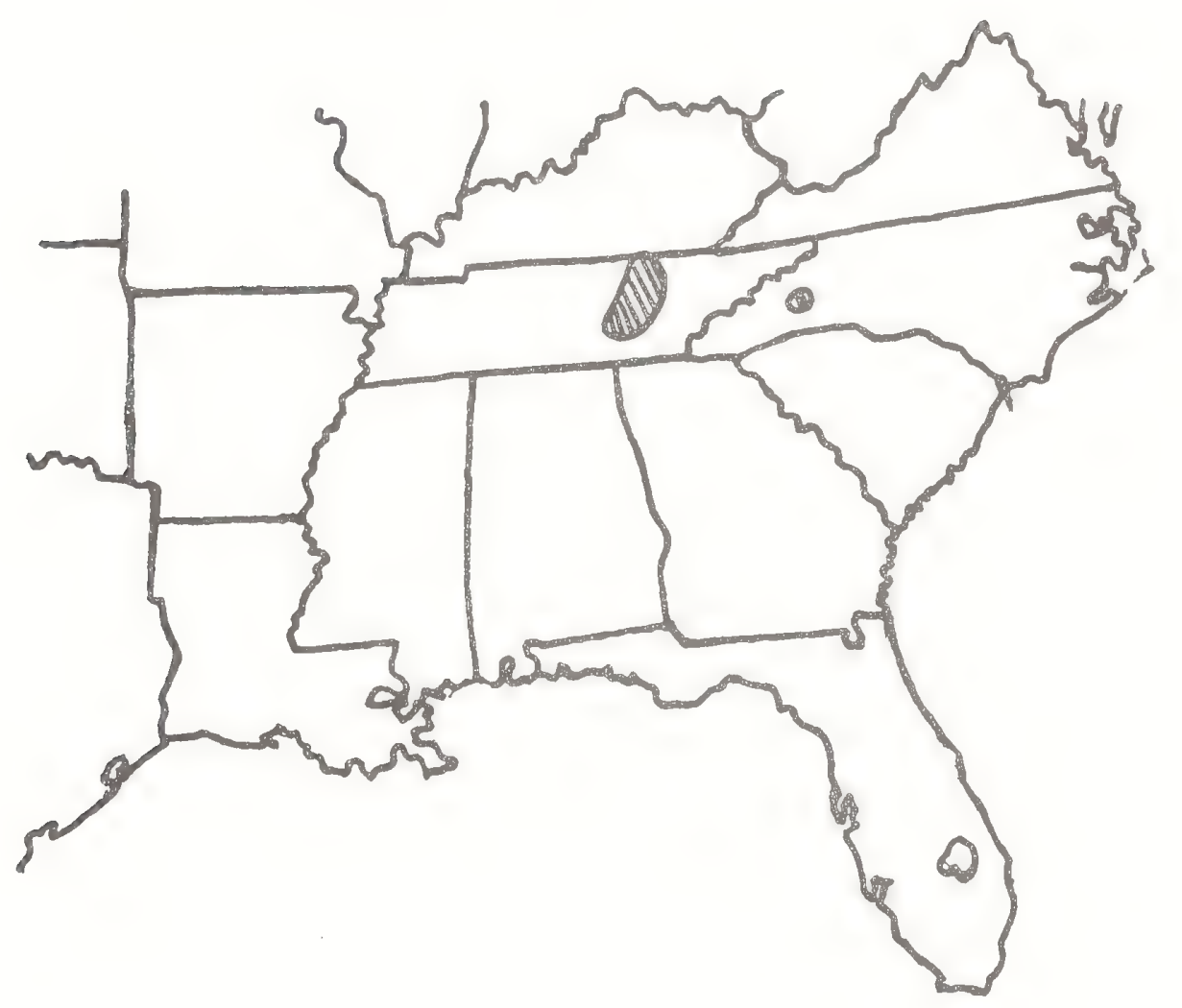




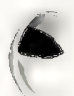

- 


\section{Hexastylis lewisii (Fernald) Blomquist \& Oosting Asarum lewisii Fernald \\ status: Threatened}

l'echnical Description:

Evergreen, ginger-smelling, perennial Heartleaf, increasing by both shallow, horizontal, pale, long-internoded, sterile rhizomes and short, bracteate, tloriferous rhizomes, the primary roots tending to be thickish, with more delicate, fibrous branches.

Leaves: of 2 sorts, one scale-like, often overlapping, subtending petioles and pedicels on short offshoots, broadly ovate or suborbicular, ca. $1 \mathrm{~cm}$ long, strongly tolded and broady talciform when viewed from side, pilose-ciliate, the other developing on both sterileelongate and short-floriferous shoots, erect on clasping based, teretish, fleshy petioles mostly $4-10 \mathrm{~cm}$ long, these grooved on upper side and there often sparsely pilose-puberulent, greenish with tints of red, and blades variable mostly $4-8 \mathrm{~cm}$ long, triangular to broadly oblong-ovate, ovate, suborbicular or reniform, apically broadly or narrowly rounded or retuse, the margin entire, narrowly revolute and tnickened,scabro-ciliate toward base, the base auriculate, the upper surface a rich green, interrupted with broad paler zones along the palmate veins, producing a mottled effect, minutely scabrowpuberulent along the veins, particularly toward the base, the lower surface usually smoother, often stongly tinged with red or purple.

Flowers: arising singly trom axils of scale leaves on shortspreading or erect rhizomatous offshoots, bisexual, regular, the peduncle erect or nodding, terete, smooth, 1.0-1.5 cm 1ong, lengthening in fruit, pale green tinged with purple; perianth $2-3 \mathrm{~cm}$ high, of sepals only; sepals 3, the calyx tube (hypanthium?) $1.5-2.0 \mathrm{~cm}$ long, broauly campanulate, flaring just above its middle to form a horizontal low ridge below the rim, the 3 lobes spreading, broadly triangular, 5-8 mm long, the surfaces externally smooth, pale green or 1 lesh-toned mottled liberally with maroon and with parallel narrow purplish veins, internally with lobes and tube down to level of stamens deep maroon, bedecked with erect, long, bristly white hairs, the lower portion of the tube smooth, pale with paralle1, strongly raised though narrowish, purple, papillose lines, these not with interconnecting ridges; stamens 12 in 2 series, erect, the fleshy tilaments united for most their length to the shortcylindric erect ovary wall and forming a ring around it, the anthers linear with purplish valves and connective, ca. $3 \mathrm{~mm}$ long, basifixed, the connective produced beyond in a short apiculus, the carpels 6 united below in a superior ovary, the 6 erect, hornlike styles and stylar extensions forming a ring around the concave ovary apex, tleshy, linear, ca. '2 mm long, purplish, bearing medially on the outside a papillose stigma "button", the extension beyond apically notched; ovules with axile placentation, numerous.

Fruit: a subglobose, berry-1ike capsule ca. $1.5 \mathrm{~cm}$ Iong, contalned within the persistent fleshy calyx; seeds wedge-shaped, comprossed, carunculate, ca. 3-4 mm long, brown.

Distribution and Flowering Season:

Sandy loam or silty sandy loam of ravine slopes, and ravine bottoms, 
inner Coastal Plain and outer Piedmont, southern Virginia south mostly along the Fall Line, into southeastern North Carolina; flowering mostly from March through April.

\section{Special Identifying Features:}

l'his Heartleaf is part of the largest group, the "Virginica" (tide Blomquist, 1957) of native Hexastylis, these al1 having style not cleft to the stigma button, leaves pale-mottled along veins, mostly cordiform, and calyx tube at least toward base strongly ridged-reticulate. E. lewisii stands out from these by being the only one of the complex to combine the character of 1ong, leafy rhizomes (these often forming extensive patches several meters in area of scattered to approximate leaves) with calyx tube vertically strong1y ridged but not reticulate inside. In addition, while some of this complex produce multicellular trichomes internally on the calyx, this species develops extra long, whitish hairs there which project stiffly inward or upward from the calyx lobes and around the orifice. No other species approaches it in these floral characters.

Habitat and Management Implications:

H. lewisii, like the other Heartleat of the southeastern U.S., Iavors an acidic substratum that is high in sand, is usually a sandy loam, a sandy silty clay loam, or a sandy silt loam, and shaded. The overstory varies considerably in that this Hexastylis is tound in everything from creek bottoms to tops of ridges. Thus it may be on low sandy rises under bottomland hardwoods, on cutbanks in same, in narrow ravines whose bottoms have mixed mesophytic torest prevalently the beech-maple tacies, in low sandy woods heavy with canebrakes and Loblolly Pine, or dry to moist ravine slopes under pine-hardwood with heavy understory of heaths, particularly Kalmia,Vaccinium, or oak-pine crests with the forest floor carpeted with lowbush Vaccinium and Braken Fern. However, the best populations are in the lower ravine slopes and bottoms, usual1y terny, and with many colorful spring torbs as associates.

Most who have seen $H$. lewisii in the field comment on the fact that it develops 1ots of leaves and length, but few or no flowers. My own observations are the same, but some light on this may be shed when one notes that the "heaviest" flowering is from plants with shoots creeping up rises around tree bases or on steep cutbanks, where the axis of the floriferous shoot is inclined. In that this plant is somewhat "viney" in character, it may be 1 ike some viney Aristolochia which may grow profusely over the ground but do not flower much except when climbing.

'l'hreats to this species is many. First, it is endangered by conversion of the upland pine-hardwood to plantation pineland. Usually this involves a clearcut, followed by mechanical site preparation. While the rich bluffland along major streams is not effected usually, the smaller ravines and bottoms are, because of siltation resulting trom such disturbance. Very often a small stream bottom may be buried under many inches or even feet. Heavy logging of bottoms 
and ravine slopes is nearly as damaging. Hexastylis plants are shallowly rooted and may be washed away in the subsequent erosion. such plants require loamy substrates and shade of the forest that contributes to the loam; they do not increase, in fact normally do not maintain, in tull sun. In addition, heavy logging results in an increase of woody weeds in genera Lonicera, Rubus, Smilax, Pueraria, etc。, which tend to choke out forest herbs. selective or group-selective cutting would be a more suitable approach to such ravine and bottom habitat if the Hexastylis is to be kept.

\section{References:}

Blomquist, H.L. 1957. A revision of Hexastylis of North America. Brittonia 8(4): 255-281.

Fernald, M.L. 1943. Asarum lewisii in Rhodora 45: 398-400.

Radtord, A.E.,H.E.Ahles \& C. Ritchie Be11. 1968. Manual ot the vascular flora of the Carolinas, pp. 400-402. 
SPECIES: Hexastylis lewisii (Fernald) Blomquist and Oosting

\begin{tabular}{|c|c|c|c|c|c|c|c|c|}
\hline $\begin{array}{l}\text { Expected } \\
\text { Effect on } \\
\text { Habltat }\end{array}$ & $\begin{array}{c}\text { Preacriba } \\
\text { Burn }\end{array}$ & $\begin{array}{l}\text { Doze or } \\
\text { Root } \\
\text { Rake }\end{array}$ & Bed & Chop & $\begin{array}{l}\text { Thin } \\
\text { Over- } \\
\text { gtory }\end{array}$ & $\begin{array}{l}\text { Cut } \\
\text { Over- } \\
\text { Story }\end{array}$ & $\begin{array}{c}\text { Over Plent } \\
\text { wth } \\
\text { trees } \\
\end{array}$ & Graze \\
\hline Destroy & & $\mathrm{X}$ & $x$ & $\mathrm{X}$ & & $\bar{X}$ & & \\
\hline Damage & $\mathrm{X}$ & & & & $\mathrm{X}$ & & & $\mathrm{X}$ \\
\hline $\begin{array}{l}\text { No Lasting } \\
\text { Effect }\end{array}$ & & & & & & & & \\
\hline $\begin{array}{l}\text { Beneficial } \\
\text { If Done } \\
\text { Properly }\end{array}$ & & & & & & & & \\
\hline
\end{tabular}

other Commente: I have observed no plants in pine plantations.

*Eat1mated effect 18 an eat1mete of the author based on h1s book knowledge of the habltat and on knowledge galned from personsl field observations. Estimates are "rough" in many 1notances. Results of practices may vary in degree of application, intensity, nearness to plant communities, etc. A column left "blank" indicates a lack of sufflcient information from which to predict expected results. As observatlons are made 1 n the fleld by users of the data, predictions should be refined by area and by intensity of forestry practices. 
Distribution of:

Hexastylis lewisii (Fern.) Blomq.\& Oosting

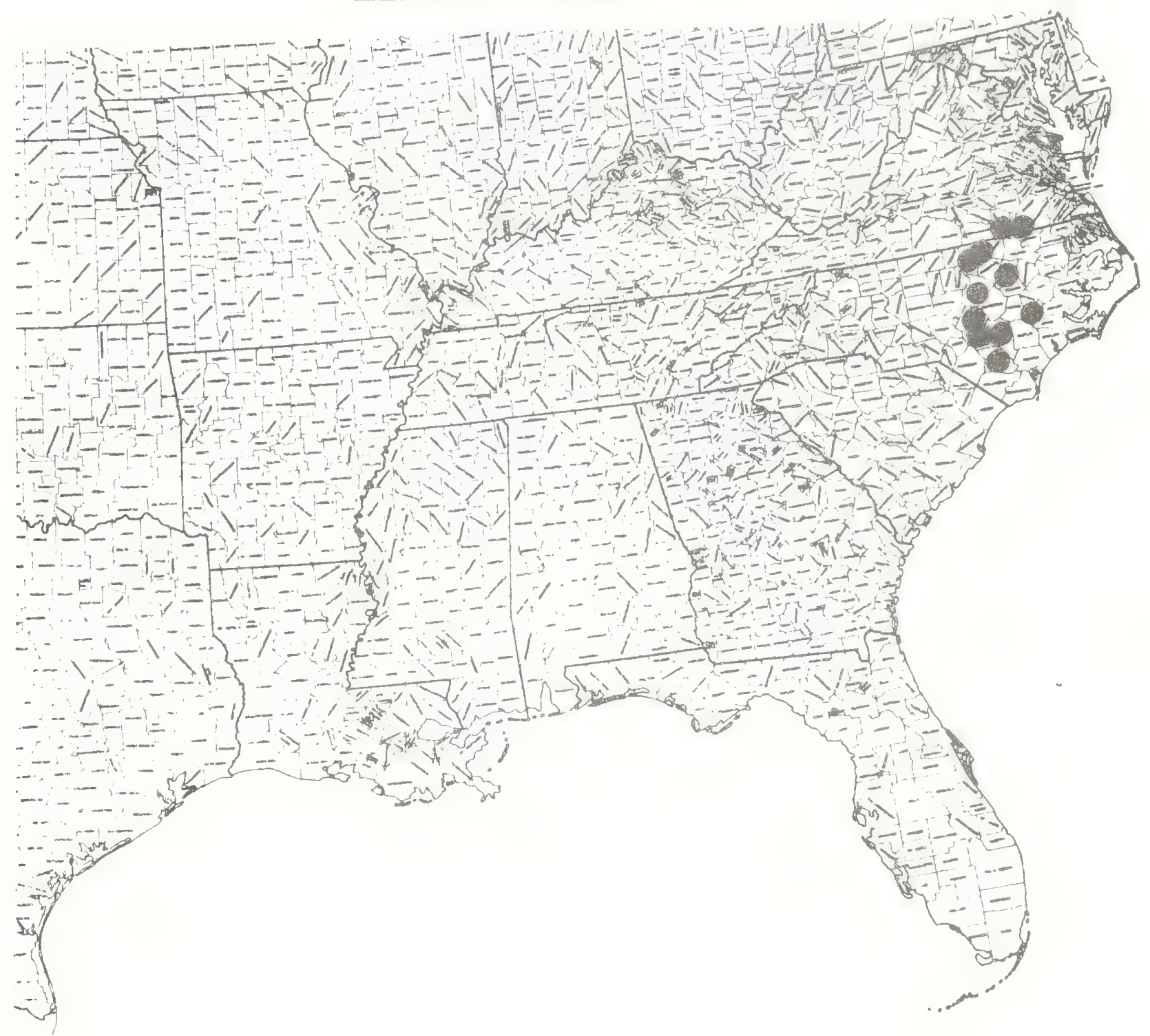


Paper 261

Text \& map by:

ASTERACEAE

Robert Kral

\section{Aster avitus Alexander}

\section{Status: Endangered}

Technical Description:

Perennial, strongly clonalizing Aster, perennating by leafy lateral offshoots from a shallow, sometimes elongate and forking, rhizome, the rhizones mostly 3-8 mm thick, terete, ribbed, often partly covered by fibrous remains of old petiole bases.

Stems: erect from a decumbent base, most1y 3-5 (-8) dm ta11, usually 1 from each leafy offshoot of the previous season, rather slender but stiffish, terete, smooth proximally, puberulent from at least mid-stem into inflorescence, low-ribbed, pale green or with maroon tints in the inflorescence, the nodes numerous and usualiy leafy.

Leaves: Alternate. Rosette (offshoot) leaves and lower cauline leaves largest, $1.5-2.5 \mathrm{dm}$ long, the blades $1 / 2$ or more the total length, linear, eliptic-1inear, linear-oblanceolate or Iinear-lanceolate, graminiform, rarely over $1.5 \mathrm{~cm}$ broad, acute and apiculate, marginally distantly spinulose-serrulate, the base attenuate to the clasping based petiole, the surfaces smooth, a rich green, with only the midrib strong or sometimes obscurely triplinerved, the rest of the surface very finely areolate; cauline leaves grading smaller upward on stem, becoming narrower, shorter, more sessile, becoming lancelinear, scabrid-margined, inflorescence bracts.

Inflorescence: Heads rather few (3) to numerous ( 15 or more) in a simple cyme or a smal1 compound of cymes, the branches densely puberulent, slender, arching-ascending in candelabra fashion, the secondary branches either terminating in 1-2-3 slender peduncles or rebranching from bract axils, in any event the peduncles usual1y longer than the heads are high; flowering heads broad1y campanulate or turbinate, from base to pappus tip $1.2-1.5 \mathrm{~cm}$ high, the bracts strongly imbricated in several series, the 1owermost grading into the short uppermost peduncular bracts, al1 green-tipped with firm (chartaceous) bases, the innermost longest, palest, thinnest, the median ones oblong, mostly $5-6 \mathrm{~mm}$ long, the green tips dilated, often somewhat squarrose, acute and apiculate, the margins ciliolate, the surfaces otherwise smooth, the mid-and-lower part of the bract body straw-colored and very firm; receptacular surface nearly flat, chaffless.

Flowers: Ray florets usually not more than 15, often few, female but usual1y non-functional, the ligules pale to deep violet (rarely pinkish), spreading, above the tube 8-10 mm long, lance-1inear; disc florets numerous, the corollas pale lavender, smooth, ca. 5 $\mathrm{mm}$ long, the slender tube dilating into a narrowly funnelform throat, the 5 spreading or ascending, triangular lobes ca. 1 mm $10 n g$, the anther tube well exsert at anthesis, the 2 style branches with appendages linear-acuminate, externally minutely scabrid. Fruit: Akenes ca. $5 \mathrm{~mm}$ long, columnar or slightly fusiform, sometimes slightly compressed parallel to phyllaries, mostly 10-12-ribbed, the ribs broader than the shallow intervals, the surface dul1 brown, 
smooth or sparsely strigillose (these hairs not usually persisting), the pappus uniform, sordid, of numerous, capillary, antrorse1y barbellate, bristles 1.0.1.5 mm 1ong.

Distribution and Flowering Season:

Shallow sandy soils in or around granitic outcrops, Piedmont, South Carolina and Georgia; flowering from September to frost.

Special Identifying Features:

A. avitus is a perplexing taxon, perhaps not truly distinguishable on the one hand from extremes of A. surculosus (which has similar leaves and rootstocks, but usual1y more heads, a double pappus, hairier truit) and on the other hand tending to the graminiformleaved A. paludosus (which has a coarser pappus, often more heads/ inflorescence and more rays florets). Consistent differences are simply not available, although extremes of A. avitus stand out very nicely from average conditions for either of the others. The entire complex requires taxonomic clarification.

Habitat and Management Implication:

The type 1ocality for A. avitus is Stone Mountain, but that population has been destroyed. My comments are confined therefore to what I have found in the few remaining known localities. Ihis aster is 1ocally abundant in granite glades, is usually rooted in shallow soils of moister depressions in the granitic openings or along the edges of such glades in light shade. l'he substrate is a highly humified, acidic sand, the humus often high in peat trom sphagnum or other mosses. Associated species in the Georgia areas are typical of what one normally tinds around the shallow poo1s, streams or seeps that dot or traverse the rock, some of the more common being Andropogon, Sporobolus, Aristida, Panicum, Cyperus, Scirpus cyperinus, Rhynchospora (mostly R. capiteliata, R. globularis), Commelina erecta, crotonopsis, Senecio tomentosus (rosettes), Hypericum gentianoides, Oenothera fruticosa subglobosa, Rhexia mariana, Agalinis tenuifolia, Liatris microcephala, Solidago erecta, S. nemoralis, Viguieria. The aster is where the substrate is usua11y moistened by seepwater and remains moist through much of the growing season, as is evident from its frequent association with various Sphagnum. Uverstory edging or over the aster is a yellow pine-oak-hickory type, the commonest pines being Virginia, Shortleaf, and Loblolly, the hickories mostly Pignut, Red, White and Sand, the oaks mainiy Black, White, Post, Scarlet, Chestnut, Blackjack, and Red. The understory is dominated by Vaccinium arborescens, Rhus, Cornus florida, Cercis, Amelahchier, Sassafras, Chionanthus, with an abundance beneath these of lowbush blueber ry, Smilax spp.,Poison Oak and Poison Ivy. Japanese Honesuck1e is a common invader, and Braken Fern is common.

l'his aster is losing habitat because of granite quarrying, various detrimental development either for recreational-promotiona1 (which is what destroyed the Stone Mountain locality) or residential (which is destroying the one remaining publicized locality in Georgia!). Logging of the woodlands surrounding or on the granites, if unaccomp- 
anied by excessive disturbance of the shallow soils, might actually tend to increase this aster, as woula fire management, in that fire has been the historical factor in reducing woody plant competition.

\section{References:}

Cronquist, Arthur. 1980. Vascular flora of the southeastern United states, Vo1. I. Asteraceae: pp. 137-162.

Sma11,J.K. 1933. Manual of the southeastern filora, pp. 1364-1394. 
SPECIES: Aster avitus Alexander

\begin{tabular}{|c|c|c|c|c|c|c|c|c|}
\hline $\begin{array}{l}\text { Expected } \\
\text { Effect on } \\
\text { Hab1tat }\end{array}$ & $\begin{array}{c}\text { Prescr } 1 \text { bo } \\
\text { Burn }\end{array}$ & $\begin{array}{l}\text { Doze or } \\
\text { Root } \\
\text { Rake }\end{array}$ & $\mathrm{Bed}$ & Chop & $\begin{array}{l}\text { Thin } \\
\text { Over- } \\
\text { etory }\end{array}$ & $\begin{array}{l}\text { Cut } \\
\text { over- } \\
\text { Story }\end{array}$ & $\begin{array}{c}\text { Over Plant } \\
\text { with } \\
\text { trees } \\
\end{array}$ & Graze \\
\hline Destroy & & & & & & & & \\
\hline Damage & & $N A$ & $N A$ & $N A$ & & & $N A$ & $X$ \\
\hline $\begin{array}{l}\text { No Lasting } \\
\text { Effect }\end{array}$ & & & & & & & & \\
\hline $\begin{array}{l}\text { Beneficlal } \\
\text { If Done } \\
\text { Properly }\end{array}$ & $x$ & & & & $x$ & $x$ & & \\
\hline
\end{tabular}

Other Commente:

*Estimated effect 18 an estimate of the author based on his book knowledge of the habitat and on knowledge gained from pereonal field ubservations. Estimates are "rough" In many instances. Results of practices tnay vary in degree of application, intensity, nearness to plant communities, etc. A column left "blank" indicates a lack of suffictent information from which to predict expected results. As observations are made 1 n the fleld by users of the data, predictions should be refined by area and by tntensity of forestry practices. 
Present Known Distribution of:

Aster avitus Alexander

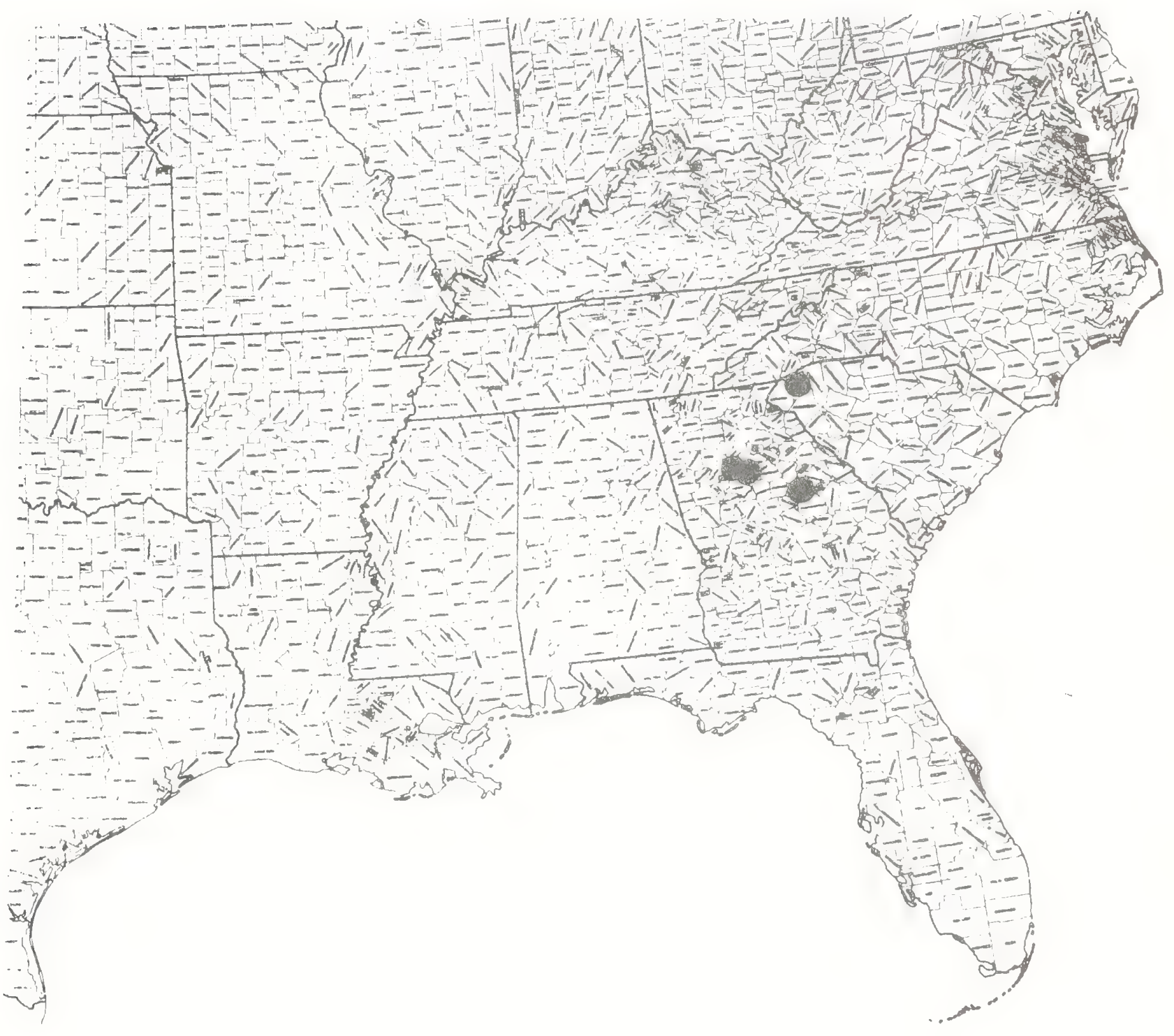




\section{Eupatorium Iuciae-brauniae Fernald}

\section{Status: Endangered or 'Threatened?}

l'echnical Description:

rerennial composite trom a short, thickwcylindrical, or roundish, knobby caudex, the roots diffuse-tibrous.

stems: Erect or ascending, Lwfew trom the caudex, most1y 5-10 dm high, stiffish but soft, slender ( $2-4 \mathrm{~mm}$ thick), smooth, or puberulent in the inflorescenee, terete, sparingly low-ribbed and sometimes grooved, proximally usually purplish, pale green above base.

Leaves: opposite, all spreading or widely ascending petiolate, the lowest smallest, the largest abore midmstem or toward stem apex, their petioles slightly shorter than to slightly longer than the blades, green with purplish tints, slightly angulate, the blades mostly 5-10 cm long, reniform to broadly ovate or suborbicular, or deltoid, apically rounded to short-acuminate, the margins coarsely serrate-dentate, the base broadly cordate to subtruncate, the texture very thin, the surfaces sott-puberulent wich simple (rarely stellate) hairs, the upper much darker yellow-green.

Inflorescence: Heads tew to many in small cymes, these either solitary and terminating the axis, or developed also from subtending nodes, overtopped by or overtopping the uppermost large toliage leaves, in the latter case then with abruptly much smaller bracteal leaves, these lance-ovate, narrowly ovate, or elliptic and grading into even shorter, linear bracteoles in the ultimate inflorescence, the primary and secondary peduncles slender, erect or arching-ascending, smooth or puberulent.

Heads: campanulate, trom base to tip of florets $5-7 \mathrm{~mm}$ high, the involucral bracts erectish, several, the longest mostly in 1 inner series, ca. $3.5 \mathrm{~mm}$ high, but uneven, the shorter few outermost, mostly lance-linear, narrowly triangular, or oblong-linear, most1y narrowly acute, very thin, only the mid-nerve at all prominent, pale green with tints of purple, the backs puberulent; surface of receptacle 1ow-convex, chattless.

Flowers: All tubular, thus regular, bisexual, $12-20 /$ head, the corollas white, ca. $3 \mathrm{~mm}$ long, the slender tube ca. $1 \mathrm{~mm}$ long, the narrowly campanulate throat ca. $1.5 \mathrm{~mm}$ long, the 5, spreading-ascending, triangular teeth ca. $0.5 \mathrm{~mm}$ long, the surface smooth, the exserted slender style branches white, papillose.

Hruit: Akenes in outline elliptic-linear or rarely columnar, sharply angulate-ribbed, 1.5-2.0 mm long, sparsely hispidulous along the ribs; pappus of many, white, antrorsely barbellate bristles, this up to $2.5 \mathrm{~mm}$ long, or in the case of outermost flowers sometimes reduced to a low crown of narrow squamellae ca. 0.3-0.4 mm $10 \mathrm{ng}$.

Distribution and Flowering season:

Shaded sandstones, ledges, rockhouses, cumberland Plateau, Kentucky southward into northern middle Tennessee; flowering from August to 1 rost.

special Identifying Features: 


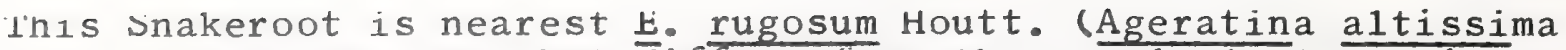
(L.) King \& Robinson, but differs from that variable taxon in its lower, weaker, softer, thinner stem and leat habit, in its smaller petiole length-leaf blade length ratio, its somewhat smaller heads, the akenes of which are hairy (rather than smooth) along the ribs.

Habitat and Management Implication:

Ihis plant, as briefly noted above, is confined to shaded sandstone ledges and overhangs in what are called"rockhouses'. The sandstones, depending on the tormation, weather either to a nearly pure sand or a sand mixed with grave1. The best sites are where shade is provided by the cliffs and ledges plus ravine slope and bottom trees, and much of the moisture is from dripping trom the rock plus mist from talling or splashing water. Sometimes the ledges or overhang bases extend for considerable distances into a cliff or ravine slope, are actually roots of caves of various size and depth. 'the floors of such are often dry as well as deeply shaded and support no vegetation; however, where water seeps, drips, or otherwise accumulates at the mouths of such caves there is usual1y a dense line of vegetation and E. luciae-brauniae abounds. some of its common associates are Carex (several species), Glyceria, Panicum, Agrostis, Stenandrium, Pilea, Boehmeria, Silene rotundifolia, 'Thalictrum clavatum, Houstonia. Herns in genera Adiantum, Dennstaedtia, Asplenium, Dryopteris, Athyrium, Usmunda are abundant, in some places dominant. Lhe overstory is mixed mesophytic in character, with gymnosperms such as White Pine and Canada Hemlock in trequent groves admixed, the hardwoods commonly Ked Uak, White Oak, tlm, Yellow Poplar, Sugar Maple, Red Maple, White Ash,Basswood, the understory with an abundance of Rhododendron maximum, Kalmia latifolia, highbush Vaccinium, liethra acuminata, Alnus serrulata, and cornus.

' 'hreats to this habitat arise trom heavy logging of the steep ravine slopes which promotes erosion of the slopes, choking of the streams and ravine bases, thus burying the bases of the plants during floods. Also, such logging admits too much light, this in turn resulting in drying of the habitat as well as "burning' the toliage of such sciophytes.

Reterences:

Ciewe11, A.F. \& J.W. Wooten. 1971. A revision of Ageratina (çompgsitą: Eupatorieae) from eastern North America. Brittonia

Ferna1d, M.L. 1950. Gray's manual of botany, ed. 8, pp. 1361-1370.

King,R.M. \& Robinson,H. 1970. Studies in the Eupatorieae (Compositae) Xix. New combinations in Ageratina. Hhytologia 19: 208-229.

Wotlurd, B.t. 1976. The taxonomic status of Ageratina luciaebrauniae (Hern.) King \& Robinson. 
SPECIES: Eupatorium LUC1aemprauniae Hernald

\begin{tabular}{|c|c|c|c|c|c|c|c|c|}
\hline $\begin{array}{l}\text { Expected } \\
\text { Effact on } \\
\text { Hab1tat }\end{array}$ & $\begin{array}{c}\text { Pracriba } \\
\text { Burn } \\
\end{array}$ & $\begin{array}{l}\text { Doze or } \\
\text { Root } \\
\text { Rake } \\
\end{array}$ & Bed & Chop & $\begin{array}{l}\text { Th1n } \\
\text { over } \\
\text { tory }\end{array}$ & $\begin{array}{l}\text { Cut } \\
\text { over- } \\
\text { story }\end{array}$ & $\begin{array}{c}\text { Over Plant } \\
\text { wth } \\
\text { trees } \\
\end{array}$ & Graze \\
\hline Destroy & $X$ & & & & $x$ & $x$ & & \\
\hline Damage & & $N A$ & NA & NA & & & $N A$ & \\
\hline $\begin{array}{l}\text { No Lasting } \\
\text { Effect }\end{array}$ & & & & & & & & \\
\hline $\begin{array}{l}\text { Beneflclal } \\
\text { If Done } \\
\text { Properly }\end{array}$ & & & & & & & & \\
\hline
\end{tabular}

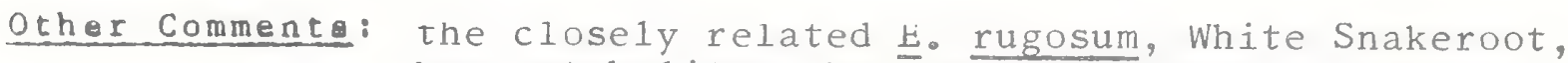
has metabolites that cause Milk Fever disease.

*Est1mated effect 18 an est1mate of the author based on h1 book knowledge of the habltat and on knowledge gained from peranal field observations. Estimates are "rough" In many 1nstances. Results of practices may vary in degree of application, intensity, neariess to plant cominunties, etc. A column left "blank" indicates a lack of sufficient information from which to predict expected results. As observations are made 1 n the field by users of the data, predictions should be refined by area and by intensity of forestry practices. 
Eupatorium Tuciae-brauniae Fern.

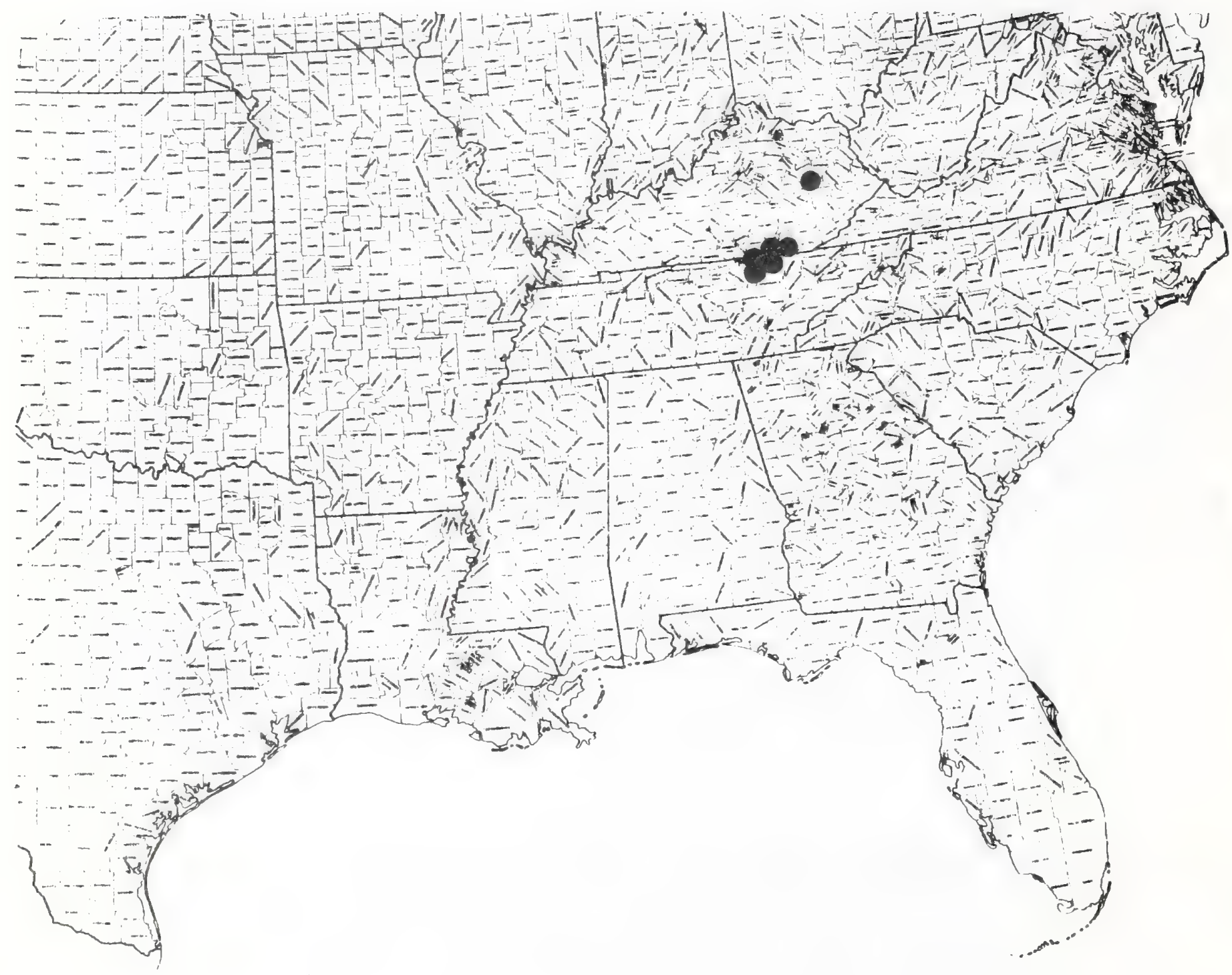




\section{Eupatorium saltuense Fernald}

\section{Status: Endangered?}

Technical Description:

Erect perennia1, most1y 1.0-1.5 meters ta11, the short-decumbent base arising from a short, fleshy, teretish rhizome, the plants increasing by offshoots from the rhizomal crown.

Stems: 1-few in a tuft, terete and 1owmribbed, toward base ca. $\overline{0.5} \mathrm{~cm}$ thick, with internodes short, numerous, brownish, smooth, upstem more elongate, purplish or reddish-brown, increasingly crisped $\rightarrow$ puberulent, the branches densely so, branching none or sparse below the inflorescence, the axillary shoots of main stem usually suppressed.

Leaves: opposite, the lowermost usualiy witherning by anthesis, those at mid-stem usually largest, thence gradually reduced upward to the inflorescence and therein abruptly smaller; larger blades sessile or nearly so, somewhat folded, elliptic-linear or (mostly) lanceolate, spreading or slightly ascending, 5-10 cm long, firm, abruptly acute, the margin regularly and sharply low-serrate, scabridulous, the base cuneate, the upper surface yellow-green, usually smooth, covered with lustrous atoms of resin, indistinctly impressedotriplinerved, the lower surface slightly paler, smooth and resin-dotted save for the raised, puberulent triplemnerves and less distinct other lateral veins.

Inflorescence: basically cymose, a compound of stiffly ascending primary branches, these with spreading, lance-linear, puberulous bracts and toward apex rebranching, the secondary branches terminating in sma11, tightish cymules of heads, the total inflorescence then nearly as wide as long or wider, shallowly dome-shaped or flat or somewhat concave; heads mostly $5-7 \mathrm{~mm}$ high (from base to tip of pappus) cylindrical, the receptacle flattish, narrow, the erect bracts in ca. 3 series, erect and loosely imbricated, the outermost ones much shorter, triangular, the mid-and-inner ones most1y 4-5 mm long, oblong, apical1y narrowly rounded or acute (rarely acuminate), the backs puberulent, greenish and resin-gland-dotted, rounded or slight1y folded along the single evident nerve, the margins toward apex broad, white, scarious, villosulous-ciliate, toward base forming a narrow white border.

Flowers: ca. 6, a 11 discoid, all fertile, the corollas tubular, white, ca. $4 \mathrm{~mm}$ long, the 5 spreading lobes triangular, externally dotted with resin glands, the 2 linear style branches spreading, glistening papillate, spreading.

Fruit: akene dark brown, columnar, acutely and sharply rib-angled, glistening gland-dotted; pappus of numerous, white, antrorsely barbellate capillary bristles ca. $6 \mathrm{~mm} 1$ ong.

Distribution and Flowering Season:

Sandy clay of brushy disturbed clearings, roadsides, edges of fields, Coastal P1ain, southeastern Virginia (Dinwiddie, Surrey, Sussex Counties); flowering from August through September. 
Special Identifying Features:

The status of this taxon is yet argued, muddled in a maze of apomicts involving E. album, E. 1eucolepis, E. hyssopifolium. The most current work done on it was by Dr. Victoria Sul1ivan (unpubiished Ph.D. Thesis, 1972) with Dr. R.K. Godfrey. They have collected from several populations and suggest that the plants are, in regard to suppressed axillary shoots, general aspect, pubescence and flowering heads, very similar to varieties of $\underline{E}$. hyssopifolium, but are broader leaved (lanceolate rather than linear!). They opine that the broader leaf may have arisen by way of $\underline{E}$. album L., or less possibly by genetic influence of E. altissimum L., both of which occur in the same area. I found what appears to be $E$. saltuense along a road in a highly disturbed, brushy ecotoñe between Lobloliy Pinemoak flats and a somewhat higher area dominated by oak and hickory with plenty of E. album in, the openings. In the same place E. hyssopifolium was abundant in clearings in both the higher and lower woods, as well as along the road. The E. saltuense was occasional, mixed with far more individuals of both E. album and E. hyssopifolium and $I$ was able to make some comparisons in the field. E. album, a stockier, firmer and broaderleaved plant with coarser stem and leaf pubescence, showed much Ionger, narrower, paler phyllary tips while the E. hyssopifolium on the other hand tended to be taller, to have shorter hairs on stem and leaves, with blades mostly 1ineal, spatulate-1inear, or elliptic-linear, with lower and fewer teeth. Thus the E. saltuense individuals give every appearance of being intermediate. Herbarium specimens show this same intermediacy.

Habitat and Management Implication:

E. saltuense, suspected to be of recent hybrid origin probably between E. album and E. hyssopifolium var. calcaratum (Sullivan, 1.c.), is to be looked for $i \frac{n}{\text { isturbed sites whe both putative parental }}$ species may grow. E. album, a cmmmon upland Thoroughwort of the area, prefers dryish sands, sandy loams or sandy clays in open stands of oak-pine or brushy upland woodland clearings and pastures created in this type. E. hyssopifolium is by far more abundant, growing in nearly any open woodlands or natural or artificial clearings nearly throughout, so long as they are not boggy or swampy. The two come together in sites such as "brushy pastures", which is what the epithet "saltuense" means. The mystery of this plant is that it is triploid, obviating a complex origin from diploid parents, in that while E. album is diploid, material of E. hyssopifolium so far studied from that area is triploid also. Another unanswered question is why, if such an event has occurred in southeastern Virginia, and if E. album and E. hyssopifolium are found in mixed populations over a many state area, are there not more examples of this hybrid (even if a sma11-chance hybrid)? Material identified as E. saltuense from three counties in eastern North Carolina appea $\bar{r}$ more 1ikely to be E. mohrii or E. anomalum, both putatively of hybrid origin involving other parents. One may conclude about E. saltuense on $1 \mathrm{y}$ (1.) that it is suspected of hybrid origin (2.) that it occurs so far on $1 y$ in recent1y disturbed sites in which the two suspected parenta1 types occur. Clearing of forest in areas where upland and lowland forest or field come together has, then, created the sort of intermedia habitat in which this particular plant can develop. The plants 


\section{E. saltuense, p. 3}

have to maintain apomictically. Preservation depends on locating known populations and maintaining disturbance so as to prevent succession to original forest types.

References:

Fernald, M.L. 1942. Additions to the flora of Virginia. Rhodora $44: 461$.

Johnson, M.F. 1974. Eupatorieae (Asteraceae) in Virginia: Eupatorium L. Castanea 39:205-228。

Sullivan, Victoria I. 1972. Investigations of the breeding systems, formation of automand alloploids and the reticulate pattern of hybridization in North American Eupatorium (Compositae). Unpublished Ph.D. Thesis, Florida State University. 


\section{Eupatorium saltuense Fernald}

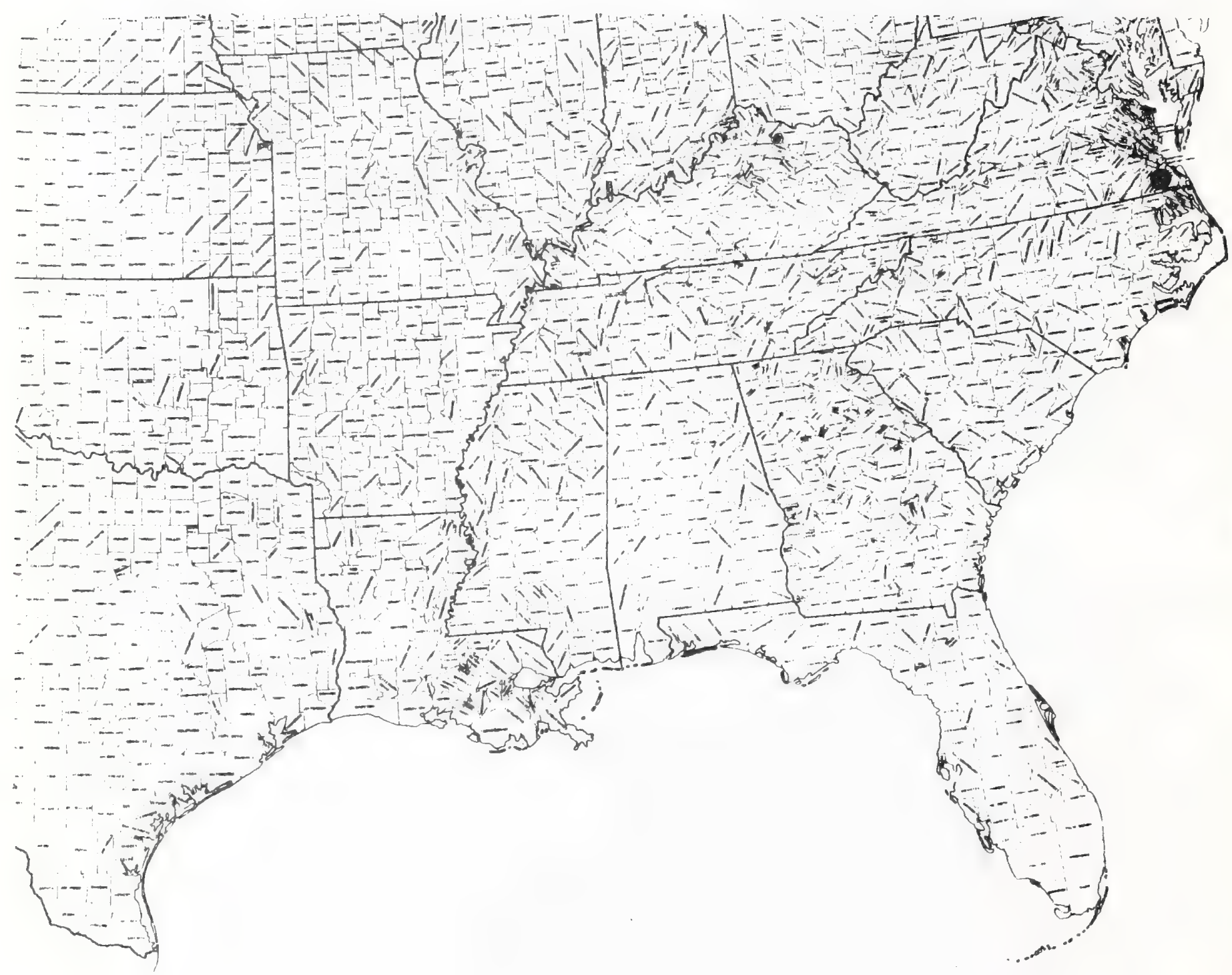




\section{ASTERACEAE}

\section{Helianthus glaucophy11us D.M.Smith}

\section{Status: Threatened}

Technical Description:

Perennial, smoothish sunflower mostly (1-) 1.5-2.5 meters high, from a rather elongate, fleshy, slender rhizome and diffusemfibrous, thickish roots.

Stems: erect, solitary or few, slender but firm, toward base most1y 5-8 mm thick, glabrous, terete, the internodes short toward base, much elongated upward on stem, there pale green, glaucous, finely longitudinally ribbed, branched usually only in the inflorescence. Leaves: opposite throughout, those of the lowex stem withered by flowering time, the larger ones at about midmstem, spreading or ascending, the petioles slender, glaucous, ciliate-based, mostly $2-3(-5) \mathrm{cm}$ long, the blades mostly lancewtriangular or narrowly ovate, $10-18 \mathrm{~cm}$ long, to $7 \mathrm{~cm}$ wide, thinnish, the apex narrowly acute, the margin irregularly corasely serrate save at base, where entire, the base narrowly to widely cuneate, the upper surface a rich deep yellow green, smooth, the lower surface much paler, even glaucous, smooth, glandless (not dotted with small resinous glands), the midrib and primary laterals raised and pale, the rest of the surface a fine reticule of green veins. Leaf blades gradually reduced upward on stem and into inflorescence branches.

Inflorescence: heads few, smallish, on slender scabrid peduncles incymes at $t$ ips of short, terete, slender-and-spreading primary branches from the axils of upper stem leaves, the bracts sma11, most $1 \mathrm{y}$ lanceolate, entire, short-petiolate. Involucre campanulate, ca. $7 \mathrm{~mm}$ high (from base to tip of longer bracts), the phyllaries erectish or with tips only spreading, loosely imbricated in about 3 series, the outer ones narrowly triangular-linear, greenish, narrowly acute, scabromciliate, the bases firm, raised-parallel-nerved, the inner series thinner, somewhat shorter, oblong-triangular, acute, scabrom ciliate, green apically, greenishobrown and raisedonerved at the chartaceous bases; surface of receptacle convex, the chaff (pales) oblong, apically trifid with 3 narrowly acute teeth, the central one longest, ca. 5-6 mm long, pale brown, ciliate, the rounded backs strongly ribbed, hirtellous or strigillose.

Flowers: both ray and disc present, the ray florets female but nonfunctiona1, about 5, the corolla with short (ca. $1 \mathrm{~mm}$ ) tube and spreading, el1ipticmoblong, ye11ow 1igules ca.1.2.1.5 cm 1ong; disc florets tubular, ca. $5 \mathrm{~mm}$ long, deeper yellow, the base constricted with a short, flanged or cupwike basal rim, above the constriction more broadly tubular into the throat, there with 5, erectish triangular lobes, externally smooth.

Eruit: akene oblong, slight1y angulate, ca. 3.5-4.0 mm 1ong, its apex broadly rounded or subtruncate, the surface smooth, lustrous, dark graymbrown; pappus rather early deciduous, of 4 unequal, subulate ciliate awns to $2 \mathrm{~mm}$ long。 


\section{Distribution and Flowering Season:}

Cool moist upland woods, Blue Ridge, western North Carolina and eastern Tennessee at elevations most1y over 2500 feet; flowering from Ju1y into ear1y September.

\section{Special Identifying Features:}

The smoothish, glaucous stems, tall, slender habit, strongly petiolate, most1y lanceolate leaves, and the small heads show that this species is closely related to $\mathrm{H}$. microcephalus, a common and widespread, ecologically ample species throughout most of the southeastern U.S.A. The main difference is that the lower surfaces of the leaves of H. glaucophyllus are smooth and lack the resinous atoms that copiously dot the usually puberulent lower leaf surfaces of $\mathrm{H}$. microcephalus.

Habitat and Management Implication:

H. glaucophy11us is found at elevations usually above 2500 feet in the Blue Ridge mountains, usually in the shade of hardwoods or at their edges, and generally on steep slopes. The substratum is norma11y a sandy loam of a sandy clay loam, this often accumulating amongst granite boulders, and is moist and cool. The overstory is mainly hardwoods such as White Walnut, Bitternut Hickory, Red Oak, White Oak, Tulip, Cucumber Magnolia, Sugar Maple, Red Maple, Ye1low Buckeye, White Ash, Basswood, with an understory of Cornus, Sassafras, Viburnum, Halesia, etc. Ferns such as Adiantum, Dryopteris, Thelypteris, Dennstaedtia, Athyrium are numerous. Grasses such as Bromus purgans, Agrostis, Cinna, Panicum, Brachyletrum, Elymus etc. and sedges in Scirpus, Carex, are frequent together with a rich representation of mesophytic forest herbs such as Disporum, Tri11ium, Polygonatum, Uvularia, Hepatica, Actaea, Cimicifuga, Ranunculus, Sanguinaria, Viola, Sanicula, Angelica, Ligustrum, Impatiens, Physostegia, Scutel1aria, Campanula americana, Eupatorium (particularly E. rugosum, E. maculatum), Heliopsis, Coreopsis, Rudbeckia (particulariy . 1aciniata), Aster, Solidago. In the southern Blue Ridge of North Carolina this sunflower may be associated with the equally rare Coreopsis 1atifolia.

It may be conclusded from the 1 ist of associated herbs above that this is a sunflower of moist, humic soils and full to light shade. The threat to it is therefore clearcutting of the often valuable hardwoods that provide shade and coolness, particularly if this disturbs the soil. There is resultant erosion of exposed soil together with an invasion or increase of woody weeds such as Rubus, Smilax, Lonicera, Parthenocissus, etc. On the other hand, selective or group-selective cutting would reduce such impact significant1y and allow this sunflower to maintain.

References:

Heiser, C.B. 1966. The North American sunflowers (Helianthus). Mem. Torr. Bot. Club 22 (3): 1.218.

Smith, D.M. 1958. Helianthus glaucophyllus D.M. Smith, in Brittonia $10: 142$. 
SPECIES: Helianthus glaucophyl1us D.M. Smith

\begin{tabular}{|c|c|c|c|c|c|c|c|c|}
\hline $\begin{array}{l}\text { Expoctad } \\
\text { Effact on } \\
\text { Habitat }\end{array}$ & $\begin{array}{c}\text { Preceribo } \\
\text { Burn } \\
\end{array}$ & $\begin{array}{l}\text { Doze or } \\
\text { Root } \\
\text { Rake }\end{array}$ & $\mathrm{Bed}$ & Chop & $\begin{array}{l}\text { Th1s } \\
\text { over } \\
\text { etory } \\
\end{array}$ & $\begin{array}{l}\text { Cut } \\
\text { Over } \\
\text { Story } \\
\end{array}$ & $\begin{array}{c}\text { Over Plant } \\
\text { with } \\
\text { trees } \\
\end{array}$ & Graze \\
\hline Descroy & & $\mathrm{NA}$ & $\overline{N A}$ & $\mathrm{NA}$ & & $\mathrm{X}$ & $\mathrm{NA}$ & \\
\hline Damage & $\mathrm{X}$ & & & & $\mathrm{X}$ & & & $\mathrm{X}$ \\
\hline $\begin{array}{l}\text { No Lasting } \\
\text { Effect }\end{array}$ & & & & & & & & \\
\hline $\begin{array}{l}\text { Banoficlal } \\
\text { If Done } \\
\text { Properly }\end{array}$ & & & & & & & & \\
\hline
\end{tabular}

Other Commente:

* Estimated effect 18 an estimate of the author based on h1s book knowledge of the habltat and on knowledge galned from personal field observations. Estlates are "rough" 1n many 1nstances. Results of practices may vary in degree of application, intensity, nearness to plant commities. etc. A column left "blank" indicates d lack of sufficlent information from which to predict expected results. As observations are made in the field by users of the data, predictions should be refined by area and by intensity of forestry practices. 
Approximate Range of:

Helianthus glaucophy11us D.M.Smith

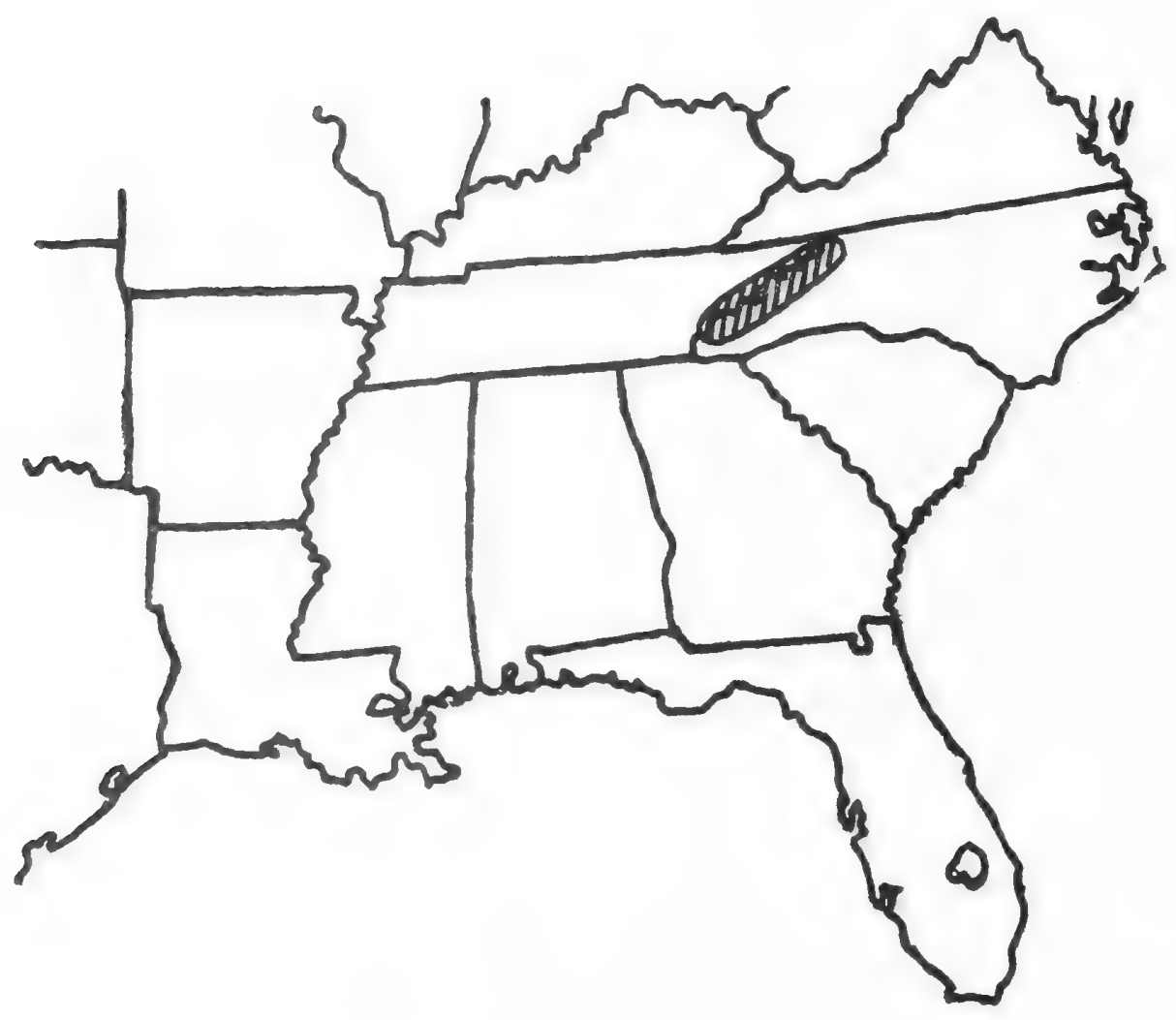




\section{ASTERACEAE}

\section{Polymnia 1aevigata Beadle}

Status: Threatened?

Technical Description:

Pungently aromatic, annual or perennial, bolting from overwintering rosettes, the roots shallow, tap or branched tap, fleshy, strongly tapering, with fibrous laterals.

Stens: one or few from the rootstock, from 1.0.2.5 meters tal1 depending on moisture and richmess of substrate, slender (most ly $0.5-1.5 \mathrm{~cm}$ thick at base), stiffly erect from a shortadecumbant base, fistulose, toward base and at nodes and young tips frequent1y purplish, otherwise pale green, by anthesis smooth, terete, multimlow-ribbed, the nodes toward base crowded and swollen, upward with internodes longer, branching usually only in the upper half, the branches slender, divaricate, opposite, the plant crown therefore broad. Leaves: opposite, spreading or ascending, the lowest and those of rosettes withering by flowering time (save for those of rosettes that do not bolt!), the largest leaves either at very base in spring or in the upper part of the stem subtending branches, these $15-25(-30) \mathrm{cm}$ long, the slender petiole $1 / 4-1 / 2$ the total length, aging smooth or with some villous hairs along the grooved upper side, the blades mostly elliptic, deeply incised-pinnatifid, the lowest lobes very short and distant, the larger lobes, including the terminal, oblong or triangular, their tips narrowly acute or acu minate, their margins saliently triangularly relobed or toothed, the sinuses rounded, sometimes nearly closed, the upper surface a rich dark green, smooth save for the puberulent major pinnate veins and midrib, the lower surface paler, similarly smooth, even to the raised pale veins. Blades of upper stem and branches increasingly distant, more sessile, less 1obed, the uppermost ones often triangular-hastate, those of ultimate branchlets becoming lance-linear or elliptic-linear, less than $2 \mathrm{~cm}$ long.

Inflorescence: heads smal1, most1y $5-6 \mathrm{~mm}$ high, in small cymes, these short-stalked, diffusely arranged on slender, villosulous primary peduncles, or even solitary; involucre very broadly campanulate or cup-shaped, rather loose, the outer phyllaries cupped, foliaceous, green, in few series, the outemost ones narrowly triangular or oblong-lanceolate, to $5 \mathrm{~mm}$ long, obtuseangled or rounded, ciliolate, the backs smooth or sparsely appressed $\rightarrow$ puberulent, the inner broader, somewhat shorter or longer, mostly broadly ovate to suborbicular, strongly cupped, apically broadly rounded, marginally ciliate, the backs approssedmpuberulent, these grading inward to broadly oblong or oblanceolate, thinner and greenish-tipped chaff on the somewhat elevated receptacle.

Flowers: ray florets 5 or fewer, fertile, strictly female, the corollas white, dotted with short, glandular hairs, the tube villosulous, the ligule spreading, apically toothed, mostly broadly obovate, ca. $3 \mathrm{~mm}$ long, the 2 style branches slender, spreading-recurved; disc florets strictly male, ca. 15, the corollas with narrowly tubular base to $2.5 \mathrm{~mm}$ long, the throat short, broadly campanulate, the lobes erect or slightly spreading, triangular, the surface smooth, greenish-yellow or yellowish-white. 
Fruit: akene obovate, ca. $3 \mathrm{~mm} 1 \mathrm{ong}$, short-stalked, subangulate, longitudinally with ca. 5 low ribs, the broadly rounded or subtruncate and indented apex with the pappus forming a short, narrow crown, the fruit surface dark brown, minute1y appressedm puberulous.

Distribution and Flowering Season:

Rich wooded slopes, shaded limerock outcrop areas, scattered localities in Cumberland Plateau, Coastal Plain, and Interior Highlands, Kentucky, Missouri, Arkansas, Tennessee, northern Alabama and Georgia, northern F1orida. Flowering from July (June in Florida) to frost.

Special Identifying Features:

P. 1aevigata is vegetatively rather similar to $\underline{P}$. canadensis, and may be actually in mixed populations with it as well as with the showy-liguled $\mathrm{P}$. uvedalia L. which it resembles not at all. It is distinguished from the former by its smoother, more deeply dissected leaves and narrower leaf segments, its smaller heads, and its akenes which are 4-5-angled rather than 3-angled.

Habitat and Management Implication:

P. 1aevigata is probab1y more abundant in the Cumberland Plateau of southern Tennessee than anywhere else in its known range. Usual1y the plants are in rocky woods, in light to dense shade of mixed mesophytic woods, on moist loamy substrates which may comprise deep soil pockets around or shallow deposits over ledges and large rocks. While early descriptions of habitat indicate that the plant favors somewhat acid soil, this is not always the case. Usually the plants are most abundant over limestone, although this may have over it a detritus of large and smal1 sandstone boulders from upslope, and the soil it is rooted in is often high in clay or is a clay loam. In Jackson County Florida, where it abounds locally in Marianna Caverns State Park, the plants are particularly common on thin moist soil mantles directly over limerock.

As stated above, the best plants appear in shade of mixed mesophytic forest and on moist loamy and rocky substrates. The overstory has in it White Oak, Red Oak (in localities north of F1orida), Shumard Oak, Yellow Oak, Beech, Bitternut Hickory, E1m, Black Locust, White Ash, Sugar Maple, Basswood, Tuliptree, various Magnolia, etc. Herbaceous associates are the typical herbs of rich woods, with abundant ferns, woodland grasses in Chasmanthium, Festuca, Bromus, Brachyletrum, Poa, Elymus, abundant carices, Muhlenbergia, Polygonatum, Uvularia, Trillium, Smilacinia,Hepatica, Actaea, Delphinium, Aquilegia, Sanguinaria, Urtica, Laportea, Tovara, Sanicula, Thaspium, Zizia, Lysimachia, Phlox, Scutellaria, Campanula americana, Impatiens, and an abundance of composites in Aster, Eupatorium (particular1y rugosum), Solidago, Helianthus, etc.

Such sites produce valuable hardwoods and most have been logged at least once; on $1 y$ the steepness of much of the terrain and the 
rockiness of the soil have prevented even more severe impact. In places where I have seen the effect of logging, it is most adverse where an area has been clearcut, in that erosion is severe, washing away the soil in which the Polymia roots. The increased light dries out the soil. Also, suchoperations are usually followed by a massive invasion of undesireable and rank weeds, vines and shrubs (i.e. Loniccra, Nueraria, Rubus, Smilax, Rhus, etc.) which tend to put a lot of pressure on other less agressive species.

References:

Beadle, C.D. 1898. Polymnia laevigata Beadle in Bot. Gaz. 25: 278 .

Sma11, J.K. 1933. Manual of the southeastern flora, pp. 1406-1407.

We11s, J.R. 1965. A taxonomic study of Polymnia (Compositae)。 Brittonia 17 (2): 144-159. 
SPECIES: Polymnia laevigata Beadle

\begin{tabular}{|c|c|c|c|c|c|c|c|c|}
\hline $\begin{array}{l}\text { Expected } \\
\text { Effect on } \\
\text { Hab1tat }\end{array}$ & $\begin{array}{c}\text { Preacriba } \\
\text { Burn }\end{array}$ & $\begin{array}{l}\text { Doze or } \\
\text { Root } \\
\text { Rake }\end{array}$ & Bed & Chop & $\begin{array}{l}\text { Th1n } \\
\text { Over- } \\
\text { etory }\end{array}$ & $\begin{array}{l}\text { Cut } \\
\text { over- } \\
\text { Story }\end{array}$ & $\begin{array}{c}\text { Over PIant } \\
\text { w } 1 \text { th } \\
\text { trees }\end{array}$ & Graze \\
\hline Deatroy & & NA & NA & NA & & $\bar{X}$ & NA & \\
\hline Damage & $x$ & & & & $\mathrm{X}$ & & & $\mathrm{X}$ \\
\hline $\begin{array}{l}\text { No Lasting } \\
\text { Effect }\end{array}$ & & & & & & & & \\
\hline $\begin{array}{l}\text { Baneficial } \\
\text { If Done } \\
\text { Proper } 1 y\end{array}$ & & & & & & & & \\
\hline
\end{tabular}

\title{
Other Commente:
}

\author{
*Estlmated effect 1 a an eet1mate of the author based on h1 book \\ knowledge of the habltat and on knowledge gained from peranal \\ field observations. Estlmates are "rough" in many 1nstances. \\ Results of practices may vary in degree of application, intensity, \\ nearness to plant communities, etc. A column left "blank" 1 ndicates \\ a lack of sufficient information from which to predict expected results. \\ As observations are made $1 \mathrm{n}$ the fleld by users of the data, predictions \\ should be refined by area and by intensity of forestry practices.
}


Distribution of:

Polymnia laevigata Beadle

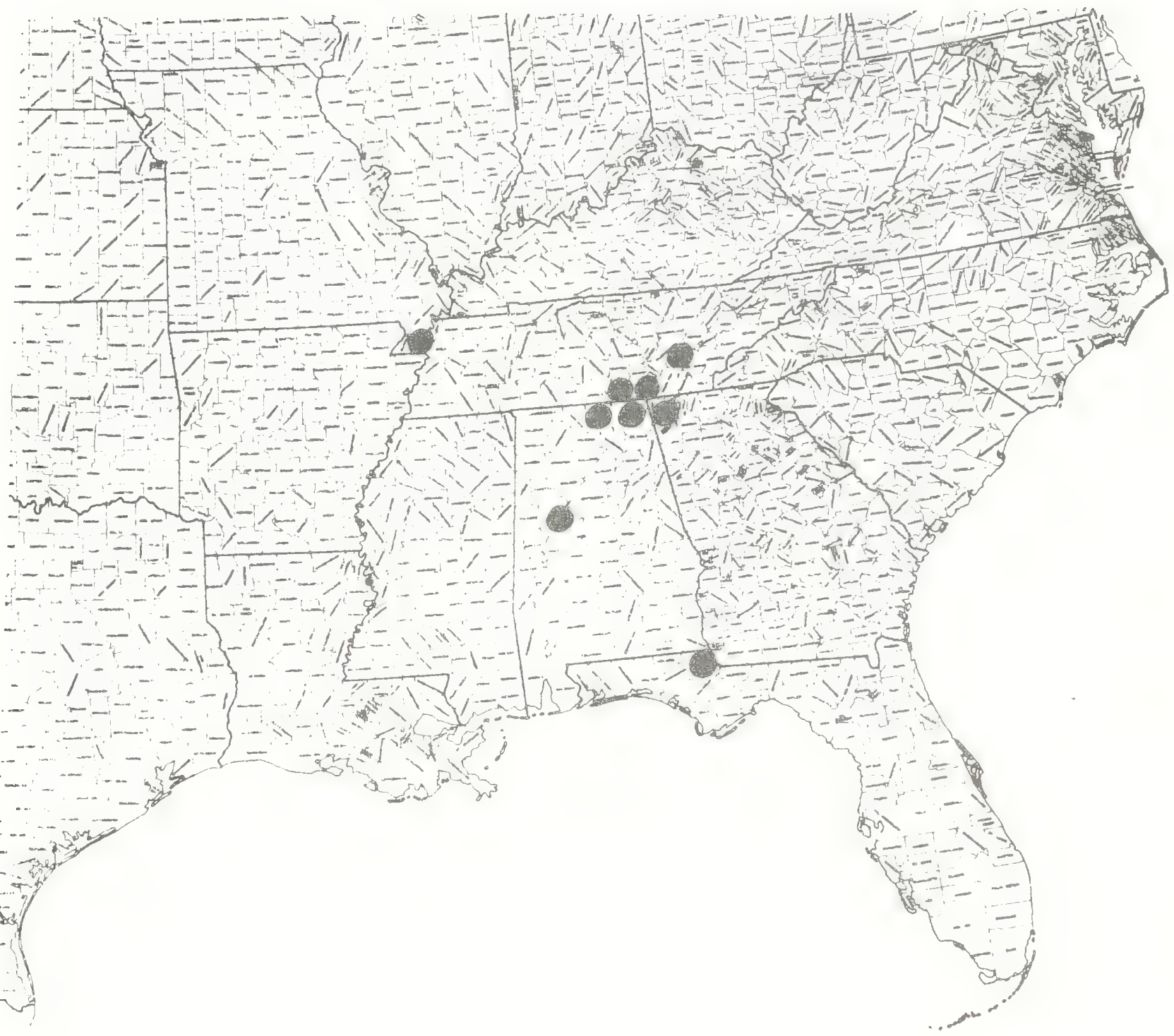


c

-

e 


\section{Solidago pulchra Sma11}

\section{Status: Endangered}

Technical Description:

Rather delicate, smooth, wand-like goldenrod perennating by short lateral rosulate offshoots from a short, erect caudex.

Stems: usually one/rosette, erect, slender (toward base ca. $2 \mathrm{~mm}$ thick $), 3-10 \mathrm{dm}$ high, terete, strongly rounded $\rightarrow$ ribbed, strongly tinged with red or purple, the nodes numerous. Leaves: alternate, plants leafy throughout, the largest stem legves lowermost, the rosette strong and its leaves largest of a11, spreading, $4.8 \mathrm{~cm}$ 1ong, the petioles $1 / 2$ or slightly more of the total length, the blades narrowly elliptic to oblanceolate, firm, acute, the entire margin somewhat thickened, reddish, the base attenuated, the surface yellow-green, only the midrib evident; stem leaves at plant base somewhat smaller than rosette leaves but similar, then grading abruptly to numerous, erect, much smaller and sessile ones, these oblanceolate to narrowly elliptic-oblong or short-linear, and which by midstem are often $1 \mathrm{~cm}$ long or shorter and at inflorescence base rarely $3-4 \mathrm{~mm} 1$ ong. Inflorescence: Heads few (3.15), in a short, rather narrow, sometimes crook-tipped inflorescence, erenly disposed or unilateral, the peduncles erect or ascending, shortish (from shorter than heads to ca. $7 \mathrm{~mm}$ long), slender, angulately ribbed, sparingly to severalm bracteolate. Flowering heads ca. $0.5 \mathrm{~cm}$ from base to tip of florets, broadly campanulate or turbinate, the phyllaries several, loosely imbricated in few series, thin, yellowish, the largest ca. $3 \mathrm{~mm}$ long, apically obtuseangled or narrowly rounded, marginally ciliolate, otherwise smooth, the midrib only evident, this a raised yellowish-resinous band; outermost phyllaries short-1inear, sometimes keeled; receptacle flat, chaffless.

Flowers: Rays about 5, the ligules a bright, pale yellow, spreading obovate, 3.0.3.5 mm long, the flowers female, non-functional; disc florets $20 m 25$, the corollas ca. $5 \mathrm{~mm} 1 \mathrm{ong}$, a deeper yellow, the short tube dilating, narrowly funnelform into the throat, the limb spreading or ascending, of 5, triangular lobes ca. I mm long, the style branches lanceolate, acute, externally papiliose. Fruit: Akene columnar, faintly longitudinal1y ribbed, ca. 1.5 mflong, pale brown, hirtellous, the pappus of white, rigid, capillary bristles reaching about the level of the disc corolla limb.

Distribution and Flowering Season:

Moist sandy peat of flatwoods savanna and pocosin borders, Coastal Plain, two counties in eastern North Carolina; flowering from September to frost.

Specia1 Identifying Features:

My own experience with this seemingly rare plant has been but one sighting, this in Onslow County, N.C. in fall of 1964. My 
reaction then was to identify the plants as rather depauperate S. stricta Ait., with which this species is unquestionably allied. The differences appear to be few, namely that $\underline{S}$. pulchra is consistent1y smaller, lower, more slender than most S. stricta. It produces a short caudex below its rosette as does s. stricta, but has no slender rhizomes as does S. stricta. The heads,inflorescence are few compared to S. str̄icta, ( $3-15$ versus 20 or more). Dr. R.K. Godfrey, a long time and field-experienced student of Asteraceae, tel1s me (pers. comm. 1980) that this kind of morphology shows up through the habitat and range of $\mathbf{S}$. stricta in northern Florida. Such forms should be investigated to clarify the real geographical and taxonomic limits of $\underline{S}$. pulchra.

Habitat and Management Implication:

S. pulchra, as presently understood, is found in moist savanna in eastern North Carolina. My own collection appears to have been the most recent one made, and the habitat information therefore is confined to what was true for that locality. This one area was grass-sedge dominated savanna. The overstory was a dotting of Pinus serotina and $\mathrm{P}$. palustris with some Nyssa biflora and Taxodium ascendens in the lower spots. The shrub growth around the grass-sedge openings was made up most1y of heaths in genera Vaccinium, Zenobia, Leucothoe, Lyonia, Rhododendron, Gaylussacia, Kalmia angustifolia, with Clethra, Ilex glabra, I. coriacea, Myrica, Aronia, Arundinaria, interspersed with taller but shrubby growths of Cyrilla,gordonia, Magnolia virginiana, Rhus vernix and Persea. The soil in such places is a moist, (seasonaliy quite wet) black sandy peat, the openings where this goldenrod was were firemcreated. Among herbaceous associates were Rhynchospora (many species, including R. pallida), Dichromena latifolia, Fimbristylis puberula, F. autumnâiis, Psilocarya, Sc1eria, Eleocharis, Xyris, Eriocau1on, Lachnocau1on, Juncus, Pleea tenuifolia, Lycopodium, Osmunda, Sarracenia, Dionaea,Drosera, Polygala lutea, $\underline{p}$. cymosa, Rhexia, Ludwigia, various compositos including Liatris spicata, Carphephorus, Bigelowia, Marshallia graminifolia, Helianthus, etc. Common Solidago in the area were S. fistulosa, S. rugosa, S. stricta.

Much of this savannambog habitat has now been converted to plantation pineland or to row crop agriculture. Both involve ditch drainage and radical soil disturbance. In the case of mechanical site preparation, plants such as the Solidago may persist for a time in the drier habitat but disappear as the pine establishes.

References:

Cronquist, Arthur. 1980. Vascular f1ora of the southeastern United States, Vo1. I. Asteraceae: pp. 116-133.

Sma11,J.K. 1933. Manual of the southeastern f1ora, pp. 1344-1360 


\begin{tabular}{|c|c|c|c|c|c|c|c|c|}
\hline $\begin{array}{l}\text { Expocted } \\
\text { Effect on } \\
\text { Habltat }\end{array}$ & $\begin{array}{c}\text { Preacribe } \\
\text { Burn } \\
\end{array}$ & $\begin{array}{l}\text { Doze or } \\
\text { Root } \\
\text { Rake } \\
\end{array}$ & $B \in d$ & Chop & $\begin{array}{l}\text { Th1n } \\
\text { over } \\
\text { atory }\end{array}$ & $\begin{array}{l}\text { Cut } \\
\text { Over } \\
\text { Story } \\
\end{array}$ & $\begin{array}{c}\text { Over Plent } \\
\text { wh } \\
\text { trees } \\
\end{array}$ & Graze \\
\hline Destroy & & & & & & & & \\
\hline Damage & & & & & & & & \\
\hline $\begin{array}{l}\text { No Lasting } \\
\text { Effoct }\end{array}$ & & & & & & & & \\
\hline $\begin{array}{l}\text { Beneficlal } \\
\text { if Done } \\
\text { Properly }\end{array}$ & & & & & & & & \\
\hline
\end{tabular}

\section{Other Commente:}

Drainage destroys the habitat!

* Est1mated effect 18 an est1mate of the author baed on h1 book knowledge of the habltat and on knowledge galned from personal field ubservations. Estimates are "rough" in many instances. kesults of practices may vary in degree of application, intensity, nearness to plant commontes, etc. A column left "blank" 1ndicates a lack of sufficient information from which to predict expected results. As observations are made 1 n the fleld by users of the data, predictions should be refined by area and by intensity of forestry practices. 
Solidago pulchra Smalt

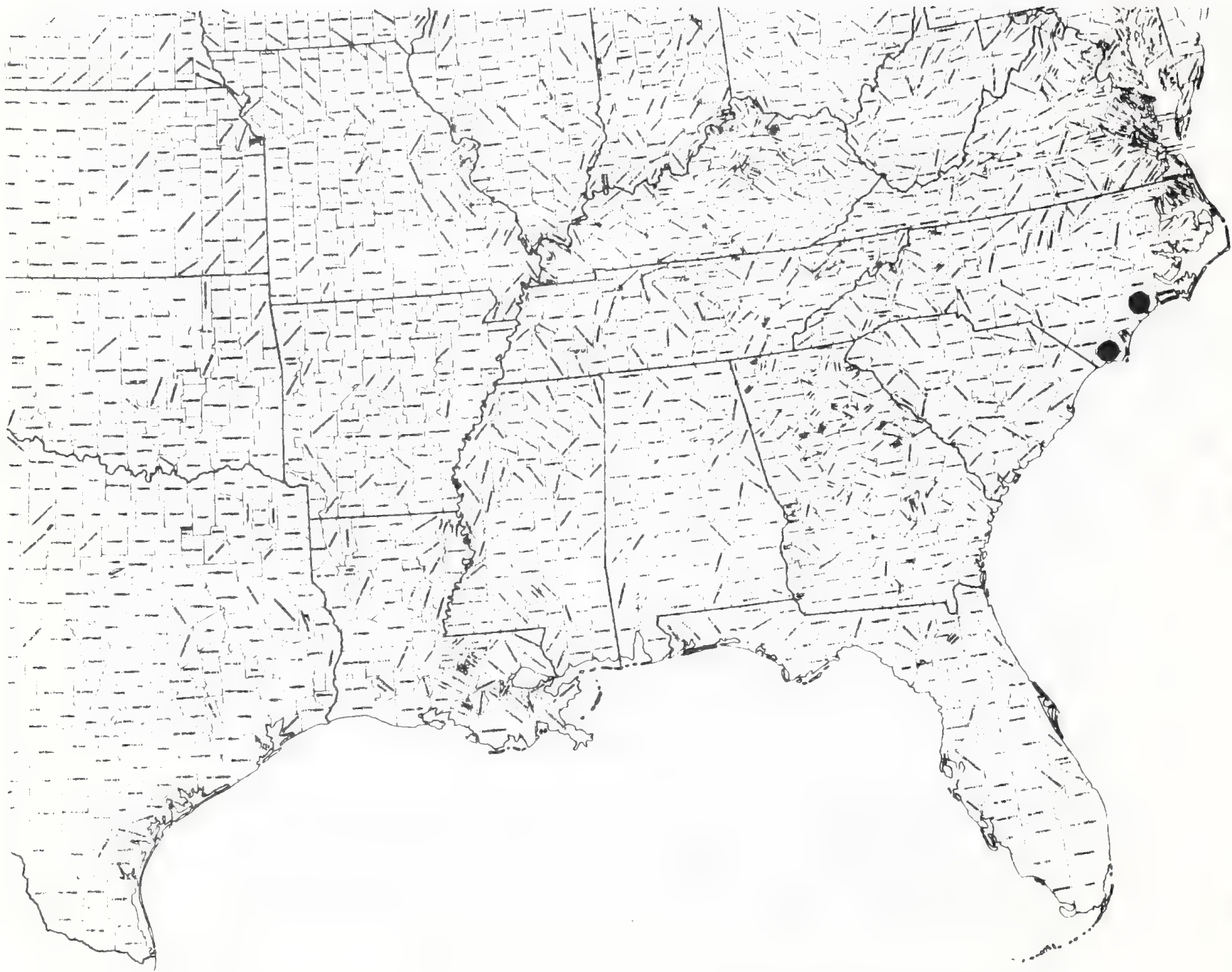


Technical Description:

Perennial goldenrod from a stout (to $1 \mathrm{~cm}$ thick), knotty ascending rhizome or caudex, perennating by short lateral offshoots from crown buds.

Stems: Erect or ascending, bolting from rosettes of the previous year, mostly $0.5-1.5 \mathrm{~m}$ high, solitary or in small clumps, stiffish and straight to somewhat flexuous, to $5 \mathrm{~mm}$ thick at base, terete with several low, rounded ribs, villosulous (with short, kinky hairs) with pale pubeescence throughout, greenish with tints of purple, the upper $1 / 3$ usual1y liberal1y branched, the lowest branches longest, arching upward, then outward.

Leaves: alternate, a1so in rosettes. Rosette leaves largest, usual1y more than $1 / 2$ petiole, $1-3 \mathrm{dm} 1$ ng, the blades suborbicular to broadiy eliptic, obovate or ovate, acute to rounded, the margin crenatemserrate to crenatemdentate, the base abruptly attenuate and decurrent to form a petiolar wing, the upper surface a bright yellow $\rightarrow$ reen, strigillose-puberulent, the lower surface paler, villose-tomentulose, particularly along the raised main veins, the pattern pinnate-arcuate, the petioles slender but winged, stiffly spreading, erect or ascending, marked with maroon along the main ribs. Stem leaves at base similar to rosette leaves, toward mid and upper stem gradually smaller, elliptic to ovate or lanceolate, erectish, grading to short, oblong, elliptic or linear inflorescence bracts.

Inflorescence: Inflorescence branches with a scattering of small bracts, usually producing abundant heads or small cymules of heads densely in the upper 1/2, these unilateral (secund) on the upper side of the branch, the total inflorescence usually spreading to become broad as long or broader than long (rarely inflorescence with laterals more ascending or shorter, thus narrower); peduncles slender but stiffish, tomentulose, from slightly shorter than heads to 1.5 times longer; heads broadly campanulate, from base to tip of pappus ca. 5-7 mm high, the receptacle flattish, chaffless, the involucral bracts (phyllaries) many in several series, the outermost, (1owest) greenest, shortest, lancemoblong, or lance-1inear, acute, grading into the few peduncular bractlets, the median and inner phyllaries 3-5 mm long, loosely imbricated, narrowly oblong, flat, thinnish and at least above the middle green on either side of a yellowish, transluscent midrib (sometimes also with an indistinct lateral nerve or two), apically rounded or acute, very thin and laceratemciliolate, the margins broad, thin, pale, ciliolate, the backs smooth.

Flowers: Ray florets most1y 8-10, the ligules spreading, a pale but rich yellow, elliptic, ca. $4 \mathrm{~mm}$ long, the appendaged style branches present but the flower non-functional; disc florets many, the corollas 4-5 mm long, the tube and throat forming a narrow funne11, the 5 erect to spreading, bright yellow lobes narrowly triangular, 1.0-1.3 $\mathrm{mm}$ long, the lance-linear style branches exserted, acute, 
papillose externa11y.

Fruit: Akene columnar, obscurely ribbed, sometimes slightly compressed, 2.0-2.5 mm long, strigillose with pale hairs; pappus about the length of the disc florets, white, simple, of numerous antrorse1y barbellate capillary bristles.

Distribution and Flowering Season:

Sandhill-pocosin ecotones, moist rises in wet flatwoods and savannas, Coastal Plain, scattered localities in the southern half of eastern North Carolina southward into northeastern South Carolina; flowering in May and June.

\section{Special Identifying Features:}

S. verna firstly is distinguished by its ear1y flowering habit, being at anthesis when most other goldenrods have not yet bolted from their rosettes, thus it is seemingly we11 isolated reproductive1y. It is part of a rather large group of species that have leaves progressively smaller from base to tip of shoot, with the lower ones persisting, and which in addition have heads arranged unilatera1ly along spreading, outward1y arching inflorescence branches. Were it not such a hairy plant, and flowering in spring, it would be quite similar superficially to some of the S. arguta complex. Some other species (s. nemoralis, S. ulmifolia, s. brachyphylla) combine hairy foliage with hairy fruit, but s. vēna has more disc flowers (14-30 versus $3-8$ ) than these, therefore has larger heads.

Habitat and Management Implication:

S. verna frequents a rather wide range of habitat within its narrow range. In the inner coastal plain of the carolinas it is most commobly found in the ecotone between high sandy Longleaf pineland and the shrub bogs (pocosins) that fringe the depressions in or border the streams and rivers that drain, the sandhills. It is a plant of full sun or light shade, with its commonest associates being part of a grassmsedge system, a 11 rooted in a dark sandy peat loam which is usually moist, not wet. In the eastern Coastal Plain of North Carolina it is found occasional1y in pine flatwoods savanna, usually again in transitional zones around Longleaf Pine-Turkey Oak rises in titi or pocosin, but not in the wettest bog. The shrubby formations no doubt were, in nature, the main competitive factor either in the sandhils or lower Coastal Plain, and these shrubs together with the pinehardwood overstory were reduced by frequent naturally occurring woods fires sufficient to produce the openings this plant frequents.

S. verna is being reduced by a combination of factors, one being the rapid expansion of urban and residential construction in the Coastal Plain, another the rapid conversion of savanna and pocosin to plantation pineland, still another the utilization of the black sandy peats for row crop agriculture or improved pasture, al1 of these involving either total habitat destruction or drainage, which ultimately achieves the same effect. Best chances for survival of this species are probably to be found in the sandhills, which are less suitable for large scale slash pine plantings or for row crop agriculture. 


\section{References:}

Cronquist, Arthur. 1980. Vascular flora of the southeastern United States, Vo1. I. Asteraceae. Solidago, pp.116m133. Chape1 Hill.

Sma11,J.K. 1933. Manual of the southeastern flora, Solidago, pp. 1344-1360. 
SPECIES: Solidago verna M.A. Curtis ex T. \& G.

\begin{tabular}{|c|c|c|c|c|c|c|c|c|}
\hline $\begin{array}{l}\text { Expected } \\
\text { Effect on } \\
\text { Hab1tat }\end{array}$ & $\begin{array}{c}\text { Prescribo } \\
\text { Burn } \\
\end{array}$ & $\begin{array}{l}\text { Doze or } \\
\text { Root } \\
\text { Rake }\end{array}$ & Bed & Chop & $\begin{array}{l}\text { ThIn } \\
\text { over- } \\
\text { otory }\end{array}$ & $\begin{array}{l}\text { Cut } \\
\text { Over- } \\
\text { Story } \\
\end{array}$ & $\begin{array}{c}\text { Over Plant } \\
\text { with } \\
\text { trees } \\
\end{array}$ & Graze \\
\hline Destroy & & & & $X$ & & & & \\
\hline Damage & & & $X$ & & & & & $X$ \\
\hline $\begin{array}{l}\text { No La tang } \\
\text { Effect }\end{array}$ & & & & & & & & \\
\hline $\begin{array}{l}\text { Baneflcial } \\
1 \text { f Done } \\
\text { groperly }\end{array}$ & & & & & & & & \\
\hline
\end{tabular}

Other Commente:

*Eat1mated effect 1 a an eat1mate of the author baed on his book knowledge of the habltat and on knowledge galned from peronal

field observat1ons. Estinates are "rough" in many 1nstances. Results of practices may vary in degree of application, intensity, nearness to plant communities, etc. A column left "blank" indicates a lack of sufficient information from which to predict expected results. As observations are made $1 \mathrm{n}$ the fleld by users of the data, predictions should be refined by area and by 1 ntensity of forestry practices. 
Approximate Known Range of:

Solidago verna M.A. Curtis ex T. \& G.
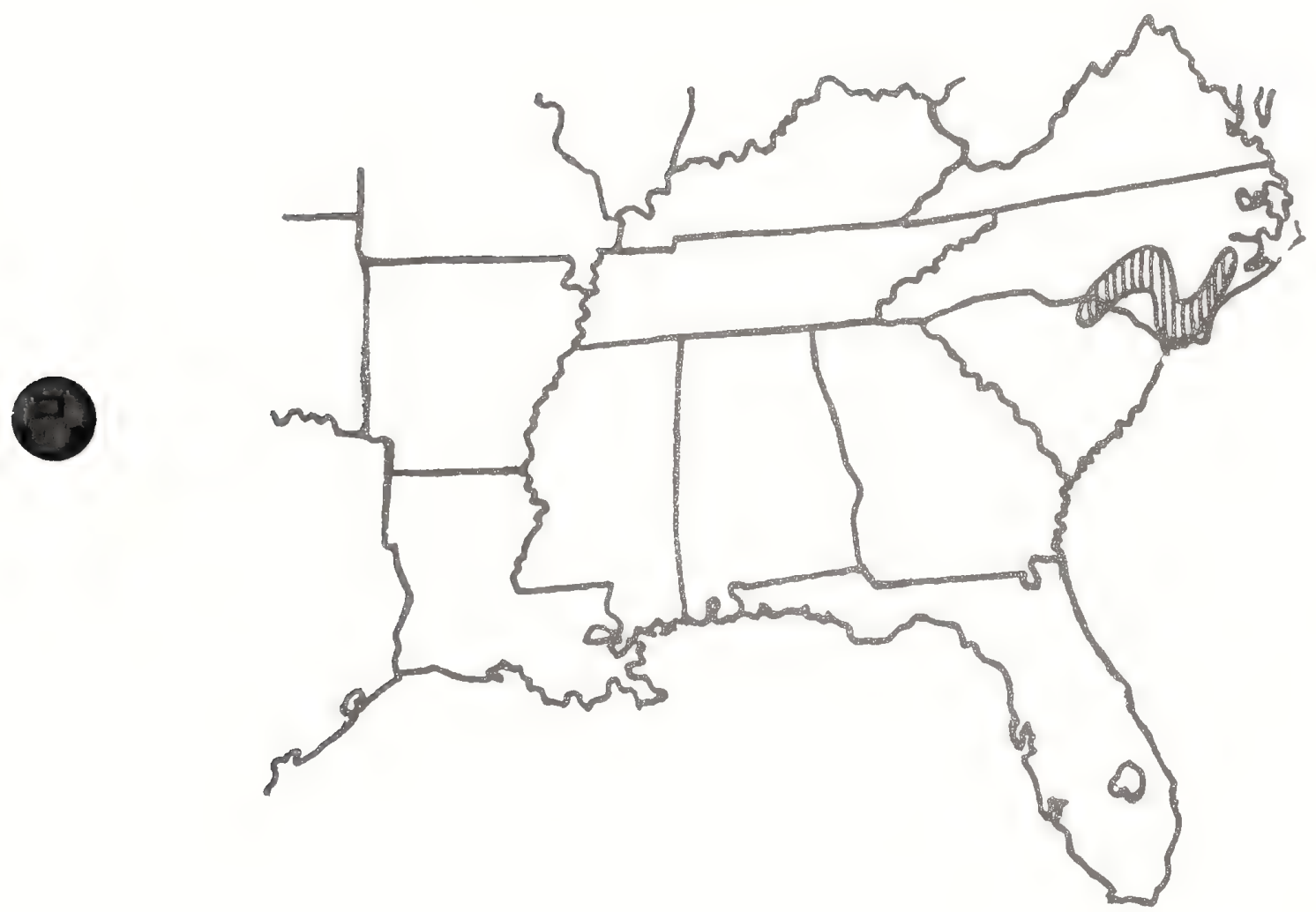


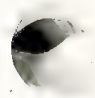




\section{Lobe1ia gattingeri A.Gray}

L. appendiculata A.DC. var. gattingeri (Gray)McVaugh status: Threatened

Technica1 Description:

Annual or biennial, bolting in late spring from an overwintering (rarely oversummering) rosette, the roots diffuse and slender.

Stems: single or few, or several, erect or ascending, simple, branching only trom very lowest nodes or in the inflorescence, (1-) 2-5 (-7) dm high, terete and strongly ribbed, or multiangulate, the angles below the leaf margins lowwinged, smooth, pale yellow green or suffused with purple distally.

Leaves: alternate, the largest in the rosette, (this sometimes withered by anthesis) sessile or nearly so, oblanceolate to oblong ovate, obovate or broadly spathulate (1-) $2-6 \mathrm{~cm}$ long, smooth, pale green or tinged with purple, apically rounded, marginally entire, sinuate, distantly denticulate, serrate or basally variously toothed; cauline leaves numerous but rarely overlapping, progressively shorter up the stem. Intlorescence: 1 lowers many, spreading, spirally arranged, distant below, close above, in narrow, stiffish, indeterminate, bracteate racemes $1 / 2-3 / 4$ the total plant height, the bracts grading into upper stem leaves below, progressively smaller upward in raceme, mostly narrowly lanceolate to lance-1inear, mostly $0.5-1.0 \mathrm{~cm} 1 \mathrm{ong}$, entire or with a few narrow teeth or glandiike denticles basally, the pedicels erect, mostly $3.5 \mathrm{~mm}$ long, granular, minutely 2 bracted at base.

Flowers: very showy at anthesis, bisexual, irregular, 1.0m1.5 cm 1ong; calyx smooth, ca. 4.0.4.5 mm long the tube campanulate, ca. $2 \mathrm{~mm}$ long, slightly dilated at base dorsally, 10-nerved, thin, pale green tinged with purple or violet, the 5, erect or slightly spreading lobes subequal ca. $2.5 \mathrm{~mm}$ long, subulate, entire, lacking auricles or auricles minute; corolla strongly bilabiate, the tube pale blue with deep blue lines, ca. $5 \mathrm{~mm}$ long, slightly dilated to an oblique orifice, and slit (fenestrate) above, the upper 1ip with 2, erect and spreading, narrowly triangular teeth, the lower 1 ip 1 ongest, projecting forward and downward, trilobed with 3 subequal, oblong, obtuseangled, spreading, flat lobes, a deep bright blue and smooth save for a villosity on the lip base and lower side of corolla tube internal1y; stamens 5, exect, bent siightly at apex, ca. $5 \mathrm{~mm}$ long, the flattened filaments pale blue, the gray-blue anthers forming a cylinder, the connective edges and anther tips whitestrigillose; ovary inferior, bicarpellate, the numerous ovules axile, the style linear, dilated and with a tuft of hairs apically at the level of the anther apex. Fruit: a loculicidal, thin-walled, ovoid capsule, its apex barely exceeding the calyx tube and with 4, incomplete cells; seeds pale red-brown, ellipsoidal, slightly flattened, finely cancellate and irregularly rugulose. 
Distribution ant Flowering Season:

Seasonally moist limestone clearings and glades, middle Tennessee and (?) northern Alabama; flowering mostly from mid May through June, intermittent1y till frost。

Special Identifying Features:

This smal1ish flowered but showy plant is nearest $\underline{L}$. appendiculata Lam., a taller, largermleaved plant with a distinct range, primarily east Texas north to Oklahoma, Kansas, (?I11inois) and eastward into the Coastal Plain of Alabama. L. gattingeri has entire or rarely distant1y glandular-denticulate, most $1 y$ exauriculate (rather than glandular-ciliate and auriculate) calyx lobes, and deeper blue corollas. Recent authors appear to be inclined to treat the two as varieties, though this may be inconsistent with general concepts of species in the gerus.

Habitat and Management 1 mplication:

L. gattingeri is abundant $10 \mathrm{ca} 11 \mathrm{y}$ on thin, seasonally moist, sticky clays such as form on and around $t 1$ at-bedded limestones. It is a plant of full sun or light shade, associated with other plants of open limestone glades in middle l'ennessee such as various vernal grasses, carices, scirpus lineatus, Eleocharis compressa, E. tenuis, Juncus tilipendulus and other rushes, Nothoscordium, Hypoxis, Schoenolirion, Delphinium virescens, Arenaria, various Leavenworthia, Lesquerella, Sedum pulchelium, petalostemon gattingeri, Psoralea subacaulis, Upuntia, Uenothera triloba, Viola, Amsonia, scutellaria parvula, verbena canadensis, Houstonia, Hedyotis nigricans, and a variety of composites. Usually it is most a bundant in the open areas along intermittent streams or at edges of moister inwash depressions.

l'he forest type is a Juniperus disclimax, precursor to a mixed hardwood assemblage involving oak (Q. shumardii, $Q$. muhlenbergii, Q. imbricaria, Q. alba, Q. stellata), hickory (Carya ovata, Ć. carolinaeseptentrionalis, C. cordiformis) e $1 \mathrm{~m}$ (U. americana, U. serotina, U. alata, U. rubra), hackberry, ash (F. quadrangulata, F- americana), Sugar Maple, persimmon, etc. under whīch and invading openings are Rhus aromatica, Khamnus caroliniana, Sassatras, "Svida" dogwoods, Symphoriocarpos, kubus and various vines in Lonicera, smilax, Rhus,Berchemia, etc. This woody stage succeeds on the 1imestones as soil develops there, ultimately shading out the herbs of open glades. It was kept in check naturally through fire and erosive torces. 'the greatest risks to this sort of habitat come from urban and industrial expansion, conversion of open areas to pasture, particularly if some tough perennial pasture grasses such as fescue, bluegrass, or orchard grass are promoted.

Reterences:

McVaugh, Rogers. 1936. Studies in the taxonomy and distribution of the eastern North American species of Lobelia. Rhodora 38: $241-263,276-298,305-329,346-362$.

- 1942. Lobe1ia in North Am. F1. 32A. New York.

Sma11,J.K. 1933. Manual of the southeastern flora, pp. 1291-1295. 
SPECIES: Lobelia gattingeri A.Gray

\begin{tabular}{|c|c|c|c|c|c|c|c|c|}
\hline $\begin{array}{l}\text { Expected } \\
\text { Effect on } \\
\text { Hab1tat }\end{array}$ & $\begin{array}{c}\text { Preacribo } \\
\text { Burn } \\
\end{array}$ & $\begin{array}{l}\text { Doze or } \\
\text { Root } \\
\text { Rake } \\
\end{array}$ & Bed & Chop & $\begin{array}{l}\text { ThIn } \\
\text { Ov日 } \\
\text { gtory } \\
\end{array}$ & $\begin{array}{l}\text { Cut } \\
\text { Ovar- } \\
\text { Story } \\
\end{array}$ & $\begin{array}{c}\text { Over Plant } \\
\text { with } \\
\text { treeg } \\
\end{array}$ & Graze \\
\hline Destroy & & $\mathrm{NA}$ & $\overline{N A}$ & NA & & & NA & \\
\hline Damage & & & & & & & & $\mathrm{X}$ \\
\hline $\begin{array}{l}\text { No Lasting } \\
\text { Effact }\end{array}$ & $x$ & & & & & & & \\
\hline $\begin{array}{l}\text { Benoficlal } \\
\text { If Done } \\
\text { Properly }\end{array}$ & & & & & $X$ & $X$ & & \\
\hline
\end{tabular}

\section{Other Commente:}

* Est1mated effect 18 an est1mate of the author based on his book knowledge of the habltat and on knowledge gained from personal field observations. Estimates are "rough" in many 1nstances. Results of practices inay vary in degree of application, intensity, nearness to plant communties, etc. A column left "blank" 1ndicates d lack of sufficient information from whych to predict expected results. As observations are made in the field by users of the data, predictions should be refined by area and by intensity of forestry practices. 
Distribution of:

Lobelia gattingeri A.Gray

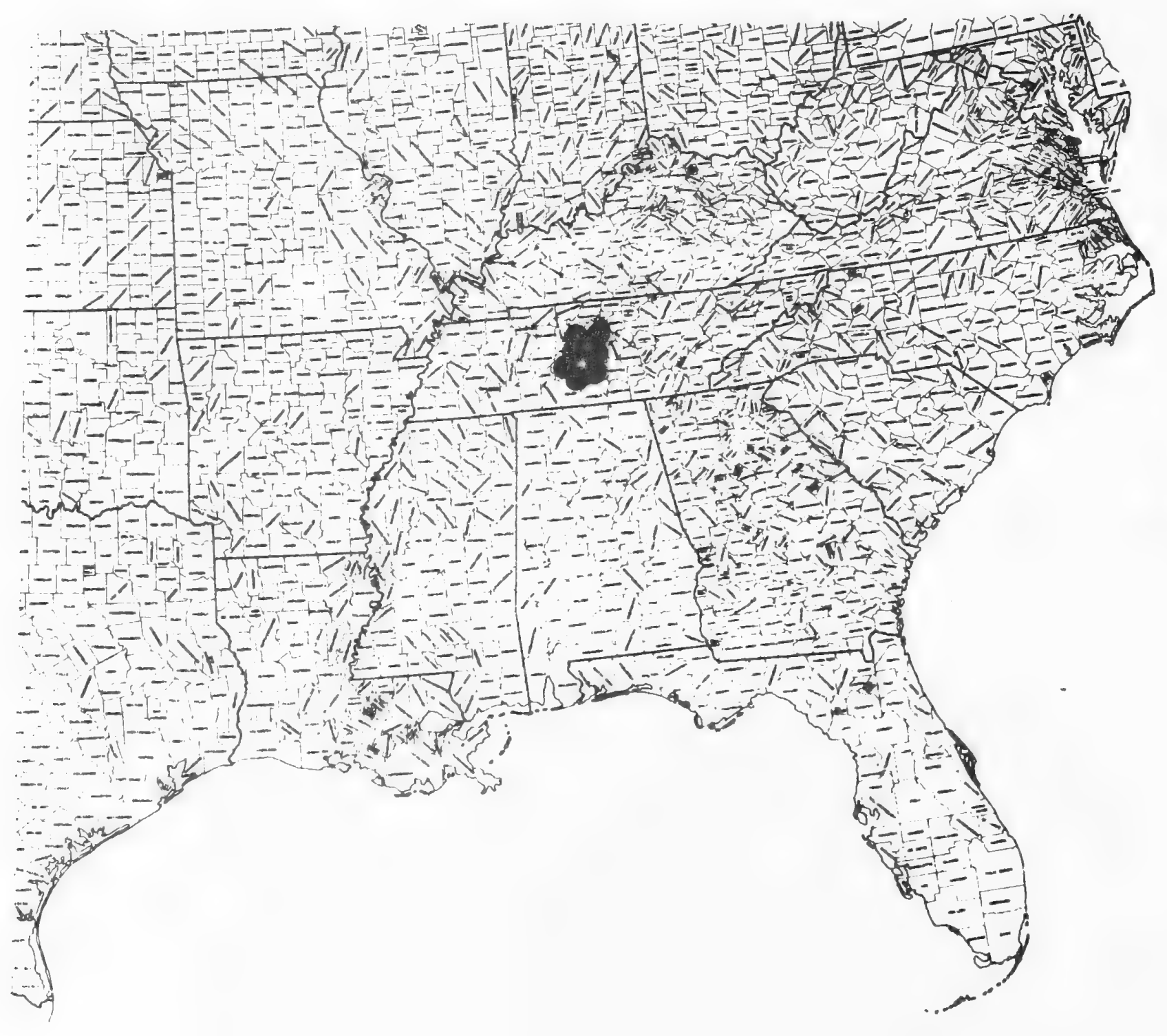


lechnical Description:

strongly tufted, delicate, smooth perennial from a slender taproot, perennating by short, basal offshoots.

Stems: erect or spreading, torming small cushions of decumbent bases, (8-) 10-15 (-20) cm high, very slender, 0.4-0.8 mm thick, terete, the nodes swollen, close-set toward plant base, intexnodes progressive1y elongating upward on stem, thus branching in the intlorescence or terminating in a single flower stalk. Leaves: opposite, estipulate, gradually reduced in length and width upward on stem, the largest near base, spreading or spreading recurved, (1-) 2-3 (-4) cm long, mostly $1-3 \mathrm{~mm}$ wide, linear-oblanceolate or Linear-spathulate, obtuse to broadly acute, entire with a narrow glassy margin, attenuated or narrowly cuneate to a narrow but clasping base, thin, equally bright green on both sides, the miarib and veins around midrib a single row, the areoles on either side elongate; leaves at base of pedicels shortest, usually $1 \mathrm{~cm}$ or less 1 ong, linear, spreading or ascending. Flowers: regular, bisexual, solitary at stem tips or 2, rarely 3 and subcymose, the pedicels capillary, 5-10 times as long as tlowers; calyx broadly campanulate, truncate and strongly indented at base, the 5 distinct sepals $2.5-3.0 \mathrm{~mm}$ long, broadly oblong, slight ly boat-shaped, afically obtuse or rounded, green and inconspicuously 3-veined, with narrow, scarious, entire margins; petals 5, distinct, at early flowering forming a broad bel1, becoming more wide-spread, the spreading blades mostly ca. $5 \mathrm{~mm}$ long, broadiy oblong or obovate, apically rounded broadly or truncate, slightly it at all emarginate, erose, tapering at the widge-shaped base, white, most1y with 5 green main veins; stamens usually 10, distinct, spreading-ascending, the tilaments linear-tapering, ca. 2.5-3.0 mm long, white, the anthers nearly round, the 2 , pale-yellow, reniform anther sacs ca. $0.4 \mathrm{~mm}$ long; ovary at anthesis broady ovoid, ca. $1.5 \mathrm{~mm}$ long, pale yellow-green, its apex strongly indented, the styles $3-4$, distinct, at anthosis 1.0-1.2 mm long, erect or slightly spreading, the 1inear, excurved, minutely clavate-hairy stigmas ca. $0.5 \mathrm{~mm}$ long. Fruit: Capsule broadly ovoid, enclosed by the persisting, erect $\overline{\operatorname{calyx}}$ and withering petals, 3.0-3.5 mm long, dehiscing to 3-4 pale-brown, thin but firm valves, these narrowed at apex, there thickened, rounded, slight1y incurved; seeds numerous, the funicles a 1 from a short columnella, tearshaped, turgid (swollen), with an indentation medially at middle of coiled embryo, U.5-0.7 mm 1 ong, the seed coat reddish-brown, reticulate, the network a strong system of irregular, wavy ridges.

Distribution and Flowering Season:

Shaded sandrock ledges and blutfs, northern cumberlands of rennessee in 4 counties (Fentress, Morgan, Pickett, Scott); flowering mostly trom early July through August.

special Identifying Features: 
A. cumberlandensis most resembles A. groenlandica, a sandwort

of more northern latitudes or at higher elevations of the southern Appalachians, or extremes of A. glabra, a common spring tlowering species of granite and sandrock glades in the Carolinas, Georgia, Alabama and Tennessee. However, it may be distinguished trom either ot these by its longer, broader, thinner, veinier leaves, leatier upper stems, which produce fewer tlowers as a rule, and by its distinctive seed sculpture. Also the flowering time of A. cumberlandensis is summer, which means that it overlaps not at $\bar{a}_{11}$ with $\underline{A}$. glabra or any other Arenaria of the complex except $\underline{A}$. groentandica. In the case of the last, a plant of full sun in high southern mountains, there is a distinctive difference in habitat, with A. cumberlandensis being tound only in shaded sites. A. glabra, while a similarly delicate plant of tull sun, is a true ànnua1.

Habitat and Management Implication:

As noted above,A. cumberlandensis is a plant of moist sandstone ledges and overhangs, is referred to as a "rockhouse" plant. l'he substrate is a thin, moist layer of nearly pure sand on which are many bryophytes, several rock ferns and fern allies, including Selaginella apus, Lycopodium porophyllum, L. Iucidulum, Dryopteris, Adiantum, Cystopteris, Asplenium montanum, A. trichomanes, etc. Herbaceous tlowering plant associates of particular and consistent note are parietaria pensylvanica, Boehmeria cylindrica, pilea pum11a, silene rotundifolia, lhalictrum clavatum, Lardamine pensylvanica, Eupatorium (Ageratina type), Agrostis, panicum, many carex.

The moist ravines and creekbanks support a rich torest cover. White pine and Canada Hemlock dominate the gymnosperms, the hardwoods comprise a rich mixed mesopytic assemblage typical of Appalachian cove torest, with an understory of Cornus, Rhododendron maximum, clethra acuminata, Ilex, and highbush blueberries such as Vaccinium erythrocarpon, V. constablei, etc. The upper ravine slopes and $\mathrm{r}$ dges support a very different torest, namely oak-nickory pine, the White Pine with a strong admixture of pinus virginiana, P. echinata, and understory woody plants such as Oxydendrum, Cornus Ilorida,Sassafras underlain by lowbush Vaccinium, Gaylussacia brachycera, $\underline{G}$. trondosa, Epigaea, Gaultheria, dewberry. I'he Arenaria does not come up into tnese drier sites or even to the higher ledges of the ravines where conditions are drier, lighter; instead it is confined to sites where the microclimate is cool, deeply shaded, more humid.

the primary danger to such habitat as this is from logging of ravine and bluff woodlands, which would admit too much light, therefore heating and drying the substrate, as well as subjecting it to erosion. In area I have seen where such clearings have been made, A. cumberlandensis 15 not in evidence, though it persists along the same drainages where such logging nas not taken place. Populations within Pickett state Park, where most of the plants have been collected and observed, have sustained some damage in that some of the more spectacular ravines have had trails constructed into them, thus some bluff ledges have been impacted by hikers who wander off marked trails.

\section{Reterences:}

Wofford, B.E. \& R. Kra1. 1979. A new Arenaria (Caryophyllaceae) Irom the Cumberlands of Tennessee. Brittonia 31 (2): 275-260. 
SPECIES: Arenaria cumberlandensis Woftord \& Kral

\begin{tabular}{|c|c|c|c|c|c|c|c|c|}
\hline $\begin{array}{l}\text { Expected } \\
\text { Efect on } \\
\text { Hab1tat }\end{array}$ & $\begin{array}{c}\text { Preacribe } \\
\text { Burn } \\
\end{array}$ & $\begin{array}{l}\text { Doze or } \\
\text { Root } \\
\text { Rake } \\
\end{array}$ & $\mathrm{Bed}$ & Chop & $\begin{array}{l}\text { Thin } \\
\text { over- } \\
\text { gtory }\end{array}$ & $\begin{array}{l}\text { Cut } \\
\text { Over- } \\
\text { Story }\end{array}$ & $\begin{array}{c}\text { Over Plant } \\
\text { w1th } \\
\text { trees } \\
\end{array}$ & Graze \\
\hline Destroy & $X$ & & & & $x$ & $x$ & & \\
\hline Damgre & & $N A$ & NA & $N A$ & & & $N A$ & \\
\hline $\begin{array}{l}\text { No Lasting } \\
\text { Ef fect }\end{array}$ & & & & & & & & \\
\hline $\begin{array}{l}\text { Beneflclal } \\
\text { If Done } \\
\text { Proper } 1 y\end{array}$ & & & & & & & & \\
\hline
\end{tabular}

Other Commente:

* Est1mated effect 18 an estimate of the author based on his book knowledge of the habttat and on knowledge galned from personal field observations. Estlmates are "rough" in many instances. Results of practices inay vary in degree of application, intensity, nearness to plant communities, etc. A column left "blank" 1ndicates a lack of sufficlent information from which to predict expected results. As observations are made in the fleld by users of the data, predictions should be refined by area and by intensity of forestry practices. 


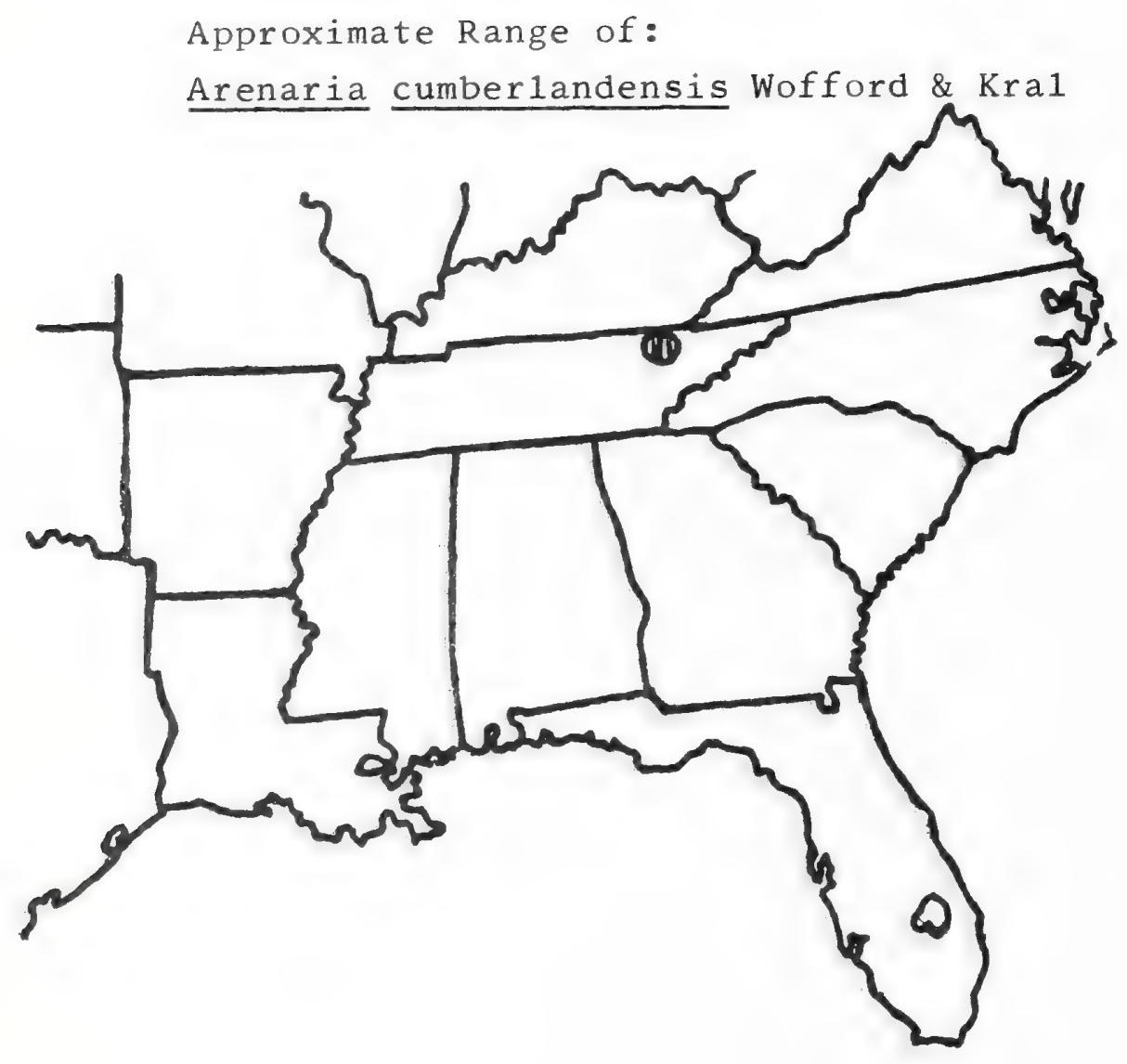


l'echnical Description:

Diminutive, smooth, ephemeral annual from a small, slender taproot.

stems: simple or branching only at very base, the branches few, at most 4, erect or spreading-ascending, mostly $3-4 \mathrm{~cm}$ high, less than $0.5 \mathrm{~mm}$ thick, terete, greenishmbrown or strongly suffused with red, the few lowermost nodes closemset, above this to around $1 \mathrm{~cm}$ apart, each node 110 riferous, the internodes $\mathrm{zig}-\mathrm{zag}$. Leaves: opposite, the lowermost pairs narrowly oblong, to $3-4 \mathrm{~mm}$ long, their bases connate-sheathing, the margins entire, somewhat involute, the apices acute; bracteal leaves triangular-connate, keeled, 2.5-3.5 mm long, acute, strongly red or purple-tinged. Hlowers: usually $1 /$ node and alternate, subsessile, erect, 3-4 $\overline{\mathrm{mm}}$ long, bisexual, regular, tunnelform-campanulate; sepals 5, 3ø4 mm long, reddish or reddish-green, joined half their length, the subequal lobes triangular-ovate, nearly erect or slightly spreading, acute, scarious margined, the lobe bases slightly overlapping, the backs each with 1 strong median nerve and a pair of fasnter laterals; petals absent; stamens 5, the slender but tlattish-based tilaments arising just below the sepal lobe sinuses, terminating in minute, bilocular, subglobose anthers; staminodes 5, rudimentary, scale-1ike, arising alternately at level of the filament bases; ovary superior, lance-ovoid, somewhat trigonous, about the length of the sepals, greenish, the narrow apex at anthesis 3-lobed, minutely glandulartoothed or retuse, the style lacking, the stigmas minute, recurved, arising subapically at the sinuses of the apical ovary lobes. HKuit: Capsule not much longer than the ovary, splitting along the 3 wirelike valve margins about halfway down the fruit trom the apex to expose the numerous, longwfunicular seed; seeds yellowish-green, transluscent, ovoid to nearly round, ca. $0.5 \mathrm{~mm} 1 \mathrm{ong}$, the rounded backs muriculate (minutely pebbled), the sides minutely and narrowly striate-cancellate.

V1stribution and Flowering Season:

Fine sandy silty substrates, moist exposures of soil, mostly over siliceous rock in glades, very intrequent, southwestern Missouri and in two counties in southern Arkansas; flowering trom March through Apri1.

special Identifying Features:

Geocarpon is monotypic. K.K. Mackenzie, who described it (1914) trom Missouri material collected by $\mathbf{E}$.J.Palmer opined that it belongs to the trıbe Aizoideae of the Aizoaceae. Later (1950) E.J. Palmer and J.A.Steyermark wrote an elaborative paper in which G. minimum was placed instead in the Caryophyllaceae in that, to be where Mackenzie placed it, it would have to have stipules and a different truit dehiscence (circumsessile rather than longitudinal). On the other hand, many Caryophyllaceae do lack stipules, may (contrary to the earlier opinion of Mackenzie) have a gamosepalous calyx, often tend to have the same reduction series from lo to 5 stamens, and 
all provide a 1-1ocular ovary with a tree-central placentation. Thus, the tinal disposition of Geocarpon has been to place it near scleranthus in between subtribe Sabulininae of tribe Alsineae and the Sclerantheae, tamily Caryophyllaceae.

Habitat and Management Implication:

Steyermark, who found most of the Missouri stations for this rare plant, noted that the habitat for it was primarily sandstone glades, where ledges of fine sandstone, interbedded with shale, are exposed along small streams, where a thin layer of humified silty sandy accumulates and appears to be held in an early successional stasis. surrounding area where deeper soils allow, is savanna, with Andropogon, Panicum scoparium, setaria, Rhynchospora, scleria, Fimbristylis, Carices, Tradescantia, Anemone caroliniana, Rubus, Baptisia leucophaea, Centunculus, Castilleja, Rhexia, Cirsium, this primarily grassmsedge landscape dotted with hardwoods such as Diospyros.

'The Arkansas localities, close together along the Bradley-Drew County line, are floristically different in some regards. First the sites are, as in Missouri, small areas of mineral earth, in this case smal1, level openings in grassmsedge on Lafe (Bonn) soils. This soil is a tuffaceous sand, yellowish or yellowishm reddish-brown with iron oxides, and the areas are what at one time were beds of shallow lakes. Low points are very wet, forested with cypress-tupe10 interspersed with Red Maple, Carolina Ash, Hackberry, Green Ash, Swamp Privet and lowland oaks, the shallower arms of the old bed dominated by a grass-sedge tormation similar in makeup to that described by Steyermark (Andropogon, Panicum, Rhynchospora, Scleria, Carex, often the same species), out this landscape dotted with sabal minor which gives it a much different look. 'lne rises, which were probably once shores and islands are torested by upland oaks, hickories, hackberry, white Ash, Loblolly Pine, with both high and lowbush blueberries, Rubus, Smilax, Cornus, Crataegus. Here and there in the grass-sedge tormation are smail open exposures of Lafe soil, these on trequent occasions washed by high waters during wet periods but not for long periods of time, often lichenencrusted, and during the time of flowering of Geocarpon populated thinly by Houstonia minima, plantago pusilla, Hypoxis hirsuta, Cerastium, Viola rafinesquii, Oenothera linifolia, Krigia,etc. Isoetes melanopoda appears in sma11 patches, together with some dichanthelium Panicum, Agrostis elliottii, A. hyema1is, Nothoscordium and the grass- $\overline{s e d g e}$ environs often have large patches of the rather rare schoenolirion wrightii sherman, another endangered species.

Some of this old lake bed has been cultivated in the past and some is presently pastured, but the site is of 1 ow agricultural quality. L'he area left as it is will continue to support good populations of Geocarpon. The poor and acid substrates continue to erode to expose new patches of mineral siliceous earth on which succession appears to be slow. There is also considerable evidence that fire was a factor in keeping this savanna, and this, if included in management of the tract would act to reduce woody invaders as we 11 as to provide impetus to the erosional. forces creating bare patches tor the Geocarpon and other shallow-rooted herbs of full sun. 
Un the other hand, a more intense pasturing would be very destructive, as would any conversion to row planted pine (for which the site is poor!)

References:

Mackenzie, K.K. 1914. A new genus from Missouri. Torreya 14: 67-68.

Palmer, E.J. \& J.A. Steyermark. 1950. Notes on Geocarpon minimum Mackenzie. Bull. Torr. Bot. Club 77 (4): 268- $\overline{273}$.

Steyermark, J.A. 1958. Another station for Geocarpon minimum. Bu11. lorr. Bot. C1ub 85 (2): 124-127. 
SPECIES: Geocarpon minimum Mackenzie

\begin{tabular}{|c|c|c|c|c|c|c|c|c|}
\hline $\begin{array}{l}\text { Expected } \\
\text { Effect on } \\
\text { Habltat } \\
\end{array}$ & $\begin{array}{c}\text { Prescribe } \\
\text { Burn } \\
\end{array}$ & $\begin{array}{l}\text { Doze or } \\
\text { Root } \\
\text { Rake }\end{array}$ & Bed & Chop & $\begin{array}{l}\text { Th1n } \\
\text { Over- } \\
\text { Btory } \\
\end{array}$ & $\begin{array}{l}\text { Cut } \\
\text { Over- } \\
\text { Story } \\
\end{array}$ & $\begin{array}{c}\text { Over Plant } \\
\text { with } \\
\text { trees } \\
\end{array}$ & Graze \\
\hline Destroy & & $x$ & $x$ & $x$ & & & $x$ & $x$ \\
\hline Damage & & & & & & & & \\
\hline $\begin{array}{l}\text { No Lasting } \\
\text { Effect }\end{array}$ & & & & & $x$ & $x$ & & \\
\hline $\begin{array}{l}\text { Benaficlal } \\
\text { If Done } \\
\text { Propor } 1 \text { y }\end{array}$ & $x$ & & & & & & & \\
\hline
\end{tabular}

\section{other Commente:}

\section{* Estimated effect 18 an ebt1mate of the author baed on hio book} knowledge of the habltat and on knowledge gatned from personal fleld observations. Estimates are "rough" in many instances. Results of practices may vary in degree of application, intenstiy, nearness to plant communities, etc. A column left "blank" Indicates a lack of sufficient information from which to predict expected results. As observations are made in the fleld by users of the data, predictions should be refined by area and by intensity of forestry practices. 


\section{Geocarpon minimum Mackenzie}

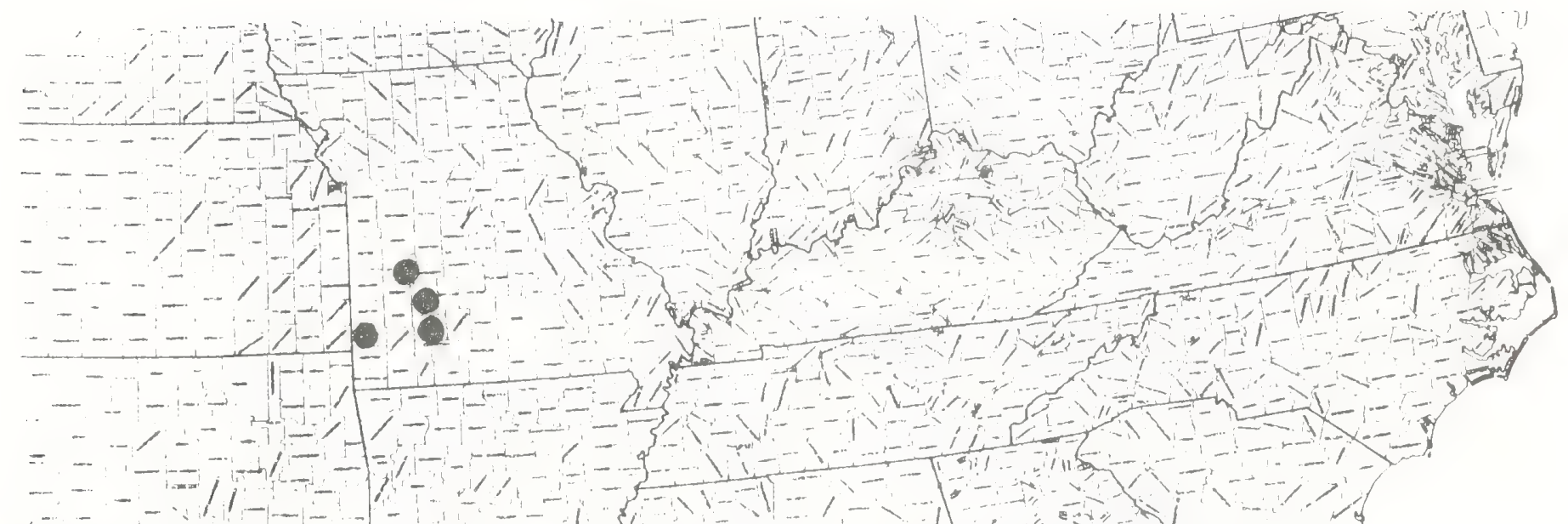

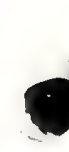

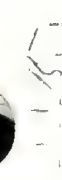

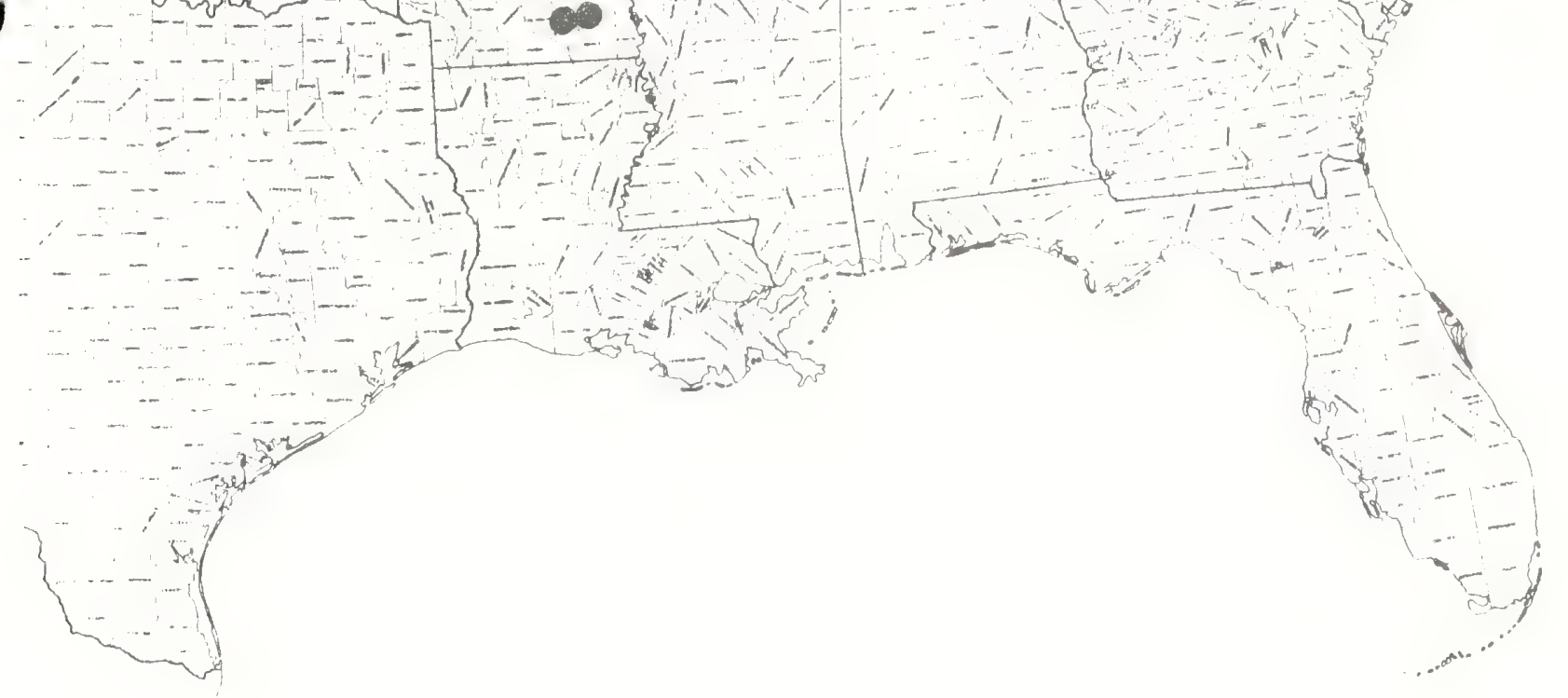


6

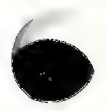

6 


\section{Paxistima canbyi Gray}

Status: Threatened

l'echnica1 Description:

Low, lax, mat-forming shrub $2-4 \mathrm{dm}$ high, increasing by rooting trom the lower nodes and adventitiously along the prostrate older branches, the roots slender, shallow, fibrous.

shoots: prostrate, sprawling or decumbent-based, slender, the older growth usually buried in litter, the rebranching often in pseudowhorls; bark of older growth dark brown, thin, forming irregular patterns of rectangular patches over the dull yellowish inner bark, that of newer growth paler brown, that of leafy shoots 1ight brown, these shoots ascending or erect at least at tips, often subquadrangular, with 4, low longitudinal corky ridges, here ca. 1.0m1.5 mm thick, the nodes numerous and close together.

Leaves: opposite and close-set, spreading, evergreen, simple, subdecussate, stipulate, the stipules narrowly triangularmsubulate, or linear, dark brown,minute, variably deciduous; petioles short, less than $1 \mathrm{~mm}$ long, erect-based, arching outward distally, the rounded backs pebbled; leaf blades leathery, oblong to narrowly eliptic, oblanceolate, narrowly cuneiform or linear, mostly $1.5-2.0 \mathrm{~cm} 1 \mathrm{ong}, 2.0-5.0 \mathrm{~mm}$ wide, apically acute or (more often) rounded, strongly revolute-margined, serrulate with strongly incurved or erect, callus-tipped teeth, the base rounded, short-attenuate, or cuneate, the upper surface dark lustrous yellow-green with midnerve prominent, the pinnate laterals indistinct, the lower surface pale green, dulier.

Intlorescence: l'he upper tew to several nodes developing axillary, $1 \mathrm{mbricate}$ inflorescence buds, these elongating to become short, tewmflowered, erectish, determinate racemes, the flowers of the lower nodes opposite, the terminal cluster a cymule of 3 , or inflorescence a simple cymule of 3 , the bracts subdecussately arranged, scalemike, triangular, the pedicels slender, terete, ascending, bibracteolate at base, most1y $3 \mathrm{am} 4 \mathrm{~mm}$ long.

Flowers: regular, bisexua1, sma11, the sepals 4, joined at very base, spreading, broadly ovate, ca. $1 \mathrm{~mm}$ long, broadly acute, somewhat cupped at the narrowed apex, greenish tinged with maroon; petals 4, distinct, strongly spreading, broadiy ovate to suborbicular, attached to receptacle under the flange of a broad, green disc, slightly longer than the sepals ( $1.5 \mathrm{~mm}$ long), apically rounded, the margin erose, the surface bright maroon; stamens 4, hooked to the receptacle under notches in the broad margin of a large,flattish,green disc, this round, ca. $1.5 \mathrm{~mm}$ broad, the filaments stubby, ca.0.4 mm long, erect, the anthers bi-gibbous, pale, the 2 round locules ca. 0.4 $\mathrm{mm}$ long; ovary superior but fused with disc so that only the very short, erect style and the shallowly bilobed stigma protrude. Fruit: lapsule broadly ellipsoidal, slightly longer than $4 \mathrm{~mm}$, $\overline{2-v a 1}$ ved, 2 loculed; seeds pale, arillate, 1/1ocule.

Distribution and Flowering Season:

Moist to dryish, shaded ravine slopes and bluffs, Appalachians and Appalachian Plateau, southeastern Ohio, and southern Pennsylvania southward through the Virginias into Kentucky and North Carolina 
(here persisting in an old nursery site!) HLowering mostly in Apri1,May. Special Identifying Features:

The only other species of this genus in North America is western. Paxistima (usually spelled pachystima) is distinguished from other native members of the Celastraceae by its low shrubby habit (it is our smallest member of the family), its oblong, unlobed fruit, its Llocular (rather than 3-5-1ocular) ovary in which the ovules, later seeds, have a basal aril.

Habitat and Management Implication:

The common name "Cliffugreen" describes the habitat rather we11, in that this small shrub is most often tound on steep, rocky ravine slopes or bluffs along Appalachian rivers and streams. 'l'he substrate is usually a snallow soil layer, very much humified, somewhat acid, although the underlying and surrounding rock is often calcareous or a calcareous shale. sometimes the habitat is more exposed and drier, the torest open and high in yellow pine. More often the overstory is tairly heavy, may be a mixture of hardwoods such as Quercus rubra, Q. alba, U1mus, Acer saccharum, A. rubrum, Aesculus octandra, Tilia, Fraxinus, etc. with gymnospermus such as Pinus strobus, Tsuga canadensis, Thuja occidentalis, sometimes Pinus virginiana, P. echinata, and an understory of Rhododendron maximum, Kalmia, Clethra, Halesia, various highbush Vaccinium, Herbaceous associates are quite varied but usually include a variety of terns such as Dryopteris marginalis, D. intermedia, Adiantum, Woodsia,Asplenium, Lycopodium, Trillium (particularly T. erectum, 'T. undulatum), Disporum, Polygonatum, Uvularia,Erythronium, Hepatica, Anemone quinquefolia, Hexastylis, Sanguinaria, various umbellifers, etc.

These steep slopes, particularly toward their bases, may support tine specimens both of hardwoods and sottwoods. Logging of such areas, if involving a clear cut, is highly destructive of the Paxistima habitat, in that the increased light promotes excessive drying as we1l as the advent of unwelcome woody weeds in genera Smilax, Lonicera, Rubus, etc. Also, such operations increase the likelihood of erosion of the thin humified layer the Paxistima roots in, so that the plants are likely to dislodge. In tact, these shrubs tend to increase by a torm of air layering taking place along the prostrate shoot bases and branches, this rooting promoted by a 100 se, moist, surrounding duff. It should be recommended that logging ot such areas be selection or group selection.

References:

Herna1d,M.L. 1950. Gray's manua1 of botany, ed. 8: p. 983.

Massey, A.B. 1940. Discovery and distribution of Pachystima canbyi Gray. Lastanea 5: 8-11.

Radtord,A.E.,H.E.Ahles \& C. Ritchie Be11. 1968. Manual of the vascular tiora of the carolinas, p. 685. 
SPECIES: paxistima canbyi A. Gray

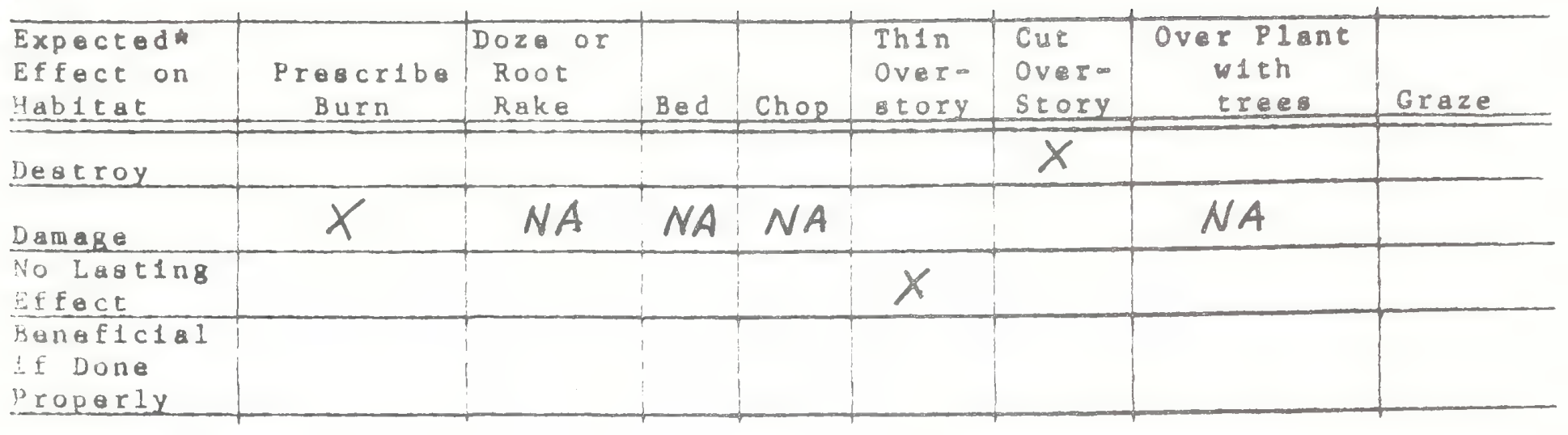

Other Comments:

*Estimated effect 18 an estimate of the author ba ed on his book knowledge of the habitat and on knowledge gained from personal field observations. Est 1 mates are "rough" in many instances. Results of practices nay vary in degree of application, intensity, nearness to plant communities, etc. A column left "blank" indicates a lack of sufficient information from which to predict expected results. As observations are made 1 n the field by users of the data, predictions should be refined by area and by intensity of forestry practices. 
Distribution of:

Paxistima canbyi Gray

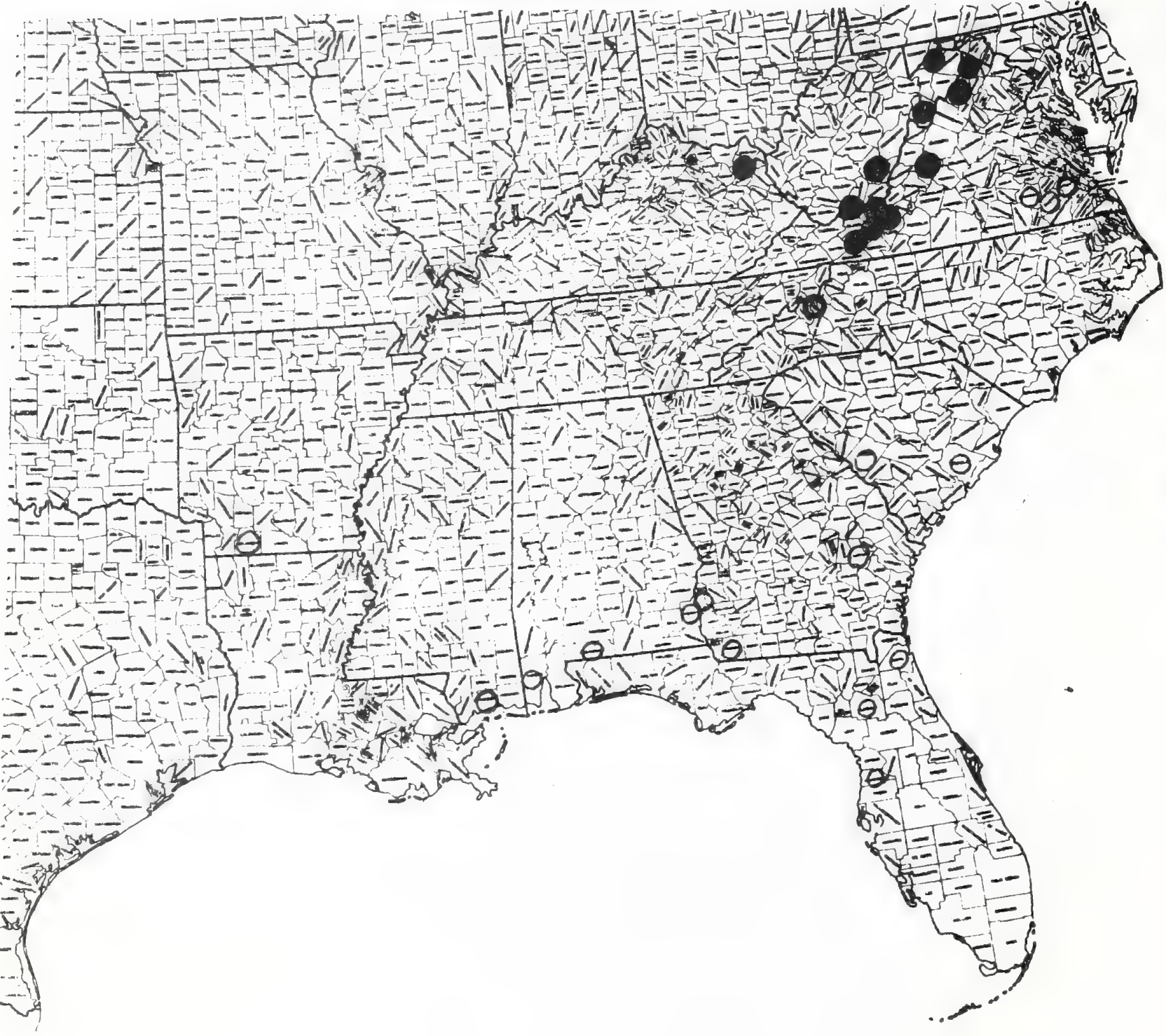




\section{CONVOLVULACEAE}

\section{Cuscuta Harperi Smal1}

Status: Endangered

Technica1 Description:

Annual parasitic vine, the stems closely twining, filiform, smooth, orangishmye11ow, putting down haustoria at frequent intervals, sometimes forming small mats of growth over clumps of host herbs.

Leaves: alternate, few on slender twining stems, usually subtending inflorescences or bracteal, mostly scale-like, narrowly triangular, acute, entire, clasping based, $0.5 \omega 0.6 \mathrm{~mm} 1 \mathrm{ong}$.

Inflorescence: few-flowered, the 2-5 (-7) flowers either in a subcymose arrangement or in a short raceme, the peduncle mostly an extension of a slender, twining branch and of various lengths, the pedice1s most1y $1 \mathrm{~mm}$ long or less, sparse1y muriculate, sometimes bearing a basal bract.

Flowers: bisexual, regular; calyx broadly and shallowly funnelform, with sepals 3-5 (mostly 4), very thin, pale yellowish-brown, ca. $0.6 \mathrm{~mm}$ high, united about 1/2 their length, the lobes broadly 1ow $\rightarrow$ triangular, the apex obtuseangled, the surface externally scattered. muriculate; corolla short-campanulate, yellowish-white, at anthesis $1.0-$ $1.2 \mathrm{~mm}$ high, the lower $1 / 3$ united, the lobes slightly spreading, broadly ovate, the tips narrowly rounded, the blade cupped and incurved; stamens alternating with corolla lobes, arising within the corolla just below the lobe sinuses and above an oblong, fimbriate-margined scale set lower in corolla tube, the filaments erect, ca. $0.5 \mathrm{~mm}$ long, linear, slight1y tapering, the anthers ca. $0.3 \mathrm{~mm}$ long, greenish, broad1y ellipsoida1, sub-basifixed, introrse, the narrowly ellipsoidal anther sacs paralle1; ovary superior, ovoid, about the 1ength of the calyx, apically indented and with a low annulus, the styles 2 , distinct, strongly spreading, the stigmas capitate.

Fruit: capsule broadly ovoid, very thin-walled, transluscent, palebrown, with an irregular dehiscence, at maturity ca. 1.2m1.3 mm high, the divaricate styles persisting, the ovules apical, usually reduced to 1 or 2 seed, the seed light brown, broadly obovoid or nearly round, mostly $1.0-1.2 \mathrm{~mm} 1$ ong or broad, brownish, minutely papillate.

Distribution and Flowering Season:

sandrock outcrops, where parasitic on outcrop herbs, Cumberland Plateau and Blue Ridge, mostly northeastern Alabama with possible outliers in northwestern Georgia and southern Alabama; flowering most1y from September to frost.

Special Identifying Features:

The genus Cuscuta is one of the most difficult in a taxonomically difficult family. However, $\underline{\text {. harperi }}$ is a distinct species of subgenus Grammica, which has the styles distinct to the base and with capitate stigmas. Within Grammica it is part of the complex Cleistogrammica in that its capsules are not circumsessile, but 
remain closed until rupturing irregular1y. Within Clistogrammica it is distinguished by its extremely slender-stemmed habit, its very tiny flowers (mostly not much exceeding $1 \mathrm{~mm}$ in height) which are mostly 4-parted (unlike most others of the complex, in which flowers are 5-parted). The corolla lobes have uniquely inflexed tips. The capsule is broadly ovoid.

Habitat and Management Implication:

C. harperi is found mainly in areas of sandstone outcrop and is parasitic on outcrop plants such as Bigelowia nutta11ii (Chondrophora virgata), Liatris microcepha1a, Crotonopsis eliiptica, Hypericum gentianoides, all of which are frequent on such outcrops. The outcrops themselves may be smal1 or several acres in irregular extent, with frequent shallow depressions or shallow runoff channel1s, these rimmed with herbaceous 1 ow vegetation dominated by annual grasses such as Aristida dichotoma, A. Iongispica, Sgorobolus, Panicum flexile Digitaria, interspersed with perennia1 Andropogon, Panicum, Paspa Ium, various annual and perennial Cyperus, Fimbristylis, Bulbostylis, succulents such as Opuntia, Talinum, Agave and forbs such as Crotonopsis, Hypericum, Polygonum tenue, and many composites including some rare and local ones such as Coreopsis pulchra, Helianthus longifolius. The commonest composites however are Liatris microcephalus and Bigelowia, the usual hosts for the dodder.

Fortunately the greatest know abundance of this rare dodder is on the outcrops bordering the Little River Canyon in Cherokee, DeKa1b and Jackson Counties of Alabama and therefore much of its area is in state ownership. The main danger is to privately owned contiguous areas of outcrop, some of which are part of 1 ow grade pasture with the vegetation badly trampled and grazed. Historically the thin oak-pine forest around the outcrops and the heath dominated shrubby understory of these same areas were periodically subjected to and kept open by natural wrods fires. With fire protection for woodlands surrounding the sandstones (or granites in the case of the type locality!) succession onto them may be more rapid than it once was. Cutting of the adjacent oak-pine woodlands may have added potential area.

References:

Sma11,J.K. 1933. Manual of the southeastern f1ora, pp. 1092-1094. Yuncker, T. G. 1921. Revision of the North American and IWast Indian species of Cuscuta. Univ. I11. Biol. Monngr. $6(2-3): 1-142$. 
SPECIES:Cuscuta harperi Sma11

\begin{tabular}{|c|c|c|c|c|c|c|c|c|}
\hline $\begin{array}{l}\text { Expected } \\
\text { Effect on } \\
\text { Habltat }\end{array}$ & $\begin{array}{c}\text { Preacribe } \\
\text { Burn }\end{array}$ & $\begin{array}{l}\text { Doze or } \\
\text { Root } \\
\text { Rake }\end{array}$ & Bed & Chop & $\begin{array}{l}\text { Th1n } \\
\text { Over- } \\
\text { gtory }\end{array}$ & $\begin{array}{l}\text { Cut } \\
\text { Over- } \\
\text { Story }\end{array}$ & $\begin{array}{c}\text { Over Plant } \\
\text { w1th } \\
\text { trees }\end{array}$ & Graze \\
\hline Destroy & & & & & & & & \\
\hline Damage & & & NA & ALA & & & & \\
\hline $\begin{array}{l}\text { No Lasting } \\
\text { Effect }\end{array}$ & & & Th & 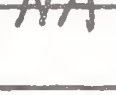 & & & & \\
\hline $\begin{array}{l}\text { Beneficlal } \\
\text { if Done } \\
\text { properly }\end{array}$ & & & & & $x$ & $x$ & & \\
\hline
\end{tabular}

Other Comments:

*Est1mated effect 18 an est1mate of the author based on h1s book knowledge of the habltat and on knowledge galned from personal field observations. Estimates are "rough" in many instances. Results of practices may vary in degree of application, intensity, nearness to plant communities, etc. A column left "blank" indicates a lack of sufficient information from which to predict expected results. As observations are made in the field by users of the data, predictions should be refined by area and by intensity of forestry practices. 
Cuscuta harperi Sma11

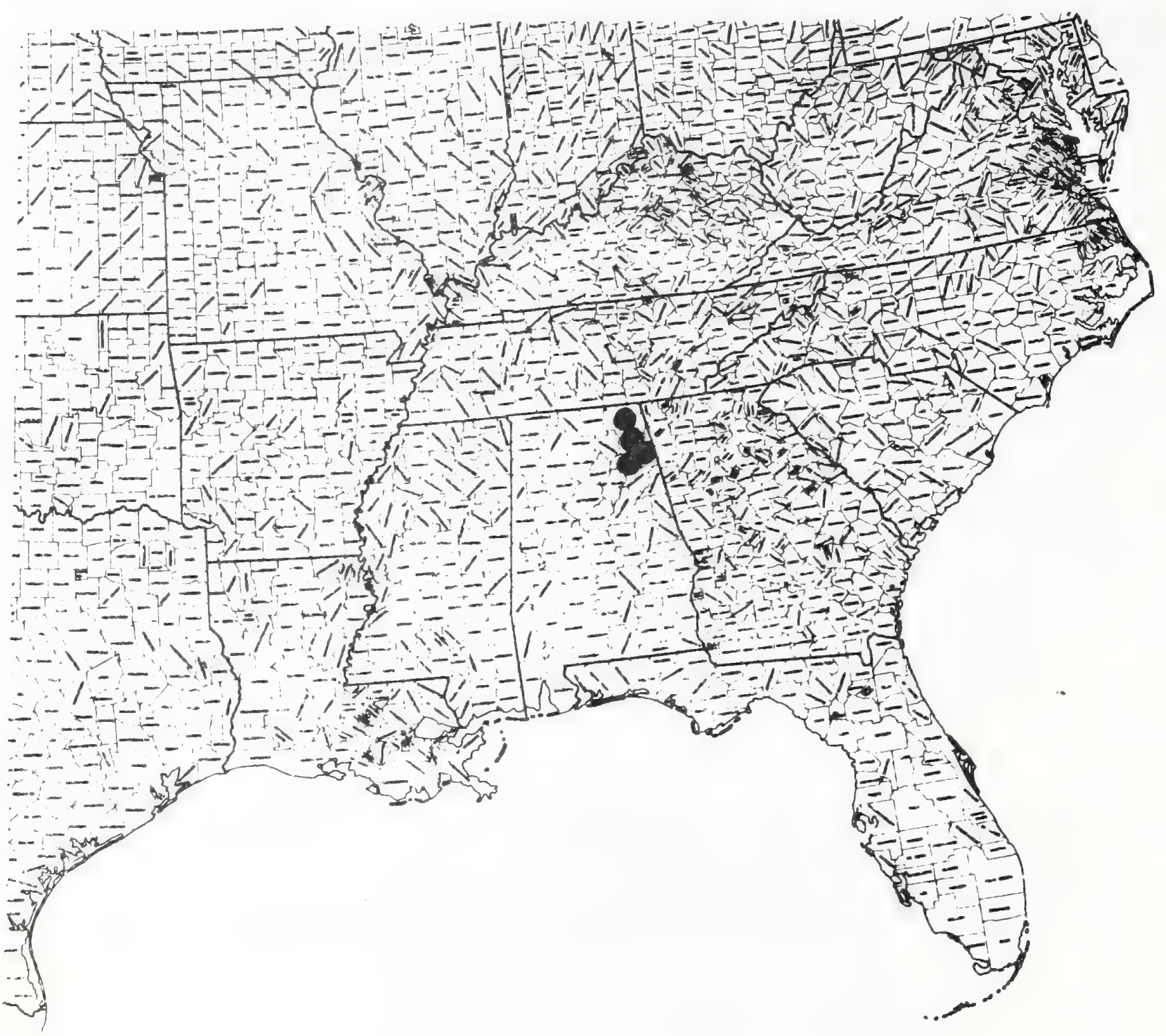




\section{Cyperus granitophilus McVaugh}

Status: Threatened?

\section{lechnical Description:}

lufted, sweetly tragrant, annual sedge, the foliage smooth, the roots slender, fibrous, reddish, shallow.

lulms: erect to spreading, 3-angled, torming small dome-shaped mats, trom base to spikelet clusters mostly 5-10 ( -15$)$ cm long, shorter than longer leaves, pale green, aging brown. Leaves: in 3 ranks, all cauline but concentrated toward culm base, the 1 ongest to $17 \mathrm{~cm}$ long, erect or spreading, the youngest scale-like, mostly sheath; mature toliage leaves with sheathes 1/4-1/6 the blade length, much broader than blades, keeled, multiribbed with broad, thin (scarious) maroon, purplish or brownish borders or entirely reddish, converging acutely to narrowly linear blades, these gradually tapering to a narrowly acute apex, the tip keeled, the margins and midrib pale, wirelike, the nerves otherwise inconspicuous, the surtaces pale green, aging maroon or brown. Int1orescence: spikelets numerous, sessile in a single dense, headlike hemispheric cluster or sometimes with 2-4 additiona1, similar, shortpeduncled clusters, subtended by 4-5 1inear,tapering, spreading unequal leatlike bracts, these sometimes full as 1 ong as culm leaves. spikelets: linear or lance-1inear, 5-10 mm long, 4-J mm wide, the bracts distichous ( 1 plane), many ( $8-12$ ), overlapping, the tertile ones lanceolate or narrowly ovate, ca. $3 \mathrm{~mm}$ long, keeled, longcuspidate, the tips ascending to somewhat spreading, the scale body thin save for the prominent (when young, greenish) midrib and the 4-5 strong lateral nerves, the whole scale aging maroon or brown; tlorets naked, perfect, but stamens maturing 1 irst, 1/f1oret, the anthers narrow1y 1ineal, nearly $1 \mathrm{~mm}$ long; ovary at first 1inea1, 3-angled, the slender style branching above or at middle to 3, filiform, spreading, exserted stigmatose branches. Fruit: Akene trigonous, most1y narrowly to broad1y cuneate-obovoid ca. $0.8-1.0 \mathrm{~mm}$ long, the angles rounded, the apex broadly rounded, somewhat shouldered or subtruncate, the 3 faces flattish save apically where somewhat concave, the surtace reddish-brown or grayish, very tinely cancellate or minutely pebbled in rows.

Distribution and Flowering Season:

Edges of shallow pools or on banks of intermittent streams and seeps in, on or around sandstone or granite outcrops, piedmont, southern Blue Ridge, cumberlands and Interior Low Plateau, middle Tennessee east to South Carolina, south into Georgia and Alabama; flowering and fruiting trom June to frost, depending on available moisture.

special Identifying Featares:

McVaugh (1937) makes a chart which has most critical differences between this and $\underline{\mathrm{C}}$. aristatus Rottb., the closest species to it. He notes that c. granitophilus is usually stouter, has the bract tips erectish or less spreading, the bract sides 4-5-nerved 
(rather than 3 or rarely 4-nerved), the akene lacking a short tipe (present in (c- aristatus). He tails to note another strong ditference, name $1 \bar{y}$ the much longer, narower anther. The only other cyperus w1th which this taxon could be contused is c. cuspidatus, a tinier weed of moist sandy waste places of the coastal P1ain and which has smaller scales whose apices are strongly notched at either side of the strong1y recurved, aristate tips. Its akenes are obovoid, but not wedge-1ike.

Habitat and Management Implication:

C. granitophilus was assumed by McVaugh to be confined to granite outcrop areas in the piedmont of Georgia. Sinee then it has been tound on or around a wide variety of outcrop types in more physiographic provinces. Its standard habitat is a thin, seasonally moist or wet, inwash substrate over rock or outwash areas nearby. It is a plant of full sun, 1 s shaded out by competing perennial herbs, and certainly by invading woody vegetation. Un the outcrops its commonest associates are various bryophytes, Isoetes, Panicum 1ithophilum, ‥ tlexile, sporobolus vaginaetlorus, Crotonopsis elliptica, lalinum, venothera truticosa, Fortulacca, Hypericum gentianoides, Juncus georgianus and other rushes, Rhynchospora, Fimbristylis, Allium, and several showy composites including Coreopsis, Liatris microcephala, Bigelowia, Viguieria porteri, etc. It is definitely a lower successional level, pioneer plant, abundant some years when raintall is normal, rarer during drought cycles. It has a high reproductive potential, can reach truit trom seed in a few weeks. It is in little danger on outcrops save from trampling from livestock or people, or trom quarrying of the rock. In the vicinity of Atlanta however, considerable acearages of outcrop are being covered by new homes or by industrial construction.

Reterences:

Godfrey, K.K. \& Jean Wooten. 1979. Aquatic and wet1and plants of the southeastern United States. Monocotyledons. Athens.

McVaugh, Rogers. 1437. A new species of Cyperus from the granite region of central Georgia. Castanea $2: 103, \mathrm{p} 1.1$, 1 igs. 4-8. 
SPECIES: Cyperus granitophilus MCVaugh

\begin{tabular}{|c|c|c|c|c|c|c|c|c|}
\hline $\begin{array}{l}\text { Expected } \\
\text { Effect on } \\
\text { Habitat }\end{array}$ & $\begin{array}{c}\text { Preacribo } \\
\text { Burn }\end{array}$ & $\begin{array}{l}\text { Doze or } \\
\text { Root } \\
\text { Rake }\end{array}$ & Bed & Chop & $\begin{array}{l}\text { Th1n } \\
\text { Over- } \\
\text { atory }\end{array}$ & $\begin{array}{l}\text { Cut } \\
\text { over } \\
\text { Story }\end{array}$ & $\begin{array}{c}\text { Over Plant } \\
\text { wth } \\
\text { trees } \\
\end{array}$ & Graze \\
\hline Destroy & & NA & NA & NA & & & $\mathrm{NA}$ & \\
\hline Damage & & & & & & & & $X$ \\
\hline $\begin{array}{l}\text { No Lasting } \\
\text { Effect }\end{array}$ & $\mathrm{X}$ & & & & & & & \\
\hline $\begin{array}{l}\text { Beneflclal } \\
\text { if Done } \\
\text { Properly }\end{array}$ & & & & & $X$ & $X$ & & \\
\hline
\end{tabular}

Other Commente:

* Est1mated effect 1 a an estimate of the author based on his book knowledge of the habltat and on knowledge galned from personal field observations. Estimates are "rough" in many 1nstances. Results of practices thay vary in degree of application, 1ntensity, nearness to plant communities, etc. A column left "blank" 1ndicates d lack of sufficient information from which to predict expected results. As observations are made $1 \mathrm{n}$ the fleld by users of the data, predictions should be refined by area and by intensity of forestry practices. 
Distribution of:

Cyperus granitophilus McVaugh

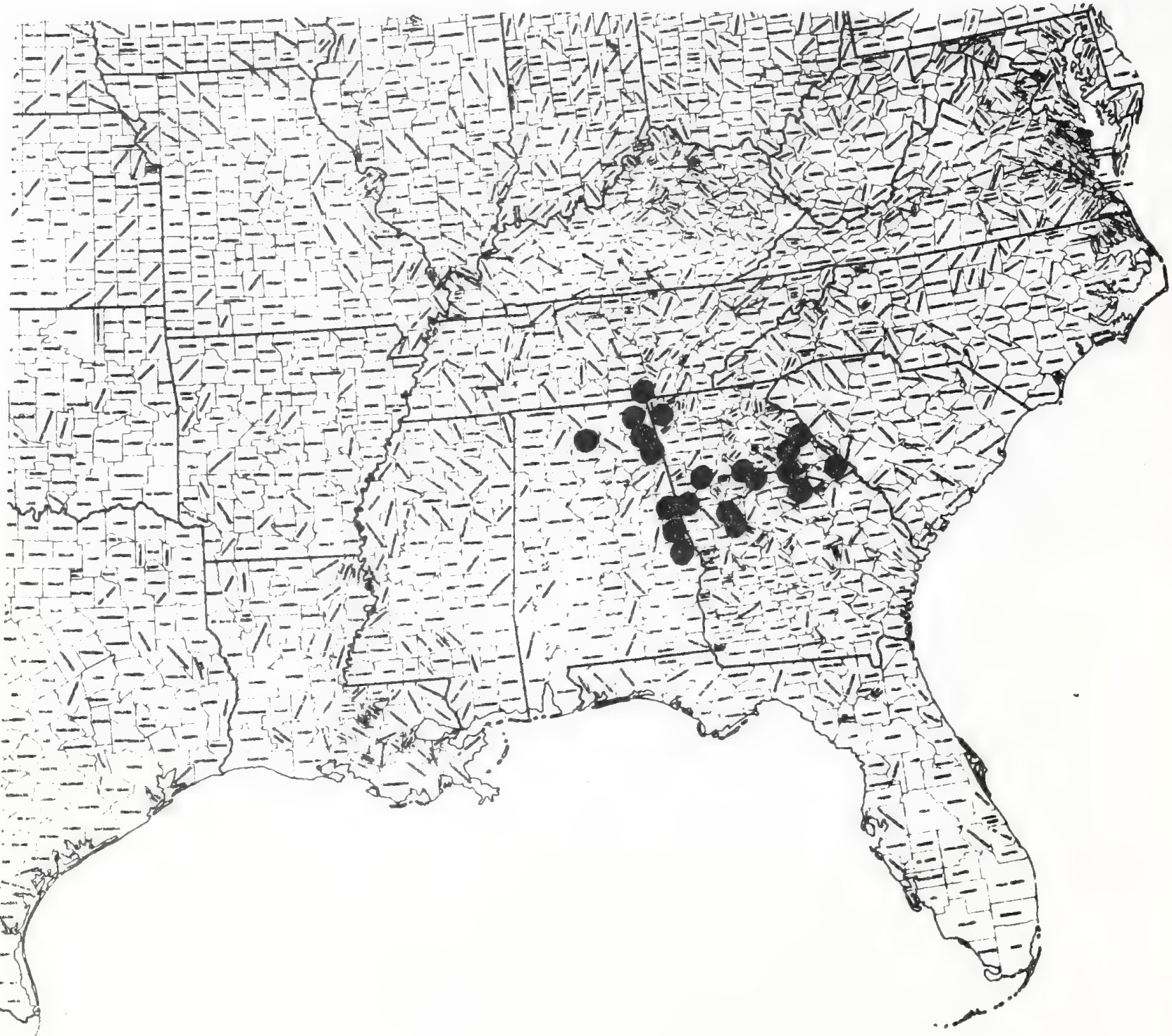




\section{Rhynchospora culixa Gale}

Status: Endangered

Technical Description:

Tufted perennial sedge, mostly 5-8 dm tall from a shallow, diffuse root system, perennating by lateral offshoot buds.

Culms: erect, slender, wand-like but somewhat stiffish, the nodes close-set proximally, remote distally, the internodes subtrigonous, the angles comprised of rounded nerves, the level interfaces shallowly and narrowly ribbed, the surfaces smooth, pale green, pale yellow green or tannish at the slightly contracted nodes. Leaves: somewhat crowded toward the base, the lowest ones chaffy, short-linear, scale-1ike, persistent, the largest up to half as long as the culm, erect or ascending, the sheathes continuous, tubular, less than $1 / 5$ as 1 ong as blades, the rounded backs pale green, multiribbed, smooth, the ventral area scarious, tannish, at the orifice slightly darker, the thin margin truncate or slightly concave, the blades narrowly 1inear, most1y $2-3 \mathrm{~mm}$ wide tapering above midblade gradually to a slightly callused, broadly acute, scabrous apex, the margin scabro-ciliate, the surface pale green with only the mid-vein strongly raised. Inflorescence: spikelets lance-ovoid or broadly ellipsoidal, narrowly acute, 1-2-flowered, ca. 4-5 mm long, a pale reddish-brown, few in cymules, the cymules few-to-several per complex on ascending or erect, unequal branches, with 1-3 complexes lateral to main axis on ascending slender peduncles, each peduncle subtended by a bracteal leaf similar to a foliage leaf but smaller and shorter, plus a terminal bracteate complex, these complexes confined to the upper $1 / 4$ of the culm, the lower ones more distant; each cymule stalk subtended by a scale-1ike, linear-subulate bract and enveloped at base by a short-tubular, scarious prophy11. Scales per spikelet few, tightly imbricated, the lowermost sterile, emarginate and strongly awned, the awns scabrid-margined, the fertile scales broadly ovate, ca. $3.0-3.5 \mathrm{~mm}$ long, strongly cupped, the apex bluntly acute, often mucronulate, the margins very thin, pale, the surface with only the midnerve evident. Florets: perianth bristles usually 6, antrorsely barbellate, unequal, the longest reaching about to middle of ripe akene; stamens 3 , the flattened filaments supporting narrowly oblong, erect, basifixed anthers; style slenderly linear, 2-branched at about the middle. Fruit: akene in outline broad1y el1iptical or obovate, ca. 1.5-2.0 mm long from base to tubercle tip, at thickest point biconvex but not tumid (in crossmsection narrowly el1iptic), pale brown, irregular1y wavy-transversemrugulose, the intervals narrower than the ridges, these and the ridges finely vertically 1 ined; tubercle depressedconic, grayish-spongy, ca. 0.4-0.5 mm high, sometimes apiculate, the basal rim definitely buttressed (forming a low "cliff" rather than having an indentation or groove around its base!)

Special Identifying Features: 
R. culixa, according to Gale (1944) is in the series Harveyae, which comprises on $1 y$ species, al1 of which have the tubercle of the akene definitely buttressed. It is the lowest plant of the four, is the most slender, with the upper culm leaves much more reduced. While the other three species (‥ megalocarpa, R. harveyi, R. grayii) have akenes that are finely to coarsely pitted with concave alveolae, this species in addition to being finely alveolate, has a low but very evident cross-ridging of its fruit surface.

Distribution and Flowering Seasnn:

Pineland savanna and edges of flatwoods bogs, evidently very rare and local, Coastal Plain, southwestern Georgia and northwestern Florida; flowering and fruiting from late May into early July.

Habitat and Management Implication:

This rare sedge, which I have seen only once in the field, seems to take moister ground than others of its complex do. Actual1y R. megalocarpa is a coarse beakrush of deep dry sands of longleaf $\bar{P}$ ine and Sand Pine sandhills or sandscrub, R. grayii is commonest in sandhills also with an affinity for the Longleaf pine-Turkey Oak formation, while the more ecologically ample $\mathrm{R}$. harveyi is found in prairies, upland clearings and upper edges of boggy swales from the prairie provinces in the mid-West eastward through much of the Coastal Plain. R. culixa however appears to prefer a moist substrate such as in pine flatwoods savanna or along the edges of hillside seep bogs in Longleaf Pine hills. Locality data from the few existing collections show that it is part of a grass-sedge complex that would include many more species of Rhynchospora (R. divergens, R. pusilla, R. rariflora, R. globularis, R. torreyana, R. schoenoides, etc.), Fimbristylis puberula, Scleria, various Cyperus, many Dichanthelium Panicum, P. agrostoides, P. tenerum, Paspalum laeve, P. 1entiferum, many Ar̆istida, and a vàriety of Andropogon, Juncus, Xyris, Aletris, manybog orchids, Polygala, Rhexia, Sarracenia, Eriocaulon,Lachnocaulon, Lachnanthes, etc. The substrate is a black sandy peat of high hydroperiod. The commonest savanna trees are Longleaf Pine, Pond Cypress, Pond Pine, Nyssa biflora, Liquidambar, Red Maple. In the shrub layer are numerous heaths in genera Vaccinium, Lyonia, Leucothoe, Lyonia, a1so Myrica, Ilex glabra and coriacea, Rubus, Smilax. Saw Palmetto is locally common, together with large clones of Cyrilla. The grass-sedge openings were created by woods fires, and removal of fire as a factor promotes invasion of the clearings by trees and shrubs.

Such savanna and bog habitat in the Coastal Plain is rapidy being drained, this followed by clear cutting and mechanical site preparation for pine plantation or for conversion to improved pasture or row crop agriculture. In any event the result is total destruction of habitat for this rare sedge and many other rarities as we11.

References:

Ga1e, Shir1ey. 1944. Rhynchospora, sect. Eurhynchospora, in Canada, the United States and the West Indies. Contr. Gray Herb. CLL. 
SPECIES: Rhynchospora culixa Gale

\begin{tabular}{|c|c|c|c|c|c|c|c|c|}
\hline $\begin{array}{l}\text { Expected* } \\
\text { Effect on } \\
\text { Habltat }\end{array}$ & $\begin{array}{c}\text { Prescribo } \\
\text { Burn }\end{array}$ & $\begin{array}{l}\text { Doza or } \\
\text { Root } \\
\text { Rake } \\
\end{array}$ & Bed & Chog & $\begin{array}{l}\text { Thin } \\
\text { Over- } \\
\text { story }\end{array}$ & $\begin{array}{l}\text { Cut } \\
\text { over- } \\
\text { story }\end{array}$ & $\begin{array}{c}\text { Over Plant } \\
\text { wth } \\
\text { trees } \\
\end{array}$ & Graze \\
\hline Destroy & & $X$ & & & & & 21 & \\
\hline Damage & & & & & & & & \\
\hline $\begin{array}{l}\text { No Lasting } \\
\text { Effect }\end{array}$ & & & & & & & & \\
\hline $\begin{array}{l}\text { Beneficial } \\
\text { If Done } \\
\text { Properly }\end{array}$ & & & & & & & & \\
\hline
\end{tabular}

Other Commente: Do not drain!

* Est1mated effect 18 an est1mate of the author based on h1s book knowledge of the habitat and on knowledge gatned from personal field observations. Estimates are "rough" in many 1nstances. Results of practices may vary in degree of application, intensity, nearness to plant communities, etc. A column left "blank" indicates a lack of sufficient information from which to predict expected results. As observations are made in the field by users of the data, predictions should be refined by area and by intensity of forestry practices. 
Rhynchospora culixa S. Gale

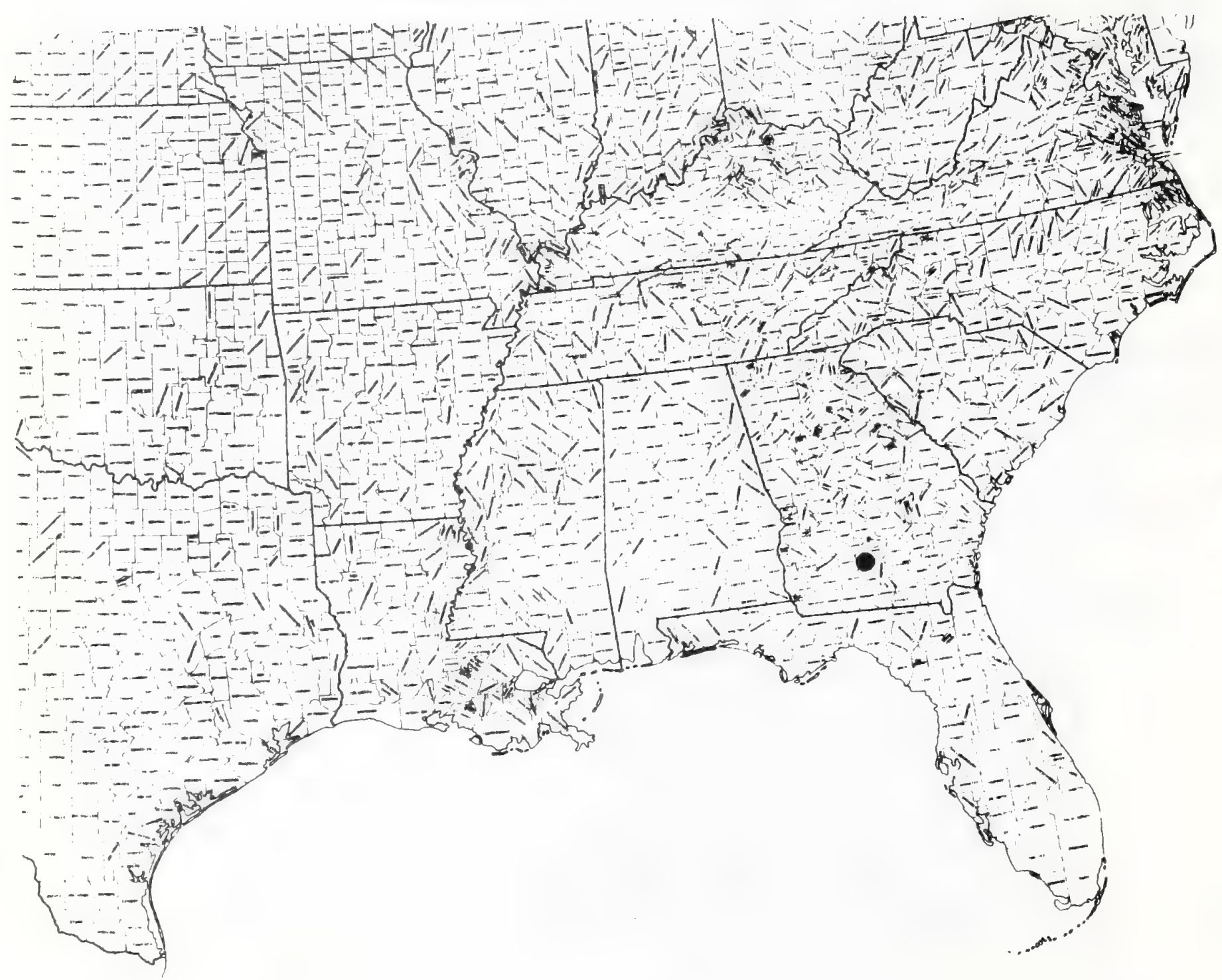




\section{Rhynchospora globularis (Chapm.) Sma11 var. saxicola (Smal1) Kukenthal \\ Rhynchospora saxicola Sma11}

Status: Threatened

Technical Description:

Perennial, slender Beak-rush from a shallow, diffuse-fibrous root.

Culms: usually stiffly erect, slender, mostly $2 \leftrightarrow 4 \mathrm{dm}$ high, in smal1 tufts or densely caespitose, triangulate, smooth, sometimes with more than 3 sharp ridges and sulcate distally, usually with 2, short erect or ascending lateral branches toward tip.

Leaves: usually in 3 planes, more crowded, largest and longest toward base of culm, there most1y $1 / 3-1 / 2$ as 1 ong as the culms, with sheathes overlapping, less than 1/5 the total leaf length, the backs rounded or slightly keeled, multiribbed, the margins narrow, scarious, this border widening distally to junction with blade, there forming a convergent pair of low, thin auricles, the blades narrowly linear, flat or somewhat folded, $1.5-3.0 \mathrm{~mm}$ wide, above the middle gradually tapering to an abruptly acute, harsh margined apex, the margins at least distally scabrid, the backs with a few low ribs, the upper surface with only the midnerve evident; leaves upward on culm progressively shortening, with shorter sheathes, and more distant, grading into bracteal blades.

Inflorescence: spikelets ovoid, or ellipsoidal, most1y 1-3-f lowered and fruited, ca. $3 \mathrm{~mm}$ long, acuminate, a rich glossy pale reddishbrown, in smal1 clusters (cymes), usually 1 terminal and 2 lateral and distant in the upper $1 / 3$ of the culm, the slender lateral peduncles subtended by erect or curvate, closed-sheathed, narrowly linear bracteal leaves, a 11 cymes either simple and made up of but 1 cymule or weak1y compound with 2 or a few more cymules, the central often sessile, prophyllate, the others on stiff peduncles of varying lengths; individual cymules of 1-few spikelets, usually subtended by chaffy, linear bracts grading into spikelet scales; outer spikelet scales barren, often scabridulousa awned or cuspidate; fertile scales broadly ovate to suborbicular, thin, only the midnerve evident, apically obtuse, the margin entire, the backs strongly rounded. Florets: perianth bristles slender, stiffish, antrorsely barbed, usualiy 6, most1y overtopping akene, often the tubercle; stamens 3 , the filaments flat, erect, the linear anthers basifixed, erect, bilocular; style 2-branched from about the middle. Fruit: akene broadly obovoid, tumidmlenticular (in cross section biconvex, not round), including tubercle $1.3-1.6 \mathrm{~mm}$ long, 1.1-1.3 mm wide, with several undulant and interrupted or anastomosing crossuridges, the intervals between strongly etched by numerous sharp, fine vertical ridges to form a system of rows of parallelsided rectangular alveoli, the surface a dark brown or chestnut brown, thistrous; tubercle (persistent style base) grayish, strongly depressedmconic or discoid, at most $0.3 \mathrm{~mm}$ high, not buttressed but invaginated around the rim, bearing at the depressed apex a sma11 apiculus. 
Distribution and Flowering Season:

Moist open areas on and around granite or grit outcrops, Piedmont and inner Coastal Plain, Georgia; flowering mostly in June but intermittent1y we11 into July.

Special Identifying Features:

This is seeming1y but one of the radiate extremes from a large matrix species, R. globularis (Chapm.) Sma11, and perhaps best should be re-evalued even at the varietal leve1. It tends to be distinguished from the rest of the Series Globulares Gale by a combination of such fruit characters as bristles overtopping ripe fruit, tubercle strongly depressed, conic-discoid, apiculate. However, a single population may vary widely even in these characters, and even a single plant may show fruit variation. Unfortunately there is sufficient overlap with other taxa such as R. obliterata Ga1e, R. sulcata Gale, even $R$. culixa Gale of the neighboring series Harveyae to make one realize why Kukenthal made these varieties, the first two of . globularis, the latter one of $\underline{R}$. grayii.

Habitat and Management Implication:

R. globularis saxicola grows on and around outcrops of granite in the Georgia Piedmont, on and around the Altamaha Grit formation in the Coastal Plain of Georgia. In the former situation it is in sha11ow, seasonal1y wet depressions or along intermittent streams or seeps on and around the granites, usually in full sun and on these shallow inwash soils is in association with various grasses and sedges such as Agrostis, Dichanthelium Panicum, Andropogon, various carices, Fimbristylis, other Rhynchospora (particularly - globularis, R. capitellata, R. glomerata), Fuirena, Scleria, Scirpus. other herbaceous associates include Juncus (particular 1 y J० georgianus), Xyris, Allium, Schoenolirion croceum, Oenothera frutīcosa, Rhexia mariana, R. virginica, Lindernia monticola,various composites, particulariy Senecio tomentosus, etc. In the A1tamaha Grit country the number and variety of grasses and sedges increases, but the character of the total herb assemblage is not much changed, except to add some of the endemics of the grit, particularly Penstemon dissectus, Bigelowia nutta11ii, Marshaliia ramosa and the shrubby Hypericum 1loydii. The forest surrounding and invading the granites is mostiy upland oak and pine, the oaks most1y $\mathrm{Q}$. montana, $\mathrm{Q}$. velutina, Q. nigra, Q. rubra, Q. coccinea, Q. marilandica and the otherwise

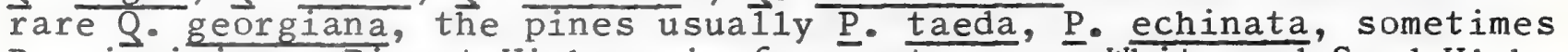
$\underline{p}$. virginiana. Pignut Hickory is frequent as ar $\bar{e}$ White and Sand Hickory, Persimmon, Winged E1m, Sassafras, Black Gum, Black Cherry. The understory has an abundance of Cornus florida, Cercis, various Rhus, particularly $\underline{\mathrm{R}}$ : copal1ina, Chionanthus, Vacciniumarboreum, with blackberry, Pōison Oak, and lowbush blueberries abundant in the shrub layer. Smilax, Gelsemium, Anisostichus and Poison Ivy are common vines, together with masses of invading Lonicera. In the Grit country Longleaf Pine is the common pine, while Q. marilandica, Q. margaretta, $\mathrm{Q}$. ste1lata and $\mathrm{Q}$. 1aevis become the common oaks. Aristida stricta and other 3-awns, a greater variety of Andropogon Panicum and cyperaceous plants shows up, but the floristic affinity to granite glades is plain. 
Threats to this beakrush are multiple. The granites are quarried, which destroys the sites. In park areas (such as Mount Arabia) hikers and sightseers trample the shallow pools and streambanks. Many outcrops contiguous to areas of high population such as Atlanta are being subdivided for residential 1ots. Other outcrops have become low grade pasture and the sedges suffer from trampling and grazing. In the grit areas the same problems exist, but also the shallow soil cover, if fairly level, is now often planted to Siash pine or other pine, this leading ultimately to a shading out of sun plants such as this one.

\section{References:}

Gale, Shirley. 1944. Rhynchospora, sect. Eurhynchospora, in Canada, the United States and the West Indies. Contribs. Gray Herb CLI.

Kukentha1, Georg. 1954. Vorarbeiten zu einer monographie der Rhynchosporideae. Botanische Yahrb. 75 Band. Heft 2: 156-168. 
SPECIES: Rhynchospora globularis (Chapm.) Sma11 var. saxicola (Sma11) Kukenth

\begin{tabular}{|c|c|c|c|c|c|c|c|c|}
\hline $\begin{array}{l}\text { Expected } \\
\text { Effect on } \\
\text { Hab1tat }\end{array}$ & $\begin{array}{c}\text { Pracer1bo } \\
\text { Burn }\end{array}$ & $\begin{array}{l}\text { Doze or } \\
\text { Root } \\
\text { Rake }\end{array}$ & $\mathrm{Bed}$ & Chop & $\begin{array}{l}\text { Thin } \\
\text { Over- } \\
\text { otory }\end{array}$ & $\begin{array}{l}\text { Cut } \\
\text { Over- } \\
\text { Story }\end{array}$ & $\begin{array}{c}\text { Over Plant } \\
\text { with } \\
\text { trees } \\
\end{array}$ & Graze \\
\hline Destroy & & & & & & & & \\
\hline Damage & & & NLA & $1 / 4$ & & & & \\
\hline $\begin{array}{l}\text { No Lasting } \\
\text { Effect }\end{array}$ & & & & & & & & \\
\hline $\begin{array}{l}\text { Beneficial } \\
\text { If Done } \\
\text { Proper y }\end{array}$ & & & & & & & & \\
\hline
\end{tabular}

\section{Other Commente: Do not drain!}

*Estimated effect 18 an estimate of the author based on his book knowledge of the habitat and on knowledge galned from personal field observations. Estimates are "rough" in many instances. Results of practices may vary in degree of application, intensity, nearness to plant communities, etc. A column left "blank" indicates a lack of sufficient information from which to predict expected results. As observations are made in the field by users of the data, predictions should be refined by area and by intensity of forestry practices. 
Approximate known Range of:

Rhynchospora globularis (Chapm.) Smal1 var. saxicola (Sma11) Kukenthal

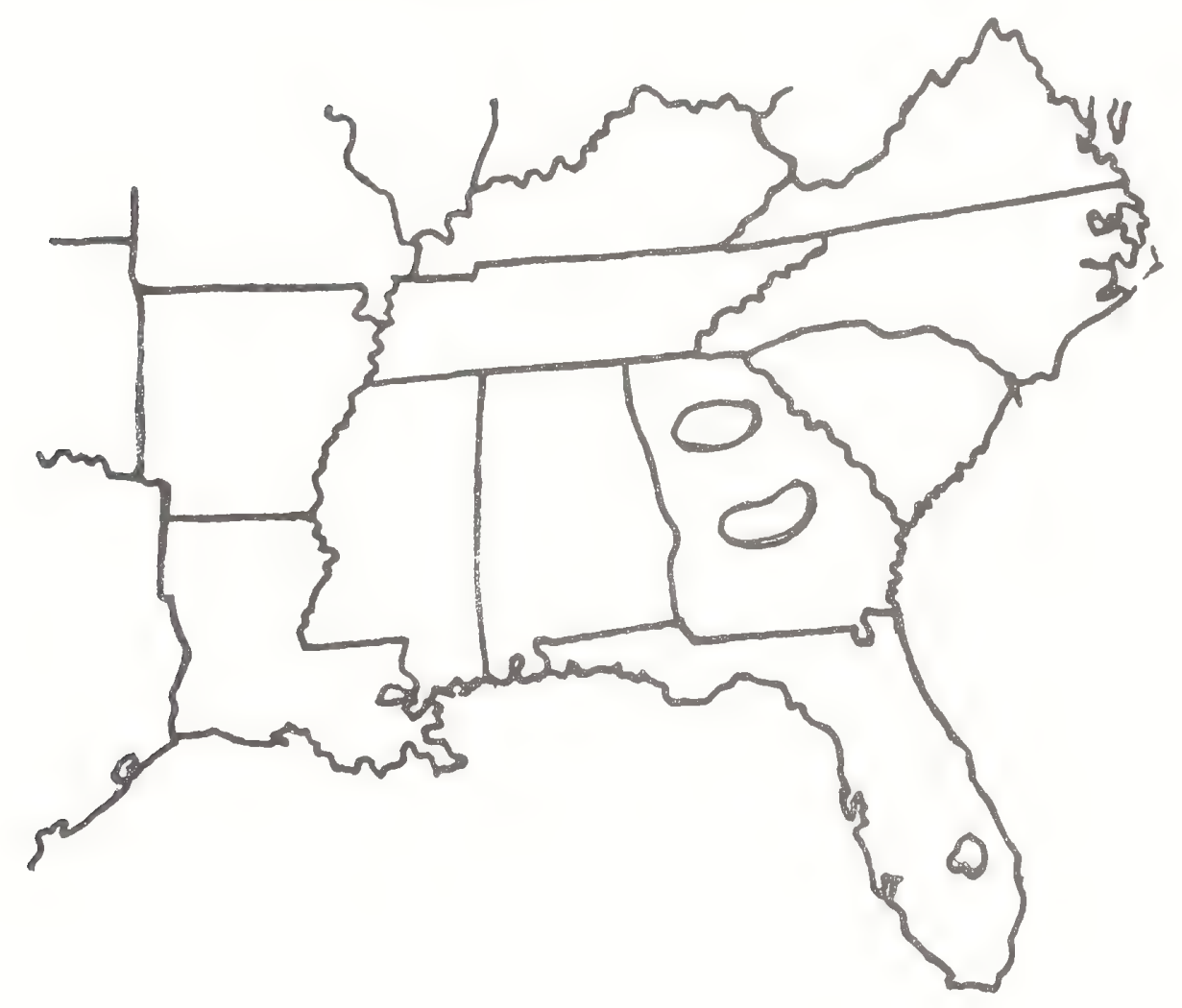


6

6

6 


\section{Rhynchospora punctata E11。}

\section{Status: Threatened}

\section{Technical Description:}

Tufted perennial sedge, between 7 and $10 \mathrm{dm}$ tal1, perennating by lateral offshoots from a diffusewibrous-rooted stock.

Culms: erect or leaning, fairly rigid but wandwlike, pale green, triangular, smooth, each edge a rounded nerve, the flattish or slightly concave intervals finely grooved and nerved, the nodes slightly contracted.

Leaves: a few widely spaced on mid and upper culm, mostly crowded toward the base, there largest save for some scale-like outer ones or fibrous remnants of dead ones, the sheaths ca. 1/5 the total leaf length, closed, the backs rounded below, sometimes strongly keeled distally, multiribbed, the ventral side scarious, at apex by junction with blade, thin, strongly concave, the blades $1.0 \rightarrow 2.5$ dm long, proximally and distally often keeled, otherwise flat, narrow 1y linear, 3-6 mm wide, narrowing gradually above midmblade, then abrupt 1y to a blunt-acute, scabrid apex, the margin narrow but thickened and white, minutely scabrid, the surface save for the midnerve pale green, finely ribbed.

Inflorescence: spikelets lancewovoid, narrowly acute, ca. $5 \mathrm{~mm}$ long, a rich, glossy reddish-brown, 4-flowered, usually 2-fruited, usually few/cymule, the cymules loosely turbinate, few to several per complex on ascending to erect, unequal branches, about 3 decompound complexes lateral to main axis, and 1 terminal, on ascending or slightly spreading slender peduncles, each peduncle subtended by a bracteal leaf similar to foliage leaf but sma11, shorter, somewhat narrower, the lowest bracteal leaf much shorter than the peduncle, the uppermost one longer, each primary peduncle terminating in $2-3$ green, linear, subulate involucral bracts subtending unequal secondary peduncles, each of these with a basal chaffy bract and enveloped by a chaffy, tubular prophy11; scales of spikelet fairly tightly imbricate, the lowest empty, smaller than the fertile, strongly cuspidate, the fertile scales broadly ovate, ca. 4.0.4.5 mm long, thin, the margins pale, the apex narrowly rounded, the backs rounded with only the mid-nerve evident, this departing subapically to form a short, minutely scabrid bristle; upper scales empty. Florets: perianth bristles 6, antrorse1y barbellate, extending at least to base of tubercle of ripe fruit and often to its tip; stamens 3, filaments flat, the short-linear anthers basifixed; style slenderly linear, cleft to about its middle. Fruit: akene including tubercle ca. $2.5 \mathrm{~mm}$ long, obovoid or ellipsoidal, evidently dorsiventrally flattened (in plane parallel with plane of bracts), body transversely wavy-rugose with many, sometimes anastomosing, ridges, the intervals sharply and concavely alveolate, the alveolae rectangular and vertical, the surface reddish-brown, dullish; tubercle conic-triangular, ca. 0.4-0.5 mm long the sides straight, the base scarcely flanged, not buttressed, siightly decurrent on the upper akene edge, the apex either acute or acute- 
apiculate.

Distribution and Flowering Season:

Wet acid pine flatwoods and savanna, southern Georgia and northern Florida; flowering and fruiting from late May into early Ju1y.

Special Identifying Features:

R. punctata is in the Series Globulares Gale, distinguished from other complexes by its rectangularalveolate fruit surfaces which are also transversely rugose, as well as by the fairly rigid habit, the development of lateral and terminal decompound clusters of cymules, the presence of usually 6 perianth bristles and a conic, depressed conic, or shortmsubulate, grayish tubercle. Within the Globulares, the tall and firm culms, broadish and firm leaves, and particularly the very flattened and rugulose fruit, place $\mathrm{R}$. punctata close to $\underline{\mathrm{R}}$. compressa Carey ex Chapm. In fact, the on 1 y way to te11 the two apart is by fruit. The perianth bristles of $\mathrm{R}$. punctata are longer, reaching at least to the tubercle base and often to its tip (rather than extending only to about the upper $1 / 3$ of the akene as in $\mathbf{R}$. compressa!), while the tubercle itself is straight-sided, apiculate (rather than concave-sided, acuminate as in $\mathrm{R}$. compressa), its base scarcely flaring or flanged, and with sides silightly decurrent (rather than strongly flaringflanged and not at a11 decurrent-sided as in $\mathbf{R}$. compressa).

Habitat and Management Implication:

R. punctata is rare and local in the Longleaf Pine-Gallberry-Saw $\bar{P}$ almetto flatwoods of southern Georgia and (according to old records) northern Florida. In the past it was doubtlessly maintained in grassosedge clearings created by natural woods fires. Associate species include many lowland Andropogon, Panicum, Erianthus, Manisuris, Paspalum, Aristida, Carex, Fimbristylis (particular1y F. puberula) Rhynchospora (among which are the similar R. compressa, R. globularis, which may account for this plant being overiooked!), Aletris, Eriocaulon, Lachnocaulon, Xyris (many species), Hypoxis, Lachnanthes, Lilium catesbaei, Tofieldia, Zygadenus, Sarracenia Cparticulariy $\underline{\text { S. minor }}, \underline{\text { S. flava) }}$ Rhexia, Ludwigia, lowland asclepiads, Lobelia, Po1yga1a, and many composites. This showy community develops only on high hydroperiod soils and in full sun.

Risks to this species in its few known localities include (1.) fire protection which allows woody vegetation to invade open areas, (2.) drainage ditching precursory to mechanical site preparation or logging of wet pinelands, which dries out the habitat as we11 as destroys the bog soils, or (3.) clearing for the purpose of development of improved pasture, in which case even without drainage the agressive introduced Paspalum or Cynodon crowd out native grasses and forbs. Large tracts are alsobeing drained,cleared, and prepared for row crops, and thus more habitat is 1ost.

References:

Gale, Shir1ey. 1944. Rhynchospora, sect. Eurhynchospora, in Canada, the United States and the West Indies. Contr. Gray Herb. CLL. 
SPECIES: Rhynchospora punctata E11.

\begin{tabular}{|c|c|c|c|c|c|c|c|c|}
\hline $\begin{array}{l}\text { Expected } \\
\text { Effect on } \\
\text { Habltat }\end{array}$ & $\begin{array}{c}\text { Prescribe } \\
\text { Burn } \\
\end{array}$ & $\begin{array}{l}\text { Doze or } \\
\text { Root } \\
\text { Rake } \\
\end{array}$ & Bed & Chop & $\begin{array}{l}\text { ThIn } \\
\text { over } \\
\text { otory }\end{array}$ & $\begin{array}{l}\text { Cut } \\
\text { Over- } \\
\text { Story } \\
\end{array}$ & $\begin{array}{c}\text { Over Plant } \\
\text { w } 1 \text { th } \\
\text { trees } \\
\end{array}$ & Graze \\
\hline Destroy & & $X$ & & & & & & \\
\hline Damage & & & $X$ & & & & & \\
\hline $\begin{array}{l}\text { No Lasting } \\
\text { Effect }\end{array}$ & & & & & & & & \\
\hline $\begin{array}{l}\text { Beneficlal } \\
\text { If Done } \\
\text { Properly }\end{array}$ & & & & & & & & \\
\hline
\end{tabular}

Other Comments: Drainage ditching destroys the habitat !

*Est1mated effect 1o an est1mate of the author based on h1s book knowledge of the habltat and on knowledge galned from personal field observations. Estimates are "rough" in many instances. Results of practices may vary in degree of application, intensity, nearness to plant communities, etc. A column left "blank" indicates a lack of sufficient information from which to predict expected results. As observations are made in the field by users of the data, predictions should be refined by area and by intensity of forestry practices. 
Rhynchospora punctata Elliott

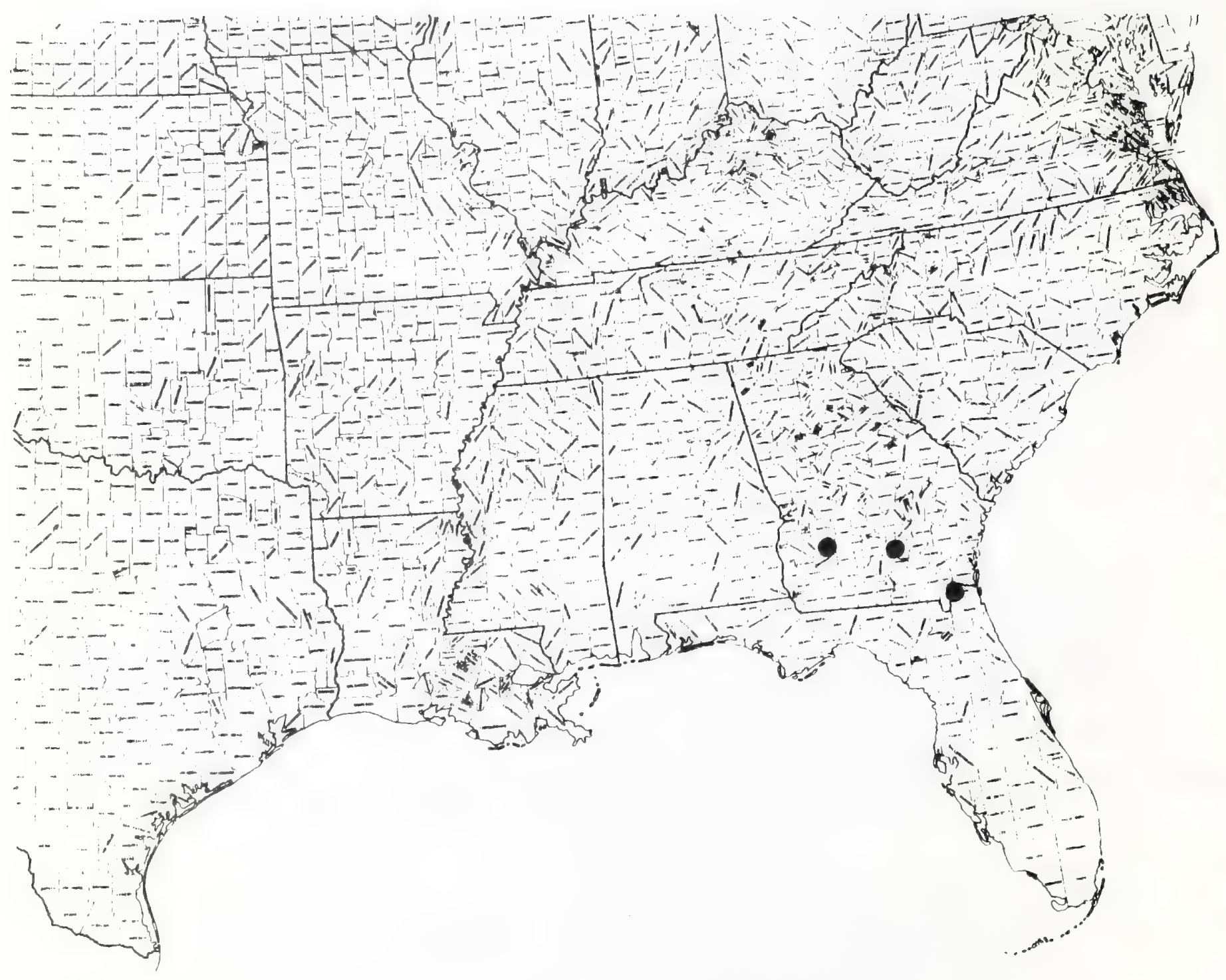




\author{
Rhododendron bakeri (Lemmon \& McKay) Hume \\ Azalea bakeri Lemmon \& McKay \\ Rhododendron cumberlandensis E.L. Braun
}

Status: Threatened

Technical Description:

Compact deciduous shrub, rarely exceeding 2 meters, the primary shoots few-to-numerous, erect or ascending, the lower bark thin, with long, longitudinal shallow cracks, forming a pattern of narrowly rectangular platelets, these shoots rebranching to form a broad crown, the rootstock shallow, spreading-diffuse.

Twiqs: New shoots of a season as in most Rhododendron, namely slender, straight, mostly subwhorled, with the nodes distant woard shoot base, close toward shoot apex, the surface pale reddish-brown or greenish-brown, from nearly smooth to sparsely puberulent or moderately puberulent with some stouter, longer hairs admixed, but no hairs glandular; older shoots becoming gray-brown, or ash gray, smooth. Winter inflorescence buds ovoid, acute, the imbricate bud scales mostly ovate, acute to rounded, often cuspidate, the backs chestnut-brown to reddish-brown, nearly smooth to appressed-white-puberulent, the thin margins pale, ciliolate. Leaves: alternate-spiral as in other Rhododendron, mostly spreading to ascending, hardened before flower buds open, prevalently oblanceolate to elliptic or narrowly obovate, acute and mucronate, entire to minutely serrulate, strigo-ciliate, on short, nearly smooth to puberulent, also sometimes sparsely hirtellous, e-glandular petioles mostly 2-4 mm long, the blade surfaces above nearly smooth or sparsely incurved-strigo-puberulent, particularly toward the margins, and white-tomentulose along the impressed midvein, beneath hirtellous along the strongly raised midvein, sparsely villosulous along the lateral veins, atherwi se nearly smooth, and with no glandular hairs.

Inflorescence: a compact, umbel-like raceme as in many Rhododendron, the slender, straight pedicels mostly under $1 \mathrm{~cm}$ long, hirtellous, e-glandular, subtended by inner bud scales and narrowly linear, hairy-tipped scales.

Flowers: bisexual, the corolla very slightly zygomorphic the calyx regular; sepals 5, low-triangular, somewhat scale-like, ca. $1.5 \mathrm{~mm}$ long, hirsute-ciliate, the backs sparsely to densely appressedhirtellous; the petals 5, fused into a tube ca. $2 \mathrm{~cm}$ long, this expanding funnelform, the lobes obliquely spreading, lance-oblong or narrowly ovate, acute, short-acuminate, the upper lobe broadest, the whole limb 4-5 cm across; external surface with tube and throat pilosulous, also sparsely short-hirsute with these hairs glandtipped, the lobes sparsely puberulent with some hairs gland-tipped; color ranging from near yellow through pale to deep orange, deep 
orange red or brick red, usually with the upper (broadest) lobe bearing a strong yellow splotch medially toward base inside. Fruit: Capsule cylindrical or lance-cylindric, ca. 2 cm long, strigillose, with no glandular hairs, opening from narrowed apex downward septicidally, the numerous wedge-shaped small seeds with axile placentation.

\section{Distribution and Flowering season:}

Sands and sandy loams, open, moistish to dry woodlands, Cumberland Mountains, Cumberland Plateau, West Virginia and southwest Virginia southward through Kentucky and Tennessee east of the Blue Ridge and local in Valley and Ridge; flowering mostly from early June into July depending on altitude or latitude.

Special Identifying Features:

Of the reddish-flowered azaleas this one is the most compact and with perhaps the greatest horticultural potential, so that one good feature is the low, heavily floriferous habit. Its range, flowering time and morphology overlaps most with the true Flame Azalea, $\underline{R}$. calendulaceum, but it differs from that species in having slightly smaller flowers, the corolia tube of which has a mixture of short eglandular hairs and longer, sparse glandular hairs (in $R$. calendulaceum the hairs are longer, often denser, with more and longer gland-tipped ones), the stamens with filaments smooth or sparsely hairy only toward base (in $\underline{R}$. calendulaceum hairs extend at least midway up the filaments). R. bakeri flowers expand weeks after the leaves have, while in R. calendulaceum the leaves and flowers expand together. Single populations of each often run the gamut from yellow to red, though $\underline{R}$. bakeri tends more toward deep reds than does $\underline{R}$ calendulaceum, and may be uniformly red. As Dr. Braun (1941) has commented, there are intergradations between the two species along the contact in the eastern Cumberlands and in the Valley and Ridge, but if degree of hybridization effected the taxonomy toward reducing hybridizing species there would be few azaleas in the southeastern flora.

Habitat and Management Implication:

This azalea is a plant of uplands, from moist to rather dry sandy loams in open woodlands whose overstory is made up mostly of oak-hickory-pine. It may share the understory with Kalmia, other Rhododendron, Oxydendrum, Leucothoe, etc. as part of a heath cover, or may be the only heath present. In areas I have seen in the Tennessee and Virginia Cumberlands it seems to persist well in woodlands that have been heavily cut over, in some cases clearcut or even burned, but is eliminated where most methods of 
mechanical site preparation have been employed. I have not seen it as understory to plantation of, or dense stockings of Shortleaf, Loblolly, or Virginia Pine. It is poisonous to livestock, though it may be used by deer. Apart from the threat it faces through wholesale blocks of land undergoing or having undergone site preparation it, because of the very showiness of the shrub, is much endangered by vandals and shrub diggers. Also, much of its heart range has been ravaged by strip mining.

\section{References:}

Braun, E.I. 1941. The red azalea of the Cumberlands. Rhodora $43: 31-35$.

Lemmon, W.P. 1937. Notes on a study of the southeastern azaleas with descriptions of two new species. Bartonia 19: 14-17.

Fernald, M.L. 1950. Gray's manual of botany, ed. 8, Rhododendron, pp. $1116-1120$. 
SPECIES: Rhododendron bakeri (Lemmon \& McKay) Hume

\begin{tabular}{|c|c|c|c|c|c|c|c|c|}
\hline $\begin{array}{l}\text { Expected } \\
\text { Effect on } \\
\text { Hab1tat }\end{array}$ & $\begin{array}{c}\text { Preecribe } \\
\text { Burn }\end{array}$ & $\begin{array}{l}\text { Doze or } \\
\text { Root } \\
\text { Rake }\end{array}$ & Bed & Chop & $\begin{array}{l}\text { Thin } \\
\text { over- } \\
\text { atory }\end{array}$ & $\begin{array}{l}\text { Cut } \\
\text { Over - } \\
\text { story }\end{array}$ & $\begin{array}{c}\text { Over Plant } \\
\text { with } \\
\text { trees } \\
\end{array}$ & Graze \\
\hline Destroy & & $\mathrm{x}$ & & $\mathrm{X}$ & & & $x$ & \\
\hline Damege & & & $\mathrm{x}$ & & & $\mathrm{x}$ & & \\
\hline $\begin{array}{l}\text { No Lasting } \\
\text { Effact }\end{array}$ & $x$ & & & & & & & $x$ \\
\hline $\begin{array}{l}\text { Beneficial } \\
\text { if Done } \\
\text { Proporly }\end{array}$ & & & & & $\mathrm{X}$ & & & \\
\hline
\end{tabular}

Other Commente:

*Eot1mated effect 18 an est1mate of the author based on h1 book knowledge of the habltat and on knowledge galned from personal fleld observations. Estimates are "rough" in many 1natances. Results of practices may vary in degree of application, intensity, nearness to plant commuties, etc. A column left "blank" Indicates a lack of sufficlent information from which to predict expected results. As observations are made in the fleld by users of the data, predictions should be refined by area and by intensity of forestry practices. 


\section{Approximate Range of:}

Rhododendron bakeri (Lemmon \& McKay) Hume

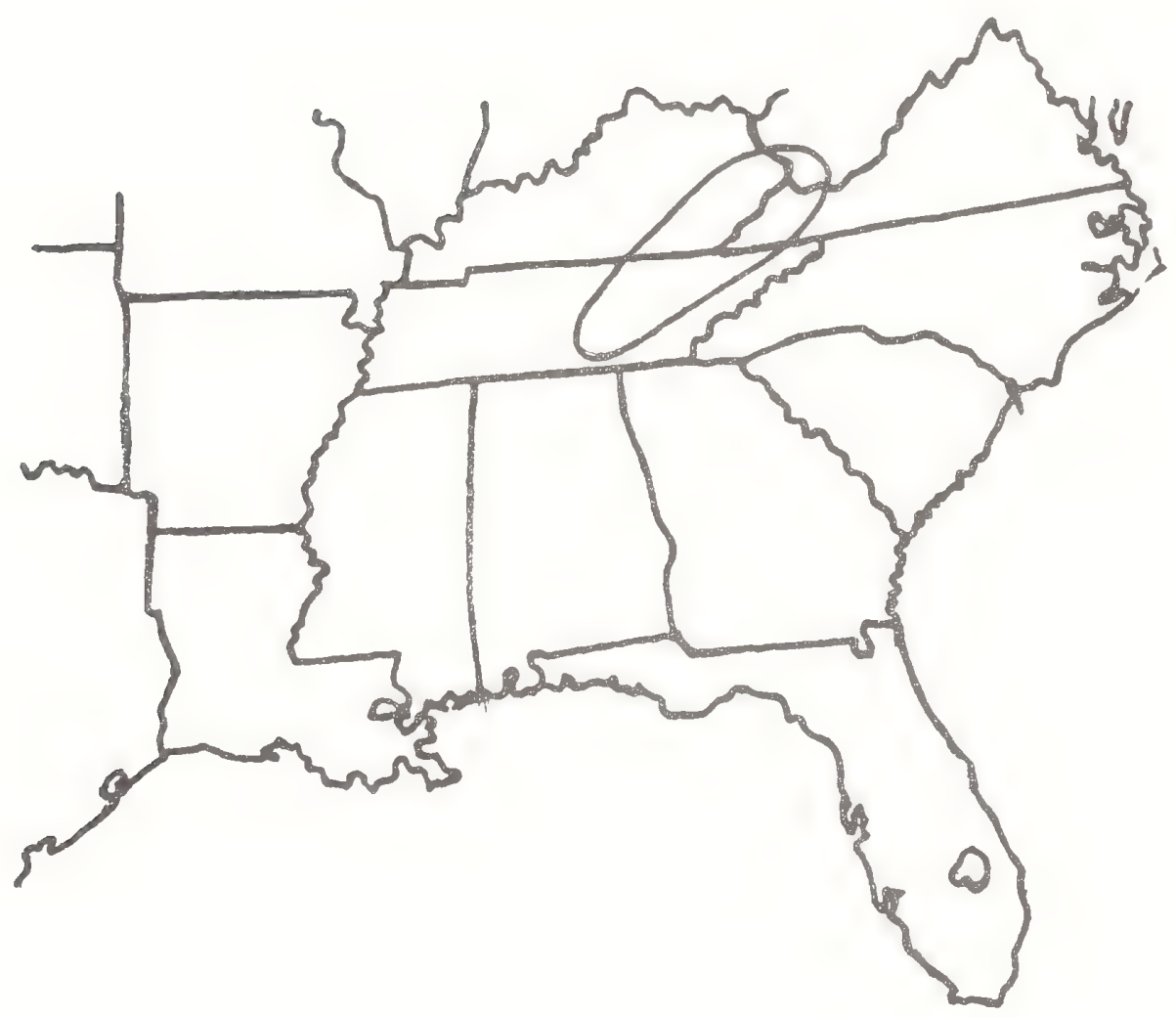


6

-

6 


\author{
Euphorbia exserta (Sma11) Coker \\ ?Tithymalopsis gracilis (E11.) Small \\ T. exserta Small \\ E. gracilior Cronq.
}

Status: Threatened

Technical Description:

Milky-juiced, smooth, slendermand-divaricately-branched perennial from a deep-set, fleshy, simple or branched, vertically oriented rootstock, the stems usually several, arising at or well below the groundine from alternate or clustered buds.

Stems: arising from or well below the ground 1ine, most1y 3-5 dm high, underground portions slender, much branched, the leaves short, scale-like; aerial branches several to many (imparting a tufted look, the primary branches often resembling individual plants), erect or ascending, repeatedly branching, usually forking either from near the ground line up, or well above the ground line, bearing a broad, low, split gland in the crotches, slender, terete, smooth, pale to deep green, usually strongly tinged with maroon, the ultimate branches becoming nearly filiform, forming a round, delicately branched crown.

Leaves: sometimes alternate, usually opposite, the lower ones often absent by anthesis, but when present highly variable in outline, in the axil either bearing a cleft gland or a branch, the stipules reduced to minute, reddish glands, the petiole short (under $3 \mathrm{~mm}$ ) or absent, the larger blades lowest, from filiform (rarely) to linear, oblanceolate, spatulate, obovate, suborbicular or even reniform, 1.5-5.0 cm long, apically narrowly to broadly rounded, the margin thickened, entire, usually reddish, the base acute to shortattenuate or rounded or truncate, the surface gray-green or tinged with maroon. Leaf blades progressively reduced in size, narrowing, up the stem, those of a pair sessile, often unequal, ultimately those of upper branches short-linear, $5 \mathrm{~mm}$ or less 1 ong, or in some cases simply narrower in outline and not much reduced in length. Inflorescence: much branched, the numerous peduncles arising at branchlet tips or from branch axils, filiform, often maroon, mostly several to many times longer than the involucres (cyathia). Cyathia campanulate, ca. $2.5 \mathrm{~mm}$ high, deep maroon, bearing at the margin of the cup 5, losenge-shaped glands, each gland marginally producing a narrow, broadly rounded or truncated petaloid appendage. Flowers: unisexual, each cyathium producing several male florets each having but 1 stamen and a single female floret, the perianth in either case vestigial, in the male each filament jointed to a stalk, the ripe round anther sacs elevated to or slightly above the cyathial rim, the female floret similarly raised on a stalk (gynophore) to slightly above the rim and evident only as a 3-1obed, rounded, maroon ovary, this with 3 short styles, each rebranched to form shortlineal stigma branches. 
Fruit: Capsule at maturity strongly exserted beyond the rim of the cyathium on a filiform stalk (1engthened pedicel and gynophore) severa1 times the height of the cyathium, nearly round in outline and strongly 3-1obed, about $3 \mathrm{~mm}$ high, 3-1oculed, 3-valved, smooth, usually reddish, producing 1 seed/locule; seeds ca. $2 \mathrm{~mm}$ long, broad1y obovoid, the small caruncle on the inside base, the broadly rounded back with a low, longitudinal ridge, the seed faces smooth, sometimes with a few low concavities, grayish or pale grayish-brown.

Distribution and Flowering Season:

Sandhils in Longleaf pineland, Coastal Plain, eastern North Carolina southward to northern Florida, westward to southwest Georgia and northwest Florida; flowering from May to early August.

Special Identifying Features:

This species is well marked by a combination of slender, though stiffish, divaricately branching habit, its strong reddish pigmentation of cyathial cups, fruit, even peduncles and branches, the shortpetioled or sessile variable leaf blades, these often maroon-margined. The capsule is smaller, the seed smaller than those of E. ipepacuanhae, which has larger cyathia and whose stems and branches, while slender, are not as delicate.

Habitat and Management Implication:

E. exserta is a plant of deep dryish sands and appears to be an integral part, if infrequent, of the Longleaf Pine-deciduous scrub oak sandhills. The most constant overstory species then are Longleaf Pine, Quercus 1aevis, $Q$. margaretta, $Q$. incana, $Q$. marilandica, Q. Stellata, $Q$. geminata (to the south in the range), Carya glabra,

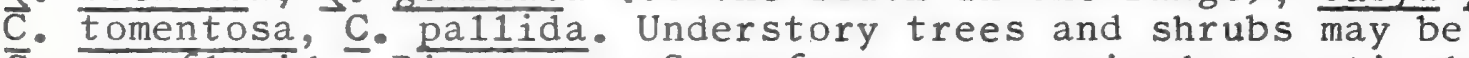
Cornus florida, Diospyros, Sassafras, many ericads, particularly Vaccinium, Gaylussacia, Lyonia mariana, etc. To the south in the range Osmanthus, Symplocos, Ceratiola, various shrubby Calamintha, Conradina may enter this type, as does Saw Palmetto. Herbaceous associates include several Aristida, Sporobolus, Andropogon, Triplasis, Cenchrus, Eragrostis, dichanthelium Panicum, Cyperus (particularly C. retrorsus, C. filiculmis), Rhynchospora such as R. grayi, R. megalocarpa, Bulbostylis, Paronychia, Lechea, various legumes such as Lespedera, Desmodium, Stylosanthes, Psoralea canescens, Cassia, Indigofera, Lupinus, Petalostemon carolinianum, Warea, Opuntia, Dicerandra, many Asclepias, and an abundance of composites, all species typical of deep sand formations, many cormophytes and a11 adapted to frequent natural woods fires which reduce woody competition and often present a landscape that hos large open stretches of 100 se sand. In fact, the way to perpetuate a species such as E. exserta is to apply fire as a management tool as has been done in this forest type. The problem becomes more difficult when any mechanical site preparatory work is done. This species, as do many other such herbs, readily occupies disturbed open sandy areas and may thrive during the earlier years of the plantation. However, it disappears as soon as the crowns close, reappearing only years later as, through thinnings, 
the stand reopens.

References:

Coker, W.C. 1912. Euphorbia exserta in Plant 1ife of Hartsvi11e: 88. Cronquist, Arthur. 1949. Euphorbia gracilior in Castanea 14: 102.

Radford, A.E.,H.E.Ahles \& C.Ritchie Be11. 1968. Manual of the vascular flora of the Carolinas, pp. 668-674.

Sma11, J.K. 1933. Manua1 of the southeastern f1ora, pp. 788-800. 
SPECIES: Euphorbia exserta (Sma11) Coker

\begin{tabular}{|c|c|c|c|c|c|c|c|c|}
\hline $\begin{array}{l}\text { Expected } \\
\text { Effect on } \\
\text { Hab1tat }\end{array}$ & $\begin{array}{c}\text { Preacribe } \\
\text { Burn } \\
\end{array}$ & $\begin{array}{l}\text { Doze or } \\
\text { Root } \\
\text { Rake } \\
\end{array}$ & Bed & Chop & $\begin{array}{l}\text { Thin } \\
\text { over- } \\
\text { Btory }\end{array}$ & $\begin{array}{l}\text { Cut } \\
\text { Over } \\
\text { Story }\end{array}$ & $\begin{array}{c}\text { Over Plant } \\
\text { w1 th } \\
\text { trees } \\
\end{array}$ & Graze \\
\hline Destroy & & & & & & & $X$ & \\
\hline Damage & & & $N A$ & & & & & \\
\hline $\begin{array}{l}\text { No Lasting } \\
\text { Effect }\end{array}$ & & $X$ & & $x$ & & & & $X$ \\
\hline $\begin{array}{l}\text { Beneflclal } \\
\text { If Done } \\
\text { Properly }\end{array}$ & & & & & & & & \\
\hline
\end{tabular}

\section{Other Coments:}

\section{*Eet1mated effect 1 an eatlmate of the author baeed on h1. book} knowledge of the habltat and on knowledge galned from personal field observations. Estlmates are "rough" In many instances. Results of practices may vary in degree of application, Intensity, nearness to plant communitles, etc. A column left "blank" indicates a lack of sufflclent information from which to predict expected results. As observations are made 1 n the field by users of the data, predictions should be refined by area and by intensity of forestry practices. 
Euphorbia exserta (Sma11) Coker

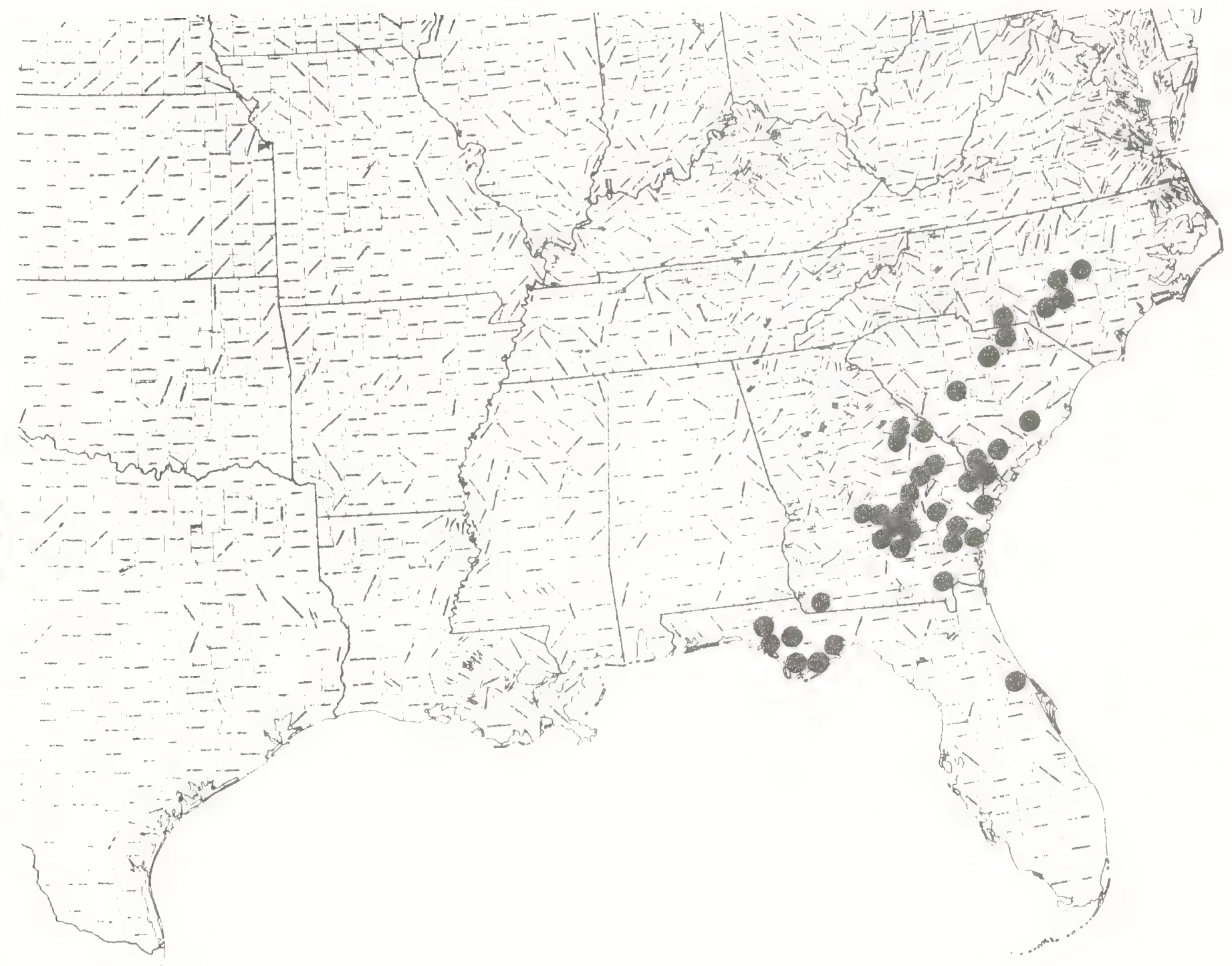


8

8

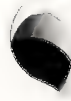




\section{Baptisia hirsuta Sma11}

Status: Threatened

Technica1 Description:

Bushy perennial mostly $3.08 \mathrm{dm}$ high from a large, knotty, often irregularly roundish or short-cylindric crown, this with thick, very deep roots, perennating by means of crown buds.

Stems: stiffly erect or ascending, 1-several per crown, regularly ascending-branched, usually from near the base and prolifically rebranching to produce a broadly rounded or oval crown; lower part of stem stoutish, to $1 \mathrm{~cm}$ thick, tapering regularly upward, the branchlets proportionately more slender, stem and branches terete, low-ribbed, greenish-yellow or greenish-brown, villousm hirsute or even shaggy tomentose with white hairs.

Leaves: alternate, stipulate, the lowermost on approximate nodes, scale-like, the largest (along main stem) with paired, foliaceous elliptic to oblanceolate or lanceolate, acute, entire stipule blades $1.0-1.5 \mathrm{~cm}$ long, the leaves palmately trifolionlate, the petiole most 1 y 3-5 mm 1ong, the leaflets spreading, obovate to oblanceolate, subequal, 1-3 cm long, rounded to acute or obtuseangled, often mucronulate, entire, the base broadly to narrowly cuneate, on short, villous petiolules, a pale dull green, the surfaces at first white-villous-hairy, villous-ciliate, later becoming smoother save on veins and margins; upper stem and branch leaves (bracts) becoming simple, elliptic, oblong or broadly lanceolate, similar in color and hair to lower leaves, the lowermost as long as leaflets of larger leaves, but progressively reduced in size toward branch tips, Inflorescence: a leafy-bracted raceme, the pedicels slender, reddish, shaggy-white-villous, wide1y ascending from all or near $1 y$ all leaf axils of branchlets, and each bi-bracteate above the middle, in length from several times to slightly longer than the flowers, the longest ones lowest on the branchlet. Flowers: bisexual, irregular, spreading, the calyx of 5 subequal sepals, fused at base into a broadly campanulate, shaggy-white-pilose tube 4-5 mm high, the lobes eliiptic or broadly oblanceolate, about $1 \mathrm{~cm}$ long, erect, acute, pilose-ciliate, colored like leaves and scattered-pilose, overtopping the petals; petals 5, the corolla papillionaceous, the petals distinct, pale yellow, the banner ca. $8 \mathrm{~mm}$ long, short-stalked, broadly obovate or broader than long, retuse, folded along the midnerve and projecting forward in the flower, the wing (lateral) petals with flat claws ca. $3.5 \mathrm{~mm}$ long, the oblong-lanceolate, rounded-tipped blades pointing forward, flat, ca. $9 \mathrm{~mm}$ long, the base auriculate, the larger auricle dorsal (uppermost), the keel petals slightly longer, the flat claw equal in length to that of the wings, the blade oblong-obovate, broadly rounded-tipped, bearing a prominent basal reflexed auricle dorsal1y at base, the lower edge more strongly curved than the upper; stamens 10 , distinct, a 11 pointing forward around the ovary, subequal, ca. $1 \mathrm{~cm}$ long, the filaments pale, slender, terete, tapering at tip to pale yellow, dorsifixed, ellipsoidal anthers; ovary superior, stipitate, the body fusiform, ca. $3 \mathrm{~mm}$ long, tapering into a slender $1 \mathrm{y}$ linear, 
abruptly upswept stylar apex, this tipped with a short stigma, the stylar surface pilose from base to ca. 2-3 mm below the stigma. Fruit: legume somewhat woody, brown, on a stipe $4-5 \mathrm{~mm}$ long, the broadly ovoid or ellipsoidal body ca. $1 \mathrm{~cm}$ 1ong, scattered pilose-hirsute, more dense1y hairy along the margined valve edges, abruptly narrowing into the linear-subulate persistent style base; seeds few, oblong-e11ipsoida1, laterally somewhat flattened, ca. 3 mm long, smooth, olivaceous.

Distribution and Flowering Season:

Sands of Longleaf Pine-deciduous scrub oak woodlands, northwestern F1orida; flowering mostly in May.

\section{Special Identifying Features:}

The most distinctive character held by this Wild Indigo is its very leaflike calyx lobes which at anthesis project forward, largely concealing the yellow petals, actually overtopping them. There is but one other species in the southeast which has that calyx

feature, name1y B. calycosa Canby, an endemic of northeastern peninsular Florida in the St. Johns River drainage in sandy pine flatwoods savanna. However, that species is glabrous, whilst this one is very pubescent, its pale villosity in the field giving the foliage a distinctive grayish aspect.

Habitat and Management Implication:

B. hirsuta decorates the deep yellow sands of Longleaf Pine-Turkey Oak sandhills and flats mostly between Defuniak Springs and Crestview in panhandle Florida, its small round crowns of gray - green foliage distinctive even at a distance. The original pine has long ago been mostiy logged out, the stocking now is poor and of low quality so that most of the area has gone over to open or rather dense stands of scrub oak dominated by $Q$. laevis, but with 1 ibera1 representation of $\mathrm{Q}$. incana, $\mathrm{Q}$. margaretta, $\mathrm{Q}$. geminata. Where the oak and associated scrubland hardwoods are densest the Baptisia is scarce or absent. Where, through fire, logging disturbance or other wood cutting, the woods have been opened up, or where powerlines or rights of way for railroad and highway have been created, the Baptisia is most abundant, there associated with such sandscrub herbs as ARistida, Sporobolus, Eragrostis, Panicum, Andropogon, Cyperus (particulariy C. filiculmis), Bulbostylis ciliatifolia, B. warei, Yucca, Commelina erecta, Tradescantia hirsuticaulis, Stipulicida, Paronychia, various Euphorbia, Polygala polygama, Lechea, Oenothera fruticosa, Opuntia, many iegumes, particulariy Desmodium, Lespedeza, Psoralea canescens, Indigofera caroliniana, Lupinus diffusus, L. vil1osa, L. nutta11ii, Ph1ox nivalis, Onosmodium virginianum, Lithospermum carolinense, Rueliia, Dyschoriste oblongifolius, and many more, including very many Asteraceae, particularly

(during the flowering time of the Baptisia) Silphium, Phoebanthus tenuifolia, Berlandiera pumila, Erigeron strigosus, Tetragonatheca helianthoides, Hymenopappus scabiaeosus, etc. Low, clonalizing shrubs such as Chrysobalanus oblongifolius, Rhus toxicodendron, Gaylussacia dumosa and running oaks are common.

This sort of habitat, once the original pine had been removed, 
languished until after World War II, after which increasingly large acerages were converted to plantation pine or to varied (some abortive) real estate ventures. In the case of pine plantings, large acerages are site prepared mechanically. Such plants as the Baptisia will readily move into the disturbed areas, providing seeding plants are left in adjacent area. However, they are shaded out as the growing crowns of the young pines close over.

References:

Lairsey, Maxine. 1940. A monograph of the genus Baptisia. Ann. Mo. Bot. Gard. $27: 119-242$.

Sma11,J.K. 1933. Manual of the southeastern f1ora, pp. 674-678. 
SPECIES: Baptisia hirsuta Sma11

\begin{tabular}{|c|c|c|c|c|c|c|c|c|}
\hline $\begin{array}{l}\text { Expected } \\
\text { Effect on } \\
\text { Hab1tat }\end{array}$ & $\begin{array}{c}\text { Preecribe } \\
\text { Burn }\end{array}$ & $\begin{array}{l}\text { Doze or } \\
\text { Root } \\
\text { Rake }\end{array}$ & Bed & Chop & $\begin{array}{l}\text { Th1n } \\
\text { Over- } \\
\text { Btory }\end{array}$ & $\begin{array}{l}\text { Cut } \\
\text { Over- } \\
\text { Story }\end{array}$ & $\begin{array}{c}\text { Over Plent } \\
\text { with } \\
\text { trees }\end{array}$ & Graze \\
\hline Descroy & & & & & & & $X$ & \\
\hline Damage & & & & & & & & \\
\hline $\begin{array}{l}\text { No Lasting } \\
\text { Effect }\end{array}$ & & $X$ & & & & & & \\
\hline $\begin{array}{l}\text { Benaficial } \\
\text { If Done } \\
\text { Proporly }\end{array}$ & & & & & & & & \\
\hline
\end{tabular}

\section{Other Commente:}

*Est1mated effect 18 an eat1mate of the author based on h1s book knowledge of the habltat and on knowledge galned from personal field observations. Estimates are "rough" in many Instances. Results of practices thay vary in degree of application, intensity, nearness to plant commuttes, etc. A column left "blank" Indicates a lack of sufficleit information from which to predict expected results. As observations are made 1 n the field by users of the data, predictions should be reflned by area and by intensity of forestry practices. 
Known Distribution of:

Baptisia hirsuta Small

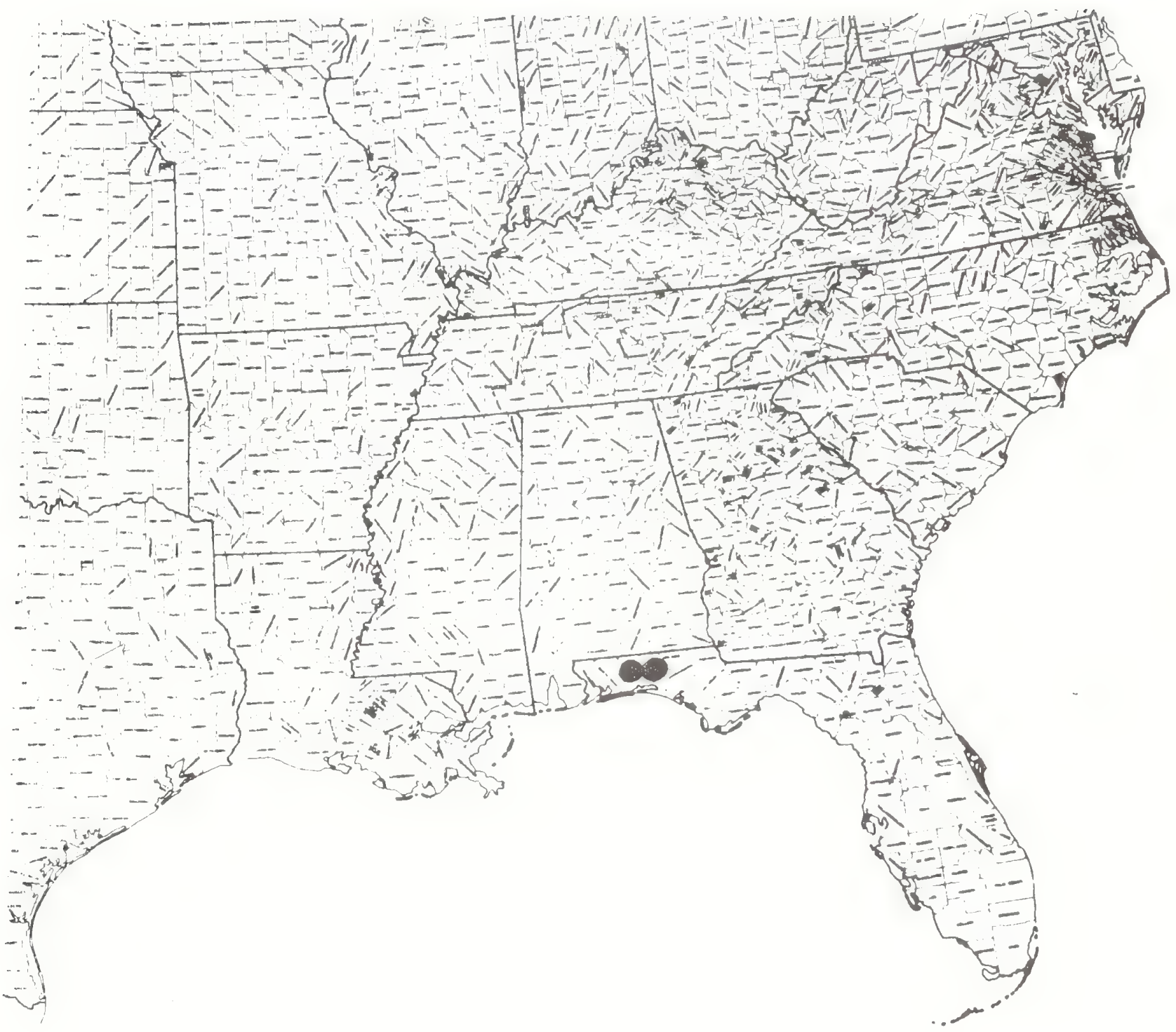


○

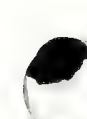

$a$ 


\section{Petalostemon gattingeri Heller}

\section{Status: Threatened?}

Technical Description:

Perennial from a stout, knotty caudex, this with a deep woody taproot or with several stout-based, elongate, spreading roots, and developing a crown of several woody branches at the groundline.

Stems: mostly spreading, or slightly ascending, simple to copiously branched, the older plants forming a circular mat of many shoots, these slender but stiffish, terete or rib-angled, pale green or sometimes with tints of purple, mostly 2-5 dm 1ong, smooth or wi h some villous-puberulence distally.

Leaves: alternate, most 1 y $2-4 \mathrm{~cm}$ 1ong, numerous, stipulate, the stipules narrowly triangular or linear-subulate, thin, tan, the petiole (rachis) spreading or ascending, slender, greenish, grooved above, sparsely pilosulous, gland-dotted; leaflets odd-pinnately coumpound, in (1-) 2-4 pairs, linear, oblong-1inear or ellipticlinear, most1y (-.5) 1.0-1.5 (-2.0) cm 1ong, 1-2 (-3) mm wide, apica11y rounded, acute or retuse, the margin revolute, the base abruptly acute to a petiolule less than $1 \mathrm{~mm}$ long, the surfaces pale yellow or gray-green, sparsely pilosulous, the upper side dotted with dark glands, the venation evident on $1 y$ as a single mid-nerve. Inflorescence: terminal on main axis and branches, densely floriferous, a tight, cylindrical indeterminate spike (2-) 3-6 (-8) cm long, ca. $1 \mathrm{~cm}$ thick, the axis villous-tomentulose, the individual flowers subtended by chaffy,tomentose-backed bracts with ovate bodies and exserted, linear-subulate tips (or rare1y these bracts replaced by large glistening black glands).

Flowers: perfect, bisexual, irregular, spreading; calyx obovoid to ellipsoida1, 4-5 mm long, the 5 sepals united to form an inequilatera11y campanulate tube ca. 2.0-2.5 mm 1ong, the 1 imb slightly bilabiate, the upper 1ip of 2, triangular-subulate teeth, the lower of 3 narrowly triangular-subulate teeth, all projecting forward and slightly upswept from the oblique orifice, the surface pale green, cloaked with a white to silvery villosulous tomentum; petals most1y 5 (to 2 or 1), strongly clawed, projecting forward, ca. 4.0-4.5 mm long, arising alternately with stamens on stamen tube, a lively bright rose, the standard longest, largest, its blade mostly broadly oblong to ovate or ellipsoidal, symmetrical, the wing and keel blades inequilaterally oblong, slightly shorter and narrower; stamens 5, united, the filaments joined into a ligule, ca. 3.()-3.5 mm 1 ong, the free portion pinkish, terete, often flexurus, ca. $3 \mathrm{~mm}$ long, exserted beyond the calyx tips, the shorthlollg or cli ipsoidal anthers dark purple, dorsifixed ca. $1 \mathrm{~mm}$ long, the pollen white; ovary superior, serecious, 1-ovulate, the style produced apically from dorsal side, slender, linear, terete, pinkish, gradually narrowing into a short, whitish, terminal stigma. Fruit: legume 1-seeded, inequilaterally oblong, ca. 3-4 mm 1ong, the upper side straight and continuous with the persistent style beak, the lower side strongly curved, the body externally scattered with gland dots, toward narrowed base nearly smooth, toward stylar 
end white-strigose-tomentose; seed ca. $1.5 \mathrm{~mm}$ 1ong, the coat smooth, brown.

Distribution and Flowering Season:

Limestone glades and barrens, middle Tennessee, northwestern Georgia and northern Alabama; flowering from mid-May through June.

\section{Special Identifying Features:}

P. gattingeri overlaps in range with but 3 other Petalostemon, namely P. foliosus, $\underline{P}$. candidus, and $\underline{\mathrm{P}}$. purpureus. Of these P. foliosus has many more pairs of leaflets, is a taller,more erect plant, more bluish-tinted in petal color, has a smooth calyx tube and begins to flower when most $P$. gattinger $i$ is in fruit; P. candidus is a taller plant with broader,smoother leaflets, a smooth calyx tube, and white petals. This leaves p. purpureus, a widespread polymorphic species of prairies and glades north west and south, with which P. gattingeri may hybridize. This species however, while it does have similar flower color, a hairy calyx tube, similar fruit and leaflets, is a taller plant tending to be more erect in habit, thus often not forming the cushionlike mats that are so typical of $\underline{\mathrm{P}}$. gattingeri. $\underline{\mathrm{P}}$. purpureus tends to have a more densely floriferous, shorter spike, narrower bract bodies that tend to be more acuminate-tipped than cuspidate (as is the common case with $\mathrm{P}$. gattingeri). Pubescence of calyx is more appressed in P. purpurreus than it is in Pattingeri.

Habitat and Management Immlications:

P. gattingeri is one of the more common limestone glade perennials in middle Tennessee and northern Alabama on limestone outcrops. It represents the perennial herbaceous stage of colonization of open glades, its 1 ong roots penetrating deeply into cracks in the limestone or into the heavy clay soils derived therefrom. Common herbaceous associates are Sporobolus, Melica, Panicum, Bouteloua, Tridens, Allium, Juncus, Carex, Arenaria,Talinum, Arabis, Leavenworthia, Lesquere11a, Sedum pulchellum, Delphinium virescens, Astagalus tennesseensis, Psoralea subacaulis, Onosmodium molle, Lithospermum canescens, Oenothera triloba, Scutellaria parvula, Penstemon tenuiflorus, P. calycosus, and many composites, in tota 1 presenting a very showy sight. Over most of the range of this vegetational type, the successional pattern is for occupancy of open glades by shrubs such as Symphoriocarpos, Rhus aromatica, Rhamnus, Forestieria, etc., trees such as Juniperus, Ulmus,Ce1tis, Quercus, Carya,Fraxinus,Diospyros, etc. which u1timately close the open areas and suppress the herbs. Removal of tree cover through fire (the historical process) or cutting wauld probably tend to favor increase of this species, providing there were contiguous seed sources.

P. gattingeri moves more readily than most other glade endemics; for example, it is coming in strongly along most new highway rightsof-way through limestone barrens, being better adapted than most because of its prostrate-stemmed habit which allows it to escape 
most mowing equipment. On the other hand it fares less well if a glade is converted to pasture, in that the plants suffer from grazing and trampling.

References:

Sma11,J.K. 1933. Manual of the southeastern flora, pp. 695-697.

Wemple, Don K. 1970. Revision of the genus Petalostemon (Leguminosae). Iowa State Journ. Sci. 45: 1-102. 
SPECIES: Petalostemon gattingeri Heller

\begin{tabular}{|c|c|c|c|c|c|c|c|c|}
\hline $\begin{array}{l}\text { Expected } \\
\text { Effect on } \\
\text { Habltat }\end{array}$ & $\begin{array}{c}\text { Preacribe } \\
\text { Burn }\end{array}$ & $\begin{array}{l}\text { Doze or } \\
\text { Root } \\
\text { Rake }\end{array}$ & Bed & Chop & $\begin{array}{l}\text { Thin } \\
\text { Over- } \\
\text { Btory }\end{array}$ & $\begin{array}{l}\text { Cut } \\
\text { Over- } \\
\text { Story }\end{array}$ & $\begin{array}{c}\text { Over Plent } \\
\text { with } \\
\text { trees } \\
\end{array}$ & Graze \\
\hline Destroy & & NA & NA & NA & & & NA & \\
\hline Damage & & & & & & & & $\mathrm{X}$ \\
\hline $\begin{array}{l}\text { No Lating } \\
\text { Effect }\end{array}$ & & & & & & & & \\
\hline $\begin{array}{l}\text { Beneficlal } \\
\text { If Done } \\
\text { Properly }\end{array}$ & $\mathrm{x}$ & & & & $\mathrm{X}$ & $\mathrm{X}$ & & \\
\hline
\end{tabular}

Other Commente:

*Egt1mated effect 18 an e日t1mate of the author based on his book knowledge of the habltat and on knowledge galned from peroonal

field observations. Estimates are "rough" in many instances.

kesults of practices may vary in degree of application, intensity, neurness to plant communties, etc. A column left "blank" indicates d lack of sufficlent inforalion from which to predict expected results. As observations are made $1 \mathrm{n}$ the field by users of the data, predictions should be refined by area and by intensity of forestry practices. 


\section{Distribution of:}

Petalostemon gattingeri Heller

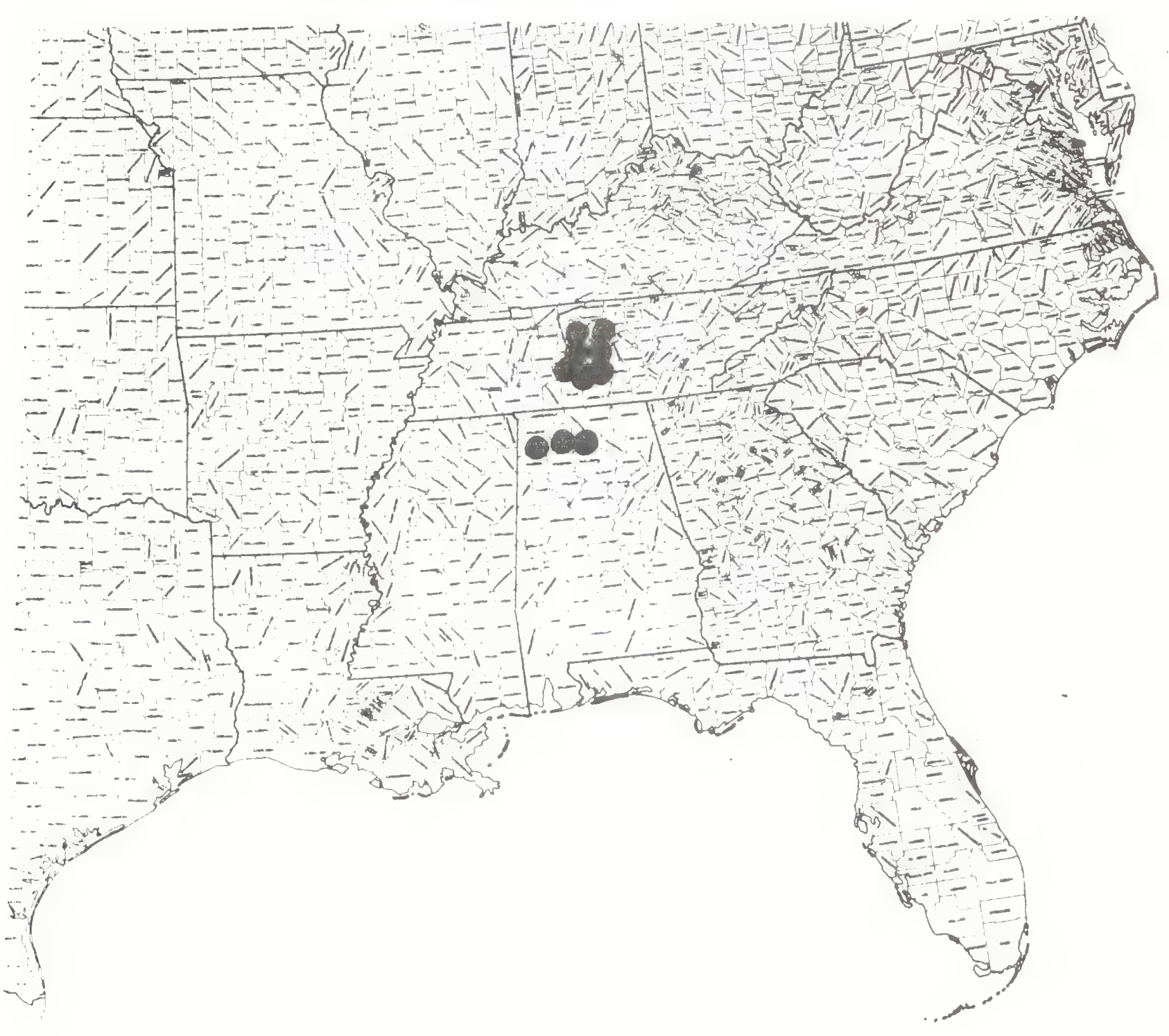




\title{
FABACEAE
}

\author{
Psoralea subacaulis T. \& G. \\ Pediomelium subacaulis (T. \& G.) Rydb.
}

Status: Threatened?

Technica1 Description:

Perennial, rosulate, the rosettes terminal to slender, erect or ascending, pale, scaley underground stems, these arising singly or severally from the crown of a deepset, simple or branched carrot or turnip-shaped tuberous rootstock.

Leaves: alternate, of 2 sorts, one scalelike on the underground stem and in the rosette and probably modified stipule, those of the underground stem erect, with strongly clasping base, oblong or triangular, brownish, those in the rosette somewhat larger, paler, broader, usually imbricated, apically acute or bifid, the backs sparsely stigose-hirsute, the margins distally densely and coarsely long-white-ciliate; foliage leaves palmately compound, numerous and in a strong sub-rosette, with petiole bases directly subtended by and hidden within the scale-like stipules, the petiole ascending or spreading, slender, teretish, ribbed, pale green with purple tints, white-hirsute, 6-15 cm long, the leaflets most 1y 5-7, spreading on stubby petiolules not longer than $2 \mathrm{~mm}$, most 1y oblanceolate, $2.0-3.5 \mathrm{~cm}$ long, apically broadly to narrow1y rounded or obtuseangled, often mucronulate or apiculate, the margin hirsute or strigonciliate, the base narrowly cuneate, the upper surface dark or pale yellowagreen, scattered strigose-hirsute, dotted with fine dark glands, the lower surfaae again gland-dotted, somewhat paler, smooth or scattered-hirsute, the strongly raised midvein hirsute. Inflorescence: spikelike, erect, terminal, indeterminate, at first compact, 3-4 $\mathrm{cm}$ long, $2-3 \mathrm{~cm}$ broad, later somewhat interrupted and to $10 \mathrm{~cm}$ long, on slender, spreading to erect, terete, white-tomentosehirsute peduncles about as long as the petioles or slightly longer, the numerous flowers mostly overlapping in several sessile 3-flowered cymules, each cymule subtended by a scarious, scale-like, ovate, purplish, hirsute-ciliate bract 5-10 mm long, the pedicels of a cymule subequal, stoutish, strigo-tomentose, purple, rarely longer than $2 \mathrm{~mm}$. Flowers: bisexual, zygomorphic, the calyx at anthesis 9-10 mm 1ong, gamosepalous, the tube asymmetrically campanulate, bulging slightly above at base, the orifice oblique, the lobes erect,hirsute-ciliate, the upper 2 lobes and the 2 laterals subequal, triangular, 1.5-2.0 $\mathrm{mm}$ long, acute, the sinuses rounded, the lowest lobe largest, elliptic or obovate, ca. $4 \mathrm{~mm}$ 1ong, apically obtuseangled or rounded, the surface hirsute, purplish, particularly distally; petals 5 , papillionaceous, bright blue-purple, the banner petal 16-20 mm 1 ong, with the claw usually ca. $3 \mathrm{~mm}$ long, the blade oblong, apically rounded or retuse, strong1y folded, projecting forward and siight1y upcurved, the wings slightly shorter, similarly projecting forward and slightly upcurvate, the more narrowly oblong blades ca. 9-10 $\mathrm{mm}$ long, bearing on the upper side basally a strong auricle, the 
kee1 petals ca. $2 \mathrm{~mm}$ shorter than the wings, with claws about 6 $\mathrm{mm}$ long and blades asymmetrically oblong, rounded, each with a strong auricle at upper side of base; stamens 10, smooth, diade1phous, ca. $10 \mathrm{~mm}$ long, the upper (vexillary) one free, the others united most of the filament length, the anthers yellow, ellipsoidal, basifixed, ca. $0.5 \mathrm{~mm}$ 1ong; ovary superior, strigose, the slender style scatteredmstrigose proximally, distally bent upward near level of anthers, there somewhat thickened, the stigma narrow1y capitate.

Fruit: legume ca. $1 \mathrm{~cm}$ long, somewhat compressed 1aterally, elliptical, strongly tapered at both ends, strigose-hirsute with white hairs; seeds usually 1, reniform, somewhat compressed lateral1y, 4.5$5.0 \mathrm{~mm}$ long, smooth, dark brown.

Distribution and F1owering Season:

Open limestone glades, calcareous clay clearings and open rocky woods, local but often aspect dominant, northwestern Georgia (Catoosa Co.) and adjacent Tennossee, most1y in 1imestone districts of middle Tennessee (the Nashville Basin); northern Alabama; flowering from early April to mid-May, dying back by late June.

\section{Special Identifying Features:}

There is no other Scurfmpea within the range of $\underline{P}$. subacauiis that remotely looks like this showy plant that actualiy to the novice botanist appears to be a lupine. Closest to it are "Pediomelium" psoraleas such as $\underline{\text {. esculenta Pursh (Bread-root) }}$ and $\underline{P}$. cuspidata which inhabit cāicareous prairies and glades in prairie provinces west of the Mississippi and which have similar turnip-like rootstocks. The former is so similar, being villousmirsute, with similar habit, flowers and leaves, that it might be considered a vicarious taxon representing western populations of a single species, the now isolated eastern populations radiating to what is now $\underline{P}$. subacaulis.

Habitat and Management Implication:

Like so many other endemics of 1 imestone glades in the mid-South, this species should be considered forest related on $1 \mathrm{y}$ in the successional sense. Origin of these limestone glades is perhaps still argued, but certainly development and continuance have to do with a combination of shallow parent rock material of flat-bedded or slightly sloping limestone together with fire during dry cycles, this last reducing or halting succession of woody plants. The assemblage of herbaceous associates gives a prairie-like aspect, with the Psoralea often being a dominant and showy feature, interspersed with other endemics such as Petalostemon gattingeri, Onosmodium melle, Viola egglestonii, Lobelia gattingeri, several Leavenworthia, Lesquerella, with other herbs such as Arenaria patula, Sedum pulchellum, Ranunculs fascicularis, $B$. sardous. Delphinium virescens, numerous carices and grasses, Denothera triloba, Lithospermum canescens, Scutellaria parvula, Verbena canadensis. Opuntia compressa and Agave virginica are frequent, as are several composites, notably Senecio anonymos, S. obovatus, Coreopsis 1anceolata, Crepis pulchra, 
The Psoralea develops where the clay has developed to some depth or accumulated as inwash in cracks or depressions in the limestone, and may form patches of thousands of plants. It gives way as woody plants invade and shade it out. Usually this invasion is by Juniperus or the juniper together with other such trees as Quercus muhlenbergil, Q. shumardii, Q. stellata, Q. imbricaria, Carya carolinae-septentriona1is, Ulmus serotina, U. americana, U. rubra, Celtis laevigata, Sassafras, Diospyros, $\bar{F}_{\text {raxinus americana, }}$. quadrangulata, and shrubs such as Rhus aromatica, other Rhus, Rhamnus caroliniana, Symphoriocarpos, Rubus. In some cases the Juniperus forms solid stands, these later to give way to a hardwood forest c1imax, but whatever the overstory the story is the same, and the Psoralea disappears as the shade increases. In the pre-Columbian past the story must have been one of old open glades giving way to woody vegetation, which during dyy cycles probably in turn would be opened up by natural fire to create a savanna-1ike aspect. Fire would also sweep the open glades, thus promoting erosion of the thin, heavy soils and in places expose limestone on wich the slow process of succession would begin anew. Today the Psoralea and other limestone glade endemics suffer from urban expansion of cities such as Nashville, Murphreesboro, Lebanon, or from conversion to pasture. A removal of tree cover, providing this is not accompanied by drastic soil disturbance, would tend to provide new area for the Psoralea, as would controlled burning.

\section{References:}

Fernald, M.L. 1950. Gray's manual of botany, ed. 8, pp. 896-898. Sma11,J.K. 1913. F1ora of the southeastern United States, pp. 620-623. - 1933. Manua1 of the southeastern flora, pp. 693-694.

\footnotetext{
$\star \star \star$ Note. For studies on strategies of Psoralea subacaulis and several other limestone glade endemics one should consult the works of Dr. Elsie Quarterman, Dr. Jerry Baskin, Dr. Carol Caudle where much pertinent ecological information is given.
} 
SPECIES: Psoralea subacaulis T. \& G.

\begin{tabular}{|c|c|c|c|c|c|c|c|c|}
\hline $\begin{array}{l}\text { Expected" } \\
\text { Effect on } \\
\text { Habitat } \\
\end{array}$ & $\begin{array}{c}\text { Preacr } 1 \text { be } \\
\text { Burn }\end{array}$ & $\begin{array}{l}\text { Doze or } \\
\text { Root } \\
\text { Rake } \\
\end{array}$ & $\mathrm{Bed}$ & Chop & $\begin{array}{l}\text { Thin } \\
\text { over- } \\
\text { etory }\end{array}$ & $\begin{array}{l}\text { Cut } \\
\text { Over- } \\
\text { Story }\end{array}$ & $\begin{array}{c}\text { Over Plant } \\
\text { vith } \\
\text { trees } \\
\end{array}$ & Graze \\
\hline Deatroy & & $\mathrm{NA}$ & $\mathrm{NA}$ & $\mathrm{NA}$ & & & NA & \\
\hline Damage & & & & & & & & $\mathrm{X}$ \\
\hline $\begin{array}{l}\text { No Lasting } \\
\text { Effect }\end{array}$ & & & & & & & & \\
\hline $\begin{array}{l}\text { Beneftclal } \\
\text { if Done } \\
\text { Properly }\end{array}$ & $\mathrm{X}$ & & & & $\mathrm{X}$ & $\mathrm{X}$ & & \\
\hline
\end{tabular}

Other Commente:

*Egt1mated effect 18 an est1mate of the author baed on h1 book knowledge of the habltat and on knowledge galned from personal field observations. Est1mates are "rough" in many 1nstances. Results of practices may vary in degree of application, 1ntensity, neurness to plant communties, etc. A column left "blank" indicates a lack of sufflcient information from which to predict expected results. As observations are made $1 \mathrm{n}$ the fleld by users of the data, predictions should be refined by area and by intensity of forestry. practices. 
Distribution of:

Psoralea subacaulis T. \& G.

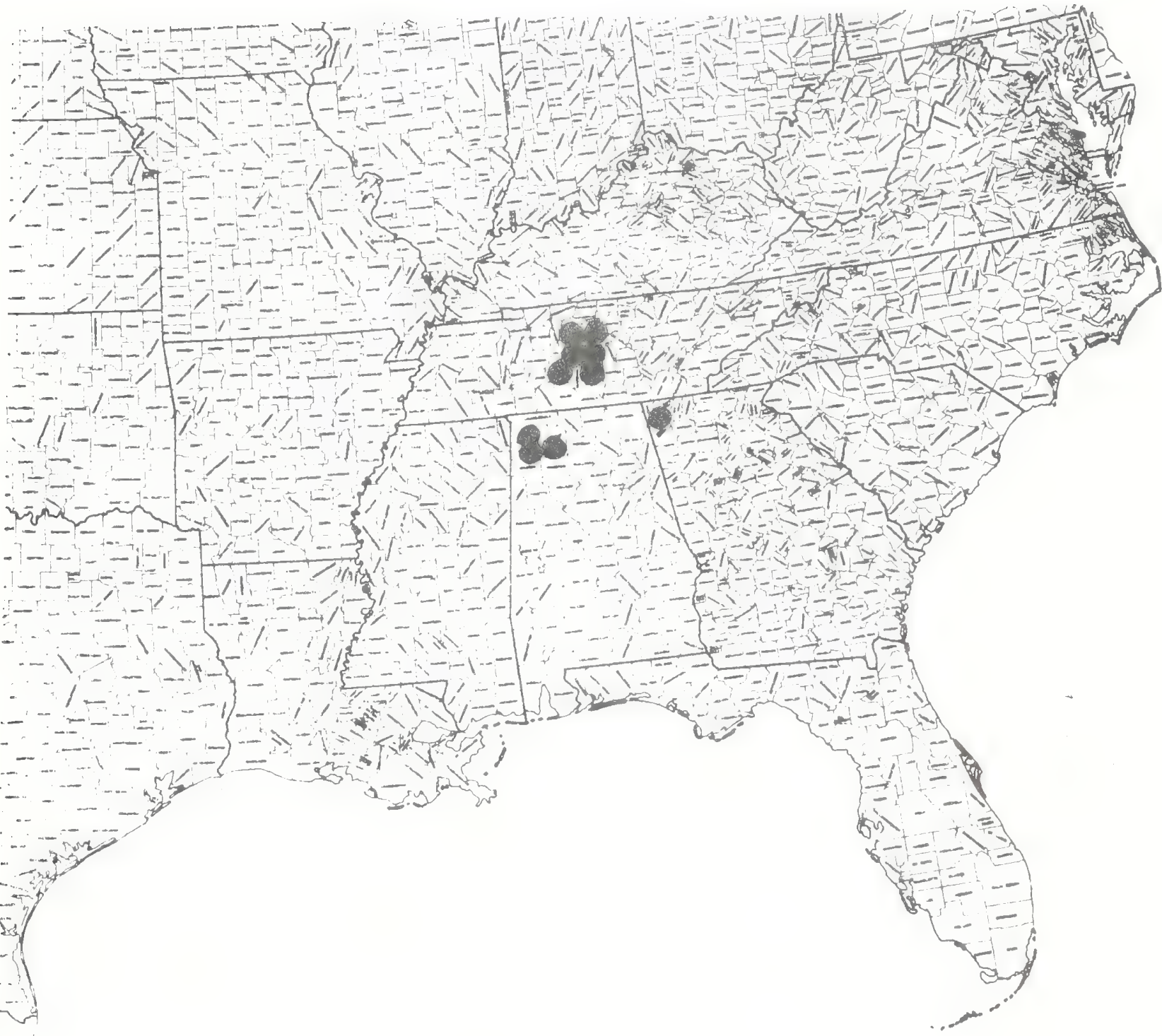


-

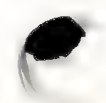


Technica1 Description:

laespitose, smoothish, perennial suntlower, the few-torseveral stems each arising trom a tleshy, stout-linear, ascending rhizome to $1 \mathrm{~cm}$ thick, the rhizomes often radiating from a parent plant.

Stems: rarely erect, usual1y decumbent-based or spreading outward from the center of a clump, mostly unbranched below the inflorescence, most1y 3-7 ( -10$)$ dm long, terete, with many low ribs, slender but stiffish, pale yellow-green or with red or maroon-tinted ribs, strongly leafy with many short internodes, the shortest at stem base, the nodes sometimes sparingly spicular-hairy, the lowermost leafless by 1 lowering time.

Leaves: opposite, the smallest lowermost, the largest toward midustem, nearly sessile, ternately dissected to the very base, the primary segments narrowly lineal, flat, again divided toward base or

pinnately divided near base, but the ultimate segments mostly 1 ong, linear or linear-spathulate, l-ribbed, ye1low-green, apically acute, marginally entire or slightly scabrid distally, the overall effect being one of dense leafiness, the segments because of their length and abundance appearing as verticels of linear leaves.

Inflorescence: Heads tew to many in a terminal cyme or occasionally some of the lower peduncles also cymose; peduncles erect or ascending, variously elongated, naked or with a pair or more of short-linear bracts; involucres at anthesis campanulate, from base to tip of chaff 7-10 mm high, very tirm, and comprised mostly of 2 series of bracts, each series joined basally into a cup (calyculus), with sometimes an additional $1-2$ smal1 bractlets at very base; outer phyllaries smallest, green, erect, linear-spatulate or oblong, obtuse, entire or ciliolate, 3-4 mm long; inner phyllaries yellowish-orange, the tree portions erect, oblong-ovate or triangular, the narrowed apices minutely ciliate, blunt, the margins toward base scarious; surface of receptacle chaffy with pales colored as in inner bracts, most 1y narrowly spatulate-1inear, to $1 \mathrm{~cm}$ long.

Flowers: Ray florets 7-10, sterile (sterile ovary and perianth tube after anthesis expanding, tlattening and elongating to form an outer ring of chaff!), the ray corollas spreading above a short, puberulent tube, the ligules elliptic-linear, $2-3 \mathrm{~cm}$ long, bright yellow; disc florets very many, in mass a dark purplish-brown, the disc corollas linearmtunnelform, 4-5 mm 1ong, the 5 short, triangular lobes erect or slightly spreading, sometimes apically puberulent. Fruit: Akene body elliptical-oblong, strongly tlattened paralle 1 to phyllaries, ca. $5 \mathrm{~mm}$ long, smooth, longitudinally low-ribbed, dark graymbrown, but with narrow yellow marginal bands; pappus ear1y deciduous, highly variable in length, of 2, subulate, yellowish awns, one on either side of an apical notch in the akene.

Distribution and Flowering season:

Sands and sandy loams in and around sandstone outcrops, northeastern Alabama and adjacent northwestern Georgia; flowering from late August through september, intermittently to frost. 
special Identifying Features:

This species most resembles $\underline{C}$. verticillata $L$. or $\underline{C}$. delphinitolia lam., but the former, which in range extends no nearer than the Blue Ridge province of western North Carolina and the 1atter, primarily of Coastal Plain Georgia and South Carolina with an out1ier in eastern Tennessee, both develop slender, elongate, yellowish rhizomes which are lacking in C. pulchra; both have yellowish, rather than purplish-brown, discs.

Habitat and Management Implication:

C. pulchra is either in shallow pockets of inwash soil over sandstone or on the shallow sandy soils around the outcrops. This substrate is usually in tull sun, subject to great extremes of temperature and moisture. Associated herbs indicate at least seasonal dryness; Talinum spp., Upuntia compressa, Crotonopsis, Panicum litnophilum, P. flexile, Deschampsia tlexuosa, Commelina erecta,Agave virginica, Polygonum tenue, Liatris microcephala, Bigelowia nuttallii, various other upland composites, and many outcrop lichens and bryophytes. Successional forces are toward gradual invasion of the shallow soils and outcrops first by perennial grasses and forbs, later by pine-oakmickory with an understory of Sourwood, Mountain Laure1, Ho11y, Fringetree, Dogwood, Blueberry, etc., with the Coreopsis and other heliophytes confined to smaller and smaller clearings, tinally suppressed. Openings were in nature probably maintained by periodic woods tires together with erosive forces. Danger to the species today comes from real estate development of private lands, particularly those along the streams which are highly scenic because of the ruggedness ot the sandstone bluffs and outcrops. Another current danger is trom wholesale denudation of some parts of this habitat by coal stripminers. It is fortunate that large stretches of bluffs and outcrops along and above the Little River in northeastern Alabama, and which support large populations of this Coreopsis, are a part of the Alabama State Park system.

References:

Sherff, E.E. 1936. Revision of the genus Coreopsis. Field M.s Nat. Hist. Bot. Ser. 11: 277-475.

Sma11,J.K. 1903. F1ora of the southeastern United States,p. 1277. - 1933. Manual of the southeastern f1ora: 1446-1450.

Smith,E.B. 1976. A biosystematic survey of Coreopsis in eastern United States and Canada. Side 6 (3): 123-215. 
PECIES: Coreopsis pulchra P. Boynton in Sma11

\begin{tabular}{|c|c|c|c|c|c|c|c|c|}
\hline $\begin{array}{l}\text { Expected } \\
\text { Effect on } \\
\text { Hab1tat }\end{array}$ & $\begin{array}{c}\text { Preacribe } \\
\text { Burn } \\
\end{array}$ & $\begin{array}{l}\text { Doze or } \\
\text { Root } \\
\text { Rake }\end{array}$ & Bed & Chop & $\begin{array}{l}\text { Thin } \\
\text { over- } \\
\text { story } \\
\end{array}$ & $\begin{array}{l}\text { Cut } \\
\text { Over- } \\
\text { Story } \\
\end{array}$ & $\begin{array}{c}\text { Over Plant } \\
\text { w1th } \\
\text { trees } \\
\end{array}$ & Graze \\
\hline \multicolumn{9}{|l|}{ Destroy } \\
\hline Damage & & $N A$ & $N A$ & $N A$ & & & $N A$ & $x$ \\
\hline $\begin{array}{l}\text { No Last } 1 \mathrm{ng} \\
\text { EIfect }\end{array}$ & & & & & & & & \\
\hline $\begin{array}{l}\text { Banaflcial } \\
\text { lf Done } \\
\text { properly }\end{array}$ & & & & & 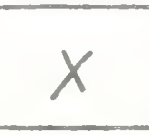 & & & \\
\hline
\end{tabular}

Other Commente:

*Est1mated effect 1 a an est1mate of the author based on his book knowledge of the habltat and on knowledge galned from peraonal field ubservations. Estimates are "rough" 1 n many 1 nstances. Results of practices may vary in degree of application, intensity, nearuess to plant communties, etc. A column left "blank" Indicates a lack of sufficlent information from which to predict expected results. As observations are made 1 n the fleld by users of the data, predictions should be reflued by area and by thtensity of forestry practices. 
Approximate Range of:

Coreopsis pulchra F. Boynt.

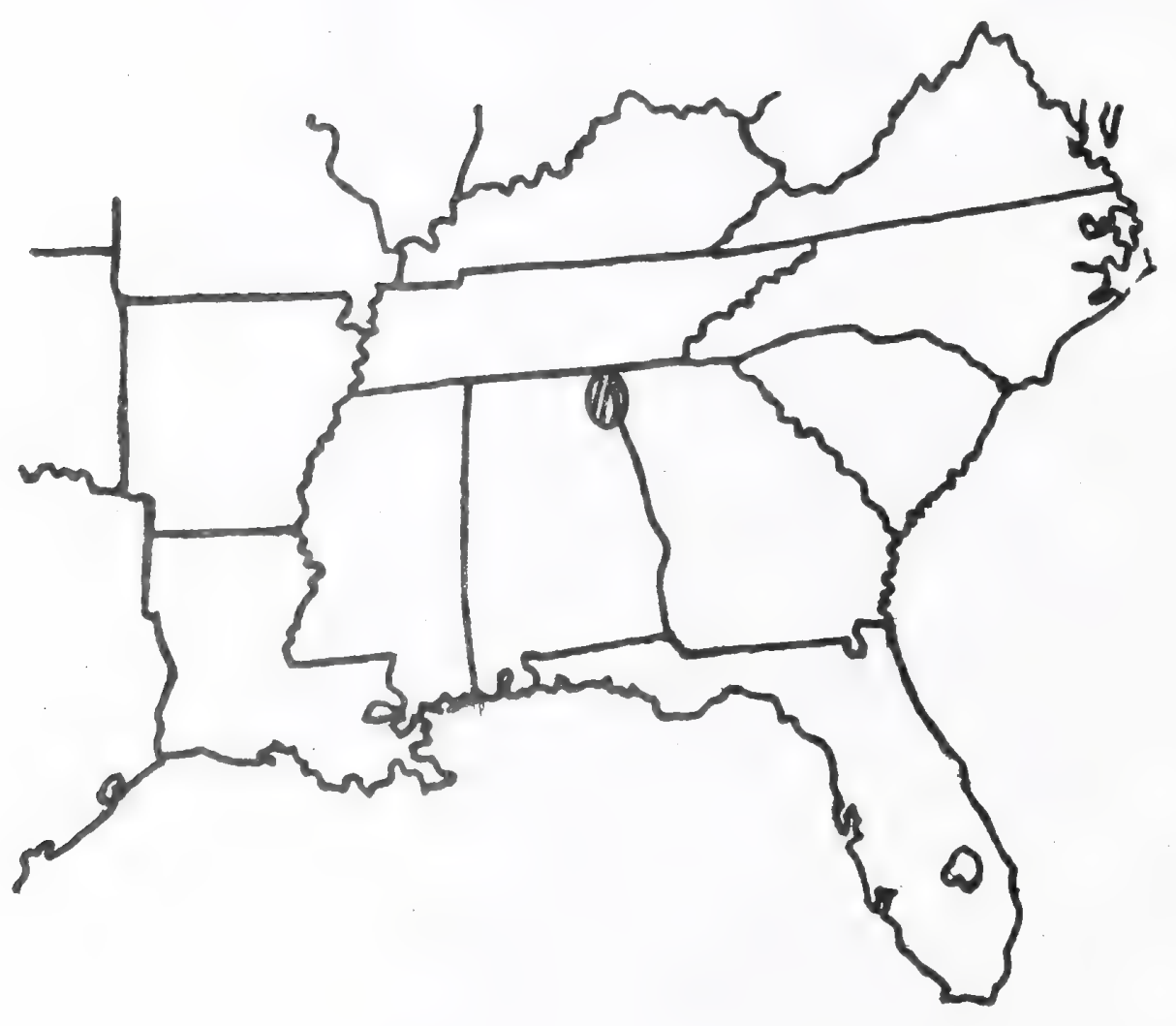




\section{Quercus arkansana Sargent \\ Q. caput-rivuli Ashe}

Status: Threatened

Technical Description:

A small to medium-sized deciduous tree in drier sites 10 w and of twisted form, on better sites often a clean straight tree to 20 meters or more tall and with a diameter to $6 \mathrm{dm}$, the 1 ower bark dark, moderately thick, blocky, grading quickly above to long, tight, narrow rectangles and 1ong, shallow, longitudinal cracks much as in Water Oak.

Twigs: Shoots of a season slender, stiffish, reddishwbrown with a scattering of small, stellate hairs and a relief of pale raised lenticels, the terminal buds lancemovoid, ca. 3-4 mm long, acute, the imbricated bud scales ovate, not angled, the margins ciliolate, the backs pale reddish-brown and smoothish. Older shoots becoming glabrous, grayish or grayishøbrown.

Leaves: alternate in a spiral, somewhat spreading, short-( $1 \mathrm{~cm}$ or less) petioled, the blades mostly obovate, similar in outline to Blackjack Oak (Q. marilandica) but most1y thinner, exclusive of those of suckers or stump sprouts $5-10 \mathrm{~cm}$ long, sometimes apical1y with 3-5 low rounded lobes, these each with an excurrent prickle, sometimes lobeless and broadly rounded, or obtuse or truncate, the margin below the broad apex always entire, the base either cuneate or narrowly rounded, the upper surface a rich, dark yellowgreen, the major veins strongly impressed and, when young, stellatehairy, the lower surface paler, the main veins strongly raised, cottonly lanose in the axils, otherwise with a scattering of ste11ate pale reddish-brown hairs (these often not persisting to fall). Fruit: Ripening in 2 years, $1-2$ per peduncle, the peduncles short, stout; acorn cup shallow, less than $1 / 3$ of the nut height in length, $1.2-1.5 \mathrm{~cm}$ across, the numerous tightly imbricated scales narrowly triangular, the narrowed tips truncate, the margins narrow, reddishbrown, the backs velutinous with very smal1, appressed gray hairs; nut dul1 brown, sometimes striped, nearly round, about $1 \mathrm{~cm} 1$ ong, minutely puberulent.

Distribution and Flowering Time:

Sandy or sandy clay uplands or upper ravine slopes, Coastal Plain, the southern counties of Arkansas and scattered localities eastward in Alabama, southern Georgia, and northwestern Florida; flowering in 1 ate March and April.

Special Identifying Features:

This tree, in the opinion of Trelease, may have arisen as a hybrid between Q. marilandica and Q. nigra. This is a reasonable assumption although other putative parental species might as well be $Q$. laurifolia or one of the lobed-leaved smoothish southern red oaks. However, one can make a good picture of this taxon by considering it as having leaves of the outline and approximate size of $Q$. marilandica, with the slender twigs and smallish, rather smooth buds of one of the willow oaks. 
Habitat and Management Implication:

Q. arkansana is a rare component of oak-hickory-ye11ow pine uplands where, if the substrate is high in clay, it achieves its largest known size. In Arkansas the associated pine are P. taeda, P. echinata, with associated hardwoods including Carya texana, C. tomentosa, Quercus falcata, Q. velutina, Q. alba, Q. nigra, Q. phellos,U1mus alata, Fraxinus americana, Acer rubrum, Nyssa sylvatica, with Cornus florida, Cercis, Bumelia, Vaccinium arboreum, Sassafras, Prunus mexicana in the understory. In the eastern localities it appears in the Longleaf Pine-deciduous scrub oak type, usually in the ravine heads and slopes of higher ridges, and is rooted in coarser sands. In such sites it is often in the understory and is a poorer, scrubbier tree that rarely exceeds 15 meters and has such associates as Pinus palustris, Quercus laevis, Q. incana, Q. margaretta, Q. velutina, Carya pallida, C. tomentosa, occasional southern Sugar Maple (on siightiy lower places), Osmanthus, Cornus florida, Cercis, Symplocos, Vaccinium.

The greatest threat to this species of oak comes from a conversion of the oak-hickory-pine uplands to plantation pine, this generally involving a poisoning of the poorer hardwoods, a salvage cutting of residual pines and better hardwoods, mechanical site preparation that usually involves root raking or bulldozing and total obliteration of the oak habitat. So far as is known, there are no populations of this rare oak known from public lands, thus it is important that existing habitat for it be identified and preserved where possible. Q. arkansana rarely reaches merchantible size, thus is mainly overlooked by loggers. On the other hand it appears not to be a weedy species. Its small niche could be maintained at little if any loss to the upland woodlot manager.

References:

Sargent, C. S. 1921. Trees of North America, ed. 2, facsimile Dover edition, Vol. 1.

Kurz, Herman, \& R. K. Godfrey. 1962. Trees of northern Florida. University of Florida Press. 
PECIES: QUERCUS arkansana Sargent

\begin{tabular}{|c|c|c|c|c|c|c|c|c|}
\hline $\begin{array}{l}\text { Expocted } \\
\text { Effect on } \\
\text { Hybitat }\end{array}$ & $\begin{array}{c}\text { Preacribo } \\
\text { Burn } \\
\end{array}$ & $\begin{array}{l}\text { Doze ox } \\
\text { Root } \\
\text { Rake }\end{array}$ & Bed & Chop & $\begin{array}{l}\text { Thin } \\
\text { Over- } \\
\text { Btory } \\
\end{array}$ & $\begin{array}{l}\text { Cut } \\
\text { Over- } \\
\text { Story } \\
\end{array}$ & $\begin{array}{c}\text { Over Plant } \\
\text { with } \\
\text { trees } \\
\end{array}$ & Graze \\
\hline Destroy & & $X$ & & $x$ & & & & \\
\hline Damage & & & & & & & & $X$ \\
\hline $\begin{array}{l}\text { No Lasting } \\
\text { Etfoct }\end{array}$ & $X$ & & NA & & & & & \\
\hline $\begin{array}{l}\text { Renaficlal } \\
1 \text { f Doue } \\
\text { Proporly }\end{array}$ & & & & & $x$ & $x$ & & \\
\hline
\end{tabular}

Other Commente:

* Est1mated effect 18 an estimate of the author baeed on his book knowledge of the habltat and on knowledge galned from personal

liteld ubservations. Est 1 inates are "rough" in many instances. Results of practices liay vary in degree of application, Intensity, nearlless to plant communities, etc. A column left "blank" lndicates a lack of suffictent informatlon from which to predict expected results. As observatlous are made 1 n the fleld by users of the data, predictions should be refined by area and by intensity of forestry practices. 
Distribution of :

Quercus arkansana Sargent
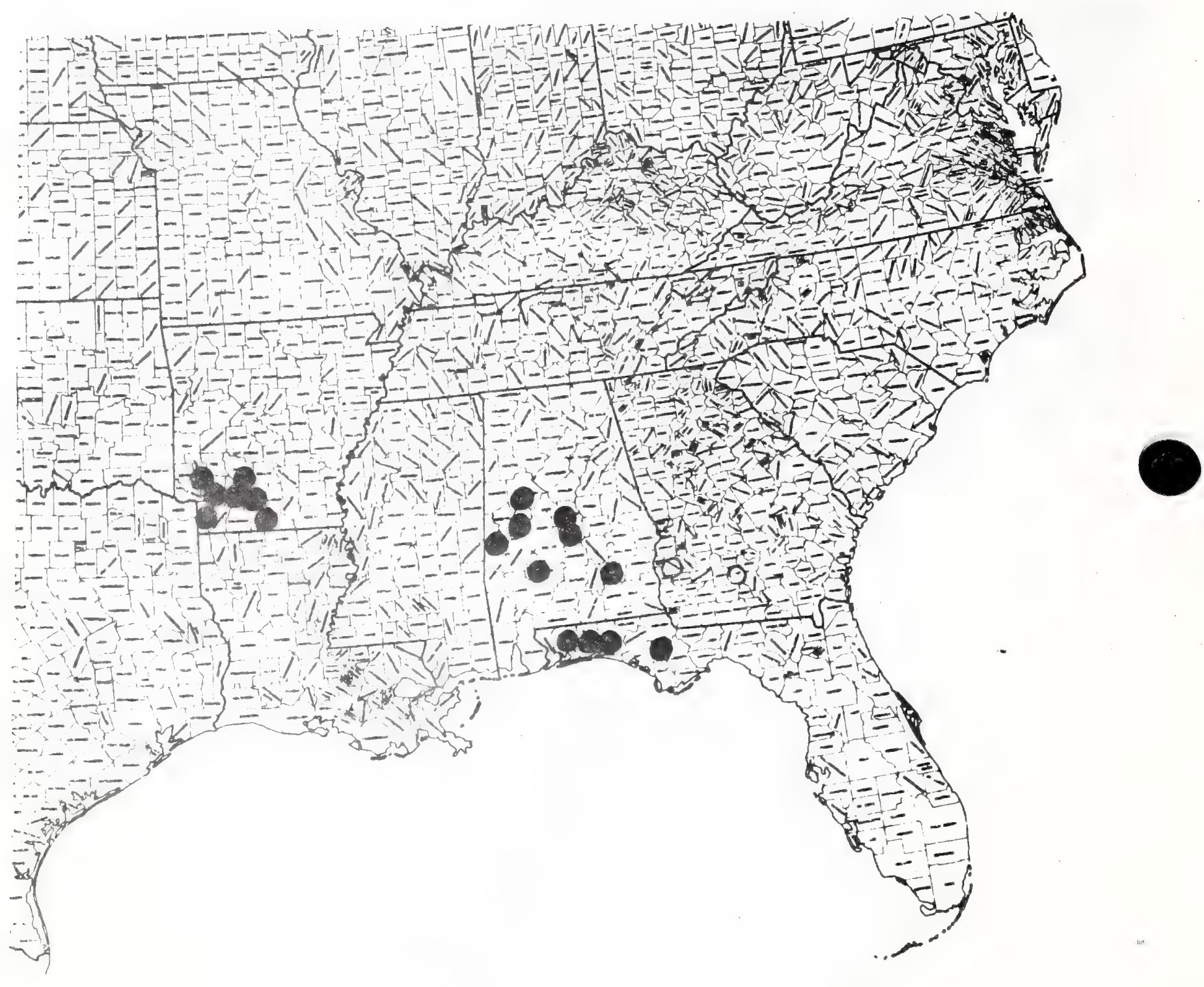
HY PER ICACEAE

Hypericum 1issoph1oeus P. Adams
Paper 284

Text \& map by:

Robert Kral

Status: Threatened

Technical Description:

Ta11 (to 3.5 meters), deliquescent-crowned, smooth shrubs from shallow, widely spreading diffuse roots and frequently producing suckers from roots, the trunks usually simple, branching only in the upper part to form the spreading crown, toward base to ca. $3 \mathrm{~cm}$ thick, the lower bark thin, smooth and exfoliating into rectangular curling sheets like some birch, a metallic gray-brown or reddish-gray-brown, upwardly still smooth but tight, more reddish, slick-looking, the primary branches slender, spreading-ascending, elongated, with the reddish or reddish-gray bark exfoliating in thin, rectangular-anastomosing flakes, and producing a mixture of very leafy, larch-1ike spurshoots as we 11 as normal branches, the latter slender, smooth, when fresh glaucous, often somewhat flattened or angulate, longitudinally ridged, with close-set nodes developing axillary fascicles, thus the branches and ultimate branchlets very 1eafy.

Leaves: 1inea1, opposite, sessile, persisting over winter, estipulate, neediemlike, the clasping bases at a node joined by a narrow ridge of tissue extending from each margin base, thus leaf base appearing jointed (articulated) to the shoot, the longer blades (not those of spur or axillary shoots!) spreading - ascending, somewhat fleshy, narrowly linear, most1y $1.5-2.0 \mathrm{~cm} 1 \mathrm{ong}$, to $0.75 \mathrm{~mm}$ wide, the narrowed tips blunt-conic, the margins revolute, entire, the upper surface dul1 green (glaucous when fresh!), flattish or slight1y concave, the midrib not evident, the rolled-down margin evidently gland-pitted; lower surface exposed as a narrow groove bordered by 2 low ridges, in combination al1 narrower than the combined width of the rolledunder margins.

Inflorescence: Flowers single or in cymes of 3 from axils of most of the upper branchlet nodes, the pedicels actually short shoots, usually each with a pair of bracts similar to foliage leaves, the actual pedicel usually shorter than the ovary, definitely shorter than the fruit.

F1owers: perfect, regular; sepals 5, early deciduous, similar to foliage leaves or very narrowly triangular-subulate, mostly $8-10 \mathrm{~mm}$ long, distinct to base, ascending or slightly spreading; petals 5 , distinct, ear1y deciduous, spreading, asymmetrically rectangularw obovate (as in Rhexia), $1.0-1.3 \mathrm{~cm}$ long, the broadly rounded or subtruncate apex pearing a spinulose apiculus laterally, the margin entire, the base subtruncate, the surface a rich orange yellow with darker orange veins; stamens very many, joined and crowded at their very base into a low ring around the ovary base, the slender deep yellow or or ange-yellow filaments erectish or ascending, forming a mass around the ovary and nearly as long as the petals, the anthers round, pale yellow, dorsifixed; ovary superior, tricarpellate, the body lance-ovoid, smooth, tapering gradual1y into a narrow erect style that projects slightly above the pale yellow anthers. Fruit: Capsule lance-ovoid, the body about $5 \mathrm{~mm} 1$ ong, deeply 3-1obed, the 3 locules with many small seed, the apex acute, tapering into 3 persistent, now divergent, styles, the surface smooth, a dark 
reddish-brown; seeds dark brown, oblongmcurvate (1ike a short banana), strongly longitudina11y ridged-and-grooved.

\section{Distribution and Flowering Season:}

Shores and shallows of limsink lakes and ponds, Coastal P1ain, northwestern Florida; flowering from late May through July and intermittent1y to frost.

\section{Special Identifying Features:}

This tal1 Hypericum is distinguished from other needle-1eaved species of its genus first by its peculiar smooth bark that below separates like birch, bu the metallic appearance of the bark of upper trunk and bases of larger branches, by the tallness and willowiness of habit, by the glaucousness of fresh shoots and leaves, and by the strongly ribbed character of the seed. According to Dr. Adams, monographer of sect. Myriandra (to which this species belongs!), two other very similar species, $\underline{H}$. reductum and $\underline{H}$. fasciculatum, grow mixed with this one but in no case have intermediates been observed.

\section{Habitat and Management Implication:}

H. 1issophloeus is found on the fluctuating shores of a few sink ponds or smal1 lakes in Bay and Washington Counties in northwestern Florida at about the longitude of Panama City. Around these ponds, it may be the most abundant shrub. At high water, its bases may be we11 submersed, only the waving tops of the upper branches exposed; on the other hand it may be we 11 exposed at low stages and it is then that abundant seedlings and small specimens are in evidence. It may be in the light shade of scattered cypress but is more often luxuriating in full sun and there forming a forest in miniature. The substratum is a moist to quite wet sand, this frequent1y with a high peat increment, and quite acid. The herbaceous cover under and around the Hypericum is primarily grass-sedge with a sprink1ing of Eriocaulon, Xyris,Drosera, Sabatia, Rhexia, Proserpinaca, Centella, Hydrocotyle, Ludwigia, various composites. The rare and local Xyris longisepala, X. isoetifolia, Rhexia salicifolia are frequently associated.

The limesink lakes and ponds are set in Longleaf Pine-deciduous scrub oak sandhills. Much of this area has, in recent years, been subjected to heavy mechanical disturbance, with the pine cleared, the oak and other hardwood scrub removed and with site preparation for plantation pine (mostly either Slash or Sand Pine). Damage to the ponds comes from erosion into them from the surrounding disturbed uplands, from overzealous clearing and bulldozing around the immediate shorelines (wherever these may be in a particular year!) and from increasing development of vacation or retirement housing around these lakes (which are scenic and once offered good fishing). There is also an unwarranted and steadily increasing number of campers, bathers, boaters, water skiers, picnickers and other 
recreators that use any unposted shoreline. All of the above activities are damaging the plants of shallows and shorelines, as well as effecting water quality. On the other hand, if access to some of these ponds is restricted, if mechanical disturbance of the contiguous slopes is kept to a minimum or prohibited, there is no reason why some good populations could not be kept.

\section{References:}

Adams, Preston. 1962. Studies in the Guttiferae I. A synopsis of Hypericum, sect. Myriandra. Contr. Gray Herb. 189: 3-51.

Sma11,J.K. 1933. Manual of the southeastern f1ora, pp. 868-874. 
SPECIES: Hypericum 1issophloeus P. Adams

\begin{tabular}{|c|c|c|c|c|c|c|c|c|}
\hline $\begin{array}{l}\text { Expected } \\
\text { Effect on } \\
\text { Habltat }\end{array}$ & $\begin{array}{c}\text { Prascriba } \\
\text { Burn }\end{array}$ & $\begin{array}{l}\text { Doze or } \\
\text { Root } \\
\text { Rake }\end{array}$ & Bed & Chop & $\begin{array}{l}\text { Thin } \\
\text { over - } \\
\text { otory }\end{array}$ & $\begin{array}{l}\text { Cut } \\
\text { over- } \\
\text { Story }\end{array}$ & $\begin{array}{c}\text { Over Plant } \\
\text { with } \\
\text { trees } \\
\end{array}$ & Graze \\
\hline Destroy & & & & & & & & \\
\hline Damage & & & & & & & & \\
\hline $\begin{array}{l}\text { No Lasting } \\
\text { Effect }\end{array}$ & & & & & & & & \\
\hline $\begin{array}{l}\text { Beneficial } \\
\text { If Done } \\
\text { proporly }\end{array}$ & & & & & & & & \\
\hline
\end{tabular}

Other Comments: Do not disturb shoreline vegetation. Do not drain areas of boggy shoreline.

* Est1mated effect 1 a an est1mate of the author baed on h1s book knowledge of the habltat and on knowledge galned from personal field observations. Estlmates are "rough" in many Instances. Results of practices may vary in degree of application, intensity, nearness to plant communities, etc. A column left "blank" indicates a lack of sufficlent information from which to predict expected results. As observations are made in the field by users of the data, predictions should be refined by area and by intensity of forestry practices. 


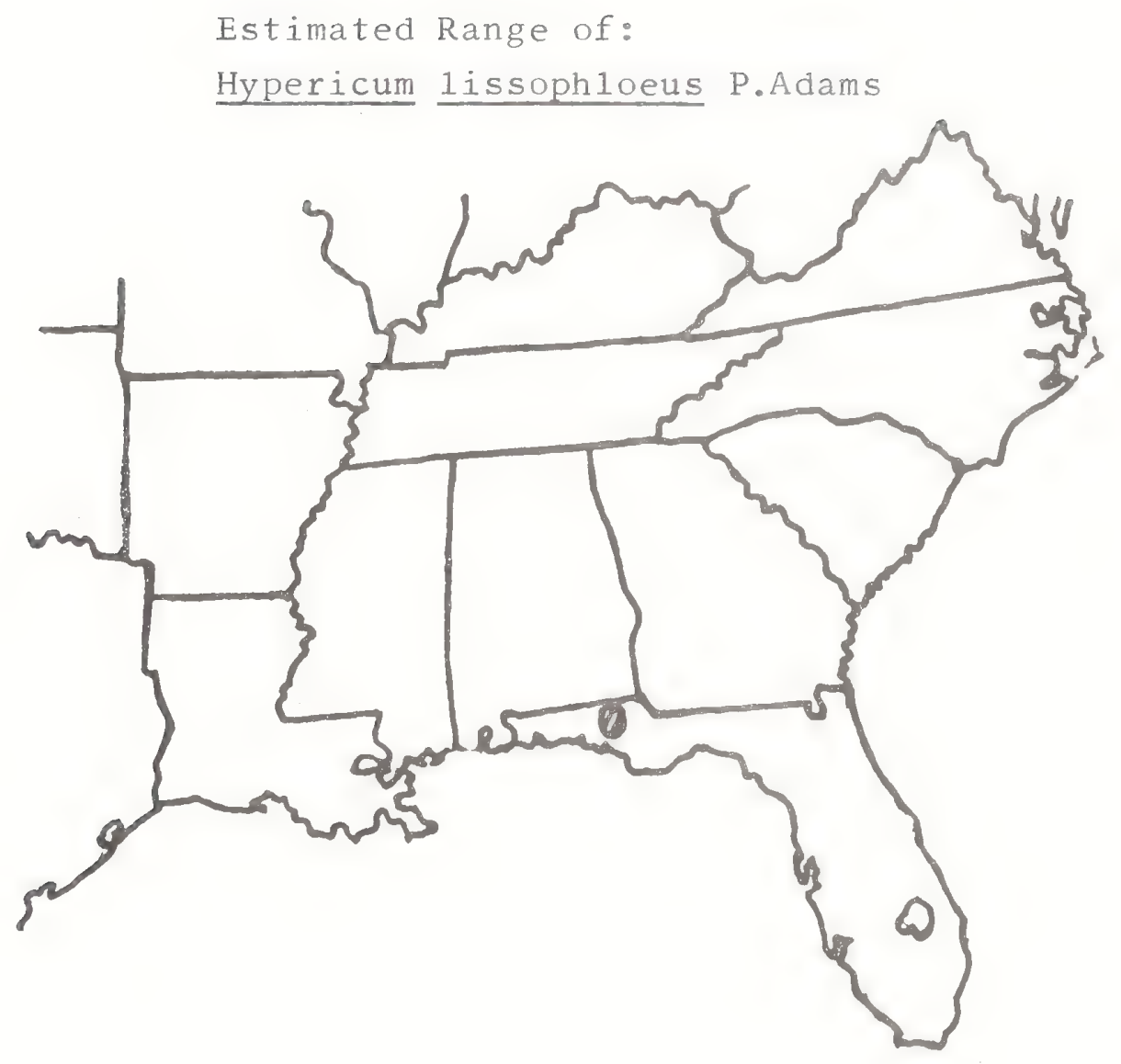




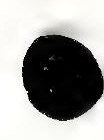


Perennial, aromatic, 2-10 dm tall, from shallow, elongate rhizomes, the roots slender, fibrous, diffuse.

Stems: Erect, usually unbranched below the middle from a short-decumbent base, quadrate, the angles being broad, rounded ribs, the intervals flat or concave, the internodes short and numerous toward stem base, lengthening upward, in the upper 1/5 developing arching-ascending, opposite branches, these usually terminating in inflorescences; stem surface yellowmgreen or strongly suffused with purple, smooth save distally where minutely incurled-puberulent with pale hairs. Leaves: opposite, spreading or ascending, the lower ones gone by flowering time, those at midrstem slightly the largest, gradually reduced to just below the inflorescence, the petioles most $1 \mathrm{y} 1-2 \mathrm{~cm}$ long, slender, troughed above, overall minutely spreading puberulent and remotely sessile $-\mathrm{gland}$ dotted, the larger blades mostly lanceolate, 6-8 cm long, narrowly acute, rather even1y low-serrate, the margin very slightly revolutewthickened, the base broadiy cuneate to roundedoblique, the upper surface a deep yellowmgreen, minutely puberulent, with a scattering of lepidote glands, the lower surface much paler, strongly gland-dotted, minutely puberulent, the hairs slightly longer and particularly dense on the midrib and lateral veins; venation pinnate, the midrib impressed above, strongly raised beneath. Inflorescence: an involucrate head, the dense floral mass exclusive of corolla hemisphaerical, 2.0-2.5 cm across the base and ca. $1.5 \mathrm{~cm}$ high, subtended by a few flat spirals of leafy involucral bracts these spreading or somewhat reflexed, lanceolate to ovate, most $1 y$ 1.5-2.0 cm long, the tips acuminate, sometimes short-aristate, the margins entire and ciliate, the broadly cuneate or narrowly rounded base subsessile, the upper surface often pale, cinereous-puberulent, the lower surface darker, similarly puberulent, many of the hairs above and below with minute glands; outer bracts grading into a few series of somewhat shorter, upcurvate, lance-1inear bracts, these strongly awn-tipped, hirsute-ciliate and also minutely stipitate-glandular $\rightarrow$ puberulent, these hairs sometimes intermixed with stouter, peg-like gland-tipped hairs.

Flowers: bisexual, with a regular calyx and a strongly irregular corolla; sepals 5, the tube cylindric, 8-9 mm long, 10-ribbed, pale green dotted with sessile orangish resin glands and minutely stipitateglandular, at its orifice and for $1-2 \mathrm{~mm}$ below the rim inside strongly villous-pilose with inward pointed white hairs, the calyx lobes subulate, awn-1ike, 1.0-1.5 mm long, erect or slightly spreading at anthesis, sparsely bedecked with coarse, spreading peglike stipitate glands; corolla bilabiate, white, ca. $3 \mathrm{~cm}$ long, the narrowly funnelform-tubular base falciform-excurvate, 1.0-1.2 cm long, the upper 1ip arching forward in line with the tube, narrowly linear, somewhat folded, its narrowly rounded apex fimbriate-villous with long white hairs, the lower lip broader, oblong, about the same length as the upper and downcurvate, also folded, apically with 1ateral lobes 1 ow, broadly rounded into a central, oblong-linear lobe ca. $3 \mathrm{~mm}$ long, this 
somewhat fimbriate at tip; external surface white-pilose, dotted with amber sessile glands; stamens 2, epipetalous, the slender, flattened tapering white filaments arising just below the corolla sinuses and arching upward and forward to just under the tip of the upper corolla lip or just beyond, there converging (connivent) the anther connective much flattened and broadened, forming a " $\Gamma$ " with the filament apex, the anther sacs linear, divergent 180 degrees, parallel to those of opposing anther; ovary superior, lobed at insertion of style base, the style slenderly linear, arching upward and under the upper corolla lobe, its unequally bifid stigmatic apex projecting just beyond the anthers.

Fruit: nutlets 4, oblong-cylindric, 1.3-1.8 mm long, smooth, brown.

Distribution and Flowering Season:

Dry, open1y wooded ridges and ravine slopes or moist, rocky, grave11y moist clearings along streams and rivers, inner Coasta1 P1ain and Interior Highlands, eastern Oklahoma and southwestern Arkansas; flowering from late May we11 into Ju1y.

Special Identifying Features:

This Beembalm is most similar to $M$. fistulosa, the commonest and most widemranging as we11 as most polymorphic species. It differs from that species in a more prevalently white corolla, in the minutely stipitate-glandular indumentum of calyx tube, bractlets and sometimes bracts. Waterfal1's original description calls for a much lower plant than may be observed on moister, lower sites such as are found for it in western Arkansas. Also, while the Waterfall description indicates only a white corolla, M. stipitoglandulosa may develop clones in which corollas are ver $\bar{y}$ 1ight lavender.

Habitat and Management Implications:

M. stipitoglandulosa frequents upland, comparatively dry, shaley or shaley-sandy woods and ravine slopes where the overstory is comprised mainly of oaks and hickories such as Quercus stellata, Q. velutina, $Q$. coccinea, $Q$. marilandica, Carya tomentosa, $\underline{\text { C. texana, }}$ together with pinus echinata. However, the plants are also found downslope in gravelly sandy clay of clearings in or streambanks through mixed mesophytic woodland. Its tolerance to wide fluctuations in soil water appears to be high, and its substrate requirements are very similar to those of Streptanthus squamiformis Goodman, a frequent associate. Like that species, it maycome into areas where clearcutting and various methods of mechanical site preparation have been employed.

References:

Waterfa11, U.T. 1970. Monarda stipitoglandulosa, a new species from Oklahoma. Rhodora 72 (792): 502-504. 
SPECIES: Monarda stipitoglandulosa U.T.Waterfal1

\begin{tabular}{|c|c|c|c|c|c|c|c|c|}
\hline $\begin{array}{l}\text { Expected } \\
\text { Effect on } \\
\text { Hab1tat }\end{array}$ & $\begin{array}{c}\text { Prescr1bo } \\
\text { Burn }\end{array}$ & $\begin{array}{l}\text { Doze or } \\
\text { Root } \\
\text { Rake } \\
\end{array}$ & Bed & Chop & $\begin{array}{l}\text { Th1n } \\
\text { over- } \\
\text { Btory }\end{array}$ & $\begin{array}{l}\text { Cut } \\
\text { over } \\
\text { Story } \\
\end{array}$ & $\begin{array}{c}\text { Over Plant } \\
\text { with } \\
\text { trees } \\
\end{array}$ & Graze \\
\hline Destroy & & & & & & & $X$ & \\
\hline Damage & & & & & & & & \\
\hline $\begin{array}{l}\text { No Lasting } \\
\text { Effect }\end{array}$ & & & $y$ & & & & & \\
\hline $\begin{array}{l}\text { Beneflcial } \\
\text { If Done } \\
\text { Properly }\end{array}$ & & & & & & & & \\
\hline
\end{tabular}

\section{Other Commente:}

* Est1mated effect 1 a an est1mate of the author based on h1s book knowledge of the habltat and on knowledge galned from personal field observations. Estimates are "rough" in many instances. Results of practices may vary 1 n degree of application, intensity, nearness to plant communities, etc. A column left "blank" indicates a lack of sufficient information from which to predict expected results. As observations are made in the field by users of the data, predictions should be refined by area and by intensity of forestry practices. 


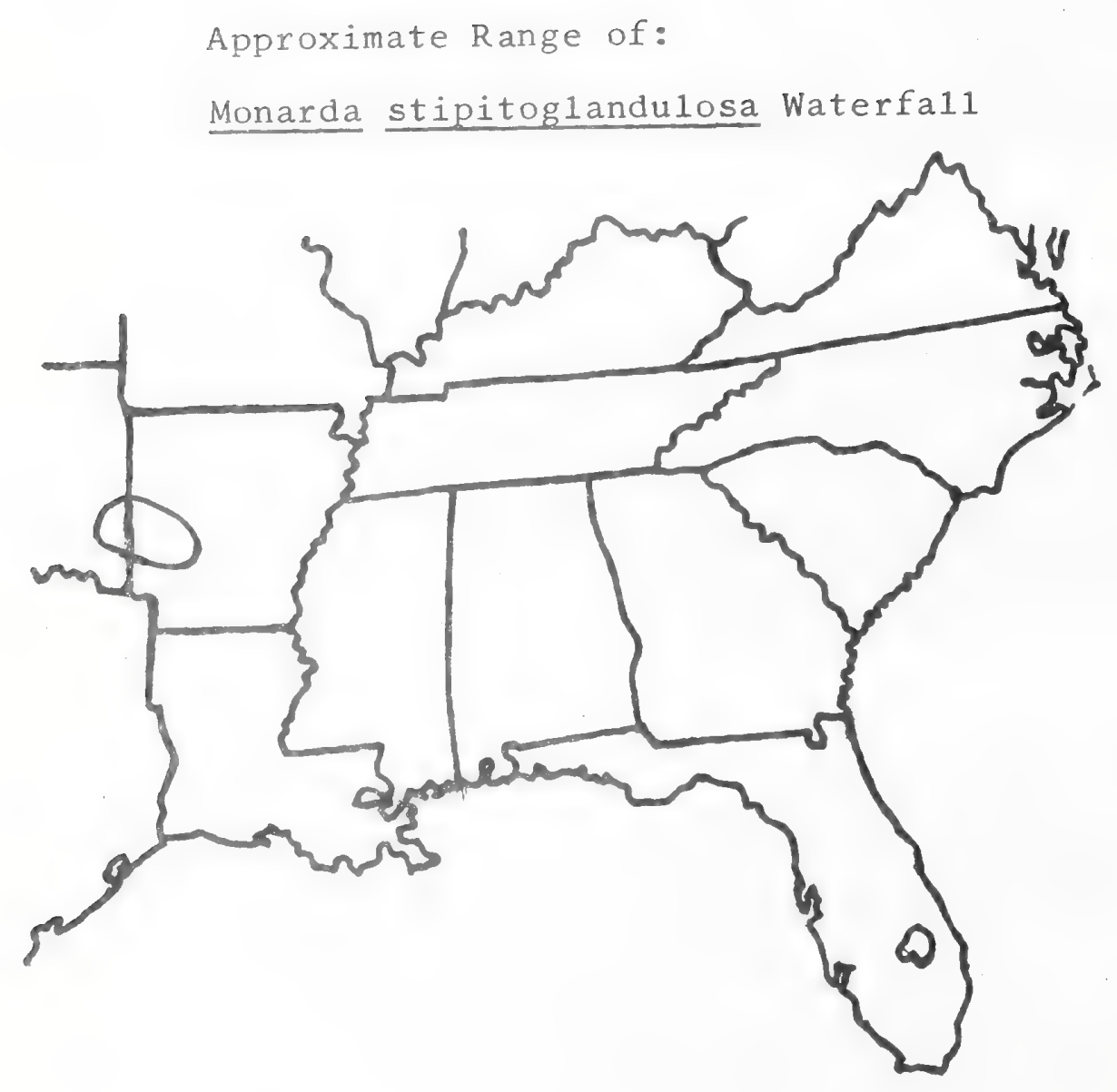


Status: Threatened

Technica1 Description:

Smooth, perennial, non-aromatic mint, mostly 7-15 dm tal1 from a stocky, fleshy caudex, this terminating a slender pale rhizome which produces also whiplike, stoloniferous rhizomes surficially.

Stems: Stiffly erect, simple, usually if branching, branching only in the inflorescence, quadrate, at base $4-8 \mathrm{~mm}$ thick, the angles rounded, toward base with nodes close set, at mid-stem and upward distant, the surface proximally and distally often purplish, otherwise pale green, in the inflorescence minutely puberulent.

Leaves: opposite, simple, the lowermost usualiy absent by anthesis, those at mid-stem usual1y largest, only the lower ones petiolate, the petioles mostly 3-6 cm long, slender, troughed above, often reddish, the blades mostly lanceolate to eliiptic or oblanceolate, erect or ascending, 6-10 cm long, obtuse to bluntly acute, the margin sinuate to low-serrate, the low teeth very ascending, each with a low, callused apiculus, the base attenuate, the surfaces yellow-green (when dry showing a clear pattern of short-oblong cystoliths), pinnate-veined with only midrib above appearing strong, beneath with midrib strongly raised, the lateral veins arcuate, faint but raised; blades upward on stem progressively shorter, narrower, sharper-pointed, more sessile, more distant, grading into bracteal ones $1 \mathrm{~cm}$ or less 1 ong.

Inflorescence: terminal, indeterminate, either a single spikelike raceme or with an additional pair of racemes, in outline lanceolate, the flowers crowded and overlapping toward its tip, more distant downward as flowers become fruit, the pedicels stiffly ascending, each subtended by a lance-subulate bract shorter than the calyx and pedicel combined, the pedicel at anthesis puberulous, $1.0-1.5 \mathrm{~mm}$ 1 ong.

F1owers: bisexua1, spreading-ascending, the calyx nearly regular, the corolla strongly bilabiate; sepals 5, united, the tube at anthesis narrowly campanulate, from base to lobe-sinus $5-6 \mathrm{~mm}$ 1ong, the lobes triangular, sharp-tipped, spreading ascending, $2-3 \mathrm{~mm}$ long, the surface puberulent externally, green as in leaves but with lobe tips often reddish-tinged; petals 5, strongly united and bilabiate, 2.5-3.0 cm 1ong, the tubular base dilating above the lower $1 / 3$ to become broadiy funne1form with the upper (posterior) side slightly arched or nearly straight, the lower (anterior) side more convex and inflated, the 1 imb of 2 lips, the upper slightly longer, ca. 3-6 mm long, from broadly rounded or truncated tip to sinus, but narrower, arched forward and sight1y folded, the lower 1ip 3-lobed, apically slight1y downcurved, the central lobe oblong and emarginate, the laterals shorter, salient, round. ed or slightly emarginate, the external surface lavender-rose with deeper 1 ines at throat apex and 1ips, grading paler toward the tubular base, the upper side puberulent, the lateral and lower sides smooth, internally purple-mottled in throat, smooth throughout; functional stamens 4, didynamous, the slender, flattened filaments epipetalous, 
arching upward and just under the upper corolla 1ip, the anthers external1y deep purple, dorsifixed, the strongly divergent, reniform anther sacs spinulose-toothed along the slits and presented either just below tip of upper corolla lip or slightly beyond; ovary superior, 4-1obed, bicarpeliate, the slender style slightly curved upward with the filaments, the 2, short-linear, excurved, sharp stigmas presented just beyond the upper corolla lip.

Fruit: Nutlets 4, near1y round in outline but often 3-angled, pale brown, smooth, ca. $2.5 \mathrm{~mm} 1$ ong.

Distribution and Flowering Season: Swamp woodlands, river and inlet banks and coastal sloughs, Coastal Plain, southeastern Virginia south to northern peninsular Florida, westward into southern Alabama; flowering mostly in May and June, intermittently to August.

\section{Special Identifying Features:}

The difficulty with Physostegia is that it is such a distinct genus, meaning that the several taxa are within complexes hard to tell apart. Nearest to P. leptophylla is probably P. purpurea (Wa1t.) Blake, of wet savañna or swamp woodland in the Atlantic Coastal Plain south into southern Florida. This tends to have the larger leaves more crowded toward the base, rather than at mid-stem or above, and broadest toward the apex and the pubescence of its calyx and inflorescence is, while short, heavier and sharper. Dr. Philip D. Cantino, current revisor of the genus for North America, doubtless knows additional characters, but, from the material I have seen in the field and in the herbarium, there appear to be several intergrading forms.

Habitat and Management Imp1ication:

D. leptophylla is a species primarily of swamp woodlands, particularly where the alluvium overlies calcareous rock or in areas where the streams and rivers empty through broad coastal sawgrass marsh. The substrate is usually a sandy peat muck or sandy silt and, save in driest periods, is saturated. The plants are strongly clonalizing, forming large, showy stands either in full shade or full sun as would be beating on hammock edges, along banks and islands in rivers, or in sweet marsh at edges of sawgrass. The overstory species in the swamp forest are most1y Bald Cypress, Water Tupe1o (A. aguatica or N. ogeche), Carolina Ash,Red Maple, Sweet Gum, Willow, wāter Hickory, Sügarberry, E1m, various swamp oaks, particularly willow oaks. Sabal palmetto is common in most Florida sites. The shrub layer normally has an abundance of Myrica, Cornus ("Svida"), Styrax americana, Ilex, Sabal minor, tangles of Smilax, Rosa, Itea, Crataegus, etc. Common associated herbs include Sagittaria, sparganium, Peltandra, Pontederia, Isoetes, Saururus, Polygonum, Penthorum, Proserpinaca, Asclepias (particularlyA. perennis), Cicuta, Eryngium yuccifolium synchaetum, Hydrolea, etc. Chasmanthium nitidumis a common as sociated grass and frequent sedges are Scirpus fontinalis, S. divaricatus, Rhynchospora corniculata, $\underline{\text { R }}$ mixta, $\underline{\text { R. miliacea, }}$ Carex lupulina, c. joorii.

P. 1eptophy11a is impacted primarily by real estate development along 
some streams as wel1 as by an increasing conversion of large tracts of swampy hammmck to slash pine plantations. This last usually involves a wholesale mechanical site preparation preceded by clear cutting and deep drainage-ditching. These activities cause excessive silting of the small streams, burying of habitat, and in addition creation of habitat too dry for swamp herbs.

\section{Reference:}

Sma11,J.K. 1933. Manual of the southeastern flora, p. 1156. 
SPECIES: Physostegia 1eptophy11a Sma11

\begin{tabular}{|c|c|c|c|c|c|c|c|c|}
\hline $\begin{array}{l}\text { Expected } \\
\text { Effect on } \\
\text { Habltat }\end{array}$ & $\begin{array}{c}\text { Prescribe } \\
\text { Burn }\end{array}$ & $\begin{array}{l}\text { Doze or } \\
\text { Root } \\
\text { Rake }\end{array}$ & Bed & Chop & $\begin{array}{l}\text { Th1n } \\
\text { Over- } \\
\text { otory }\end{array}$ & $\begin{array}{l}\text { Cut } \\
\text { Over- } \\
\text { story }\end{array}$ & $\begin{array}{c}\text { Over Plant } \\
w 1 \mathrm{th} \\
\text { treeg } \\
\end{array}$ & Graze \\
\hline Destroy & & $X$ & $x$ & $x$ & & & $X$ & \\
\hline Damage & $A / A$ & & & & & $x$ & & 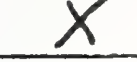 \\
\hline $\begin{array}{l}\text { No Lasting } \\
\text { Effect }\end{array}$ & & & & & $X$ & & & \\
\hline $\begin{array}{l}\text { Beneficlal } \\
\text { If Done } \\
\text { groperly }\end{array}$ & & & & & & & & \\
\hline
\end{tabular}

Other Comments:

Drainage destroys the habitat!

* Est1mated effect 18 an est1mate of the author based on h1s book knowledge of the habltat and on knowledge galned from personal field observations. Est1mates are "rough" in many instances. Results of practices may vary in degree of application, intensity, nearness to plant communties, etc. A column left "blank" indicates a lack of sufficient information from which to predict expected results. As observations are made in the field by users of the data, predictions should be refined by area and by intensity of forestry practices. 
Physostegia leptophylla Sha71

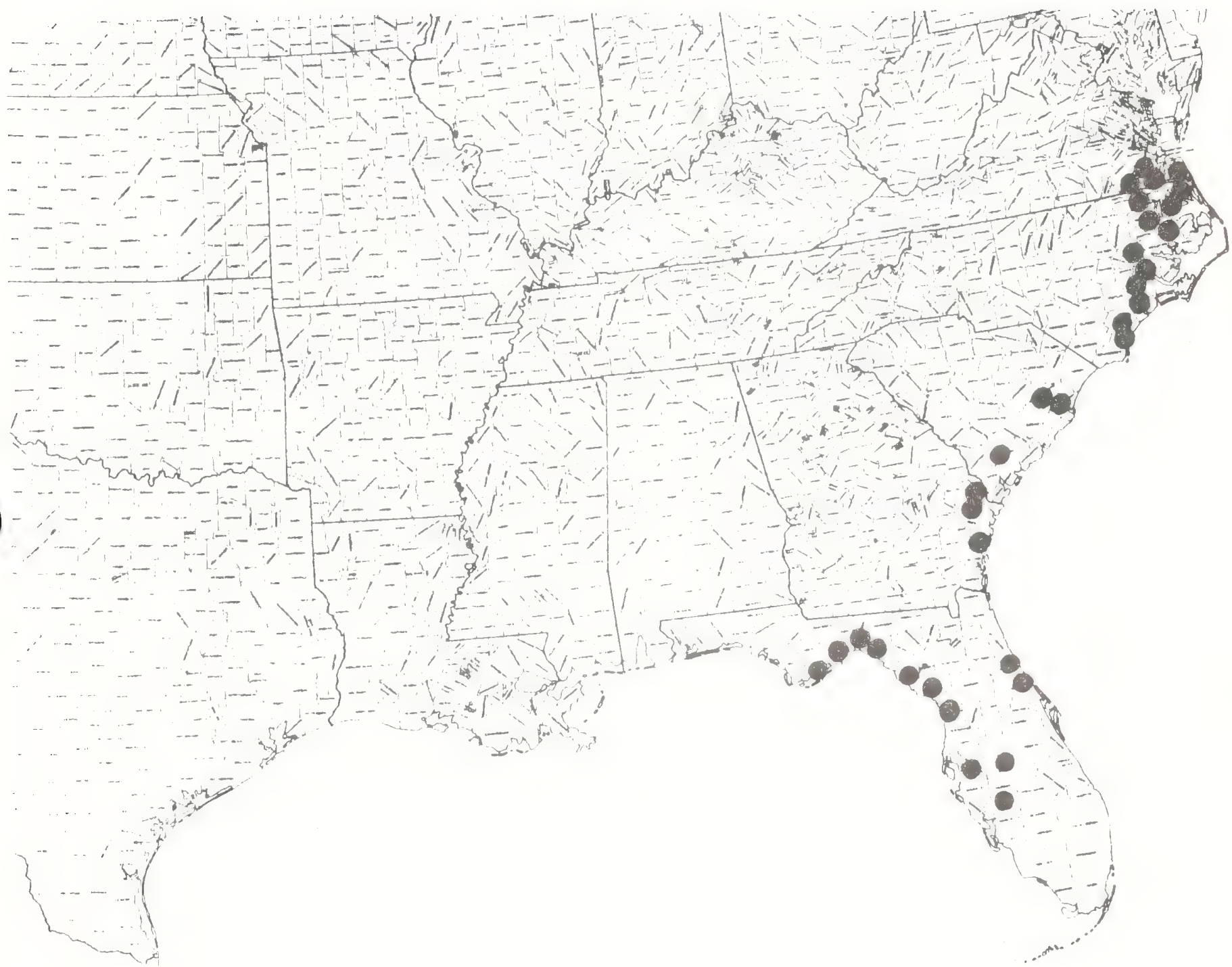


•

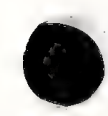


Leitneria floridana Chapm.

Status: Threatened

Technical Description:

Sma11, strongly clonalizing, sparingly-branched, dioecious, deciduous tree, rarely to 7 meters tall, forming large but local populations of stick-like erect stems from a shallowly diffuse and spreading root system, the diameter of the trunk at base rarely to 12 or $13 \mathrm{~cm}$, the bark pale brown, thin, longitudinally cracking and crossmchecking to form long, narrowly rectangular tight plates.

Twigs: New shoots slender but stiffish, densely villousmtomentose, $\overline{\text { later }}$ in season becoming progressively smoother, often nearly smooth by fall, then dull gray-brown, with paler, strongly raised elliptical lenticels, teretish but decurrent-ridged below leaf scars, these semicircular, with lower edge strongly raised, the corky surface with 3 large bundle scars, the axillary buds triangular-ovoid, ca. 3-4 mm long, the scales several, tight1y imbricate, dark chestnut brown, the outer ones nearly smooth, the inner pale pubescent toward tips, acute, slightly keeled; 2-year and older shoots becoming perfectly smooth, somewhat lustrous, deep purple-brown, the lenticels and leaf scars pale in contrast. Leaves: Aiternate in spiral, estipulate, spreading or ascending on teretish petioles ca. 1/5-1/0 the total leaf length, at first villous-tomentose, later nearly smooth; leaf blades most 1y narrowly elliptic to lanceolate, (8-) 10-15 (-18) cm long, firm, acute, entire, slightly and narrowly revolute, the base cuneate to shortattenuate, pinnately veined, the upper surface yellow-green, paler when young and coated with a soft blonde or pale wooly tomentum, and impressed veiney, later with a persistent fine coat of appressed hairs, the lower surface paler, more densely tomentose, particularly on the strongly raised veins.

Inflorescence and Flowers: Most axillary buds expanding in early spring before leaves emerge to form short, strong1y bracteate-scaley conelike catkins. Male catkins oblong, narrowly ellipsoidal or lance-ovoid, most1y $2-3(-6) \mathrm{cm}$ 1ong, of many, spirally imbricated chaffy bracts, all but the lowermost subtending a flower, these bracts 6-7 mm long, rigid, erectish, lanceolate, narrowly acute, the backs pale-lanate-tomentose, the inner surfaces smooth, dark redmbrown; male florets witout perianth, supposedly 3 per bract forming a cymule but appearing like a single flower with $3-12$ stamens, these with yellowish, nearly round, bilocular anthers these basifixed on slender filaments about as long. Female plants with catkins narrower, fewer-flowered, the lowermost bracts sterile, broadly triangular - ovate, the backs nearly smooth, the fertile bracts similar to those of the male catkin in shape and pubescence, but each subtending a single flower, this subtended by a ring of a few glandmmargined small scales; ovary superior, unicarpellate with 1 apical ovule, narrowed at base, the ellipsoidal or obovoid body serecious tomentose, shorter than the subtending primary bract, subapically bearing an elongate, excurved style projecting beyond the bract tip stigmatic along its inner side halfway to the style base. Fruit: an el1ipsoidal or narrowly obovoid drupe $1.8-2.0 \mathrm{~cm}$ long 
and pale brown when ripe.

Distribution and F1owering Season:

Pond margins, wet swampy swales, swamp hardwood formations, palmettosawgrass marsh, in the Coastal plain from eastern and south-central Texas, eastward sporadically along the coast (exclusing Mississippi and Alabama) to Gulf Coastal Florida southward to the mouth of the Suwannee River; $10 \mathrm{cal}$ in the Atlantic Coasta1 Plain (perhaps extirpated from the mouth of the Altamaha River in southeastern Georgia); in the Mississippi Embayment northward bypassing Louisiana but 1oca11y abundant and perhaps of its best development in the delta of Arkansas and southeastern Missouri.

Special Identifying Featires:

Corkwood is the only member of the family Leitneriaceae, a family whose evolutional position is yet debated. No other southeastern tree combines the sparsely branched, sticklike habit, simple, entire, estipulate leaves, dioecious habit, the strange stylar character, and drupaceous fruit. The wood is unique in being the lightest of any southeastern tree and larger specimens were once cut into short lengths to be used for fishing net floats.

Habitat and Management Implication:

Leitneria appears in two rather different habitats. Along the Gulf coast, it is typically found in the narrow zone between sawgrass brakish marsh and contiguous coastal pine-hardwoodCabbage Palm hammock. In such sites it has become quite rare, probably because in the past it was thinned by fishermen in quest of net floats. In the eastern counties of Arkansas and southern Missouri it is in fresh water marsh, usua11y along drainages (many now ditched) that traverse bottomland hardwoods. Common associates are Black Willow, Cottonwood, various bottomland oaks including Overcup, Willow, Water, Nutta11, Pin, Swamp Chestnut, Water Hickory, Green Ash, Swamp Red Maple, Drummond Maple, Box Elder, Catalpa, etc. In such bottomland formations it is usually occurring along the edges, not in the deep shade of mature stands, and it is always on high hydroperiod, silty clay substrates. Common shrub associates are in genera Cornus, Styrax, Salix, Sambucus, Cephalanthus, Ilex, Crataegus.

Along the seacoasts the species is threatened by commercial development, particularly as the recreational and fisheries facilities of the Gulf coast are expanded. Inland it is threatened by wholesale conversion of bottomland hardwood systems to cleared and drained fields of row crops such as soybeans, or irrigated fields of rice. Maintenence of this species would be easy, in that it is such a strong clonalizer, but it is not the most esthetically pleasing species, neither has it any significant economic use, thus the motives for its preservation are less. Logging operations in bottomland hardwoods contiguous to Leitneria would themselves pose no threat providing these were selective, involving no drainage and a minimum mechanica. disturbance of the substratum. 
References:

Kurz,Herman \& R.K.Godfrey. 1962. Trees of northern Florida. University of Florida Press.

Sargent, C.S. 1921. Trees of North America, ed. 2, facsimile edition, Vo1. 1. Dover Press. 
SPECIES: Leitneria floridana Chapman

\begin{tabular}{|c|c|c|c|c|c|c|c|c|}
\hline $\begin{array}{l}\text { Expected } \\
\text { Effect on } \\
\text { Habltat }\end{array}$ & $\begin{array}{c}\text { Prascr1ba } \\
\text { Burn }\end{array}$ & $\begin{array}{l}\text { Doze or } \\
\text { Root } \\
\text { Rake }\end{array}$ & Bed & Chop & $\begin{array}{l}\text { Th1n } \\
\text { over- } \\
\text { Btory }\end{array}$ & $\begin{array}{l}\text { Cut } \\
\text { over- } \\
\text { Story }\end{array}$ & $\begin{array}{c}\text { Over Plant } \\
\text { with } \\
\text { trees } \\
\end{array}$ & Graze \\
\hline Destroy & & & & & & & & \\
\hline Damage & $\Delta / \Lambda$ & & & & & & & \\
\hline $\begin{array}{l}\text { No Lasting } \\
\text { Effect }\end{array}$ & & & & & & & & \\
\hline $\begin{array}{l}\text { Benaficlal } \\
\text { If Done } \\
\text { Properly }\end{array}$ & & & & & & & & \\
\hline
\end{tabular}

Other Comments: Do not drain!

*Est1mated effect 18 an egt1mate of the author baeed on h1 book knowledge of the habltat and on knowledge galned from personal field ubservations. Estimates are "rough" in many instances. Results of practices may vary 1 n degree of application, intensity, nearness to plant communities, etc. A column left "blank" 1ndicates a lack of sufficient information from which to predict expected results. As observations are made in the fleld by users of the data, predictions should be reflned by area and by intensity of forestry practices. 
Leitneria floridana Chapm.

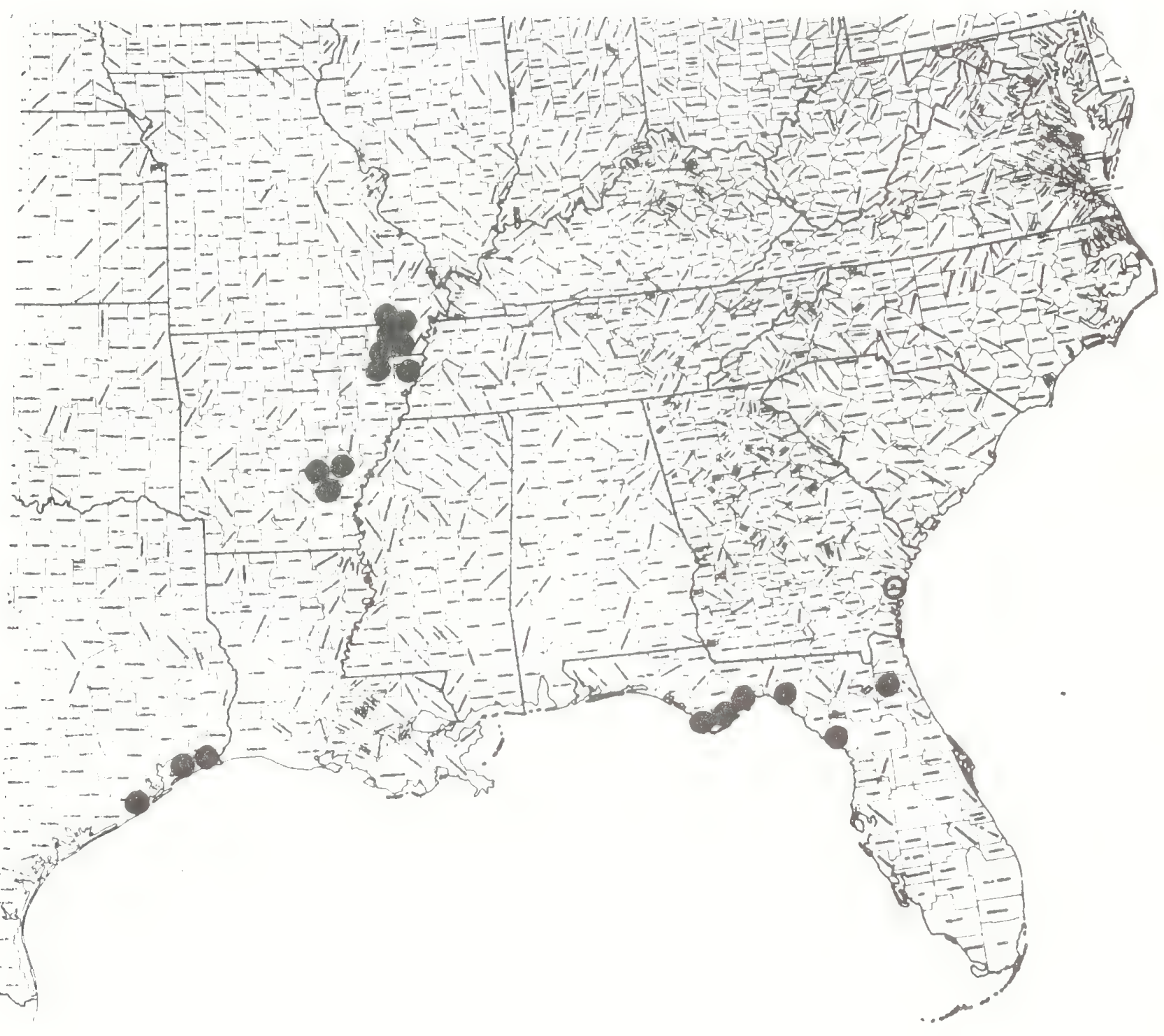


-

•

0 


\section{Oenothera pilosella Raf. ssp. sessilis (Pennel1)Straley ve. sessilis (Penne11) Munz}

status: Endangered

Technical Description:

Perennial trom a short, stout rootstock, the roots diffusenibrous, slender, the shoots bolting from an overwintering rosette.

stems: erect or ascending, mostly unbranched or branching only above the middle, 3-7 dm long, 3-4 mm thick, terete, nearly smooth and tannish proximally, shortly above base becoming pubescent with incurved or appressed whitish pilosulous hairs less than $1 \mathrm{~mm}$ long, more densely hairy upward toward and into inflorescence, there becoming tomentose.

Leaves: alternate, those of the rosette smaller than mid-cauline ones, mostly oblanceolate, entire to distantly low-dentate; lowermost stem leaves mostly lacking by full flowering time, if present oblanceolate or spatulate, somewhat smaller than and grading into mid or upper cauline ones which are linearwelliptic to lanceolate, 6-10 cm long, ascending, acute, entire to distantly low-toothed, denticulate, the base narrowly acute to attenuate, decurrent to leat base or to a short petiole, the surfaces pale yellow-green, tomentose with appressed white hairs less than $1 \mathrm{~mm}$ long; stem leaves gradually diminishing in size upward into the inflorescence. Intlorescence: tlowers stipitate, axillary to bracteal leaves in an indeterminate terminal spike, this solitary or compound by several ascending, elongating branches. Hlowers: bisexual, the calyx irregular, the corolla regular, strongly ascending, showy, mostly $6-7 \mathrm{~cm}$ long from base of ovary to petal apex, 4-5 cm across the petals; sepal lobes in bud narrowly lance-ovoid, ca. $2 \mathrm{~cm}$ long, the narrowly linear sepal tips erect and parallel, ca. $2 \mathrm{~mm}$ long; perianth tube from ovary summit to base of sepal limb narrowly tubular, ca. 2 cm long, grayish-pink, appressed. white-pilosulous, the calyx limb of 4 fused sepal lobes ligulate, ovate or broadiy lanceolate, tipped with the 4 1inear teeth, appressedpilosulous externally; corolla with distinct petals 4, pale yellow, spreading, broadly obtriangular, ca. $3 \mathrm{~cm}$ long, nearly as broad at slightly emarginate apex; stamens 8, the slender, smooth, pale yellow tilaments arising at orifice of perianth tube, $5-10 \mathrm{~mm} 1 \mathrm{ong}$, the anthers linear-oblong, dorsifixed, deeper yellow, ca. $5 \mathrm{~mm}$ long; ovary inferior, clavate (shape of ovary as covered by perianth tube), 1.0-1.5 cm long at anthesis, 4-angled, pilosulous, the erect style slender, 3.0-3.5 cm 1ong, smooth, the 4 stigmatose branches narrowly linear, spreading, 3.5-4.0 mm long.

Fruit: Capsule narrowly ellipsoidal, ca. 1 cm long, 3-4 mm thick, $\overline{4-a n g l e d, ~ p i l o s u l o u s, ~ t h e ~ s t i p e ~} 1-2 \mathrm{~mm}$ long; seeds not seen.

Distribution and Flowering Season:

Sandy silts, sandy-silty clay loams, tine sandy loams, Mississippi Embayment of northern Louisiana, eastern Arkansas, with an out1ier 
1n the Gulf Coastal Plain of Texas (Galveston Co.); flowering in May, June.

Special Identifying Features:

Oe. pilosella sessilis is in sect. Kneiffia of the genus. In this section only two other species, O. fruticosa, o. perennis, are truly perennia1. O. perennis is distinguishable on the basis of its smaller petals $(5-10 \mathrm{~mm}$ long) and its nodding inflorescence; O. truticosa (and subspecies) has clavate to oblong truit, the sepal tips are shorter (ca. $1 \mathrm{~mm}$ long or less). In o. pilosella the capsules which are narrowly clavate to elliptic, and the linear sepal tips are longer. O. piloselıa sessilis is distinguished Irom O. piloselia piloselia by its shorter, more copious pubescence, its shorter ovary, its sepal tips which are erect and closely paralle1 (rather than spreading).

Habitat and Management Implication:

U. pilosella sessilis appears to be extirpated over much of its former range. Straley, the last monographer of sect. Kneiffia (1977) opines that it is probably now tound only in the de1ta of Arkansas. No collections of it have been made in Texas for more than 150 years! Thus, my statements about habitat related only to where I have seen 1 t in Arkansas.

the habitat appears to have been original1y one of 1 ow rises in Mississippi delta pra1rie. Sometimes these are referred to as "rice prairie"; indeed much of this land has been converted to rice culture. The original forest was mostly mixed bottomland hardwoods, the wettest typically cypress-tupelo-swamp privet, the less flooded populated by stands of Nutta11 Oak, Willow Oak, Overcup Oak, Sugarberry, Swamp Red Maple, Swamp Ash, Water Hickory, etc., with some higher rises producing mixed upland hardwoods. Much of the higher terrace land was once savanna prairie, kept from being dominated by trees primarily by tire. The dominant vegetation was Big and Little Bluestem, Panicum virgatum, sorghastrum nutans, Tripsacum, Manisuris, etc., a great variety of carices, Juncus, Sisyrinchium, Tradescantia, Khexia, polytaenia, Eryngium,Lysimachia, various PhIox, Physostegia angustifolia,Penstemon digitalis, $\underline{\text { P. }}$ tubaef1orus, Amsonia illustris, and many showy compositae in Liatris, Silphium, Helianthus, Echinacea, etc.

What remains of the Uenothera appears to be confined to small areas of original prairie in railroad and highway rights of way. Here the plants appear in very small patches, are rooted in dark prairie earths of what must have been parts of 1 ow rises, thus rarely if ever flooded. Such sites, if left undisturbed and protected Irom tire, would probably be closed by invading woody plants, lirst snrubs such as Styrax, Cornus, Salix, later by mixed hardwoods, particularly oaks, ash, hickory,elm. Kisks to this Evening Primrose are obvious; an increasing acerage is now, because of the richness of the soil, devoted to row crops of corn, cotton, soybeans, as well as rice. Aggravating the problem is the tendency for large areas of railroad right of way, a last retuge, to be given over to cultivation, thus these bits of natural prairie land vanisning forever. 


\section{Reterences:}

Gleason, H.A. 1963. The new Britton \& Brown illustrated flora of the northeastern United States and adjacent Canada, New York.

Munz, P.A. 1965. Onagraceae. N. Am. F1. ser.2, 5: 1-278.

Penne11, F.W. 1919. A brief conspectus of the species of Kneiffia with the characterization of a new allied genus, Bul1. Torr. Bot. C1ub 46: 363-373.

straley, G.B. 1977. Systematics of Oenothera sect. Kneiffia (Onagraceae). Ann. Mo. Bot. Gard. 64: 381-424. 
SPECIES: Oenothera pilose11a RaI. ssp. sessilis (Penne11) Straley

\begin{tabular}{|c|c|c|c|c|c|c|c|c|}
\hline $\begin{array}{l}\text { Expocted } \\
\text { Effect on } \\
\text { Habitat } \\
\end{array}$ & $\begin{array}{c}\text { Preacriba } \\
\text { Burn } \\
\end{array}$ & $\begin{array}{l}\text { Doza or } \\
\text { Root } \\
\text { Rake }\end{array}$ & Bed & Chop & $\begin{array}{l}\text { Th1n } \\
\text { Over- } \\
\text { gtory }\end{array}$ & $\begin{array}{l}\text { Cut } \\
\text { Over- } \\
\text { Story }\end{array}$ & $\begin{array}{c}\text { Over Plant } \\
\text { w1th } \\
\text { trees }\end{array}$ & Graze \\
\hline Destroy & & & & & & & $X$ & \\
\hline Damage & & $N A$ & $N A$ & NA & & & & $X$ \\
\hline $\begin{array}{l}\text { No Lasting } \\
\text { Effect }\end{array}$ & & & & & & & & \\
\hline $\begin{array}{l}\text { Boneflclal } \\
\text { If Done } \\
\text { properly }\end{array}$ & & & & & $X$ & > & & \\
\hline
\end{tabular}

other Comments:

* Est1mated effect 18 an estimate of the author based on his book knowledge of the habltat and on knowledge galned from personal field ubservations. Estlmates are "rough" in many instances. Results of practices may vary $1 \mathrm{n}$ degree of application, intensity, nearness to plant communttles, etc. A column left "blank" 1ndicates a lack of sufficlent information from which to predict expected results. As observations are made 1 in the fleld by users of the data, predictions should be refined by area and by intensity of forestry practices. 
Known Distribution of:

Oenothera pilose11a Raf. ssp. Sessilis (Pennell)Straley

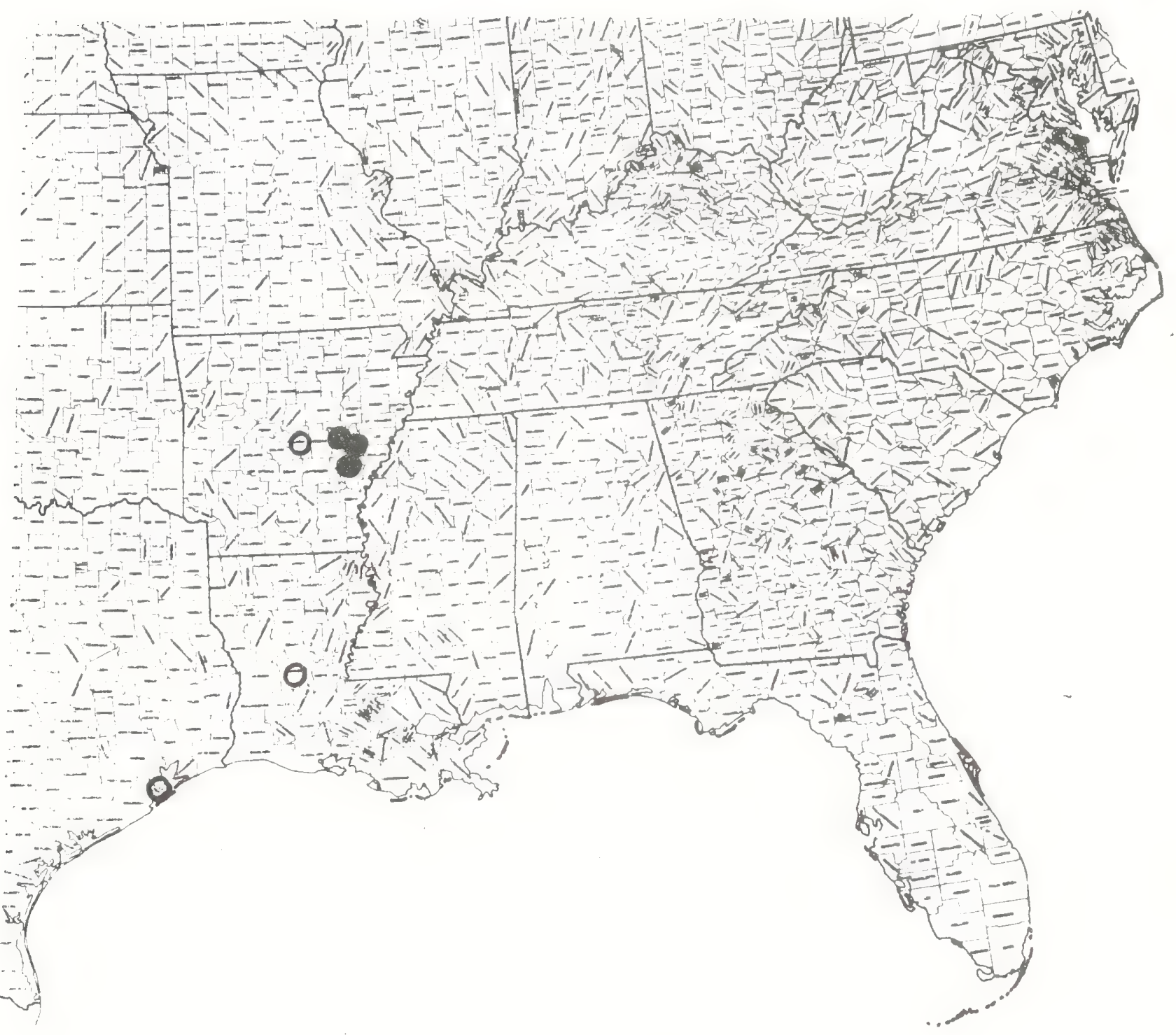


-

-

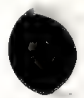




\section{ORCHIDACEAE}

\section{Genus: Platanthera (Habenaria, in part)}

Several species of Platanthera have been placed on various Federal and state lists of threatened and endangered species. In that the floral structure in orchids is so involved, and to avoid lengthy and repetitive detail for each writeup, I am giving a brief general description of vegetative and floral character for platanthera.

All Platanthera are perennial, have a fascicle of fleshy, sometimes tuberous roots, and an erect, fleshy, leafy stem, the lowest leaves mostly sheath, those above toward mid-stem larger, with well-developed sheaths and the largest blades, mostly of a narrow outline, while those in the upper part of the stem are usually, often abruptly, much smaller, becoming sheathless, and perhaps best described as peduncular bracts.

The inflorescence is often referred to as racemose, but is actually a bracteate spike of (usually) many flowers, these disposed in an open or tight system, and variously oriented.

The flower in basic construction is a central type for orchids, with a lot of adnation and asymetry. The ovary is, of course, inferior, tricarpellate, enveloped by and adnate to the floral tube which has a narrowed base, is expanded over the narrowish. ovary, then slenderly tubular, quite elongated, and flaring abruptly into the very irregular perianth limb of 3 sepals and 3 petals. The sepals tend to be more uniform, with the upper (dorsal) sepal tending to be more concave and broader, spreading upward and arching forward, and the other 2 flatter, usually narrower, spreading out and downward at an angle of about $45^{\circ}$. The petals are 3,2 of which are spread upward at an angle of about $45^{\circ}$, with their inner edges usually under the overarching dorsal sepal; the 3rd petal is largest, is referred to as the labellum (Iip), and is directed outward and downward. The labellum may be variously shaped, entire or 3 -lobed or fringed or in places callused; in the taxonomy of Platanthera, the lip character is probably the most important criterion. At the base of the lip is a small pore, this the opening to a slender-tubular, downward or backwarddirected, spur, the dilated base of which produces nectar (reached only by long-tounged insects!) The perianth and male and female parts of this genus, as in other orchids, is coalesced into what is called a "column", which in Platanthera is short, rather broad, capped by a single broad, bilocular anther, the anther sacs each containing a pollinium (a clavate mass of agglutinated pollen 
grains) but separated by stigma and connective tissue. On the column face,between the bases of the anther locules, is a stigmatic zone ( 2 coalesced), which is located just above the opening into the spur. As a long-tounged insect reaches the flower, its face comes into contact with that of the orchid, meeting the narrowed sticky (viscidial) exposed ends of the pollinia and at the same time contacting the stigma. When the insect withdraws, it of ten pulls away the sticky-ended pollinia, thus insuring pollination of the next flower visited.

The fruit in orchids is always capsular, the seeds minute, with no endosperm; germination must take place soon after the capsule ripens. 


\title{
ORCHIDACEAE
}

\author{
Platantianthera flava (L.) Lind. \\ Habenaria flava (L.) R.Br.
}

Status: Threatened?

Technical Description:

Stems: slender, stiffly erect, 1.5-4.0 dm ta11, usually solitary, terete below and multiribbed, usually entirely concealed there by leaf sheaths and to $4 \mathrm{~mm}$ thick, pale green, in the inflorescence with low, sharp, pappillose ribs, the longer internodes at mid-stem or lower, to $1.5 \mathrm{dm}$ long.

Leaves: in a loose spiral, ascending to erect, the larger foliage leaves 2-4, the lowest usually largest, its tubular sheath somewhat loose, 12-15 cm long, its blade narrowly eliiptic or lanceolate, 1-2 dm long, narrowly acute, the margins entire, papillose the base broadly cuneate, folded,clasping, the upper surface a dull deep green, the lower surface markedly paler; leaf blades abruptly smaller, sheathless, sessile upward on stem, margins with the short, lancetriangular-1inear inflorescence bracts. Inflorescence: Spike narrow, $6-15 \mathrm{~cm}$ 1ong, about $1.5 \mathrm{~cm}$ wide, the flowers ascending in a loose spiral, rather distant in the lower spike, closer in the upper spike at anthesis, each subtended by a green, lanceolate bract (southeastern plants of this species have lower floral bracts no longer than the flower subtended!) most $1 \mathrm{y}$ $1 \mathrm{~cm}$ or less in length。

Flowers: Perianth lobes a pale yellow-green, the floral tube including the inferior ovary short-stipitate,ca. 7-8 mm 1ong, slenderly ellipsoidal-fusiform, the narerowed upper part of the tube pale yellowgreen, arching outward, the lower part longitudinally low ribbed, the floral face directed somewhat downward; dorsal sepal ovate, apically narrowly rounded, concave, cupped forward, ca. $4 \mathrm{~mm}$ long, the

lateral sepal lobes elliptic-oblong, narrower than the dorsal, ca. 3.5 mm long; lateral petals ovate, somewhat asymmetrical, narrowly rounded apically, projecting upward and forward, their inner edges under the overarching dorsal sepal; 1ip directed downward and backward, broadly oblong, ca. $4.5 \mathrm{~mm}$ long, trilobate, the central lobe much the longest and oblong, its apex broadly rounded or truncate, entire, the inner lip surface bearing mediallv at its base a thickened wide ridgelike process (tubercle); spur clavate-1ineal, ca. 1C mm long, curved backward and downward along the perianth tube; column short, $1.5 \mathrm{~mm}$ high, its truncate apex oblique and with lateral tubercles.

Fruit: Capsule nearly erect, ellipsoidal, to $8 \mathrm{~mm}$ long, finely ribbed.

Distribution and Flowering Season:

Sandy silty alluvium of swamp forest, Coastal plain, Piedmont, southern Appalachians including Interior Low Plateau, Maryland south to northern peninsular Florida, thence west to eastern Texas, inland to southeastern Missouri, southern I11inois, Western Kentucky, middle and western Tennessee; in the Southeast flowering from late June into early August. 
Special Identifying Features:

This inconspicuous Rein-orchid is distinguished from the other southeastern greenish-flowered species by a combination of ( .. $_{\text {) }}$ fringelsss labellum (2.) anther cells divergent on column head to either side of compound stigma and (3.) a strong, somewhat alate tubercle at 1ip base. The description and range given above pertain only to the southern variety "flava", not to the 1ongerbracted northern var. herbiola (R.Br.) Luer.

Habitat and Management Implication:

P. flava, as mentioned above, is a species of swamp woodland, typically roots in moist to mucky silty sands, in the shade of Bald Cypress and hardwoods such as Salix, Carya aquatica, Populus, various willow oaks, Overcup Oak, Basket oak, Nutta11 or Pin Oak, Shumard Oak, Swamp Maple, Nyssa aquatica, N. biflora, Green Ash, Pumpkin Ash, Carolina Ash, Sycamore, Hackber $\bar{r} y$, E1m (exact species composition differs from one part of the range to another). Common understory shrubs are Cephalanthus, Sambucus, Itea, Lindera, with Myrica, Ilicium, Leucothoe, etc. present in more southern latitudes. Some common herbaceous associates are various Eupanicum, Dichanthelium Panicum, Glyceria, Leersia, Echinodorus, several carices, including

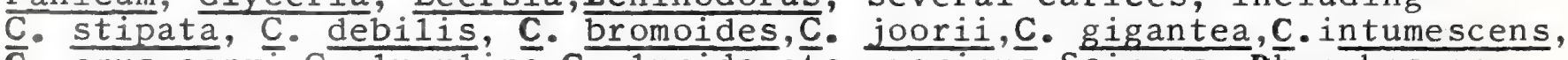
C. crus-corvi, C. Iupulina, . 1urida, etc., various Scirpus, Rhynchospora, many Juncus, Commelina virginica and others, Hypoxis (particulariy H. leptocarpa), Sagittaria, Echinodorus, Saururus, Rumex, Polygonum, penthorum, Luwwigia, Proserpinaca, Cicuta, Sium, Hydrocotyle, Sabatia calycina, Lindera, Chelone, Micranthemum, swamp woodland Lobelia such as L. Cardinalis and swamp woodland composites. Swamp ferns such as Osmunda, Woodwardia, Onoclea, Athyrium, may be abundant.

From the abovementioned associates is is evident that this orchid grows in places that are very often flooded, sometimes for long periods. Interestingly, it is pollinated by an Aedes mosquito (Luer, 1975), and many herbarium collections stilis show a fine dust of alluvium placed on them by floodwater!

The greatest danger faced by this particular orchid comes from the wholesale clearcutting of large tracts of bottomland throughout its range. Such cutting results in a raising of water table, thus more than normal flooding of the bottoms. It also results in a conversion from a relatively clean alluvial forest floor to a sunny jungle of invading woody weeds. Another hazard to the orchid comes from conversion of such forest by drainage and clearing either to lowland improved pasture or to row crops, particularly soy beans.

\section{References:}

Corre11,D.S. 1950. Native orchids of North America north of Mexico.

Luer,C.A. 1975. The native orchids of the United States and Mexico. The New York Botanical Garden. 


\begin{tabular}{|c|c|c|c|c|c|c|c|c|}
\hline $\begin{array}{l}\text { Expected } \\
\text { Effect on } \\
\text { Hab1tat }\end{array}$ & $\begin{array}{c}\text { Preacriba } \\
\text { Burn } \\
\end{array}$ & $\begin{array}{l}\text { Doze or } \\
\text { Root } \\
\text { Rake } \\
\end{array}$ & Bed & Chop & $\begin{array}{l}\text { Th1n } \\
\text { over- } \\
\text { Btory } \\
\end{array}$ & $\begin{array}{l}\text { Cut } \\
\text { oyer } \\
\text { story } \\
\end{array}$ & $\begin{array}{c}\text { Over Plant } \\
\text { wth } \\
\text { trees } \\
\end{array}$ & Graze \\
\hline Destroy & $\mathrm{NA}$ & $\mathrm{X}$ & $\mathrm{X}$ & $\mathrm{X}$ & & $\mathrm{X}$ & $\mathrm{X}$ & $\mathrm{X}$ \\
\hline Damage & & & & & & & & \\
\hline $\begin{array}{l}\text { No Lasting } \\
\text { Effect }\end{array}$ & & & & & $\mathrm{X}$ & & & \\
\hline $\begin{array}{l}\text { Beneficlal } \\
\text { 1f Done } \\
\text { reoperly }\end{array}$ & & & & & & & & \\
\hline
\end{tabular}

Ocher Comments: Clearcutting and drainage destroy this habitat.

*Est1mated effect 18 an e日timate of the author based on his book knowledge of the habltat and on knowledge galned from personal field observations. Estimates are "rough" in many instances. Results of practices may vary in degree of application, intensity, nearuess to plant communities, etc. A column left "blank" Indicates d lack of sufficient information from which to predict expected results. As observations are made $1 \mathrm{n}$ the fleld by users of the data, predictions should be refined by area and by intensity of forestry practices. 
Approximate Range of:

Platanthera flava (L.) Lind1. var. flava

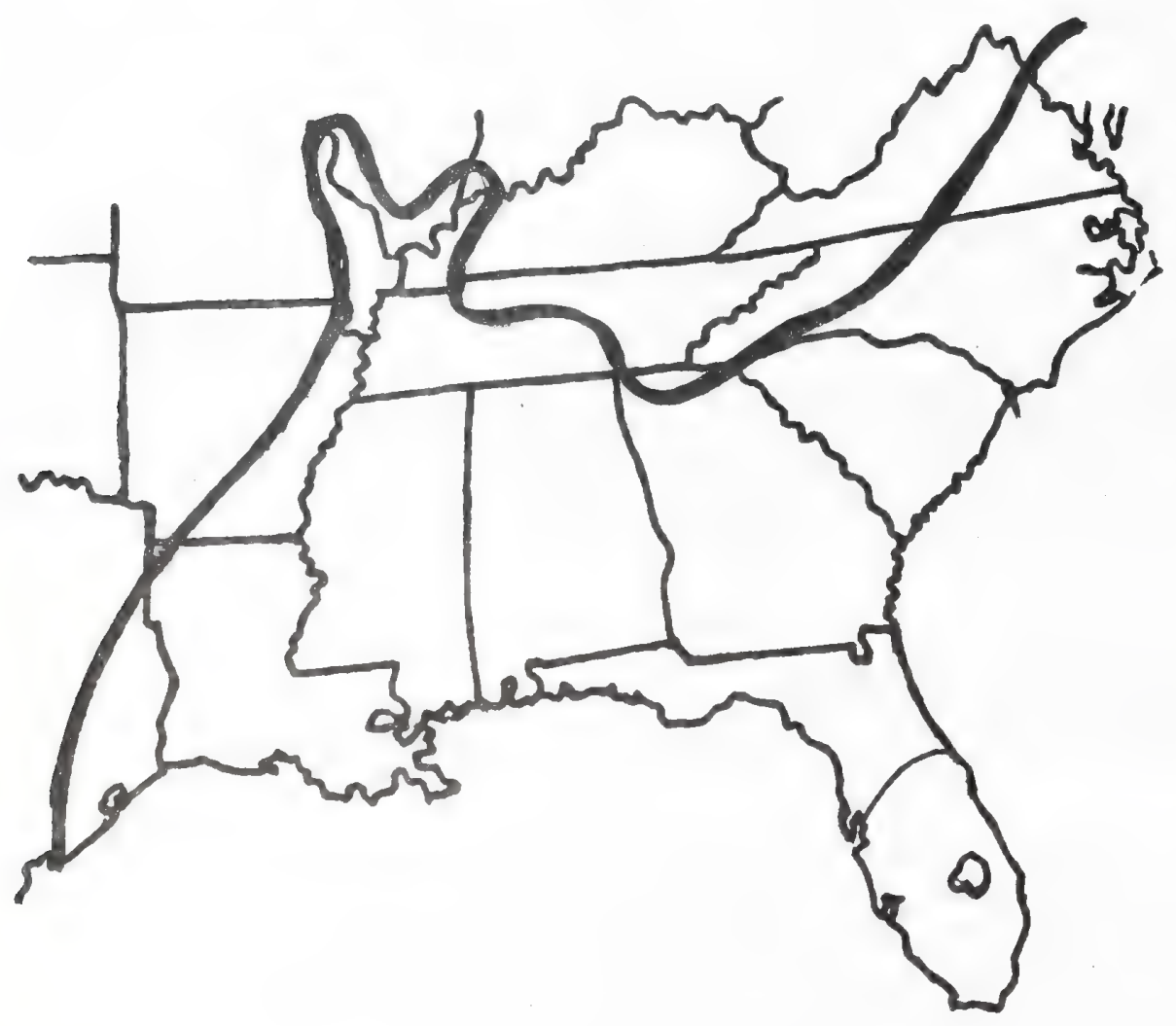




\section{Platanthera integra (Nutt.) Gray ex Beck Habenaria integra (Nutt.) Spreng.}

Status: Threatened

Technical Description:

Smooth, leafy-stemmed orchid 4-8 dm tal1.

Stems: slender, stiffly erect, terete, pale green, finely ribbed, at base in sheath ca. $4 \mathrm{~mm}$ thick, the nodes several, the internodes in 1 ower $1 / 2$ longest. Leaves: in a loose spiral, ascending or erect, the largest ones 1 or 2 , the sheaths somewhat loose, overlapping to $2 \mathrm{dm} 1$ ong, the blades somewhat folded, narrowly elliptical or lance-linear, $5-20 \mathrm{~cm}$ long, narrowed gradually to the bluntly acute apex, the margins entire, the base narrowly cuneate, clasping; blades and sheathes gradually or abruptly reduced up the stem, the blades becoming lance-1inear, sessile, clasping, and merging with inflorescence bracts.

Inflorescence: Spike cylindrical or narrowly conical, $2-10 \mathrm{~cm} 1 \mathrm{ong}$, the flowers very many $(-60)$ in a series of tight spirals, each bloom subtended by a narrowly lanceolate-subulate green bract, the lower bracts $1.0-1.5 \mathrm{~cm}$ long, gradual1y reduced up the spike. Flowers: perianth lobes a deep yellow orange, the floral tube including the inferior ovary, stipitate, lance-1inear, ca. 8-9 mm 1 ong, the expanded base green, the ribs papillose, narrow, the narrowly tubular apex yellowish; dorsal sepal broadly elliptic or ovate, concave, rounded apically, ca. $4 \mathrm{~mm}$ long, arching upward and forward, the lateral sepals nearly round or very broadly ovate, blunt-tipped, oblique, ca. $5 \mathrm{~mm}$ long; lateral petals elliptic,acute, ca. $4 \mathrm{~mm}$ long, their inner edges under the hooded dorsal sepal, the lip oblongelliptic, very short-stalked, rounded, irregularly crenulate, projecting forward and downward, unlobed, the spur lineal-tubular, projecting backward and slightly downward, more or less parallel with perianth tube, 5-6 mm long; column short (ca. $1 \mathrm{~mm}$ ), truncate oblique with lateral calluses opposite anther cells. Fruit: Capsule spreading, narrowly ellipsoidal, the narrow ribs papiliate.

Distribution and Flowering Season:

Savanna flatwoods, bogs, sunny sphagnous seepage areas, various provinces but mostly in the Coastal Plain, New Jersey south to northern peninsular Florida, west in the Gulf Coastal J1ain to eastern Texas, inland throughout South Carolina, Georgia into southwestern North Carolina, through Alabama into middle Tennessee; flowering from late July into September.

Special Identifying Features:

P. integra looks exactly like P. cristata from a distance, on 1 y $\vec{c} 10 \overline{s e}$ inspection revealing that its labellum is unfringed rather than fimbriate. 


\section{Habitat and Management Implication:}

This is a species of sunny, acidic, usually sphagnous seeps. The substrate is at least moist, highly organic, usually a black sandy peat. In the Coastal Plain it is usually in bogs or low places in pineland, is part of a grass-sedge system high in bog Andropogon, Aristida, Panicum, Calamagrostis, Rhynchospora, Dichromena (D. latifolia), bog carices, etc. Some showy associated herbs include other Platanthera, Pogonia, Cleistes, Xyris, Eriocaulon, Aletris, Lilium catesbaei, Tofieldia, Zygadenus, Sarracenia,Drosera, Rhexia, Sabatia and many composites in Coreopsis, Bigelowia, Liatris, Eupatorium, Aster, Helianthus, etc. In inland provinces it is usually very local, mostly confined to small seeps in clearings, or savanna swales in oak-pine woodland.

Throughout its range it is fire dependent, whatever the overstory forest type, and wherever fire is kept out it is overwhelmed by bog, pocosin, or shrub bay types or shaded out by invading pines and hardwoods.

In that it is a bog plant it is destroyed by establishment of drainage ditches. The greatest threat to it is in the heartland of its range, namely the lower terraces of the Gulf and Atlantic Coastal Plain, much of this once expanses of savanna but now converted to plantation pineland.

\section{References:}

Corre11,D.S. 1950. Native orchids of North America north of Mexico. Luer, C.A. 1975. The native orchids of the United States and Mexico. The New York Botanical Garden. 
SPECIES: $\quad$ Platanthera integra (Nutt.) Gray ex Beck

\begin{tabular}{|c|c|c|c|c|c|c|c|c|}
\hline $\begin{array}{l}\text { Expected* } \\
\text { Effect on } \\
\text { Hab1tat }\end{array}$ & $\begin{array}{c}\text { Praecrlbe } \\
\text { Burn } \\
\end{array}$ & $\begin{array}{l}\text { Doze or } \\
\text { RoOt } \\
\text { Rake } \\
\end{array}$ & $\mathrm{Bed}$ & Chop & $\begin{array}{l}\text { Th1n } \\
\text { Over } \\
\text { Btory } \\
\end{array}$ & $\begin{array}{l}\text { Cut } \\
\text { Ovar } \\
\text { Story } \\
\end{array}$ & $\begin{array}{c}\text { Over Plant } \\
\text { with } \\
\text { trees } \\
\end{array}$ & Graze \\
\hline Destroy. & & $\mathrm{X}$ & & $\mathrm{X}$ & & & 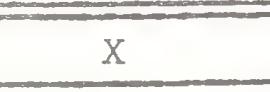 & $\mathrm{X}$ \\
\hline Damage & & & $\mathrm{X}$ & & & & & \\
\hline $\begin{array}{l}\text { No Lasting } \\
\text { Effact }\end{array}$ & & & & & & & & \\
\hline $\begin{array}{l}\text { Beneflcial } \\
\text { If Done } \\
\text { Properly }\end{array}$ & $X$ & & & & $\mathrm{X}$ & $\mathrm{X}$ & & \\
\hline
\end{tabular}

Other Comments: Drainage destroys the habitat.

*Eatlmated effect 18 an estimate of the author based on h1e book knowledge of the habltat and on knowledge galned from peranal field observations. Estlmates are "rough" 1n many 1nstances. Results of practices may vary in degree of application, intensity, nearuess to plant communities, etc. A column left "blank" indicates d lack of sufficient information from which to predict expected results. As observations are made in the field by users of the data, predictions should be reflued by area and by intensity of forestry practices. 
Approximate Southeastern Range of:

Platanthera integra (Nutt.) Gray ex Beck

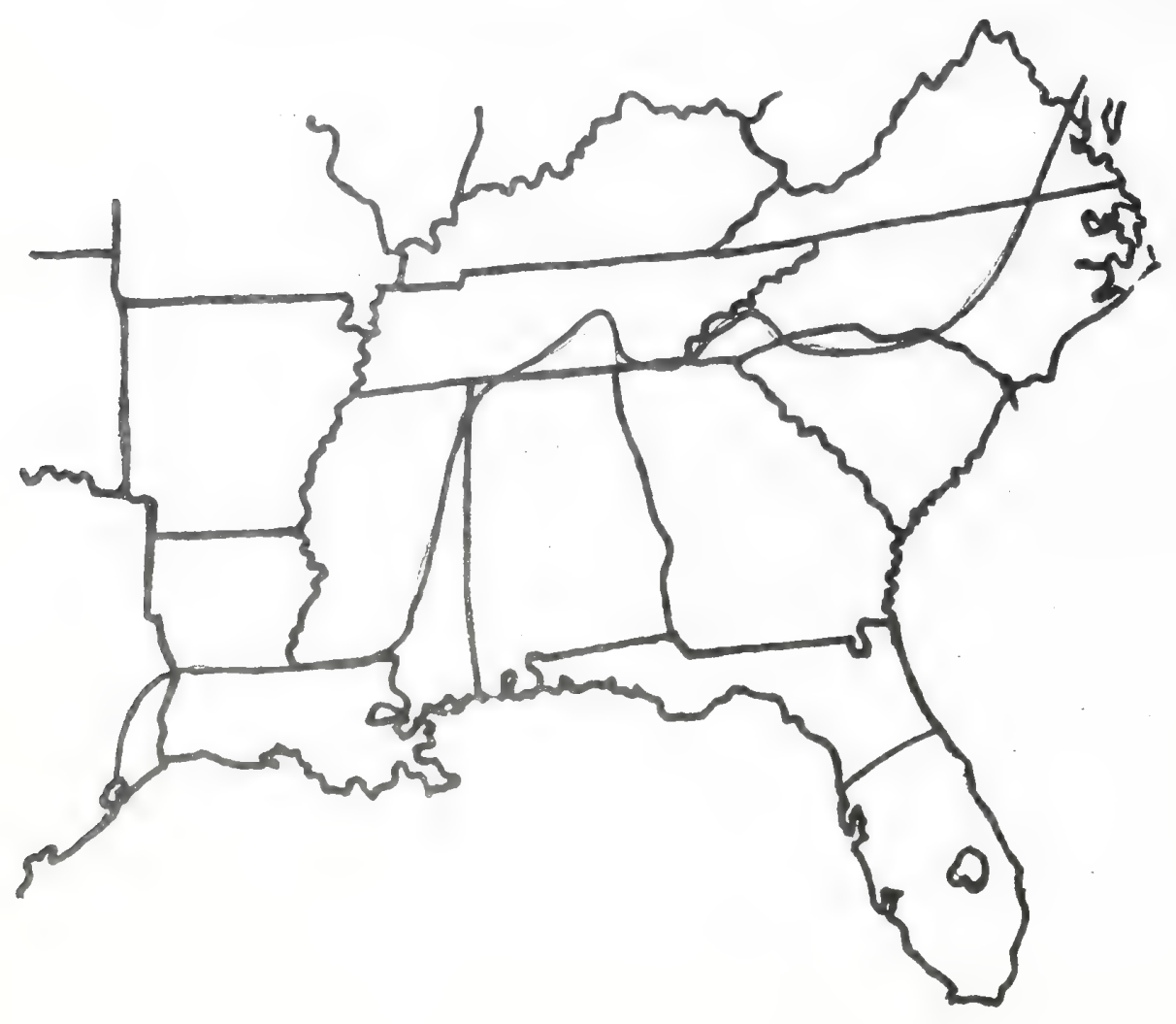


Paper 291

Text \& map by:

Robert Kral

ORCHIDACEAE

\begin{abstract}
Platanthera integrilabia (Correl1) Luer
Habenaria blephariglottis (Wil1d.) Hook. var. integrilabia Correll
\end{abstract}

Status: Endangered

Technical Description:

Stems: stiffly erect, usually 1 per rootstock(but plants tending to be gregarious), terete and ribbed, proximally to $5 \mathrm{~mm}$ thick, sheathed by leaf sheaths, pale green. Leaves: alternate in spiral, the larger foliage leaves 2-3, the sheaths 100 se-tubular, sometimes to $2 \mathrm{dm} 10 n g$, overlapping the blades narrowly elliptic or lanceolate, to $2 \mathrm{dm} 1$ ong, $3 \mathrm{~cm}$ wide, the apex narrowly but bluntly acute, the margin entire, papillose, the base strongly troughed, clasping; leaf blades rather abruptly narrowing and shortening upward into the inflorescence, clasping but sheathless.

Inflorescence: a terminal, rather 1oose, few-to-many-f1owered $(-20)$ bracteate, racemelike spike, round or short-oblong in outline, 4-10 cm long, ca. $5 \mathrm{~cm}$ broad, the axis angulately sharp-ribbed, the lower bracts longest, green, ascending, narrowly lance-triangular, to $2 \mathrm{~cm}$ long, gradually reduced upward in spike. Flowers: white, spreading-ascending, very fragrant in evening, the floral tube narrowly linear-fusiform, at anthesis ca. $3 \mathrm{~cm} 1 \mathrm{ong}$, the body and narrowed base strongly ribbed, minutely scabro-papillose, the narrowed tubular apex greenish white or white, slightly excurved; calyx lobes 3 , the dorsal broadly obovate, shallowly cupped, ca. $8 \mathrm{~mm}$ long, the laterals broadly ovate, blunt-tipped, more strongly rounded on the lower side, $\mathrm{ca} .8-9 \mathrm{~mm}$ long; upper 2 petals narrowly oblong or oblong-elliptic, blunt-tipped, ca. $7 \mathrm{~mm}$ long, the labellum unlobed, lance-spatulate, the lower part a flat claw, the upper $2 / 3$ erose toward the narrowed apex, the spur 1inear-clavate, 4-6 cm long, directed downward and curving forward; column ca. 4 mm 1 ong.

Fruit: capsule narrowly 1ance-e11iptic, strongly papillose-scabrid, ca. 1.5 mm 1ong.

Distribution and Flowering Season:

Boggy, seepy, usually wooded streambanks and ravines, Cumberland Plateau and southwestern Blue Ridge, southeastern Kentucky southward through middle and eastern Tennessee and southwestern Kentucky southward through middle and eastern Tennessee and southwestern North Carolina into northern Alabama and northwestern Georgia; flowering from late July into early September.

Special Identifying Features:

This orchid was first treated as part of Platanthera (Habenaria) blephariglottis, a more robust bog orchid which also has an unlobed lip. However, the labellum of $\underline{p}$. blephariglottis is fimbriately fringed, while that of $\underline{P}$. integrilabia is at most shallowly erose-toothed. 


\section{Habitat and Management Implications:}

This Reinmorchid is mostly a plant of shade, rarely small wet clearings, prefers boggy deciduous forested ravine woods, and a moist to wet sandy peaty silt or sandy peat, this often with a sphagnum mat. The overstory will often be dominated by Red Maple; Black Gum, Sweet Gum,Tuliptree,Willow Oak, Water Oak, Beech, with wild Azalea, Viburnum, Alder, Itea, "Svida" dogwood, Cephalanthus, Sambucus, Calycanthus, Xanthorrhiza, highbush Blueberry, frequent invaried proportions in the understory. The herbaceous layer is ferny, with Thelypteris noveboracensis, Athyrium, Pelystichum, Woodwardia, Onoclea, Osmunda. Also present may be grasses such as Cinna arundinacea, Calamagrostis cinnoides, Chasmanthium, Agrestis, Leersia, sedges such as Scirpus cyperinus, S. pelyohyllus, many carices, several Juncus, particularly J. canadensis, and many dicots such as Rhexia, Oxypolis, Phlox, Lfcopus, Chelone, Eupatorium. (particularly E. fistulosum, E. perfoliatum), Helenium, Helianthus.

While the soils this orchid grows in are permanently moist they are not often or for long periods flooded. Clearcutting of the hardwood overstory or of the oak-pine woodland of adjacent slopes results in more runoff from these uplands, this burying the bottoms of the small branches in silt. Clear cutting followed by mechanical site preparation exaggerates the problem stil1 more. Thus 1 ogging in the vicinity of known populations would have the least damaging effect if it were selective or group-selective. Habitat is also lost when these sma11 bottoms are pastured, the plants quick1y disappearing as a result of trampling and grazing.

References:

Corre11,D.S. 1950. Native orchids of North America north of Mexico.

Luer, C.A. 1975. The native orchids of the United States and Canada. The New York Botanical Garden. 
SPECIES: Platanthera integrilabia (Corre11) Luer

\begin{tabular}{|c|c|c|c|c|c|c|c|c|}
\hline $\begin{array}{l}\text { Expected } \\
\text { Effect on } \\
\text { Hab1tat }\end{array}$ & $\begin{array}{c}\text { Preocrlbo } \\
\text { Burn } \\
\end{array}$ & $\begin{array}{l}\text { Doze or } \\
\text { Root } \\
\text { Rake }\end{array}$ & Bed & Chop & $\begin{array}{l}\text { Thin } \\
\text { over } \\
\text { etory } \\
\end{array}$ & $\begin{array}{l}\text { Cut } \\
\text { over- } \\
\text { Story }\end{array}$ & $\begin{array}{c}\text { Ove Plant } \\
\text { w th } \\
\text { trees } \\
\end{array}$ & Graze \\
\hline Destroy & & $x$ & $\mathrm{x}$ & $\mathrm{x}$ & & & * & $\mathrm{x}$ \\
\hline Damage & & & & & & $\mathrm{x}$ & & \\
\hline $\begin{array}{l}\text { No Last1ng } \\
\text { Effect }\end{array}$ & $\mathrm{X}$ & & & & $\mathrm{x}$ & & & \\
\hline $\begin{array}{l}\text { Beneficial } \\
\text { 1f Done } \\
\text { properly }\end{array}$ & & & & & & & & \\
\hline
\end{tabular}

ocher Commente: * in that overplanting with trees would doubtless involve pine plantation the result would be negative. ** any drainage of the soil would have a negative result.

* Eat1mated effect 18 an estlmate of the author based on h1s book knowledge of the habltat and on knowledge galned from peranal field observations. Estimates are "rough" in many instances. Results of practices may vary in degree of application, intensity, nearness to plant communitles, etc. A column left "blank" 1ndicates a lack of sufficient information from which to predict expected results. As observations are made 1 n the fleld by users of the data, predictions should be refined by area and by intensity of forestry practices. 


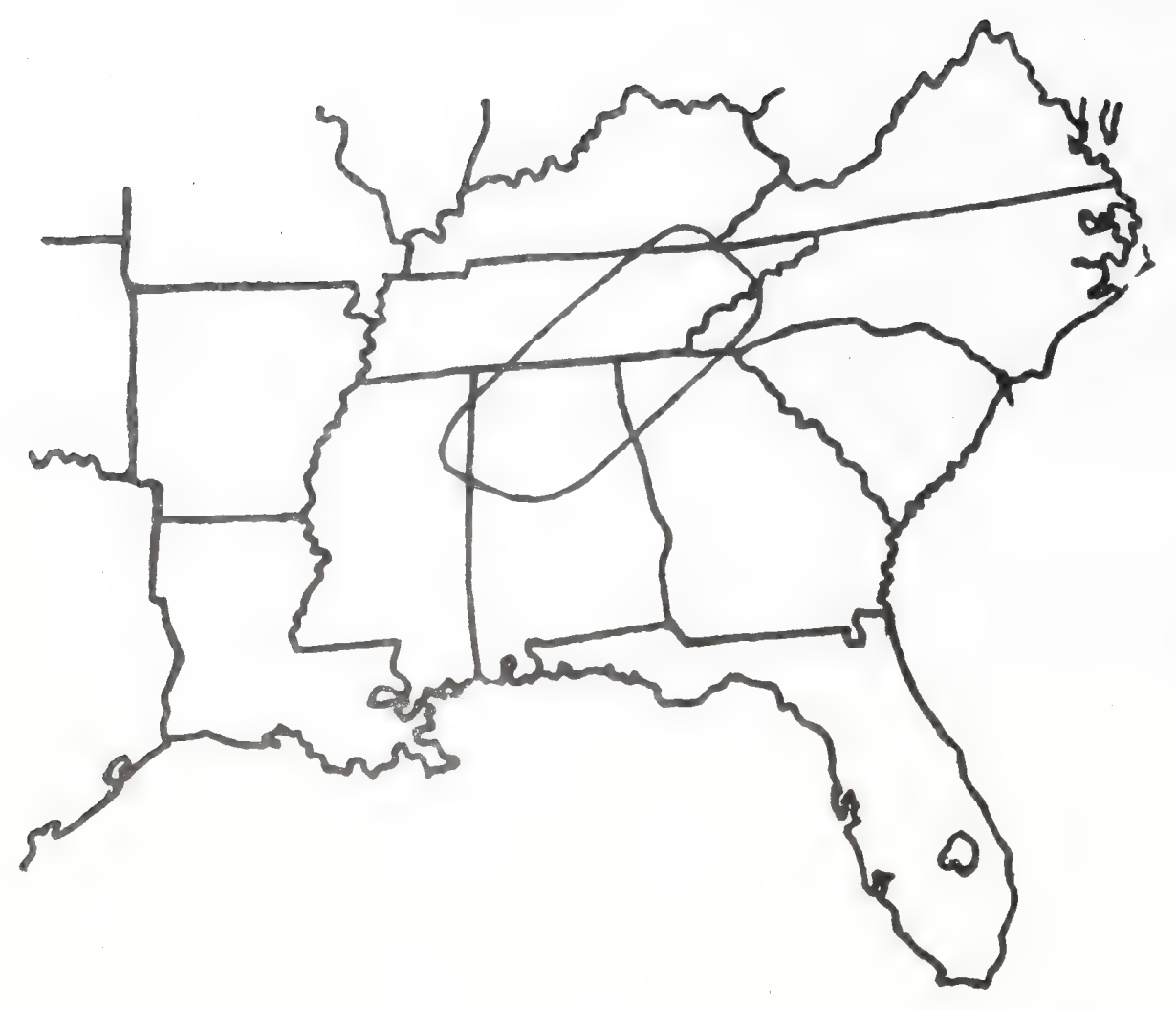




\author{
Platanthera peramoena (Gray) Gray \\ Habenaria peramoena A. Gray \\ Blephariglottis peramoena (Gray) Rydb. \\ Status: Threatened?
}

Technical Description:

Smooth, leafy-stemmed orchid to 1 meter tal1.

Stems: erect, terete but with longitudinal ribs, pale green, the several internodes stiffish, mostly concealed by overlapping sheathes, at base to $6 \mathrm{~mm}$ thick. Leaves: alternate-spira1, the lowest bladed ones usually largest, 2-5, with sheathes 1oosely tubular, fully $2 \mathrm{dm} 1$ ong, the blades

narrowly el1iptical or lanceolate, $10-20 \mathrm{~cm}$ long, spreading-ascending, acute, entire and pappilose-margined, the bases acute and clasping, the upper surface deep dull green, the lower surface paler;

blades gradually reduced in length and size on stem, becoming sessile, grading into peduncular and inflorescence bracts.

Inflorescence: Spike 100 sely to densely cylindrical, with up to 50 flowers, the lowest bracts to $3 \mathrm{~cm}$ long, lance-linear, grading gradual1y upward.

Flowers: a showy, bright rose-purple, the floral tube from ovary base to tip 2.5-3.0 cm long, narrowly wing-ribbed over the ovary, green with purple tints, the dorsal sepal broadly elliptic, 5-9 mm long, erect-based but arching forward apically, the lateral sepals asymmetrically broadly obovate, oblique at the truncated, erose apex, 6-9 mm long; upper petals broadly spatulate, 4-8 mm long, the suborbicular, entire apices shallowly cupped, arching upward and forward under and to either side of the dorsal sepal, the labellum 10-15 mm long, with a narrow base and 3 broadly obtriangular, strongly erose-and-truncated-tipped lobes, the laterals spreading at right angles and slightly shorter than the central, the central lobe apical1y with a narrow sinus; spur narrowly clavate-1inear, 2.5-3.0 $\mathrm{cm}$ long, projecting backward parallelling the ovary; column viewed from side broadly obtriangular, ca. $3 \mathrm{~mm}$ high.

Fruit: capsule ellipsoidal, ca. $1.5 \mathrm{~cm}$ long.

Distribution and F1owering Season:

Moist grass-sedge meadows, ditchbanks, stream and river bottoms, various provinces, western New York south to western North Carolina, southwest to southern Missouri, eastern Arkansas, northern Mississippi and Alabama; flowering mostly in July and August.

Special Identifying Features:

This species is distinguished readily from other purple-fringed Platanthera of the southeast by its erose (shallowly notchedmaryined) rather than fimbriate (fringed) labellum.

Habitat and Management Implication:

P. peramoena appears to be ample in regard to substratum and 1ight but requires constant soil moisture. Moist grass-sedge meadows 
and open streambanks appear to be an optimum habitat in the northern parts of its range, although in the south the plants are common1y found in silty-sandy wooded creek and river bottoms, usually in fairly heavy shade. My own experiences with it have been in swampy woodland where the overstory is Nyssa, Liquidambar, Salix, Acer rubrum, bottomland oaks, Populus, Green Ash, Sycamore, with understory shrubs or sma11 trees being Alnus, "Svida" dogwood, Itea, Ilex decidua, Sambus, etc. Ferns $\overline{\text { such }}$ as osmunda, Athyrium, Thelypteris noveboracensis, Woodwardia areolata, Onoclea, Adiantum are common, along with shade grasses in genera Cinna, Bromus, Festuca, Chasmanthium, Panicum, Elymus, Agrostis in association with numerous carices, Scirpus, and lowland species in Laportea, Urtica, Pilea, Impatieris, Cryptotaenia, Cicuta, Thaspium, Phlox,Blephilia, Cacalia, Eupatorium, Rudbeckia, Verbesina. The orchid is usually scattered in small groups, tends to avoid the muckiest areas which have dense gromths of Saururus, Polygonum, Ludwigia, Sagittaria, Commelina virginica, etc.

Danger to this orchid comes from draining of the wet meadows for conversion to improved pasture or to row crop agriculture as we11 as from clear-cutting of swamp woodland and creek bottoms which causes an abrupt upswing in rank woody and herbaceous growth. Many other creek bottom woodlands have been lost because of channelization of streams which tends to alter soil water conditions.

References:

Corre11, D.S. 1950. Native orchids of North America north of Mexico. Luer, C.A. 1975. The native orchids of the United States and Canada. New York Botanical Garden. 
SPECIES: Platanthera peramoena (Gray) Gray

\begin{tabular}{|c|c|c|c|c|c|c|c|c|}
\hline $\begin{array}{l}\text { Expected } \\
\text { Effect on } \\
\text { Heb1tat }\end{array}$ & $\begin{array}{c}\text { Preacribo } \\
\text { Burn } \\
\end{array}$ & $\begin{array}{l}\text { Doz or } \\
\text { Root } \\
\text { Rake } \\
\end{array}$ & Bed & Chop & $\begin{array}{l}\text { Thin } \\
\text { Over - } \\
\text { etory }\end{array}$ & $\begin{array}{l}\text { Cut } \\
\text { Over- } \\
\text { Story } \\
\end{array}$ & $\begin{array}{c}\text { Over Plont } \\
\text { with } \\
\text { trees } \\
\end{array}$ & Graze \\
\hline bestroy & NA & $x$ & $x$ & $x$ & & & & $x$ \\
\hline Damage & & & & & & $x$ & & \\
\hline $\begin{array}{l}\text { No Lasting } \\
\text { Effect }\end{array}$ & & & & & & & & \\
\hline $\begin{array}{l}\text { Beneficlal } \\
\text { Lf Dune } \\
\text { yroperly }\end{array}$ & & & & & $x$ & & & \\
\hline
\end{tabular}

Other Commente:

Area should not be drained!

*Est1mated effect. 18 an est1mate of the author based on h1s book knowledge of the habltat and on knowledge galned from personal field observations. Estimates are "rough" in many 1nstances. Results of practices may vary ln degree of application, intensity, nearuess to plant commulties, etc. A column left "blank" indicates a lack of sufficient information from which to predict expected results. As observations are made 1 n the fleld by users of the data, predictions should be reflued by area and by intensity of forestry practices. 
Approximate Southeastern Range of:

Platanthera peramoena (Gray) Gray

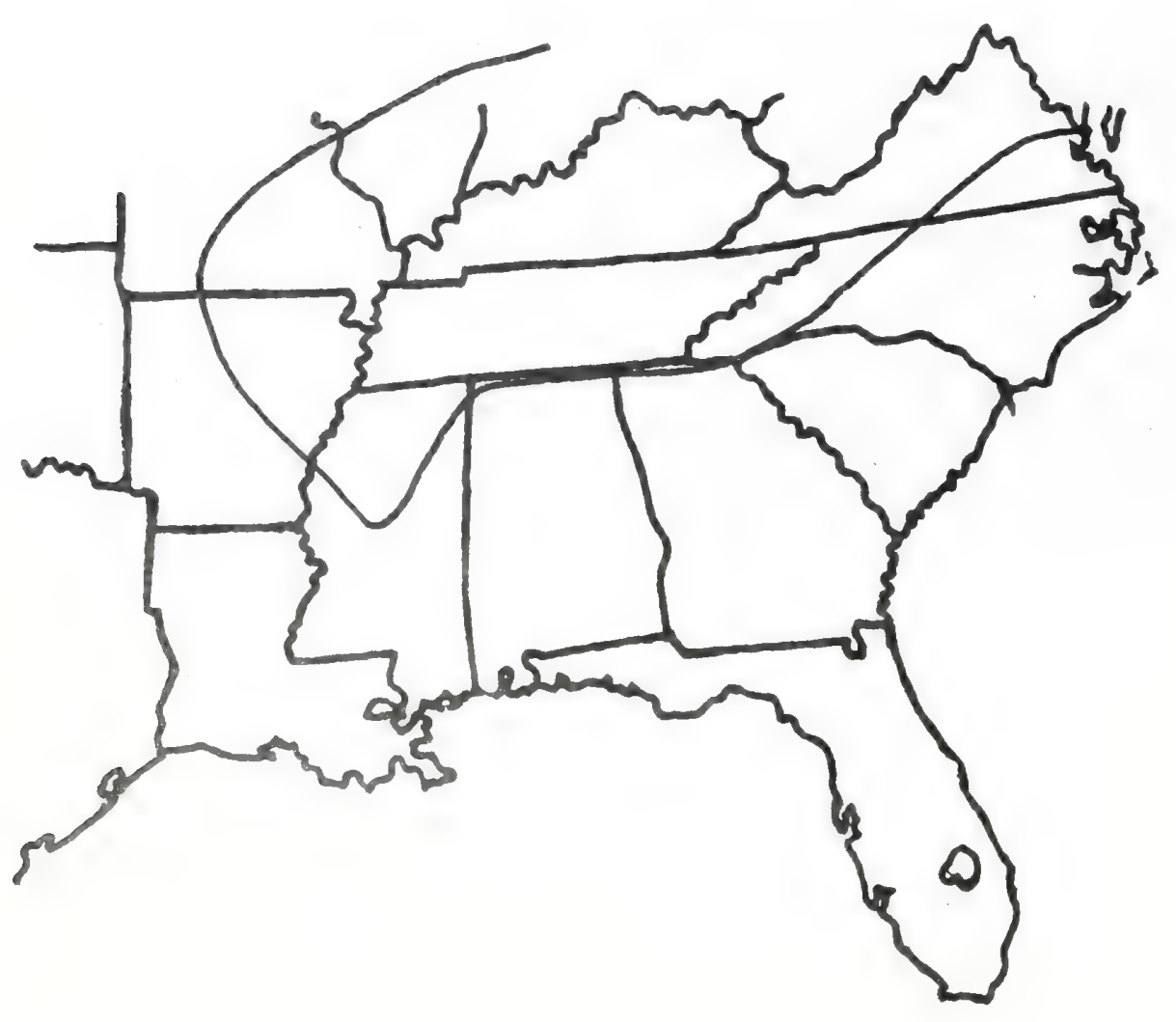


l'echnical Description:

Strong1y tufted perennial grass 3-5 ( -7$)$ dm tall from slender tibrous roots, perennating by short lateral offshoot buds trom base.

Culms: erect, slender but stiffish and wiry, the internodes numerous and rather short, smooth, terete to oval in cross-section, $0.2-0.5$ mm thick, pale green to straw-colored, the nodes thickened, smooth. Leaves: Sheathes strongly overlapping at culm base and persisting as fibres, more distant dista11y, smooth, strongly ribbed, slight1y inflated, somewhat keeled; 1igule an erect, tirm-edged, otherwise thin, keeled, subtruncate, erose to minutely ciliate, scale U.2-0.4 $\mathrm{mm}$ long; blades shortest toward culm base and tips, longest at midculm, spreading to reflexed, there lineal, ca. $1 \mathrm{~mm}$ wide, most $1 \mathrm{y}$ 2-5 (-9) cm long, tapering trom about midblade to a narrowly acute, scabrid apex, the margins slightly thickened, smooth or minutely scabrid, the midrib strongly raised beneath, the upper surface opposite the midrib strongly grooved, both surfaces at first pale green, later brownish or maroon-tinted, smooth.

Inflorescence: Racemes (2-) 3-5, narrowly lineal, mostly $3-5 \mathrm{~cm}$ long, rather distant, rarely overlapping, erect, solitary on slender peduncles 5-6 cm long, these usually well exserted beyond a slender, inrolled peduncular sheath (spathe); rachis of raceme jointed, the joints narrowly clavate, truncate to oblique at hollowed summit, ca. 4-5 mm long, the margins trom near base to apex strongly ciliatebearded with white hairs, those toward joint apex tully $3 \mathrm{~mm} 10 \mathrm{~g}$. spikelets: one pair to each rachis joint and taling with them, the sessile ones perfect or unisexual, the first glume $5-6 \mathrm{~mm}$ long, narrowly triangular-lanceolate, tirm, the back rounded, stramineous, apically green, the narrow apex with 2 narrow, short, erect teeth, the second glume about as long, keeledmfolded, the keel green, the tertile lemma and palea shorter than the glumes, scarious, the floret awned \pm rom base, the awn twisted, $\mathrm{ca} \cdot 1 \mathrm{~cm}$ long, bent slightly above the middle; stalk of stalked spikelet densely bearded ciliate as in rachis joints, ca. 4-5 mm long, the spikelet narrowly triangular, green, 1ncluding the apical long but weak awn ca. $3 \mathrm{~mm}$ long; stamens 3 , the anthers ca. $3 \mathrm{~mm}$ long.

Distribution and Flowering Season:

Deep white or yellow sands of sandhil1s, central peninsular Florida; tlowering from september to trost.

Special Identifying Features:

A. niveus 1s part of a complex of andropogonids that have the raceme rachis joints hollow at apex, there truncated, and which have primary peduncles terminating in but a single raceme of spikelets (genus Schizachyrium, according to Gould et al). Within this group 1 t stands out from the rest by a combination of its slender, rather low, habit, 
1ts very slender, strongly white-villous-margined rachis joints and spikelet stalks (which give it a strong superticial resemblance to some Andropogon in sect. Arthrolophis!), its nearly completely smooth toliage and its densely caespitose habit. Also distinctive is the tendency tor the mature raceme to be straight, rather than sinuous as it is in closely related species.

Habitat and Management Implication:

A. niveus appears to be confined to dry sandy areas in sandhills $\bar{s} c r \overline{u b}$, where, along with various Aristida, Cenchrus, Panicum, Sorghastrum secundum, and other Andropogon (particularly A. tloridanus), Paronychia, STipulicida, Lechea, Petalostemon carolinianum, Heterotheca,

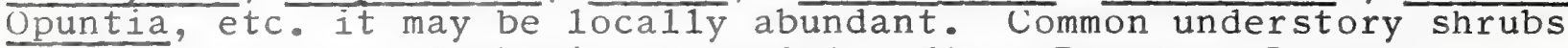
and 1ow trees are Garberia, Ceratiola, Ilex, Bumelia, Lyonia, Asimina, Osmanthus, Ximinea, Myrica, shrubby evergreen Quercus, Persea, etc. Common overstory. as sociates are Pinus clausa, ‥ elliottii, or $\underline{\text { P. }}$ palustris, though of the pines the first is usūaly the most tréquent. With the pines on white sands such hardwoods as Quercus myrtifolia, Q. chapmanii, Q. geminata, Carya floridana dominate with a shift over toward Quercus incana, Q. margaretta, Q. laevis on the yellow sands where pinus palustris is more abundant. In natural conditions such shade intolerant grasses as this Andropogon give way to invading reproduction of shrubs and trees, but increase directly atter natural tires sweep through. Mechanical clearing of scrubland provides open sandy area tor its increase, it there are contiguous seed sources available.

Reterences:

Hitchcock,A.S. \& Agnes Chase. 1951. Manual of the grasses of the United States, ed. L (revised by Agnes Chase). U.S.D.A. Misc. rub1. 200 , U.S.Govt. Printing Uttice.

Swallen, J.S. 1941. Andropogon niveus, sp. nov. 1n Wash. Acad. Sci. Journ. 31: 354 . 
SPECIES: Andropogon nIveus Swallen

\begin{tabular}{|c|c|c|c|c|c|c|c|c|}
\hline $\begin{array}{l}\text { Expected } \\
\text { Effect on } \\
\text { Habitat }\end{array}$ & $\begin{array}{c}\text { Prascribo } \\
\text { Burn }\end{array}$ & $\begin{array}{l}\text { Doze or } \\
\text { Root } \\
\text { Rake }\end{array}$ & Bed & Chop & $\begin{array}{l}\text { Th1n } \\
\text { Over } \\
\text { Brory }\end{array}$ & $\begin{array}{l}\text { Cut } \\
\text { over- } \\
\text { Story } \\
\end{array}$ & $\begin{array}{c}\text { Over Plant } \\
\text { with } \\
\text { trees } \\
\end{array}$ & Graze \\
\hline Destroy & & & & & & & $X$ & \\
\hline Damage & & & $N A$ & $X$ & & & & \\
\hline $\begin{array}{l}\text { No Lasting } \\
\text { Effect }\end{array}$ & & & & & & & & \\
\hline $\begin{array}{l}\text { Banaficial } \\
\text { if Done } \\
\text { Properly }\end{array}$ & $\Lambda$ & & & & $\lambda$ & & & \\
\hline
\end{tabular}

\section{Other Comments:}

* Est1mated effect 1 a an eatrmate of the author baed on hio book knowledge of the habltat and on knowledge galned from peronal field ubservations. Estimates are "rough" in many 1nstances. Kesults of practices may vary in degree of application, Intensity, nearness to plant communties, etc. A column left "blank" 1ndicates a lack of sufficient information from which to predict expected results. As observatlons are made 1 n the fleld by users of the data, predictions should be reflued by area and by intensity of forestry practices. 
Estimated Range of:

Andropogon niveus Swa11en

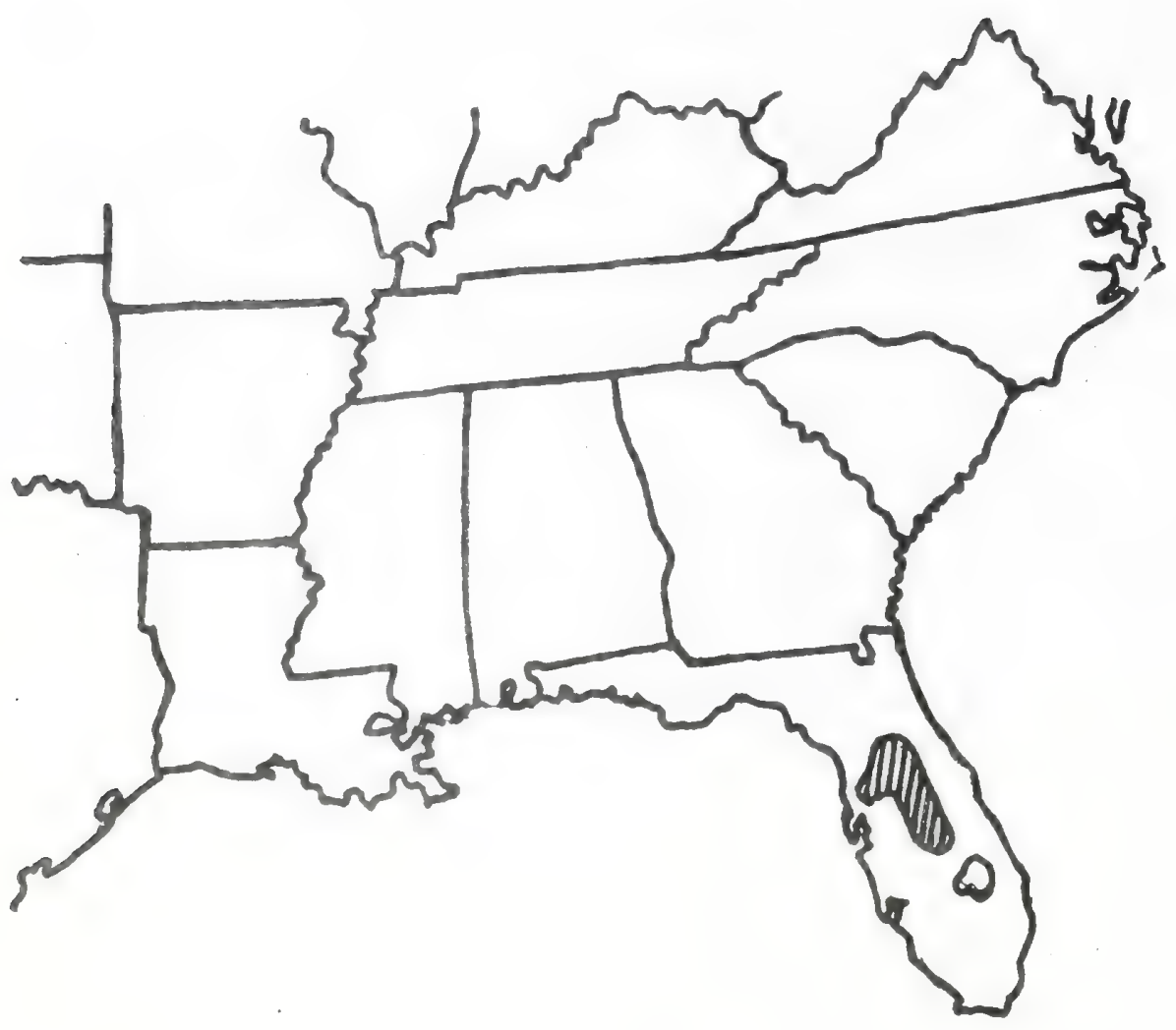


Paper 293

Text \& map by:

POACEAE

Robert Kral

\author{
Andropogon niveus Swallen \\ sch1zachyrium niveum (swa11en) Gould \\ status: Threatened
}

l'echnical Description:

strongly tufted perennial grass 3-5 (-7) dm tall from slender tibrous roots, perennating by short lateral offshoot buds trom base.

Cu1ms: erect, slender but stiffish and wiry, the internodes numerous and rather short, smooth, terete to oval in cross-section, $0.2-0.5$ mm thick, pale green to straw-colored, the nodes thickened, smooth. Leaves: Sheathes strongly overlapping at culm base and persisting as tibres, more distant distal1y, smooth, strongly ribbed, slightly intlated, somewhat keeled; 1igule an erect, tirm-edged, otherwise thin, keeled, subtruncate, erose to minutely ciliate, scale U.2-0.4 $\mathrm{mm}$ long; blades shortest toward culm base and tips, longest at midculm, spreading to reflexed, there lineal, ca. $1 \mathrm{~mm}$ wide, most $1 \mathrm{y}$ 2-5 (-9) cm long, tapering trom about midblade to a narrowly acute, scabrid apex, the margins slightly thickened, smooth or minutely scabrid, the midrib strongly raised beneath, the upper surface opposite the midrib strongly grooved, both surfaces at first pale green, later brownish or maroon-tinted, smooth.

Inflorescence: Racemes (2-) 3-5, narrowly lineal, most 1 y $3-5 \mathrm{~cm}$ long, rather distant, rarely overlapping, erect, solitary on slender peduncles $5-6 \mathrm{~cm}$ long, these usually well exserted beyond a slender, inrolled peduncular sheath (spathe); rachis of raceme jointed, the joints narrowly clavate, truncate to oblique at hollowed summit, ca. 4-5 mm long, the margins trom near base to apex strongly ciliatebearded with white hairs, those toward joint apex tully $3 \mathrm{~mm}$ long. spikelets: one pair to each rachis joint and talling with them, the sessile ones perfect or unisexual, the first glume 5-6 mm long, narrowly triangular-lanceolate, firm, the back rounded, stramineous, apıcally green, the narrow apex with 2 narrow, short, erect teeth, the second glume about as long, keeled-tolded, the keel green, the tertile lemma and palea shorter than the glumes, scarious, the floret awned trom base, the awn twisted, ca. $1 \mathrm{~cm}$ long, bent slightly above the middle; stalk of stalked spikelet densely bearded ciliate as in rachis joints, ca. 4-5 mm long, the spikelet narrowly triangular, green, 1 ncluding the apical long but weak awn ca. $3 \mathrm{~mm}$ 1ong; stamens 3 , the anthers ca. $3 \mathrm{~mm}$ long.

Distribution and F1owering Season:

Deep white or ye11ow sands of sandhi11s, central peninsular F1orida; tlowering from september to trost.

special Identifying Features:

A. niveus $1 \mathrm{~s}$ part of a complex of andropogonids that have the raceme rachis joints hollow at apex, there truncated, and which have primary peduncles terminating in but a single raceme of spikelets (genus Schizachyrium, according to Gould et a1). Within this group 1t stands out from the rest by a combination of its slender, rather low, habit, 
1ts very slender, strongly white-villous-margined rachis joints and spikelet stalks (which give it a strong superticial resemblance to some Andropogon in sect. Arthrolophis!), its nearly completely smooth toliage and its densely caespitose hadit. Also distinctive is the tendency tor the mature raceme to be straight, rather than sinuous as it is in closely related species.

Habitat and Management Imp1ication:

A. niveus appears to be contined to dry sandy areas in sandhi11s $\bar{s} c r \overline{u b}$, where, along with various Aristida, Cenchrus, Panicum, Sorghastrum secundum, and other Andropogon (particularly A. t1oridanus), Paronychia, STipulicida, Lechea, Petalostemon carolinianum, Heterotheca, opuntia, etc. it may be 1ocal1y abundant. Common understory shrubs and low trees are Garberia, Ceratiola, Ilex, Bumelia, Lyonia, Asimina, Usmanthus, Ximinea, Myrica, shrubby evergreen Quercus, Persea, etc. common overstory associates are Pinus clausa, ‥ elliottii, or $\underline{\text { P. }}$ palustris, though of the pines the first is usualiy the most tréquent. With the pines on white sands such hardwoods as Quercus myrtifolia, Q. chapmanii, Q. geminata, Carya floridana dominate with a shift over toward Quercus incana, Q. margaretta, $Q$. laevis on the yellow sands where pinus palustris is more abundant. In natural conditions such shade intolerant grasses as this Andropogon give way to invading reproduction of shrubs and trees, but increase direct1y atter natural tires sweep through. Mechanical clearing of scrubland provides open sandy area for its increase, it there are contiguous seed sources available.

Reterences:

Hitchcock,A.S. \& Agnes Chase. 1951. Manual of the grasses of the United States, ed. \& (revised by Agnes Chase). U.S.D.A. Misc. rubl. 200, U.S.Govt. Printing Uttice.

Swa11en, J.S. 1941. Andropogon niveus, sp. nov. in Wash. Acad. Sci. Journ. $31: 354$. 


\begin{tabular}{|c|c|c|c|c|c|c|c|c|}
\hline $\begin{array}{l}\text { Expectod } \\
\text { Effect on } \\
\text { Habitat }\end{array}$ & $\begin{array}{c}\text { Proscribo } \\
\text { Burn } \\
\end{array}$ & $\begin{array}{l}\text { Doze or } \\
\text { Root } \\
\text { Rake }\end{array}$ & Bed & Chop & $\begin{array}{l}\text { IhIn } \\
\text { over- } \\
\text { Btory }\end{array}$ & $\begin{array}{l}\text { Cut } \\
\text { over- } \\
\text { story }\end{array}$ & $\begin{array}{c}\text { Over Plant } \\
\text { w } 1 \mathrm{th} \\
\text { trees } \\
\end{array}$ & Graze \\
\hline Destroy & & & & & & & $X$ & \\
\hline Damage & & & $N A$ & $X$ & & & & \\
\hline $\begin{array}{l}\text { No Lasting } \\
\text { Effect }\end{array}$ & & & & & & & & \\
\hline $\begin{array}{l}\text { Banaficlal } \\
\text { lf Done } \\
\text { Proper } 1 y\end{array}$ & $n$ & & & & & & & \\
\hline
\end{tabular}

other Comments:

* Estrmated effect 1 a an estlmate of the author based on his book knowledge of the habltat and on knowledge galned from peronal field ubservations. Estimates are "rough" in many 1nstances. Results of practices tady vary in degree of application, intensity, llearness to plant communities, etc. A column left "blank" 1ndicates a lack of sufficient information from which to predict expected results. As observations are made $1 \mathrm{n}$ the fleld by users of the data, predictions should be refined by area and by intensity of forestry practices. 
Estimated Range of:

Andropogon niveus Swa11en

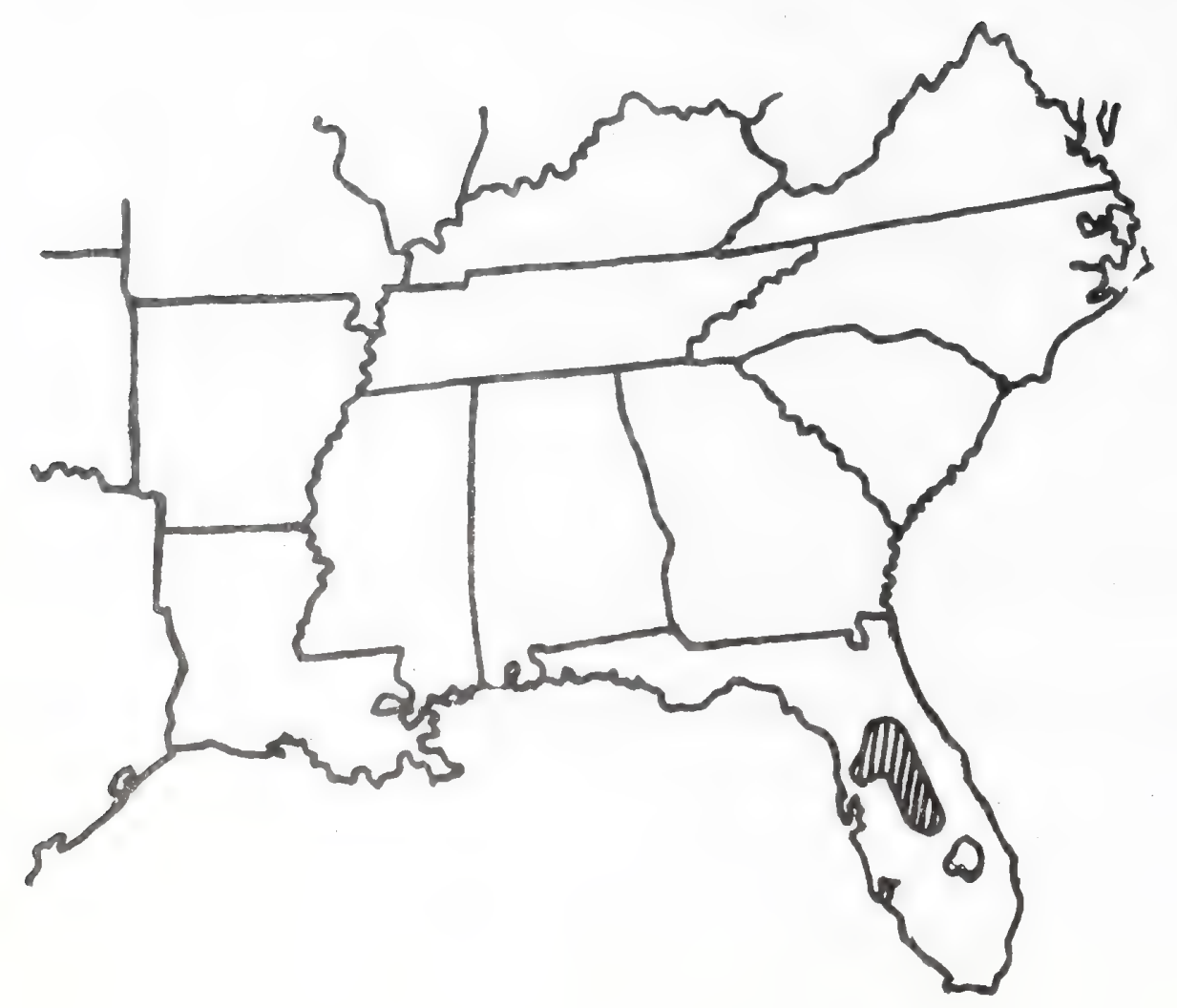




\section{POACEAE}

\section{Elymus svensonii Church}

Status: Proposed endangered

\section{Technical Description:}

Tufted, e-rhizomatous perennial glaucous grass from a diffuse-fibrous root.

Culms: Erect but arching nodding-tipped in flower and fruit, terete, pale yellow green, numerously leafy and therefore with lower nodes and internodes mostly covered by sheath, exposed nodes subtended by a slightly concave purplish or dark green band. Leaves: $6-8$, the leaf sheaths mostly overlapping, pale green, straw colored or pinkish, rather tight when young, the thin edges meeting or overlapping save at apex, there flanged to form at the collar a firm, lustrous-cartilaginous auricle, this produced outward to a pair of spreading, narrowly triangular, brownish or purplish lobes; ligule continuous, an erect, when young purplish, erose-edged scale $0.2-0.3 \mathrm{~mm}$ high; leaf blades spreading or erect, the lowest withered by anthesis, lineal, flat save for the very slender, long-tapering involuted tips, the longer blades 1.5-3.0 dm long, the margins slightly thickened, scabrid, the upper surfaee deep green, finely ribbed, scattered-pilose, the lower surfaee markedly paler, smooth, finely raised - ribbed.

Inflorescence: Spikelets numerous, sessile in pairs in a slender, somewhat interrupted, narrow, excurved spike $10-18 \mathrm{~cm}$ 1ong, $5-10 \mathrm{~mm}$ thick (exclusive of awns!), the spike rachis somewhat sinuous, the joints flattened, $0.7-0.8 \mathrm{~cm}$ long, the margins harsh, with the spikelet pairs alternate on opposite sides, thus in 2 opposite rows with lemma tips (exclusive of awns) barely or not at a11 overlapping on a side.

Spikelets: $4(-5)$-flowered, flattened somewhat in a plane perpendicular to the rachis (edges to it), erect, exclusive of awns $1.0-1.5 \mathrm{~cm} 10 \mathrm{ng}$, the glumes 2, subulate-setaceous, scabrid, $1-10$ (-18) mm 1 ong or (particularly on basal spikelets) absent, from a strong, purplemargined callus, erect, terete save toward base, smooth proximal1y, antrorsely scabrid apically, often purplish-tinted; fertile florets usually not more than 3, the terminal one sterile, much reduced at tip of a conspicuous rachilla joint, the fertile lemmas ca. $1 \mathrm{~cm}$ long, narrowly elliptic or elliptic-lanceolate, the broadly rounded backs smooth, pale yellow green, the nerves confined to the inrolled margins, with the midrib evident on $1 y$ apical1y where excurrent as a strong, ascending-excurved, antrorsely scabrid, often purplish, awn 2.0-2.5 cm 1ong; palea elliptic-1inear, thinner than the lemma and slightly shorter, its apex narrowed, truncate to slightly emarginate, its back slightly concave, sharply involute at the marginal green nerve; stamens 3, the anthers yellow, 1 ineal, ca. $5 \mathrm{~mm}$ long. Fruit: Grain oblong, brown, ca. $6 \mathrm{~mm}$ long.

Distribution and Flowering Season 
Dryish calcareous rocky river bluffs, so far known only from along the Cumberland River near Nashville and along the Caney Fork River in middle Tennessee; flowering in late May and June.

\section{Special Identifying Features}

This rare grass is distinguished as part of a small complex of eastern North American species which have setaceous glumes unequal in length or even vestigial. There are but two others besides E. Svensonii, namely E. hystrix L. (Hystrix patula Moench) and E. diversiglumis Scribn. \& Bal1. The former, which shares the same habitat, has stiffly erect spikes and spikelets spreading horizonta11y; its glumes often do not develop at a11 (in E. svensonii the spikes tend to nod or excurve strongly, the spikelets tend to be erect and usually at least some spikelets have we 11 developed glumes. The latter, which does not overlap in range, has erect spikelets as in E. Svensonii but its lemma backs are densely hirsute. Its foliage is not glaucous as it is in E. svensonii. Were it not for the unequal.glumes, E. svensonii most resembles $H_{\text {interruptus }}$ Buck1. (E. canadensis L. var. interruptus (Buck1.) Church̆), a taxon now considered to be endemic to western Texas.

Habitat and Management Implication

E. svensonii thus far has been found only on shallow soils over bluff limestones, usually in full sun but sometimes in light shade. In the two known localities is is abundant and reproducing freely. The soil is thin, sticky when wet, basic in reaction, quite dry in summer. The forest of these areas is indicative of the basic character of the soil, is mostly hardwoods with patches of Juniperus virginiana in various stages of succession to hardwoods. Common trees are Carva carolinae-septentriona1is, C. ovata, Quercus shumardii, Q. muhlenbergii, Q. alba, Ulmus serotina, U. americana, U. rubra, J. alata, Celtis laevigata, Morus rubra, Gleditsia, Robinia pseudo-acacia, Acer saccharum, Fraxinus americana, F. quadrangulata, Tilia americana, etc. The understory is heavy in Cercis, Rhus, Viburnum rufidulum, Rhamnus caroliniana, Bumelia 1ycioides with the lower shrub layer dominanted by Hypericum frondosum, Rhus aromafica, Symphoriocarpos orbiculatus. Herbaceous associates include Woodsia obtusa, Asplenium, Pellaea, Bromus purgans, Chasmanthium latifolium, various Panicum, Festaca obtusa, other E1ymus, particularly E hystrix, E. virginicus, Danthonia spicata, carious carices, Mirabilis, Arabis laevigata, A. canadensis, Ranunculus fascicularis, Aquilegia canadensis, Geum vernum, G. canadensis, Spigelia, Lithospermum, Campanula americana, Rudbeckia triloba, various Solidago, etc. In the Caney Fork locality are rarities that either are found to the west or north (Erysimum capitatum), to the south (Eriegonum harperi) or northeast (Draba ramosissima). This Wild-rye is most abundant on rocky slopes and ledges where it gets full sun, and in fact is thriving on one stretch of road cut.

Logging would pose a threat, making the thin soils more susceptible to erosion, but the very steepness of the terrain makes this activity unlikely. In that the Elymus is a species of light shade or woodland edges, careful removal of some trees might actually increase suitable habitat. Pasturing has undoubtediy caused some damege in the Caney Fork area, but the stock has been fenced away from the steepest slopes and bluffs where the Elymus is most abundant. 
It is encouraging that this grass will occupy freshly disturbed area such as road cuts.

References:

Church, George L. 1967. Taxonomic and genetic relationships of eastern North American species of with setaceous glumes. Rhodora 69 (778): 121 162 .

Hitchcock, A.S. \& Agnes Chase. 1950. Manual of the grasses of the United States, ed. 2, pp. 247-267. 
SPECIES: ELYMUS svensonii Church

\begin{tabular}{|c|c|c|c|c|c|c|c|c|}
\hline $\begin{array}{l}\text { Expected } \\
\text { Effect on } \\
\text { Habltat }\end{array}$ & $\begin{array}{c}\text { Prescribe } \\
\text { Burn } \\
\end{array}$ & $\begin{array}{l}\text { Doze or } \\
\text { Root } \\
\text { Rake } \\
\end{array}$ & Bed & Chop & $\begin{array}{l}\text { Thin } \\
\text { Over- } \\
\text { Btory }\end{array}$ & $\begin{array}{l}\text { Cut } \\
\text { Over- } \\
\text { Story }\end{array}$ & $\begin{array}{c}\text { Over Plent } \\
\text { with } \\
\text { trees } \\
\end{array}$ & Graze \\
\hline Descroy & NA & NA & $\mathrm{NA}$ & NA & & & $\mathrm{NA}$ & \\
\hline Damage & & & & & & $\mathrm{X}$ & & $\mathrm{X}$ \\
\hline $\begin{array}{l}\text { No Lasting } \\
\text { Effoct }\end{array}$ & & & & & $\mathrm{x}$ & & & \\
\hline $\begin{array}{l}\text { Benef1c1 al } \\
\text { If Done } \\
\text { properly }\end{array}$ & & & & & & & & \\
\hline
\end{tabular}

\section{other Commente:}

\section{*Estimated effect 18 an est1mate of the author based on h1 book} knowledge of the habltat and on knowledge gained from personal field observations. Estlmates are "rough" in many instances. Results of practices may vary ln degree of application, intensity, nearness to plant communities, etc. A column left "blank" indicates a lack of sufflclent information from which to predict expected results. As observations are made 1 th the fleld by users of the data, predictions should be refined by area and by intensity of forestry practices. 
Distribution of:

Elymus svensonii Church

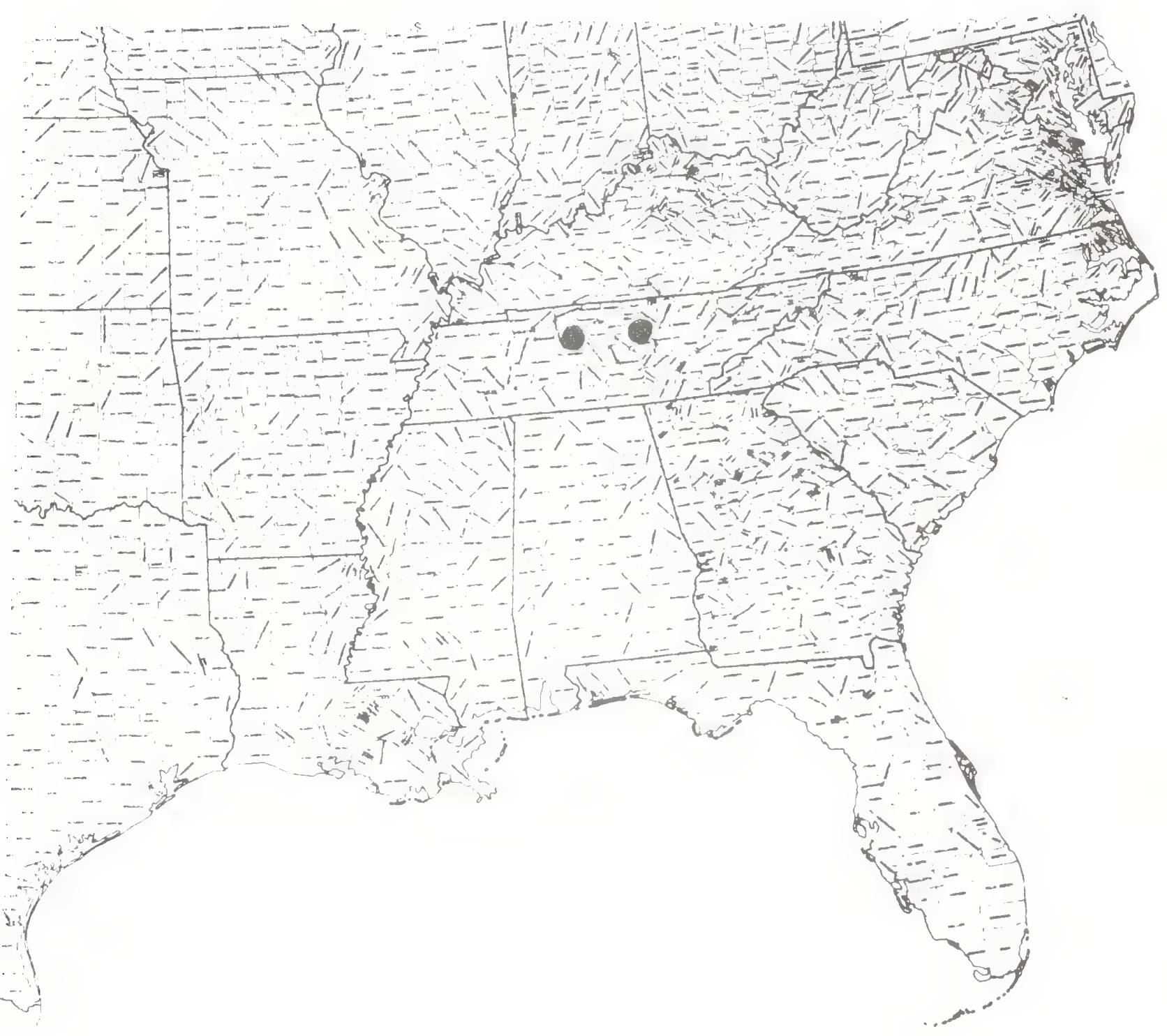




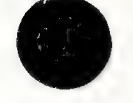

○

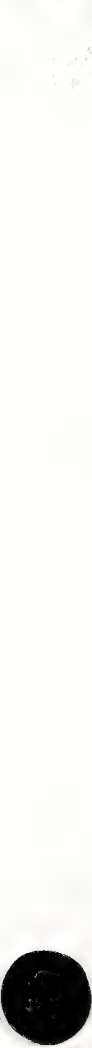




\section{Manisuris tuberculosa Nash \\ status: I'hreatened}

lechnical Description:

Perennial, smooth, tall grass, the culms solitary or in small tufts, sometimes stocky-rhizomatous, the roots fibrous.

Culms: erect or ascending, 8-15 dm tall, slender but rather stiff, brittle, wand-like toward apex, terete, the internodes several, the lower internodes most1y covered by sheath, the middle and upper ones shortest, mostly exposed, green or pale purplish or reddish-gren, 4-5 mm thick, the nodes swollen, the collar a narrow purplish band.

Leaves: distichous, toward base crowded, the sheathes there strongly overlapping strongly keeled (tolded sharply) and torming a chevron pattern, those upward on culm increasingly more distant, the larger ones less than $1 / 2$ the leat length; ligule a thin, erect, ragged margined scale $1.5-2.0 \mathrm{~mm}$ high; leaf blades erect or ascending, narrowly linear, to $6 \mathrm{dm}$ long, proximally somewhat tolded, upwardly tlattened but midrib prominent throughout, toward apex gradually narrowing to a narrowly acute tip, the margins distally minutely scabrid, the surtaces when youn green, but usually by tlowering and truiting time turning brown or maroon.

Intlorescence: culms branching trom upper nodes, the ultimate peduncles branching from these branches, all branches ascending or arching slightly outward, the total inflorescence narrow, tne many peduncles 5-10 cm long, sleeved half or more their slender length by tubular spathe sheaths, and each terminating in a narrowly cylindric raceme, this 3-6 cm long, straight or excurvate, the raceme rachis jointed, the joints thickish, rectangular in out1ine, ca. 3.0$3.5 \mathrm{~mm}$ long, separating at maturity, each in cross-section semicircular, thus the back rounded and ribbed, the inner face flattisn or slight $1 \mathrm{y}$ concave, producing at its base 2 spikelets, I sessile and fertile, the other reduced, smaller, sterile, and borne on a stubby stalk (rachilla) similar to the rachis joint and of the same length. Splkelets: paired as stated above, the sessile one 1-tlowered, lance-triangular, tlattened against the rachis joint and stalk ot sterile spikelet, ca. $4 \mathrm{~mm}$ long, the tirst glume external, giving the spikelet its shape, Iirm, lustrous, nearly smooth or with a tew widely spaced domeshaped processes or transverselymoriented low, truncated tubercles on its back, its abruptly intolded margins narrow, scarious, and entolding much of the rest of the spikelet; second glume thinner, about as long as the tirst glume but sharper pointed and keeled; tertile lemma very thin, pale, keeled, triangular, acute, about as long as the tirst glume; tertile palea also thin, slightly shorter than the lemma, blunter, the back slight1y convex, not keeled; mature anthers 3, on shortish tilaments, oblong, ca. $3 \mathrm{~mm}$ Long, cinnamon-red; stalked spikelet similar to sessile one but smaller, and of only the $\angle$ glumes. Grain: oblong-linear, slightly shorter than the palea.

Distribution and Flowering Season:

sandy peaty margins and shallows of pineland ponds, karst lakes 
and ponds, savanna swales, northern peninsular Florida, west into the Florida panhandle and southern Alabama. Flowering and fruiting trom June till frost.

\section{special Identifying Features:}

There is no doubt that the nearest species to $\underline{M}$. tuberculosa is M. rugosa (Nutt.) Ktze. lhe two might well bé considered varieties or mereforms of one species in that the only difference between them is the degree of rugosity of the backs of the glumes, which in M. rugosa are strongly and deeply transversely rugose. The raceme rachis joint in the latter is also medially contracted, a teature not held by $\underline{M}$. tuberculosa.

Habitat and Management Implication:

M. tuberculosa appears to be confined to karst areas in F1orida and Alabama and there may be abundant locally on the margins or in shallows of lakes and ponds or in wet savanna swales. Its shallow roots are in sandy peat or sandy peat-muck, a substratum that is usually at least moist, generally satarated. It may be in pure stands or scattered in an essentially grass-sedge meadow with such grasses as panicum tenerum, $\underline{\underline{P}}$. hemitomon, $\underline{\mathrm{P}}$. condensum, $\underline{\mathrm{P}}$. rigıdulum, various Andropogons, ㅌileocharis celiūlosa, E. melañocarpa, E. vivipara, $\mathbb{E}$. interstincta, E. Tricostata, Dichromena colorata,

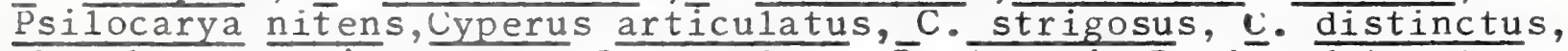
Rhynchospora microcarpa, $R$. perplexa,$\underline{\mathrm{R}}$. tracyi, $\underline{\mathrm{R}}$. inundata,etc., Scirpus americanus, many $\bar{X} y$ ris, many pölygonum, many Ludwigia but especia11y L. alata, L. suftruticosa, Rhexia, Proserpinaca, shrubby and herbaceous Hypericum, etc. Such areas are typically very unstable as regards water level, during some seasons drying completely, during others filling up to surrounding forest. l'hus the Manisuris may be part of a large belt or expanse of waving grass-sedge or not much in evidence at all during times of extreme drought or extreme flooding. This makes meaningful population estimates difficult. shallower ponds tend to fill up gradually, Hypericum, Stillingia, Crataegus (wet1and species), Nyssa biflora, N. ogeche, Taxodium ascendens, Ilex taking over. Immediate uplands may be dominated by Live Oak, the higher ground above these Longleat Pinedeciduous scrub oak, Sand Pine-evergreen scrub oak, or sometimes high hammok with plenty of Cabbage Palm.

Logging of the better trees, these usually at the upper edge of maximum pool or above would probably have 1ittle adverse effect unless it were accompanied by extensive soil disturbance or tollowed by some of the more destructive methods of site preparation. It is a 1 so suggested that drainage ditching into the high hydroperiod soils of the pondshores and bottoms, as has sometimes been done, is detrimental.

Reterences:

Hitchcock, A.S. \& Agnes Chase. 1951. Manual of the grasses of the United States, ed. 2 (revised by A. Chase). U.S.D.A. Misc. Pub1. 200, pp. 785-787. 
Kral,R. 1973. Some notes on the flora of the southern states, -particularly Alabama and middle Tennessee. Rhodora 75 (803): 366-410.

Sma11,J.K. 1933. Manual of the southeastern t1ora, pp. 41. 
SPECIES: Manisuris tuberculosa Nash

\begin{tabular}{|c|c|c|c|c|c|c|c|c|}
\hline $\begin{array}{l}\text { Expected } \\
\text { Effect on } \\
\text { Habitat } \\
\end{array}$ & $\begin{array}{c}\text { Prescribo } \\
\text { Burn }\end{array}$ & $\begin{array}{l}\text { Doze or } \\
\text { Root } \\
\text { Rake }\end{array}$ & Bed & Chop & $\begin{array}{l}\text { Th1n } \\
\text { Over- } \\
\text { otory }\end{array}$ & $\begin{array}{l}\text { Cut } \\
\text { Over- } \\
\text { Story }\end{array}$ & $\begin{array}{c}\text { Over Plant } \\
\text { w } 1 \text { th } \\
\text { trees }\end{array}$ & Graze \\
\hline Destroy & & NA & $\overline{\mathrm{NA}}$ & $\mathrm{NA}$ & & & $x$ & \\
\hline Damage & & & & & & & & $\mathrm{X}$ \\
\hline $\begin{array}{l}\text { No Lasting } \\
\text { Effect }\end{array}$ & & & & & & & & \\
\hline $\begin{array}{l}\text { Beneficial } \\
\text { if Done } \\
\text { Properly }\end{array}$ & $\mathrm{X}$ & & & & $\mathrm{X}$ & $\mathrm{X}$ & & \\
\hline
\end{tabular}

Othar Commente: Upslope clearcutting or mechanical site preparation may cause problems with sedimentation. Drainage destroys the habitat!

*Est1mated effect 18 an est1mate of the author based on h1s book knowledge of the habltat and on knowledge galned from personal field observations. Estimates are "rough" in many 1notances. Results of practices may vary in degree of application, Intensity, nearness to plant communities, etc. A column left "blank" indicates a lack of sufficient information from which to predict expected results. As observations are made in the fleld by users of the data, predictions should be refined by area and by intensity of forestry practices. 
Known Distribution of:

Manisuris tuberculosa Nash

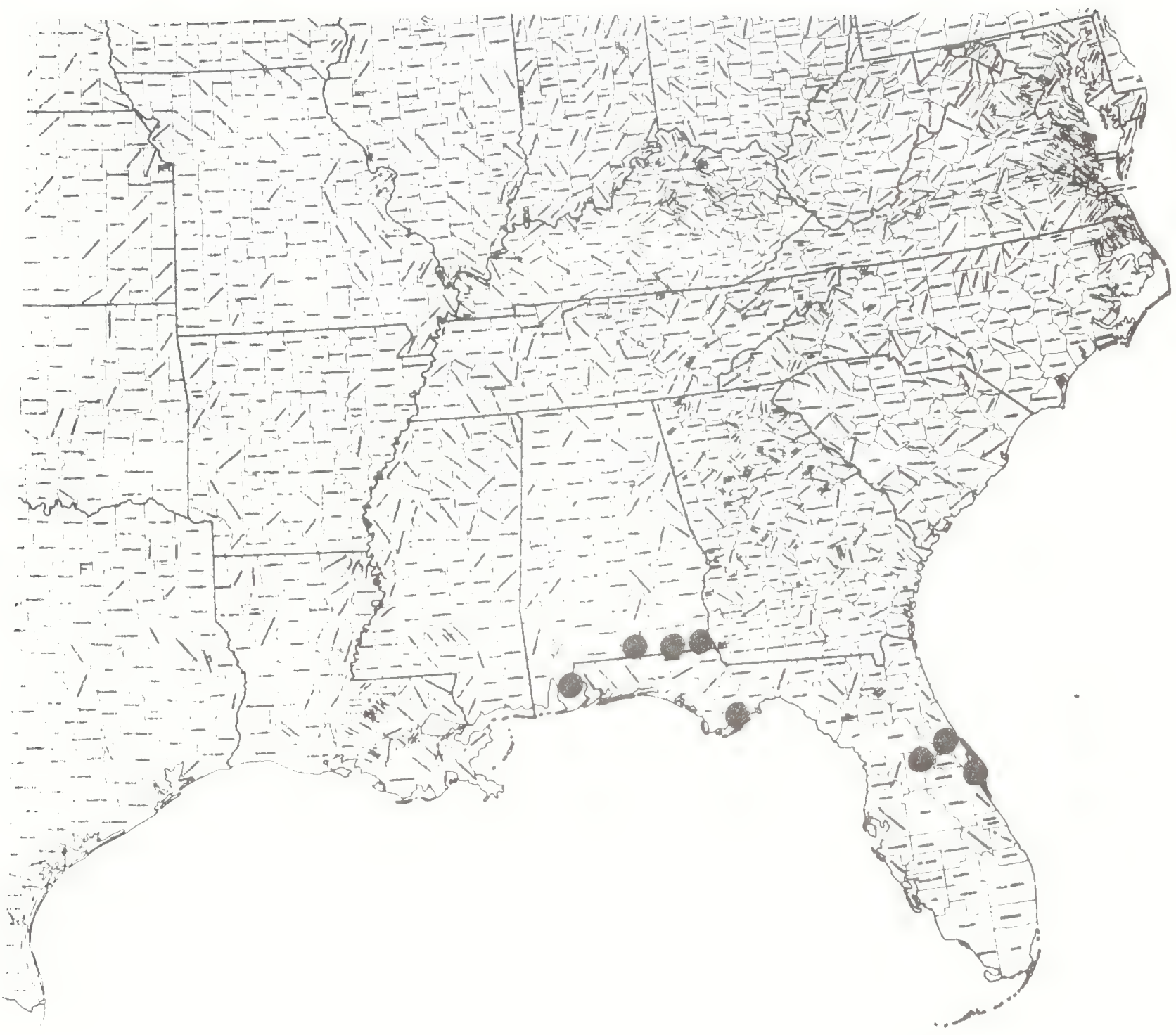


-

• 


\section{Panicum nudicaule Vasey}

\section{status: Threatened}

\section{'lechnical Description:}

'Lufted perennial Dichanthelium, the vernal culms therefore arising from a strong overwintering rosette.

culms: Vernal culms erect, mostly $2-5 \mathrm{dm} 10 n g$, slender but stiffish even though soft, terete and multiribbed, the internodes few, shortest and crowded toward plant base, elongated upculm, therefore leaves concentrated toward base.

Leaves: Rosette leaves largest, with short, 1oose, 1oose1y pilose sheathes, with blades 1ance-1inear to elliptic-1inear, 5-15 cm long, $0.5-1.2 \mathrm{~cm}$ wide, narrowly acute, the margin smooth, a narrow, pale, thin band; ligule a narrow band of white, erect hairs to $0.4 \mathrm{~mm}$ long; upper and lower blade surfaces smooth, bright yellow $\mathrm{green}$, sometimes tinged with maroon, the lower surface finely but prominently ribbed, the upper surface ribs inconspicuous; lower culm leaves similar to and but slightly smaller than those of rosette; mid-andupper culm leaves erect, abrupt1y much smaller, distant, and few. Inflorescence: spikelets numerous in a ditfuse, broadly ovoid panicle mostly $4-8 \mathrm{~cm}$ long, the sinuous slender branches widely ascending, pale green with tints of maroon, minutely scabrid, the peduncle of the panicle usually well extended above the uppermost culm leat. Spikelets: glabrous, on pedicels of varying length, ellipsoidal to lance-ovoid, 2.8-3.0 mm long, pale green or tinged with purple, the first glume ca. $1 \mathrm{~mm}$ long, broadly to narrowly ovate, very thin with only the mid-nerve prominent, the second glume ca. 2.5 $\mathrm{mm}$ long, lanceolate, acute and apiculate, pointed byond the fruit, the back prominently but widely nerved; sterile lemma slightly shorter than to as long as the second glume and similar to it; fruit (fertile lemma, palea and enclosed grain) planoconvex (convex backed, flat on side of fertile palea), narrowly ovoid, ca. 2 mm 1 ong, pale green, smooth and lustrous.

\section{Distribution and Flowering Season:}

Acid organic sands, peaty or silty muck of open stream and river bottoms, seep bogs, wet savanna, Gulf Coastal Plain, western F1orida west into southern Mississippi; vernal culms flowering from late April through May; autumnal culms presumably flowering from midsummer to frost.

\section{Special Identifying Features:}

Most Dichanthelium panicums have hairy spikelets. This one does not, and can be distinguished readily from the others that do not by a combination of short ligule, leaves crowded toward plant base, uf those in this complex that have rather large spikelets with second glume and sterile lemma pointed beyond the fruit ( P. Scabriusculum, $\underline{\text { P. cryptanthum, }}$. yadkinense) the first has hispid and 
spreading (rather than pilose and ascending) sheath hairs and is a taller plant; the second and third are taller and somewhat more slender plants with smooth sheathes, and the second has sma11er ( 1.5 $\mathrm{mm}$ ) fruit.

Habitat and Management Implication:

This rare grass is most frequent in boggy sites or acidic openings in the titi dominated woods along streams, is on wet peaty or silty sandy substrates that are frequently flooded. It, like most other wet savanna and bog herbs and grasses, is a plant of ful1 sun, thus is suppressed by invasion of shrub and overstory woody species, increases with release through fire or timbering if this is unaccompanied by soil disturbance or draining. $1 \mathrm{t}$ is eliminated if the land is drained and is either strongly reduced or totally eliminated by most site preparatory methods, with bedding perhaps being the least damaging.

References:

Hitchcock, A.S. Y Agnes Chase. 1950. Manual of the grasses of the United States, Ed. 2 (revised by A. Chase). U.S.D.A. Misc. Pub1. 200. U.S.Govt. Printing Office.

Sma11,J.K. 1933. Manual of the southeastern flora, p. 73.

Vasey, George. 1889. . nudicaule in U.S.Dept. Agr.Div. Bot. Bu11. $8: 31$. 
SPECIES: panicum nudicaule Vasty

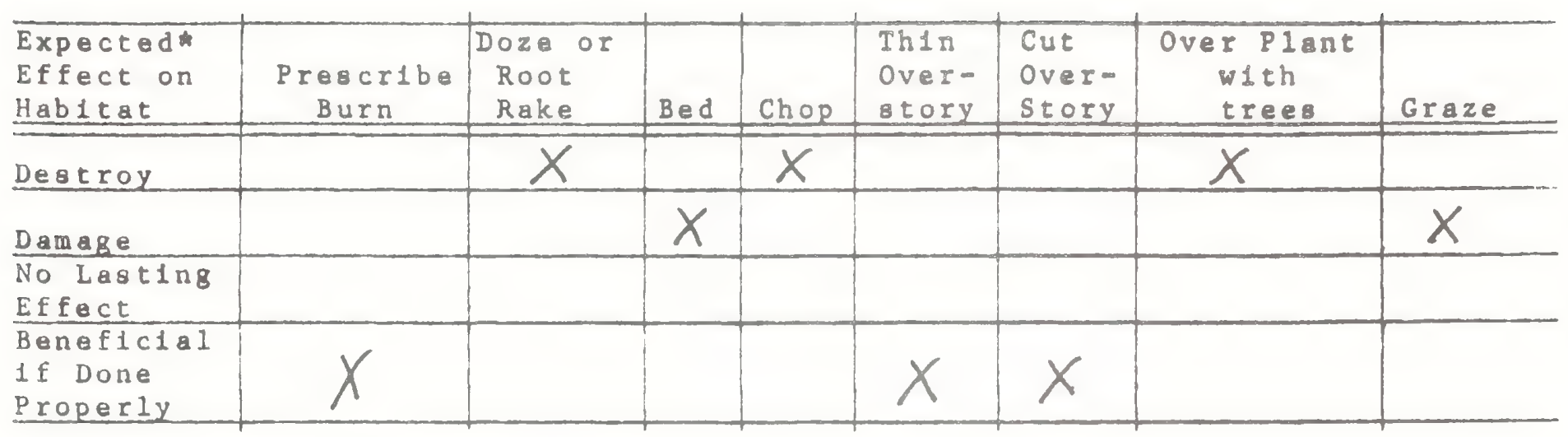

Other Comments: Drainage destroys the habitat!

*Estimated effect 18 an estimate of the author based on his book knowledge of the habitat and on knowledge gained from personal field observations. Estimates are "rough" in many instances. Results of practices may vary in degree of application, intensity, nearness to plant communities, etc. A column left "blank" indicates a lack of sufficient information from which to predict expected results. As observations are made in the field by users of the data, predictions should be refined by area and by intensity of forestry practices. 
Approximate Range of:

Panicum nudicaule Vasey

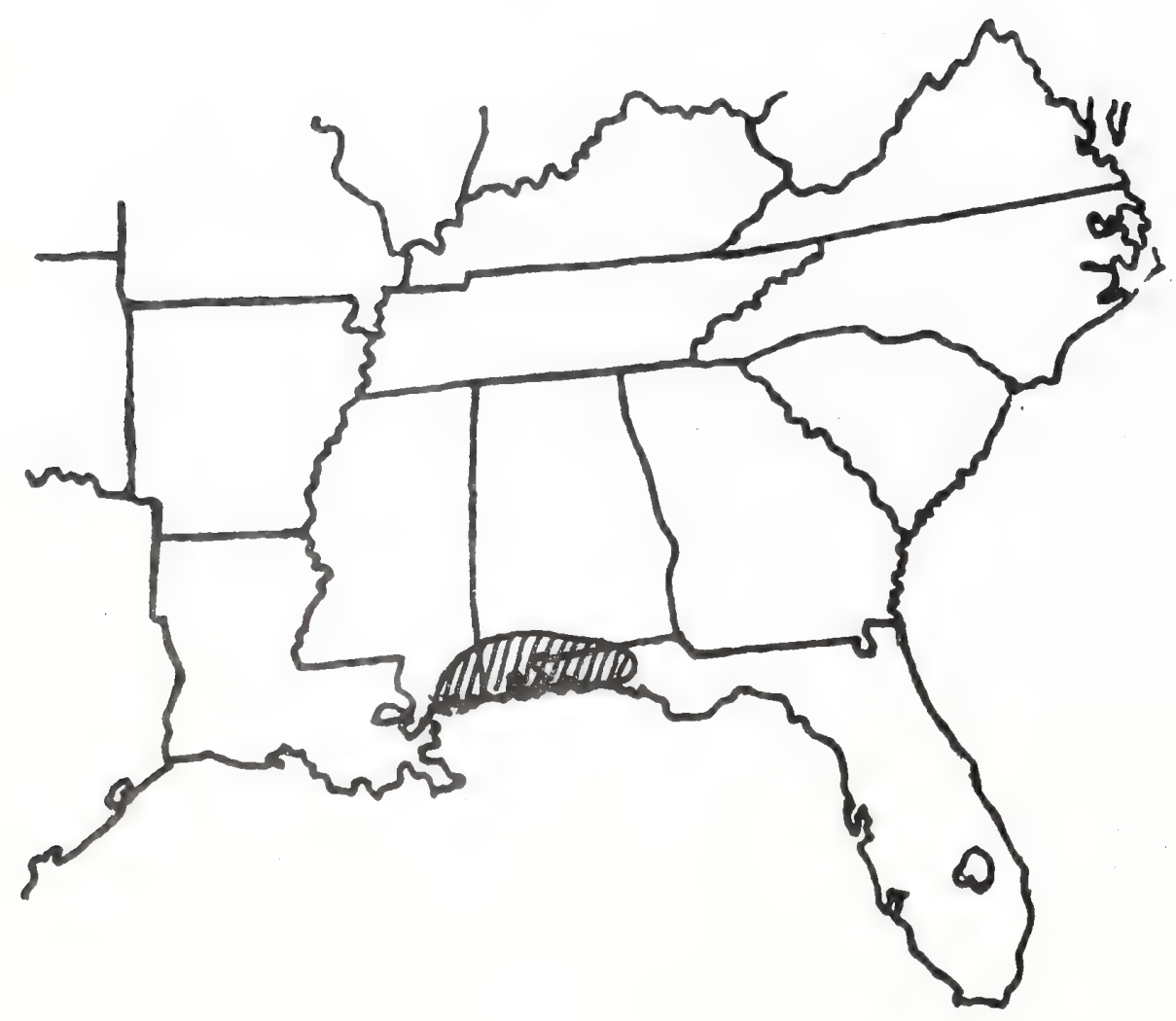




\section{Sporobolus teretifolius Harper}

Status: Threatened

\section{Technical Description:}

Strongly tufted, wirey- 1 eaved-and-culmed perennial grass $6-10 \mathrm{dm}$ ta11, increasing by compact-compressed lateral-basal offshoots, the roots rather thick, diffuse-fibrous.

Culms: erect to ascending, straight and slender but rather stiff, terete, smooth, pale yellowomgreen.

Leaves: crowded toward culm base, few, shorter and more distant upward on culm, the longest, including sheath, ca. 1/2 the plant height, the older sheath bases persisting as a stubble of chaff and fibers, the fresh sheath about $1 / 3$ the leaf length, firm, flavescent with red or purple tinges distally, toward base broad and clasping with thin, paler, hyaline margin, the back rounded, 1ow-ribbed, gradually tapering into the blade, there silvery pilose, the blades filiform, erectish or slight1y spreading, medially and basally flat or somewhat inrolled with a narrow, slight1y thickened, minutely scabrid margin and ca. 1-2 mm wide, above middle strongly folded so as to be terete or oval in cross section, or terete from base to tip, always finely low nerved, always smooth, narrowing very slightly to a narrow, bluntish, scabrid tip. Inflorescence: spikelets very many in a diffuse panicle of numerous subwhorled or alternate, smooth, primary branches with pilose or pilosulous axillee, the peduncles slender, narrowly clavate, ascending, the whole inflorescence in outline elliptical, lancemovate or narrowly ovate, $2 \rightarrow 4 \mathrm{dm}$ long.

Spikelets: Glumes 2, lanceolate, strawmcolored or purplish-brown, the first 2.5-3.0 $\mathrm{mm}$ 1ong, the second 4.5-5.0 (-5.5) $\mathrm{mm}$ long, narrowly acute, chaffy, the backs proximally rounded, distally somewhat keeled, on 1y the midnerve evident; fertile florets 1 (not even a vestigial rachilla joint evident!), ca. $3 \mathrm{~mm}$ long, the lemma and palea subequal, oblong-lanceolate, acute, with narrowed but bluntish tips, smooth, folded but not keeled, the back of the palea with a 1ongitudinal gruove; stamens 3, the anthers 1inearmoblong, purplish, ca. $3 \mathrm{~mm}$ long.

Fruit: caryopsis cylindrical-oblong, ca. $2.5 \mathrm{~mm} 1$ ong.

Distribution and Flowering Season:

moist to wet pineland savanna and hillside seep bogs, Coastal Plain, eastern North Carolina; Georgia in the Altamaha Grit region; flowerng from September into October.

Special Identifying Features:

of the perennial, tufted dropseeds frequenting the southeastern 
Coastal Plain and having diffuse inflorescences there are but two with which this one could be confused, namely $\underline{S}$. floridanus and S. curtisii. The former is a taller, coarser grass with leaves tending to be flat and much broader (to $5 \mathrm{~mm}$ ) and having subequal glumes; the latter, while it has narrow leaves that tend sometimes to be involute, has darker colored spikelets whose erect, short peduncles tend to be nearly appressed to the panicle branches; it too has subequal glumes and spikelets that do not exceed $4 \mathrm{~mm}$ in length.

Habitat and Management Implication:

S. teretifolius frequents moist or even wet pinelands, its dense Eufts with bases set fairly deeply in a black sandy peat, It is part of a grassmsedge bog type that includes such associates as Andropogon, Aristida, Panicum, Paspalum, Ctenium, many Rhynchospora, Scleria, Fimbristylis, Dichromena latifolia, bog Eleocharis and Carex, Juncus, particularly J. canadensis, J. trigonocarous, Eriocaulon, Lachnocaulon, Syngonanthus, many xyris, Habenaria, Lilium catesbaei, Zygadenus, Sabatia, many Polygala, Lobelia, oxypo1is rigidior and o. filiformis, Eryngium integrifolium, and a wealth of showy composites in Coreopsis, Liatris, Helianthus, Balduina, Bigelowia, etc. The overstory is usually dominated by Longleaf Pine, with scattered Pond Cypress, Pond Pine, Virginia Bay, Red Bay, Red Maple, Nyssa biflora ( $N$. ogeche in Georgia), etc. The shrub layer is made up of gallberry, wi $\overline{1 d}$ Azalea, various blueberry and huckleberry, Staggerbush, Fetterbush, Sweet Pepperbush, Zenobia. Cyrilla forms broad belts in the lower areas and in Georgia there may be large patches of Serenoa. Smilax, particular1y S. laurifolia, and various Rubus, together with Arundinaria form dense growths 1ocally. Frequent natural woods fires were paramount historically in establishing the openings dominated by grass-sedge, in that they reduced the shrub and tree competition; conversely, fire protection results in increase of woody vegetation, this ultimate1y replacing the herbs.

The greatest threat to $S$. teretifolius habitat comes from grandmscale pine monoculture with hüge tracts of low savanna being first drained, then mechanically sitemprepared for Slash Pine.The result is a drier, ultimately shadier site which will not support this grass. Other tracts are being drained and cleared either for improved pasture or for row crop agriculture.

References:

Harper, R.M. 1906. Sporobolus teretifolius Harper in Bu11. Torr. Bit. Club 33: 229 .

Hitchcock, A.S. 1950. Manual of the grasses of the United States, ed. 2, revised by Agnes Chase: U.S.D.A. Misc. Pub1. 200: Sporobolus, pp. $413-432$. 
SPECIES: Spurobolus teretifolius R.M.Harper

\begin{tabular}{|c|c|c|c|c|c|c|c|c|}
\hline $\begin{array}{l}\text { Expected } \\
\text { Effect on } \\
\text { Habitat }\end{array}$ & $\begin{array}{c}\text { Prascribe } \\
\text { Burn } \\
\end{array}$ & $\begin{array}{l}\text { Doze or } \\
\text { Root } \\
\text { Rake }\end{array}$ & Bed & Chop & $\begin{array}{l}\text { Th1n } \\
\text { over- } \\
\text { Btory } \\
\end{array}$ & $\begin{array}{l}\text { Cut } \\
\text { over- } \\
\text { Story }\end{array}$ & $\begin{array}{c}\text { Over Plant } \\
\text { with } \\
\text { trees } \\
\end{array}$ & Graze \\
\hline Destroy & & $x$ & & X & & & & \\
\hline Damage & & & & & & & & \\
\hline $\begin{array}{l}\text { No Lasting } \\
\text { Effect }\end{array}$ & & & & & & & & \\
\hline $\begin{array}{l}\text { Beneficlal } \\
\text { If Done } \\
\text { Properly }\end{array}$ & & & & & & & & \\
\hline
\end{tabular}

Other Comments: Do not drain site!

* Est1mated effect 18 an est1mate of the author based on hio book knowledge of the habltat and on knowledge galned from personal field observations. Estimates are "rough" in many instances. Results of practices may vary in degree of application, intensity, nearness to plant communities, etc. A column left "blank" indicates a lack of sufficient information from which to predict expected results. As observations are made in the field by users of the data, predictions should be refined by area and by intensity of forestry practices. 
Known Distribution of :

Sporobolus teretifolius Harper

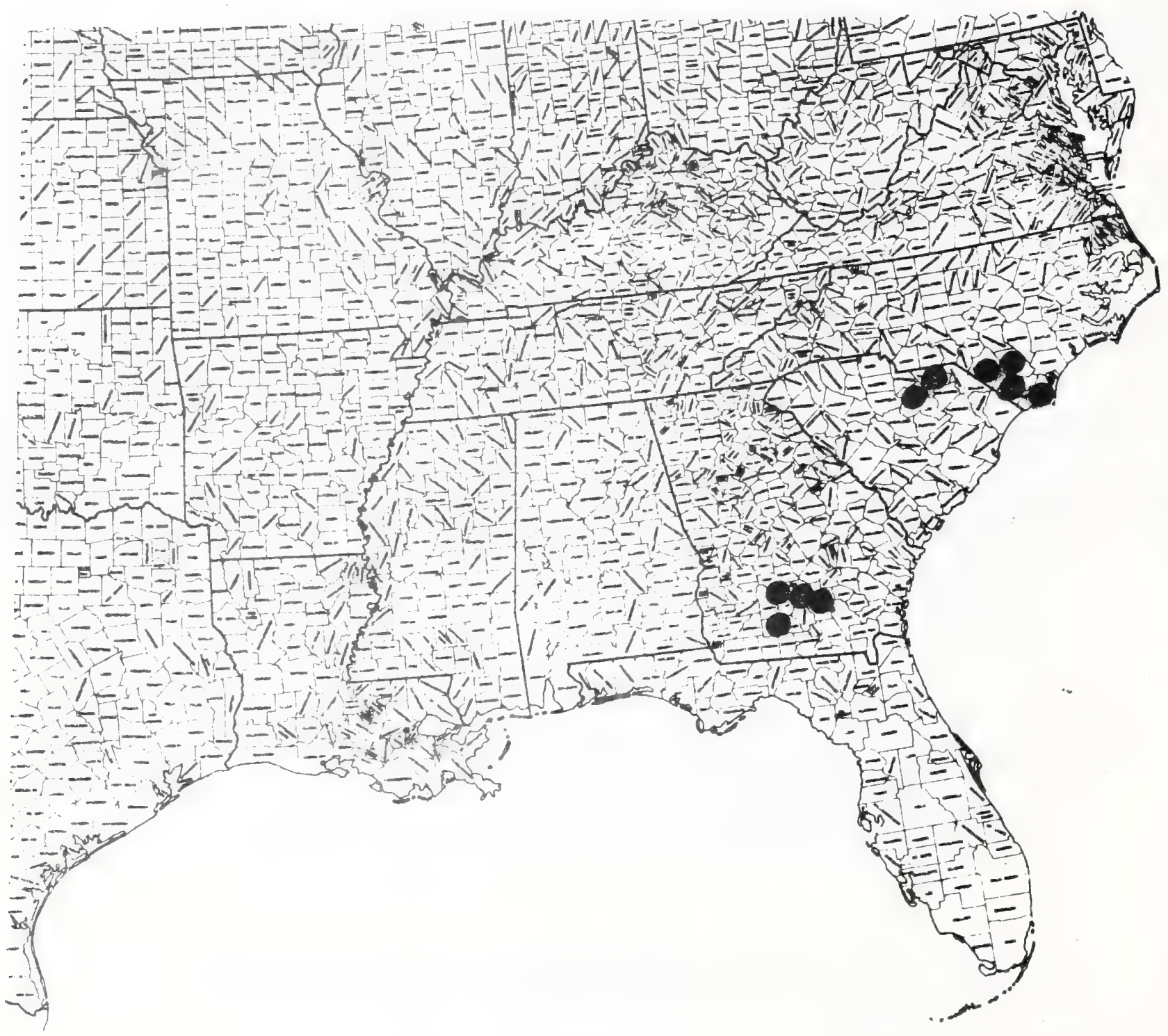




\title{
Phlox bifida Beck ssp. stellaria (Gray) Wherry
}

\author{
P. stellaria Gray \\ P. bifida var. cedaria Brand \\ P. bifida var. stellaria (Gray) Wherry
}

Status: Threatened

Technical Description:

Mat-forming subshrub spreading and rooting from prostrate older shoots, the roots shallow, diffuse-fibrous, save at plant center where deeper, thick and woody, the foliage overwintering.

Stems: several from a root cluster, the older spreading low in all directions, slender, lax, the bases usually prostrate, often rooting at lower nodes, some sterile, functioning as stolons, with internodes crowded and leafy at tips which arch downward to root and form overwintering rosettes, others bolting directly from such rosettes and from nodes of procumbent branches, erect or nearly so, few-noded, mostly 10-15 cm high, slender, floriferous at tip, terete, scattered-short-pilose with whitish hairs, otherwise pale green or tinged with red or pink. Leaves: opposite, estipulate, those of shoot buds or lowermost on new shoots scale-like, those upward on stems sessile, spreading or erect, often with axillary shoots and thus appearing fascicled, lance-linear, linear, elliptic-linear, (1-) 2-4 (-6) cm long, mostly 1-3 mm wide, the longer ones shorter or longer than the internode subtended, gradually shortening into inflorescence leaves, these usually 1 cm or less long, all narrowly acute, also mucronate or short-spinulose-tipped, the margin entire, sparsely to evenly ciliate or ciliate only proximally, flattish to somewhat revolute, the upper surface gray-green, smooth or sparsely pilose, the lower surface paler, smooth or pilose, particularly along the single, strongly rai sed vein. Inflorescence: Numerous branches arising from a mat to form a mass of erect, few-noded stems, each terminating in a few-toseveral-flowered cyme, the cyme branches arising from the upper leafy nodes, terminating in a single flower or in cymules of 3 , the pedicels slightly shorter or longer than the flowering calyces, erect or arching upward, slender, purplish or eeddish-tinged, smooth or with a scattering of minute, spreading, peg-like hairs. Flowers: Perfect, regular; sepals 5, at anthesis mostly 6-8 cm long, fused, externally smooth or sparsely pilose, the tube tubular, 5nerved, each nerve bordered by a firm green or reddish-green zone and each bordered nerve alternating with a scarious pale blue or purplish membrane, the calyx lobes narrowly triangular-subulate 
ca. $3 \mathrm{~mm}$ long, erect or with slightly spreading tips, reddish-green, entire, scarious-bordered below the middle to the membranous, acutish sinus: petals 5, the corolla salverform, from base to narrow mouth 10-15 mm long, the tube very pale blue with tints of yellow, dilating gradually to the tip, the 5 lobes 10-12 mm long, spreading, pale blue, narrowly obovate and deeply split into 2 narrowi sh lobes to form a short-based "Y", externally and internally smooth;

stamens 5, epipetalous, set at different levels at about middle of corolla tube, the yellowish oblong anthers ca. 1.0-1.5 mm long, erect, basifixed, sagittate; ovary superior, smooth, greenish, the slender terminal style producing 3, short-linear,erect,glandular stigmas at or slightly above the level of the anthers. Fruit: Capsule thin-walled, trilocular, broadly ellipsoidal or obovoid, held within the persistent, ascending-lobed calyx, and about as long as the calyx tube; seeds oblong, usually l/locule, pale brown, smooth.

Distribution and Flowering season:

Calcareous barrens, cliffs, open sandy or gravelly slopes, southern tips of Illinois and Indiana southward, very locally, through Kentucky into northern and central middle Tennessee; flowering from late April into June.

Special Identifying Features:

There are several Phlox that are matted subshrubs with needle-like leaves and which produce low masses of bloom. Most are referred to as "Moss-phlox" and several are cultivated. The one commonly grown in the east, according to wherry (1955) is $\underline{\text {. subulata; this }}$ has flowering shoots with closer nodes, shorter, more subulate-tipped leaves, thus is much more densely, compactly leafy; while its petals are notched apically, the notch is shallower, at most a longbased "Y" rather than the near "V" of $\underline{P}$. bifida, and its corolla limb has a definite, deeper toned "eye". This is the only Mossphlox to overlap at all the range of $\underline{P}$. bifida stellaria. $\underline{P}$.

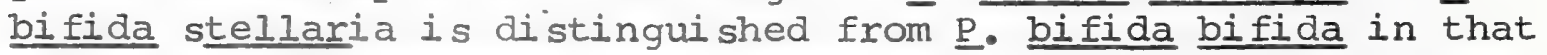
it has sepals united more than half-way (rather than half-way), the calyxis externally smooth or sparsely hairy (rather than glandular-hairy), the petal notch is slightly shallower. $\underline{\text { p. bifida }}$ proper is found in rocky open areas or open woodlands, sandhills, northward in the Central Iowlands or to the west in the Interior

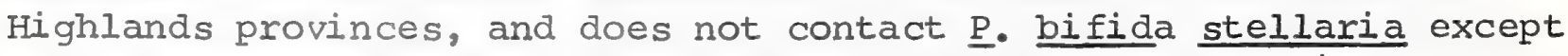
at the southwest comer of the range. The taxonomy here is difficult and questionable, and perhaps should be more conservative.

Habitat and Management Implication:

My comments here are confined to observations of Tennessee populations only. These appear to be scattered in a few counties of middle Tennessee, though the plant may be an aspect dominant, forming extensive masses of pale blue by early May. These are limestone 
appearing either in full sun or in open stands of Juniper or Juniper mixed with upland hardwoods. Climax forest is usually a mixture of Shumard Oak, White Oak, Yellow Oak, Black Walnut,Persimmon, Carolina Hickory, Shagbark Hickory, Bitternut Hickory, Elm, Sassafras, Hackberry and Sugarberry, White Ash,Blue Ash, Sugar Maple and an occasional Beech; disclimax forest is Juniper. Understory shrubs or shrubs of more open areas include Rhus aromatica, Rhamnus caroliniana, Symphoriocarpos, with shrubby growth of Cercis, Rhus qlabra, R. typhina. Opuntia and Agave are common.

The soil of the open glades is thin, heavy, overlies flat-bedded limestone, usually contains a rubble of limestone chips. It produces a fine array of associated herbaceous species such as Hypoxis hirsuta, Allium (Nothoscordium), Ranunculus fascicularis, Delphinium virescens, Leavenworthia, Petalostemon gattingeri, Psoralea subacaulis, Astragalus tennesseensis, Oenothera triloba, Scutellaria parvula, Blephilia ciliata, Satureja glabella, Iithospermum canescens, Onosmodium molle, etc., many of which are endemic to such glades.

The Phlox is part of a successional stage leading to occupation by shrubs and Juniperus, finally to mixed-mesophytic forest climax, thus it disappears as the open glades close. The main threat to this Phlox in Tennessee comes from urban, residential and industrial expansion, as well as from the damming up of the streams in its area (i.e. Percy Priest Lake, which has flooded the bulk of the best Tennessee populations!).

References:

Sma11,J.K. 1933. Manual of the southeastern flora, pp. 1101-1105. Wherry,E.T. 1955. The genus PhIox. Morris Arboretum Monographs III: $174 \mathrm{pp}$. Lancaster,Pa. 
SPECIES: Phlox bifida Beck ssp. stellaria (Gray) Wherry

\begin{tabular}{|c|c|c|c|c|c|c|c|c|}
\hline $\begin{array}{l}\text { Expected } \\
\text { Effect on } \\
\text { Hab1tat }\end{array}$ & $\begin{array}{c}\text { Preacribo } \\
\text { Burn } \\
\end{array}$ & $\begin{array}{l}\text { Doze ot } \\
\text { Root } \\
\text { Rake } \\
\end{array}$ & $\mathrm{Bed}$ & Chop & $\begin{array}{l}\text { Th1n } \\
\text { over - } \\
\text { etory }\end{array}$ & $\begin{array}{l}\text { Cut } \\
\text { over- } \\
\text { Story }\end{array}$ & $\begin{array}{c}\text { Over Plant } \\
\text { vith } \\
\text { trees } \\
\end{array}$ & Graze \\
\hline Destroy & & $\mathrm{NA}$ & $\mathrm{NA}$ & $\mathrm{NA}$ & & & $\mathrm{X}$ & \\
\hline Damage & & & & & & & & $\mathrm{X}$ \\
\hline $\begin{array}{l}\text { No Lasting } \\
\text { Effect }\end{array}$ & & & & & & & & \\
\hline $\begin{array}{l}\text { Beneficial } \\
\text { If Done } \\
\text { Properly }\end{array}$ & $\mathrm{X}$ & & & & $\mathrm{X}$ & $\mathrm{x}$ & & \\
\hline
\end{tabular}

\section{Other Commente:}

* Est1mated effect 18 an est1mate of the author based on his book knowledge of the habltat and on knowledge galned from peranel field observations. Estimates are "rough" in many instances. Results of practices may vary in degree of application, intensity, nearness to plant communities, etc. A column left "blank" indicates a lack of sufficient information from which to predict expected results. As observations are made $1 \mathrm{n}$ the field by users of the data, predictions should be reflined by area and by intensity of forestry practices. 
Approximate Range of:

Phlox bifida Beck ssp. stellaria (Gray) Wherry

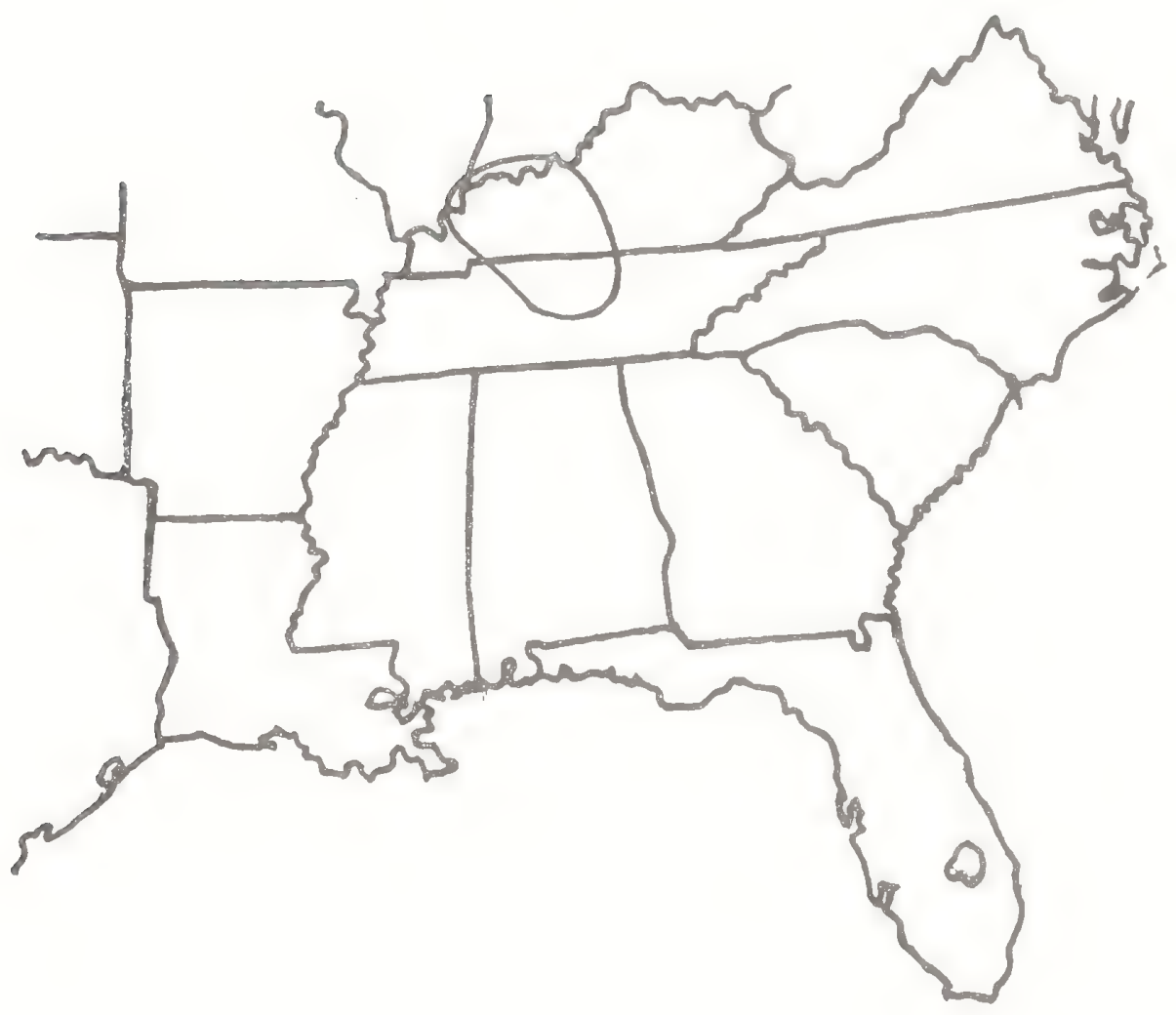


0

-

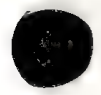


lechnical Description:

succulent, smooth perennial trom a stout, tleshy, knobbly, elongate to compressed, simple or branched, erect or spreauingarscendingbranched caudex, its crown otten bearing the tibres of old,persistent leat tibres, 1 ts base tibrous-rooted.

Stems: subterranean or surticial part as described above, the Ieaty shoots arising singly, oppositely or alternately, simple or torking or alternately branched trom the caudex, stitfly erect or ascending, pale green sutfused with pink or red, 3-6 (-1U) cm 1 ong, the nodes close-set and spirally arranged.

Leaves: L1near, terete, $3.5 \mathrm{~cm}$ Long, apically narrowly conic and callused, basaliy clasping like a suction cup, gray-green or deep green suffused with some reddish pigment, ascending and approximate, usually rather dense.

Intlorescence: reduncle slender, terminal, erect or ascending, 5-15 cmlong, pale green with tints of pink or red, simple and bractless below, branching only in the upper ca. I/5, there forming a cyme of tew-tomany showy tlowers, the slender but stiftish pedicels otten maroon, bo $1.5 \mathrm{~cm}$ long, each subtended by a connatempertoliate, bilobed, thin, bract, this whitish, each lobe more or less triangular, at most $3 \mathrm{~mm}$ long, short-cuspidate.

Flowers: regular, bisexual; sepals 2 , distinct, thin (scarious) pale, $\overline{\text { broad1y }}$ ovate to suborbicular, entire, ca. $3 \mathrm{~mm}$ long, persisting on Iruit; petals 5, distinct, unfolding in afternoon, then spreading, a deep, bright rose, narrowly obovate, ca. $1 \mathrm{~cm}$ long, apically rounded, sometimes mucronulate, entire, cuneatembased; stamens numerous, somewhat variable in length but up to $5 \mathrm{~mm}$ long, the filaments tiliform, reddish, the anthers basifixed, oblong, ca. $1.0 \mathrm{~mm}$ long, yellow; ovary superior, usually tricarpellate, with ovules many, tree-central, the ovary body ovoid to broadly ellipsoidal, ca. $2.5 \mathrm{~mm}$ high, the style tiliform, exserted beyond the longest of the stamens, there trilobed and papillate-stigmatose.

Fruit: Lapsule ovold to obovoid, 4-6 mm long, yellowish-green, opening by 3 subequal valves, subtended and clasped by the 2 , erect and persistent sepals; seeds dull gray, round but laterally compressed, ca. $1 \mathrm{~mm}$ wide.

Distribution and Flowering season:

Nashville Basin and calcareous lowlands of middle Tennessee and northern Alabama respectively; open limestone glades or limey clearings, locally abundant; tlowering trom early June through August.

special Identifying reatures:

southeastern l'alinum are more easily recognized to genus than as species, this being the case usually where genera are as distinctive as this one. However, of the 4 known southeastern species, $T$. appalachianum has the least stamens (usually but 5); $\underline{\Gamma}$ - terétifolium 
has a style shorter than the stamens, or rather its style is not exserted. The only similar species as to stylar character is I. mengesii, and $\underline{\Gamma}$. calcaricum differs trom it by having tewer seeds (10-25, rather than more than 2د), grayish and du11 seed coat (rather than nearly black and lustrous), a detinitely trilobate stylar apex and stigma (rather than capitate or nearly so), an ovoid to obovoid (rather than subglobose) capsule. While habitat differences are risky to use with many groups, that is not the case here, in that, unlike other southeastern Talinum, ' 1 . caıcaricum is as the name suggests, a calciphilic species.

Habitat and Management Implications:

I. calcaricum 1s a species of open limestone glades, sharing tne thin outcrop soils with Nostoc, various lichens and mosses, annual Panicum and Sporobolus, Cyperus, Juncus, A11ium, Commelina, Arenaria, sedum, various Leavenworthia, De 1phinium virescens, psoralea

subacaulis, Petalostemon gattingeri, scutellaria parvula, satureja glabella, . arkansana, verbena, and many composites. Al 1 these are rooted in the thin, 1nwash or outwash detrital soils over limestones of Urdovician age, or on the clayey soils that accumulate around the outcrops. All might be considered pioneer invaders of such outcrops, giving way to increasing numbers of woody plants, usually tirst to junipers, which in turn are succeeded by mixed hardwoods predominated by oaks, hickories and hackberries with ash, elm, hard maples. Lhe rocky clearings were maintained or created historically by tire and/or erosive torces, perhaps occasiona11y by severe storms such as the tornadoes that periodically strip lanes through some of these areas today.

l'he greatest current risk to these habitats today comes from urban expansion and the need tor more and more industrial and residential space, together with a more pastoral hazard involving conversion of some open glades to 1ow-quality pasture. This last damages or destroys the plants, in that the stock trample them or compact the thin soils.

Reterences:

Sma11,J.K. 1933. Manual of the southeastern flora, pp. 493-494.

Ware, Stewart. 1967. A new Talinum (portulacaceae) trom the cedar glades of middle l'ennessee. Rhodora 69 (780): 466-475.

1969. Seed germination in cedar glade Talinum.

Écology 50 ( 1 ): $137-140$. 


\begin{tabular}{|c|c|c|c|c|c|c|c|c|}
\hline $\begin{array}{l}\text { Expected } \\
\text { Effect on } \\
\text { Hab1tat }\end{array}$ & $\begin{array}{c}\text { Preacribe } \\
\text { Burn } \\
\end{array}$ & $\begin{array}{l}\text { Doz or } \\
\text { Root } \\
\text { Rake } \\
\end{array}$ & Bed & Chop & $\begin{array}{l}\text { ThIn } \\
\text { Over- } \\
\text { Btory }\end{array}$ & $\begin{array}{l}\text { Cut } \\
\text { over- } \\
\text { Story }\end{array}$ & $\begin{array}{c}\text { Over Plant } \\
\text { wth } \\
\text { trees }\end{array}$ & Craze \\
\hline Deatroy & $x$ & & & & $\mathrm{X}$ & $x$ & & \\
\hline Damage & & NA & NA & NA & & & NA & \\
\hline $\begin{array}{l}\text { No Lasting } \\
\text { Effect }\end{array}$ & & & & & & & & \\
\hline $\begin{array}{l}\text { Beneficlal } \\
\text { If Done } \\
\text { y roperly }\end{array}$ & & & & & & & & \\
\hline
\end{tabular}

\section{Other Commente:}

* Est1mated effect 1 a an eatimate of the author based on his book knowledge of the habltat and on knowledge gained from peranal field observations. Estlmates are "rough" in many 1nstances. Results of practices may vary ln degree of application, incensity, nearness to plant communities, etc. A column left "blank" indicates a lack of sufficlent information from which to predict expected results. As observations are made in the fleld by users of the data, predictions should be refined by area and by intensity of forestry practices. 
Distribution of:

Talinum calcaricum S. Ware

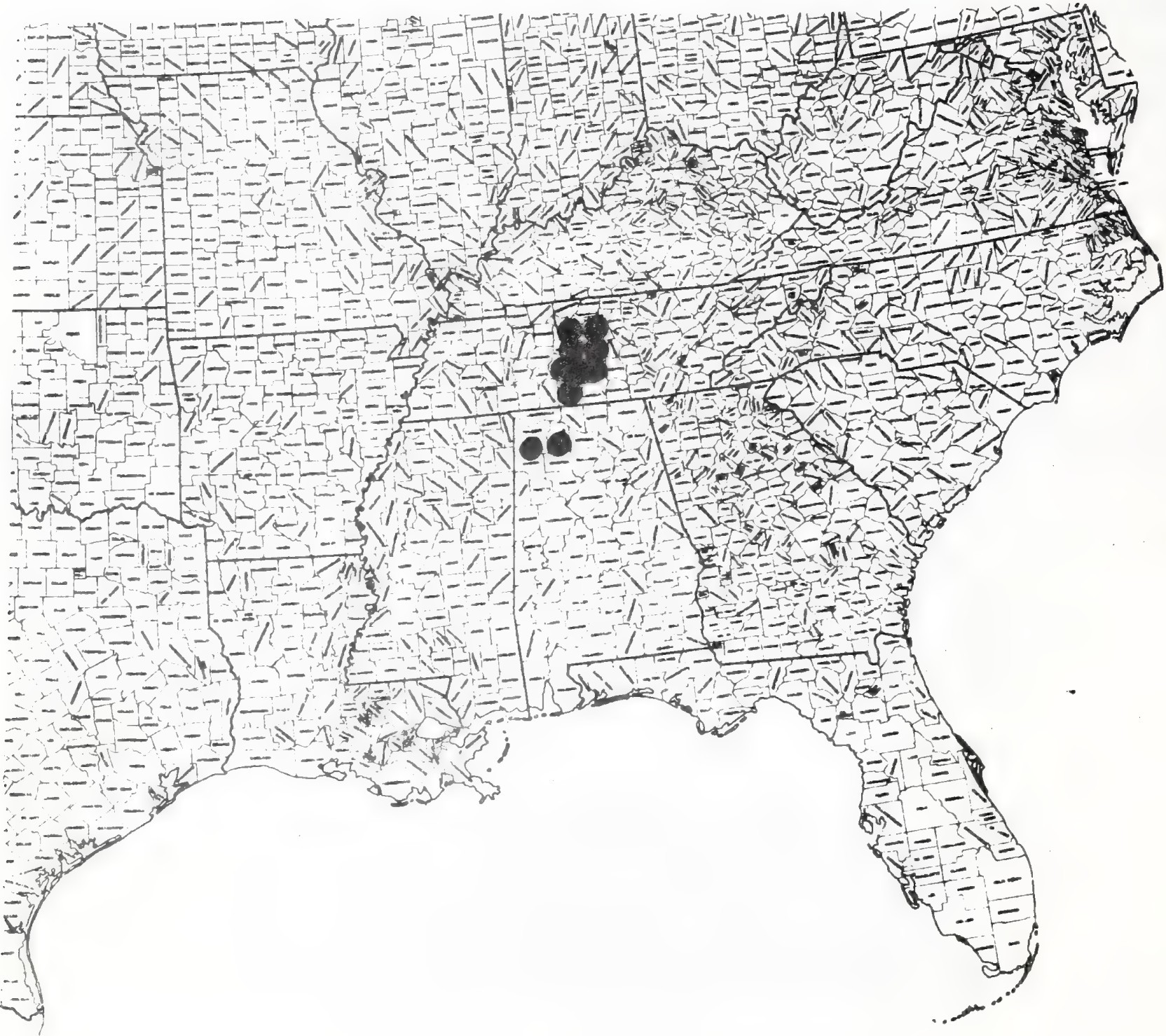


Talinum mengesii W. Wolt

status: Threatened

lechnical Description:

succulent, smooth perennial from a tleshy, stout, knobby, elongate, terete to compressed, simple or branched, erect or spreading-ascendingbranched caudex, the crown often bearing old leat base fibres; roots slender, tibrous.

Stems: aerıal part of caudex simple or stiffly alternately or oppositely branched, or branches several trom the apex, densely leaty, erect or ascending, pale green suffused with red or pink, most1y 5-15 cm high, terete, thickish.

Leaves: close-set and spirally arranged on the main stem and branches, particularly toward shoot bases, ascending, linear, to $6 \mathrm{~cm}$ long, $3 \mathrm{~mm}$ thick, terete, deep green, sharply conical apically, the bases attaching suctioncup-like, bearing internally just above the attachment a thin, ligule-like pair of stipules. Intlorescence: reduncles bractless, arising apically trom main axis and branches, most1y 1-2 dm long, slender, terete, stittish and wirelike, producing an open cyme of few-to-many tlowers, usually this scorpioid, with an average of 3 primary branches, the stiffish, pedicels arising trom lnner side, subtended by scarious, lance-1inear or subulate, connate-perfoliatembased bracteoles and to $1 \mathrm{~cm}$ long. Hlowers: showy, regular, bisexual; sepals 2 , distinct, broadly to narrowly ovate, thin, 4-5 mm long, pale green tinged with pink or maroon, early deciduous trom truit; petals 5, distinct, spreading, openıng in afternoon, elliptic to narrowly obovate, a bright rose-pink, ca. $1.5 \mathrm{~cm}$ long, apically rounded, entire, cuneate-based; stamens 40-100, distinct, the filaments tiliform trom short-scarious bases, somewhat unequal, but up to $5 \mathrm{~mm}$ long, the anthers snort-oblong, basitixed, $0.5-0.8 \mathrm{~mm}$ long, bright yellow; ovary superior, tricarpellate, the numerous ovules iree-central but concentrated toward apex of columella, the style well exserted beyond the longer stamens, linear, unbranched, the stigma capitate, 3-1obed, not branched.

Fruit: Capsule subglobose or very broadly ovoid, yellow-green, when ripe 5-6 mm high, 3-valved; seeds numerous, laterally 11 attened, round in outline but concave on the sides at center of coiled embryo, ca. $1 \mathrm{~mm}$ wide, nearly black, shining.

Distribution and Flowering Season:

Granite and sandrock outcrops, cumberland plateau, Ridge and Valley, Blue Ridge, and riedmont, southern Middle Tennessee south into riedmont Georgia and Alabama; flowering trom late June through August, intermittent1y to trost.

special ldentifying reatures:

As Wolt (1920) and Ware $(1967,1969)$ have noted, 1t was thought tor years that there was but one terete and linear-leaved tametlower in the southeastern U.S. east of the Mississippi, and that was called $\underline{T}$. teretifolium. Wolt discovered two more in Alabama (192U et al), and Ware a third (1967). T. mengesii Wolf stands out from all thése in its larger tlowers, In having more stamens (40-100), 
and in having the longest style exsertion (often half again longer than the tilaments). The style apex in this species is lobeless, only the capitate stigma being lobed. Nearest it in tlower size and overlapping in stamen number and stylar character is 1 . calcaricum ware, but this species is a calciphlle, 1 ts sepals persist on the Iruit, its seeds at maturity are grayish, du11, rather than nearly black and lustrous. Ut the characters used by wolf and Ware, stylar length appears to be the most troublesome and variable, in that in 'T. mengesii the style may in some cases so short as barely to be exserted, thus in this regard overlapping 1 . calcaricum. (1t $1 \mathrm{~s}$ suggested that tlowers of each species be pressed in the field so as best to preserve the most critical characters; many collections have not been made this way, and are virtually useless for critical comparison!)

Habitat and Management Implication:

'L' mengesii is locally abundant on and around acidic rock outcrops such as granites and sandstones. lhese outcrops, where soil can accumulate to depths to support torest, produce an oak-hickorypine type, the oaks being mostly upland species (except where streams cut through) such as Quercus falcata, $\underline{Y}$. coccinea,, . marilandica, $Q$. stellata, Q. Margaretta,Q. rubra, $\underline{\text { P. prinus, }}$ sometimes in the riedmont $\underline{Q}$. Georgiana, the hickories mostly carya

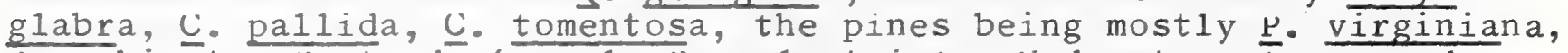

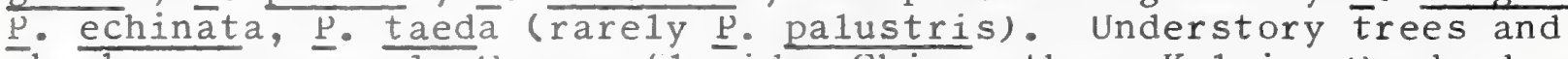
shrubs are commonly Cornus tlorida, Chionanthus, Kalmia, Uxydendrum, vaccinium (high and low bush), Rhus; smilax and poison-ivy, Gelsemium, Anisostichus, parthenocissus, vitis, Lonicera abound. Herbaceous associates are typical of perennial and annual pioneers ot granite and sandstone, such as, bryophytes, lichens, selaginella, panicum, Agrostis, Andropogon, Ligitaria, sprobolus, Bulbostylis, Fimbristylis, Juncus, Allium, rolygonum tenue, Lrotonopsis, Hypericum gentianoides, Uenothera, Liatris microcephaia, Loreopsis, many Aster, Solidago, Viguieria (in piedmont and Blue Ridge),etc. The Talinum is tound in tuli sun or light shade, roots in cracks in rock or in areas sueh as shallow drying pools on the rock or around it, anyplace where shallow inwash or outwas accumulates in tull sun. As soil depth increases and as woody plants move in, the herbaceous plants lose ground, are tinaliy eliminated. As in the case of other granite and sandstone glade plants the openings are maintained through tire or erosion, closed through invasion by trees, shrubs and shade tolerant perennials. 'his habitat is damaged or destroyed by quarrying of the rock, by development of outcrop areas tor residential, recreational or industrial use. Logging of the rather low quality torest on or around such glades may have comparatively light impact. conversion of outcrop areas to pasture has a negative etfect, in that livestock tend to trample and crop the plants around the temporary pools. The same trampling etfect can be gotten in some parks, when hiking or motorized vehicles are allowed on the sensitive areas.

References: 
Smal1, J.K. 1433. Manua1 of the southeastern IIora, pp. 493-494.

Ware, Stewart. 1969. On the ecologv of llalinum mengesii (rortulacaceae). Bu11. Torr。Bot。Ciub y6 (1): 4-1U.

Wolf, W. 1920. Notes on Alabama plants. Am. Mid1. Nat. 6 (8): 151-155. 
SPECIES: l'alinum mengesii W. Wolf

\begin{tabular}{|c|c|c|c|c|c|c|c|c|}
\hline $\begin{array}{l}\text { Expected } \\
\text { Effect on } \\
\text { Hab1tat }\end{array}$ & $\begin{array}{c}\text { Preecribo } \\
\text { Burn }\end{array}$ & $\begin{array}{l}\text { Doze or } \\
\text { Root } \\
\text { Rake }\end{array}$ & Bed & Chop & $\begin{array}{l}\text { Th1n } \\
\text { over- } \\
\text { Btory }\end{array}$ & $\begin{array}{l}\text { Cut } \\
\text { Over- } \\
\text { story }\end{array}$ & $\begin{array}{c}\text { Over Plant } \\
\text { with } \\
\text { trees } \\
\end{array}$ & Graze \\
\hline Destroy & & $\overline{N A}$ & NA & NA & & & $\mathrm{NA}$ & \\
\hline Damage & & & & & & & & $\mathrm{X}$ \\
\hline $\begin{array}{l}\text { No Lasting } \\
\text { Effect }\end{array}$ & $x$ & & & & & & & \\
\hline $\begin{array}{l}\text { Beneficlal } \\
\text { If Done } \\
\text { Properly }\end{array}$ & & & & & $\mathrm{X}$ & $\mathrm{X}$ & & \\
\hline
\end{tabular}

Other Commente:

*Est1mated effect 1 s an est1mate of the euthor based on his book knowledge of the habltat and on knowledge galned from peraonal

field observations. Estimates are "rough" in many 1nstances.

Results of practices may vary in degree of application, intensity, learuess to plant communitles, etc. A column left "blank" lndicates a lack of sufficient information from which to predict expected results. As observations are made in the fleld by users of the data, predictions should be refined by area and by intensity of forestry practices. 
Approximate Known Range of:

Talinum mengesii W. Wolf

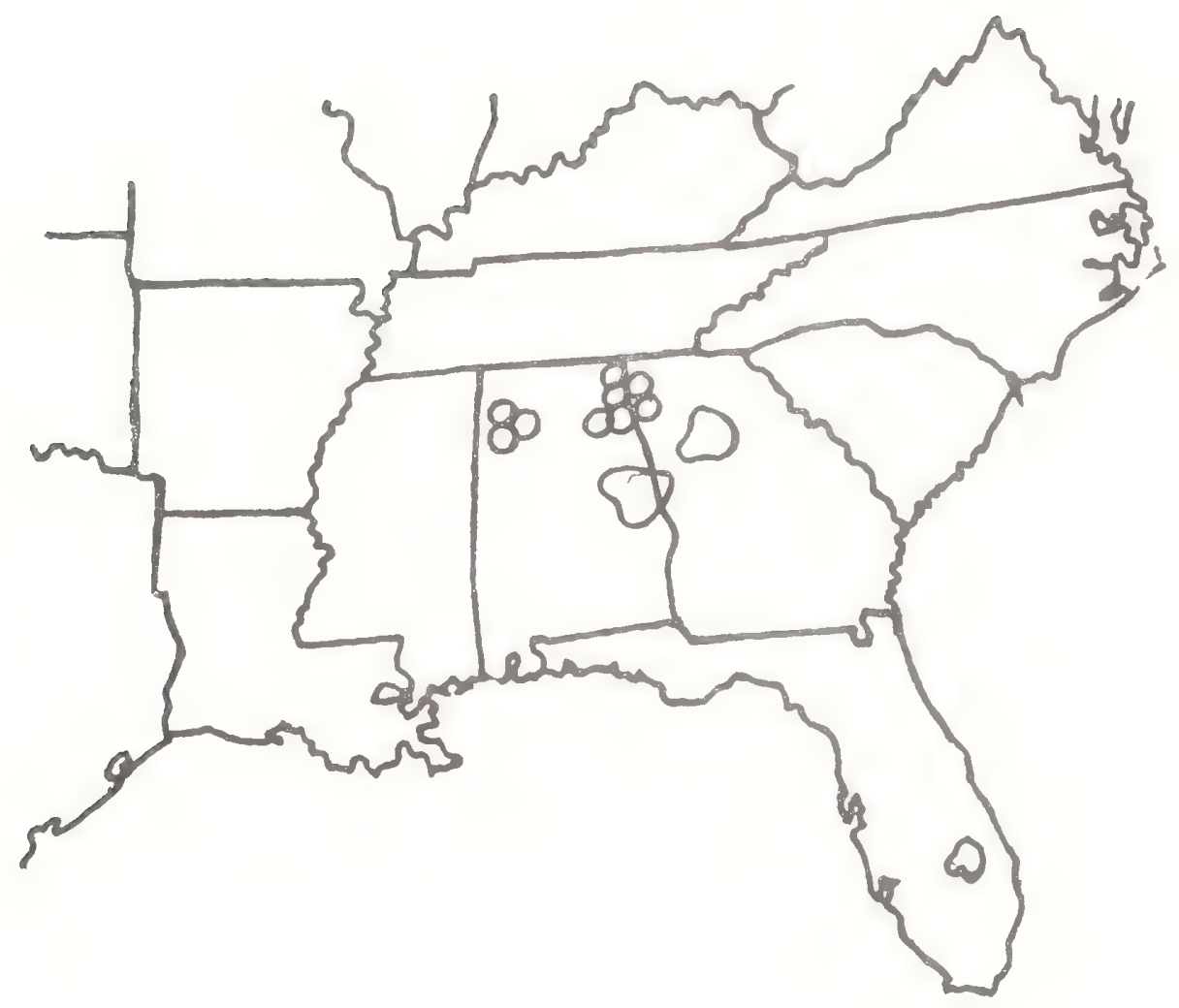


0

-

- 


\section{Lysimachia asperuliaefolia Poirett}

\section{Status: Endangered}

\section{Technical Description:}

Perennial clonalizing herb from a moderately deepset, horizontal, fleshy, terete rhizome, this elongate, ca. $5 \mathrm{~mm}$ thick, pinkish, the numerous nodes producing opposite, low triangular scales as we 11 as diffuse-fibrous roots.

Stems: erect, stiffish, terete, smoothish, mostly 3-6 dm tall, unbanched below the inflorescence, the lowest nodes approximate, the internodes progressively lengthening up the stem, below with flesh-pink tones and finely ribbed, upardiy becoming pale yellow-green and ribless, proximally smooth, distally and in inflorescence minutely stipitateglandular, the glands reddish.

Leaves: lowermost leaves orect, scaley, mostly narrowly triangular, firm, brownish, $1 \mathrm{~cm}$ or less 1 ong, in whorls of 3 , increasing in length gradualiy up to mid-stem or above, where largest, in whorls of 4, spreading, sessile or subsessile, narrowly to broadly lanceolate, 2-5 cm long, 8-20 $\mathrm{mm}$ wide, acute or acuminate, entire or slightly revolute, broadest at the rounded base, the upper surface deep yellow green, smooth, lustrous, minutely glandular-punctate, impressed veiney, the main veins subparallel, palmatemarcuate, with at least 1 strong pair of laterals, the lower surface much paler with the glandular punctations darker by contrast, smooth, the veins, particularly the midrib, strongly raised, the uppermost leaves abruptly smaller in the inflorescence, usual1y minute1y stipitate-glandular, particular1y on the veins beneath.

Inflorescence: a compact to somewhat loose, indeterminate, terminal cylindrical raceme $3-8 \mathrm{~cm}$ long of several whorls of bracts each subtending a whor 1 of as many pedicels, these spreading or ascending, slender, straight, at anthesis most1y $8-10 \mathrm{~mm} 1 \mathrm{ong}$, pale green, stipitate-glandular-puberulent.

Flowers: bisexual, regular, showy; sepals spreading, narrowly triangular, to $5 \mathrm{~mm}$ long, green strongly dotted with large red glands, narrowly acute, apically ciliate with stipitate glands, parallel-nerved, the surfaces smooth; petals 5, joined only at very base into a short, broad tube, the spreading lobes mostly oblanceolate or spatulate, ca. $1 \mathrm{~cm}$ long, broadly acute, the margin apically erose or ragged, the lower margin entire, the base cuneate, the marginal area on both sides stipitate-glandular with yellow glands, the surface a bright, deep butter yellow, medially with a zone of sma11 reddish-orange, lensw shaped mottlings (glands); stamens 5, epipetalous toward petal tube base, the filaments attached opposite corolla lobes, forming a low yellow corona ca. $2 \mathrm{~mm}$ high, its external surface pebbled with sessile yellow glands, the free filament pale yellowish, taperingminear, 3.0-3.5 mm long, erect, stipitate-yellow-glandular, the anthers lanceolate, ca. $1.5 \mathrm{~mm}$ long, orange-ye11ow, basifixed, erect, the 2 locules somewhat divergent at base; ovary superior, greenish, concealed in the staminal tube, the style elongate, narrowly lineal, tapering gradually into the simple short stigma.

Fruit: a broadly ovoid or subglobose capsule ca. $4.5 \mathrm{~mm}$ high, externally smooth, strawncolored, with red mottlings, the slender e ect style persisting, stipitate-glandular. 
Lysimachia asperulaefolia,

p. 2

Distribution and Flowering Season:

Sandy moist peat of pine flatwoods savanna and seep bogs in sandhills, very rare and local in the Coastal Plain of the Carolinas; flowering in May and June.

Special Identifying Features:

Of those southeastern Lysimachia with whorled leaves and terminal, racemose inflorescences there is but one other with which $\underline{L}$. asperulaefolia might be confused, namely L. 10omisii. The two are often found together. However, L. Ioomisii has narower leaves, these rarely reaching $8 \mathrm{~mm}$ in width, which lack the small stipitate glands found on leaves and bracts of $\underline{L}$. asperulaefolia, and which have a stronger taper at the base (those of L. asperulaefolia are broadest near the very rounded base!). The $\bar{f} 1$ owers of L. asperulaefolia are appreciably larger, with more glands on sepals and b̆oth sides of petals, these not evident or as evident in L. 1oomisii.

Habitat and Management Implication:

This is a genuinely rare and 1 ocal plant, undoubtedly endangered. It normally roots in high hydroperiod, black sandy peats such as are found either in seep bog pocosin or boggy flatwoods savanna. In varied proportion in the overstory are Pinus palustris, $\underline{\text { P. serotina, }}$ Taxodium ascendens, occasionally Chamaecyparis, mixed with such hardwoods as Nyssa biflora, Acer rubrum, Magnolia virginiana. The shrub layer is charactexized by an abundance of Ilex glabra, I. coriacea, Myrica cerifera, M. heterophylla, Persea, Cyri11a, Clethra alnifolia, together with many sorts of ericads such as (percentages vary with 1ocale) Kalmia angustifolia, many high and low-bush Vaccinium, Gaylussacia, Zenobia, Leiophylium, several Rhododendron, particular1y . at1anticum, Lyonia, Leucothoe, etc. Sphagnum and other bog bryophytes carpet the ground.

Where fire has been of common occurrence, substantial clearings dominated by grass-sedge bog communities have developed and these are suited to the Lysimachia. Frequent associates are Lycopodium, Woodwardia virginica, Osmunda, Ctenium, various Paspalum and Panicum, Andropogon, Aristida, Carex, Rhynchospora, Scirpus, Dichromena 1atifolia Xycis, Eriocaulon, Lachnocaulen, Zygadenus, Tofieldia,Aletris, Iris, Spiranthes, Pogonia, Cleistes, Sarracenia, Drosera, Dionaea, Psoralea psoralioides, various Polygala, Hypericum, Rhexia, Phlex, and bog asclepiads. Composites are many, but most1y not in flower, though Helenium, Coreopsis (falcata), Erigeron (annuus) may be present and showy.

As may be deduced from the above description of associates, L. aspeculaefolia is then a plant of highly organic, high-hydroperiod, sands and has been maintained historically through creation of area for it by periodic woods fires. It may grow for a time in savanna that is being invaded by woody species, but is ultimately crowded out unless a new burn occurs. Similarly, it will not persist in dense stands of pines or hardwoods. The few remaining known populations would best be maintained by saving them from drainage, by removal of trees with minimal damage to substrate, by periodic controlled burns. Pine plantations preceded by drainage and mechanical site 
preparation are definitely not the answer.

References:

Radford, A.E.,H.E.Ahles \& C. Ritchie Be11. 1968. Manual of the vascular flora of the Carolinas, pp. 819-823.

Sma11,J.K. 1933. Manual of the southeastern f1ora, pp. 1023-1024. 
Approximate Distribution of:

Iysimachia asperuliaefolia Poirett

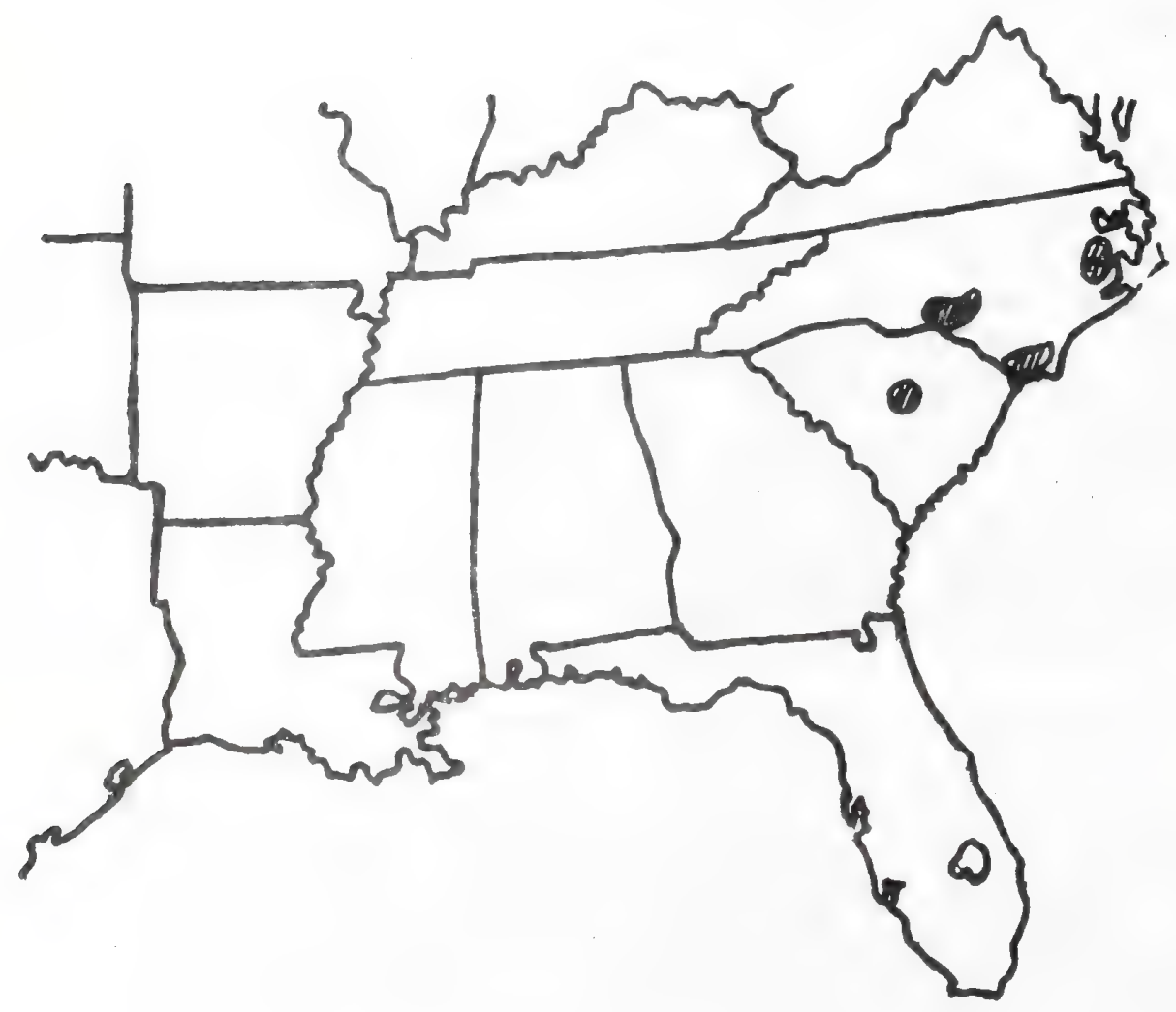




\section{Status: Threatened}

Technical Description:

Solitary or in small clumps, perennial, the stems arising from a compact, sma11, tuberous thickened caudex, increasing by imbricatescaley lateral buds, the roots diffuse-fibrous, sometimes tuberiferous.

Stems: erect or ascending, simple or fewmbranched, but usually wandlike, mostly 5-10 dm tal1, at base above thickened rootstock ca. 3-4 $\mathrm{mm}$ thick, terete, tapering gradually upward, hairy with 3 sorts of hairs, name1y scattered-hirsute, incurved-puberulent and, particularly toward base, strigose, the nodes several, approximate toward base, more distant upward on stem.

Leaves: alternate, ascending or spreading, once-odd-pinnately compound, the largest to $1 \mathrm{dm}$ long, strongly stipulate, the stipules foliaceous, broadly reniform, half-clasping the stem, strongly and saliently triangularmdentate; lowermost leaves mostly absent by flowering time, leaving only sheathes and stipules, those in lower $1 / 3$ of stem largest, grading somewhat smaller up about halfway, then more or less abruptly reduced and distant, the inflorescence axis leafless; larger blades short-petiolate, interruptedly pinnate, the leaflets mostly opposite, sometimes staggered, the larger ones to $\mathrm{ca} .2 \mathrm{~cm}$ long, the terminal slightly largest, all narrowly obovate or cuneiform, apically rounded or obtuse, strongly and salient1y triangular-dentate or serrate, the tooth tips narowly acute, often with a small tuft of long stiff hairs and somewhat recurved, the leaflet base usually broadly to narrowly cuneate, sessile, the smaller leaflets also sessile, less than $1 / 2$ as 1 ong as the larger ones, variable in outline and fewer-toothed, the upper surfaces of leaves dark yellow-green, impressed-pinnate-veiney, soft puberulent, the lower surfaces paler, strongly raised-veiney, inconspicuously sessile-glandular, scattered-pubescent, also viliose-tomentulose, the leaf rachis hairy as in stems.

Inflorescence: Racemes spikelike, rarely few-branched, usually simple, termina1, slender, the flowers numerous, the lowest, particularly in fruit, distant, but internodes shortening upward, each pedicel subtended by a sma11, chaffy-scaley, few toothed, strigose and ciliate bract. Flowers: Pedicels short, $1 \mathrm{~mm}$ long or less, jointed to and reflexed from an ascending, stiffish, apically cupuliform, scarious-bracted peduncle to ca. $3 \mathrm{~mm}$ long (shorter at anthesis), the peduncle and pedicel usually puberulont-villosulous; flowers perfect, regular, the hypanthium at anthesis broadly campanulate or turbinate, ca. 2 mm high, green, hairless, externally pebbled with round, transluscent resin-droplets, rimmed apically by many suberect, stiff, yellowish uncinate (1ike fish hooks) bristles; sepals 5, at anthesis spreading, triangular - ovate, ca. $2 \mathrm{~mm}$ long, acute, green, glabrous, the backs gland-pebbled as in hypanthium; petals 5, short-clawed, spreading, ca. 3.0 mm 1ong, e11iptic or obovate, pale ye11ow; stamens most1y 5, 
alternating with petals on hypanthial rim, the filaments pale yellow, smooth, erect, slender-tapering, ca. $2 \mathrm{~mm}$ long, terminating in a fleshy connective wider than long, the anther sacs latera1, narrowly reniform, the whole connecting with the filament to form a broadheaded "T"; ovary most1y inferior, at apex nearly even with hypanthial rim, there forming a fleshy disc concave in the middle from which arise 2 (-3) distinct, erect or slight1y divergent, short-1inear styles. Fruit: a pair of planoconvex nutlets ca.2.0-2.5 mm 1 ong, the pericarp pale brown, parchmentlike, incased in the hypanthium, this by fruiting time broadly turbinate-obovoid, ca. $2.5-3.0 \mathrm{~mm} 1 \mathrm{ong}$, the base attenuate, the rim with inwardly hooked stiffish bristles 2.0$2.5 \mathrm{~mm}$ long and capped by the persistent green convergent sepals which make a cone above the fruiting styles.

Distribution and Flowering Season:

Sandy open woodlands, dryish ravine heads, bluffs and smal1 clearings, Coastal Plain, North Carolina south to northern Florida and west into southern Mississippi; flowering in August and September.

\section{Special Identifying Features:}

This Agrimony is distinguished from the others by a combination of characters such as the small leaflets, even the terminal one at most barely exceeding $2 \mathrm{~cm}$ and the leaflet margins which are very coarsely and saliently few-toothed.

Habitat and Management Implication:

A. incisa is infrequent in sandy, usually upland woods in the Iower Coastal Plain. It appears to be always a part of the Longleaf Pinedeciduous scrub oak type, is rooted in deep dryish sands or sandy loams, usually with the overstory an open stand. Occasiona11y it will be in shade of open stands of more mesic character (i.e. Beech-Maple-Magnolia) but on $1 y$ in the ecotonal sense. Its herbaceous associates are almost consistent1y those typical of dry sandy sites, and include Aristida (mostly A. purpurascens,A. 1anosa), Andropogon, Panicum, Gymnopogon, Erianthus, Paspalum, Triplasis, Triodia (flava, caroliniana), Digitaria, Leptoloma, Cenchrus, Cyperus retrorsus, C. plukenetii, Rhynchospora grayii, Paronychia, Polgone11a,Dicerandra, several Euphorbia, Stillingia,Cnidoscolus, Croton argyranthemus, C. glandulosus, many Desmodium and Lespedeza, Stylosanthes and very many species of composites in Liatris, (particularly L. gracilis, L. tenuifolia, L. graminifolia), Heterotheca (especia11y H. trichophy11a, H. gossypina, H. graminifolia,H. adenolepis), Solidago (S. odora, S. tortifolia, S. petiolaris, S. arguta), Vernonia (particularly V. angustifolia) Silphium (S. asteriscus, S. compositum), Kuhnia, Aster (A. concolor,A. linariffolia,A. patens,etc.). All these are suggestive of the droughtyness and fire susceptibility of such sites. The shrub layer is made up of many Vaccinium, Gaylussacia, Opuntia, Poison Oak, Winged Sumac, Ceanothus, I1ex ambigua,Rubus cuneifolius, various Smilax, Crataegus uniflora, Prunus umbellata and other shrubs of dry woodlands.

This particular species has become, or seems to be, very 1 ocal 
in that much of the original Longleaf pineland has been replaced by plantation pineland. It does not appear readily to move into mechanically disturbed sites. It is a fire successional species, like many other pineland herbs increasing as a result of competition being reduced by natural woods fires.

References:

Radford, A.E.H.E. Ahles \& C. Ritchie Be11. 1968. Manual of the vascular flora of the Carolinas, pp. 455-457.

Sma11,J.K. 1933. Manua1 of the southeastern f1ora, pp.615-616. 
SPECIES: Agrimonia incisa T.\& G.

\begin{tabular}{|c|c|c|c|c|c|c|c|c|}
\hline $\begin{array}{l}\text { Expectedk } \\
\text { Effect on } \\
\text { Hab1tat }\end{array}$ & $\begin{array}{c}\text { Prescribe } \\
\text { Burn }\end{array}$ & $\begin{array}{l}\text { Doze or } \\
\text { Root } \\
\text { Rake } \\
\end{array}$ & Bed & Chop & $\begin{array}{l}\text { Thin } \\
\text { over - } \\
\text { otory }\end{array}$ & $\begin{array}{l}\text { Cut } \\
\text { Over- } \\
\text { story }\end{array}$ & $\begin{array}{c}\text { Over Plant } \\
\text { with } \\
\text { trees } \\
\end{array}$ & Graze \\
\hline Destroy & & $X$ & & $x$ & & & $X$ & \\
\hline Dawage & & & & & & & & \\
\hline $\begin{array}{l}\text { No Lasting } \\
\text { Effect }\end{array}$ & & & & & & & & \\
\hline $\begin{array}{l}\text { Beneflclal } \\
\text { If Done } \\
\text { Properly }\end{array}$ & & & & & & & & \\
\hline
\end{tabular}

Other Comments:

* Est1mated effect 18 an estimate of the author based on h1s book knowledge of the habltat and on knowledge galned from peroonal

field observations. Estimates are "rough" in many 1nstances.

Results of practices may vary in degree of application, intensity, nearness to plant communities, etc. A column left "blank" 1ndicates a lack of sufficient information from which to predict expected results. As observations are made in the field by users of the data, predictions should be refined by area and by intensity of forestry practices. 
Estimated Range of:

Agrimonia incisa T. \& G .

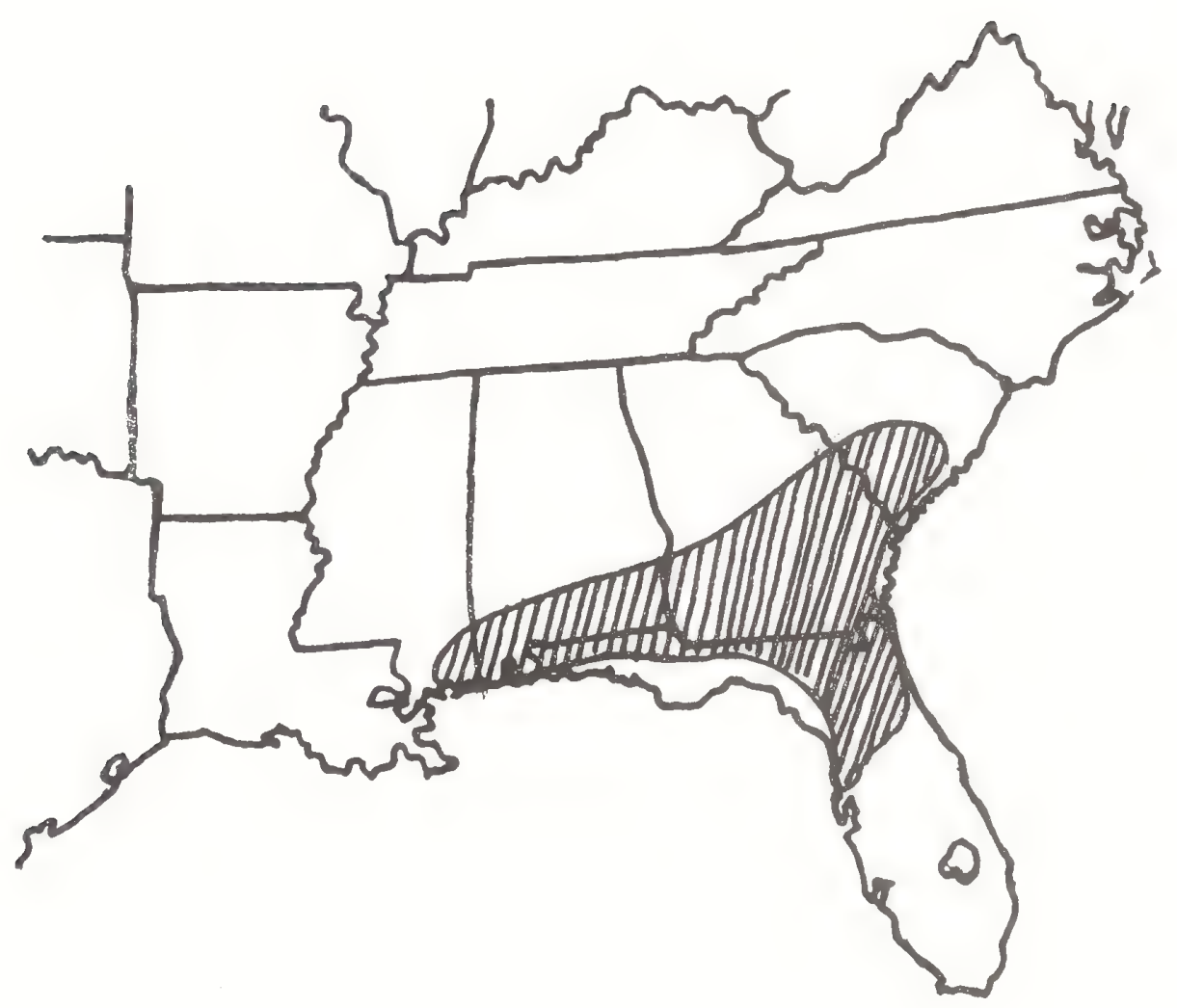


0

0

0 
Houstonia montana (Chickering) Small

Hedyotis purpurea (L.) Hook. var. montana (Chick.)Fusb.

Status: Endangered

Technica1 Description:

Perennia1, low, forming loose tufts by short, ascending leafy lateral shoots which overwinter and by slender,forking, superficial rhizomes, the roots shallow, diffuse-fibrous.

Stems: very slender, but stiffish, the bases decumbent, often rooting at lower nodes, erect or spreading above, most1y $1.0-1.5$ $\mathrm{dm}$ long $(-2.0 \mathrm{dm})$, some strict, some few-branched, branching from mid and upper nodes and fertile, some sterile,bearing only leaves; main axis ca. $1 \mathrm{~mm}$ thick, subquadrate, the angles narrowly winged or sharp, smooth, deep green or tinged with purple, the nodes close proximal1y, few and well separate at mid-stem, close in the influrescence.

Leaves: opposite, decussate, stipulate, the stipules scarious, triangular, the blades most1y elliptical, narrowly ovate or broadly lanceolate, firm, spreading, sessile or short-petiolate, the larger blades $1.5-2.0 \mathrm{~cm}$ long, apically narrowly rounded, obtuse or broadly acute, the margins entire, minutely ciliate-scabrid, the base rounded or cuneate, then abruptly attenuate (1owermost leaves much smaller, mostly spatulate, mostly withered by anthesis). Upper bracteal leaves usually not much reduced and often partly concealing the inflorescences. Surface above deep green, papillate, only the midnerve evident, the lower surface smooth, pale green. Inflorescence: terminal, either a single 3-flowered subsessile cyme or with the lateral branches terminating in similar cymes, in any case few flowered, and the the inflorescence base often concealed by bracteal leaves.

Flowers: bisexual, regular, the sepals 5, united at base to form a campanulate tube ca. $1.5 \mathrm{~mm}$ high, the ascending lobes oblong, ca. 2.0-2.5 mm long, acute, entire, the surface pale green; corolla 5-parted, salverform, a lively pale but bright purple, the narrowly funnelform throat to $8 \mathrm{~mm}$ long, the slightly spreading limb with lobes triangular, ca. $5 \mathrm{~mm}$ long, the surface externally smooth, internally with lobes pilosulous with smal, pale, soft, short, sharp-tipped or claviform purple-tipped hairs, the tube simply pale-pilosulous; stamens 5, alternating with the corolla lobes, epipetalous, the purplish slender filaments arising just under the lobe sinuses and arching slight1y inward, 0.5-0.7 mm 1ong, the anthers linear-excurved, extrorse, ca. $1 \mathrm{~mm}$ long, pale blue; ovary bicardellate, half-inferior, smooth, the slender terminal style reaching barely midway up the corolla tube, its stigma capitate, papillose.

Pruit: capsule very broadly obovoid, nearly as wide as long, slightly compressed, bilobate, emarginate, ca. $3 \mathrm{~mm} \mathrm{high,} \mathrm{about} 2 / 3$ covered by the tube of the persisting calyx, the cyme and fruit stalks somewhat elongating as fruit matures; seeds numerous, axile, irregularly blocky-angulate, pebbled, nearly black.

Distribution and Flowering Season: 
Moist granitic summit elevations, cliffs and bluffs, Blue Ridge, Roan Mountain, North Carolina (and Tennessee?); flowering mostly in Ju1y and ear1y August.

\section{Special Identifying Features:}

Conventional treatments of this genus whether it be called Houstonia or Hedyotis have $\underline{H}$. montana as a variety of $\underline{H}$. purpurea. Yet,

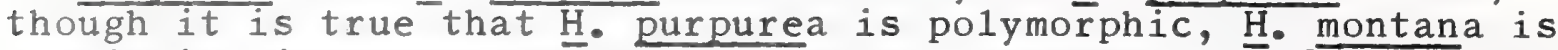
so distinctive as to cause any observer who has much familiarity with the range of variation of $H$. purpurea to reconsider the taxonomy. H. purpurea in al1 its forms is taller, has either longer or broader leaves (or both!), has a much more floriferous inflorescence and much smaller flowers (corollas rare1y much over $7 \mathrm{~mm}$ long), the sepals of which are narrower. H. purpurea proper is often found at high elevations in the Blue Ridge, even around some high baids, and yet retains characters distinct from the Roan Mountain endemic.

Habitat and Management Implications:

H. montana is indeed a very rare herb! It is presently known only from the North Carolina side of Roan Mountain and is scarce there. The ideal habitat appears to be a mossmsedge-grass mantle that carpets a thin, moist to wettish, black humified fine sand over outcrops of granitic rock, steep slopes and bluff ledges, or the rocky detritus around outcrops. Its herbaceous associates are mostly high mountain carices and grasses, with Houstonia serpyl1ifolia, Potentilla tridentata, Saxifraga michauxii,Heuchera villosa,Geum radiatum, Gentiana, sometimes the rare Solidago spithamea, and various ferns and fern al1ies. Sometimes it may be found in areas of grass bald where Alnus, Rhododendron, Leiophy11um and other heaths are invading, and doubtlessly it then gives way to shade and root competition. The best chance of finding it is to pick one's way along the narrow ledges of steep, moist bluffs along the spruce-fir summit ridges. In such places it has its least danger of being trampled by hikers or swamped by invading woody vegetation. Pactors for its continuance are much the same as for Geum radiatum. It needs sma11, coo1, moist cleared areas. Where these are too level or have deeper soil layer, successional pressure is toward woody invaders unless some factor such as clearing or burning maintains the openings. Where the country is steepest, it may be lost through rockslide or slipping of soil mantles, but these forces also create new area for it to occupy. Fortunately the known small populations are on public parkland, and some are harboring in areas too steep or risky for most people to tread.

\section{References:}

Fosberg, R. 1954. Notes on plants of the eastern United States. Castanea 19: 25-37.

Sma11, J.K. 1903. F1ora of the southeastern United States, 1325,1338. 1933. Manual of the southeastern flora, pp.1253-1256. 
SPECIES: Houstonia montana (Chickering) Sma11

\begin{tabular}{|c|c|c|c|c|c|c|c|c|}
\hline $\begin{array}{l}\text { Expected } \\
\text { Effect on } \\
\text { Hab1tat }\end{array}$ & $\begin{array}{c}\text { Prescribe } \\
\text { Burn } \\
\end{array}$ & $\begin{array}{l}\text { Doze or } \\
\text { Root } \\
\text { Rake } \\
\end{array}$ & Bed & Chop & $\begin{array}{l}\text { Th1n } \\
\text { over } \\
\text { story }\end{array}$ & $\begin{array}{l}\text { Cut } \\
\text { Over- } \\
\text { Story } \\
\end{array}$ & $\begin{array}{c}\text { Over Plant } \\
\text { w } 1 \text { th } \\
\text { trees }\end{array}$ & Graze \\
\hline Destroy & & & & & & & & \\
\hline Damage & & & & & & & & \\
\hline $\begin{array}{l}\text { No Lasting } \\
\text { Effect }\end{array}$ & & & $7 \mathrm{Y}$ & 787 & & & & \\
\hline $\begin{array}{l}\text { Beneficial } \\
\text { If Done } \\
\text { Properly }\end{array}$ & & & & & & & & \\
\hline
\end{tabular}

Other Coments:

* Est1mated effect 18 an est1mate of the author based on h1s book knowledge of the habltat and on knowledge galned from personal field observations. Estimates are "rough". In many instances. Results of practices may vary in degree of application, intensity, nearness to plant communties, etc. A column left "blank" indicates a lack of sufficient information from which to predict expected results. As observations are made in the fleld by users of the data, predictions should be refined by area and by intensity of forestry practices. 
Houstonia montana (Chickering) Sma 11

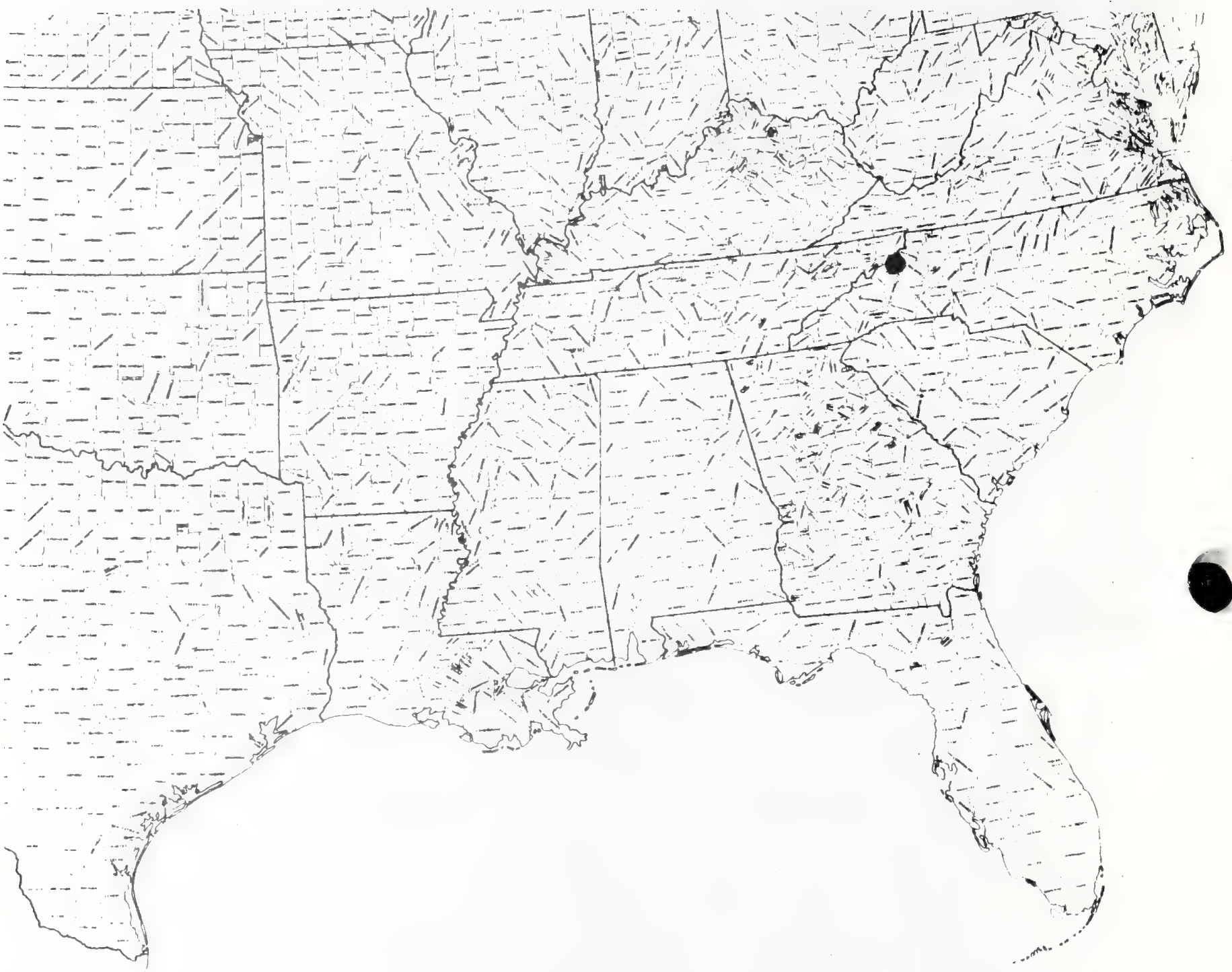


Agalinis pseudaphy11a(Penne11) Penne11

Gerardia pseudaphy 11 a penne11

Agalinis oligophylla var. pseudaphylla (Pennel1)Pennell

status: Threatened

Technical Description:

Annual, root-parasitic, 4-7 dm tal1, the shallow roots sparse, slender, fibrous.

Stems: erect or ascending, usually single from the rootstock,branching abundantly at or above middle to form a broad crown of arching, ascending to spreading, elongate, slender but brittle branches, the main axis subterete, decurrently low-wire-ridged below the scattered nodes, dul1 green, papillose, the slender, usually opposite, branches arching upward or outward, often purple-tinged, prominent1y ribbed and grooved, the ribs scabrid.

Leaves: acicular, sma11, the largest usually $5 \mathrm{~mm}$ or less 1 ong, spreading-ascending, fleshy, alternate, less often subopposite, most1y distant along stem (the lowest absent by anthesis), in intlorescence branches becoming very short and in cross section angulate, the surfaces dull green, scabrid. Inflorescence: a compound of racemes, these developing flowers and/or branchlets most1y in the distal 1/2, the flowers severa1-to-many either on simple short pedicels or short, few-tlowered branchlets, each pedicel or branchlet subtended by a single ascending or erect bractlet $3 \mathrm{~mm}$ long or shorter.

Flowers: bisexual, the calyx regular, the corolla slightly irregular, the pedicels slender, stiffly spreading ascending, most $1 \mathrm{y} 3-5 \mathrm{~mm}$ long (be sure to check "longer" pedicels as these may, by jointing, showy that they are actually short branches!), otten reddish-tinged, smooth, teretish or slightly angulate; calyx broadly campanulate, at anthesis ca. $2.5 \mathrm{~mm}$ high, thin, faintly veiney, the rim entire, subscarious, bearing externally just below its edge 5, equidistant, callus-1ike, bristly scabrid, narrow and low-conical teeth, these $0.2 \mathrm{~mm}$ long or less; corolla showy, trom base to tip of lower lobes ca. $2 \mathrm{~cm}$ long, the short tube flaring abruptly to the funnelform throat, the throat rim oblique (throat longer on the lower side), the limb ca. $2 \mathrm{~cm}$ across, the 5 lobes suborbicular or broader than long, broadly rounded or apically somewhat truncated, erose, ciliate, equally spreading but on an oblique plane, the external surface pale pink, smooth, grading downward to more yellow-tinged and minutely puberulent, internally with lobes pink, smooth, the throat from base of lobes downward becoming villous with 1ong, slender purplish hairs and more yellowish, usually with 2 strong yellowish bands anteriorally (on lower side as flower is oriented); stamens 4, epipetalous, didynamous ( 2 pairs set at 2 different levels), the slender filaments filiform, slightly to shaggy-villous, purplish, the anthers suberect but dorsifixed, pale yellow, ca. $2 \mathrm{~mm}$ long, elliptic-oblong, shaggy-white villous on the backs, each locule horned at the base; ovary superior, narrowly ovoid, shorter than the calyx rim, bicarpellate, the slender style ca. $1 \mathrm{~cm}$ long, the 2 linear, erect stigmas ca. $1-3 \mathrm{~mm}$ long.

Fruit: Capsule at maturity subglobose, ca. $4.5 \mathrm{~mm} 1 \mathrm{ong}, 1 / 2$ or 
less its length included by the persistent calyx, smooth, pale brown; seeds numerous, ca. $1 \mathrm{~mm}$ long, somewhat compressed, wedgeshaped, strongly reticulate with sharp, thin, raised ridges, a pale lustrous brown.

Distribution and Flowering Season:

Moist acidic pine flatwoods or savannas, hardwood flats, coasta1 Plain and Interior Low Plateau, southern Mississippi, middle Alabama, the H1ghland Rim of middle Tennessee; flowering from September into October.

\section{Special Identifying Peatures:}

This is a difficult genus, as yet unsolved for the southeastern U.S. However, the only species in our area that combine a fairly tall stature with reduced, linear-acicular leaves and very small (callose) calyx lobes are A. microphy11a, A. aphy11a and A. pseudaphy11a. Ihe first has longer calyx Iobes and $1 / 2$ or more of its ripe capsule is enclosed by calyx tube. A. pseudaphylla and A. aphy1la differ (perhaps only varieta11y!) in that the former has narrower and at the same time longer, more spreading leaves (3-6 mm versus $1-3 \mathrm{~mm}$, narrowly linear-triangular versus scale-1ike) and longer pedicels (3-6 mm versus $1-3 \mathrm{~mm}$ ).

Habitat and Management Implications:

Given that the same entity is involved throughout the stated range, the habitat of A. pseudaphylla includes a wide variety of site conditions. The problem is that one set of specimens has been gotten from Sumter County, Alabama, in what is known as blackbe1t prairie, which in that area is a heavy clay over lying chalk and is probably at least circumneutral. On the other hand the type locality, near Biloxi,Mississippi, is, or was, presumably flatwoods-savanna, moist, sandy-peaty, and quite acidic. This 1ast is the sort of situation found for plants in Tennessee referable to the species, even though Penne11 (1935) did not indiacate that the range of $A$. pseudaphy11a includes Tennessee. The southern Mississippi populations are found in Longleaf Pine-GallberryTiti-Vaccinium tormations where fire and other disturbance has greated grass-sedge openings. The Tennessee localities are homogeneously "oak-barren", again savannalike, relatively level, underlain by hardpan and frequently quite moist. These places also have a history of fire, this increasing the spacing of trees, and allowing a grass-sedge assemblage to develop, this savanna having a lower Coastal Plain character but with no pines. Instead the overstory is largely oak-hickory, with the major species being Quercus phellos, Q. nigra, $\mathrm{Q}$. falcata, $\mathrm{Q}$. stellata, $\mathrm{Q}$. alba, Carya tomentosa, $\underline{\mathrm{C}}$. glabra,Acer rubrum, Liquidambar, Liriodendron. The shrub cover is a mixture of Vaccinium (high and low bush), Rhododendron canescens, Dwarf Willow, Viburnum, Rhus, Spiraea tomentosa, Crataegus, Aronia, etc. The more open sites in which the Agalinis is local are, during its anthesis, Andropogon virginicus-A. elliottii-A. scopariusA. glomeratus-A. gerardi-Sorghastrum nutanstPanicum virgatum-P. anceps-Chasmanthium 1axum \& sessilif 1 orum-Gymnopogon-Paspalum 1 aeveP. floridanum-Aristi da-Carex glaucescens and other carices-Rhynchospora capitellata-R. Eorniculata-Fimbristylis puberulamXyris torta several orchids, particularly Spiranthes, Habenaria, Linum, many Polygala, 


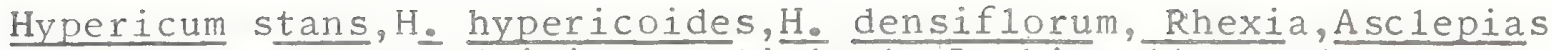
hirtella, several Ludwigia, particlarly L. hirtella, and a large number of composites including Silphium mohrii, S. terebinthinaceum, Helianthus angustifolius, Parthenium integrifolium, Vernonia, several Eupatorium, Liatris spicata, L. earlei, Bidens, Coreopsis tripteris, many Aster. Other Agalinis may be abundant, these mainly . tenuifolia, A. obtus $\overline{i f o l i a, ~ A . ~ d e c e m l o b a, ~ A . ~ p u r p u r e a, ~}$ A. virgāta. The greatést threat to midile Tennessee populations comes from clearing and draining of the oak barrens either for real estate or for improved pasture or row crop agriculture.

Habitat in the Gulf South is, in addition to having the problems mentioned above, much of it converted by way of drainage and mechanical site preparation for Slash Pine. Any mechanical site preparation involves radical disturbance of the grass-sedge system that this Agalinis is an integral part of. Protection of these areas from fire ultimately causes another problem, with shrubs and trees increasingly taking over.

References:

Penne11, F.W. 1935. The Scrophulariaceae of eastern temperate North America. Acad. Nat. Sci. Phila. Monogr. 1: 453-456.

Sma11,J.K. 1933. Manual of the southeastern flora, pp. 1216-1221. 
SPECIES: Agalinis pseudaphy11a (Penne11) Penne11

\begin{tabular}{|c|c|c|c|c|c|c|c|c|}
\hline $\begin{array}{l}\text { Expectedh } \\
\text { Effect on } \\
\text { Habltat }\end{array}$ & $\begin{array}{c}\text { Preocribe } \\
\text { Burn } \\
\end{array}$ & $\begin{array}{l}\text { Doze or } \\
\text { Root } \\
\text { Rake }\end{array}$ & Bed & Chop & $\begin{array}{l}\text { Thin } \\
\text { over- } \\
\text { otory }\end{array}$ & $\begin{array}{l}\text { Cut } \\
\text { Over- } \\
\text { Story }\end{array}$ & $\begin{array}{c}\text { Over Plant } \\
\text { wth } \\
\text { trees } \\
\end{array}$ & Graze \\
\hline Descroy & & $\bar{X}$ & & $\mathrm{X}$ & & & $\mathrm{X}$ & \\
\hline Damage & & & $X$ & & & & & $X$ \\
\hline $\begin{array}{l}\text { No Lasting } \\
\text { Effect }\end{array}$ & & & & & & & & \\
\hline $\begin{array}{l}\text { Benef } 1 \text { c1al } \\
\text { If Done } \\
\text { Properly }\end{array}$ & $\mathrm{X}$ & & & & $X$ & $X$ & & \\
\hline
\end{tabular}

Other Commente: Drainage is a major problem!

*Eatimated effect 18 an eBtimate of the author based on h1 book knowledge of the habltat and on knowledge galned from peroonal field observations. Estimates are "rough" in many instances. Results of practices may vary in degree of application, Intensity, nearness to plant communties, etc. A column left "blank" Indicates a lack of sufficient information from which to predict expected results. As observations are made 1 n the fleld by users of the data, predictions should be refined by area and by intensity of forestry practices. 
Distribution of:

Agalinis pseudaphy11a (Penne11) Penne11

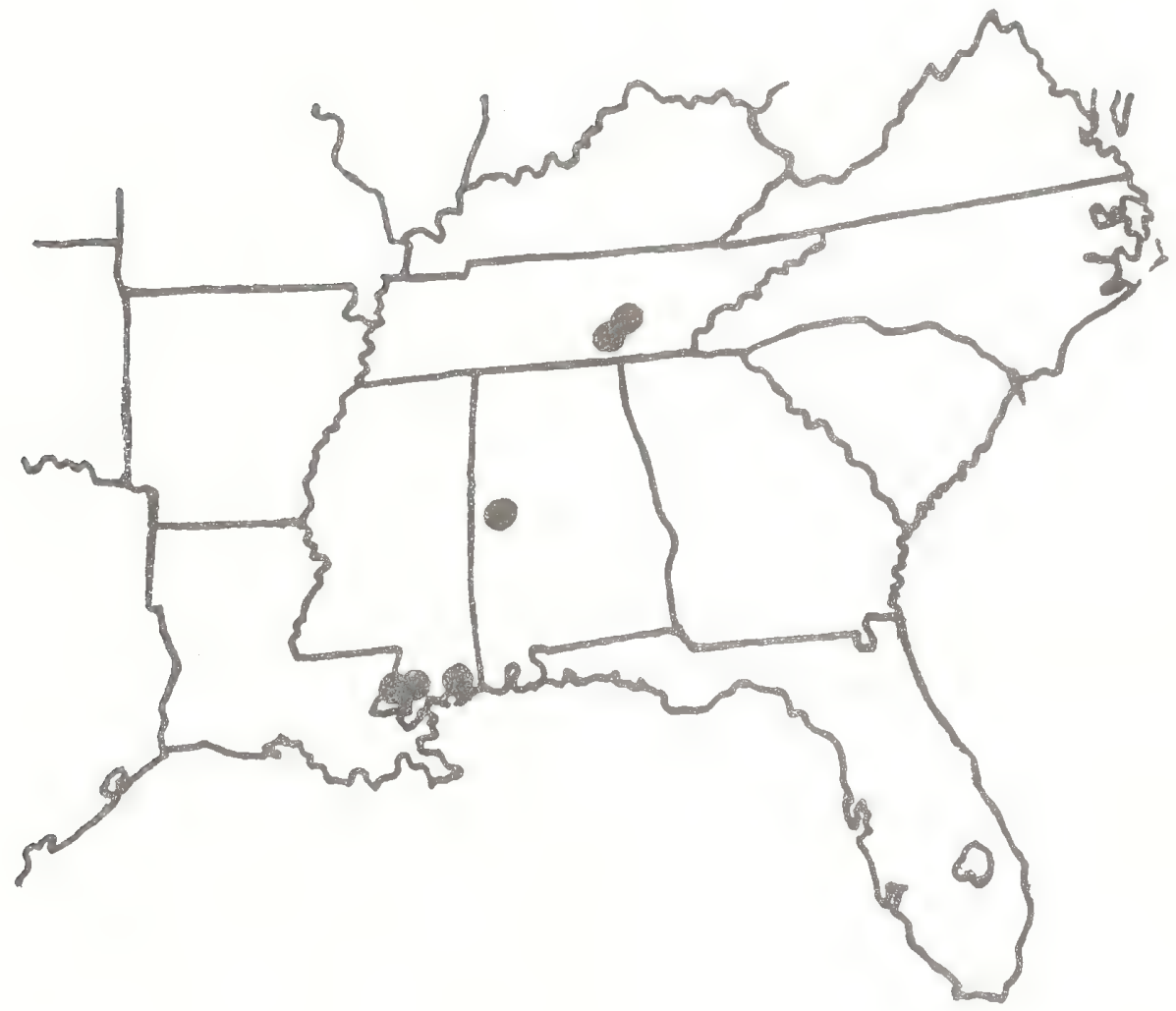


6

-

0 


\section{Aureolaria patula (Chapm.) Penneli}

Dasystoma patula Chapm.

Gerardia patula (Chapm.) Gray

Status: Threatened

lechnical Description:

Rather coarse perennial, root-parasitic, False-foxglove, trom stout $\rightarrow$ branched, though shallow, roots.

Stems: erect to decumbent, usually several from rootstock in older plants and spreading out, leaning or prostrate as season advances, to $12 \mathrm{dm}$ long, terete, with 1 ow ridges below petioles proxima11y, and dul1 green, dista11y sub-quadrate and tinged with red or maroon, sparsely puberulent, the branching sparse or absent below the inflorescence, within the inflorescence opposite and sometimes from every node. Leaves: opposite, estipulate, the largest produced in tufts of rosettes in spring, these and lower stem leaves usually absent by anthesis, the largest persistent leaves lowest, to $2 \mathrm{dm}$ long, the blades ovate or lance-ovate, strongly incised-pinnatifid, the deepest lobes lowest, themelves pinnately lobed or at least coarsely triangulartoothed, the base hastate or truncate or abruptly attenuated, forming a wing on most of the petiole, the surface above dull yellow-green, smooth except for a puberulence along the impressed midrib, the lower surface raised-reticulate, paler yellow-green, sparsely puberulent, particularly on the veins, the blades progressively shortening and shorter petiolate upward on stem and branches, becoming mostly lanceolate, entire, serrate or serrulate, sessile in the intlorescence. Inflorescence: a compound, oppositely branched system of racemes, the slender but stiffish pedicels most $1 \mathrm{y} 1.2-2.5 \mathrm{~cm} 1 \mathrm{ong}$, dense1y to sparsely puberulent, usually reddish-tinted, arching upward, thus the flowers erect or spreading on the branch. Flowers: bisexual, somewhat zygomorphic, showy, the sepals 5, united below into a campanulate tube $3-5 \mathrm{~mm}$ long, the lobes narrowly linear-triangular, subequal, slightly venose, $4-7 \mathrm{~mm} 1 \mathrm{ong}$, the whole surface externally puberulent, green, the inner face of the lobes puberulent; corolla butter-yel1ow, $3.0-3.5 \mathrm{~cm}$ long, the short tube expanding in funnelform fashion, the lobes 5, somewhat spreading, suborbicular, the upper 2 slightly larger, ca. $1 \mathrm{~cm}$ long, the lower 3 slightly more spreading, all somewhat ciliate, the surface externally smooth, internally villous, particularly toward the base; fertile stamens 4, didynamous, attached near corolla base, the longer pair ca. $2 \mathrm{~cm}$ long, the shorter pair ca. $1.5 \mathrm{~cm} 10 n g$, the slender filaments villous, arching up under the upper throat, the anthers ellipsoidal, dorsifixed, ca. $4 \mathrm{~mm}$ long, externally villous-hirsute, each locule bearing proximally a sharp narrow horn ca. $1 \mathrm{~mm}$ long; ovary superior, bicarpellate, ellipsoidal, smooth, the numerous ovules with axile placentation, the slender style arching up under the upper (dorsal) side of the corolla and terminating in an erect pair of short-linear, laminar stigmas presented slightly beyond the level of the longer stamens. 
Fruit: Capsule ovoid, 5-6 mm 1ong, smooth; seeds curvate-angulate, to $2.5 \mathrm{~mm}$ long, brown, reticulate.

Distribution and F1owering Season:

Calcareous river and creek bluffs and cliffs, middle Kentucky southward into middle Tennessee and northwestern Georgia; flowering from August to frost.

Special Identifying Features:

This False-foxglove is in subgenus Aureolaria (Euaureolaria Penne11), distinguishable trom subgenus Panctenis by having at least narrowly winged seed, an e-glandular capsule, an externally smooth corolla and a perennial habit. It is distinguished from the seven other species of subgenus Aureolaria by a combination of puberulent stem and pedicels, puberulent, entire calyx lobes. This combination would place it nearest $A$. dispersa, a Coastal Plain species, from which A. patula is distinguished by its 1onger (15-2s mm versus $8 \mathrm{~m} 10 \mathrm{~mm}$ ) pedicels, its longer, narrower calyx lobes, its smaller (35-45 mm long versus $40-50 \mathrm{~mm}$ long) corollas. The tlowering branches are usually strongly spreading (erect on prostrate stems), slender but stiffish, the numerous nodes with spreading, subequal lanceolate bract pairs, at anthesis sometimes quite showy with double rows of fine yellow blooms.

Habitat and Management Implications:

A. patula appears to be genuinely narrow in range and rather rare within that range, w1th certain and recent sightings being made from along the bluffs of the Tennessee and Clinch Rivers and tributaries in the Valley and Ridge Province of eastern Tennessee and along the Coosa River in northwestern Georgia near Rome ( the type locality). Dr. Leo Collins has recently located several smal1 populations in the area of Kingston, Tennessee, along river bluffs, and may be the only living botanist to have seen much of the species. My own experience with it is from but two areas, one near Kingston, the other from bluffs of the Coosa River near Rome.

'I'his species appears to be a calciphile, is reportedly root-parasitic on oaks. It is generally found on steep limestone bluffs, in the shade of rather open stands of mixed hardwoods and occasional Juniperus. The soil is heavy, often shallow. Commonest overstory trees are Quercus muhlenbergii, Q. alba, Q. shumardii, Acer saccharum, Fraxinus guadrangulata, F. americana, U1mus americana, U. rubra,

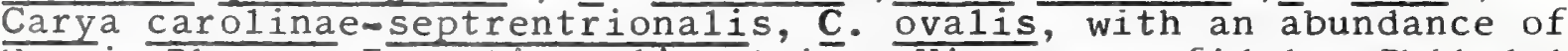
Cercis, Rhamnus, Forestiera 1igustriña, Viburnum rufidulum, Philadelphus, Rhus spp. in the understory. Common herbaceous associates are Chasmanthium latifolium, Melica,Bromus purgans, Elymus, various calciphilic carices, Anemone Virginica, Aquilegia, Galium circaezans, spigelia marilandica, Asclepias quadrifolia, Saxifraga, Heuchera viliosa, Penstemon, Solidago sphacelata, S. ulmifolia, Aster shortii, etc.

'Lhe steepness of the terrain frequented by this species precludes heavy logging. The timber is not easily accessible and any heavy removal of it would have an adverse effect in terms of erosion of the soil mantle. Recent observations of the plants appear to have it in light to fairly heavy shade thus it is likely that 
removal of overstory would, in addition to exposing this herb to too mucy light and drying, invite invasion of undesireable woody and herbaceous weeds such as Smilax, Lonicera, Pueraria, Rubus.

Reterences:

Chapman, A.W. 1878. Dasystoma patula in Bot. Gaz. 3: 10.

Penne11, F.W. 1928. Aureolaria patula in Proc. Acad. Nat. Sci. Phila. 80: 409-410.

1935. Aureolaria in Scrophulariaceae of eastern

temperate North America. Acad. Nat. Sci. Phila. Monogr. 1: 397.

Sma11,J.K. 1933. Manual of the southeastern f1ora, pp. 1213-1216. 
SPECIES: Aureolaria patula (Chapm.) Pennell

\begin{tabular}{|c|c|c|c|c|c|c|c|c|}
\hline $\begin{array}{l}\text { Expected } \\
\text { Effect on } \\
\text { Habltat }\end{array}$ & $\begin{array}{c}\text { Preocribo } \\
\text { Burn }\end{array}$ & $\begin{array}{l}\text { Doze or } \\
\text { Root } \\
\text { Rake }\end{array}$ & Bed & Chop & $\begin{array}{l}\text { Th1n } \\
\text { Over- } \\
\text { Btory }\end{array}$ & $\begin{array}{l}\text { Cut } \\
\text { Over- } \\
\text { Story }\end{array}$ & $\begin{array}{c}\text { Over Plant } \\
\text { with } \\
\text { trees } \\
\end{array}$ & Graze \\
\hline Deatroy & NA & $\mathrm{NA}$ & NA & $\mathrm{NA}$ & & $\mathrm{x}$ & NA & \\
\hline Damage & & & & & $\mathbf{x}$ & & & \\
\hline $\begin{array}{l}\text { No Lasting } \\
\text { Effact }\end{array}$ & & & & & & & & \\
\hline $\begin{array}{l}\text { Benef } 1 \text { c18l } \\
\text { If Done } \\
\text { proporly }\end{array}$ & & & & & & & & \\
\hline
\end{tabular}

Other Commenta:

* Est1mated effect 18 an est1mate of the author baed on h1. book knowledge of the habltat and on knowledge galned from personal field observations. Estlmates are "rough" 1n many 1nstances. Results of practices may vary in degree of application, intensity, nearness to plant communties, etc. A column left "blank" Indicates a lack of sufficient information from which to predict expected results. As observations are made in the fleld by users of the data, predictions should be reflned by area and by intensity of forestry practices. 
Aureolaria patula (Chapm.) Pennell

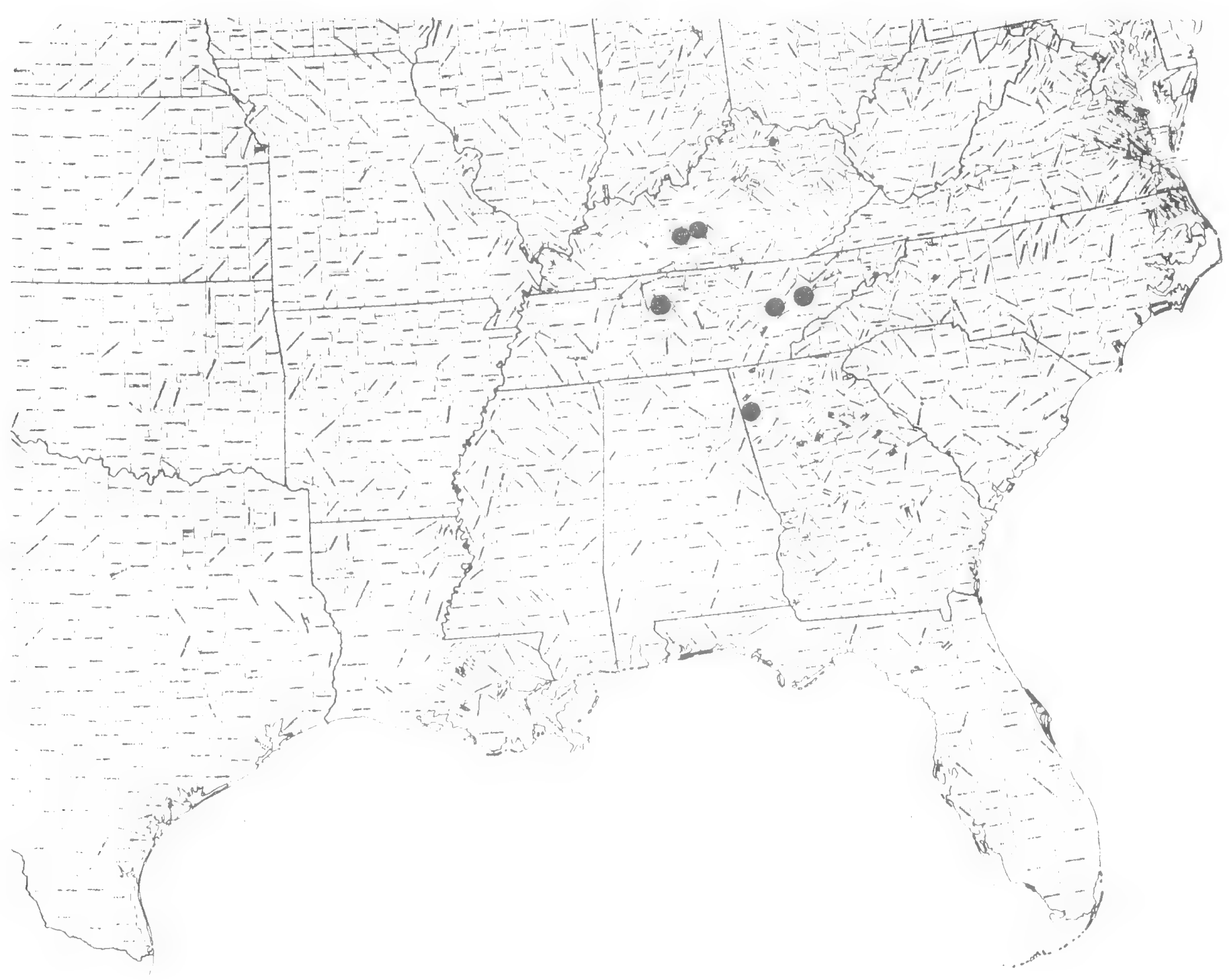


-

-

- 


\title{
SCRO PHULAR IACEAE
}

\author{
Schwalbea americana L. \\ S. austra1is Penne11
}

Status: Endangered

Technica1 Description:

Perennial, caulescent, root-parasitic herb.

Stens: erect, simple or branched only at base, rarely taller than $\overline{6 \mathrm{dm}}$, the nodes numerous, the internodes terete, villous proximally, puberulent distally, yellowmgreen tinged with red or purple distally. Leaves: alternate, estipulate, sessile, the larger sometimes spreading, but mostly al1 ascending or erect, overlapping in a tight spiral, the smallest scale-like at stem base, the largest in the lower $1 / 3$ of the stem, elliptic, lanceolate, rarely oblanceolate, mostly $2.4 \mathrm{~cm}$ long, rather fleshy, acute, entire, slightly revolute, the base cuneate, the surface yellow-green or deep dull green with reu undertones, both sides pale-villousmpuberulent, the venation sparsely pinnate, improssed above, only the midvein much raised beneath, or triplenerved; foliage leaves grading gradually smaller and narrower upward into bracteal leaves. Inflorescence: Flowers ascending, shortopedicellate from axils of leaflike bracts, in a tight, usually many-flowered, spikelike raceme, the pedice1s ca. 2.0-2.5 mm long, villosulous, apically bibracteolate, the bracteoles linear, shorter than the calyx. Flowers: bisexua1, strong1y zygomorphic; calyx $1.5-2.0 \mathrm{~cm} 10 \mathrm{ng}$, the 1obes 5, unequal, triangular, 1-nerved, shorter than the narrow1y campanulate tube and projecting forward, the upper 1ip shallow $1 \mathrm{y}$ $2-1$ obed distally, the lower 3-1obed and longest, the tube strongly 10 nerved; corolla strongly bilabiate, narrow, ca. 3 cm long, pro imally yellow, distally purplish or reddish, the lips about as long as the tube and projecting forward, the upper a galea, longer, shallowly 2 -lobed distally the lower 3-1obed and with a hairy palate inside; stamens 4, epipetalous, included in the upper lip, didynamous ( 1 pair shorter), the filaments slender, smooth, longer than the oblong, dorsifixed yellow anthers; ovary superior, erect, bicarpellate, the slender style curved up and arching within the upper corolla lip in line with the filaments, its narrow stigma protruding slightly beyond.

Fruit: Capsule mostly contained in the persistent calyx, oblongcylindrical, ca. $1 \mathrm{~cm}$ long, septicidal, its narrowed apex developing an annulus around the persistent style base; seeds numerous, pale greenish-brown, 1inear-fusiform, somewhat compressed and bordered, ca. 2.5-3.0 mm 1ong, very minutely cancellate.

Distribution and Flowering Season:

Moist pine flatwoods, savannas, bog borders, open oak woods, Coastal Plain with extensions inland in New York and in Massachusetts and the southern Appalachians, southward to northern Florida and westward into Louisiana. Rare and extremely local. Flowering in the south mostly from April into June. 
Prepared by:

Robert Kral

Schwalbea americana,p. 2

Special Identifying Features:

Chaffseed is monotypic and is, in habit and general appearance of bloom as we 11 as in its alternate leaves, most similar to other root parasites such as Castilleja, Orthocarpus, but, un1ike any of the other seven genera in the Tribe Euphrasieae that occur in eastern North America, its pedicels bear two bracteoles. Its slender seeds, as in Castilleja, Orthocarpus, have a loose and reticulate seed coat. It is the only genus in the complex that has septicidal capsule dehiscence. These plants darken in drying, as do most others of the complex.

Habitat and Management Implication:

My field observations of this rare plant are confined to but two populations in the Gulf Coastal Plain; however they appear to agree with label notes on specimens from other areas in the South. The Schwalbea plants are in grass-sedge systems, in moist acidic sandy loams or sandy peat loams. The tree-dotted landscape is best described as savanna, with higher elevations dominated by Longleaf Pine and deciduous scrub oak, the lower elevations boggy, sometimes Titi-Magnolia virginiana bays, sometimes Pond Pine-Pond Cypress-Nyssa biflora. Schwalbea is intermingled with a large variety of grasses in Andropogon, Panicum,

Aristida, Paspalum and sedges in Rhynchospora, Scieria, Dichromena, Carex, Fimbristylis. Lachnocaulon, Eriocaulon (E. decangulare), Xyris, Aletris, Calopogon, various Juncus and a variety of colorfu1 Savanna dicots such as Eryngium, Polygala, Asclepias, Phlox, Psoralea,Erigeron, Helenium, Heterotheca (H. oligantha) are common associates. The grass-sedge complexes are interrupted by stands of shrubs in Myrica, Ilex (I. glabra, I. coriacea), Cliftonia, Vaccinium, Gaylussacia, Lyonia, Leucothoe. The savanna is

fire maintained.

Such sites are well suited to plantation of Slash Pine and also are of high potential for crop agriculture. In either case they are drained and the grass-sedge system destroyed.

\section{References:}

Penne11, F.W. 1935. Scrophulariaceae of eastern temperate North America. Acad. Nat. Sci. Phil. Monogr. 1, pp. 482-487.

Radford, A.E.,H.E.Ahles \& C. Ritchie Be11. 1968. Manual of the vascular flora of the Carolinas, p. 261.

Sma11,J.K. 1933. Manual of the southeastern flora, p. 1223. 
SPECIES: Schwalbea americana L.

\begin{tabular}{|c|c|c|c|c|c|c|c|c|}
\hline $\begin{array}{l}\text { Expected } \\
\text { Effect on } \\
\text { Habltat }\end{array}$ & $\begin{array}{c}\text { Preacribe } \\
\text { Burn } \\
\end{array}$ & $\begin{array}{l}\text { Doze or } \\
\text { Root } \\
\text { Rake } \\
\end{array}$ & Bed & Chop & $\begin{array}{l}\text { Thin } \\
\text { over- } \\
\text { gtory }\end{array}$ & $\begin{array}{l}\text { Cut } \\
\text { Over- } \\
\text { Story } \\
\end{array}$ & $\begin{array}{c}\text { Over Plant } \\
\text { with } \\
\text { trees } \\
\end{array}$ & Graze \\
\hline Destroy & & $X$ & & $X$ & & & $x$ & \\
\hline Damage & & & & & & & & \\
\hline $\begin{array}{l}\text { No Lasting } \\
\text { Effect }\end{array}$ & & & & & & & & \\
\hline $\begin{array}{l}\text { Beneficlal } \\
\text { lf Done } \\
\text { Properly }\end{array}$ & & & & & & & & \\
\hline
\end{tabular}

Other Comments: Do not drain!

* Est1mated effect 18 an est1mate of the author based on his book knowledge of the habltat and on knowledge galned from personal field observations. Estimates are "rough" in many instances. Results of practices may vary in degree of application, intensity, nearness to plant communities, etc. A column left "blank" indicates a lack of sufficient information from which to predict expected results. As observations are made in the field by users of the data, predictions should be refined by area and by intensity of forestry practices. 


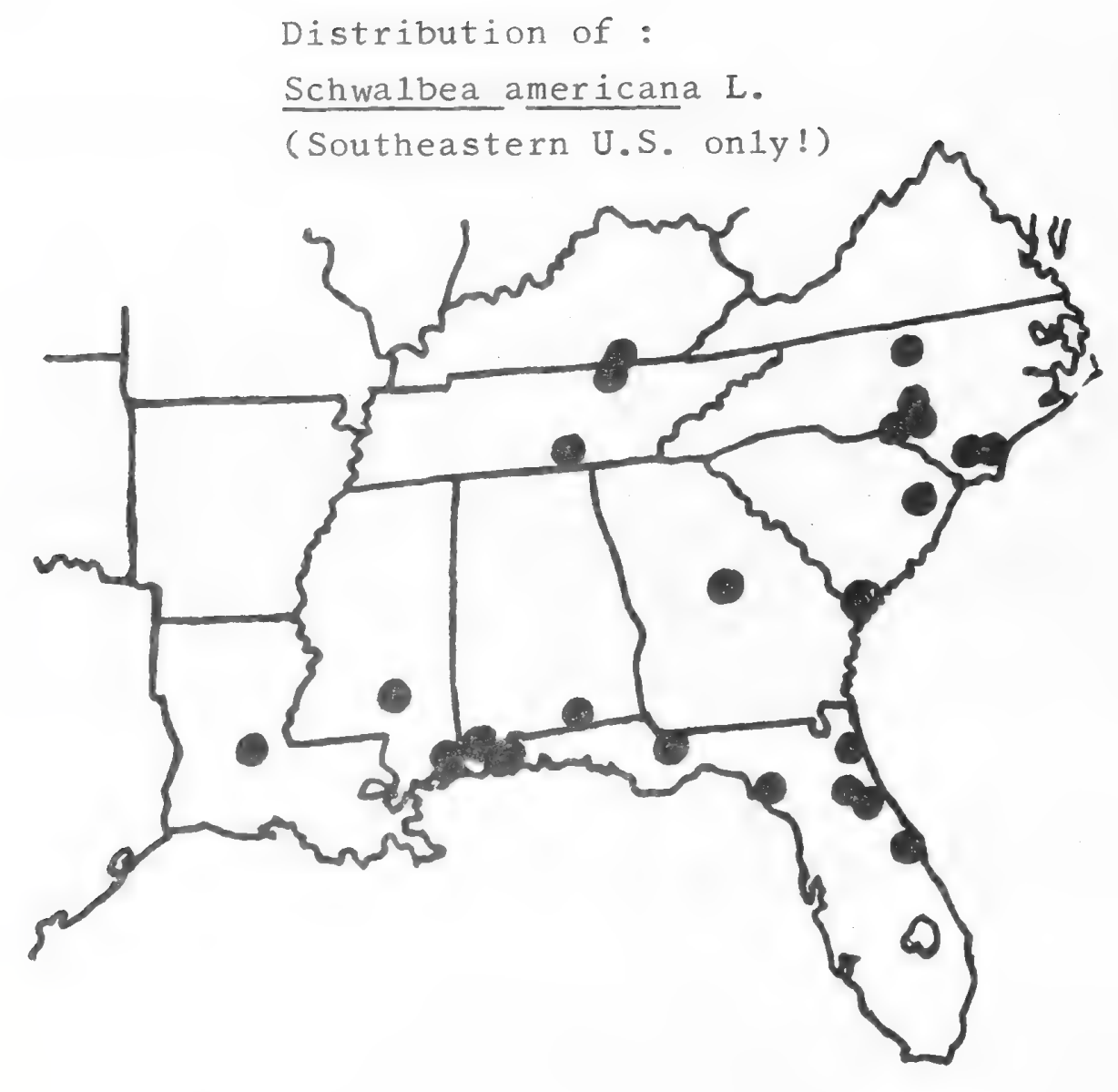

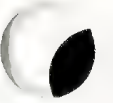


Verbena maritima small

Glandularia maritima Sma11

status: l'hreatened

l'echnical Description:

Perennial from a tap-and-diffuse root system.

stems: rarely erect, usually several from a short crown, quadrangular, sprawling, leaning, procumbent or repent, rooting trom nodes of creeping stems, often to 1 meter long, the Internodes many, the branches tew to several, strigose and strigillose, with whitish, antrorse hairs, purplish or green, the nodes bristly hairy.

Leaves: opposite, and usually erect trom the sprawling or prostrate stems (secund), petiolate, the blades narrowly ovate, cuneate, spathulate, or oblanceolate, most1y 2-5 cm long, the apices broadiy rounded to obtuseangled, the margins above mid-blade coarsely serrate, incised-lobed or lacerate, entire and attenuated below to near base of petiole, both surfaces yellowgreen, the upper sparsely strigose, the lower smoothish or sparsely hairy along the raised veins.

Intlorescence: A densely floriferous to slightly interrupted, cylindrical spike most $1 \mathrm{y} 2-5 \mathrm{~cm}$ long, fully $5 \mathrm{~cm}$ broad across the flowers, 1.5-2.0 cm wide across the fruiting calyces, terminal, raised, somewhat above the upper stem leaves of main axis and branches on erect or ascending, stiffish peduncles, the individual flowers each in the axil of an ascending or erect, green, narrowly triangularsubulate, strigose bract ca. $5 \mathrm{~mm}$ long.

Flowers: slightly irregular, bisexual; calyx strongly ascending or nearly erect, ca. $1 \mathrm{~cm}$ long, the 5 sepals fused into a 5-ribbed narrow tube this green or tinged w1 th purple, strigillose and long-stipitateglandular, its oblique orifice with 5 somewhat upswept brist1y teeth, the lower ones subulate-linear, to ca. $1 \mathrm{~mm}$ long, the upper \& shorter, more broadly trianguiar-based; corolla gamopetalous, salverform, the slender tube and narrowly campanulate, short throat pilose-tomentose, ca. $2.0 \mathrm{~cm}$ long, the spreading 1 imb $1.5-2.0 \mathrm{~cm}$ wide, of 5 strong but unequal lobes, the upper 2 broady cuneate-oblong, the laterals slight1y longer, oblong-emarginate, the lowest lobe largest, narrowly obovate, apically very retuse, the limb surface a lively lavender with an orangish-red "eye" above, paler beneath, the tube and throat paler lavender; corolla surface internally scattered pilose in the tube, densely hirsute in the throat, the tips of some of the stiffish hairs exserted; stamens 4, didynamous, 1 pair (fertile) with filaments arising at level slightly above that of the other, these with anthers sessile or nearly so; anthers short-oblong or ellipsoidal, yellow, ca. I mm long, the filaments flattish, no longer than the anthers: ovary superior, oblong, the style terminal, narrowly linear, slight1y dilated toward apex, the stigma subcapitate, bilobed, l lobe triangular, somewhat flattened, the other roundish, glandular.

Fruit: Fruiting. calyx tightish around nutlets, the intervals between the 5 ribs thinnish; nutlets 4 , ca. $4 \mathrm{~mm} 1 \mathrm{ong}$, cylindrical, pale brown, all but a narrow ventral groove strongly ridged-reticulate, the areoles more elongated-rectangular toward truit base. 
Distribution and Flowering Time:

Sandy clearings, particularly duneswales, in coastal sandscrub and open Live Oak-Cabbage Palm woods along the coast, peninsular Florida; flowering mostly in early spring, but intermittently al1 year.

Specia1 Identifying Features:

V. maritima overlaps in range and habitat only with one other "Glandularia" ( $\underline{V}$. tampensis, which see!) but that species, which tends to be more abundant on the Gulf coast of F1oriaa, has somewhat larger leaves tending to be more ovate, more regularly toothed, the stems less procumbent or repent, the calyx lobes with longer bristle tips (the longer ones mostly over $1.5 \mathrm{~mm}$ long).

Habitat and Management Implications:

v. maritima is we 11 named in that it is most abundant in and around open sandy areas close to the present coast of peninsular Florida or along sandy ridges paralleling inlets. Some common herbaceous associates are Uniola paniculata, panicum amarum, $\underline{\text { P. amarulum, }}$ Lragrostis oxylepis, Cenchrus, Cyperus ligularis, $\bar{c}$. retrorsus, Crotalaria pumila, Lupinus, phaseolus, rribulus, Ipomoea, Ipomopsis, Monarda punctata, Physalis viscosa, shrubby Solanum, Gaillardia pulche11a, Heterotheca subaxillaris. Yucca and Opuntia are common. The dunescrub surrounding the sandy clearings is heavy in Saw Palmetto, but has abundant representation of Myrica, Persea, Ardisia, Rapanea, Eugenia, Ilex, Smilax, evergreen scrub oaks, this often interspersed with hammocks largely of Cabbage Palm and Live Oak, or stands of Sand Pine mixed with S1ash Pine. The sandy clearings in the past were probably maintained through a combination of natural fire and wind, which continues to move shifting sands inward \pm rom the beaches.

Much of the original habitat of this species has been lost in the last $t$ ew decades not so much through the removal of merchantible timber such as Silash Pine as through commercial development, urban expansion, beachfront exploitation. Some areas cleared tor these purposes may be colonized by the Verbena along with other sand dune pioneers, but this is a temporary respite. Problems are also arising for such herbs in beach areas of southern F1orida because of the unwelcome increase of the introduced and pernicious Australian Pine (Casuarina equisetoides) whose takeover of some sites approaches $100 \%$, and swamping also by the equally bad grass Rhyncheletrum roseum.

Reterences:

Perry, Lily M. 1933. A revision of the north American species of Verbena. Ann. Mo. Bot. Gard. 20 (2): 239-363.

Sma11,J.K. 1933. Manual of the southeastern f1ora, pp. 1138-1139. 
SPECIES: Verbena maritima smal1

\begin{tabular}{|c|c|c|c|c|c|c|c|c|}
\hline $\begin{array}{l}\text { Expected } \\
\text { Effect on } \\
\text { Hab1tat }\end{array}$ & $\begin{array}{c}\text { Preacribe } \\
\text { Burn } \\
\end{array}$ & $\begin{array}{l}\text { Doze or } \\
\text { Root } \\
\text { Rake } \\
\end{array}$ & Bed & Chop & $\begin{array}{l}\text { Th1n } \\
\text { Over } \\
\text { Btory } \\
\end{array}$ & $\begin{array}{l}\text { Cut } \\
\text { Over- } \\
\text { Story }\end{array}$ & $\begin{array}{c}\text { Over Plant } \\
\text { with } \\
\text { trees } \\
\end{array}$ & Graze \\
\hline Destroy & & & & & & & $\mathrm{X}$ & \\
\hline Damage & & & & & & & & \\
\hline $\begin{array}{l}\text { No Lasting } \\
\text { Effect }\end{array}$ & & & & & & & & \\
\hline $\begin{array}{l}\text { Beneficlal } \\
\text { lf Done } \\
\text { Properly }\end{array}$ & $\mathrm{X}$ & & & & $\mathrm{X}$ & $X$ & & \\
\hline
\end{tabular}

other Commenta: Site preparation methods not observed in

this area, probably because the land is

such expensive real estate.

* Eat1mated effect 18 an est1mate of the author based on h1s book knowledge of the habltat and on knowledge galned from personal field observations. Estimates are "rough" in many 1nstances. Results of practices may vary $1 \mathrm{n}$ degree of application, intensity, nearness to plant communities, etc. A column left "blank" Indicates d lack of sufficient information from which to predict expected results. As observations are made in the fleld by users of the data, predictions should be refined by area and by intensity of forestry practices. 
Verbena maritima Sma11

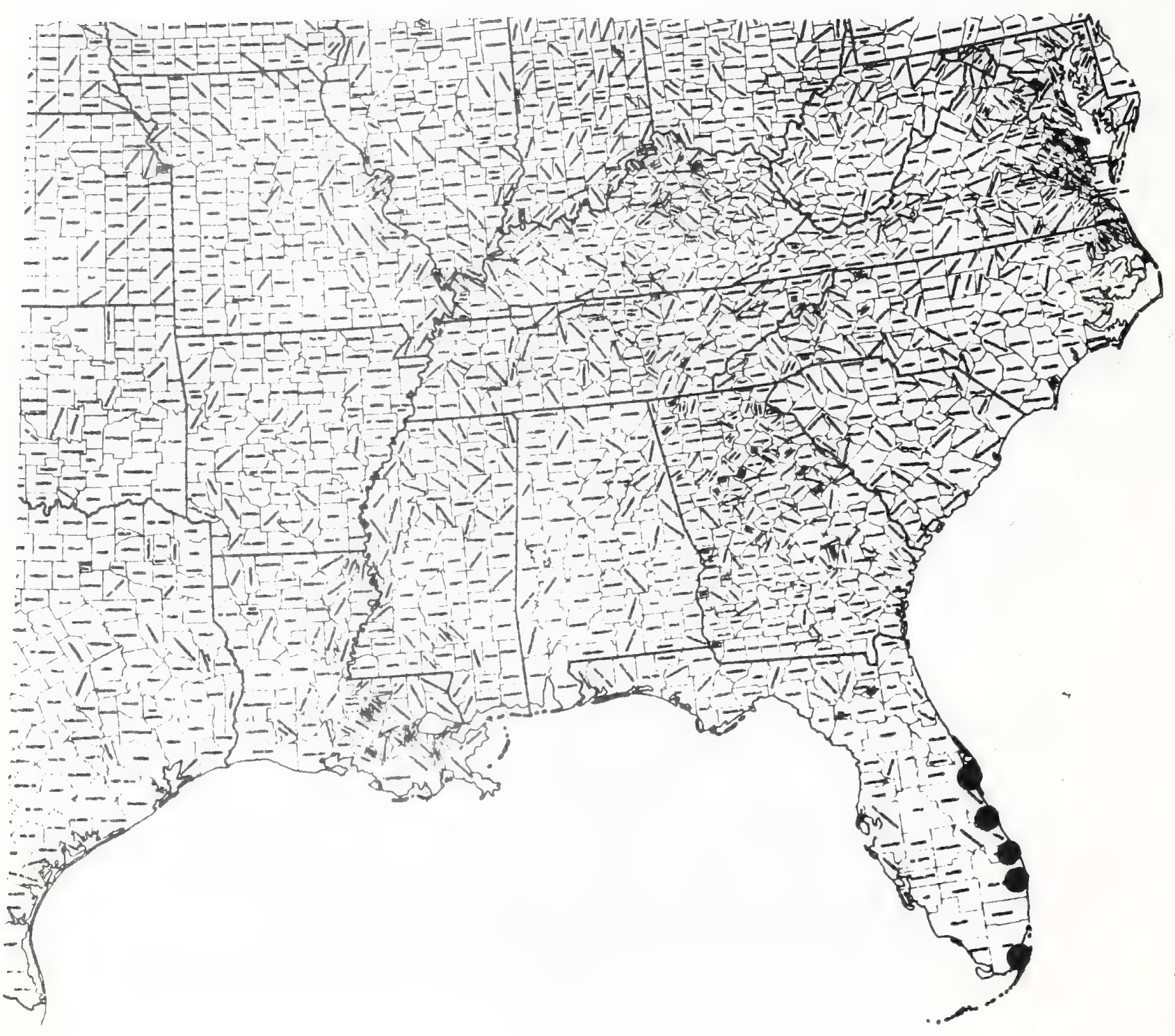




\section{XYR IDACEAE}

\section{Xyris tennesseensis Kral}

\section{Status: Endangered}

lechnical Description:

Yerennial, smooth, Yellow-eyedmgrass, the plant base sott, somewhat 1 leshy, often bulbous, usually encased in dark, scale-like outer leaves, the roots slender, shallow, tibrous.

Leaves: all basal, the outermost scale-like, the larger ones linear, $\overline{14-45} \mathrm{~cm}$ long, the blades linearmgladiate (narrowed at base and apex), U.5-1.0 cm broad, flat or slightly twisted, bright green, the apex incurved, bluntly acute, somewhat thickened, the margins slightly thickened, entire; equitant base $1 / 3-1 / 8$ the 1 ength of the blade, pink, red or purple, the margin pale, broad, scarious (very thin), the surfaces smooth or tinely papillate.

scapes: sheaths of scape shorter than the toliage leaves, reddish or brownish proximally and with short blades; scapes linear, straight, $30-70 \mathrm{~cm}$ long, usually 1 lattened and 2-5-ribbed distally and with at least 2 ridges quite wide and tuberculate-scabrid, subterete and L-several ribbed proximally.

Inflorescence: spikes solitary and terminal on scapes, broadly ovoid, 1.0-1.5 cm long, blunt, of several tightly and spirally imbricated bracts, all except the lowermost and uppermost producing a single tlower in the axil; fertile bracts suborbicular, rounded, entire or slightly erose, tan save for greenish, ovate-triangular dorsal areas.

Flowers: Slight1y zygomorphic (calyx), bisexual; calyx 3-parted, the outer sepal membranous and entolding the flower in bud, the inner 2 subequal, opposite, boat-shaped, included, curvate, the keels thin, narrow, the distal half lacerate, broader, reddishbrown; petals 3, distinct, long-clawed, the blades obovate, ca. 4.5 $\mathrm{mm} 1 \mathrm{ong}, 3.0 \mathrm{~mm}$ broad, ye11ow, apically rounded, lacerate, untolding in morning; staminodes bi-brachiate, distinct, 3, the long hairs beaded; fertile anthers 3, arising just above the petal claw and erect, the anthers ca. $2 \mathrm{~mm}$ long, lance-1inear, the sacs near paralle1, their tips projecting apical1y $0.4 \mathrm{~mm}$ beyond the tlat connective apex; ovary superior, 3-carpellate, compressed-ovoid, the many ovules marginal in the single locule, the style elongatelinear, tubular, branching at level of the anthers into 3, linear, spreading, tubular branches, the stigmatic tips horseshoe-shaped, minutely hairy.

Fruit: A thin walled capsule splitting open by 3 valves; seeds ellipsoidal, ca. U.5-0.6 mm long, slightly to very tarinose (mealy surfaced), with 18-20 fine, longitudinal lines, these sometimes irregular or joining, also interconnected by finer crossmines.

\section{Distribution and Flowering Season:}

Wet peaty seep slopes or shallow peaty swales, streambanks, Highland Rim of Middle Tennessee (Lewis County) and Valley and Ridge of northwestern Georgia; 1 lowering trom August through September. 
special Identitying reatures:

'this narrow endemic is distinguished from most other North American species by a combination of bulbous, colored bases, tuberculatescabrid scape ridges, lacerate lateral sepal keels, and dark, farinose coated seeds. L'his essentially tropical and subtropical genus has but tew representatives in. Tennessee and northern Georgia and only one of these, namely $x$. torta, superticially resembles it. However, $X$. torta, which is strongly bulbous - based and has very twisted, strongly ribbed leaves, has fertile bracts tipped by crisped reddish hairs (lacking in $x$. tennesseensis), ciliate lateral sepal keels (those of $X$. tennesseensis are lacerate), and clear, rather than tarinose seéds. Ot al1 southeastern Xyris, the var. Iloridana of $X$. difformis most resembles $X$. tennesseensis but this variety has toliage generally scabrid overall, its spikes are more acute, its tertile scales are darker colored, its leaves tend to be

tlatter and to spread tanlike.

Habitat and Management Implication:

So tar as is now known this Xyris is a genuinely rare and definitely endangered species. In middle Tennessee 1 t is found only in Lewis County, in the swan creek watershed, either in open very local bog slopes where water seeps over and out of an upper Paleozoic calcareous sand, or in small openings along shale - bedded streams. l'he dominant vegetation of the Tennessee seep areas is grass-sedge, with the sedges in late season being mostly Rhynchospora capitellata, scirpus, kleocharis, the grasses being Leersia, Panicum, Agrostis, Cinna, Andropogon. Juncus is common, with a constant associate species being J. brachycephalus (Engelm.) Buch., an essentially northern plant. Dominant late season dicots are parnassia grandit1ora (in l'ennessee), phlox glaberrima, Lysimachia, Kudbeckia fulgida umbrosa, solidago patula, and variots wetland Aster. I'he Georgia site I have visited is similar, but is a swale rather than a seepslope, and lacks the parnassia. Ihe substrate is usually shallow, but is continuously saturated and highly peaty. surrounding woody vegetation is, in l'ennessee, upland hardwoods, mostly Uak, Hickory, White Ash, Elm,Hackberry, Maple (both Sugar and Red), with a scattering of Juniper, with an understory mostly of Dogwood, Viburnum, Kedbud, Sourwood, Ustrya, Carpinus, Vaccinium arboreum, Khamnus; Alnus serrulata, salix nigra and s. caroliniana, sambucus and Cephalanthus abound along the streambanks and lower seep slopes.

contiguous upland and ravine slope hardwoods in Lewis county have sustained much logging and are undergoing intensive logging today. Damage to the Xyris may be sustained through the disturbance ot the seep areas by heavy equipment used in the logging operacion. It care were taken not to do tnis, the Xyris might be tavored to increase into areas previously too shady tor it. However, the small openings it now occupies give every impression of having been there for a long time, and were probably maintained largely because of the wetness and shallowness of the substrate which would make it unsuitable tor growth or colonization by most arborescent species, as well as by accasional natural woods tires. 
l'he known Georgia populations of $X$. tennesseensis are now destroyed. l'he Bartow County site, a seep slope, was demolished through construction of a portion of Interstate Highway 75; the Gordon county locality which was along a railroad right of way beside U.S. Highway 411, has been drained out of existence.

References:

Kra1,R. 1966. Xyris (Xyridaceae) ot the continental United States and Canada. Sida 2 (3): $177-260$. - 1978. A new species of Xyris (sect. Xyris) trom Tennessee and northwestern Georgia. Rhodora 80 (823): 444-447. 
SPECIES: Xyris tennesseensis Kral

\begin{tabular}{|c|c|c|c|c|c|c|c|c|}
\hline $\begin{array}{l}\text { Expected } \\
\text { Effect on } \\
\text { Habltat }\end{array}$ & $\begin{array}{c}\text { Prescribe } \\
\text { Burn }\end{array}$ & $\begin{array}{l}\text { Doze or } \\
\text { Root } \\
\text { Rake } \\
\end{array}$ & Bed & Chop & $\begin{array}{l}\text { Th1n } \\
\text { over- } \\
\text { etory }\end{array}$ & $\begin{array}{l}\text { Cut } \\
\text { Over- } \\
\text { Story } \\
\end{array}$ & $\begin{array}{c}\text { Over Plant } \\
\text { with } \\
\text { trees } \\
\end{array}$ & Graze \\
\hline Destroy & & NA & NA & NA & & & NA & \\
\hline Damage & & & & & & & & $\mathrm{X}$ \\
\hline $\begin{array}{l}\text { No Lasting } \\
\text { Effact }\end{array}$ & & & & & & & & \\
\hline $\begin{array}{l}\text { Beneficlal } \\
\text { If Done } \\
\text { properly }\end{array}$ & $\mathrm{X}$ & & & & $\mathrm{X}$ & $\mathrm{X}$ & & \\
\hline
\end{tabular}

Other Commente: Upslope clear-cutting or site preparation may result in excessive erosion, this choking out vegetation in ravine bases.

* Eat1mated effect 18 an estlmate of the author based on his book knowledge of the habltat and on knowledge galned from peranal field observat1ons. Estimates are "rough" in many instances. Results of practices may vary in degree of application, intensity, nearness to plant communities, etc. A column left "blank" indicates a lack of sufficlent information from which to predict expected results. As observations are made $1 \mathrm{n}$ the fleld by users of the data, predictions should be refined by area and by intensity of forestry practices. 
Approximate Range of:

Xyris tennesseensis Kral

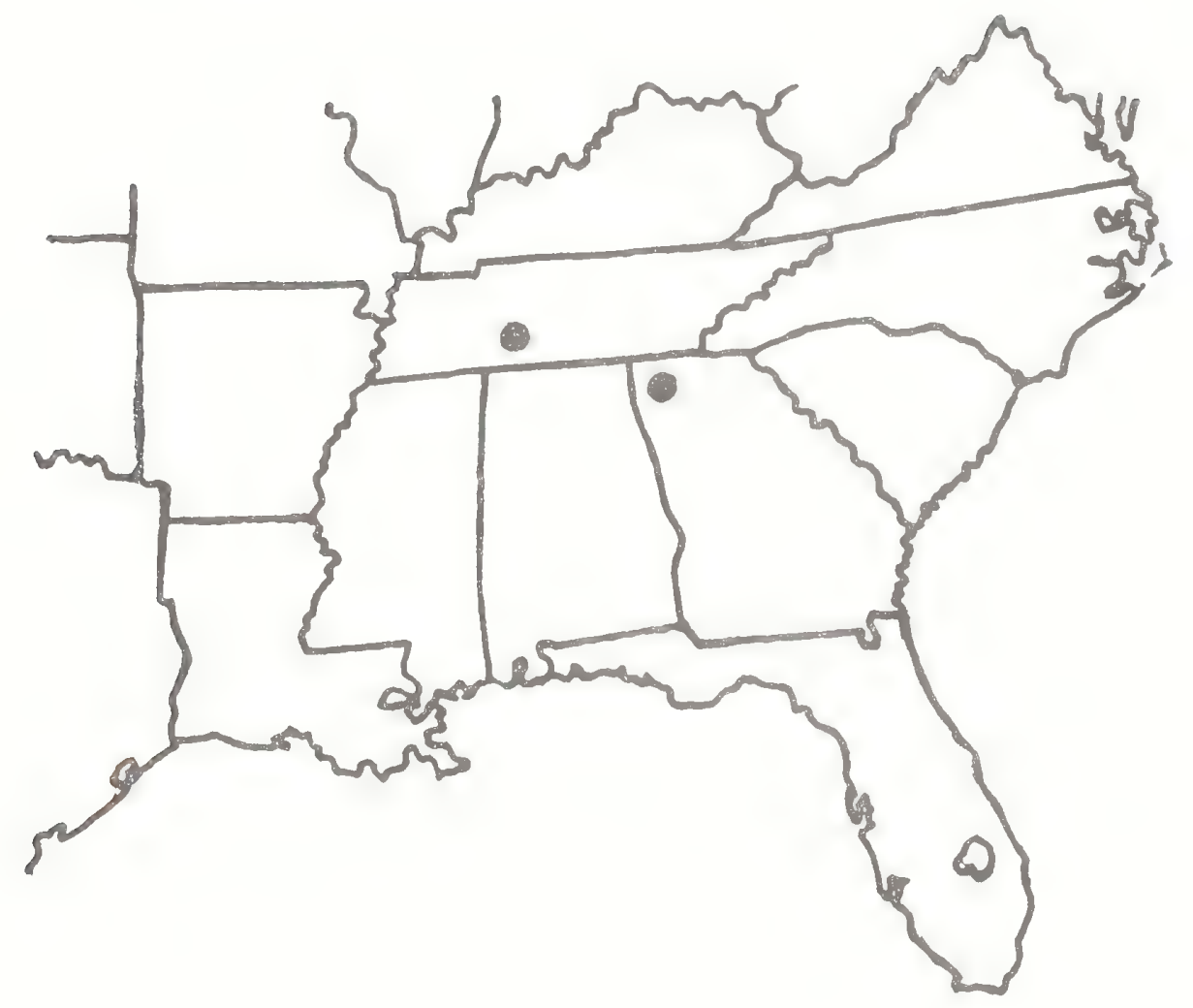


6

(

6 


\title{
CARYOPHYLLACEAE
}

\section{Arenaria godfreyi Shinners. Godfrey's sandwort}

\author{
Stellaria paludicola Fern. \& Schub.
}

\section{Technicar Description}

Short lived perennial or winter annual from a shallow, flimsy, diffuse-fibrous root, producing mats of slender, prostrate, creeping or ascending wintering steris that root at lower nodes.

Stelis.--Primary stems erect or ascending, decumbent-based, softish, 1-3 din high, arising from axils of wintering stems, simple or sparingly branched toward base, ca. $1 \mathrm{~mm}$ thick, sharply longitudinally rib bed, also grooved, pale green, smooth save at the thickened nodes where sparsely puberulent with capitate pale hairs.

Leaves.--Opposite, estipulate, those of winter shoots glabrous, mostly $\overline{1.5 \mathrm{~cm}}$ long or less, distinctly petiolate, the petioles troughed above, clasping based, with blades spathulate, oblanceolate or elliptic, acute, entire, yellowing as floriferous shoots flower; leaves of main stems spreading to erect, at mid-stem and above rather distant and progressively more sessile, linear-oblanceolate, linear or linear-spathulate, $1.5-3.0 \mathrm{~cm}$ long, acute with tips somewhat callused, margins entire, surfaces pale green, smooth save toward clasping bases and along the single evident vein beneath, there with pale, weak capitate hairs; upper leaves subtending lower inflorescence branches somewhat reduced, grading abruptly or gradually into short, oblong-linear bracteal leaves.

Inflorescence.--A terminal, compound, open diffuse cyme, the pedicels slender, glandular pilosulous at least basally and apically, the central or lower ones longest, 1-4 cm long, exceeded only by main or lateral branches. Flowers.--Regular, perfect; sepals 5, distinct, erect, lance-oblong, ca. 4 mm long, pale green, apically rounded-apiculate, the apiculus purplish, marginally entire, pale-scarious, the bases bowed outward, glandular-puberulent externally, the outer surfaces distinctly triple-nerved, the ribs puberulent proximal1y; petals 5, distinct, spreading toward apex, oblong-spatulate, 10-12 $\mathrm{mm}$ long, white, the broadly rounded tips shallowly notched; stamens 8-10, ascending, the filaments slender, white, flattened and dilating proximally, 5-8 min long, the anthers basifixed, bilocular, broad-oblong, ca. 0.7-1.0 min long, yellow-green or pinkish; ovary smooth, ovoid or ellipsoidal, ca. $3.5 \mathrm{rm}$ long, thin walled with a thicker concave (umbilicate) apex, the styles 3 , distinct, linear, ca. $2.5 \mathrm{~mm}$ long, papillose-stigmatic from middle to slightly dilated tip; placent ation free-central.

Fruit.--Ovoid, ca. $4 \mathrm{~mm}$ long, lustrous, green, later pale brown, umbilicate, the 3 valve tips hard-margined, truncate; seeds nearly round, ca. $0.8 \mathrm{~mm}$ wide but lateraliy slightly flattened, dark red-brown, the surfaces muriculate, with tubercle tips round-dilated and minutely papillate.

Distribution and Flowering Season

Full sun or light shade of springy creekbanks, seeps, meadows, and shores, usually over calcareous rock, Valley and Ridge of Virginia and Tennessee, Coastal Plain of the Carolinas, northern peninsular Florida, Alabama, Arkansas (Louisiana?); flowering from March into May. 


\section{Special Identifying Features}

This taxon, once described as a Stellaria by Fernald and Schubert, with its lineal leaves, ribbed sepals, and conspicuous, white, apically shallowiy notched petals, is superficially nearest to the calciphilic A. patula Michx. of limestone barrens of the inner Coastal Plain, Interior Low Plateau and various other central physiographic provinces in the east or mid-west, or to A. muriculata Maguire of seeps and wet meadows west of the Mississippi in Missouri, Arkansas, Oklahoma, Louisiana. A. godfreyi is particularly to be distinguished by the stipitate-glandula $\bar{r}$ pubescence of its nodes, leaf bases, pedicels and sepals, together with the unique character of its seed papillae, these being rounded-dilated apically and there minutely granular-papillose (unlike those of A. muriculata, which are simply tubercle-like and not dilated-papillose apically).

\section{Habitat and Management Implications}

A. godfreyi frequents permanently moist to wet, springy banks of springs and streams, seep slopes or wet grassy swales, usually in full sun, sometimes in light shade. It has a wide, scattered distribution, thus is found in a variety of forest systems. In the type locality area it is usually along small streams that course through slash pine-saw palmetto, through titi, or through low hammock composed of mixed hardwoods, slash and loblolly pine, and cabbage palnetto. The underlying rock is limestone. In the Valley and Ridge Virginia locality it is in seeps over calcareous shale, the surrounding forest being a mixture of upland yellow pines, with various upland hardwoods along and around the seeps. In the Coastal Plain of the Carolinas it is found on seeps over marl in lowland hardwood-pine complexes. In southern Arkansas it is on moist tuffaceous sand in old shallow lake bed, situated in swamp hardwood-loblolly pine-palmetto, and is largely fire-maintained. In Alabama it is known thus far only from a limited area of wet grassy meadow that was cleared from swamp hardwoods, and has marl underlying.

Requirements of the species appear uniformly to be a substratum that is kept permanentiy moist, but not inundated for long, full sunlight or at most light shade, and a substratum that is fertile, usually basic. In Taylor County Florida, where plants appear to be most abundant, much of the low land has been cleared of hardwoods and residual lowland pine and has then been planted to slash pine. This has had to produce a negative effect on the Arenaria in that soil disturbance along the shallow streams is often extreme, much altering the drainage pattern. Also a more uniform overstory and a heavier shade is created, which has eliminated fine habitat for this plant of sun. The best patches of it now appear in ditches along main and access roads, usually in the vicinity of culverts through which the small streams flow. It would probably be best for this species were forest managed without artificial drainage or any mechanical manipulation of the seep soils. Windthrow of overstory species, fires during drier cycles, were doubtless historical factors in providing suitable habitat.

\section{References}

Fernald, M.L. \& B. Schubert, 1948. Studies in the British herbaria. Rhodora 50: 197. 
Magliire, B. 1957. Studies in the Caryophyllaceae--V. Arenaria in America north of Mexico, Amer. Midl. Naturalist 46: 493-511.

Shinners, L. H. 1962. New names in Arenaria (Caryophyllaceae). Sida I: 49-52.

Wofford, B. E. 1981. External seed morphology of Arenaria (Caryophyllaceae) of the southeastern United States. Systematic Botany 6 (2): 126-135. 

Arenaria godfreyi shinners. Godfrey's sandwort

\begin{tabular}{l|c|c|c|c|c|c|c|c|}
\hline & \multicolumn{7}{|c|}{ Management Practices } \\
\cline { 2 - 9 } $\begin{array}{l}\text { Expected* } \\
\begin{array}{l}\text { Effect on } \\
\text { the Species }\end{array}\end{array}$ & $\begin{array}{c}\text { Prescribe } \\
\text { Burn }\end{array}$ & $\begin{array}{c}\text { Bulldoze } \\
\text { or } \\
\text { Root Rake }\end{array}$ & Bed & Chop & $\begin{array}{l}\text { Thin } \\
\text { over- } \\
\text { story }\end{array}$ & $\begin{array}{l}\text { Cut } \\
\text { over- } \\
\text { story }\end{array}$ & $\begin{array}{l}\text { Establish } \\
\text { Plantation }\end{array}$ & Graze \\
\hline \begin{tabular}{l} 
Destroy \\
\hline Damage
\end{tabular} & & $x$ & $x$ & $x$ & & & $x$ & $x$ \\
\hline $\begin{array}{l}\text { No Lasting } \\
\text { Effect } \\
\text { Beneficial } \\
\text { if Done } \\
\text { Properly }\end{array}$ & $x$ & & & & & & & \\
\hline
\end{tabular}

\section{Other Comments:}

*Expected effect on the species is an estimate made by Dr. Robert Kral based on his knowledge of the habitat and on knowledge gained from personal field observations. Estimates are "rough" in many instances. Results of practices may be modified depending upon the degree of application, intensity of treatment, nearness to plant communities, etc. A management practice for which no entry is made indicates a lack of sufficient information from which to predict expected results. As observations are made in the field by users of the data, the expected effect will be refined. 
Arenaria godfreyi Shinners

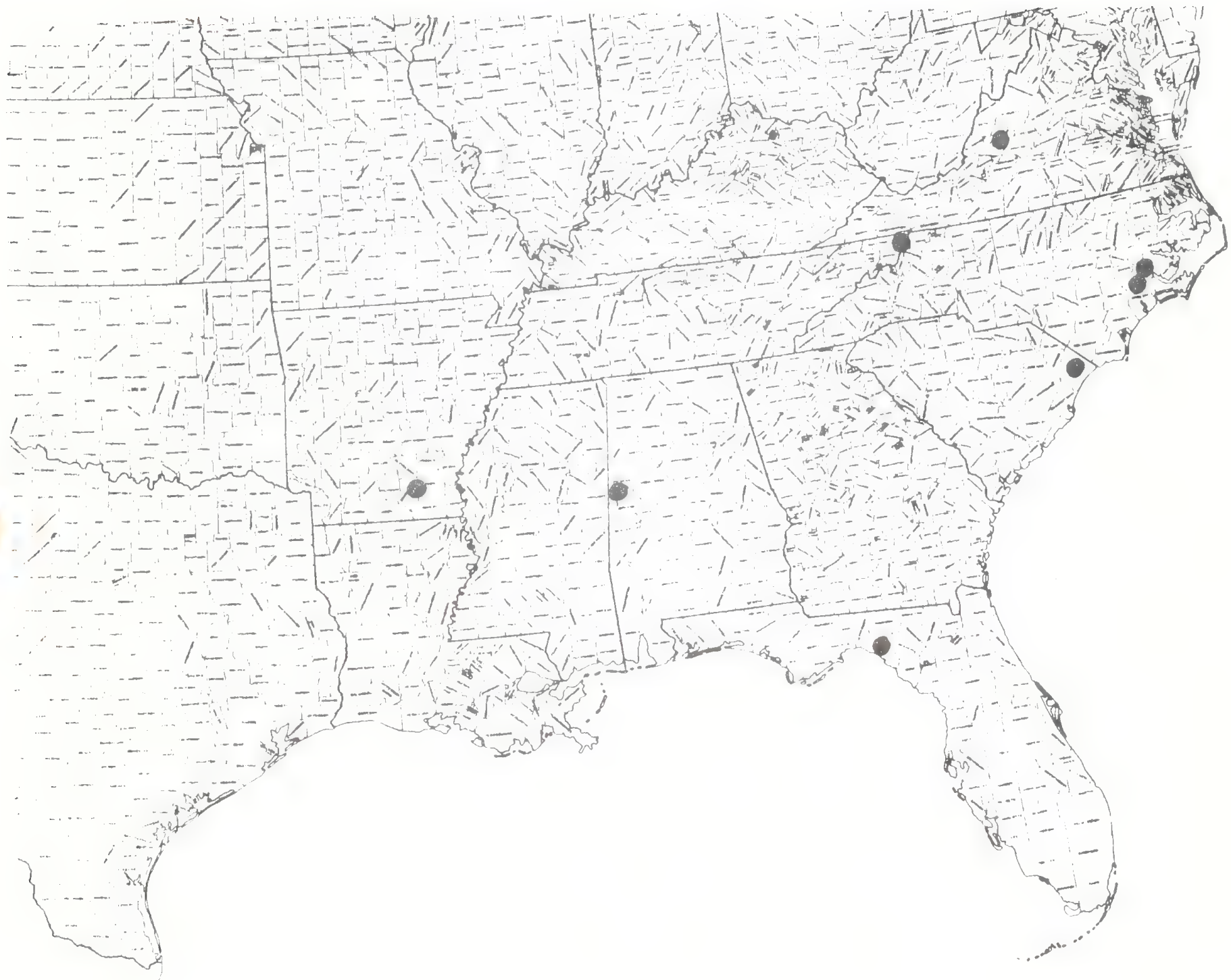


6

6

6 




\section{GLOSSARY}

Abaxial. - On the side of the appendage away from stem or axis. Acaulescent.--Lacking a stem (plants with pedunclus arising from rosettes often appear to have stems, but are acaulescent). Actinomorphic.--Radially symmetrical, as in the graphic "star", starfish, snowflake, tube or cylinder; any longitudinal plane through the central axis produces similar halves.

Acuminate.--Apex tapering concavely to a sharp point.

Acute.--Apex with sides straight, forming an angle of $90^{\circ}$ or less.

Adaxial.--On the side of the appendage toward stem or axis. Adnate.--Part or parts of one cycle of a flower variously united to a part or parts of another cycle.

Adventitious.-mGrowth of one organ from another in some other way than customary (i.e. new shoots directly from fire-scarred trunk of pond pine or pitch pine: "prop' roots of mangrove, $\operatorname{corn})$.

Akene.--A single-seeded, dry, indehiscent fruit with pericarp usually thin, attached to seed at but one point but superficially appearing tight.

Allopatric.--Species or subdivisions of species in a genus are allopatric if their geographic ranges do not overlap. Alternate.-Arrangement of parts on a common axis one per node. Amplexicaul. - - Strongly clasping the axis.

Anastomosing,--Veins, nerves or chains of cells converging or cross-joining to form a closed network.

Androgynophore. - A common stalk supporting both male and female floral parts above the level of departure of perianth.

Androphore. - stalk as in above producing only stamens.

Angiosperm.--Class of vascular plants in which ovules are borne within ovary wall; flowering plant.

Annual.- - A plant going from seed to seed in a single growing season, drying at the end.

Anther.--POIlen-producing part of the stamen.

Anther sac.--Pollen chamber.

Anthesis.-mThe time of receiving and/or sending pollen.

Antrorse.-Directed forward or upward on a surface.

Apex.--Tip.

Apical. $-\infty$ Referring to apes.

Apiculate.-Apex ending druptiy in a short-pointed tip.

Apomixis.-mode of reproduction bypassing gametic fusion.

Appressed.--Flattened against.

Aquatic. - living in water.

Arachnoid. - A cobwebby pubescence is arachnoid.

Ari1.- An outgrowth of the hilum or the funiculus of a seed, or a fleshy, modified appendage of the sporophyll.

Aristate. - -Bristiemawred.

Ascending.-Curved upward from the base.

Attenuate.-Gradually and finely tapering (usually referring to plane base). 
Auricle,--Ear-lobed-like, usually paired, appendages at base

of a blade or bract, or at leaf sheath apex.

Awl-shaped.--Rigid, narrowly-triangular, tapering to a sharp

point, as in leaves of many Juniperus.

Awn.--A rigia, bristle-like appendage (as in wheat, barley,

etc.)

Axil.--The intemal angle formed at junction of appendage and axis.

Axile.-At the axis, as in axile placentation.

Banner.--The upper petal of many leguminous plants.

Barbellate. -Finely barbed, as in the pappus of many composites. Basal.-mosition of appendages on an axis (i.e. basal rosette),

or a placentation type in which one or more ovules are at

the 1ocule base.

Basifixed.--A basal attachment of an organ or organ part.

Bearded.--Bearing a tuft or beard of longish trichomes. Berry.--A fleshy, indehiscent, two or more-seeded fruit. Biennial.- A plant that completes its life cycle in two years, usually producing a rosette the first season, bolting from it the next.

Bifid.-Forking at apex.

Bilabiate.--Two-lipped, as in the corolla of many mints, snaparagons.

Bipinnate.--An arrangement in compound leaves where the main rachis has rachises pinnately arranged along it.

Bisexual.--Producing both sexes in one flower. Blade.--The flattened "laminar" part of an appendage such as leaf, sepal, bract, petal, etc.

Bract. - A leaflike appendage within an inflorescence, subtending an inflorescence, or along a pedicel below the receptacle; usually smaller than the foliage leaf, sometimes modified to resemble perianth (as in Nyctaginaceae, Cornaceae, etc.)

Bracteole.-Diminutive of bract.

Bud.- -An unexpanded shoot or flower.

Bulb. - An underground storage organ primarily made up of imbricate fleshy leaves (i.e. onion, tulip). Bulblet.-Diminutive of bulb, often aerially formed (as in axils of lily leaves, onion inflorescences): bulbil. Caducous.-Falling off early, as in sepals of bloodroot. Caespitose.-Tufted.

Calciphilic.--Requiring calcareous substrate.

Callus.-A hard, local thickening; in grasses the hard, often hairy or pointed base of the floret.

Calyculus.--A cup formed by connation of one or more series of bracts or bractlet $s$.

Calyx.--outermost cycle or cycles of perianth, often the only perianth in many specialized flowers; a collective term for a11 sepals.

Cambium.--The lateral meristem in vascular plants.

Campanulate. --bel1-shaped. Cancellate.-A finely latticed surface. 
Canescent. ma grayish short pribescence.

Capitate. - Headminke.

Capsule.-m dry, several to manymseeded fruit, usually the product of a compornd of two or more carpels.

Carpel.-m seed producing specialized lcar: a mogasporophyll;

one or more make up the female part of the flower.

Caruncle, - An outgrowth from or around the hilum of a seed

(i.e. outgrowth in castor bean).

Caryopsis. - A dry, single-seeded, indehiscent fruit with a

tight pericarp: the fruit of most grasses.

Castaneous. chestnut brown.

Catkin. - A lax, often elongate, manym fowered unisexual inflorescence of smal1. bracteate but otherwise naked flowers.

caudate. $m$ Producing a tail mijke appendage.

Caudex.--A short vextical axis involving either rhizome apex

or stem base.

Caulescent.mproducing an abovemground stem.

Cauline.-Pertaining to stem.

Chaff.--Collective for thing papery bracts, as in the heads of many sunflowers.

Channeled.-mIongitudinaliy grooved.

Chasmogamous.-w lowers open, usually showy. mostly outcrossing.

Ciliate. - Bearing a froinge of hairs marginally.

Ciliolate. miminutive of ciliate.

Circumsessile-mehis scence around the equator of fruit or anther. Clavate. - cluboshaped.

Claw.-A petiole-likje narrowing at base of sepal or petal blade. Cleistogamous. Flowers remaining closed, usualy selfing.

Clone.-Vegetative replicates of a biotype.

Collar.-Zone opposite the Jigular zone in the leaf of grass-like plants.

Column, - welding of sterile portions of male flowers (Hibiscus) or of male and female payts of a flower (Orchidaceae).

Compound.-A grouping of leaflets (compound leaf), carpels (compound ovary), or inflorescences (compound cyme, umbel,etc.)

Connate musion of like parts in a floral cycle.

Connective sterile tissue connecting fertile parts of anther. Contorted. - flat spiral clockwise or counterclockwise over lapping of parts of a floral cycle (usually petals) in the bud, as in PhIOX.

Convolute.msymonym of above.

Cordate.-In the shape of the Valentine "heart": cordiform. Coriaceous.-meathexy in texture.

Corm.--Underground storage organ, cypically roundish or oblate, anatonically a compacted stem invested by thin scale leaves and producing daughter coxms (comels) apically (Gladiolus, many orchids, etc.

Comophyte.-Ecological term for an herbo with strong underground. storage organs, such as would be comon in droughty or savanna soils.

Corolla.-Collective term for petals. 
Corona.--Tissue formed in development of petals and stamens in a floral tube to produce "webbing" between filaments; may be staminal solely (Hymenocallis) or staminal and corollal (Narcissus).

Corymb.-A specialized raceme, determinate and convex, in which the symmetry is as wide as long or wider, the lowest flowers with the longest stalks.

Costa. - - A strong rib or midrib.

Costate.--Strongly longitudinally ribbed.

Cotyledon.--The first leaf (Monocotyledons) or leaves (Dicotyledons) to develop from the embryo.

Crenate.-A scalloped leaf margin; diminutive is crenulate. Crown.--Inner, often coronal or corona-like outgrowth from

perianth base or corolla throat.

Culm.--The stem in grasses or grass-like plants.

Cuneate. - An acute base.

Cuspidate.--Apex tipped with a narrow, firm, sharp point.

Cyme. - A broad, flat-topped or somewhat concave inflorescence

with the central flower or flowers opening first.

cymule.-A cymose unit of a compound cyme.

Cystolith.--Crystallized calcium deposits in cells, often visible in leaf epidermis as lens-shaped bodies (Acanthaceae, Urticaceae, etc.)

Deciduous.--Seasonal shedding, usually by abcission, usually in reference to leaves.

Decumbent.--Base of stem or shoot arching outward and downward, then erect.

Decurrent.--Base of appendage running evidently downward from its point of attachment on axis.

Decussate. - Arranged oppositely or whorled on axis so that members of alternate nodes are in vertical alignment (i.e. Juniperus, Cupressus, Rhexia, etc.)

Dehiscence.--Splitting, as in valves of mature fruits, anthers, etc., usually along a suture.

Deltoid.--"Delta" shaped.

Dentate.--Toothing of a blade margin so that the teeth are spreading, roughly equal-sided.

Denticulate.--Diminutive of dentate.

Determinate.--With definite number; in inflorescences, a type in which the apical bud is first to open.

Di.chasium.--A basic aymose inflorescence; a simple dichasium is a symmetrical, triflorous, cyme; a compound dichasium is 3-branched, the central branch a pedicel, the laterals developing simple dichasia.

Dicotyledon.--An angiosperm with two embryonic leaves.

Didymous.--Pwo-paired, as in stamens of mints, etc.

Didynamous.--Several stamens, two equal and shorter than the others.

Dimorphic.--Two forms of the same part or organ. Dioecious.--Species having unisexual individuals.

Disc.--An outgrowth of tissue from the receptacle around the base of an ovary and often between filament bases. 
Distichous. mispangement of leaves or parts into a single plane oppositely along a common axis. Dorsal. - Backiside of an appendage.

Dorsifixed.-Attachment of stamen filament to back of connective. Drupe. $-\infty$ single seeded. fleshy "scone" Emuit.

Echinate. spiny. sharoly tuberculate. or prickly surface. EIIiptic.mowith the outline an elinpse.

EIIIpsoidalm-m solid with an eldiptic outline.

Emarginate - -Shal Iowly notched at apex.

Embryo.-Evergthing inside a seed except seed coat and endosperm. Endemic.-Confined in distribution to but one geographic area. Endocarp. mnnemosto ofter vasculazized, sometimes stony, layer of ovary wall.

Endosperm. $\Rightarrow$ Triplojd os polypoloid nutritive product of double fertilization in angiosperms Entire. - The untoothed or unapendaged. strajght-line edge of a blade.

Epidermis.wise outer tissue layer of the plant body.

Epigynous.m.n loral parts appearing to arise from ovary apex. Epipetalous,-stamess appearing to arise from petals. Epiphyte.marowing upon another plant. Equitant. - Arrangement of a distichous sort, in which each base fits into the base of the leaf or part directIy beneath. Erect. amorientation of axis plumb.

Erose. - A finely irenegular edge.

Exocarp. - - Outermost layer of ovary wa.1.

Exserted. - Projecting beyond.

Extrorse.-Anthers opening away from floral axis.

Falcate, -Scimitrawshaped oxtine of blade.

Fascicle.m Numerous parts clustered (nesdies in pines, stamens in Hyperi. cum)

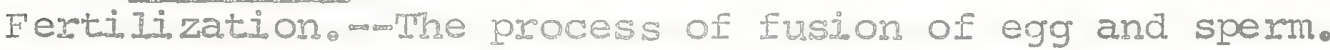
Filament. mThe sterile, usvally slender, tis sue connecting the anther with the flower.

Filifom, miair $-1 i k e$ in slendemess.

Fimbriate - closemset, narsow divisions of a margin, usually a strong fringe or turt of long hairs.

Flabel. late, - Spreading fan $\rightarrow$ like。

Floccose.m. woolyomatted covering.

Flower.mA short seproductive shoot in angiosperms, with the axis forming a receptacle, whoth appendages modified from leaves, some reproductive (stamens, carpels), others (perianth) sterile, more leaflike or vestigial or absent.

Follicle $\infty A$ dry dehiscent frujitg product of a single carpel, splitting prrselike along one line (i.e. milkweed, dogbane). Free-central. -A placentation in which there are no cross-walls in the ovary, the placental zones muning along a central axis, the columella, in a mi.locular ovary. 
Fruit.--A ripened ovary wall and contents, sometimes also

ripened receptacle and other floral parts as well.

Funiculus.--The connector of an ovule, later seed, to the

placenta.

Funnelform.--Funnel-shaped.

Fusifom.--Spindlemshaped, a narrow, bi-caudate, ellipsoid.

Gamopetalous.--Petals variously joined.

Gamosepalous.--Sepals variously joined.

Geniculate.-Abruptly bent.

Glabrous.--Smooth-surfaced.

Gland.--Any organ or modified cell having a secretory function.

Glaucous.--With a "bloom", this usually a wax and usually a

powdery whitening.

Globose. - A solid round.

Glomerule.-A small, tight cluster of flowers.

Glume.- -A chaffy bract as in many grass-like plants.

Gymnosperm.--A seed-bearing vascular plant with ovules not

covered by ovary wall (cycads, pines, etc.)

Gynobasic.--Term for styles that are continuous through the

ovary to the receptacle center in such groups with lobed

ovaries as borages, mints.

Gynoecium.-Collective for all female parts in a flower.

Gynophore:--A stalk subtending an ovary.

Habit.--A collective term for mode of perennation, overall form.

Hastate.--Used for plane outlines with basal lobes prominent,

projecting strongly and narrowly at right angles, as in the

guard of a sword hilt.

Haustorium, --In seed plants a specialized, tissue-boring, root produced by parasites (i.e. Cuscuta).

Head.--An inflorescence in which all flowers are sessile on

a common receptacle.

Helicoid.-Coiled in one plane, as in inflorescences of borages. Heliophyte. - An obligate sun plant.

Herb. - -A non-woody plant, one that dies back to the rootstock

or totally dies at the end of a season.

Hilum.-The attachment scar left on the seed with the seed

detaches.

Hirsute. - A coarse, spreading, long pubescence, slight ly less

stiff than in hispid pubescence.

Hispid. - A stiffish, long, spreading pubescence of sharp hairs. Hispidulous.-Diminutive of hispid, the surface thus scabrid.

Hydrophyte. - An aquatic plant.

Hypanthirm.--That meld of perianth and receptacle that forms a

cup, tube or disc from whose rim come perianth lobes and other

floral appendages exclusive of carpels.

Hypogynous.-Floral parts attached to receptacle below the ovary. Imbricate.--overlapping as in shingles (i.e. bud scales, per-

ianth parts in bud).

Incised.--Deeply and sharply ixregularly cut margins of blades. 
Indehiscent. compound structure, usually a fruit, that at maturity does not split along sutures.

Indusium. Outgrowth from leaves of fems that covers the sori. Inferior. - Below: tem usually denoting a floral type in

which free parts depart above the ovary.

Inflorescence.-Any areangement of flowers on a plant.

Integument. - The outer layer or layers of an ovrle, later seed. Internode. - The area of an axis between two nodes.

Introrse, - with line of dehiscence toward the axis, as in anthers. Involuce 1. ma whor I of bractiets.

Involucre.-System of bracts set numerously at base of inflorescence or subdivision of inflorescence.

Involute. margin rolled inward.

Irregular.-Denoting a dack of radial symetry in a flower. Keel.-A dorsal-Longitudinal widge as in the keel of a boat. Keel petal mone of tro loner perals in a leguminous flower. Labellum.-mip: the lower (ox upper) specialized petal in orchids. Lacerate. - Iregegularly jagged masogin whith divisions and sinuses sharp.

Laciniate wangin jagged with consistentiy narrow Iobes.

Lanate. -A pubescence of Iorg, wooly. jointed hairs.

Lanceolate. mise outline of a lancemhead.

LateraI. - -Arising from the side of an axis or part.

Latex. - A usually white colloid secreted by tubular systems

of plant ceIIs called lacticifers (i.e. milsweeds, dogbanes).

Leaf.-A nodal oucgrowth. usualy photosynthetic, usually plane. Leaflet.-Any leaflike subdi vision of a compound leaf.

Legume.-A two-valved. usually dehiscent dry fruit, the product of a single carpel.

Iiana. $-\mathrm{A}$ vine.

Iigulate. - Developing a Iigule, a flat, strap-shaped structure. Iigule. $-\infty$ scalemlike or fringe-like outgrowth adaxially from the apex of a sheath (as in grass leaves) or at junction of a blade with a claw (as iss petals of camation).

Iimb. - mhe divided or undivided usually spreading part of a gamosepalous calyz os gamopecalous corolla above the orifice.

Iinear. An elongate nanrow ortine with widh ranging from that of a heavy pencil line to a crayon line: a long narrow parallel sided ouriine.

Iip.--one of two majox divisions of the limb of a gamosepalous calyx ol gamopetalous corolla in bilabiate flowers.

Lobe. - Any roundedwipped strong division of a margin.

Locule. $-\mathrm{A}$ chamber of ar ovary, fmit, or anther.

Loculicidal. - A mode of debiscence where the suture Iies over the locule.

Margin.--The border or peripsery of a plane appendage.

Marginal placentation ma lacentae on the outex wall of the locule, not intruding.

Membranaceous. minin in textuse.

Mericasp.-A single and often singlemseeded subunit of a dry dehiscent fruit where each subunit is completely separable at maturity. 
Mesocarp.-The middle; often vascularized, layer of ovary wall. Mesophyte.-A plant of "middle" environment as to moisture

requirement.

Midrib.--The central vein of a leaf, bract, petal, etc. Monadelphous.--Filaments joined to form a tube. Monocotyledon.--An angiosperm developing but one embryonic leaf. Monoeciolus.--Denoting a condition in a species where both

sexes of unisexual flowers are produced on the same plant. Monotypic.--Term for family or genus with but one species. Mucro.--A short, narrow protuberance at the apex. Muricate.--A surface roughened with small,hard, points. Nectary. - A gland made up of one or more cells secreting sugary fluid.

Node.-Zone along an axis at which appendages form. Numerous.--Used in reference to floral parts of a large number, at least over 10.

Nut. - A dry, indehiscent, single-seeded fruit with a bony wall. oblanceolate. - An inverted lanceolate out line.

obovate. -An inverted ovate outline.

obtuse. $-\mathrm{A}$ blunt apex.

ocrea.-A sheathing, often tubular, often fringed stipule; the

diminutive is "ocreola".

opposite.--Paired appendages at node.

Orbicular. $-\rightarrow$ Round in outline.

ovary.--That part of the grnoecium developing and enclosing the ovriles.

Ovate.--Outline as in a hen's egg.

ovoid.--solid with an ovate outline.

pale.--The chaffy bract on the receptacular surface of some composites.

Palmate. -Digital arrangement of lobes of simple leaves or

leaflets in compound leaves.

Pandurate.--Shaped as in the fiddle body.

Panicle:-A compound inflorescence, longer than broad, made

up of fascicles, cymes, racemes, etc. as subunits.

Papilionaceous.--The butterfly-like corolla of many leguminous plants, made up of a banner petal, two "wing" petals and two keel petals.

Pappus.-The specialized calyx in composites, this usually persisting atop the maturing fruit and made up of fine to coarse bristles, awns,scales, etc.

Parasite.--An organism deriving nourishment from another living organism (i.e. Cuscuta).

Parietal.--Placentation in which the placentae intrude into

the locule.

pectinate. - A pinnate arrangement of segments in which these are very fine.

Pedicel.--The stalk of a flower connecting it to the inflorescence.

Peduncle.--The stalk of an inflorescence or the stalk of a flower if that flower is single on a plant or on a branch. Peltate.-A central or subcentral attachment of stalk to blade in leaves or in leaflike structures. 
Perennial. min herbaceous plant that lives for more than two years, dying back to the rootstock at the end of a growing season.

Perfect flower. fom fower having both sets of sexual parts.

Perfoliate. - Ieaf blade base that completely surrounds the stem. Periantis-Collecitve term for floral envelope, both sepals and peta.15.

Pericarp.-Ihe ovary wa.1. in angiosperms.

Perigynim.m. The modified bract covering the ovary, later fruit, in Carex and Cymophy 1 1us.

Perigynous. - Parts arising at level around the ovary, usually their fused bases forming parot of a disc or hypanthial rim. petal. mhe inner. Usually broghty colored, cycle or cycles of perianth, ustally less vasculardzed than sepals.

Petiole, - The sialk of a leaf.

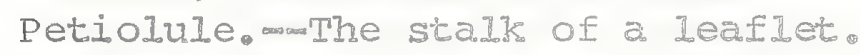

Phyllary - - The involucral bract in composites.

Phyllode. - A leaf comprised only of petiole or rachis.

Pilose.-A soft, usually spreading, long pubescence.

Pinnate. - -An aroangement of leaflets or leaf blade lobes in two rows on opposite sides of a rachis or midrib.

Pith.--The soft, mostly parenchymous, core of twig or stem. Placenta.- That part of the inner ovary wall that develops ovules. Plumose.-mroducing fine, elongate hairs as does the pappus of some composites such as thistle.

Pollen.-mThe product of reductiondivision of the pollen mother cel1 in spermatophytes. 2 sta.11 resulting in a tetrad of small spores, later male gamerophytes.

Pollination.-mine process of transfer of pollen from the anther to the siligma of a filower.

Pollinium, An agglutinated mass of pollen (as in orchids, milkweeds).

Primocane, whe first wood of a shrub from which the flowering shoots, or Ėoricanes, ari. se。

Prismatic.- Angledwsolid, with plane faces, as in a prism.

Procumbent. mAxis groving Elat over surface, not rooting at nodes. Proxima. - maxis end of an appendage.

Puberulent. $m$ A shost pubescence.

Pubescent. collective term for a hairy surface.

Punctate.mshallowly pitted.

Pyxis.--Specialized capsule with circumsessile dehiscence. Quadrate. $-\mathrm{F}_{\text {Trour }}$-angled.

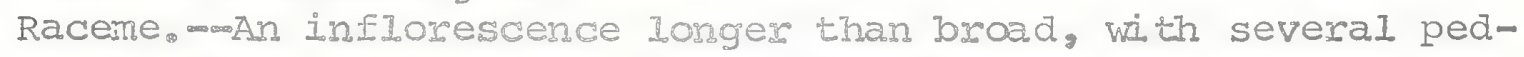
icellate flowers, the pedicels subequal.

Rachilla.mentral, often jointed, axis of spikelets or florets in many grassulike plants.

Rachis.-mAxis of compound leaf op compound inflorescence. Receptacle. - mhe Eloral axis.

Recurved.-ApicaIIy curved or bent backward toward base.

Reflexed.-SharpIy recurved. 
Regular:-Radially symmetrical; actinomorphic.

Relict,-Endemic leftovers from past geologic times.

Reni form.-Kidney-shaped.

Retrorse. - Directed downward.

Retuse. $-\mathrm{A}$ shallowly notched, broadly rounded apex.

Rhizome.--An underground, often horizontally oriented, stem.

Rhombic.-With the outline of a rhombus.

Root.--MostIy underground organ with functions of support, an-

chorage, absorbtion, storage.

Rosette.--Arrangement of leaves when spreading from a basal,

tightly spiralled attachment (i.e. dandelion).

Rostrate. -- Beaked.

Rotate.--Radially symmetrical calyx or corolla with lobes longer

than tube:

Rugose.-A wrinkled surface.

Runner. $-A$ slender stolon.

Sagittate.--The shape of an arrowhead, with basal lobes directed outward and downward, acute.

Salverform.-Tmmpet-shaped, as in the corolla of Phlox.

Samara. - A dry, indehiscent, winged fruit.

saprophyte.-A plant without chlorophyll, feeding on dead

plant or animal matter.

Scabrous. - -A roughened, sandpapery, surface.

Scale,-Usually a modified leaf that is small and chaffy (i.e.

bud scales, bracts in grasses and sedges).

Scape.--An elongate, leafless peduncle or flower stalk, often

developing from a rosette (i.e. bladderworts, butterworts).

Scarious.--Thin, as in translucent fine paper.

Sciophyte. - An obligate shade plant.

Schizocarp. - A dry fruit splitting at maturity to one-seeded

mexicarps.

Scorpioid raceme.--A unilaterally coiled, usually zig-zag raceme.

Secund.--Unilateral arrangement of parts along an axis.

Seed.-A fertilized, ripened ovule.

sepal.-The outer, usually most leaf-like, perianth; usually green, but sometimes colored as in petals.

septate.--Cross-partitioned.

septicidal.-.Dehiscence so that carpel walls separate at the cross walls of the fruit.

Serrate.-A toothed margin in which teeth are directed upward, the lower side of a tooth longest.

serrulate.-Diminutive of serrate.

Sessile.--Iacking a stalk, thus attached directly.

Sheath.--The tubular, stem-sleeving base of a leaf, bract, or perianth member.

Shoot.--An aerial stem or branch; a new branch or twig of a woody plant.

Shmib. - A woody plant, usually with numerous shoots from the groundine with diameter under four inches and lower than

15 feet. 
Silicle.-A short, bicarpellate fruit whose septum persists after the valves have fallen (many mustards).

Silique. $-\infty$ An elongate version of a silicle.

Simple. - Refereing to simpleabladed leaves: not compound.

Sinuate - margin that is wary, as in the sine curve.

Sinus.-The interval between two adjacent lobes of a margin.

Soboliferous.-.-Producing rumerous shoots from an underground.

base.

Solitary. - In reference to flowers, one that appears singly. Sorus.--Sporangial cluster in ferms.

Spadix.-A fleshy spike, the flowers often sunken or basally embedaed in the IDeshy axis.

Spathe A single bract or fused bract compound that sheathes an inflorescence or inflorescence base.

Spatulate. miade outine in whin the rounded apex tapers concavely to an elongate narrow base (as in the old-fashioned spatula.)

Spike.-A variousIy elongated inflorescence of sessile flowers. Spikelet. A small chaffy or paperybracted inflorescence as in grasses or sedges: may be actually nodified racemes or other sorts of inflorescence).

Spine.-A rigid, shawp outgrowth, modified. from a leaf,leaf tip, leaf margin, stipule, etc. but essertially foliar; not to be confused with thorrs which are modified shoots.

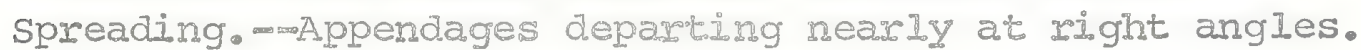

Spinulose - whort spines along margin.

Sporangium.

Spur.-mhe hornlike projection from base of anther (i.e. ericads), perianth (bladderwort. columbirses, larkspurs).

squarrose. The margin toward apes of bract. Ieaf or other appendage abrupt Iy spreading or recurved.

Stamen. - A single male unit of a flower, composed of filament, connective, anther.

Staminode. $\rightarrow$ A reduced, non $\rightarrow$ pol 1en - producing stamen.

Stellatemstror Iije.

Stem. A leaf producing axis in vascular plants, usually producing leaves and buds at each node.

Stigma. - $\mathrm{A}$ various Iy dilated, branched, lobed, pollen-receptive zone of the gynoecium, usually at stylar apex.

Stipe. sta A $_{\text {A }}$ sta

Stipitate. $\rightarrow$ Stalked.

Stipule.-A leaflike appendage, spine or gland lateral to leaf base on some stems: may be persistent or deciduous.

Stolon.-A modified slender stemg the internodes long and arching, the nodes rooting.

Stomata-Epidermal pores through which gas exchange occurs.

Strigillose. - Stiff, short, suloappressed pubescence.

Strigose. - Stiff, comparatively longer, subappressed pubescence.

Strumose. - Swollen-based, as in some stiffish hairs.

style.-mhe narrowed stexile apex of an ovary, teminating in stigma tissue. 
Stylopodium.--A disc-like tissue around the stylar bases

in many Apiaceae.

Succulent.--Fleshy, usually swollen with water.

Superior ovary.--Free base of ovary at or above level of

other floral parts (hypogyny).

Suture.--Zone of union of carpels, usually marked by a ridge

or groove; line of dehiscence.

sympatric.--overlapping geographic range of allied taxa in

a genus.

Taproot.-A strong and dominant, usually plumb, primary root.

Tepal.--A perianth part superficially identical to all other

perianth in a given flower.

Terete.--Round in cross-section.

Terminal.--An apical position in reference to shoot.

Ternate.--A three-palmate system of branching of compound leaves

or inflorescences.

Throat.--Zone where limb and tube of calyx or corolia come

together: orificial area.

Tomentose.--A surface densely covered by a mat of hairs, thus

obscured, is tomentose

Tomentulose.--Having a fine tomentum.

Tree.--A woody plant, usually with distinct growth rings of

wood, with one or few strong trunks having diameters of four

inches or more and heights of 15 feet or more at maturity.

Triangular.--Three-angled in cross-section; trigonous.

Trichome.--Any plant hair.

Trifoliolate.--With three leaflets.

Tube.--Joined tubular bases of sepals and/or petals; hollow cylinder.

Tuber.--A contracted, swollen, food-storage branch, with numerous, often irregularly arranged buds or "eyes"; usually underground, rarely aerial (Dioscorea).

Tuberculate.--Surface beset with numerous small, narrow bumps (tubercles).

Tubular.--A hollow cylinder.

Umbe1.--An inflorescence in which the pedicels or primary

branches arise at a common level at peduncle or branch apex.

Undulate. - A wavy margin or surface.

Unifoliolate. - -A compound leaf with but one leaflet.

Unisexual.--of one sex only.

Urecolate.--Urn shaped.

Utricle.--A dry single-seeded fruit with a thin, bladdery pericarp.

Valvate.--In buds, when edges of scales meet but do not overlap. Valve.--A unit of wall of a dehiscent fruit; a flap of anther wall tissue.

Velum.--The indusium in Isoetes.

Ventral.--The inner face of an organ or appendage relative to axis. 
Verticil. $-\mathrm{A}$ whorl.

Verticillate. $-A$ whorled arrangement.

Villous.--A covering of long, soft, straight hairs; a dense pilosity.

Weed.--A pioneer plant quick to occupy bare areas or disturbed soils, a poor competitor but with high reproductive potential; a plant out of place; a species known to be part of lower seral stages and which invades area intended by man to produce other species of known value.

Zygomorphic.--A floral form that has but one ideal plane of division. 
Figure 1. Blade outlines or forms.

a. filiform
b. linear
c. subulate
d. acicular
e. lorate
f. spatulate
g. lanceolate
h. oblanceolate
i. oblong
j. elliptic

Figure 2. Blade margins.

a. entire
b. undulate
c. sinuate
d. crenate
e. crenulate
f. ciliate
g. ciliolate
h. serrate
i. serrulate
j. doubly-serrate
k. spinose (aculeate)
l. denticulate

Figure 3. Blade apices.
a. acute
b. aristate (awned)
c. acuminate
d. caudate
e. cuspidate
f. obcordate
g. retuse
h. emarginate
i. mucronate
j. mucronulate
k. cirrhous
1. apiculate

k. rhombic

1. ovate

m. obovate

n. mancinate

- pandurate

p. deltoid (triangular)

q. obdeltoid (obtriangular)

r. orbicular

s. orbicular

t. reniform
Figure 4. Blade bases.
a. acute
b. attenuate
c. oblique
d. truncate
e. cordate
f. peltate
g. auriculate
h. hastate
i. sagittate
j. perfoliate
k. connate-perfoliate 

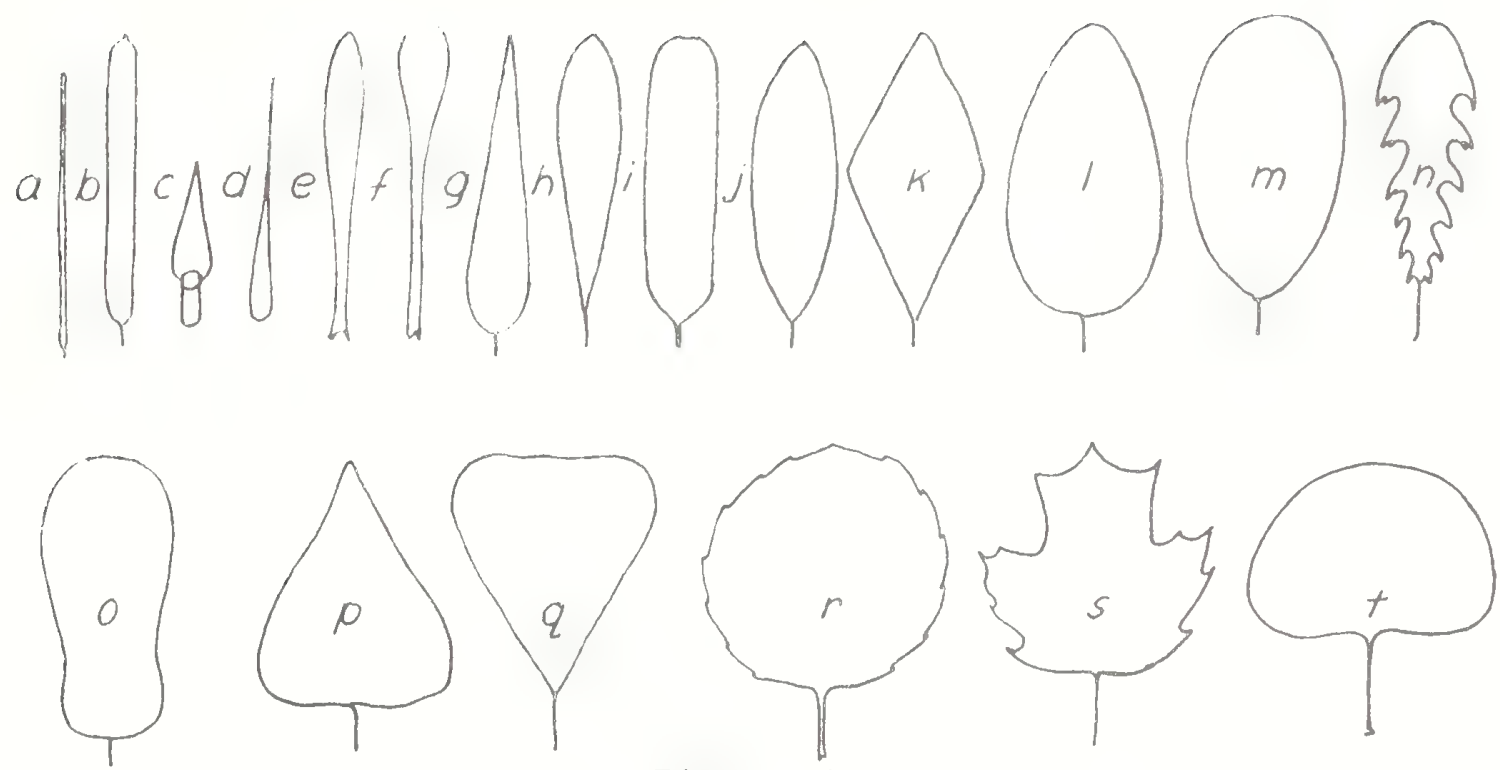

Figure 1 .
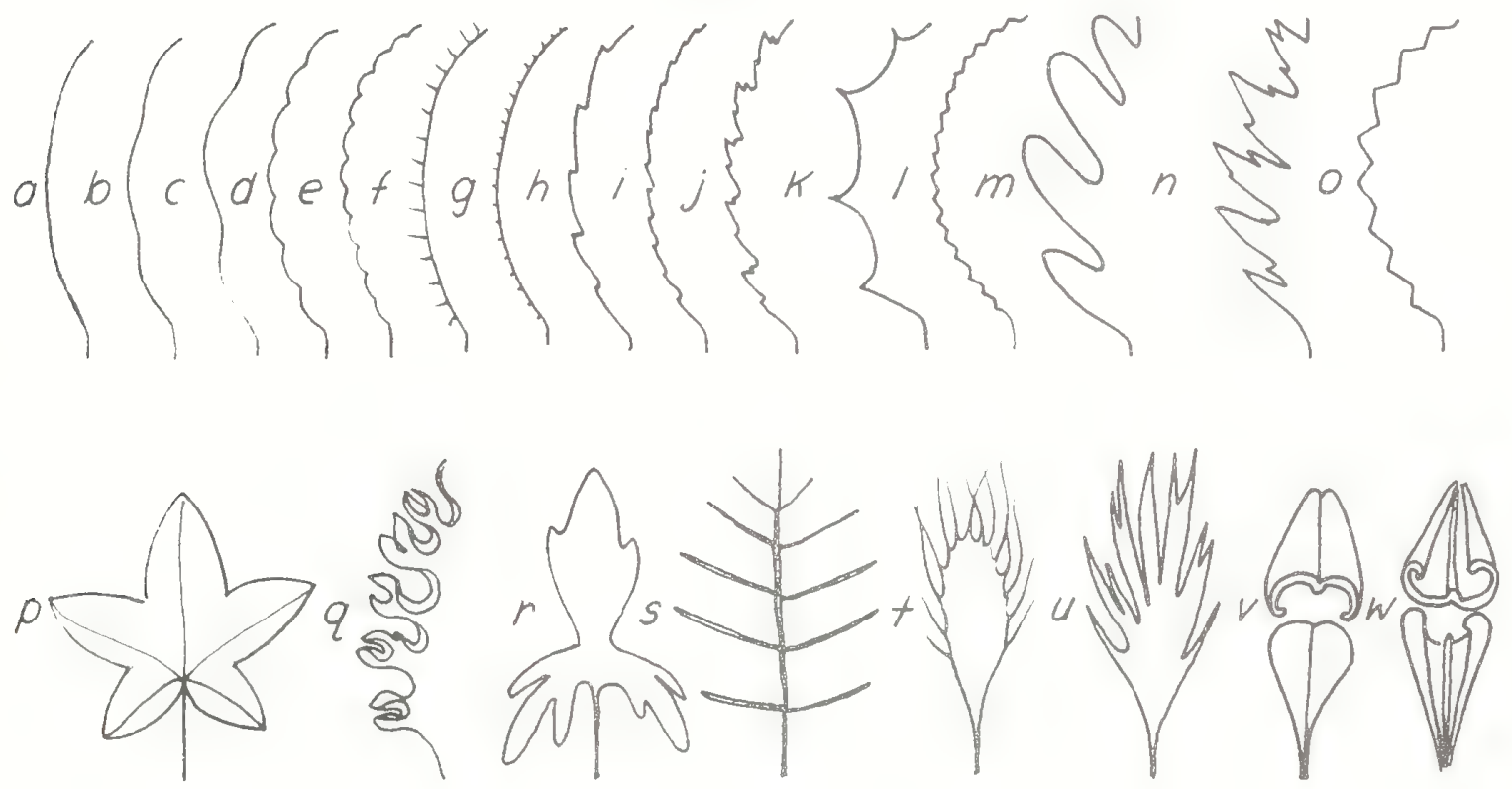

Figure 2.

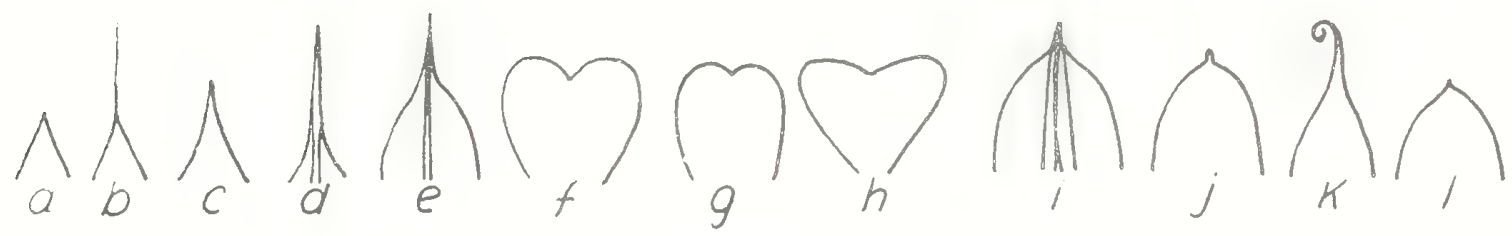

Figure 3.

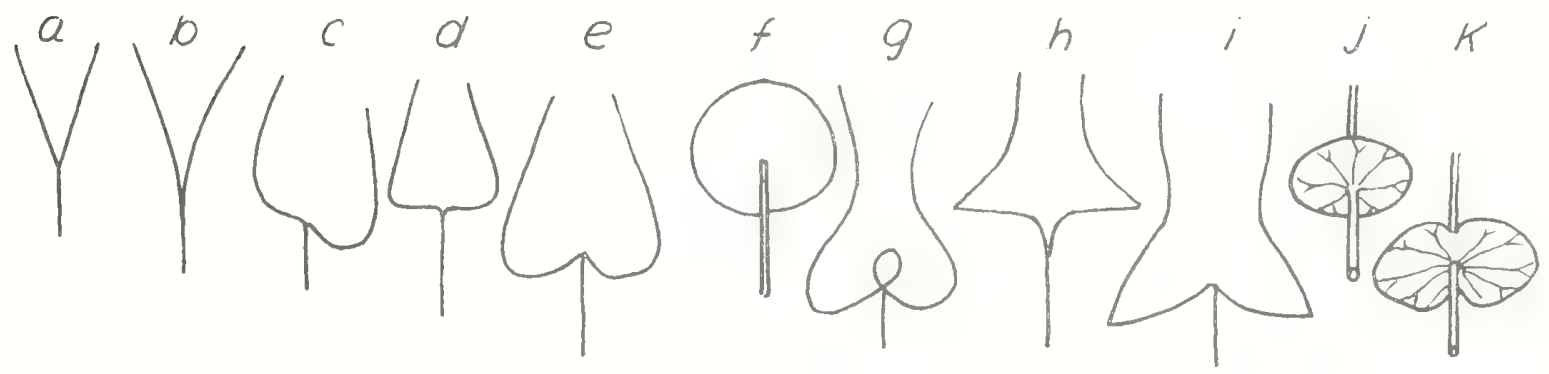

Figure 4. 
Figure 5. Inflorescence types; corolla types.

a. spike (indeterminate)

b. raceme

c. panicle

d. corymb

e. cyme

f. $\operatorname{spadix~(subtended~by~spathe)~}$

g. catkin (ament)

h. simple umbel

i. compound umbel

j. head (capitulum)

k. scorpioid

1. campanulate

m. funnelform

n. urceolate

o. bilabiate (zygomorphic)

p. salverform

q. tubular

r. rotate

s. ligulate

t. papilionaceous 
1

$C$

$C$ 




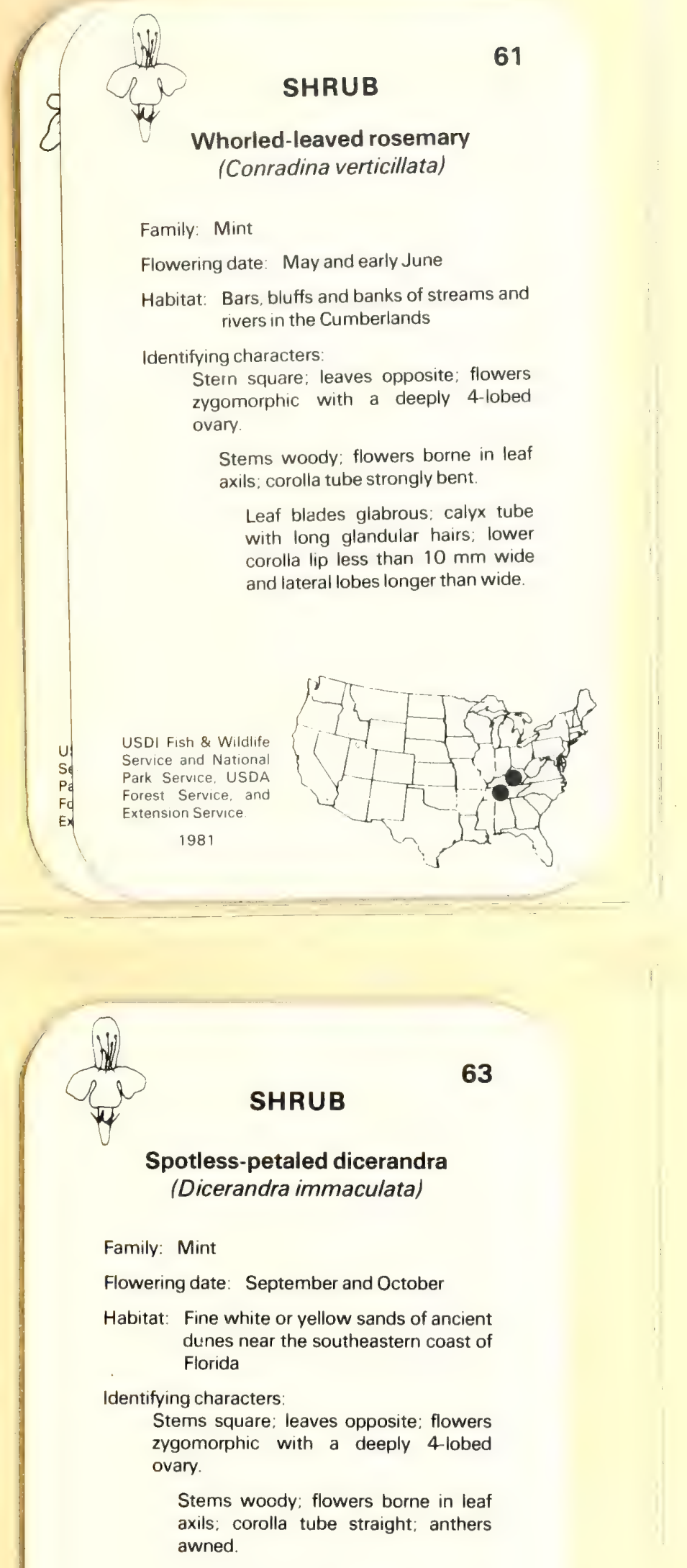

Shrubs; petals spotless.

USDI Fish \& Wildlife Service and National Park Service, USDA Forest Service, and Externsion Service.

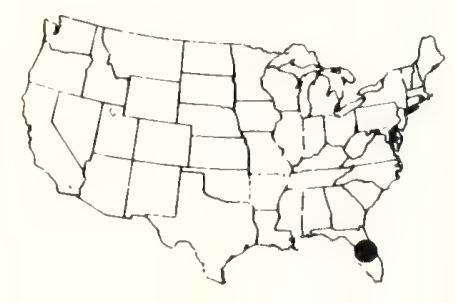




\section{SHRUB}

\section{Opposum pawpaw}

(Asimina tetramera)

Family: Custard-apple

Flowering date: May through October

Habitat: Sand scrub on the southeast coast of Florida

Identifying characters:

Trees or shrub; leaves simple with net veination; flowers hyogenous bisexual; sepals 3 to 4 ; petals multiples of 3 and free to the base; stamens with connective truncate tissue that overtops anther sacs; carpels 2 or more, separate.

Receptacle hemispheric; petals 6 or less, oblong to ovate; anther sacs separate; fruit with smooth skin.

Stems greater than $1 \mathrm{~m}$ tall, glabrous; leaves coriaceous, oblong to oblanceolate; flowers arise from axil of new leaves, less than $3.5 \mathrm{~cm}$ broad.

USDI Fish \& Wildlife Service and National

Park Service, USDA

Forest Service, and

Extension Service

1981

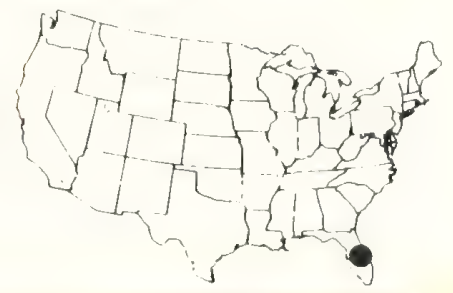




\section{FORB}

Heller's gay-feather

(Liatris helleri)

Family: Aster

Flowering date: July through September

Habitat: Open rocky outcrops at high elevations of Blue Ridge Mountains

Identifying characters:

Flowers in involucrate heads; anther united, forming a tube; ovary inferior

Stems erect; stem leaves entire, alternate and smaller than basal leaves: heads arranged in spikes containing only purplish disc flowers; involures lacking spins or prickles

Heads with 7 to 10 flowers, less that $1 \mathrm{~cm}$ wide; corolla including lobes less than $11 \mathrm{~mm}$ long. evidently hairy towards the base within: pappus barbellate, notably short and not reaching the sinus of the corolla tube.

USDI Fish \& Wildlife Service and National Park Service, USDA Forest Service, and Extension Service. 1981

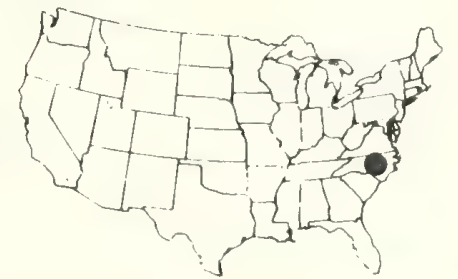

FORB

\section{Blue Ridge goldenrod (Solidago spithamaea)}

Family: Aster

Flowering date: Late July to September

Habitat: Rock crevices at high elevation of Blue Ridge Mountains

\section{Identifying characters:}

Flowers in involucrate heads: anthers un ited forming a tube; ovary inferior

Fibrous-rooted perennial herbs leaves alternate and without oil glands; receptacle naked; heads radiate small, less than $2 \mathrm{~cm}$ wide; in volucre less than $1.5 \mathrm{~cm}$ long, imbricate and in several series: rays less than $5 \mathrm{~mm}$ long and more numerous than disc flowers; pappus of capillary bristles, simple and of 1 series.

Plants less than $4 \mathrm{dm}$ tall; in florescense corymbiform; rays yellow

USDI Fish \& Wildlife Service and Nationai Park Service USDA Forest Service, and Extension Service 1981

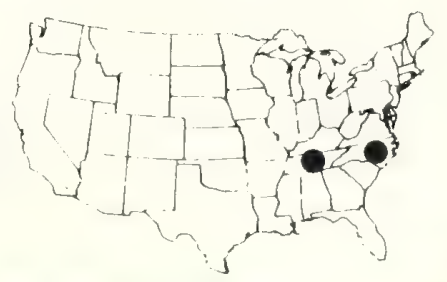

\section{FORB}

\section{Tennessee purple coneflower (Echinacea tennesseensis)}

Family: Aster

Flowering date: Late June through July

Habitat: Open limestone glades of Tennessee.

Identifying characters:

Flowers in involucrate heads: anthers un ited forming a tube; ovary inferior.

Leaves alternate and entire: recep Leaffy: heads radiate; the 6 or tacle chaffy, heads radiate, the 6 or more ray flowers are greater than 2 cm long: pappas a short toothed crown: achenes quadrangular

Stems softly hirsute; leaves softly Stems sofly hirs 5 to 20 hirsute, linear to lancelate, 5 to 20 times as long as wide, attenuate to base; heads conical; rays purple, 2 to $4 \mathrm{~cm}$ long: achenes 3.5 to $5 \mathrm{~mm}$ long.

USDI Fish \& Wildlife Service and National Park Service USDA Pank Service, USDA Forest Service, and
Extension Service. Extension Servic

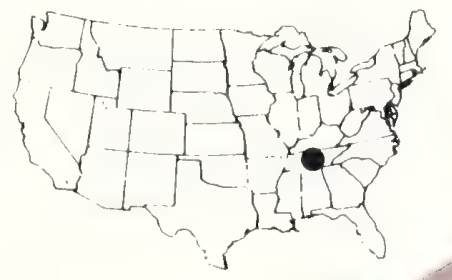

TREE

Manac palm

(Calyptronoma rivalis)

Family: Palm

Flowering date: November

Habitat: Along marshy streams in moist Almestone hills of Puerto Rico.

dentifying characters:

Trees or shrubs with plicate leaf blades (hide; perianth petaloid. Trunks solitary, less than 25.4 at the diameter; leaf sheath closed column base forming a conspicuous leaves pinand less than $0.7 \mathrm{~m}$ long. leavan $2.4 \mathrm{~m}$ nate, spineless and greater than $2.4 \mathrm{~m}$ long. Only one species in Puerto Rico.

Fish \& Wildife Usol Fish \& Nitional Service and N USDA Park Service. USD and Extension Service

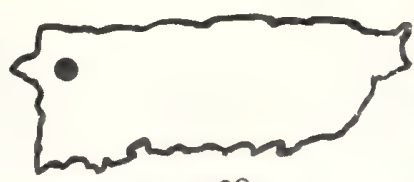

PUERTO RICO 


\section{Heller's gay-feather} (Liatris helleri)

Family: Aster

Flowering date: July through September

Habitat: Open rocky outcrops at high elevations of Blue Ridge Mountains

\section{Identifying characters:}

Flowers in involucrate heads; anther un ited, forming a tube: ovary inferior.

Stems erect: stem leaves entire. alternate and smaller than basal leaves: heads arranged in spikes containing only purplish disc flowers: involures lacking spins or prickles.

Heads with 7 to 10 flowers, less that $1 \mathrm{~cm}$ wide; corolla including lobes less than $11 \mathrm{~mm}$ long. evidently hairy towards the base within: pappus barbellate, notably short and not reaching the sinus of the corolla tube.

USDI Fish \& Wildlife Service and National Park Service, USDA Forest Service, and Extension Service

1981

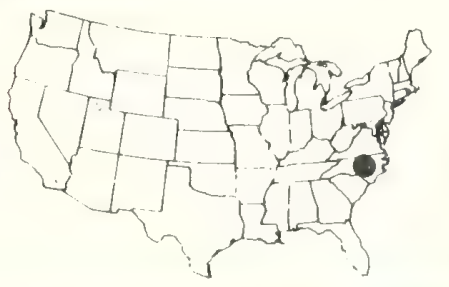

\section{Blue Ridge goldenrod \\ (Solidago spithamaea)}

Family: Aster

Flowering date: Late July to September

Habitat: Rock crevices at high elevation of Blue Ridge Mountains

Identifying characters

Flowers in involucrate heads: anthers un ited forming a tube; ovary inferior.

Fibrous-rooted perennial herbs: leaves alternate and without oil glands: receptacle naked; heads radiate, small, less than $2 \mathrm{~cm}$ wide; in volucre less than $1.5 \mathrm{~cm}$ long. imbricate and in several series; rays less than $5 \mathrm{~mm}$ long and more numerous than disc flowers; pappus of capillary bristles, simple and of 1 series.

Plants less than $4 \mathrm{dm}$ tall; inflorescense corymbiform; rays yellow.

USD! Fish \& Wildlife Service and National Park Service. USDA Forest Service. and Extension Service

1981

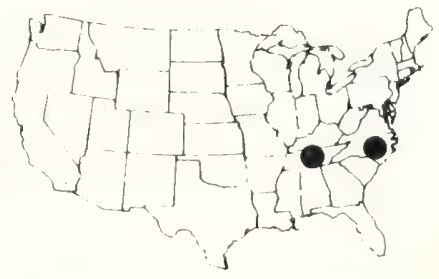

\section{SHRUB}

\section{3}

\section{Panhandle rosemary (Conradina glabra)}

Family: Mint

Flowering date: From March into June, then intermittently until frost

Habitat: Sandy, high, open, longleaf pinescrub oaks woodlands

Identifying characters:

Stem square: leaves opposite; flowers zygomorphic with a deeply 4-lobed ovary.

Stem woody; flowers borne in leaf axils: corolla tube strongly bent.

Leaf blades glabrous; calyx tube glabrous; lower corolla lip less than $10 \mathrm{~mm}$ wide and lateral lobes longer than wide

\section{TREE}

\section{Manac palm \\ (Calyptronoma rivalis)} (a)

Family: Palm

Flowering date: November

Habitat: Along marshy streams in moist limestone hills of Puerto Rico.

Identifying characters. Trees or shrubs with plicate leaf perianth greater than $3 \mathrm{dm}$ wide. petaloid.

Trunks solitary, less than $25.4 \mathrm{~cm}$ in diameter: leaf sheath closed at the forming a conspicuous column base forming a $7 \mathrm{~m}$ long: leaves pinand less than $0.7 \mathrm{~m}$ long, leave $2.4 \mathrm{~m}$ nate, spineless and greater than $2.4 m$ long. Only one species in Puerto Rico.

USDI Fish \& Wildife Service and National Sark Service. USDA Forest Service, and Extension Service 1981

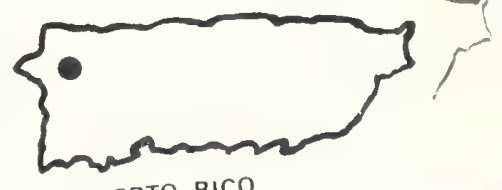
PUERTO RICO 


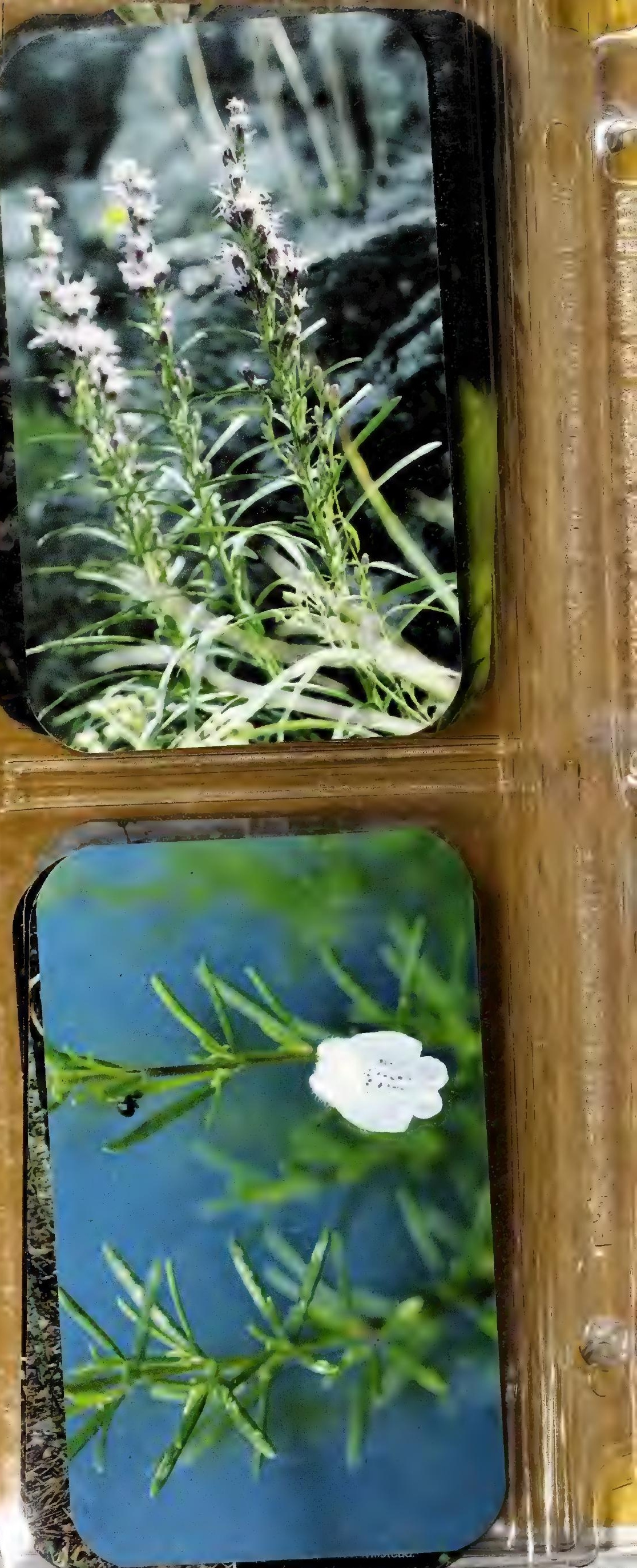


EVERGREEN TALLSHRUB

\section{Vahl's boxwood} (Buxus vahlii)

\section{Family: Boxwood}

Flowering date: Spring to fall

Habitat: Semi-evergreen, limestone forests of Pueto Rico

Identifying characters

Flowers unisexual, perianth fused, corolla axent: placentation axile, ovules 2 per locule.

Erect, evergreen shrub, leaf margins entire.

Leaves oblong or obovate, less apex rounded in than $5 \mathrm{~cm}$ long, apex rounded Service and National Park Service. Forest Service. an Extension Service. 1981

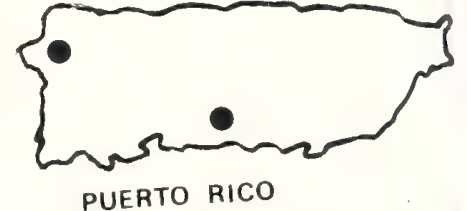

and the VIRGIN ISLANDS

\section{SHRUB}

Fragrant Florida cereus

(Cereus eriophorus fragrans)

Family: Cactus

Flowering date: April

Habitat: Coastal hammocks on high sand dunes

Identifying character:

Stem succulent, bearing spines: leaves reduced or lacking: flowers solitary and sessile; petals and sepals numerous. separate; stamens numerous, pistil 1 . compound, inferior with partial placentation.

Stems cylindrical with ridges and grooves. lacking leaves and glocidium; flowers greater than $3 \mathrm{~cm}$ wide.

Stems round in cross section reclining: floral tube greater than $3.5 \mathrm{~cm}$ long: hairs in areoles of floral tube 10 or more $\mathrm{mm}$ long petals entire; berry obovoid

USDI Fish \& Wildlife Service and National Park Service, USDA Forest Service, and Extension Service

1981
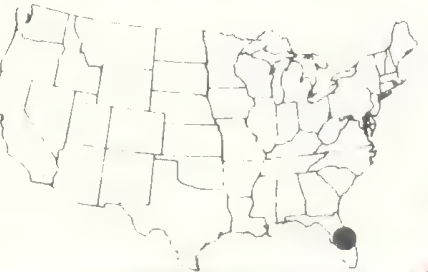

TALL SHRUB

\section{Original prickly-apple cereus} (Cereus gracilis aboriginum)

\section{Family: Cactus}

Flowering date: April to October

Habitat: Shell mounds and shore hammocks Identifying characters

Stem succulent bearing spines; leaves reduced or lacking. flowers solitary and sessile petals and sepals numerous separate stamens numerous, pistil 1. compound inferio with parietal placentation

Stems cylindrical with ridges and grooves. lacking leaves and glocidium: flowers greater than $3 \mathrm{~cm}$ wide.

Stems round in cross section, floral tube greater than $3.5 \mathrm{~cm}$ long: hairs in areoles of floral tube $8 \mathrm{~mm}$ or less long. petal apices erase - denticulate; berry depressed globuse.

Young buds covered with brown hairs, berry dull yellow

USDI Fish \& Wildlife Service and National Park Service, USDA Forest Service, and Extension Service.

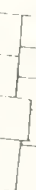

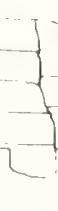

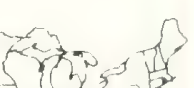




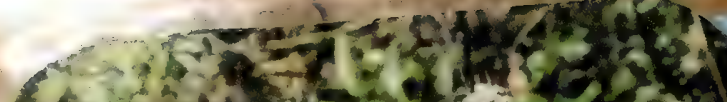

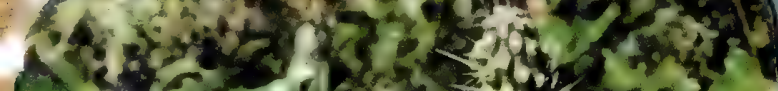

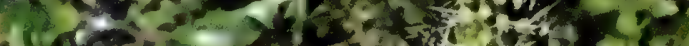

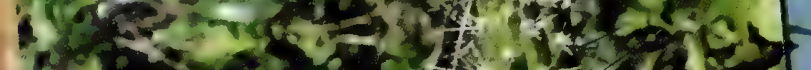

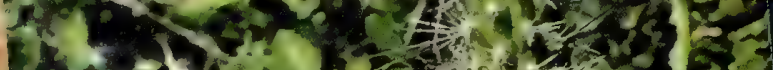

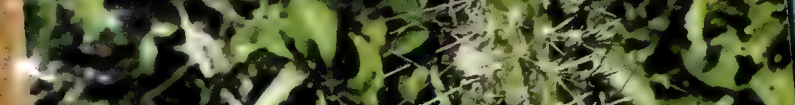

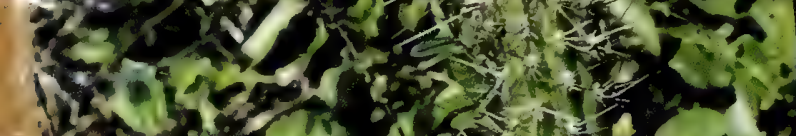

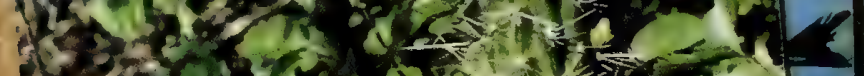

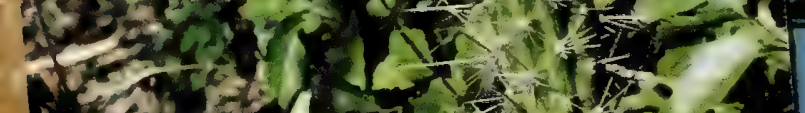
(1) - 00 and

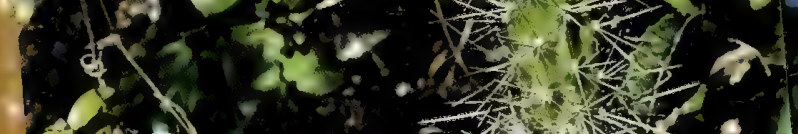

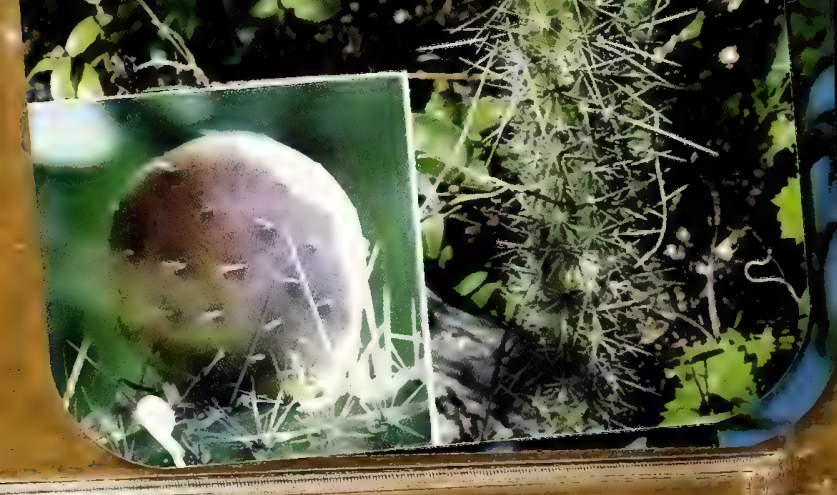
(Wi: $=$
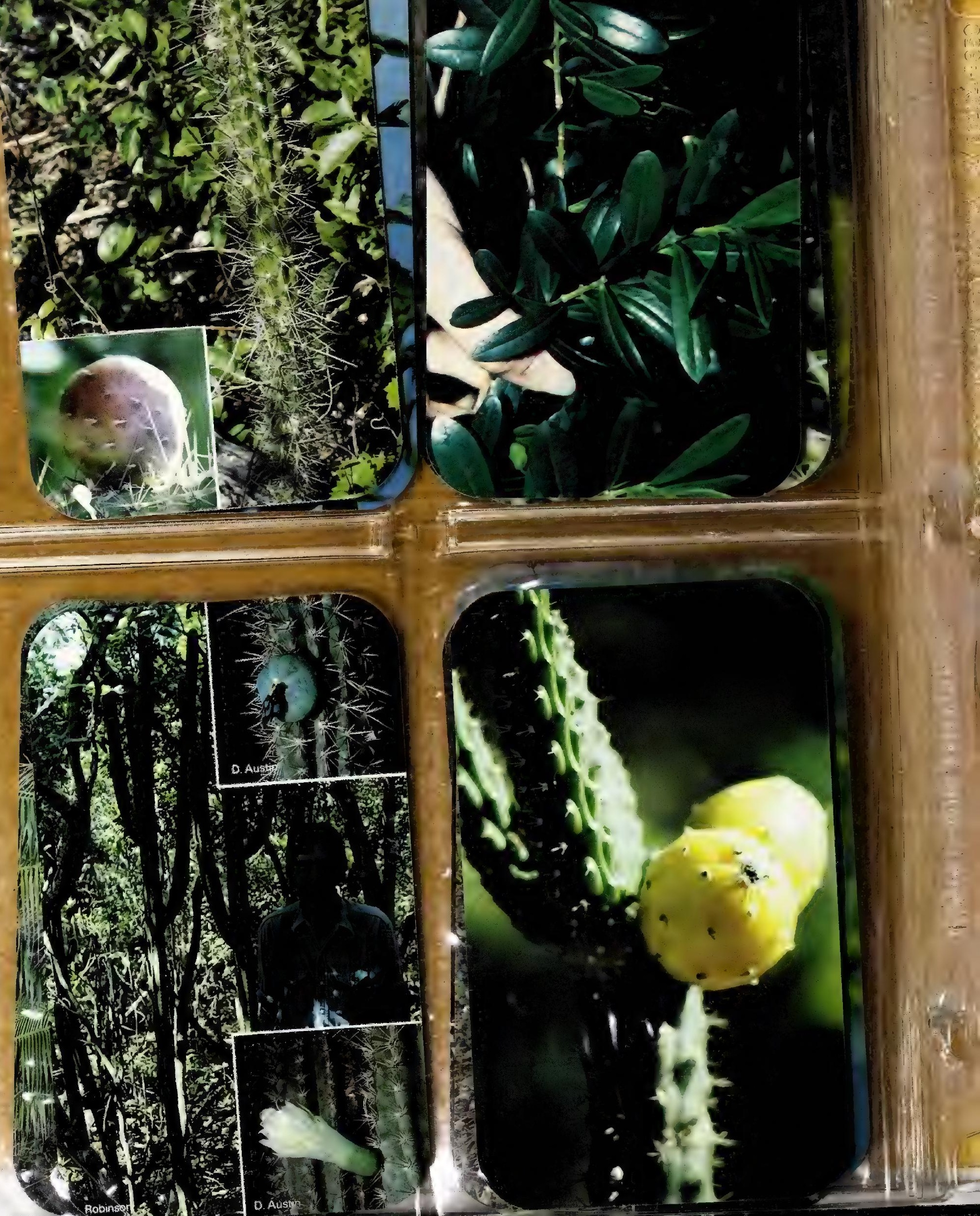


\section{LOW SHRUB \\ Puerto Rico senna \\ (Cassia mirabilis)}

Family: Legume

Flowering date: December

Habitat: Open, disturbed, sandy areas of Puerto Rico

Identifying characters

Flowers zygomorphic; pistil 1, simple: fruit a legume.

Leaves evenly 1 -pinnate and without tendrils at tip; leafiets 4 or more: flower yellow, caesalpinaceous; pods dry with a double wall.

Low, prostrate shrub; leaflets 3 or more pairs. 4 to $6 \mathrm{~mm}$ long, membranecous and finely veined; stipules persistent; flowers $2 \mathrm{~cm}$ or more wide; peduncles not longer than the smallest leaf; calyx lobes accumenate; pods not longer than $2.5 \mathrm{~cm}, 2$ to $2.5 \mathrm{~mm}$ wide, elastically deshiscent.

USDI Fish \& Wildlife Service and National Park Service, USDA Forest Service, and Extension Service. 1981

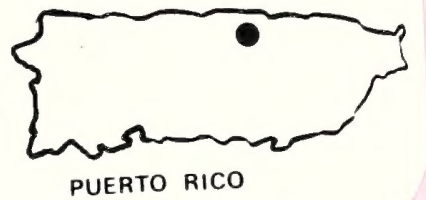

FORB

\section{Small-whorled pogonia (Isotria medeoloides)}

Family: Orchid

Flowering date: Mid-May to Mid-June

Habitat: Open, dry, deciduous woods

Identifying characters:

Flowers zygomorphic: ovary inferior. stamens situated on a column.

Plants terrestrial: leaves smooth not plicate, in a whorl of 5 or 6 leaves terminating the stem and present at flowering time.

Stems greenish white; leaves deflexed as the bud opens; pedicles about $5 \mathrm{~mm}$ long.

USDI Fish \& Wildlife Service and National Park Service USDA Forest Service, and Extension Service. 1981

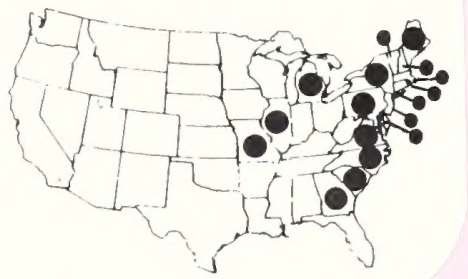

\section{FORB}

\section{Jones' pitcher plant (Sarracenia rubra jonesii)}

Family: Pitcher-plant

Flowering date: April into early June

Habitat: Bogs, streambanks and seeps of Blue Ridge Mountains

Identifying characters:

Flowering stem leafless; leaves pitchershaped, hollow: stigma umbrellashaped.

Only one genus in the Southeast

Leaves erect; hood flat, green, more or less veined with purple corolla maroon

Solid portion of petiole onethird the length of the leaf, abaxial portion of petiole flattened in cross section; leaf tissue below orifice thick, waxy and outer surface glabrous: flowers about equal to height of leaves

USDI Fish \& Wildlife Service and Nationa Park Service, USDA Forest Service Extension Service.

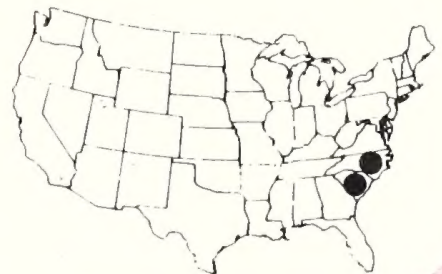

\section{迹 EVERGREEN TALL SHRUB \\ Malabuey \\ (Goetzea elgans)}

Family: Nightshade

Flowering date: May to August

Evergreen and semi-evergreen seasonal forest of Puerto Rico

Identifying characters: alternate, estipulate Leaves mostly alternate, or contorted corolla lobes fused, folded or contor with rarely valvate in bud; Ovary superion axile; fruit a cap2 locules; place sule or berry

Leaves elliptic. shiny with straight allel raised side veins: corolla 6 parallel raised side veins; corolla 6 lobed, orange, funnerries orange nearly 1 inch long. berries orange.

Only one species in Puerto Rico

SDI Fish \& Wildlife USDI Fish \& National Service and Ne USDA Farkst Service, and Extension Service

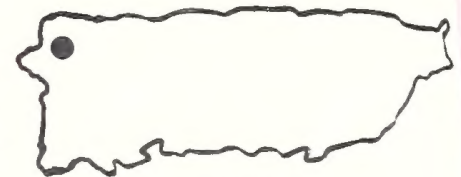

PUERTO RICO 


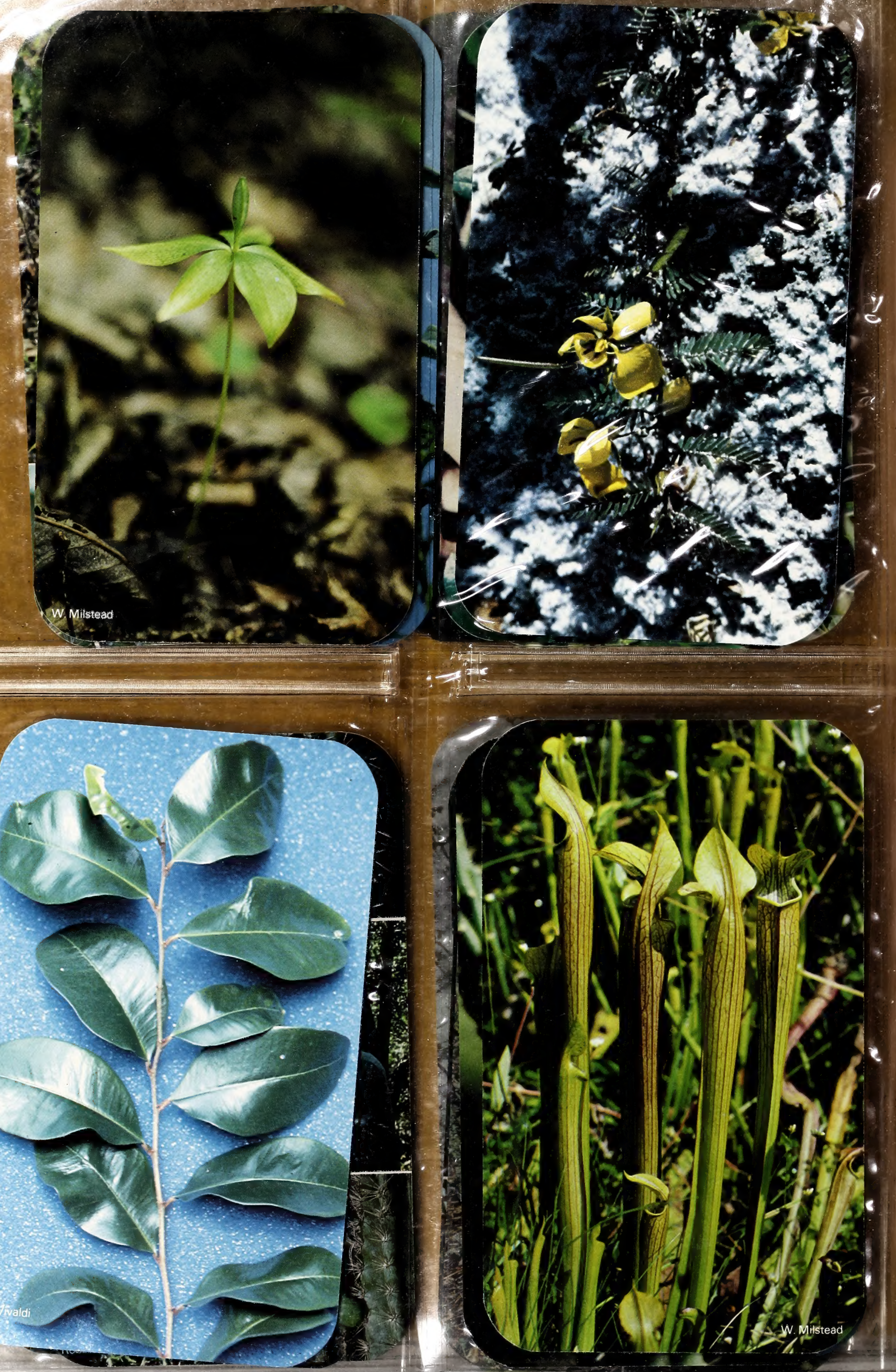


